DOE/EIS - 0131

Bonneville Power Administration
DOE/EIS-. 0131-Vol.2-Final

DE92 012664

Final Environmental Impact Statement

DE92 012664
INITIAL

NORTHWEST

POWER ACT

POWER SALES

CONTRACTS
U.S. Department January 1992 of Energy

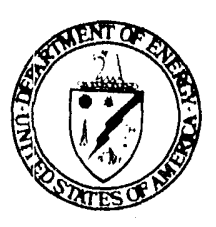

Volume 2:

Appendices A - L 
TABLE OF CONTENTS

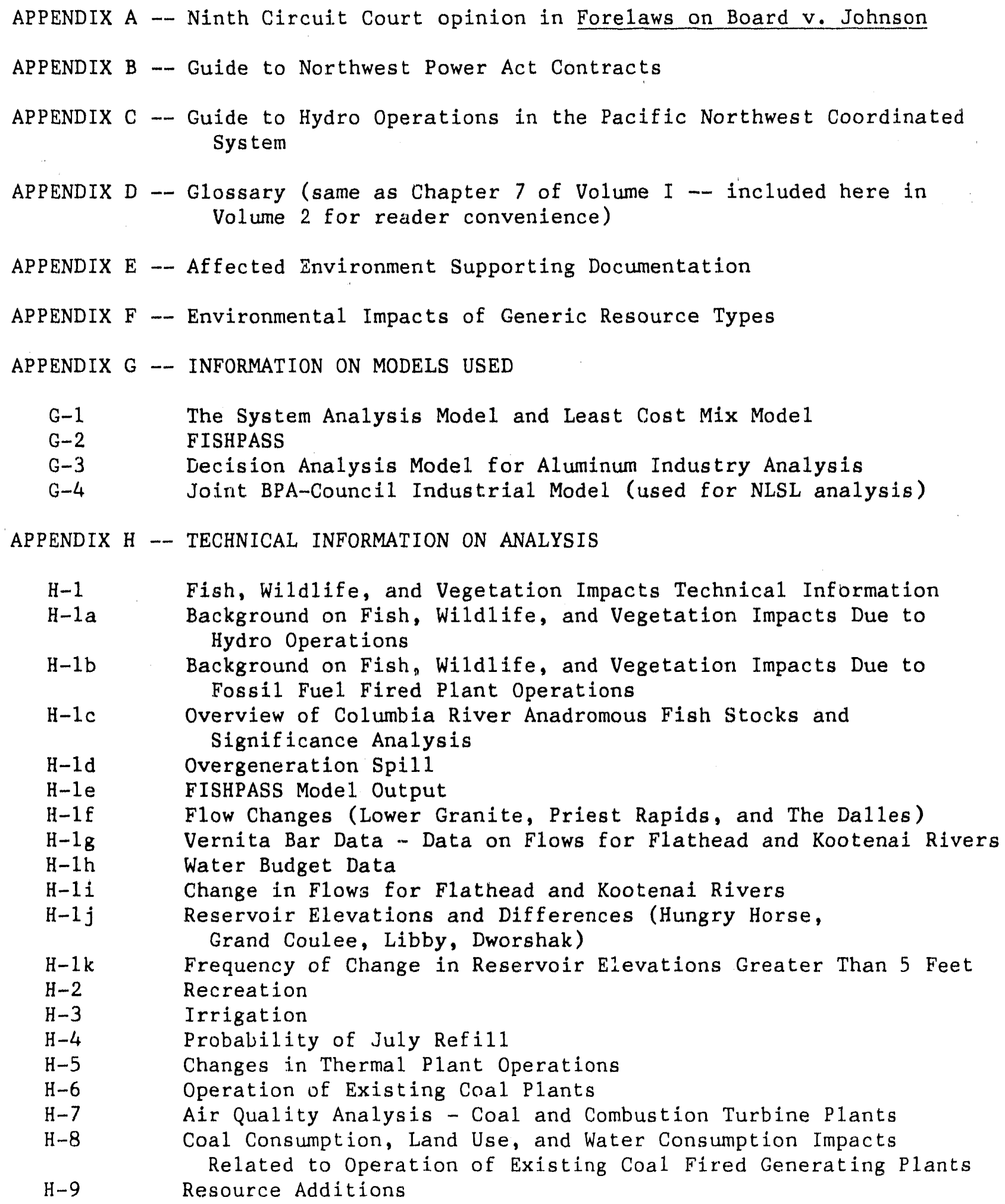


APPENDIX I -- Pub1ic Involvement Activities

APPENDIX J -- Bibliography

APPENDIX K -- Pacific Northwest Electric Power Planning and Conservation Act APPENDIX L -- Biological Assessment

(VS6-PG-1746I) 


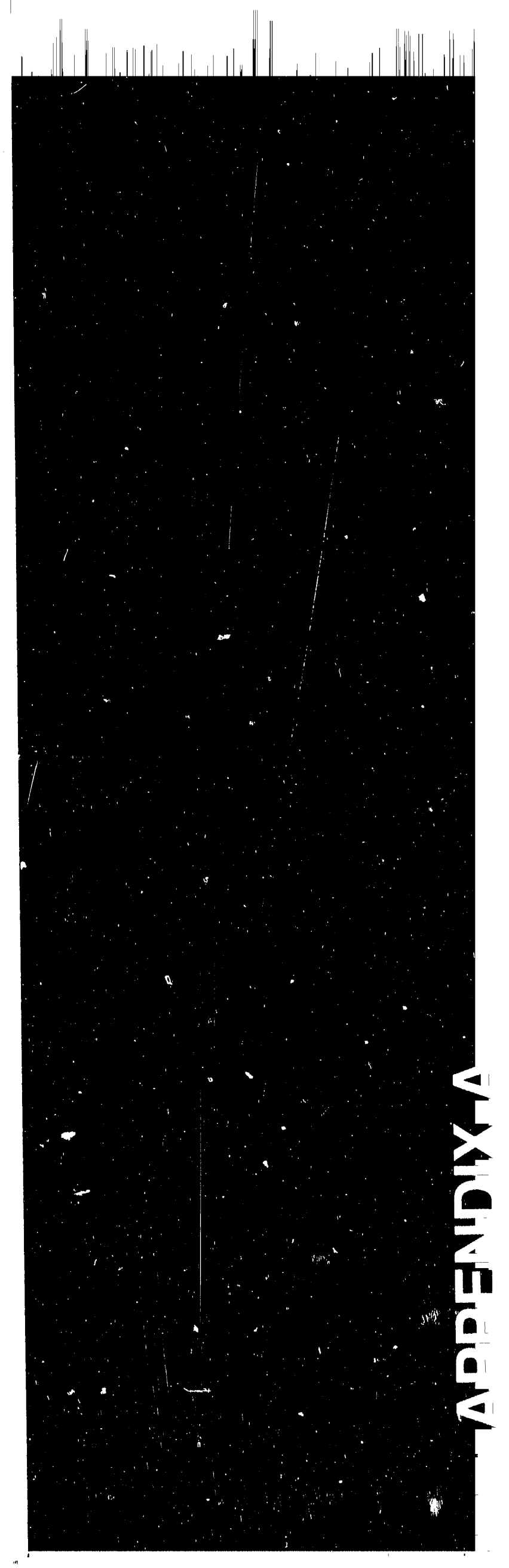


Appendix A

Ninth Circuit Court Opinion In

Forelaws on Board $v$. Johnson

743 F.2d 677 (1984) 
H()RELAWS (ON B(OARI) V. JOIINS()N

Clte an 743 l.2d 677 (19N4)

H(IKELA WS ON BOARI), an unincorporated association; and Lloyd

Murbet, Plaintiffs,

v.

Peter JOHNSON, as Administrator of the Bonneville Power Administration, Department of Energy; James Edwards, as Secretary of the Department of En. ergy and the United States of America, Defendants.

No. 82-7319.

United States Court of Appeals, Ninth Circuit.

Argued and Submitted March 6, 1984.

Decided Sept. 25, 1984.

As Amended Jan. 21, 1985.

Linda K. Williams, Portland, Or., for plaintiffs.

George M. Galloway, Washington, D.C., for Pacific Power \& Light Co.

Eric Redman, Seattle, Wash., for Martin Marietta Aluminum.

Frank W. Ostrander, Portland, Or., for Northwest Power Planning Council.

David J. Adler, Portland, Or., for Peter Johnson, Dept. of Energy.

Original Proceeding to Review the Bonneville Power Administration Offer of Initial Contracts Pursuant to the Pacific Northwest Electric Power Planning and Conservation Act.

Before SCHROEDER, FARRIS, and REINHARDT, Circuit Judges.

SCHROEDER, Circuit Judge.

This is a challenge to the Bonneville Power Administration's offers of long term contracts for power delivery pursuant to the Pacific Northwest Electric Power Planning and Conservation Act (Regional Act), 16 U.S.C. $\$ 839-839$ h (1982), without compliance with the requirements of the $\mathrm{Na}$ tional Environmental Policy Act of 1969
(NEPA), 42 U.S.C. \$\$ 4321-4i3(il (1976). We have previously hold that this is a review of final arency action which, under the Regional Act, must be filed originally in this court rather than in the district court. Forelaws on Board v. Johnson, 709 F.2d 1310 (9th Cir.1983) (Forelaw' I).

Plaintiffs seek an order compelling the preparation of an Environmental Impact Stutement and enjoining operation of the contracts. We hold that an Environmental Impact Statement is required and should be utilized in connection with consideration of any further amendments, to which NEPA will also apply and for which additional EIS's may be required. We decline, how. ever, to enjoin operation of the contracts pending completion of the initial EIS.

\section{Statutory Background}

On December 5, 1980, the Regional Act became law. It is a "unique piece of energy legislation" designed to allocate the finite supply of inexpensive hydroelectric power, generated on the Columbia River System, among competing consumers as well as to provide for the acquisition of new energy resources. See Central Lin. coln Peoples' Utility District v. Johnson, 735 F.2d 1101, 1106 (9th Cir.1984). In the early 1970's, BPA, faced with increasing demand for low-cost hydroelectric power and possible power shortfalls, notified its nonpreference customers that their power contracts would not be renewed and in. formed its preference customers that it, could iut satisfy any load growth after 1983. Aluminum Co. of America $v$. Central Lincoln Peoples' Utility District, U.S. - 104 S.Ct. 2472, 2477-78, 81 L.Ed.2d 301 (1984). In response to the resulting confusion, Congress passed the Regional Act, which was designed to avert "regional civil war" by allocating BPA's finite supply of hydroelectric power between competing consumers and by providing for the acquisition of new energy re. sources. See Central Lincoln Peoples' Utility District v. Johnson, 735 F.2d 1101, 1106 (9th Cir.1984). The Regional Act required BPA to offer new long-term con- 
tracts to both freference and nonpreference customers "[a]s soon as practicable within nine months after December 5, 1980." 16 U.S.C. \$ $839 \mathrm{c}(\mathrm{g})(1)$. Each customer was given one year from the date of the offer to accept the contract. 16 U.S.C. $5839 \mathrm{c}(\mathrm{g})(2)$. Thus, within 21 months of the Act's effective date, a new system of contracts allocating BPA's supply of hydropower was to be in place.

The Act also required BPA to encourage energy conservation by its customers as well as to take measures to protect the environment of the Pacific Northwest. 16 U.S.C. $\S 839 b, d, f(j)$. Congress said the Act was to be "construed in a manner consistent with applicable environmental laws." 16 U.S.C. $\$ 839$. The questions presented in this case thus implingte two of the Acts' most important objectives: a new system of contracts governing BPA's delivery of power to its customers and an energy program for the Pacific Northwest that is sensitive to environmental concerns.

\section{Procedural Objections to this Suit}

Before reaching the merits of the case, there are two preliminary procedural objections by the defendant BPA, and intervenors Martin Marietta Aluminum, Public Power Council, and Pacific Power \& Light Company, relating to plaintiffs' standing and the timeliness of the action.

(1) Intervenor Martin Marietta contends that Forelaws lacks standing because it has not alleged that BPA's contract offers caused it any injury within the zone of interest to be protected by NEPA, citing Port of Astoria, Oregon v. Hodel, 595 F.2d 467, 474 (9th Cir.1979). The complaint, however, alleges that plaintiff Forelaws is an environmental group whose members live in the Pacific Northwest and that one of its members, Mr. Marbet, is a resident of that region and a consumer of electric power there.' Those allegations coupled with the allegations of the environmental consequences of the contract are sufficient to establish standing. See United States $v$.

1. The name Forelaws on Board is apparenlly derived from Barry Commoner's "four law's of
SCRAF, 412 U.S. 669, 6833-90, 93 S.Ct. 2405, 2414-17, 37 L.Ed.2d 254 (1972) (even general allegations of potential hal'm by one who lives in or uses an area dimon. strate standing); Pacific Legal Founda. tion v. State Energy Resources, Etc., 659 F.2d 903, 911-12 (9th Cir.1981), cert. denied, 457 U.S. 1133, 102 S.Ct. 2956, 73 L.Ed.2d 1348 (1982), See also Sierra Club v. Morton, 405 U.S. 727, 739, 92 S.Ct. 1361, 1368, 31 L.Ed.2d 636 (1972) ("[A]n or 3 anization whose members are injured may represent those members in a proceeding for judicial review.").

[2] The timeliness question arises from the confusion generated by the statute's provision that suits challenging final actions of the BPA administrator "shall be filed within the United States court of ap. peals for the region ... within ninety days ..." 16 U.S.C. $\$ 839 \mathrm{f}(\mathrm{e})(5)$. The complaint in this case was not actually filed with the clerk of this court until more than 90 days after the action being challenged. However, it is undisputed that Forelaws attempted to file a complaint the day before the expiration of the 90-day period, but the clerk of this court rejected the complaint because normally this court does not have jurisdiction of original complaints. In fact the plaintiffs had also filed a complaint in the district court, and jurisdictional issues were still in litigation. See Forelaws I, 709 F.2d at 1311-13. Qur clerk's mistak. en rejection of the complaint when it was timely offered should not bar its considera. tion, and it should be deemed timely filed. See Loya v. Desert Sands Unified School District, 721 F.2d 279, 280-81 (9th Cir. 1983). We therefore must consider the merits of plaintiffs' claim that BPA has violated NEPA by failing to prepare an environmental impact statement.

The Contracts' Environmental Significance

[3] Section 102(2)(C) of NEPA, 42 U.S.C. \& $4332(2)(\mathrm{C})$, requires that federal agencies, "to the fullest extent possible," ecology." B. Commoner, The closing Cincle (1971). 
Clle as 743 F.2.1677 (1944)

do a detailed statement of the environmental impact of any proposed major federal action which would significantly affect the quality of the environment." BPA did not prepare an environmental impact statement in connection with its contract offors. It did what it termed an "Environmental Report," a document not contemplated hy NEPA, and which did not analyze in detail any possible adverse environmental consequences of the contracts and ways that they might be avoided. The environmental report did not, in short, do what an environmentai impact statement is supposed to do, and what plaintiffs contend under the provisions of NEPA, the agency was required to do.

BPA does not deny that these 145 contracts of 20-year duration constitute major federal action. It argues that the contracts themselves do not significantly affect the human environment. It also argues more strenuously that the time limitations of the Regional Act indicate Congress's intent to waive NEPA's application to these contracts by making it impossible for the agency to comply with NEPA. We deal with each of these arguments in turn.

BPA initially contends that because Congress has mandated it to offer contracts, BPA had no discretion with respect to contract terms that might have varying effects upon the environment. Because the principal purposes of NEPA include making considerations of environmental concerns a part of the decision-making process, see Weinberger $v$. Catholic Action of Hawaii, 454 U.S. 139, 143, 102 S.Ct. 197, 201, 70 L.5.2d 293 (1981), other circuits have developed the principie that an EIS is not required where the agency's action is

2. Section $102(2)(C)$ of NEPA requires that:

[T]o the fullest extent possible: ...

(2) all agencies of the Federal Government shall ...

(C) include in every recommendation or re. port on proposals for legislation and other major Federal actions significantly affecting the quality of the human environment, a de. tailed statement by the responsible official on-

(i) the environmental impact of the pro posed action, "mandatory." S'ee, c.ly., Pacific Legal Foundation v. Ancims, 657 F.2d 829, 839$40 \&$ n. 13 (6th Cir.1981) (mandatory agency duty to list endangrered species upon specifled factual finding); South Dakota $v$. Andrus, 614 F.2d 1190, 1193 (8th Cir.), cert. denied, 449 U.S. 822, 101 S.Ct. 80, 66 L.Ed.2d 24 (1980) (non-discretionary acts not subject to NEPA); Natural Resources Defense Council, Inc. v, Berklund, 609 F.2d 553, 558 (D.C.Cir.1979) (NEPA not applicahle when Secretary has no discretion as to coal leases).

The difficulty with BPA's position that the contract action was completely mandated by statutes is that, as BPA recognized in its environmental report, "the adminis. trator possesses a great deal of discretion in contract matters." This includes contract provisions directly aimed at environmental concerns. Congress expressly authorized the administrator to include, in the contracts, provisions designed to achieve the Act's environmental purposes, such as encouragement of conservation, development of renewable resources, fish and wildlife protection and enhancement. The content of these contract provisions is not mandated but is clearly discretionary. See Aluminum Co. of America v. Central Lincoln Util. Dist., - U.S. - , 104 S.Ct. 2472, 2484, 81 L.Ed.2d 301 (1984) ("Because the Regional Act does not comprehensively establish the terms on which power is to be supplied ... under the new contracts, it is our view that the [BPA] has broad discretion to negotiate them.").

BP.A nevertheless argues that we should regard its discretion as limited principally to matters of power allocation which, it

(ii) any adverse environmental effects which cannol be avoided should the proposal be implemiented,

(iii) alternatives to the proposed action,

(iv) the relationship between local short. term uses of man's environment and the maintenance and enhancement of long-term productivity, and

(v) any irreversible and irretrievable com. mitments of resources which would be in. volved in the proposed action should it be implemenled.

42 U.S.C. 64332 (Supp. 1982). 
argues, as a matter of law, cannot affect the human environment. It relies ujon our decision in City of Santa Clara 1: Andrus, 672 F.2d 660 (9th Cir.1978), and Sierra Club v. Hodel, 544 F.2d 1036 (9th Cir.1976), for the proposition that federal agency actions that merely allocate federal power to different customers do not significantly affect the environment.

Although BPA accurately characterizes the holding of these cases, they do not control this case. City of Santa Clara and the relevant portion of the Sierra Club decision involved a simple determination of which customers were entitled to a finite supply of power. See City of Santa Clara, 572 F.2d at 680; Sierra Club, 544 F.2d at 1039-41. The contracts in this case involve considerations of far greater historic and regional import and significantly affect the environment. For example, by defining the federal base system and "new large single loads" the contracts help determine the magnitude of BPA power obligations in the future and thus will have an impact upon long-range regional energy plans. See Port of Astoria, Oregon v. Hodel, 595 F.2d 467, 477-78 (9th Cir.1979) (holding that action creating significant new commitments of BPA power affecting future regional energy planning requires an environmental impact statement).

In addition, the contracts significantly affect the environment because they in. volve important policy choices affecting energy conservation. Incentives for conservation which could have been included in the contracts were suggested by several commentators during the time the agency was developing its proposals." These incentives included rate schedules that reward users who succeed in reducing demand; encouragement of utilities to attach conservation related conditions to electric

3. In response to BPA's draft prototype power sales contracts published in the July 12, 1981 Federal Register, a number of groups including the Natural Resources Defense Council, the En. vironmental Protection Agency, Fair Electric Rates Now, and the Oregon Department of Energy commented on the conservation provi. sions. service; shortfall allocation plans which luke into account utility conservation poli. cies, and implementation of tiered rates to increase the incentive to conserve. BPA did in fact include certain measures in the contracts to encourage conservation, but, they were fewer and weaker than those proposed by several public groups. In the absence of an environmental impact statement, we do not know to what extent BPA considered the merits of the other proposals and their feasibility from an environ. viental standpoint.

Still other significant envircumental aspects of the contracts are the fish and wildlife provisions, the most often commented upon environmental provisions of this statute. Several sections of the Act detail BPA's fish and wildlife responsibilities, 16 U.S.C. $\S 839(3)(6), b(e)(2),(h)(10) \&$ (11), which include planning, management, protection, mitigation, and enhancement. See generally Blumm, Implementing the Parity Promise: An Evaluation of the Columbia Basin Fish and Wildlife Program, 14 Envtl.L. 277 (1984). In the record before BPA, a great many groups suggested provisions which would mitigate fishery damage and improve conservation efforts. As the National Marine and Fishery Service pointed out to BPA, a major purpose of the Regional Act was to treat fish and wildlife interests as coequal partners in management of the Northwest hydrosystem. Again, without an EIS, we do not know to what extent these pr pposals were evaluated as feasible alternatives to the provisions eventually proposed.

Also undercutting BPA's present position is the fact that, despite the repeated insistence by plaintiffs and other groups, BPA never, throughout the period that it was developing its contract proposals, argued that the contracts were not federal

4. Comments on the July 12,1981 draft prototype sales contracts were received from groups including the Columbia River Citizens Compact. the Northwest Steelhead Salmon Councll, the Upper Skagit Tribes, the National Marine and Fisheries Service, the Columbia River Fisher. man's Protective Union, and the Washington Department of Fisheries. 
actions significantly affecting the environment. Kuther, its "Environmental Report" reflects acknowledgenent of environmen. tal consequences of a contract but defend. ed the noncompliance with NEPA on grounds of time constraints. We therefore hold that the contracts are significant federal actions affecting the environment and turn to the issue of time constraints.

\section{The Regional Act's Statutory Time Constraints as Implied Waiver of NEPA Requirements}

BPA's principal argument in this case is that the statutory deadlines for contract offer and acceptance made it impossible to prepare an EIS. The Regional Act, which was effective December 5, 1980, gave BPA until September 5, 1981, or nine months to offer the contracts, 16 U.S.C. $\S 839 \mathrm{c}(\mathrm{g})(1)$. Customers then had up to one year from the date of the offer to accept the contracts. 16 U.S.C. $\$ 839 \mathrm{c}(\mathrm{g})(2)$.

NEPA's legislative history reflects Congress's concern that agencies might attempt to avoid any compliance with NEPA by narrowly construing other statutory directives to create a conflict with NEPA. Section 102(2) of NEPA therefore requires government agencies to comply "to the fullest extent possible." The Senate and House conferees, who added that language to the statute, explained it in the following manner:

The purpose of the new language is to make it clear that each agency of the federal government shall comply with the directions set out in $\therefore$ [Section 102(2) ] unless the existing law applicable to such agency's operations expressly prohibits or makes full compliance with one of the directives impossible .... Thus, it is the intent of the conferees that the provision 'to the fullest extent possible' shall not be used by any Feder. al agency as a means of avoiding compliance with the directives set out in section $102 \ldots .[\mathrm{N}] \mathrm{o}$ agency shall utilize an ex. cessively narrow construction of its exist. ing statutory authorizations to avoid compliance.
Conference Report, 115 Cong. Rece (Part 29) 39702-703 (1969), quoted in Caliert Cliffs' Coordinating Committen, Inc. $v$ United States Atomic: Energy Commission, 449 F.2d 1109, 1114-15 (D.C.Cir.1971).

This Circuit recently echoed the conferees' concern for ensuring NEPA compliance, In State of California v, Block, 690 F.2d 753 (9th Cir.1982), we held that a section of the National Forest Management Act did not preempt NEPA because neither the statute nor its legislative history sup. ported a NEPA exemption. Id. at 775. See also Southeast Alaska Conservation Council, Inc. $v$. Watson, 697 F.2d 1305, 1310 (9th Cir.1983) (compliance with envjronmental statutes strictly construed).

There is nothing in the legislative history or the language of the Regrional Act sug. gesting that Congress intended an exemp. tion from NEPA requirements. On the contrary, given the clear statutory emphasis on environmental concerns, see 16 U.S.C. $\$ 839, b, d, f(j) \&(k)$, an exemption from NEPA requirements is inconsistent with the congressional objectives of the Regional Act.

BPA, however, seeks to bring itself within the principle announced by the Supreme Court in Flint Ridge Development Co. 2 . Scenic Rivers Association of Oklahoma, 426 U.S. 776, 96 S.Ct. 2430, 49 L.Ed.2d 305 (1976). The Supreme Court there considered whether an EIS was required prior to a real estate developer's filing a disclo. sure statement under the Interstate Land Sales Full Disclosure Act, when that Act required that the statement be effective 30-days after filing. Observing that the preparation of an EIS often required many months, the Supreme Court held that NEPA presented "an irreconcilable and fundamental conflict" with the 30-day requirement of the Interstate Land Sales Act. The 30-day requirement led the Court to conclude that when there is a "funda. mental conflict of statutory duty," NEPA is inapplicable. Id. at 791, $96 \mathrm{~S} . \mathrm{Ct}$. at 2440.

BPA argues that the contract offer requirements fall squarely within Flint Ridge because BPA had only 30 days to 
prepare an ElS, Its argument is based not so much on what Congress required in the statute us it is on the schedule which BPA actually followed in the nine-month period which Congress provided for the develop. ment of a contract of fer. During that period, BPA did not prepare ain EIS but it did negotiate with customers, hold public meetings, and issue draft prototype contracts. Its activities cun be summarized on the following time line:

December 5, 1980-Regrional Acl takes effect.

December 31, 1980-BPA puts together a list of the types of contracts to be offered as well as negotiating teams for each type.

January 23, 1981-Organization meeting for negotiating teams held. Teams, made $1 ; p$ of BPA employees and customer groups, meet three days per week, all day, from February until August to con. sider various contract provisions. Notice of meeting mailed to all interested parties and posted at BPA headquarters.

Mid-May, 1981--BPA holds three public meetings in Seattle, Boise, and Portland to receive public comment about the contracts. Sends summaries of the meeting with responses to the comments to all interested parties on June 8 .

June 11, 1981-Draft prototype contracts available for public inspection. See 46 Fed.Reg. 31238 (1981). BPA opens 30-day comment and review period.

July 13, 1981-End of comment period.

Late July to early August, 1981-Status drafts mailed to customers; contracts individualized.

August 28, 1981-Contracts offered to BPA customers.

September 5, 1981-End of statutory nine-month period.

BPA's position is that under the procedures it followed, which included six months of active negotiations before issuance of prototype contracts for inspection, the EIS would have had to have been

5. Giving full deference to BPA's interpretation of the Bonneville Power Act, which it adminis. ters, see Aluminum Co. of America v. Central Lincoln People's Utility District, - U.S. 104 S.Cl. 2472, 81 L.Ed.2d 301 (1984); Chevron prepared between June 11,1981 when the prototype contracts became available and July 13, 1981, the end of the comment period, and before BPA began final con. tract preparation. If such a restrictive time schedule was mandated in this case, then, under Flint Ridge, there would be a statutory conflict and an EIS need not have been prepared.

BPA's position, however, represents the type of "excessively narrow construction" that NEPA cautions against. ${ }^{5}$ The root of BPA's interpretation is its perception that the September 5, 1981 offers were already to have been negotiated and acceptable to the customers. Section $839 \mathrm{c}(\mathrm{g})(1)$ states: As soon as practicable within nine months after December 5, 1980, the Administrator shall commence necessary negotiations for, and offer, initial longterm contracts....

16 U.S.C. $\$ 839 \mathrm{c}(\mathrm{g})(1)$. The only time limitation is that the Secretary begin negotiations and offer contracts within nine months. The statute allows a further year before acceptance is required. 16 U.S.C. $\S 839 \mathrm{c}(\mathrm{g})(2)$. BPA argues that it could not begin an EIS until it had a "proposal" for federal action, or until the draft prototype contracts were available on June 11. But it does not explain why it was required to negotiate for six months before developing the contract proposals. Representatives John Dingell and Richard Ottinger, chairmen of subcommittees of the House Energy and Commerce Committee, pointed out in a July, 1981 letter to the Administrator, which is a part of the record in this case, that BPA moved "with greater speed than necessary in initiating contract negotiations." After making the initial offer mandated within nine months of the Act's passage, "[t]he customers and BPA had a whole year to negotiate and execute a contract."

In fact the statute did not mandate the schedule which BPA followed. BPA could have used the initial nine months to formu-

USA V. NRDC - U.S. - 104 S.C1. 2778, 81 L.Ed.2d 694 (1984), we find its position is unrea. sonable, particularly when viewed in the light of the congressionally mandated objectives of NEPA. 
late a proposal, perform an EIS, and still have met the statulory deadline for making its contract offer and commencing negotia. tions. If necessary, BPA could have utilized a "fast track" EIS schedule to speed the process. See 40 C.F.R. \& 1506.10(d).

Finally, the Supreme Court has recog. nized in Vermont Yanke Nuclear Power Corp. v. Natural Resources Defense Council, 435 U.S. 519, 551, 98 S.Ct. 1197, 1215,55 L.Ed.2d 460 (1978), that NEPA requires an agency to address all signifi. cant allernatives to a proposed action. isec 42 U.S.C. \$ $4332(2)(\mathrm{C})$. Under the "arbitrary and capricious" standard of review authorized by the Administrative Procedures Act, 5 U.S.C. \$ $706(2)($ A), a court may require an agency's decision to be "based on a consideration of relevant fac. tors." Citizens to Preserve Overton Park v. Volpe, 401 U.S. 402, 416, 91 S.Ct. 814, 824, 28 L.Ed.2d 136 (1971). This requirement that an agency examine alternative courses of action has long been a part of the APA's standard of review, see The Supreme Court, 1982 Term, 97 Harv.L.Rev. $70,236-37$ (1983), and has recently been reaffirmed by the Supreme Court. See Mo. tor Vehicle Manuf. Ass'n vi State Farm Insur. Co., 463 U.S. 29, 103 S.Ct. 2856, 77 L.Ed.2d 443 (1983).

[4] Major policy choices affecting both energy conservation and the preservation of fish and wildlife were made by BPA during its negotiation of over 140 power contracts. But without an EIS, we cannot know to what extent the many alternative proposals put forth by other groups and agencies were evaluated as alternatives to the provisions eventually adopted by BPA. Given BPA's statutory duty both to conserve energy use and to preserve fish and wildlife, 16 U.S.C. $\$ \$ 839(3)(6), 839 \mathrm{~b}(\mathrm{e})(2)$, (h)(10) \& (11), and the multitude of alternative proposals suggested by government agencies and citizen groups, the failure to prepare an EIS demonstrating that the agency has considered all significant alternatives violates both NEPA and the APA.

[5] Given the language and history of this Act, the lack of any mandated dead. lines remotely similar to the 30 days in
Flint Ridge, and the brond construction we are compelled to grive NEl'A, we nust conclude that there is no irreconcilable conflict between the Regional Act and NEPA re. quirements and that BPA violated NEPA when it uffered contracts without dovelop. ing an EIS.

\section{Renredy}

Having agreed with plaintiffs that an EIS should have been prepared prior to the offer of contracts, and having disagreed with the government that Congress had mandated a lime schedule which made preparation of an EIS impossible, we face the question of remedy. Forelaws asks this court not only to order BPA to comply with NEPA by preparing an environmental impact statement, but to enjoin the operation of the contracts until the EIS is prepared.

(6) Forelaws correctly points out that an injunction is the most common judicial response to a NEPA violation, sec, e.g., American Motorcyclist Association 2'. Watt, 714 F.2d 962, 965-66 (9th Cir.1983). The purpose of enjoining government action pending preparation of the environmental impact statement is, generally, to maintain the status quo while additional environmental data is obtained, in order to preserve the decision makers' opportunity to choose among policy alternatives. See State of Alaska v. Andrus, 580 F.2d 465, 485 (D.C.Cir.1978); see also F. Grad, Treatise on Environmental Law, §9.03(b) (1980).

[7] In this unusual case, the major federal action subject to the requirements of NEPA constitutes ongoing 20-year contracts, most of which are now in the third year of their term. They have gone into effect pursuant to a statutory mandate re. quiring implementation of a contractual system no later than 21 months after enact. ment of the Regional Act, or by September, 1982. The history of the Recional Act reflects a certain amount of urgency in preventing "an emergingr customer strug. gle for BI'A power." Central Lincoln People's' Utility District, 104 S.Ct. at 2476. 
At this point in the history of the Regiona) $\mathrm{Act}$, there is at least a clear tension between NEPA's charge to the agency to evaluate the effects of action upon the environment and the command of the Regional Act that the contracts be in place within 21 months of its passage. NEPA, however, allows for some flexibility in remedy because Congress has mandated compliance with NEPA procedures "to the fullest extent possible." Faced with reconciling NEPA and the Regional Act, we conclude that an injurnstion of the operation of the contracts themseives is inappropriate. See National Audubon Society, Inc. $v$. Watt, 678 F.2d 299, 309-10 (D.C.Cir.1982) (NEPA does not give the Secretary of Interior unlimited discretion to put off construction of a water development project that was statutorily authorized, relying upon Gulf Oil Corporation v. Morton, 493 F.2d 141, 146 (9th Cir.1973)).

Our decision not to enjoin the operation of the contracts does not render the case moot or deprive plaintiffs of any meaning. ful relief. The contracts will be in force for seventeen more years. Provisions in the contracts themselves contemplate changes in terms. All the contracts allow. periodic adjustment of rates. All the contracts contain a clause setting forth the procedures for amendment. Most important for NEPA purposes, all the contracts include language "by which the parties ... agree to negotiate amendments to the power sales contracts, as necessary" to coordinate the conservation, renewable resource, and fish and wildlife provisions with the regional plan. 46 Fed.Reg. 44344 (1981). Thus, the contracts are not completed projects for which an EIS will no longer be useful. Rather, they are agreements with the flexibility to accommodate the ongoing, changing relationship among BPA, its customers, and the public interest represented by the Regional Council established under the Act. 16 U.S.C. $\$ 839 \mathrm{~b}(\mathrm{a})$.

As the Supreme Court pointed out in Catholic Action of Hawaii, 454 U.S. at

6. Forelaws attempted to argue in this action that the October, 1982 contract amendments required an EIS. Because the amendments were clearly a "final action" within the meaning of the Regional Act, and because Forelaws did
143, 102 S.Ct. at 201, the purpose of NEPA is "to inject envirommental considerations into the federal agency's decision-making process" and "to inform the public that an agency has considered environmental concerns in its decision-making process." Id. 102 S.Ct. at 201; see also 40 C.F.R. $\$$ 1502.1. BPA's "Environmental Report" was not a sufficiently detailed analysis to inform BPA and the public of the environmental consequences of the choices represented by the contracts. Even less informative was the finding of no significant im. pact (FONSI) which BPA filed in connection with the contract amendments of October, $1982 .{ }^{6}$ Only a full environmental impact statement will inform BPA, its custumers, the public and the Regional Council of all the environmental consequences of the contracts and serve as a guide to future actions. BPA must, therefore, perform an EIS on the contracts.

It is so ordered. The panel will retain jurisdiction over any further proceedings related to enforcement of this order.

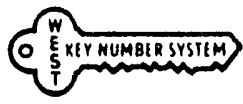

not separately challenge them or amend its complaint in the action to include them within the ninety days provided by the $A C l$, the chal. lenge is time barred. 


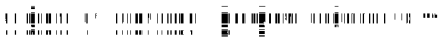


Appendix B

Guide to Northwest Power Act Contracts 


\section{Áppendix B}

\section{Table of Contents}

Overview of the 1981 Generic Contracts . . . . . . . . . . . . .

The Utility Power Sales Contract . . . . . . . . . . . . B-2

B.1 BPA Obligation to Maintain Sufficient Resources to Serve Firm load . . . . . . . . . . . . . . . . . B-2

B.2 Acknowledgement of Northwest Power Act Policies Regarding Resource Priorities and Fish and Wildlife . . . . B-2

B.3 Provisions in the Event of Resource Insufficiencies . . . . . B-2

B.4 Types of Purchasers . . . . . . . . . . . . . . . . B-3

B.5 Purchaser's Firm Resources . . . . . . . . . . . . . B-5 Resource Additions (Decrease Purchase From BPA) . . . . . . B-5 Resource Deletions (Increase Purchase From BPA) . . . . . . B-8 General . . . . . . . . . . . . . . . . B-8

B.6 New Large Single Loads . . . . . . . . . . . . . . . . B-8

B.7 Billing Provisions, References to Rates.......... . B-9

The DSI Power Sales Contract . . . . . . . . . . . . . . B-9

B.8 Contract Term and Termination . . . . . . . . . . . . B-9

B.9 Sale and Purchase of Power . . . . . . . . . . . . B-10

B.10 Estab1ishment of Demand Levels . . . . . . . . . . . . B-10

B.11 Establishment of the Four Quartiles . . . . . . . . . . . B-10 First Quartile ................. B-10 Second Quartile................... B-11 Third Quartile ... . . . . . . . . . . . B-11 Fourth Quartile................... . B-11 A11 Quartiles..................... B-11 Forced Outage and Stability Reserves . . . . . . . . B-11

B.12 BPA Resource Obligation . . . . . . . . . . . . B-12

The Residential Purchase and Sale Agreements (Resi intial Exchange) . B-12

B.13 Mutual Purchases .................... B-12

B.14 In Lieu Furchase by BPA . . . . . . . . . . . . . . . B-12

B.15 Average System Cost Exhibit . . . . . . . . . . . . B-13

B.16 Residential Load Exhibit (Exhibit D) ............ B-13

B.17 Pass-Through of Benefits ............... B-13

B.18 No Net Disbenefit................... B-13 


\section{APPENDIX B}

\section{OVERVIEW OF THE 1981 GENERIC CONTRACTS}

Coples of the generic Power Sales Contracts, along with detalled indexes for the utllity and DSI Power Sales Contracts and a copy of the General Contract Provisions (GCPS), are contained in Appendix A. The following overviews will describe key features of these coritracts. They are meant to be informative for readers who are not famllitar with the contracts. They do not supply interpretations of the contracts and cannot substitute for reading the contracts themselves to understand important provisions.

The Northwest Power Act required BPA to offer initial new long-term Power Sales Contracts within 9 months of the effectlve date of the Act to:

(1) requesting public body and cooperative customers and investor-owned utility customers; (2) existing DSI customers; (3) existing Federal agency customers; and (4) electric utillty customers requesting participation in $B P A$ 's residential exchange program.

The Power Sales Contracts contain many provisions that are specifically required by the Northwest Power Act or other laws. Certain sections of the Northwest Power Act set forth the general power sales contract frameworks to be offered to certain types of customers. The generic Power Sales contracts are based on these frameworks. The Power Sales Contracts contain much additional detail and many other provisions necessary to accomplish the intent of the parties.

Section $5(b)$ of the Northwest Power Act contains a general description of the contract that must be provided to requesting Pacific Northwest customers which are publicly owned utilities or cooperatives, investor-owned utilities, or Federal agencies. The Northwest Power Act requires BPA to offer to meet the firm power load of regional customers to the extent that firm power load exceeds firm resources of the customer (specifically defined in sections $5(b)(1)(A)$ and $(B))$. This is commonly referred to as a requirements contract.

Section 5(c) of the Northwest Power Act contains a general description of the purchase and sale agreements that implement the Residential and Small Farm Power Exchange (Residential Exchange). This section originally placed limits on the percentage of residential load which may be exchanged, allowing for gradual phase-in. It also specifies that cost benefits are to be passed through directly to Residentlal Exchange loads and provides for a consultation process to develop a methodology to compute each exchanging utility's "average system cost." It further provides that BPA may purchase cheaper power, if available from other sources, in lieu of the power that the utility offers to exchange. 
Section $5(d)$ of the Northwest Power Act contains the general framework for the contracts to be offered to BPA's DSI customers. Section 5 (d) requires BPA to offer initial contracts to the DSIs, providing them with an amount of power equal to the amount the customer is entitled to under its then-existing contract. Section $5(d)$ also specifies that these DSI contracts shall provide a portion of BPA's reserves for regional firm loads.

\section{THE UTILITY POWER SALES CONTRACT}

This contract applies to all BPA utility and Federal agency customers. In the past, different contracts were written for individual customers. Terms varled, depending largely on whether the utilities had significant resources of their own which they could operate, or whether they operated their own automatic generation control systems. These individual differences are now addressed in a standard contract by including provisions applicable to each different purchasing basis.

The following are some of the key features of these contracts:

\section{B.1 BPA Obligation to Maintain Sufficient Resources to Serve Firm Load}

Because BPA was given authority to acquire new resources under the Northwest Power Act for the first time, BPA Power Sales Contracts included a best efforts obligation on BPA to acquire resources if necessary to provide service to its firm loads. References to this obligation are found in the Utility Power Sales Contract under Section 5, BPA's Decision in Acquiring Resources to Serve Loads; Section 7, Allocation Provisions in the Event of Planning Insufficiencies; and GCP 44, Resource Acquisition and Management. Under GCP 44, BPA is required to use its authority to acquire resources under the Northwest Power Act and also its short-term power purchase authority under the Transmission System Act of 1974.

\section{B.2 Acknowledgment of Northwest Power Act Policies Regarding Resource Priorities and Fish and Wildlife}

The contracts acknowledge BPA's obligations under the Act to give resource acquisition priority to conservation resources and renewable resources. BPA's obligations with respect to fish and wildlife are also ackncwledged. These Northwest Power Act policies are referred to in section 5; Section 6 , Interpretation of Fish and Wildlife Responsibilities; GCP 44; and GCP 45 , Cooperation with Regional Council. The desirability of applying Northwest Power Act resource priorities to activities of the purchasing utility is also acknowledged in section 5, and in Section 12, Purchasers Firm Resources.

\section{B.3. Provisions in the Event of Resource Insufficiencies}

These provisions are contained primarily in section 7 and in an exhibit setting forth allocation formulas. Federal Base System resources are identified. Statutory notice provisions are incorporated, such as BPA's 
obligation to give 5 years notice of power insufficlencies to investor-owned utilities prior to giving notice of insufficiency to preference customers. Notice of insufficiency may not be given to preference customers unless their loads exceed the capability of the Federal Base system resources.

\section{B.4 Types of Purchasers}

Section 13 of the utility contract sets forth the criteria for which purchasing basis shall apply to a specific customer. Figure $8-1$ shows the relationship between the customer's loads, its own resources, and its purchase from BPA under the different purchasing types. Customers that do not own resources of significant size which they can control will be designated as purchasers on the Metered Requirements basis. Most of BPA: s customer utilities are Metered Requirements purchasers. Under this purchasing basis, the customer purchases from BPA an amount of power equal to its actual firm loads less the actual output of its resources, if any. These customers are generally in BPA's own generation control area, so that BPA's resources respond automatically to changes in their loads.

Customers that do own resources of significant size are designated as purchasers under one of three different computed Requirements forms. These customers are generally not in BPA's control area and therefore operate a generation control area of their own. I/ BPA's rescurces do not generally respond automatically to changes in the loads of these customers. Instead, they must request amounts of power to be generated and transmitted by BPA to them in a process called "scheduling."

Computed Requirements customers are responsible for serving a portion of their own loads with the assured capability of their own firm resources. BPA is obliged to provide power to the extent that a customer's loads exceed its assured capability. Computed Requirements customers may purchase under one of three different forms: Actual Computed Requirements, Planned Computed Requirements, and Contracted Requirements. These differ from each other in the degree to which BPA assumes the responsibility for meeting actual loads which may differ from forecasted loads.

Under the Actual Computed Requirements basis, BPA assumes a great deal of this responsibility. After each month, the amount of power the customer had a right to receive from BPA, that is, its Computed Requirement, is figured for the month. Under the Planned Computed Requirements basis, the customer sets its BPA energy and capacity purchases for the coming Operating Year. The customer then must be responsible for acquiring additional power if loads are

II A few Computed Requirements customers are within BPA's generation control area, and therefore do not operate control areas of their own. BPA's resources respond automatically to their changing loads. These customers do not schedule amounts of power from BPA, but, instead, account for their Computed Requirements purchases after the fact. 
Fig. B-1

\section{Different Purchasing Methods Available Under The Utility Power Sales Contract}

These diagrams are schematic. Actual load and resource shapes vary constantly.

Metered Requirements Contract

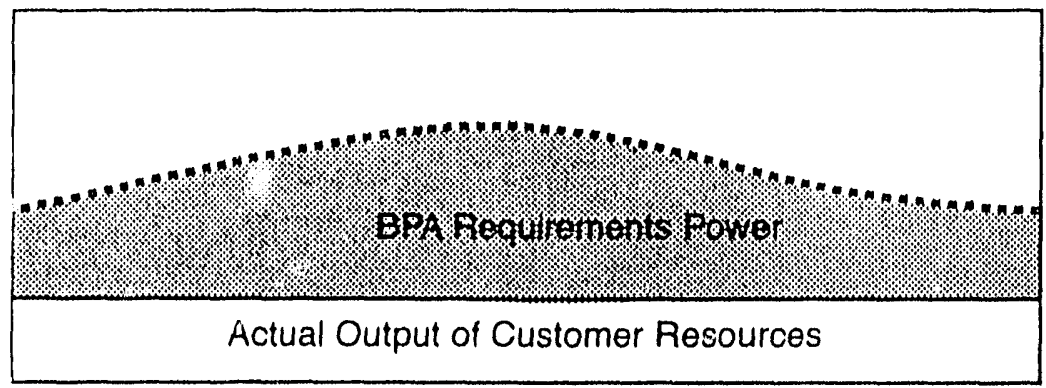

Actual Computed Requirements Contract *

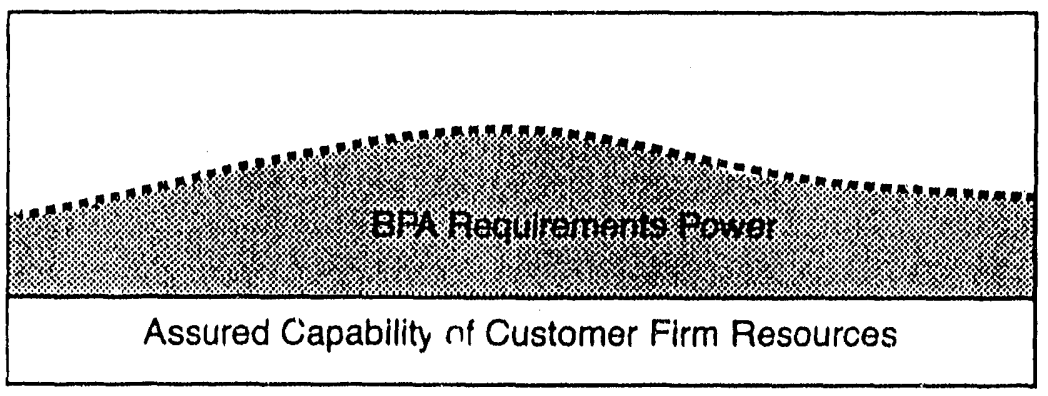

$\leftarrow$ Actual Firm Loads

*Customers may use some other resources subject to availabiltiy charge in rate schedules.

\section{Contracted Requirements Contract ${ }^{*}$}

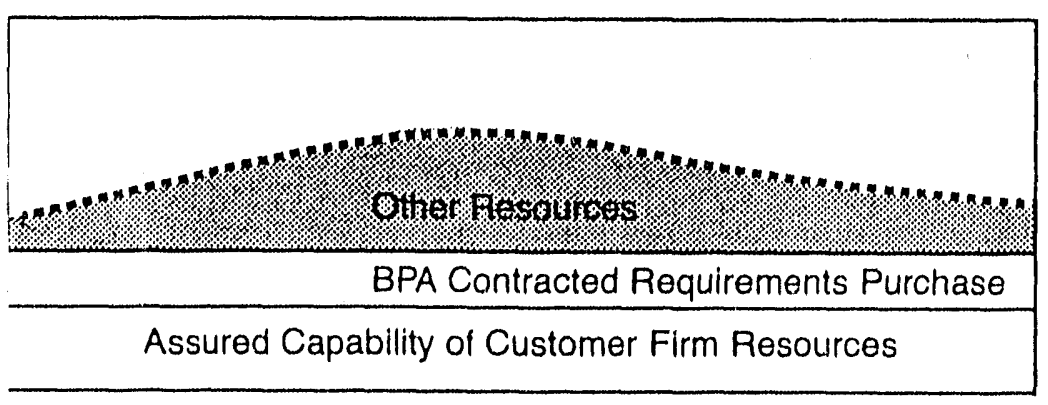

4 Actual Firm Loads

"Applies to the single Planned Computed Requirements customer. 
larger or shaped differently than forecast. Under the Contracted Requirements basis, the customer sets its BPA energy and capacity purchases for 7 years in advance. The Contracted Requirements customer has limited rights to change this 7-year schedule of purchases. These rights are similar to the notice provisions for firm resource changes, explatned below.

\section{B.5 Purchaser's Firm Resources}

Section 12, Purchaser's Firm Resources, establishes an exhibit consisting of a table for each customer showing all the resources that the purchaser will use to serve its own load. (See Table B-1 showing an example Firm Resources Exhibit (FRE).) The assured capability of these resources is used to define the limits of BPA's obligation to provide firm requirements power to the utility. (See Table B-2 showing an example Assured Capability Exhibit.) Assured Capability is calculated each year in accordance with the provisions of section 16 .

The utilities are required to give BPA advance notice of changes in firm resources. The notice requirements are contained in section $12(b)(1)-(14)$. In general, the peak capability may be changed with 5 years notice and the energy capability may be changed with 7 years notice. There are some shorter notice requirements which may apply if the change would cause no detriment to $B P A$ or is beyond the control of the purchaser for vartous reasons.

The notice requirements of section 12(b) for FRE changes are as follows:

\section{Resource Additions (Decrease Purchase from BPA)}

- Peak capability may be added for the fifth year; energy capability may be added for the seventh year.

- Any firm Resource may be added for any year if in accordance with BPA's annual program which implements the plan (e.g., BPA's Resource Program).

- Any Firm Resource may be added for any year if BPA can dispose of surplus without adverse economic effect. For purposes of this paragraph, BPA load-resource balance will not include purchases BPA is not committed to at the time of determination.

- Renewable or cogeneration resources of 50 aMW or less may be added for the Operating Year 30 months from the January 1 when first shown in the FRE. PURPA-qualifying facilities may be added at any time, but the customer must use best efforts to give BPA early notice of the resource.

- If a resource acquisition option has been granted to BPA, a Firm Resource may be added within 2 years of the date $B P A$ declined to exercise such option. 
Revision 4

Exhibit 1, Page 1

Contract No. DE-MS79-81BP90493

Cowlitz County PUD No. 1

Effective at 2400 hours on June 30, 1986

\section{Table B-1 \\ FIRM RESOURCE EXHIBIT}

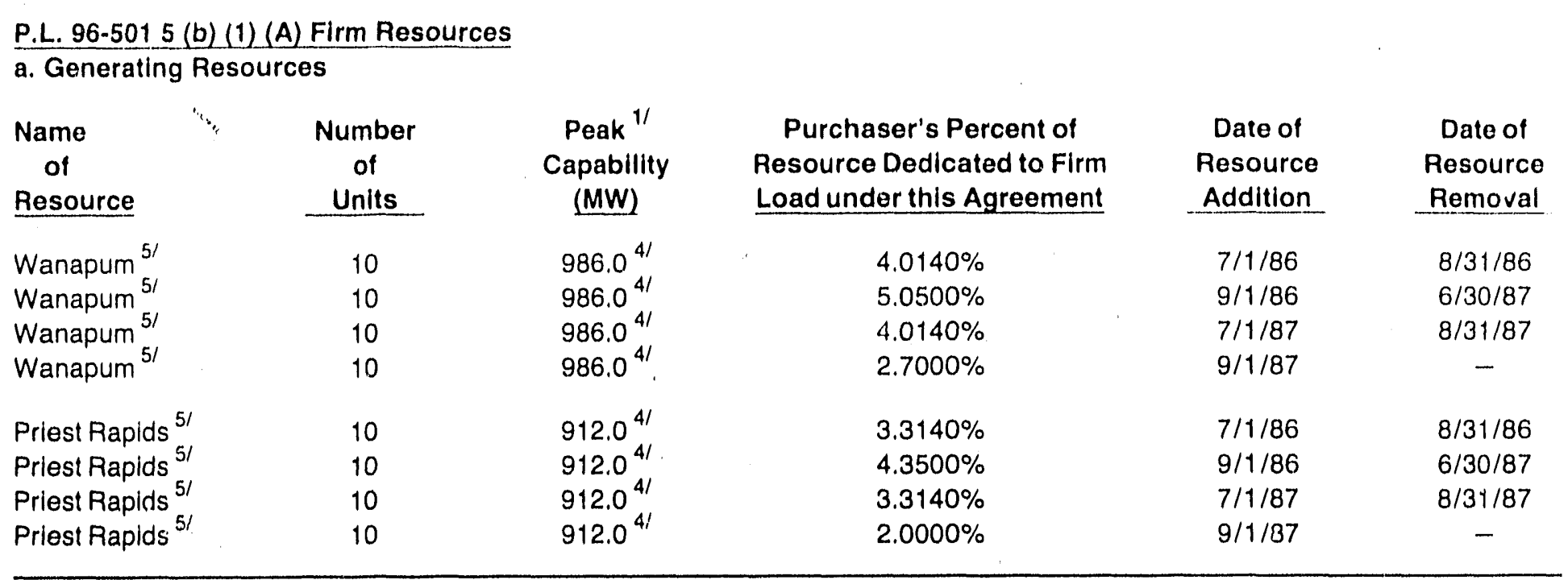

\section{b. Contract Resources}

$\begin{gathered}\text { Name } \\ \text { of } \\ \text { Resource }\end{gathered}$
PURCHASES
CSPE
Supplemental and
Entitlement Capacity
OBLIGATIONS
Canadian Entitlement
Return
Restoration

$\begin{array}{cc}\text { Suppller } & \begin{array}{c}\text { Identifying } \\ \text { Number 2/ }\end{array} \\ \text { CSPE } & \begin{array}{l}14-03-47291 \\ 14-03-47454 \\ 14-03-47455\end{array} \\ \text { Bonneville } & \\ & 14-03-47454 \\ & 14-03-47455 \\ \text { Purchaser } & 14-03-48221\end{array}$

Resource

Addition

Resource

Removal

$7 / 1 / 86$

3)

3/

$\begin{array}{cc}3 / & 3 / \\ 7 / 1 / 86 & -\end{array}$

\section{P.L. 96-501 5 (b) (1) (B) Firm Resources}

a. Contract Resources

PURCHASES

$\begin{array}{lll}\text { SWift Project }^{5 /} \quad \text { Pacific P\&L } & \text { PUD No. SW6 }\end{array}$

\footnotetext{
1/ At full reservoir for hydroelectric resources.

21 Purchaser's entitlement to a Firm Resource supplied pursuant to a contract purchase which is not tied to the capability of a generating project shall be determined from the contract identified herein.

3/ Purchaser's entitlement to Firm Resource is based on Purchaser's share of Priest Rapids and Wanapum.

4/ Pre-encroached value and unadjusted for derated units.

5/ These resources include all rights or obligations for Restoration pursuant to the Pacific Northwest Coordination Agreemen: (Contract No. 14-03-48221).
} 
COWLITZ COUNTY PUD

Power Sales Contract

Section 17 (i) Submittal

01/14/86

\section{Table B-2*}

\section{ASSURED CAPABILITY}

\section{ENERGY (ave. Megawatts)}

\begin{tabular}{|c|c|c|c|c|c|c|c|c|c|c|c|c|}
\hline & JUL & AUG & SEP & OCT & NOV & DEC & JAN & FEB & MAR & APA & MAY & JUN \\
\hline Estimated Firm Load & 368.0 & 403.0 & 375.0 & 428.0 & 461.0 & 417.0 & 493.0 & 474.0 & 455.0 & 431.0 & 415.0 & \\
\hline Plus: Canad Eni Alloc & 1.6 & 1.6 & 2.1 & 2.1 & 2.1 & 2.1 & 2.1 & 2.1 & 2.1 & 1.9 & 17 & \\
\hline Less: Priest \& Wanapum & -34.7 & -33.3 & -45.0 & -47.0 & -42.1 & -41.8 & -39.6 & -53.0 & -32.7 & -43.0 & -40.0 & \\
\hline Less: Swift & -8.7 & -7.3 & -8.6 & $-18,4$ & -25.4 & -44.5 & -54.3 & -26.2 & -18.3 & -0.0 & -15.8 & \\
\hline Less: CSPE & -9.2 & -9.2 & -10.8 & -10.8 & -10.8 & -10.8 & $-10,8$ & -10.8 & -10.8 & -8.6 & -8.6 & \\
\hline Comp Avg Engy Reqmt ' 86.87 & 318.0 & 354.8 & 312.7 & 353.9 & 384.8 & 322.0 & 390.4 & 386.1 & 395.3 & 381.3 & 352.5 & 343 \\
\hline Estimated Firm Load & 373.0 & 407.0 & 379.0 & 432.0 & 464.0 & 420.0 & 497.0 & 477.0 & 458.0 & 435.0 & 419.0 & \\
\hline Plus: Canad Ent Alloc & 1.5 & 1.5 & 0.9 & 0.9 & 0.9 & 0.9 & 0.9 & 0.9 & 0.9 & 0.8 & 0.8 & \\
\hline Less: Priest \& Wanapum & -34.7 & -33.3 & -22.4 & -23.4 & -21.0 & -20.8 & -19.7 & -26.4 & -16.2 & -21.4 & -20.1 & \\
\hline Less: Swift & -8.7 & -7.3 & -8.6 & -18.4 & -25.4 & -44.5 & -54.3 & -26.2 & -18.3 & -0.0 & -15.8 & \\
\hline Less: CSPE & -8.6 & -8.6 & -10.2 & -10.2 & -10.2 & -10.2 & -10.2 & -10.2 & -10.2 & -8.1 & -8.1 & \\
\hline
\end{tabular}

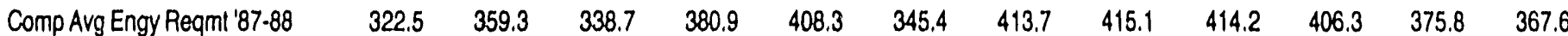

\begin{tabular}{|c|c|c|c|c|c|c|c|c|c|c|c|c|}
\hline Estimated Firm Load & 377.0 & 411.0 & 383.0 & 435.0 & 468.0 & 423.0 & 500.0 & 481.0 & 462.0 & 439.0 & 423.0 & 419.0 \\
\hline Plus: Canad Ent Alloc & 0.8 & 0.8 & 0.8 & 0.8 & 0.8 & 0.8 & 0.8 & 0.8 & 0.8 & 0.8 & 0.8 & 0.8 \\
\hline Less: Priest \& Wanapum & -22.3 & -21.3 & -22.4 & -23.4 & -21.0 & -20.8 & -19.7 & -26.4 & -16.2 & -21.4 & -20.1 & -21.0 \\
\hline Less: Swift & -8.7 & -7.3 & -8.6 & -18.4 & -25.4 & -44.5 & -54.3 & -26.2 & -18.3 & -0.0 & -15.8 & -19.1 \\
\hline Less: CSPE & -8.1 & -8.1 & -9.5 & -9.5 & -9.5 & -9.5 & -9.5 & -9.5 & -9.5 & -7.7 & -7.7 & -7.7 \\
\hline
\end{tabular}

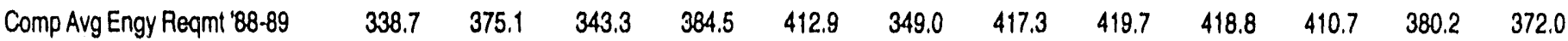

\begin{tabular}{|c|c|c|c|c|c|c|c|c|c|c|c|c|}
\hline Estimated Firm Load & 381.0 & 415.0 & 387.0 & 439.0 & 472.0 & 426.0 & 504.0 & 485.0 & 465.0 & 442.0 & 427.0 & 423.0 \\
\hline Plus: Canad Ent Alloc & 0.8 & 0.8 & 0.8 & 0.8 & 0.8 & 0.8 & 0.8 & 0.8 & 0.8 & 0.7 & 0.7 & 0.7 \\
\hline Less: Priest \& Wanapum & -22.3 & $-21,3$ & -22.4 & -23.4 & -21.0 & -20.8 & -19.7 & -26.4 & -16.2 & -21.4 & -20.1 & -21.0 \\
\hline Less: Switt & -8.7 & -7.3 & -8.6 & -18.4 & -25.4 & -44.5 & $-54,3$ & -26.2 & -18.3 & -0.0 & -15.8 & -19.1 \\
\hline Less: CSPE & -7.7 & -7.7 & -9.0 & -9.0 & -9.0 & -9.0 & -9.0 & -9.0 & -9.0 & -8.0 & 8.0 & -8.0 \\
\hline Comp Avg Engy Reqmt ' 89.90 & 343.1 & 379.5 & 347.8 & 389.0 & 417.4 & 352.5 & 421.8 & 424.2 & 422.3 & 413.3 & 383.8 & 375.6 \\
\hline
\end{tabular}

- This sample, Assured Capability Exhibit, shows energy only. 
- Resources which qualify for priorlty under section $9(1)(3)$ of the Northwest Power Act may be added on 2-year notice. Section $9(1)(3)$ provldes a prlority for projects which were under construction on the effectlve date of the Northwest Power Act, were offered to BPA for sale, but were not accepted by BPA for purchase within 1 year of the offer.

- If BPA has a firm power deficlt, a Flrm Resource may be added for any year. BPA load/resource balance shall not include purchases unless BPA has actually committed itself to make the purchase.

\section{Resource Delet lons (Increase Purchase From BPA)}

- A Firm Resource may be deleted if use is permanently discontinued due to loss of resource or loss of contract rights. (If returned to the Exhibit later, the same rules apply as if it were a new resource.) For obsolescence or retirement, the customer must consult with BPA, but the resource may be deleted even if BPA is requiled to purchase replacement power.

- A firm Resource may be deleted in any year if BPA has a firm power surplus in the first operating year of the removal.

- A resource may be deleted in any year if an equivalent amount of resource is added.

- A resource may be deleted or added at any time if it is the result of a transfer of resources among BPA customers such that there is no net change in the total load on BPA.

- Resources may be added or removed if there is a resource transfer between the purchaser and BPA.

- Shorter notice is allowed for pre-Northwest Power Act contracts which contain shorter notice provisions for withdrawals.

\section{General}

- Resources may be added or deleted for other reasons with BPA written consent.

\section{B.6 New Large Single Loads}

Section 8, Determination of New Large Single Loads, deals with the Northwest Power Act provistons requiring that new large single loads be separately identified and be subject to different rates. Section 9, Limitations on Increases of single Loads, also sets forth some llimitations on BPA's obligation to serve load increases. Unllke the new large single load provisions, the section $911 \mathrm{mitations}$ were not specified in the Act. They are simllar to provisions in BPA contracts which pre-date the Act. The section 9 provisions limit BPA's obligation to serve such loads if they increase by more than 35 aMW in 1 year or more than 75 aMW in 5 years to allow BPA time to acquire resources to serve large increases in industrial loads. 


\section{B.7 Billing Provisions, References to Rates}

Blling provisions for Metered Requirement customers are in section 15, and for Computed Requirement customers in section 19. Section 8, Equitable Adjustment of Rates, contalns the general contract provisions regarding the establishment of rates and conservation surcharges.

\section{THE DSI POWER SALES CONTRACT}

The quality of service to DSIs under the Northwest Power Act contract is somewhat different than it was prior to the Act. Prior to 1975, there was no unlform quality of service to the DSI customers. .Contract terms varted from customer to customer. Some DSIs had contracts for 100 percent firm service, while others did not. BPA sold large amounts of interruptlble power to some DSIs in some years. These interruptible power sales were supported with use of provistonal energy, $1, e$. , borrowing energy from later in the critical pertod for use early in the critical period.

Between 1961 and 1971, Modifled Flrm (MF) contracts were negotiated with the DSIs. These contracts were also nonuniform. Most DSIs recelved firm service under the MF contracts equal to 75 percent of the $1 r$ load, but some DSIS recelved contracts for 100 percent of their requirements. Any portion of DSI load not served as flrm under these contracts was served with nonflrm energy, or with borrowed firm energy (provistonal energy) provided under separate agrements.

In 1975, Industrial Firm (IF) contracts were negotiated with the DSIs as part of the implementation of Phase II of the Hydro-Thermal Power Program. BPA and the DSIs operated under these contracts on an interim basis--because of the need to complete an EIS on the Hydro-Thermal Power Program--unt 11 the Northwest Power Act contracts, which are the subject of this EIS, were signed in 1981. The If contracts provided service to 100 percent of each DSI's load with a single grade of power known as Industrlal Firm power. The IF contracts divided each DSI load into quartlles, each of which was subject to specific rights for BPA restriction. The IF contracts provided for nonfirm and borrowed firm (Advance Energy) for serving the First Quartlle. Separate Provislonal Energy Agreements were, therefore, unnecessary. The If contracts specifled a single rate for power, including that for the First Quartile. The DSIs were compensated for any interruptions, including those to the first Quartile, through an "avallability credit."

The following are some of the key features of the current DSI contracts:

\section{B. 8 Contract Ter:m and Termination}

Section 2, Term of Contract, sets forth term and termination provisions. It provides that the DSIs cannot terminate their contracts and purchase from another supplier unlesS BPA determines that there would be no adverse limpact on BPA. 


\section{B.9 Sale and Purchase of Power}

Section 4, Sale and Purchase of Power, provides that BPA shall sell to a DSI, and the DSI shall purchase from BPA, Industrlal Firm Power in an amount up to and Including the DSIS' Contract Demand as specifled by the USIs' Operating Demand, Curtalled Demand, or Restricted Demand, as each is in effect from time to time. This provision precludes the need for a DSI to acqutre resources or additional service from another utility except posstbly for a plant expansion (see section $4(d)$, or for industrial replacement energy (IRE). 2 I

\section{B.10 Establishment of Demand Levels}

Section 5, Amount of Power, defines important terms relating to demand levels. Contract Demand is the maximum level of power that can be taken by a DSI under its contract. Operating Demand may be less than Contract Demand and can be changed more flextbly. Technological 11 lowances for certain technical improvements and plant modifications may be used for limited increases to Operating Demand and Contract Demand. Wheel Turning Load, which is load at a DSI plant that is not integral to its industrial process and is not part of a Technological Allowance, may be served by BPA or by a local utility.

\section{B.11 Establishment of the Four Quartiles}

Each DSIs' load is divided into four quartlles, of which three are firm load for which BPA must plan resources. Section 7, Restriction of Deliveries, describes the restriction rights which apply to each of the four quartiles. Section 8, Operations, describes the operations that BPA will engage in to provide service to the Flrst Quartile. See Appendix C. Section 3, on Borrowing Techniques Used by the Coordinated System, for an explanation of these operations.

The section 7 restriction rights are summarized below.

\section{First Quartile:}

- Power Sales Contract language states that BPA may restrict the First Quartile at any time for any reason to protect BPA's firm loads. BPA's firm loads include the other three quartiles of DSI load, as well as other firm customers.

- If BPA has previously shifted FELCC (see Appendix C for description of FELCC shifting), BPA must attempt to purchase power at "Reasonable Cost" before restricting the DSI First Quartile.

2I IRE is purchased on behalf of DSIs and at their expense by BPA under the terms of a separate contract. IRE is purchased by DSIs under specified conditions to replace power from BPA. 


\section{Second Quartile:}

- BPA can restrict the Second Quartile because of

-- Resource delays, including conservation;

-- Unexpected poor performance of resources, including conservation, or

-- A governmental order causing delay or shut-down of resources.

- Before restricting the second quartile, BPA has an obligation to purchase or recall energy from any source, including the industrial purchasers.

- There are no Second Quartile restriction rights for the purpose of meeting unanticipated load growth or for the region's failure to plan adequate resources.

- Second Quartile restriction rights provide reserves for those Federal system and conservation resources listed in an annual BPA notice issued each June 1 to the industries.

\section{Third Quartile:}

- BPA may restrict the Third Quartile in the amount of a DSI's obligation to replace shifted FELCC, Advance Energy, or Flexibility Energy.

(See Appendix C.)

- Each June 1, BPA provides to all DSIs a notice of potential third quartile restrictions related to shifted FELCC.

\section{Fourth Quartile:}

- BPA has no Fourth Quartile restriction rights per se. The load may, however, be restricted as necessary under the forced outage and stability reserve provisions outlined below.

\section{All Quartiles:}

- Forced Outage and Stability Reserves. When necessary to minimize restrictions of $\mathrm{BPA}^{\prime} \mathrm{S}$ Firm Obligations, BPA can restrict the industries. This restriction right is not directly related to the concept of "Quartiles." For forced outages and stability purposes, BPA can restrict the DSIs as follows:

-- One-hundred percent of Operating Demand for 15 minutes (which may be followed by a 30 minute restriction of 50 percent of the load operating at the time of the original restriction;

-- Fifty percent of the load "then operating" for 2 hours per day;

-- Twenty-five percent of the Operating Demand subject to various limitations in section $7(b)(3)$ of the DSI contract. 


\section{B.12 BPA Resource Obligation}

BPA must plan to have sufficient firm resources to serve three quartiles of the DSI load. Section 12, Mid-Term Contract Review, provides for the parties to review the status of BPA's plan and existing resources. It also provides that BPA will promptly proceed to attempt to acquire resources for DSI load in the years after the expiration of the current contract if DSIs request new. Power Sales Contracts by the end of the twelfth year (1992). If BPA acquires resources or makes other expenditures to serve DSI load for the period following expiration of these initial contracts, and the DSI fails to sign the new contract after a good faith offer by BPA to negotiate, the DSI must reimburse BPA for unrecoverable costs.

\section{THE RESIDENTIAL PURCHASE AND SALE AGREEMENTS (RESIDENTIAL EXCHANGE)}

The background of the residential exchange concept will aid an understanding of this issue. The purpose of the residential exchange was to provide access to the Federal Base System for residential and rural consumers in the region served by BPA customers that are not entitled to preference under the Bonneville Project Act, that is, IOUs. The program was created largely in response to a proposal made by the State of Oregon prior to the passage of the Northwest Power Act. Under this proposal, the State would have created a new municipal corporation to apply for an allocation of BPA's then limited amounts of power to serve the State's domestic and rural customers. The residential exchange program was a compromise conceived under the provisions of the Northwest Power Act that allowed immediate access to the FBS for these types of consumers, without placing the entire immediate need to acquire resources on BPA.

The following are some of the key features of these contracts:

\section{B.13 Mutual Purchases}

Sections 2 and 3 provide for BPA and the utility to "purchase" equal amounts of power from each other. The utility will pay BPA at the rate that applies to its preference customers (the priority firm or PF rate) and BPA will pay the utility's average system cost, as finally determined by the administrator.

\section{B.14 In Lieu Purchase by BPA}

Section 4 allows BPA to purchase from a cheaper source than the utility, while continuing to supply power to the utility at the PF rate. BPA's Residential Exchange contracts allow BPA to purchase resources other than the utility's exchange power under certain circumstances and after 7 years notice. BPA must give 7 years notice before making a purchase in lieu of exchange under the Residential Exchange contracts. The purchase in lieu of exchange must last at least 5 years. Some parties argue that BPA surplus cannot be purchased as the in lieu resource, but BPA's position is that this is not prohibited by the contract. Alternative 3.4 discusses this more fully. 


\section{B.15 Average System Cost Exhibit}

The methodology for determining the average system cost of a utility is contained in Exhibit $C$ to the Residential Exchange Agreement. It provides that the BPA Administrator may change the methodology for calculating average system cost after a consultation process and approval by the Federal Energy Regulatory Commission (FERC). Exhibit $C$ is changed whenever the methodology is changed. BPA adopted its present methodology in 1984.

\section{B.16 Residential Load Exhibit (Exhibit D)}

The utility residential and farm loads eligible for the exchange are specified according to requirements set forth in Exhibit $D$. The load information is updated periodically.

\section{B.17 Pass-Through of Benefits}

Section 8 requires any reduction in wholesale power costs resulting from the residential exchange to be passed through to the residential and farm loads that are defined in Exhibit $D$.

\section{B.18 No Net Disbenefit}

Section 10, Election to Equalize Rates, sets forth provisions dealing with the possibility that a utility's average system cost might at times be less than BPA's PF rate. It is intended to prevent the utility from being forced to pay BPA during such times, but also limits the amount of later benefits the utility can receive. (See Figure B-2.) 
Figure B-2

\section{Effect of Election to Equalize Rates}

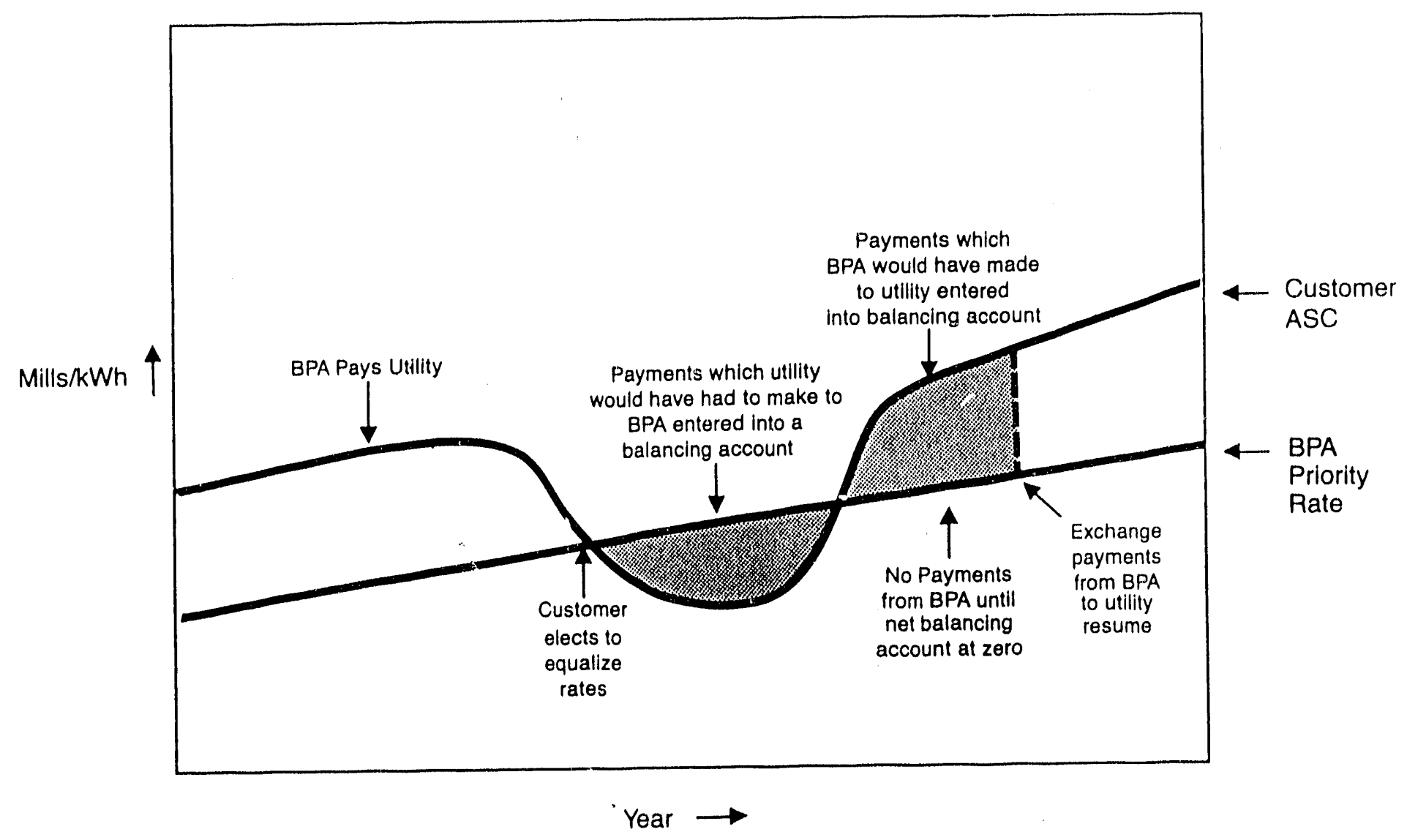




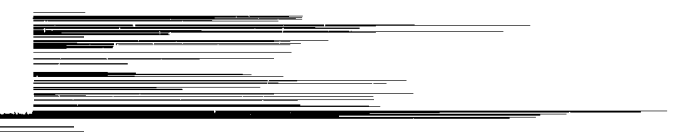




\section{Appendix C}

Guide to Hydro Operations in the Pacific Northwest Coordinated System 


\section{Appendix C}

Table of Contents

PAGE

Section 1: Important Terms ..................... . C-1

C.l Federal Columbia River Power System (FCRPS) as a Multi-Use

C.2 The Pacific Northwest Coordination Agreement (Coordination

Agreement) . . . . . . . . . . . . . . . . . . .

C.3 Operating Constraints . . . . . . . . . . . . . . . .

C.4 Water Budget. . . . . . . . . . . . . . . . . . . . .

C.5 Annual Splil plans.......................

C.6 The Critical Perlod . . . . . . . . . . . . . . . . . . . . . .

C.7 Firm Energy Load Carrying Capability (FELCC). . . . . . . . . .

C.8 Refill. . . . . . . . . . . . . . . . . . . . . . . . .

Section 2: The Operations Planning Process . . . . . . . . . . . . . C -5

C.9 Annual Operating Plan . . . . . . . . . . . . . . . . C-5

C. 10 Determination of the Multi-Year Critical Period and FELCC... .

C. 11 Permitted Changes

C-5

C. 12 The Final Regulation

C-5

C.13 The Critical Rule Curve-Levels to Meet Firm Loads........

C-6

C.14 Energy Content Curve--Levels to Protect Reflll . . . . . . . .

C-6

C. 15 Periodic Updates--Variable Energy Content Curves . . . . . . . .

C-7

C. 16 Proportional Draft Points. . . . . . . . . . . . . . . . . . .

C.17 Weekly Planning . . . . . . . . . . . . . . . . . . C-7

Section 3: Borrowing Techniques Used by the Coordinated System . . . C-8

C.18 Borrowing Techniques Used by All Coordinated System Parties . . C-8

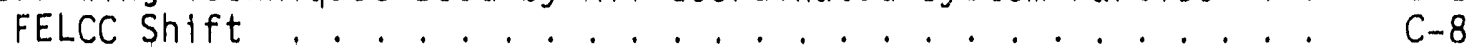
Flexibility Energy . . . . . . . . . . . . . . . . . . . . C-9

C.19 Use of Borrowing Techniques for DSI Customers . . . . . . . . . C-10 Advance Energy. . . . . . . . . . . . . . . . . . C-10 FELCC Shift. . . . . . . . . . . . . . . . . . C-11

Flexibility Energy. . . . . . . . . . . . . . . . C-11 Combination of Techniques ............... . C-12 


\section{APPENDIX C}

This appendix has three sections. Section 1 describes important terms essential to an understanding of Pacific Northwest hydro operations planning. Section 2 describes the processes of perlodic operations planning undertaken by BPA and other Pacific Northwest parties. Section 3 describes borrowing techniques which allow Coordination Agreement partles to shape the avallabllity of firm energy from month to month and from year-to-year of the critical perlod.

\section{SECTION 1: IMPORTANT TERMS}

\section{C.1 Federal Columbia River Power System (FCRPS) as a Multi-Use System}

The Federal Columbia River Power system serves multiple purposes in addition to power generation: flood control, navigation, recreation, irrigation, fishery benefits, and other such nonpower uses. BPA markets the power from FCRPS projects pursuant to the Bonneville Project Act and other Federal legislation and orders. FCRPS projects are operated by the U.S. Army Corps of Engineers and the Bureau of Reclamation. BPA and these agencies have Memorandums of Understanding recognizing each others' responsibilities and establishing operating arrangements. Nonpower uses and electric power production are brought together in the development of "operating constraints" (see discussion of Operating Constraints below), and "operations planning" (see Section 2 of this appendix).

\section{C.2 The Pacific Northwest Coordination Agreement (Coordination Agreement)}

The electric utilities of the Pacific Northwest plan and operate their systems in a coordinated manner. BPA plays a major role in this planning. This planning is carried out under the specifications of the Agreement for Coordination of Operations among Power Systems of the Pacific Northwest, also known as the Pacific Northwest Coordination Agreement. The Coordination Agreement's major provisions deal with preparation of the Annual Operating plan, and the monthly, weekly, and dally operations of the parties generating systems. Coordination of reservoir operations is given special attention, particularly when there is diverse ownership of generating plants downstream from a reservoir.

The Coordination Agreement provides for a Coordination Contract Committee, which is responsible for preparing studies and the required Annual Operating Plan. The committee receives technical assistance from the Northwest Power Pool Coordinating Group.

The Agreement does not cover two significant aspects of coordination: long-range planning of new resources, and short-term hour-by-hour coordinated operation of generating facilities. 
All major generating utillties in the Pacific Northwest are parties to the Coordination Agreement, except The Idaho Power Company. Idaho Power does coordinate its Brownlee Reservolr operations in concert with the Agreement to a certain extent. Joint planning is essential because the system utilities are interconnected electrically through shared transmission facllitles, and ilydraulically through the effect of released water on downstream hydroelectric projects. The advantages to the region of operating a coordinated system are:

- ablitty to take advantage of more efficient operation of hydro resources;

- ability to exchange power among member utilities;

- assistance gained during emergency outages of transmission lines or generators;

- ability to take advantage of diversities among systems in loads, generation, and maintenance outages; and

- reduced overall costs from coordinated use of all facllities and elimination of duplicative or multiple generation, transmission, and control facilities.

Reservoir-owning parties and parties with downstream generating plants coordinate storage and release of water and interchange power among systems to achieve more efficient use of the hydro system for the region and greater guarantees of meeting firm load.

\section{3 Operating Constraints}

FCRPS plants are operated to produce power within "operating constraints," some of which describe the physical operating limits of the project, and some of which prioritize the use of the project between power and nonpower uses. Operating constraints may limit maximum or minimum reservolr levels, project outflows, spills, rates of change of outflows, or many other operating parameters. These limits are often different for various times of the year.

Operations planning is another important guide to FCRPS operation, and to the trade-offs between power and nonpower functions of each project.

At the time each hydroelectric project is designed, numerous operating parameters are defined. These include the maximum and minimum reservoir elevations, minimum outflows, and other parameters. Operating limits sometimes include maximum rates of change of reservoir levels or outflows. Some may be the direct result of physical design parameters: for example, the minimum reservoir elevation may be determined by the vertical placement of the outlet works. Some may be to preserve existing river uses. A good example of this is the minimum project outflow. Some operating constraints may be established to obtain benefits for uses other than power, for example, minimum outflows may be established to provide water for irrigation or for downstream navigation. Minimum reservoir elevations may be established to permit 
navigation or recreation on the reservolr. Flood control operation of typical Paciflc Northwest reservolrs results in some of the most complex operating constraints. These usually vary both seasonally and with for"ecasts of runoff. To the extent these constraints are established during the design phase, they are taken into account in the studles which deiermine the feaslbility of the project. After a profect begins operating, additional operating constraints may have to be established, possibly because some effect of operations was overlooked in the design phase or because conditions have changed. Hopefully, these constraints w111 not be so great as to undo the feaslbllity of the project.

While some constraints are very defintte, for example those based on the physical characteristics of the project, others may be simply a priority of use. Not infrequently, nonpower constraints can be met without adversely impacting power production. However, when simflar constraints are applled to many FCRPS projects, meeting them all may become impossible. Some constraints are more definite, whlle others express a desire for a certain operation. If it is possible without impacting other uses.

\section{C.4 Water Budget}

As mentioned previously, the Northwest Power Act gave BPA significant new responsibilities to mitigate the effects of the development and operation of the FCRPS on fish and wildlife. These activities are conducted with the guldance of the Northwest Power Planning Councll's Fish and Wildlife Program. One of the flrst measures taken by BPA and hydroproject operators to carry out the Council's first Program was the implementation of the first Water Budget in 1983. BPA treats the Water Budget as a firm operating constraint that allows for the Fish Passage Managers to request certain levels of flow in the Columbia and Snake Rivers between April 15 and June 15 to help juventle salmon and steelhead achieve their downstream migration to the sea. For the Water Budget, water is reserved in the reservoirs and is released, efther through the turbines or as sp 111 , depending on the demand for energy, at times and in quantities as specified by the Fish Passage Managers within the guidelines of the Water Budget plan. The Water Budget results in an amount of Firm Energy Load Carrying Capabllity (FELCC - see following discussion of FELCC) to be produced in the April 15 to June 15 perlod which is in excess of the demand for firm energy. It results in an overall decrease in the amount of firm power which can be produced to meet the reglon's firm loads. This decrease is borne collectively by the Coordination Agreement parties. Affected parties, including BPA, attempt to store the excess firm energy from April 15 to June 15 outside the Columbia River Basin or market it.

\section{C.5 Annual Spill Plans}

Until mainstem Columbia and Snake River projects are properly screened to protect fish runs, the Council's Fish and Wildlife Program calls for spills of water to carry fish over dams instead of letting the fish pass through the turbines. Enough spill must be provided to protect at least 90 percent of the young fish at each project through the middle 80 percent of the runs. The 
Program calls for project owners and operators to develop and lmplement splll plans. These plans 11 st percentages of splll for speclfic profects.

Development and Implementation of splll plans are multiparty efforts involving flshery agencles and Trlbes and project owners and operators. BPA and fishery agencles and Trlbes have developed a 10-year spll1 agreement which would set torth splils at speclfic projects pending completion of other acceptable bypass methods.

\section{C.6 The Critical Period}

The critical period is that portion of the historlcal 50-year streamflow record which, when combined with draft of all avallable reservoli storage, wlll produce the least amount of energy, with energy used according to seasonal load patterns. At present, the coordinated system's critical perlod is about $31 / 2$ years long, encompassing the historical pertod from September 1928 through February 1932.

Prior to the construction of the three "Canadian Storage" reservolrs and the Llbby dam, the coordinated system's critlcal perlod was about 9 montis long, encompasing the historical months from September 1936 through Aprll 1937. The data on actual water conditions that prevalled during the critlcal period are used with current data on loads and resources to determine FELCC.

\section{C.7 Firm Energy Load Carrying Capability (FELCC)}

FELCC is the level of energy capable of being produced by the hydrogeneration system using all of the reservolr storage in comblnation with critical perlod streamflows. FELCC is used to determine the levels to which the coordinated system's reservoirs may be drafted to produce firm energy. As will be described in Section 2, FELCC for the multi-year critical perlod is calculated for the Final Regulation. The Coordination Agreement's published annual operating program includes the firm energy load carrying capability (FELCC) for each month of the coming operating year for the coordinated system and for each participant.

\section{C.8 Refill}

Each year, Coordinated System Operations endeavor to refill reservolrs each summer to what is referred to in the Coordination Agreement as "normal top elevation." Operations during the year are constantly analyzed in light of best avallable data to check their effect on probability of refill. (See also Varlable Energy Content Curves in Section 2 below.) If refill standards are not achieved, Coordination Agreement parties must adopt the FELCC for a critical period year other than the first year. In such a case, FELCC Shift is not avallable. (See Section 3 below.) If first year FELCC is not adopted, parties may have to increase expensive thermal operations, make outside purchases, or use restriction rights such as those in the DSI Power Sales Contracts. (See Alternative 4.3, Increase Quality of Service to DSI First Quartile.) 


\section{SECTION 2: THE OPERATIONS PLANNING PROCESS}

\section{C.9 Annual Operating Plan}

Each year, an operatling plan is prepared for the next July-june operating year. It comblnes the operating characteristics of thermal and hydroelectric plants, load forecasts, and historlcal streamflows to determlne system capabliltles. It uses monthly (sometlmes half-month) tlme fincrements. It describes loads and resource capabllitles in terms of two quantltles-average energy for monthly perlods, and peakload or generating capabllity during the month. The purpose of the Annual Operating Plan Is to determine how much load can be served with extsting resources.

\section{C.10 Determination of The Multi-Year Critical Perlod and FELCC}

Preparation of the Annual Operating Plan starts in February of each year. Participants in the Coordination Agreement (BPA, varlous Investor-owned utflitles, public utilities, and hydroelectrlc profect operators) submit loads, resources, and operating constraints for a multiyear perlod (that 15 , each year they submit data for the next 4 years) for use in developing an Annual Operating Plan. The Northwest Power Pool Coordinating Group then uses a computerized model to produce the Actual Energy Regulation study to determine the critical perlod for the coordinated system and the total FELCC for the coordinated system and for each member system. The planning model takes into account the constraints imposed on the system (flood control, navigation, Irrigation, the Water Budget, and other factors).

An important concept of the Coordination Agreement is that the energy studies are made by using the total coordinated system as if it were a singleownership system.

\section{C.11 Permitted Changes}

In preparing the Annual Operating Plan, individual systems in the coordinated system determine thermal plant capabilities, planned malntenance, outages, power sales and purchases, and constralnts on reservolr draft rates of individual reservolrs. The goal is to match generation more closely to load. These changes may somewhat reduce the coordinated system's capabllities from those developed for a single-ownership system, but changes are carefully limited in order not to invalidate the basic concept of operating a single system of resources to meet a single load.

\section{C.12 The Final Regulation}

After permitted changes have been made, the final study results are published. The published results of the final regulation include the FELCC for each month of the year for the coordinated system and for each participant. These numbers normally come from the first year of the critlcal period in the study just completed. If coordinated system reservotrs have falled to refill during the summer, they may come from the second, third, or 
even fourth year in a study completed in a prlor year. The results of the Final Regulation are important because they deterinine the extent to which the coordinated system's reservotrs may be drafted to produce flrm power if normal or better flows occur. (When lower than normal flows occur, proportional draft polnts, descrlbed below, are used.) If a particlpant has ued the Coordination Agreement to shape its FELCC into a pattern diffei fil from its firm load (for example, to Increase an amount of marketable surplus as descrlbed in Section 3 below), this wlll be reflected in that particlpant's and the coordlnated system's monthly FELCC shape.

\section{C.13 The Critical Rule Curve--Levels to Meet FIrm Loads}

After permitted changes have been made, the results of the find regulation study are published. Two lmportant: guldes to seasonal reservoli operations are developed from the studles. One is the "crltical rule curve." It is a tabulation for each reservolr of the end-of-month elevation that corresponds to the reservolr's draft under crttical perlod streamflow conditions to produce the flrm energy capabtlity. Because the crltical perlod is longer than one year, several crlttcal rule curves are necessary to descrlbe each reservolr's draft reglme during the flrst-year, second-year, third-year, and fourth-year of the critical perlod. The critical rule curves for an individual system or for the coordinated system can be constructed by converting the remaining storage in each reservolr at the end of the month to units of energy, then totalling all reservolis in the system. The critical rule curve is an important gulde to operations. If the coordinated system reservolrs are below the critical rule curve level, then the reoccurrence of one or possibly more histortcal sequences of low streamflows could result in the inablitty of the system to generate its firm energy capability, even if all its reservoirs were drafted empty. Thus, operation of the coordinated system reservotrs below thelr critical rule curves could jeopardize the system's ability to meet its firm loads for the remainder of the critical period.

\section{C.14 Energy Content Curve--Levels to Protect Refill}

A second rule curve developed from the final study is the "energy content curve." The energy content curve for each reservolr is the higher of its critical rule curve or the lowest level from which the reservolr would have a 95 percent probabllity of refllling by the following July 31 . Reflll probabllitles are based on an analysts of 50 -year historical streamflows at the reservoir.

The energy content curve is a very important gulde to operations. In order to protect the system's abllity to develop its firm energy capabllity in future years, systems are not permitted to generate energy in excess of the ir FELCC loads if their system of reservolrs is below the energy content curve as long as such energy can be stored. This means that the use of streamflows to refill a reservolr is given prtority over their use for generating nonfirm energy. Thus, the energy content curve is the primary guide that system operators use to determine whether nonfirm energy is avallable for sale from 
thelr systems. The energy content curve also deflnes the rights and obligations of parties to recelve or deliver in lleu energy, and rights and obligations between reservolr operators and downstream plant operators regarding the release of stored water for use at downstream plants (or delivery and return of energy in lien of such releases).

\section{C.15 Perlodic Updates---Variable Energy Content Curves}

Almost every year, an analys is of snowpack, preclpitation, and other vartables will indicate that current-year conditions are better than conditions during the historlcal year on which the energy content curve was based. In accordance with procedures in the Coordination Agreement, each reservoir operator prepares forecasts of each reservolr's volume of spring snowmelt runoff as soon after the beginning of each month, January through July, as the necessary data become avallable. Statistical formulas are applied to the hydrometecrological observations and the resulting forecasts are used to compute a "variable energy content curve" simflar to the energy content curve prepared prior to the operating year. The variable energy content curve is the best estimate of the lowest level to which the reservolr may be drafted without jeopardizing the coordinated system's abtlity to refill the reservolrs. Once it becomes avallable, the varlable energy content curve supersedes the energy content curve for all purposes under the coordination Agreement.

\section{16 Proportional Draft Points}

Reservolrs may be operated to their proportional draft points instead of their critical rule curves if this is necessary to develop the FELCC of the coordinated system. This is likely to happen during years of below-normal to we 11-below-normal water. Proportional draft points are determined by assuming that historical critical water conditions were present and that loads were exactly equal to FELCC. The reservolis are drafted proportionally between thelr critical rule curves. The Northwest Power Pool Coordinating Group, in producing the Actual Energy Regulation study for the Northwest utfilties, also produces the proportional draft points. The time span of the Actual Energy Regulation covers the present month and the month following. This study is done at least twice a month, and is based on estlimated streamflows and FELCC, which may cause the end of month proportional draft points to change significantly. This causes the project operators to continually reassess the planned operation of their reservoirs and, if necessary, change their operations to increase or reduce drafts on their projects to adhere to the proportional draft points.

\section{C.17 Weekly Planning}

Each week, BPA personnel prepare an operating plan for the FCRPS encompassing the coming month. This plan is divided into 10 one-day intervals, a 1-week interval, and a 2-week interval. The plan reflects the current levels of reservoirs, the operational status of thermal plants, balances in certain types of power sales, and other systen conditions. The load forecasts used in 
this plan, while based on the trend and general magnitude of the monthly load estimates used in resource planning and the Annual Operating Plan, are updated as much as possible. The weekly operating plan forecasts reflect recent trends relative to the operating plan and current weather forecasts. The weekly operating plan also differs from the Annual Operating Plan in that forecasted probable streamflows are used, based on current streamflow levels and weather forecasts.

The most recent energy content curves (or proportional draft points) are used to guide the weekly operation of major storage reservoirs. The weekly plan regulates the water level behind pondage projects such as Bonneville Dam, as opposed to the Annual Operating Plans, which use monthly intervals and assume no net water regulations at pondage projects during the month.

BPA personnel preparing the weekly operating plan are in frequent contact with the Corps of Engineers, the Bureau of Reclamation, entities operating thermal plants supplying BPA, and utility and industrial customers of BPA.

Information coming from all these sources is reflected in BPA's weekly operating plan. A large, complex computer program is used to make the necessary ialculations arid simulate water regulation of the river. Normally, the weekly plan is based on forecasts of loads and streamflows most likely to occur, although occasional situations call for special studies, such as studies using streamflow levels that have some low probability of occurring. These weekly operating plans are one of the important tools used by BFA management in making decisions regarding availability of nonfirm energy for Northwest utility and industrial customers and surplus energy for export from the region. The weekly plan permits BPA maragers to anticipate operating capability, and is used to determine the best manner of project operation for the near term. It also can be used to determine the probable Federal generating system ability to meet requests of nonpower interests for special river operations.

The weekly operating cycle supplies some of the information BPA managers use to make major decisions regarding reservoir operations, service to nonfirm loads, operation of thermal resources, operations for nonpower purposes such as Water Budget and flood control, and power purchases where such purchase is optional.

\section{SECTION 3: BORROWING TECHNIQUES USED BY THE COORDINATED SYSTEM}

\section{C.18 Borrowing Techniques Used by All Coordinated System Parties}

\section{FELCC Shift}

- As described in Section 2 above, FELCC for the coordinated system is first determined as a whole amount for the multiyear critical period, distributed across the years as recessary to meet firm obligations. This is done pursuant to a submittal of data from the parties, made approximately February 2 of each year. The previously described 
lengthening of the critical period to more than l year introduces some difficult to understand but important concepts into the annual planning and operating processes. FELCC Shift is a planning mechanism by which the Coordinated System plans to generate more FELCC in one portion of the critical period while generating less in another. Usually, FELCC is shifted into the first year of the critical period, resulting in deeper drafts of reservoirs. This borrowed water has a high probability of being restored each year by normal annual snowpack and runoff.

- In early April, the parties again submit data, this time specifying "Estimated Adjusted Firm Energy Loads," and indicating how much FELCC they desire for each month. This Estimated Adjusted Firm Energy Load must equal the average critical period FELCC previously developed. This data submittal shows the parties' desires for FELCC shift and for shaping of energy among the months of an operating year.

- These amounts are required to average the same as that participant's generating system capability during the critical period and to meet certain other constraints on their monthly distribution. The month-to-month shaping of FELCC to the extent permitted affects the monthly distribution of the coordinated system's hydro generation, and therefore the end-of-month levels of reservoirs shown in the critical period study. After the final regulation is completed, these become the basis for each participant's FELCC and for the critical rule curves of the coordinated system's reservoirs.

- The combined requests for shifting and shaping cannot result in a need for generation which exceeds the amount of power the system can produce within its various operating constraints. Constraints set by the U.S. Army Corps of Engineers and the Bureau of Reclamation on end-of-year drafts limit the total amount of system FELCC shift.

- Other constraints on FELCC shift are imposed by the Coordination

Agreement. Parties may not shift FELCC so as to create a surplus in one period at the expense of a deficit in another period. If there is surplus FELCC for the critical period, parties may move it forward. If there .ere an overall deficit in FELCC for the critical period, parties may delay it to a later year. If the system fails to refill such that planning must be based on a second or third year of the critical period, FELCC shift is not available.

\section{Flexibility Energy}

- The Coordination Agreement allows parties to make limited changes in the amounts of FELCC allocated to each month of the Operating Year. A Flexibility Account is kept for each party showing the accumulated increases or decreases for an Operating Year. The amounts of FELCC increased in an early month must be balanced by corresponding decreases in later months, and vice versa. Each Flexibility Account starts at zero on July 1 of each Operating Year and must be brought to zero by the end of 
the Operating Year, or the end of the critical period, if the critical" period ends within an Operating Year.

The amounts of monthly changes are limited by a number of constraints in the Coordination Agreement. For example, at any time, the net total of increases in monthly FELCC shown in the Flexibility Account may not exceed 5 percent of that party's FELCC remaining between that date and the date on which the Flexibility Account balance must be brought to zero.

- All the above-described borrowing techniques are used by BPA and other parties to the Coordination Agreement for service to their customers. Flexibility Energy is especially important for BPA's Actual Computed Requirement customers to match their FELCC to actual load. In addition, a party with firm surplus FELCC or with loads which underrun the estimates used in preparing the AOP may use Flexibility to better market this energy.

\section{C.19 Use of Borrowing Techniques for DSI Customers}

Under the Northwest Power Act, BPA is to continue to plan firm resources to serve 75 percent of the total DSI requirements in addition to its other firm loads. As stated in the Senate Energy Report (p. 59) for the Northwest Power Act, the balance of the DSI load is to be served with resources which are in excess of critical planning amounts but which are operated to meet the entire DSI load "as if it were firm."

As explained in Appendix B, BPA divides the DSI load into four quartiles. BPA is not obligated to acquire resources to meet the First Quartile of the DSI load; instead, BPA uses techniques to serve the first Quartile that are defined in the DSI Power Sales Contract. Aluminum smelters may elect service under the Variable Rate contract, which will then temporarily supercede the Power Sales Contract provisions regarding rates and quality of service. These techniques include nonfirm energy when available, borrowed firm energy from future months or years (FELCC Shift, Advance Energy, and Flexibility Energy), and Surplus Firm Energy Load Carrying Capability (Surplus FELCC). Advance Energy is a borrowing technique which is primarily relevant to DSI service. FELCC Shift and Flexibility Energy are borrowing techniques used by all Coordination Agreement parties for various purposes.

\section{Advance Energy}

- Advance energy is energy which is produced by drafting a particular reservoir below the lowest level otherwise permitted under the Coordination Agreement. The resulting energy is delivered to a customer with the provision that the customer replace it if the delivering party later determines that it needs the energy to meet its firm obligations.

- With respect to BPA use of this technique, the U.S. Army Corps of Engineers and the Bureau of Reclamation have defined limits within which BPA may draft specified reservoirs. Coordination Agreement parties other than BPA have generally not used this technique except to retain and market the energy produced at their downstream plants when BPA makes provisional drafts from Federal reservoirs. 
- Advance Energy has its beginning in the 1950s, when BPA delivered what was then called provisional energy to its DSIs during fall months. This energy was produced by drawing water from the Hungry Horse reservoir. The iimited energy available was delivered "provisionally" to serve DSI interruptible loads when nonfirm energy was not available. (The amount of interruptible load was not the same percentage of each DSIs' load under the pre-Northwest Power Act contracts in place at this time.) If BPA later needed the energy which that increment of water was planned to produce to meet BPA's firm loads, the DSIs would replace the energy, even, if necessary, by reducing their firm loads. This contractual agreement called for the energy to be replaced only if BPA needed the energy the water could have produced, but for the provisional drafts, treating that water as the last water to be released from the reservoir. Only once--following the 1974 drought--was return energy requested.

- Later, but before the Northwest Power Act, this arrangement was expanded to use other major Federal reservoirs and the name was changed to Advance Energy. Many documents use the term provisional energy, but the DSI Power Sales Contract uses the term Advance Energy. The practice of provisional drafting of reservoirs was formalized in section $9(n)$ of the Pacific Northwest Coorcination Agreement.

\section{FELCC Shift}

- FELCC Shift is also used to serve the DSI First Quartile. FELCC Shift used to serve the First Quartile of DSI customers is the same borrowing technique as is used by Coordination Agreement parties for various loads. However, DSIs are subject to future restrictions of their Third Quartile loads if coordinated system reservoirs fail to refill, the year from which the shift was made is adopted, and BPA needs the energy to meet its firm obligations. Other customers are not subject to such restriction rights though they may have to bear the costs of purchases or operation of more expensive resources. Advance Energy differs from FELCC Shift in that FELCC Shift is done at the time the Annual Operating Flan is prepared, whereas the Advance Energy operation is not reflected in the annual planning process. Also, Advance Energy had, in the past, been reserved by BPA for use only for its DSI loads, and is still used predominantly for that purpose. FELCC Shift is used by BPA for service to DSI loads and other markets, and is used by other regional utilities for various purposes.

\section{Flexibility Energy}

- BPA uses its Coordination Agreement flexibility rights to shape its FELCC among months of an Operating Year for service to the DSI First Quartile, among other purposes. 


\section{Combination of Techniques}

- During DSI contract negotiations, negotiators realized that FELCC shift could not provide full service to the flrst Quartile load throughout a contract year following reservolr refill. Instead, the contract provides for the use of FELCC Shift. Advance Energy, and use of Coordination Agreement flexibility accounting until the date of avallability of the forecast, determined by BPA to be the first rellable forecast, of the Columbia River Basin volume runoff. This date is considered to be January 10. The DSI Power Sales Contract calls for all three techniques--FELCC Shift, Flexibility Energy, and Advance Energy--to be used by BPA to serve the First Quartile loads up to the date of that forecast. This was done mainly because studies made at the time of the negotiations indicated that use of all three of these devices would be needed to meet the First Quartile load for the entire period from about Labor Day to January 10. 


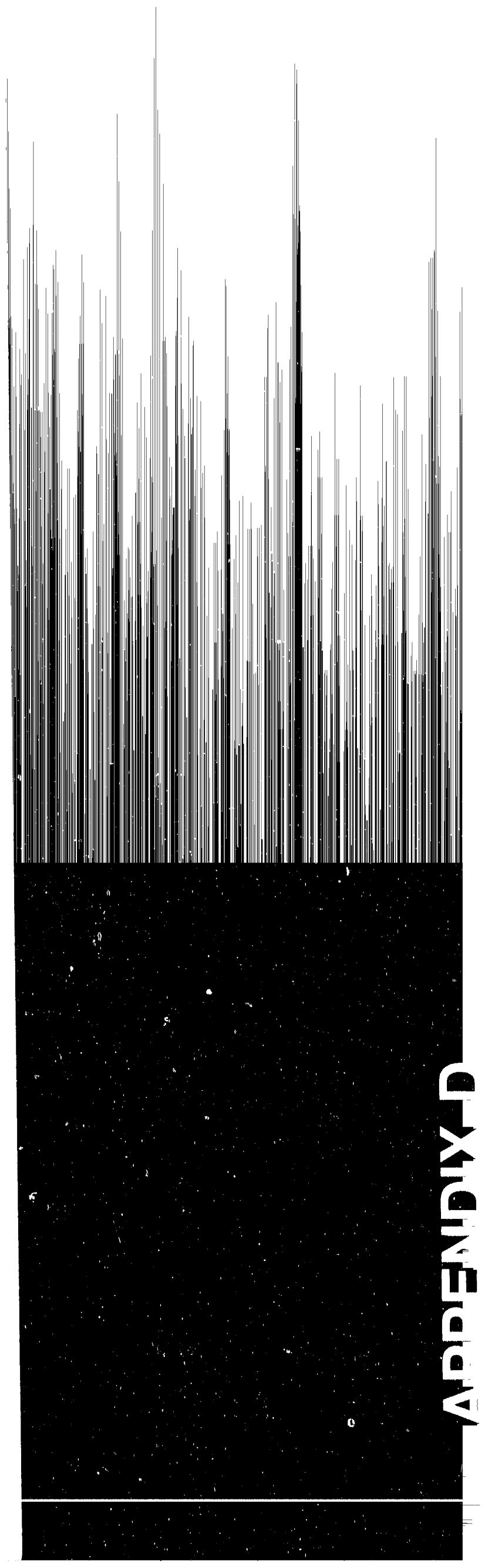


Appendix D

Glossary 


\section{GLOSSARY}

The words below are defined for the reader as they are used in this Environmental Impact Statement.

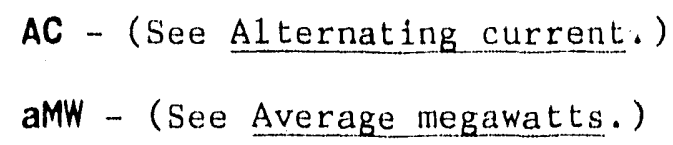

Absolute - Being fully as indicated; independent of any other value or standard; not comparative or relative (opposed to relative).

Access - (See Intertie access.)

Acid deposition - The combination of oxides of nitrogen and sulfur, in the air, with water, forming acid rain or snow, which may adversely affect water resources and plant and animal 1 ife.

Acre-foot - The volume of water that will cover an area of 1 -acre to a depth of 1 foot.

Advanced Energy - Electric energy delivered by BPA to industrial customers in lieu of restricting $\mathrm{firm}$ power deliveries when the Federal Columbia River Power System's reservoirs are being filled. BPA may call this energy if it is later needed to meet BPA's firm loads.

Air basins - Defined areas which generally confine the air-borne pollutants produced within them. Air pollutants tend to circulate and mix together within a basin.

Alluvial fan - A low cone-shaped deposit of sediment laid down by a swift-flowing stream as it enters a plain or an open valley, commonly in dry regions with interior drainage.

Alpha - In the field of statistics, the probability (percentage) of erring by rejecting the null hypothesis when it is actual.1y true.

Alternating current (AC) - Term applied to an electric current or voltage that reverses its direction of flow at regular intervals and has alternately positive and negative values, the average value of which (over a period of time) is zero.

Ambient Air - Ambient air is the air surrounding a particular spot, such as a power plant.

Anadromous Fish - Fish species that spawn and initially rear in fresh vater, migrate and mature in the ocean and return to fresh water as adults. 
Applicable rate - The rate(s) contained in rate schedules for service of a defined type.

Aquatic biota - The plant and antmal life of a water body, considered as a total ecological entity.

Aquifer - Any geological formation containing water, especially one that supplies water to wells, springs, etc.

Artifact - An object of any type made by human hands. Tools, weapons, pottery, and sculptured and engraved objects are representative artifacts.

Average megawatts (aMW) - The average amount of energy (number of megawatts) supplied or demanded over a specified period of time.

Avoided-cost methodology - A method used to determine the payments from utilities to qualifying facilities (QF's) under PURPA. The utility pays the $Q F$ an amount based on the costs for power the utility avoids by purchasing power from the $Q F$.

Baseload - In a demand sense, a load that varies only slightly in level over a specified time period. In a supply sense, a plant that operates most efficiently at a relatively constant level of generation.

Benthic insects - Insects living on the bottom of reservoirs or streams.

Block slump - The (usually limited) downward displacement of a mass of earth as a unit, often caused by excessive soil saturation.

Boreal - Pertaining to the forest areas and tundras of the North Temperate zone and Arctic region.

Bottom-ash - Uncombusted materials which accumulate in the bottom of a boiler and which must be removed and, generally, disposed of as solid waste.

Brackish - Containing some salt. Brackish water of ten results where fresh waters meet the ocean.

Buffering capability - The ability of a material to resist a change in pll (acidity or basicity) when an acid or base is added.

Bypass - Water released from a project which does not go through the turbines or over the spillway. Bypass may include leakage, navigation lork releases, and $\mathrm{E}$ ish 1 adders.

cfs - (See Cubic feet per second.)

CFM VI - (See Common Forecasting Methodology VI.) 
Capacity - The amount of power that can be produced by a generator or carried by a transmission facility at any instant. Also, the service whereby one utility delivers firm energy during another utility's perfod of peak usage with return made during the second utility's offpeak perfods; compensation for this service may be with money, energy or other services.

Capacity additions - Proposals to increase the power carrying capability of the Intertie--the Third AC/CO'TP and the DC Terminal Expansion Project.

Capacity/energy diversity exchange - A transaction in which one utility provides another with capacity service during its peak season, with compensation as the delivery of additional amounts of energy to the first utility during its peak season. This type of exchange benefits utilities that do not peak at the same time, if deliveries and returns can be made at the time of each utility's system peak.

Capacity/energy exchange - A transaction in which one utillty provides another with capacity service in exchange for additional amounts of firm energy (exchange energy) usually during offpeak hours or money under spectfied conditions.

Capital costs - The costs to construct a power plant, including the costs of materials, permits, and interest on borrowing.

Capital investment in new resources - (see Capital costs)

Carrying capacity - The amount of energy that a Transmission faci?tty can carry under specified conditions.

Cogeneration - The generation of power in conjunction with (usually) an industrial process, using waste heat from one process to fuel the other.

Common Forecasting Methodology VI (CFM VI) - Filings of projected 1oads, costs, and prices by California utilities to the California Energy Commission.

Composite retail rates - The average retail rates calculated for (1) all the publicly owned utilities and (2) all the investor-owned utilities in the Pacific Northwest.

Computed Requirements - BPA utility customers with large power generating resources, or shares of large resources, purchase power on the basis of computed requirements. This means that the customers' entitlement to power is computed within certain minimums and maximums. This differs from metered requirements which entitles a customer to whatever it needs during a month to serve its regional firm load. Al1 computed requirements customers "assure" the capability of their firm power generating resources. Some computed requirements customers may purchase all of the firm power needed to serve the remainder of their firm load. Other computed requirements customers fix in advance the amount of power they are going to purchase from BPA either for a year or for 7 years based on estimates of their power needs which exceed their assured capability. 
Coordination Agreement - An agreement among several of the reglon's largegt generating utilities and BPA which provides rules for operation of the parties' hydroelectric profects as if they were all owned by a gingle entity. This agreement makes the best use of the water and storage capabillty of the region by assuring that the whole system is operated as if 1 t. was all owned by a single entity.

Critical Rule Curve - A set of end-of-month reservotr contents whlch take the reservoir from full to empty during a crittcal pertod. Crititcal rule curves are used to guide reservolr operation during actual operation.

Crustaceans - Aquatic creatures such as barnacles and crabs, which have a segmented body, an extertor shell-1ike skeleton, and paired, jointed limbs.

Cubic feet per second (cfs) - A unit of measurement pertaining to flow of water. One cfs is equal to 449 gallons per minute.

Cultural resources - The nonrenewable evidence of human occupation or activity as seen in any district, site, buflding, structure, artifact, ruin, object, work of art, archttecture, or natural feature that was important in human history at the nationa1, State, or loca1 level.

DC - (See Direct current.)

DSI - (See Direct-service industries.)

Dam passage - The percentage of fish which get from one side of a dam to the other alive.

Damage functions - Mathematical expressions based on scientific and socioeconomic observations which can be used to relate exposure to an environmental condition to an economic or social condition.

Declining block rate structure - In a rate schedule for a particular. customer class, a structure that specifies lower kWh rates as consumption increases for specified ranges of usage.

Decremental cosi - The cost that a utility could avoid by not operating a power plant; a utility's decremental cost is considered by some regulators to be a "fair" rate for the utility to pay for purchased power.

Deoxygenation - The depletion of dissolved oxygen in water.

Detailed Fisheries Operating Plan - A Columbia Rlver hydroelectric system operation manual prepared by $\mathrm{f}$ ish and wildlife agencies and Indian Tribes for fish passage related to the mainstem Columbia River.

Dewater - (a) To remove water from a solution containing wastes in order to concentrate and then dispose of the wastes. (b) To divert or remove water from a stream or river channel in order to construct or rebuild dams and related hydroelectric facilities. 
Direct current (DC) - T'erm applfed to an electric current or voltage which may have pulsating characteristics, but whlch does not reverse direction at regular intervals.

Direct Service Industries (DSIS) - Industrlal customers (primarlly aluminum compantes) which purchase energy directly from BHA.

Dispatch - The montiorling and regulation of an electrical system to provide coordination; or the sequence by which electidcal generating resources are called upon to generate power to serve changing amounts of load.

Displacement - The substitution of less-expenslve energy (usually hydrotectric energy transmltted from the Paclfic Northwest or Canada) for more expenslve thermal energy produced in Calfornfa. Such displacement means that the thermal plants may reduce or shut down their production, saving money and of ten traducing afr pollution as well.

Dissolved gas concentrations - The amount of chemicals normally occurring as gases, such as nitrogen and oxygen, which are held in solution in water, expressed in units such as infl1igrams of the gas per liter of 1iquid.

Distribution costs - Costs faced by a ut11ity that sells electriclty at retal1 to consumers, the costs of transporting the power from the transmisston substation to the consumer.

Double-circuit - The placing of two separata electrical circuits on the same row of towers. For alternating current, each circutt conststs of three separate conductors or bundles of conductors.

Downstream Migrant Survival - The survival of an individual fuventle salmon or steelhead from the time it enters the malnstem Snake or Columbla rivers, until it gets below Bonneville Dam.

Drawdown - The distance that the water surface of a reservoir is lowered from a given elevation as water is released from the reservoir (drafted).

Economy energy - Nonfirm energy that can be generated on a partially loaded generating unit, or purchases of energy, at a price less than decremental. cost. Economy energy is unconditionally interruptible.

Electrostatic precipitators - Devices used to remove particulate air pollutants from an alr stream by establishing an electric charge on the particles which then are attracted to an oppositely charged collector.

Emergence - Migration of hatched salmon fry up through the gravel of a redd preparatory to continuing their life cycle in open water.

Endangered - A plant or animal spectes which is ln danger of extinction throughout all or a signiffcant portion of its range becaluse lis habitat is threatened with destruction, drastic modification, or severe curtaliment, or because of overexplotitation, disease, predation, or other factors; federally endangered species are offloially designated by the U.S. Fish and Wildlfe Service and published in the FEDERAI, RECis'TER. 
Energization - The point at which a completed energy factlity la put lnto operation.

Energy Content Curve (ECC) - A set of end-ot -month reservolt contents whitch aisure a high probability of reftlitng the reservolrs.

Energy losses - The difference between power supplied and power recelved, due to dissipation by the transmission line or other factifty.

Energy surplus - A condition in which a utfitty system car supply more energy than is demanded; the energy may be nonf $1 \mathrm{rm}$, due to water condtitons, or Eirm, due to excess generating capability.

Entrainment - The drawing of flsh and other aquatic organisms into tubes or tunnels carrying water for cooling purposes into thermal plants or for generating purposes into hydroelectric plants. Entrainment increases mortality rates for those organisms.

Environinental Impact Statement (EIS) - A document propared by a Federal agency on the environmental impact of 1 ts proposals for legislation and/or other major actions significantly affecting the quality of the human enviroment. EISs are used as tools for decisionmaking and are required by the National Environmental Policy Act of 1969.

Equilibrium values - For the projection of $B C$ Hydro's retall power rates for the EIS, the rates that reflect an economic equilibrium of supply and demand, considering the cost. to supply the power (less revenues from secondary sales) and the loads.

Estuary - A coastal inlet where salt water meet:; fresh water, as at a river's mouth.

Eutrophication - The increase of aquatic vegetation (at the expense of animal 1 ife) as more plant nutrients are supplied.

Exchange energy - Under a capacity/energy exchange contract, the energy that must be generated or purchased by a utility as compensation for capacity service that was provided by another utility.

Export sales - The sales of electricity from one region to another.

Extraregional - Any entity or place not within the Pacific Northwest.

FCRPS - (See Federal Columbia River Power System.)

Federal Base System - Resources consisting of hydroelectric facilities of the Federal government, as well as Washington Nuclear Project No. 1 and No. 2, and 70 percent of No. 3, part of the Hanford Nuclear Project, and a portion of the Trojan Nuclear Profect, along with a few other miscellaneous power generating resources. BPA uses these resources to serve the firm energy loads of its customers. When BPA allocates power during periods of insufficiency, it is the Federal. Base System resources that are used in the allocations formula. 
Federal Columbla River Power System (FCRPS) - The hydroelectrte dams on the Columbla River linauced by the U.S. Treasury, whlch operate as a coordinated generation system, and for whlch BPA gerves as the power marketer.

Federal Energy Regulatory Commission - A Federal agency which reviews hydroelectric projects and submitted appltcatons for operating lifenses.

FELCC Shift - (See Fitrm Energy load Carrying Capahility.) A plamnlng action, under the Coordination Agreement, fn which they hydrosystem generates more electrictiy in one portion of the critical perfod while generating leas in another portion of the perlod. Usually FELCC is shifted futo the first year of the crittcal perfod, resulting in lower reservolr levels.

FGD - (See Flue-gas desulfurlzatlon.)

Fingerlings - Young or small fish, especially very small salmon or trout.

Firm - In the power industry, guaranteed or assured. May reler to a guaranteed supply of power, to guaranteed access to a means to transmlt power, or, with reference to loads, to guaranteed service for a defined need. Usually defined for a given period of time.

Firm Energy Load Carrying Capabillty (FELCC) - The level of energy capable of betng produced by the hydrogeneration system using all of the reservolir storage in combination with critical period streamilows. (Critical period refers to that portion of the historical 40-year streanflow record which produces the least amount of energy, with energy being used according to seasonal load patterns.)

Firm energy load carrying capability - The minimum level of energy that can be produced and shaped to load during the period it would take reservolirs to be drafted from full to empty under critical streamflow conditions.

First Quartile - The DSIs electric operating demands are divided into four quartiles. The upper quartile (also called Eirst or top) is that portion of the DSI's electric load which BPA may restrict for any reason or which DSI's may curtall for any reason.

Fish ladder - A series of ascending pools constructed to enable salmon or other fish to swim upstream around or over a dam.

Fish passage facilities - Features of a hydroelectric or other type of dam to enable fish to move around, through, or over them without harm.

Fish Spill Plan - A plan to provide a certain percentage of the total flow of a project as spil1, for Federal and non-fiederal projects.

Flaring - The practice of disposing of a waste combustible gas by burning it in a open flame without recovery of heat and, typically, at the top of a stack. 
Flow rate - The volume of a fluid which passes a point in a defined channel per unit of time.

Flow regimes - The pattern of flow as it changes with time over the course of some specific time period.

Fluctuation zone - The area between the maximum and minimum water levels in a reservoir.

Flue-gas desulfurization (FGD) - The process of removing sulfur dioxide and other oxides of sulfur from gases generated by combustion or some other process before they are discharged to the atmosphere.

Fly-ash - Particulate matter remaining after combustion of a material which is entrained into the gas stream, and which may in large part be captured by an air pollution control device and, generally, disposed as a solid waste. rly-ash not so captured is discharged as particulate matter into the atmosphere.

Foodweb - The interlocking pattern of food chains that results from their interconnection with one another; a way of presenting the flow of energy through an ecosystem.

Forced outage - The unexpected failure of some part of the power sy:item to perform its function.

Forebay - The portion of the reservoir at a hydroelectric plant which is immediately upstream of the generating station.

Formula allocation - Conditions established by the NTIAP for allocating access to the Intertie, specified by formula.

Fossil fuel - A combustible, carbonaceous material formed from the remains of ancient plants and animals. Common fossil fuels include coal, natural gas, and derivatives of petioleum such as fuel oil and gasoline.

Functional capacity - The actual power carrying capability of a transmission line.

Fuel conversion efficiencies - The ratio (commonly expressed in percent) of the heating value of the fuel used per unit time to the power output of a generating plant.

General Contract Provisions (GCPs) - Power sales contract provisions contain detailed information on charges, rates, delivery, equipment, billing, metering, and other provisions required by statute. These provisions are common to $111 \mathrm{BPA}$ power sales contracts and are also contained in other BPA contracts. (A11 references to GCP Form PSC-1, dated 8-25-81.)

Geothermal (energy) - The heat energy available in the rocks, hot water, and steam in the earth's subsurface. 
Groundwater - The supply of fresh water under the earth's surface in an aquifer or soil.

Hydraulic head - The vertical distance between the surface of the reservoir and the surface immediately downstream of the turbine and dam.

Hydraulic residence times - The average travel time for a particle of water through a reservoir or other body of water.

Hydro Block - The electrical energy available from the hydro system which is divided into various portions or "blocks," depending on conditions applied to its use.

Hydrocarbons - Chemical compounds containing hydrogen and carbon. Some hydrocarbons may become air pollutants. Some hydrocarbon air pollutants are carcinogenic, and some react with other air pollutants to form photochemical smog .

Hydroelectric - With reference to a power system, the production of electric power through use of the gravitational force of falling water.

Hydrology - The localized conditions relating to the occurrence, circulation, distribution, and properties of ground and surface waters.

Hydrostatic testing - The use of pressurized water to test a tank, pipeline, or other equipment for leaks.

100 - (See Investor-owned utilities.)

Investor-Owned Utilities (10U's) - Privately owned utilities whose programs are financed by private (nongovernment) investors in the utility's stocks and bonds. (In contrast to publicly owned utilities.)

ISW - (See Inland Southwest.)

Impoundment - The accumulation of water in a reservoir.

Incubation - The period between fertilization of an egg and its hatching.

Inland Southwest (ISW) - For the purposes of this EIS, the States of Nevada, Arizona, Colorado, Utah, and New Mexico.

Instantaneous flow rate - The minimum amount of flow required (usually in terms of fish survival and functioning) at a given moment in time.

Interruptibility - The extent to which the flow of power can be stopped for a given period of time. By agreement, the supply of interruptible power can

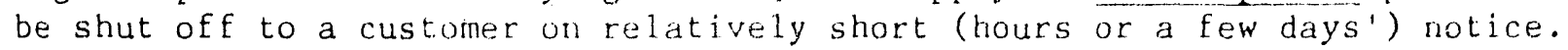

Inundation - The flooding or covering up of an area with water. Inundation occurs when a reservoir is first filled. 
Juvenile - The stage in the life cycle of anadromous fish when they migrate downstream to the ocean.

kcfs - One thousand cubic feet per second. A measure of speed and volume of water flow. (See Cubic feet per second.)

Kilowatthour ( $k$ Wh) - The common unit of electric energy equal to 1 kilowatt of power supplied to or taken from an electric circuit for 1 hour. A kilowatt equals 1,000 watts.

LCMM - (See Least Cost Mix Linear Program Mode1.)

LP - (See Marketing Linear Program Mode1.)

LTIAP - (See Long Term Intertie Access Policy.)

Laissez-faire - A hypothetical hands-off policy of Intertie access that would allow the Intertie to be used on a first-come, first-served basis; no restrictions would be imposed on access to the Intertie for new resources.

Larvae - The newly hatched, earliest stage of anadromous fish.

Lead Federal agency - The Federal agency charged with primary responsibility for evaluating in conformance with the National Environmental Policy Act the potential environmental effects of a project involving Federal action.

Leakage - An amount of water which leaks around a dam without passing through the turbines, spillway gates, or navigation locks.

Lockage - An amount of water which passes through the navigation locks and does not pass through the spillway gates or turbines of a dam.

Least Cost Mix Linear Program Model (LCMM) - A linear program computer model that estimates the amount of regional generation and conservation resources that should be acquired to yield a least-cost resource mix to meet a given firm load over a 20-year planning horizon.

Least cost mix of resources - The combination of generating (including conservation) resources that would meet a given amount of load at a given time or for a given period most economically.

Leveed islands - An area of land completely surrounded by water protected from flooding during high water by levees, embankments of earth rimming the is land.

Levelized - of costs, a method of calculating equal, periodic payments or receipts from unequal cost data for the same time period, considering the time value of money.

Linear regression analysis - The derivation of a mathematical relationship between dependent and independent variables based on a random sample of observations. 
Littoral zone - The shallower waters near the shore of a reservoir or lake.

Load - The amount of electric power or energy delivered or required at any specified point or points on a system. Load originates primarily at the energy-consuming equipment of the customers.

Load growth - Increase in demand for electricity.

Load management - Influencing the level and shape of the demand for electrical energy so that it matches resources available as well as long-run objectives and constraints.

Load profiles - Information on the shape of customers' demands for electricity over time.

Load/resource balance - The point at which the demand for electricity matches or balances the amount and type of resources available to serve that demand.

Long Term Intertie Access Policy (LTIAP) - The policy being developed by BPA to allocate use of the Federal portion of the Intertie for the long term, an indefinite period that would at least encompass long-term power sales (up to 20 years) and long-term transmission contracts.

Low water years - Years in which less water than usual is received in a river system producing power from water flow. This is usually a consequence of reduced rain/snow fall over the fall and winter months.

MW - (See Megawatts.)

Macroinvertebrates - Nonmicroscopic animals without a spine.

Marginal energy costs - For a generating resource, the cost to produce one more kilowatthour of electricity.

Marketing Linear Program Model (LP) - A linear program computer model that calculates decremental cost for each utility in the Southwest.

Megawatts (MW) - A megawatt is one million watts, an electrical unit of power.

Microclimate - The climate of a small area, as of houses, of plant communities, or of urban communities.

Mine-mouth - Used to refer to thermal generating plants located close enough to the fuel source (generally coal) that no long-distance fuel transport is necessary.

Minimum generation constraints - For thermal power plants, the ninimun leve 1 of operation that must be maintained to keep the plant ready to generate power when needed. 
Model Conservation Standards - A conservation program developed in accordance with the Pacific Northwest Power Act by the Northwest Power Planning Council to define and adopt cost-effective conservation standards as one of the region's electric generating resources.

New Large Single Load (NLSL) - Any load associated with a new facility, and existing facility, or an expansion of an existing facility which:

-- is not contracted for, or committed to, as determined by BPA, by a public body, cooperative, investor-owned utility, or Federal agency customer prior to September 1, 1979; and which

- will result in an increase in power requirements of such customer of 10 average megawatts or more in any consecutive 12 -month period.

Nitrogen supersaturation - A condition of water in which the concentration of dissolved nitrogen exceeds the saturation level of the water. Excess nitrogen can lead to bubbles of nitrogen in the circulitory systems of Eish.

Nominal dollars - For economic analysis, dollars in the year specified, not adjusted for the effects of inflation or the time value of money.

Nonfirm energy - Energy available due to water conditions better than critical, sold on an interruptible (nonguaranteed) basis.

Northwest Power Act - (See Pacific Northwest Electric Power Planning and Conservation Act.)

Northwest Power Planning Council (Council) - The Pacific Northwest Electric Power and Conservation Planning Council, established by the Northwest Power Act. They are charged with devising a regional electric energy plan for the Pacific Northwest and a regional program to protect, mitigate, and enhance $\mathrm{fish}$ and wildlife in the Columbia River Basin. The Council is composed of two appointed representatives from the States of Oregon, Idaho, Washington, and Montana.

Null hypothesis - A statistical hypothesis to be tested and accepted or rejected in favor of an alternative; specifically, the hypothesis that an observed difference is due to chance alone and not due to a systematic cause.

Nutrient loading - The quantity of elements or compounds essential as raw materials for organism growth and development which are dissolved or suspended in a sample of water.

Offpeak hours - Period of relatively low system demand for electrical. energy, as specified by the supplier (such as the middle of the night).

Outplantings - Fish hatched and initially reared in a hatchery, which are then planted into natural habitats to continue juvenile rearing.

Overburden - The topmost layers of soil. In this EIS, the 30-50' layers of soil stripped off to reveal coal seams in the process of strip mining. 
PCB's - (See Polychlorinated bipheny1s.)

PF rate - (See Priority Firm rate.)

PNW - (See Pacific Northwest.)

PSD - (See Prevention of Significant Deterioration increments.)

PURPA - (See Public Utilities Regulatory Policy Act.)

Pacific Northwest (PNW) - For this EIS, the States of Washington, Oregon, and Idaho; the portion of Montana west of the Continental Divide; and areas in Montana, Nevada, and Wyoming surrounding coal plants that serve the PNW.

Pacific Northwest Electric Power Planning and Conservation Act - Signed into law December 5, 1980, the Act provides for coordinated planning of the Pacific Northwest's energy future, through a Regional Planring Council. with representation from Oregon, Idaho, Montana, and Washington.

Paired t-test - A statistical comparison between two sets of data used to determine to what extent they are dissimilar.

Passage survival - The survival rate of migratory fish through, around, or over dams or other obstructions in a stream or river.

Peak loads - The maximum electrical demand in a stated period of time. It may be the maximum instantaneous load or the maximum average load within a designated interval of the stated period of time.

Percolation - The movement of water through the subsurface soil layers, usually continuing downward to the groundwater and water table reserves.

Photochemical smog - A type of air pollution resulting when sunlight induces chemical reactions of other pollutants, notably nitrogen dioxide and hydrocarbons. Elevated ozone levels are an indicator of photochemical smog since ozone is one of the products of the photochemical reaction.

Phytoplankton - The plant portion of the floating or weakly swimming organisms, often microscopic in size, in a body of water.

Plume - The discharge of gas and other pollutants into ambient air, or the discharge of polluted or heated water into a body of water from its source to the point where the discharge is no longer identifiable since it has mixed with the ambient air or the water.

Plunging flows - Water flow over a very steep surface or off of a precipice into a pool. This situation is one which produces high levels of dissolved gases in the water, such as nitrogen supersaturation.

Polychlorinated biphenyls (PCB's) - A group of noncombustible synthetic insulating/dielectric fluids used in certain electrical equipment; found to be very persistent in the environment and strongly suspected of having carcinogenic effects. 
Pool Mortality - Death that occurs to a juvenile salmon or steelhead as it migrates through the pool or reservoir of a run-ö-the river project.

Power pool - A power pool is two or more electric systems intercomected and coordinated to supply power in the most economical manner for their combined load requirements and maintenance program.

Power Sales Contracts - Contracts which establish the terms and conditions of BPA's power sales. The maximum term of power sales contracts established by the Bonneville Project Act is 20 years. .11 such contracts specify the quantity of the sale and the rate schedule or schedules to be used for billing, and incorporate the General Rate Schedule Provisions and the applicable General Contract Provisions. Generally they include a description of the point or points of delivery and specify the voltage or voltages at which the power will be delivered. Other provisions cover special conditions applicable to the specific customer.

Pre-emergent fry - Fish after they have hatched from their eggs but before they have left their incubation environment.

Predation - The capturing of prey as a means of maintaining life.

Preference customers - Cooperatives and public bodies (States, public utility district, counties, and municipalities, in the Northwest which have been given preferential rights by Congress to federally generated hydroelectric power.

Prevention of significant deterioration (PSD) increment - Any one of several incremental changes in ambient total suspended particulate or sulfur dioxide concentrations established by the Environmental Protection Agency to protect existing air quality from being degraded significantly through new developments, such as construction and operation of a new air pollution source.

Priority Firm (PF) rate - The priority firm (PF) rate schedule is for sale of firm power to be used within the Pacific Northwest by public bodies, cooperatives, Federal agencies, and IOU's participating in the residential and smal1 farm exchange under Section 5(C) of the Northwest Power Act.

Project outflow - The volume of water per unit of time downstream from a project.

Public Utilities Regulatory Policy Act (PURPA) - Enacted in 1978, it is the Federal legislation that requires utilities to purchase electricity from qualified independent power producers at a price that reflects what the utilities would otherwise have to pay for the construction of new generating resources.

Pumped Storage - An arrangement whereby electric power may be generated during peak load periods by hydroelectric plants using water previously pumped into a storage reservoir during offpeak periods.

Qualifying Facilities (QF's) - Renewable and cogeneration resources developed under the Public Utilities Regulatory Policy Act of 1.978. 
Real cost escalations - The increase in cost over a period of time due solely to the time value of money; that is, adjusted for price fuflation.

Real discount rate - The factor used to compute the present value of a future amount, which adjusts solely for the time value of money and does not include price inflation.

Reclamation - The restoration of land to resemble its original condition or an acceptable substitute as to shape, vegetation, and wild ife; reclamation takes place after an area has been stripmined or after an energy facility has been built.

Record of Decision - The document notifying the public of a decision taken on a power project, together with the reasons for the choices entering into that decision. The Record of Decision is published in the FEDERAL REGISTER.

Recordation - The making of appropriate records (following National Park Service guidelines) to insure that a permanent record of a cultural resource's present appearance and context are made before the resource is disturbed through destruction, demolition, or inundation. Such a record might consist of written description, photographs, and so on.

Redds - Gravel. nest created by female salmon or trout where its eggs are laid, subsequently hatched, and fry emerge.

Regional - Referring to the characteristics of an area, as opposed to those of a surrounding or adjacent area. Generally used in this EIS to distinguish between the Pacific Northwest and Canada or California or the Inland Southwest. (See Extraregional.)

Regional Council's Energy Plan - A plan to encourage conservation and efficient use of electric power and the development of renewable resources within the Pacific Northwest. The Northwest Power Act mandated the development of the program.

Regional Council's Fish and Wildlife Program - A program to protect, mitigate, and enhance fish and wildlife. The Northwest Power Act mandated this Program.

Relative - Considered in relation to a Base Case condition; comparative; not absolute or independent (opposed to absolute).

Relative change in survival - The difference in survival between the two alternatives divided by the Base Case survival value. The change in survival in relation to the Base Case survival.

Reliability level - For a power system, a measure of the degree of certainty that the system will continue operation for a specified period of time.

Relic collecting - The seeking out and removal of artifacts or other cultural resources by private persons. The practice consequently excludes opportunities for study or preservation of the site, and of ten results in destruction of artifacts, the site itself, and/or nearby sites. 
Renewable resources - Resources for energy which are continually replenished. Water, for instance, is a renewable resource, while coal which is converted into carbon dioxide, water, and ash when burned is not.

Replication - A copy or reproduction of a cultural artifact. Replication is most of ten done for rock art or engravings, by making a mold or cast of the work.

Ruserve margins - For a power plant or transmission facility, extra capacity atove the amount projected to be needed, to allow for unanticipated demand for pcwer, equipment failure, or other unforeseen events.

Reservoir draft rate - The rate at which water, released from storage behind a dam, reduces the pool elevation of the reservoir.

Reservoir elevations - The various levels reached by water stored behind a dam.

Resident fish - Fish species which reside in fresh water during their entire life cycle.

Residential Exchange Program - An exchange of power prescribed by section $5(c)$ of the Northwest Power Act. Pacific Northwest utilities sell BPA an amount of power equal to their residential and small farm load, in exchange for less-expensive Federal electricity. The cost benefits are directly passed on by the utilities to their residential and small farm consumers, in the form of lower retail rates to those customers.

Residual fuel oil - Fuel oil that remains after separation of valuable distillates (such as gasoline) from petroleum through distillation.

Resource dispatch - For this EIS, the order of access or the monitoring of power resources for access to the Intertie.

Resource mix - The different types of resources used to generate power (e.g., hydroelectric, thermal, etc.) within a given area or for a given utility.

Resource schedule - The planned schedule of when and what resources will be available in the future to serve load in a given area or of a given utility.

Retrofit - To weatherize an existing structure.

Riprap - Broken rock, cobbles, or boulders placed on the bank of a stream or river for protection against the erosive action of water.

Run-of--the-River Dams - Hydroelectric generating plants that operate based only on available streamflow and some short-term storage (hourly, daily, or week 1.y).

Run-of-River Plant - A hydroelectric plant with little or no ability to regulate flow. 
Running costs - Also called variable costs-the costs that are fincurred or are increased when a power plant operates.

Salmonids - Fish belonging to the family of salmonldae, lucluding salmon, trout char, whitefish, and all lied freshwater and anadromous fish.

Scheduling Utilities - Pactfic Nothwest schedulfing utilities finclude Bonneville Power Administration, Seattle City Light, l'acoma City Light, Grant County PUD, Douglas County PUD, (helan County PUD, Pend Orellle PUD, Eugene Water and Electric Board, Cowlltz County PUD, Snohomlsh County PUD, Montana Power Company, Idaho Power Company, Pacif te Power \& Light Company, Porthand Ceneral Electric Company, Puget Sound Power \& Light, and Washington Water Power Company. Utilities that either operate a generation control area or are within BPA's control area that schedule with BPA.

Scoping - The definition of the range of issues requiring examination in studying the environmental effects of a proposed action. Scoping generally takes place through public consultation with interested individuals and groups, as well as with agencies with jurisdictions over parts of the project area or resources in that area. Scoping is mandated by the council on Environmental Quality regulations.

Secondary power - The excess above firm power to be furnished to a customer when, as, and if available.

Secondary revenues - Revenues received from sales of secondary energy, which is the energy produced in excess of firm power due to favorable water conditions.

Secondary sales - Surplus power, both firm and nonfirm, in the Pacific Northwest that is available for sale to the Pacific Southwest.

Sedimentation - The settling of material (such as dust or other particles) into water and eventual deposition on the bottoms of streams, rivers, and so on.

Settling ponds - A pond into which water containing suspended solid material is discharged to allow the solid material to separate from the water by gravity.

Shaping - The scheduling and operation of generating resources to meet load of changing levels. Load shaping on a hydro system ustatly involves the adjustment of storage releases so that generation and load are continuously in balance.

Short-run marginal cost -.. The cost per unit of buying (or the anount saved by not buying) or producing a specified amount of a product in the near future.

Short-term sales - Sales made for a relatively short period of time.

Simulation - The representation of an actual system by analogous characteristics of some device easier to construct, modify, or malerstand, or by mathematical equations. 
Slag - In the context of this EIS, molten or golidifled ash formed from noncombustible matertal. In a fuel by chemlcal action and fuston at boller operating temperatures.

Sludge - The wet, solfd or semisolid matertal former when parteulate atr pollutants and/or sulfur dtoxide ta removed by a wet scrubber alr pollut lon control device.

Slurry pipeline - A means of coal transport fin which the coal is finely ground, mixed with water, and run through a plpeline to the destinatoll, where it is dewatered and combusted.

Small hydro - Generating resources which use runntng water to generate electric energy, but: which are small In generating capaclty. BPA generally considers small. hydro projects to be those capable of producing 25 average MW or less.

Smolt - A juventle salmon or steethead that is migrathe to the ocean and 1 s In a physiological state to transtion from fresh to salt water.

Snowmelt freshet - Increased streamf low from the melting of accumulated snowtall.

Spawning - The act of flsh releastng and fortillalng eggs.

Spill (forced) - Water for which there is not storage capabllity ln the system reservoirs and which could not be used for power producton because the resulting flows would exceed turbine capacity.

Spill (inadvertent/overgeneration) - An anount of water which could have been used to generate electricity but was not because of lack of avaliable market, and fnability to store for later use.

Spill (programmed or planned) - Water intent:lonally passed through a hydroelectric project wthout producting electriclty. This is usually done for tisheries mitigation proposes.

Spoil piles - Heaps of soll and other matertal removed durlng surface minlng, and later used to reclaim the stle.

Sport fish - Fish which are sought by recreational lishermen.

Spot market - A market for electricity characterlzed by negotiation almost solely on the basis of price, for relatively short-term sales.

Storage reservoirs - Reservoirs maintained behind dans for the purpose of retaining excess water readily avallable durting sprtingtime flows as snow melts. Retained water is then released, as necessary, during perfods of lower flow in order to malntain necessary levels of power production. (Water may also be released for other purposes, such as navigation, irrigaton, and matntunance of life support for fish.) 


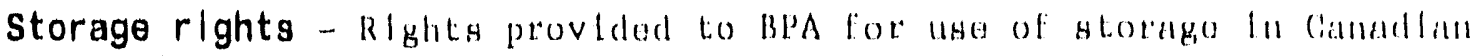
reservolis.

Stratification (chemical) - The separation latio layors allferentiated by chemlat compostiton.

Stratification (thermal) -.. the separation luto layers diflurentiated by temperature.

Subalpine - A terrestrtal zone of hlgh mpland slopes, fmedlately below the

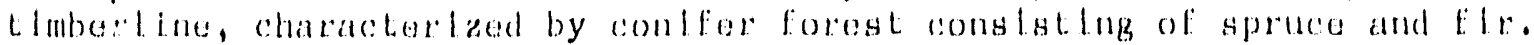

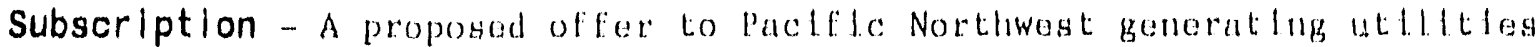
that after complethon of the 'thled AC profect would allow them to buy a portion of 800 MW of uprated lintertite.

Subyearling - A fuvenlle salmonld, normally a fall or summer chlnook salmon, that hatches and migrates to the ocean ln the same your.

Surplus capacity - The anount of excess Intertie capactiy avallable after resurving suffictent capactey for sale of BeA surplus firm and nontem energy.

Surplus energy - Generally energy generated that is beyond the fmmedlate

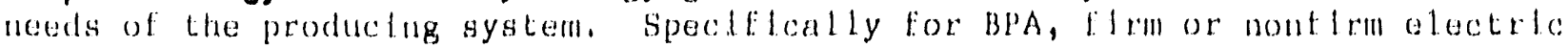
energy generated at f'ederal hydroelectrle profects which would otherwtog be wasted if there' was not a market for the energy.

Surplus flim energy - Energy that can be generated and guaranteed to be provideal, but is excess to demand.

Surplus firm power - Power that can be provided on a guaranteed basls, that is excess to system demand, and that can be provided 1 n an agroed upon shape.

Surplus nonfirm energy - An excess of Interruptible energy that is avallable due to water condtitong better than critical.

Surplus peaking capacity - Electric peaklng capacity for whlch there is no

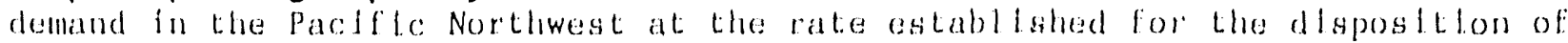
such capacity.

System Reflll - The coordinated hydro system is constdered full, for the purposes of the IDU EIS modeling, when the amount of water stored in reservolrs tis equal to 94 percent of the total avallable space.

System Stock Survival - The survival of mlgrating fuvenile salmon or steelhead of a partecular fish stock from the polnt of entry lato lhe hydroelectric systesm to a polnt below Bonneville Dam.

TSP -.. (See Total suspended partloulates.)

Tallwater ... The water surface inumedlately downstreand from a dian or hydroelectris: powerplant. 
Thermal resources - Gonerating plante whlch convert heat onergy finto electrte enorgy. Coal, ofl, and gats-f fred power plante and muclear power: plants aro common thermal resources.

Thermal structure - Reservolis stratify Lnto thres layers la ammer months:

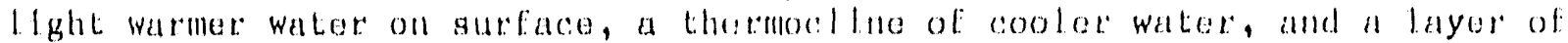
cold axygen deftelent wator on bottim. Kapld drawdowne canse this stratiffeation to breakdown, reductang product lon of food organtame, and coollig water temperatures.

Thermally enhanced oll recovery - A plocess by which heavy cride petroleaul underground ta subfoeted to live stean, whleh reduces the oll's viscostity so It can flow up the pipe to the surfact. Steam trom the process can be lused to coganerate energy, which can be sold to utilltilos pursuant to PuRPA. Thermally enhanced oll recovery is being used fin Calffornta's San foaquin Valley.

Total Suspended Particulates (TSP) - An alr polluthon tertil referting to all mater contalned ln a sample of afr which ls in solid or lifquld form regardless of its particle stze or chemfal compostiton.

Trace elements - Pollutants, of ten metals in lonfo or chemically combined form, which appear in very smell concentrations in water, or hil reference to alr pollution, whlch constitute a very small part of the total anount of particulate pollution by welght.

Transfer capabillty - The amount of power that can be transimlted between one Interconnected system and another, based on installed facllities.

Transfer capacity - (See Iransfer capability.)

Transmission grid - An lnterconnected system of electrical transmission lines and assoctated equipment for the transfer of electric energy tn bulk between points of supply and points of demand.

Transmission losses - Power lost in transmission between one point and another.

Turbldity - A measure of the optical clarity of water, which depends on the 1. lght scatterling and absorption charactertstics of both suspended and dissolved material in the water.

Turbine Capacity - The maximum amount of water that can be passed through the turbines of the dam at any instant.

Utility retall rates - the prices for electrlcity that a utility charges its classes of consumers.

Varlable ECC - The January through July portion of the licc. It is based on expected anount of sprtng runoff wt th avallable forccasts. The vartable can be no higher than the Base liCO. 
Venting ... The release of $1.1 \mathrm{mlted}$ enounts of gases or vapors to malntaln prossures within tanks, plpes, and other equipment involved Ln oll and natural. gas processing and transportation withen deslgn limits.

Water Budget - A part of the Padfle Northwest Power Planning Counctide fish and Whldlffe program ealling for a volume of water to be reserved on a plamnlng basts and released when and te needed to angment strean flows in order to asstst fin the downstieam migration of fuvenlite salmon and steelhead.

Water conditions -.. The overall supply of water to operate the Paclfice Northwest hydroeloctric generating system at any given time, taking finto account reservolr levels, snowpack, needs to provide water or retatn water to meet varlous operating constraints (such as the Water Budget, flood control, How constralnts, ete.), weather condtions, and other factors.

Wholesale rates - The prlces for electrfclty that a utllity charges for power that w\$ll be resold. In BPA's case, BPA also charges wholesale rates to its DSL customers because they buy at relatively high voltage.

Yearlings - Juvenile salmon and steelhead that migrate to the ocean, of ten spending a full year rearing in fresh water.

Zooplankton - Aquatic animals which canot actively swim against the current and which cannot make their own food by photosynthesis.

(VS6-PG-1.445I) 


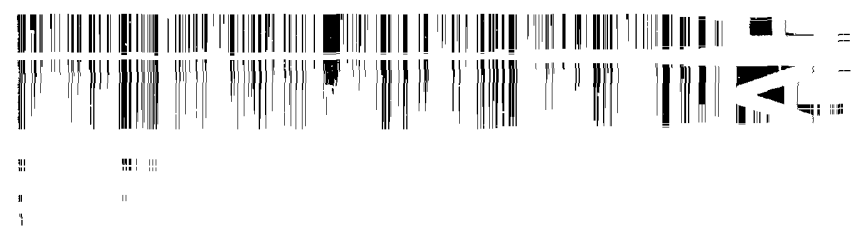




\section{Appendix E}

Affected Environment: Supporting Material 


\section{APPENDIX E}

\section{AFFECTED ENVIRONMENT: SUPPORTING MATERIAL}

Appendix E contains supplemental data on generation resources, both hydro and thermal, and the study reglon's natural environment as described in Chapter 3 of the text, Affected Environment. Tables E.1-4 list characteristics of the region's generating resources. Tables E.5-7 are concerned with air quality. Tables E.8-10 describe water quality and fish. Table E.ll lists wildife species in the study area and its subareas. 


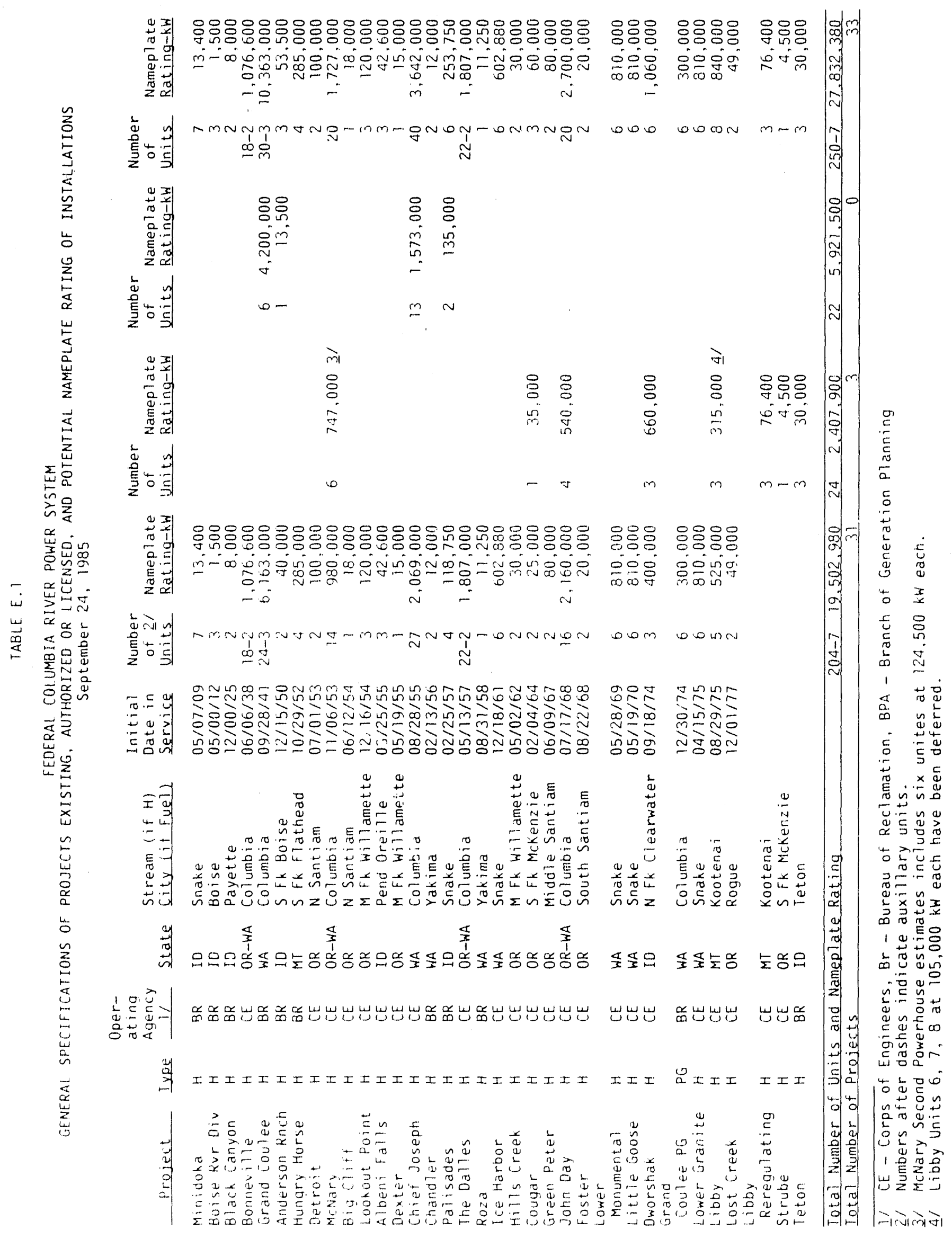


Table E. 2

MAJOR THERMAL GENERATING RESOURCES IN THE PACIFIC NORTHWEST

\section{plant}

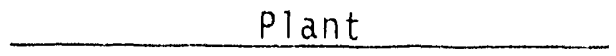

Nuclear

Trojan

WPPSS No. 2

WPPSS No. 1 \& 3 (suspended)

Coal

Colstrip No.

No. 2

No. 3

No. 4

Jim Bridger No. 1

No. 2

No. 3

No. 4

Centralia No. I

No. 2

Boardman

Valmy No. 1 \& 2
Location

Net Capability (MW)

Rainier, OR Hanford, WA

1,080

1,100

Hanford/Satsop, WA

2,490

Colstrip, MT

330

Colstrip, MT

Colstrip, MT

Colstrip. MT

330

700

700

500

500

500

500

640

640

530

522

Source: Western Systems Coordinating Counci1," "Summary of Estimated Loads and Resources" issued April 1986. 


\section{Table E.3}

\section{ELEVATION VARIATIONS IN PNW RESERVOIRS (feet)}

$\begin{array}{lccc}\text { Dam } & \begin{array}{c}\text { Filled } \\ \text { Elevation }\end{array} & \begin{array}{c}\text { Minimum } \\ \text { Elevation }\end{array} & \begin{array}{c}\text { Drawdown } \\ \text { Difference }\end{array} \\ \text { Libby } & 2,459 & 2,287 & 172 \\ \text { Albengry Horse } & 3,560 & 3,336 & 224 \\ \text { Grand Coulee } & 2,062.5 * / & 2,050 & 15 \\ \text { Dworshak } & 1,290 & 1,208 & 82 \\ & 1,600 & 1,445 & 155\end{array}$

* Normal full pool. Maximum lake elevation is 2076 feet. 
Table E.4

LOCATIONS OF SELECTED COAL-FIRED POWER PLANTS AND LOCAL POPULATIONS

\begin{tabular}{|c|c|c|c|c|c|}
\hline Plant & Utility & $\begin{array}{l}\text { Location } \\
\text { Co., State }\end{array}$ & $\begin{array}{l}\text { County } \\
\text { Pop. }\end{array}$ & $\begin{array}{l}\text { Plant Site } \\
\text { Community } \\
\text { Population }\end{array}$ & $\begin{array}{l}\text { Nearby }{ }^{*} / \\
\text { Communities } \\
>1000\end{array}$ \\
\hline \multicolumn{6}{|c|}{ PACIFIC NORTHWEST } \\
\hline Boardman & PGE & Morrow, OR & 7,519 & $\begin{array}{l}\text { Boardman } \\
1,261\end{array}$ & $\begin{array}{l}\text { Umatilla, } 3199 \\
\text { Hermiston, } 9,408 \\
\text { Stanfleld, }\end{array}$ \\
\hline Centralia $1-2$ & $P P L$ & Lewis, WA & 56,025 & $\begin{array}{l}\text { Central ia } \\
11,555\end{array}$ & $\begin{array}{l}\text { Chehal is, } 6,100 \\
\text { Tumwater, } 6,705 \\
\text { Olympia, } 27,447 \\
\text { Fords Prarie, } 2,582 \\
\text { Raymond, } 2,991\end{array}$ \\
\hline Colstrip $1-3$ & MPC & Rosebud, MT & 9,899 & $\begin{array}{l}\text { Colstrip } \\
1,476\end{array}$ & \\
\hline Jim Bridger 1-4 & $P P L$ & Sweetwater, WY & IY 41,723 & $\begin{array}{l}\text { Rock Springs } \\
19,458\end{array}$ & Green River, 12,807 \\
\hline Valmy $1-2$ & SSP & Humbolt, NV & 9,434 & $\begin{array}{l}\text { Valmy } \\
<1,000\end{array}$ & $\begin{array}{ll}\text { Battle Mt., } & 2,749 \\
\text { Winnemucca, } & 4,140\end{array}$ \\
\hline
\end{tabular}

Source: U.S. Department of Commerce, Bureau of the Census, General Social and Economic Characteristics, (states indicated) (Washington, D.C., USGPO, 1983)

\# Nearby communities within approximately $40 \mathrm{miles}$ of the plant site. 
Table E.5

AMBIENT AIR QUALITY $\left(\mu \mathrm{g} / \mathrm{m}^{3}\right)$

\begin{tabular}{|c|c|c|c|c|c|}
\hline & Year & $\begin{array}{l}\text { Annua } \\
\mathrm{SO}_{2}\end{array}$ & $\begin{array}{r}\text { Average } \\
\text { TSP }\end{array}$ & $\begin{array}{l}24 \text { Hour } \\
\mathrm{SO}_{2}\end{array}$ & $\begin{array}{l}\text { Maximum } \\
\text { TSP }\end{array}$ \\
\hline PNW & & & & & \\
\hline $\begin{array}{l}\text { Centralia (1) } \\
\text { Boardman (2) } \\
\text { Colstrip (3) } \\
\text { Bridger (4) } \\
\text { Valmy (5) }\end{array}$ & $\begin{array}{l}1984 \\
1984 \\
1984 \\
1984 \\
1984\end{array}$ & $\begin{array}{r}<5 \\
- \\
3 \\
1 \\
<5\end{array}$ & $\begin{array}{l}53 \\
83 \\
16 \\
51 \\
28\end{array}$ & $\begin{array}{r}104 \\
- \\
27 \\
8 \\
30\end{array}$ & $\begin{array}{r}195 \\
247 \\
43 \\
166 \\
110\end{array}$ \\
\hline
\end{tabular}

Note: Dash means that data are not avallable. 1981 data for concentrations and emissions were used for the air basin modeling.

Sources:

(1) Washington Air Programs (1985)

(2) Oregon Department of Environmental Quality (1984)

(3) Montana Air Quality Bureau (1985)

(4) Wyoming Air Quality Division (1984)

(5) Nevada Division of Environmental Protection (1984) 
Table E.6

FEDERAL AIR QUALITY STANDARDS

\begin{tabular}{|c|c|c|c|}
\hline \multicolumn{2}{|r|}{ Averaging Time } & $\begin{array}{r}\text { Federal } \\
\text { Primary } \\
\text { (Health) } \\
\end{array}$ & $\begin{array}{l}\text { tandards } \\
\text { Secondary } \\
\text { (Welfare) }\end{array}$ \\
\hline $\begin{array}{l}\text { Particulate } \mathrm{PM}_{10} \\
\text { particulate with } \\
\text { aerodynamic } \\
\text { diameter } \leq \text { nomina } \\
10 \text { micrometers }\end{array}$ & $\begin{array}{l}\text { Annual Arithmetric Mean } \\
24 \text { hours (1) }\end{array}$ & $\begin{array}{c}50 \mu g / m^{3} \\
150 \mu g / m^{3} \\
-\end{array}$ & $\begin{array}{r}50 \mu g / m^{3} \\
150 \mu g / m^{3}\end{array}$ \\
\hline $\begin{array}{l}\text { Total Suspended } \\
\text { Particulate }\end{array}$ & $\begin{array}{c}\text { Annual Geometric Mean } \\
24 \text { hours (1) }\end{array}$ & - & $\begin{array}{r}60 \mu \mathrm{g} / \mathrm{m}^{3} \\
150 \mu \mathrm{g} / \mathrm{m}^{3}\end{array}$ \\
\hline Ozone & 1 hour (1) & $235 \mu \mathrm{g} / \mathrm{m}^{3}$ & $235 \mu \mathrm{g} / \mathrm{m}^{3}$ \\
\hline Carbon Monoxide & $\begin{array}{l}8 \text { hours (1) } \\
1 \text { hour (1) }\end{array}$ & $\begin{array}{l}10 \mathrm{mg} / \mathrm{m}^{3} \\
40 \mathrm{mg} / \mathrm{m}^{3}\end{array}$ & - \\
\hline Sulfur Dioxide & 3 hours (2) & - & $1300 \mu \mathrm{g} / \mathrm{m}^{3}$ \\
\hline $\begin{array}{l}\text { Nitrogen } \\
\text { Dioxide }\end{array}$ & Inual Arithmetic Average & $100 \mu \mathrm{g} / \mathrm{m}^{3}$ & $100 \mu \mathrm{g} / \mathrm{m}^{3}$ \\
\hline Lead & $\begin{array}{l}\text { Calendar Quarter } \\
\text { Arithmetic Mean }\end{array}$ & $1.5 \mu \mathrm{g} / \mathrm{m}^{3}$ & $1.5 \mu \mathrm{g} / \mathrm{m}^{3}$ \\
\hline
\end{tabular}

NOTES:

$\mu \mathrm{g} / \mathrm{m}^{3}=\quad$ Micrograms of pollutant per cubic meter of air.

$\mu \mathrm{g} / \mathrm{m}^{3}=\quad$ Milligrams of pollutant per cubic meter of air.

(1) Not to be exceeded on more than 1 day per year.

(2) Not to be exceeded more than one time per year.

Source: $\quad 40$ CFR Part 50 Revised as of July 1, 1987 
Table E.7

COMPARISON BETWEEN EMISSIONS FROM POWER PLANTS AND TOTAL.

EMISSIONS FOR THE REGIONS IN WHICH THEY ARE LOCATED

(1000 TONS/YR)

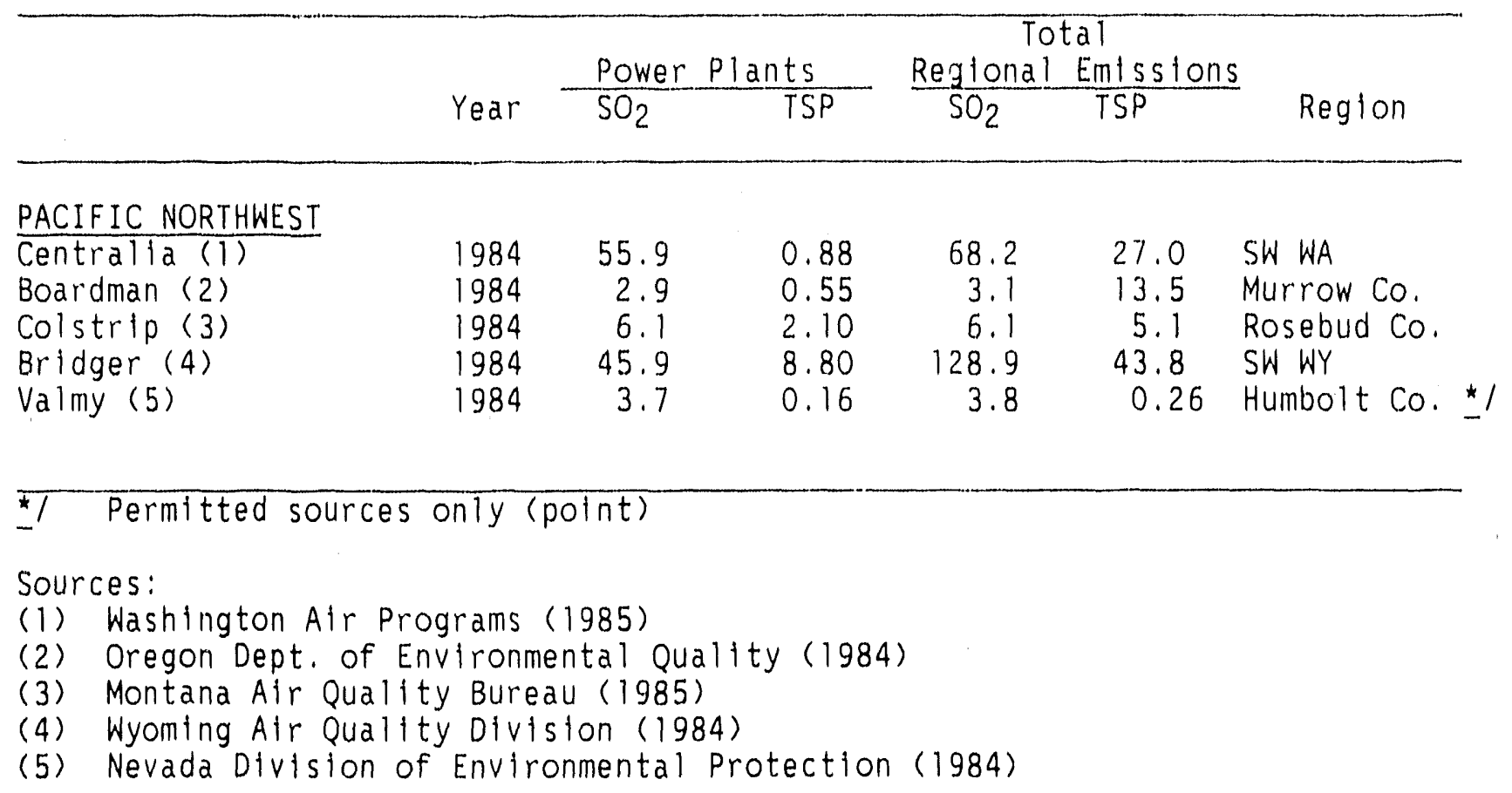


Table E.8

PRECIPITATION CONCENTRATIONS FROM WESTFRN MONITORING STATIONS

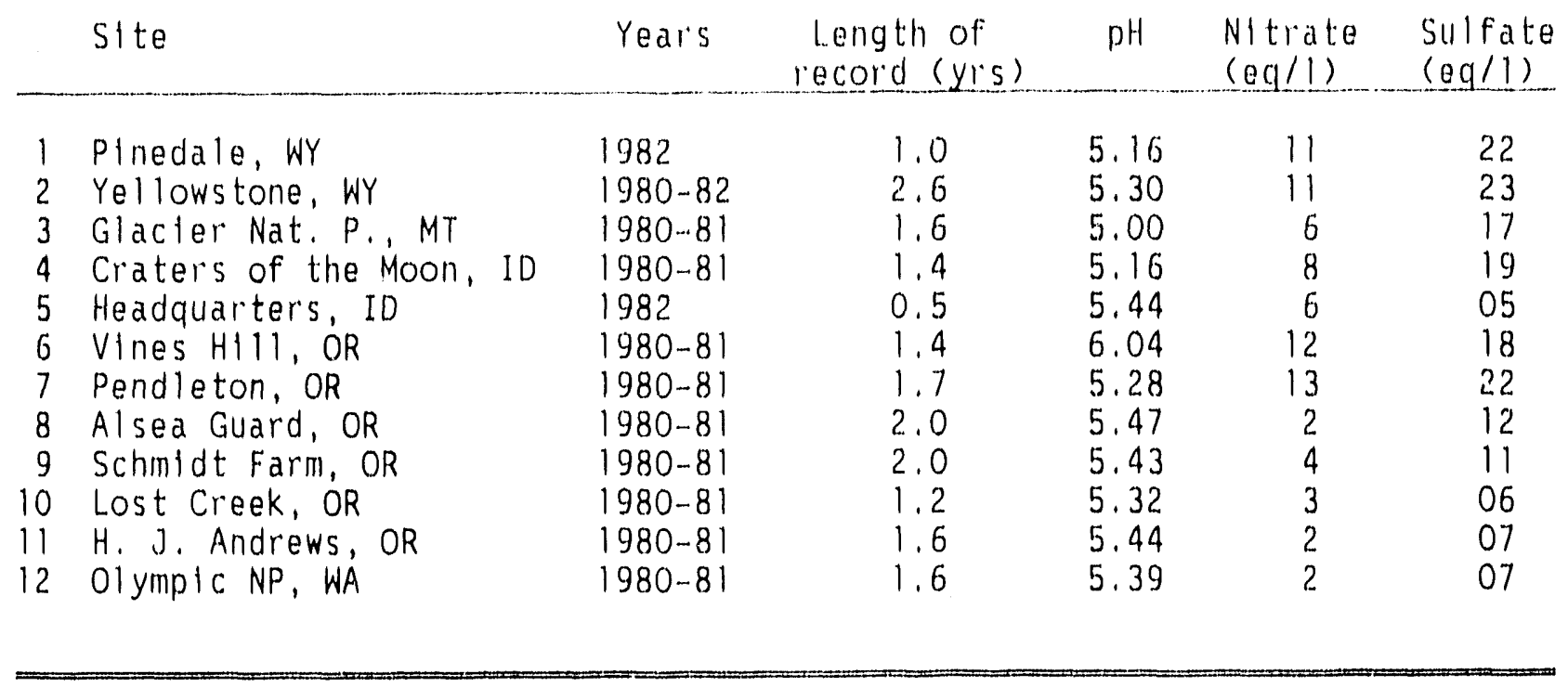

Source: Roth et al. (1985)

eq $/ 1$ = equlvalents per liter 
Table E.9

CHARACTERISTIC FISH SPECIES OF THE COLUMBIA AND

PEACE RIVER BASINS IN THE AFFECTED ENVIRONMENT

Hater Resourco

Matnstem Paca Rivar

Whll tstan Rasarvolr

Peace River Canyon

Johnson \& Gething Creeks

Mica Dam Reservolr

\& Tributarles

Duncan Reservotr

Duncan River

Koocanusa Reservoir

Columbla Bas in

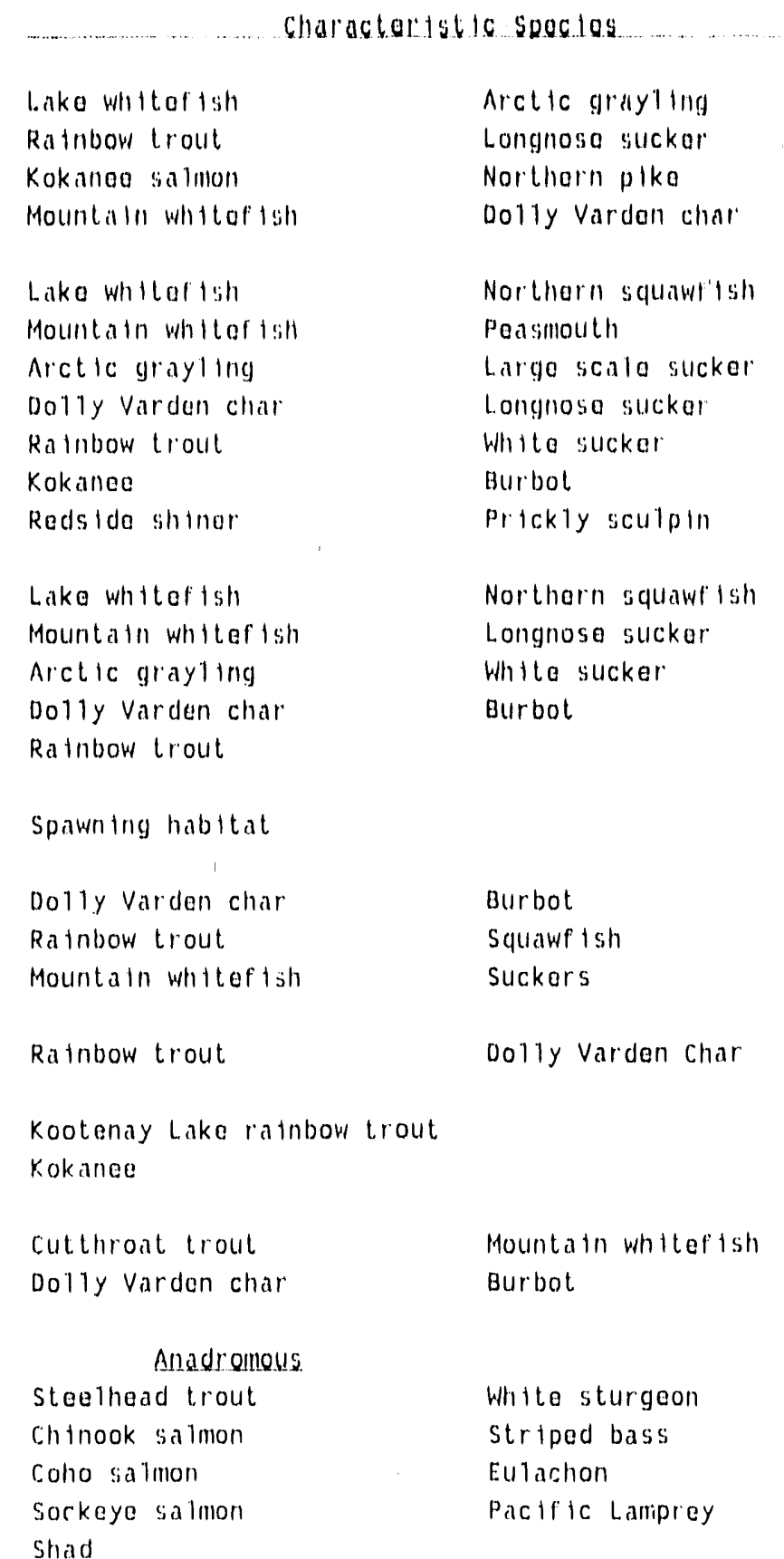




\section{Table E.9 (Cont Inued)}

Colunib) bastu (conl, )
Bas 1 dont

cutthrost trout

Bull trout

Ra lnbow trout

Brook trout

Laka trout

Brown trout

Dolly vardon

kokanec

Laka whiteof ish

pygmy whitafish

Mountaln whlleftsh

slimy sculpin

shorthead sculpth

Hottlod sculptn

Longnose suckar

largescale sucker

peamouth

Nor thern squawf tsh

Northern ptke
Largenoulh bass

Simallmoulh bass

Black crappla

blueg 111

Pumpk inseed

Yollow perch

Black bu11head

Brown bulthead

Yollow bullhead

suckors

Carp

DACD

ranch

shiner:

channel catfish

Chisolmouth

Burbot

Three splned st tcklaback 
Table E.10

\section{CHARACTERISTIC FISH SPECIES INHABITING WATER RESOURCES SUPPLYING ELECTRIC GENERATING PLANTS IN THE AFFECTED ENVIRONMENT}

\begin{tabular}{|c|c|c|c|}
\hline Plant Name & Type & $\begin{array}{l}\text { Assoclated } \\
\text { Water Resource } \\
\end{array}$ & $\begin{array}{l}\text { Charactertstic } \\
\text { Spectes Present }\end{array}$ \\
\hline Colstrip & Coa 1 & $\begin{array}{l}\text { Yellowstone } \\
\text { River \& } \\
\text { Castlerock Reservolr } \\
\text { Castlerock Reservolr }\end{array}$ & $\begin{array}{l}\text { Sauger } \\
\text { Channel Catflsh } \\
\text { Burbot } \\
\text { Shovelnose Sturgeon } \\
\text { Goldeye } \\
\text { Flathead Chub } \\
\text { Walleye PIke } \\
\text { Smallmouth Bass }\end{array}$ \\
\hline Bridger & Coal & $\begin{array}{l}\text { Green Rlver \& } \\
\text { Flamlng Gorge Reservolr }\end{array}$ & $\begin{array}{l}\text { Brown Trout } \\
\text { Ralnbow Trout }\end{array}$ \\
\hline Centralla & Coa 1 & Skookumchuk River & $\begin{array}{l}\text { Chinook Salmon } \\
\text { Coho Salmon } \\
\text { Chum Salmon } \\
\text { Steel head } \\
\text { Cutthroat Trout }\end{array}$ \\
\hline Boardman & Coal & Carty Reservolr & $\begin{array}{l}\text { Sculpins } \\
\text { Smallmouth Bass }\end{array}$ \\
\hline
\end{tabular}


TABLE E.11

\section{CHARACTERIST IC WILDL IFE SPECIES IN FOUR PLANT COMMUNITY
TYPES FOUND IN THE AFFECTED ENV IRONMENT}

Iypical Mamma1s:
Mule Deer
Black Bear
Coyote
Bobcat
Red or Grey Fox
Mountain Lion
Raccoon
Striped Skunk
Long-taileu Wease1
Deer Mouse
Golden Mantled
Ground Squirre1
Porcupine
Beaver
Shrews
Moles
Bats

In Northern Arsds
Only:
Marten
Mink
Mountain Beaver
Northern Flying
Squirrel

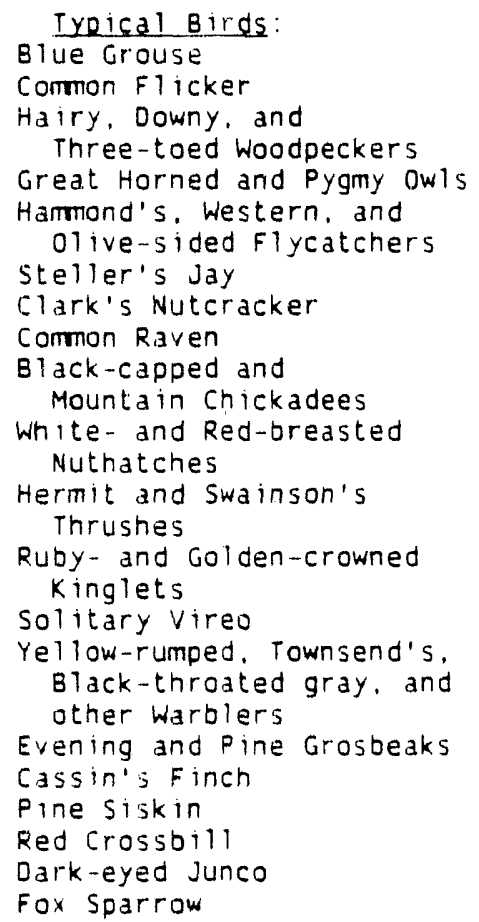

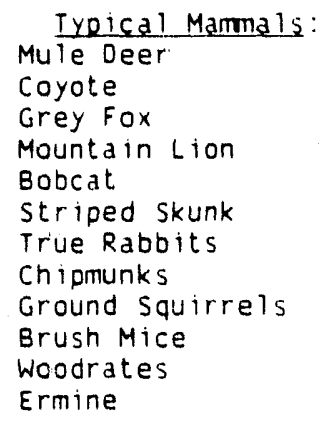

Typica1 Mammals:
Mule Deer
Coyote
Fox
Bobcat
Badge
Kanga oo Rats
Pocket Mice
Pocket Gophers
Ground Squirrels
Prarie Dogs
Harvest Mice
White- and Black-
talied Jackrabolt
In the great plains:
Pronghorr Antelope
Black-footed Ferret
(endangered)

\section{Iypical Birds}

Horned Lark

Shrikes

Western Meadowlark

Brewer's Blackoird

sparrows

Tyoteal Raotors

Red-tailed Hawk Rough-legged Hawk Swainson's Hawk

Ferruninous Hawk

Northern Hareier Burrowing ow 1 american kestrel Frairie Falcon

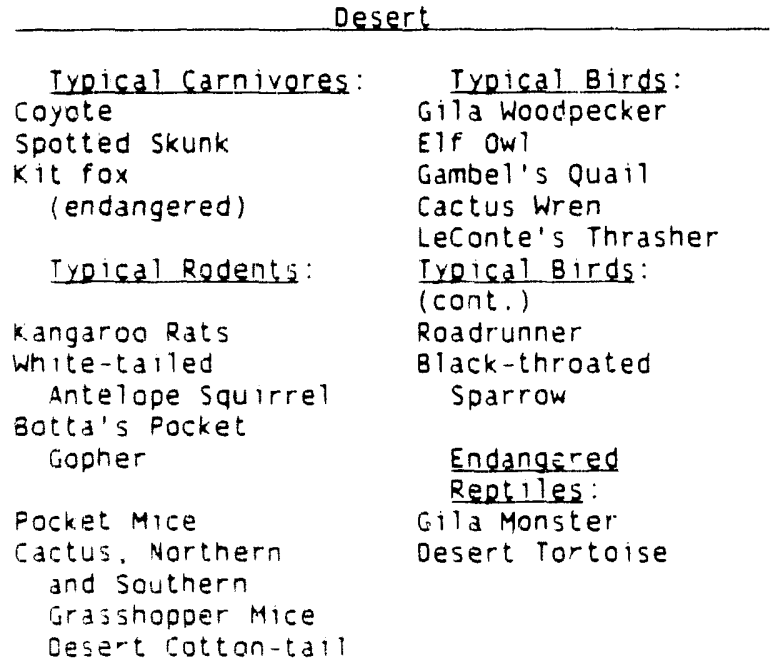




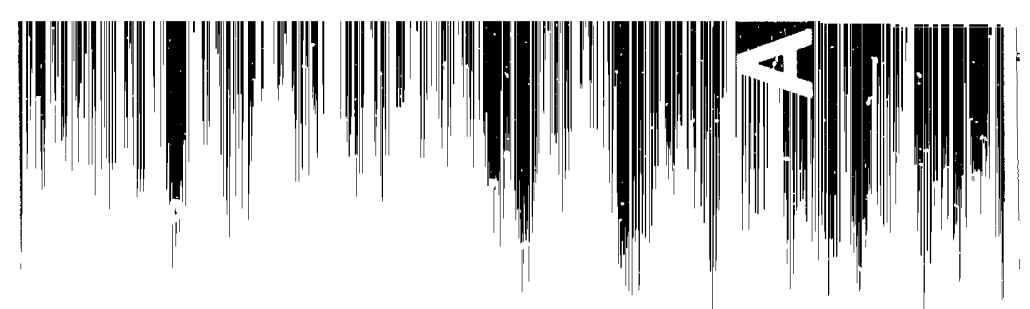




\section{Appendix F}

Environmental Impacts of Generic Resource Types 


\section{APPENDIX F \\ ENVIRONMENTAL IMPACTS OF GENERIC RESOURCE TYPES}

This appendix provides a summary of potential environmental impacts for the various types of resources that BPA or other utilities could use to meet electrical demand (load). The types of resources discussed include conservation, cogeneration, hydro, nuclear, coal, and combustion turbines (CTs). For detail on impacts related to specific existing resources, see Chapter 4 of this Environmental Impact Statement (EIS). Because of their number, all Tables are located at the end of this Appendix.

\section{CONSERVATION}

\section{Indoor Air Pollution}

One of the easiest and most economical ways to increase the efficiency of energy use in a home or business is to prevent loss of heated or cooled air from the building. Conservation programs often are based on tightening buildings; for example, caulking cracks and installing double- or triple-paned windows and storm doors in existing buildings. New buildings also may be built to standards that limit air infiltration. Efforts to tighten buildings may lead to problems of indoor air pollution and moisture problems caused by inadequate air flow into and out of the buildings. Inadequate air flow indoors can result in the buildup of pollutants produced in the building, such as gases and particles produced by combustion (for example, furnaces and people smoking); formaldehyde and other chemicals released by new building materials and furnishings; and chemicals used in cleaners and pesticides. Pollutants in the outside environment also may seep into buildings. The effect of tightening in this case is not clear, however: a tight building may either prevent pollutants from escaping or prevent pollutants from entering. In some situations, house tightening has been shown to reduce indoor concentration of pollutants. Indoor air pollution may lead to adverse health effects given exposure for long periods or to high concentrations.

Particulates are particles or fibers in the air that are small enough to be inhaled. They are suspended in tobacco smoke and wood smoke; are produced by unvented gas appliances, kerosene heaters, and asbestos construction materials; and come from soap powders, pollen, lint, and house dust. When inhaled, particulates may cause nose, throat, and eye irritation. When they lodge in the lungs, particulates may cause lung cancer, emphysema, heart disease, bronchitis, and respiratory infections. Particulates also carry radon and its progeny (see below).

Combustion gases include carboll monoxide and nitrogen oxides. They are colorless and odorless gases that are produced by kerosene heaters, wood stoves, and unvented gas appliances. Carbon monoxide, also found in tobacco 
smoke, can cause lung ailments and impaired vision and brain functions. In high concentrations carbon monoxide can be fatal. Nitrogen oxides can cause lung damage and lung disease.

Formaldehyde is a component of urea-formaldehyde foam insulation and some glues used in plywood, particle board, and textiles such as furniture, drapes, and carpet. Formaldehyde has especially been a problem in mobile homes, with their relatively small living area and construction with more particle board and plywood than conventional houses. However, new board standards for manufactured housing have solved this problem. Relatively high levels of formaldehyde are likely to be found in new houses and businesses, where materials have not had time to release much of the gas. Levels also increase with higher temperatures and humidity. Formaldehyde, a strong-smelling, colorless gas, can cause nose, throat, and eye irritation; studies have shown that it can cause nasal cancer in animals.

Other chemicals that may provide indoor air pollutants include those in synthetic materials, pesticides, aerosol sprays, cleaning products, and paints. These chemicals may irritate skin, eyes, nose, and throat, and affect the central nervous system and metabolic processes. Interactions of two or more chemicals may be particularly harmful.

Moisture is produced by leaks; activities using water such as laundry, dishwashing, bathing, and cooking; people breathing and perspiring; and the soil beneath the building. Moisture can aid the growth of mildew, mold, bacteria, and viruses. It also can act a: a solvent for formaldehyde and other pollutants, increasing the rate of release of harmful gases.

Radon is a colorless, jorless, radioactive gas, a decay product of uranium. Radon seeps into homes and other buildings from the soil beneath and from some building materials such as concrete and brick. Radon quickly decays into several types of "progeny" that can be carried by particulates in the air to lodge in the lungs. Increased levels of particulates thus increase the potential levels of exposure to radiation from radon emissions, al though radon unattached to particulates has a greater chance of sticking in the lungs. As radon progeny decay, they emit alpha radiation that may damage lung tissue. Prolonged exposure to radon increases the risk of lung cancer: between 5 and 15 percent of all lung cancers may be caused by radon (the Surgeon General attributes 85 fercent of all lung cancers to smoking). Exposure to radon also may cause birth defects and genetic damage.

Currently little information exists related to acceptable levels or direct health effects of these indoor air pollutants, and individual sensitivity to each pollutant varies. BPA has performed extensive monitoring and research on radon, however. About 3.5 percent of the Northwest houses monitored so far appear to have levels of radon higher than BPA's "action level." BPA's current residential weatherization programs for existing homes include the following steps: 
1. Informing residents about the sources of indoor air pollution and about practical steps to reduce indoor pollutants.

2. Offering to monitor each participant's house for radon levels.

3. Paying 85 percent of the cost of ain air-to-air heat exchanger (up to $\$ 850$; if radon levels exceed $50 / 1$ (picocuries per liter of air) inside the house. For low-lom participants, BPA pays 100 percent up to $\$ 1000$.

In the Record of Decision for BPA's New Energy-Efficient Homes Programs, BPA states that it has decided to offer four "pathways" to guide construction of energy-efficient new homes. BPA designed the pathway concept to provide builders and consumers with a menu of construction methods. The selection of the four construction pathways chosen was based on balancing five major factors: environmental, economic, technical, public concerns, and legal. The chosen pathways exhibit health effects close to those assuming current construction practices were continued without change; substantial energy savings; and maximum program flexibility at reasonable cost. The chosen pathways all include several environmental mitigation requirements: exhaust fans for kitchens and bathrooms; designated air supplies for combustion appliances; information on indoor air quality; Housing and Urban Development product standards for formaldehyde emissions from structural board materials; and the offer of radon monitoring and radon source control.

Several methods can mitigate the impacts of indoor air pollution. The most effective mitigation is prevention. Homeowners should avoid or isolate from the living area building materials and household chemicals that are sources of harmful gases. Smoking should be discouraged. Fireplaces and woodstoves should have tight-fitting doors and sources of outside air for combustion. Fires should not be allowed to smolder. Dehumidifiers may be used to remove moisture from the air. Air-to-air heat exchangers and other types of mechanical ventilation systems may be used to provide ventilation needed to dilute all types of indoor air pollutants.

\section{Sources:}

Bonneville Power Administration 1983 Wholesale Power Rate Final Environmental Impact Statement, September 1983, p. IV-49-51.

BPA, Issue Backgrounder: Energy Efficient New Homes \& Indoor Air Pollutants, August 1987.

BPA, Backgrounder: Understanding Indoor Radon, June 1987.

BPA, Report No 10: Radon Monitoring Results from BPA's Resident al Weatherization Program, January 1989, p. 2.

BPA, Final Environmental Impact Statement on New Energy-Efficient Homes Programs: Assessing Indoor Air Quality Options, Volume 1. August 1988, Summary. 
BPA, New Energy--Efficlent Homes Programs Record of Decision, February 1989.

\section{Other Environmental Impacts}

The most feasible types of conservation efforts include weatherization and other means of increasing the efficiency of energy use in bulldings; increased efficiency of energy use by irrigation pumps and other machinery; and increased efficiency of transmission and distribution of electricity. Increasing the efficiency of energy use in buildings involves the production and transportation of insulation materlals, weatherstripping, caulking, storm windows, infiltration barriers, and so on. It also could require the installation or replacement of machinery. Increasing the efficiency of irrigation pumps could require replacement of existing pumps wholly or in part. Increasing the efficiency of transmission and distribution al so could require the replacement of equipment. All conservation efforts require personnel to audit and test existing buildings and equipment and to install or replace equipment and machinery.

Environmental impacts can be caused by the steps needed to provide the materials and machinery to the user. Such steps include: mining raw materials; manufacturing materials such as metals, glass, and insulation; fabricating the finished products; transporting the raw and finished materials; and installing the conservation measures at the point of use. Each step involves energy consumption and labor.

Sophisticated devices such as heat pumps and air-to-air heat exchangers require more raw material, manufacturing, and fabrication than construction materials such as insulation. They also may require more energy in transportation, more highly trained installers, and more maintenance.

Potential environmental impacts from manufacturing and transporting conservation devices and materlals include increased energy use, air and water emissions, land use, employment, and other economic effects. Disposal of such devices and materials also could cause adverse impacts.

In general, however, the potential adverse environmental impacts that could result from the production and transportation of conservation materials are relatively insignificant. In addition, any adverse effects likely would be orfset completely or partially by the environmental benefits of conservation. Because conservation measures result in increased efficiency of energy use, they could result in reduced operation and development of generation resources. Reduced operation and development of generation resources could result in less related environmental effects. A possible increase in employment for manufacturing, transporting, installing, and inspecting conservation measures could be a positive socio-economic effect. 


\section{Sources:}

BPA, Final Environmental Impact Statement: The Role of the Bonneville Power Administration in the Pacific Northwest Power Supply System, December 1980, p. IV-123.

BPA, Environmental Assessment: Proposed Power System Changes to Implement the Water Budget, May 198j, Appendix C, p. C-1 - C-4.

\section{COGENERATION}

Cogeneration is the generation of power in conjunction with (usually) an industrial process, using waste heat from one process to fuel the other. Cogeneration is a well-established technology that was relatively common at manufacturing plants early in this century. Cogeneration peaked as an electricity generating technology in 1950, but declined as electric utilities dev loped larger central station generation with its economies of scale. With the passage of the Public Utility Regulatory Policies Act (PURPA) in 1978, interest in cogeneration has grown. The relative decline in fossil fuel (especially natural gas) prices and the growing avallabllity of "off-the-shelf" equipment has increased the popularity of cogeneration.

The use of cogeneration can result in less wasted thermal energy and greater fuel efficiency than if industrial and electric generating processes were carried out separately. The efficiency of jointly producing electricity and (industria1) "process" heat is estimated to reduce fuel consumption on the order of 15-30 percent when compared with separate production. Cogeneration of electricity can result in reduced need for operating and bullding central-station generators, with a concomitant reduction in emissions and other environmental impacts.

\section{Technology}

Cogeneration technologles are of three busic types. The first type, the steam topping-cycle sjstem, includes a steam generator in which fuel is fired to produce steam. The steam turns a turbine-generator first and then is used for process applications. In the second type, a bottoming-cycle system, residual heat left after process use is used to generate electricity. The third type, a gas turbine cogeneration cycle, uses a CT to drive a generator. The exhaust heat from the turbine is used for process applications, either directly or by way of a steam cycle.

Off-the-shelf equipment for the cogeneration of electricity and steam is available from several manufacturers. Flexible acquisition arrangements can meet the specific needs of most individual users. Available generators for steam topping- or bottoming-cycle systems can be fitted to use gas, oil, coal, wood wastes, red and black liquors, carbon monoxide and other gases, and other fuels. The gas turbine cogenerating systems generally use natural gas, \#2 distillate, or naphtha fuels for commercial applications. 


\section{Potential}

The region has about 790 megawatts (MW) of installed cogeneration capaclty, most in the wood and paper industrles. The largest percentage of the potential for cogeneration in the Pacific Northwest is in the same industry (paper and lumber). Other major industrlal applications in the Northwest are chemicals and oll and food processing. Municlpal sponsors account for some potential, also. Most cogenerators in the Northwest are expected to generate electricity for their own use only. Some, however, encouraged by PURPA, may sell excess power to their local utflities.

Energy production by cogenerators is difficult to predict. It depends on varlous factois, such as fuel prices, retall electricity prices, electricity buyback prices, and industrial production activity. When called upon to operate, however, cogeneration facllities generally have high availabilities, 80 percent or higher.

As might be expected, utllities that are faced with loss of load caused by cogeneration often offer special rates or service to retain the load of potential cogenerators. Because of reliability considerations, utility backup of cogeneration is required.

\section{Expected Impacts}

The types of environmental impacts to be expected from cogeneration facllities are approximately the same as those of the technology from which the system derives its energy. That is, for example, the expected impacts from a cogenerating facllity that burns oll for fuel are simllar to the impacts from either an industrial or a power-generating ofl-fired plant. The impacts would be primarlly local and may be greater than either the industrial or generation process alone. The type of process that fires fuel to produce steam first for generation and then for an industrial use typlcally burns 10 to 20 percent more fuel when cogenerating than when producing solely process steam. Depending on the fuel used and the efficiency of the plant, adding cogeneration of electricity to an industrial plant may increase the emission of particulates and gaseous products of combustion and may increase water pollution and consumption.

In particular, since the greatest potential for cogeneration in the Northwest is in the wood products industry, the result could be an increase in the release of particulate matter, heavy organic materials, and fine particles of inorganic ash. Particulates from wood burning are most often blamed for reduced visibility and respiratory irritation. Other products of combustion are sulfur dioxides, carbon monoxide, hydrocarbons, and nitrogen oxides. other, lesser, potential environmental impacts of wood burning for cogeneration include water pollution from discharged waste water or from runoff. Domestic water sipplies, fisheries, and recreational areas could be affected. Disposal of solid wastes from wood fuel burning generally is not an environmental problem as long as proper wet handling methods are used and there were no toxic chemicals in the wood fuel or the combustion process. 


\section{Mitigation!}

Existing factiltes retrofited for cogeneration ma be regulaed to add alr pollution control egulpment to handle the addlthonal releace of gases and pollutant: Boflers and firing techntques deslgned for efficlency also can reduce emisstons over those to he expected from less effictent factlities. Cogenerators also are required to comply with federal, state, and local environmental reguliations.

If cogeneration becomes a significant energy producer lin a particular area, a net reduction in environmental impact"s could occur if the need for central-station generating plants is reduced.

\section{Sources:}

BPA, Final Environmental Impact Statement: The Role of the Bonneville Power Administration in the Pacific: Northwest Power Supply System, December 1980, pp. IV - 129...133.

BPA, Lnvironmental Assessment: Proposed Power system Changes to Implement the fater Budget, May 1983, Appendix C, pp. C-1 - C..8.

Bonneville Power Adninistration 1983 Wholesale Power Rate Final Environmental lmpact Statement, September 1983, pp. IV-51-52.

BPA, Cogeneration Potential in the Pacific Northwest, December 1988 , Appendix B.

Northwest Pover Planning Counci1, 1989 Supplement to the 1986 Northwest Conservation and Electric: Power Plan, Volume 1, pp.50-51.

\section{HYDROELECTRIC}

Hydroelectricity is a renewable resource. Water spins turbines, which drive generators to produce electicily. The Pacific: Northwest has many streams with flow and head (difference in water level) sufficient to produce economical electrical energy. A hydro facility may have purposes in addition to power generation, including irigation, navigation, flood control, recreation (for example, fishing, boating, and camping), and water supply for domestic and industrial use. letermining an acceptable balance of these often-conflicting uses is a mater for considerable debate within the region.

Large Hydre

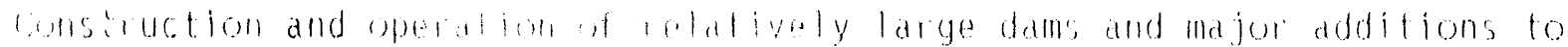
those tacilities have modeninhly ignificant environmental impacts. Dur ing

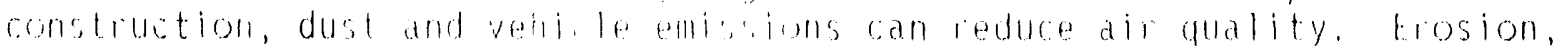
dust, and other dishage, an redme water quality and increase siltation.

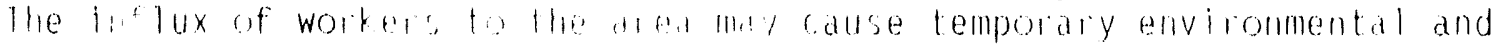


socloeconomic effects as workers seek housing, transport, and food. The factllties themselves requlre huge quantitles of earth flll, steel, and concrete.

The dams lmpound huge volumes of water, flooding and eroding extenslve areas and disrupting land use, lncluding wlldiffe and human habltat and cultural (such as histortcal) sttes. Dams dlsrupt certain recreational uses of the river but perint others by the creation of reservotrs. Dams can assist "rrigation and flood control by enabling water storage.

One of the most significant envfronmental fimpacts dams can have is harm to anadromous (migratory) and resident fish. Impounded water disrupts the migration of juvenlle fish downstream to the ocean and adult fish upstream to spawning areas. Problems artse due to water turbldtty, increased water temperature, and slow or absent current. Delay of migration can reduce the survival rate of juventle fish and decrease spawning success of adults. Impounded water also can adversely affect the food chain, including the organisms eaten by fish and the species that prey on game/anadromous fish.

Lack of passage facillties can prevent migratory specles from reaching spawning and rearing areas. Even with passage factlities, migration is generally impaired. Fish migrating downstream may be caught in the turbines and be killed; or, If stunned, fish may become prey to scavenger species on the downstream (tallwater) side of the dam.

The extent of turbine mortality depends, at least in part, on the type of turbine used. Bulb turbines, usually used on low-head hydro facilitles, may result in less harm to fish than conventional types of turbines.

Water spilled at the dam can cause nitrogen supersaturation of fish in the tallwater, another potential cause of death. Reduction in numbers of fish can reduce the food supfly for bald eagles and other animals.

Hourly, dafly, and seasonal operations of the river for power purposes can conflict with other uses. Forebay (upstream side of the dain) and tallwater fluctuations can discupt recreation and navigation for safety and access reasons. Fluctuations also can reduce the abllity to withdraw water for irrigation and cause erosion of riverbanks. Animal habitats, nesting areas, and spawning gravels can be alternately stranded and flooded. The more the hydro system is used to meet peak rather than base loads, or to provide reserves and short-term replacement power, the more frequent and rapid (and thus harmful) fluctuations could be.

Increased Ffficlency of Existing Hydro

The Northwest Power Planning Council (Council) has Investigated the benefits and cost of increasing the efficiency of existing major hydroelectric facilities in the Northwest. Various ietrofit measures potentially can improve project efficiency and capacity and energy capability. Improvenents to turbine efficiency also appear to reduce the mortality of fish passing 
through the turblnes. The Counc 11 has estlmated that 112. MW of hydropower efflclency lmprovements are currently cost effectlve (lndtvidual measure costs range from I to 11 mllis per k: lowathour In 1988 \$), Increasting the efficlency of the hydro system could mitlgate the slgnlficant environmental Impacts of the factilties by reducing the lmpact per kllowathour of generation. Hydropower tiffictency Improvements are included as a resource fn the Councll's 1989 Supplement to the 1986 Northwest Conservation and Electric Power Plan.

"Flrming" Nonftrm

Another facet of hydropower factlity efficlency is identifled by the councll as "better use of the existing hydropower system." This strategy also is known as "flrming" the nonftrm energy that is avallable in water years that are better than critical. The beneftt of flrming nonflrm energy is in making the avallabllity of inexpensive nonflrm energy more rellable. The councll has identlfled several methods to back up the region's hydro resources: lmproved coordination of the U.S. and Canadian sections of the Columbla River; purchase of energy from existing power plants; load management techniques; and use of new power plants. These suggested methods for firming nonfirm energy could have significant environmental effects, particularly the methods involving use of existing or new power plants.

The Councll has investigated cost-effective ways to firm the energy production of existing hydropower facilities and suggests using CTs. The Council's studies show that about 3500 MW of CT capaclty may be cost effectlve to add to the reglon's power system before adding typlcal baseload generation such as coal plants. Firming the hydro system's nonfirm energy production with that amount of CTs would produce about $3000 \mathrm{MWN}$ of flrm energy. See the CT section of this appendix for a discussion of CTs' potential environmental impacts.

Sma 11 Hydro

The region generally agrees that the Columbla River and the other regional streams will support no further major hydro development. However, sites do exist for small hydro installations, and small energy producers are encouraged by PURPA. Small hydro potentlal could come from three sources: presently existing plants; newly installed generation facilitles at existing nonpower (for example, irrigation or flood control) dams; and generation facllities at new dams. Small hydro plants generally are low-head projects; reservolrs are small or nonexistent. Technology for small hydro is similar to that for large hydro, except that low-head projects often use a bulb turbine rather than the Francis or Kaplan turblnes nearly always used for high-head projects. Bulb turbines may result in less harm to fish than conventional types of turbines.

Small hydro installations generally may be constructed at reasonable cost. The Council estimates that 410 average megawatts (aMW) of firm energy may reasonably be assumed to be avallable at a levelized cost of $60 \mathrm{mlll}$ s per kilowathour or less $(1988$ s). Construction times also dre relatively short, a) though licensing may take considerable time. 
The potential envfromental fmpacts of sillall hydro factllthes are stmllar to those ror large hydro, but would be of proportionately smaller scale.

Development of hydroelectilc potental at an extsting dam llkely would result In less envtronmental harm than development of a new ste. Site-specific constderations for small hydro development would include current and filtura recreational uses of the land and water; extsting flsh and whldife migratlon, habltat and spawning areas; and htstorlc and archoologlcal sites.

The Federal Energy Regulatory Commlsston (ftrC) has Jurtsdictlon over the terms of llcenses that govern sind l hydro operating comdtlons. Many Federal laws apply to hydroelectrie profects. The FlRC revlew process addresses fish, wlldlffe, and envtronmental tssurs. local, state, and Federal agencles

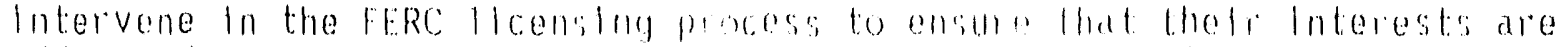
addressed. In addition, local and "tate regulatlams apply to hydro projects.

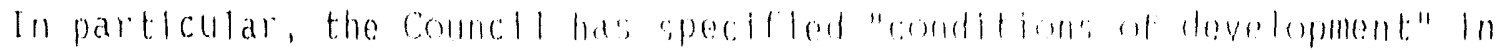

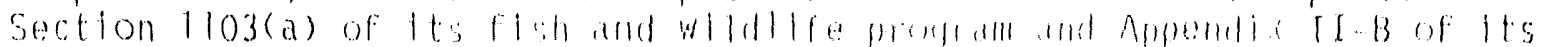

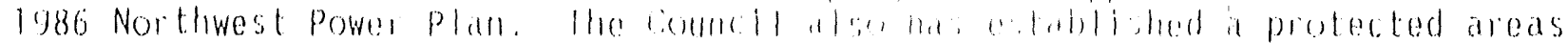

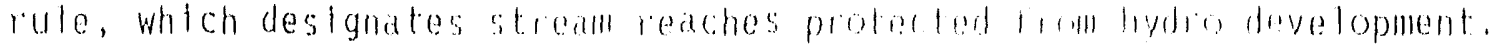
Hydropower development in the'se protected stomall baches conld callse unacceptable risk of loss to fish and whllife poeser, the li productive

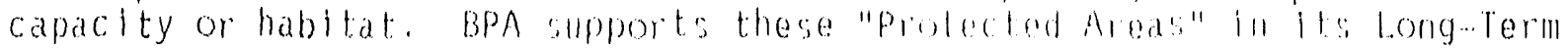
Intertle Access Pollcy by precluding lotertilo accos for power from plants on protected stream reaches. The counct1's destgnatlon of protected areas is based on the Paclfic Northwest Hydropower Site Database developed by the Counc 11, the U.S. Corps of Englneers, and BPA; and the Hydropower Assessment. study conducted by the council, BPA, Federal agomites, states, and tribes.

Table F-1 presents information regarding environmental concerns associated with a small hydroelectric plant. Even if individual sillall hydro factlities have relatively mincor environmental effects, the cummlative lmpacts of many silall hydro faclilties within a single river basincould be signiflcant. BPA, the Council, reglonal interest groups, and the FERC IIcensing process all wili monitor and assess cumblatlve impacts of small hydro facillties fo the Northwest.

Solrces:

BPA, Flad Lnvironmental Lmpact Statement: The Role of the Bonneville Power Administration in the Pacific Northwest Power Supply System, December 1980, pp. IV-133-137.

BPA, Environmental Assessment: Proposed Power system Changes to Implement the Water Budget, May 1983, Appendix C, pp. C, a $, C,-6$.

Bonneville Power Adninlstiation 1983 wholesale Power Rate Flnal Environmental Impact statenent, september 1983, mp. IV 5s.53. 
Northwest Power Planning Counc11, 1989 Supplement to the 1986 Northwast Conservation and Electric Power Plan, Volume 1, pp. 47-48.

U.S. Department of Energy, Energy Technology Characterizations Handbook, Envlromental Pollution and Control lactors, Thlid Edtiton, March 1983.

U.S. Departiment of Energy, Energy Technologles and the Environment, Envfronmental Informatlon Handbook, october 1988.

\section{NUCLEAR}

The Pacillc Northwest recelves electrical energy from two operating nuclear plants within the regton, the rrojan plant, owred and operated by portiand coneral Electrle company (PGE), and the Washlngton Publle: Power Supply system (Supply system) Nuclear Plant (WNP) No. 2. r:o other supply system plants, hinp I and 3, doe partially completed and are mothballed. If completed, they could supply power for the regton's future needs. BPA and the supply sycten are cooperating to develop a plan for partally reflnancing the plants; future flnancling for preservation and completion is uncerlialn. (BPA and the Supply system also are considering repowerlng the Hanford Generating Project, which was powered by steam from the plutomlum-producing Hanford N-Reacior.

Repowering llkely would use cod or natural gas rather than nuclear fuel to generate steam.)

Nuclear generation involves plant construction; urantum minting and preparation; fuel fisstoning to generate electrlcal energy; spent fuel disposal: and plant decominissioning. All phases of plant construction and fluel processing lise substantial quantities of energy, for transportation, machinery use, process use, and so on. Tables F-2 through F-.10 show the natural resource use and envtronmental lmpacts of the steps in nuclear generation, whlch are discussed below.

Fuel Mining and Processing

Mtning. The uranium for generating plants in the Northwest probably will be mported from outste the reglon. Urantum is mined by both underground and open..plt technlques; most of the current U.S. production of urantum comes from open plt mines. Surface (plt) mining of urantum has several adverse environmental tmpacts. The mining necessary to support a 1,000-.MW nuclear plant disturbs 54.6 acres per year. Mining produces significant amounts of alp pollution from the operation of heavy mining equipment and the breakup of the uranium ore. Alr pollution consists of particulates, sulfur dloxide, nitrogen oxides, and radon and radon daughters. Surface mining al so can produce water pollution caused by runoff from plles of soll and mined surfaces. Alr and water pollution contains heavy metals and low-level radioactivity. Radiation exposure is strlctly monttored and llmited for underground uranium miners. Radiation hazards are not signtficant in U.S. low-grade open-pit mines. 
Milling. During milling, at the mine site, uranium is extracted from the ore and concentrated, using chemical and mechanical processes. The milling process produces significant amounts of particulate and thermal emissions and releases radioactive and other minerals into the air and water. It also results in close to 200,000 tons of radioactive solid waste (tailings) annually, which must be stabilized to prevent wind and water erosion.

Conversion. The refined uranium ("yellowcake") then is converted to a volatile uranium hexafluoride. Conversion occurs in only a few U.S.

locations, which are outside the West. The conversion process results in air and water pollution, some of which is radioactive, and heat discharge to the air. The resulting radioactive sludge is held for reprocessing or burial.

Enrichment. Next the volatile uranium hexafluoride compound is enriched by means of gaseous diffusion or gas centrifuge. Enrichment in the U.S. is done by Department of Energy contractors in a few locations outside of the West. Enrichment uses substantial amounts of energy, water, and other resources, and results in air and water pollution and thermal discharge.

Fabrication. Fuel fabrication consists of chemical conversion of uranium hexafluoride to uranium dioxide and mechanical processing of the fuel pellets and fuel elements. Fuel fabrication results in air pollution as a result of the process itself and of the energy needed for the process. Air, water, and solid wastes all are radioactive to some extent; solid wastes must be buried. In addition, heat is released to the air.

Plant Construction and Operation

The environmental impacts of constructing a nuclear plant are similar to those for constructing any large generation plant or other industrial facility. Plant construction disturbs land areas, uses large quantities of building materials, and can have socioeconomic impacts due to the large number of workers employed.

The two most common types of reactors are boiling water and pressurized water. The Trojan plant is a pressurized water reactor; WNP-2 is a boiling water reactor. The two types have similar envircnmental effects.

In the reactor, atoms split in a chain reaction called fissioning, producing energy. The released energy heats water to steam. The steam turns a turbine, which drives an electrical generator. The plants use considerable amounts of water for cooling. The water, generally from a nearby river, is recycled through the plant, but that lost through evaporation must be made up. Levels of radioactivity in air and water discharges are low, and are regulated by Federal law. Water vapor from cooling towers carries harmful salts, which fall onto surrounding land areas. Nuclear plants also produce solid and other waste products, some of which are radioactive at a low level. For example, a boiling water reactor nuclear plant produces 18,900 cubic feet arnually of wet low-level radioactive waste that must be embedded in concrete for disposal and 3,360 cubic feet annually of dry low-level radioactive waste that is encased in drums for disposal. 
Fossil fuel emissions result from the periodic operation of auxiliary equipment, including diesel-powered emergency generators and pumps, for testing.

Spent nuclear fuel elements are removed periodically during refueling and generally are stored at the plants pending designation of a permanent disposal site. During decommissioning, the parts of a nuclear plant must be dismantled and stored safely for hundreds of years to prevent release of massive quantities of long-lived radiation. Final disposal of radioactive parts of decommissioned nuclear plants also will await establishment of a permanent radioactive waste disposal site.

Within the region, design is underway for the Hanford Waste Vitrification Plant, to be built near Richland, Washington. Construction of the plant is scheduled to start in mid-1990, with operation projected for 1999. At the plant, highly radioactive liquid wastes now held in underground storage tanks at Hanford will be solidified. The wastes, including chemicals, heavy metals, and other toxic materials, will be heated and poured into cylinders to harden. The vitrified wastes will be shipped offsite for permanent disposal underground. Operation of the plant will be for at least 15 years to complete processing the existing waste.

\section{Sources:}

BPA, Environmental Assessment: Proposed Power System Changes to Implement the Water Budget, May 1983, Appendix C, pp. C-10-C-12.

Bonneville Power Administration 1983 Wholesale Power Rate Final

Environmental Impact Statement, September 1983, pp. IV-53 and IV-70-7I.

Northwest Power Planning Council, 1989 Supplement to the 1886 Northwest Conservation and Electric Power Plan, Volume 1, p. 62.

Bonneville Power Administration, Final Environmental Impact Statement, Intertie Development and Use, April 1988, Volume 4, Appendix F, pp. F. 1-7 - F-1-8.

"Solidifying radioactive wastes," Electric Light \& Power, Volume 67. Number 3 (March 1989), page 44.

U.S. Department of Energy, Energy Technology Characterizations Handbook, Environmental Pollution and Control Factors, Third Edition, March 1983.

U.S. Department of Energy, Energy Technologies and the Environment, Environmental Information Handbook, October 1988.

COAL

The Northwest receives power from 13 coal-fired generation plants. Because coal generation is a proven technology, in recent years coal plants have been 
considered to be the baseload resources of the future. The Western U.S. has about half of the nation's coal reserves, most near the surface and with low sulfur content. Because of low production costs and low sulfur content, most of the nation's incremental consumption of coal is expected to be met from Western sources.

Increasing knowledge about the "greenhouse effect," the possible warming of the Earth caused by growing amounts of carbon dioxide in the atmosphere, has made future coal use for power generation less certain. Acid precipitation, caused by emissions of sulfur dioxide and nitrogen oxides, also has been linked to coal-fired generation plants. In addition, several factors may affect the development of coal reserves in the West: resource scarcity, especially of water; high transport costs to primary coal-use regions in the East; and ecological fragility of many western coal-producing areas. Coal mining and use are regulated by Federal and state laws that restrict water use and impact on water quality, preclude mining in certain areas including prime farm land, restrict air emissions, and require reclamation of mine sites.

Coal generation involves coal mining and preparation and plant construction and operation. Tables $F-11$ through $F-18$ show the natural resource use and environmental impacts of the steps in coal generation, which are discussed below. This section also discusses advanced technologies for electricity generation with coal, including coal gasification and fluidized bed combustion.

\section{Fuel Mining and Processing}

Mining. Coal is mined at several sites in and near the Pacific Northwest, including sites in the States of Washington. Montana, Wyoming, and Utah. The coal in the West generally has low energy value and low sulfur content.

Almost all of the coal mines from which regional plants receive their coal are surface (strip) mines. In surface mining, topsoil is removed for later use in reclamation. The area is blasted and the overburden (earth overlying the coal seam: is removed in long parallel cuts. The exposed coal is removed and loaded into trucks for transport to a coal cleaning area and then to rail lines or mine-mouth plant. Reclamation consists of grading the soil. replacing the topsoil, and replanting vegetation. Federal laws require mining companies to reclaim mined lands by approximating the original ropography and planting suitable vegetation.

Mining disrupts land uses, including agriculture and grazing. Even with reclamation, the land is not returned to its original form and may not recume its former productivity. The solid waste produced by mining can eventually be used as fill for reclamation. Coal mining to support a loog...MA coal plant. would permanently disturb about 251 acres and temporarily disturb about 52 acres each year. Aquifers in mined areas may be disturbed and may be contaminated by mining wastes. New and expanded mining operitions may hay significant socioeconomic impacts if many new worker are attracted to the area. 
Air pollution results from emissions of the diesel-powered equipment that digs and hauls coal and overburden. It also arises from dust raised by the wind and by vehicular operation. Dusi suppression practices, including spraying the area with water, can reduce the particulates caused by wind erosion and movement of vehicles. Water pollution may occur when suspended solids are produced by runoff from piles of overburden. Under controlled conditions, coal pile drainage and runoff are collected and treated prior to discharge, which reduces suspended solids and results in a zero acid content. Surface coal mining causes noise during drilling, blasting, and operation of equipment.

Table F-13 assumes that a preparation plant is sited near the coal mine. Coal preparation or beneficiation includes removing impurities from the coal, sizing the coal, and removing sulfur. The degree and type of beneficiation depends on the type of coal. Coal from the Western States generally is relatively clean and does not require washing. However, the coal goes through a "breaking and sizing" process that results in noise and requires small amounts of recycled water for dust control. The breaking and sizing operation and loading and storage require the long-term disturbance of about 63 acres of land for a 1000-MW plant. Table F-14 shows the resource use and environmental impacts of beneficiation. Beneficiation results in air and water pollution and solid wastes, as shown on the table.

Coal plants receive coal by truck or train, depending on the plant's distance from the coal mine(s) that supply it. Coal that must be transported long distances generally is moved by unit trains. Unit trains are dedicated to this purpose and operate regularly between two fixed points. Coal also may be transported by conventional trains, which carry cargoes of various types in addition to coal. Transporting coal by either type of train results in similar types and levels of pollutants. Table F-15 lists the environmental effects of coal unit trains.

A 1000-MW plant requires, as an annual average, over 9000 tons of coal per day. Hauling by train results in noise, emissions from diesel fuel combustion, and wind-borne particulates. Air pollution consists chiefly of particulates, sulfur dioxide, nitrogen oyides, hydrocarbons, and carbon

monoxide. Particulate emissions during transportation are estimated to be 2 percent of coal tonnage carried by conventional trains and 1 percent of tonnage carried by unit trains and trucks. Other methods of transport are barge, slurry pipeline, truck, and conveyer belt (used between the Jim Bridger Mine and Plant in Wyoming).

\section{Plant Construction and Operation}

Factors that must be considered when siting a coal-fired power plant include the current condition of the airshed and its ability to dilute the atmospheric discharges of the plan:; availability of water for cooling; proximity to the transmission grid; proximity to and reliability of rail or water

transportation for coal; and availability of land for disposal of ash and flue gas desulfurization products. About 156 acres of land must be dedicated to housing the plant and solid waste disposal for 30 years. Construction of a coal plant is similar to that of any large industrial facility. 
Modern coal plants include pollution control devices including elactrostatic precipitators or other devices to control particulate emissions; scrubbers to control sulfur dioxide emissions; onsite solid waste disposal. to prevent loss during transport; and onsite water treatment. so water ma be recirculated to eliminate discharges. The Clean Air Act requires that power plants constructed after passage of the act include systems for control of nitrogen oxide, sulfur dioxide, and particulates. Coal plants are subject to federal and state regulations regarding pollutants.

In a conventional generating plant, the coal is pulverized and burned in a boiler to generate steam to power a turbine. The turbine drives an electrical generator. Combustion of the coal produces a flue gas contaminated with several air pollutants, most notably sulfur dioxide, nitrogen oxides, and carbon monoxide. Enissions fron coal plants result in acid precipitation, which corrodes butlding materials and harms aquatic and terrestivial life, insluding fish, forests, and food crops. Data on acid precipitation are being gathered to determine the long-term environmental effects.

In the 11 Western states, the second...largest source of sulfur dioxide and nitrogen oxide is electricity generation inonferrous metal smelting produces more sulfur dioxide, and motor vehicles produce more nitrogen oxide). Acid deposition tends to be concentrated around the sources of emissions, although pollutants are transported by storms and prevailing winds. Acid deposition is extremely variable over time, depending on localized weather conditions; snownelt patterns (snowmelt causes "pulses" of acidic water); and existing acidity of soil and water.

The west has many areas that are potentially sensitive to acidity. The thin soil of the mountains is not sufficient to neutralize the acid from precipitation runoff. The flora and fauna of fragile mountain and desert areas, because of the relatively short growing season, can take years to recover from acid damage. The deep snows trat fall on the mountains can provide pulses of acidity during spring snowmelt.

Sulfur dioxide must be largely removed from combustion gases before disharge. A wet schober to pelform this function colld produce ovel

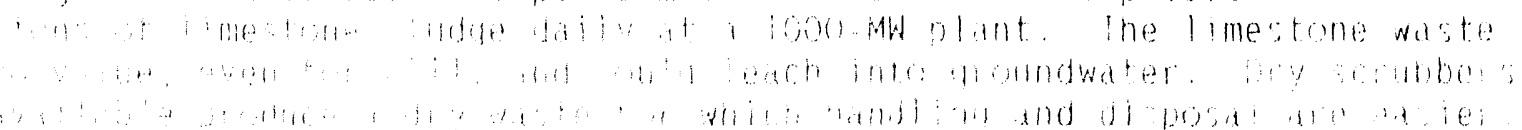

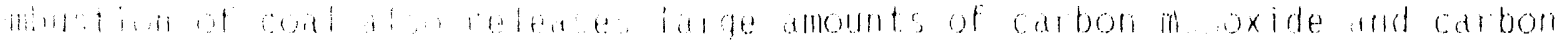

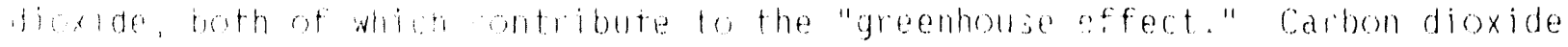

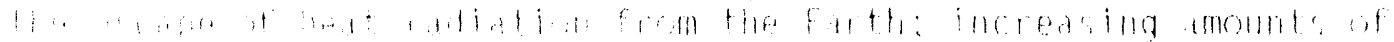

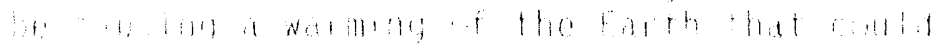


evaluate the teasibility of using algae and other plants to absorb the carbon dioxide output of thermal plants. Laboratory results dre promising.

A loo0 MW coal plant burning conl with a 10 -percent ash content will produce an average 900 tons of ash each day. Some of the ash is slay (bottom ash) from the boilu, and some is fly ash captured by the ait pollution control device. Fly ash may be sold for uses such as for roda building material. The other solid wastes must be disposed of in landfills.

Advanced Technologies

Two advanced technologies, gasification and flutdized bed combustion, can generate electricity using coal more efficiently and with les: hamful emissions than conventional coal burning.

Gasification. Coal gasification is the conversion of cod or coal char to gaseous products sy reaction with steam mixed with air or oxygen. The product is a low.. to medium.-Btu gas. To provide heat to enable the chemical leactions, generally some of the coal is burned. The resulting gas would be used as a substitute for natural gas in a CT or combined-cyclu generator (see section on CTs, following).

Gasification was the original application of fluidized-bed combustion, discussed in the next section. A gasifier burns coal in a fluidized bed with less dir than is required for complete combustion, resulting in a high concentration of combustible gases in the exhast. Cod gasticication is aoplied in severa! pilot plants in the U.S.; it is an opt ion to be used if natural gas prices increase significantly. The environmental impacts of coal mining and transport are not eliminated by gasification, al though generating electricity with synthetic ads would increase the efficiency of coal use.

Fluidized Bed Combustion. Fluidized bed combustion is a method of burning fuel in which the fuei is continually fed into a "bed" of particles supported by upflowing air. During fluidization, the bed of material expands (bulk. density decreases); as the air velocity increases, the palticles mix more violently. The proper air velocity, operating temperature, and bed material cause the bed to function as a chemical reactor.

for high-sulfur cod combustion, the bed may be composed ot limestome. The

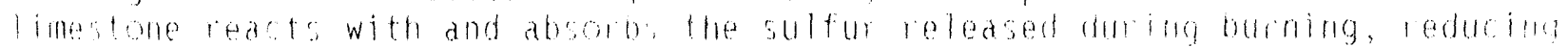

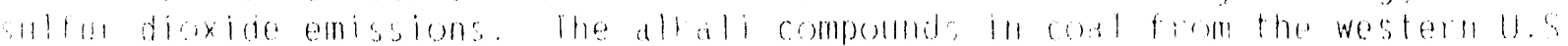

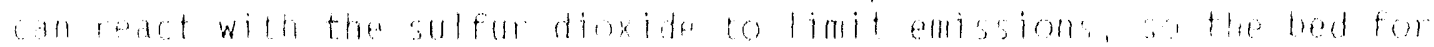

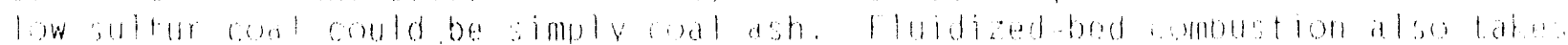

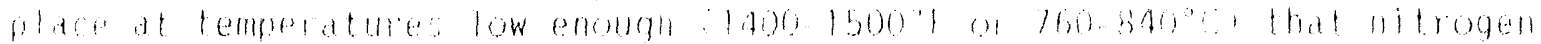

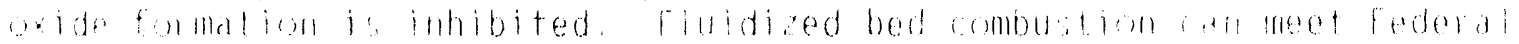

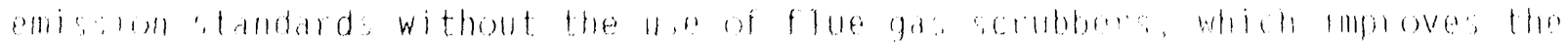

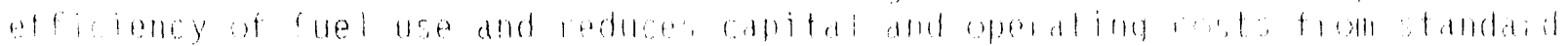
(a) deflet ation 
Generation with fluidized-bed combustion involves immersing heat-transfer tubes within the hot fluidized bed. The high efficiency of heat transfer results in the need for relatively less tube surface area, reducing tube requirements and costs. This technology, and plants with pressurized fluidized-bed combustors, are being tested within the U.S.

\section{Sources:}

BPA, Environmental Assessment: Proposed Power System Changes to Implement the Water Budget, May 1983, Appendix C, pp. C-12 - C-15.

Bonntillle Power Administration 1983 Wholesale Power Rate Final Environmental Impact Statement, September 1983, pp. IV-71 and IV-80-81.

Northwest Power Planning Council, 1989 Supplement to the 1986 Northwest Conservation and Electric Power Plan, Volume 1, pp. 57 and 61.

Bonneville Power Administration, Final Environmental Impact Statement, Intertie Development and Use, April 1988, Volume 4, Appendix F, pp. F. 1-1 - F.1-5.

World Resource Institute, "The American West's Acid Rain Test: Research Report \#1," March 1985.

The Seattle Post-Intelligencer, "Power council contemplates 'greenhousing' of America," February 14, 1989.

James, Peter. The Future of Coal. Second Edition, 1984. MacMillan Press, London.

McGraw-Hill Encyclopedia of Science \& Technology, 6th Edition, 1987. Volume 4, pp. 72-74 and Volume 7, pp. 198-200.

U.S. Departmerit of Energy, Energy Technology Characterizations Handbook, Environmental Pollution and Control Factors, Third Edition, March 1983.

U.S. Department of Energy, Energy Technologies and the Environment, Environmental Information Handbook, October 1988.

\section{COMBUSTION TURBINES}

\section{Technology}

CTs are rotary engines similar in design and operation to a turbojet aircraft engine. Outside air passes through a rotary compressor into a combustion chamber. The hot combustion gases flow through the turbine blades, turning a shaft that powers the turbine, air compressor, and electrical generator. In a simple cycle CT, the gases are then exhausted to the atmosphere through a muffling system. In a combined-cycle operation, the hot exhaust gases are 
used to produce steam in a boller. The steam is used to produce additional power in a steam turbogenerator. Because of the time needed to heat the boiler, the steam portion of a combined-cycie CT cannot be used to meet short-term peakloads. Combined-cycle operations are most efficiently used during longer perlods of high loads. CTs usually are powered by fossil fuels, either natural gas or oil, but also may use gaseous or liquid synthetic fuels.

CTs are relatively quick to build, and several manufacturers offer "turn-key" facilities. CTs also are relatively inexpensive to build, although their costs are extremely sensitive to site characteristics such as distance to gas lines and electrical transmission lines. Newer plants are designed to be more efficient and reliable than older facilities.

\section{Potential}

In the Northwest, CTs have in the past been used rarely, mainly to supplement baseload generation plants such as nuclear and coal. CTs tend to be operated infrequently and for short periods due to their design as peaking units, relatively high fuel and operating costs, and Federal and local regulations governing fuel use, emissions, and noise.

PGE, for example, used its 534-MW Beaver combined-cycle CT during the Trojan Nuclear Plant's 1989 spring refueling outage. PGE was able to sign 3-month supply contracts for natural gas, which made the short-term operation of the Beaver plant economical.

The Council has suggested the possibility of "firming" nonfirm hydro energy using CTs to back up existing hydropower facilities. The council points out that the availability of natural gas is unknown: the regional gas transmission system may not be adequate to support future electric generation plants. CTs would require that gas transmission facilities be avallable, but might not require gas deliveries even every year because of their potential intermittent use. Table F-19 gives planning characteristics for CTs.

\section{Expected Impacts}

CT plants are manufactured, and have environmental impacts assumed to be typical of manufacturing facilities. At the turbine site, construction of access roads, gas and electrical transmission lines, fuel storage, and the plant housing bullding all have iypical construction-related impacts. Impacts of construction are less for CTs than for larger generation plants, however.

Production of gas and oil have significant environmental impacts, but only an insicnificant fraction of the impacts could be attributed to CTs in the Northwest using those fuels.

The operational effects of CTs include noise and air pollution. The emissions emitted in greatest quantity are nitrogen oxides, which result from high temperatures in the combustion chamber. Nitrogen oxides, as explained in the section on coal, are precursors of acid precipitation. Nitrogen oxides may be 
relatively cheaply and effectively reduced by water or steam injection into the gas turbine combustors. Water and solid waste pollution from this mocess is minimal. The most effective method of reducing emissions of sulfur ox ide is to minimize the use of high sulfur fuel oil. The Environmental protection Agency (EPA) has established standards limting emisstons of nitrogen oxides and sulfur oxide for new gas turbine generators. Oil storage and handling can result in additional emisstons of hydrocarbons. Other emissions of concern are particulates and carbon dioxide, although combustion of natural yas produces less carbon dioxide than combustion of the same amount of coal.

To control noise impacts, sound deadening is normally required. Buffer space surrounding CTs also can reduce noise pollution. A combined-cycile plant of $300 \mathrm{MW}$ ma require a 400 -acre parcel as an adequate noise buffer.

Simple...cycle CTs usually have negligible impact on water supply or gunlity. Water or steam injection for control of air pollution requires a supply of demineralized water and produces a waste stream containing the minerals removed from the water. Treatment of fuel oll to remove minerals also can result in water consumption and pollutants. Plant site runoff and vil spills are additional potential sources of water pollution.

Combined-cycle units require both demineralized water for use in the stodu cycle and makeup water for cooling towers or ponds.

\section{Sources}

BPA, Environmental Assessment: Proposed Power System Changes to Implement the Water Budget, May 1983, Appendix C, pp. C.9 ... C 10.

Bonneville Power Administration 1983 Wholesale Power Rate Final Environmentai Impact Statement, September 1983, pp. IV -81 83.

Northwest Power Planning Counci1, 1989 Supplement to the 1986 Northwest Conservation and Electric Power Plan, Volume 1, pp. 55-57. 


\section{SMALL HYDROELECTRIC PLANT}

\section{AEFERENCE ENERGY SYSTEM}

Small hiviroetectric phantw are those with bess ituan 15 MWe of capecity and usuatity fed by is dar, with haght root more than 65

16. Impournding is gerver athy less than 500 acion. Compononts of a rypucal system (not an exthaustive listurcy) ikchude the dam. peristock, hydraubs: turbrie, generator(s) trams/ormes, and other miscellarketris structures and equipment.
FACILITY OPERATING PARAMETERS

Sire:

Anmuat Capacity Facior:

Armulal Energy Frodiction:

EHiciencr.

Lifetimer.
4 MWo

0.35 for new plants, 0.37 for retrofits

$004 \times 10^{12} B 111$

$90 \%$

$50 \mathrm{rr}$

\section{HESOUACES USED}

Frend Matorials

Water

$0.792 \times 10^{6}$ ikcre-1t

$0.977 \times 10^{12} 1$

$19.8 \times 10^{\circ}$ acreift

Kirvetic enoxgy of falling or flowing water

\section{Energy fiequiremerity}

Auxiliary

Nor Deterrnined

Total Usange

Cunstruition Materiats

Not Determined

Trpical srytem components are listod in Reference Energy Srstem description

Larnd

Not Determined

Perscamen

Cixismucoman

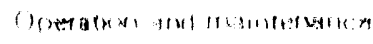

Not determaned

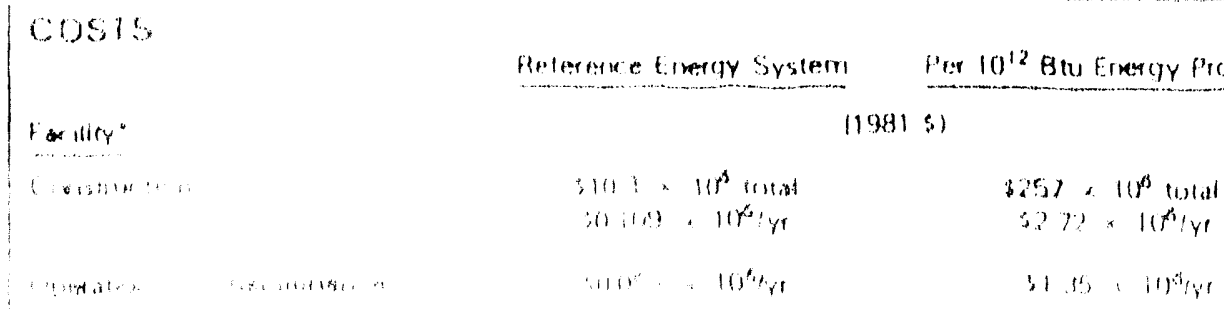

Horruarks

Folererne yents for costs ure $197 \%$ for recrestruclese

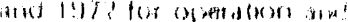

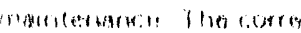

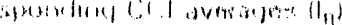
" :

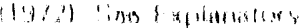

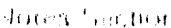


Table F-1 continued

\section{SMALL HYDROELECTRIC PLANT}

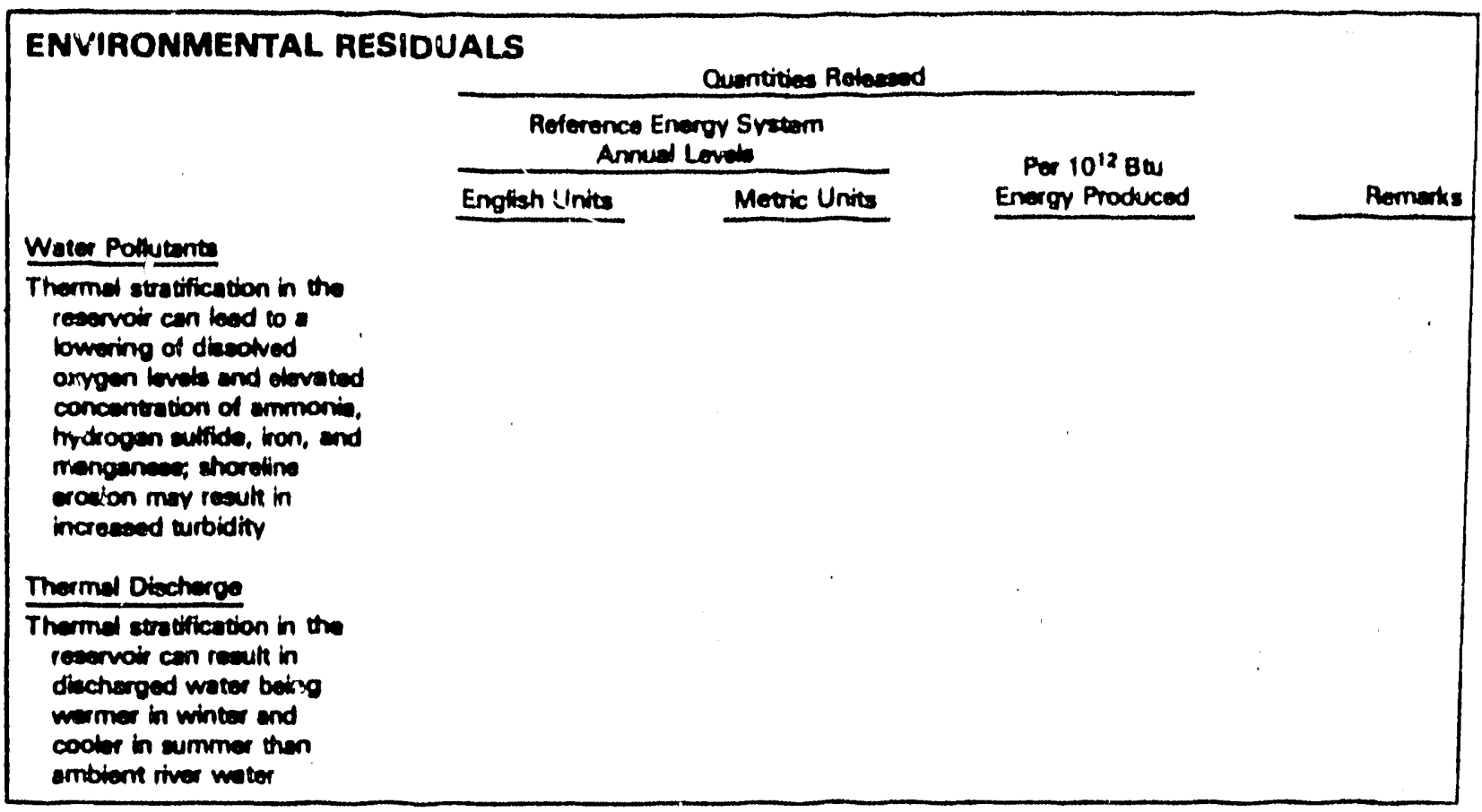

\section{PRODUCTS}

Quantitios Produced

\begin{tabular}{|c|c|c|c|c|}
\hline & \multicolumn{3}{|c|}{ 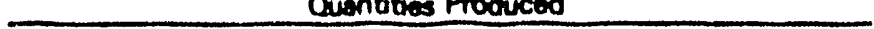 } & \\
\hline & \multicolumn{2}{|c|}{$\begin{array}{l}\text { Rolerence Energy Srstom } \\
\text { Anmied Production }\end{array}$} & \multirow{2}{*}{$\begin{array}{c}\text { Por } 10^{12} \mathrm{Btu} \\
\text { Energy Produced } \\
\end{array}$} & \multirow[b]{2}{*}{ Rornark } \\
\hline & Englash Units & Metric Units & & \\
\hline $\max$ & & & & \\
\hline becricity & $0.012 \times 10^{9} \mathrm{kWh}$ & $0.012 \times 10^{9} \mathrm{kWh}$ & $0.293 \times 10^{9} \mathrm{kWh}$ & \\
\hline
\end{tabular}

OCCUPATIONAL SAFETY AND HEALTH

Not Defermined 


\section{OPEN PIT URANIUM MINING}

\section{REFERENCE ENERGY SYSTEM}

Open pie mining is conducted when the ore body los under reta. theny fribbe maturiel at depthe $10120 \mathrm{~m}$. The components of the mining opermion inctude onsito support faclities such as offices and werehousea mine water pumped intc local surface drainege or holding ponds, and mine spols and ore storage erencen

\section{FACILITY OPERATING PARAMETERS}

Sizer.

$528 \times 10^{3}$ tons $/ \mathrm{h}$ lactual outpuet

Annual Capocity Foctor: $\quad 80 \%$

Arnual Energy Production: $115 \times 10^{12} \mathrm{Btw}$

Efficiency:

80\% (recovery officiency)

Lifotime:

\section{RESOURCES USED}

Enorgy

Eloctricity

Diesed fued and kubricants

Procossing Materials

Explosives

Woter

Mine wote from dewatering

Sprovs for dust control

\section{Construction Materials}

\section{Cocorate}

Totad stred and castings

Copper, brase, and bronxe

Aluminum and castings

Manganese

Chrornium

Nicked

Cest iron

Land

\section{Personned}

Construction $\mathrm{H}$ wt

Operation and maintenance
Chantition Used

\begin{tabular}{|c|c|c|}
\hline \multicolumn{2}{|c|}{$\begin{array}{c}\text { Relerence Energy System } \\
\text { Anmual Usege }\end{array}$} & \multirow{2}{*}{$\begin{array}{l}\text { Por } 10^{12} \mathrm{Btu} \\
\text { Enveror } \\
\text { Proctuced }\end{array}$} \\
\hline English Units & Metric Units & \\
\hline $\begin{array}{l}1.32 \times 10^{3} \mathrm{MWh} \\
1.46 \times 10^{6} \mathrm{gat}\end{array}$ & $\begin{array}{c}1.32 \times 10^{3} \mathrm{MWh} \\
5.53 \times 10^{8} !\end{array}$ & $\begin{array}{c}11.5 \mathrm{MWh} \\
127 \times 10^{3} \mathrm{gal}\end{array}$ \\
\hline
\end{tabular}

Not Determined

$2.00 \times 10^{3}$ acrote

$2.46 \times 10^{9} 1$

17.3 acro-11
Romarks

\section{Total Usage}

16 tons
$3.73 \times 10^{3}$ tons
46 tons
22 tons
17 tons
8 tons
0.23 ton
155 tons
300 acros
15 tonnes
$3.38 \times 10^{3}$ tonnes
42 tonnes
20 connes
16 tonnes
7 tonnes
0.21 tonne
141 ionnes

$120 \mathrm{ha}$

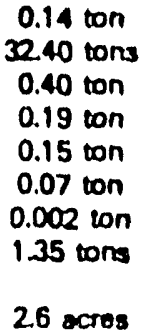

0.14 ton

0.19 ton

0.15 ton

0.002 lon

2.6 acres

\section{Costs \\ Facility \\ $(19818)$ \\ Construction $\mid 4$ vi \\ Operation and maintenanca

$$
\begin{aligned}
& \$ 76.0 \times 10^{8} \text { lotat } \\
& \$ 29.2 \times 10^{6} / \mathrm{yr}
\end{aligned}
$$ \\ Emvironmontal Controta \\ Divervion of untace waters Water sxroping los dust control Rovegetation

Reference Energy System Por $10^{12}$ Bas Energy Produced

Rernork:
$\$ 0.662 \times 10^{6}$ total
$0.253 \times 10^{6} / \mathrm{r}$

Reterence your for costs is 1978 1978 $\mathrm{CCl}$ average $\left(I_{n}\right)=$ 27r6. Sow Explart story Notes Section.

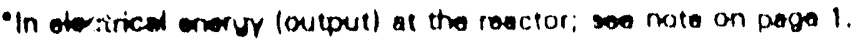




\section{OPEN PIT URANIUM MINING}

\begin{tabular}{|c|c|c|c|c|}
\hline \multicolumn{4}{|c|}{ ENVIRONMENTAL RESIDUALS } & \multirow[b]{3}{*}{ Plemerks } \\
\hline & \multicolumn{2}{|c|}{$\begin{array}{l}\text { Reterence Energy Syotom } \\
\text { Anmued Lovots }\end{array}$} & \multirow{2}{*}{$\begin{array}{l}\text { Por } 10^{12} 8 \mathrm{Bu} \\
\text { Enerov Produced }\end{array}$} & \\
\hline & Engtish Unite & Motric Units & & \\
\hline \multicolumn{5}{|l|}{ Ai Pollutents } \\
\hline 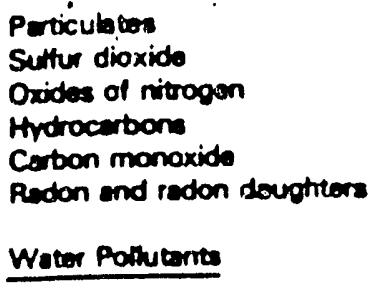 & $\begin{array}{l}31 \text { tons } \\
49 \text { tons } \\
29 \text { tons } \\
23 \text { tom } \\
0.12 \text { ton } \\
3.37 \times 10^{-3} \mathrm{Ci}\end{array}$ & $\begin{array}{l}28 \text { tonnes } \\
45 \text { tonnes } \\
26 \text { tornes } \\
21 \text { tornes } \\
0.10 \text { torne } \\
3.37 \times 10^{3} \mathrm{Ci}\end{array}$ & $\begin{array}{c}0.27 \text { ton } \\
0.43 \text { ton } \\
0.25 \text { ton } \\
0.02 \text { ton } \\
0.001 \text { ton } \\
29.3 \mathrm{Cr}\end{array}$ & \\
\hline 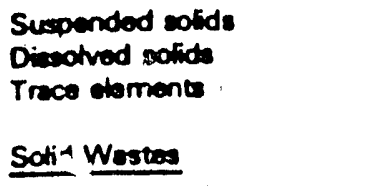 & & Not Detormined & & \\
\hline Overbunden moved & $16 \times 10^{6}$ torn & $15 \times 10^{4}$ torness & $0.14 \times 10^{0} \mathrm{con}$ & \\
\hline \multirow{4}{*}{ PRODUCTS } & \multirow{2}{*}{\multicolumn{3}{|c|}{ Quentitios Produced }} & \\
\hline & & & & \\
\hline & \multicolumn{2}{|c|}{$\begin{array}{c}\text { Roteronce Envoror Sritom } \\
\text { Ammeal Production }\end{array}$} & Per $10^{12}$ Bus & \\
\hline & Engtian Units & Motric Units & Energy Producod" & Remorks \\
\hline \multicolumn{5}{|l|}{ Primary } \\
\hline $\begin{array}{l}\text { Uronium ore : } \\
U_{5} \mathrm{O}_{\mathrm{Q}} \text { concentrote }\end{array}$ & $\begin{array}{l}0.53 \times 10^{6} \text { torn } \\
1.06 \times 10^{3} \text { tor }\end{array}$ & $\begin{array}{l}0.48 \times 10^{60} \text { tormes } \\
960 \text { romes }\end{array}$ & $\begin{array}{l}4.6 \times 10^{3} \text { tons } \\
92 \text { tom }\end{array}$ & \\
\hline
\end{tabular}




\section{URANIUM MILLING}

\section{REFERENCE ENERGY SYSTEM}

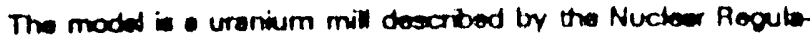
rony Commiasion in the Final Generic Ervirormomtal Impact Stosoment on Uranium Milling. NUREG-0706, Vol 1-111, Septumber 18:0. Tailings controt and disposed inctudes retention besin, clor liner. ovoporation pond, in situ solicto fiturion and enth cover.

\section{FACILITY OPERATIING PARAMETERS}

Siro.

635 tonatyr uraninum concentrate (vollowcake at $90 \% \mathrm{U}_{3} \mathrm{O}_{3}$ )

Anrual Capocity Facior. $85 \%$

Anmual Energy Production: $68.3 \times 10^{12} \mathrm{Bta}$

Efficioncr

$93 \%$ Irecovoryt

Lifetime. $15 \mathrm{r}$

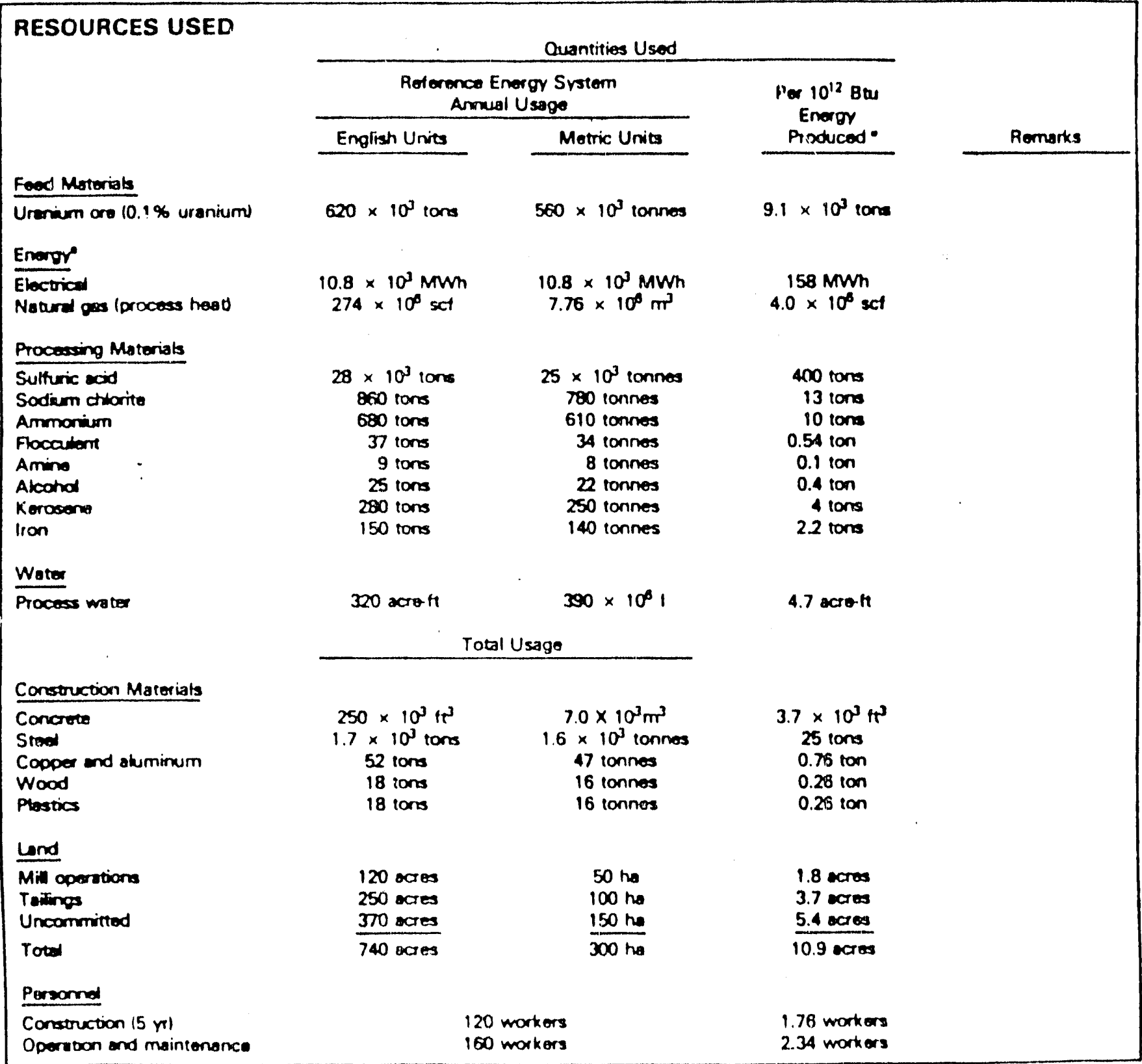

-In dectrical energy loutpull at the reactor: 200 note on pege 1 


\section{URANIUM MILLING}

\begin{tabular}{|c|c|c|c|}
\hline cOSTS & Roference Eneror Syotem & Por $10^{12}$ Bru Eneroy Produced " & Aorrients: \\
\hline Facility & & & \\
\hline $\begin{array}{l}\text { Construction } 15 \mathrm{mt} \\
\text { Operation and maintenance }\end{array}$ & $\begin{array}{l}37.1 \times 10^{6} \text { total } \\
18.5 \times 10^{6} / r\end{array}$ & $\begin{array}{l}0.54 \times 10^{6} \text { total } \\
0.13 \times 10^{6} / \mathrm{r}\end{array}$ & \\
\hline $\begin{array}{l}\text { Environmental Controts } \\
\text { Oro crusting } \\
\text { wet scrubbers }\end{array}$ & $\begin{array}{l}\$ 155 \times 10^{3} \text { toted } \\
\$ 18.8 \times 10^{3} / r\end{array}$ & $\begin{array}{l}\$ 2.3 \times 10^{3} \text { totw } \\
\$ 0.275 \times 10^{3} / r\end{array}$ & $\begin{array}{l}\text { Total copital coste } \\
\text { Operating costs per vour }\end{array}$ \\
\hline $\begin{array}{l}\text { Yolbucake diving } \\
\text { wot scrubbers } \\
\text { Teilingul control and disposal }\end{array}$ & $\begin{array}{l}\$ 50.4 \times 10^{3} \text { total } \\
\$ 6.2 \times 10^{3} / \mathrm{r} \\
\$ 13.7 \times 10^{4} \text { total }\end{array}$ & $\begin{array}{l}\$ 0.7 \times 10^{3} \text { total } \\
\$ 0.091 \times 10^{3} / \mathrm{r} \\
\$ 0.200 \times 10^{8} \text { total }\end{array}$ & $\begin{array}{l}\text { Total capital costs } \\
\text { Operating costs per voen } \\
\text { Inctudes capital and total } \\
\text { operating cost over hifetime }\end{array}$ \\
\hline
\end{tabular}

\section{ENVIRONMENTAL RESIDUALS}

Quantities Revessed

\begin{tabular}{|c|c|c|c|}
\hline \multicolumn{2}{|c|}{$\begin{array}{l}\text { Reference Lineroy Svetom } \\
\text { Aninual Lovots }\end{array}$} & \multirow{2}{*}{$\begin{array}{c}\text { Por } 10^{12} \mathrm{Btu} \\
\text { Energy Produced }\end{array}$} & \multirow[b]{2}{*}{ Remarks } \\
\hline Engliah Unit & Motric Units & & \\
\hline $\begin{array}{l}370 \text { ton } \\
0.34 \text { ton } \\
28 \text { ton } \\
24 \text { tons } \\
0.160 \mathrm{Ci} \\
0.122 \mathrm{Ci} \\
4.5 \times 10^{3} \mathrm{Ci}\end{array}$ & $\begin{array}{l}340 \text { tonnes } \\
0.31 \text { tonnes } \\
25 \text { tonnes } \\
22 \text { tornes } \\
0.160 \mathrm{Ci} \\
0.122 \mathrm{Ci} \\
4.5 \times 10^{3} \mathrm{Ci}\end{array}$ & $\begin{array}{c}5.4 \operatorname{tans} \\
5.0 \times 10^{-3} \mathrm{ton} \\
0.41 \mathrm{krs} \\
0.35 \mathrm{ton} \\
23 \times 10^{-3} \mathrm{CI} \\
1.8 \times 10^{-3} \mathrm{Ci} \\
68 \mathrm{Ci}\end{array}$ & : \\
\hline $\begin{array}{c}326 \text { acroft } \\
13 \times 10^{3} \text { tons } \\
440 \text { tors } \\
22 \text { ton } \\
0.88 \text { ton } \\
1.3 \mathrm{Cl} \\
0.1 \mathrm{Ci} \\
36 \mathrm{Ci}\end{array}$ & $\begin{array}{c}402 \times 10^{61} 1 \\
12.1 \times 10^{3} \text { tornes } \\
400 \text { tomes } \\
20 \text { tonnos } \\
0.80 \text { torm } \\
1.3 \mathrm{Ci} \\
0.1 \mathrm{Ci} \\
38 \mathrm{Ci}\end{array}$ & $\begin{array}{c}4.8 \text { acth } \\
190 \text { tons } \\
6.5 \text { tons } \\
0.32 \operatorname{ton} \\
0.01 \operatorname{ton} \\
19 \times 10^{-3} \mathrm{Ci} \\
1.4 \times 10^{-3} \mathrm{Ci} \\
0.53 \mathrm{Ci}\end{array}$ & \\
\hline $\begin{array}{c}610 \times 10^{3} \text { ton: } \\
21.8 \mathrm{Cl} \\
156 \mathrm{Ci} \\
156 \mathrm{Ci}\end{array}$ & $\begin{array}{c}560 \times 10^{3} \text { tornes } \\
21.8 \mathrm{Ci} \\
156 \mathrm{C} \\
156 \mathrm{Cl}\end{array}$ & $\begin{array}{c}9.0 \times 10^{3} \text { tons } \\
0.32 \mathrm{Ci} \\
23 \mathrm{Ci} \\
2.3 \mathrm{Ci}\end{array}$ & \\
\hline $0.3 \mathrm{Cl}$ & $0.3 \mathrm{Ci}$ & $4 \times 10^{-3} \mathrm{Ci}$ & \\
\hline $280 \times 10^{0} \mathrm{Bas}$ & $300 \times 10^{12} \mathrm{~J}$ & $4.1 \times 10^{\circ} \mathrm{Btu}$ & \\
\hline
\end{tabular}

Air Pollutonts

Perticulatio

Sultur diaxide

Oxides of nitrogen

Kerooone

Uranium-232, Uranium 234

Thorium-230

Ridon

Water Pollutants

Water discheraed

- Sultato

- Iron

- Mandonas

- Solenium

Uranium-naturel

Radium-228

Thorium-230

Solid Wastes

Tailings

Uraniumnaturad

Pisdium-228

Thorium 230

Lead 210, potonium-210.

bismuth-210

Therrial Diacherge

Process hoat to eir
Quantition Produced

Reference Enorgy Sritem Anmual Production

\section{Engliah Unio}

635 tons

Matric Unita

580 tonnes

$160 \times 10^{4}$

135 acrett
Pew $10^{12} \mathrm{Btw}$ Energr Produced

9.3 torm

Yelovreake $\left.190 \% \mathrm{U}_{3} \mathrm{O}_{8}\right)$

Pecovercblea/ Recrelables

$30 \%$ of the tainge liquid

1.99 ecreh 


\section{URANIUM MILLING}

\begin{tabular}{|c|c|c|c|}
\hline \multicolumn{4}{|c|}{ OCCUPATIONAL SAFETY AND HEALTH'b } \\
\hline & $\begin{array}{c}\text { Reference Envergy Svatem } \\
\text { Annual }\end{array}$ & Per $10^{12}$ Bru Energy Produced " & Remarks \\
\hline Qeaths & 0.47 & 0.007 & 1977 Data \\
\hline Injuries & 34 & 0.50 & \\
\hline
\end{tabular}

U.S. Atomic Energy Commission, Environmental Survey of the Uranium Fuel Cycle, WASH.1248, 1974.

'Oak Ridge National Laboratory. An Tntegrated Assessment of the Impacts Associated with Uranium Mining and Milling, ORNUTM-6677, Juty 1979.

-In obectrical onergr loutputl at the reactor: 200 noto on pege 1. 


\section{URANIUM HEXAF!!'ORIDE CONVERSION}

\section{REFERENCE ENERGY SYSTEM}

Cormorsion of "yellowcake" uranium concentsate into volatile uranium hexalluoride compound for enrichment by the gaseous diffusion process; uranium hexafluoride conversion by either the dry hydrofluor process or the wet sotvent exchange process: offos treatment to minimize arborne residuals; neutratization and impoundment of liquid wastes.

\section{FACILITY OPERATING PARAMETERS}

Size:

$5.5 \times 10^{3}$ loms/yr lactual outpull

Annual Capacity Factor: $\quad 80 \%$

Annual Energy Production: $655 \times 10^{12}$ Btu

Efficiency.

$100 \%$ (recovery etficiency)

Lifetime:

$20 \mathrm{n}$

\section{RESOURCES USED}

Quantities Used

\begin{tabular}{|c|c|c|c|c|}
\hline & \multicolumn{3}{|c|}{ Quantities Used } & \multirow[b]{3}{*}{ Rermerks } \\
\hline & \multicolumn{2}{|c|}{$\begin{array}{l}\text { Reference Energy System } \\
\text { Annual Usage }\end{array}$} & \multirow{2}{*}{$\begin{array}{l}\text { Per } 10^{12} \text { utu } \\
\text { Eneror } \\
\text { Produced }\end{array}$} & \\
\hline & Enghash Units & Metric Units & & \\
\hline \multicolumn{5}{|l|}{ Feed Materials } \\
\hline $\begin{array}{l}\text { Yellowcake } 75 \% \text { U, } \\
U_{3} \mathrm{O}_{8} \text { (puritied) }\end{array}$ & $\begin{array}{r}7.34 \times 10^{3} \text { tons } \\
5.5 \times 10^{3} \text { tons }\end{array}$ & $\begin{array}{l}6.66 \times 10^{3} \text { tonnes } \\
5.0 \times 10^{\mathrm{J}} \text { tonnes }\end{array}$ & $\begin{array}{r}11.2 \text { tons } \\
8.4 \text { tons }\end{array}$ & \\
\hline \multicolumn{5}{|l|}{ Energy } \\
\hline $\begin{array}{l}\text { Elocticity } \\
\text { Natural gas }\end{array}$ & $\begin{array}{l}46 \times 10^{3} \mathrm{MWh} \\
540 \times 10^{6} \mathrm{sct}\end{array}$ & $\begin{array}{l}46 \times 10^{3} \mathrm{MWh} \\
15 \times 10^{6} \mathrm{~m}^{3}\end{array}$ & $\begin{array}{l}71 \mathrm{MWh} \\
0.83 \times 10^{6} \text { set }\end{array}$ & \\
\hline \multicolumn{5}{|l|}{ Processing Materists } \\
\hline 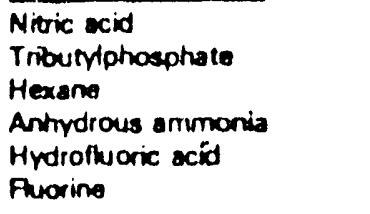 & & Not Determined & & \\
\hline \multicolumn{5}{|l|}{ Water } \\
\hline $\begin{array}{l}\text { Disctraged to air } \\
\text { Discherged to water }\end{array}$ & $\begin{array}{l}0.28 \times 10^{3} \text { acrolt } \\
1.92 \times 10^{3} \text { acro-lt }\end{array}$ & $\begin{array}{l}0.34 \times 10^{91} \\
2.38 \times 10^{91}\end{array}$ & $\begin{array}{l}0.42 \text { acrate } \\
2.94 \text { acro-fl }\end{array}$ & \\
\hline \multirow[t]{2}{*}{ Total } & $2.20 \times 10^{3}$ acro-1t & $2.72 \times 10^{91}$ & $\overline{3.36 \text { acre. } 1 t}$ & \\
\hline & \multicolumn{2}{|c|}{ Tocal Usoge } & & \\
\hline \multicolumn{5}{|l|}{ Construction Materials } \\
\hline 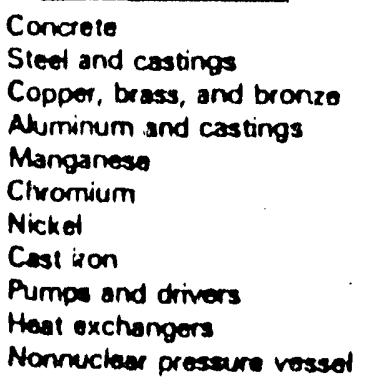 & $\begin{array}{c}259 \times 10^{3} \text { tons } \\
8.19 \times 10^{3} \text { tons } \\
120 \text { tons } \\
39 \text { tons } \\
39 \text { tons } \\
39 \text { tons } \\
7 \text { toms } \\
98 \text { tons } \\
7 \times 10^{3} \mathrm{hp} \\
30 \times 10^{3} \mathrm{ft}^{3} \\
220 \text { tons }\end{array}$ & $\begin{array}{c}235 \times 10^{3} \text { tonnos } \\
7.43 \times 10^{3} \text { tonnes } \\
110 \text { tonnes } \\
36 \text { connus } \\
36 \text { tonnes } \\
36 \text { connes } \\
6 \text { connes } \\
89 \text { tonnes } \\
5 \times 10^{4} \mathrm{~W} \\
3 \times 10^{3} \mathrm{~m}^{2} \\
200 \text { connes }\end{array}$ & $\begin{array}{l}395 \text { tons } \\
12.5 \text { tons } \\
0.19 \text { ton } \\
0.06 \text { ton } \\
0.06 \text { ton } \\
0.06 \text { ton } \\
0.01 \text { ton } \\
0.15 \text { ton } \\
0.01 \times 10^{3} \mathrm{hp} \\
0.05 \times 10^{3} \mathrm{ht}^{2} \\
0.33 \text { ton }\end{array}$ & \\
\hline Lond & 65 acres & 27 ho & 0.10 acro & \\
\hline \multicolumn{5}{|l|}{ Perrsonnel } \\
\hline $\begin{array}{l}\text { Cunstruction } 13 \mathrm{rl} \\
\text { Operation and maintenance }\end{array}$ & \multicolumn{2}{|c|}{$\begin{array}{l}200 \text { work ers } \\
300 \text { work ors }\end{array}$} & $\begin{array}{l}0.3 \text { worker } \\
0.4 \text { morker }\end{array}$ & \\
\hline
\end{tabular}

-In etectrical energr loutput) at the rasctor; 200 note on page 1. 


\section{URANIUM HEXAFLUORIDE CONVERSION}

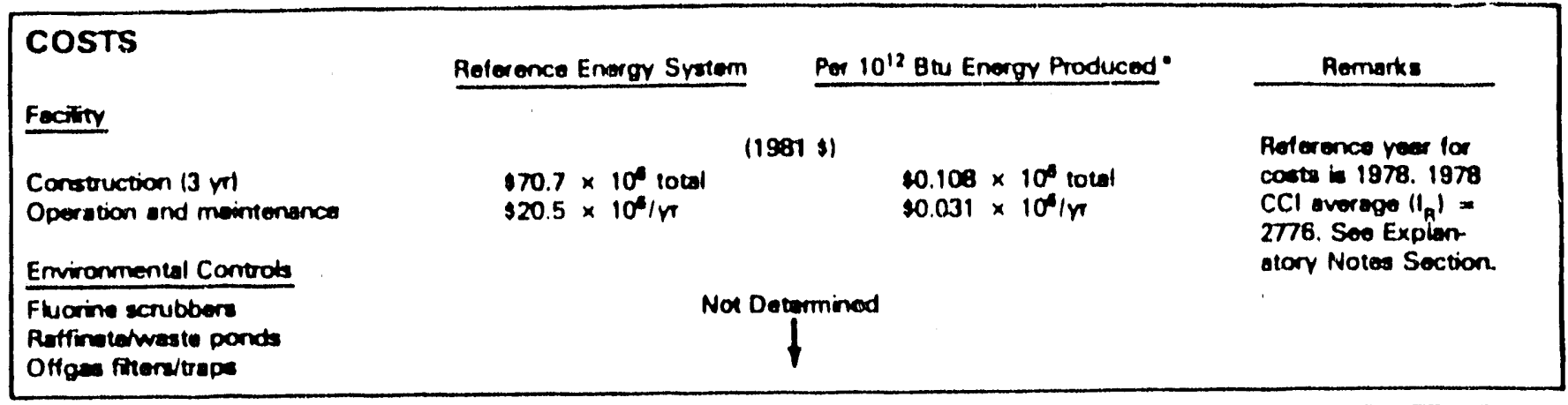

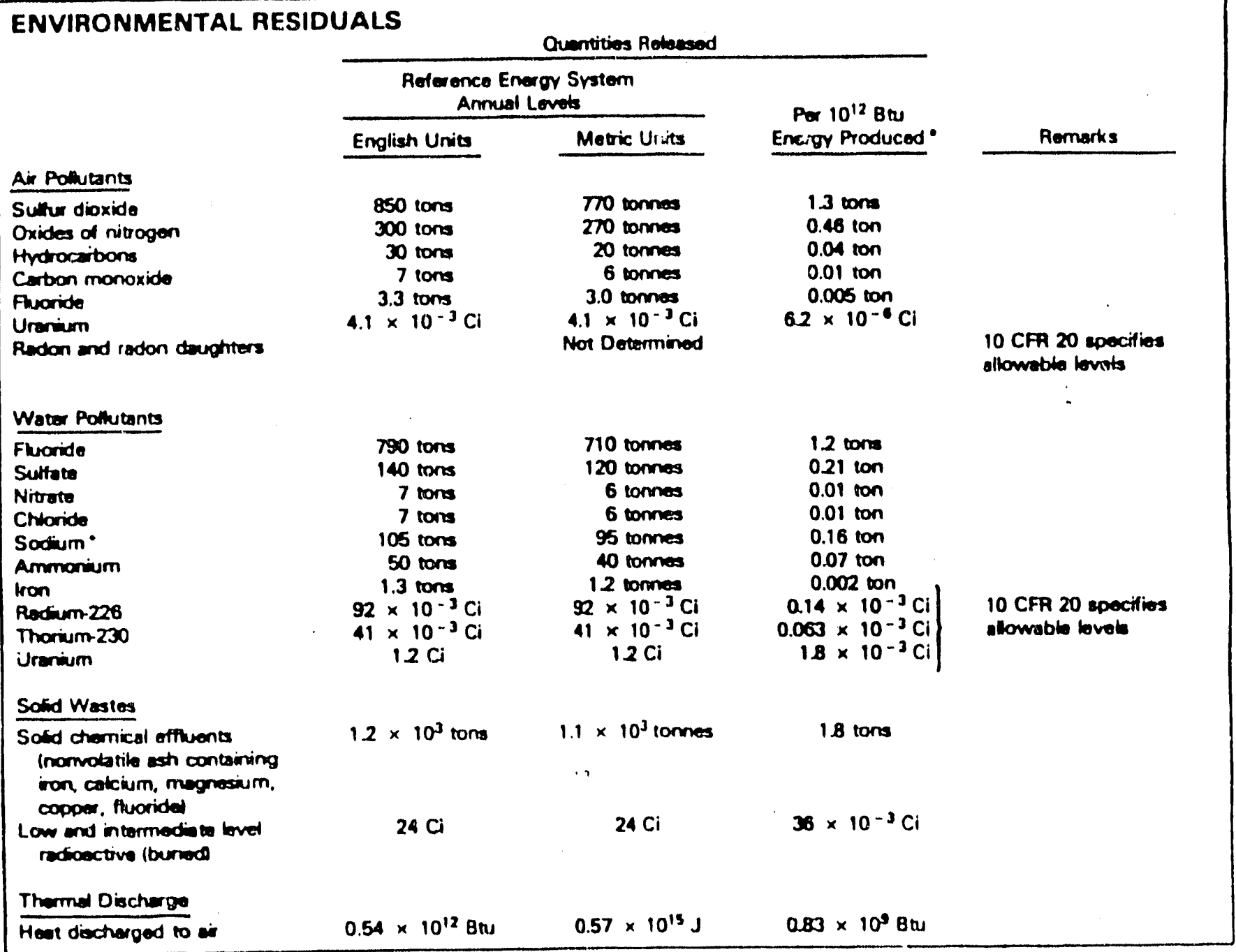

\begin{tabular}{|c|c|c|c|c|}
\hline \multirow[t]{3}{*}{ PRODUCTS } & \multicolumn{3}{|c|}{ Quantitios Produced } & \multirow[b]{3}{*}{ Rormarks } \\
\hline & \multicolumn{2}{|c|}{$\begin{array}{l}\text { Poference Energr Srstem } \\
\text { Anmual Prooduction }\end{array}$} & \multirow{2}{*}{$\begin{array}{c}\text { Por } 10^{12} \mathrm{Btu} \\
\text { Energy Produced }\end{array}$} & \\
\hline & Engliah Units & Motric Units & & \\
\hline \multicolumn{5}{|l|}{ Privnery } \\
\hline Urenium haxaftuande & $5.5 \times 10^{3}$ tom & $5.0 \times 10^{3}$ tormes & 8.4 rons & \\
\hline
\end{tabular}

OCCUPATIONAL SAFETY AND MEALTH

Not Datorminod

-In enctrical oneror loutpurl at the reector; sen note on 


\section{URANIUM ENRICHMENT GASEOUS DIFFUSION}

\section{REFERENCE ENERGY SYSTEM}

Gemow ditfucion enrichment ptent using porous berriems and compreseon arrenged in evives to produce urarium hawefluoride enriched to 4\% urenium-235; onate support fectitiox tals

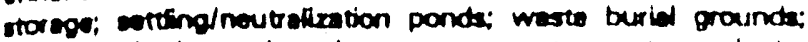
leod veporization and product recovory svsterns: steam plant.

\section{FACILITY OPERATING PARAMETERS}

Sker.

$12 \times 10^{3}$ tonatre lenriched urarium-235 as urarusm haxe furoride: taits assory $0.2 \%$ uraniuml

Annul Capacity Factor: $\quad 80 \%$

Anmual Energy Production: $2190 \times 10^{12}$ Btu

Efficioner.

$65.1 \%$ (recowory efficioncy)

$20 \mathrm{rr}$

\section{RESOURCES USED}

Eaed Matorials

Uranium hexerturoride lunenrictiod

Enory

Electricin

Water

Diectierged to air

Diecheroed to moter bodies

(at diftusion plant)

Diecherged to wheter

bodien lat power planto

\section{Conesuction Materials}

Concrets

Total sted and castings

Copper, bren and bronse

Aluminum and cesting

Manganewes

Chromium

Nickol

Cestiron

Steem turtoogenerators

Pumps and drivers

Axid compressor

Centrituge compressors and drturen

Heal oxchengers

Lend

\section{Ountition Uned}

\begin{tabular}{|c|c|c|}
\hline \multicolumn{2}{|c|}{$\begin{array}{c}\text { Reforonce Energy Sritem } \\
\text { Annual Unege }\end{array}$} & \multirow{2}{*}{$\begin{array}{l}\text { Per } 10^{12} \mathrm{Btw} \\
\text { Energr } \\
\text { Prodused. }\end{array}$} \\
\hline English Units & Motric Units & \\
\hline $18 \times 10^{3}$ tons & $17 \times 10^{3}$ tonnes & 2.4 tons \\
\hline $28 \times 10^{6} \mathrm{MWn}$ & $28 \times 10^{6} \mathrm{MWh}$ & $13 \times 10^{3} \mathrm{MWh}$ \\
\hline $\begin{array}{l}23 \times 10^{3} \text { scroth } \\
18 \times 10^{3} \text { scrote }\end{array}$ & $\begin{array}{l}29 \times 10^{9} 1 \\
22 \times 10^{9} 1\end{array}$ & $\begin{array}{l}11 \text { ocrott } \\
0.8 \text { ecrott }\end{array}$ \\
\hline $3.07 \times 10^{\circ}$ acto-ft & $3.8 \times 10^{12} 1$ & $1.4 \times 10^{3}$ acrott \\
\hline
\end{tabular}

\section{Total Usege}

$$
\begin{aligned}
& 1670 \times 10^{3} \text { tons } \\
& 723 \times 10^{3} \text { tors } \\
& 25.6 \times 10^{3} \text { tons } \\
& 16 \times 10^{3} \text { tons } \\
& 39 \times 10^{3} \text { tons } \\
& 5.0 \times 10^{3} \text { tons } \\
& 0.90 \times 10^{3} \text { tons } \\
& 58.0 \times 10^{3} \text { tons } \\
& 520 \mathrm{MW} \\
& 590 \times 10^{3} \text { ho } \\
& 8300 \times 10^{3} \text { hp } \\
& 22 \text { tom }
\end{aligned}
$$

$79 \times 10^{6} \mathrm{ft}^{2}$
$1510 \times 10^{3}$ tormes

$566 \times 10^{3}$ ronnes

$23.3 \times 10^{3}$ tonnes

$15 \times 10^{3}$ tonnes

$3.6 \times 10^{3}$ tonnes

$4.6 \times 10^{3}$ tornes

$0.82 \times 10^{3}$ tormes

$52.7 \times 10^{3}$ tornes

$520 \mathrm{MWO}$

$40 \times 10^{6} \mathrm{~W}$

$0200 \times 10^{6} \mathrm{~W}$

20 tonnes

$730 \times 10^{3} \mathrm{~m}^{2}$

Not Determined
760 tora

330 tons

11.7 tons

7.5 tons

1.8 tons

2.3 tons

0.41 ton

26.5 tons

$0.24 \mathrm{MW}$.

$0.27 \times 10^{3} \mathrm{hp}$

$3.8 \times 10^{3} \mathrm{hp}$

0.01 ton

$3.6 \times 10^{3} \mathrm{t}^{2}$

\section{Personned}

Conctruction $19 \mathrm{rt}$

Operation and maintenance

$6.1 \times 10^{3}$ work ers

$2.2 \times 10^{3}$ morkers
2.8 morkers 1.0 worker

-In obectical onsoy loutputl at the reactor; sos note on page 1. 


\section{URANIUM ENRICHMENT GASEOUS DIFFUSION}

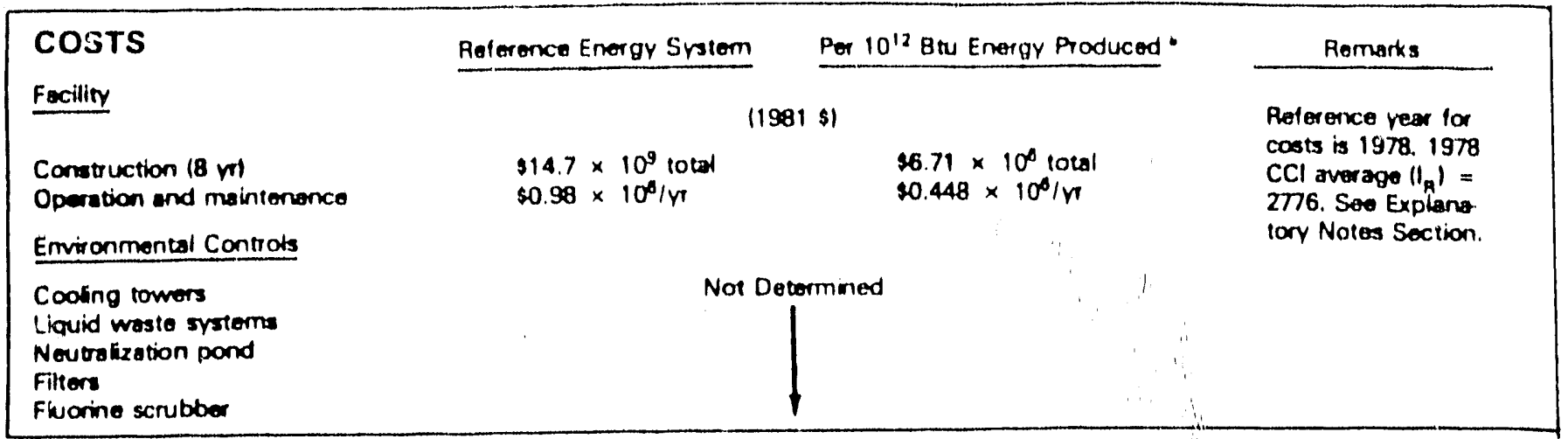

\section{ENVIRONMENTAL RESIDUALS}

Quantities Released
Reference Energy Systom Annual Levets

Air Pollutants

Particulates

Sultur dioxide

Oxides of nitrogen

Hydrocartons

Carbon monoxide

Fusoride

Uranium

Technetium-99

Water Pollutants

Cakcium

Chitoride

Sultate

Iron

Nitrate

Uranium

Technetium-99

Solid Wastes

Equipment components

Shudges

Thermal Discherge

Hout discharged to water

Heat discharged to air

Noise Pollution

Inplant

Cooling tower
Ruthenium 106

Sodium .

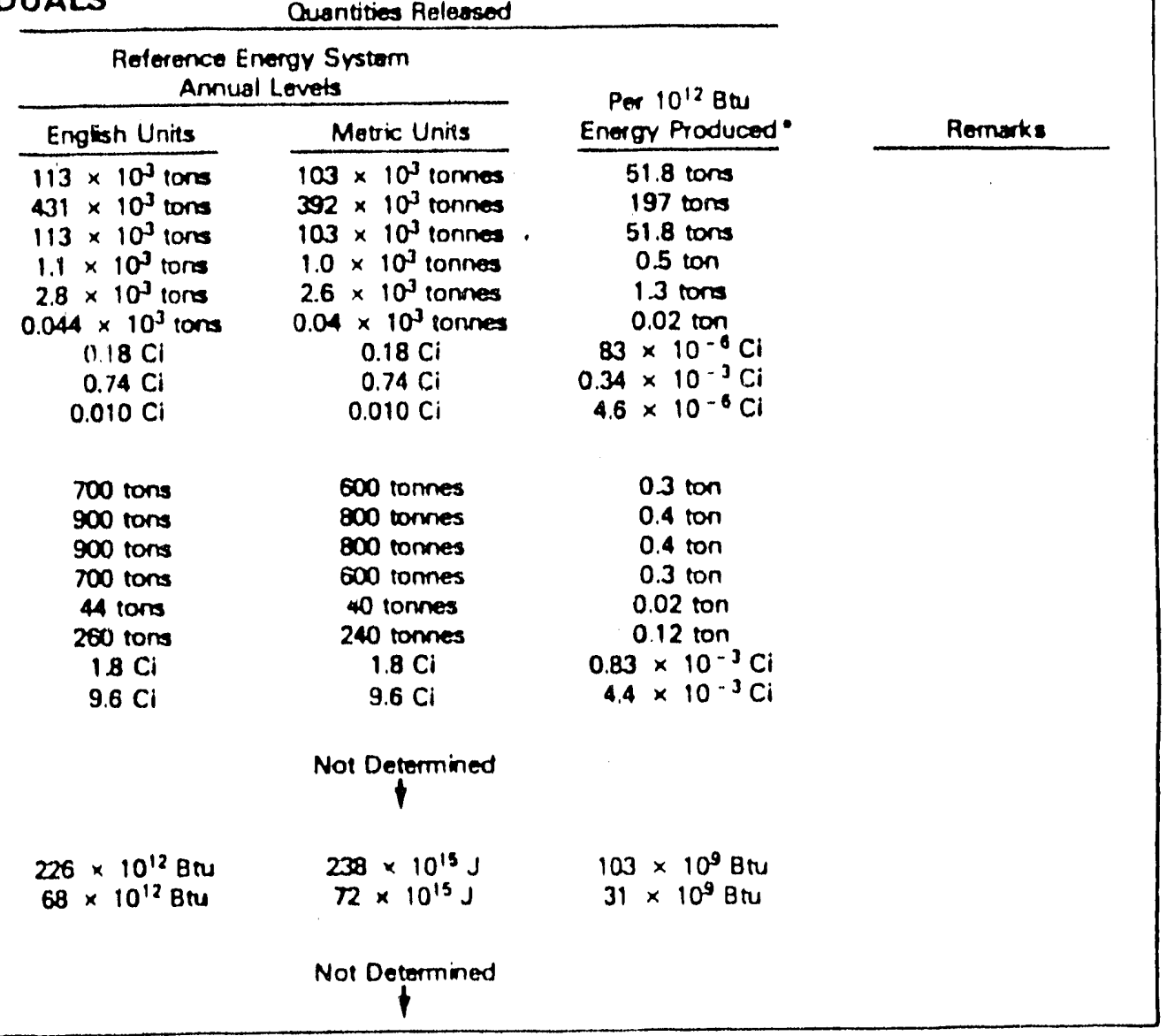

\begin{tabular}{|c|c|c|c|c|}
\hline \multirow[t]{3}{*}{ PRODUCTS } & \multicolumn{3}{|c|}{ Quantities Produced } & \multirow[b]{3}{*}{ Remorks } \\
\hline & \multicolumn{2}{|c|}{$\begin{array}{l}\text { Reference Energr Srstern } \\
\text { Anmual Production }\end{array}$} & \multirow{2}{*}{$\begin{array}{l}\text { Per } 10^{12} \text { Bru } \\
\text { Energy Produced. }\end{array}$} & \\
\hline & English Units & Metric Units & & \\
\hline Primery & & & & \\
\hline $\begin{array}{l}\text { Enriched uranium- } 235 \\
\text { in uranium hexsfluoride }\end{array}$ & $12.0 \times 10^{\mathrm{J}}$ tora & $10.9 \times 10^{s}$ tonnes & 5.49 tom & \\
\hline$\frac{\text { Byproducts }}{\text { Uranium } 235 \text { in tuits }}$ & 22 tom & 20 tonness & 0.01 ton & Toks $0.2 \%$ uraninum \\
\hline
\end{tabular}

\section{OCCUPATIONAL SAFETY AND HEALTH}

Not Determinod

$$
1+31
$$




\section{URANIUM ENRICHMENT GAS CENTRIFUGE}

\section{REFERENCE ENERGY SYSTEM}

The ges centrituge enrichmem process uses a systom of centrit hopes to envich uranium in uranium 235 to 2-4\%. System com ponents inctude production facifitios; lood, product, and taits withdrowal snstem decontamination tacilitios; recirculating and saritary water systomac sowage systerna otc.

\section{FACILITY OPERATING PARAMETERS}

Sirex

$10 \times 10^{3} \mathrm{cons} / \mathrm{r}$

(taits assay $0.2 \%$ )

Anmul Capacity Factor. $\quad 80 \%$

Armual Elvergy Production: $1821 \times 10^{12} \mathrm{Btu}$

Elficioncy. $\quad 65.4 \%$

Lifetime: $\quad 20 \mathrm{rr}$

\begin{tabular}{|c|c|c|c|c|}
\hline \multirow[t]{3}{*}{ RESOURCES USED } & \multicolumn{3}{|c|}{ Cuannities Used } & \multirow[b]{3}{*}{ Remarks } \\
\hline & \multicolumn{2}{|c|}{$\begin{array}{c}\text { Reter ence Energy Srstem } \\
\text { Armual Usage }\end{array}$} & \multirow{2}{*}{$\begin{array}{l}\text { Per } 10^{12} \text { Btu } \\
\text { Energy } \\
\text { Produced }\end{array}$} & \\
\hline & English Units & Metric Units & & \\
\hline \multicolumn{5}{|l|}{ Feed Materials } \\
\hline $\begin{array}{l}\text { Uranium haxafluaride } \\
\text { Energy }\end{array}$ & $15 \times 10^{3}$ tons & $14 \times 10^{3}$ tonnes & 8.4 tors & \\
\hline $\begin{array}{l}\overline{\text { Cod }} \\
\text { Geofine and diesed fuel } \\
\text { Electricity }\end{array}$ & $\begin{array}{l}66.8 \times 10^{3} \mathrm{rons} \\
208 \times 10^{3} \mathrm{gad} \\
20 \times 10^{6} \mathrm{MWh}\end{array}$ & $\begin{array}{c}60.7 \times 10^{3} \text { tonnes } \\
786 \times 10^{3} 1 \\
2.0 \times 10^{6} \mathrm{MWh}\end{array}$ & $\begin{array}{c}36.7 \text { tons } \\
114 \mathrm{gat} \\
1.1 \times 10^{3} \mathrm{MWh}\end{array}$ & $\begin{array}{l}\text { Heating and procens } \\
\text { stean }\end{array}$ \\
\hline \multicolumn{5}{|l|}{ Water } \\
\hline $\begin{array}{l}\text { Discharged to air } \\
\text { Diecharged to water }\end{array}$ & $1.82 \times 10^{3}$ acroft & $\begin{array}{l}1.1 \times 10^{9} 1 \\
224 \times 10^{9} 1\end{array}$ & $\begin{array}{l}0.49 \text { acreft } \\
1.00 \text { acreft }\end{array}$ & \\
\hline & \multicolumn{2}{|c|}{ Total Usage } & & \\
\hline \multicolumn{5}{|l|}{ Construction Materials } \\
\hline $\begin{array}{l}\text { Concrete } \\
\text { Stoed } \\
\text { Aluminum } \\
\text { Copper } \\
\text { Znc } \\
\text { Transtormex cooling oil } \\
\text { Paving maturiats } \\
\text { Miscellaneous metal products }\end{array}$ & $\begin{array}{r}600 \times 10^{3} \text { tons } \\
280 \times 10^{3} \text { tons } \\
25 \times 10^{3} \text { tons } \\
4.9 \times 10^{3} \text { tons } \\
0.22 \times 10^{3} \text { tons } \\
0.33 \times 10^{3} \text { tons } \\
1.3 \times 10^{3} \text { tons } \\
1.2 \times 10^{3} \text { tons }\end{array}$ & $\begin{array}{r}540 \times 10^{3} \text { tonnes } \\
250 \times 10^{3} \text { tonnes } \\
23 \times 10^{3} \text { tonnes } \\
4.5 \times 10^{3} \text { tornes } \\
0.20 \times 10^{3} \text { tornes } \\
0.30 \times 10^{3} \text { tonnes } \\
1.2 \times 10^{3} \text { tonnes } \\
1.0 \times 10^{3} \text { tonnes }\end{array}$ & $\begin{array}{l}330.00 \text { tons } \\
151.00 \text { tons } \\
14.00 \text { tons } \\
2.70 \text { tons } \\
0.12 \text { ton } \\
0.18 \text { ton } \\
0.70 \text { ton } \\
0.63 \text { ton }\end{array}$ & \\
\hline Lond & 840 acres & 340 tha & 0.46 acre & \\
\hline \multicolumn{5}{|l|}{ Personnel } \\
\hline $\begin{array}{l}\text { Construction }(7 \mathrm{rl} \\
\text { Operation and maintenance }\end{array}$ & $\begin{array}{l}5.1 \\
1.8\end{array}$ & $\begin{array}{l}\text { workers } \\
\text { morkers }\end{array}$ & $\begin{array}{l}2.8 \text { workers } \\
1.0 \text { worker }\end{array}$ & \\
\hline
\end{tabular}

\begin{tabular}{|c|c|c|c|}
\hline Costs & Reforence Energy Systern & Por $10^{12}$ Btu Energy Produced - & Rombrks \\
\hline \multicolumn{4}{|l|}{ Fecility } \\
\hline $\begin{array}{l}\text { Construction }(7 \mathrm{rr}) \\
\text { Operation and maintenance } \\
\text { Environmental Controts }\end{array}$ & $\begin{array}{l}\$ 5.7 \times 10^{5} \text { total } \\
\$ 755 \times 10^{6} / r\end{array}$ & $\begin{array}{l}\$ 3.13 \times 10^{6} \text { rocal } \\
\$ 0.415 \times 10^{6} / \mathrm{r}\end{array}$ & 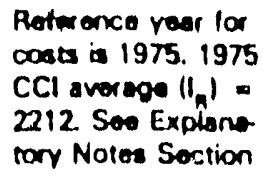 \\
\hline $\begin{array}{l}\text { Fiters } \\
\text { Liguid weste processing } \\
\text { Neutralieation focilities } \\
\text { Cooling rowers } \\
\text { Fhooring scrubbers }\end{array}$ & \multicolumn{2}{|c|}{ Not Determined } & \\
\hline
\end{tabular}

"In ofoctrical onergy (outjull) at the coector: sea note on page 1. 


\section{URANIUM ENRICHMENT GAS CENTRIFUGE}

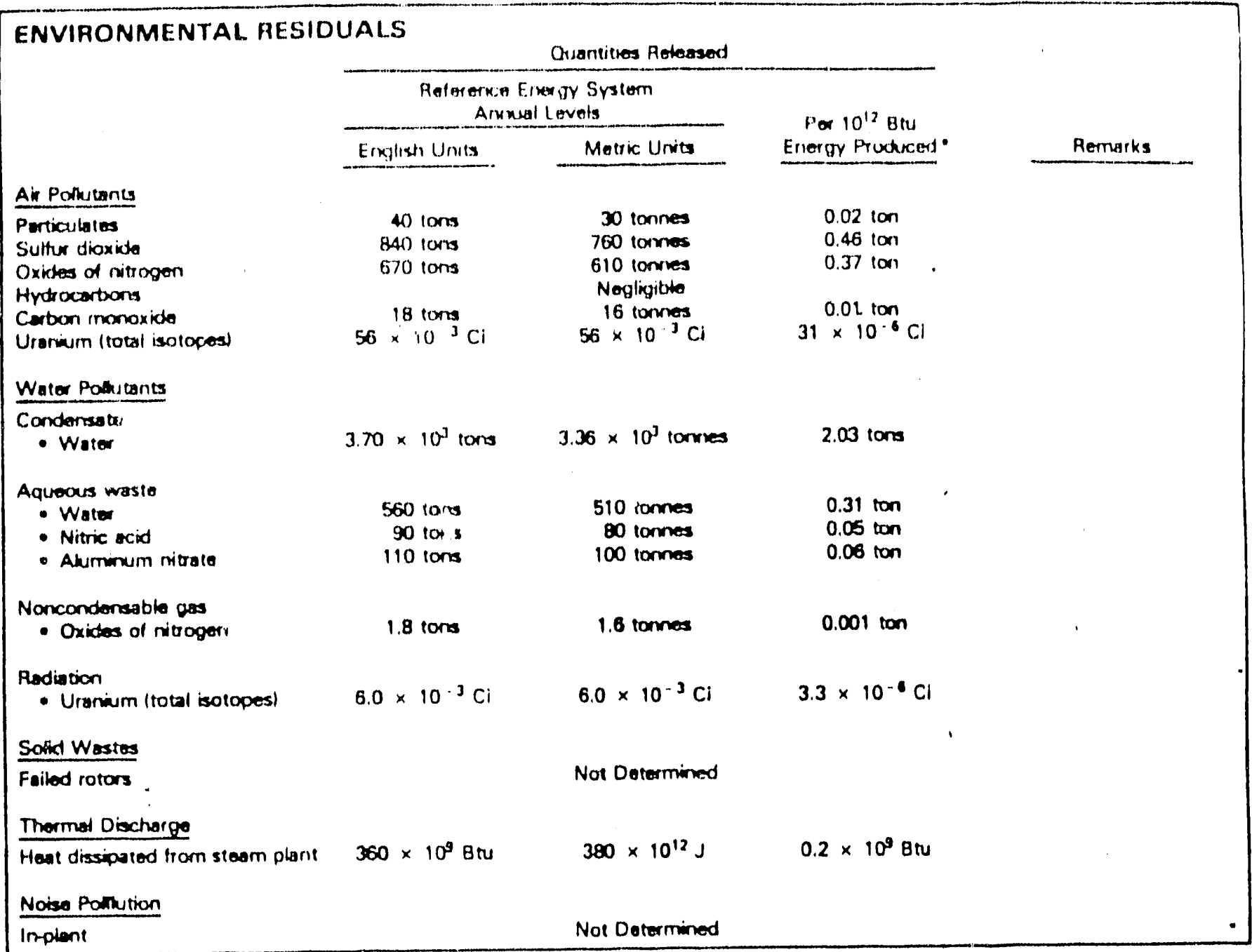

\section{PRODUCTS}

Ouantities Produced

\begin{tabular}{|c|c|c|c|}
\hline \multicolumn{2}{|c|}{$\begin{array}{c}\text { Reference Energy Systern } \\
\text { Anmual Production }\end{array}$} & \multirow{2}{*}{$\begin{array}{l}\text { Per } 10^{12} \text { Btu } \\
\text { Energy Produced" }\end{array}$} & \multirow[b]{2}{*}{ Remarks } \\
\hline English Units & Metric Units & & \\
\hline $1.00 \times 10^{3}$ tons & $9.08 \times 10^{3}$ tonnes & 5.49 tons & \\
\hline 18 tons & 16 tonnes & 0.01 ton & $0.2 \%$ uranium in taits \\
\hline
\end{tabular}

OCCUPATIONAL SAFETY AND HEALTH 


\section{FUEL FABRICATION PLANT}

\section{REFERENCE ENERGY SYSTEM}

Fued tabricution becomplistiod by chemical corrversion of urenium hoxafluoride to uranium dioxida and mechanical proc osing including pellel protuction and heet obment fabrication looded in zircalloy or stuintess stoet tubes, litted with end caps. and welded.

\section{FACILITY OPERATING PARAMETERS}

Size: 990 lonalyr

Anound Copacity Foctor: $\quad 80 \%$

A' mual Energy Production: $619 \times 10^{12}$ Bru

ctticiency:

$100 \%$ luranium-235 outpurs va uranum 235 input) $20 n$

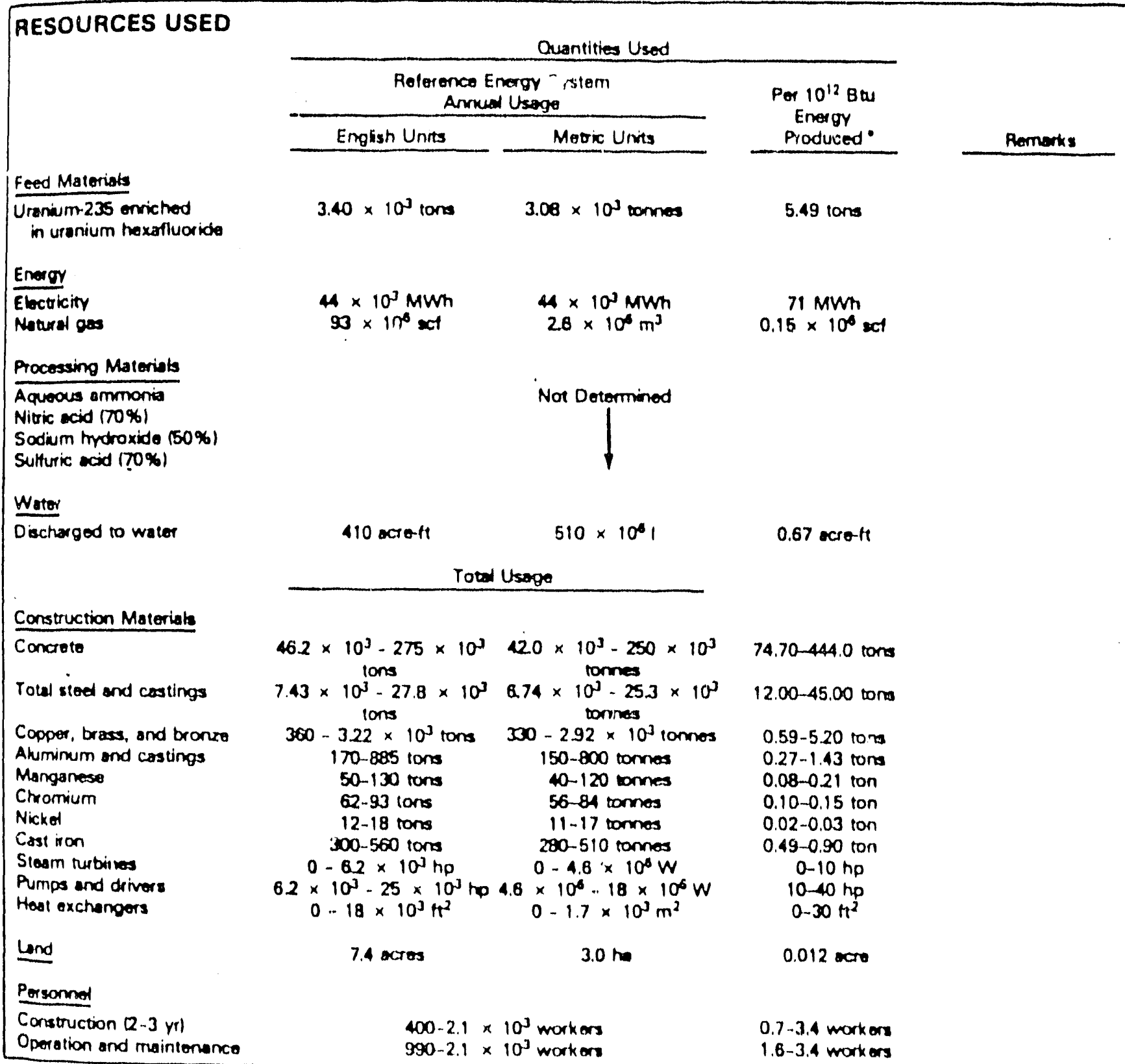

\footnotetext{
-In efoctrical onergy loutputl at the roectar; 300 nota on paga 1.
} 


\section{FUEL FABRICATION PLANT}

\begin{tabular}{|c|c|c|c|}
\hline COSTS & Relererce Erengy Srstem & Per $10^{12}$ Btu Energy Produced & Reinutiks \\
\hline \multicolumn{4}{|l|}{ Facility } \\
\hline & \multicolumn{2}{|c|}{$(19813)$} & \multirow{3}{*}{$\begin{array}{l}\text { Reference yea for } \\
\text { costs is } 1978.1978 \\
C C l \text { average }\left(I_{R}\right)= \\
2776 \text {. See Explana. } \\
\text { tory Notes Section. }\end{array}$} \\
\hline $\begin{array}{l}\text { Construction } 12-3 \mathrm{r}) \\
\text { Operation and mainternance } \\
\text { Environmental Contuots }\end{array}$ & $\begin{array}{l}\$ 248 \times 10^{6}-792 \times 10^{6} \text { lotat } \\
\$ 177 \times 10^{6}-257 \times 10^{6} / v\end{array}$ & $\begin{array}{l}\$ 0.400 \times 10^{0}-1.28 \times 10^{6} \text { total } \\
\$ 0.287 \times 10^{8} / \mathrm{rr}-0.415 \times 10^{6} / \mathrm{rr}\end{array}$ & \\
\hline 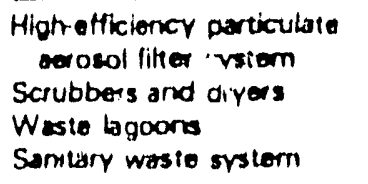 & \multicolumn{2}{|c|}{ Nor Determined } & \\
\hline
\end{tabular}

\begin{tabular}{|c|c|c|c|c|}
\hline \multicolumn{4}{|c|}{ ENVIRONMENTTAL RESIDUALS } & \multirow[b]{3}{*}{ Flomarks } \\
\hline & \multicolumn{2}{|c|}{$\begin{array}{c}\text { Relerence Energy System } \\
\text { Annual Levets }\end{array}$} & \multirow{2}{*}{$\begin{array}{c}\text { Per } 10^{12} \mathrm{Btu} \\
\text { Energr Produced" }\end{array}$} & \\
\hline & Englesh Units & Metric Units & & \\
\hline \multicolumn{5}{|l|}{ An Pollutants } \\
\hline $\begin{array}{l}\text { Sullur dioxide } \\
\text { Oxides of nitrogen } \\
\text { Carbon monoxide } \\
\text { Uranium }\end{array}$ & $\begin{array}{l}681 \text { tons } \\
170 \text { tons } \\
6.2 \text { tons } \\
5.1 \times 10^{-3} \mathrm{Cl}\end{array}$ & $\begin{array}{c}618 \text { tonnes } \\
160 \text { tonnes } \\
5.6 \text { tonnes } \\
51 \times 10^{-1} \mathrm{Cl}\end{array}$ & $\begin{array}{c}1.10 \text { tons } \\
0.28 \text { ton } \\
0.01 \text { ton } \\
8.3 \times 10^{-6} \mathrm{Ci}\end{array}$ & \\
\hline \multicolumn{5}{|l|}{ Water Pollutants } \\
\hline $\begin{array}{l}\text { Nitrogen as ammonia } \\
\text { Nitrogen as nitrate } \\
\text { Fluoride } \\
\text { Urarwism } \\
\text { Thorium } 234\end{array}$ & $\begin{array}{l}280 \text { tons } \\
681 \text { tons } \\
120 \text { tons } \\
0.51 \mathrm{Ci} \\
0.26 \mathrm{Ci}\end{array}$ & $\begin{array}{l}260 \text { connes } \\
618 \text { connes } \\
110 \text { tonnes } \\
0.51 \mathrm{Ci} \\
0.26 \mathrm{Ci}\end{array}$ & $\begin{array}{c}0.46 \text { ton } \\
1.10 \text { tons } \\
0.19 \text { ton } \\
0.83 \times 10^{-3} \mathrm{Cl} \\
0.42 \times 10^{-3} \mathrm{Cl}\end{array}$ & \\
\hline \multicolumn{5}{|l|}{ Solid Wastes } \\
\hline $\begin{array}{l}\text { Catcinum fluoride } \\
\text { Ammonis } \\
\text { Fhorine } \\
\text { Suthr axide } \\
\text { Nitrate } \\
\text { Uranium lburied }\end{array}$ & 743 ions & $\begin{array}{l}674 \text { tonnes } \\
\text { Nor Defermined }\end{array}$ & $9.6 \times 10^{-3} \mathrm{Cl}$ & \\
\hline \multicolumn{5}{|l|}{ Thermal Oischarge } \\
\hline Heol dissipated & $200 \times 10^{9} \mathrm{Bru}$ & $300 \times 10^{12} \mathrm{~J}$ & $0.4 \times 10^{9} \mathrm{Btu}$ & \\
\hline
\end{tabular}

\begin{tabular}{|c|c|c|c|c|}
\hline \multirow[t]{3}{*}{ FRODUCTS } & \multicolumn{3}{|c|}{ Quantities Produced } & \multirow[b]{3}{*}{ Remarks } \\
\hline & \multicolumn{2}{|c|}{$\begin{array}{l}\text { Relerence Energy System } \\
\text { Anmual Production }\end{array}$} & \multirow{2}{*}{$\begin{array}{c}\text { Por } 10^{12} \mathrm{Btu} \\
\text { Energy Produced }\end{array}$} & \\
\hline & English Units & Meuic Units & & \\
\hline \multicolumn{5}{|l|}{ Primary } \\
\hline $\begin{array}{l}\text { Uranum (uranium dioxide) } \\
\text { fuet elements }\end{array}$ & 990 ions & 900 tonnes & 1.6 toms & \\
\hline
\end{tabular}

\section{OCCUPATIONAL SAFETY AND HEALTH}

Nol Deferminert

-In ofectrical onergy loutpull at the reactor; see note on perpe 1. 


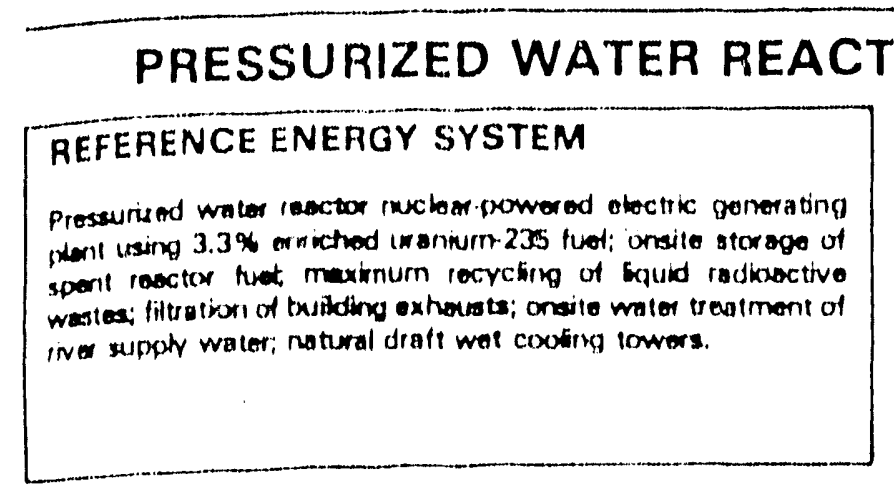

(iilin

\begin{tabular}{|c|c|}
\hline \multicolumn{2}{|c|}{ FACILITY OPEAATING PARAMETERS } \\
\hline Sire: & $1 \times 10^{3} \mathrm{MWn}$ \\
\hline Aomual Capacity Foctor: & $70 x_{0}$ \\
\hline Anmual Energy Proxduction: - & $\begin{array}{l}21 \times 10^{12} \mathrm{Htu} \\
\left(8.13 \times 10^{6} \mathrm{MWII}\right)\end{array}$ \\
\hline Efficioncy: & $33 x_{1}$ \\
\hline L.Jfotime: & $30-40 \mathrm{r}$ \\
\hline
\end{tabular}

\begin{tabular}{|c|c|c|c|c|}
\hline \multirow[t]{3}{*}{ RESOURCES USED } & \multicolumn{3}{|c|}{ Quantities Usod } & \multirow[b]{3}{*}{ Remorks } \\
\hline & \multicolumn{2}{|c|}{$\begin{array}{c}\text { Referonce Energy Systern } \\
\text { Annual Usage }\end{array}$} & \multirow{2}{*}{$\begin{array}{l}\text { Por } 10^{12} \text { Btu } \\
\text { Energy } \\
\text { Produced" }\end{array}$} & \\
\hline & English Uniry & Metric Units. & & \\
\hline \multicolumn{5}{|l|}{ Feed Materiats } \\
\hline $\begin{array}{l}\text { Urarmin fuet (3.3\% } \\
\text { unamim } 235 \text { ) }\end{array}$ & 26.7 tons & 24.2 tonnes & 1.27 torn & $\begin{array}{l}33 \% \text { of core } \\
\text { annualty }\end{array}$ \\
\hline Watex & & & $\cdot$ & \\
\hline \multirow[t]{2}{*}{$\overline{\text { Powe ntant make up water }}$} & $16 \times 10^{3}$ acreft & $19 \times 10^{9} 1$ & $0.74 \times 10^{3}$ acto- 11 & Wat cooling \\
\hline & \multicolumn{2}{|c|}{ Total Usage } & & \\
\hline \multicolumn{5}{|l|}{ Construrtion Materials } \\
\hline $\begin{array}{l}\text { Concretu } \\
\text { Metal conduit } \\
\text { Cable troy } \\
\text { Lerpo process pipe } \\
\text { Small pipe } \\
\text { Wire and cable }\end{array}$ & $\begin{array}{l}250 \times 10^{3} \mathrm{nd}^{3} \\
500 \times 10^{3} \mathrm{H} \\
100 \times 10^{3} \mathrm{H} \\
160 \times 10^{3} \mathrm{H} \\
200 \times 10^{3} \mathrm{H} \\
7 \times 10^{6} \mathrm{H}\end{array}$ & $\begin{array}{l}190 \times 10^{3} \mathrm{~m}^{3} \\
150 \times 10^{3} \mathrm{~m} \\
30 \times 10^{3} \mathrm{~m} \\
50 \times 10^{3} \mathrm{~m} \\
60 \times 10^{3} \mathrm{~m} \\
2.1 \times 10^{6} \mathrm{~m}\end{array}$ & $\begin{array}{l}11.9 \times 10^{3} \mathrm{yd}^{3} \\
2.4 \times 10^{3} \mathrm{ft} \\
4.8 \times 10^{3} \mathrm{ft} \\
7.6 \times 10^{3} \mathrm{Ht} \\
9.5 \times 10^{3} \mathrm{ft} \\
0.3 \times 10^{8} \mathrm{ft}\end{array}$ & \\
\hline \multicolumn{5}{|l|}{ Lend } \\
\hline $\begin{array}{l}\text { Sine eres } \\
\text { Lowloved radioective waste } \\
\text { disposial aree }\end{array}$ & $\begin{array}{c}1.85 \times 10^{3} \text { acres } \\
0.02 \text { acre }\end{array}$ & $\begin{array}{l}749 \mathrm{ha} \\
0.008 \mathrm{ha}\end{array}$ & $0.9 \times 10^{88.1}$ acres & \\
\hline \multicolumn{5}{|l|}{ Personnel } \\
\hline $\begin{array}{l}\text { Construction } 9 \mathrm{yrt} \\
\text { Operation and meintenance }\end{array}$ & \multicolumn{2}{|c|}{$\begin{array}{l}2.31 \times 10^{3} \text { workers } \\
230 \text { workers }\end{array}$} & $\begin{array}{l}110 \text { workers } \\
11 \text { morkers }\end{array}$ & \\
\hline
\end{tabular}

\begin{tabular}{|c|c|c|}
\hline COSTS & Pea $10^{12}$ Btu Energy Produced " & Remarks \\
\hline Foctiry & $(1981 \$)$ & \\
\hline $\begin{array}{l}\text { Construction } 9 \mathrm{rit} \\
\text { Operation and makitenence }\end{array}$ & $\begin{array}{l}\text { Total lite crete costs lexcluding utimate decommissioning } \\
\text { and decontaminetion) } ₫ 97.0 \mathrm{milts} / \mathrm{kWh}\end{array}$ & 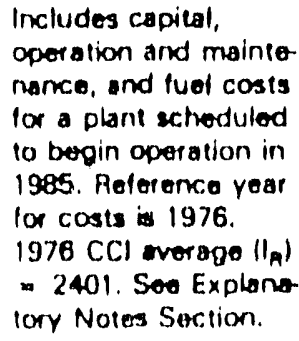 \\
\hline Emmonmental Controts & & $\begin{array}{l}\text { Included in lacility } \\
\text { costs }\end{array}$ \\
\hline
\end{tabular}

in extrical onergy (outpull at tho racion; seo notb on page 1. 


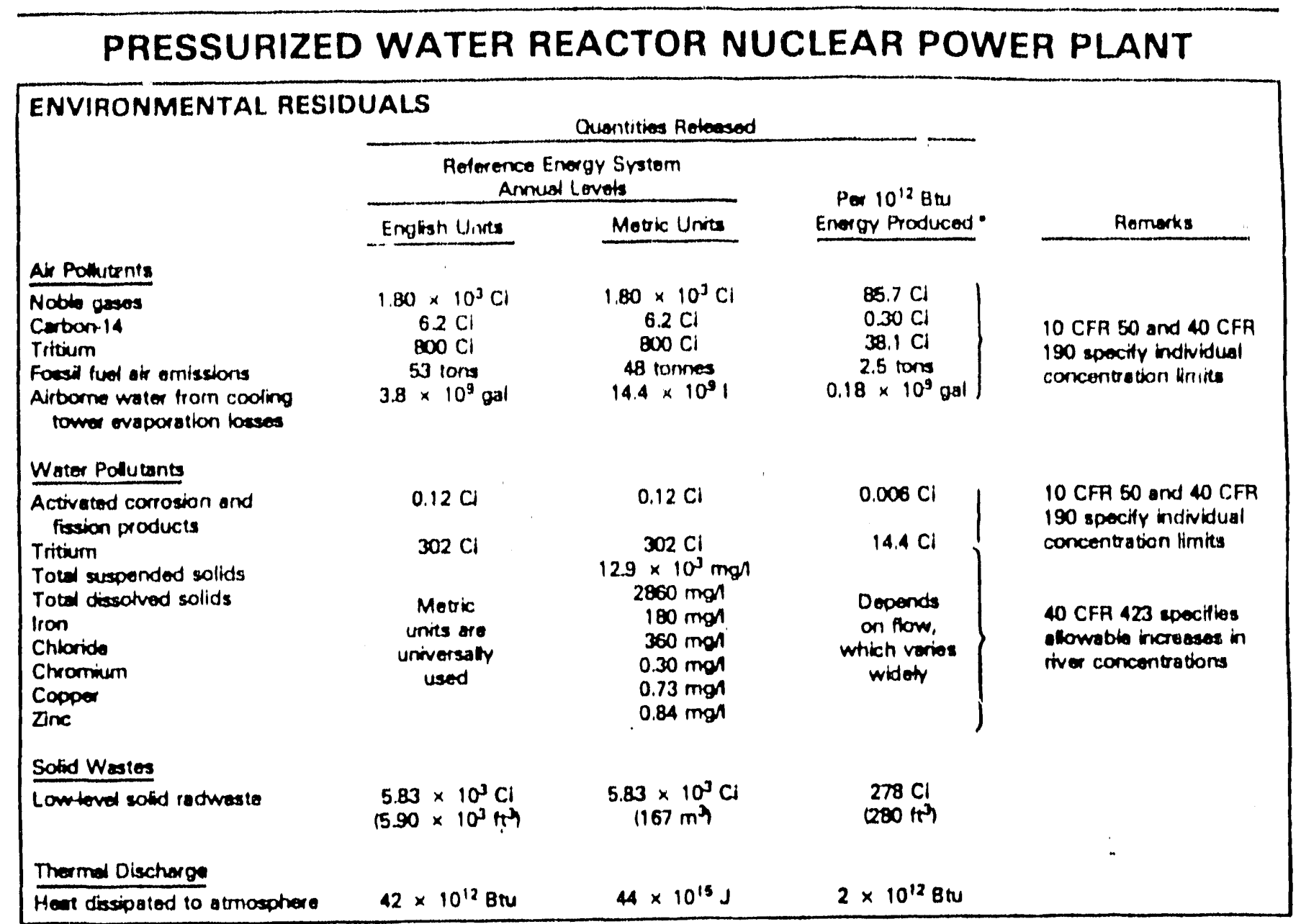

\begin{tabular}{|c|c|c|c|c|}
\hline \multirow[t]{3}{*}{ PRODUCTS } & \multicolumn{3}{|c|}{ Quantitios Produced } & \multirow[b]{3}{*}{ Rernaks } \\
\hline & \multicolumn{2}{|c|}{$\begin{array}{l}\text { Reference Energr Srsiem } \\
\text { Armual Production } \\
\end{array}$} & \multirow{2}{*}{$\begin{array}{l}\text { Per } 10^{12} \mathrm{Btu} \\
\text { Energy Produced. }\end{array}$} & \\
\hline & English Units & Metric Units & & \\
\hline \multicolumn{5}{|l|}{ Primery } \\
\hline Eloctricity & $6.1 \times 10^{6} \mathrm{MWh}$ & $6.1 \times 10^{8} \mathrm{MWh}$ & $0.29 \times 10^{6} \mathrm{MWh}$ & \\
\hline \multicolumn{5}{|c|}{ Recovorables/Recrclables } \\
\hline Spent mucloar fuet & 28.7 tons & 24.3 connes & 1.30 tors & \\
\hline
\end{tabular}

\begin{tabular}{|c|c|c|c|}
\hline OCCUPATION & $\begin{array}{l}\text { Y AND HEALTH } \\
\text { Reference Energy Srsiem } \\
\text { Annual }\end{array}$ & Per $10^{12}$ Btu Energy Prockucod. & Rornerks \\
\hline Dowthe & 0 & 0 & \\
\hline Inquives & $0.5-3.0$ & $0.02-0.14$ & \\
\hline Ractivition Expoeura & 128 mantom & 20.4 mancem & \\
\hline
\end{tabular}

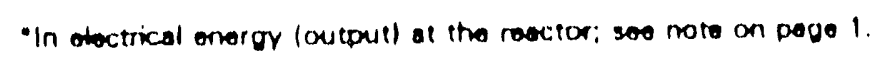




\section{BOILING WATER REACTOR NUCLEAR POWER PLANT}

\section{AEFERENCE ENERGY SYSTEM}

Genorel Electric Compery's stenderdized BWR/6 reactor with the Merk MI contrinment deaion. Neturel draft cooting lowere. Ful is 3\% enriched urenium-235; onsite storege of thavid redioective whisters filtration of building exhousta; onsine water bestoment of rive apply water, and natural drate wot cooling towere.

\section{FACILITY OPERATING PARAMETERS}

Sixp:

$1 \times 10^{3}$ MWe

Annual Capecity Fector: $\quad 70 \%$

Annual Energy Pruduction: $21 \times 10^{12}$ Btu

Efficiencr. $30 \%$

Lifotimer: $\quad 30.40 r$

\section{RESOURCES USED}

Feod Matorials

Uranium fuet $13.0 \%$ enrichod urenium-235)

Procesaing Moterials

Woter

Meke-up water for cooling

towers and miscollenoous

phont senvice

\section{Construction Materiats}

\section{Concrete}

Roinforcing atid

Structural gent

Lend

Sits land requiremonta.

tranamision route, diserupted land autuce (aital, and committed land
Quantities Used

\begin{tabular}{|c|c|c|c|}
\hline \multicolumn{2}{|c|}{$\begin{array}{c}\text { Roference Eneror Svsterm } \\
\text { Annual Usage }\end{array}$} & \multirow{2}{*}{$\begin{array}{c}\text { Per } 10^{12} \mathrm{Btu} \\
\text { Enorgy } \\
\text { Produced }\end{array}$} & \multirow[b]{2}{*}{ Rernarks } \\
\hline English Units & Metric Units & & \\
\hline 34 tons & 31 tonnes & 1.6 tons & $\begin{array}{l}\text { One- fourth of } \\
\text { core snnualiy }\end{array}$ \\
\hline
\end{tabular}

Natural dratt wot $10.9 \times 10^{3}=00.11$ $21 \times 10^{9} 1$

$0.8 \times 10^{3}$ acrott cooling towers used.

\section{Personnd}

Construction $19 \mathrm{mt}$

Operation end maineenance

\section{Total Usoge}

$\begin{array}{llc}4.5 \times 10^{6} \mathrm{H}^{3} & 130 \times 10^{3} \mathrm{~m}^{2} & 210 \times 10^{2} \mathrm{H}^{3} \\ 17 \times 10^{3} \text { tons } & 15 \times 10^{3} \text { tomnes } & 810 \text { tons } \\ 87 \times 10^{3} \text { tons } & 7.9 \times 10^{3} \text { tomes } & 420 \text { tors }\end{array}$

$3.30 \times 10^{3} \cos$

$1.38 \mathrm{ho}$

161 actes

$23 \times 10^{3}$ morkers

110 mokers
For two 1250.MWs units with cooling towers

\section{costs}

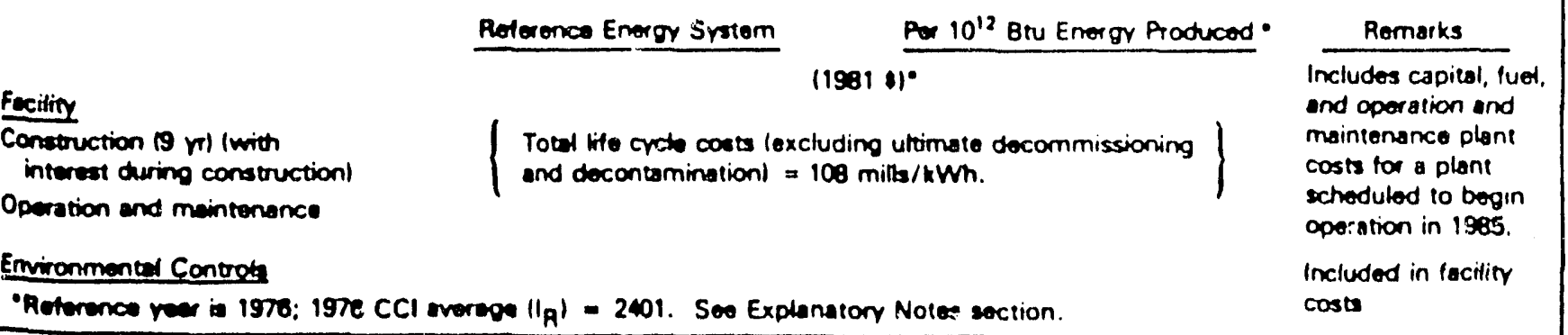

"If electrical energy (outpull at the ractor; wee note on peos 1. 


\section{BOILING WATER REACTOR NUCLEAR POWER PLANT}

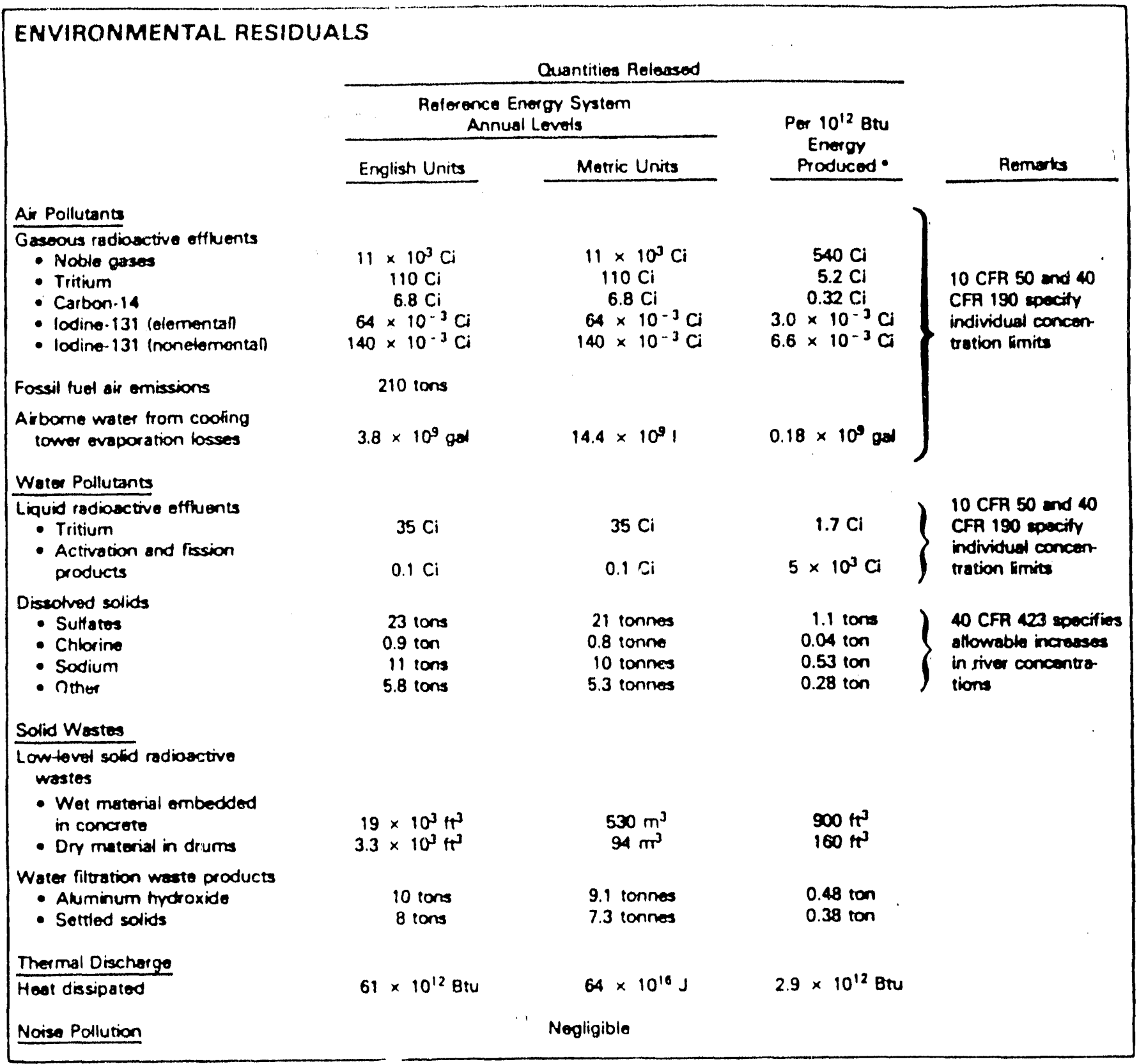

-In efoctrical onergr loutpull al the reoctor; soe nore on page $i$. 


\section{BOILING WATER REACTOR NUCLEAR POWER PLANT}

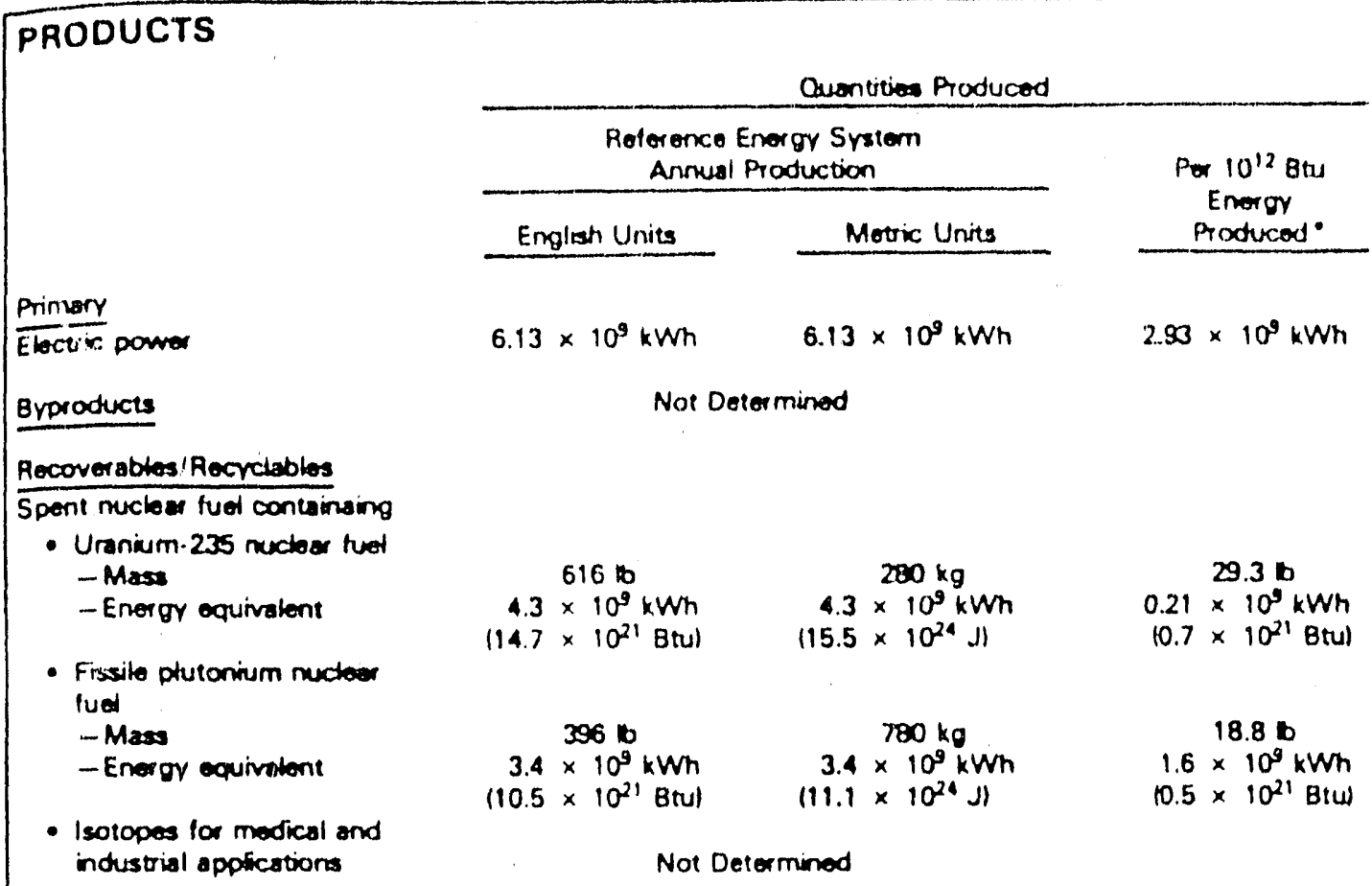

\section{OCCUPATIONAL SAFETY AND HEALTH}

\begin{tabular}{|c|c|c|c|}
\hline & $\begin{array}{c}\text { Rolerence Energy Srstem } \\
\text { Annual }\end{array}$ & Per $10^{12}$ Btu Energy Produced & Remarks \\
\hline Deacts & 0.0 & 0.0 & \\
\hline \multicolumn{4}{|l|}{ Injuries } \\
\hline $\begin{array}{l}\overline{\text { Number }} \\
\text { Total bost dars }\end{array}$ & $\begin{array}{l}0.51 \cdot 3.0 \\
14.91\end{array}$ & $\begin{array}{l}0.02 \cdot 0.14 \\
0.67-4.33\end{array}$ & \\
\hline Occupational Radiution Exposurs & $1.1 \times 10^{3}$ manrems & 53 manierns & $\begin{array}{l}\text { Average colloctive } \\
\text { dose }\end{array}$ \\
\hline
\end{tabular}

\footnotetext{
- In ectrical onergr (outpull al the reactor; seo noto on poge 1.
} 


\section{COMMERCIAL HIGH-LEVEL NUCLEAR WASTE REPOSITORY}

\section{REFERENCE ENERGY SYSTEM}

Deen (jeokogic Repository tacility capable of handling solibitied hightevel westes and transurance wassies from the reprox.essing of anemt fuet; located 6002.m doep in axich of two candidale rock

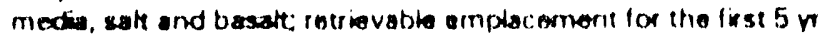
of operation with optional permanerit dispossal; packaging facil ity included in surface operations. Construction tirme is $10 \mathrm{w}$. mining operations caking place during the last $7 \mathrm{r}$.

\section{FACILITY OPERATING PARAMETERS}

Ropusitory For

Roprocessing Whste

\begin{tabular}{cc}
\hline Soll & Bosen \\
\hline 3,000 & 3,000 \\
62,000 & 58,000 \\
$49 \times 10^{15} \mathrm{Btu}$ & $44 \times 10^{15} \mathrm{Btu}$ \\
19 & 18 \\
\hline
\end{tabular}

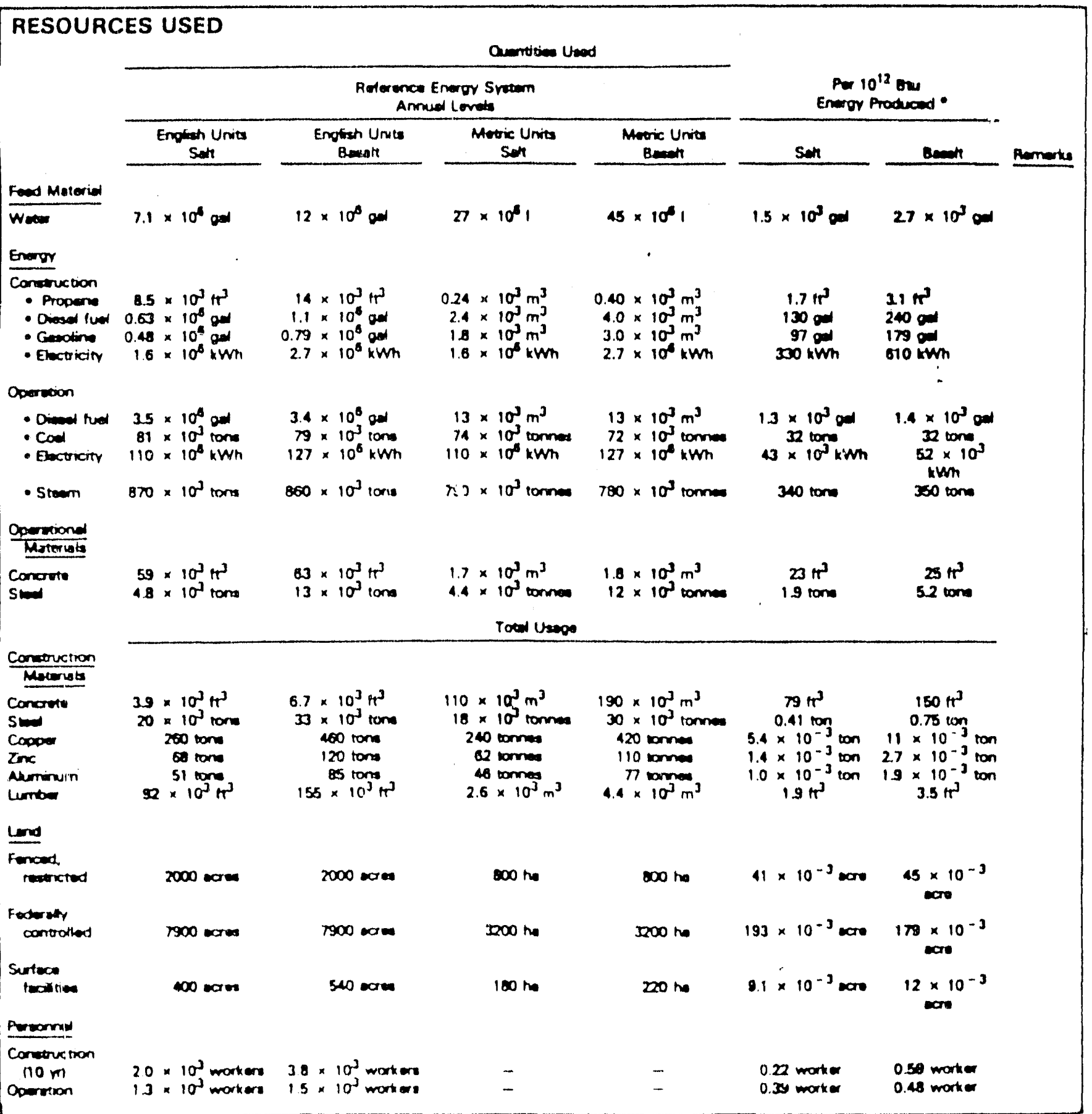

- In cectrical onergr loutpull el the recctor: see note on peos 1. 
COMMERCIAL HIGH-LEVEL NUCLEAR WASTE REPOSITORY

\begin{tabular}{|c|c|c|c|c|c|}
\hline \multicolumn{5}{|l|}{ COSTS } & \\
\hline & Solt & Besalt & Soll & Besell & Remorks \\
\hline & - & & 11 & & \\
\hline \multicolumn{6}{|l|}{ Fuciltir } \\
\hline Construction (10 $\mathrm{m}$ ) & $\begin{array}{l}11.0 \times 10^{9} \\
11.0 \times 10^{9}\end{array}$ & $\begin{array}{l}13.1 \times 10^{6} \\
12.4 \times 10^{\circ}\end{array}$ & $\begin{array}{l}133 \times 10^{3} \\
833 \times 10^{3}\end{array}$ & $\begin{array}{l}.70 \times 10^{3} \\
.55 \times 10^{3}\end{array}$ & \\
\hline
\end{tabular}

\section{ENVIRONMENTAL RESIDUALS}

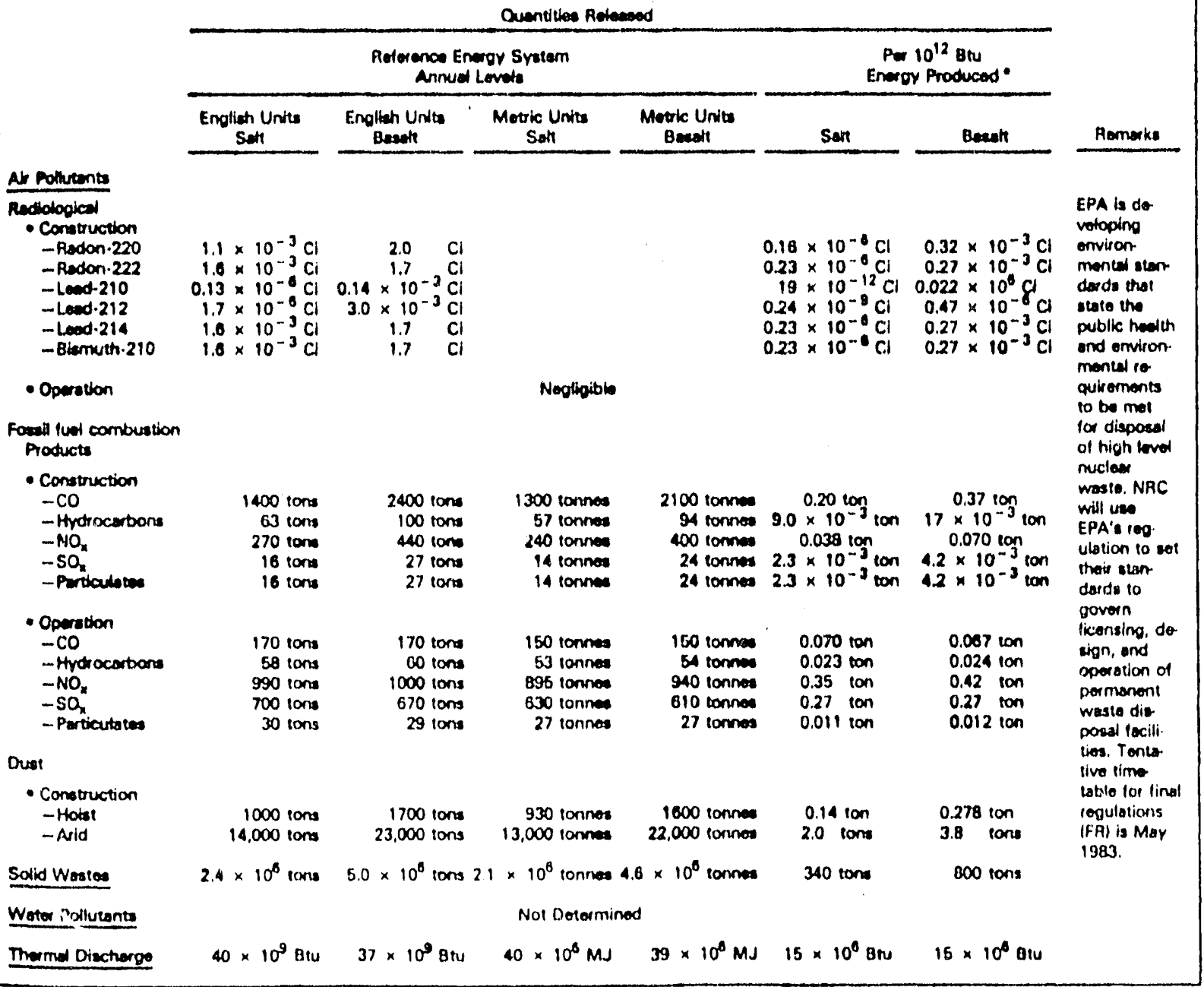

\begin{tabular}{|c|c|c|c|c|c|}
\hline OCCUPATIO & \multicolumn{2}{|c|}{$\begin{array}{c}\text { Rateronce Energy Svitom } \\
\text { Annual Averogo }\end{array}$} & \multicolumn{2}{|c|}{$\begin{array}{l}\text { Pew } 10^{12} \text { atu } \\
\text { Eneroy Produced. }\end{array}$} & \multirow[b]{2}{*}{ Rorriarky } \\
\hline$\because$ & Sall & Beanit & Salt & Bomalt & \\
\hline \multicolumn{6}{|l|}{ Nonredtotogical } \\
\hline 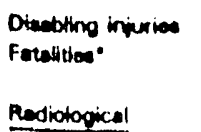 & $\begin{array}{l}50 \\
1.0\end{array}$ & $\begin{array}{l}130 \\
2.6\end{array}$ & $\begin{array}{c}0.010^{-3} \\
0.20 \times 10^{-3}\end{array}$ & $\begin{array}{c}0.029 \\
0.59 \times 10^{-3}\end{array}$ & \\
\hline $\begin{array}{l}\text { Compruction } \\
\text { Operation }\end{array}$ & $\begin{array}{l}0.028 \text { mantern } \\
7.4 \times 10^{3} \text { maritions }\end{array}$ & $\begin{array}{l}890 \text { menterne } \\
72 \times 10^{3} \text { ineriroms }\end{array}$ & $\begin{array}{l}3.7 \times 10 \div \text { manion } \\
29 \text { menctoms }\end{array}$ & 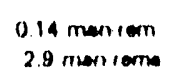 & \\
\hline
\end{tabular}

- In enectrical energy (outputl at the reector; see note on pege 1 


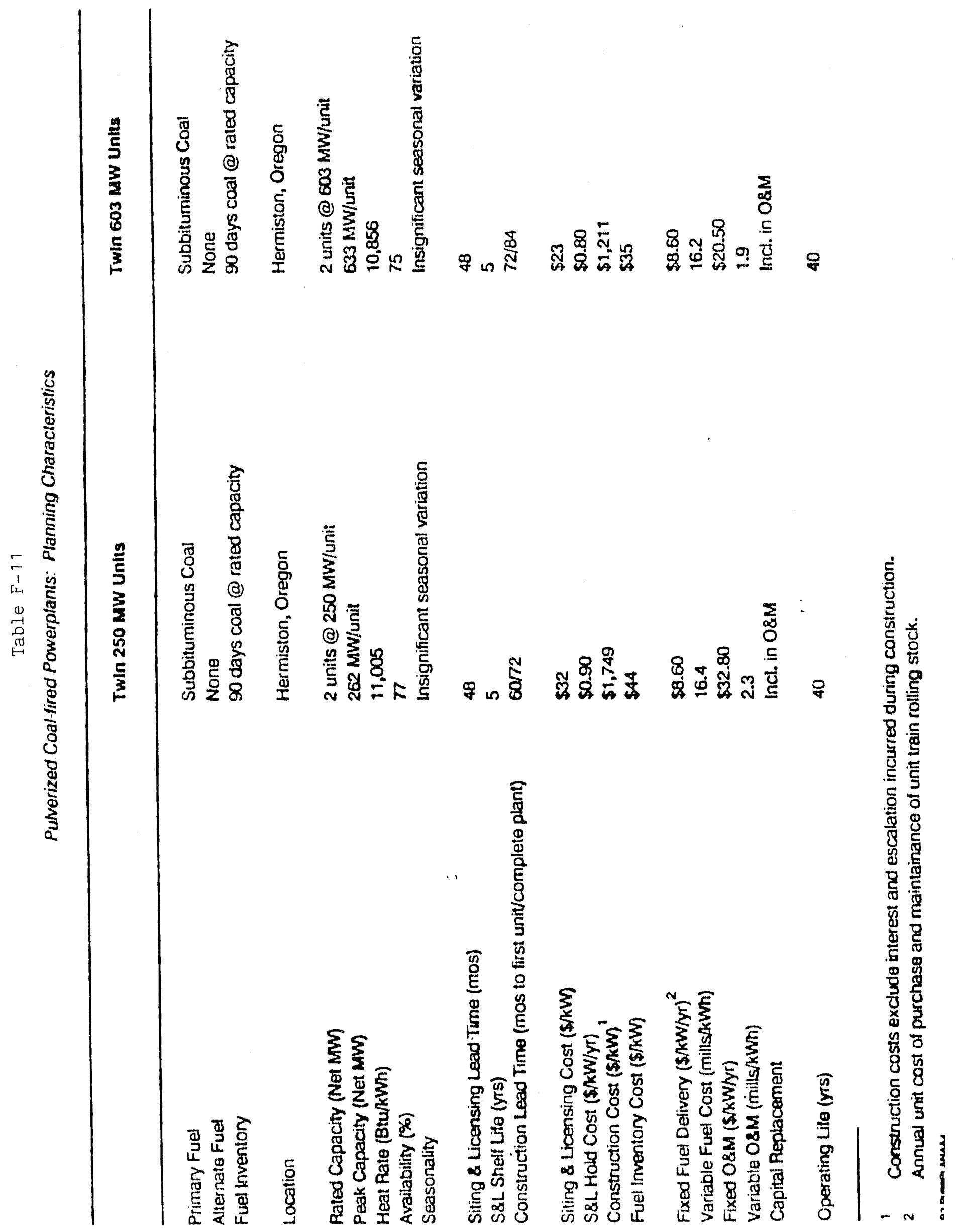




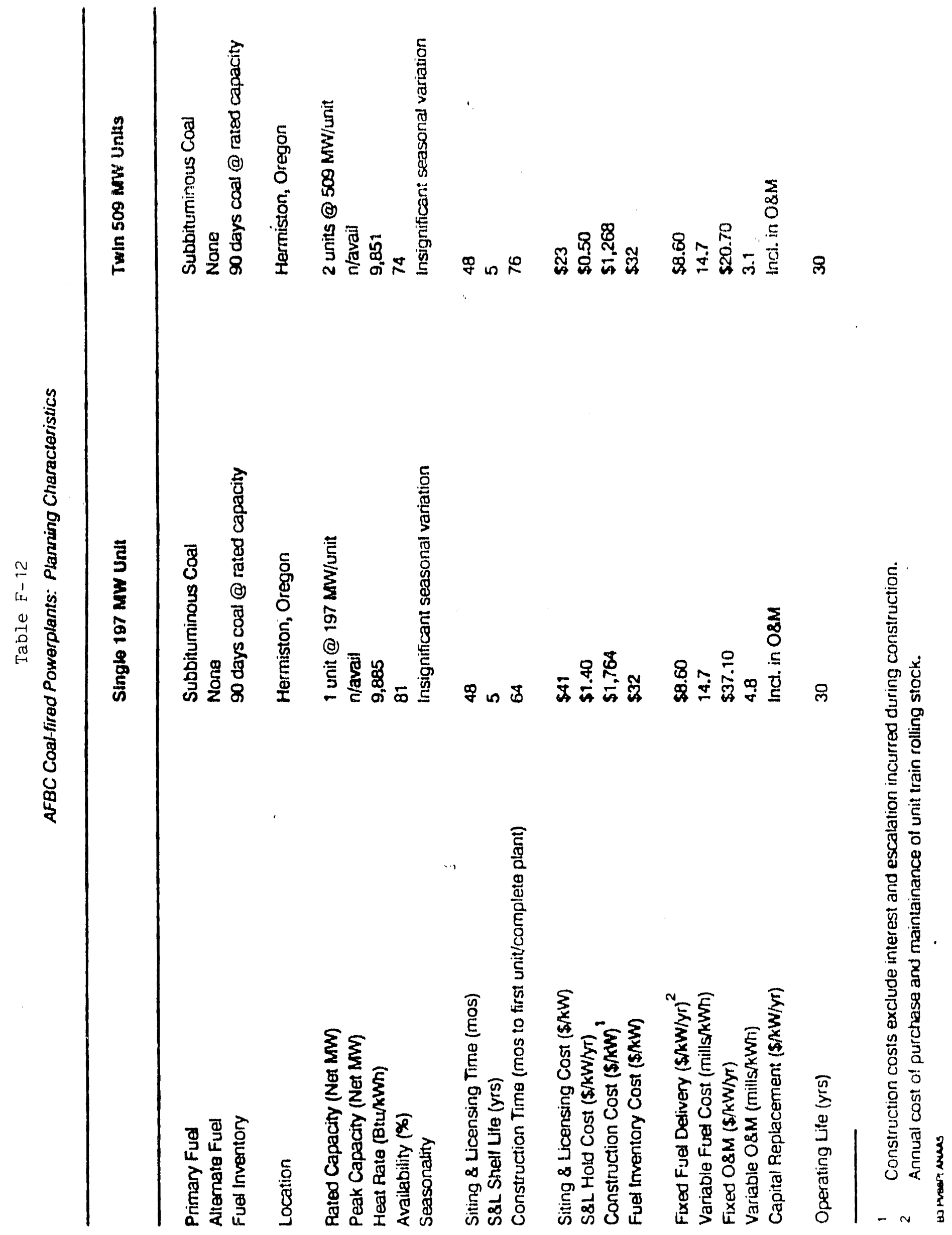




\section{WESTERN SURFACE COAL MINING \\ (WITH PREPARATION PLANT)}

\begin{abstract}
REFERENCE ENERGY SYSTEM

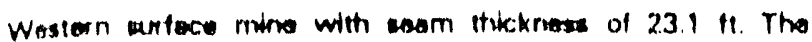

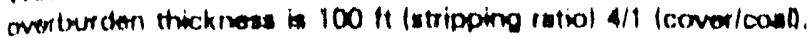
The overturden removed b dowe by chaghine stripping shovels.

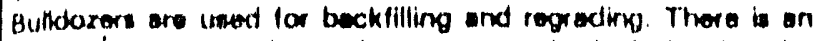
onsite ixeparation plam using wat mathod of charing the coul, end unit irains or used for firul shiprent. The capecity und production of this mirio wo relativety ckesse. Terrain, ropopraphy, and overtburden thicknesss limit tiva mine capacity. The estimated production is $85.90 \%$ of capacity.
\end{abstract}

\section{FACILITY OPERATING PARAMETERS}

Slro:

Conal mirna: $9.7 \times 10^{6}$ rexis/ve Properation phent: $8.73 \times 10^{n}$ tons/y

Armual Copacity Foctor: $\quad 85.50 \%$

Armual Energy Production: Coal mirn: $170 \times 10^{12}$ Blu Preperation plant: $152 \times 10^{12}$ Btu

Efficiency. $\quad 90 \%$ (properation plarit)

Lifotime: $\quad 40 \mathrm{rr}$

- Heating value of coal $=8750$ Btu/h.

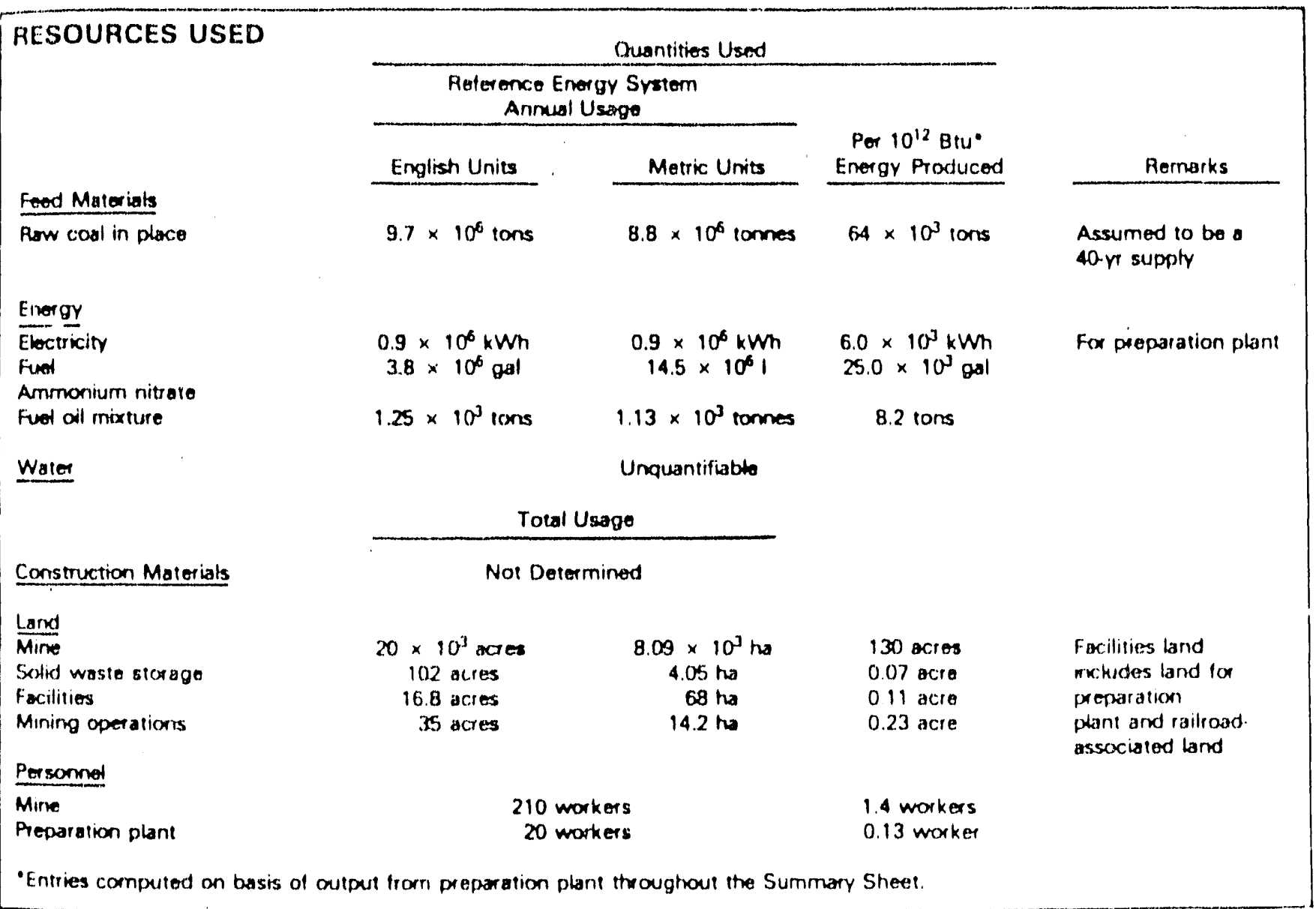

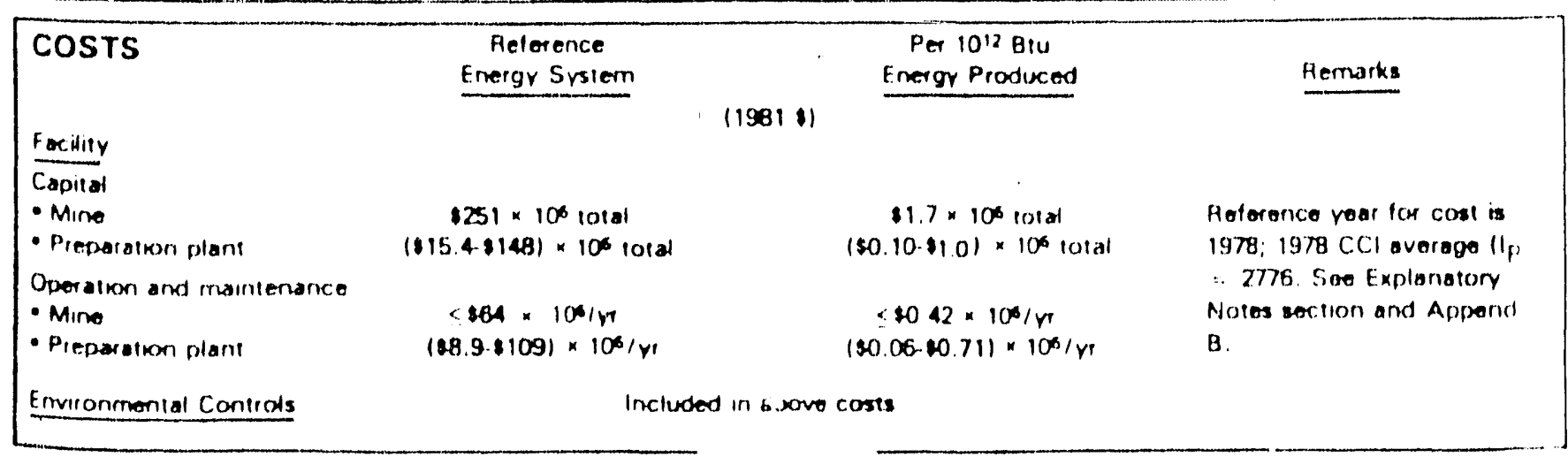




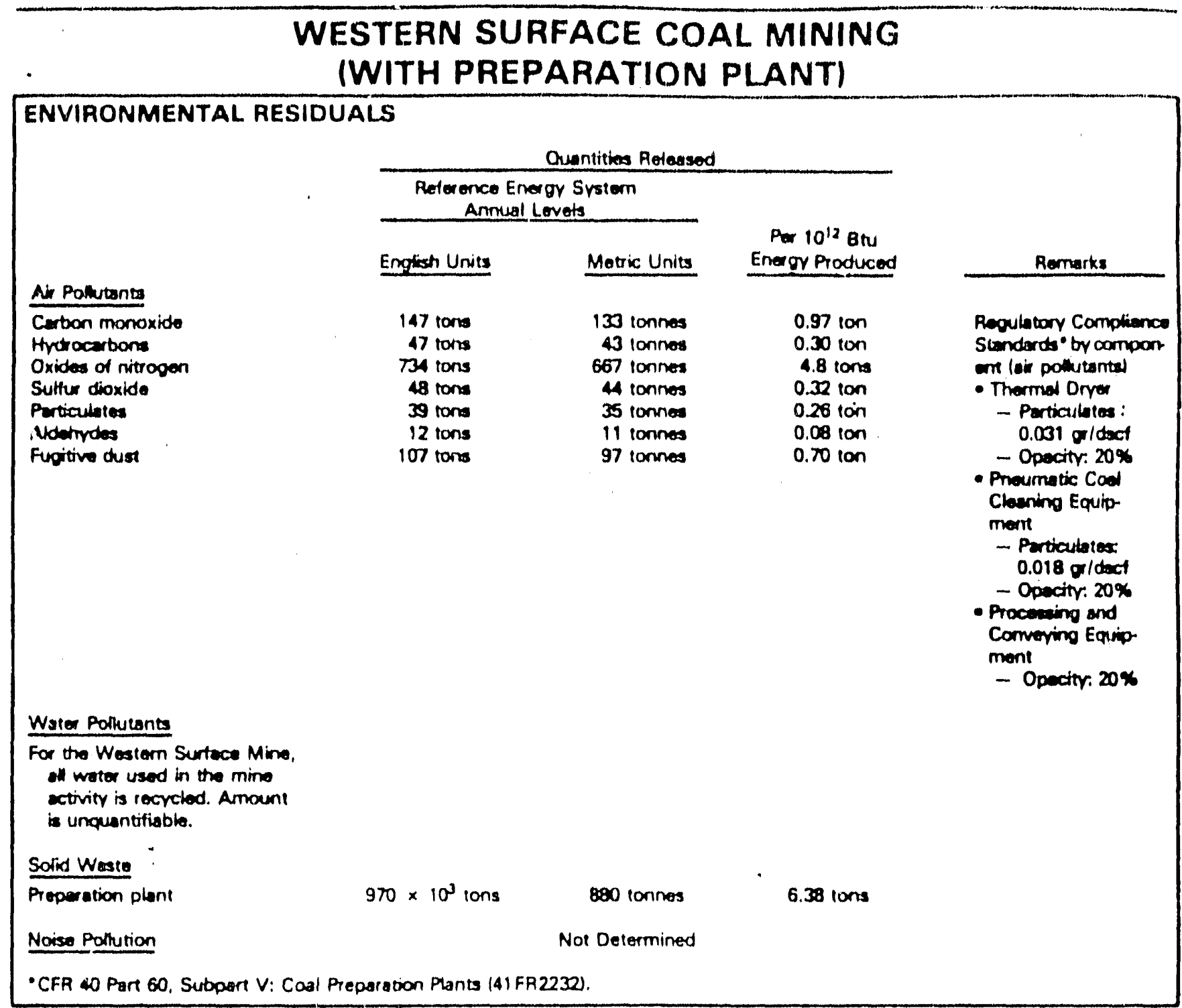

\begin{tabular}{|c|c|c|c|c|}
\hline \multicolumn{5}{|c|}{ PRODUCTS } \\
\hline & \multicolumn{3}{|c|}{ Quantities Producod } & \multirow[b]{3}{*}{ Remarks } \\
\hline & \multicolumn{2}{|c|}{$\begin{array}{c}\text { Refer ence Energy Srstern } \\
\text { Annual Production }\end{array}$} & \multirow{2}{*}{$\begin{array}{l}\text { Por } 10^{12} \text { Btu } \\
\text { Energy Produced }\end{array}$} & \\
\hline & Engtesh Units & Metric Units & & \\
\hline \multicolumn{5}{|l|}{ Primary } \\
\hline Coal (cheonodl & $8.73 \times 10^{6}$ ions & $7.92 \times 10^{6}$ tonnes & $57.4 \times 10^{3}$ tons & $\begin{array}{l}\text { Plopresents } \\
\text { epproximutoty o } 90 \% \\
\text { recovery from ROM } \\
\text { cool outpurt }\end{array}$ \\
\hline
\end{tabular}

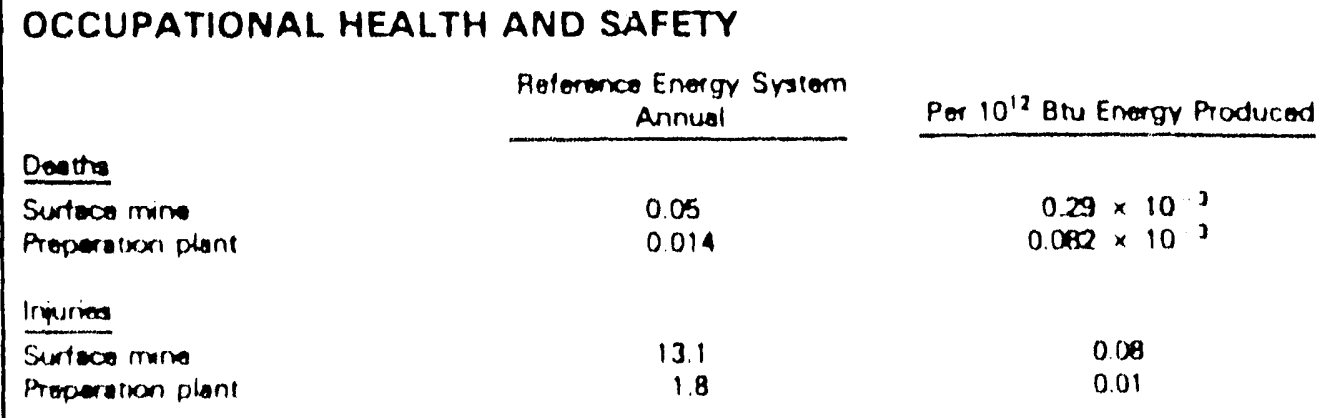




\section{COAL BENEFICIATION}

\section{REFERENCE ENERGY SYSTEM}

The oysom is compried of a number of wol circuin coul

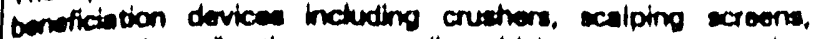

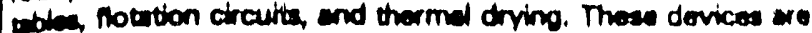
devioned to remove unwerted compononts from the rew call, the whitur oxide eminsiona. The resultant cleaned caal can then be utilkzed in a munner essentially identical to other unprocessed cod thet has not undergone this degres of beneticiation. rotery branker, vibrating screvens, Hos, thickenen, concentrating wach as to improve the energy content or sultur to reduce

\section{FACILITY OPERATING PARAMETERS}

Sira:

Annual Capocity Factor:

Annual Energy Pioduction:

EHiciency:

Lifetime:

\section{$2.857 \times 10^{6}$ tons/yr}

$83 \%$ lbased on 230 days/yr of operationl

$65.0 \times 10^{12} \mathrm{Btu}$

$87.5 \%$

$20 \mathrm{n}$

\section{RESOURCES USED}

Fead Murteriats

Energy

Eloctricity

Ot

Proceusing Matorials

Water

Consumptive uses

Construction Materials

Lend

\section{Porsonned}

Construction $11 \mathrm{y} /$

Operation and maintervance
Cod inunof-minel
Qusmotios Used

\begin{tabular}{|c|c|c|}
\hline \multicolumn{2}{|c|}{$\begin{array}{c}\text { Reforence Enorgy System } \\
\text { Anmual Usage }\end{array}$} & \multirow{2}{*}{$\begin{array}{c}\text { Per } 10^{12} \text { etu } \\
\text { Energr } \\
\text { Produced }\end{array}$} \\
\hline English Units & Metric Units & \\
\hline $286 \times 10^{6}$ tons & $2.59 \times 10^{6}$ tonnes & $51.945 \times 10^{3}$ to \\
\hline $\begin{array}{l}11 \times 10^{6} \mathrm{kWh} \\
32 \times 10^{9} \mathrm{Btw}\end{array}$ & $\begin{array}{c}11 \times 10^{6} \mathrm{kWh} \\
34 \times 10^{12} \mathrm{~J}\end{array}$ & $\begin{array}{l}0.20 \times 10^{6} \mathrm{kWh} \\
0.59 \times 10^{9} \mathrm{Btu}\end{array}$ \\
\hline
\end{tabular}
200 ocrott
$250 \times 10^{6} 1$
3.7 acrolt

Total Usage

Not Determined

240 acres $\quad 96$ ha $\quad 4.3$ acles

440 workers 8.1 workors

\begin{tabular}{|c|c|c|c|}
\hline costs & Reterence Energy Srstom & Per $10^{12}$ Bru Energy Producud & Rernarks \\
\hline \multicolumn{4}{|l|}{ Fecinty } \\
\hline $\begin{array}{l}\text { Construction ( } 1 \mathrm{r}) \\
\text { Operation and maintervence }\end{array}$ & $\begin{array}{l}\$ 35.3 \times 10^{6} \text { total } \\
\$ 26.5 \times 10^{6} / r\end{array}$ & $\begin{array}{l}\$ 0.63 \times 10^{6} 10 \text { tal } \\
\$ 0.47 \times 10^{6} / \mathrm{r}\end{array}$ & $\begin{array}{l}\text { Reference yoer lor } \\
\text { costs is } 1976.1976 \\
\mathrm{CCl} \text { avorage }\left(I_{H}\right)= \\
2401 \text {. Soo Explana } \\
\text { fory Notes Section. }\end{array}$ \\
\hline \multicolumn{4}{|l|}{ Envionmontal Contruts } \\
\hline \multicolumn{4}{|c|}{ Not Determined } \\
\hline
\end{tabular}




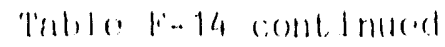

\section{COAL BENEFICIATION}

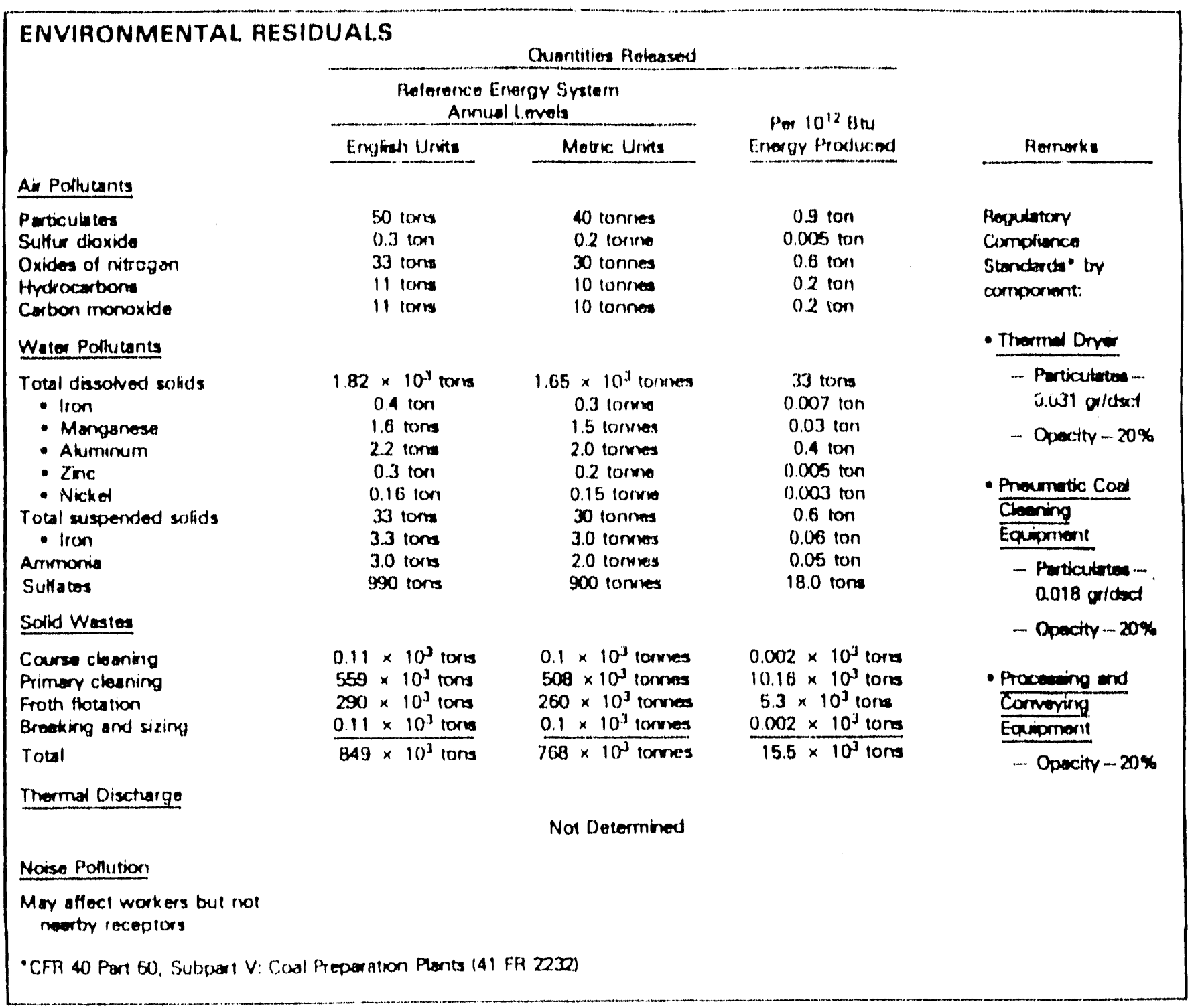

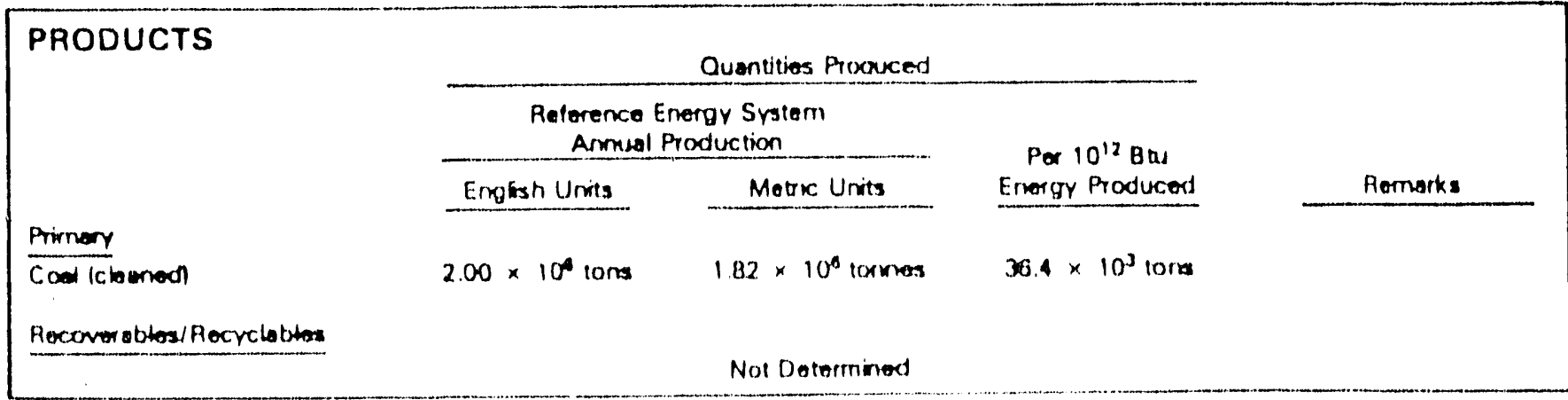

OCCUPATIONAL SAFETY AND HEALTH 
linlle Fin,

\section{WESTEAN COAL UNIT TRAIN}

\section{REFERENCE ENEHGY SYSTEM}

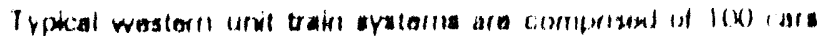

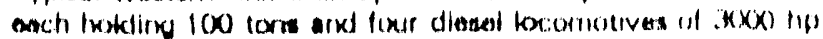

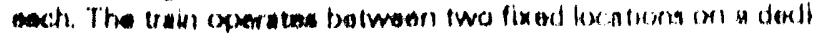

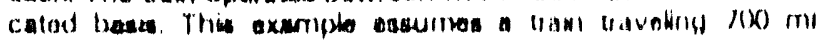

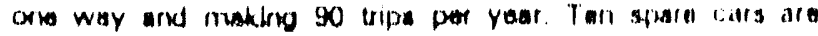

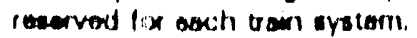

\section{FACILITY OPERATING PARAMETERS}

Sixn

$1(0)$ cars, 100 torso prer ces, $10 \times 10^{3}$ tons per trant

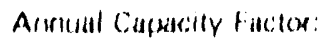
Armual Elongey Production: Hot detamimined $17.01 \times 10^{12}$ Btu lcosial tharsportad)

Efficiark:y: $99.69 \%$ basod on enorgy delivered

Lifotime: unesgy baded + enorgy experdac

$30 \mathrm{rr}$

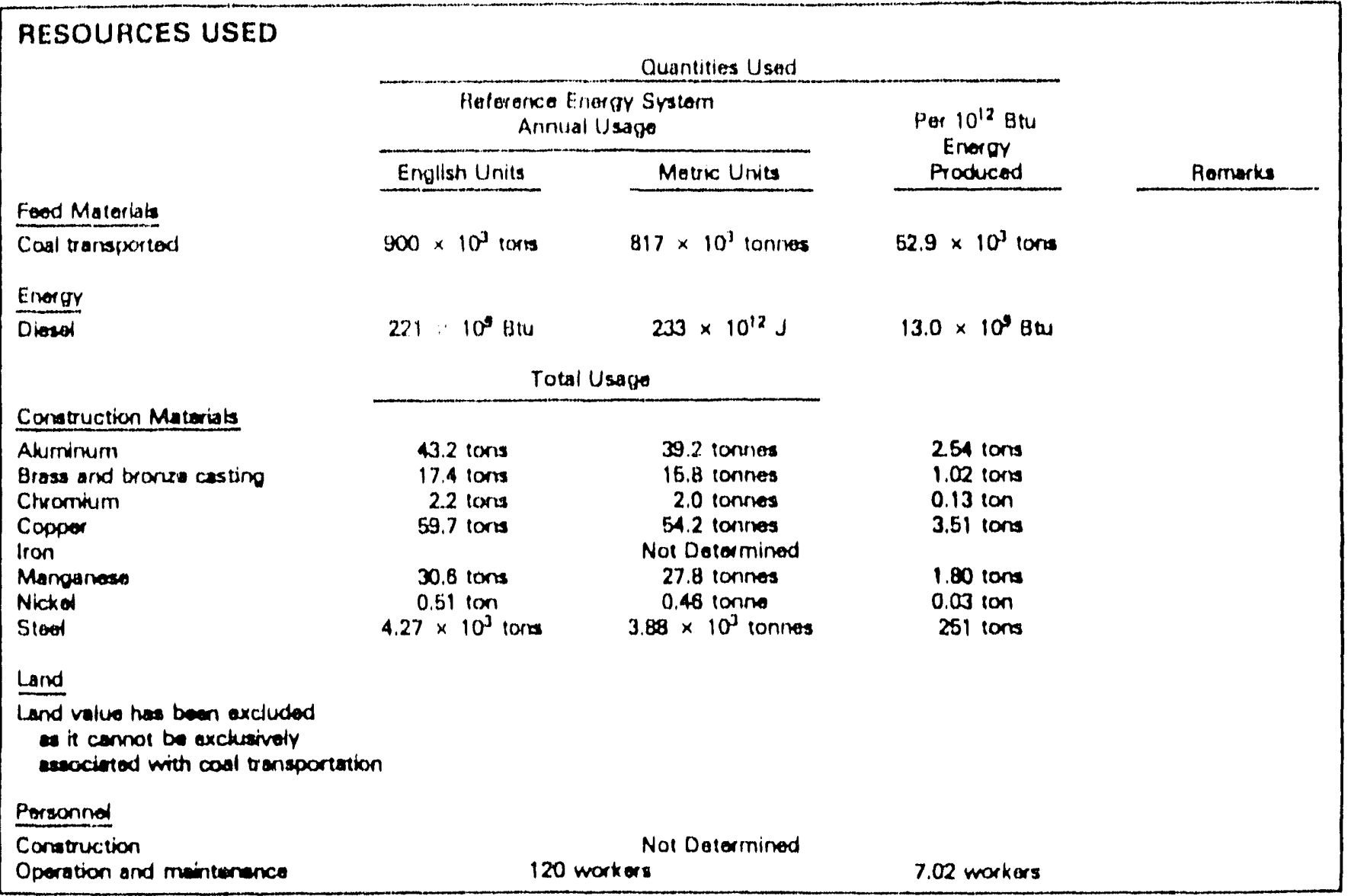

\begin{tabular}{|c|c|c|c|}
\hline & Referonce Energy Systern & Por $10^{12}$ Bru Energy Producod & Remarks \\
\hline \multicolumn{4}{|l|}{ Facility } \\
\hline $\begin{array}{l}\text { Construction } \\
\text { Operation and meintenance }\end{array}$ & $\begin{array}{l}19.80 \times 10^{8} \mathrm{rot} / \mathrm{l} \\
88.74 \times 10^{8} / \mathrm{yr}\end{array}$ & $\begin{array}{l}\$ 0.578 \times 10^{6} 10 \mathrm{ctal} \\
30.61 .3 \times 10^{8} / \mathrm{r}\end{array}$ & 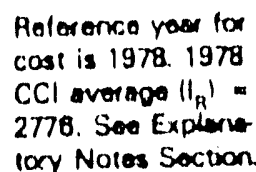 \\
\hline
\end{tabular}


Table F-15 continued

\section{WESTERN COAL UNIT TRAIN}

\begin{tabular}{|c|c|c|c|c|}
\hline \multicolumn{4}{|c|}{ ENVIRONMENTAL RESIDUALS } & \multirow[b]{3}{*}{ Romerks } \\
\hline & \multicolumn{2}{|c|}{ 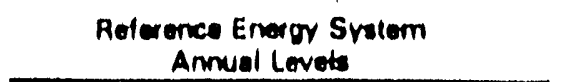 } & \multirow{2}{*}{$\begin{array}{l}\text { Per } 10^{12} \text { Btu } \\
\text { Energy Produced }\end{array}$} & \\
\hline & Enotah Untu & Mouric Units & & \\
\hline \multicolumn{5}{|l|}{ Alf Polmutantes } \\
\hline 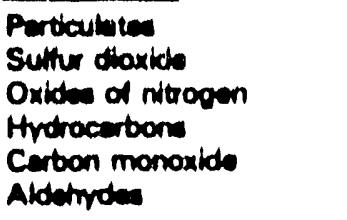 & $\begin{array}{c}2.38 \times 10^{3} \text { tons } \\
90 \text { tons } \\
76 \text { ton } \\
61 \text { tom } \\
78 \text { tons } \\
14 \text { ton }\end{array}$ & $\begin{array}{l}2.16 \times 10^{3} \text { tonnes } \\
60 \text { tonnes } \\
68 \text { tonnes } \\
56 \text { tornea } \\
71 \text { tonnes } \\
12 \text { tonnes }\end{array}$ & $\begin{array}{l}140 \text { ton } \\
5.0 \text { tons } \\
4.4 \text { tons } \\
3.6 \text { tons } \\
4.6 \text { tons } \\
0.8 \text { ton }\end{array}$ & \\
\hline \multicolumn{5}{|l|}{ Notes Polution" } \\
\hline 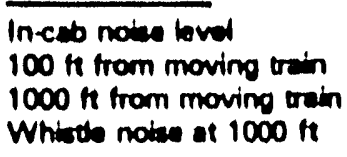 & & $\begin{array}{l}=112 \mathrm{dBA} \\
\sim 95 \mathrm{dBA} \\
-\pi 5 \mathrm{dBA} \\
\leq 85 \mathrm{dBA}\end{array}$ & & $\begin{array}{l}\text { Federal deaton lovetax } \\
65 \mathrm{dBA} \text { - residence } \\
75 \mathrm{dBA} \text { - open land }\end{array}$ \\
\hline - Nolar camnot be expresers & of mergy pro & & & \\
\hline
\end{tabular}

\section{PRODUCTS}

Priman

Coel traneported

\begin{tabular}{|c|c|c|c|}
\hline \multicolumn{3}{|c|}{ Ounntitio: Produced } & \multirow{3}{*}{ Remurks } \\
\hline \multicolumn{2}{|c|}{$\begin{array}{l}\text { Reference Energy Srotem } \\
\text { Amnual Production }\end{array}$} & \multirow{2}{*}{$\begin{array}{l}\text { Pew } 10^{12} \text { Btu } \\
\text { Energy Produced }\end{array}$} & \\
\hline Enopish Units & Motric Units & & \\
\hline $900 \times 10^{3}$ torn & $817 \times 10^{3}$ tonnes & $52.9 \times 10^{3}$ tons & \\
\hline
\end{tabular}

OCCUPATIONAL SAFETY AND HEALTH 


\section{WESTERN COAL CONVENTIONAL TRAIN}

\section{REFERENCE ENERGY SYSTEM}

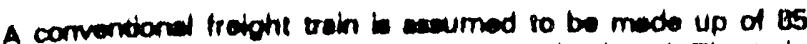
frototh carre 17 of which carry 86 tons each of coel. The train may have multiple deatrutions and thus be mode up of a mix of cars from mery sources requining more than one make-up and breakdown of the train during a single trip. This examplo aseumes 300 mi onowey trip using a dioset powered locomo. the. The bain ta aseumed to make the equivitent of 20 round trips per vear.

\section{FACILITY OPERATING PARAMETERS}

Sire.

$29 \times 10^{3}$ tonsaly (transportad)

Anrusal Capacity Foctor:

Armual Eneroy Production:

Not dotermined

$0.548 \times 10^{12}$ Btu lonul transported

Elficioncr:

$98.3 \%$ besed on

coal detivered casl boded + oneroy consumed

LHetime: $\quad 30 \mathrm{vr}$

\section{RESOURCES USED}

Foed Matorials

Coal transported

Energy

Diesel fued

Construction Materials

Aluminum

Brass and bronze

Chromium

Copper

Iron

Manganesos

Nicket

Stood

Lund

Land use value has been excluded as it cannol bo exchusivety associated with coal transportation

\section{Portonned}

Construction

Operation and maintenance
Quantitios Used

\begin{tabular}{|c|c|c|}
\hline \multicolumn{2}{|c|}{$\begin{array}{c}\text { Roterence Energy Srstem } \\
\text { Armulal Usago }\end{array}$} & \multirow{2}{*}{$\begin{array}{c}\text { Per } 10^{12} \text { Btu } \\
\text { Enorgy } \\
\text { Produced }\end{array}$} \\
\hline Engliah Units & Motric Units & \\
\hline $29.1 \times 10^{3}$ tons & $26.4 \times 10^{3}$ tonnes & $53.04 \times 10^{3}$ to \\
\hline $8.06 \times 10^{8} \mathrm{Bar}$ & $8.50 \times 10^{12} \mathrm{~J}$ & $14.7 \times 10^{9} \mathrm{Btu}$ \\
\hline
\end{tabular}

Total Usage

$\begin{array}{lcc}4.20 \text { tons } & 3.82 \text { tonnes } & 7.67 \text { tons } \\ 2.48 \text { tons } & 2.25 \text { tonnes } & 4.52 \text { tons } \\ 0.30 \text { ton } & 0.27 \text { tonne } & 0.54 \text { ton } \\ 7.27 \text { tons } & 6.60 \text { tonnes } & 1327 \text { tors } \\ & \text { Not Doternined } & 8.18 \text { tons } \\ 4.48 \text { tons } & 4.07 \text { tonnes } & 0.12 \text { ton } \\ 0.066 \text { ton } & 0.060 \text { tonne } & 11.47 \text { tons }\end{array}$

Aermarks

\begin{tabular}{|c|c|c|c|}
\hline costs & Reference Energy System & Per $10^{12}$ Btu Energy Produced & Rernarks \\
\hline Facifity & \multirow{2}{*}{\multicolumn{2}{|c|}{$\begin{array}{l}\$ 1.24 \times 10^{6} \text { total } \\
50.837 \times 10^{6} / \mathrm{y}\end{array}$}} & \\
\hline $\begin{array}{l}\text { Conatruction } \\
\text { Operation and maintensince }\end{array}$ & & & $\begin{array}{l}\text { Reterence yoer for } \\
\text { cost is ig78. } 1978 \\
\text { CCI overepe }\left(I_{A}\right)^{-n} \\
2776 \text {. Soe Explans. } \\
\text { tory Notes Section. }\end{array}$ \\
\hline
\end{tabular}


Tabile F-16 continued

\section{WESTERN COAL CONVENTIONAL TRAIN}

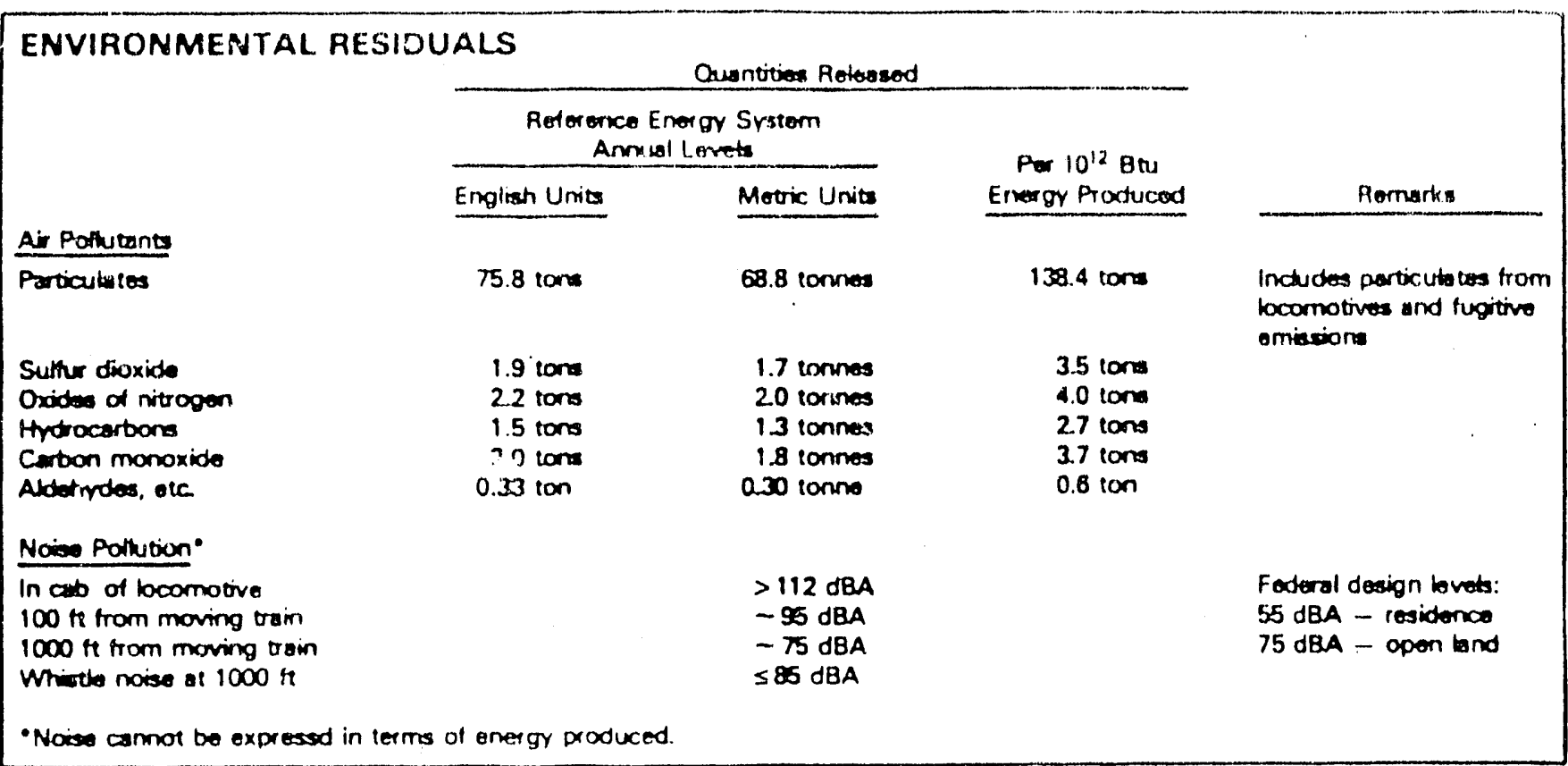

\begin{tabular}{|c|c|c|c|c|}
\hline \multirow[t]{3}{*}{ PRODUCTS } & \multicolumn{3}{|c|}{ Quentities Produced } & \multirow{3}{*}{ Remarks } \\
\hline & \multicolumn{2}{|c|}{$\begin{array}{c}\text { Referonce Energr Srstem } \\
\text { Anmual Production }\end{array}$} & \multirow{2}{*}{$\begin{array}{c}\text { Per } 10^{12} \mathrm{Btu} \\
\text { Energr Produced }\end{array}$} & \\
\hline & English Units & Motric Units & & \\
\hline Primary & & & & \\
\hline Cost trorsported & $29.0 \times 10^{3}$ tons & $26.3 \times 10^{3}$ tonnes & $529 \times 10^{3}$ ions & \\
\hline
\end{tabular}




\section{COAL-FIRED POWER PLANT - WESTERN COAL}

\section{REFERENCE ENERGY SYSTEM}

The oretem is composed of a conventional stonim olectric powe plant uxing trpical western fow-sultur subbiturrinous coal zuppised by unit train operation. No cogemerstion is included. Environmentel control svetems include olectrocestic procipitrion for perticulato control, wel simellmastono scrubbers for sulfur dioxide control, orseite solid wasto dispossal, and onsite water trestment for water recirculation to eliminate liquid dis. changes. The plant is assumod to bo aubject in current regula. tions.

\section{FACILITY OPERATING PARAMETERS}

Size:

$500 \mathrm{MWe}$

Annual Capacity Factor: $\quad 80 \%$

Annual Energy Production: $12 \times 10^{12}$ Btu

Effictancy: $35 \%$

Lifetime: $\quad 30 \mathrm{yr}$

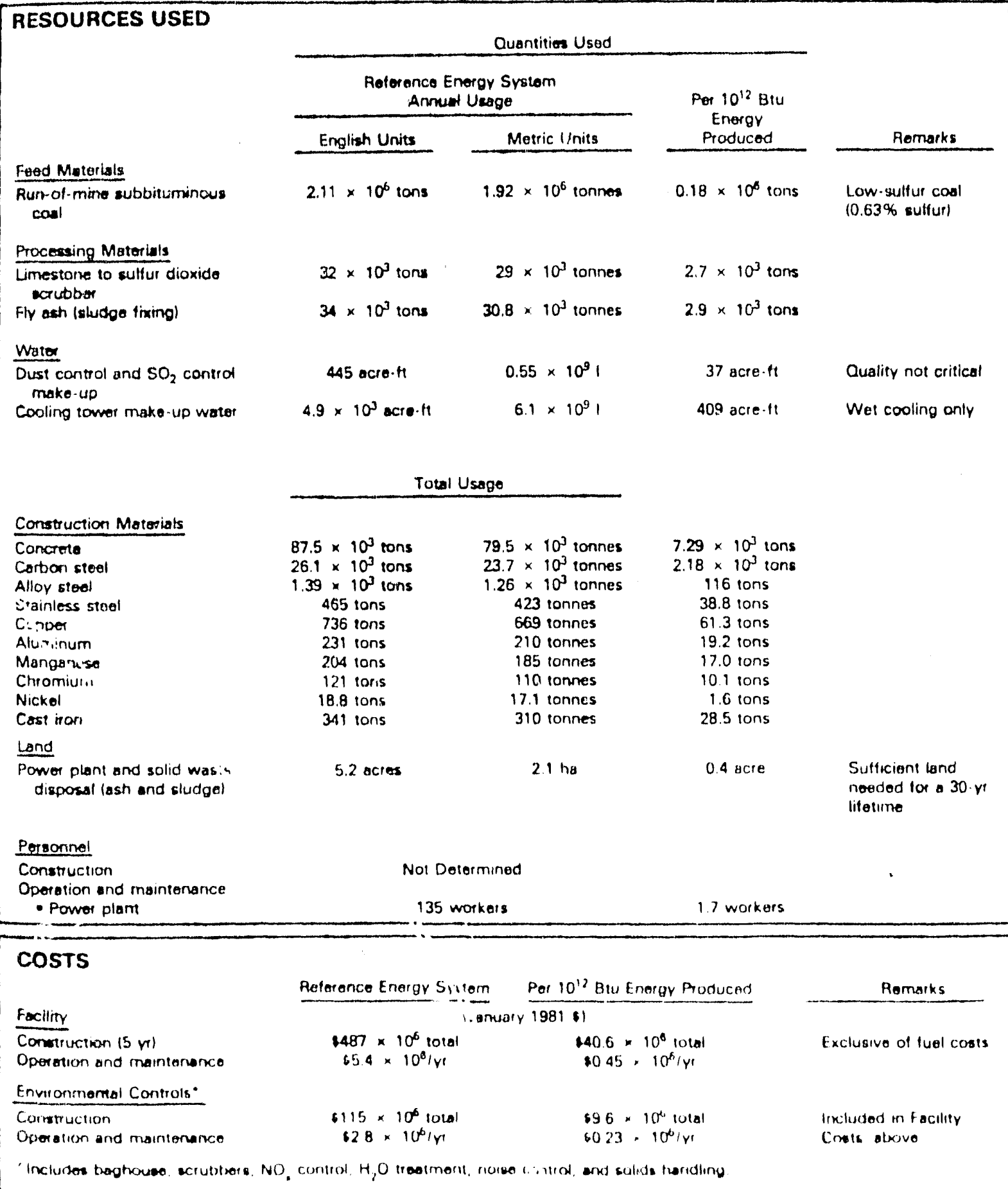




\section{COAL-FIRED POWER PLANT - WESTERN COAL}

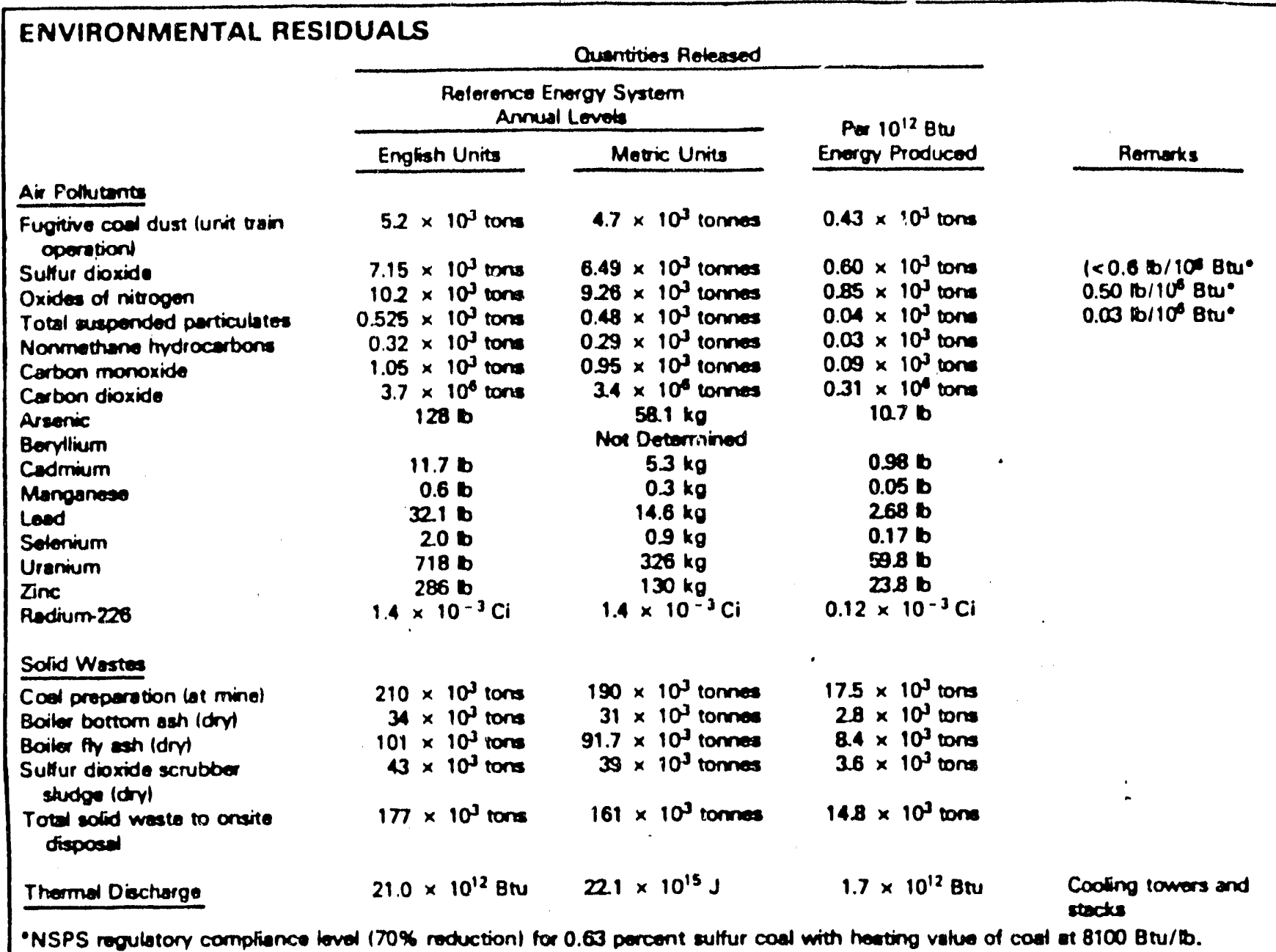

\section{PRODUCTS}

Quantitios Produced

\begin{tabular}{|c|c|c|c|}
\hline \multicolumn{2}{|c|}{$\begin{array}{l}\text { Reference Energy Srstem } \\
\text { Anmuet Production }\end{array}$} & \multirow{2}{*}{$\begin{array}{c}\text { Por } 10^{12} \mathrm{Btw} \\
\text { Energy Produced }\end{array}$} & \multirow[b]{2}{*}{ Remarks } \\
\hline English Units & Metric Units & & \\
\hline $12 \times 10^{12} \mathrm{Bru}$ & $13 \times 10^{15} \mathrm{~J}$ & $1.0 \times 10^{12} \mathrm{Bbs}$ & \\
\hline $34 \times 10^{3}$ tons & $31 \times 10^{3}$ tonnes & $29 \times 10^{3}$ tons & \\
\hline $96 \times 10^{4}$ gal & $742 \times 10^{6} 1$ & $16.3 \times 10^{6} \mathrm{goll}$ & Zero-dschargo design \\
\hline
\end{tabular}

\section{OCCUPATIONAL SAFETY AND HEALTH}

\begin{tabular}{|c|c|c|c|}
\hline \multirow[b]{2}{*}{ Deoths } & $\begin{array}{c}\text { Relerence Energy Srstem } \\
\text { Annual }\end{array}$ & Por $10^{12}$ Bnu Enorgy Produced & Romatk: \\
\hline & & & \\
\hline$\overline{\text { Power plant }}$ & $0-0.11$ & $0-9.5 \times 10^{-3}$ & \\
\hline Iniuries & & & \\
\hline Power plant & $19-2.3$ & $0.18-0.19$ & \\
\hline
\end{tabular}




\section{ATMOSPHERIC FLUIDIZED BED COMBUSTION - WESTERN SUBBITUMINOUS COAL.}

\section{REFERENCE ENERGY SYSTEM}

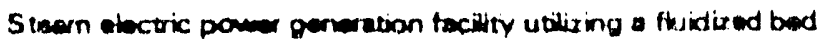

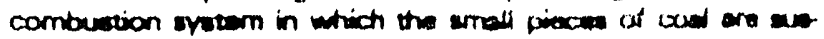
pended atong whth similaty sined bed metrial in a continuounty moving ma of air. The bed materiv roferred to warbend and compand of cruched limestone or dobomite in responatol for the copture of a portion of the sulfur dioxide generated during combuxtion. Other emirommental control syterne include - beghouse fiter with grester then 98\% efficioncy and con ventional water treatment tacilities as necesury. The low

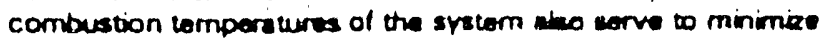
nitrogen oxide formation.

\section{FACUTY OPERATING PARAMETERS}

Sirn:

536 MWe

Armun Cepacity Factor. $\quad 96 \%$

Armul Energy Production: $\quad 152 \times 10^{12} \mathrm{Bru}$

Efficiency: $34.4 \%$

Lifterime. $20 \mathrm{rr}$

\section{RESOURCES USED}

Feed Materials

Coed lsubbituminous mexterns

Procescing Matorials

Limestone (sorbent bed materiad

Water

Coneumptive usea

\section{Construction Matoriats}

Land

Perronnel

Approximatoly same es conventional powa stition of equivalere cespecin

\section{Quantives Used}

\begin{tabular}{|c|c|c|c|}
\hline \multicolumn{2}{|c|}{$\begin{array}{l}\text { Raference Energy Srstem } \\
\text { Annual Usoos }\end{array}$} & \multirow{2}{*}{$\begin{array}{c}\text { Per } 10^{12} \mathrm{Bou} \\
\text { Energy } \\
\text { Produced }\end{array}$} & \multirow[b]{2}{*}{ Remurks } \\
\hline Engliah Units & Metric Units & & \\
\hline $275 \times 10^{6}$ tora & $250 \times 10^{4}$ tonnes & $181 \times 10^{3} \operatorname{tons}$ & $8.05 \times 10^{3} \mathrm{Brw} / \mathrm{b}$ \\
\hline $194 \times 10^{3}$ torm & $177 \times 10^{3}$ tonnos & $12.8 \times 10^{3}$ tons & $\cdot$ \\
\hline $8.86 \times 10^{3}$ acrott & $10.9 \times 10^{9} 1$ & 583 actoh & \\
\hline \multicolumn{2}{|c|}{ Total Usage } & & \\
\hline & Not Determined & & \\
\hline $42=0$ & $179 \mathrm{ha}$ & 29.1 acres & \\
\hline
\end{tabular}

\begin{tabular}{|c|c|c|c|}
\hline costs & Roterence Energy Sratem & Per $10^{12} \mathrm{Btu}$ Energy Produced & Remurks \\
\hline \multicolumn{4}{|l|}{ Fecitity } \\
\hline 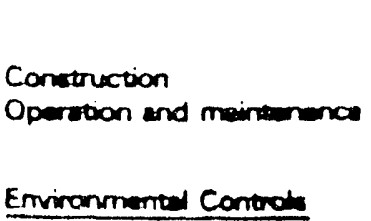 & \multicolumn{2}{|l|}{$\begin{array}{l}8381 \times 10^{6} \text { toted } \\
\$ 7.42 \times 10^{8} / 4\end{array}$} & 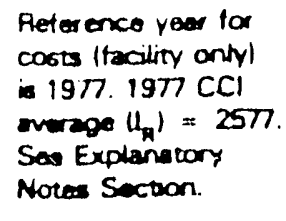 \\
\hline Capital & $249.6 \times 10^{6}$ & $\$ 3.3 \times 10^{4}$ total & \\
\hline
\end{tabular}




\section{ATMOSPHERIC FLUIDIZED BED COMBUSTION - WESTERN SUBBITUMINOUS COAL}

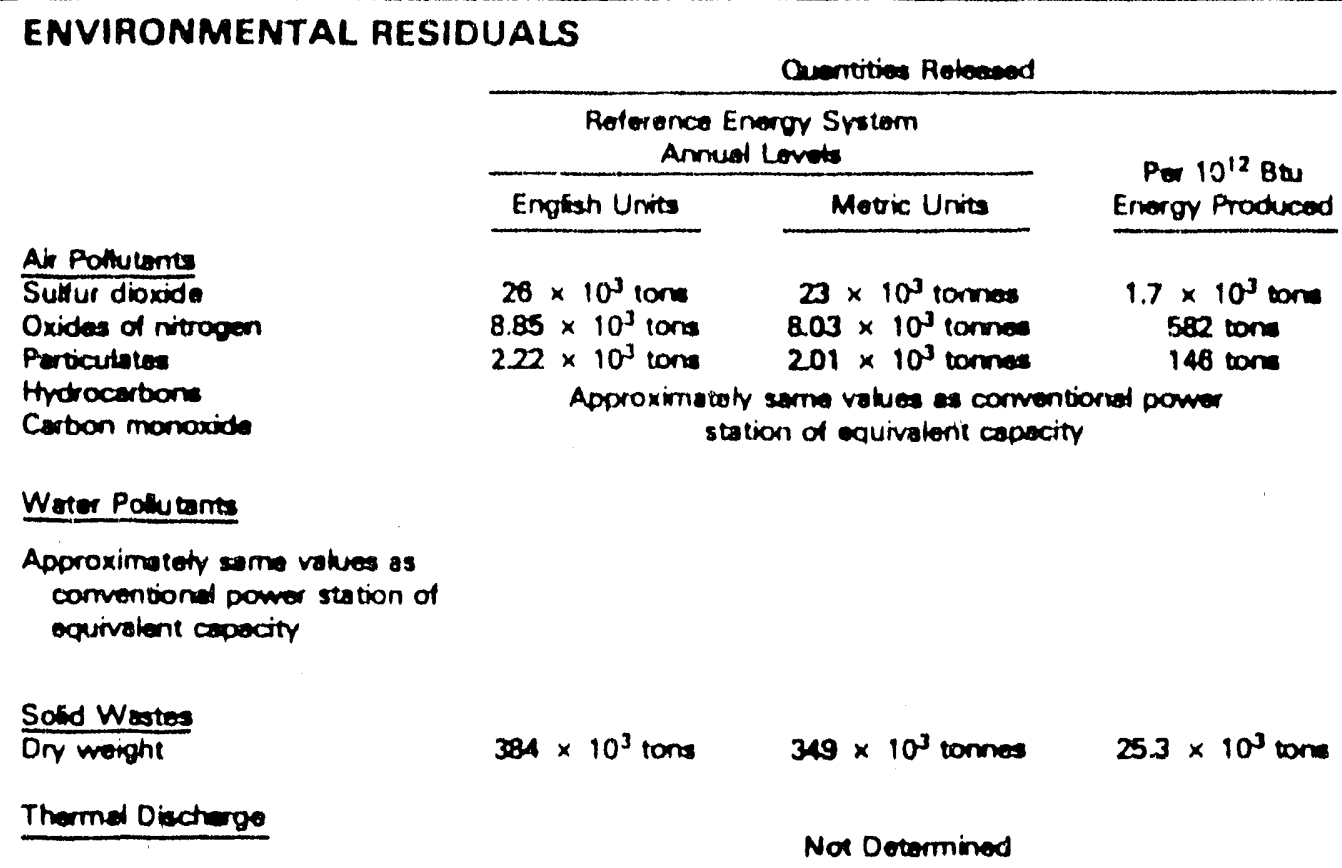

Water Pollutams

Approximotety sems vahes as comentional power station of ocuivilent capecity

Solid Wootes

Dry woight

$$
384 \times 10^{3} \text { tons } \quad 349 \times 10^{3} \text { tonnes } 25.3 \times 10^{3} \text { tom }
$$

Therrned Diecherge

Not Dotermined

\section{PRODUCTS}

Primary

Eloctricity

Byproducts

Recovernbles/Recrelables

Quntitios Produced

\begin{tabular}{|c|c|c|}
\hline \multicolumn{2}{|c|}{$\begin{array}{l}\text { Roterence Energy Srstem } \\
\text { Armual Proctuction }\end{array}$} & \multirow{2}{*}{$\begin{array}{c}\text { Per } 10^{12} \text { Bu } \\
\text { Energy Produced }\end{array}$} \\
\hline English Units & Metrix: Units & \\
\hline
\end{tabular}

Not Detormined

Not Determinad 


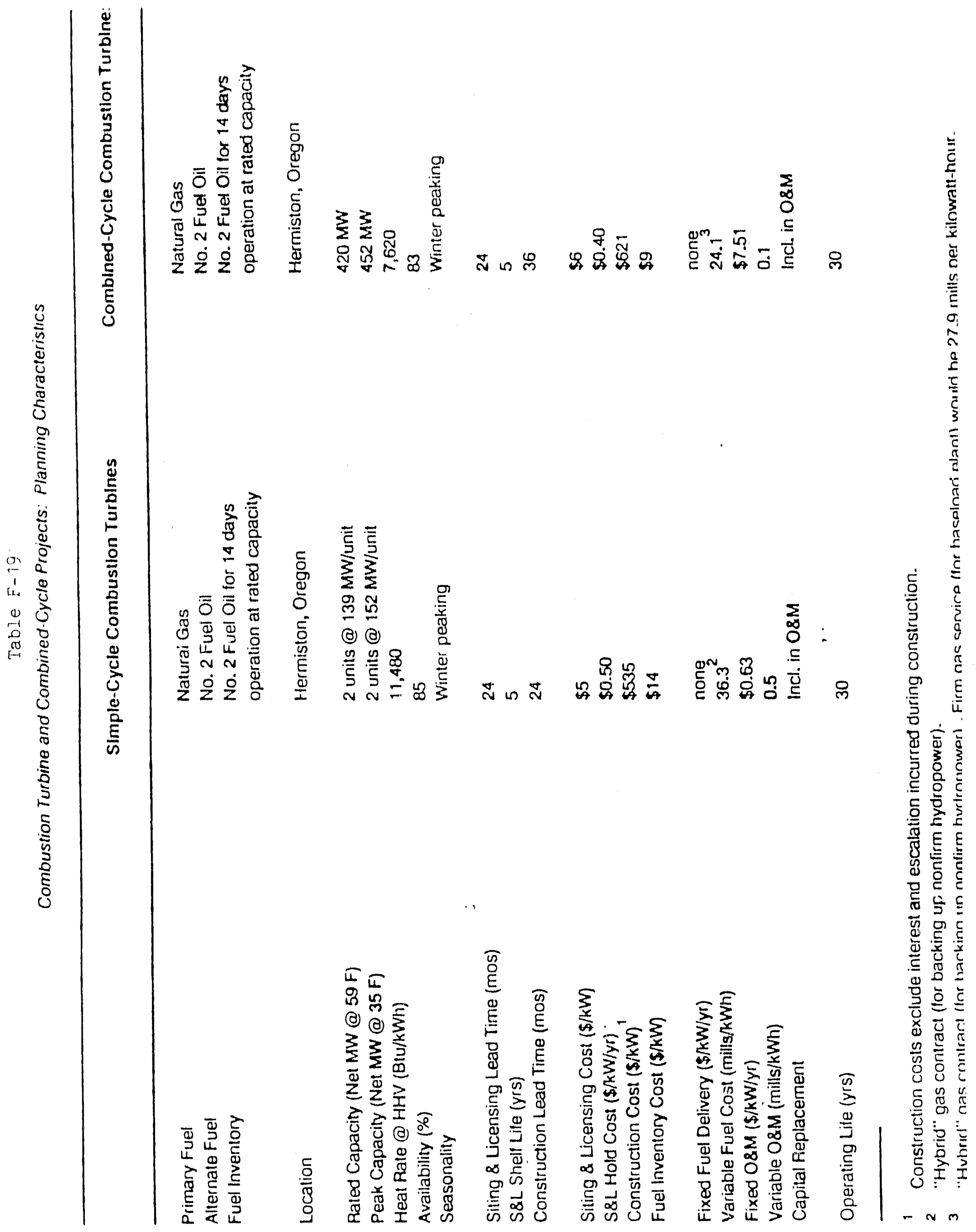




\section{APPENDIX G}

\section{INFOPHATION ON MODELS USED}




\section{G-1}

The System Analysis Model and

Least Cost Mix Model 


\section{Description of Models and Their Use}

\section{$\underline{S A M}$}

The System Analysis Model (SAM) was used to generate data for the PSCEIS. SAM simulates, monthly for 20 years, the oneration of the Pacific Northwest hydro/thermal system. It provides information regarding the rellability of the system, the expected operation of individual thermal resources, and the expected operation of the hydro system, including reservoir elevations, flows, and spil1. SAM input includes information from the Least Cost Mix Model (LCMM) regarding future resource development.

The SAM simulates the Pacific Northwest's power system. It models the operation of existing and planned resources to meet load, season by season and month by month over a 20-year planning period. The model simulates both planning policies and operational policies, on a monthly basis.

The following major components of the region's power system are accounted for in SAM:

$$
\begin{aligned}
& \text { policies of regional planning and operation, } \\
& \text { uncertainties of loads and resources, } \\
& \text { physics of hydro and thermal resources, } \\
& \text { nonpower constraints on the hydro system, } \\
& \text { transactions outside the region, and } \\
& \text { net reglonal revenue requirements. }
\end{aligned}
$$

The model makes assumptions about the region and the load to be served, so that the region defined for this model conforms to that mandated in the Pacific Northwest Power Act. The defined region, however, is assumes to be a single-owner system.

SAM models the region's energy resources: hydro, thermal (including nuclear plants, combustion turbines, and coal projects), and miscellaneous (such as renewables, cogeneration units, existing steam plants, small diesel

generators). Conservation is also considered a resource.

SAM models uncertainty in the following:

- Regional load. The energy load reflects the variations in weather conditions and economic trends. SAM does not, however, consider load growth uncertainty.

- Major hydro. Hydro conditions are selected from a detalled 40 -year historical record of individual project inflows.

- Thermal plants. The two sources of uncertalnty modeled are the availability of a thermal plant and the arrival date for a new plant. 
SAM slmulates these uncertalnties using a Monte Carlo process, randomly selecting values for each of these varlables for each month of the study porlod (in this case, 20 years). SAM runs each study many tllmes, each the selecting a new set of varlables. For this EIS, each study was run 200 tlomes. Fach alternative used the same 200 sets of vartables for each month of the 20 years. In most cases, values for the $200 \mathrm{~s} l$ mulations were averaged (monthly or annually). However, for certain allalyses (for example, flsh impacts), indtutdual simulations were examined.

Given the loads, resources, and the established pollcles for the reglon, SAM operates the hydro system in confunction with the non-hydro resources to meet observed loads in the most economic manner possible. Included in these polictes are the following economic: consideratlons:

- All avaflable regional resources are used to meet flill regtonal load.

- A portion of the direct service industrlal customer load is not flrm and can be restricted and futerupted, but is met, provlded that reasonably prlced resources are avallable. (Note that thls changes depending on the alternative belng studied.)

- If the power outlook and streamflow forecast permlt, the reglon sells energy to Callfornia.

SAM models three major declston points in operating a hydro system:

(1) the annual planning process, which determines how to shlft and shape water over a two-year critical pertod; (2) the perlod planning process, which looks at such items as flrm surplus, the runoff forecast, and reflil, to determine the use of hydro over the following four months; and (3) the pertod operatling process, which dispatches Paciflc Northwest resources to meet loads in the most economic manner possible. If there is suffictent energy, economy energy sales are made to Californla, taking into account the Intertie Access Policy, avallable secondary energy from Canada, and the Californta market.

Insluded in SAM is a model of BC Hydro's resources and loads. BC Hydro's recources are run to meet is own loads; any additional energy is available for sale to the U.5. BC Hydro may use this energy to drectly serve any unmet PNW load (firm or nonfirm), to displace higher cost PNW resources, or to sell to Californla markets.

Modeling of Power Sales Contracts in SAM. In SAM, the region is assumed to be a single-owner system, and regional resources dre operated to meet the total regional load. With one major exception, specific provisions of Individual Power Sales contracts between BPA and its customers are not speciflcally modeled by SAM, and would have little or no effect even if they were modeled.

In other words, sim is interested in knowing what the total reglonal firm load is, but not the breakdown of individual loads for each utflity. Glven the total load, the model will dispatch resources ds required to meet that load. 


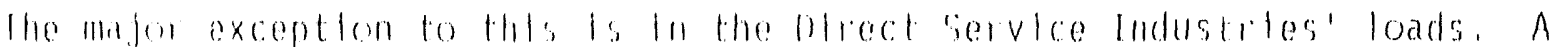

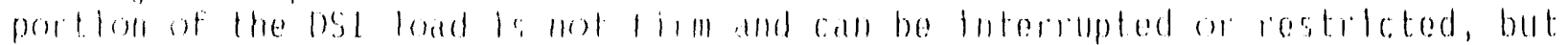

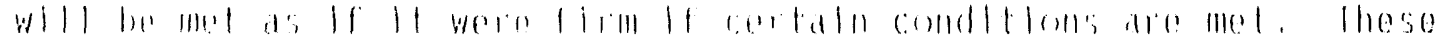

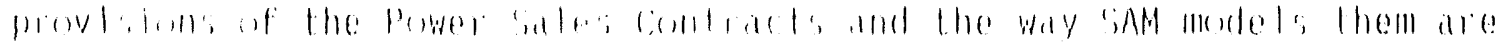

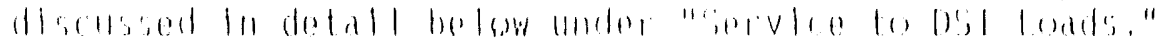

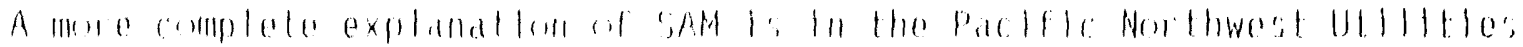

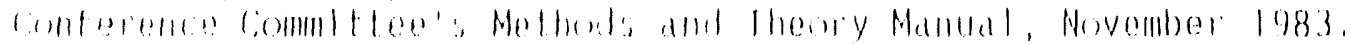

$11 \%+1$

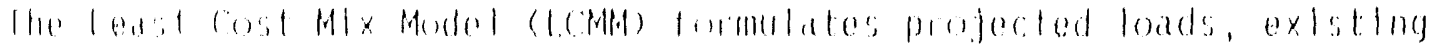

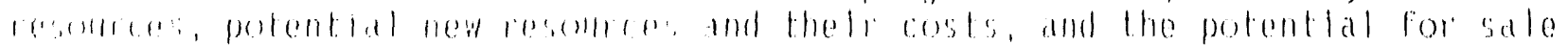

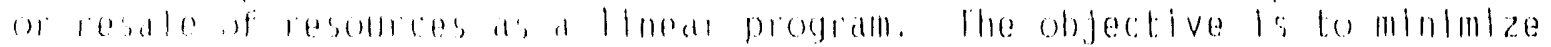

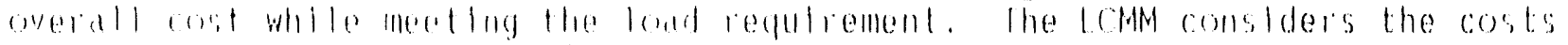

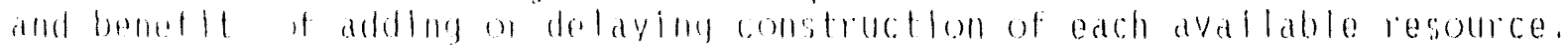

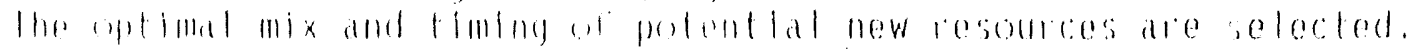

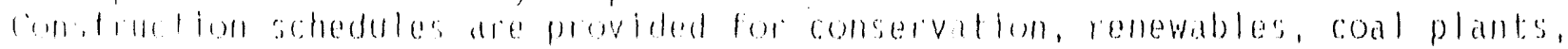

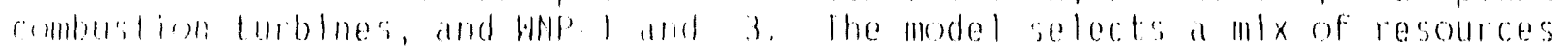

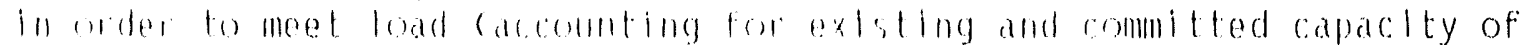
resomres, whthin the limits of moject avaliablitiy, reserve marghs, hydro avallability on a caltical water basts, and malntenance requtrements.

The LCHM was run for each alternative in which a dlfferent amount of DSI load was constdered to be flim. Changling the amount of reglonal flrm load leads to different resource requlrements. Those alternatives (1.2 and 4.4 ) which result in a change in system operation but do not change the amount of flrm load, did not requile a separate run of the LCMM. 


\section{Model Assumptions}

Loads

DSI loads are from BPA's January 1988 medlum long...ter'll USI load forecast. FIrm DSI loads range from 2245 average MW (aMW) In 1989 to 1924 aMW in 2008 , whlle nonflrim loads range from 853 to 698 aMW 1112008 . All other Pactfic Northwest loads are based on BPA's July 1986 long...ange medlum load forecast reduced by Model Conservation Standards.

Sensitivities involving Paciflc Northwest loads used low and high forecasts for DSI loads as well as total reglonal loads. Flrm DSI loads ranged from 1991 to 527 aMW under the low load case, and from 2454 to 2494 aMW in the hlgh case. Low nonflrm DSI loads ranged from 696 to 176 aMW, whtle the high loads were between 852. and $884 \mathrm{aMW}$. Reglonal l inds range from 18,000 to 16,000 aMW In the low load case and from 19,000 to 30,000 amw th the high case.

BC. Hydro loads and resonrces are based on thelr March 1988 Twenty-Year

Resource Plan. The Non-Treaty Storage Agreement was assumed to expire in 1993.

Callfornta loads are based on the medlum Common Forecasting Methodology (CFM-6) forecast. These loads range from approxlmately 24,000 to 35,000 aMW over the study horlzon. For sensitivity analyses, it was assumed the load varles plus (high) and minus (low) $2000 \mathrm{MW}$ from the medtum forecast.

\section{Resources}

The Paclfic Northwest resources include extsting hydro and thermal plants, and currently planned resources, as publtshed in the 1 . 87 Paclfic Northwest Loads and Resources, excluding Hanford. Additional resources were Included as chosen by the Least Cost MIx Model to achleve load/resource balance. See Figure $\mathrm{G}-1$ - 1 .

BPA's Aprll 1988 medlum long-term gas price forecast was assumed. Prices range from 22 to $44 \mathrm{~m} 111 \mathrm{~s} / \mathrm{kwh}$ over the study horlzon. For the sensitivity andyses involving gas prices, the low and high long-term forecasts were used. Low gas prices range form 16 to $23 \mathrm{~m} f 1 \mathrm{ls} / \mathrm{kwh}$, whlle high gas prices range from 33 to $63 \mathrm{~m} 11 \mathrm{ls} / \mathrm{kwh}$ over the study hortzon. 


\section{Service to DSI loads}

The following gives an overview of DSI restriction rights as modeled In SAM. Under the alternative descriptions, only changes from the No-Action Alternative are mentioned. All assumptions for the alternatives are effective For the entire study horlzon, 1989 through 2008. For more detalls regarding DSI load service as modeled in SAM see the Paciflc Northwest Utillties Conference Commttee's Methods and Theory Manual, November 1983.

\section{No-Action Alternative}

Flist Quartlle:

The flist quartlle is interruptible. Resources are not planned to meet thts load on a flrm basls. However, the Flrst Quartlle may be served with surplus Ftrm, nonftrm, or outside purchases. In addttion, if the coordinated system has refllled at the end of July, shifted FELCC, provlslonal energy, and flexibility may be used to serve the Flrst Quartlle th the fall coptember December). These are llmited respectlvely to 1,000,000 MWh, 800,000 MWh, and 750,000 MWh; however, this is currently sufficlent to serve the entire fall Flrst Quartile load. If shlft, provtstonal, or flextbility have been committed to Flist Quartlle service, the system is operated to meet this load during the fall as if it were firm. In exchange for seivice to the first. Quartlle with these borrowing technlques, future restriction rights to the Third Quartlle load are granted.

Second Quartlle:

The second quartile is considered to be firm wt th one exception. If a planned resoulce is delayed or does not perform as expected, restriction rights may be granted. These rights are the amount of the delay (or underperformance), limited by the lesser of the projected deficlt for the current year and the amount of the second quartlle.

Third Quartile:

The third quartile is also considered to be firm; however, it may be restricted as a result of ustng borrowing technlques to serve the top quartile. Depending on which technique was used, the restriction rights are granted efther in the current year or the upcoming operating year. If the hydro system reflils at the end of the year, any restriction rights for the upcoming year are canceled.

Additional notes:

The remaining quartile is modeled as entirely firm. SAM is an energy model and so does not consider restriction rights on a capacity basis. Also, restriction rights are not automatically exercised even though they are avallable. A reasonable attempt is made to serve the load prior to any restrictions occurring. 


\section{Alternative 1.2}

For this alternative, borrowing techniques are no longer available for service to the top quartile. As a result, the top quartile may only be served with surplus firm, nonfirm, or outside purchases.

\section{Alternative 4.1 (100 percent)}

Under this alternative, all four quartiles are considered interruptible. Resources are not planned to meet any of this load. Instead it is to be served with surplus firm, nonfirm, or outside purchases. Borrowing techniques, however, are not available. Without a firm quartile there can be no associated restriction rights to backup the borrowed energy.

\section{Alternative 4.1 ( 50 percent)}

For this alternative, two of the four quartiles have the same interruption rights and service rights as does the top quartile currently. Resources are not planned for these two quartiles. The remaining two quartiles are still considered firm, with certain restriction rights. Since this firm portion is available to provide the e restriction rights as backup, borrowing techniques are still allowed at their current levels. For modeling purposes, the second quartile was chosen to be the additional interruptible quartile. As a result, this alteinative has no restriction rights due to plant delay.

\section{Alternative 4.3}

All loads under this alternative are firm. Resources are acquired to meet the top quartile load. There are no restriction rights for any quartile.

\section{Alternative 4.4}

Under this alternative, second quartile restriction rights due to plant delay are no longer allowed. Plant delay, however, still occurs as in the No-Action Alternative. 

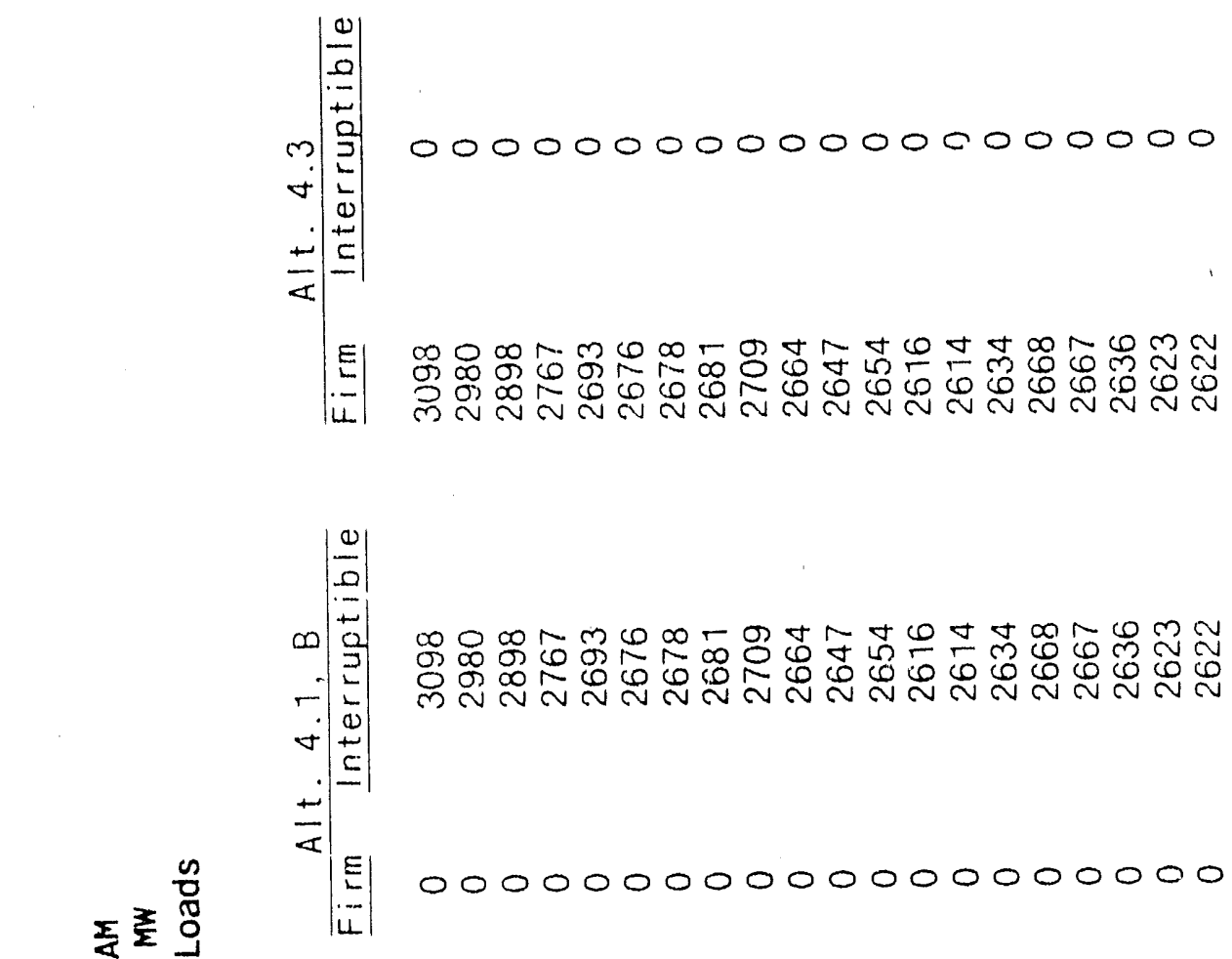

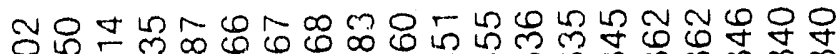

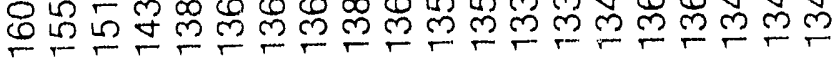

প요

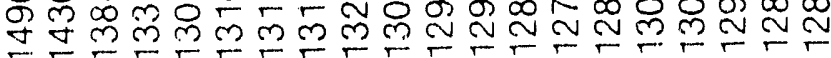

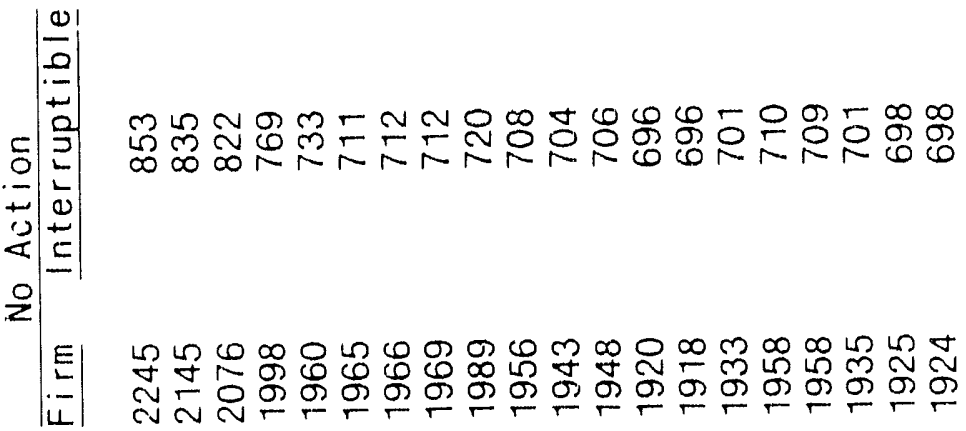

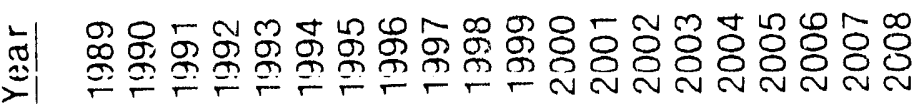



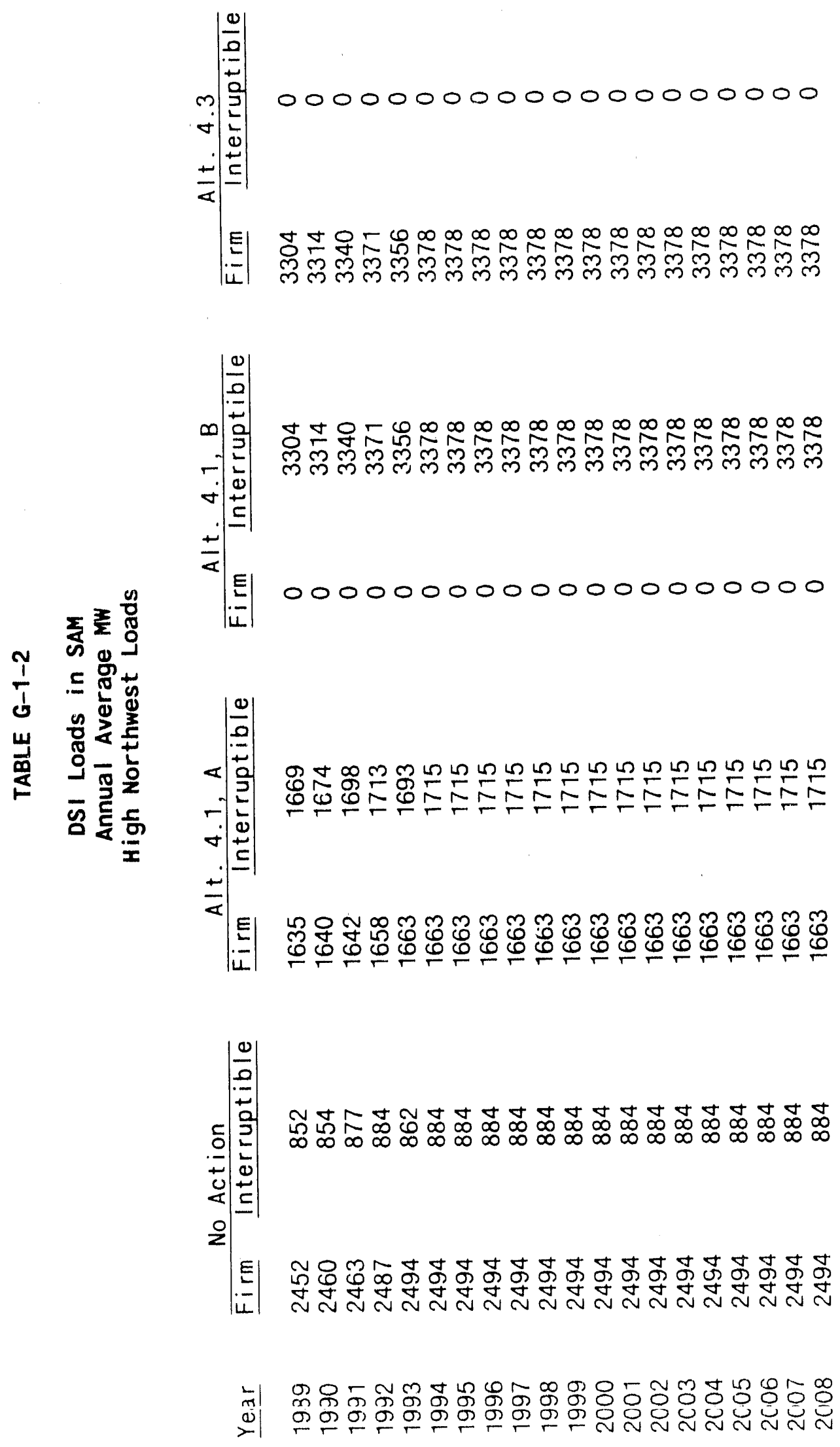


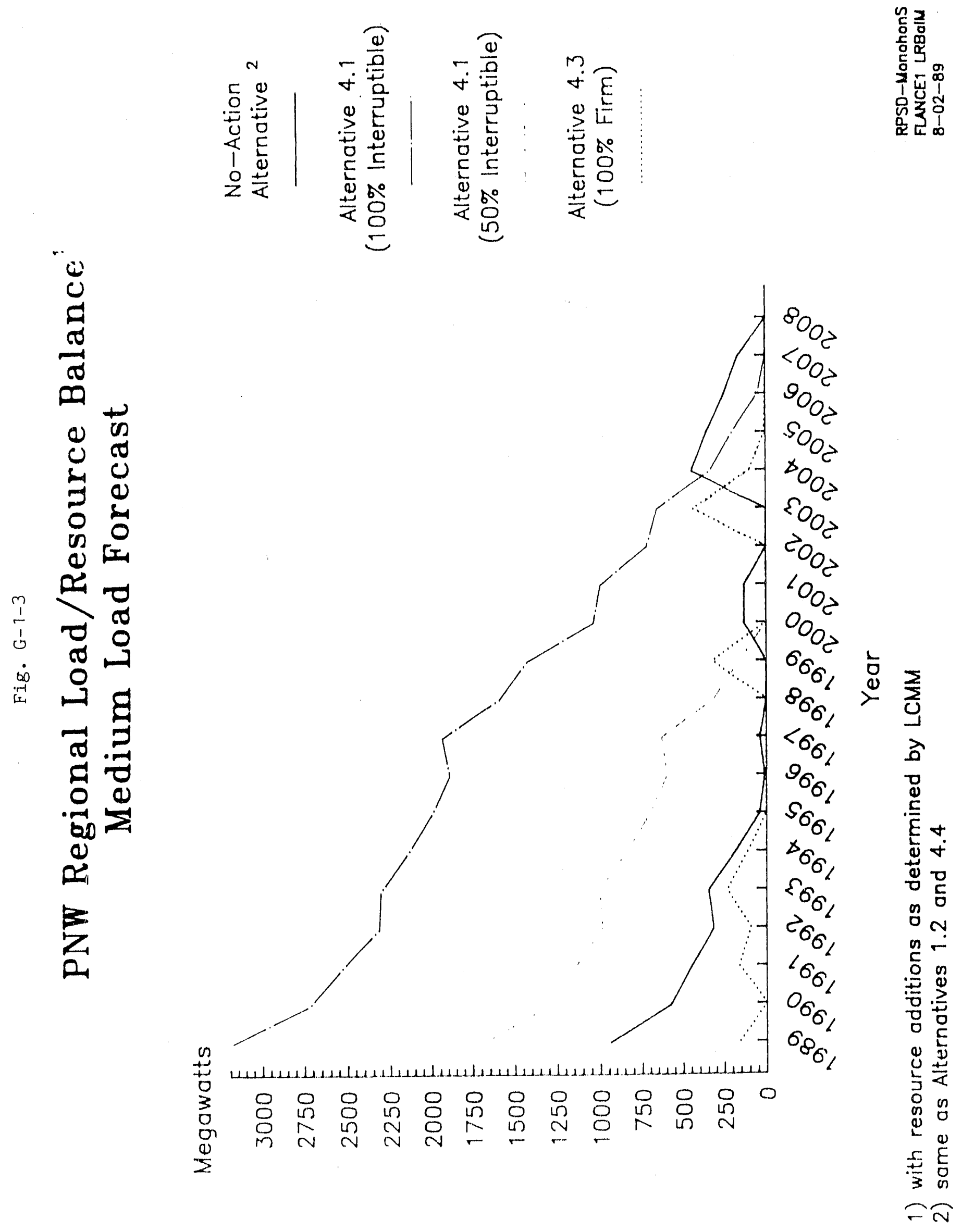




$$
\text { G-2 }
$$

Use of FISHPASS in Analysis 


\section{Use of FISHPASS in Analysis}

The analysis of downstream anadromous fish passage survival, as it may be affected by changes in spill and flows, was performed using a modified version of the Corps of Engineers' FISHPASS model. (A detailed description of the FISHPASS model is given in the Corps' model documentation titled "FisHPAss Model Concept and Application," March 1986.) BPA's version of EISIIPASs has been revised to include the Mid-Columbia Public Utility District dams, and to accept the spill and flow data from the SAM model.

BPA's FISHPASS model simulates downstream fish passage survival for anadromous fish passing the Lower Snake, Mid-Columbia, and Lower Columbia hydroprojects duriug the April through August period of downstream migration. Juvenile fish survival is calculated from the point of entry into the hydrosystem, to below Bonneville Dam. Survival projections are developed for species entering at specific projects (e.g. system survival. Lo below Bonneville Dam is calculated for yearling chinook salmon entering the river system at. Lower Monumental. pool).

FISHPASS simulates project specific system survival for yearlings (spring chinook and Snake River sumber chinook salmon), subyearlings (fall chinook and Mid-Columbia summer chinook salmon), steelhead trout, and sockeye salmon. Yearling, steelhead, and sockeye tend to migrate in the spring, April through June, and subyearling in the summer, June through August.

Analytical Methods. Given the time, location, and number of hatchery and natural stocks of fish entering each pool, and the project/species specific: characteristics for dan passage survival, pool survival, and travel time; FISHPASs uses the flow and spill information from SAM to compute the system survival (from point of origin) and the overall system survival for each species. Inputs and assumptions for the FISHPASS model can be found following this explanation. A more detailed description of the FISHPASS model can be found in Appendix E-3 of the Fina1 Intertie Development and Use EIS.

FISHPASS uses 40 rather than 200 random simulations from SAM to determine average survival for a given year. Analysis is then performed on 6 years of the 20 year sequence. In this case, the years of study are 1991, 1993, 1995, 1997, 2001, and 2003. The survival statistics evaluated include:

a. The relative change in mean survival. (Appendix H-1e). (This is determined by taking the difference in survival between each alternative and the No Action base case and dividing the difference by the base case survival.)

b. The frequency of change in relative survival being greater than and less than one and five percent. (Appendix H-1e).

A potential for impact is considered to occur if the change in relative survival exceeds one percent or if the decrease in frequency of a survival chatuge greater than one percent exceeds 30 percent or the decrease in the frequency of a survival change greater than five percent, exceeds five percent.

A biological assessment for both the critical and non-ritical stocks potentially eftected by any of the altematives is included in Appendix HI-c..

$$
(6-2-1
$$




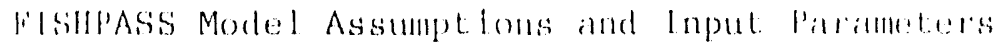

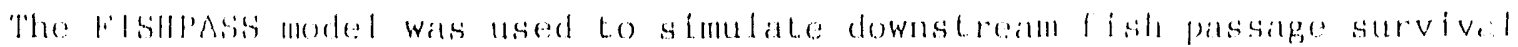

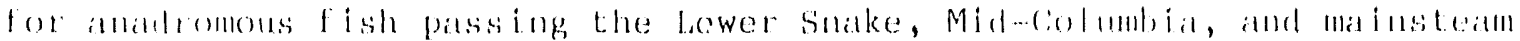

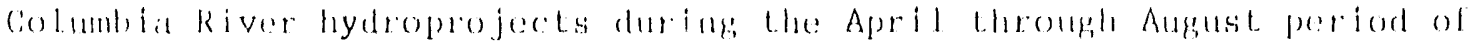

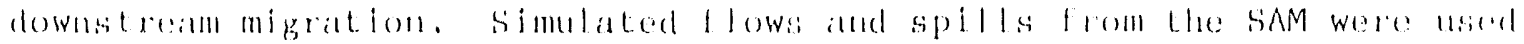

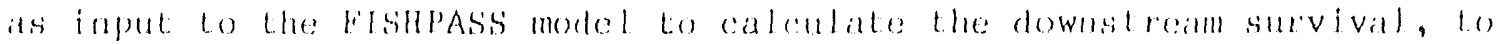
helow Romoville. This Appendix provides additional information for the key fismpnss model assumptions and input parantelers.

The period average values of planned, overgeneration, and foreed spill from the SAM were shaped into separate values of spill within a $2 / 4$ hollor period: (a) spill during planed fish-splll hours; and (b) spill duting, nonf ish-spill hours. On a real-time operational bassis, overgonerat ion spill can be shaped into the hours with the greatest benefit to fish (plamned fish-spill homrs), while forced spill is not controllable. therefore, for the FisHPAss analyses, the planned and overgoneration spill are shaped into the lish-spllithours for the specific project, while the forced spill is ma intained as a flat daily average rate occurring during both fish-spill and nonfish-spill hours. Table (-2-2 -1 shows the fish-spill hours used in the analysis and the percont of fish in a given day which pass the dall durling those spill hours.

The period average flows simulated by the SAM were modulated to daily values within each period before entry into FISHPASS using the 1986 historical (within period) flow shapes. the 1986 daily flows at Priest Rapids, Ice Harbor, and The Dalles were used to modulate (shape) the period average SAM data for the Mid-Columbia, Lower Snake, and Lower: Columbia hydroprojects, respectively. The modulated tlows for the SAM-FISHPASS runs were daily average values and were the same for both fish-spill and nonfish-spil1 hours. Spil1 rates were not affected by the daily modulation of period average flows.

Both hatchery and natural fish numbers for fish above Lower Granite Dam are based on dam counts as used in the 1987 development of the Corps of Engineers' Juvenile Fish Passage Plan. For other projects, hatchery fish release numbers and timing are based on 1986 hatchery releast data reported in the Smolt Monitoring Program Annual Report by the Fish Passage Center. Natural fish numbers and migration timing are based on (a) the 1984 final report on Stock Assessment of Columbia River Anadromous Salmonids; (b) the 1985 report on Downstream Migrant Estimates for Rocky Reach and Rock Island; and (c) consultation with the National. Marine Fisheries Service.

The planned fish spill at Federal projects is based on the Corps of: Engineers 1987 Juverile Fish Passage Plan with sliding scale spill at The Dalles, John Day, and Lower Monumental. Planned fish spill at Mid-Columbia PUD projects is based on the current federal Energy Regulatory Commission stipulation agreement. Planned spill is only an interim protection that is assumed to be eliminated at each project when bypass improvements are completed. 
Villues and relatiomships msed for spill efficiencies, dam passalse

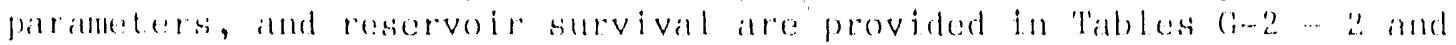

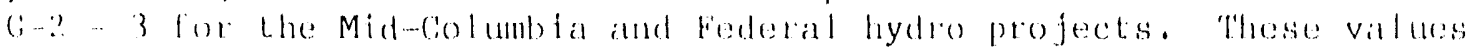

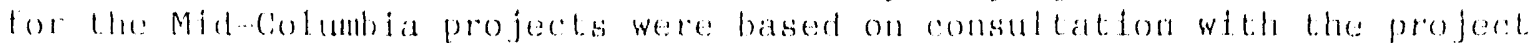
mathigers. For the federal propects, the values are those sperif fed by

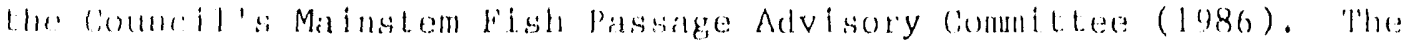
rescrvoir mortal ity rale for the Mid-Columblit projects was recent.ly indrased based on comments frem the National Marine Fisheries stervfoe and reviow of the test imony in the conrt procedings for the Mid columbia stipulation Agleement. The fish guidance elficiency values projected lor: fuldre hypass impovements al feleral projerts are lest aval able:

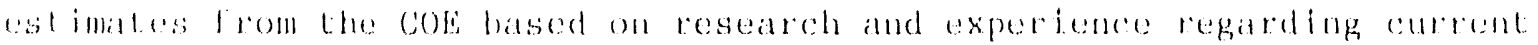
systems. For the Midmolumbia projects, the values for future tish

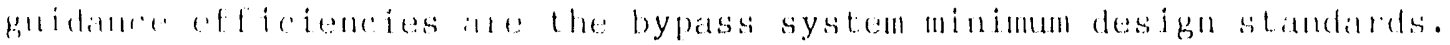

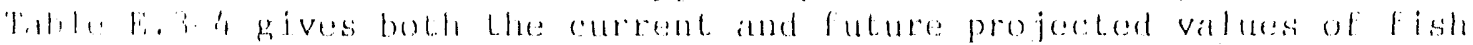

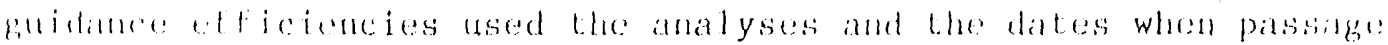
improvementss are expereled to oreur.

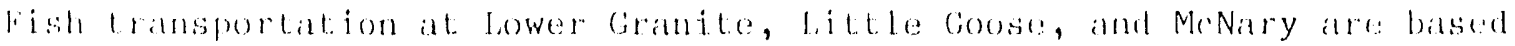
on the corrent guidelines developed by the fish Transportation oversight leall (fol') comprised of fishery agencies, Tribes, and the corps. Tramsportation survival is assumed to be 9 g percent at lower litante and

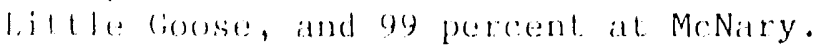

()verpeneration spill was allocated to different hydro projects based on the spill priority lists given in Table G-2 - 5 which were developed from a review of fish passage Center spill requests. 
Table $6-2-1$

HOURLYY FISH PASSAGE DISTRIBU'LIONS

\begin{tabular}{lllc}
\multicolumn{1}{c}{ Project } & \multicolumn{1}{c}{ Stocks } & Spi11 Hours & Percent Fish * \\
\cline { 2 - 3 } lel1s & Spring Chinook & $20: 00-6: 00$ & 71 \\
& Summer Chinook & $20: 00-6: 00$ & 58 \\
Steelhead & $20: 00-6: 00$ & 58 \\
Rock Reach & Sockeye & $20: 00-6: 00$ & 43 \\
Rock Island & A11 & $20: 00-6: 00$ & 43 \\
Wanapum & A11 & $20: 00-6: 00$ & 71 \\
Priest Rapids & A11 & $20: 00-6: 00$ & 58 \\
Lower Granite & A11 & $20: 00-6: 00$ & 58 \\
Litt1e Goose & A11 & $18: 00-6: 00$ & 82 \\
Lower Monumental & A11 & $18: 00-6: 00$ & 82 \\
Ice Harbor & A11 & $18: 00-6: 00$ & 82 \\
McNary & A11 & $18: 00-6: 00$ & 66 \\
John Day & Al1 & $18: 00-6: 00$ & 82 \\
The Dalles & A11 & $18: 00-6: 00$ & 82 \\
Bonneville & A11 & $18: 00-6: 00$ & 66 \\
\end{tabular}

* Percent of the daily total of fish arriving at the project which pass during the given hours of spill. 
Iable G-2 - 2

DAM PASSAGE PARAMETERS

\begin{tabular}{|c|c|c|c|c|c|}
\hline Project & Spli1 Efficiency $1 /$ & $\begin{array}{c}\text { Splil } \\
\text { Mortallty } \\
(\%)\end{array}$ & $\begin{array}{l}\text { Turblne } \\
\text { Mortality } \\
(\%)\end{array}$ & $\begin{array}{l}\text { Collection } \\
\text { Mortality } \\
(\%)\end{array}$ & $\begin{array}{c}\text { Bypass } \\
\text { Mortal } 1 \text { ty } \\
(\%)\end{array}$ \\
\hline Well.s & $\begin{array}{l}80 \% \text { Fish/21\% Spill } \\
94 \% \text { Fish/30\% Spll1 }\end{array}$ & 0 & 15 & 1 & 1 \\
\hline Rocky Reach & $\begin{array}{l}y=0.663 x \\
\text { (range } 20-80 \%)\end{array}$ & 0 & 15 & 1. & 1. \\
\hline Rock Is land & $\begin{array}{l}y=\exp (0.054 x) \\
(\text { range } 15-80 \%)\end{array}$ & 0 & 6.5 & 1 & 1 \\
\hline Wanapun & $\begin{array}{l}y=15.42 \ln (x) \\
\text { (range 20-85\%) }\end{array}$ & 0 & 11 & 1 & 1. \\
\hline $\begin{array}{l}\text { Priest } \\
\text { Rapids }\end{array}$ & $\begin{array}{l}\ln (y)=0.819 \ln (x) \\
(\text { range } 20-85 \%)\end{array}$ & 0 & 11 & 1. & 1 \\
\hline $\begin{array}{l}\text { Federal } \\
\text { Projects } 2 /\end{array}$ & $y=x$ & 2 & 15 & 1. & 1 \\
\hline $\begin{array}{l}\text { 2/ For The } \\
\text { for } x / y\end{array}$ & $\begin{array}{r}\text { ficiency }-y=\% \text { fish } \\
x=\% \text { rive } \\
\text { Spill outs } \\
\text { interpolate } \\
\text { and } 100 \% \text { f } \\
\text { Dalles the following } \\
0 / 0,20 / 52,41 / 80\end{array}$ & $\begin{array}{l}\text { spilled } \\
\text { spilled } \\
\text { de ranges } \\
\text { d toward en } \\
\text { sh/100\% spi } \\
\text { pili effici } \\
00 / 95\end{array}$ & $\begin{array}{l}\text { nstantaneol } \\
\text { iven for da } \\
\text { d points of } \\
\text { 1.1 } \\
\text { ency relati }\end{array}$ & $\begin{array}{l}\text { 5) } \\
0 \% \text { fish } / 0 \% \\
\text { miship is us }\end{array}$ & spi11 \\
\hline
\end{tabular}


Pabla G-2-3

RESLRVOIR FLOW/SURVIVAL, RLIATIONSIIIISS (KCES/\%)

For MId-Columbla l'rojects"

Rocky Reach
Elow/Survival
$0 / 21.3$
$10 / 24.8$
$50 / 85$.
$100 / 92.5$
$250 / 97$
$750 / 97$

Rock Is land
Filow/survival
$0 / 76.6$
$10 / 80.1$
$50 / 96.0$
$100 / 98.0$
$250 / 99.2$
$750 / 99.2$

Wanapun
Fiow/survival
$0 / 0$
$10 / 0$
$50 / 79.4$
$100 / 89.7$
$250 / 95.9$
$750 / 95.9$

Prlest Flow/siutivival $0 / 61.5$ $10 / 65.0$ $50 / 93.0$ $1.00 / 96.5$ $250 / 98.6$ $750 / 98.6$

for Snake River Profectsk

\begin{tabular}{c} 
Little Coose \\
\hline Flow/Survival \\
$0 / 53.0$ \\
$12 / 54$ \\
$50 / 67$ \\
$75 / 79$ \\
$100 / 87$ \\
$125 / 92$ \\
$150 / 92$ \\
$175 / 88$ \\
$1000 / 88$
\end{tabular}

\begin{tabular}{c} 
Lower Monumental \\
\hline Flow/Survival \\
$0 / 61$ \\
$1.2 / 62$ \\
$50 / 73$ \\
$75 / 83$ \\
$100 / 90$ \\
$1.25 / 94$ \\
$1.50 / 94$ \\
$175 / 91$ \\
$1.000 / 91$
\end{tabular}

Ice Harbor
Filow/Survtval
$0 / 58$
$12 / 59$
$50 / 71$
$75 / 81$
$100 / 89$
$125 / 93$
$150 / 93$
$1.75 / 90$
$1000 / 90$

For Malnstem Columbia Profects

\begin{tabular}{cccr} 
McNary & John Day & The Dalles & Bonnevtlie \\
\cline { 2 - 3 } Flow/Survival & Flow/Survival & Fiow/Survival & Flow/Survival \\
$0 / 55$ & & & $0 / 30$ \\
$50 / 56$ & $50 / 31$ & $50 / 68$ & $0 / 49$ \\
$150 / 72$ & $150 / 52$ & $150 / 81$ & $50 / 50$ \\
$175 / 79$ & $175 / 62$ & $175 / 86$ & $150 / 68$ \\
$200 / 85$ & $200 / 72$ & $200 / 90$ & $1.75 / 76$ \\
$225 / 89$ & $225 / 80$ & $225 / 93$ & $200 / 82$ \\
$250 / 92$ & $250 / 85$ & $250 / 95$ & $225 / 87$ \\
$275 / 93$ & $275 / 86$ & $275 / 95$ & $250 / 91$ \\
$300 / 92$ & $300 / 84$ & $300 / 95$ & $275 / 92$ \\
$350 / 84$ & $350 / 71$ & $350 / 90$ & $300 / 90$ \\
$1000 / 84$ & $1000 / 71$ & $1000 / 90$ & $350 / 81$ \\
& & & $1000 / 81$
\end{tabular}

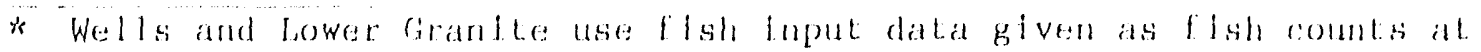
the dand and there ls no resservold mortallty applied to these flah numbers. 
'lable (i- - :

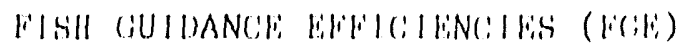

(Porcont)

Projuct

Yoarllng

(i) li

We 11 \&

R. Reach

R. Is land

Wancipuill

Prlesti R.

() 72
s/Yearllng

(! r

70) 7()

() 5()

() 50

() 5()

() 50

1.. Ciranlte $77 \quad 88$

l. Cioose $77 \quad 88$

L. Monumental 273

1. Llarbor 078

slulceway 510

MeNary $\quad 7590$

John Day $72 \quad 90$

The Dalles () 80

silutceway 40 ()

Bonnevilie $176 \quad 76$

Bonneville 2 $19 \quad 65$
$188 \quad 60$

$48 \quad 60$

235

$0 \quad 35$

510

$40 \quad 60$

$30 \quad 60$

$0 \quad 63$

$40 \quad 0$

$30 \quad 30$

$24 \quad 24$

$\begin{array}{cc}\text { Stoglhoud } \\ 0 & 1 \\ 80 & 80 \\ 0 & 70 \\ 0 & 70 \\ 0 & 70 \\ 0 & 72\end{array}$

$79 \quad 88$

$79 \quad 88$

$4 \quad 74$

0 92

510

7590

8690

) 83

$40 \quad 0$

$78 \quad 78$

3550
Sorkuye

(i) li

70 70

() 5()

() 50

() 50

) 50

$48 \quad 60$

$1,8 \quad 60$

235

0 35

510

$40 \quad 60$

$30 \quad 60$

) 63

$40 \quad 0$

$30 \quad 30$

$24 \quad 24$
Your

$11 / a$

1.992

1.992

1.995

1.995

1.995

1995

1.992

1.993

$\mathrm{n} / \mathrm{a}$

1.996

1997

1.997

$\mathrm{n} / \mathrm{a}$

$11 / a$

1.996

$C=$ Current bypiss FGE.

$\mathrm{F}=$ Future Bypass FGE

Year = Estimated date of bypass installation or upgrade. 
Trable $(4-2-5$

PRIORITY LIS'TS FOR ALLOOCATION OF OVERGENERATION SPILL. WITHIN SAM I/

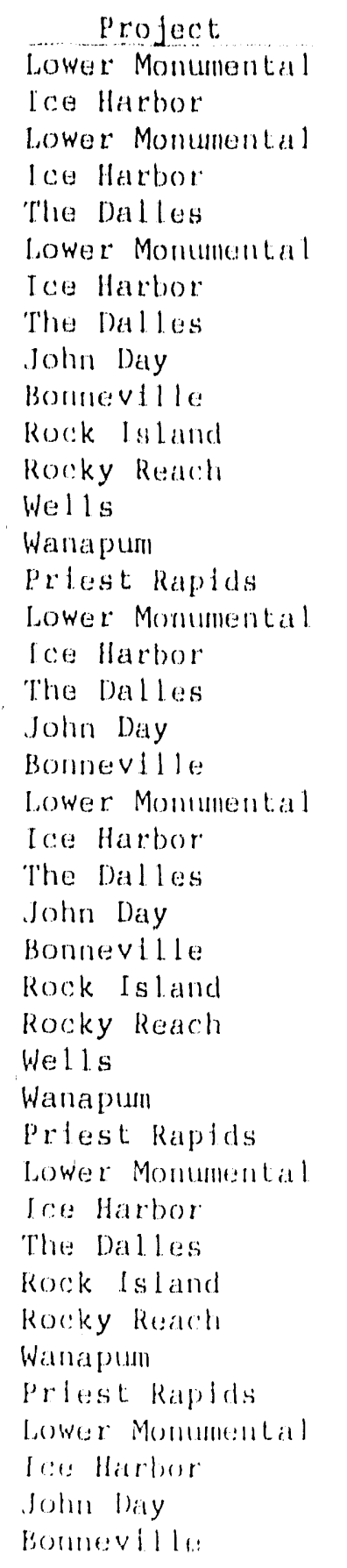

APRII.

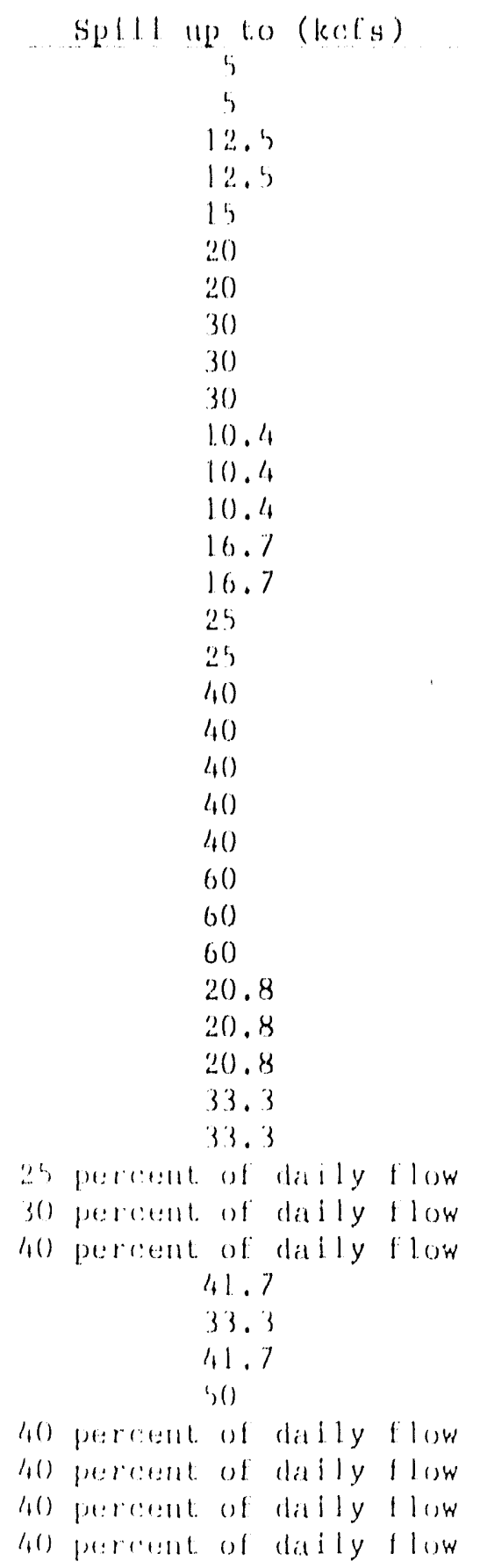


Thable (i-2 - 5 (Cont lnued)

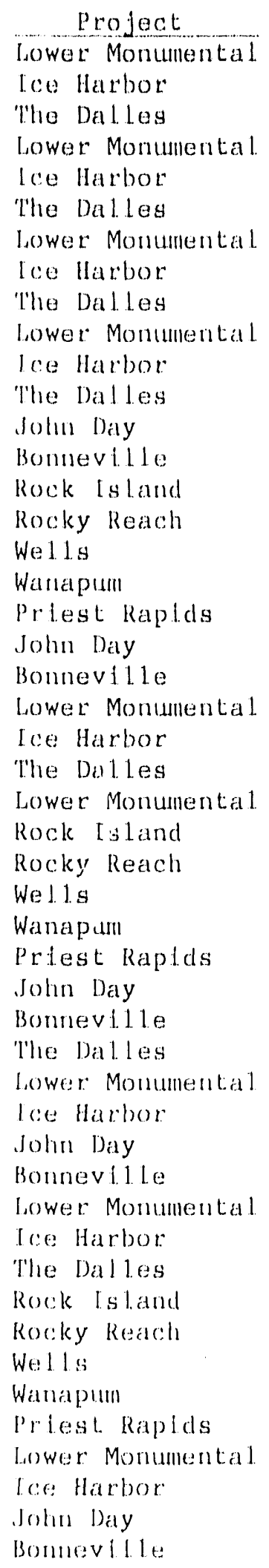

MAY

Spt1. up to (kcfs)
5
5
7.5
7.5
7.5
12.5
12.5
12.5
17.5
17.5
17.5
22.5
10
10
20.8
10.4
10.4
12.5
12.5
15
15
25
25
30
40

33.3

20.8

20.8

25

25

30)

30

60

4.)

40)

60

60

25 percent of daily flow

30 percent of dally flow

40 percent of dally flow 41.6

33.3

33.3

41.6

50

40) percent of daily flow

40) percent of dajly flow

40 percent. of datly 1 low

10) percent of daily flow 


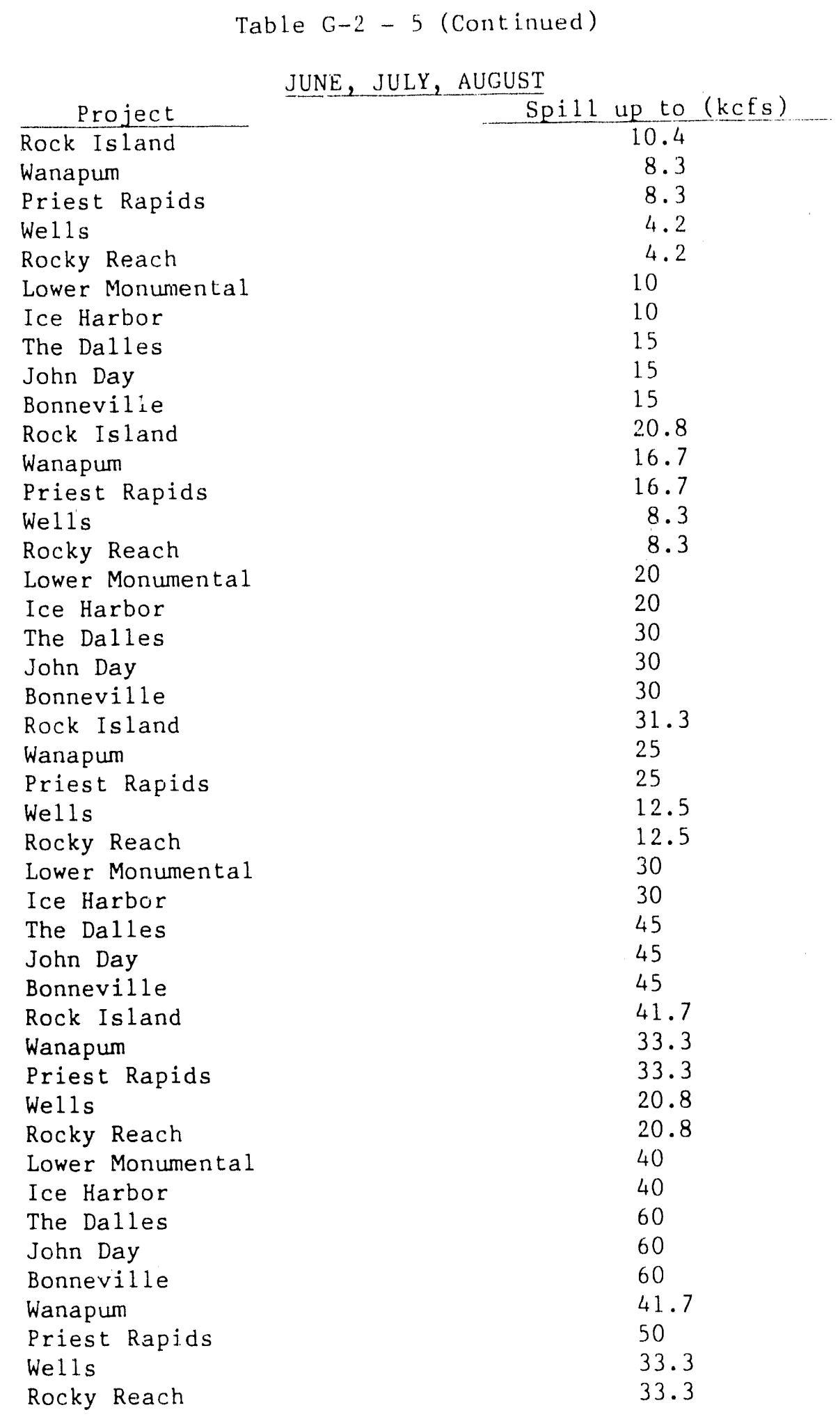


Lower Monumental

Ice Harbor

The Dalles

Lower Monumental

Ice Harbor

John Day

Bonneville
25 percent of daily flow

30 percent of daily flow

40 percent of daily flow

40 percent of daily flow

40 percent of daily flow

40 percent of daily flow

40 percent of daily flow

I/ Spill rates are in addition to planned spill, but include forced spill and are applied to monthly average flows in SAM. Total spill at Bonneville is limited to 60 percent of the monthly average flow.

(VS6-PG-1551I) 


\section{G-3}

The Decision Analysis Model for Aluminum Industry Analysis 


\section{THE DECISION ANALYSIS MODEL FOR ALUMINUM INDUSTRY ANALYSIS}

This document describes the analyses for the Draft Environmental Impact Statement (EIS) which were carried out using the Decision Analys is Model (DAM). This model was originally designed for Bonneville Power Administration's (BPA) Direct Service Industries (DSI) Option Study of 1985 , an assessment of the economic effects of various policy options directed towards the DSI. Its selection as one principal analytical tool for the EIS was made because of several of its features.

1. The model was basically conceived to deal with the complexities of regional aluminum smelter economics. It allows consideration of a variety of policy or contract options relating to the Northwest aluminum industry.

2. The model combines condensed versions of several BPA system models, and therefore was much faster than attempting to perform these analyses using BPA's more detailed models such as the Aluminum Smelter Model or Systems Analy's is Model (SAM).

3. The model focuses broadly on an overall picture of the Northwest's utility economics and operations and therefore produces a variety of outputs useful to the EIS. Some of these outputs, such as employment on a regionwide basis, are not produced by other BPA models and would have had to be derived exogenously had the DAM not been used.

For purposes of this discussion, only a brief overview of the DAM is provided. For a more detailed description, refer to the DSI Options Study Final Report, parts 1 and 2, June 1985, and Appendix B of the Draft EIS Direct Service Industry Options, January 1986. The Decision Analysis Model links together three basic components of the region's power supply system: load forecasting, power system operation and capacity expansion, and rates and finances. In addition, it calculates changes in employment. Each of these areas have traditionally been modeled separately and in greater detail than in the DAM. The strength of the DAM is in its ability to integrate these diverse areas and thereby provide a reasonable method for assessing the relative merits of alternative policy or contract options across a broad spectrum of impacts. See Figure 1 for an overview of the DAM.

One of the model's unique characteristics is its ability to deal with the probabilistic nature of major variables which are inherently uncertain. These include regional load growth, availability of water for the operation of the hydro system, and the market price of aluminum. When the model is set to run in its probabilistic mode (which was the basis for this draft EIS analysis), a random draw is made for each of these variables in each run. Such a set of random values comprises one "game." Typically, a probabilistic run comprises 100 games. The results for all games are averaged together to find the expected value of the results. The DAM produces a number of different outputs, including electric load, aluminum industry production levels, power 
Fig. $(j-3-1$

SYNOPSIS OF THE DSI DECISION ANALYYSIS MODEL

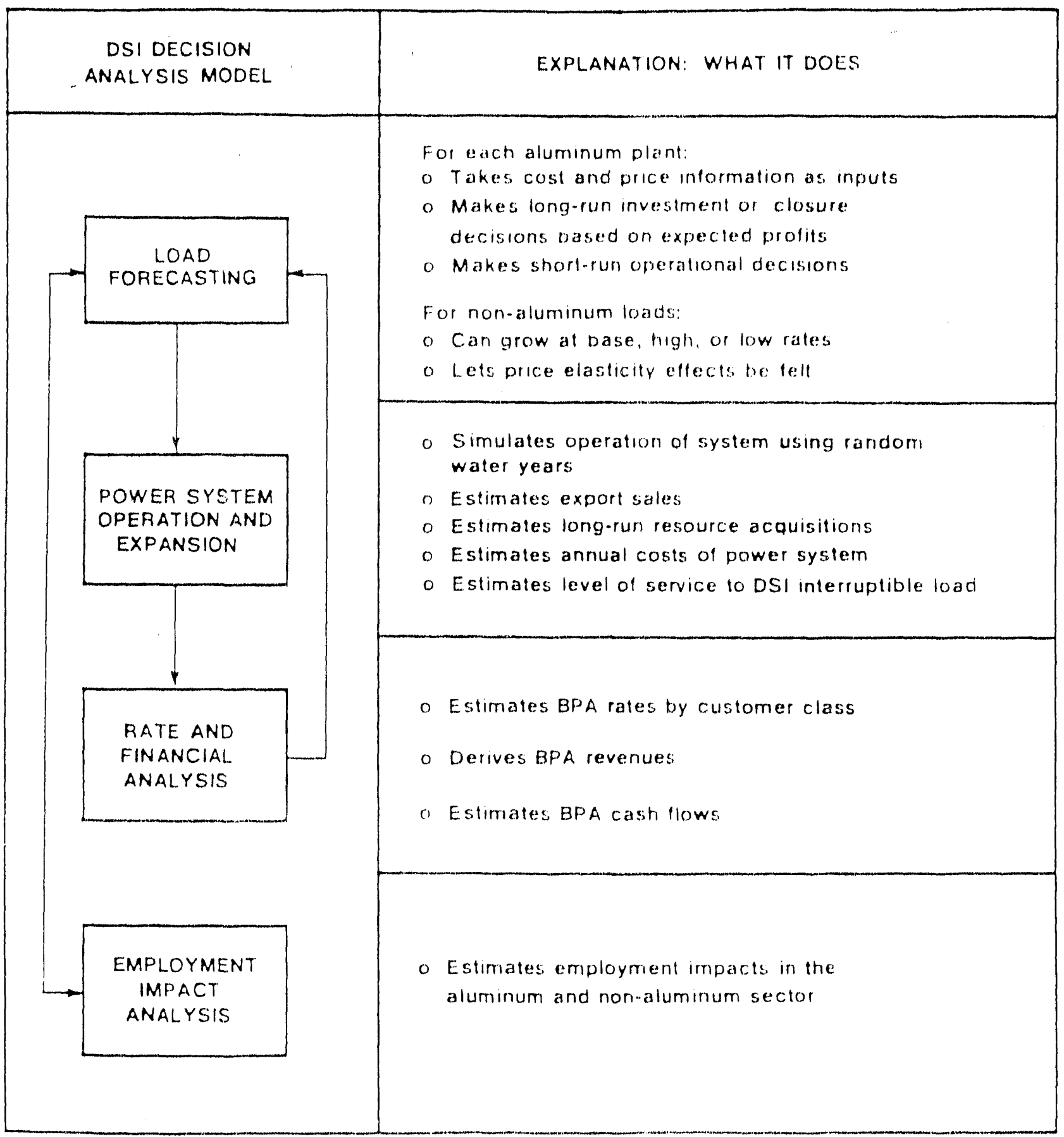


rates, and a varlety of others. However, the simplest overall measure of relative economic impacts of alternatives is "customer benefits." For the aluminum customers this represents the present value of the discounted net cash flow resulting from the operation of the region's 10 smelters according to the production levels determined by the model. For the other customers, the net benefits refer to the present value of changes in total expenditures adjusted for changes in quantity consumed of electric energy. The DAM measures effects of a policy or contract option relative to an option of taking no action.

The model output should be vieved with some caution. The model is not as accurate as BPA's more detailed, specialized models in determining some of the impacts of the options. Also, any model is only a simplification of the operations of the "real world." While the quantification within the model implies that some precision exists, in practice only approximations are pussible becaluse of the limits of both the model structure and the quality of the available data.

The model is a useful tool for determining the relative changes caused by the different alternatives. Thus, valid comparisons among the alternatives can be made, but the absolute values of results should be viewed with caution.

Conclusions and interpretations based on the model output are, therefore, supplemented by judgment, results of other studies, knowledge of the DSIs gained through BPA's dealings with them over the years, the DSI Options study, and other sources.

\section{Aluminum Industry Modeling}

The dluminum industry portion of the DAM models both the short-run (operational) and long-term (capacity) planning decisions of the region's 10 aluminum smelters. The logic employed in both the short-run and long.run portions of the model is based on previous industry modeling (e.g. the Aiuminum smelter Model) and traditional approaches to capital investment analyi: (i.e. discounted net cash flow). Reliance was placed on past studies and andysis for the development of input parameters, most importantly "flminum production coste and prices. Th the long-run portion of the model. current long-run margind ( $i$. e. , both fixed and variable) costs of aluminum production for each smelter are compded to a long-run expected aluminum price (all costs and prices are in constant 1985 dollars). If the present value of the expected long-iun pice exceeds the present value of the long-run marginal costs of production over a 10 year planning period, the smelter is assumed to lemain in operation.

The power rates calculated in the rates module of the DAM dre based upon BPA's mo'. 1985 cate design, and are determined by quarterly short level do isions within the model, and are aggregated to anmal values. The power rates, along with other short-term maginal costs of aluminum production, are compared to forecasted quarterly aluminum prices to detrinine 
short-term profltabllity. The model increases production to full capacity if: a smelter is profttable, and reduces production rates to the equivalent of one potline if it is not profitable. (This particular assumption is based on emplrical observation of minlmum operating levels during the past several years.)

Production levels directly determine electric load requirements through the electricity usage estimate for each smelter (in kWh/lb of aluminum produced). Loads are apportioned by type (i.e., flrm and top quartile) and revenues to BPA from these load levels are determined.

\section{Aluminum Prices and Production Costs}

In these analyses, long-run aluminum prices of $70 \not / 1 \mathrm{~b}$, and $60 \not / 1 \mathrm{~b}$. (in 1985 dollars) were used. In the model this price is comblned with a random component (with a standard deviation of $6 \not / 1 b$. to reflect market price uncertainty) used in the long-run capacity decision making portion of the DAM. In other words, with a long-term aluminum base $\mathrm{price}$ of $60 \% / 1 \mathrm{~b}$, and a standard deviation of $6 \not / 1 \mathrm{~b}$., two-thirds of the forecasted prices would fall between 54-66 //1b. in 1985 dollars or $61-75 \not / 1 b$. In 1989 dollars. The remaining one-third of the prices would be beyond this range. For a $70 \not / 16$. long-term aluminum base price, the two-thirds of the forecasted prices would be between 64-76 $\not / 1 \mathrm{~b}$. In 1985 dollars or $72-86 \not / 1 \mathrm{~b}$. in 1989 dollars. These long-term forecasted prices are combined in the model with short-term (essentially current) prices to derive the quarterly expected prices for use in the short-term operational decisionmaking portion of the DAM.

The power rates for the aluminum smelters are determined by a variable rate module in the model which calculates the rates based on the forecasted aluminum price.

The aluminum smelting production costs used in the model are essentially derived from two studies on regional smelter production costs conducted by independent industry analysts for BPA. These are: (1) Primary Aluminum Production Costs in the Paciflc Northwest (PNW), John Moberly Associates, July 1984; and (2) Aluminum Costs and Supply Arrangements in the PNW, Resource Strategies, Inc., May 1985. These reports, as well as BPA's own estimates and analyses, are the basis for all the production costs used in the DAM. Table 1 summarizes the most recent aluminum production cost estimates used in the DAM. 


\section{Table 1: 1987/1988 Estimated Costs DAM ALUMINUM PRODUCTION COSTS \\ (1985 \$)}

\begin{tabular}{lccc}
$\begin{array}{c}\text { Alumina } \\
\text { Cents/Lb }\end{array}$ & $\begin{array}{c}\text { Wages } \\
\$ / H r\end{array}$ & $\begin{array}{c}\text { Other Cost } \\
\text { Cents/Lb. }\end{array}$ \\
\cline { 2 - 3 } Vancouver & 0.102 & 15.30 & $\begin{array}{c}0.180 \\
\text { Wenatchee }\end{array}$ \\
Columbla Falls & 0.110 & 21.60 & 0.176 \\
Ferndale & 0.125 & 15.30 & 0.162 \\
Mead & 0.102 & 21.60 & 0.169 \\
Tacoma & 0.112 & 18.90 & 0.184 \\
Goldendale & 0.102 & 18.90 & 0.183 \\
The Dalles & 0.104 & 15.30 & 0.194 \\
Longview & 0.113 & 15.30 & 0.187 \\
Troutdale & 0.102 & 21.60 & 0.190 \\
& 0.104 & 21.60 & 0.187
\end{tabular}

\section{Resource Operation and Development}

The DAM makes a number of assumptions regarding the power system's operation and expansion. These assumptions relate to water conditions, intertie size, Southwest market sales, placement of future investor-owned utility luads on $B P A$, the future of WNP-1 and -3 , etc. Generally these resource assumptions are the same as were used in the final BPA 1987 Resource Program. These assumptions are specified in Resource Analysis Documentation, 1987 Resource Strategy, Bonneville Power Administration, May 1987.

\section{Required Rate of Return}

The Required Rate of Return (RROR) in the DAM functions as a real (net of inflation) discount rate in the long-term capacity planning and decisionmaking module. As such, an increase in the RROR reduces the present value of future benefits of smelter modernization or increases in production capacity in the calculation of discounted net cash flow. Similarly a decrease in the RROR has the opposite effect, increasing the present value of future cash flows. The current analysis used a RROR of 20 percent. This high RROR is consistent with an assumption that firms would use a higher discount rate when evaluating potential investments in a situation characterized by a high degree of uncertainty.

\section{Time Horizon}

The DAM is designed to run over a 30-year period ending in the year 2015, although this can be varied. Model results are tabulated for the time periods 1986-92, 1993-99, and 2000-15. 


\section{Results}

Results of the analysis are presented in terms of changes from the base case in rates, in aluminuin loads, and in "reglonal net benefits" using units of millions of dollars, discounted to a net present value using a 3 percent real rate over 30 years. (Note that the discount rate used for comparing reglonal benefits is significantly lower than the rate assumed to be used by the aluminum industry for long-term decisionmaking with respect to regional sinelters.) 


$$
\text { G-4 }
$$

The Joint BPA-Councll Industrial Model

(used for New Large Single Load analysis) 


\section{THE JOINT BPA-COUNCIL INDUSTRIAL MODEL II}

Industrlal sector. The Industrial sector is the largest of the four consumlng sectors. In 1988, the industrlal sector consumed 6.491 alm of firm electriclty, accounting for 39 percent of the reglonal total.

Forecasts of Industrlal electrictty use reflect production output forecasts for the varlous industrial sectors, the amount of energy used per unlt of output, and the effects of electrlclty and other fuel prlces on energy use. Table G-a-1 shows Industrlal sector forecasts of firm electriclty use of selected years under all five cases. In the high case, consumptlon of electrlcity by the Industrlal sector grows to 11,013 aMW by 2010 , an average annual growth rate of 2.4 percent. In the low case, Industrial electriclty use decreases due to signiftcant reductlons in drect servlce industry use whlle other fndustrles remaln largely unchanged. The more likely range of growth in industrial electriclty use if from 0.1 percent to 1.3 percent per year, with medlum case growth at 0.6 percent per year.

\section{Table G-4-1 \\ Pacific Northwest Industrial Sector \\ Forecasts of Firm Electricity Use \\ (aMW)}

\begin{tabular}{|c|c|c|c|c|c|}
\hline & $\begin{array}{r}\text { ACTUAL } \\
1988 \\
\end{array}$ & 1995 & $\frac{\text { ORECAS }}{2005}$ & 2010 & $\begin{array}{c}\text { GROWTH RATE } \\
(\% \text { PER YEAR) } \\
1988-2010\end{array}$ \\
\hline $\begin{array}{l}\text { Hlgh } \\
\text { Med I um-h I gh } \\
\text { Med l um } \\
\text { Med l um- low } \\
\text { Low }\end{array}$ & $\begin{array}{l}6,491 \\
6,491 \\
6,491 \\
6,491 \\
6,491\end{array}$ & $\begin{array}{l}8,025 \\
7,054 \\
6,454 \\
5,894 \\
5,094\end{array}$ & $\begin{array}{l}9,890 \\
8,030 \\
7,064 \\
6,290 \\
5,107\end{array}$ & $\begin{array}{r}11,013 \\
8,580 \\
7,432 \\
6,597 \\
5,204\end{array}$ & $\begin{array}{r}2.4 \\
1.3 \\
0.6 \\
0.1 \\
-1.0\end{array}$ \\
\hline
\end{tabular}

Industrial electriclty use in the Northwest is highly concentrated in a few subsectors. Flve industries (food, chemlcals, paper, lumber, and metals) account for almost 90 percent of this. Metals production, primarlly by Bonnevflle's 10 aluminum direct service industrial customers, accounts for nearly half the total. Direct service industrlal customers accounted for 37 percent of industrial sector electricity use in 1988, or about 15 percent the total for all sectors. The aluminum smelters represent about 90 percent: of electricity use by Direct Service Industries.

II For more detall, see Model Documentation--Draft Flnal Report, Charles Rivers Assoclates Report No, 642, Vol, 1, Ch. 3, September 12 , 1982. 
In addition to the flrin electrlatty use doscrlbed above, the direct service Industrlal customers consume varylng amomits of nonflim electricity, depending on economlc and hydroelectrle condltons. Inciluding nonflim power, the Industrial sector used a total of 7,044 alyh to 1988. Only the flim portions are lncluded ln Table II; however, the nonfirill portilons are considered ln system operation and electilcity pricho and yses.

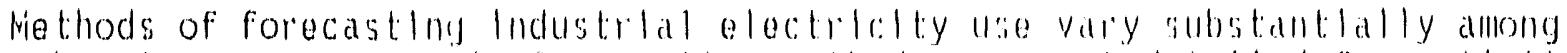
subsectors, In general, forecating methods are mest delalled for activities that consume the greatest anomes of olectilcily, ll la necossary to forecast

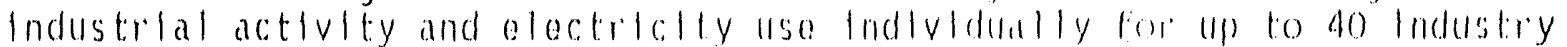

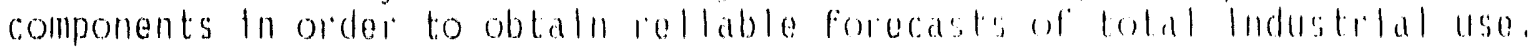

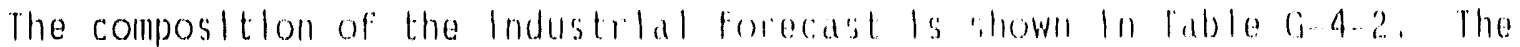

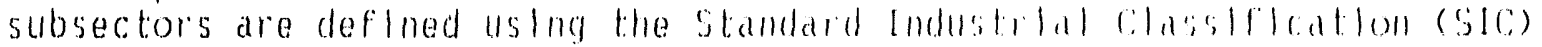

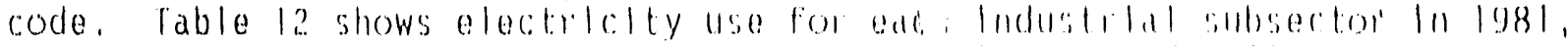
the most recent yoar date ls avallable at lils lovel of delall.

There are four methods used to forecast lndustital soctor electilcity use. They are: (l) key lodustry models; (2) ecomometh lo molels: (3) slmple relat lonshlps: and (4) assumptions. All of the forecasting methods, except assumptlons, die dreven prlmarlly by forecasts of lndustilal production for each todustidal subsector. In additton, each of these methods modf tes the retat tonshlp between production and electiciclty use to reflect the offects of changlng energy prices and other factors. The assumptlons method as used to forecast the electidclly requlrements of both the alumlanm and non-alumlnum dract service Industiles. It: Is labeled as such becallse Bommevllle forecasts these Industries using models and methods that are separate from the maln Bonneville and Counctl Industrial process model.

The three largest non-dlrect sarvice Industries In terms of electilcity use are rorecast us Ing Bonnevllle and Counc:Il key Industiy models. The key Industry models are detalled approaches to forecasting electilcity use. three key Industrles are lumber and wood products, pulp and paper, and chemicals. First, each fodustry is further separated into the most energy intensive activitles. For those activitles, the uses of electriclty are divided into several types, such as motors for speciflc processes, electroloysis, or lighting. The fraction of electilclty use attributable to each of these end uses is estimated for an average plant. In the case of chemical production of phosphorous and chlorine, the model is speclffed separately for each of the sixplants in the region.

The forecast requires a spectflcation of how the share of end uses may change over time. In addition, the degree to which electilclty for each type of end use could be conserved in response to price changes is spectfied. The degree of price response varles across forecast cases, belng largest in the low case and smallest in the hlgh case. Glven these speclflcatlons, electricity use per unt of production changes as production and electilcity prices change. 
The key Industry models requlin a great deal of data gotng beyond readly avallable sources, For thls reason, speciflcatlon of the key lndustry nodels relles heavlly on the fudgment and advice of Industry representatives and trade organladtons.

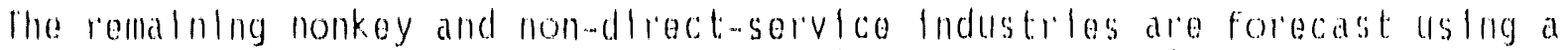

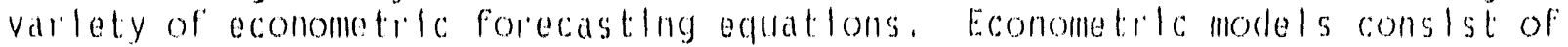
equatlons astlented from historlcal data. The equatlons attempt to measure the effect of Industiry product lon and energy prices on the use of dfferent: types of eneryy, Includleg olectrlctty. Becalse hlstorlcal data are generally

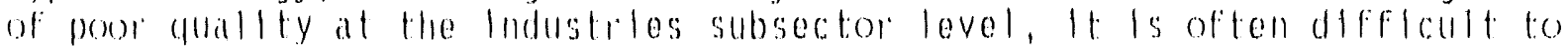

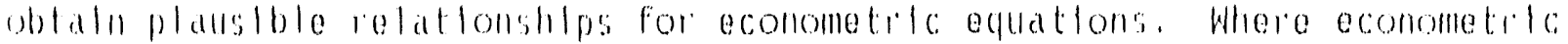
results appoared lmplatisthle, stmple relationshlps between output and

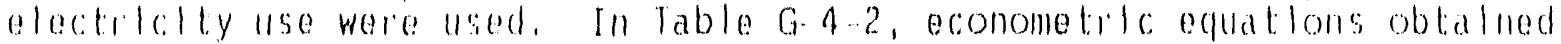

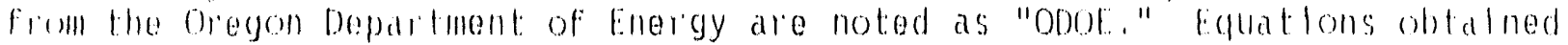
Hom Bommevllle ale labeled "AtA" for Applled fonomls Assoclates, the comsultimg flam that estimated the equatlons. 21

The subectors whose forecasting mothods are llsted as "slimple" are those for whlch aconometrlc results were unsatsfactory. In these stmple forecasts. alectrictly use lis assumed to form at the same rate as producton, but is modlfted by an assumed trend In electilcity use per unlt of production. There Is substantal agreement In conometrlc models and other influences, energy use wlll grow with production.

There is much less agreenent about the degree of Influence price changes whll have on energy use. To reflect this uncertalnty, assumed changes in use per unlt of production were varled across forecast cases. Electrict ty use per unlt of production was assumed constant ln the high case for subsectors that were forecast us lng the slmple method. In the medlum high case, the electilc Intensity was assumed to decrease by 0.5 percent per year; in the medlumm- low case, by 1.5 percent per year; and in the low case by 2.0 percent per year. The medlum case assumes a 1.0 percent per year reduction ln electricity use per unt of output. These assumptions are simflar to the range of econometric results which were more acceptable theoretically and behavlorally.

2I Applied Economic Assoclates, Inc., Update and Re-estlmation of the Northwest Energy Pollcy Project Energy Demand Forecasting Model, report to Bonnevfile Power Admintstration, December 1981. 
Table G-4-2

Industrial Forecasting Methods

by Industry Type

\begin{tabular}{|c|c|c|c|c|c|}
\hline \multicolumn{2}{|c|}{ SIC CODE } & $\begin{array}{r}1981 S \\
M F G E L E C \\
\end{array}$ & $\begin{array}{l}\text { HARE OF } \\
\text { TRICITY } \\
\end{array}$ & $\begin{array}{l}\text { FORECASTING } \\
\text { METHOD }\end{array}$ & $\begin{array}{l}\text { MODEL } \\
\text { VERSION }\end{array}$ \\
\hline \multicolumn{6}{|c|}{ MANUFACTURING } \\
\hline \multirow{7}{*}{$\begin{array}{l}2.0 \\
22 \\
23 \\
24\end{array}$} & & Food \& Kindred Products & 4.1 & Slmple & \\
\hline & & Textlles & .1 & Econometrlc & AEA \\
\hline & & Apparel & .1 & stimple & \\
\hline & & Lumber \& Wood Products & 6.8 & & \\
\hline & 2421 & Sawml11s \& Plannting Ml11s $(2.8 \%)$ & & Key Industry & \\
\hline & 2436 & Softwood Veneer \& Plywood $(1.5 \%)$ & & Key Industry & \\
\hline & & Remainder of SIC $24(2.5 \%)$ & & Slimple & \\
\hline \multirow{6}{*}{$\begin{array}{l}25 \\
26\end{array}$} & & Furnt ture & 21.1 & Stmple & \\
\hline & 2611 & $\begin{array}{l}\text { Pulp Paper } \\
\text { Pulp Mil1s }(1.6 \%)\end{array}$ & 2.1 .0 & Key Industry & \\
\hline & 2621 & Non-DSI Paper M111s (12.1\%) & & Key Industry & \\
\hline & 262.1 & DSI Paper Mllls - Port Townsend $(0.2 \%)$ & & Assumption & \\
\hline & 2631 & Paperboard M+11s (4.4\%) & & Key Industry & \\
\hline & $26 \times x$ & Remalnder of SIC $26(2.7 \%)$ & & Stimple & \\
\hline \multirow{6}{*}{$\begin{array}{l}27 \\
28\end{array}$} & & Printing \& Publisnting & .5 & Econometrtc & ODOE \\
\hline & 2812 & Non-DSI Chlortne \& Alakalles $(1.9 \%)$ & 11.0 & Key Industry & \\
\hline & 2812 & DSI Chlortne \& Alkalles - & & & \\
\hline & & Georgla Paclfic, Pennwalt $(1.1 \%)$ & & Assumption & \\
\hline & $\begin{array}{l}2819 \\
2819\end{array}$ & $\begin{array}{l}\text { Non-DSI Elemental Phosphorous }(5.6 \%) \\
\text { DSI Elemental Phosphorous-- } \\
\text { DOE RIchland (Federal Agency), }\end{array}$ & & Key Industry & \\
\hline & & Pacific Carbide $(0.8 \%)$ & & Assumption & \\
\hline \multirow{4}{*}{$\begin{array}{l}29 \\
30 \\
32\end{array}$} & $28 \times x$ & Remainder of SIC $28(2,2)$ & & Econometric & CDOE \\
\hline & & Petroleum Refining & 1.4 & Stmple & \\
\hline & & Stone, Clay, Glass, \& Concrete & .5 & Econometric & AEA \\
\hline & 3291 & $\begin{array}{l}\text { DSI Abrasive Products - } \\
\text { Carborundum }(0.3 \%)\end{array}$ & & As sumption & \\
\hline & $32 x x$ & Rematnder of SIC $32(0.9 \%)$ & & Econometric & ODOE \\
\hline \multirow[t]{5}{*}{33} & & Primary Metals & 49.0 & & \\
\hline & 3334 & DSI Aluminum $(43.2 \%)$ & & Assumption & \\
\hline & 3313 & DSI Electrometallurglcal $(1.3 \%)$ & & As sumption & \\
\hline & 3339 & DSI Nonferrous NEC - Oremet $(0.1 \%)$ & & As sumption & \\
\hline & $3.3 \times x$ & Remainder of SIC $33(4,4 \%)$ & & Econometric & DDEO \\
\hline 34 & & Fabricated Metals & .8 & Stmple & \\
\hline 35 & & Machinery Except Electrical & .8 & Slimple & \\
\hline 36 & & Electrical Machinery & .4 & Econometric & ODOE \\
\hline 37 & & Transportation Equlpment & 1.9 & Simple & \\
\hline 38 & & Professional Instruments & .4 & Simple & \\
\hline 39 & & Miscellaneous Manufacturing & .1 & Stimple & \\
\hline$x x$ & & Residual Categorles & .4 & Simple & \\
\hline \multicolumn{2}{|c|}{ AINING } & & $n ! \mathrm{a}$ & $\begin{array}{l}\text { Grows with } \\
\text { Employment }\end{array}$ & \\
\hline
\end{tabular}




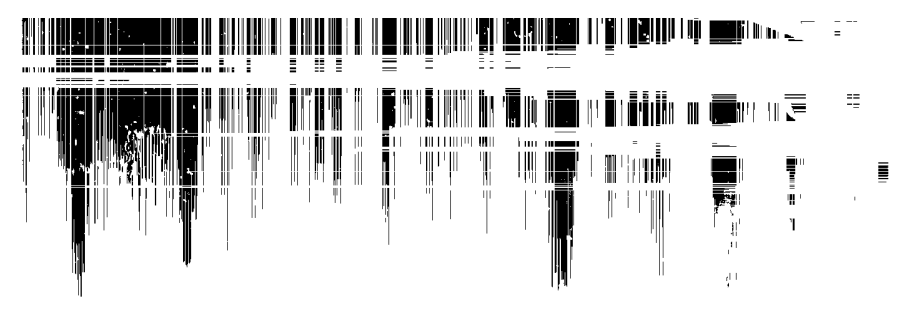


H-1a

Background on Fish, Wildlife, and

Vegetation Impacts Due to Hydro Operations 


\section{Background on Fish, Wildlife, and Vegetation Impacts Due to Hydro Operations}

Resident Fish. Resident fish are freshwater fish that live and migrate within the streams and lakes of the Columbia River Basin, but do not travel to the ocean as do andadromous fish. They have become particularly important to areas where anadromous fish runs have been blocked by natural or manmade obstructions. Resident fish continue to be a popular component of recreation associated with many of the storage reservoirs in the Columbia River Basin.

Production in Reservoirs. Drawdown of reservoirs for power production, irrigation, or flood control can affect game fish populations by altering the physical and blological characteristic within the reservoir. Lowered elevations reduce the productive shallow areas near the shoreline. This can result in reduced habitat (particularly spawning habitat) for both game fish and their food organisms. Increased reservoir fluctuations can change water temperatures or expose nests, killing the eggs. Table $\mathrm{H}-1 \mathrm{a}-1$ contains information on critical months for spawning of resident game fish.

Table H-1a-1

\section{Critical Months for Reservoir Game Fish Spawning}

\begin{tabular}{|c|c|c|c|c|}
\hline \multirow{2}{*}{ Species } & \multicolumn{4}{|c|}{ Reservoir } \\
\hline & $\begin{array}{l}\text { Hungry } \\
\text { Horse }\end{array}$ & Libby & $\begin{array}{l}\text { Grand } \\
\text { Coulee }\end{array}$ & Dwor shak \\
\hline $\begin{array}{l}\text { Kokanee } \\
\text { Cutthroat } \\
\text { Rainbow Trout } \\
\text { Dol'y Varden } \\
\text { Walleye } \\
\text { Smallmouth Bass } \\
\text { Mountain Whitefish }\end{array}$ & $\begin{array}{l}\text { N/A } \\
M a y-j u l y \\
\text { April, May } \\
\text { Aug.-Oct. } \\
\text { N/A } \\
\text { N/A } \\
\text { Nov. -Jan. }\end{array}$ & $\begin{array}{l}\text { Sept. -Nov. } \\
\text { May-July } \\
\text { April, May } \\
\text { Aug.-Oct. } \\
\text { N/A } \\
\text { N/A } \\
\text { Nov.-Jan }\end{array}$ & $\begin{array}{l}\text { Sept.-Nov. } \\
\text { N/A } \\
\text { April, May } \\
\text { N/A } \\
\text { April, May } \\
\text { April-July } \\
\text { Nov.-Jan. }\end{array}$ & $\begin{array}{l}\text { Sept.-Nov. } \\
\text { May-July } \\
\text { April. May } \\
\text { Auq.-Oct. } \\
\text { N/A } \\
\text { June-July } \\
\text { Nov.-Jan. }\end{array}$ \\
\hline
\end{tabular}

The primary Federal reservolrs of concern are Hurigry Horse and Libby reservolrs located in northwestern Montana, Grand Coulee on the Columbia River in central Washington, and Dworshak Reservoir on the Clearwater River in Idaho. Common game fish species in Hungry Horse include westslope cutthroat trout, Jolly Varden, and mountain whitefish. Westslope cutthroat being the prlmary species sought by angles. Westslope cutthroat generally spawn from May through July and achieve most of their growth during the september through November period. Common game fish species in Libby Reservoir include western cutthrodt trout, rainbow trout, Dolly Varden, and kokanee salmon. Grand Coulee iports an economically valuable recreational fishery for walleye and rainbo wut. The most popular sport fish caught in Dworshak is the kokanee salmon lowed by rainbow trout and smallmouth bass. 
Information remains limited on the extent of biological impacts to resident fish associated with changes in seasonal draft of the reservoirs. Based on past consultations with the U.S. Army Corps of Engineers (Corps) and the Montana Department of Fish, Wildlife, and Parks (MDFWP), decreased reservoir elevations are considered to have the potential for adverse fishery impact if they occur during the April through November period of biological activity, September through November being most important for fish growth. Likewise, increases in reseivoir elevations are considered to have the potential for fishery benefits when occurring in the same time period.

The changes in reservoir elevations associated with the various alternatives under study, as simulated by the Systems Analys is Model (SAM), were analyzed for Hungry Horse, Libby, Grand Coulee, and Dworshak. The following reservoir statistics were evaluated:

a. The average end-of-period elevations ( 14 periods, 20 contract years). Analyses were broken down into three groups by runoff condition: (1) the lowest 10 percent of the runoff years; (2) the middle 80 percent of the runoff years; and (3) the highest 10 percent of the runoff years (Appendix $\mathrm{H}-\mathrm{l} \mathrm{j}$ ).

b. Frequency of end-of-period elevation changes from the No Action case greater than 5 feet for the years 1991, 1993, 1995, 1997, 2001, and 2005 (Appendix H-lK).

Production in Streams. The Kootenai River below Libby Dam and the Flathead River Below Hungry Horse Dam support important populations of resident game fish, specifically, kokanee in the flathead river system and westslope cutthroat, rainbow trout, and Dolly Varden in the Kootenai River. Reduced flows below the dams can interfere with spawning, incubation, emergence, rearing, and migration of resident fish and can lower the production of aquatic fish food organisms. In addition, lack of high spring flushing flows can create sediment problems. To protect fish populations in the Kootenai River the Council has recommended that Libby Dam be operated to provide a minimum flow of 4 thousand cubic feet per second (kcfs) except in years of extremely low runoff, when no less than 3 kcfs should be provided.

To aid reproduction of kokanee in the flathead River, the Council has recornmended Hungry Horse Dam be operated to provide specified flows at Columbia Falls on the mainstem Flathead River. For spawning (October 15 through December 15), flows should be between 3.5 and $4.5 \mathrm{kcfs}$. An instantaneous minimum flow of at least $3.5 \mathrm{kcfs}$ is recommended at Columbia Falls throughout incubation (July I through October 15).

The kokanee that spawn in the Flathead River system below Hungry Horse migrate upstream from Flathead Lake. Currently, this population of kokanee is severely depressed. Montana Department of Fish, Wildlife, and Parks is in the process of developing a mitigation plan for the Flathead s;stem. It is uncertain at this time whether mitigation will include rebuilding the kokanee population. 
The changes in flows in the Kootenal River below Libby Dam and in the Flathead River at Columbia Falls below Hungry Horse Dam were analyzed for all months of the years 1991, 1993, 1995, 1997, 2001, 2005. The following flow changes were evaluated:
a. The average change in flow for each period (Appendix $\mathrm{H}-1 \mathrm{i}$ ).
b. The frequency of monthly average flows at Columbia falls that are:
(1) less than $3.5 \mathrm{kcfs}$ (all periods); (2) greater than $4.5 \mathrm{kcfs}$ October through December (kokanee spawning period); and (3) less than 4.5 kcfs January through September (kokanee incubation, emergence, and migration) (Appendix $\mathrm{H}-\mathrm{I} i$ ).
c. The frequency of occurrence of flows at Libby Dam that are less than 4.0 KCfs (Appendix $\mathrm{H}-1 \mathrm{i}$ ).

\section{Anadromous Fish}

The Columbia River Basin supports a large number of anadromous fish (species which migrate downriver to the ocean to mature, then return upstream to spawn). The principal anadromous fish runs in the Columbia Basin are steelhead trout, and three species of salmon (chinook, coho, and sockeye). These fish remain an important resource to the Pacific Northwest both for their substantial economic value to the sport and commercial fisheries, and for their high cultural and religious value to Columbia River Basin Tribes and others.

The development of hydroelectric projects on the Columbia and Snake Rivers has reshaped the natural flows of the rivers. Runoff during the spring is retained in storage reservoils for use during periods when flows are naturally low. Hydroelectric dams have transformed the rivers into a series of slow-moving lakes. Regulating river flows in this manner increases the capability to produce firm energy and provide flood control, irrigation and recreation benefits. But it reduces river flows during the spring and early summer when juvenile salmon and steelhead are migrating downstream to the ocean. Prolonged delays expose juveniles to predation and disease and can cause them to lose their ability to adapt to saltwater when they reach the ocean. Addition mortality occurs as fish attempt to pass each dam. Fish not guided through power nouse bypass systems or over spllilways can sustain 5 to 30 percent mortality passing through generator turbines.

Water Budget and Flow. In 1982, the Council established a Water Budget to increase river flows during the April 15 through June 15 period. This coincides with the peak out-migration of spring fish, predominately yearling chinook, steelhead, and sockeye which depend on adequate river flow for a successful migration. The Water Budget is a specified volume of water totaling 4.64 million acre feet (maf). Fish Passage Managers are responsible to call upon this volume to enhance flows when it will provide the greatest benefit to migrating fish. Separate Water Budgets were established for the mid-Columbia and Snake Rivers. Priest Rapids and Lower Granite dams are the respective points of Water Budget measurement. 
Flow data, as simulated from SAM was analyzed for the Dalles, Priest Rapids and Lower Grantte dams for each perlod of the 20 contract years. An average decrease in flow of greater than 5 kcfs at Lower Granlte and 10 kcfs at Priest Rapids, April through June was used to indicate the potentlal for delayed travel time (Karr 1982). Decreases of this magnitude would increase travel time by approximately I day for fish entering the Lower Snake or Mid-Columbia projects.

Analysis was broken out to shows gurs of ench alternative on flow during the lowest 10 percent of the water colititions (those in which the January through July runoff at The Dalles was less than 70 MAF), the middle 80 percent of the water conditions, and the highest 10 percent of the runoff conditions (The Dalles January through July runoff greater than 125 MAF). The following flow statistics were analyzed:

a. The mean change to monthly average flow at The Dalles, Priest Rapids, and Lower Granite (Appendix H...1f).

b. The frequency of Water Budget flows less than $115 \mathrm{kcfs}$ at Priest Rapids during the second half of April and May (Appendix $\mathrm{H}-1 \mathrm{~h}$ ).

\section{Hanford Reach Flow Regulation}

In 1988 BPA and the mid-Columbia operators signed a long-term Vernita Bar Agreement which specifies protection requirements :or fall chinook spawning, incubation arid emergence on Vernita Bar (located downstream of Priest Rapids Dam). Mid-Columbia operators are required to reverse load factor (maintain low daytimes flows which moves generation to the nighttime) during the spawning season, approximately October 15 through November. This attempts to promote lower spawning elevations on the bar as spawning occurs primarily during daylight hours. Flows required for incubation and emergence are determined by the spawning elevations which occurred the preceding fall, but are not required to exceed 70 k.cfs.

Simulated monthly averare flows from SAM were evaluated at Priest Rapids. Analyses were broken out to shows effects in different water conditions; low, medium, and high. The following flow statistics were analyzed:

d. The frequency of flows greater than $125 \mathrm{kcfs}$ in October and November at Priest Rapids (Appendix H-lg).

b. The frequency of flows less than 70 kcfs December through April at Priest Rapids (Appendix $\mathrm{H}-\mathrm{lg}$ ).

Spill. Anadromous fish must pass a series of dams on their way downstraan to the ocean. Fish must elther pass through the dams by way of the turbines or mechanical bypass systems (or be collected for transport by truck or barge), or pass over the spillway when water is being spilled. Until adequate bypass systems are installed at the dams, spill remains a necessary means of moving juveniles downstream. 
ro do this they must either pas through the turbines, find their way through mechanfcal bypass systems and continue their journey inriver (or be collected for transport via truck or barge), or pass over the spillway when water is being spilled. Until adequate bypass systems are installed at the dams, spill remalns a necessary means of moving juveniles downstream.

Spill is of three types: planned fish spll1; forced spill; and overgeneration spill. Planned fish splll is inplemented by the Corps annually in conjunction with the "Juvenile Fish Passage Plan;" it also includes spill levels specified by FERC for non-Federal projects. Forced spill occurs when flows exceed the hydraulic: capacity of the powerhouse at a particular project. Overgeneration spill is water that is spilled when energy markets are not sufficient to require full powerhouse generation. All three types of spill are useful in moving fish downstream. Changes in river operations have the greatest effect on overgeneration spill.

The change in mean monthly hydro system overgeneration spill was analyzed based on SAM data of 200 simulation for each period and for each year of the analysis (Appendix H-.. Id).

Survival. The analysis of downstream anadromous fish passage survival, as it may be affected by changes in spill and flows, was performed using a modified version of the Corps of Engineers' FISHPASS model. (A detailed description of the FISHPASS model is given in the Corps' model documentation titled "FISHPASS Model Concept and Application," March 1986.) BPA's version of FISHPASS has bean revised to include the Mid-Columbia Public Utility District dams, and to accept the spill and flow data from the SAM model.

BPA'S FISHPASS model simulates downstream fish passage survival for anadromous fish passing the Lower Snake, Mid-Columbia, and Lower Columbia hydroprojects during the April through August period of downstream migration. Juventle fish survival is calculated from the point of entry into the hydrosystem to below Bonneville Dam. Survival projections are developed for species entering at specific projects: for example, system survival to below Bonneville Dam is calculated for yearling chinook salmon entering the river system at Lower Monumental pool).

FISHPASS simulates project-specific system survival for yearlings (spring chinook and Snake River summer chinook salmon), subyearlings (fall chinook and Mid-Columbia summer chinook salmon), steelhead trout, and sockeye salmon. Yearling, steelhead, and sockeye tend to migrate in the spring, April through June, and subyearling in the summer, June through August.

Analytical Methods. Given the time, location, and number of hatchery and natural stocks of fish entering each pool, and the project/species specific characteristics for dam passage survival, pool survival, and travel time; FISHPASS uses the flow and spill information from SAM to compute the system survival (from point of origin) and the overall system survival for each species. Inputs and assumptions for the FISHPASS model can be found in Appendix G-2. A more detailed description of the FISHPASS model can be found in Appendix E-3 of the Final Intertie Development and Use EIS. 
FISHPASS uses 40 rather than 200 random simulations from SAM to determine average survival for a given year. Analysis is then performed on 6 years of the 20-year sequence. In this case, the years of study are 1991, 1993, 1995, 1997, 2001, and 2003. The survival statistics evaluated include:

a. The relative change in mean survival. (This is determined by taking the difference in survival between each alternative and the No Action Base Case and dividing the difference by the Base Case survival.) (Appendix H-le.)

b. The frequency of change in relative survival being greater than and less than 1 and 5 percent (see following paragraph). (Appendix H-le.)

A potential for impact is considered to occur if:

- the change in relative survival exceeds 1 percent; or

- the decrease in frequency of a survival change

- greater than 1 percent exceeds 30 percent; or

- greater than 5 percent, exceeds 5 percent.

A blological assessment for both the critical and noncritical stocks potentially effected by any of the alternatives is included in Appendix $H$.

Sensitivity Analyses. Six sensitivity studies were evaluated to determine their effect on the operation of the hydro system and on fish survival. They included: (1) high Pacific Northwest loads; (2) low Pacific Northwest loads; (3) high Pacific Southwest gas prices; (4) low Pacific Southwest gas prices; (5) high Pacific Southwest loads; and (6) low Pacific Southwest loads.

None of these six sensitivities caused the hydro system operate in a significantly different manner. Flows and reservoir operations remained within the limits examined for each alternative.

\section{Vegetation and Wildlife}

Reservoir elevations can affect wildlife, both directly and indirectly, through the timing, duration, and amount of release. Changes to system operations may result in increased fluctuations relative to existing system operations. However, all reservolr operations will always remain within the operational constrains set by the operating agencies and the physical characteristics of the dams.

The greatest effect on wildife of reservoir water level fluctuations, in the Columbia River is through effects on wildlife habitat. This can occur in three ways. First, any effect on prey or browse species of plants or animals will have a corresponding effect on wildlife species. For example, water level fluctuations can affect shoreline vegetation, which may in turn affect deer and elk dependent on riparian browse, smaller mammals and birds dependent on aquatic insects or other riparian invertebrates, waterfowl dependent on aquatic vegetation or invertebrates for food, and mammals and birds dependent 
on fish for fool. This effect is especialiy important if vegetation is damaged at a critical time of the year, such as when deer and elk need it for winter food or waterfowl need it for shelter or nesting.

Second, erosion of islands would decrease habltat used for bird nesting and deer fawning, and also decrease the amount of shoreline used by reptiles for laying eggs. This is most significant on small islands where such areas may be in short supply.

Third, during low water perlods, land bridges may be formed to river islands allowing predators easy access to habitat that would otherwise be inaccessible. This is of particular concern a few months out of the year when nesting and fawning is taking place, or when inigratory birds use the lslands as resting places. However, effects can be long-term if substantial predation occurs during the breeding seasons.

Hydroelectric operations may also have direct adverse effects on wildlife. For example, beaver and muskrat can drown when rapidly rising water inundates their dens; or bird nesting and deer fawning islands may be flooded when young are present; or dormant reptiles (summer or winter) may be affected near the low-water levels. Banksloughing caused by erosion could destroy nests of such species as swallow and king fisher; rapidly dropping water levels could strand and dessicate anphibian egg mases.

In accordance with the Endangered Species Act (16 U.S.C 1531 et. seq.), BPA actions must avoid jeopardizing the existence of any endangered or threatened species. The biological assessment of effects on endangered or threatened species is contalned in Appendix $L$. 
$H-1 b$

Background on Fish, Wildlife and Vegetation Impacts Due to Fossil Fuel Fired Plant Operations 
Background on FIsh, WIIdIIfe and Vegetation

Impacts Due to Fossil Fuel Fired Plant Operations

\author{
WATER USE AND FISH
}

As discussed elsewhere in Section 4.3, Intertle dectstons may affect the operation and construction of power plants. Thls sectlon addresses how such changes may affect water use and supply, and flsh resources. It dlscusses, by power generation plant type, how the operation of the power system ma affect water resources and fish.

Overview and Summary

Changes in the operation or composition of the power system iesulting from changes in power sales contracts, may affect water use, water supply, and fish by several means, including changes in hydroelectric and thermal plant operations.

\title{
PLANT OPERATIONS
}

The operation of a thermal generating plant requires that fuel be acquired, prepared, transported, and consumed, and that any wastes be dlsposed of. Hydroelectric plants, whlle requiring none of these steps, can stlll significantly affect aquatlc resources. The discussion below focuses on how the operation of fossil fuel fired power plant types may affect water resources and fish.

$\underline{\operatorname{Cod} 1}$

Surface mining may affect both, surface water and groundwater. Water bodles can be contaminated by fuels; ierbicldes; blasting residues (ammonlum nitrate); polychlorinated blphenyls (PCBs); and trace elements leached from piles of soll and other materlals removed during surface mining, and later used to reclaim tile site ("spoll plles"). If water is used In the mining process, the water table may be lowered, indirectly affecting streams, lakes, and other water resources. Where water is scarce (as in the nor thern Great Plains, and Rocky Mountain regions), livestock, wildlife, and human consumers may be affected. Water use is heaviest for irrigating revegetation projects at mine sites. A typlcal water requirement for a surface mine is around 360,000 gallons per average negawatt of energy produced by the coal that is mined.

Strip mining removes vegetation and disturbs the ground, leading to increased runoff, erosion, and wind-blown dust. Increased sediment and silt deposition in nearby waters may reduce the kind and number of invertebrate fauna and fish species. Less light penetrates the waters and primary production is reduced. Increased runoff also increases nutrient loading, which at higher levels may reduce fish populations while increasing vegetation (eutiophication). 
Runoff from surface dtsturbances becomes more rapld during storils and may affect the varlabllity of streanflows, changlng flow reglong can change flsh habltat, and may shift spectes abundance Bovee, 1982; Ralolgh ot al, 1984; Moyle and Nichols, 1974). Temperature and oxygen content of the water may also change (Garcla et al., 1985).

Most detrlmental lmpacts on water resomces can be mlnlmized by suppresilng dust, controlling eroston, and treating runoff wates s la settilng ponds to collect sediment or hazardous materlal. Many of the lmpacts dlscussed above are regulated by Federal. State, and local minlng laws. The Surface Mlnting Control and Reclamatlon Act of 1977 mandates sitate perinlt systems governing environmental standards for maxlmum recovery of coal: restoration of land to its orlgtnal contour; use of explosives; wasto dlsposal; constriction of access roads; and revegetatlon. Wastewater dlscharges from surface mtnes are also regulated under the Clean Water Act though walor guallty standards: effluent limtations for new and extsting somres; permit programs; and areawlde planning (Offlce of Technology Assessment, 19\%). The Clean Water Act requlres the best practicable control technology currentily avallable for area runoff from coal mines. All Western surface mines currently operate In complfarce with the Surface Mlning and Clean Water Acts (M. Shlliling, personal communtcation). Assuming that compllance continues, the power sales contract induced indrect effects related to coal minting upon water use will be negliglble.

Coal transportation has mintmal impacts on water resources. Dust may enter the water, but only when roads or train tracks are near water. Coal processing and storage has 11 tte or no lmpact on water use. Since western solls are largely alkallne in the area of coal storage plles, actalc dratnage is not likely to be a problell, as the natural alkallntty in the soll quickly neutralizes any acidlc runoff.

At many plants, limestone is used in alr pollution control processes. Limestone preparation and storage generate dust and runoff, which can carry calcium, carbonates, bicarbonates, and other dissolved and suspended solids to local waters, increasing thelr hardness and alkallnity (Dvorak et al., 1978; APHA, 1980). Impacts from llmestone processing and storage are site-specific, depending on amount of limestone, rainfall, runoff potential, the size of receiving water body, and environmental controls. Runoff and dust controls are required under the Federal Water Pollution Control Act (1972), as amended (Clean Water Act), and under the Resource Conservation and Recovery Act (Office of Technology Assessment, 1979; Hittman, 1974).

The major impacts on water use and fisherles associated with the coal piant fuel cycle are related to coal combustion: the acidification of natural water bodies via alrborne pollutants ("acid rain"); and water consumption, heat discharge, and fish entralnment related to plant cooling. 
Acld Deposit!on

Finl sistons from coal plants have been ldentifted as a factor In acid preciptiation in some parts of the country. However, the contributions of Indlvidual solrces of emlsstons are relatively small, and becallse the emlsislons and the re products are often transported great dlstances by complex metecrologlcal processes, acld precipltaton ts a regtonal problen that has proved lomposstble to llnk preclsely and quantitatively with particular sources (Dvorak et: al., 1978; Schlndler et al., 1981). Wt th intense ralnfall, decreases In laln pH (1.e., greater acidlty) have been observed downwind in close proxlmlty (wthln $5 \mathrm{~km}$ ) to coal-fired plants. In Western states, the water bodies that are more sensltive to acidffication are those at hlgh elevations In mountalnous areas (Potter, 1982; EPA, 1982; logan et al., 1982).

In generd there are $n o$ long records of acld deposition rates at any site in the West. However, as shown In Appendlx E, Table E-.8, some areas have recently expertenced ratnfall with a pH below that generally considered natural (pH 5.6) for pure ralla (Glbson, 1981). It is not possible to link the ply of ratin at these stations to discharges at indlvidual, or groups of, power" plants.

The major lmpacts of actd deposttion on water use and aquatic life can be summartzed as follows. Very actdic (low pH) runoff may enter streams and rivers qulckly and in large quantitles durtng perlods of snowimelt. Different fish spectes vary greatly in the $1 \mathrm{r}$ tolerance of low pH. Among the salmonlds present th the high mountaln streams, ralnbow lrut are most sensitive. Some specles are more sensittive at certaln times of the year; and smaller, younger fish are often more sensitlve than larger, older ones. Low pH may alter reproduction rates or may kill eggs, larvae, flngerlings, or adults. Death may be a direct response to low $\mathrm{pH}$ or to increased metal concentrations at low $\mathrm{pH}$ (e.g., aluminum toxicity). Increased acldtty may klll Indirectily, through gradual losses due to chrontc low-level contamination. Sensltive spectes may be elfminated from a community, and shifts may occur in predator-prey relationships, competition, or other communlty-level interactions. Other aquatic blota in the communtty may be simtlarly affected.

Aciuatic systems with a pH below 5.0 are generally very restricted in flshery resources, but these low pH levels are not now occurring in areas examined in thls EIS. The effects can be Illustrated by example from other U.S. reglons. About 90 percent of high elevation Adirondack (Now York) lakes that are acldifliad and have a pH below 5.0 are not supporting any fish life (Schofle!d, 1981). In Nova Scotia, nine rivers with a $\mathrm{pH}$ of 4.7 no longer support silmon or trout reproduction. In general, most lakes in the sierra Nevada have a low buffering capacity and $\mathrm{pH}$ levels between 6 and 7 (K. Tonnesstn, 1981). The acldity of Pardee and Hetch Hetchy reservotrs has been Increasing somewhat since at least 1954, but was not lower than 6.8 in the early 1980:'s (McCa11, 1981). At Shaver Lake, also in the Sterras, pH values were between 6.8 and 7.0 in 1986 and in the past 19 years were generally above 5.7 (excluding bottom readings). Readings varted with depth and location within the lake. 
At cialena lake in the Rocky Mountalns, acld raln has been rocorded (medn pll of 4.2 in the summer of 1980), alkalinlty levels were low, and the lake ph was about 6. The sources of the acldity were unknown (Harte, 1981), often, acldity cannot be llnked to speclflc power plants. Although hlgh altitude reglons in the study area are sensitive, they are not now exhlbiting slgnificant, negatlve impacts from the acld deposttion they are recelving.

\section{Trace Elements}

Coal combustion also releases particulates that can carry trace elements. These particulates may fall Inmedtately in wet or dry form or may be alrborne and fall far from the source. Trace elements react in complex ways fin acquatlo environments. The effects of these elements on btota can finclude acute mortallty, recuced survival and growth, tmpalred reproduction, structural damage, modffled behavlor, and reduced crop production (Potter, 1982). Effects on water bodles can also be insigniflcant, as water temperature, hardness, $\mathrm{pH}$, and dilution volume may modlfy toxiclity. A modeling study by Dvorak et al. (1977) concluded that, for a power plant in a given dralnage basin, a streain with a mean annual flow of 1,000 cublc feet per second provides enough dilution to reduce trace element concentrations to below levels toxic to aquatlc blota and current water quallty thresholds. Many streams near coal plants influenced by power contract decistons fall below this flow level durling at least part of the year. Most studles of trace element contamination near specific plants have shown few signlficant effects (Office of Technology Assessment, 1979). However, it is posstble that slgniflcant effects due to lower levels of contamination over wider areas may exist.

\section{Thermal Plant Cooling Systems}

The use of ground or surface water for cooling in a coal-ftred plant can adversely affect both water use and quantity. Further, aquatic blota may be drawn into (entrained in) cooling water intakes. The extent of such impacts depends on the water source (natural surface water, groundwater, or power plant reservolr), the type of cooling system (once-through or closed-recycle), and the organlsins present in the water bodles from which cooling water is drawn and to which it is discharged. Because the impacts on water quality and flsh due to the cooling cycle in oll/gas plants are essentlally the same as the cooling cycle lmpacts of coal plants, both types of lmpacts are covered here.

Closed-cycle cooling systems. These systems include cooling ponds and towers. They cool the plant by circulating water through the plant and then into a spectal pond or tower, where evaporation and exposure to alr cool the water. Water is recirculated through the plant and cooling tower or pond, and replenished only to the extent that it evaporates. These systems discharge heat to the atmosphere rather than to water. In general, entralnment of flsh is not a significant problem for these systems. However, evaporatlve losses can make water consumption very high (see Table H-1b-1). 
Water consumption can be a significant issue when the amount of the withdrawal due to plant cooling is high relative to the amount of water at the source.

For streams and rivers, this may be an issue only at certain low-flow periods, when additional flow reductions might be harmful to fish spawning and migration, and to other wildifelor uses. Cooling water consumption from underground sources can be an issue when the amount of the withdrawal is a significant portion of the total recharge of the aquifer.

Table H-1b-1

WATER REQIJIREMENT OF ALTERNATE COOLING SYSTEMS FOR FOSSIL FUEL POWER PLANTS

\begin{tabular}{|c|c|c|c|c|}
\hline \multirow[b]{2}{*}{ TYPE } & \multicolumn{4}{|c|}{ Acre-Feet/Average Annual MW } \\
\hline & Eväporation & $\begin{array}{l}\text { Blowdown } \\
\text { and drift } \\
\end{array}$ & $\begin{array}{l}\text { In Plant } \\
\text { Use } \\
\end{array}$ & $\begin{array}{c}\text { Net } \\
\text { Consumption }\end{array}$ \\
\hline Once-through & 8.7 & 0 & 1.1 & 9.8 \\
\hline $\begin{array}{l}\text { Mechanical Draft } \\
\text { Evaporation Tower }\end{array}$ & 13.6 & 6.9 & 1.1 & 21.6 \\
\hline $\begin{array}{l}\text { Natural Draft } \\
\text { Evaporation Tower }\end{array}$ & 12.8 & 6.4 & 1.1 & 20.3 \\
\hline Cooling Pond & 18.7 & 7.4 & 1.1 & $24.4 \pm 1$ \\
\hline Spray Pond, & 13.4 & 15.5 & 1.1 & 30.0 \\
\hline Dry Tower & - & - & 1.1 & 1.1 \\
\hline Wet/Dry Tower & $\begin{array}{l}\text { intermediate between } \\
\text { dry and wet tower }\end{array}$ & 1.1 & $4.3-21.4$ & \\
\hline
\end{tabular}

Adapted from Thomas (1975)

* Some contribution due to precipitation on pond.

Because closed-cycle cooling can cause substantial consumption of water through evaporation, consumption of ground and surface water was calculated for the power sales contract alternatives analyzed with SAM. Colstrip, Centralia, and Bridger draw makeup water from rivers, Valmy uses well water, and Boardman uses a cooling lake (Carty Reservoir) replenished by the Columbia River. All these plants use closed-cycle cooling systems.

Water consumption varies among power plants. Withdrawal requirements vary with evaporation losses, cooling system needs, and water quality. 
Entrainment. Changes in levels of generation are expected to have little influence on existing entrainment. Cooling water pumps at most plants usualiy operate at full capacity regardless of generation. Pumps are shut down only if the plant is idle for relatively long periods; for this reason, reductions in entrainment may not occur if the plant is being operated cyclically, as it might under an exchange, even though its average generation is less. If substantial reductions in generation occur, one of several pumps may be turned off (Bernard Rapan, personal communication, February 1986).

Cooling System Wastes. Substances added to condenser cooling waters to minimize corrosion, deposits, and biological growth may be toxic if released to ground or surface waters (Elonka, 1963). Power plant operations may also impair water quality by discharging cooling system water and boiler water containing dissolved solids. The impact depends upon site characteristics. Some generating units recycle these waters until they are evaporated, so no wastewater is released. This effect is considered comparatively minor and is not analyzed in this EIS.

Disposal of combustion wastes can also affect water quality. Water can be consumed if ash and slag wastes are slurried or sluiced to settling basins and storage ponds. Net water consumption is greatest if this water evaporates and least if it is released to surface waters (Table $\mathrm{H}-1 \mathrm{~b}-2$ ). Water use is higher in facilities that handle each combustion waste separately.

Wastewater may be released through a breach of storage dikes, overflow, or percolation to groundwater (Dvorak et al., 1978). Unintentional discharges should not occur if the facility is designed and operated in conformance with the Effluent Limitations Guidelines, New Source Performance Standards (NSPS), and provisions of the Resource Conservation and Recovery Act (Soholt et al., 1980; Hittman, 1974). Runoff from onsite waste ponds is unlikely if they are lined and if protective dikes are built high enough (Lewis et al., 1978). Most basins are designed to contain runoff from a once-in-10-years storm (Soholt et al., 1981). Excessive rainfall and/or dike failure may cause spills (Dvorak et al., 1978), but the wastewater would likely be contained on-site. Seepage can contaminate soil and groundwater, especially if waste is deposited as a slurry. However, storage ponds are lined in order to minimize such hazards.

Table H-1b-2

WATER REQUIREMENTS FOR WASTE DISPOSAL AT A COAL-FIRED POWER PLANT

TYPE

Bottom Ash

Fly Ash

Lime Sludge

Limestone Sludge

\begin{tabular}{cc}
$\frac{\text { Water }}{\text { No Recycling }}\left(10^{3} \mathrm{Gal} /\right.$ Average MW $)$ \\
\hline $47.3 \mathrm{a} /$ & $\frac{\text { Recycling }}{5.1 \mathrm{c} /}$ \\
$184.2 \mathrm{a} /$ & $19.7 \mathrm{c} /$ \\
$147.4 \mathrm{~b} /$ & $26.9 \underline{c} /$ \\
184.2 b/ & $33.8 \underline{c} /$
\end{tabular}

al Assumes slurry with 30 percent solids by weight.

b/ Assumes sludge with 30 percent solids by weight.

c/ Assume 70 percent solids by weight.

$$
H-1 b-6
$$


Qil and Natural Gas

The oil and natural gas industries have potential for significant adverse effects on ground and surface waters and aquatic life. Many of these potential effects result from unplanned events such as accidental spills or equipment failure. Although potential water quality and aquatic life impacts resulting from the provision of fuel oil and natural gas for electric power generation are significant, it is difficult to tie projected changes in generation at oil and gasufired power plants resulting from BPA's power sales contract alternatives to changes in operation of specific oil and gas industry facilities. Therefore, a quantitative andysis of the impacts of contract alternatives on water quality and aquatic life effects of the oil and gas industries within this EIS is precluded.

The environmental effects of oil and gas extraction ciepend on local site characteristics and the specific drilling method employed. Exploration can significantly affect water quality. Groundwater ma supply solvent for drilling muds and for well injection. Aquifers may be contaminated if drilling muds, fluids, brines, and hydrocarbons escape into porous

formations. However, casing and other techniques protect aquifers, greatly reducing the risk of contamination. Oil spills may occur at the wel1-head; however, these are typically confined, low-volume spills which do not seriously contaminate surface waters (Garcia et al., 1983).

Water quality problems resulting directly from operation of oil-and gas-fired power plants are minimal. However, oil and gas generation can lead to substantial consumption of ground and surface water for cooling, or to the entrainment of fish and the discharge of heated waters, as discussed earlier in this section. Impacts from limestone preparation and storage at oil plants, and from condenser cooling at oil and gas-fired plants, are the same as those discussed above for coal plants. The lower sulfur levels involved in burning oil (relative to coal) result in less scrubber sludge and ash waste (Dvorak et al., 1978). Gas combustion produces none of these wastes. Impacts of gas combustion are generically similar to but much less than those described fur coal.

\section{VEGETATION AND WILDLIFE EFFECTS OF THERMAL POWER PLANTS}

Through their effects on the operation of thermal plants, decisions on power contracts have the potential for impacting vegetation and wildiife. This section considers the effects of cranges in the operations of codl, oil, gas, and nuclear generation facilities on these environmental factors.

Coal Mine Effects. Strip-mining involves excavation, backfilling, and grading that removes vegetation from large tracts. This affects wild ife primarily through loss and disturbance of habitat. Displacement of species may cause species to move into adjacent areas, where overcrowding and competition for limited resources may increase mortality, especially in critical habitat 
areas. (Other sources of information on wildlife impacts include an annotated bibliography by Rolston, Hilbut, and Swift (1977), and a summary of practices to protect fish and wildlife on mined lands in Utah by Procter et al. (1983)).

Uncontrolled runoff and the resulting soil erosion may contaminate surface and groundwaters, altering species composition and soil characteristics.

Accidental fires may temporarily affect vegetation and wildife. Hauling of coal and overburden may result in noise, dust, air emissions, soil compaction, and road-kills.

Exploration and mine development involve the use of drill rigs and test pits which have localized impacts on soil, vegetation, and wildlife due to grading, clearing, noise, dust, runoff, excavation, and related activities, but on a far smaller scale than actual mining operations. By delaying mine

development, the Intertie could have a beneficial effect. Mines will operate within standards set by the U.S. Department of the Interior and other governmental standards and therefore will not affect Federally listed threatened and endangered species. Therefore, mine operation's will have no impacts on threatened and endangered species or the ir habitat.

Reclamation attempts in the Northern Great Plains and Rocky Mountains have typically succeeded in establishing nonnative plant cover. The reclamation of Western coal mines is hampered by a combination of nutrient-poor soll and arid or semiarid climate. All reclamation efforts to date require high inputs of energy, manpower, fertilizer, and water. In effect, these reclamation activities have been short-term in nature and have required high maintenance levels (Curry, 1980; R. Giurgevich and M. Moxley, Wyoming Department of Environmental Quality, personal communication, 1985). To be successful, reclamation requires 15 years or more for long-lasting results. (NAS, 1974; Aldon, 1978).

The Rosebud Mine in Montana, and the Belle-Ayre and Bridger Mines in Wyoming are on Federal lands and are operating under permits granted by the office of Surface Mining (OSM). Permits require compliance with the Natioml Environmental Policy Act (NEPA), including a requirement dealing with threatened and endangered species. The U.S. Department of the Interior must approve the permit and assure compliance with all Federal laws including the Thieatened and Endangered Species Act (Holbrook, 1987, personal

communication). These permits apply only to a certain surface area; if expansion is necessary, a new permit must be obtained. All NEPA requiremerits and other applicable laws such as the Threatened and Endangered Species Act must be reviewed again.

\section{Coal-Fired Plant Effects}

For existing coal-fired plants, impacts on vegetation and wildlife can occur from increased water withdrawals for cooling or increased return-water temperature. Tables 1.2.1, 4.1.3, 4.1.5, and 4.3.2 in Chapter 4 of Volume 1 of this EIS show projected maximum changes in water withdrawals for the plants considered in the SAM analyses. Maximum changes in water consumption shown in these tables are small. 
Coal-fired power plant emissions may affect wildlife directly and indirectly. The direct effects of these emissions on wildlife involve acute or chronic exposure to gaseous or particulate substances contained in stack gases. Animal response to air pollution varies seasonally and in relation to habitat quality, sex, and age. Indirect effects on wildlife occur through contaminated food sources and habitat. Species that are most susceptible to such indirect effects include eagles, ospreys, kingfishers, and other fish-eating birds; bears; and water-associated maminals such as mink, beaver, and river otters. However, all projected changes in ambient air quality are so small that changes in effects on vegetation and wildlife of air pollution would be negligible (see Appendix $\mathrm{H}-7$ ).

Dvorak et al. (1978), and Dvorak and Pentacost (1977) cite modeling studies to suggest that trace elements may have relatively little impact on terrestrial organisms and their communities, provided that the power plants meet New Source Performance standards (NSPS) for particulates, and provided that tall stacks are used.

Of the primary gaseous pollutants, $\mathrm{SO}_{2}$ is likely to have the greatest impact on terrestrial ecosystems, particulariy on vegetation. Gases such as $\mathrm{SO}_{2}$ and $\mathrm{NO}_{2}$ can damage plants by destroying all or part of their foliage, reducing vegetation biomass and species diversity, or damaging reproductive ability (Gordon and Tourangeau, 1974). It has been determined that the alternatives analyzed with SAM will produce no significant change in air quality.

Acid deposition may also affect terrestrial environments and wildlife. The impacts of acid deposition are reviewed in Dvorak et al. (1978), Gage (1980), Peterson and Adler(1982), and Newmann (1980). Bark beetle attacks in ponderosa pine forests, for example, are more prevalent and devastating when trees are injured by oxidants (Wood, 1973). Parts of Arizona, New Mexico, Washington, Oregon, and Idaho may also be subject to acid deposition. Steep slopes with thin, rocky soils, and riparian habitats are particularly vulnerable locations (Peterson and Adler, 1982).

Acidification of lakes and streams may change the composition and structure of aquatic vegetation, affecting riparian wildiife, particularly amphibians. Acid deposition has been shown to produce changes in soil pH and water chemistry to such a degree that aqualic and terrestrial producers have drastically declined, resulting in subsequent loss of primary and secondary consumers (Gage, 1980).

Because terrestrial vertebrates are protected by feathers, fur, or scales, the direct effects of acid deposition are minima?. Acute direct effects on animals are restricted to areas very near point sources of the acidifying air pollutants. Such effects as irritation of eyes or respiratory tract (Newinann, 1980) can lead to emigration, abnormal behavior, or reductions in inter-and intra-specific competitiveness (Chilgren, 1978). 
Chemicals added to cooling-tower waters to prevent corrosion in the pipes can be released with drifting vapor from cooling towers, and may be deposited on the ground nearby. Trace amounts of heavy metals, including arsenic, cadmium, lead, chromium, and mercury, have also been found in tower drift. Salt drift from plants cooling with ocean water may lead to vegetation shifts where salt..intolerant species are prevalent (BSAI, 1982.).

Impacts of diverting water for use in coal plants depends on the source of the water, particularly if diverted from surface drainages. There may be some reduction in the amount of riparian vegetation, a shift in composition to less moisture-dependent species, and a reduction in the habitat value to wildife. This would be of greatest concern in arid environments.

Where spills or seepage from coal plant waste storage ponds contaminate soil or groundwater, vegetation may accumulate toxins and pass them on to herbivores. Dvorak et al. (1978) discuss the adverse effects of unlined ash and waste-disposal sites on groundwater and terrestrial food chains. Leaching from lined sites is negligible (Soholt et al., 1981). The Resource Conservation and Recovery Act forbids placing waste storage facilities in environmentally sensitive areas (e.g., wetlands), in criticai habitat for endangered species, in selsmically active areas, or within recharge $z$ les of sole-source aquifers (Soholt et al., 1981). Waste-handling facilities cannot discharge pollutants into surface waters in violation of the requirements of the National Pollution Discharge Elimination System established through the clean Water Act. Therefore, only accidental spills or poorly operated facilities are likely to affect vegetarion and wildlife.

Disposal ponds may attract waterbirds, especially if there are nearby sources of food. Birds using these ponds for resting ard feeding can ingest potentially toxic particles or slag. Surface-feeding waterfowl are most vulnerable to ingesting slag, which may contain beneficial as well as detrimental trace metals. Birds may also collide with transmission towers and lines situated close to the ponds. There would be a slight change in the amount of ash deposited into disposal ponds as a result of the power sales contract alternatives.

Gas and Oil-Fired Power Plant Effects. Air pollutants emitted by oil or gas plants affect wildiffe and their habitat much as those emitted by coal plants, but the magnitude of these impacts are much smaller in most cases, because of the lower level of emissions from oil/gas plants. Effects on vegetation and wildlife related to air quality from changes in operation of oil/gas plants are negligible since the projected ambient air quality differences (see 4.3 .3 ) are so small.

Nuclear Plant Operations. Effects from nuclear power plants depend on the plant's location and cooling system used. Nuclear plants produce radioactive waste, radioactive emissions, waste heat, and chemical residuals from the cooling water system. The impact of nuclear power plants on terrestrial vegetation is most likely to oncur through the deposition of drifting steam that is released from cooling towers. This drifting steam can damage nearby 
vegetation, especially if salt water is used for cooling. Improved engineering design can control the problem through the use of baffles or drift eliminators, which reduce the amount of water droplets in the air stream.

Thermal discharges from once-through cooling systems near estuaries could affect terrestrial wildife and vegetation through a change in distribution of some marine fish. Waste heat released in other areas does not appear to affect wildife or vegetation. Operation of existing nuclear plants are not projected to change with power sales contract alternatives. However, some alternatives do affect the liklihood of and timing of additional nuclear plant capacity being developed. 
$H-1 \mathrm{C}$

Overview of Columbia Basin Anadromous

Fish Stocks and Significance Analys is 


\section{SPECIAL NOTE \\ Effect on Fish Stock Analysis of Proposed Listings under the Endangered Species Act}

PLEASE NOTE: The fish stocks discussed in this appendix are those which were considered at the time of analysis to be potentially impacted by alternatives in the power sales contracts EIS. The analysis focused on Columbia River stocks and passage measures at projects through which those stocks must travel during migration. Since this analysis was completed, the National Marine Fisheries Service (NMFS), in response to petitions from fisheries groups, has proposed listing three species of snake River salmon as threatened or endangered species under the Endangered Species Act. The species proposed for listing are Snake River sockeye salmon, Snake River spring and summer chinook (as a single species), and snake River fall chinook.

Regional organizations with authority and activities affected by the proposed listings are working to develop plans to enhance the survival of these species through a variety of activities. Several short-term measures were implemented at federal hydro projects immediately following the proposed listings to improve inigration conditions for the candidate species. The Northwest Power Planning Council is considering amendments to its Fish and Wildlife Program. The U.S. Army Corps of Engineers, in cooperation with the Bureau of Reclamation and BPA, is considering alternative water management actions at lower Snake and Columbia River projects to help juvenile and adult migration in 1992 and beyond. Alternative actions are analyzed in the "1992 Columbia River Salmon Flow Measures Options Analysis/EIS." Simillarly, longer term options for system operation to enhance the survival of runs proposed for listing will be considered in the system Operation Review EIS, also under preparation by the Corps, the Bureau, and BPA.

Impacts discussed in this appendix are those of alternatives other than the proposed action. The proposed action continues current operations of the hydro system. The EIS analys is of the proposed action did not identify any additional impacts beyond those of current hydro operations. Actions adopted through the above planning efforts and changes in the survival of spectes proposed for listing as a result of those actions will supersede the analysis in this appendix of fishery impacts of EIs alternatives.

Initiatives taken in response to proposed listings will benefit system operations to enhance fish survival. Operations of the existing system will be subject to any new limitations adopted by project operators or imposed as part of a recovery plan if species are listed. Improved operations to protect fish runs would tend to diminish the fishery impacts of the EIS alternatives as described in this appendix. Measures to enhance the survival of species proposed for listing will also benefit other stocks discussed in this appendix.

In short, responses to proposed listings will reduce adverse impacts of EIS a! ternatives on fish. As a result, adverse effects of EIS alternatives on fish runs will probably be smaller than the EIS discussion states. 


\section{Overview of Columbia Basin Anadromous Fish Stocks}

A large number of anadromous fish stocks are produced in the Columbia River Basin. These include upper river spring and summer chinook, fall chinook, coho and sockeye salmon and steelhead trout.

Upper River Spring Chinook. Upper River spring chinook spawn throughout the Columbia and Snake River Basin's. The adults enter the Columbia River on their spawning migration in the spring with the run peaking at Bonneville Dam in April and May. The adults spawn in the fall. Juventles migrate to the ocean a year from the following spring as "yearlings." The upriver spring chlnook run averaged at 168,000 between 1939 and 1974. This average decllned in recent years to a 1975-1985 average of 85,000 fish, with d record low upriver run in 1979 of $51,500 \mathrm{fish}$. This compares to the management goal of 115,000 spring chinook over Bonneville Dam with 25,000 natural/wild and 10,000 hatchery fish over Lower Granite Dam. This was met in 1986 when 125,600 spring chinook passed over Bonneville Dam. The 1987 and 1988 rlln sizes were 103,200 and 92, 700 respectively.

Spring chinook are not harvested in significant number's by the ocean fishery. Prior to 1970, in-river fisheries harvested substantial numbers of fish, but due to declines in the run since that time, significant catches occurred only in 1977 and 1986. In 1988 the Columbia River Fish Management Plan (CRFMP) resulted from the settlement of the U.S. District Court case of U.S. V. Oregon (Case No. 68-513), through an agreement between the Federal agencies, Indian Tribes, and state agencies. This agreement entitles the Treaty fisheries to a minimum of 10,000 spring and summer chinook with the majortty being spring chinook. Treaty fishery harvest rates when runs are below the passage goal will not exceed 7 percent of the run. In 1988 the Treaty commerclal and ceremonial/subsistence fisheries harvested 6,429 spring chinook.

Upper River Summer Chinook. The Upper River summer chinook run contains two distinct runs divided between the Snake and the Upper Columbia rivers. Both groups return as adults to Bonneville dam in June and July. However, the snake River summer chinook liave a life-cycle similar to spring chinook in that the juventles migrate from the system as yearlings. In contrast. Upper

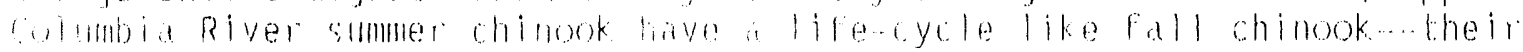

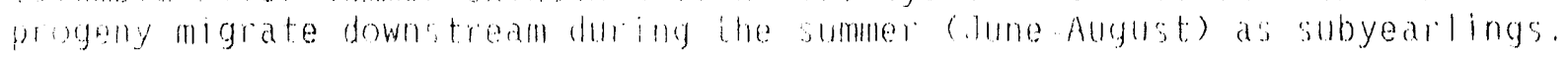

Both the Snake and Upper Columbia River summer chinook runs have decreased dramaticaliy in recent years. The 1938 -1969 average run at Bonneville Dam was $111,000 \mathrm{fish}$, while the $1978 \cdots 1987$ average was $26,000 \mathrm{fish}$. Since 1986 the average has been exceeded but the run is well below the management goal of 80,000 to 90,000 fish over Bonneville Dam.

summer chinook continue to be harvested in substantial numbers. The ocean firheries occur primarily in Alask and British Columbia. A 1989 estimate placed ocean havest at 62.9 percent of the stock. In river incidental havest of summer chinock does ocom and is limited to jacks during the steethead sport fishery and the lower r iver gill mel sockeye fishery; adults

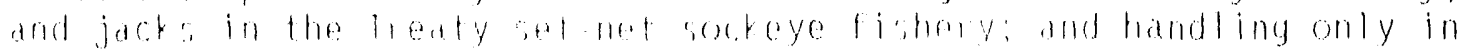


the lower river shad gf11...net fishery. In 1988, an estlmated 1, 100 summer chinook were harvested.

Fall chinook. While a limited number of some fall chinook migrate as yearlings, the majorlty of juventles move down river in thefr flrst summer as subyearlings. Adults enter the river to spawn from August through November, with counts peaklng at Bonneville bam during September. Fall chinook may be divided into two groups Tule and Upilver Bright. The Tule chinook are a lower river, predominantly Bonneville Pool Hatchery (BPH) stock which ts produced primarlly at Spring Creek Hatchery. BPH fall chinook malntalned their numbers well until 1982. Since then, the run has been depressed primarily due to hatchery disease problems.

Upriver Bright fall chinook are divided into two major segments, one which spawns in the Mid-Columbia River and the other in the snake River. The Mid...Columbia fish are for the most part, elther naturally produced in the free flowing Hanford Reach of the Columbla, are hatchery production from Priest. Raplds, and Ringold hatcheries or recent releases into the Yakima River. The Snake River population, until recently, was an entirely naturally produred run. The Lyon's Ferry Hatchery is now producing a substantlal number of snake River fall chinook.

Recently another group of fall chinook has been developed, this is the Mid-Columbia Bright (MCB). The MCB is comprised of brights reared and released at Bonneville Hatchery and brights from Bonneville, Little White Salmon, Spring Creek, and Klickitat hatcheries released in areas between Bonneville and McNary dams.

The Upriver Bright fall chinook count at McNary Dam has, since 1960, often fallen below the 40,000 adult escapement goal. For example, from 1974 to 1982, the escapement goal was not reached. It appears the decline is attributable to a virtual loss of the snake River segment of the run. The 1962-1977 annual average total Snake River fall chinook count was 16,400, compared to a 1975-1984 average of 2,000 fish. The Mid-Columbia segment, on the other hand, has grown in strength, with 1984-1986 counts vastly exceeding desired escapement levels. Both Tule and Upriver Bright fall chinook are heavily harvested in the ocean fisheries, Tules at 65.9 percent and Brights at 67.4 percent. Tules are harvested most heavily in the U.S. Coastal Fishery (39.9 percent), while Upriver Brights are harvested predominantiy in the British Columbia Fishery (40.6 percent). Both stocks are harvested in-river as well, Tules at 10.7 percent and Brights at 7.9 percent. Since 1983, the Pacific Fisheries Management Council has attempted to decrease the harvest of $\mathrm{BPH}$ Tules to allow the stock to recover.

Coho Salmon. Coho salmon runs above Bonneville Dam are small and are largely limited to the Bonneville Pool. Nearly 90 percent of the 1980-1984 average Bonneville Dam count of 22,468 adult coho remalned in the Bonneville Pool. Since the 1970's coho releases have occurred at the Rocky Reach-Turtle Rock complex, and recently releases of coho have begun in the Yakima and Umatilla Rivers, as outlined in the CRFMP. Efforts to obtain Snake River Brood Stock in 1983-1984 falled when no coho were trapped, even through dam counts indicated that a small number of coho were counted at the Snake River dams. 
Uprtver coho are harvested by ocean and in river flsherles. Harvest of stocks above Bonneville Dam th the Treaty Indian fisherles was 2, 300 in 1988.

Harvest have been minor due to restrictions to protect steelhead and because the run migrates only through the lowermost portion of the treaty fishing area enroute to Bonneville pool area hatcheries.

Sockeye Salmon. Columbla River sockeye orlginate from both the Snake and Mid-Columbla Rivers. By far the majority of the run, Mid-Columbta sockeye, comes from the Wenatchee and Okanogan Rivers. Over the perlod 1970 to 1984 , the Okanogan system annually produced 58.5 percent of the 77.895 fish total. Total sockeye numbers from the Mir-Columbia have been stable since 1970, except for recent filuctuation: $1985=166,500 ; 1986=58,100 ; 1987=$ $117,000 \mathrm{fi} i \mathrm{~h}$.

Sockeye are not harvested to any appreciable extent in the ocean commercial or sport fisheries. In-river fisheries have been sporadic, harvesting the larger runs when fish numbers exceeded escapement goal: $(65,000$ at Preist Raplds Dam). The CRFMP has set up harvest levels based on Bonneville Darii passage with harvest, by ceremonial/subsistence fisheries for runs under 75,000, not to exceed 7 percent of the run. The harvest is divided between Treaty and non-Treaty fisheries for runi above 75,000 sockeye salmon.

Steelhead Trout. Steelhead trout are widely distributed throughout the Columbla and Snake River Basins. Their broad geographic distribution is matched by the great span of their ruir timing. Steelhead cross Bonneville Dam every day of the counting season (March-November) and beyond. The summer steelhead migration is generally divided into an "A" run, distribution throughout much of the system, and a "B" run, which consists of larger fish destined for the Snake River. The "B" run crosses Bonneville Dam after August 25. The timing of the peak of the "B" run depends on the contribution of its sub-populations and has varied from mid-July to early september. In addition to the summer steelhead discussed above, winter steelhead return to several streams within the Bonneville Pool.

Juvenile steelhead migrate to the ocean in the spring, with timing similar to that of yearling chinook. Their age at migration is variable ( $1-4$ years), with 2 years as an average. Steelhead runs have increased substantially in recent years after reaching a low point in 1975. The 1986 Bonneville Dam total upriver run of 384,400 steelhead was exceeded only by the 1940 return of 422,800. The 1983-1987 "A" run sizes have all exceeded the 1969-1987 average of 121,000, with the 1988 minimum run size of 194,700 showing a decrease from the 1985-1987 highs. The "B" run from 1969-1985 averaged 58,000 fish. This figure has been exceeded each year since 1983, with the 1988 run reaching 90,200 steelhead.

Steelhead are not harvested in ocean fisheries and in-river commercial harvest by non-Treaty fishermen has been prohibited since 1975. Commercial harvest by the Treaty Indian fishery has averaged 78,400 steelhead during the period 1984-1988, a vast improvement over the 1979-1988 average of 43,800 steelhead. Lower river sport harvest also occurs with the 1988 harvest of upriver steelhead estimated to be 4,900 fish. Small numbers of steelhead are also harvested by the ceremonial and subsistence fisheries. No escapement goal has been set through the CRFMP for steelhead, but fisheries managers desire to continue to increase the run size. 


\section{Significance Analysis}

\section{Stocks Potentially Impacted by Power Sales Contract Alternatives Critical and Noncritical Stocks}

\section{Wells Pool}

Yearlings: Methow River Spring Chinook

Winthrop National Fish Hatchery Spring Chinook

Subyearlings: Methow River Summer/fall Chinook*

Okanogan - Similkameen River Summer/Fall Chinook*

\section{Rocky Reach Pool}

Subyerrlings: Wells Hatchery Summer/Fall Chinook*

\section{Rock Island Pool}

Yearlings: Wenatchee River Spring Chinook

Rocky Reach - Turtle Rock Complex Coho

Subyearlings: Wenatchee River Summer Chinook

Rocky Reach - Turtle Rock Complex Fall Chinook

\section{Lower Monumental Pool}

Yearlings: Tucannon River Spring Chinook *

Steelhead: Tucannon River Summer Steelhead

\section{In Nary Pool}

Yearlings: Yakima River Spring Chinook Yakima River Coho

\section{John Day Pool}

Yearlings: John Day River Spring Chinook Umatilla River Spring Chinook Umatilla River Coho

Subyearlings: John Day River Fall Chinook Umatilla River URB

* Indicate a critical stock. 


\section{The Dalles Pool}

Yearlings: Deschutes River Spring Chinook

WSNFH, RBH Spring Chinook

Steelhead: Deschutes River Summer Steelhead

Based on a relative decrease in survival of one percent in any year (FISHPASS) 


\section{WELLS POOL}

\section{Yearling Stocks}

The Fishpass model identified decreased system survival of greater than 1 percent for all yearling stocks originating from the Wells Pool, for the alternative 4.10 (Increase First Quartile-Type Interruptability 100 percent). There are two stocks identified in the Wells Pool: the Methow River spring chinook, and the Winthrop National Fish Hatchery spring chinook.

There is at present no sport or Indian terminal fisheries in the subbasin. Upriver spring chinook are harvested incidental to the Lower Columbia River winter gill-net, sport and Zone 6 (above Bonneville Dam) Treaty Indian fisheries. Seasons are regulated to minimize the number of upriver spring chinook harvested. As part of the U.S. vs Oregon agreement, Treaty Indian Commercial and Ceremonial and Subsistence fisheries are allowed to harvest 7 percent of the upriver spring chinook run up to 10,000 fish. The 1987 Treaty Indian Zone 6 harvest was 6,429 adults. It is assumed that even with this harvest that no significant numbers of Methow River or Winthrop NFH spring chinook are taken in any fishery.

Under alternative 4.10 the average system survival decreased 1.0 percent in 1 year and increased by 1.6 percent in another for yearling stocks originating in the wells Pool.

Methow River Spring Chinook: This run is a mixture of natural returning fish and fish from the winthrop NFH. This stock has shown improvement with an estimated return in 1985 of 3,433 fish, an increase from a low of 838 in 1979. The estimated return can include hatchery strays, and is still at a depressed level. Supplementation with Winthrop NFH stock in 1985 was 1,167,600, and in 1986 was 1,098,700 smolts, and will increase by 675,000 smolts as part of the Wells Settlement Agreement with Douglas County PUD.

The stock is considered to be managed as a critical hatchery - supplemented stock.

Winthrop National Fish Hatchery: This hatchery stock relies on returns to the Methow River and has used in the past stocks from Leavenworth NFH, Carson NFH, Little white Salmon NFH, and Cowlitz Hatchery. The present run is depressed with returns reaching a peak 1,200 in 1985 with an average return of 887 adults $(1982-86)$, which is an increase over the returns of less than 100 in the late 1970s. Spring chinook are managed as a hatchery stock with current production at 1.1 million smolts. In the U.S. Vs Oregon agreement, a provision calls for the production to increase to $1.4 \mathrm{million}$ smolts, and a future developement plan will increase production to 2.0 million smolts.

It is assumed that this run is a viable hatchery stock.

Subyearling Stocks

The Fishpass model has identified a decrease in system survival for subyearling stocks originating in the Wells Pool. The two stocks that are identified are the Methow River summer/fall chinook, and the okanogan - 
Similkameen River summer/fall chinook. Due to confusion which exists regarding the identification of discrete races of summer and fall chinook for these subbasins, the subspecies will be treated as one race (i.e., summer/fall (hinook).

There is presently no terminal sport or Treaty Indian fisheries targeting the summer/fall chinook in these subbasins. There are nc lower river fisheries that target summer/fall chinook but incidental harvest of summer chinook does occur and is limited to jacks during the steelhead sport flshery and the lower river gill-net sockeye fishery; adults and jacks in the treaty set-net sockeye fishery; and handling only in the lower rivei shad gill-net fishery. In 1987, out of a run of 33,000 , a harvest of 1,200 adults occuired in the zone 6 commercial and ceremonial and subsistence fisheries. It is assumed that insignificant numbers of summer/fall chinook from the llells Pool are taken in any fishery.

System survival for subyearlings under alternative 4.10 showed a decrease as great as 1.8 percent with other years, except one, showing decreases greater than 1.5 percent.

Methow River Summer/Fall Chinook: Spawning ground surveys show a decreasing trend for Methow River summer/fall chinook from a high in 1979 of 2,433 adults to 630 in 1985. This trend should show a turn around with the implementation of the Rock Island Dam Agreement which will increase the present release of 400,000 smolts by an additional 400,000 smolts It is possible an additional production of 410,000 smolts will come from the Wells settlement agreement depending on the success of the sockeye net pen rearing project. The stock is managed as a potentially critical supplemented stock.

Okanogan - Similkameen River Summer/Fall Chinook: The natural escapement has shown a slight rebound to a high of 2,244 adults in 1984 from a low of 526 in 1982. The 1977-85 average is 1,149 adults, with 1984 and 1985 showing a increase over the average. This stock has had no direct supplementation, but returns to Wells Hatchery may have entered the subbasin. As part of the Rock Island Settlement, 560,000 smolts will be released into the subbasin. The stock has been managed for natural production but will be enhanced with the above supplementation. The stock is managed as i critical natural

supplemented stock.

\section{ROCKY REACH POOL}

\section{Subyearling Stocks}

The fishpass model has identified a decrease in survival under alternative 4.10 for subyearlings originating in the Rocky Reach pool. There is one subyearling stock that has been identified in the Rocky Reach Pool: Wells Hatchery summer/fall chinook. Due to confusion which exists regarding the identification of discrete races of summer and fall chinook for this hatchery, the sub-species will be treated as one race (i.e., summer/fall chinook).

There is presently no terminal sport or Treaty Indian fisheries targeting the returns to the hatchery. Ther: are no lower river fisheries that target summer/fall chinook but inciderital harvest of summer chinook does occur and is 
limited to jacks during the steethead sport fishery and the lower river. gill-net sockeye fishery; adults and jacks in the treaty set net sockeye fishery; and handling only in the lower river shad gillwnet fishery. In 1987, out of a run of 33,000, a harvest of 1,200 adults occurred in the zone 6 commercial, and ceremonial and subsistence fisheries. It is assumed that insignificant numbers of summer/fall chinook. from the Wells Hatchery are taken in any fishery.

Under alternative 4.10 the average system survival for subyearlings originating in the Rocky Reach Pool wicreased by as much as 2.1 percent, with decreases occurring for all years.

Wells Hatchery Summer/Fall Chlnook: The hatchery traps brood stock for its rearing program from the fish ladder at Wells Dam. The only information available for stock returns are dam counts at Wells Dam. A high count of 6,696 adults occurred in 1979, the recent low of 1,975 adults was in 1983, and a slight decreasing trend is seen with returns of 2,772 adults in 1987 . The dam counts include brood stock trapped and summer/fall chinook bound for subbasins above Wells Dam. Wells Hatchery plans include production of 1,440,000 fingerlings and 250,000 yearlings for on station release. The hatchery also will produce 400,000 fingerilings for release into the Methow River, and possible additional production of 400,000 fingerlings for release into the Methow and Okanogan Rivers. The 1988 releases on station were 390,000 yearlings, and 1,963,000 fingerlings. This stock is managed as a potentially critical hatchery stock.

\section{ROCK ISLAND POOL}

\section{Yearling Stocks}

The fishpass model has identified an impact on the survival of yearling stocks originating from the Rock Island pool. There are two yearling stocks that originate in the pool, these are the Wenatchee River spring chinook, and the Rocky Reach - Turtle Rock Complex coho. The later of the two was not identified as a stock in the IDU EIS, but was identified as one in the NPPC's draft system Subbasin Planning report.

There presently is a terminal sport fishery that targets surplus hatchery returns to Icicle Creek and the Leavenworth Hatchery, some incidental harvest of wild fish does occur. Tribal harvest in recent years has concentrated on the hatchery stock. In 1985 the sport harvest was 4,280 adults, in 1986, the sport harvest was 4,717 adults.

Upriver spring chinook are harvested incidental to the Lower Columbia River winter gill-net, sport and Zone 5 (above Bonneville Dam) Treaty Indian fisheries. Seasons are regulated to minimize the number of upriver spring chinook harvested. As part of the U.S. vs Oregon agreement, Treaty Indian Commercial and Ceremonial and subsistence fisheries are allowed to harvest 7 peicent of the upriver spring chinook run up to $10,000 \mathrm{fish}$. The 1987 Treaty Indian Zone 6 harvest was 6,429 adults.

In the 1970 s a sport fishery targeting the coho returns produced by a new coho program at Rock Island Dam had several annual harvests exceeding 3,000 fish. 
Presently, pressure is very light, and the sport harvest of coho in the mid-Columbia is not available, but is assumed to be less than $50 \mathrm{fish}$. The coho returning to the Rock Island Pool are the early race of coho which use to predominate the areas above Priest Rapids. There is a major lower Columbia river fishery in the fall on returning coho salmon, mainly concentrating on stocks originating in the lower river below Bonneville Dam. There is a Treaty Indian fishery in Zone 6 above Bonneville Dam, but this is minor and limited by season and gear restrictions to protect upriver steelhead, and by the fact that most of the run is limited to returns to Bonneville Pool hatcheries. In 1987, the Zone 6 Treaty harvest was 2,300 adults, and in 1988 the harvest was 7,000 adults. This is the second highest harvest since 1973, the record harvest was 16,800 adults in 1986. Under U.S. VS Oregon, the management goal is to increase harvests in tributary fisheries.

The alternative 4.10 when compared to the Base Case shows a decrease in system survival for yearling stocks by as much as 1.5 percent for 1 year, but also showed increases of 1.7 percent and 1.3 percent in other years.

Wenatchee River Spring Chinook: This run consists of wild and Leavenworth National Fish hatchery returns, some straying of hatchery fish does occur. The Leavenworth NFH production goal to release 2,300,000 smolts into Icicle creek. The 1988 release was 2,337,500 smolts and 348,500 presmolts (greater than 30 to the pound). A possible future release sight in the subbasin would release 670,000 smolts as part of the Rock Island Settlement agreement. Total returns (hatchery, wild and sport harvest), increased in 1985 and 1986 to 18,998 and 20,345 adults from a low of 4,097 in 1981. The greatest increase coming in the wild portion of the run. This stock i; managed as a viable natural population and is not in critical condition, but consistent high returns are needed to allow a terminal fishery on the natural portion of the run. The hatchery portion of the run is managed for hatchery production, and in recent years the hatchery returns have shown an increasing trend, wilch is illustrated by the increased harvest opportunities below the hatchery.

Rocky Reach - Turtle Rock Complex Coho: The hatchery program at Rocky Reach was started in the 1970s after coho stocking programs for the Wenatchee, Entiat, and Methow rivers were discontinued in the 1960s. Lower river stocks are used to supplement hatchery returns which have been highly variable in the past. Returns have ranged from 260 in 1983 to 2,179 in 1984, and show a decreasing trend to 503 in 1986. The hatchery has used eggs from a number of sources: Lower Kalama, Elokomin, Washougal and Cowlitz hatcheries. Current production goal is 500,000 yearlings, the 1988 release was 417,000 . This stock is managed for hatchery production, and is in depressed, but not critical condition.

\section{Subyearling Stocks}

The fishpass model has identified a impact to subyearling salmon originating in Rock Island Pool. There are two subyearling stocks that originate in the Rock Island Pool: Wenatchee River summer chinook, and Rocky Reach - Turtle Rock Complex fall chinook, the latter was not listed as a stock in the IDU EIS, but was identified as one in the NPPC's draft System Subbasin Planning report. 
There are presently no terminal sport or Treaty Indian fisheries targeting the summer chinook returns to the subbasin. There are no lower river fisheries that target summer chinook but incidental harvest of summer chinook does occur and is limited to jacks during the steelhead sport fishery and the lower river gill-net sockeye fishery; adults and jacks in the treaty set-net sockeye fishery; and handling only, in the lower river shad gill-net fishery. In 1987, Out of a run of 33,000 , a harvest of 1,200 adults occurred in the zone 6 commercial, and ceremonial and subsistence fisherles.

Columbia River fall chinook salmon stocks consist of five groups: Lower River Hatchery, Lower River Wild, Bonneville Pool Hatchery (BPH), Upriver Brights (URB), and Mid-Columbia Brights (MCB). All five groups are targeted in the mainstem Columbia River by sport, commercial and Treaty Indian fishertes and by ocean commercial fisherias. The MCB portion of the run is comprised of brights reared and released at Bonneville Hatchery and brights from Bonneville, Little White Salmon, Spring Creek, and Klickitat Hatcheries released in areas between Bonneville and McNary dams. The URB portion of the run has set record returns with an estimated 400,000 in 1988, and a record high of 419,000 in 1987. Harvests of URB have also set records with 254,800 taken in the Commercial fishery and 14,500 taken in the sport fishery in 1987. Annual passage goals of 40,000 URB at MCNary Dam have been exceeded since 1983. Commercial gill-net harvests occurred in 1986 and 1987 in the area between Priest Rapids and Wanapum Dams, with the 1987 harvest totaling 2,215 chinook, and in 1988, 2,300 chinook were harvested. URB runs also have benefited from ocean and in river harvest regulations set to protect depressed returns of $B P H$ stocks.

Under alternative 4.10 the average system survival for subyearlings originating in the Rock Island pool decreased by a maximum of 1.7 percent, ranging down to .5 percent.

Wenatchee River Summer Chinook: Presently the stock is a wild run of fish with no hatchery supplementation. Returns to the subbasin have shown an increasing trend from a low in 1983 of 4,169 chinook to 10,609 in 1986. A possible facility as part of the Rock Island Settlement would produce 864,000 smolts from adults collected at Dryden Dam. This stock has been managed as natural stock but this will change if the facility is built. Presently it is an improving and viable stock.

Rocky Reach - Turtle Rock Fall Chinook: This is an URB hatchery stock, with production goals of 200,000 yearling fall chinook, with the 1988 release of 230,000 yearling fall chinook. URB fall chinook mainly spawn in the Hanford Reach area below Priest Rapids Dam, but spawning has been observed below Wells and Wanapum Dam. This is assumed to be a viable hatchery stock, managed for rarvest in the mainstem Columbia river

\section{LOWER MONUMENTAL POOL}

Yearling Stocks

The fishpass model has identified a decrease in survival under alternative 4.10 for yearling stocks originating in the Lower Monumental Pool. There is 
only one yearling stock identified in the Lower Monumental Pool: Tucannon River spring chinook.

There is presently no terminal harvest in the subbasin. Upriver spring chinook are harvested incidental to the Lower Columbia River winter gill-net, sport and Zone 6 (above Bonneville Dam) Treaty Indian fisheries. Seasons are regulated to minimize the number of upriver spring chinook harvested. As part uf the U.S. vs Oregon agreement. Treaty Indian Commerclal and Ceremonial and iubsistence fisheries are allowed to harvest 7 percerit of the upriver spring uhinook run up to $10,000 \mathrm{fish}$. The 1987 Treaty Indian Zorle 6 harvest was 6,429 adults.

The system survival for yearling stocks under alternative 4.10 recreased in 1 year by 1.5 percent, but showed increases of 1.8 percent and 1.1 percent in other years.

Tucannon River Spring chinook: The historic returns were estimated to average about 2,400 adults, with some returns exceeding 5,000 adults. The Lower Snake River Plan sets the mitigation level at 1,152 adult escapement. Since 1971, the annual escapement has averaged about 200 adult spring chinook. In 1987, the return to the WDF trap for the Tucannon Fish Hatchery was 203 adults. Stocking started in 1962 with a release of 16,000 k.lickitat stock; and in 1964, 10,500 Willamette River spring chinook stock smolts. In 1987, the first spring chinook release of Tucannon stock reared at Lyon's Ferry Hatchery occurred. In 1988, 150, 000 spring chinook smolts were released from the Tucannon Hatchery. The management goal is to build the stock to allow increased Treaty Indian harvest. The stock is now managed as a critical hatchery-supplemented stock.

\section{Stoelhead}

The fishpass model identified decreased survival for steelhead stocks originating in the Lower Monumental Pool when comparing alternative 4.10 to the Base Case. The only Steelhead stock originating from Lower Monumental Pool is the Tucall:ion River summer steelhead.

No harvest occurred in the Bas in from mid 1977 to 1985. Harvest still occurs in the Zone 6 Treaty Indian fisheries, and the mainstem sport fishery. In 1987, the Zone 6 harvest of summer steelhead was 71,800, and in 1986, the harvest was 64,100. The Basin sport harvest is 1 imited to hatchery fish only, with the release of all wild fish. The sport harvest in 1987 was 209 with an estimated escapement of 611, and in 1988, the sport harvest was 189 within estimated escapement of 905 summer steelhead.

The system survival for steelhead originating in the Lower Monumental Pool decreased by 1.1 percent in 1 year, under alternative 4.10 .

\section{Tucannon River Summer steelhead}

Supplementation of the Tucannon river summer steethead has occurred since 1936 with stocks from Tucannon/Touchet river, Priest Rapids, Wells, Skamania, Wallowa, and Lyon's ferry being used. The lower snake River plan has a goal of returning 3,400 adults to the Basin. Tucannon hatchery now being remodeled by LSRP. In 1988, 161,500 smolts from the Lyon's ferly hatchery were released 
in the Tucannon River. Returns to the Basin are below goals set by LSRP but show signs of improvement. The stock is managed as a hatchery supplemented natural stock.

\section{MCNARY POOL}

\section{Yearling Stocks}

The fishpass model has identified an impact on yearling stocks originating from the McNary Pool. There are two yearling stocks that have been identlfied in the McNary Pool: Yakima River spring chinook, and Yakima River coho.

Presently there is a Tribal subsistence fishery with in the Basin, with a future goal of increasing the Tribal exploitation rate to 25 percent of the run. Upriver spring chinook are harvested incidental to the Lower Columbla River winter gill-net, sport and Zone 6 (above Bonneville Dam) Treaty Indlan fisheries. Seasons are regulated to minimize the number of upriver spring chinook harvested. As part of the U.S. vs Oregon agreement, Treaty Indian Commercial and Ceremontal and Substistence fisheries are allowed to harvest 7 percent of the upriver spring chlnook run up to $10,000 \mathrm{flsh}$. The 1987 Treaty Indian Zone 6 harvest was 6,429 adults.

There is a major lower Columbia river fishery in the fall on returning coho salmon, mainly concentrating on stock originating in the lower river below Bonneville Dam. There is a Treaty Indlan fishery in Zone 6 above Bonneville Dam, but this is minor and limited by season and gear restrictions to protect upriver steelhead, and by the fact that most of the run is $1 \mathrm{imited}$ to returns to Bonneville Pool hatcheries. In 1987, the Zone 6 Treaty harvest was 2,300 adults, and in 1988 the harvest was 7,000 adults, this is the second highest harvest since 1973, the record harvest was 16,800 adults in 1986 . Under U.S. vS Oregon, the management goal is to increase harvests in tributary fisheries.

The alternative 4.10 when compared to the Base Case showed a 1 year decrease in system survival for yearling stocks of 2.1 percent. In another year, system survival increased by 1.3 percent, and the remaining years shows a slight improvement in system survival.

Yakima River Spring Chinook: Returns have varied in the past few years from a low of 1,324 in 1983 to a high of 9,452 in 1986, dropping to 4,390 adults in 1987. An estimated return of 6,000 adults is needed to meet hatchery and harvest goals. Supplementation has occurred since 1958 using Leavenworth, Carson and Yakima River stocks. Supplementation will increase with the completion of the Yakima/Kilickitat Production Facility, where production will be 1.6 million smolts annually. Two stock will be used, Naches River and Upper Yakima, and management will try to insulate the American River stock from supplementation. This stock is managed as a hatchery supplenented stock.

Yakima River Coho: This stock was not listed in the IDU EIS because it is a recent re-introduction to the Basin. No harvest of coho has occurred since the 1930s, and there are presently no estimates on returns. Under U.5. vs Oregon, 700,000 coho smolts will be released into the Yakima annually for 5 years (1988-1992) to diversify fishing opportunities. Future studies 
will determine if natural production is warranted. The Yakima/kilckitat facillty will release 2,009,250 smolts using 2,350 spawners, with the goal of producing a total return of 40,000 natural and hatchery adults. This stock is presently managed as a buflding hatchery stock.

\section{JOHN DAY POOL}

\section{Yearling Stocks}

The fishpass model has identified an impact on yearling stocks that originate in the John Day Pool. There are three yearling stocks that originate in the John Day Pool: John Day River spring chinook; Umatilla River spring chinook, and Umatllla River coho.

Upriver spring chinook are harvested incidental to the Lower Columbia River winter gill-net, sport and Zone 6 (above Bonnevflle Dam) Treaty Indian fisheries. Seasons are regulated to minimize the number of upriver spring chinook harvested. As part of the U.S. vs Oregon agreement, Treaty Indian Commercial and Ceremonial and Subsistence fisheries are allowed to harvest 7 percent of the upriver spring chinook run up to $10,000 \mathrm{flsh}$. The 1987 Treaty Indian Zone 6 harvest was 6,429 adults.

There is a major lower Columbia river fishery in the fall on returning coho salmon, mainly concentrating on stock originating in the lower river below Bonneville Dam. There is a Treaty Indian fishery in Zone 6 above

Bonneville Dam but this is minor and 1 imited by season and gear restrictions to protect upriver steelhead, and by the fact that most of the run is 11 imited to returns to Bonneville Pool hatcheries. In 1987, the Zone 6 Treaty harvest was 2,300 adults, and in 1988 the harvest was 7,000 adults, this is the second highest harvest since 1973, the record harvest was 16,800 adults in 1986 .

Under U.S. VS Oregon, the management goal is to increase harvests in trlbutary fisheries.

The alternative 4.10 when compared to the Base Case showed a decrease in system survival for yearlings as high as 1.7 percent with decreases in other years ranging from 0.2 percent to 1.4 percent.

John Day River Spring Chinook: Returns have increased from a recent low of 918 in 1980 to a high of 4,637 in 1987. The sport fishery has been closed since 1978, but there is a small harvest by Umatilla and Warm Springs Tribal members. The Tribal harvest in 1986 was 31, and, in 1987, was 41 adults. The goal for the Basin is to harvest 15 percent of the run in sport and Tribal fisheries, when the run at the mouth is over 5,000 adults, a smaller percentage when the run size is lower. There has been no supplementation of the John Day River spring chinook stock, and no future supplementation is planned. The stock will be managed as a wild stock, and is not in critical condition.

Umatilla River Spring Chinook: There are no run size records at present for this stock that is being re-introduced to the Basin. No harvest has occurred in recent years. There is planned a Umatilla Hatchery that will produce 1.29 million smolts annually, plus an additional 939,000 smolts will come from other sources (Carson stock, Lookingglass, Yakima, Rapid River, and 
Bonneville). In 1988, Bonnevflle Hatchery released 540,00 smolts into the Umatilla Basin. The planning goal is to get a return of 11,000 adults to the Basin. This stock is managed as a buflding hatchery stock.

Umatilla River Coho: Smolt releases first occurred in 1966-69 with no results, supplementation resumed in 1987 as part of U.S. vs Oregon with an annual release of $1.0 \mathrm{mflli}$ in smolts. Coho are stocked to support terminal and malnstem flsheries. In 1987, 29 Jacks returned, and in 1988 Tribal dip netting occurred with very few coho harvested. This stock is managed as a hatchery supplemented stock to enhance Tribal and mainstem fisheries.

\section{Subyearling Stocks}

The fishpass model identified an impact to subyearling stocks originating from the John Day Pool. There are two subyearling stocks that have been Identifled as originating from the John Day Pool: Jchn Day River fall chinook, and Umatilla River upriver bright (URB). The , lohn Day River fall chinook was identifled as a critlcal stock in the IDU EIS, but was not listed as a stock in the NPPC's System Subbasin Planning draft report, so it will not be included here.

Columbia River fall chinook salmon stocks consist of flve groups: Lower River Hatchery, Lower River Wild, Bonneville Pool Hatchery (BPH), Upriver Brights (URB), and Mid-Columbia Brights (MCB). All five groups are the targeted in the mainstem Columbla River by sport, commercial and Treaty Indian fisheries and by ocean commercial fisheries. The MCB portion of the run is comprised of brights reared and released at Bonneville Hatchery and brights from Bonneville, Little white Salmon, Spring Creek, and Klickltat Hatcherles released in areas between Bonneville and McNary dams. The URB portion of the run has set record returns with an estimated 400,000 in 1988, and a record high of 419,000 in 1987. Harvests of URB have also set records with 254,800 taken in the Commercial fishery and 14,500 taken in the sport fishery. Annual passage goals of 40, 000 URB at MCNary Dam have been exceeded since 1983. Commercial gill-net harvests occurred in 1986 and 1987 in the area between Priest Rapids and Wanapum Dams, with the 1987 harvest totaling 2,215 chinook, and, in 1988, 2,300 chinook were harvested. URB runs also have benefited from ocean and in river harvest reguiations set to protect depressed returns of $B P H$ stocks.

Umatilla River URB Fall Chinook: Returns have been improving since releases started in 1982. The 1985 Three Mlle Dam and carcass counts were 85 adults, in 1986, 435, and in 1987, 461, showing an improving trend. Umatilis/Irrigon facility will produce 5.94 million subyearlings and an additional 1.06 million subyearlings will come from the Bonneville Hatchery. Presently URB are being released from the Irrigon hatchery, in 1988 3,350,000 subyearlings were released. The goal of the master plan is to achleve a return of 21,000 adults of which 10,000 will be hatchery fish and 11,000 will be naturally spawning fish. This stock is managed as a building hatchery/natural stock. 


\section{THE DALLES POOL}

Yea!ling Stocks

The fishpass model identified an lmpact on yearling fish orighating fiom The Dalles Pool, under alternatlve 4.10. There are two yearling stocks that have Deen identlfled as orlglnating from The Dalles Pool: Deschutes River spring chlnook, and Warm Splings Natlonal Fish Hatchery (WSNFH), Round Butte Hatchery (RBH) spiting chinook.

Upilver spring chlnook are harvested Incidental to the Lower Columbla Rlver winter gill-net, sport and Zone 6 (above Bonneville Dam) Treaty Indlan fisherles. Seasons are regulated to mintmize the number of upriver spring chlnook harvested. As part of the U.S. Vs Oregon agreement, Treaty Indian Commerclal and Ceremonlal and Subsistence flshertes are allowed to harvest 7 percent of the uprlver spring chinook run up to $10,000 \mathrm{fish}$. The 1987 Treaty Indian zone 6 harvest was 6,429 adults. Sport and Tribal harvest of both stocks occur at Sherars falls.

The system survival for yearling stocks under alternative 4.10 decreases in all years. The range of derreases when compared to the Base Case was 0.3 percent to 1.6 percent.

Deschutes River Spring Chinook: This is a natural/wild stock that spawns naturally only in the Warm Springs River and in Shltike Creek. Warms Springs Hatchery passes fish to spawn naturally above the hatchery. Estimated escapement of natural/wild fish consistently above 1,000 since 1980, with 1987 escapement estimated to be 1,783 adults and jacks. Planning goals for the Basin is to have a natural run escapement of 1,300 adults. Some hatchery spawners may have been allowed to pass upstream from 1982 to 1986 diluting the wild stock. In 1985, the sport and Trlbal harvest was 648 jacks and adults, in 1987, it was estimated that 911 were harvested. This stock is assumed to be a viable natural/ wild stock, subject to a terminal fishery.

WSNFH, RBH Spring Chinook: Round Butte Hatchery is part of the PGE mitigation for Round Butte and Pelton Dams. Returns to WSNFH have fluctuated from a high of 1,079 in 1985 to a low of 346 in 1986, but showed an increase to 725 in 1987. RBH hatchery returns have shown better improvements increasing from a low of 453 in 1981 to high of 1,820 in 1986, with 1987 returns being 1,348 Jacks and adults. Excess adult returns to the Pelton Trap are given to the Warm Springs Trlbes or recycled to the Sherars falls fishery. In 1985, an estimated 1,656 hatchery jacks and adults were harvested by the sport and Trlbal fishery at Sherars Falls, in 1987, the harvest was 1,135. RBH releases 60,000 smolts and 210,000 subyearlings are stocked into the Pelton Fish Ladder for additional rearing capacity. WSNFH currently produces 700,000 smolts with a design capacity of 1.3 million smolts. In 1988 the WSNFH released 950,000 smolts and RBH released 54,000 smolts directly and 210,000 reared in the Pelton Fish Ladder. The stock is assumed to be a viable hatchery stock.

Steelhead

The fishpass model identified an impact to steelhead origlnating from the Dalles Pool. There is one stock of steelhead that comes from this pool: Deschutes River summer steelhead. 
Terminal sport harvest starts in July and contlnues to December. A Tribal fishery occurs below Sherars Falls, the recent harvest high of 3,800 in 1986 was above the 1980-87 average of 2,198 steelhead. The sport harvest reached a high in 1985 of 9,287 and for the same pertod 1980-87, averaged 4,731 steelhead. Harvest of wild steelhead was restricted in 1979 and has been prohlbited since 1987.

Harvest st 111 occurs in the zone 6 Treaty Indlan fisheries, and the mainstem sport fishery. In 1987, the Zone 5 harvest of summer steelhead was 71,800 , and in 1986 the harvest was 64,100.

Deschutes River Summer Steelhead: This is a natural/hatchery stock with supplementation occurring only in the upper river. Hatchery releases from Warm Springs NFH OCcurred from 1973-84 and are presently from Round Butte hatchery. The present RBH initigation goal is to get a return of 1,300 steelhead and releases 162,000 smolts. In 1988, 162,500 smolts were released into the Deschutes River. Subbasin goals call for escapements of 10,000 steelhead above Sherars Falls out of a total return of 16,000 to 22,000 steelhead. This is managed as a natural/ hatchery stock supporting a sport and Tribal fishery. 
$H-1 d$

OVERGENERATION SPILL

(incremental monthly) 


\section{KEY TO LABELS FOR ALTERNATIVES}

$\mathrm{H}-1$ d through $\mathrm{H}-1 \mathrm{~K}$

$\begin{array}{ll}\text { BA000MED } & \text { Base Case (No Action Alternative), Medium Loads } \\ \text { BD120MED } & \text { Alternative } 1.2 \text {, Medium Loads } \\ \text { BE410MED } & \text { Alternative } 4.1, \text { Case B }(100 \%) \text {, Medium Loads } \\ \text { BB415MED } & \text { Alternative } 4.1 \text {, Case A }(50 \%) \text {, Medium Loads } \\ \text { BA430MED } & \text { Alternative } 4.3 \text {, Medium Loads } \\ \text { BC440MED } & \text { Alternative } 4.4 \text {, Medium Loads }\end{array}$




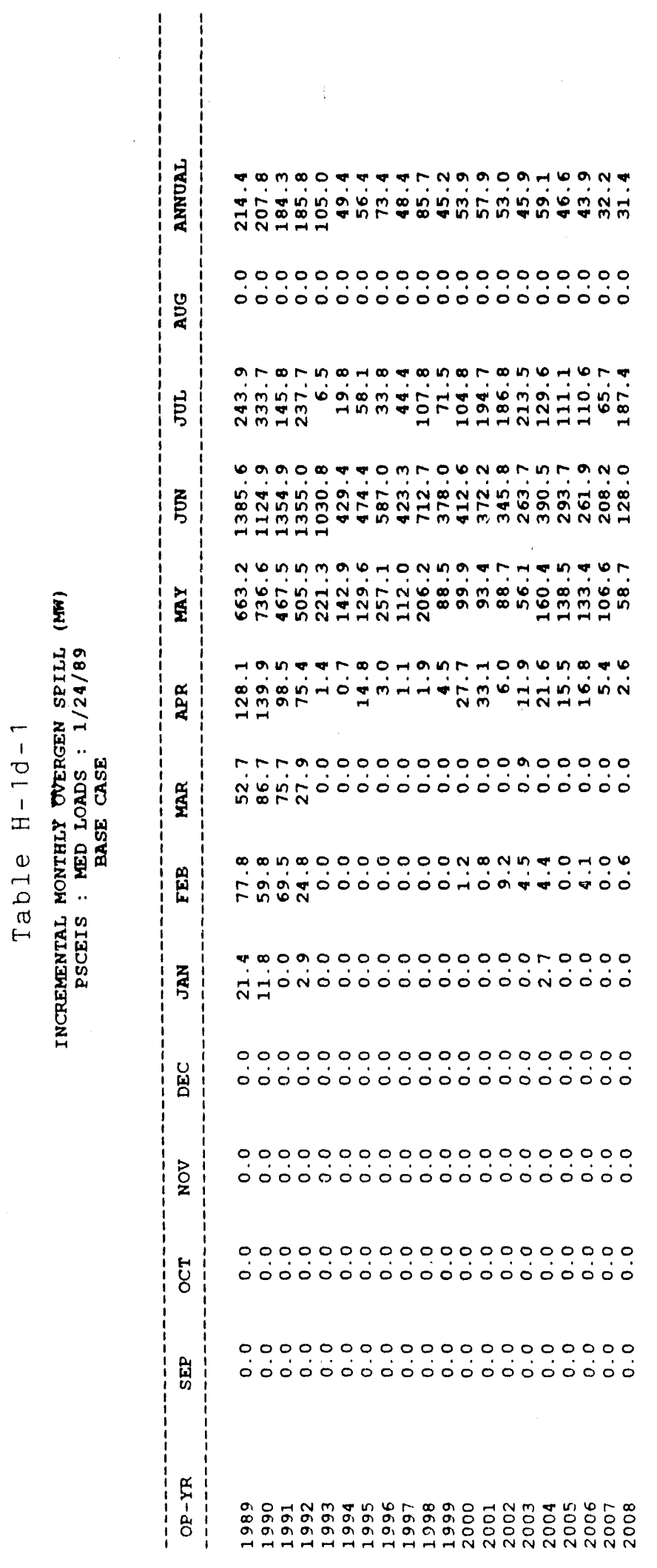


romoaromontoromm-rom

ดั

00000000000000000000 0000000000000000.

roromnomobaonmminam

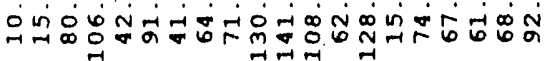

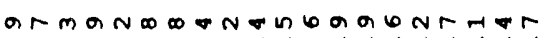

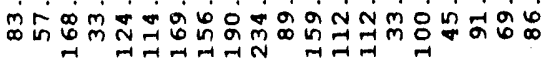

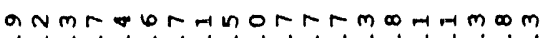
vंन

- nomunnrramromatnmin

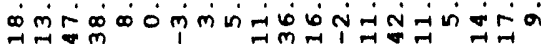

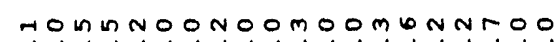
N 1

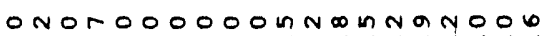
rifon in $m$ win $0000000000 \mathrm{H}$ in 0000 o 00000000000000000000 0000000000000000 00000000000000000000 00000000000000000 00000000000000000000 0000000000000000

00000000000000000000

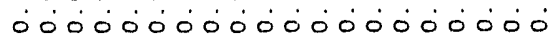

$\alpha$

이의

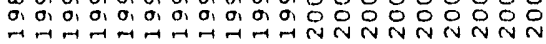




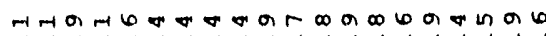

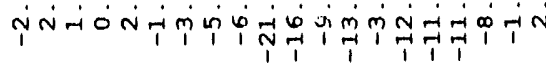
00000000000000000000

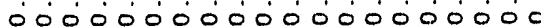

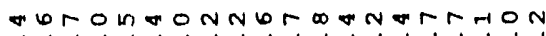
im

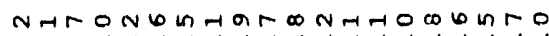

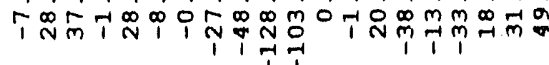

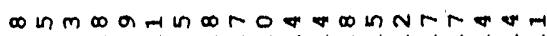
NNon

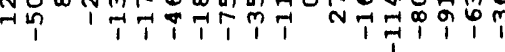

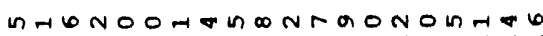

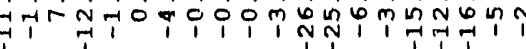
woramo00000000000000 Tinatró000000000000

$000000000 \mathrm{CONDONONDOOD}$ Oíñ

NTw 000000000000000000 ímióo

00000000000000000000 00000000000000000000

00000000000000000000 00000000000000000000

00000000000000000000 00000000000000000000

00000000000000000000 00000000000000000000

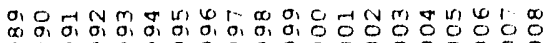

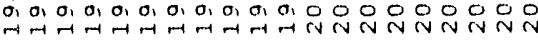




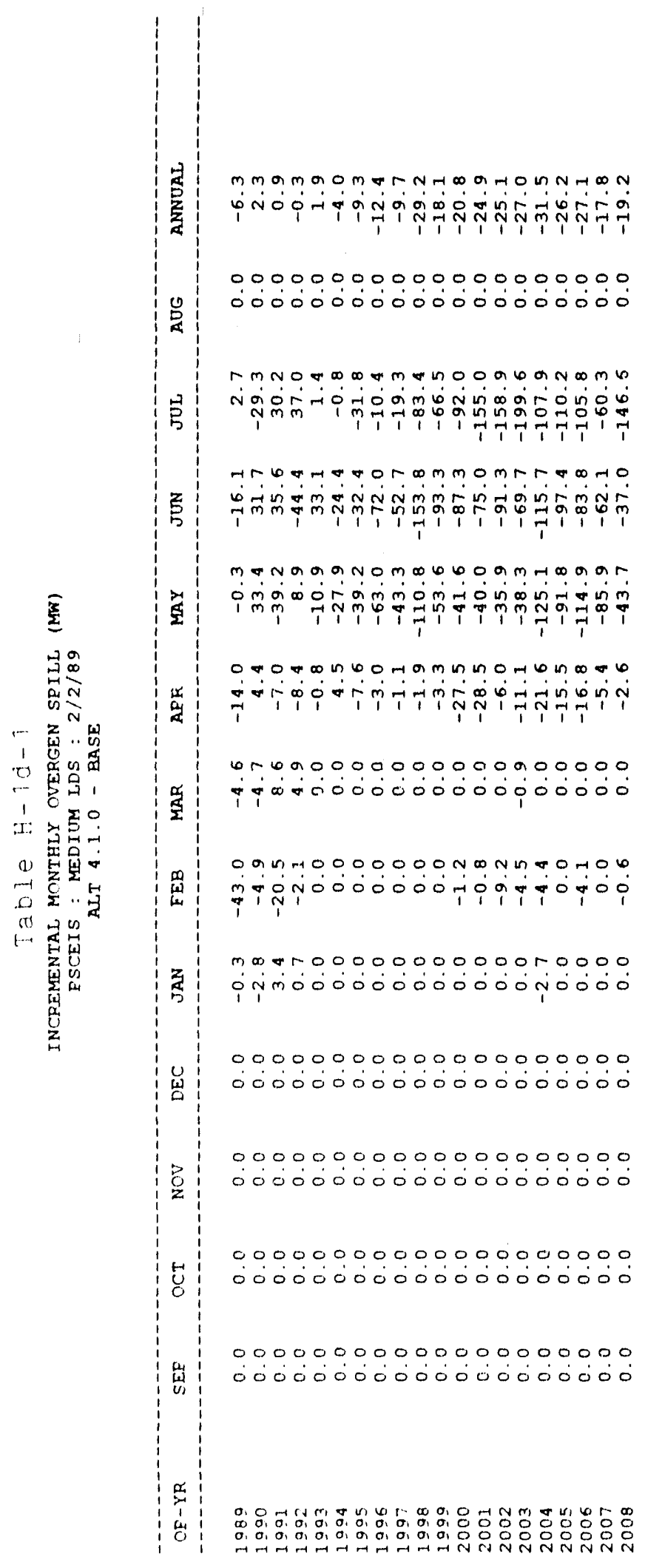




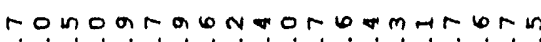

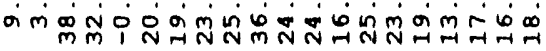

00000000000000000000

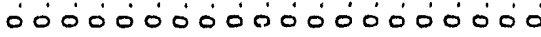

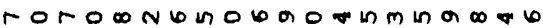
D

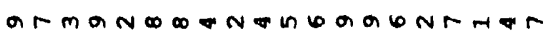

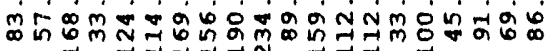

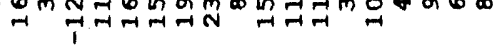

a NmT-

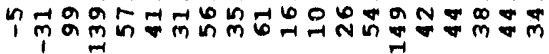

- nOm m nn

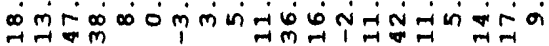

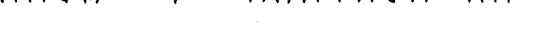

TOInINOONOOMOOMUNNTOO N⿴囗十心

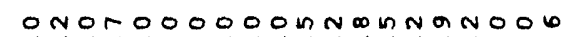
rion in $m$ in 0000000000 m n 0000

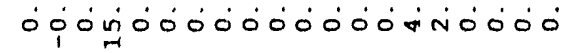
00000000000000000000 -0000000000000000

00000000000000000000 00000000000000000000

00000000000000000000

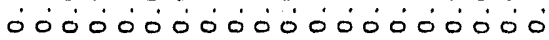

00000000000000000000

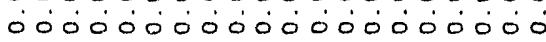

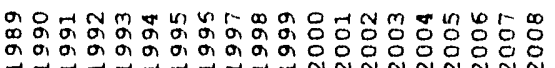


00000000000000000000

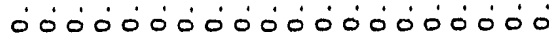

00000000000000000000 00000000000000000000

00000000000000000000 00000000000000000000

00000000000000000000 00000000000000000000

00000000000000000000 00000000000000000000

00000000000000000000 00000000000000000000

00000000000000000000 00000000000000000000

00000000000000000000 00000000000000000000

00000000000000000000 00000000000000000000

00000000000000000000 00000000000000000000

00000000000000000000 00000000000000000000

00000000000000000000 00000000000000000000

00000000000000000000

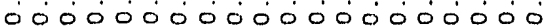

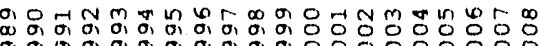

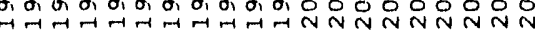

$$
H-1 d-6
$$


H-1e

FISHPASS MODEL OUTPUT

Relative Changes in System Stock Survival

Frequency of Relative Survival Changes Exceeding $1 \%$ and $5 \%$ 


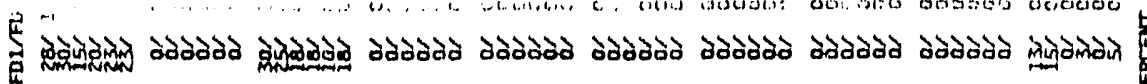

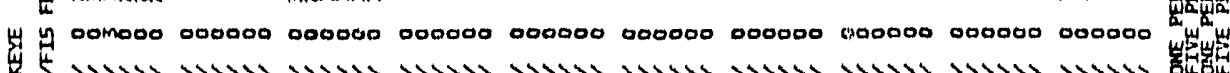

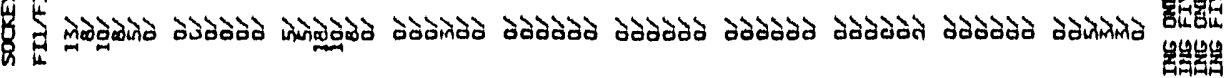

In mo000in mo0000 00000 m 00000000000 in 00000 in pomunnm 000000000000000000

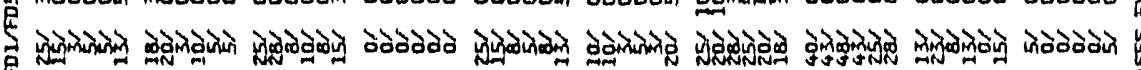

跑热

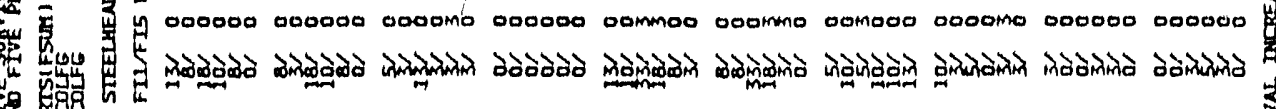

锠

8 㻤.

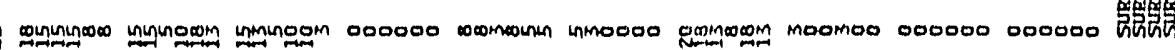

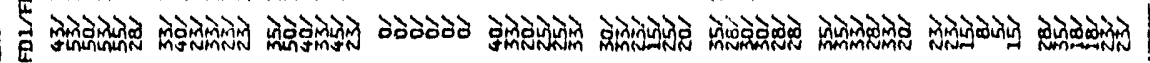

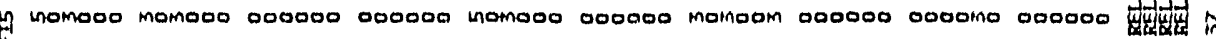

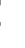
故梈

焉题

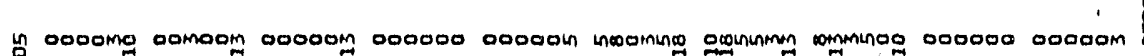
比管

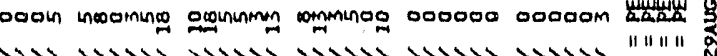

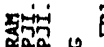

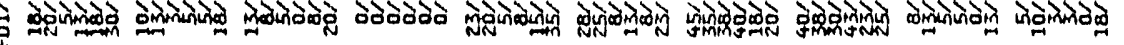

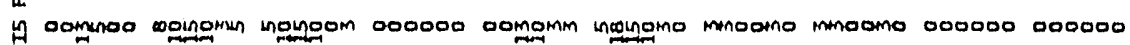

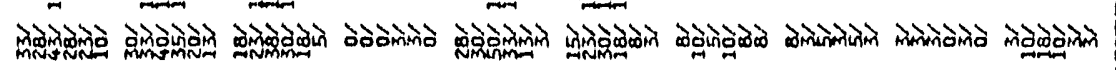

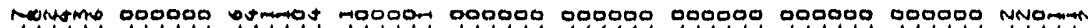

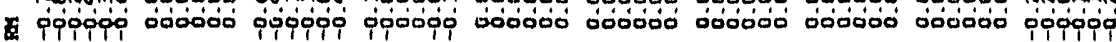

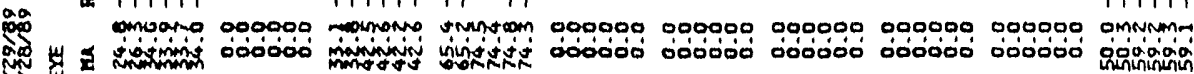

J

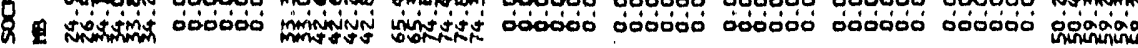

然

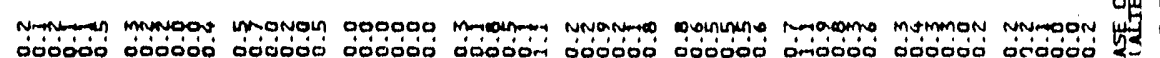

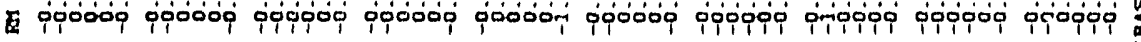

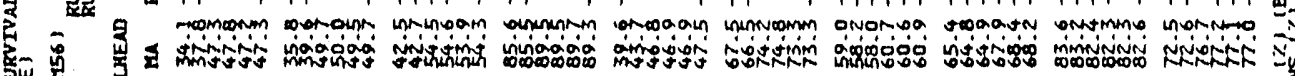

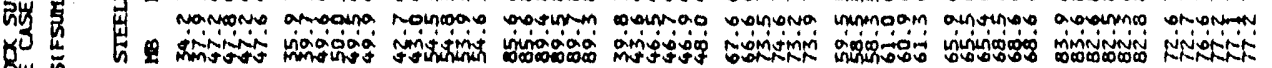

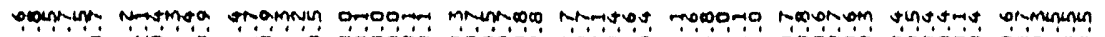

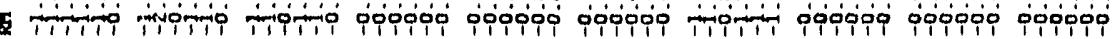

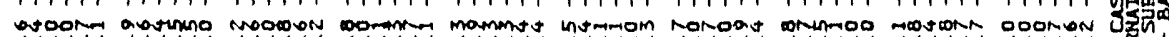

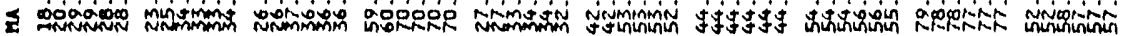

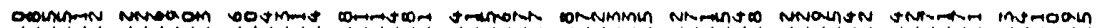

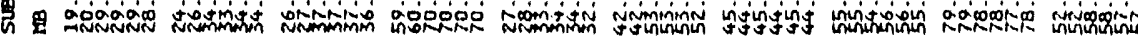

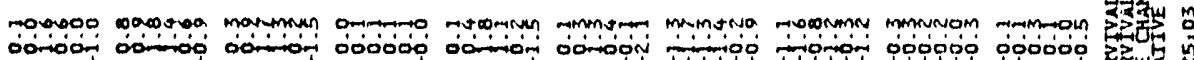

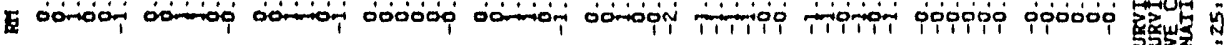

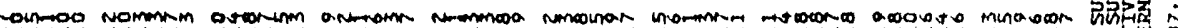

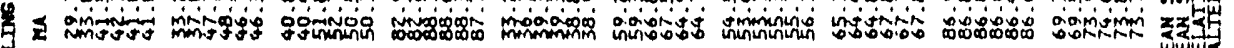

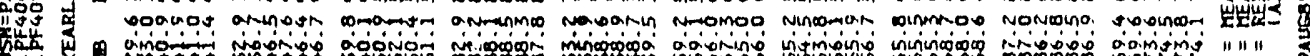

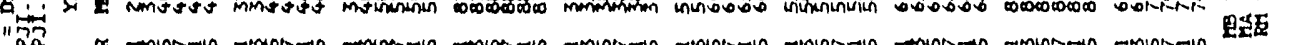

"בan

总落 


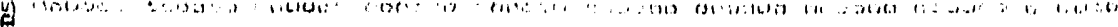

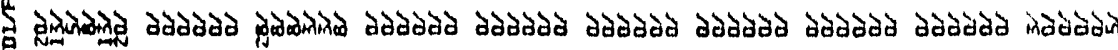

Hy 000000000000000000000000000000000000000000000000000000000000

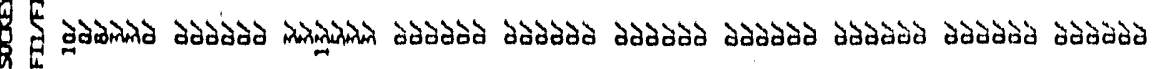

nn m0000m mo0000 0100000 000000 00000m $00000 m$ 000000 1100000 000000 000000

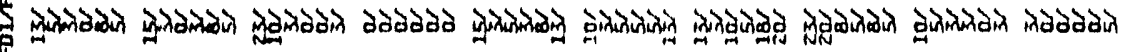
y 000000000000 0000m0 0000c10 000 m00 00mmo0 000000 0000mm 000000 000000

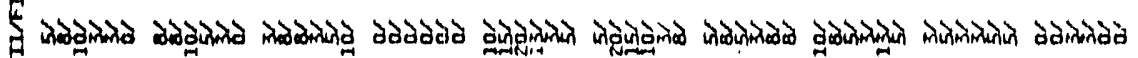

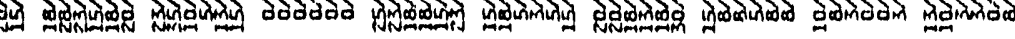
y momano uno0000 mo0000 000000 m00000 000000 000000 000000 0000m0 000000 353

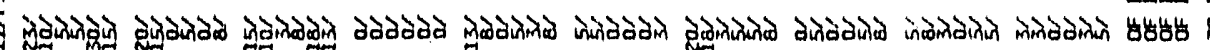

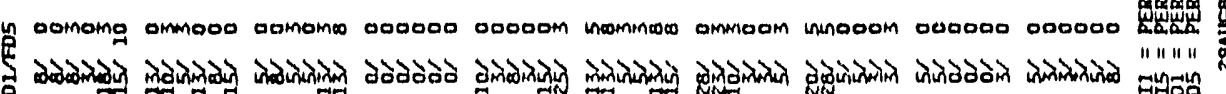

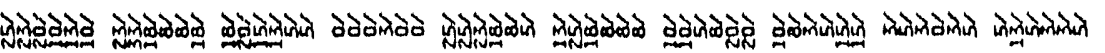

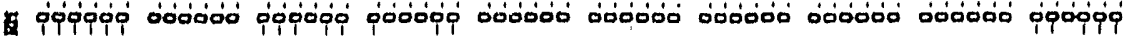

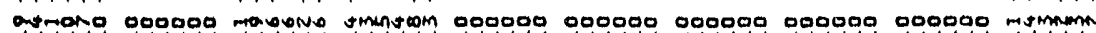

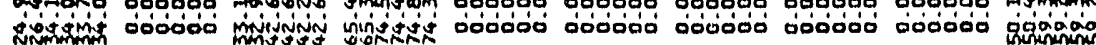

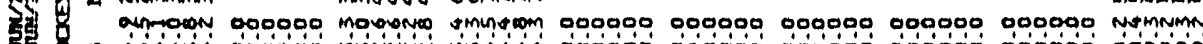

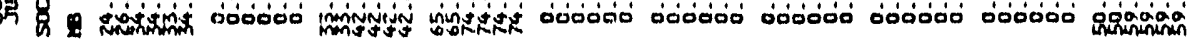

䕡

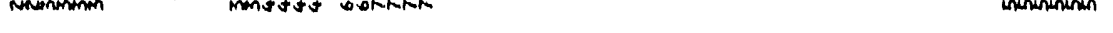

â.

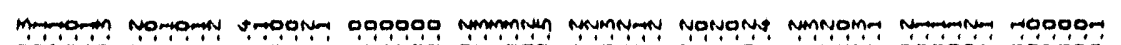

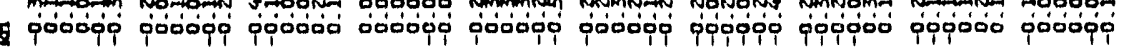

尊

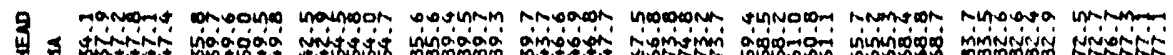

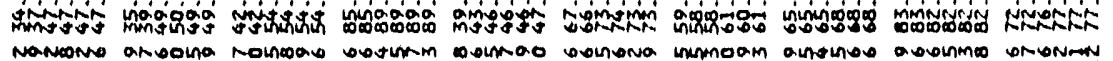

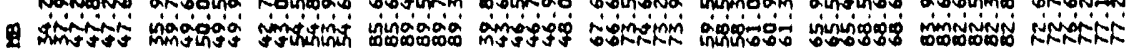

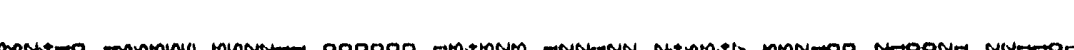

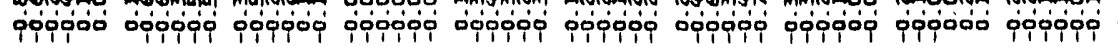

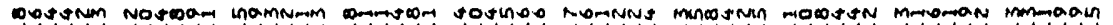

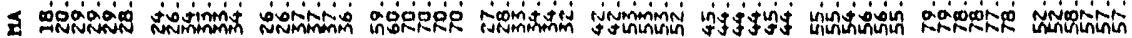

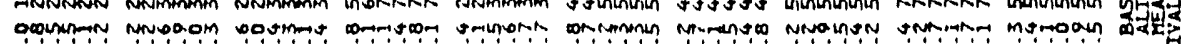

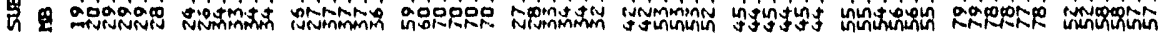

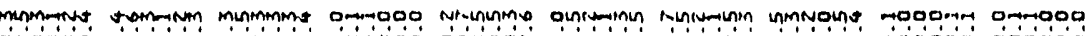

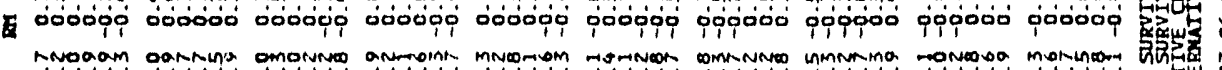

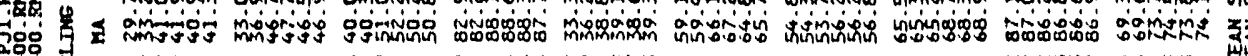

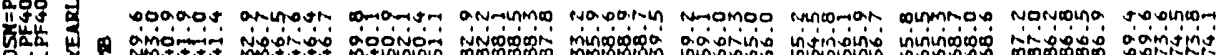
"Th"3a. 销出 을 总 $\vec{b}$$$
\text { म. }
$$

$$
5
$$




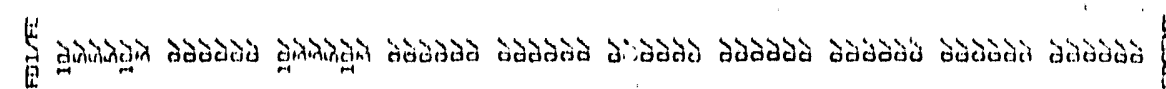

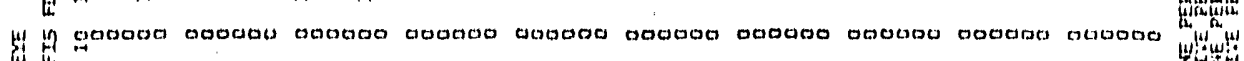

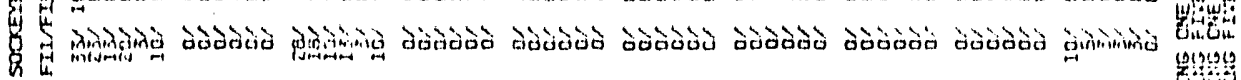
1.

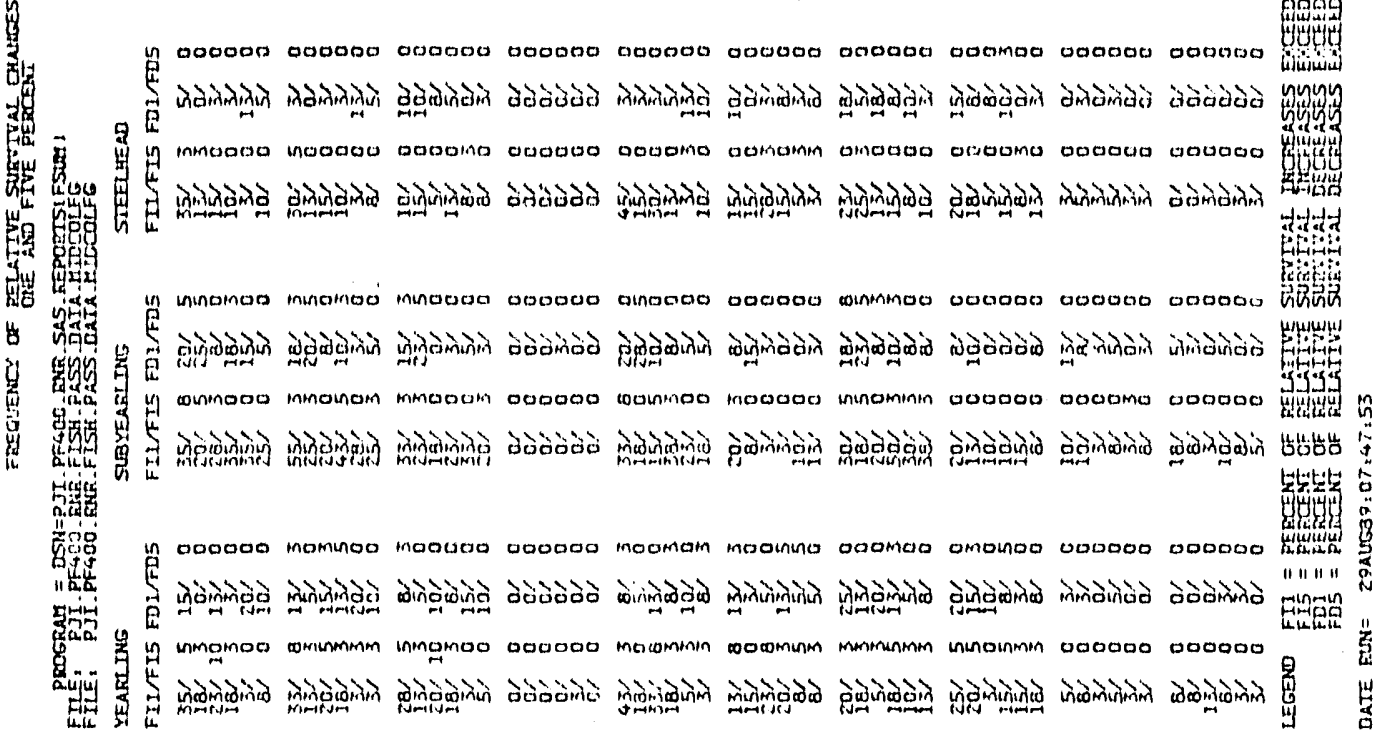

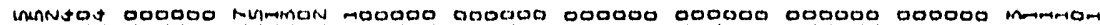

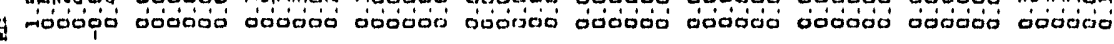

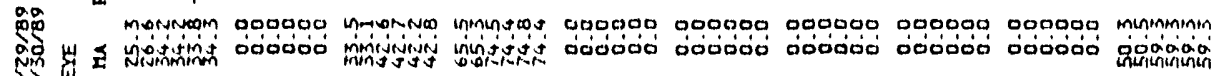

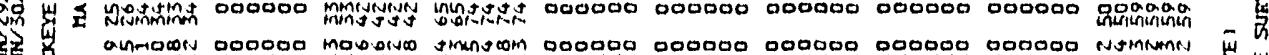

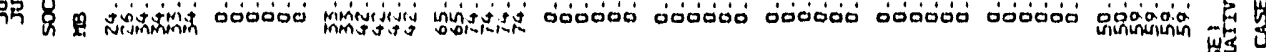
药

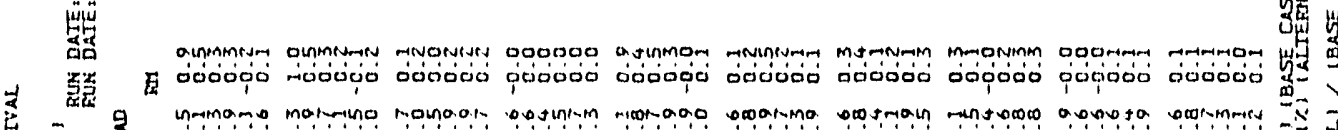

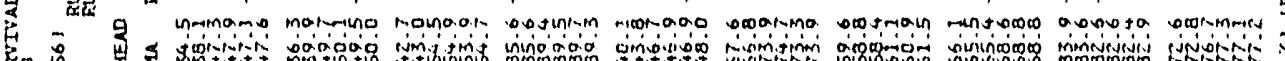

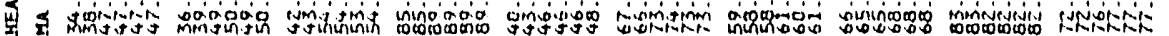

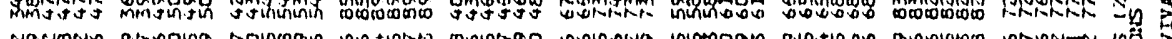

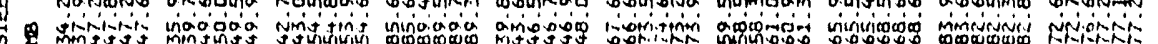

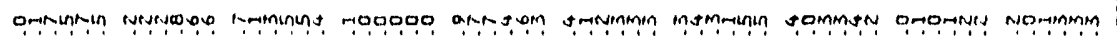

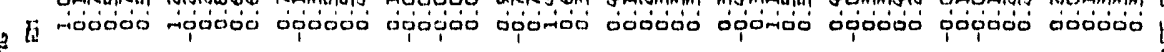

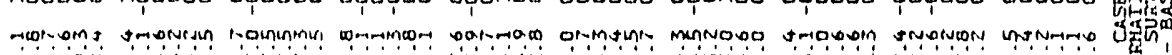

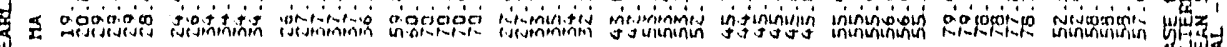

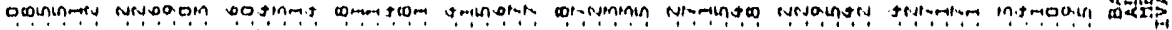

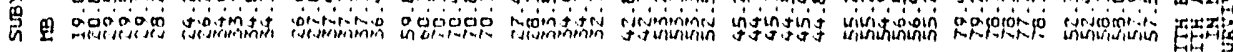

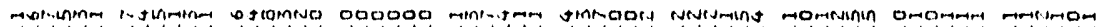

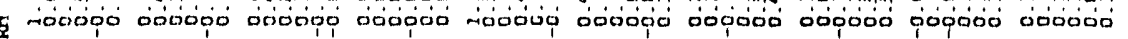

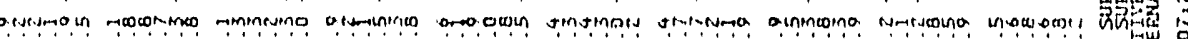

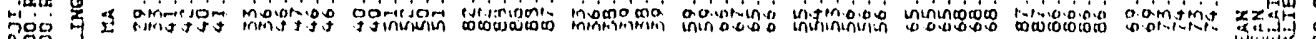

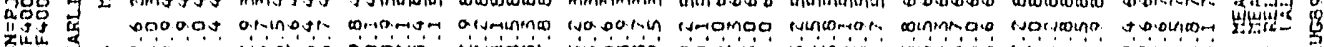

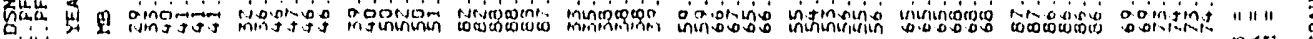

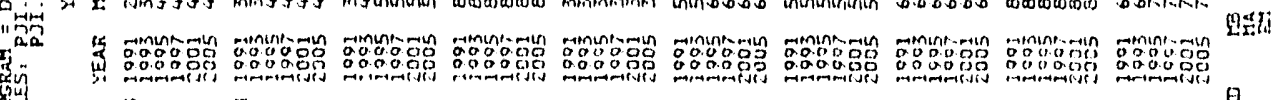
密, 象 i.

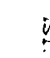

$$
\text { ( }
$$$$
\text { . }
$$ 


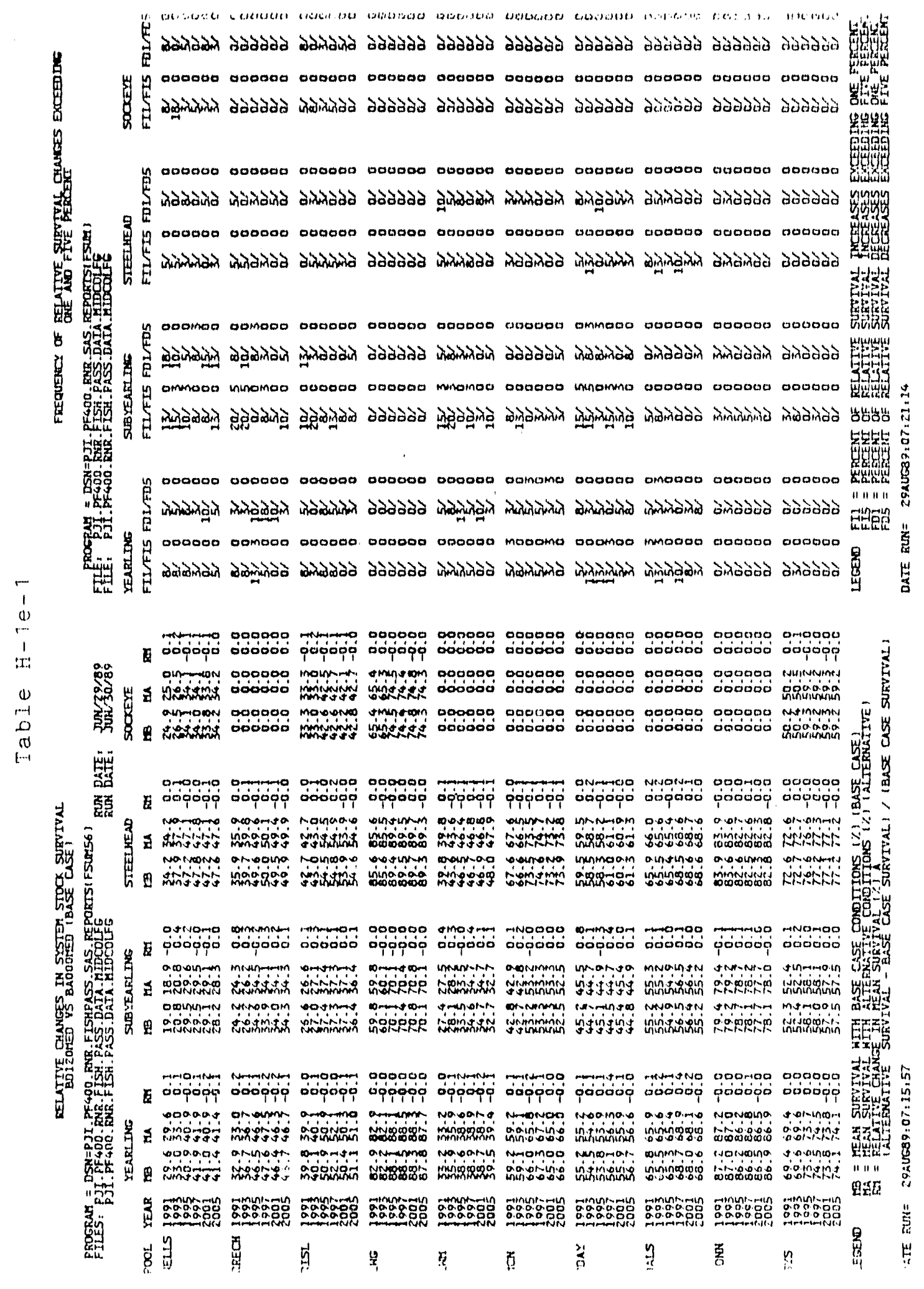




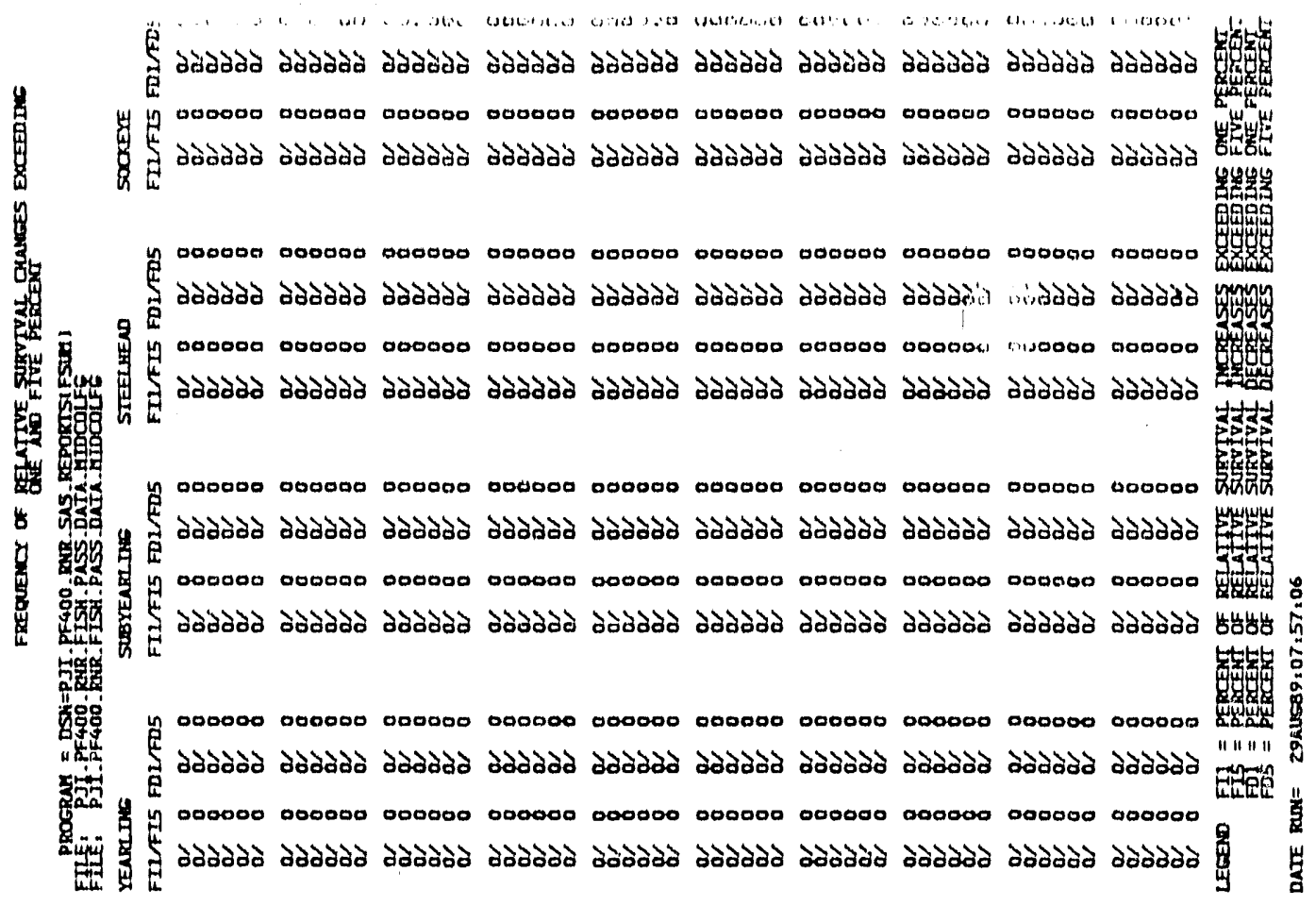

$\underset{1}{1}$

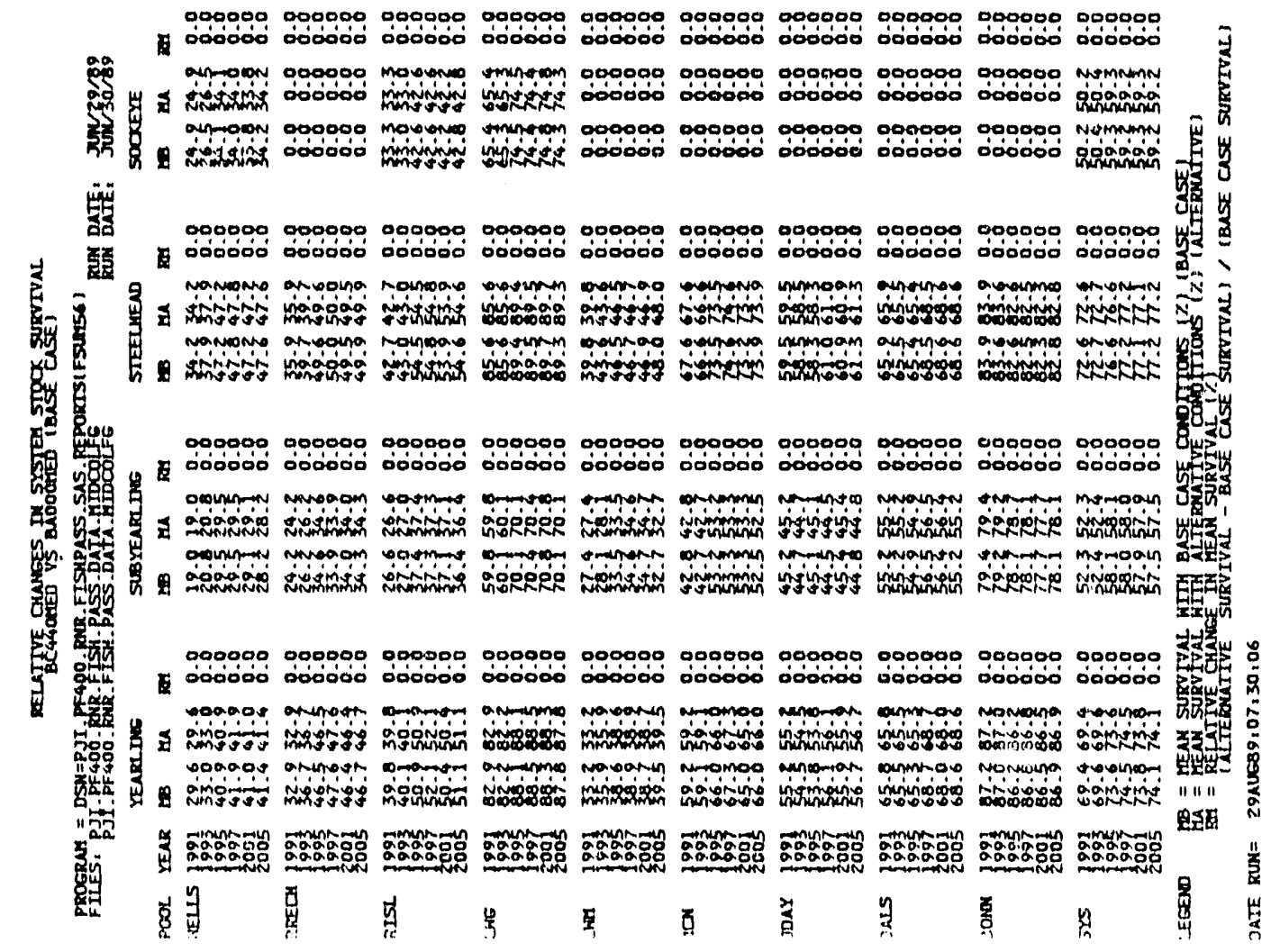

$$
H-1 e-5
$$


$H-1 f$

FLOW CHANGES

Discharges and Differences for

Lower Granite, Priest Rapids and The Dalles 


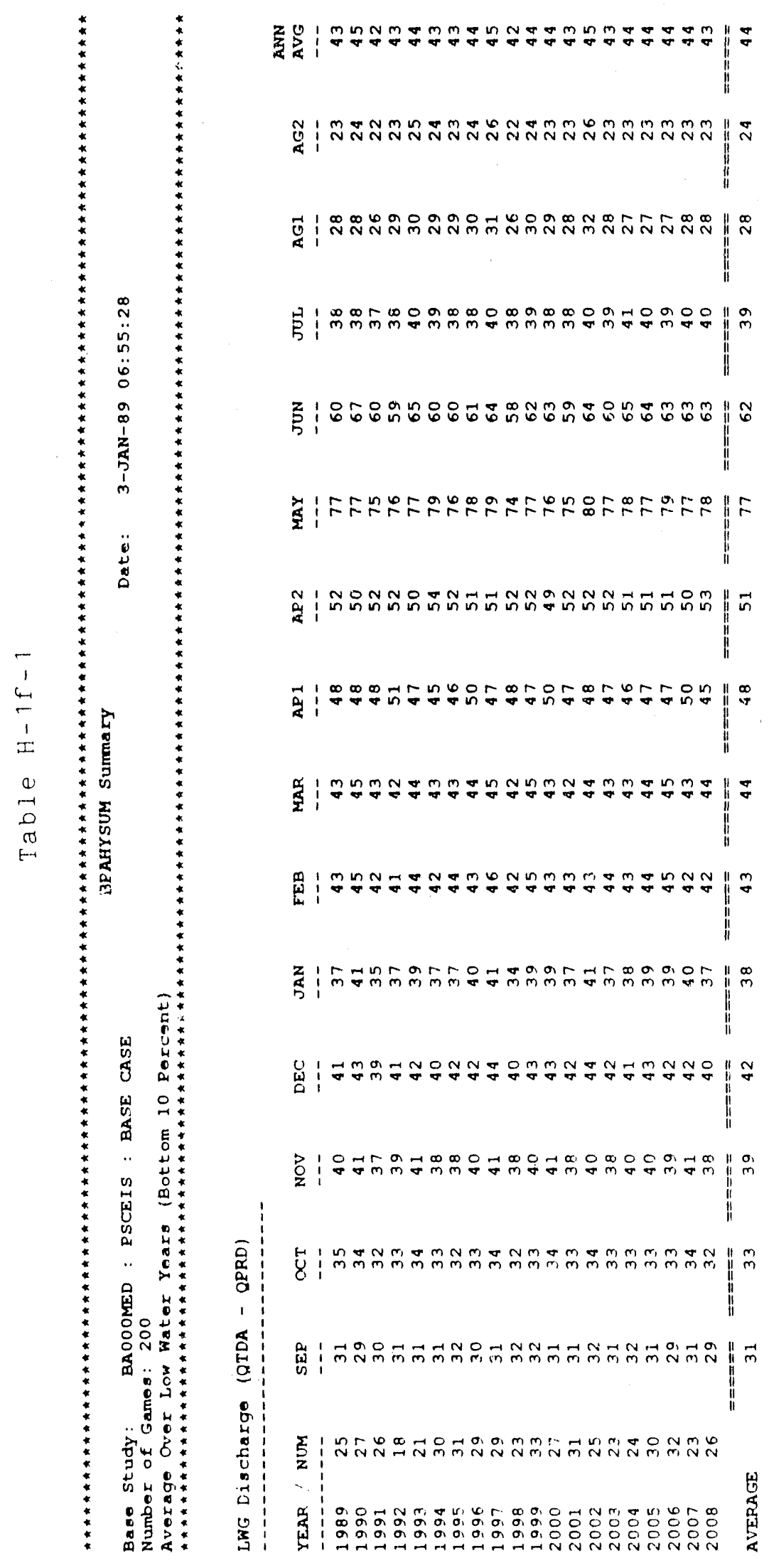




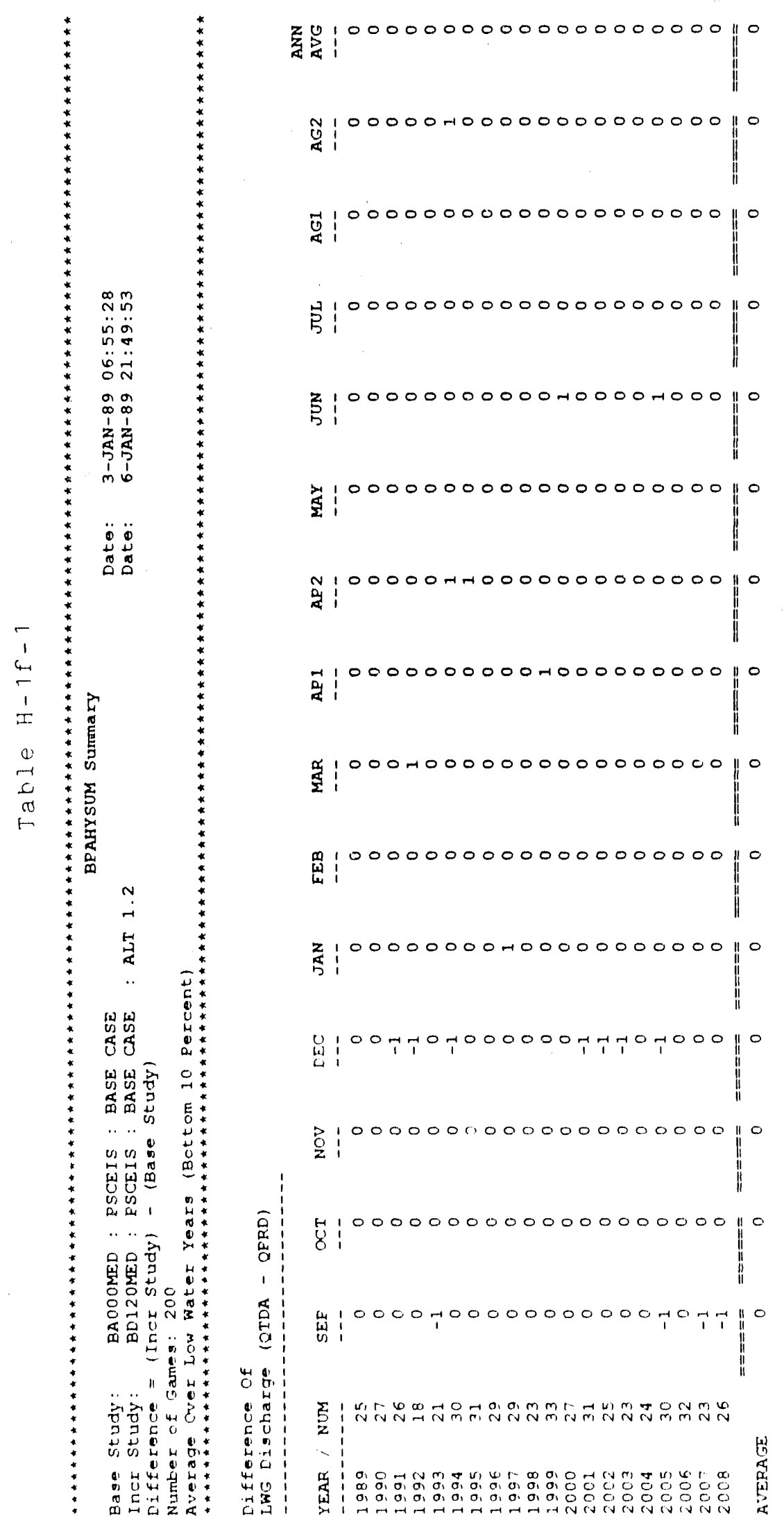

$$
11-11)-?
$$




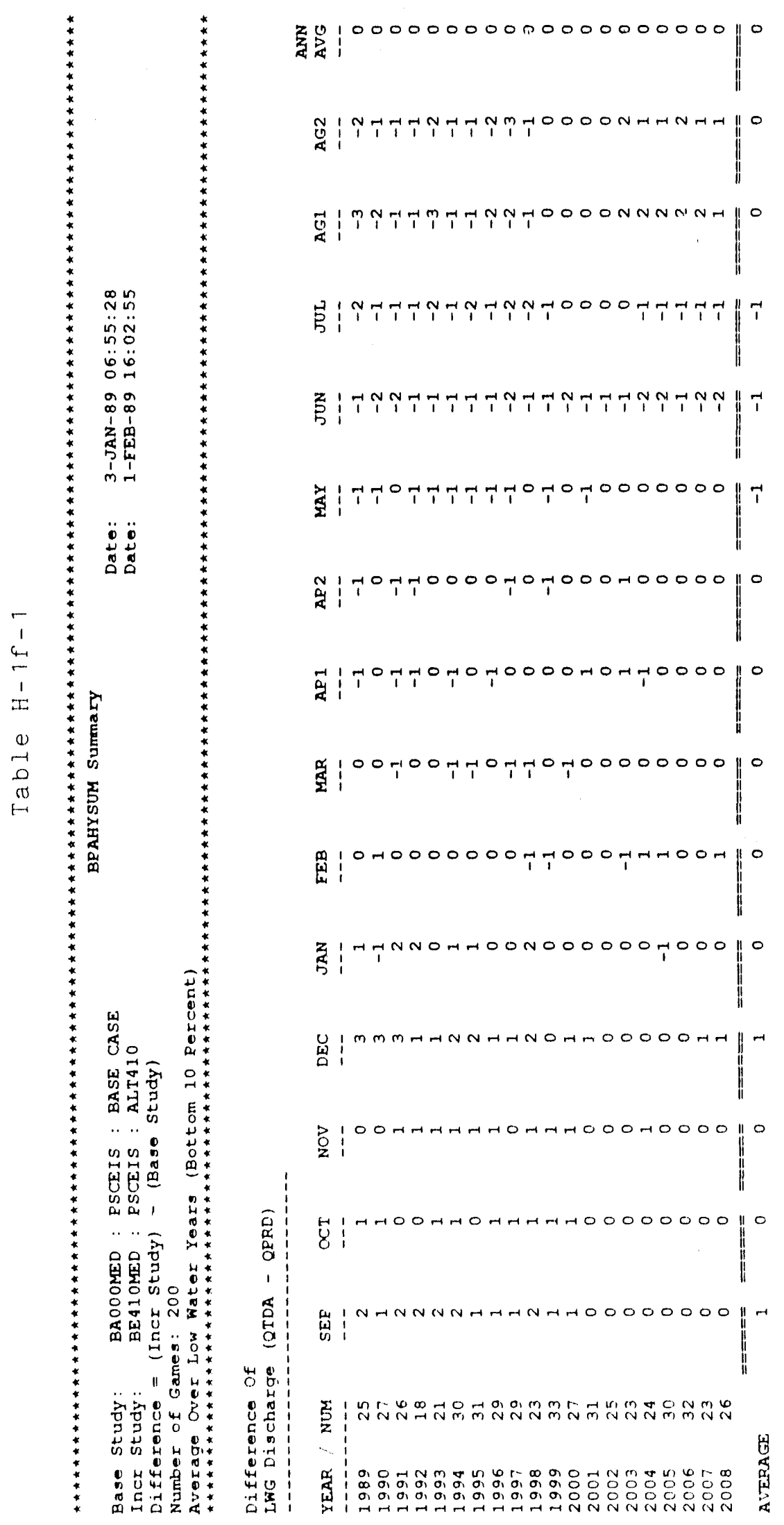




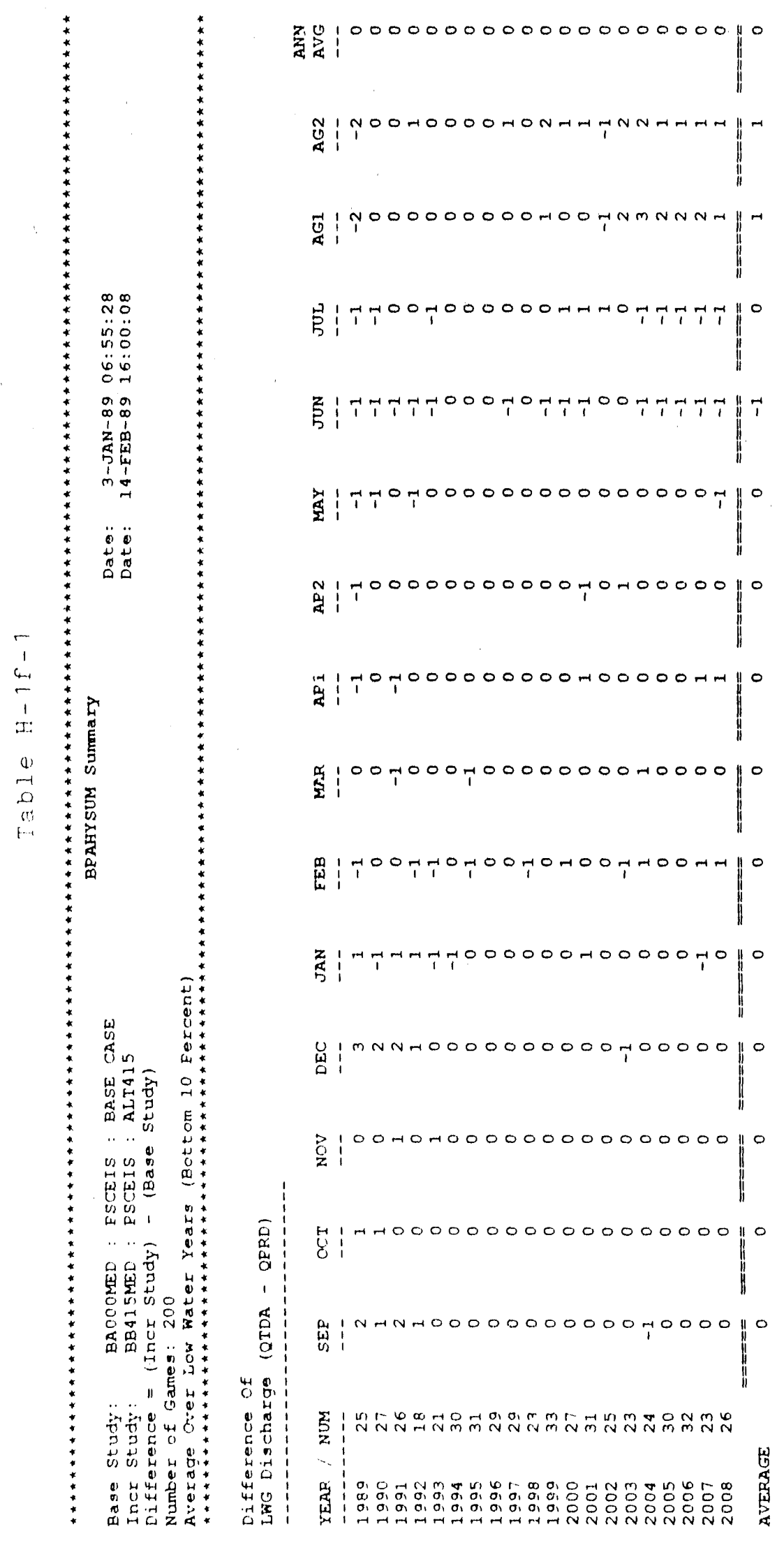

$$
4-1 f^{2}-4
$$




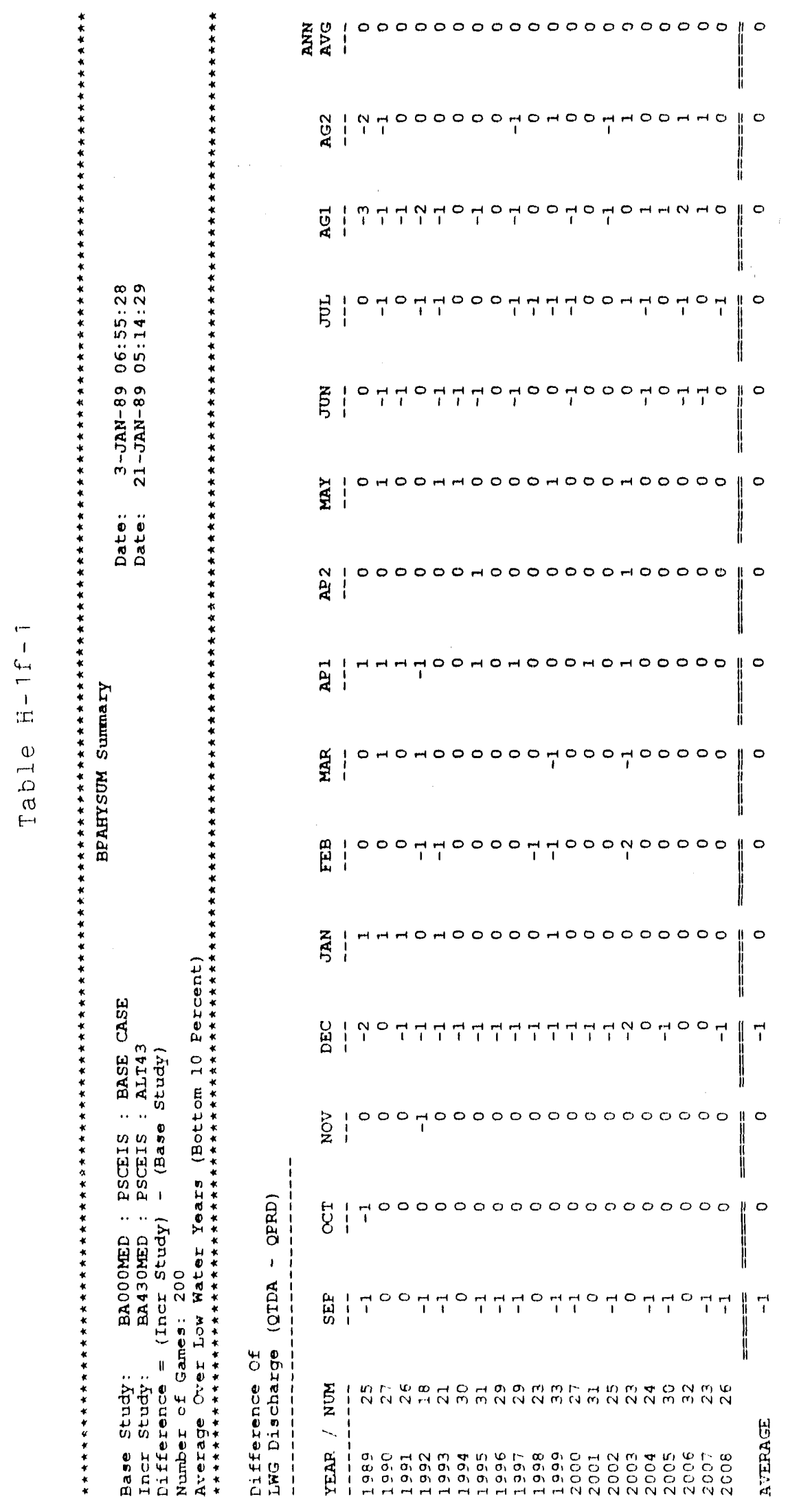




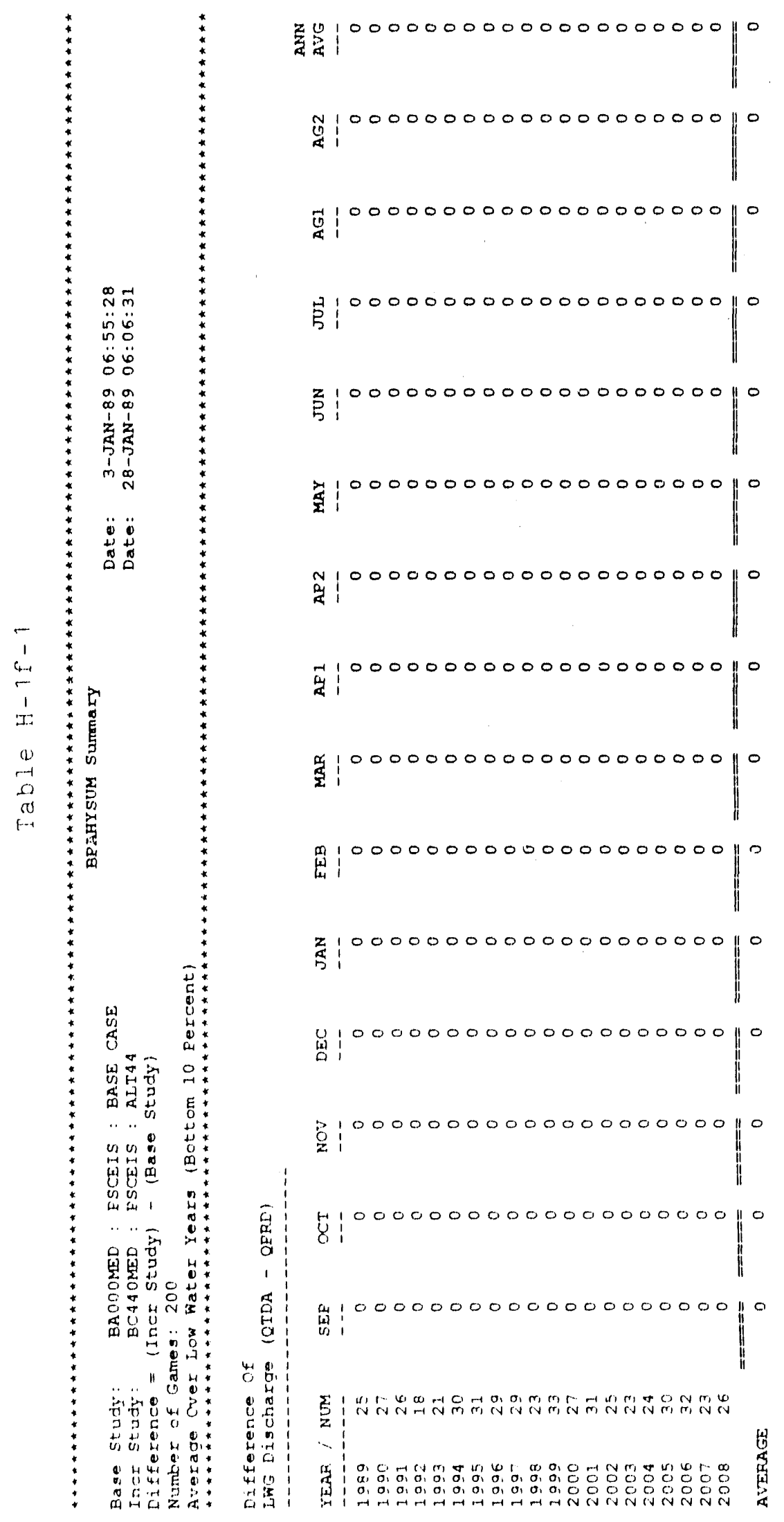




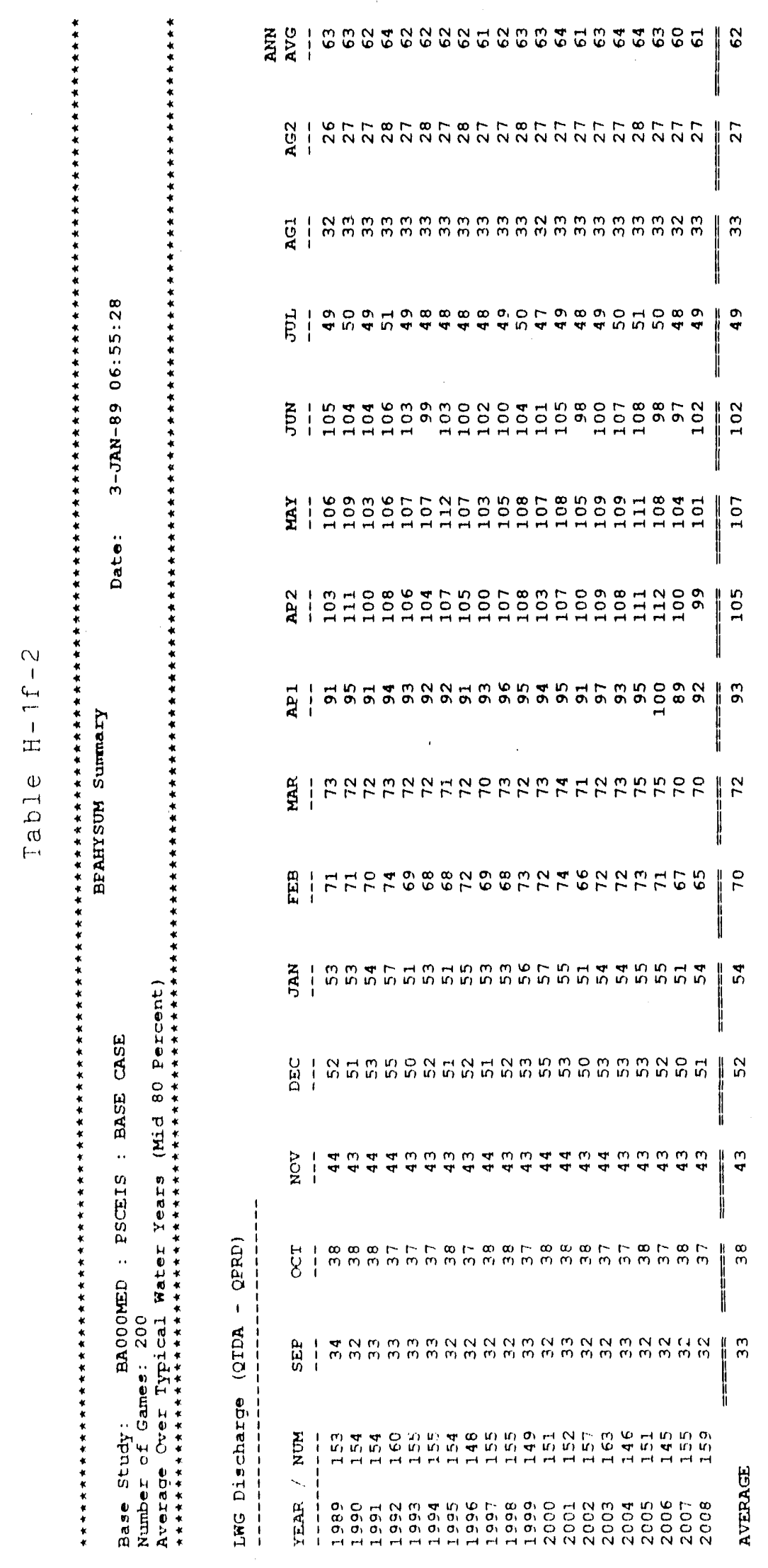

$H-1 f^{\prime}-7$ 


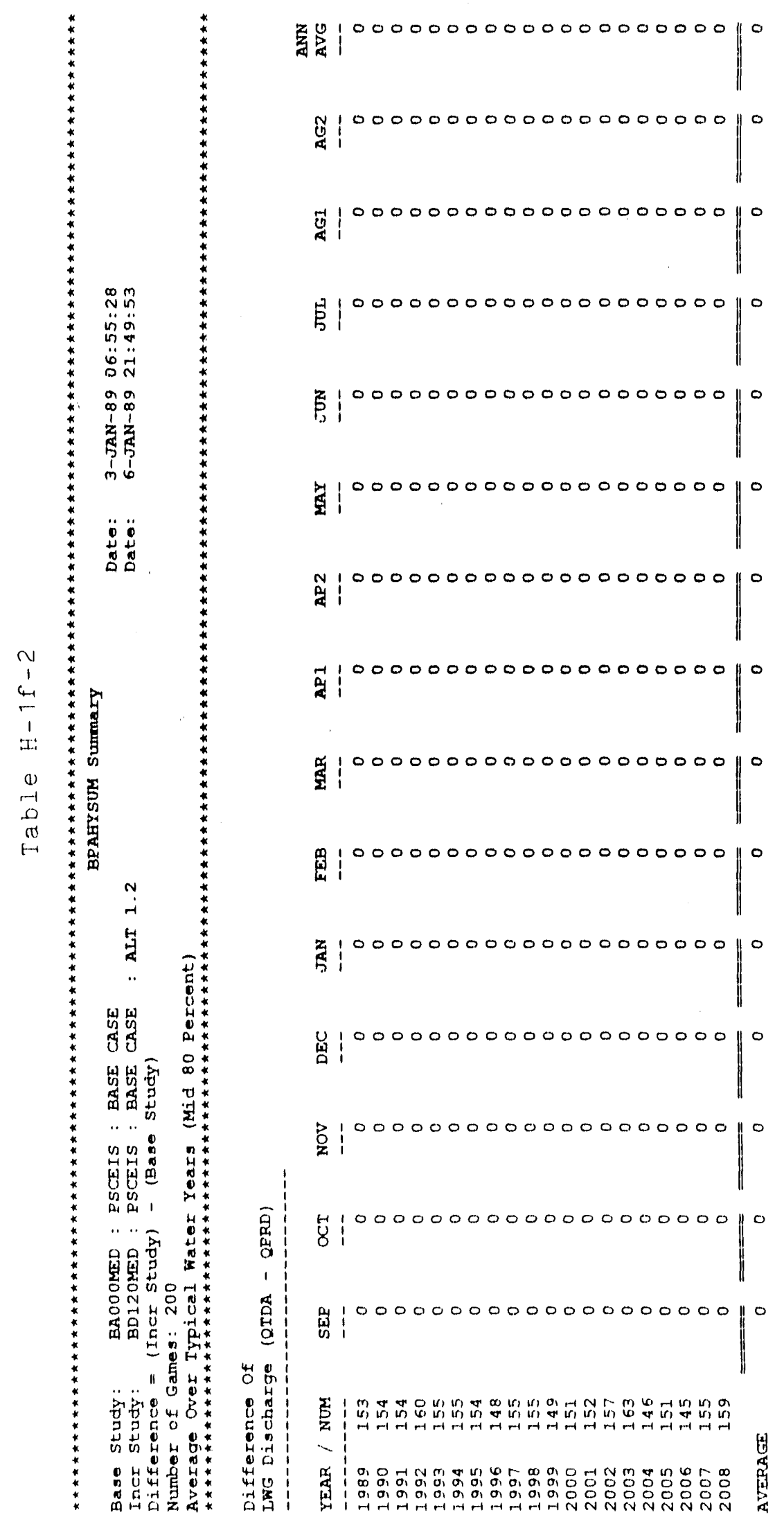




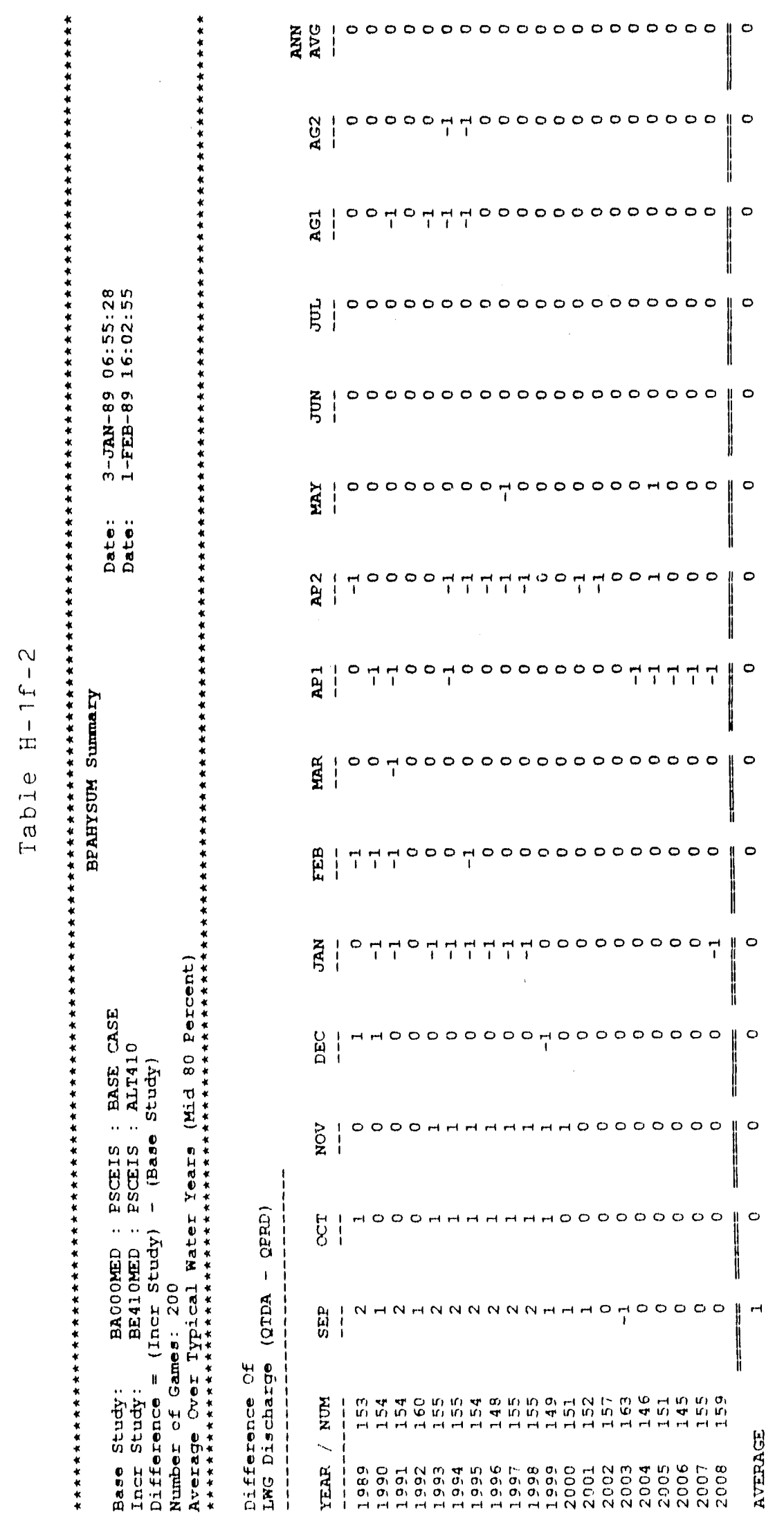




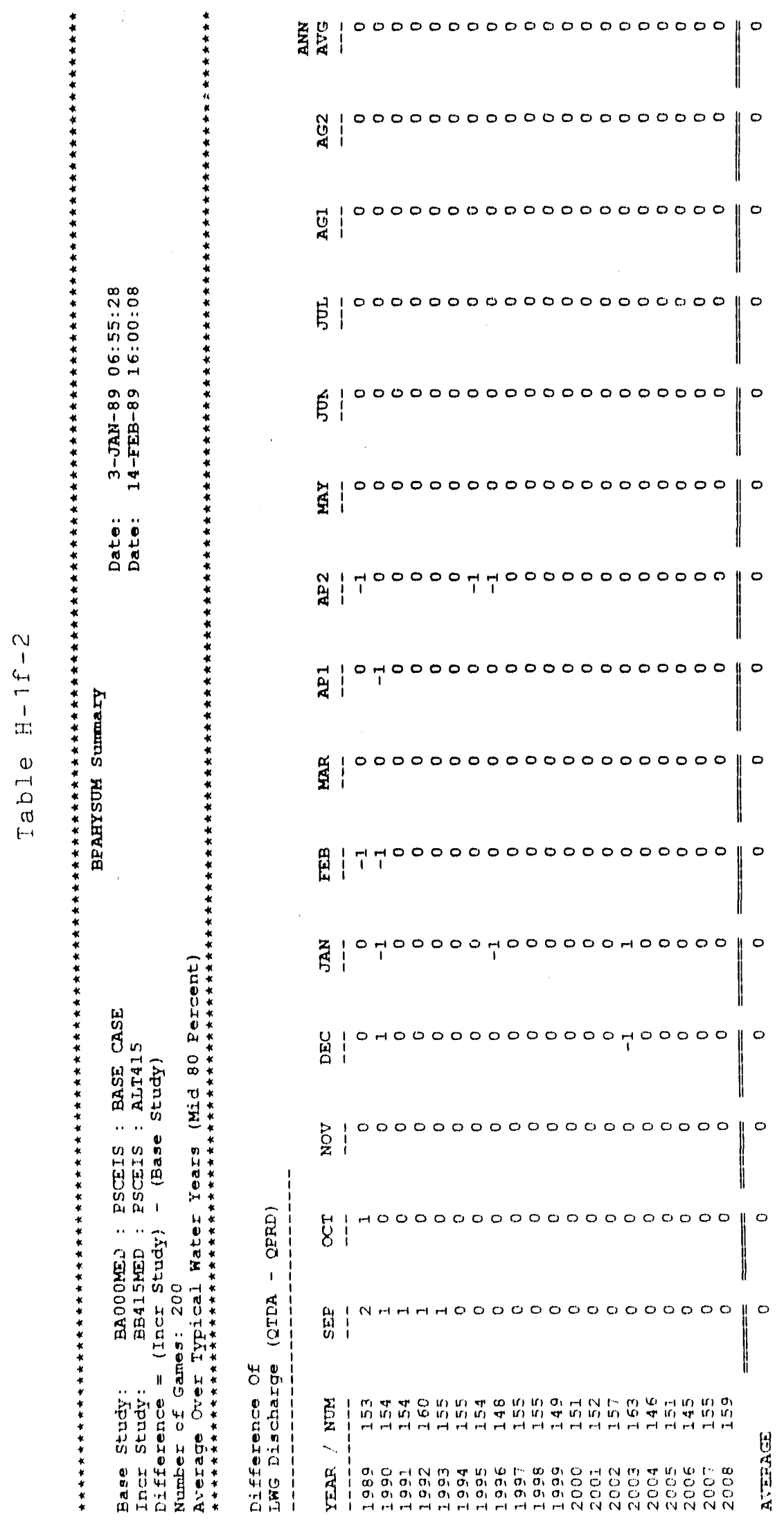




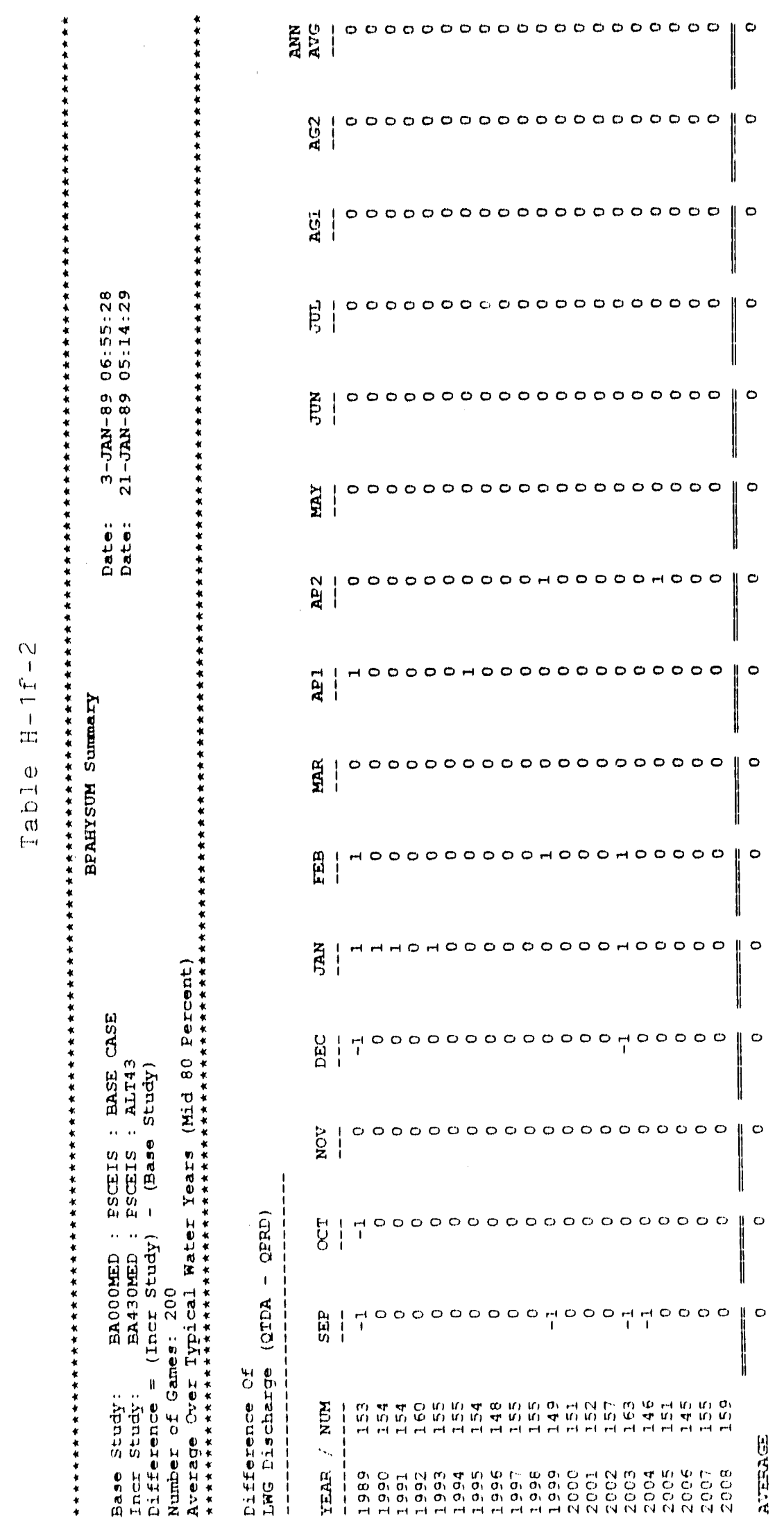




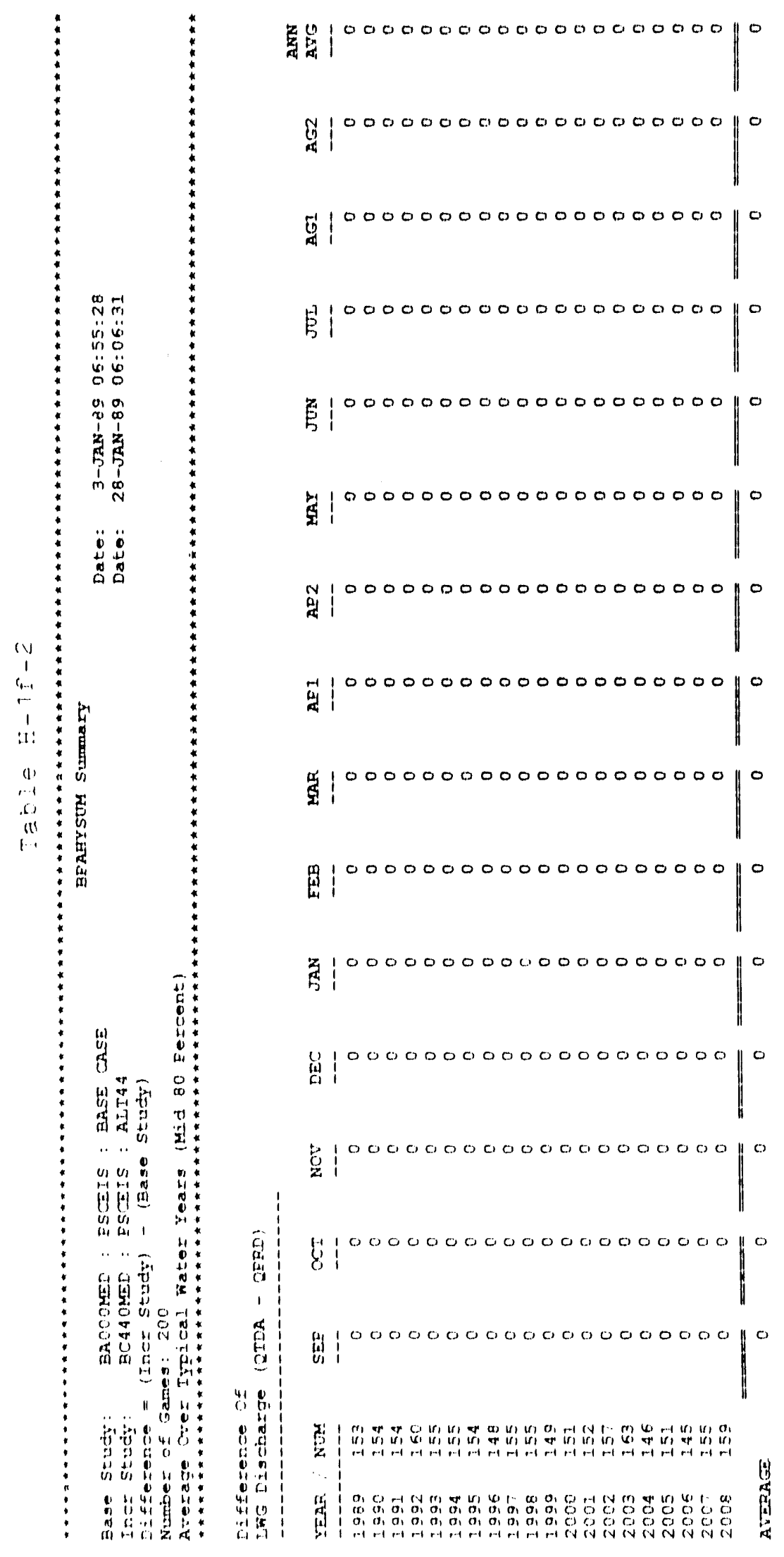




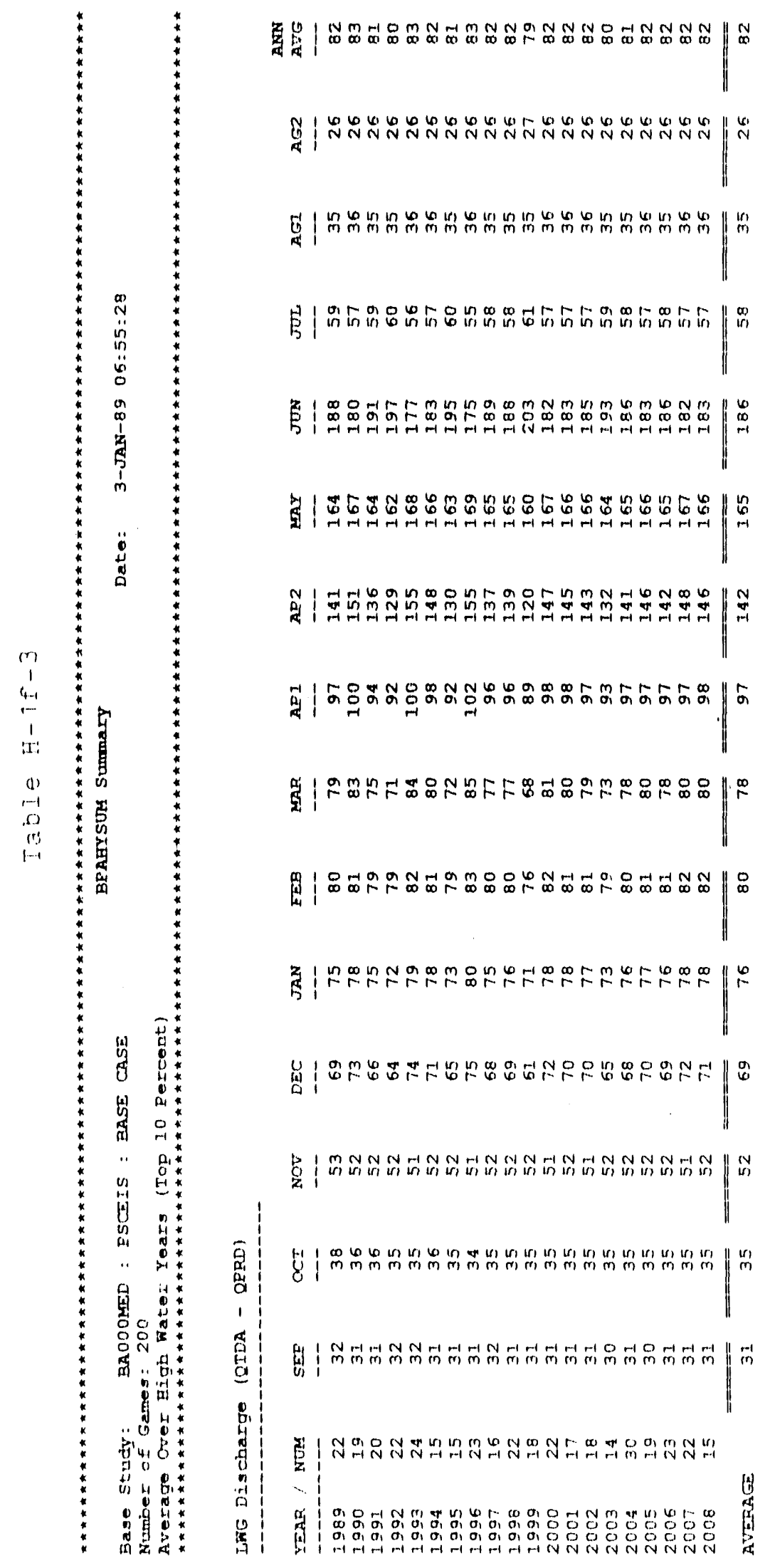




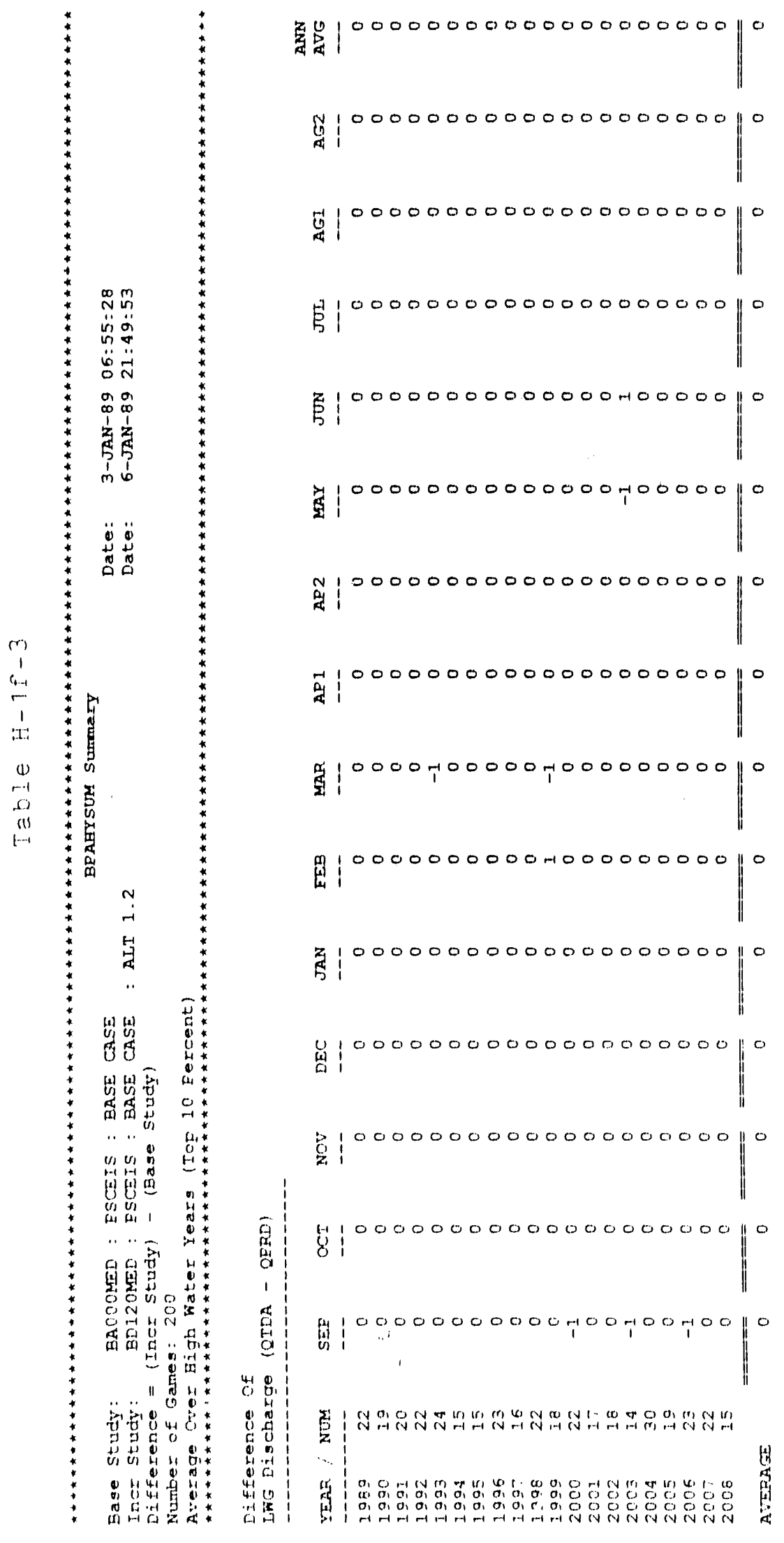




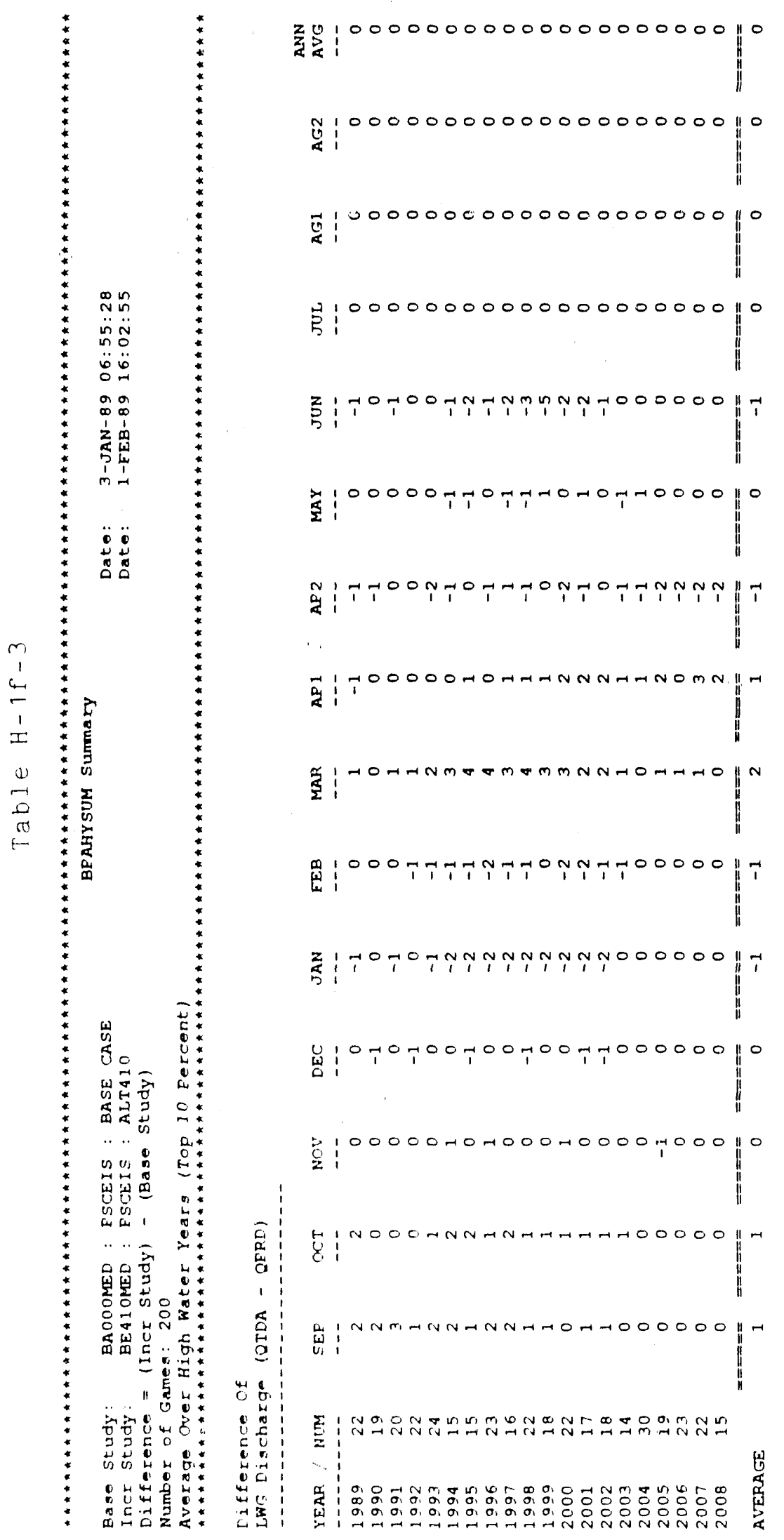




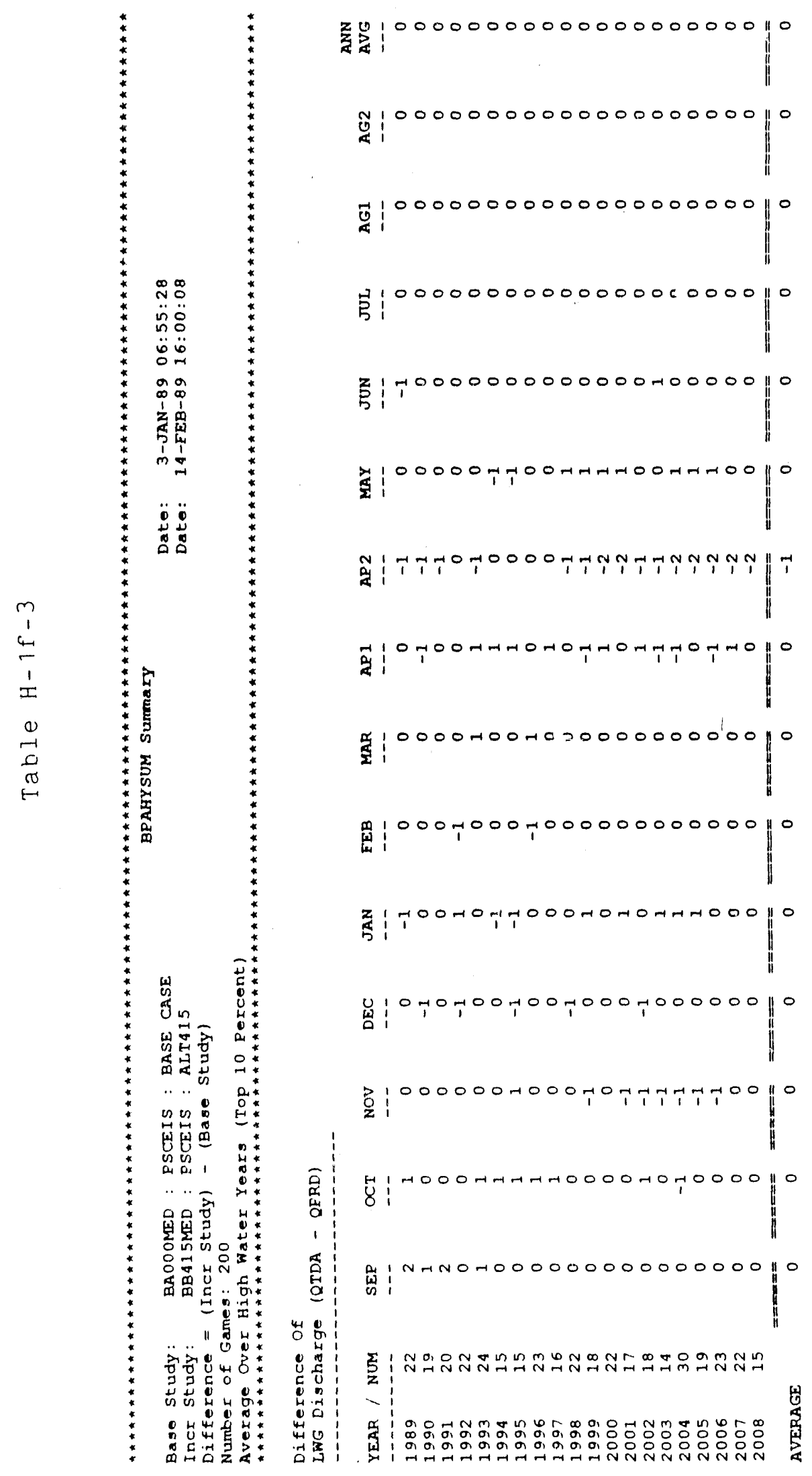

$$
H-1 f-16
$$


硬最: $00000000000000000000 \|^{0}$

Uू:

पू山

$\overrightarrow{5}: 00000000000000000000 \|^{0}$

है।

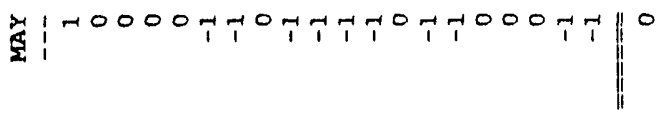

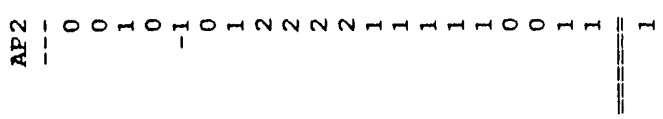

H:

类:

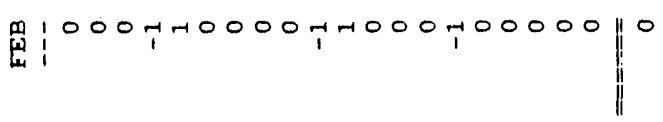

等:10000000070007070000

㟒! $00000000000000070000 \|^{0}$

S:

凷出邑

की

*. 5

目昆

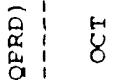

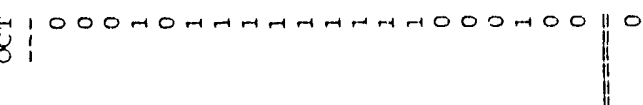

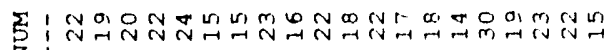




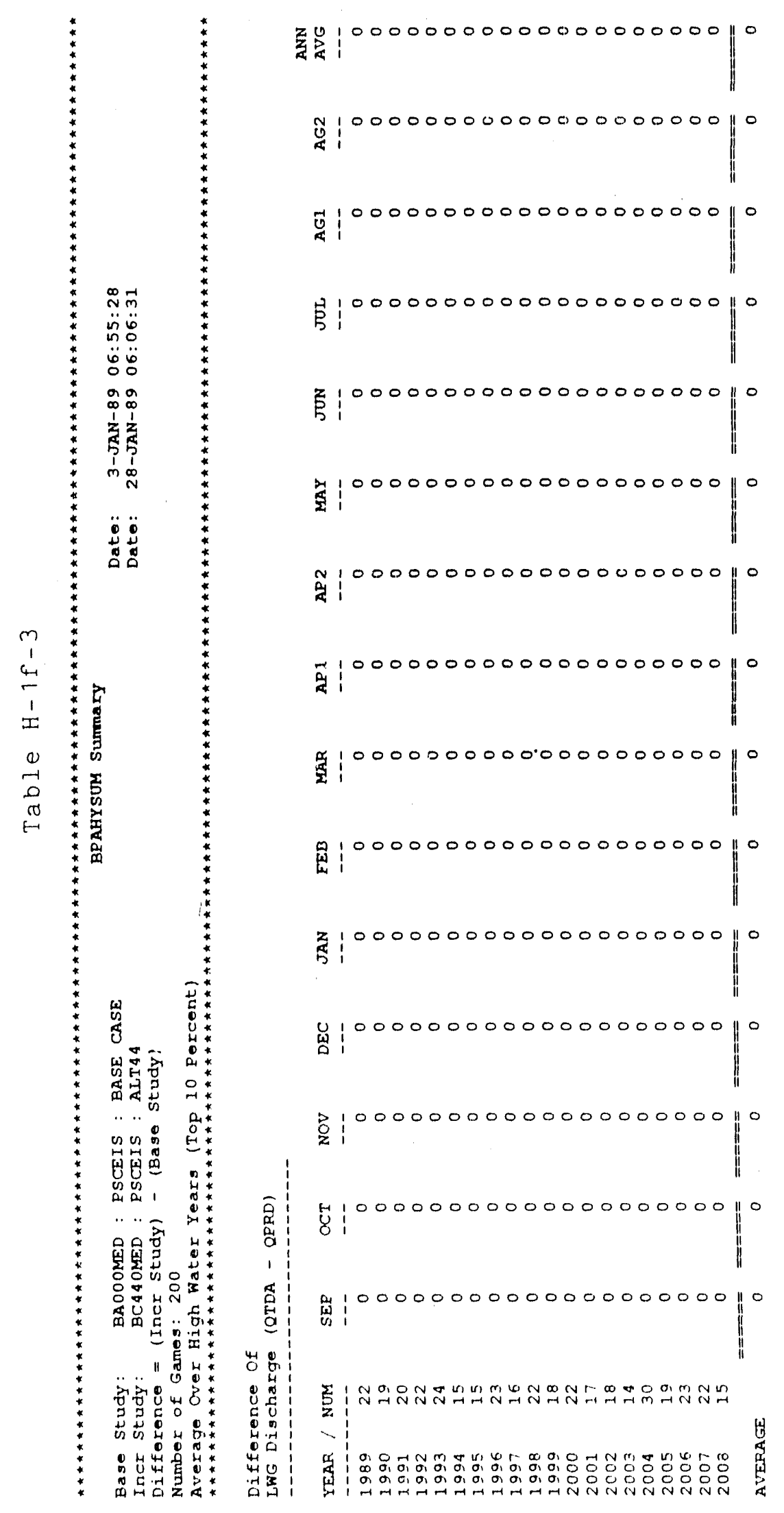




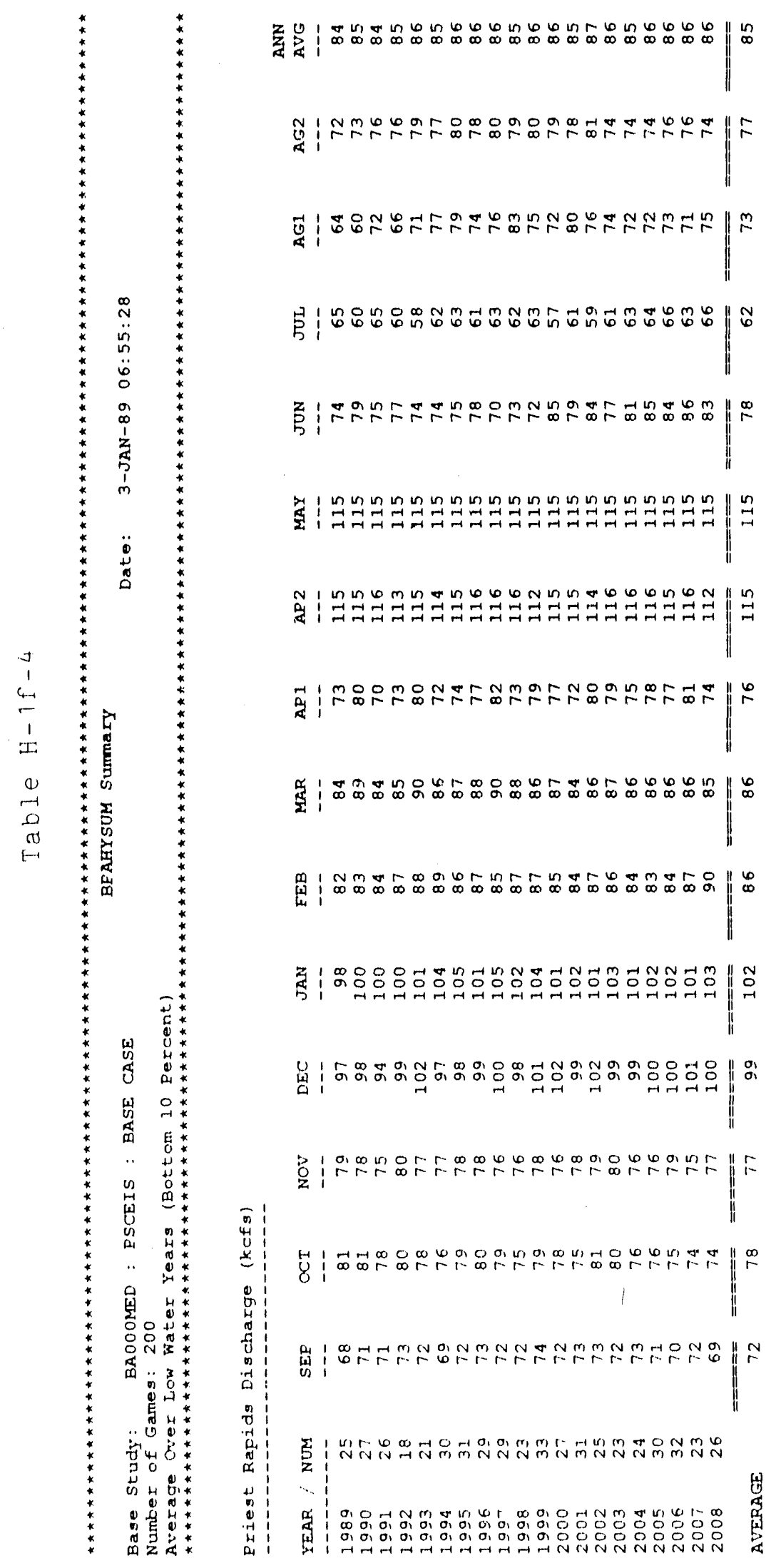




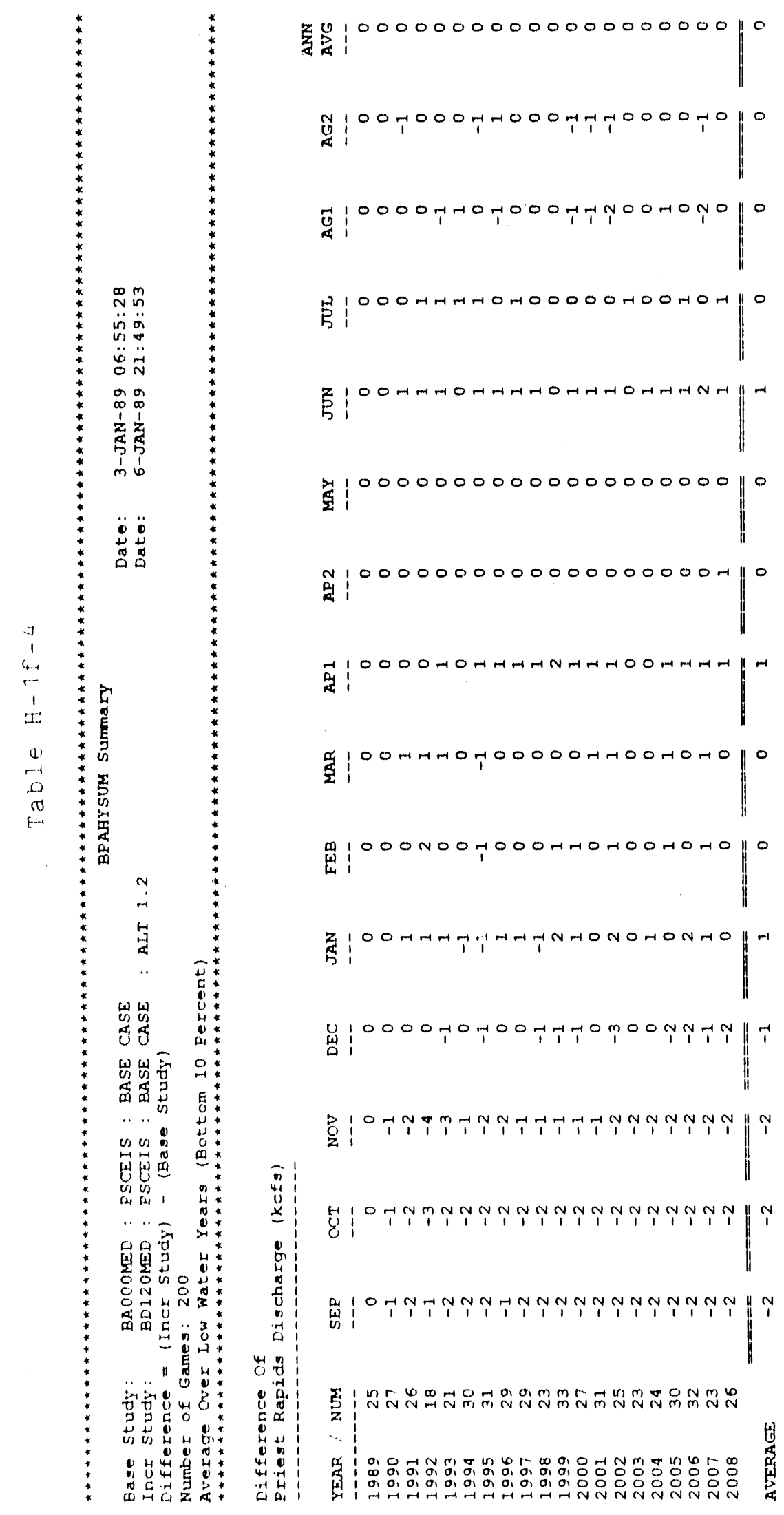

$$
H-1 f-20
$$




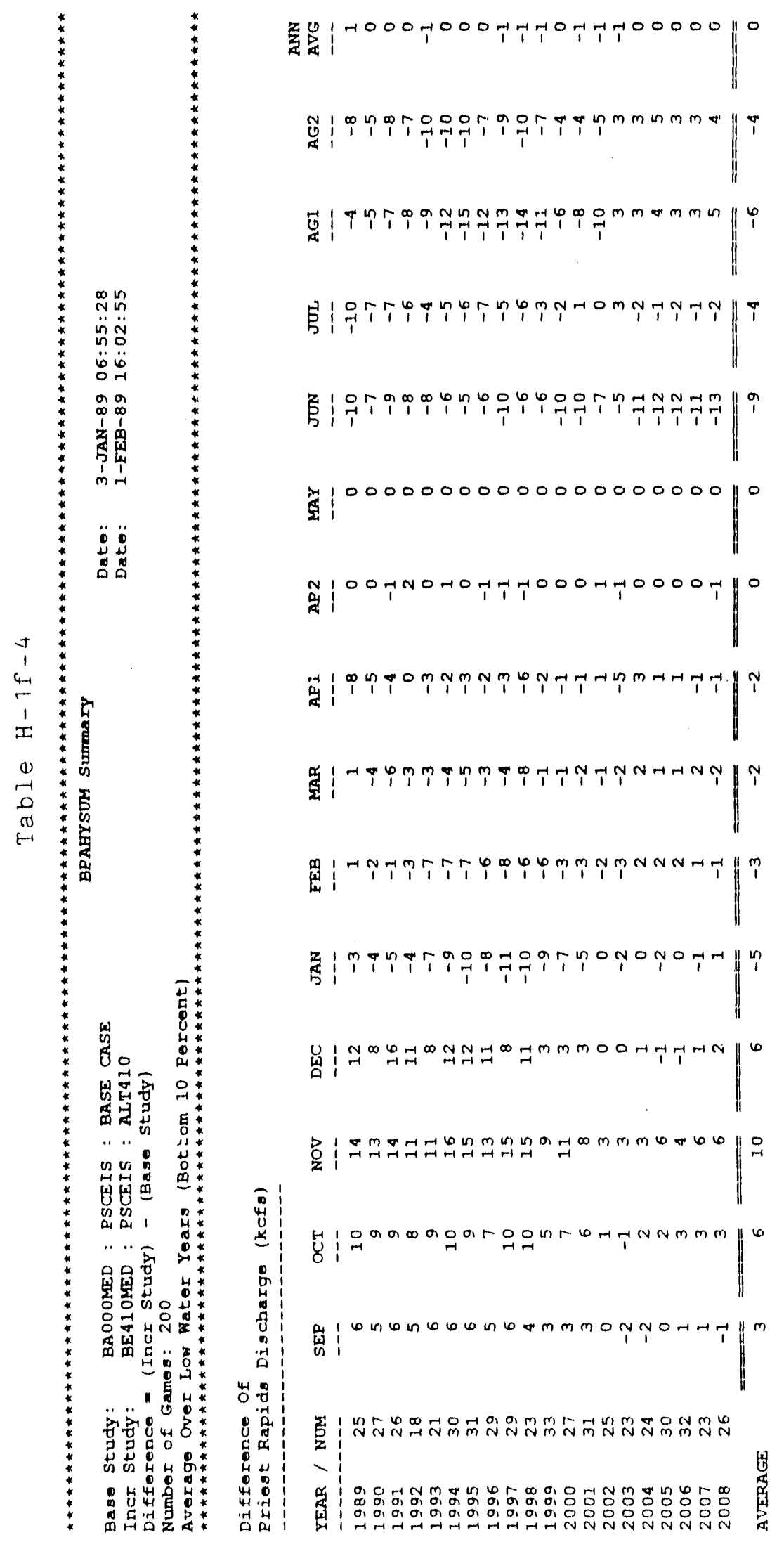




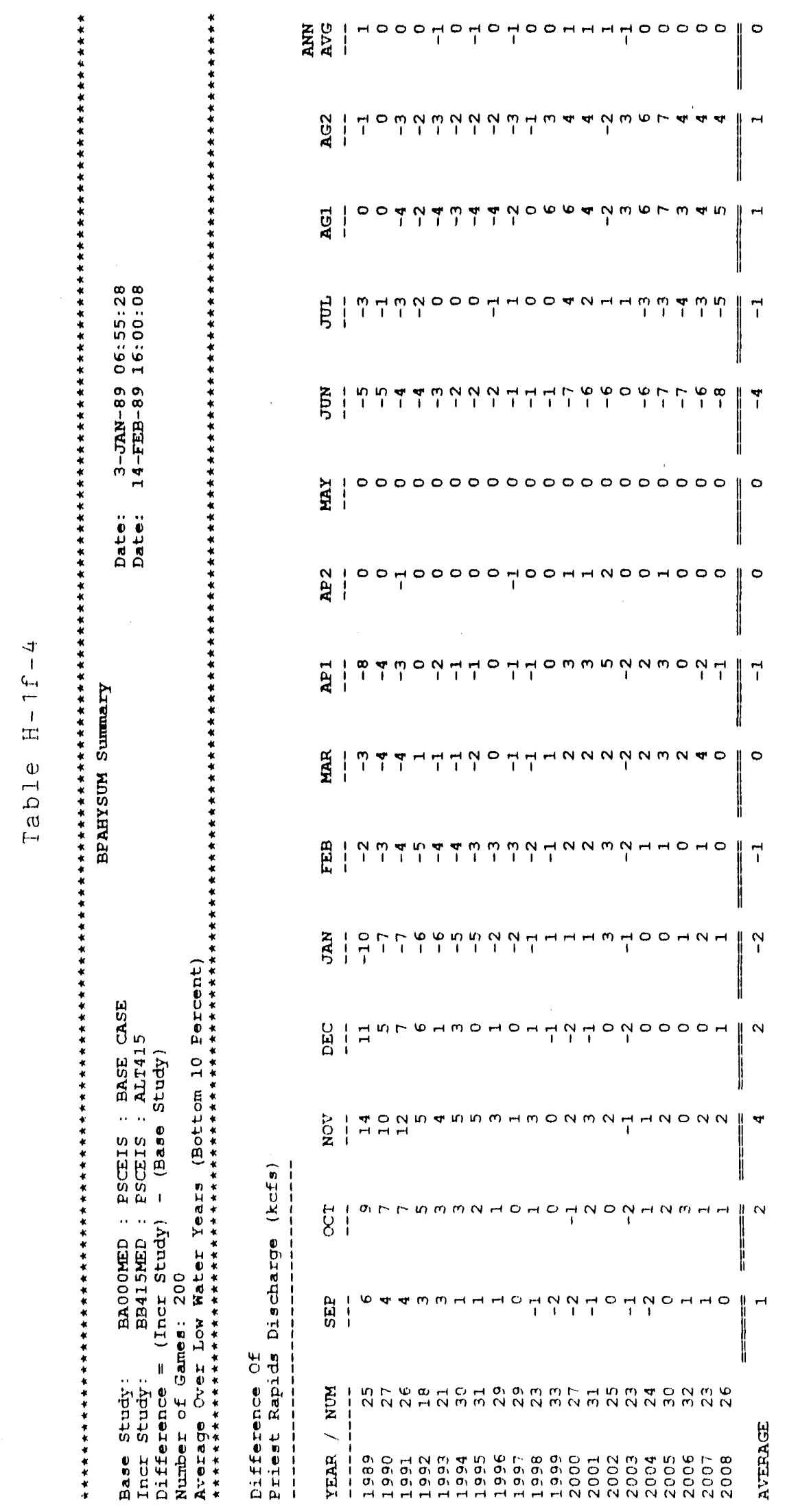




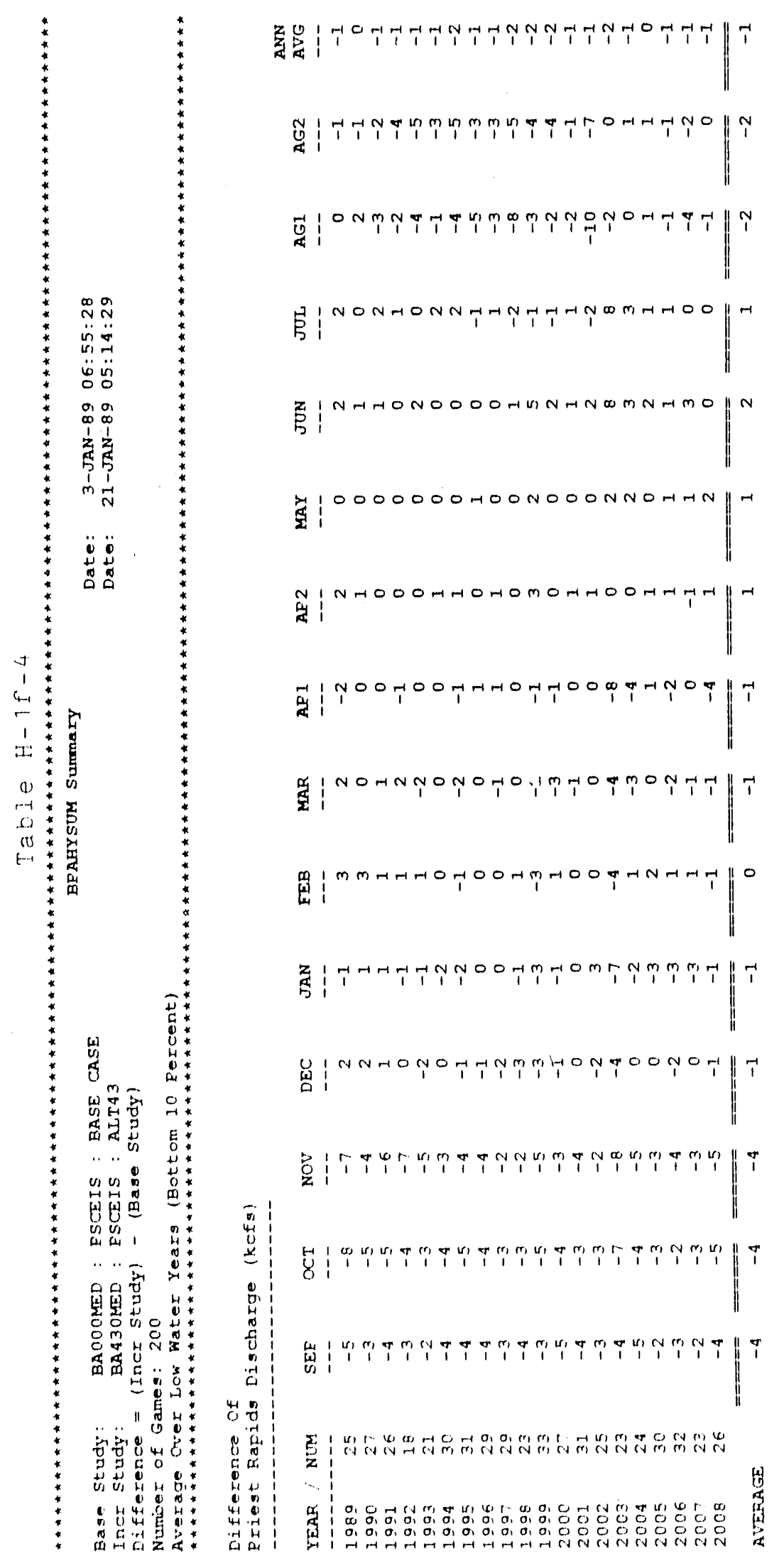




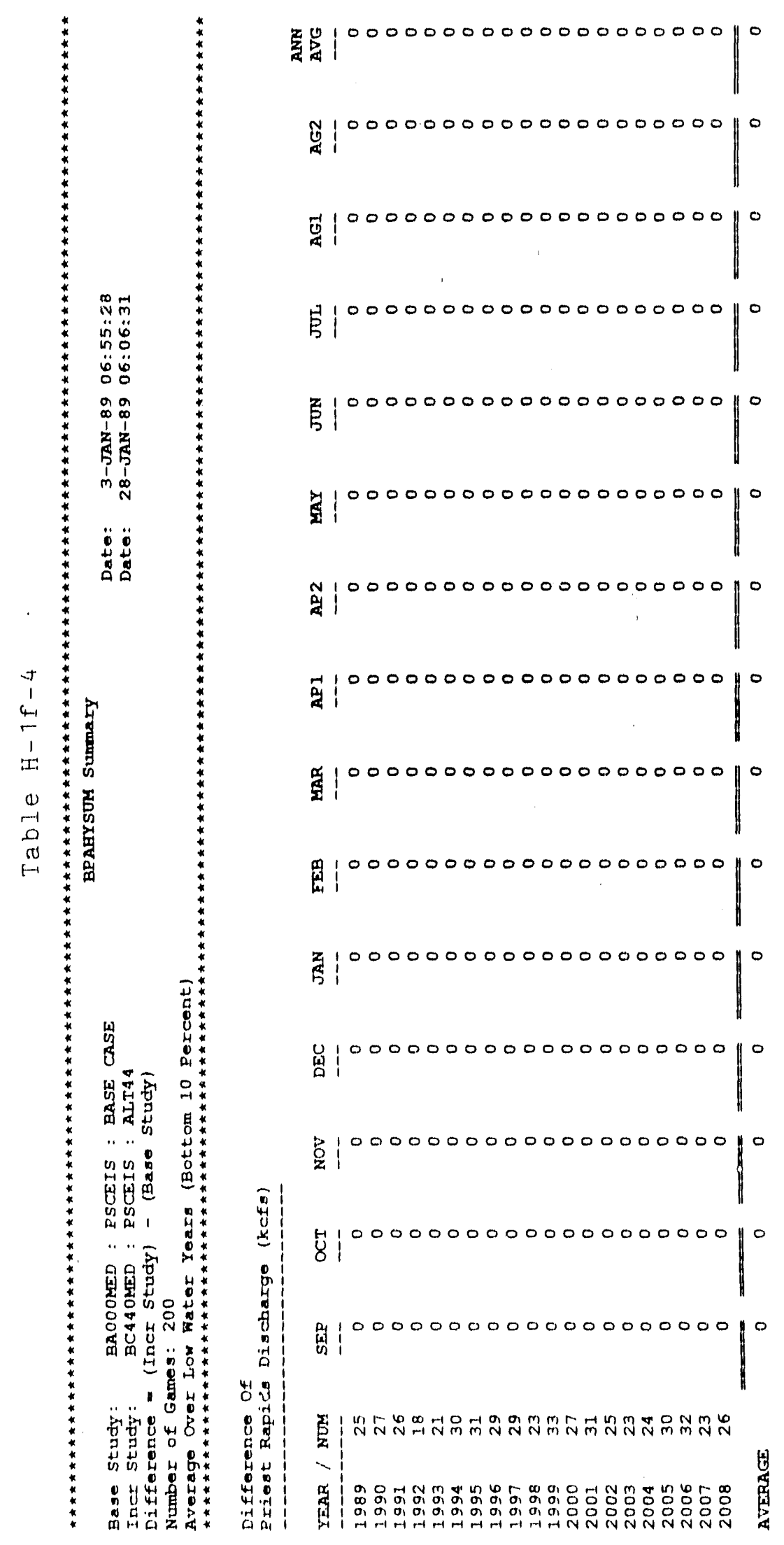

$$
H-1 \rho-\rho 4
$$




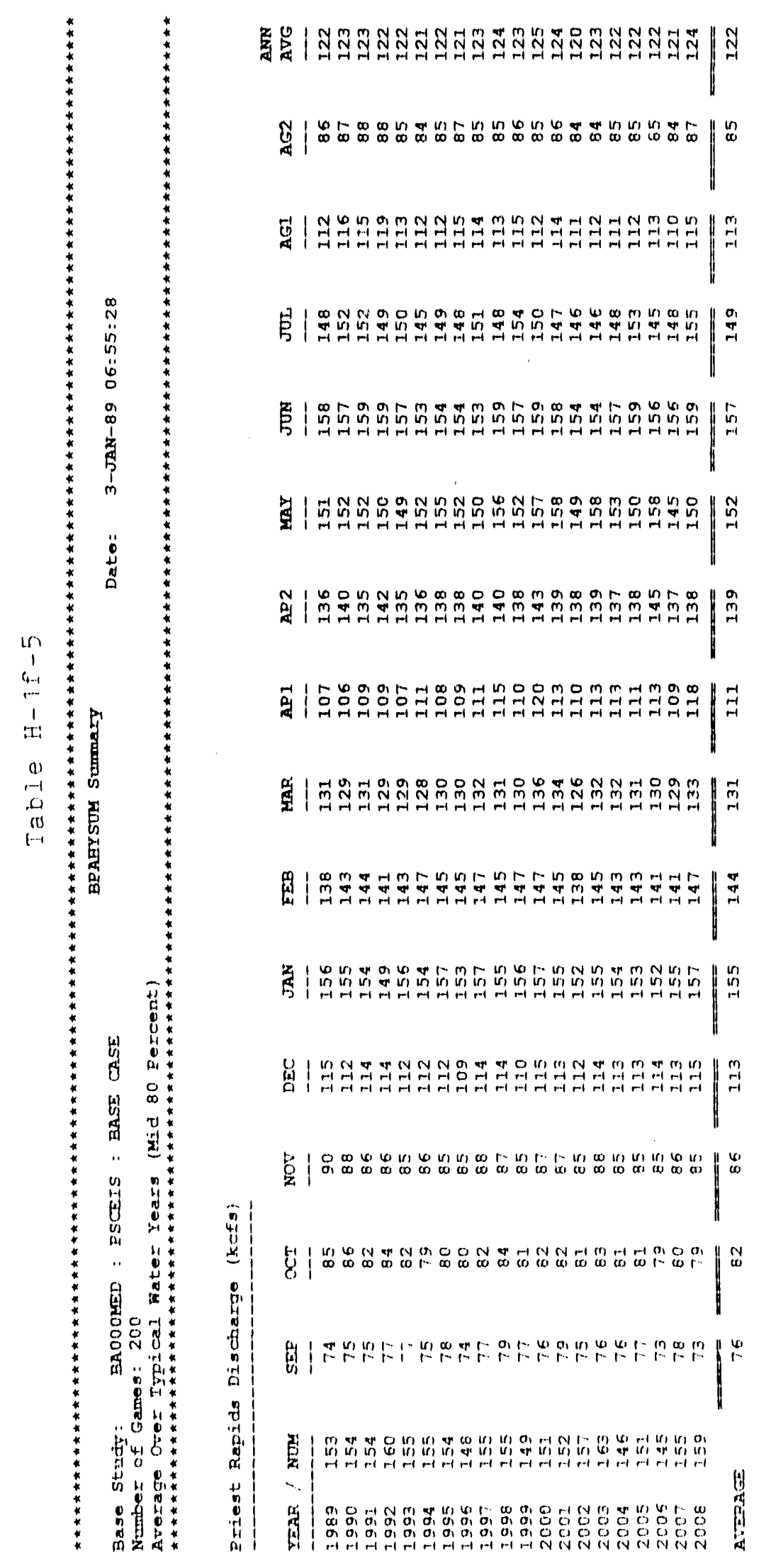




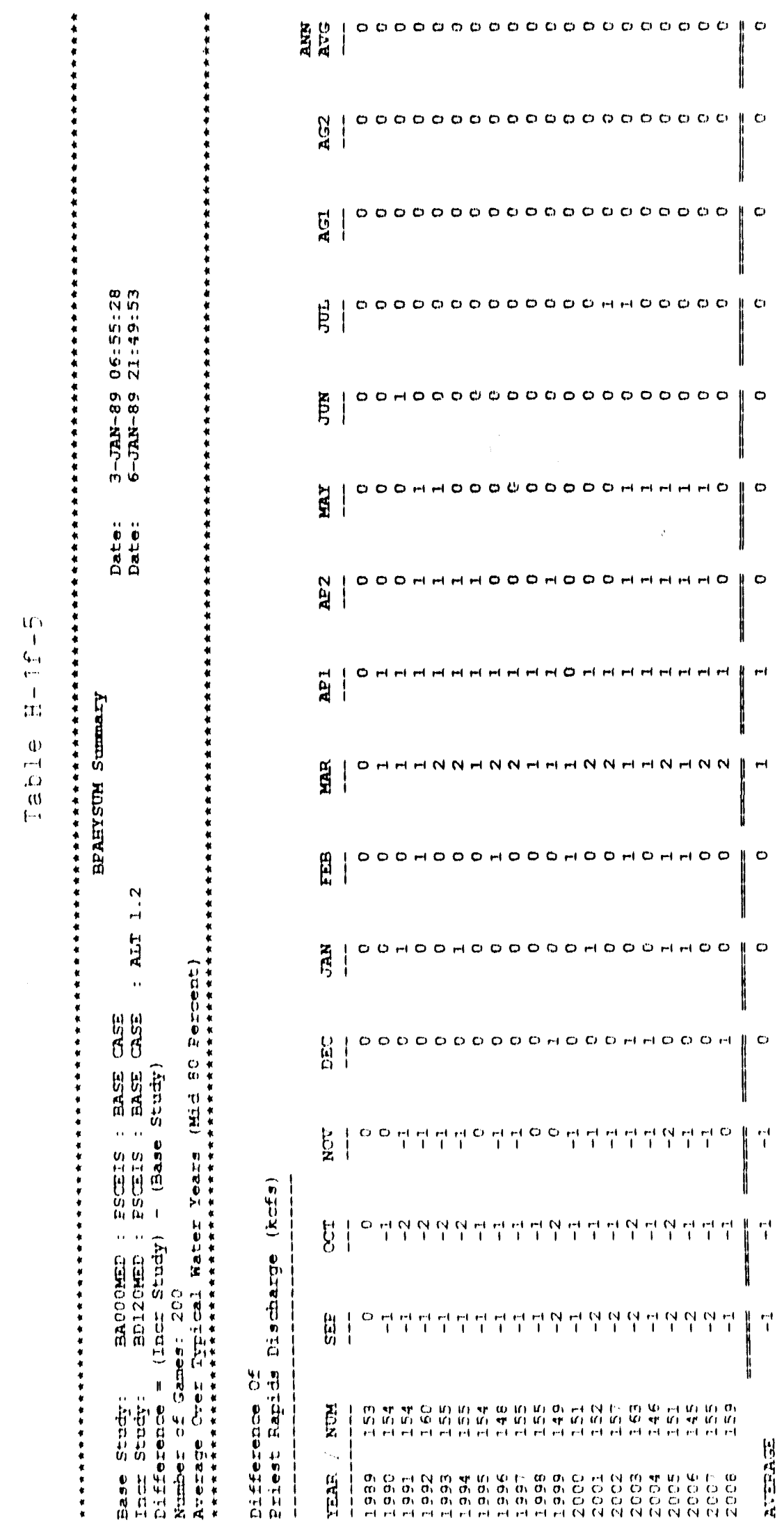




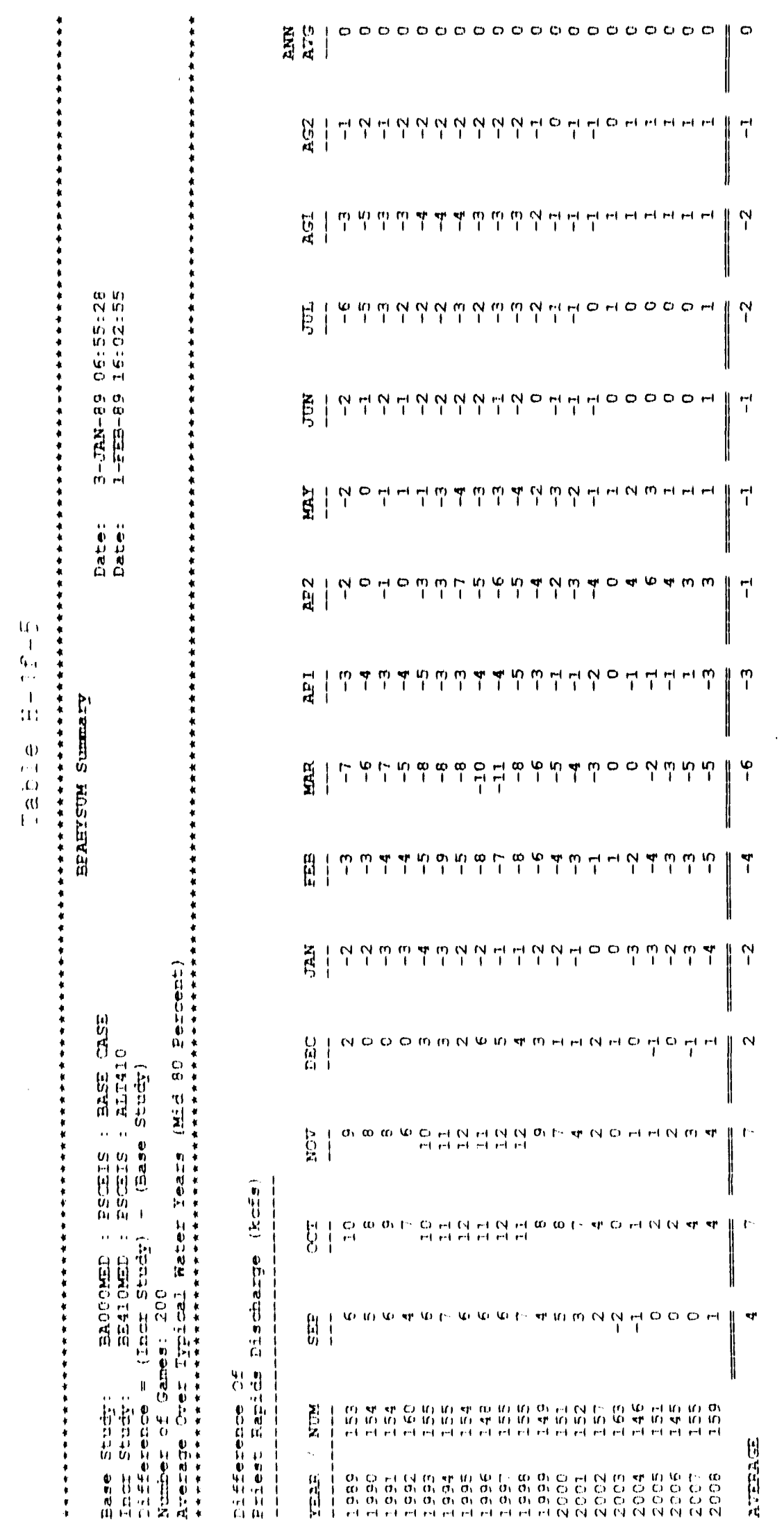

$11-11^{\prime}-.17$ 


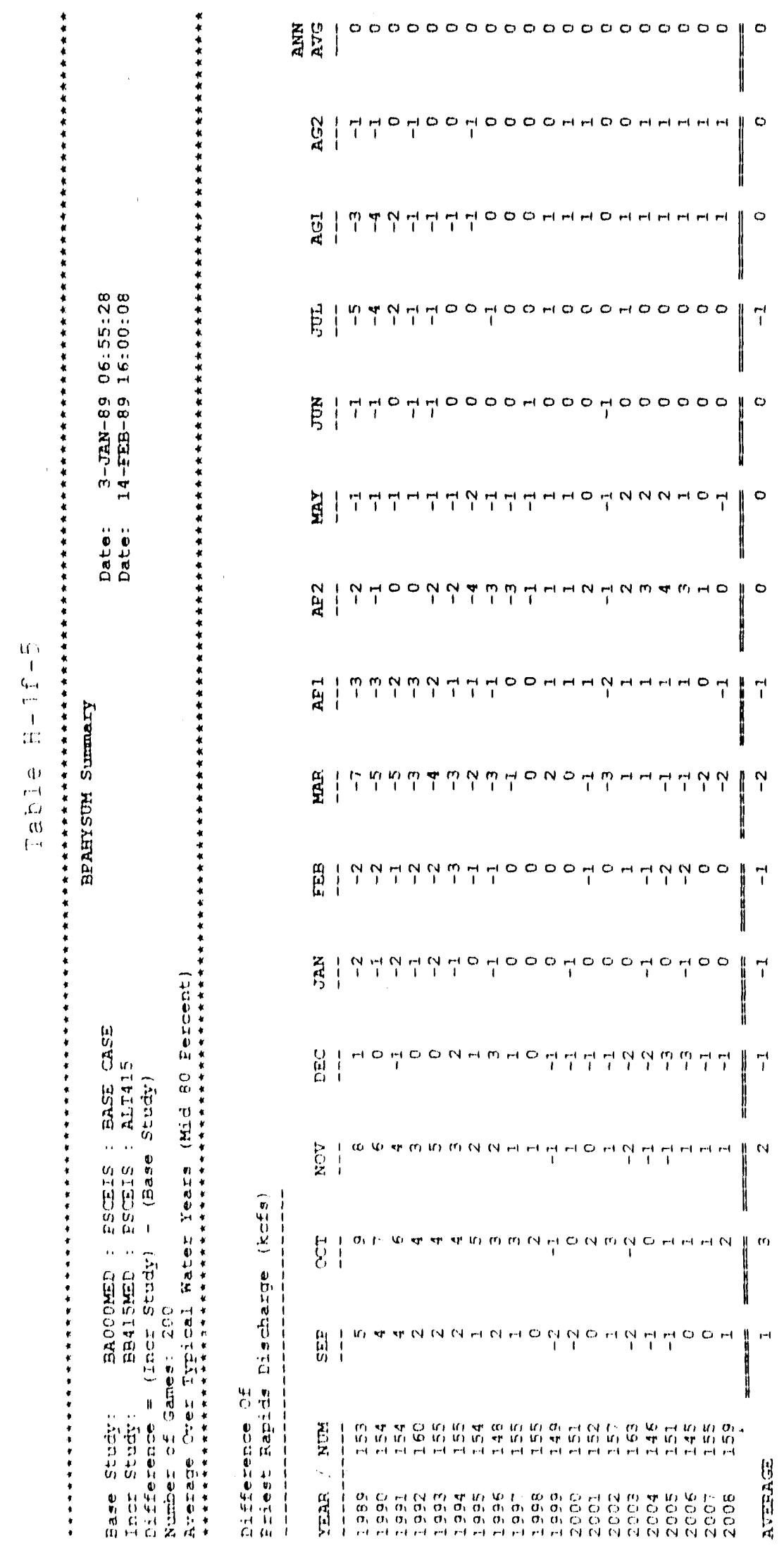




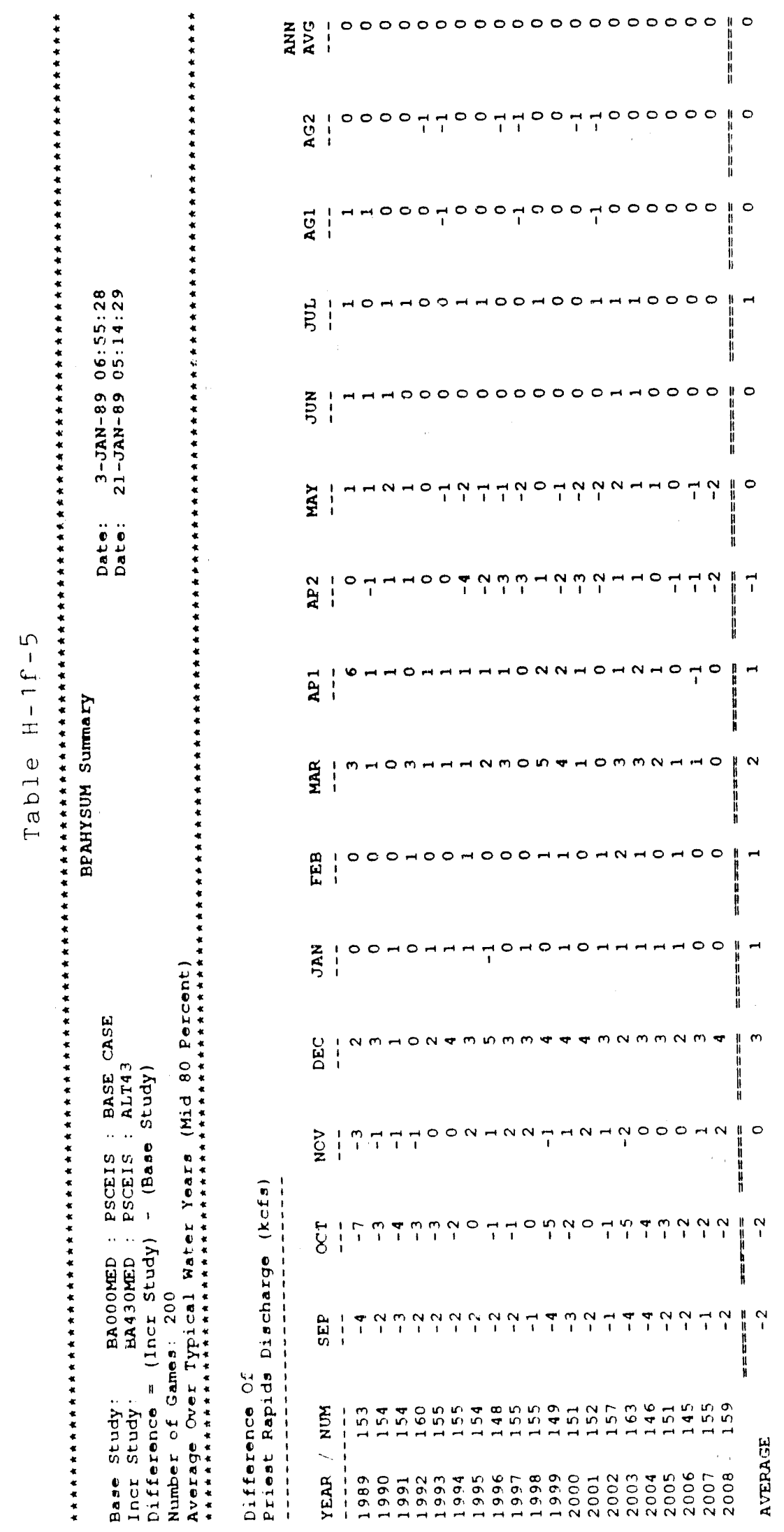




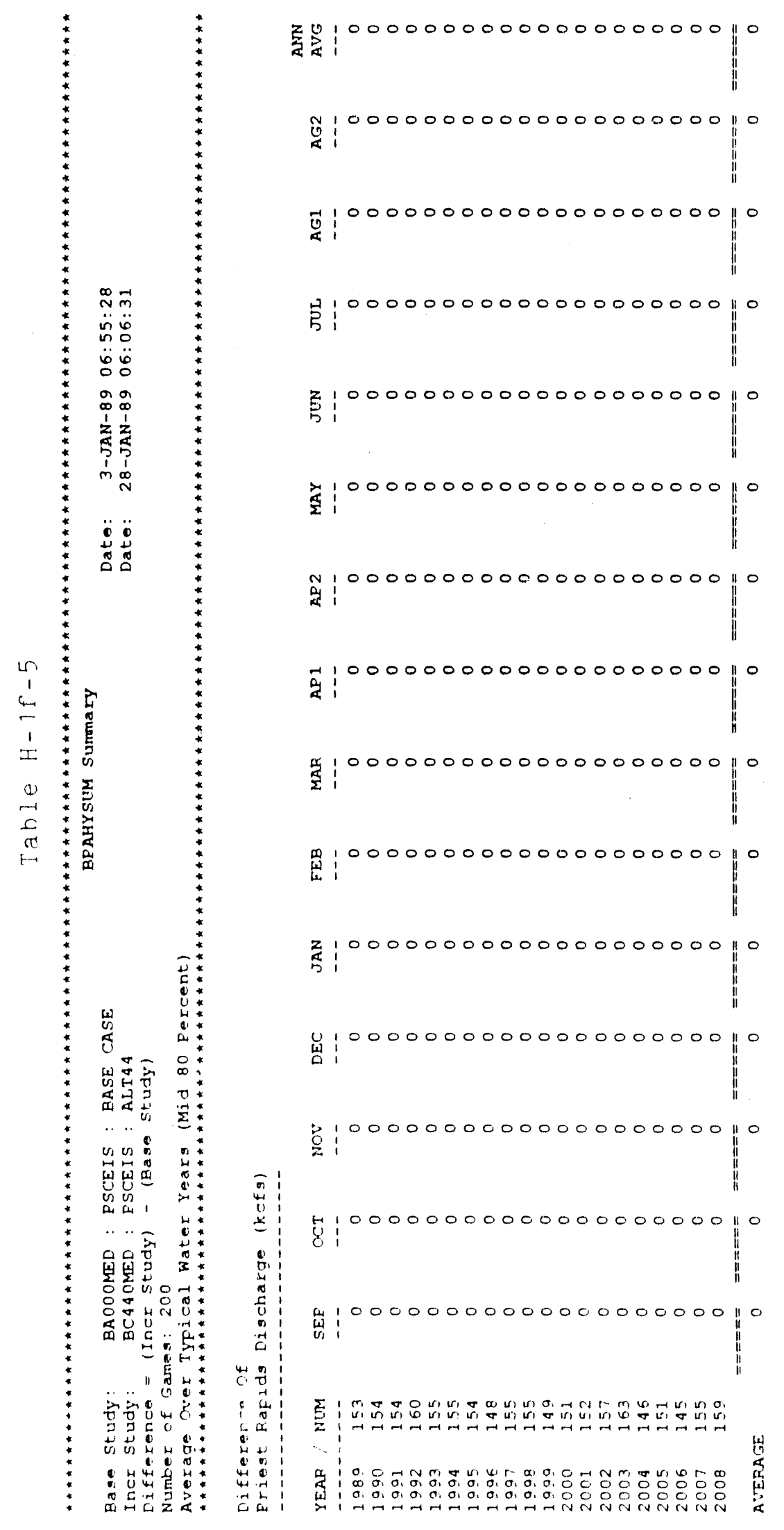




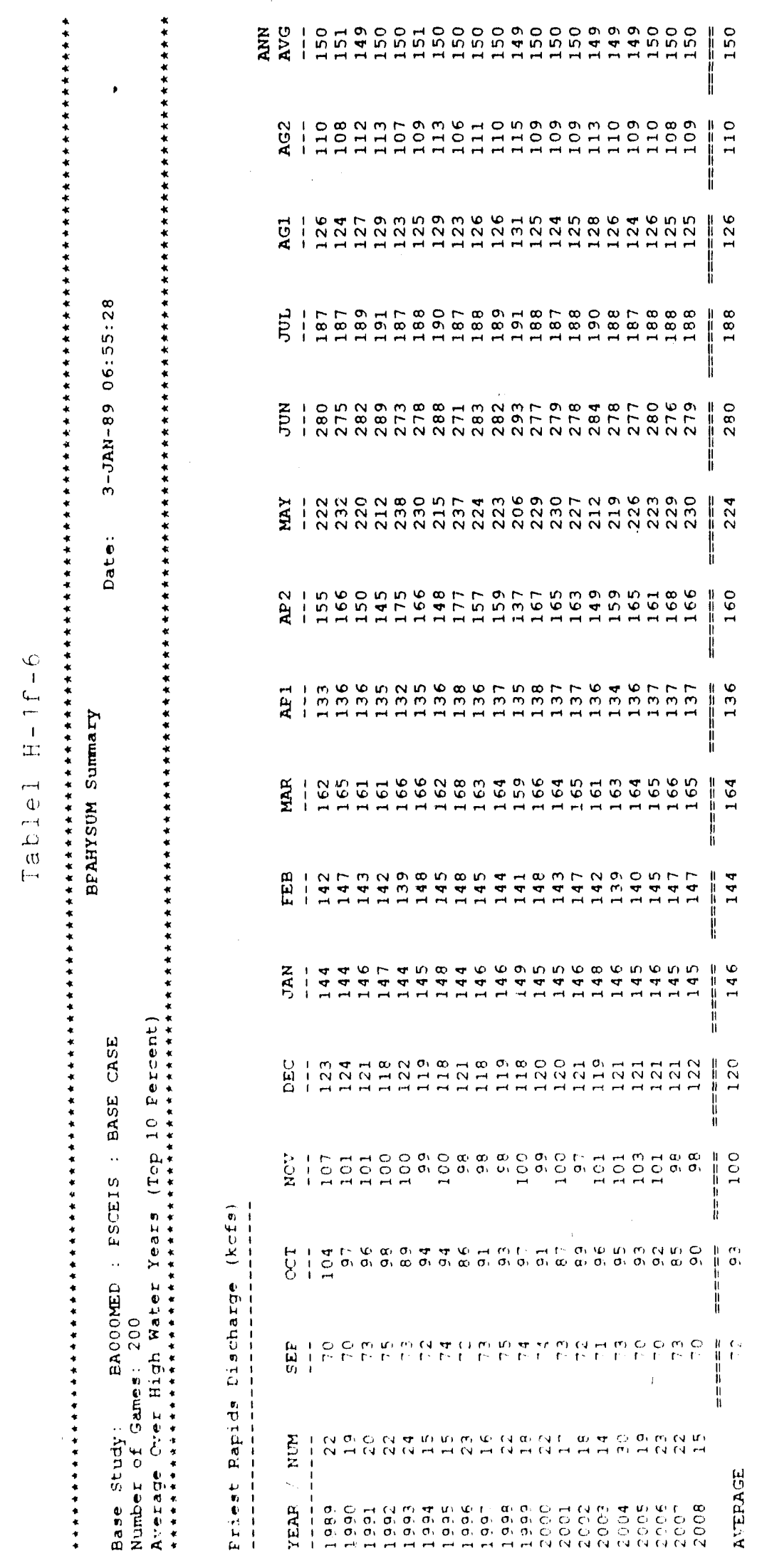




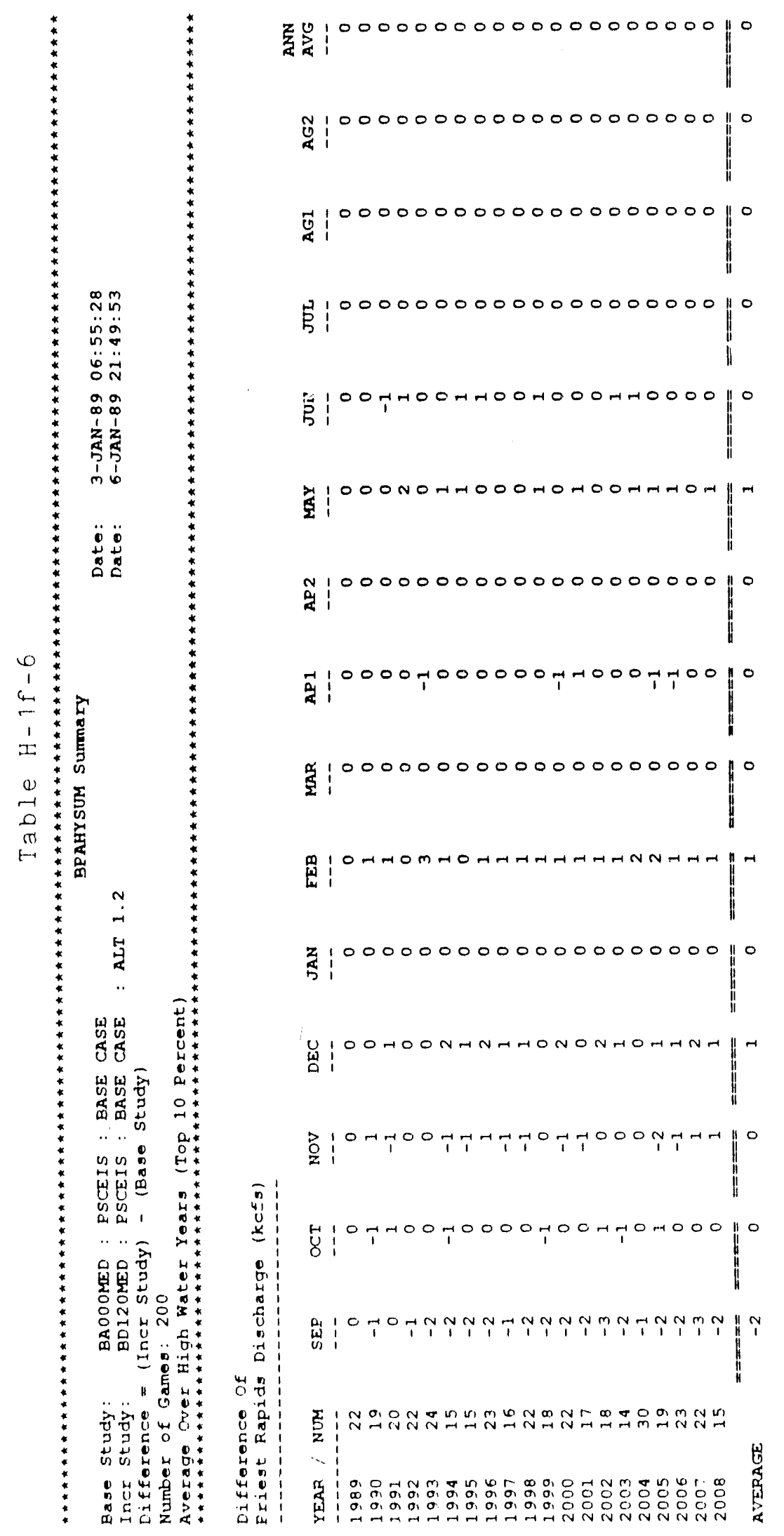




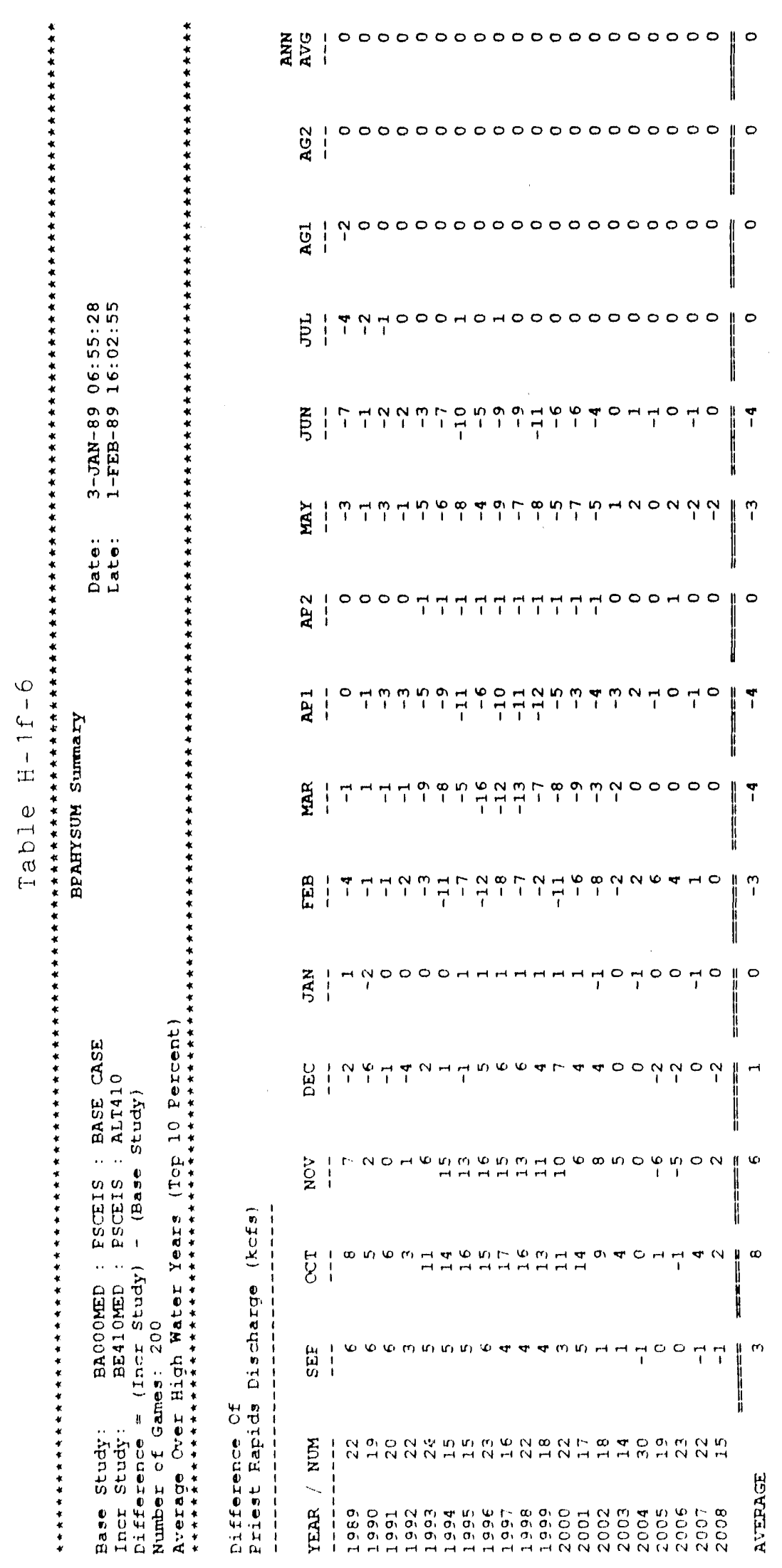




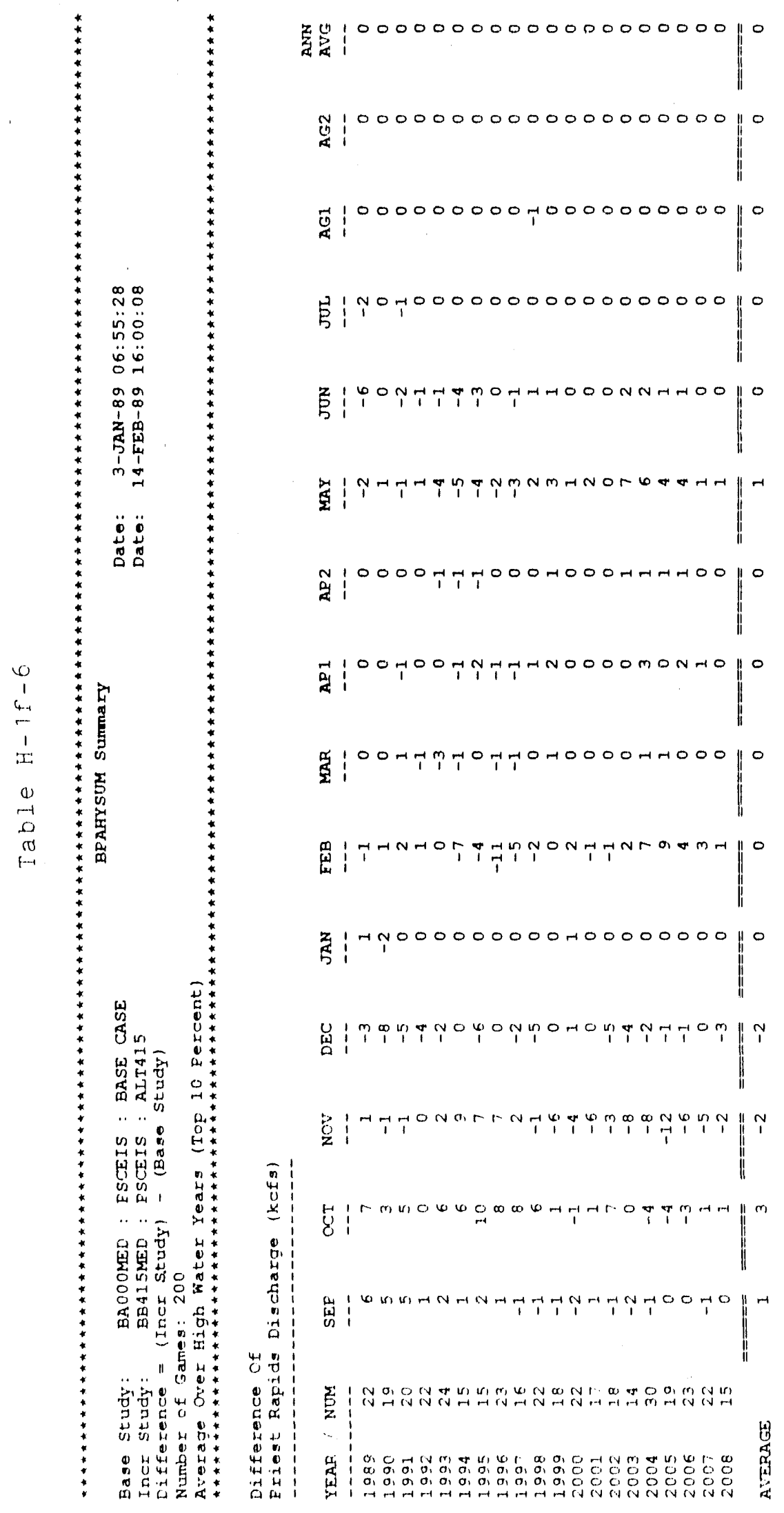




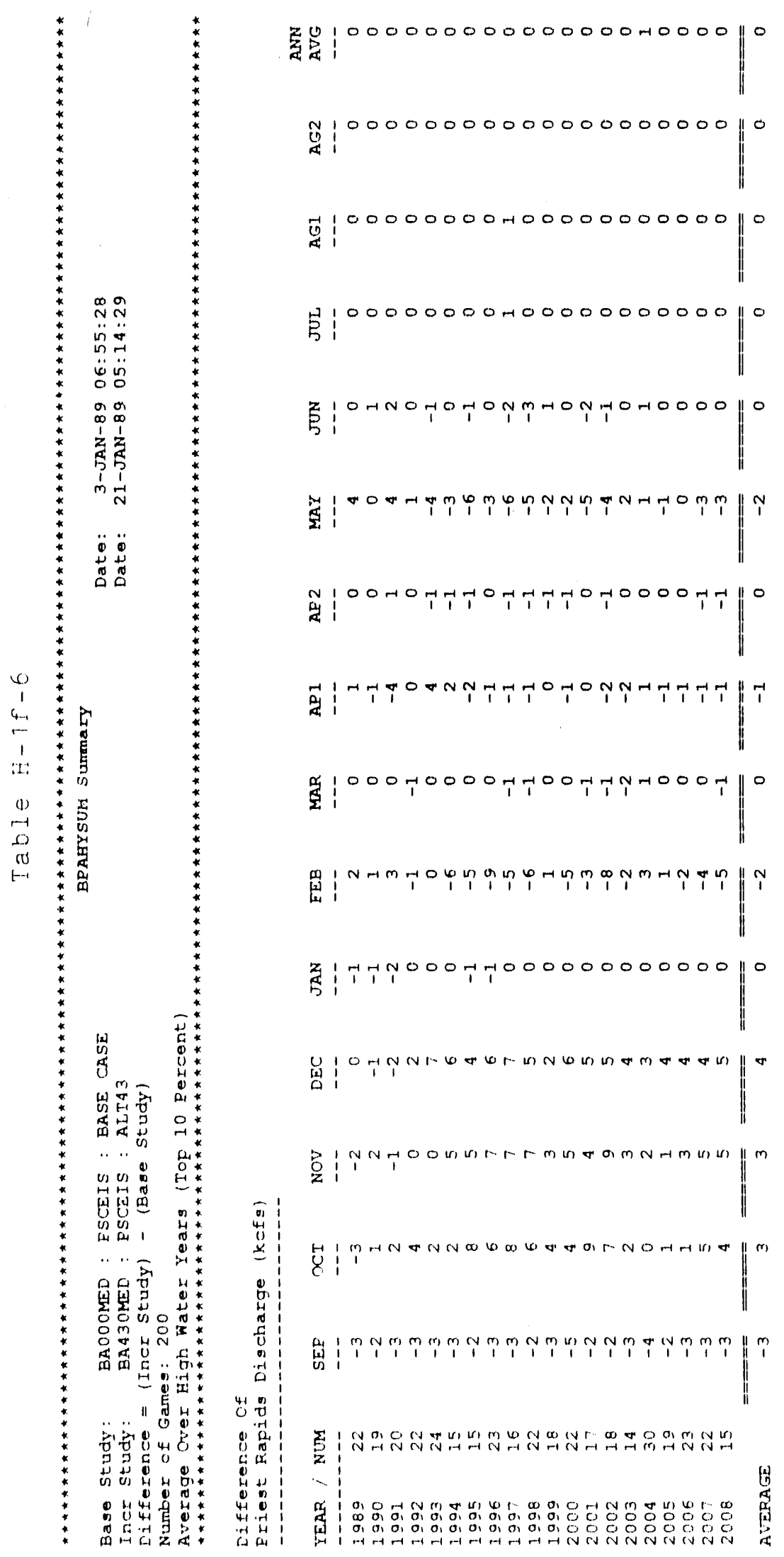




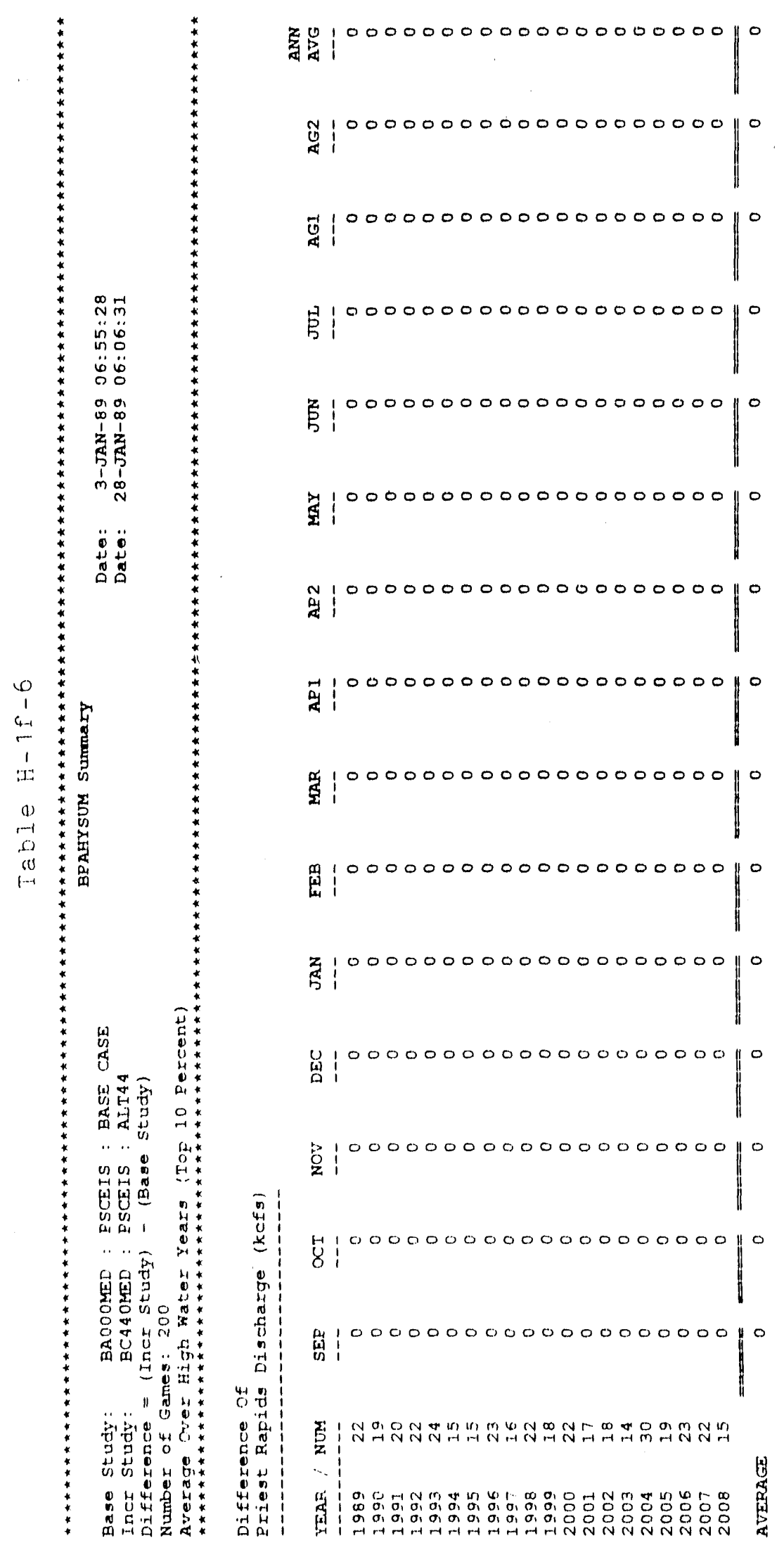




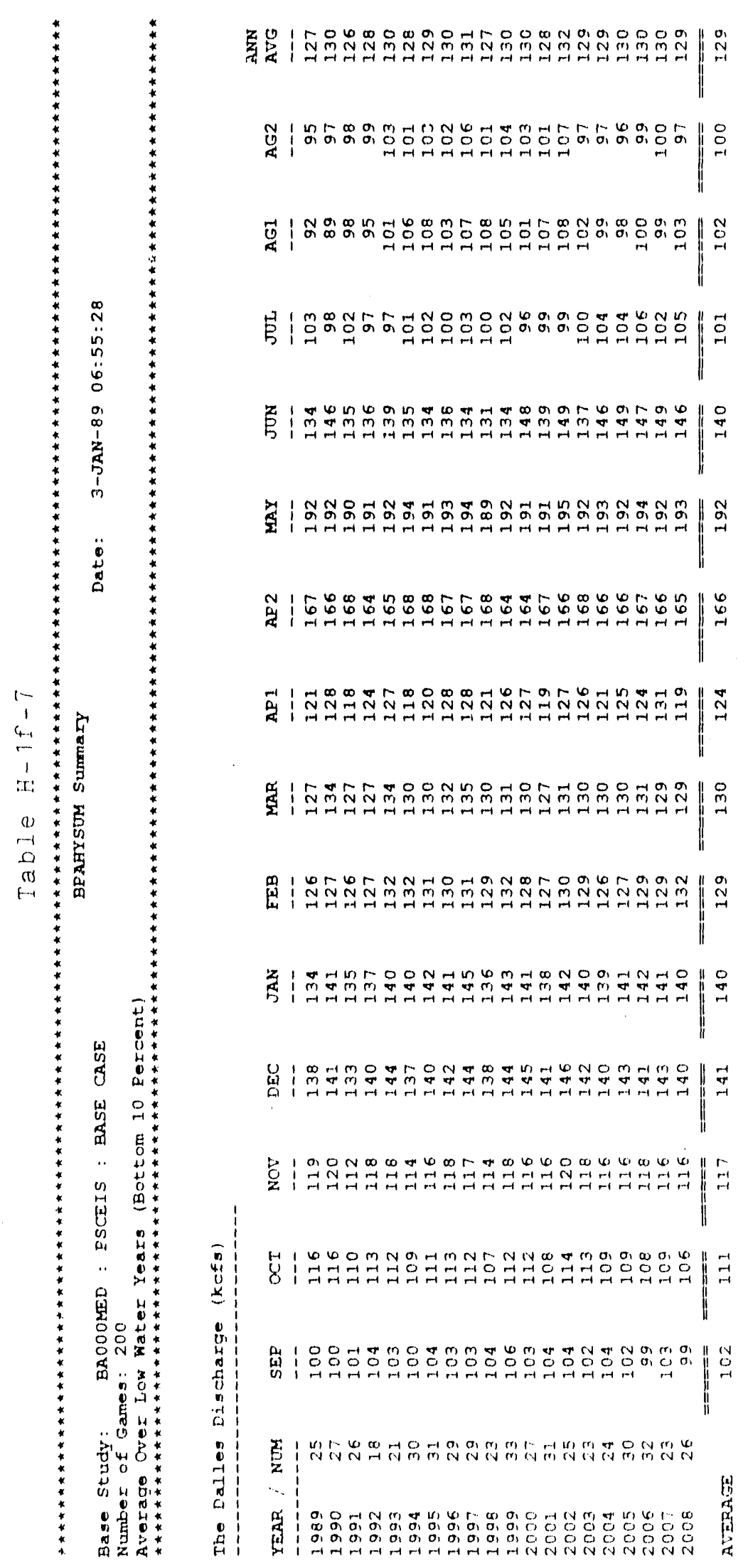




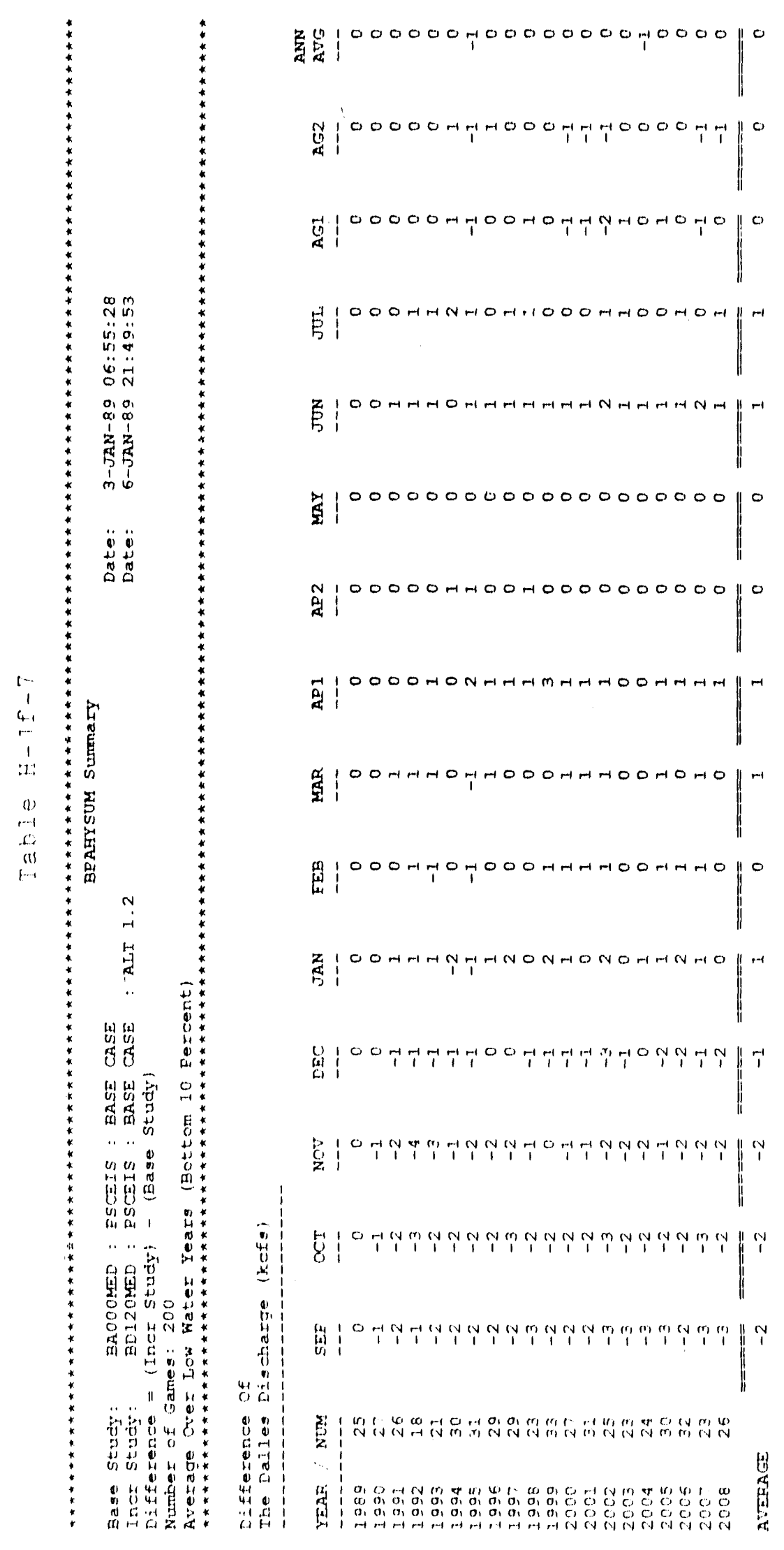

$11-11^{\prime}-38$ 


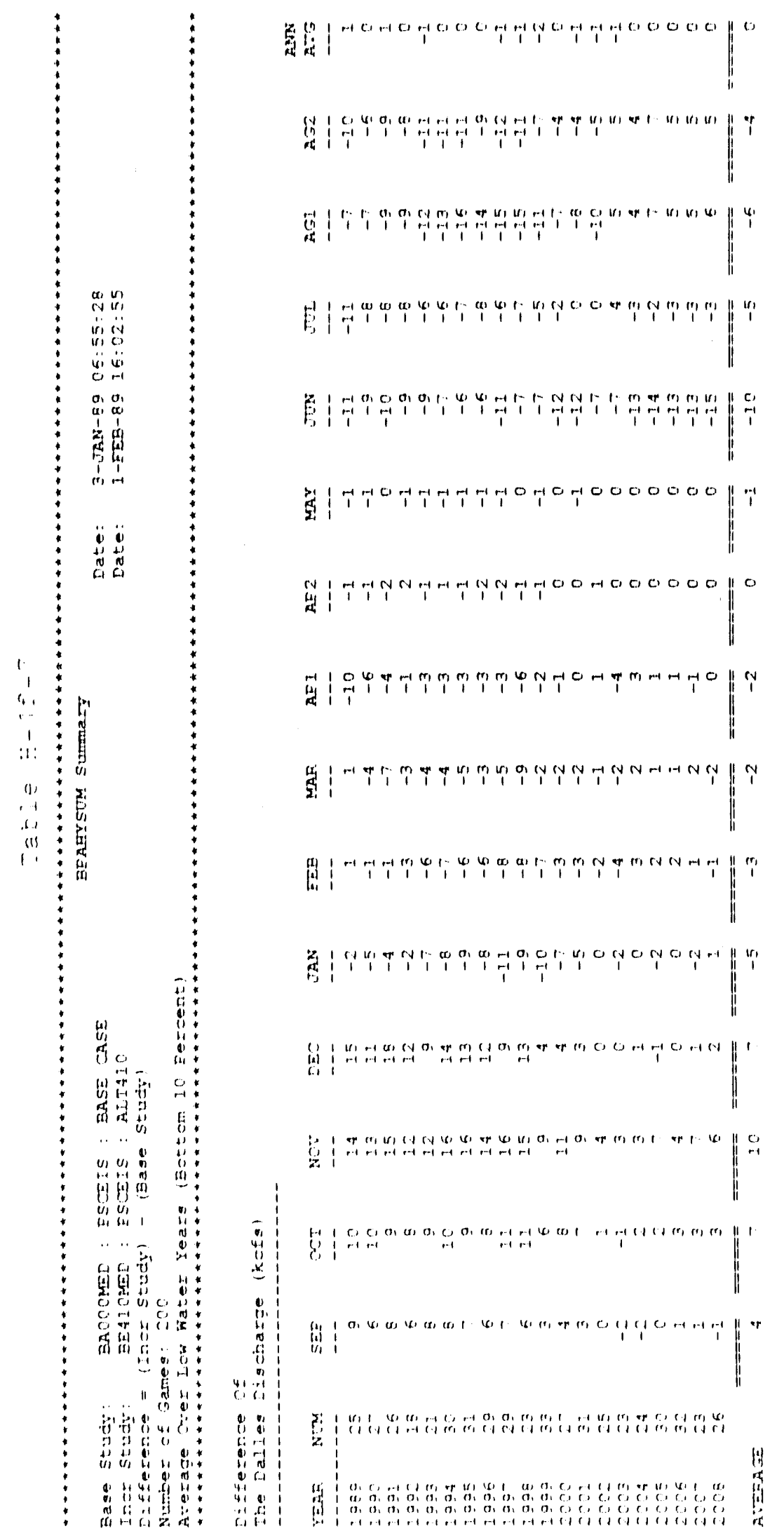




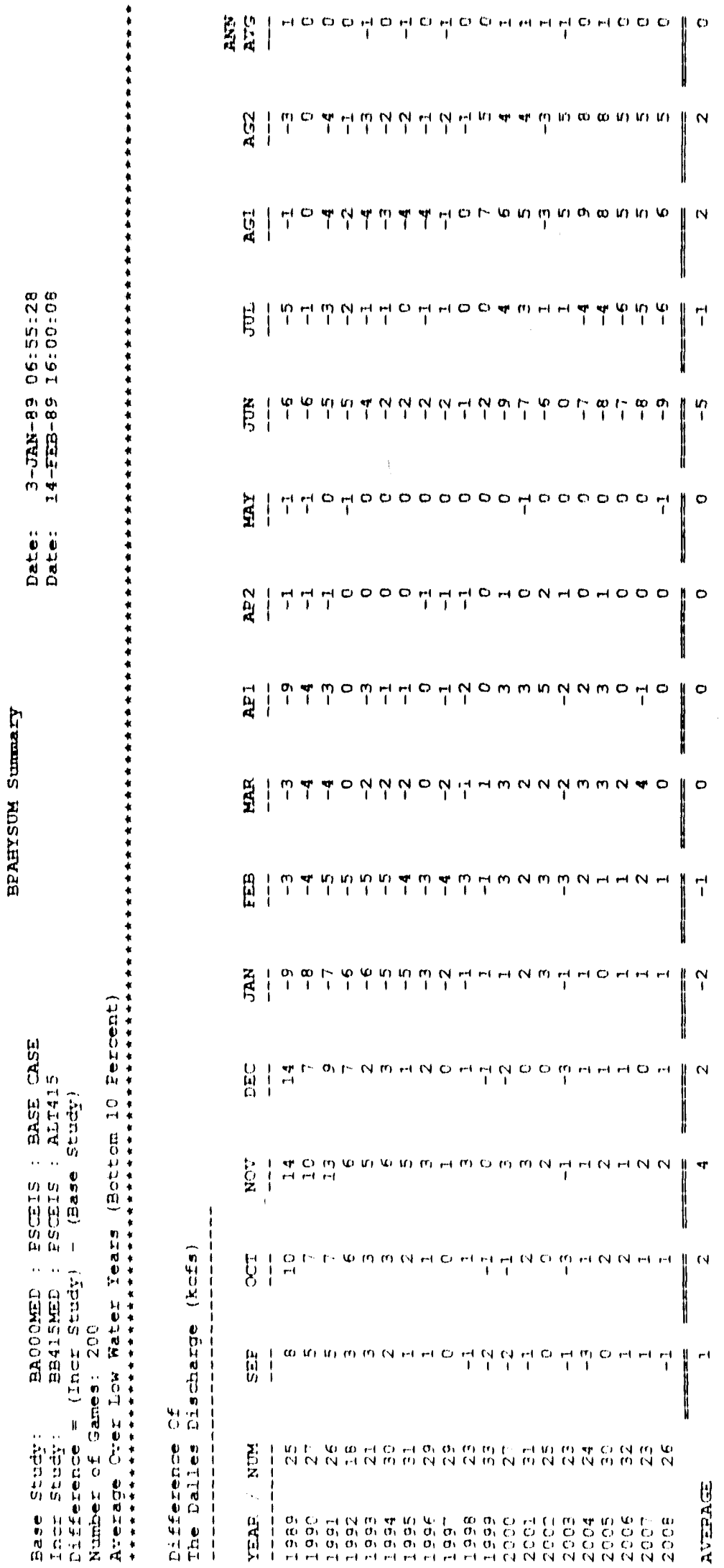




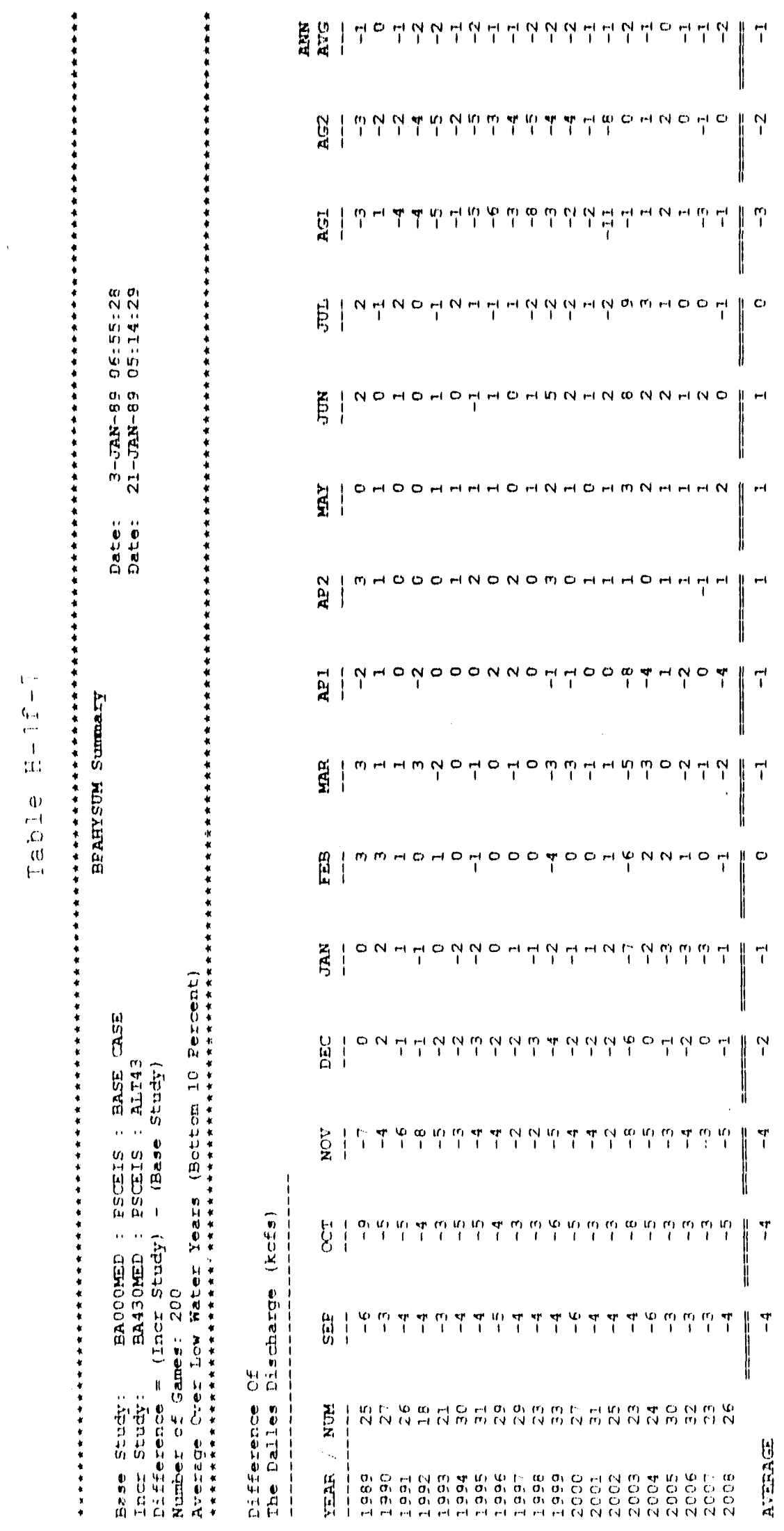




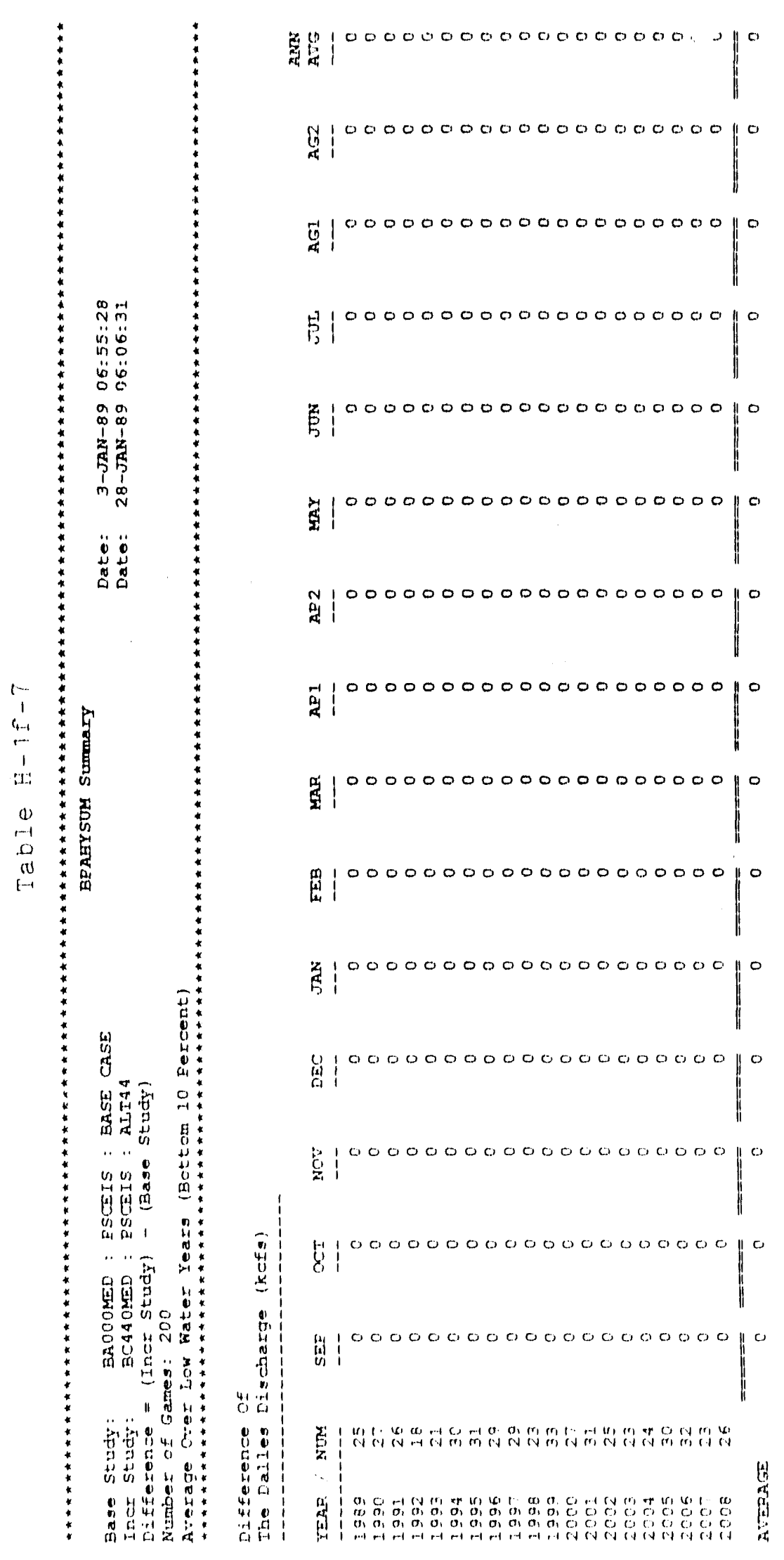




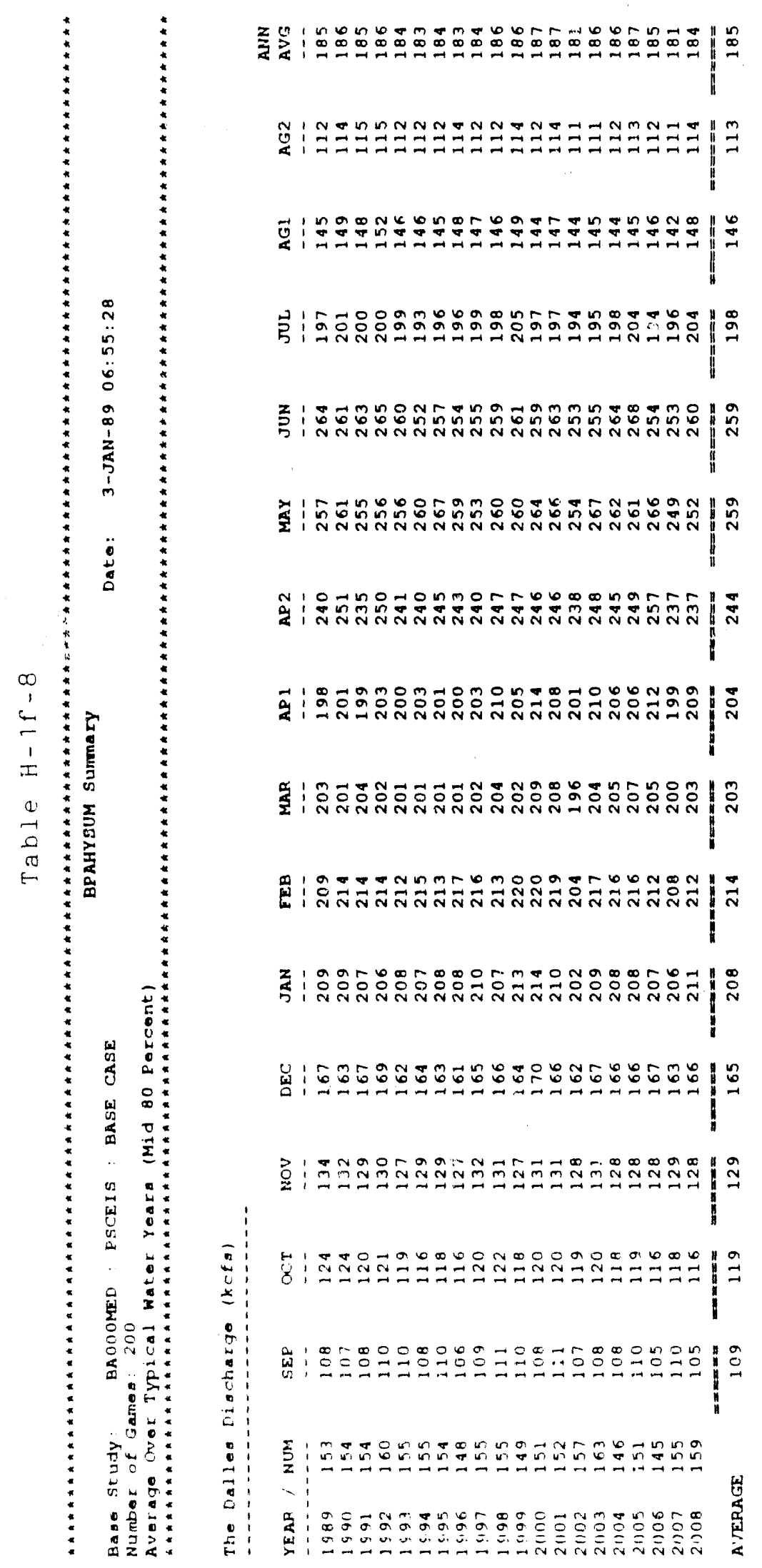




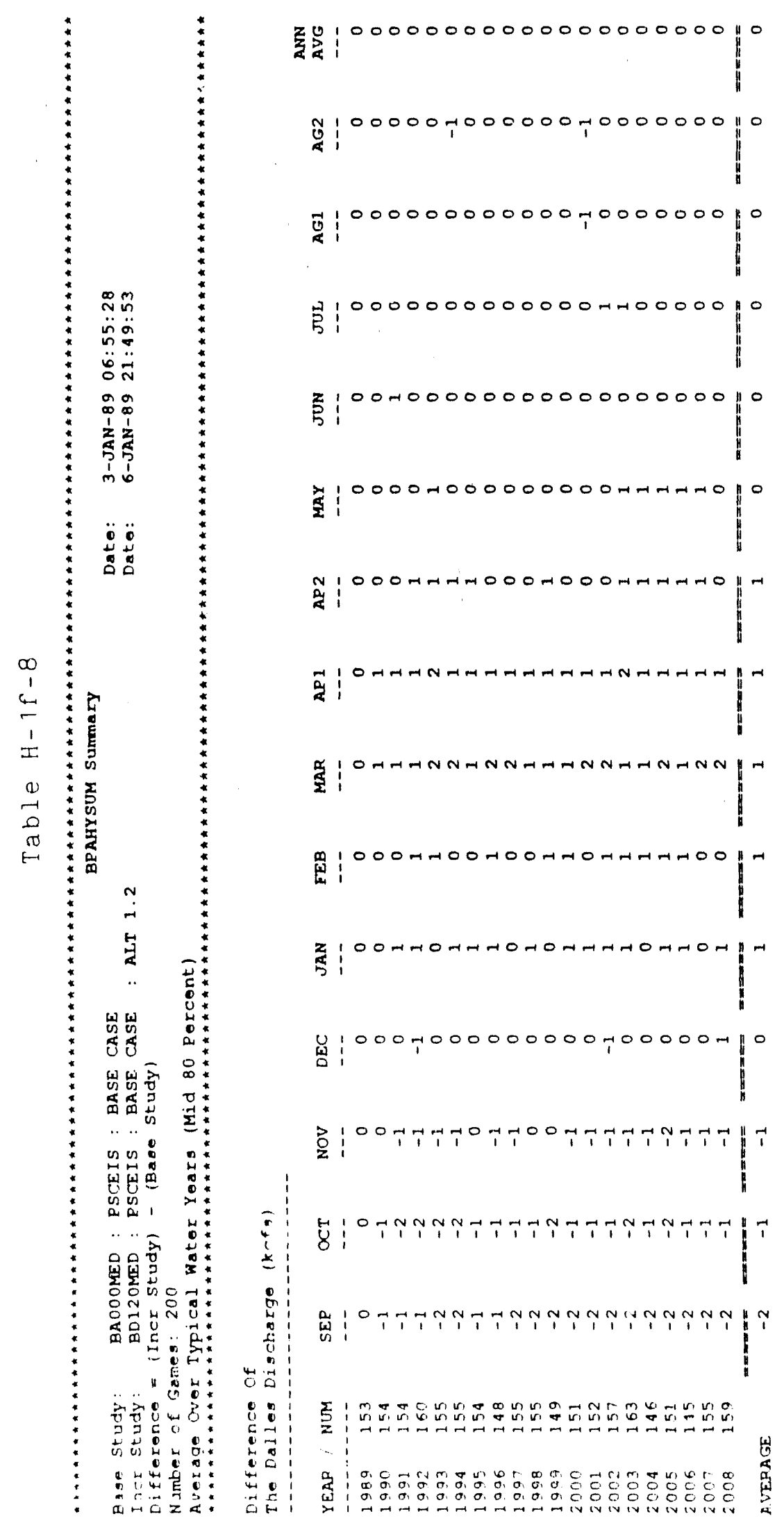




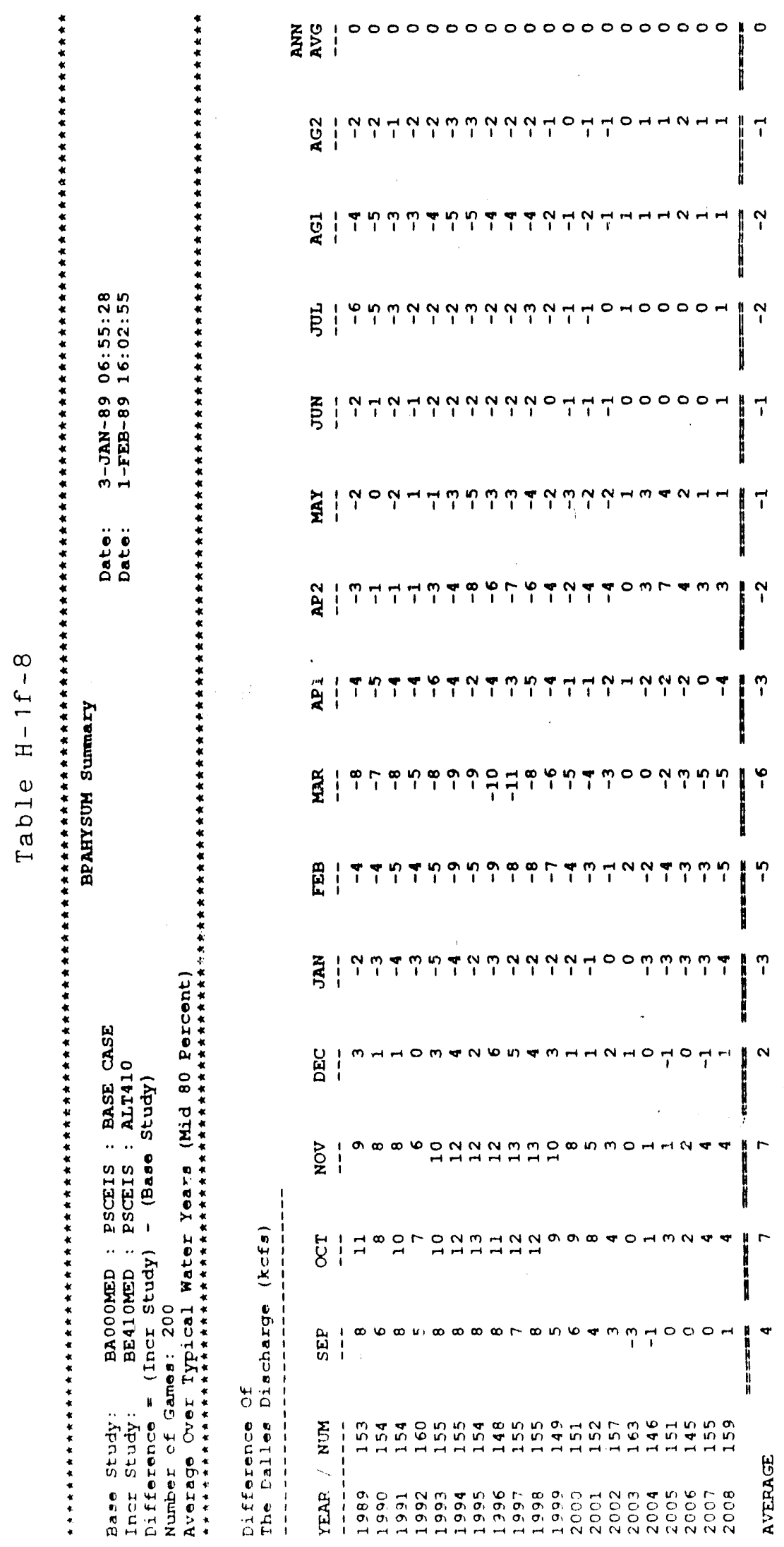

$H-1 f-45$ 


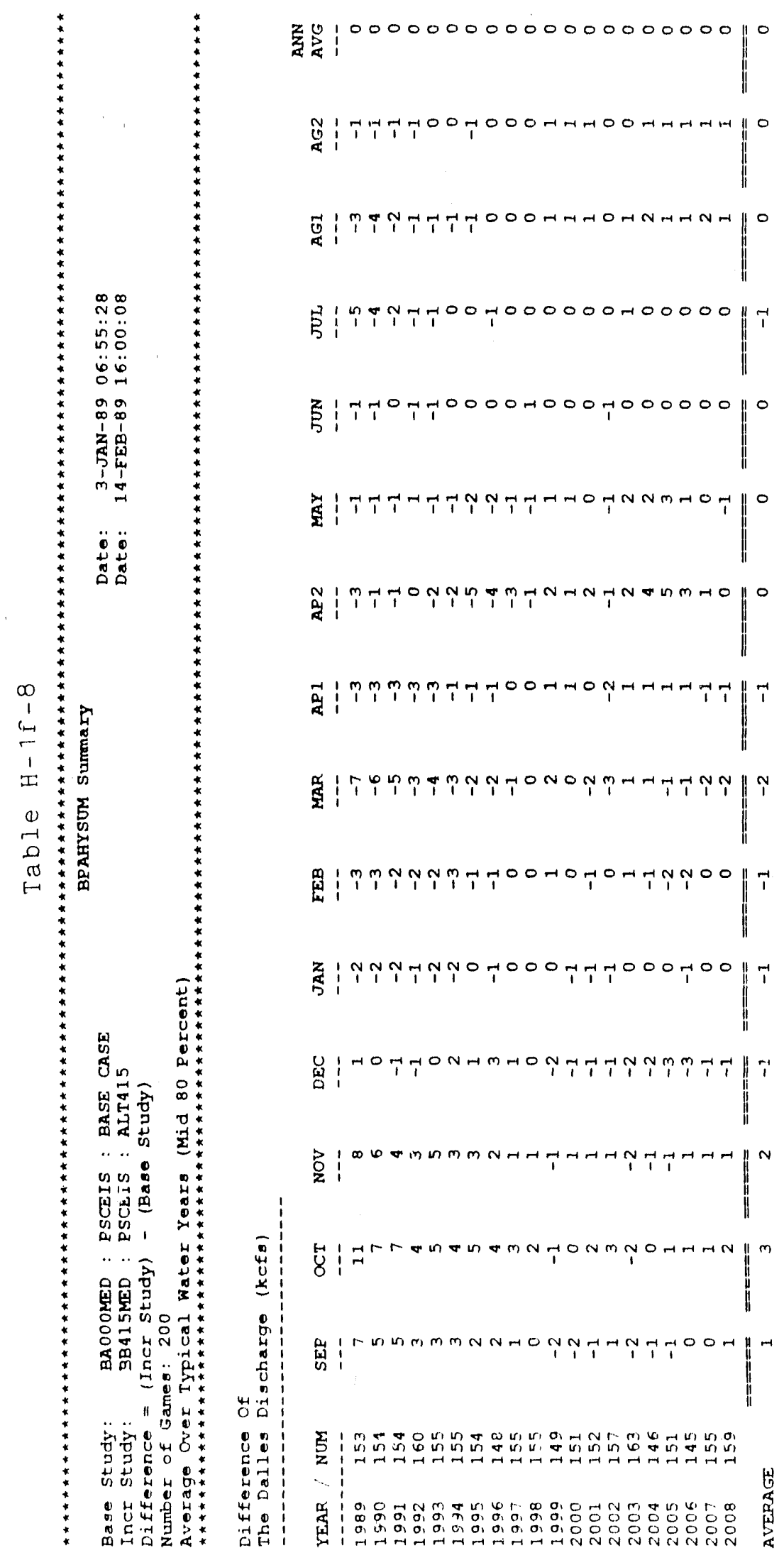




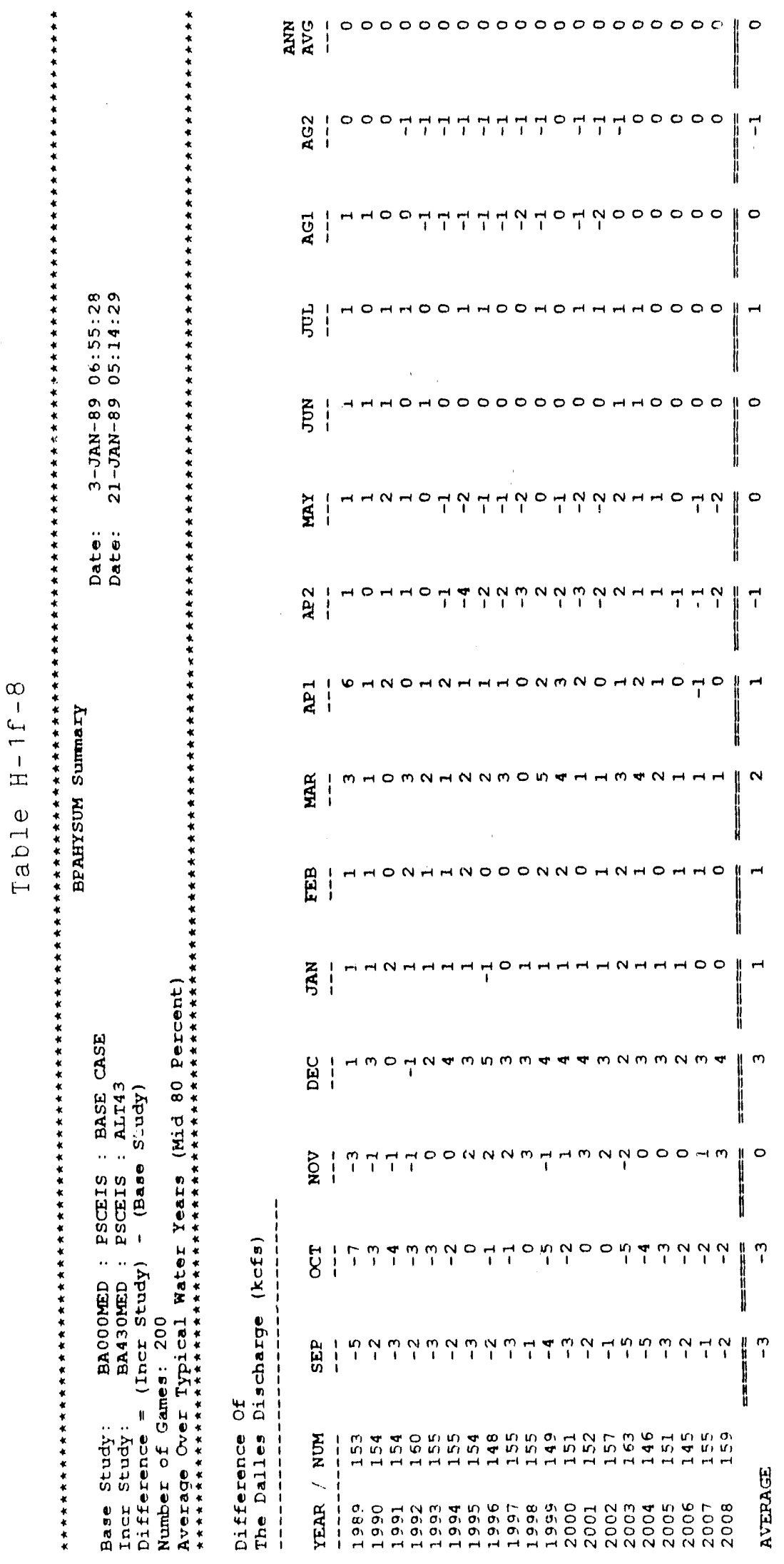




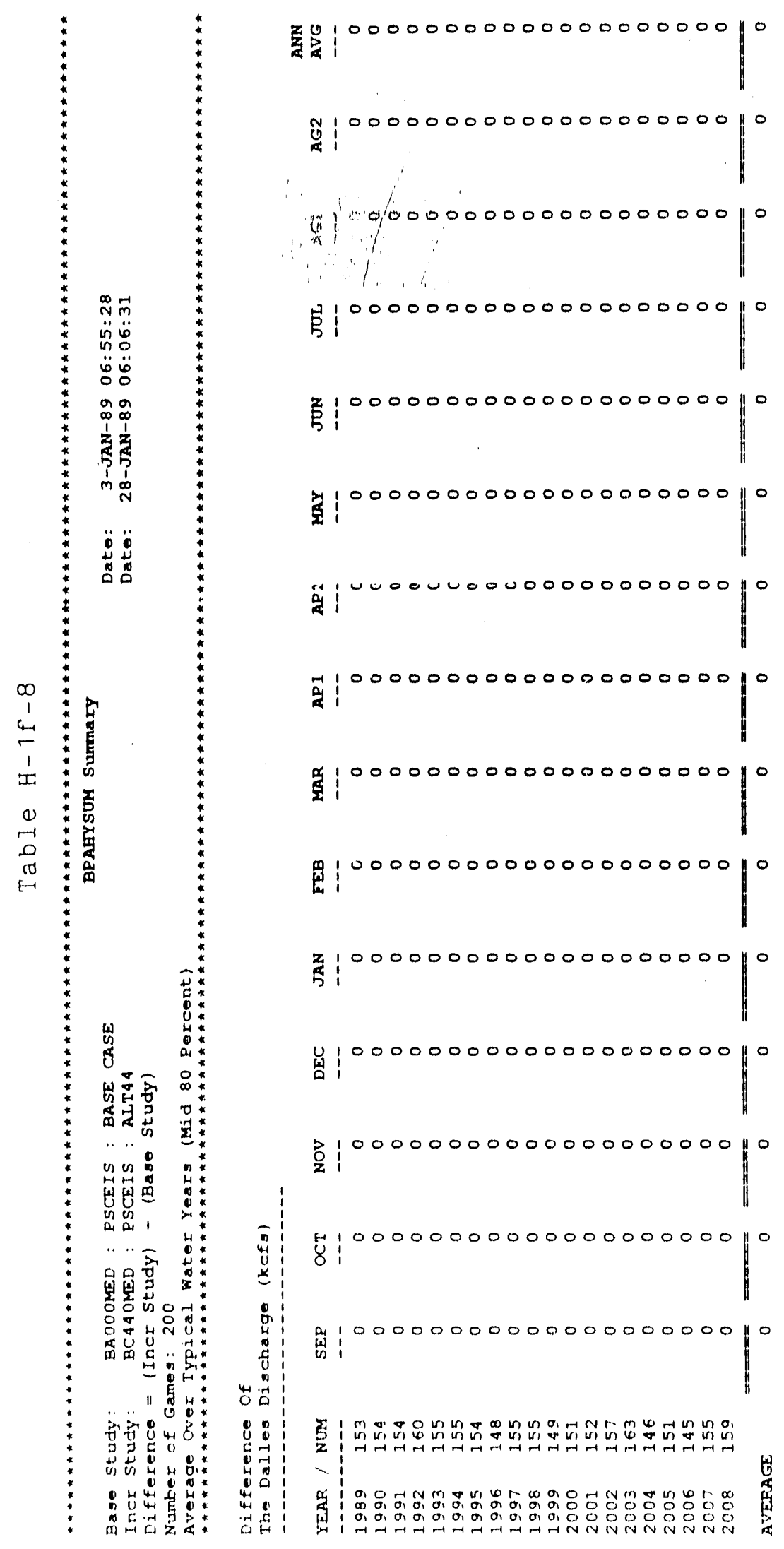

$H-1 f^{\prime}-48$ 


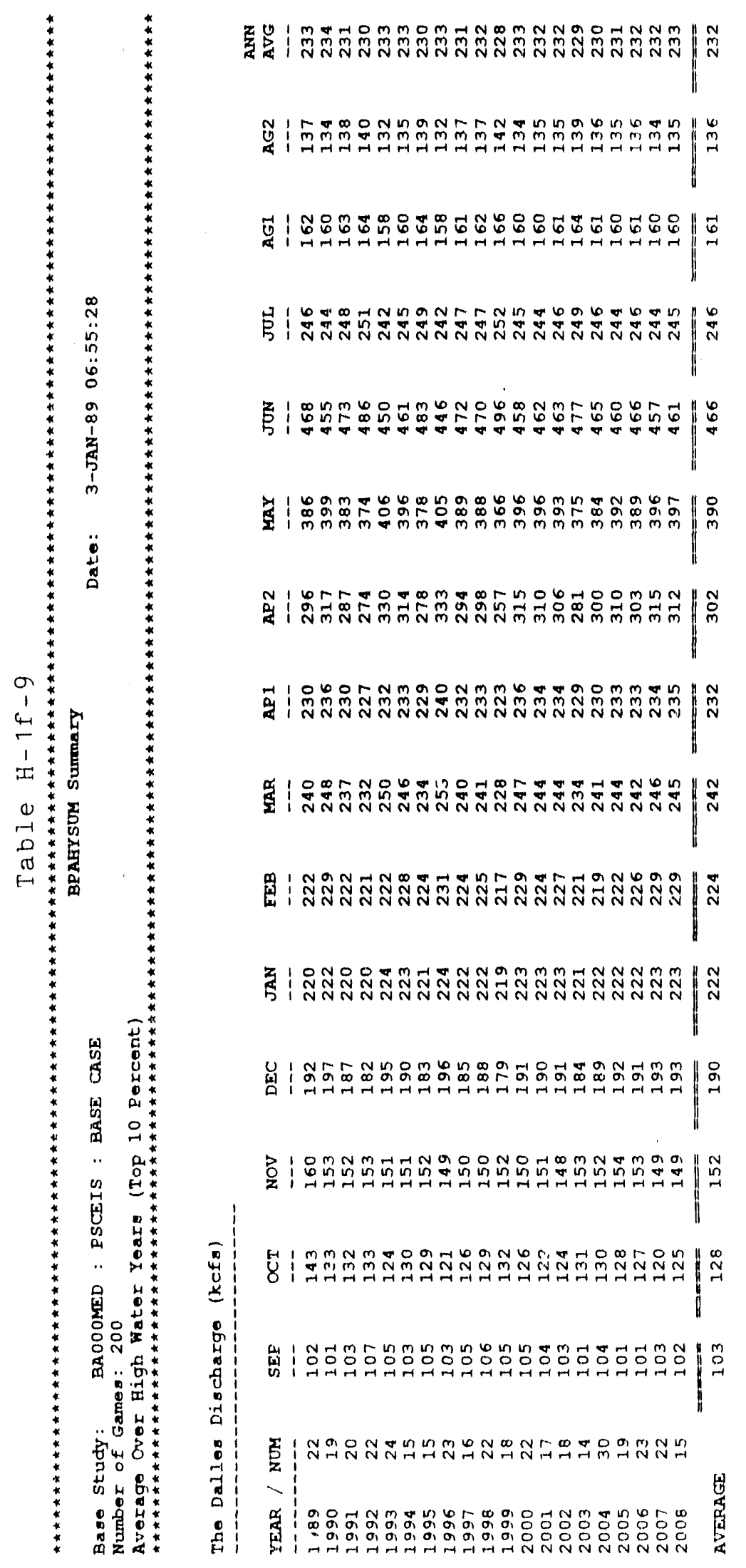




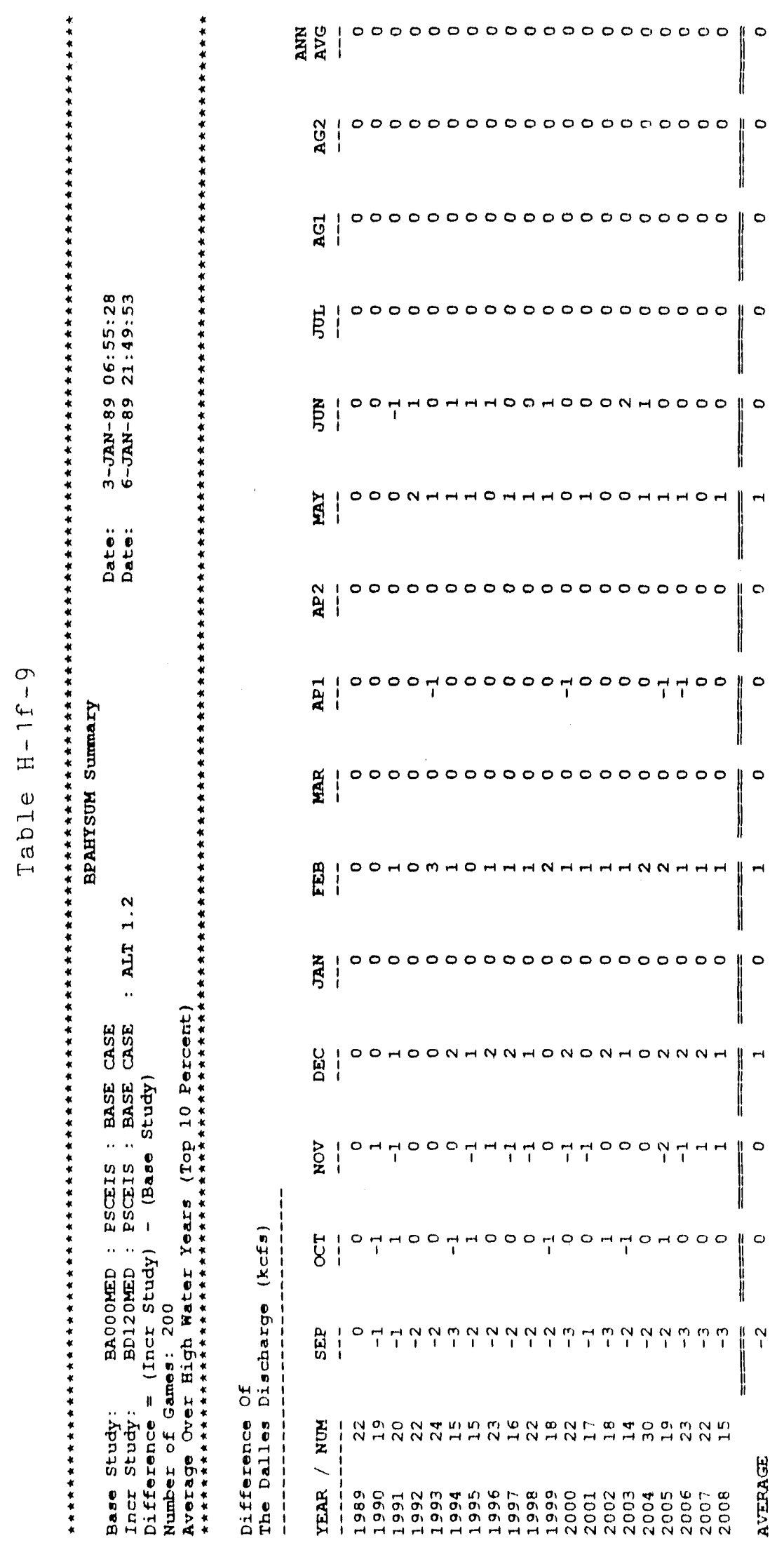




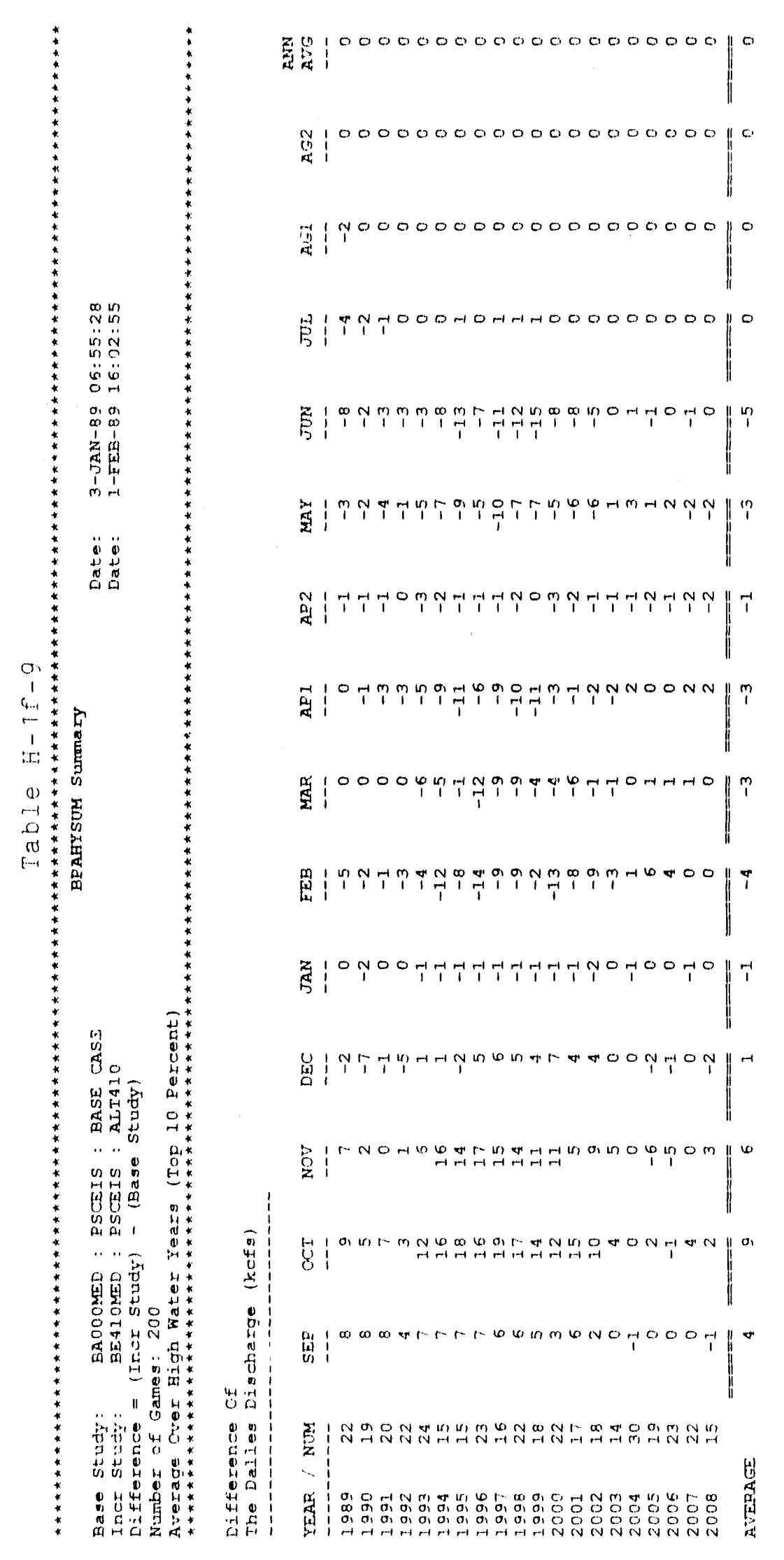

$11-1 f-51$ 
宏 100000000000000000000

हु!

$\left.100000000000000000000\right|^{0}$

पू

ह

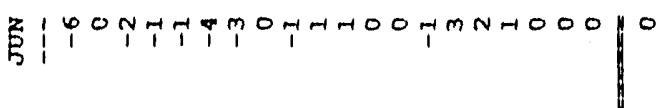

S

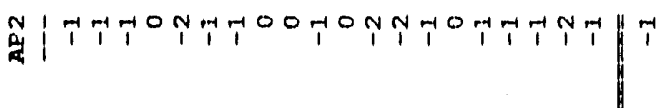

g)

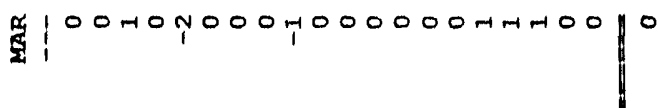

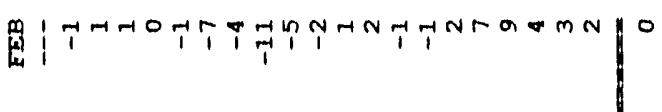

否

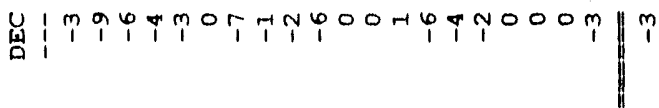

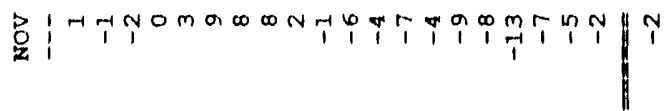

我的

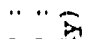

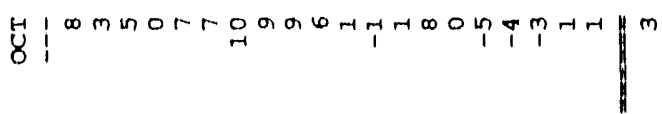

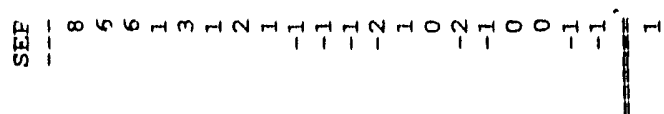

品:

$110^{5} 0^{*}$

出.

की क्षे

足要

$\begin{array}{lll}0 & 0 & 0 \\ 0 & 0 & 1\end{array}$

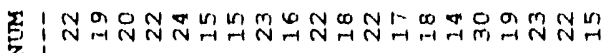

2

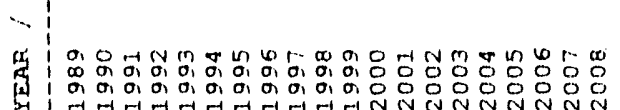

\section{幽}




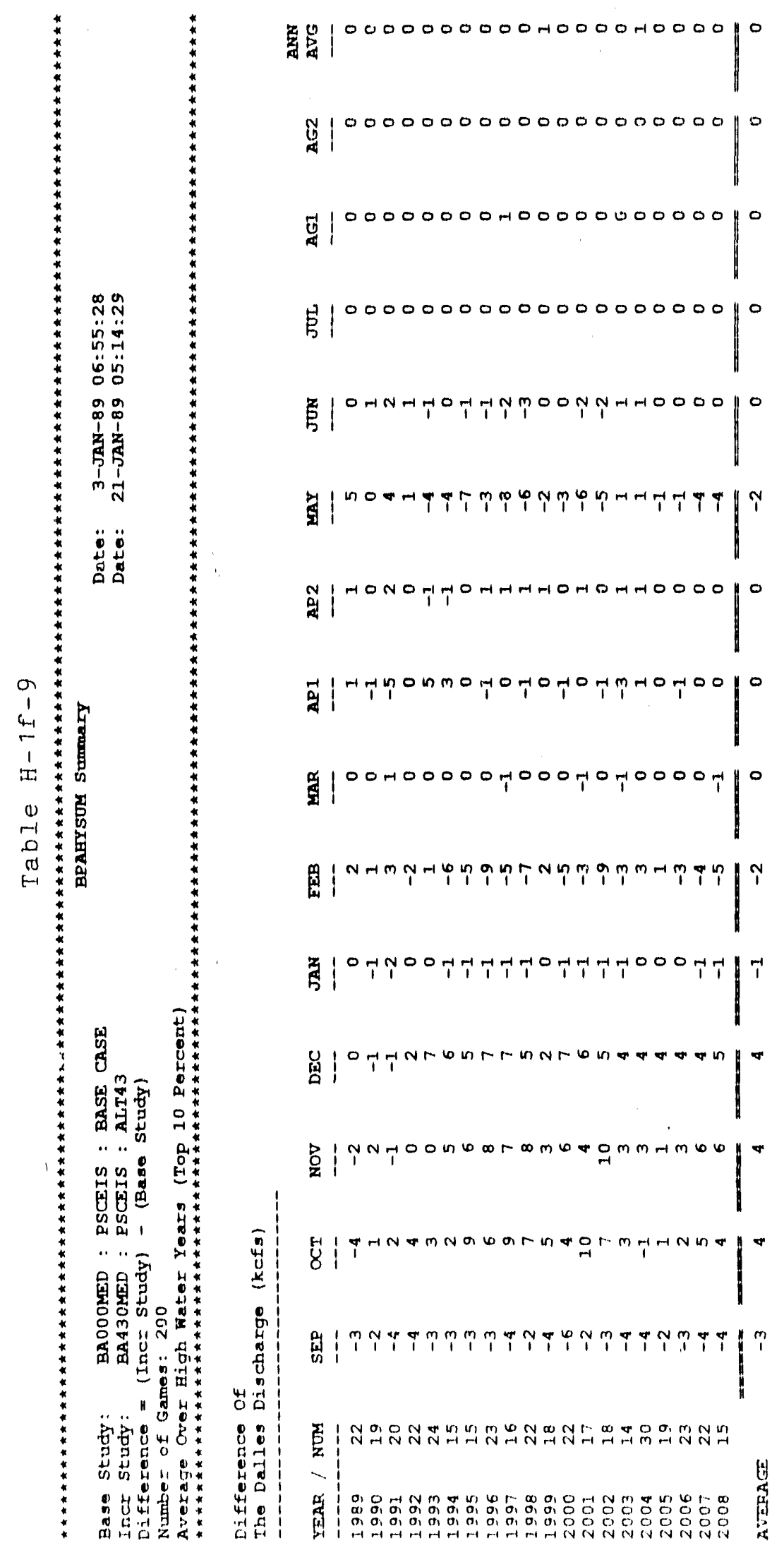




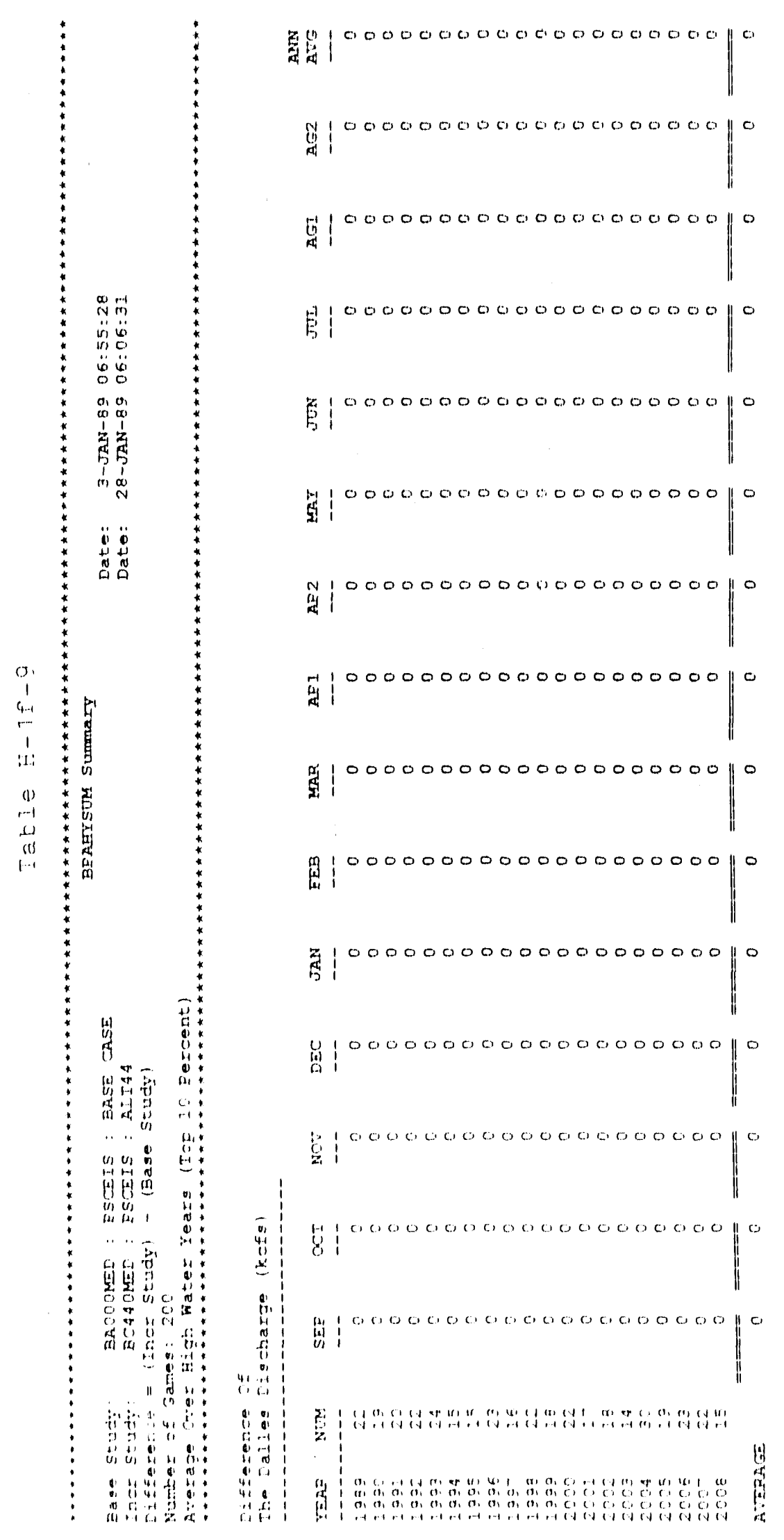

11. $11 \cdot-1,4$ 
$H-19$

VERNITA BAR DATA

Data on Flows for Flathead and Kootenal Rivers 


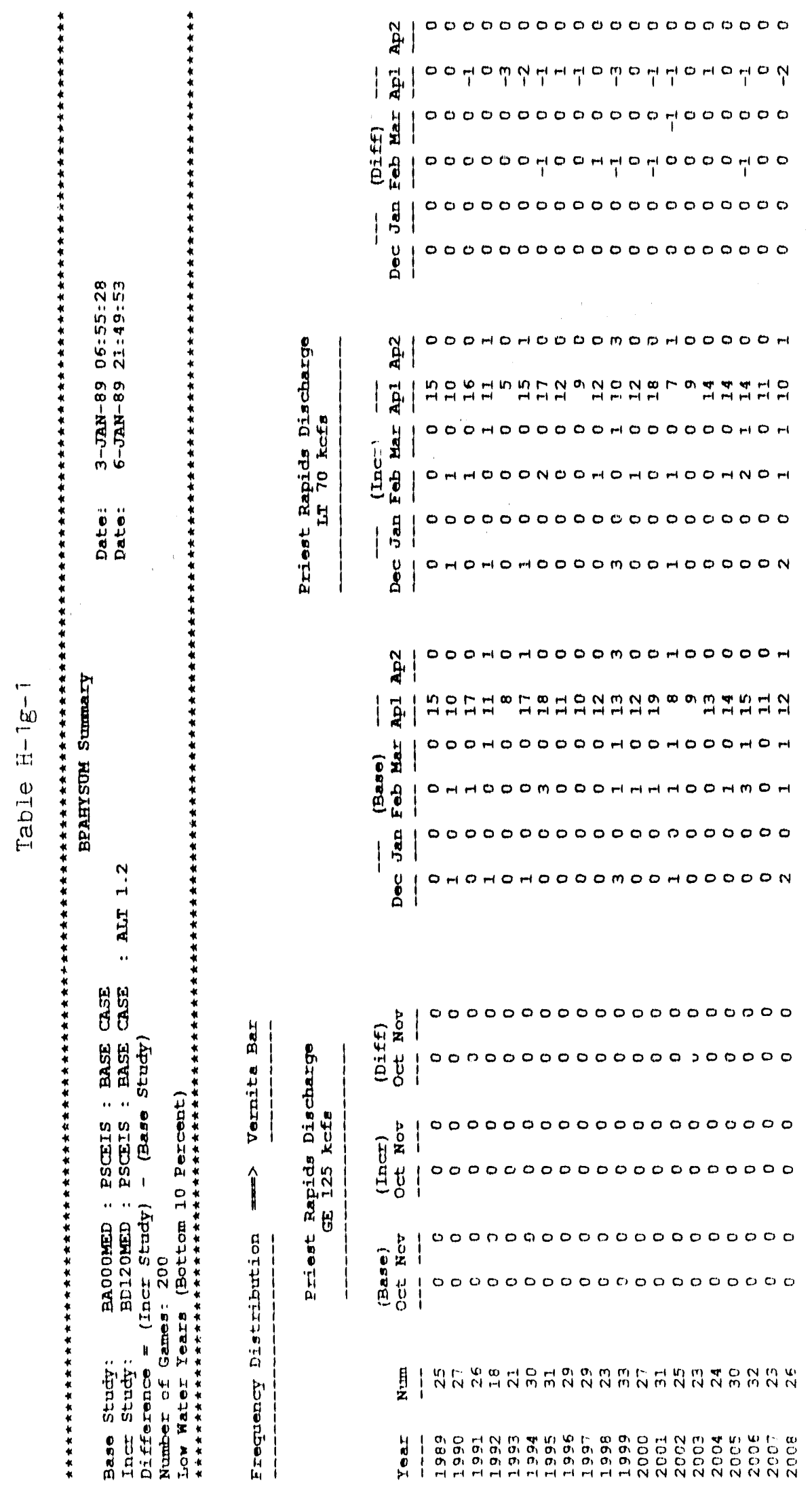




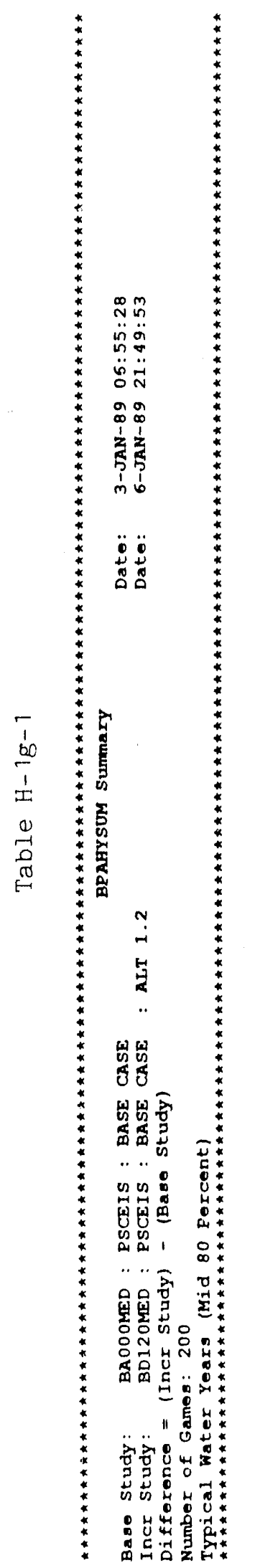

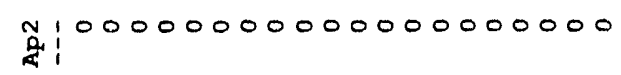

$$
\begin{aligned}
& \text { 䓪: } \\
& \text { 西缹: }
\end{aligned}
$$

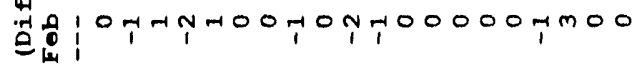

$$
\begin{aligned}
& \text { \$ } 100000000000000000000 \\
& \text { is } \\
& \text { : }
\end{aligned}
$$

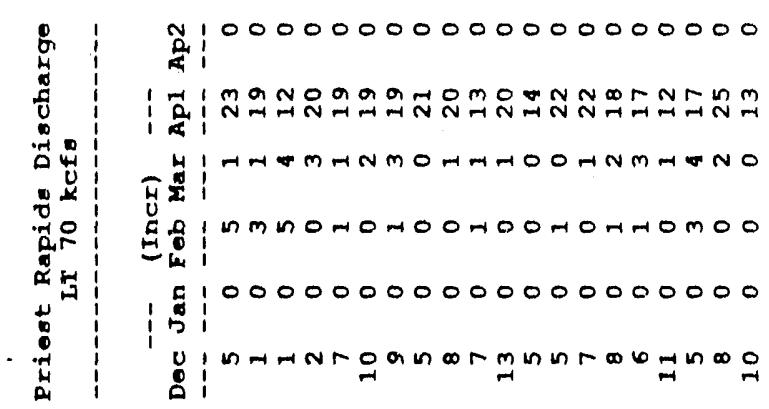

N100000000000000000000 告

|

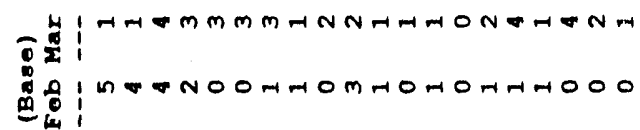

I 100000000000000000000 का

:

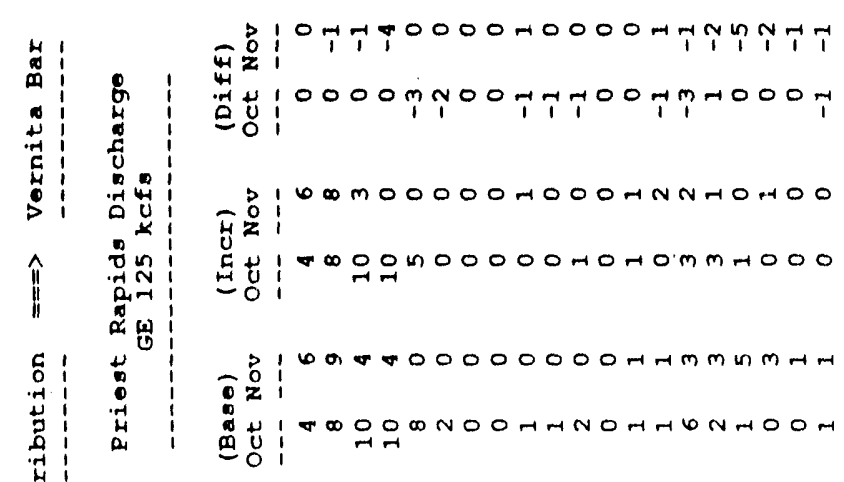

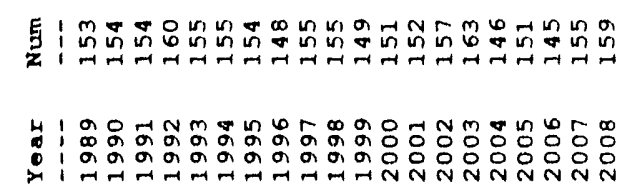




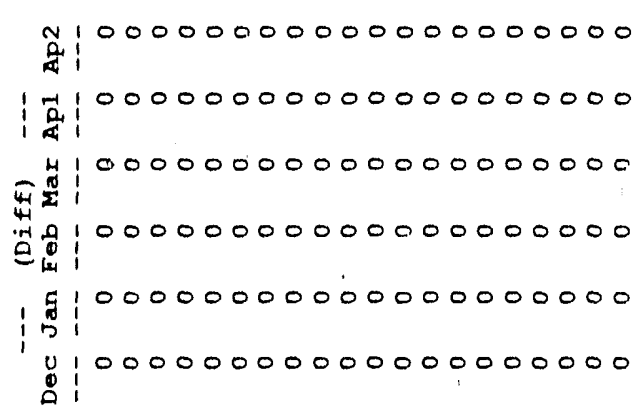

8100000000000000000000 出莎! 出 100000000000000000000 $D 100000000000000000000$ 可要:

$\Xi \begin{aligned} & 0 \\ & 0\end{aligned}$ $\$ 100000000000000000000$ 20 苞: 100000000000000000000

夏|

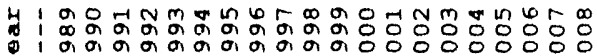

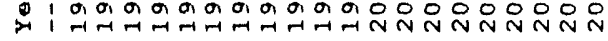


N100000000000000000000

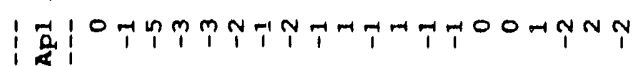
D: 崖: I 100000000000000000000 in

:

Q

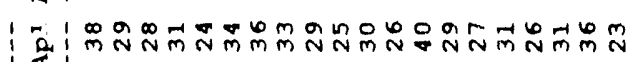

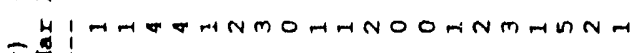

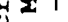

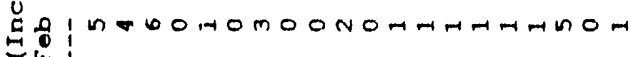

: in

:

N:000H0H0000m00-100000

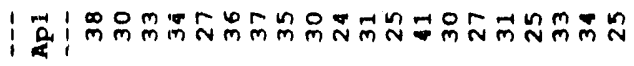
- HTHOMMMANNNATHNTHENN $0 x$

要:

I 100000000000000000000 势

:

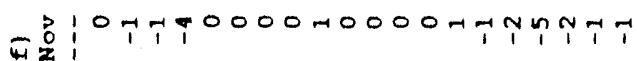
$\mathbb{w}^{2}=1$

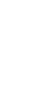




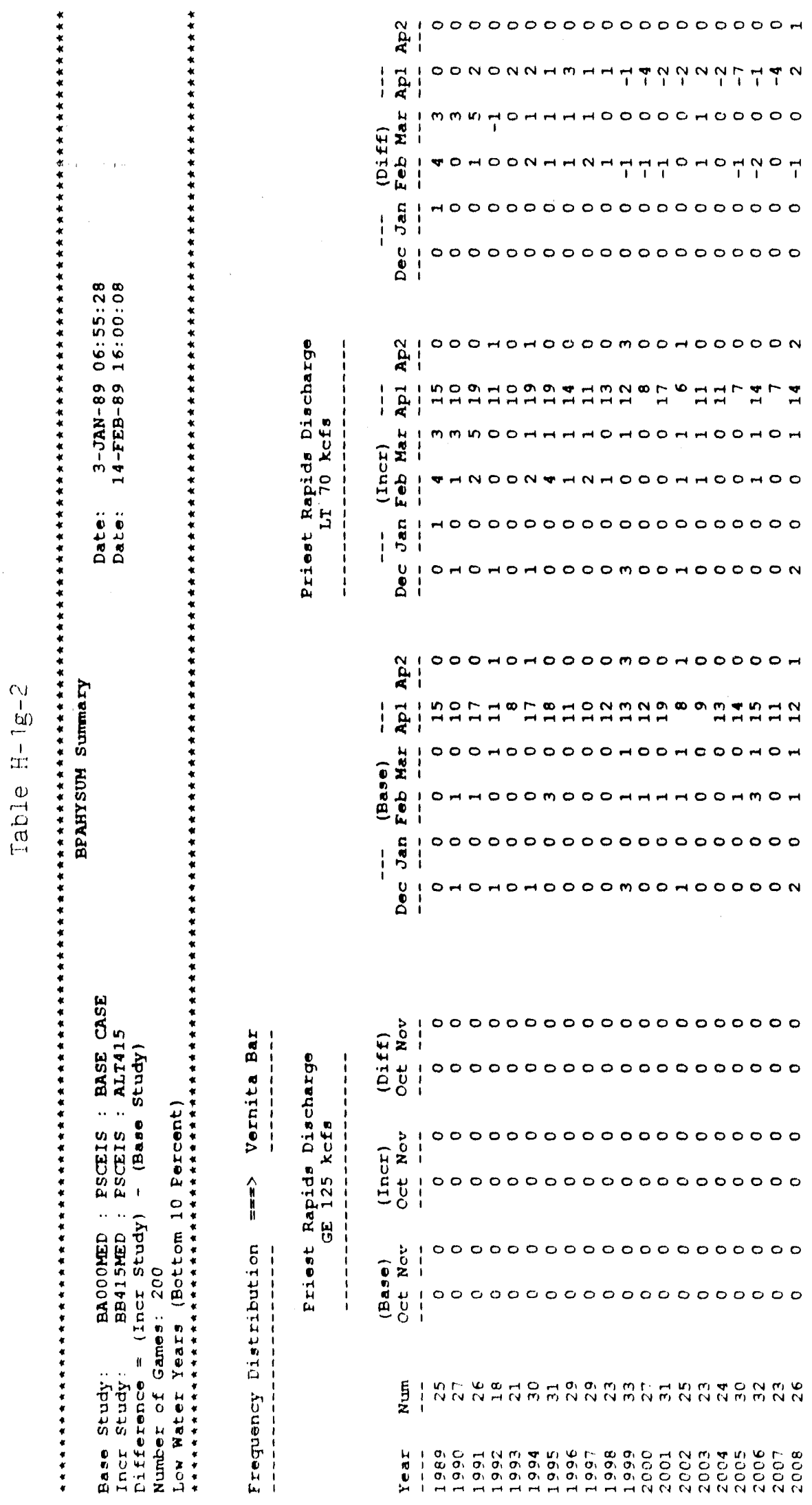




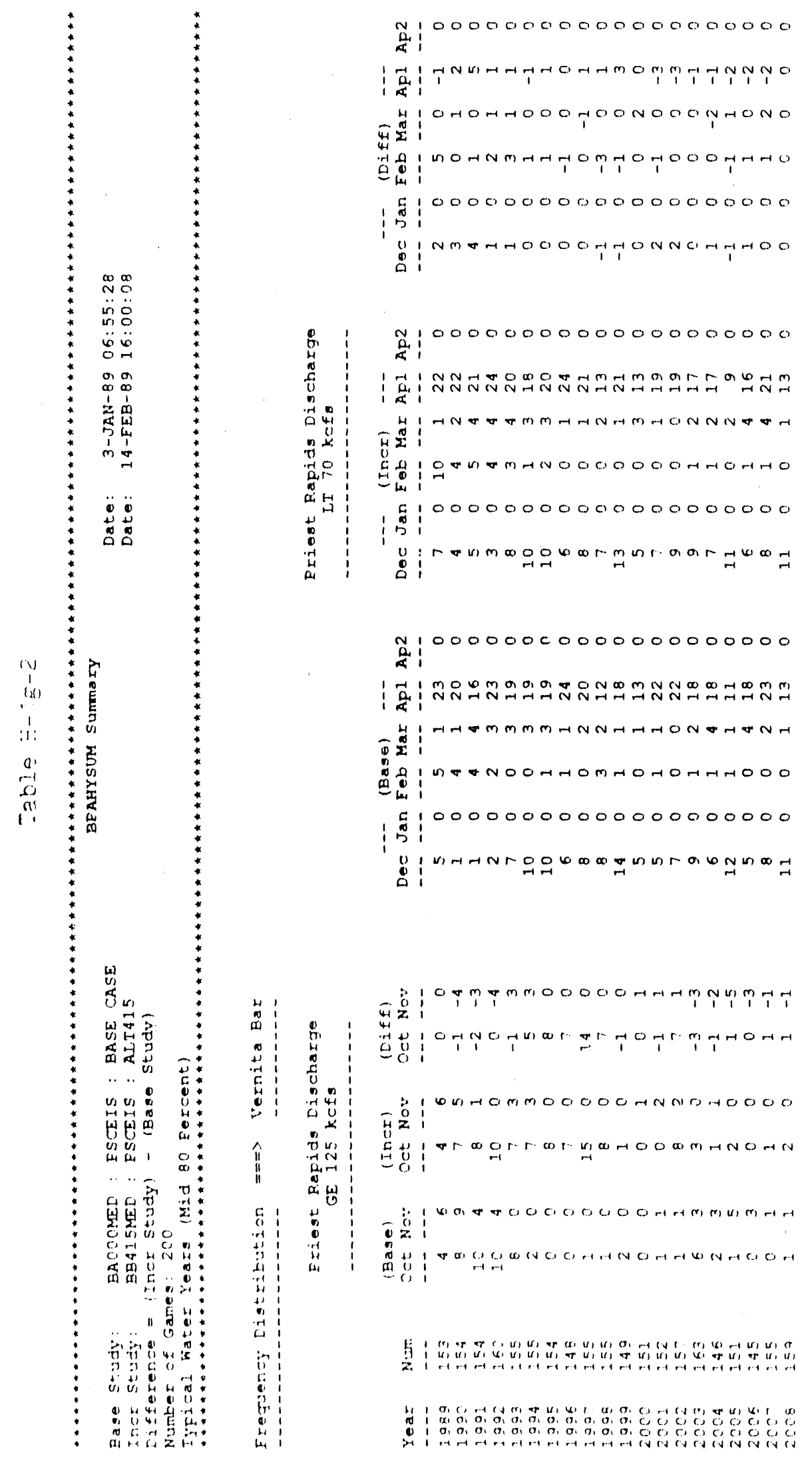

$11,1, \ldots 1$. 

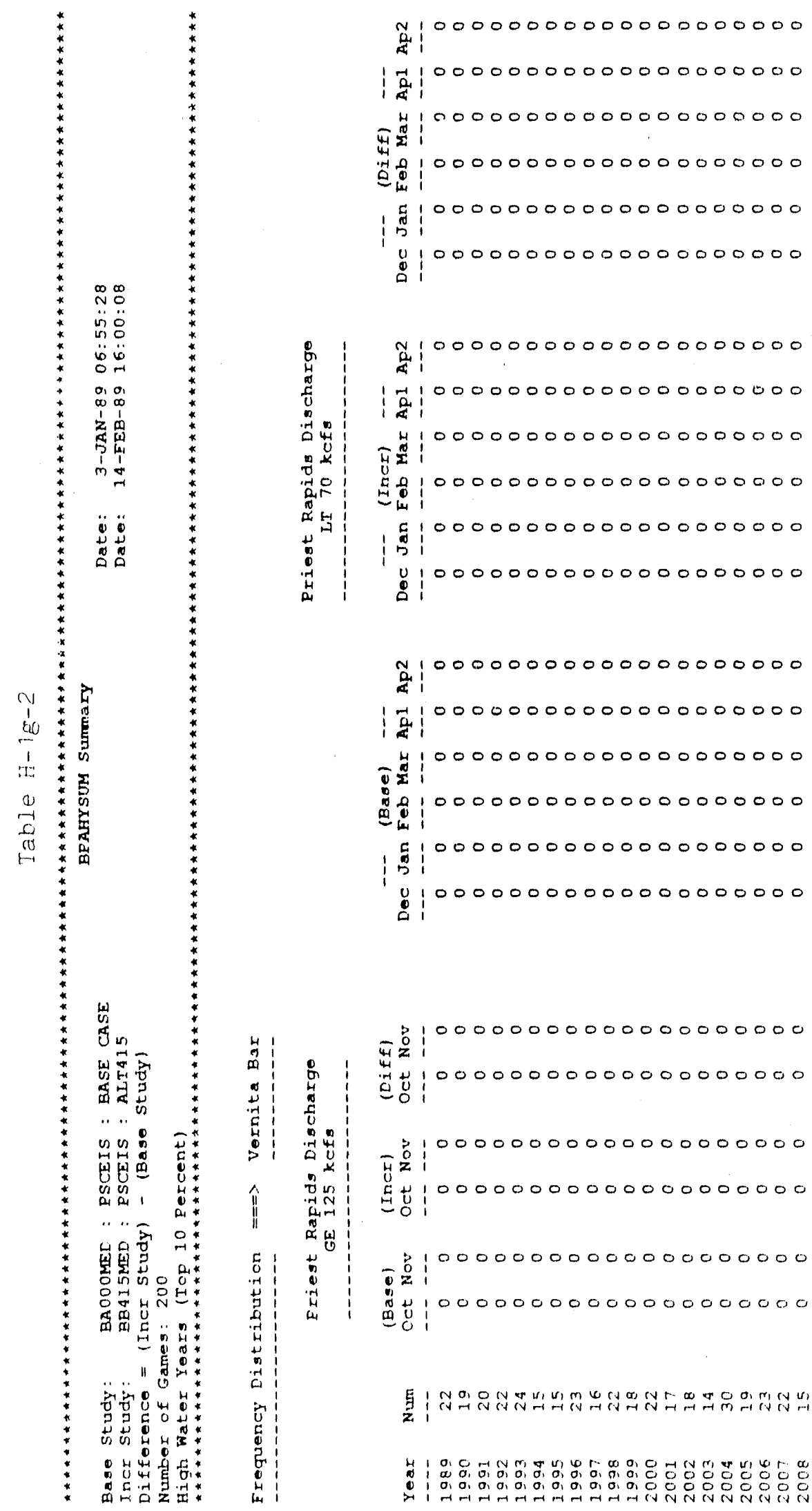

3100000000000000000000 出

岁苟:00000000000000000000 $\$ 100000000000000000000$ 可要

出 100000000000000000000 0

苟: 100000000000000000000

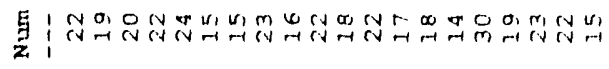

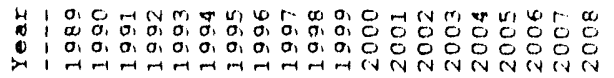


菒!

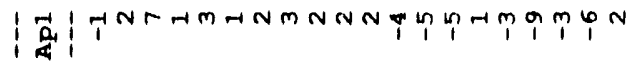

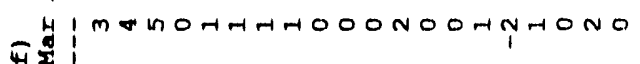
क्षे।

Q

a

:

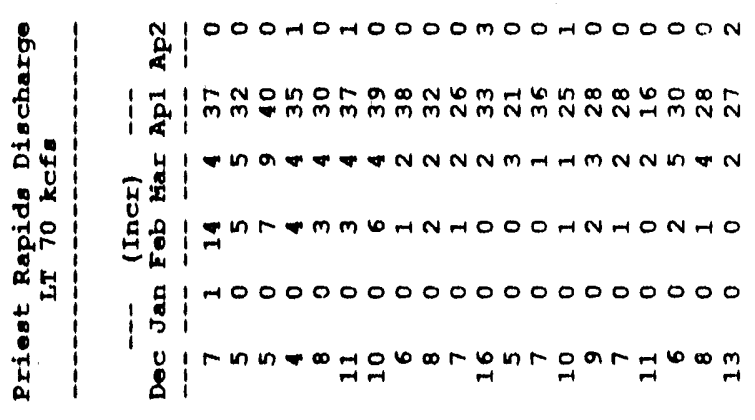

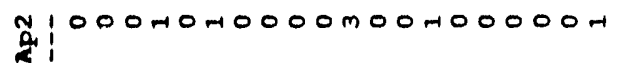

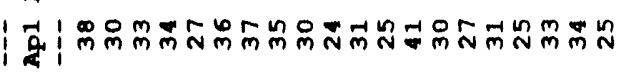

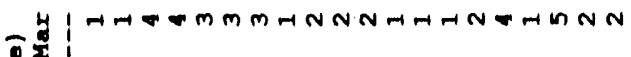

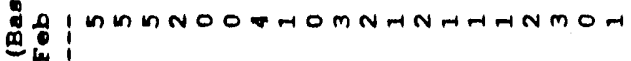
罗

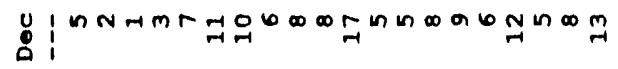

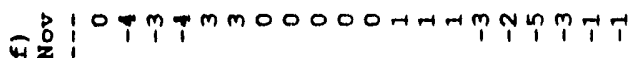

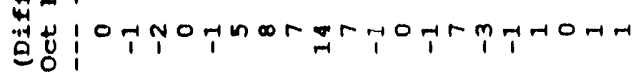

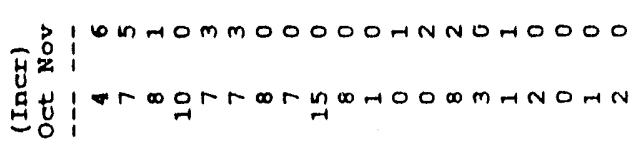

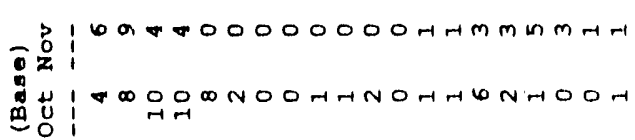

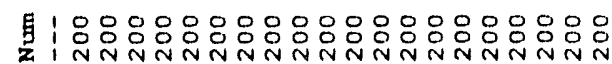

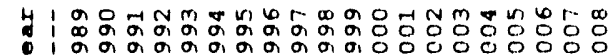

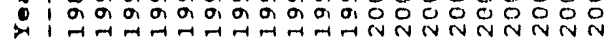




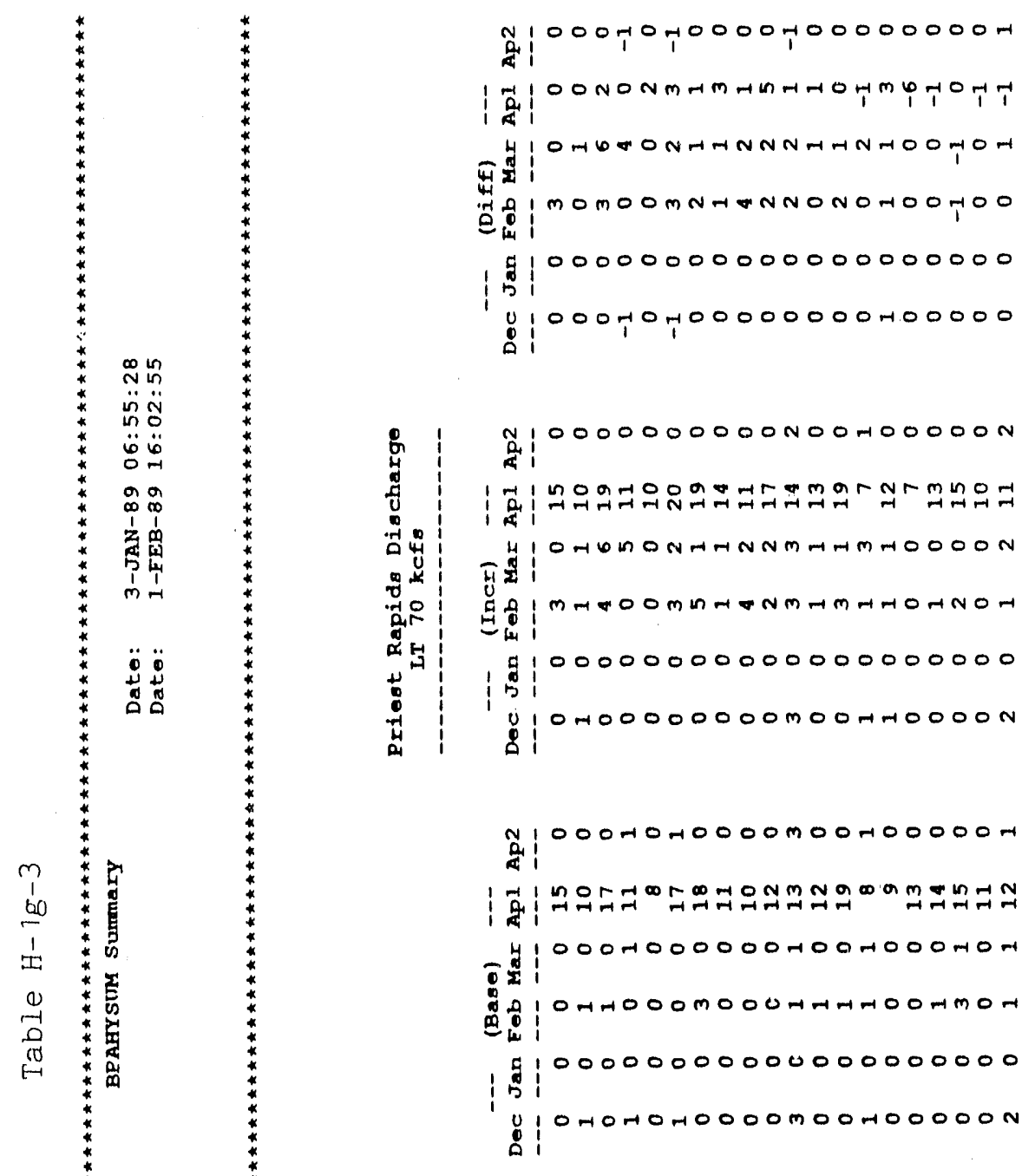

8100000000000000000000

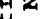

药: 00000000000000000000 100000000000000000000 मुํํㄹ

苞若:00000000000000000000

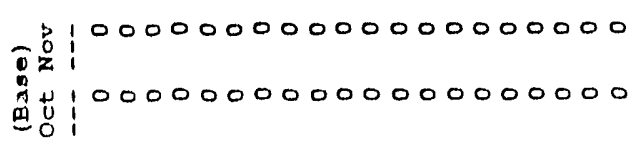

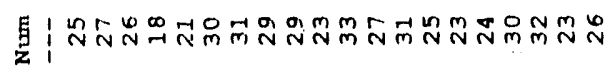

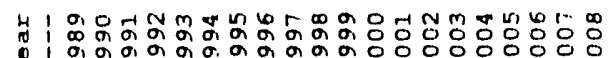

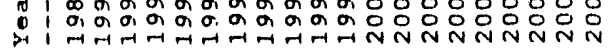




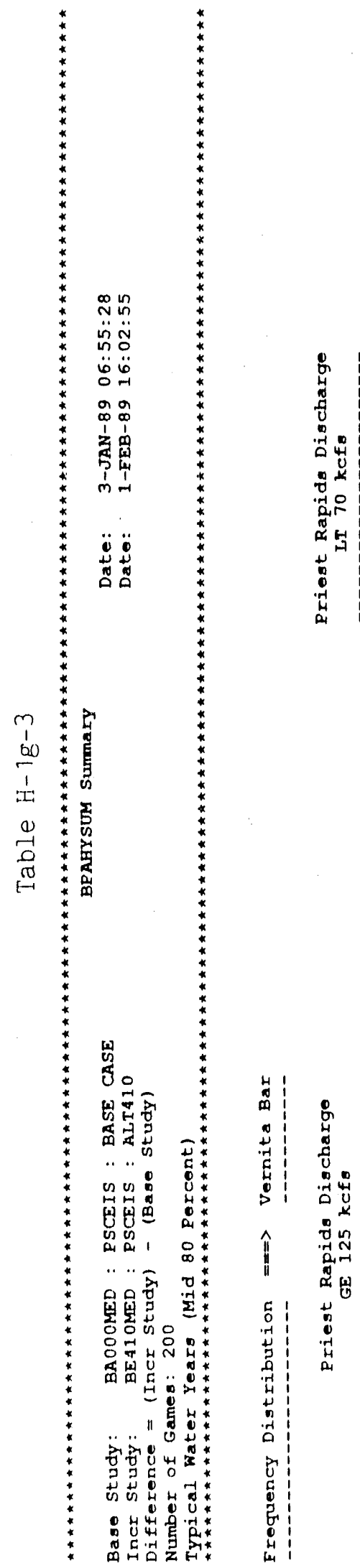

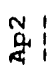

$$
\begin{aligned}
& \text { | } \\
& \text { W } \\
& \text { 出 } \\
& \text { I: } 000-10000000000000000
\end{aligned}
$$

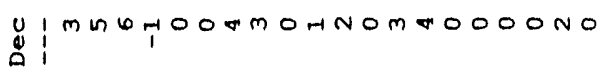

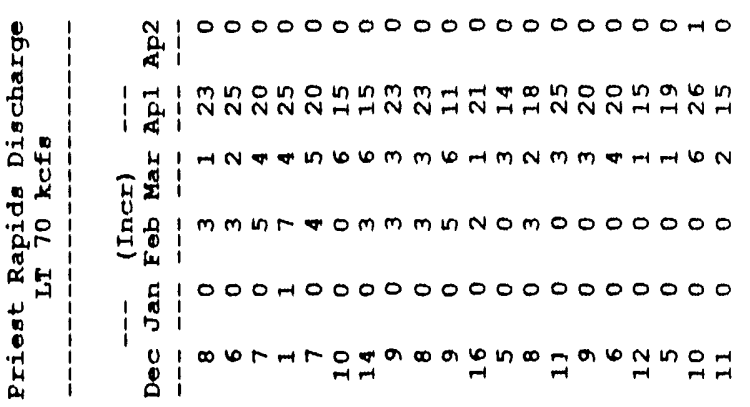

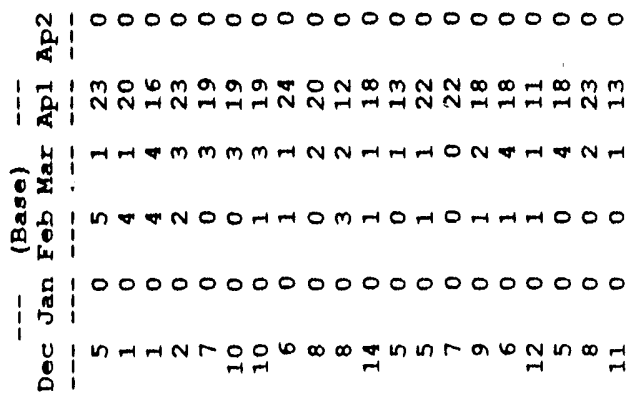
B! H

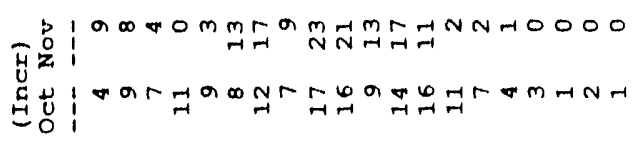

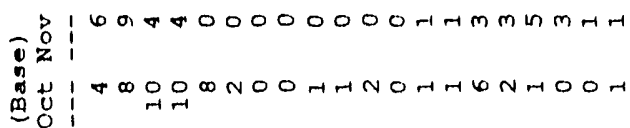

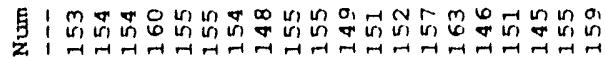

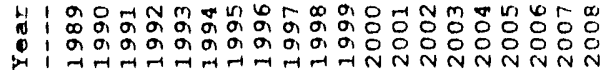




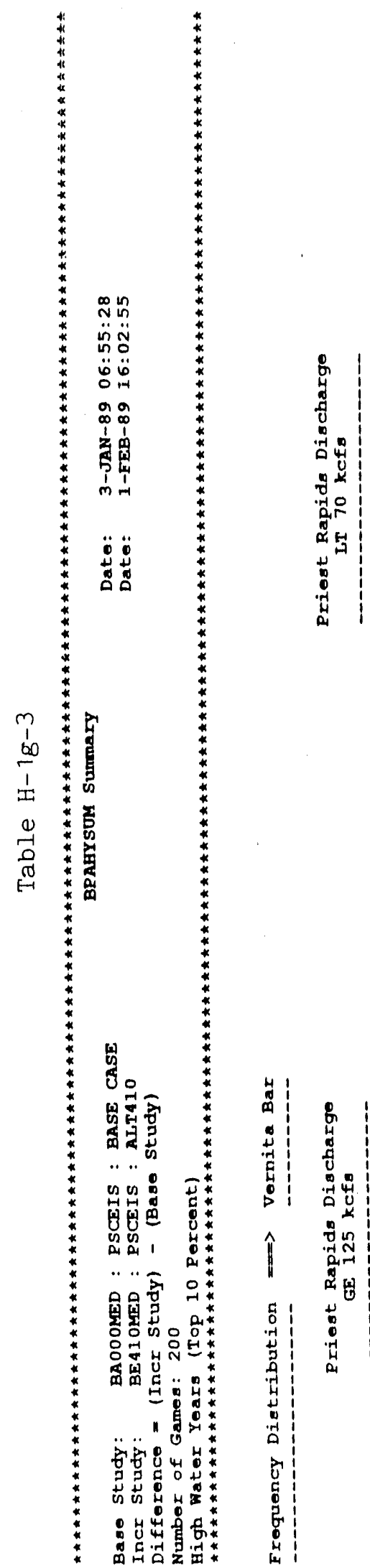
$W_{1} 100000000000000000000$
$\mid$ in $\mid$
H 100000000000000000000 出
然要
100000000000000000000 क
0
0
100000000000000000000

N/100000000000000000000

$|\overrightarrow{0}| 00000000000000000000$

4100000000000000000000 सु

: 100000000000000000000

5100000000000000000000

8100000000000000000000

N 100000000000000000000 4

$|\mathrm{g}| 00000000000000000000$ 4100000000000000000000 空

100000000000000000000 क

:

100000000000000000000

$\$ 100000000000000000000$ 出政

HU 100000000000000000000

$\$ 100000000000000000000$ 可要:

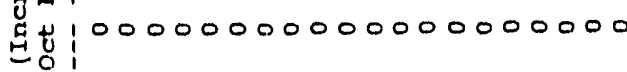

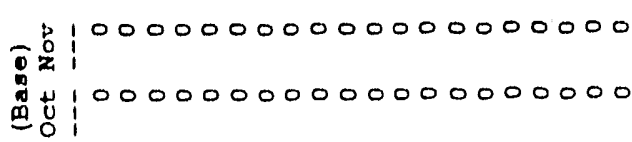

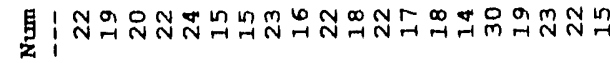

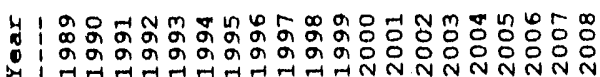




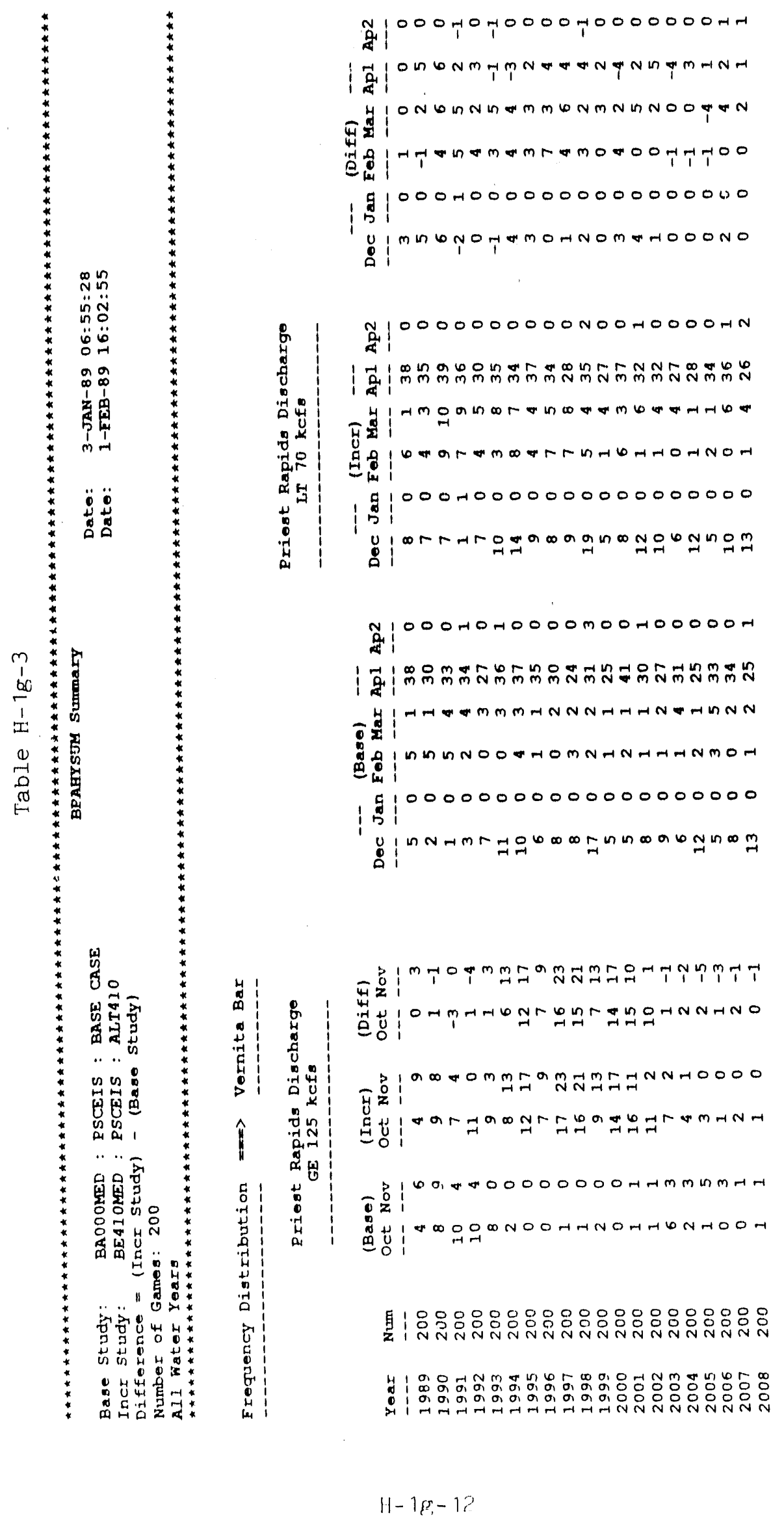



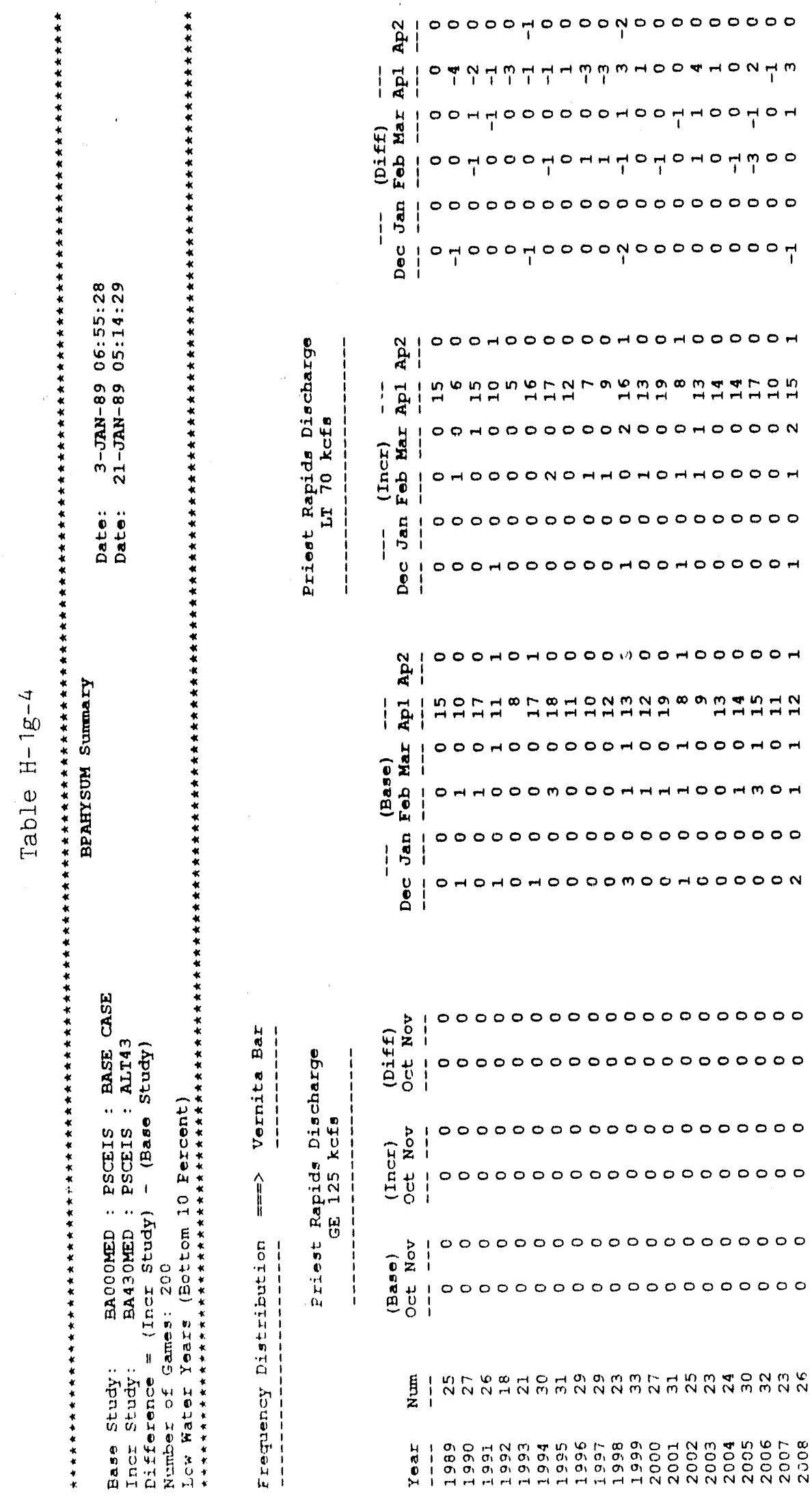

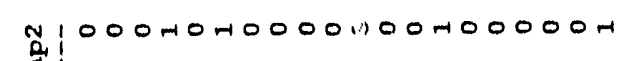
| - y1000 $1000000-100 \mathrm{~m} 000 \mathrm{mom}$

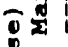

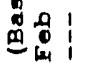

100000000000000000000 का :

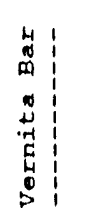

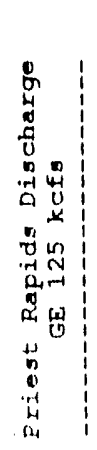

40

每苔:

00000000000000000000 1000 $p 100$

可要1

萝:100000000000000000000

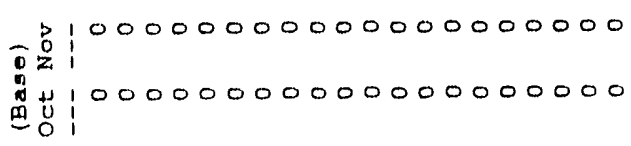

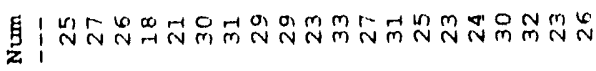

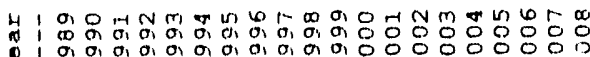

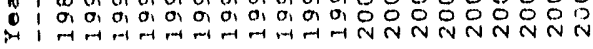



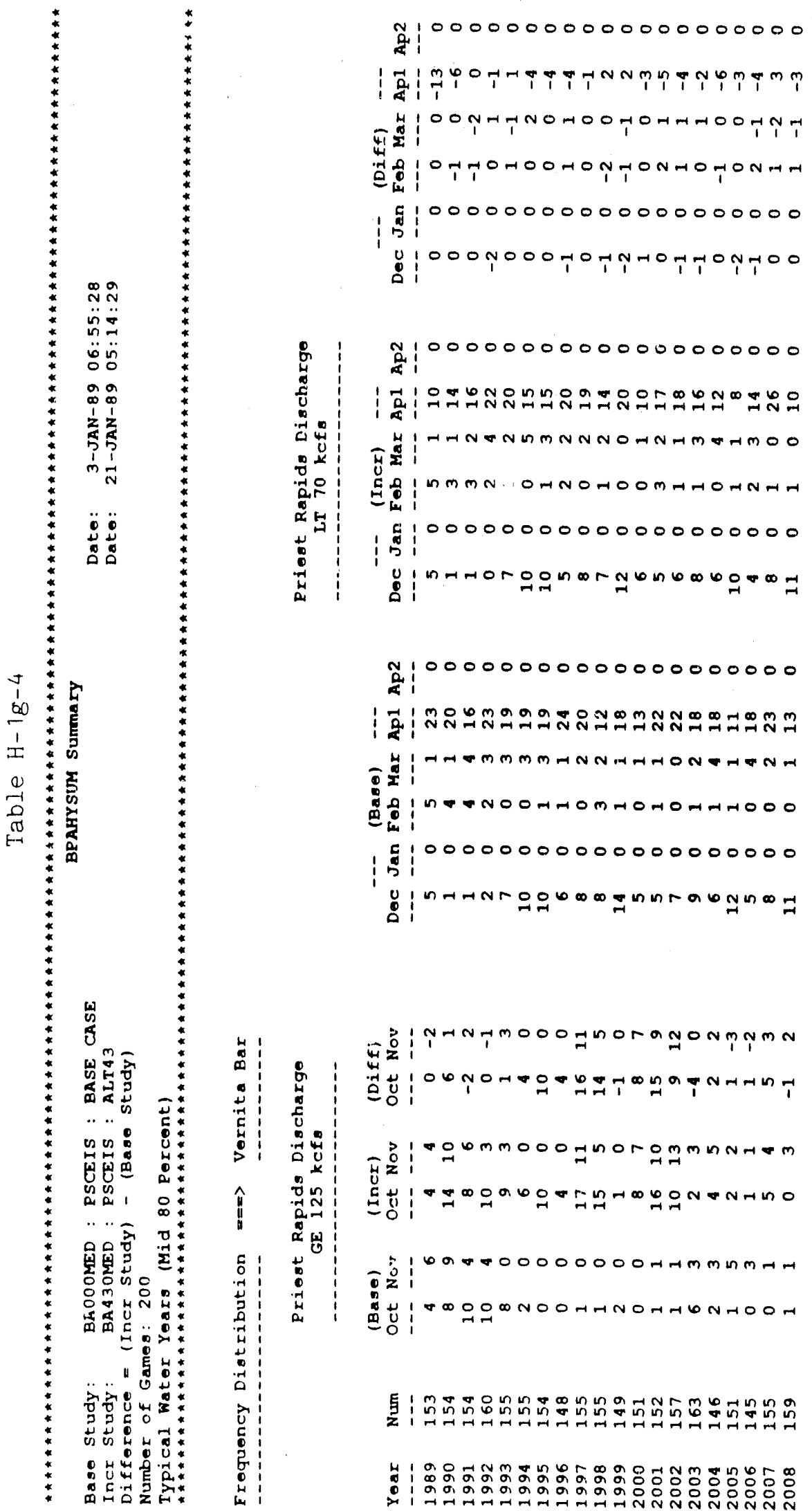

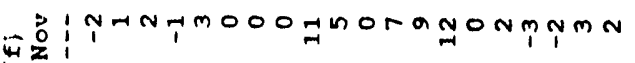
苟:

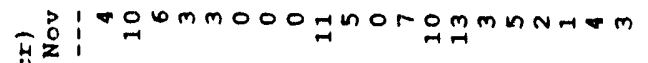
荡:

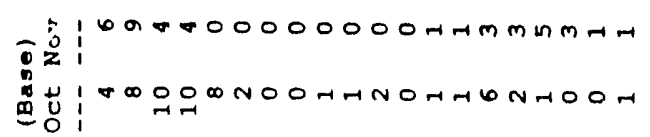

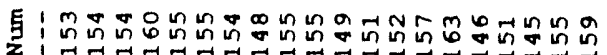

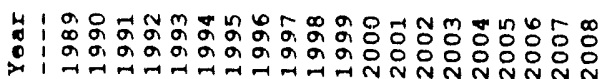




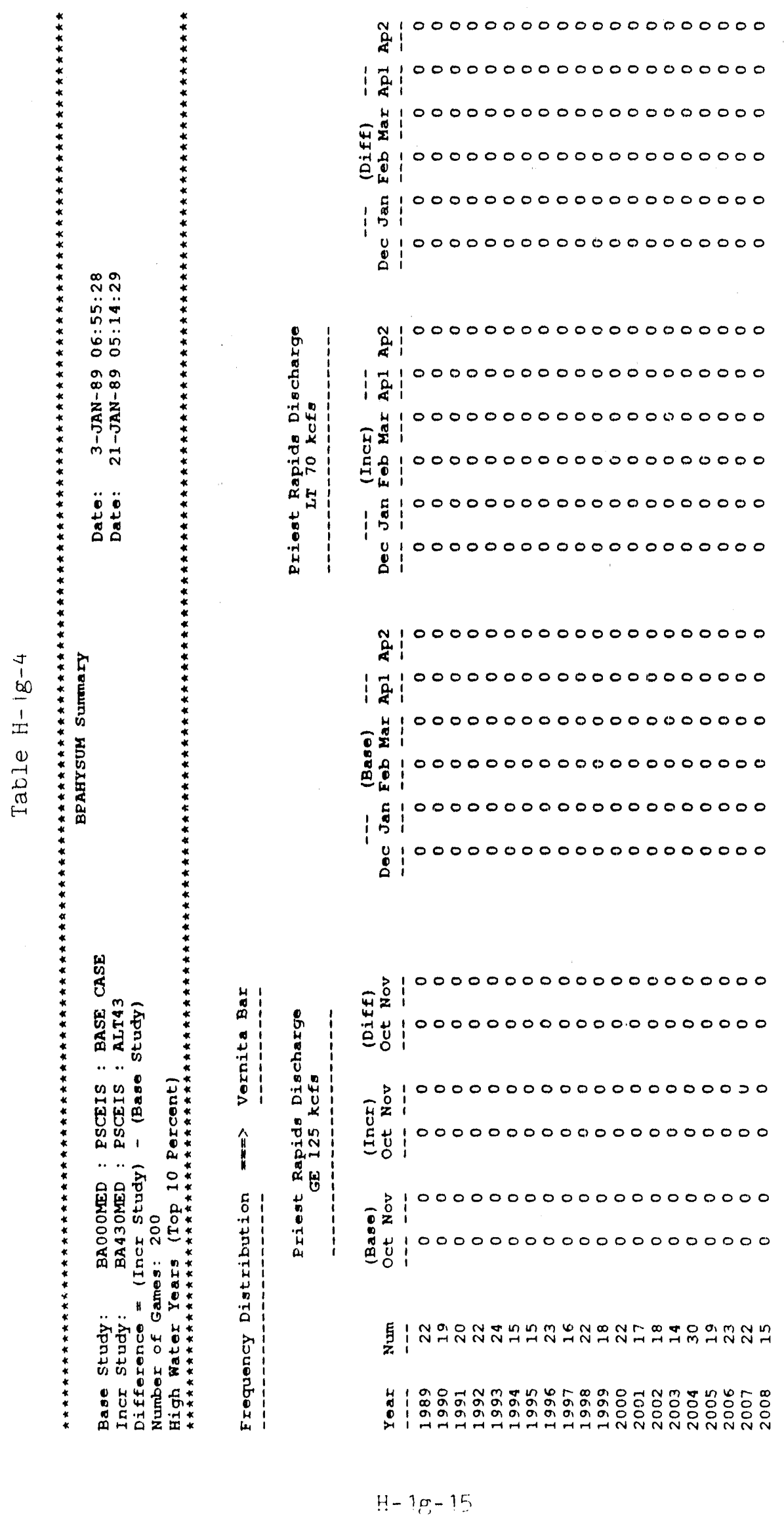




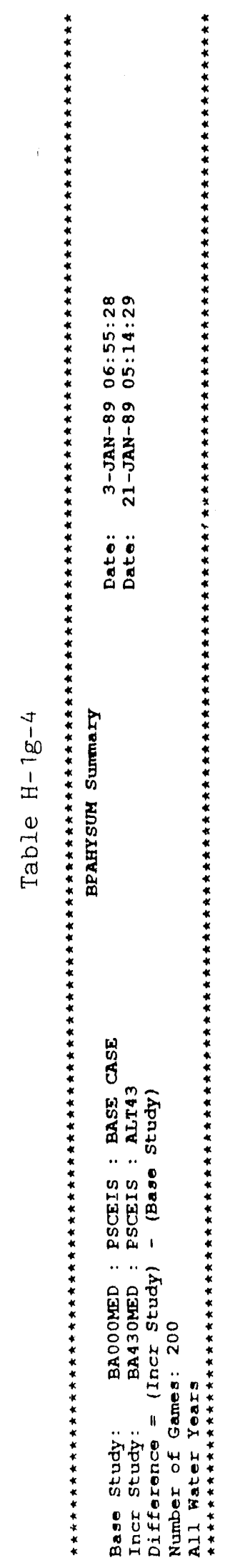

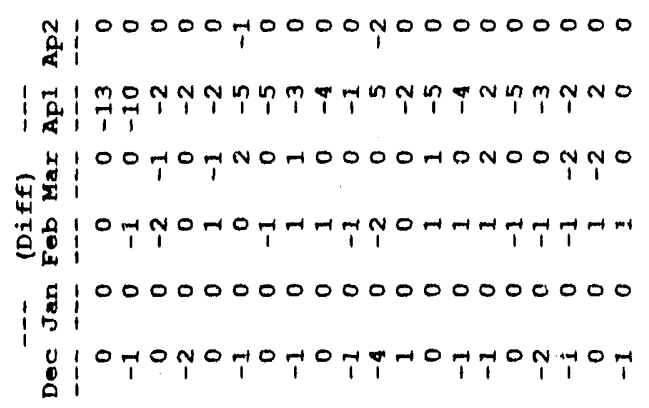

م:000-1000000700-100000

| HIMTMONGMNNNNMNHTHMON मु०

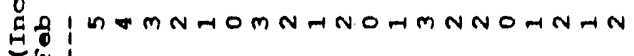

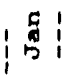

100000000000000000000 : i

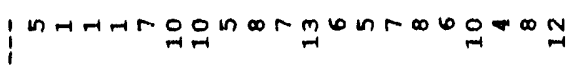

N:00070-0000m00m00000

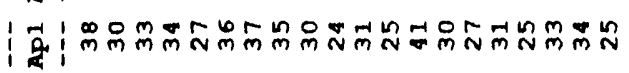

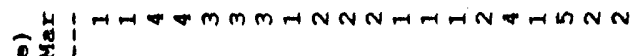
每 OUMUNOORHOMNHNHAHNMOH 垈 100000000000000000000 : UnNMR

出苟

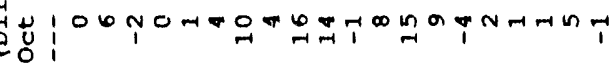

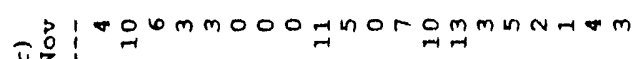
पू

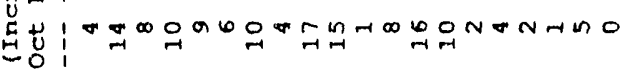

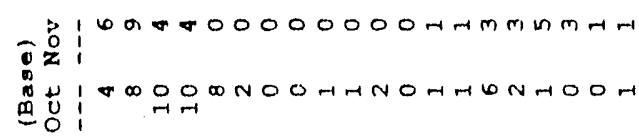
z

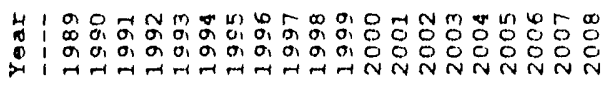


H-1h

WATER BUDGET DATA 

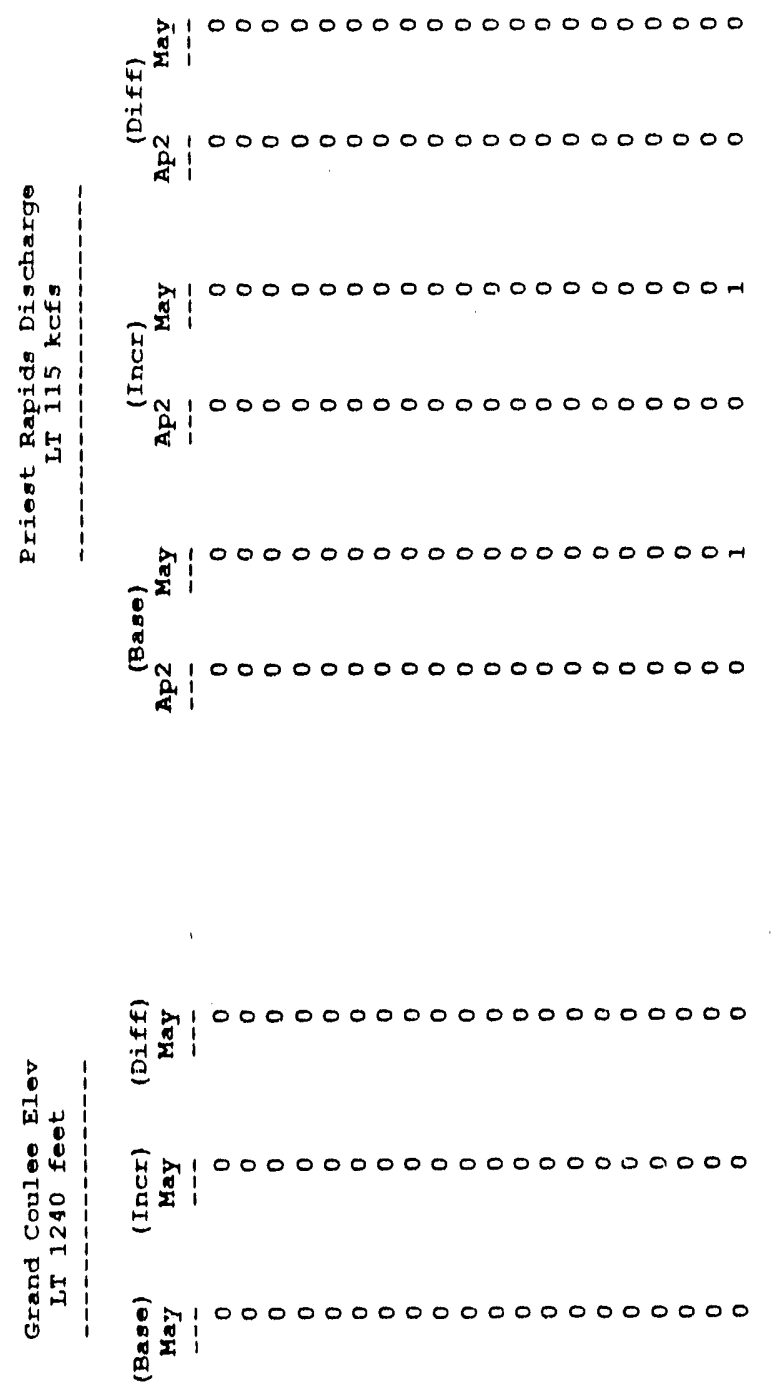

or

4)

ज证 ,

A. $0 *$

...

氨医出。出*

음

迎吕

$11 \mathrm{y}^{*} \mathrm{o}^{*}$

$\ddot{0} 0$

4 

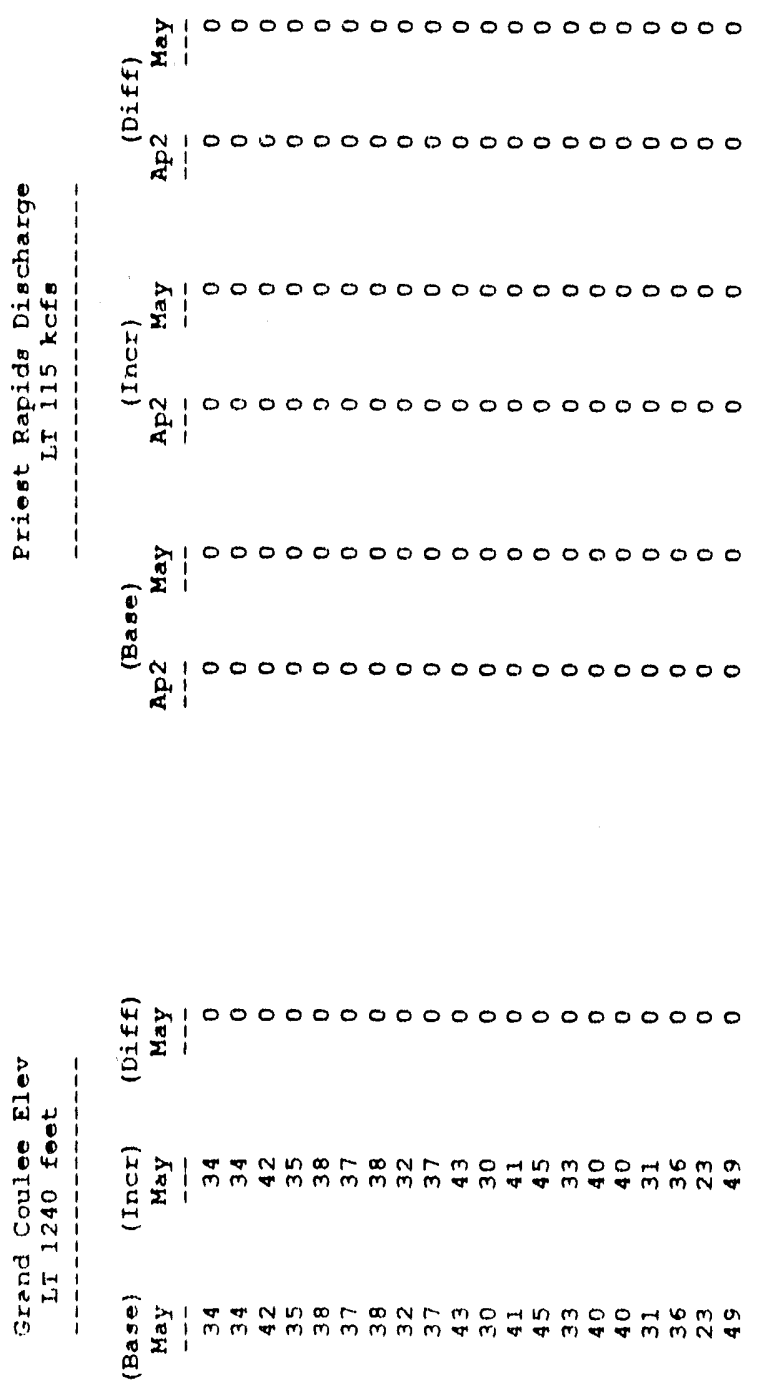

象

武出点

in $w_{0}$,

1 只

尚家苟

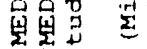

o

a

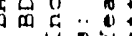

tin

. II

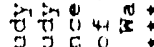

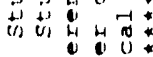

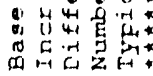

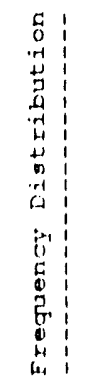

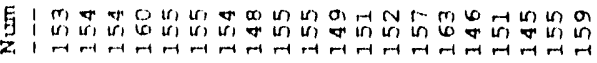

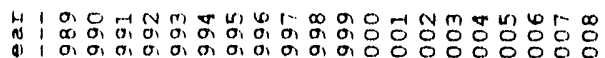
in 

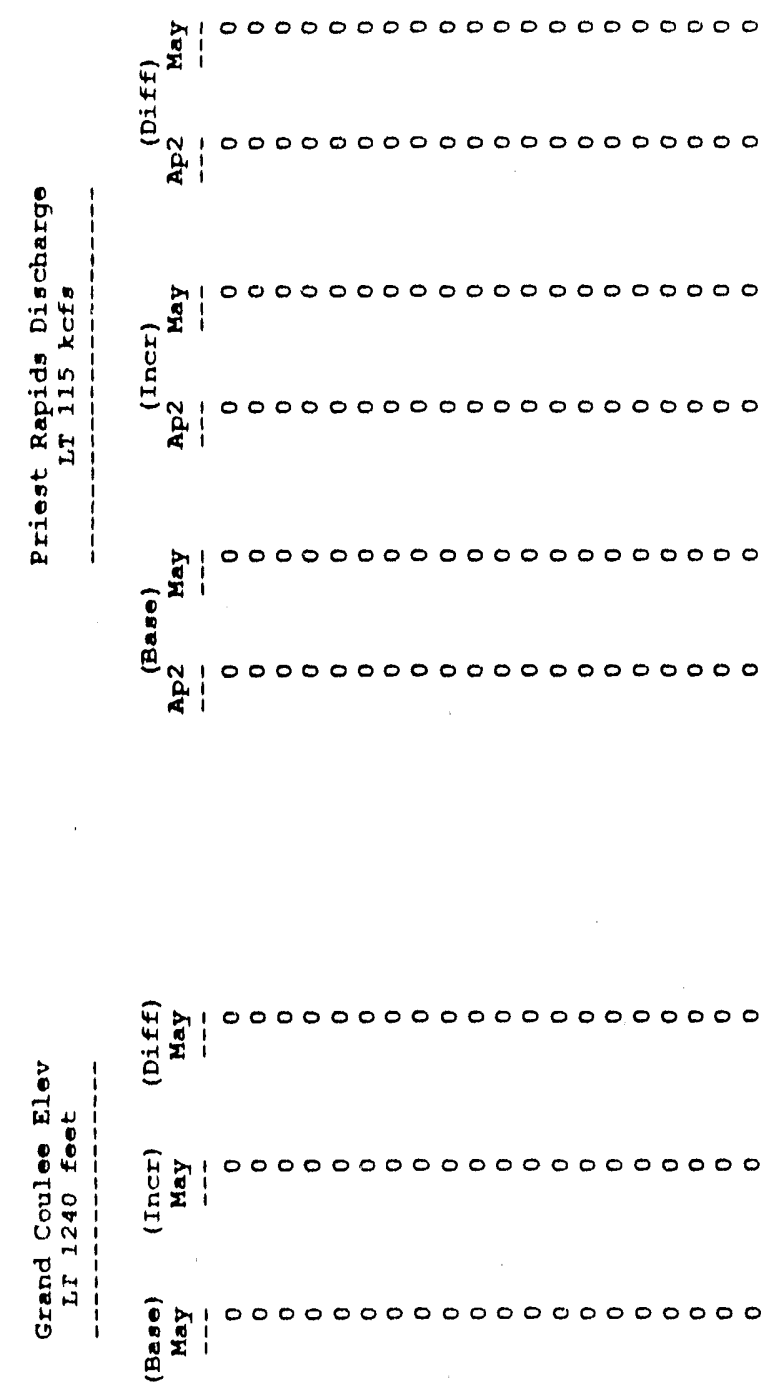

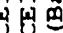

...

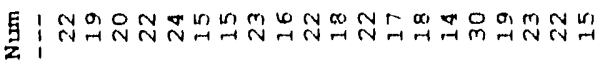

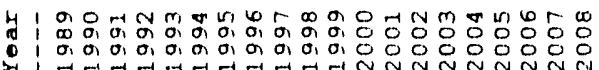



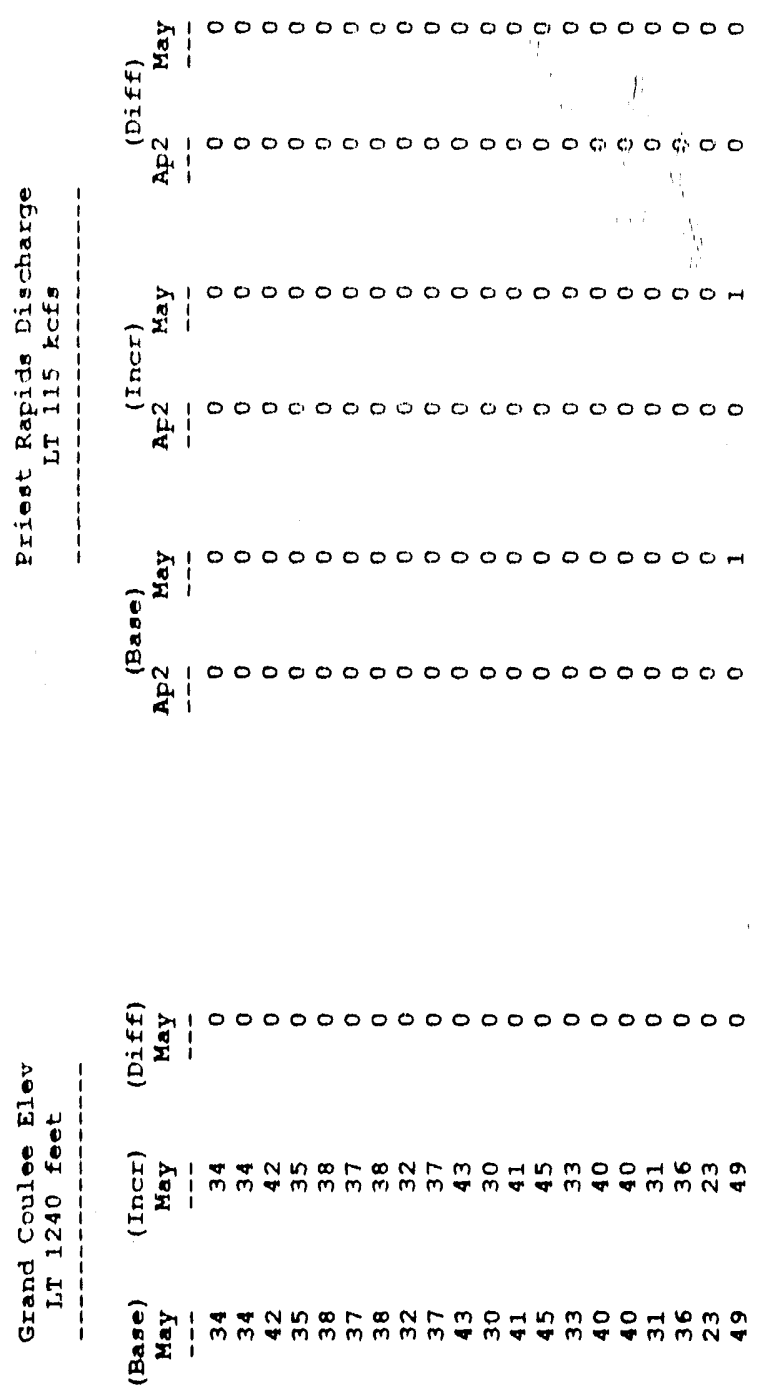

os

式

की

舫安

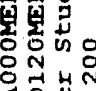

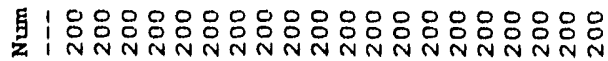

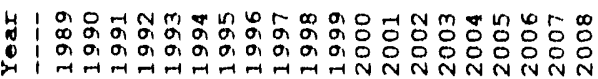



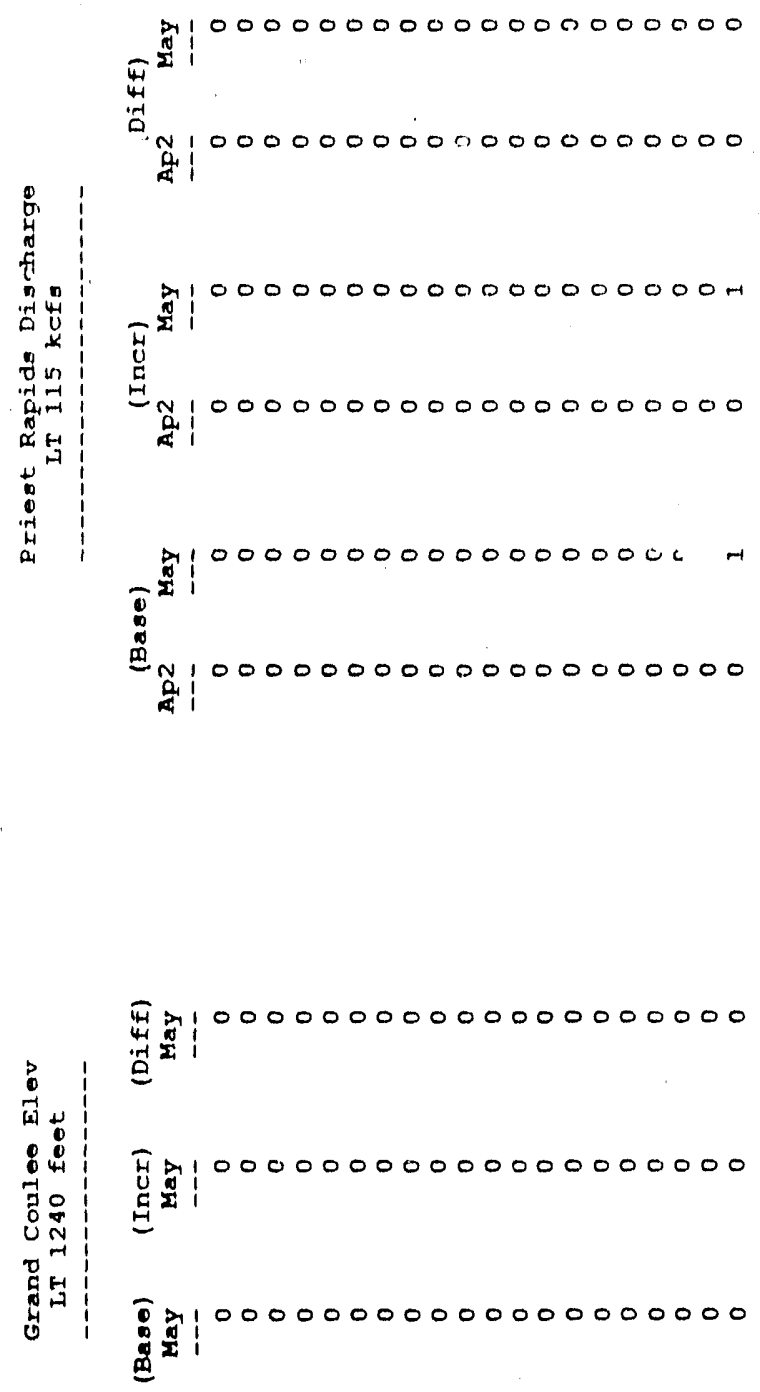


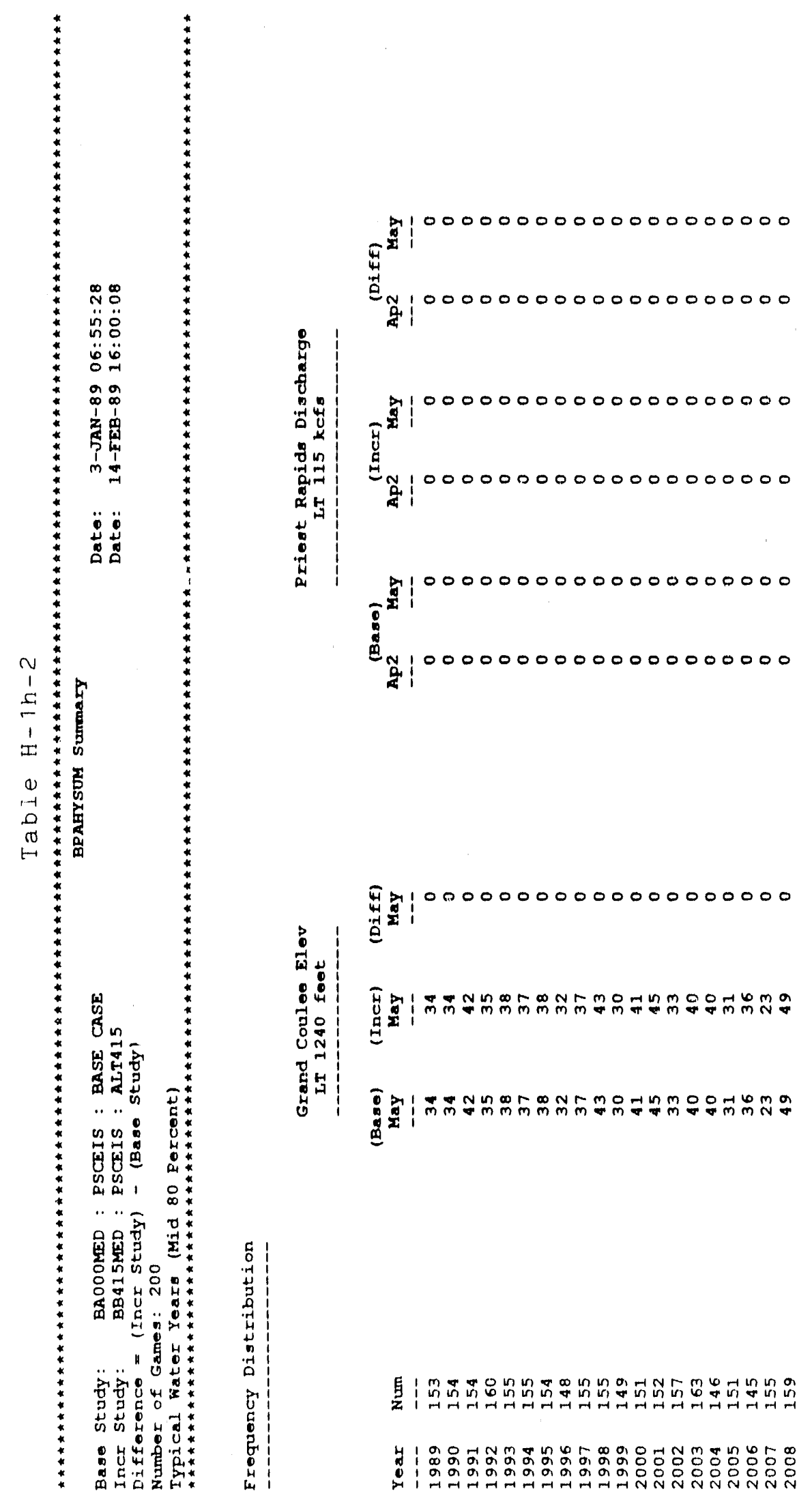

$H-1 h-6$ 


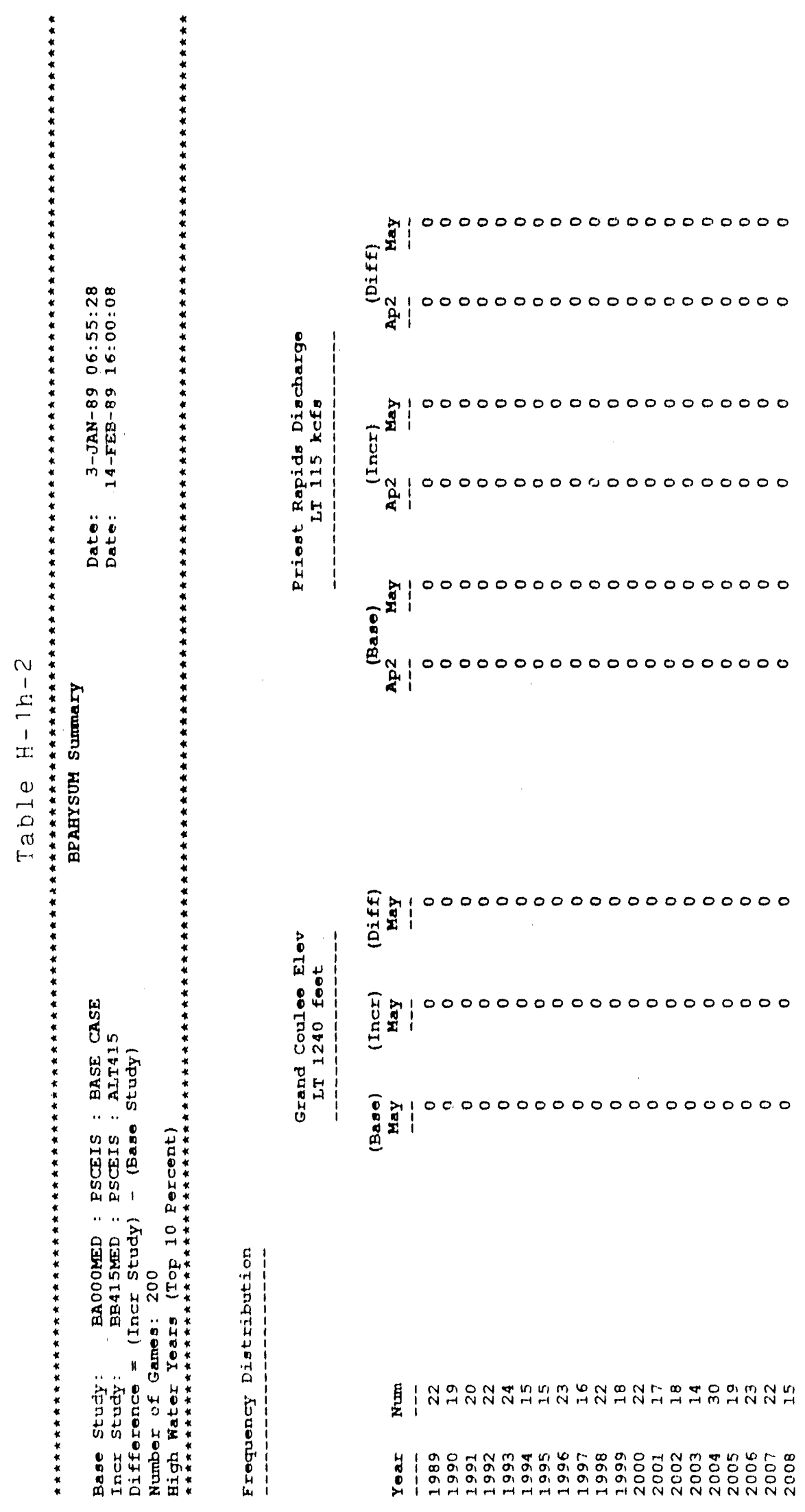

$$
H-1 h_{1}-7
$$



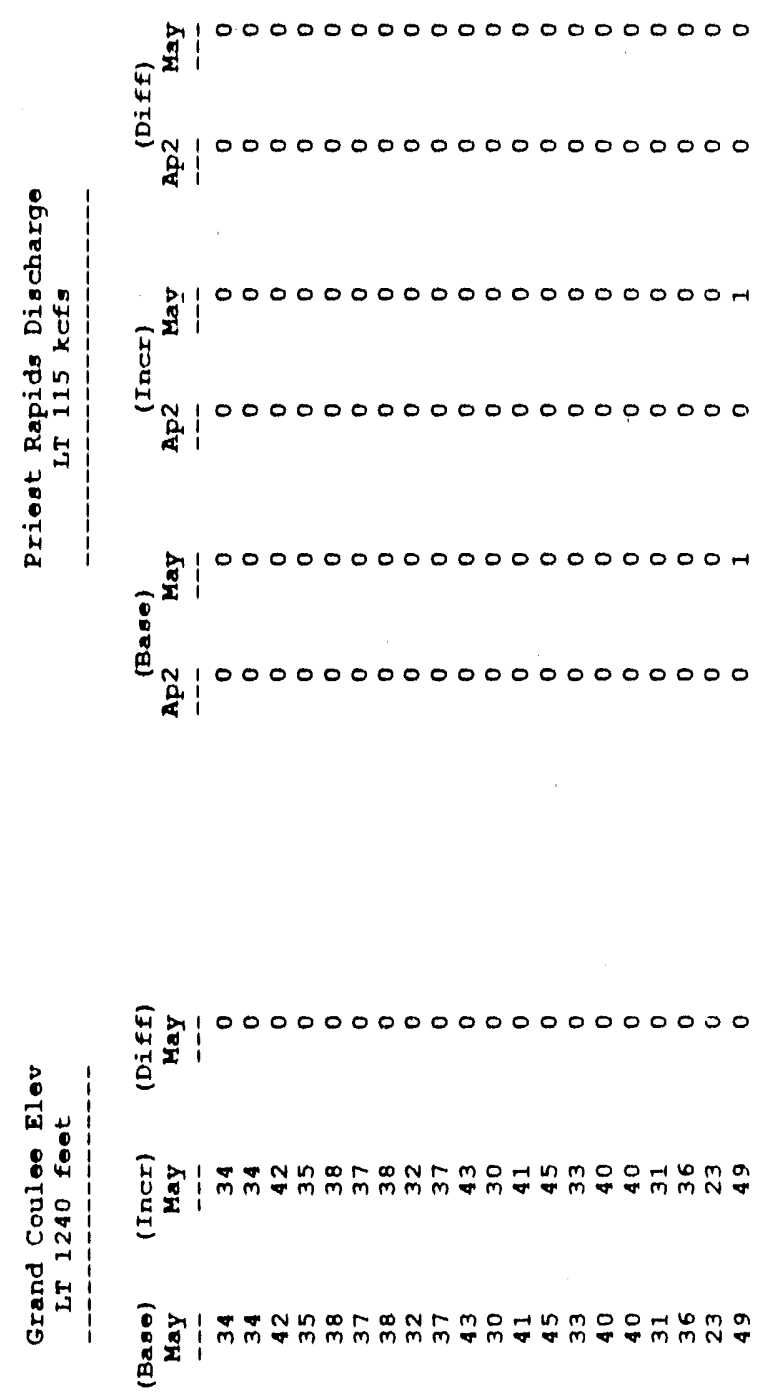

$\sin _{-1}$

번

की

“. . 


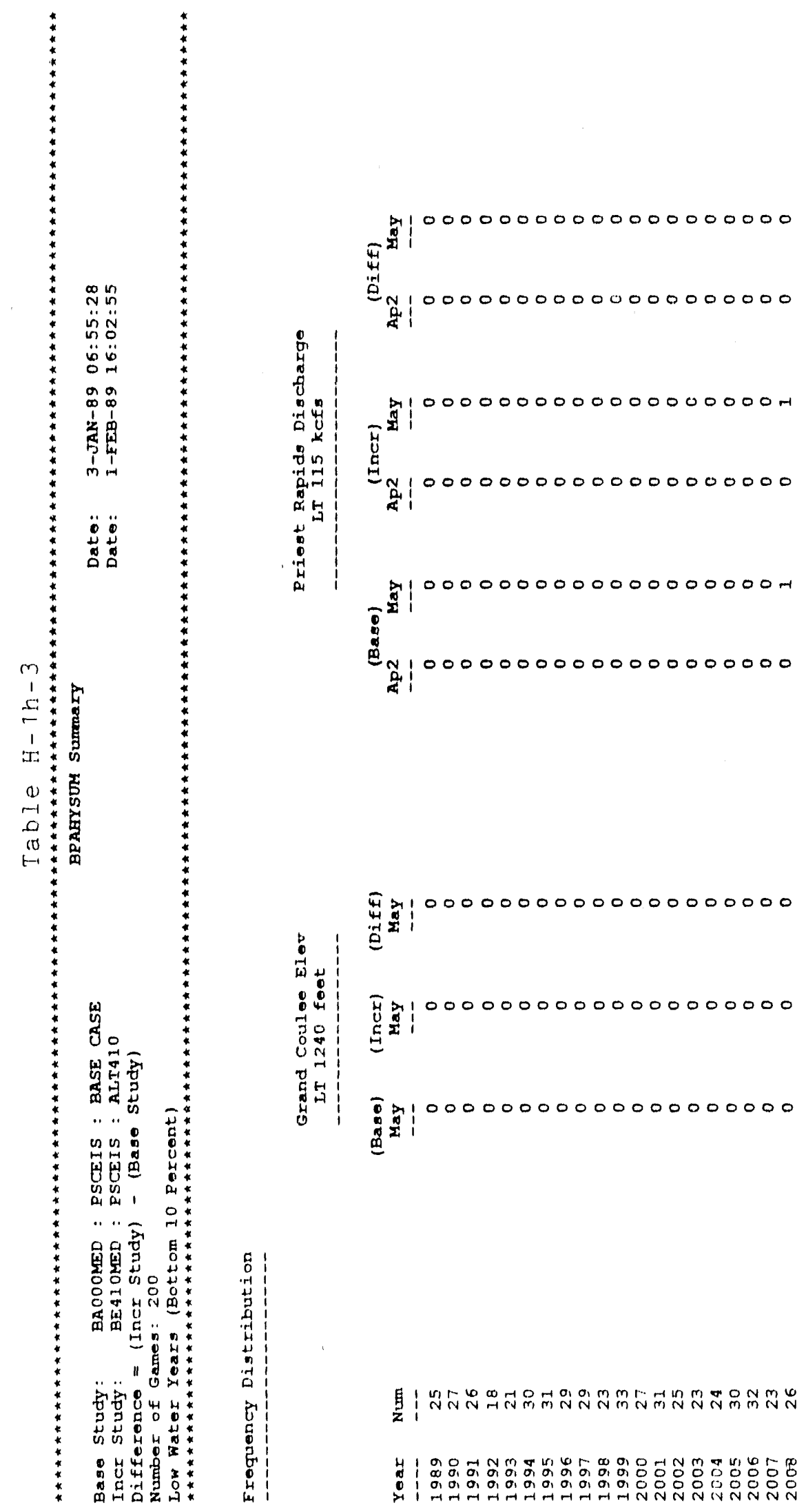

$11-1 h-4$ 

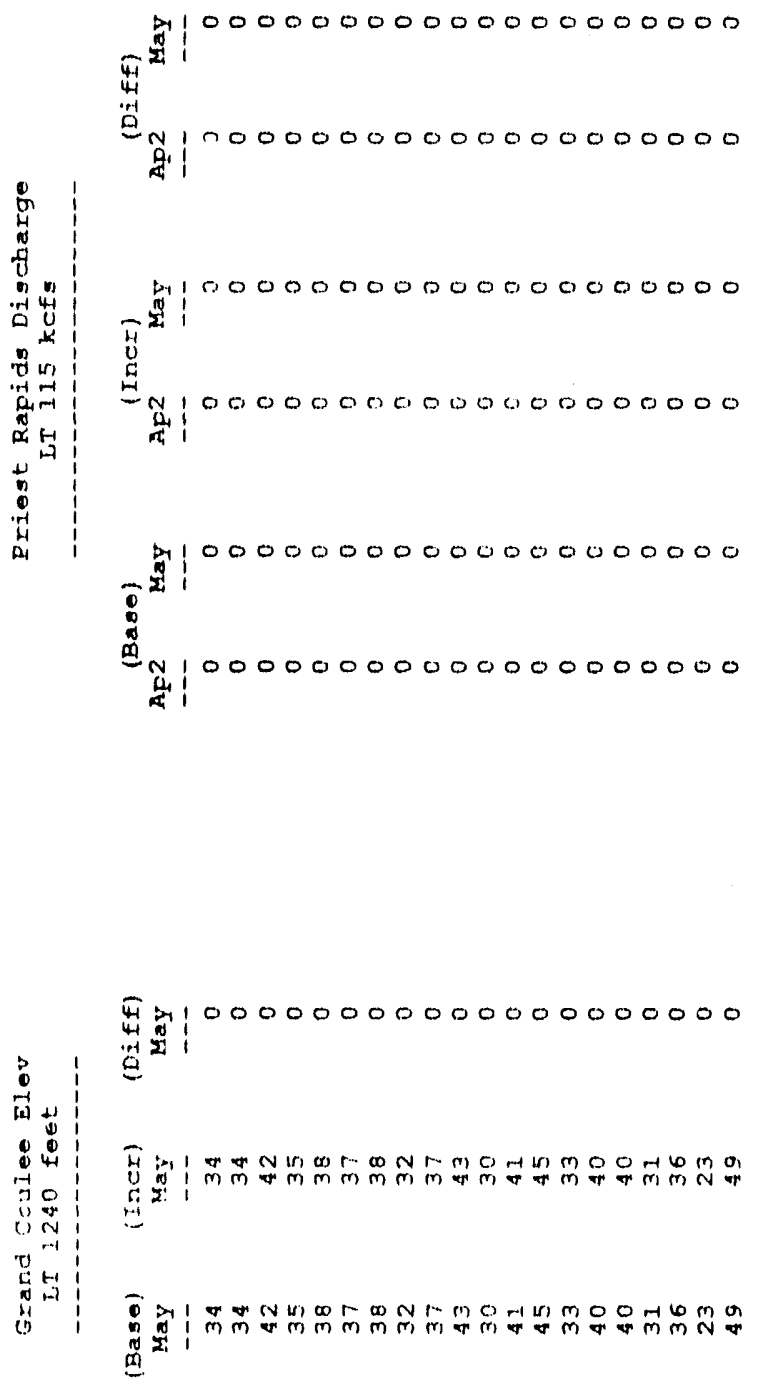

代出

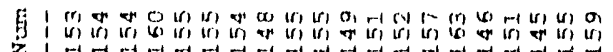



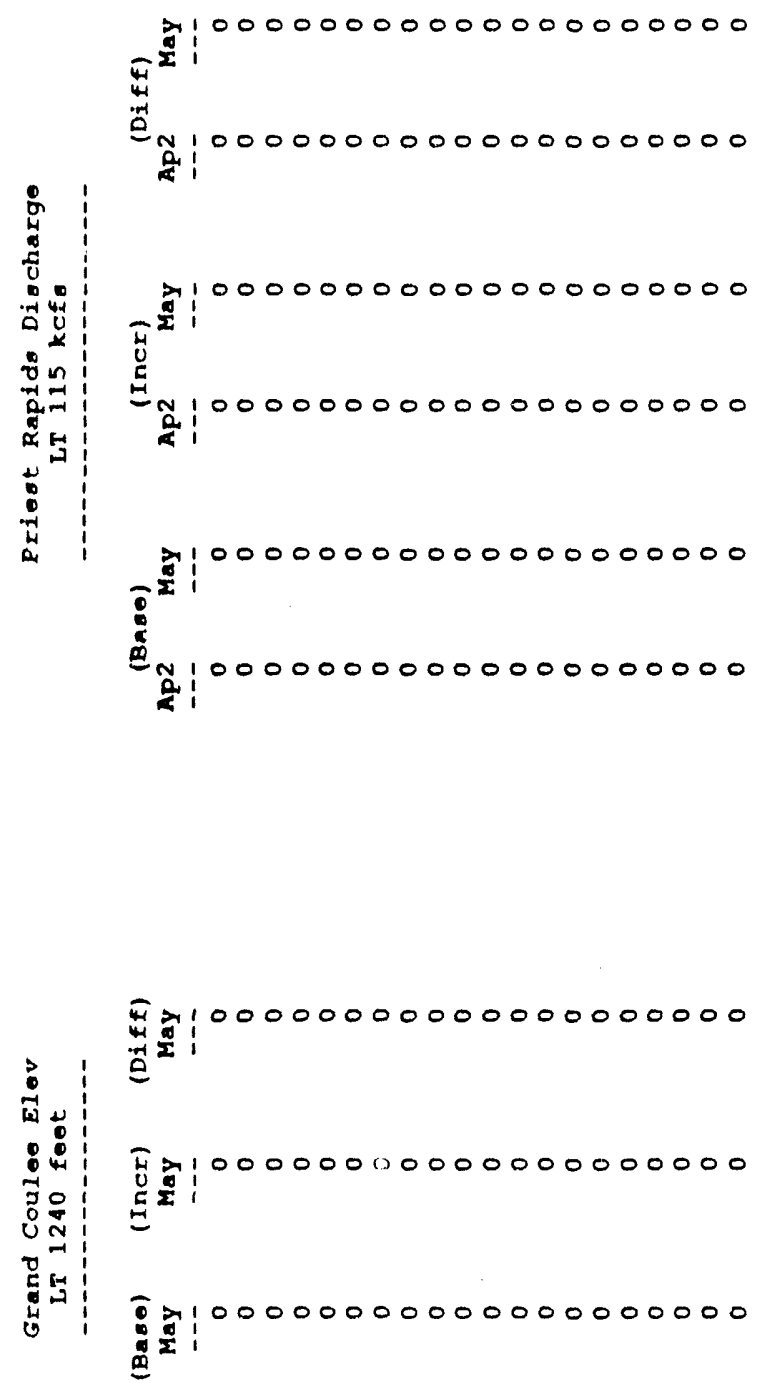

का ए

..

일당

O 0 in 0

은 은

in 4 *

1. 5

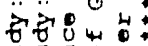

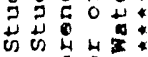

कण 4 :

c热是宫 

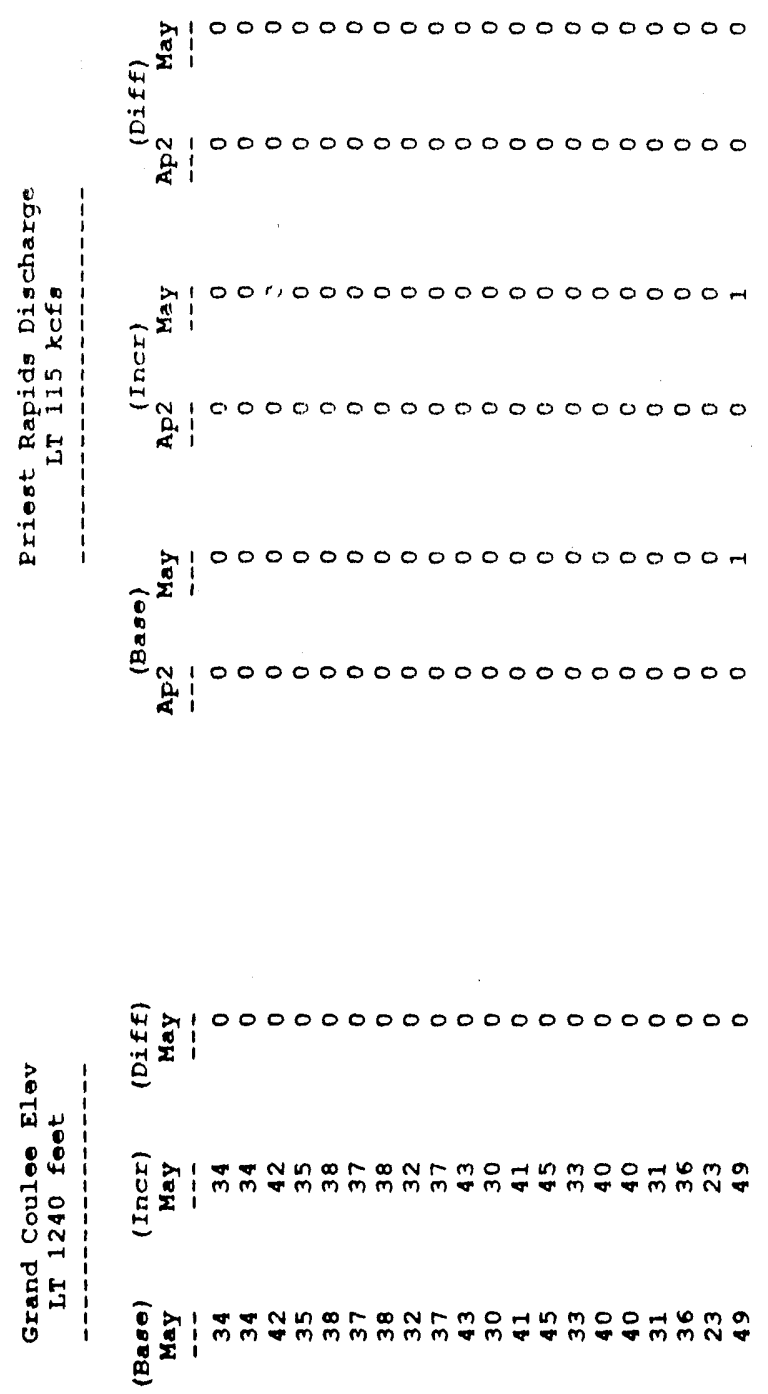

os 0

崫狊息

in

...

을 

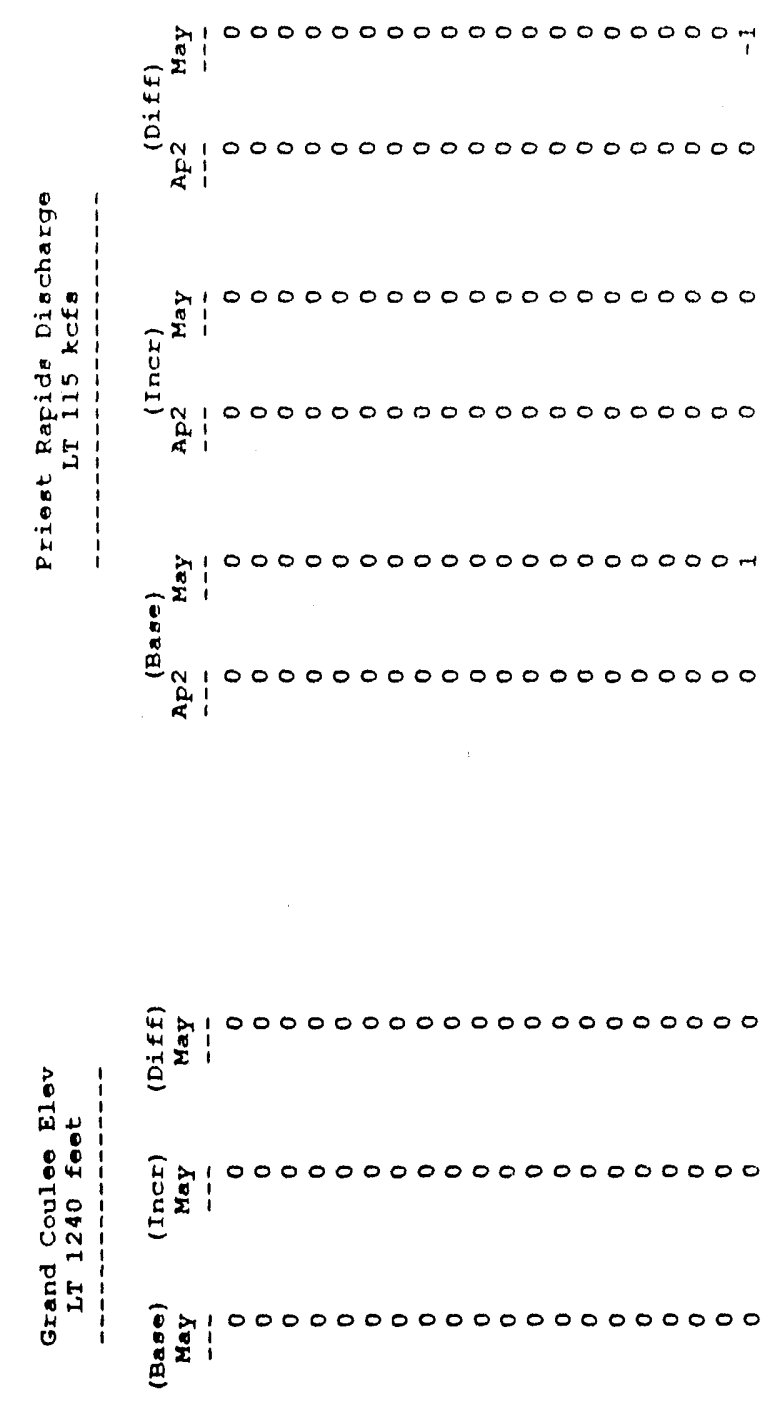


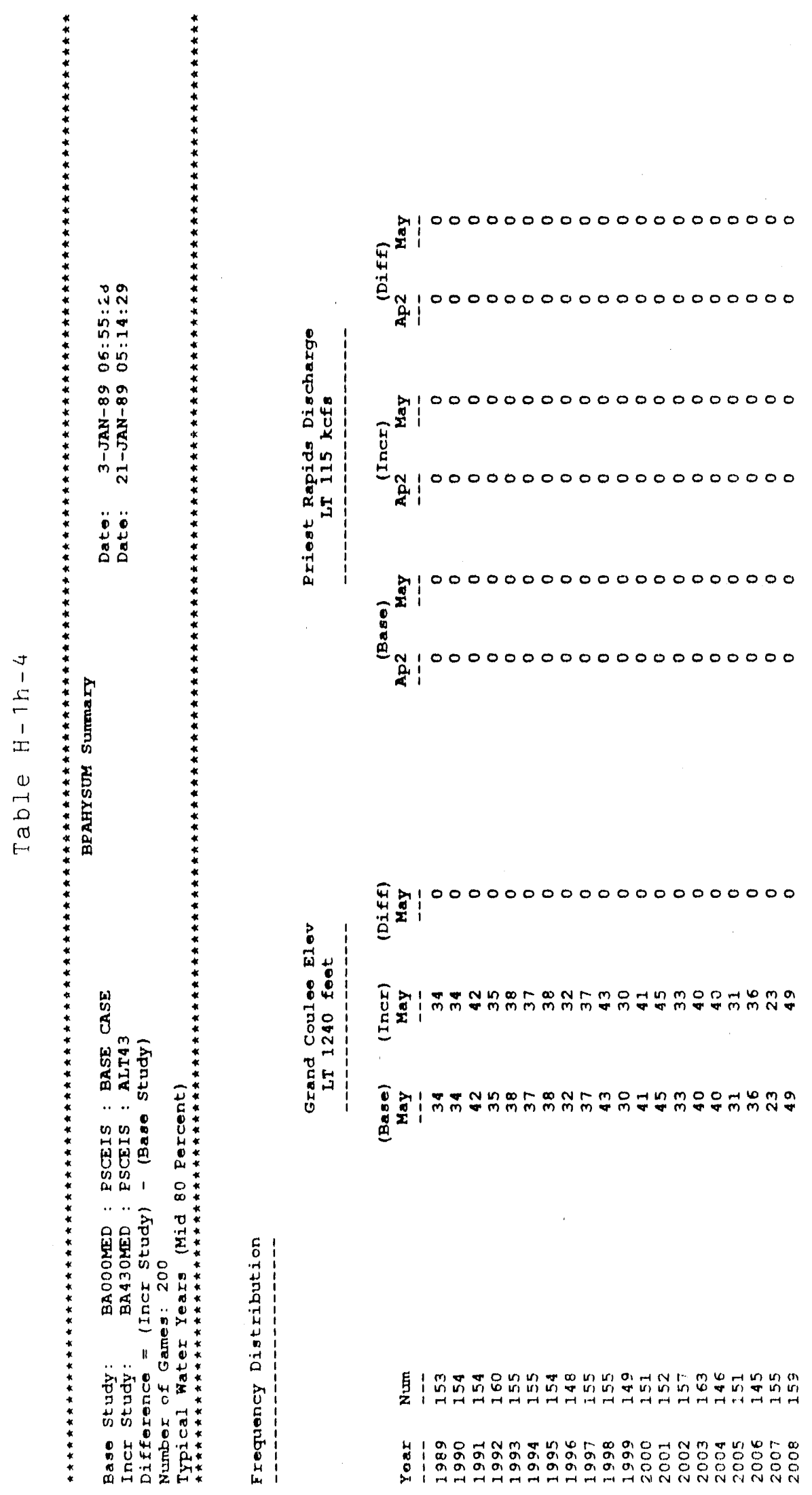

$H-1 h-14$ 


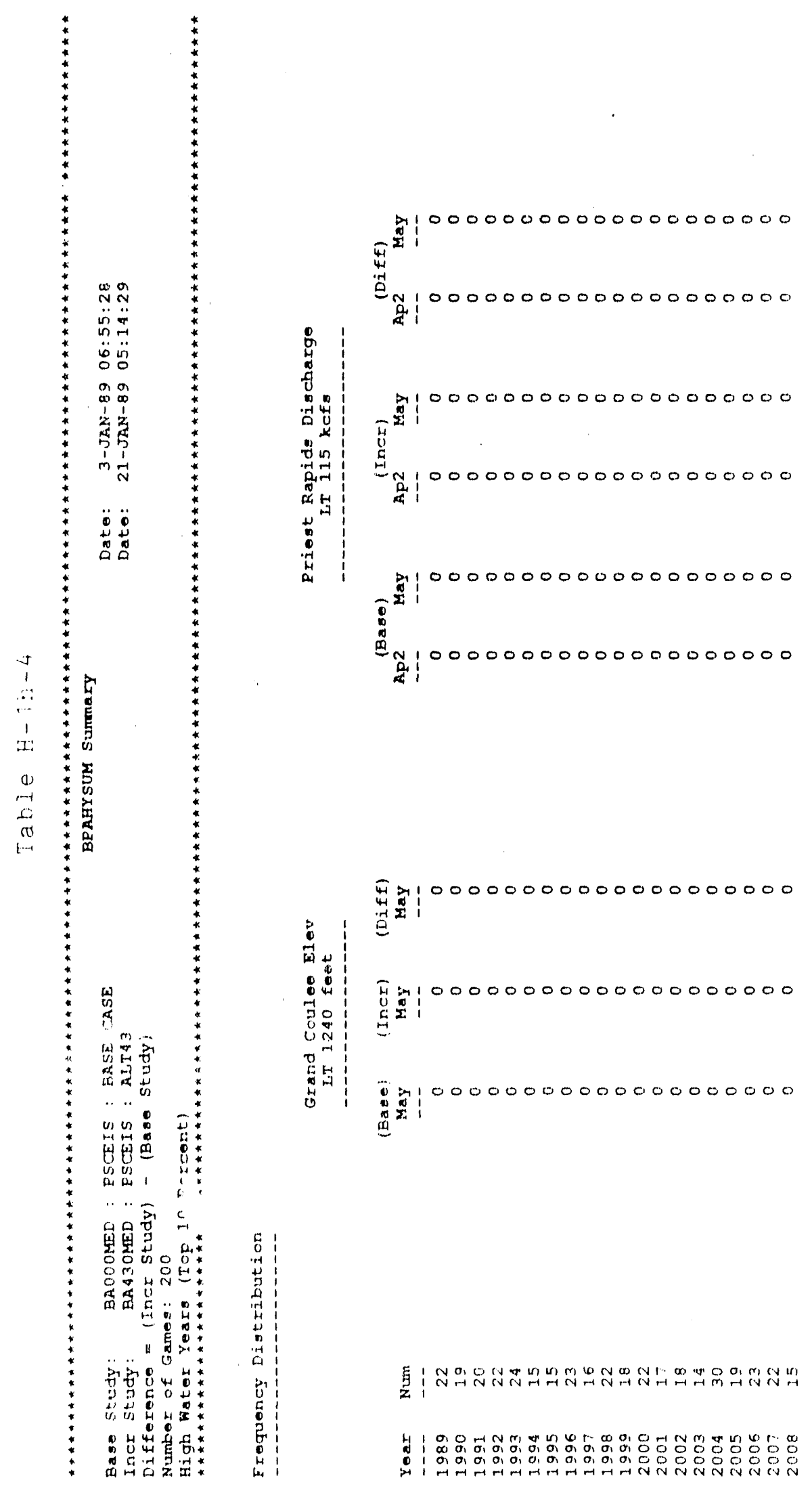

$$
n-1 h-15
$$



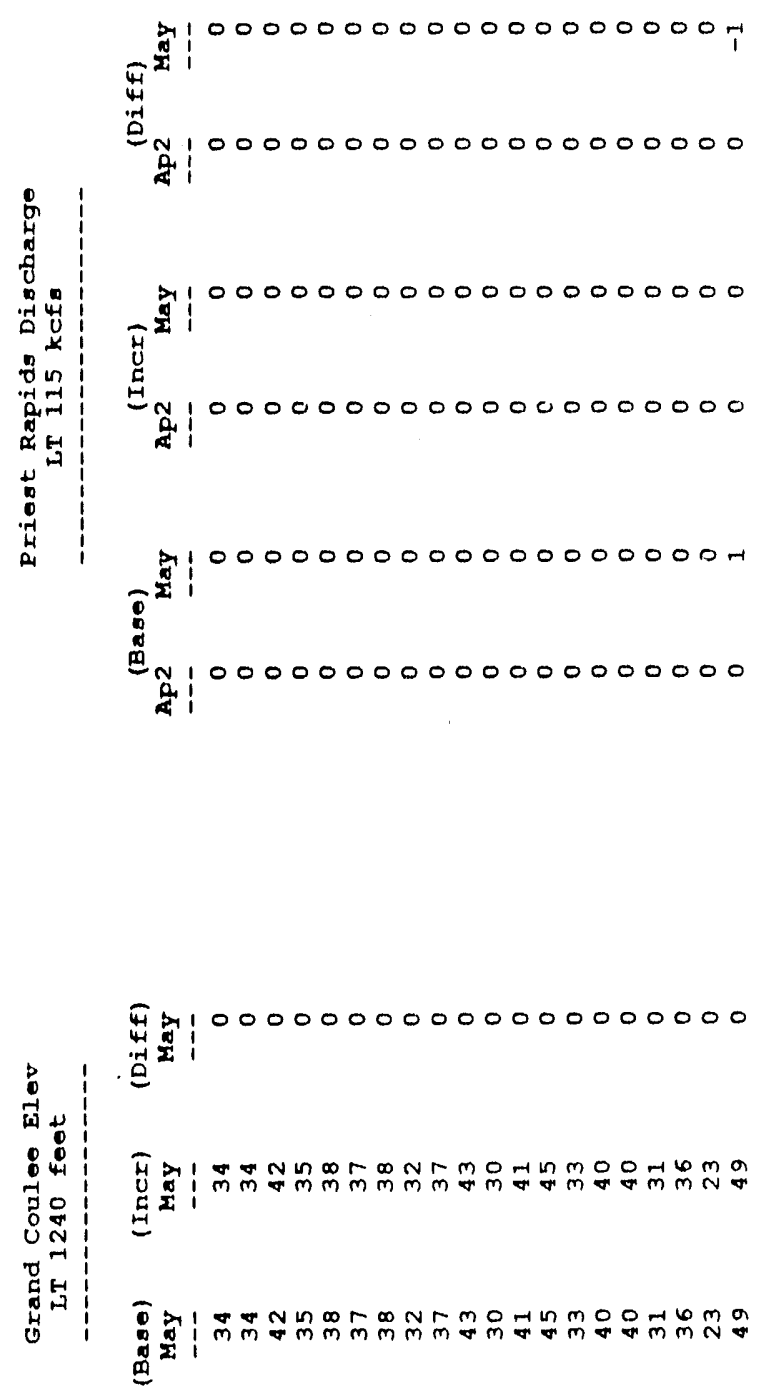

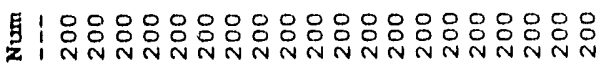

象

可然些

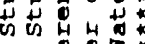

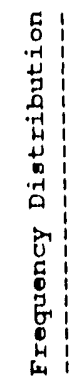


$H-1 i$

CHANGE IN FLOWS FOR FLATHEAD \& KOOTENAI RIVERS

Libby:

Mean Change in End of Period Flows

Frequency of Flows Less Than 4 KCFS (\%)

Columbia Falls:

Mean Change in End of Period Flows

Frequency of Flows Less Than 3.5 KCFS (\%)

Frequency of Flows Less Than 4.5 KCFS (\%) 


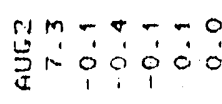

10

$\begin{array}{cccc}r+4 & -r & 0 \\ 10 & 0 & 0 & 0\end{array}$

r)

riorim

c O M M O

- or m m r o

-

vit + 40

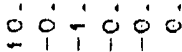

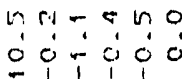

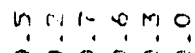

i.tirio

क o cico

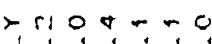

NOM-OO

nordroo

$m \circ m-0$

11

oorroos

ri o o o ci

artoo

झूं

nO

- 00000

पiog o

aOromo

$a-4000$

$\sigma-\sin -0$

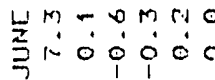

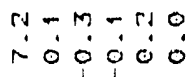

- 0 i 0 0

- OO O०

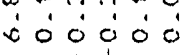

renrtho

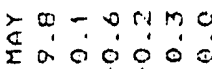

$\pi=-110$

wonor

$0 \div \div \div 0$

momrioo

- 0000

$m-m-n$

우웅요

- 0 i 0 i

a 1

$400-7=9$

in $000-0$

$0-00110$

- 00000

- $0 \dot{0} 0 \dot{0} 0$

$\therefore \dot{0} 0 \dot{0} 0$

mín:

mico:0:00

non-0

mं: 000 :

rí

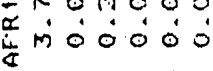

M.

Mípi

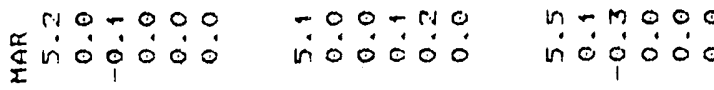

no 0 - 0

$m-a-40$

$2-2-140$

nं०िं

$a-m \ln m o$

$n-n \ln 0$

$-0<0$

$0-2000$

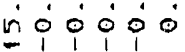

ńi í í

ñ்

OMMMMO in

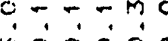
崖向

$n 0 n 000$

$\operatorname{rin} \pi 000$

$\because \div-90$

क்-0ல0

थ

Di०0:00

DO 0 Oं

-0400
-19400

non mo

$-000.00$

drat

崖- $\begin{aligned} & -0 \\ & 0\end{aligned}$

-

rij 0 i 000

बिं

$0 \div 0-9$
$00 \div-0$

$0 r=-90$
nom-0

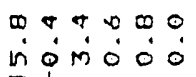

$\because M \div 090$

نि $\dot{0}-\dot{0} \dot{0}$

$\begin{array}{llll}50 & 0 & 0 & 0 \\ 1 & 0 & 0 & 0\end{array}$

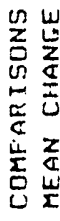

tú

an $0+00$

$r: r m r ?=0$

$n+4 \ln$
nom

$-4-n 00$

mom OMO

o criolo

$\therefore 000$ c

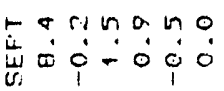

$\because m 0 n=0$

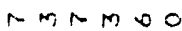

onm-no

कí-:0

$0 \times n o$
0.00

$m m-n m o$

की - 0 0

rarara

a. a a a a

명ㅇㅇ

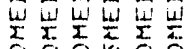

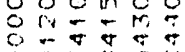

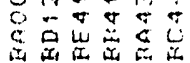

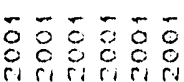

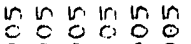

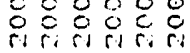

ADOA

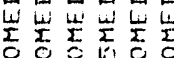

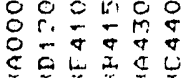

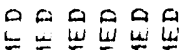




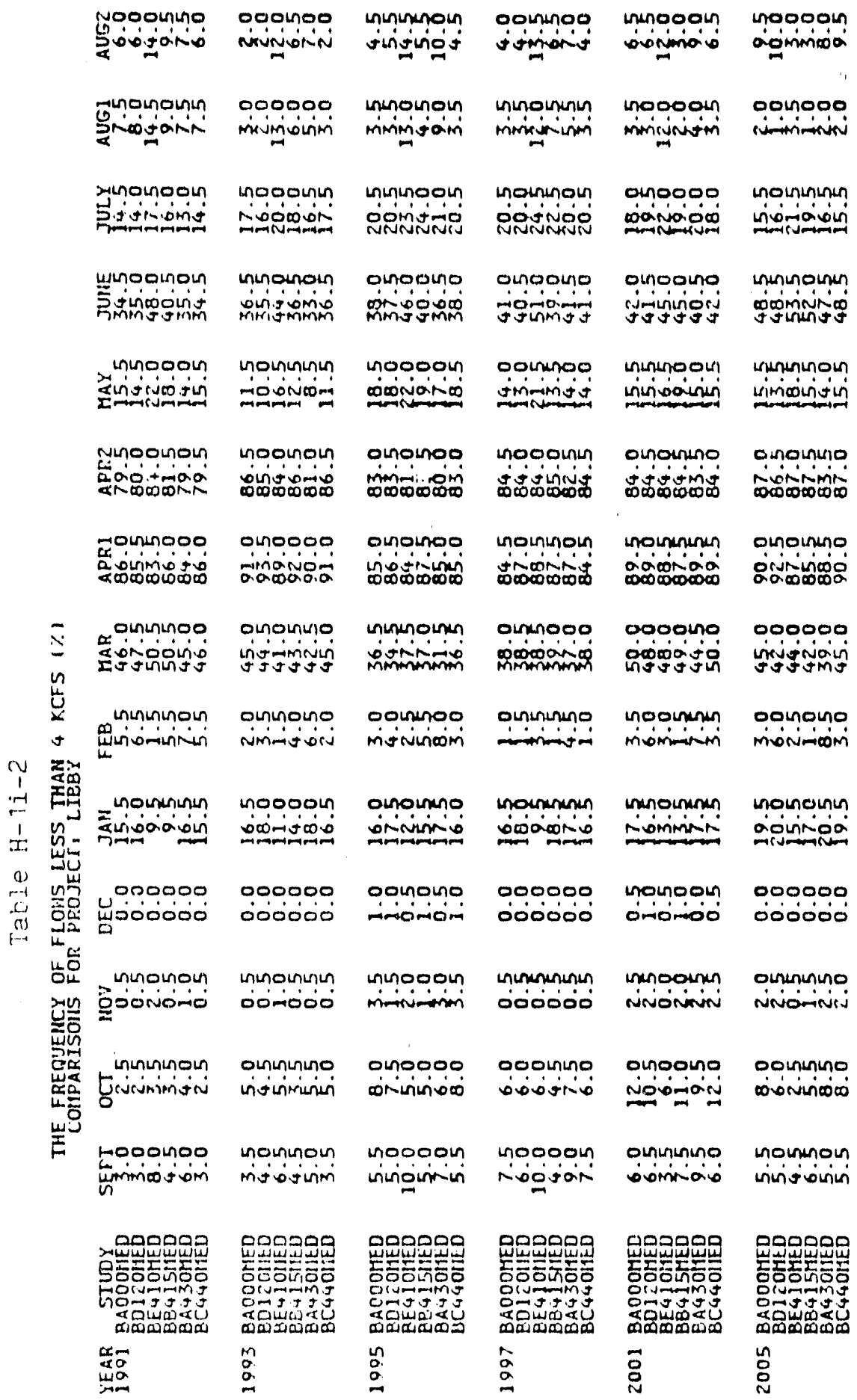




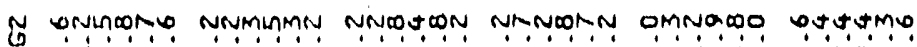

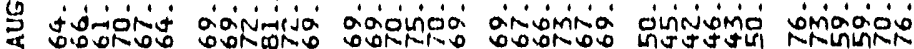

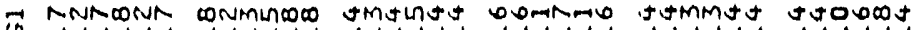

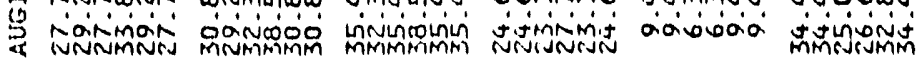

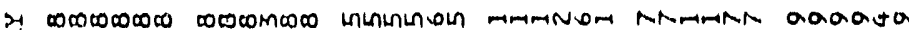

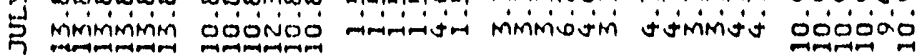

y 000000 000000 000000000000000000000000 F

000000000000000000000000000000000000 I

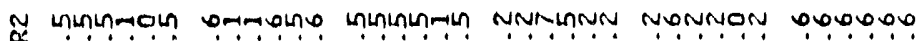
o.

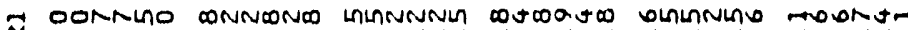

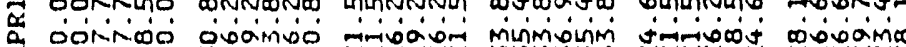

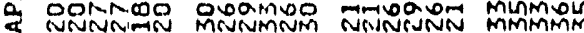
$\hat{x}$

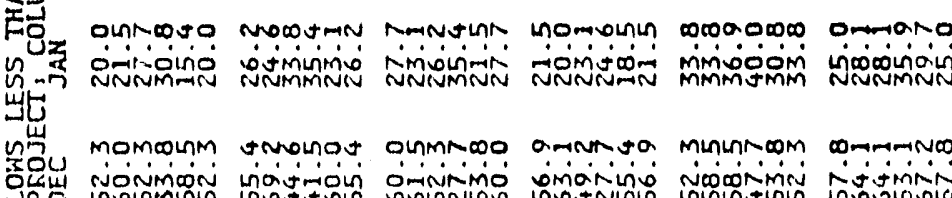
뻔드

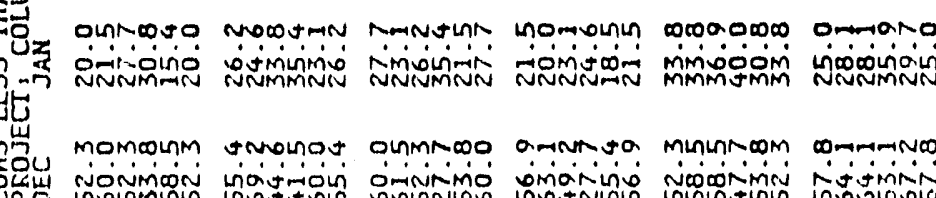
농

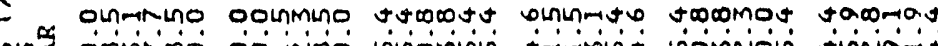

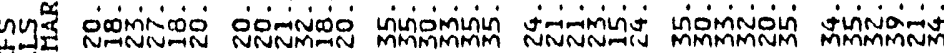
W.

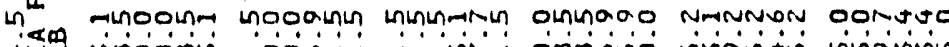

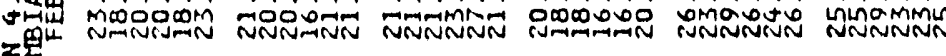

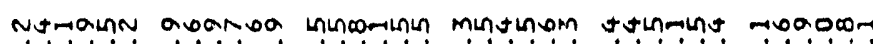

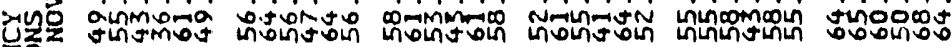

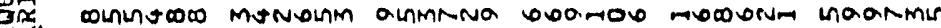

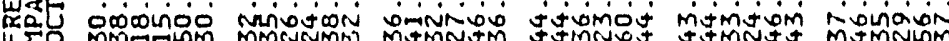
wO

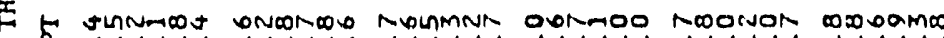

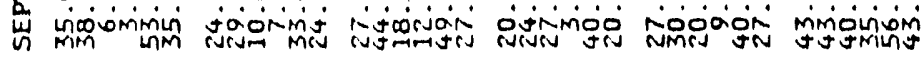

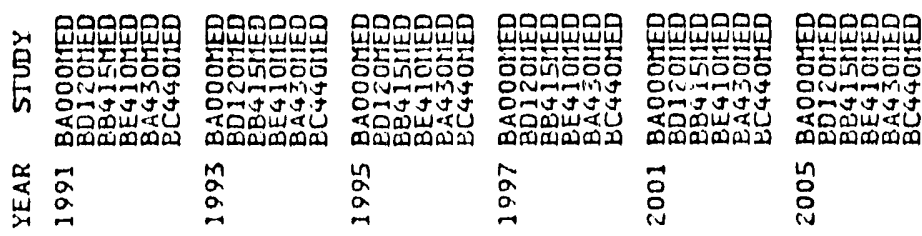




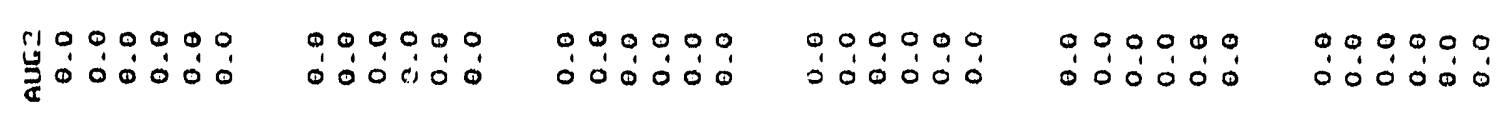

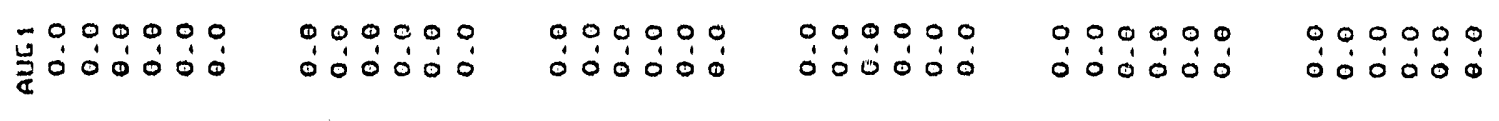

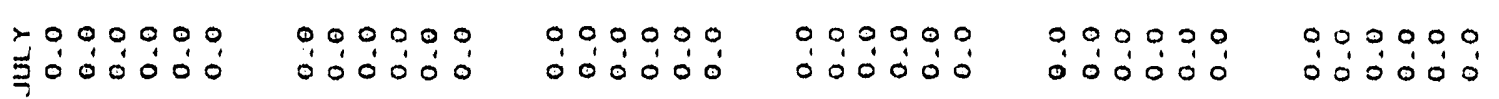

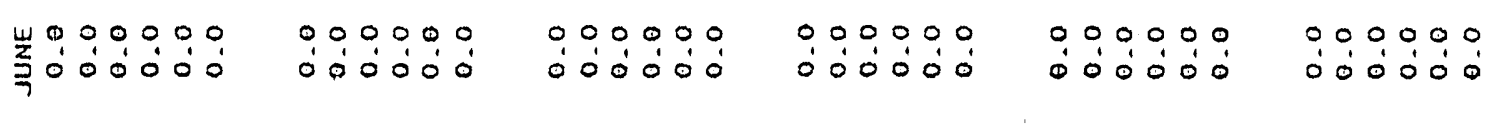

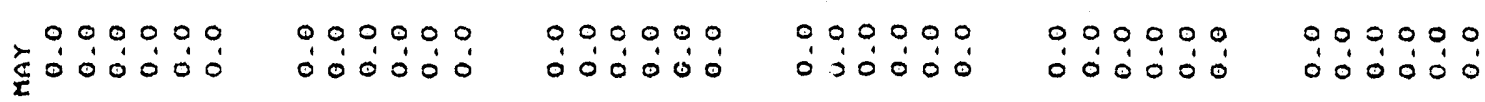

$1000000 \quad 000000 \quad 000000 \quad 000000 \quad 000000 \quad 000000$

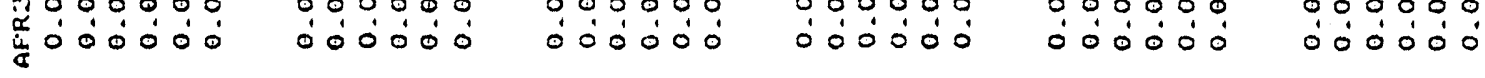

- $000000 \quad 000000 \quad 000000$ nonnom $000000 \quad 000000$

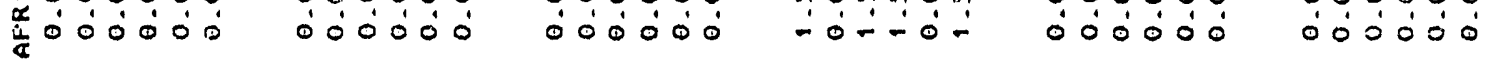

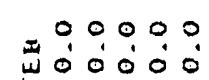

ó

000000

$\ln 0-00 n$

i.

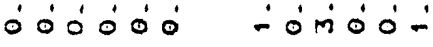

$\begin{array}{llllll}0 & 0 & 0 & 0 & 0 & 0 \\ 0 & 0 & 0 & 0 & 0 & 0\end{array}$

000000 L.

000000

000000

000000

000000

ல்- -

2000000

$00,00 \%$

$\therefore \circ 0000$

000000

- 00000

000000

000000

00900

0.9000

000000

000000

000000

- 0001000

000000

000000

00009

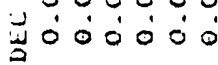

000000

000000

000000

000000

000000

00000

000000

$-00000$

○ं 01010

○ं

000000

000000

000000

000000

000000

Z

○ं 0 O

- 0001010

ல் $\dot{0} 0 \dot{0} 0$

ல் 0 ○்

000000

000000

$000 ? \% ?$

000000

000000

000000

000000

ज̆

00000

०00000

¿ 00000

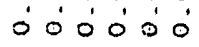

000000

1000000
in 00000

000000

000000

000000

000000

000000

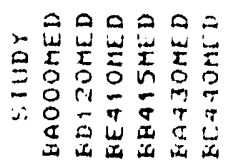

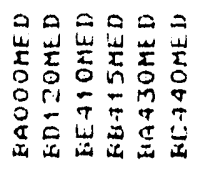

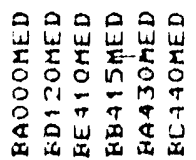

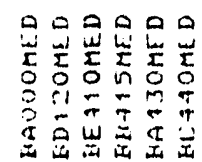

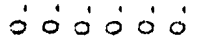

000000

$\frac{\pi}{\pi}$
$\frac{1}{2}$

$n$
2
2

$\ddot{i}$

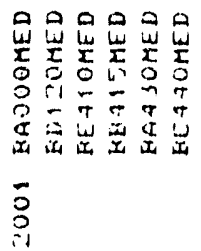

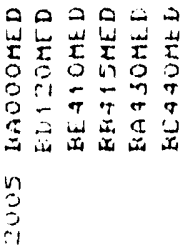




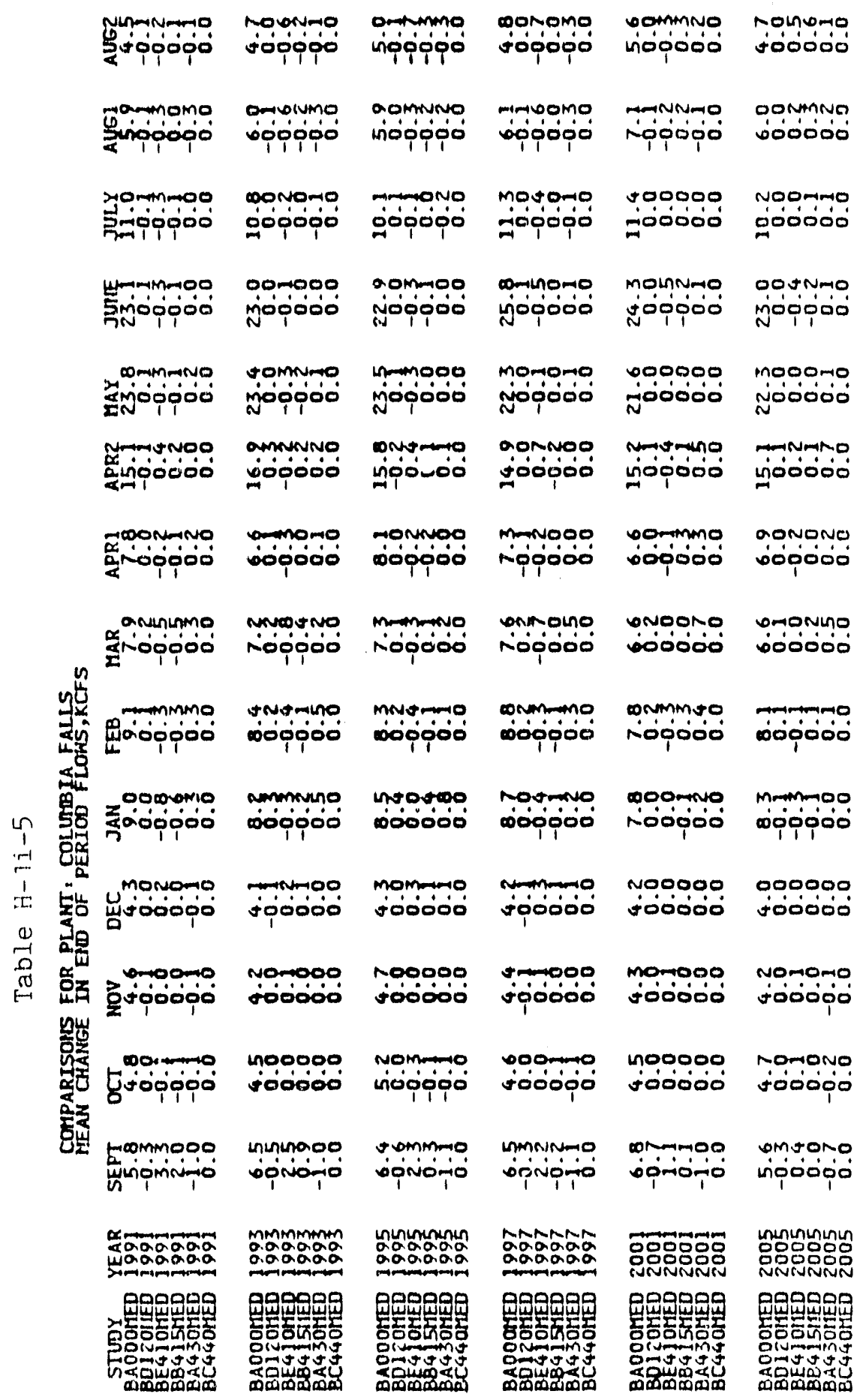


$H-1\}$

RESERVOIR ELEVATIONS AND DIFFERENCES

Hungry Horse

Grand Coulee

Libby

Dworshak 


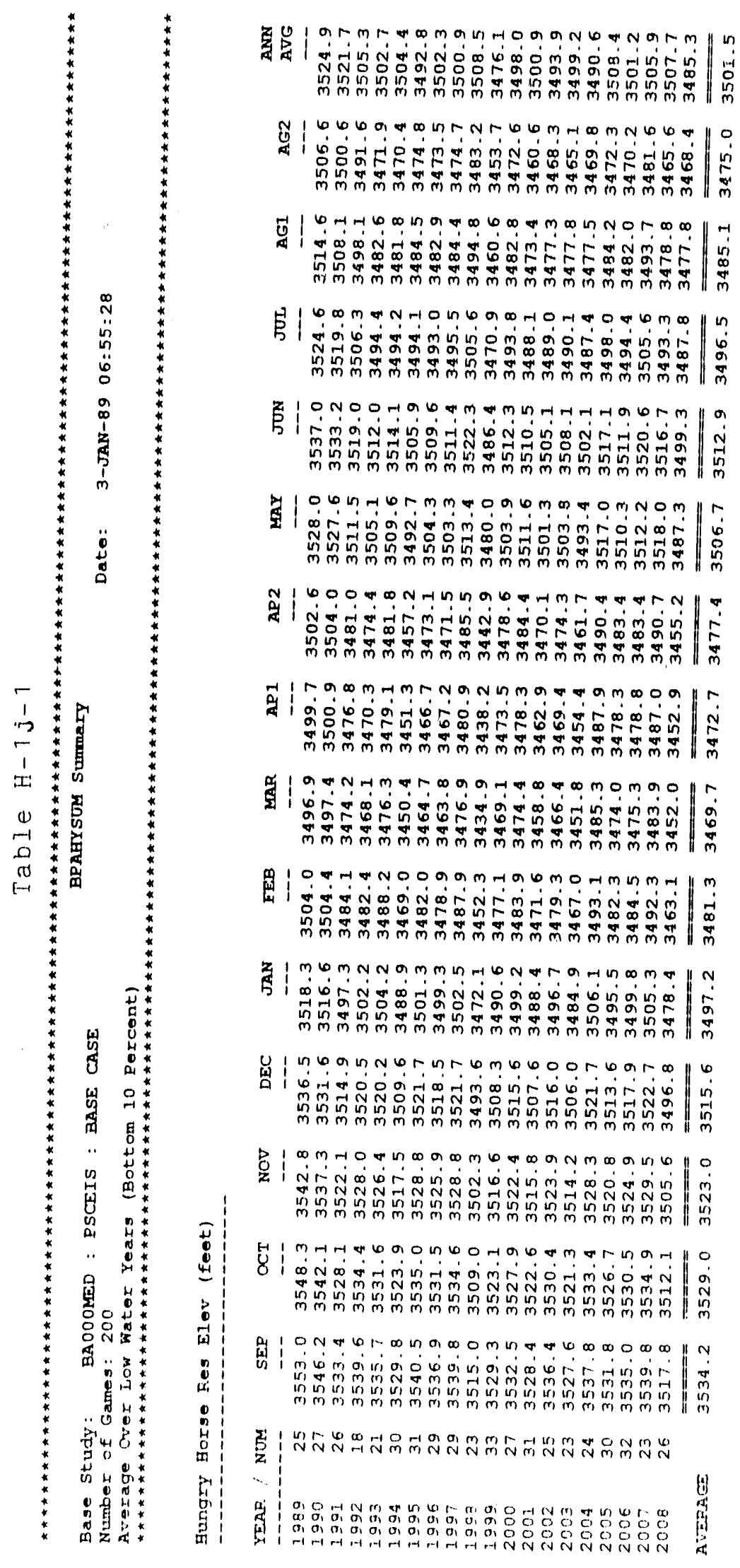




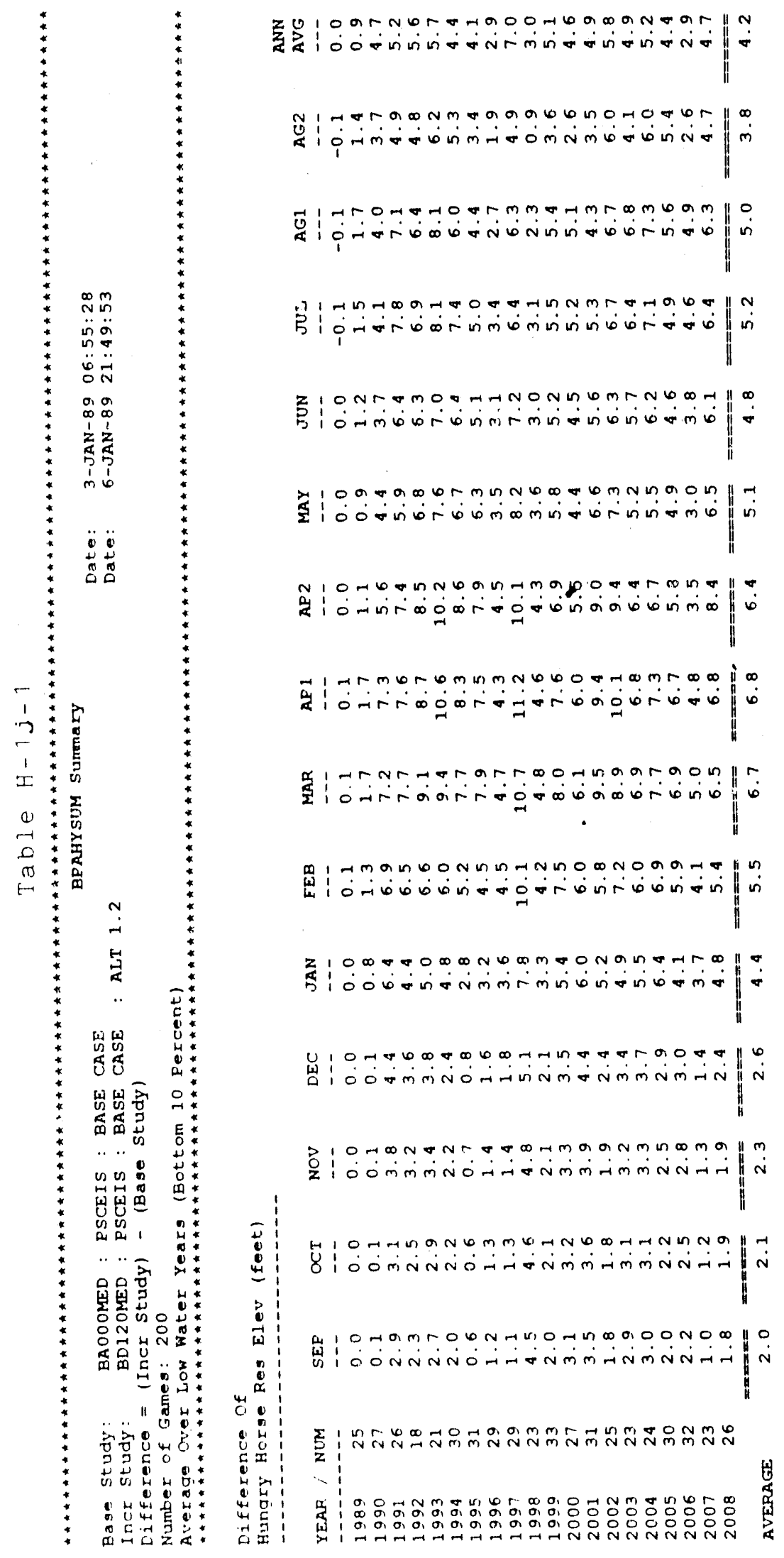

$$
H-1 j-2
$$




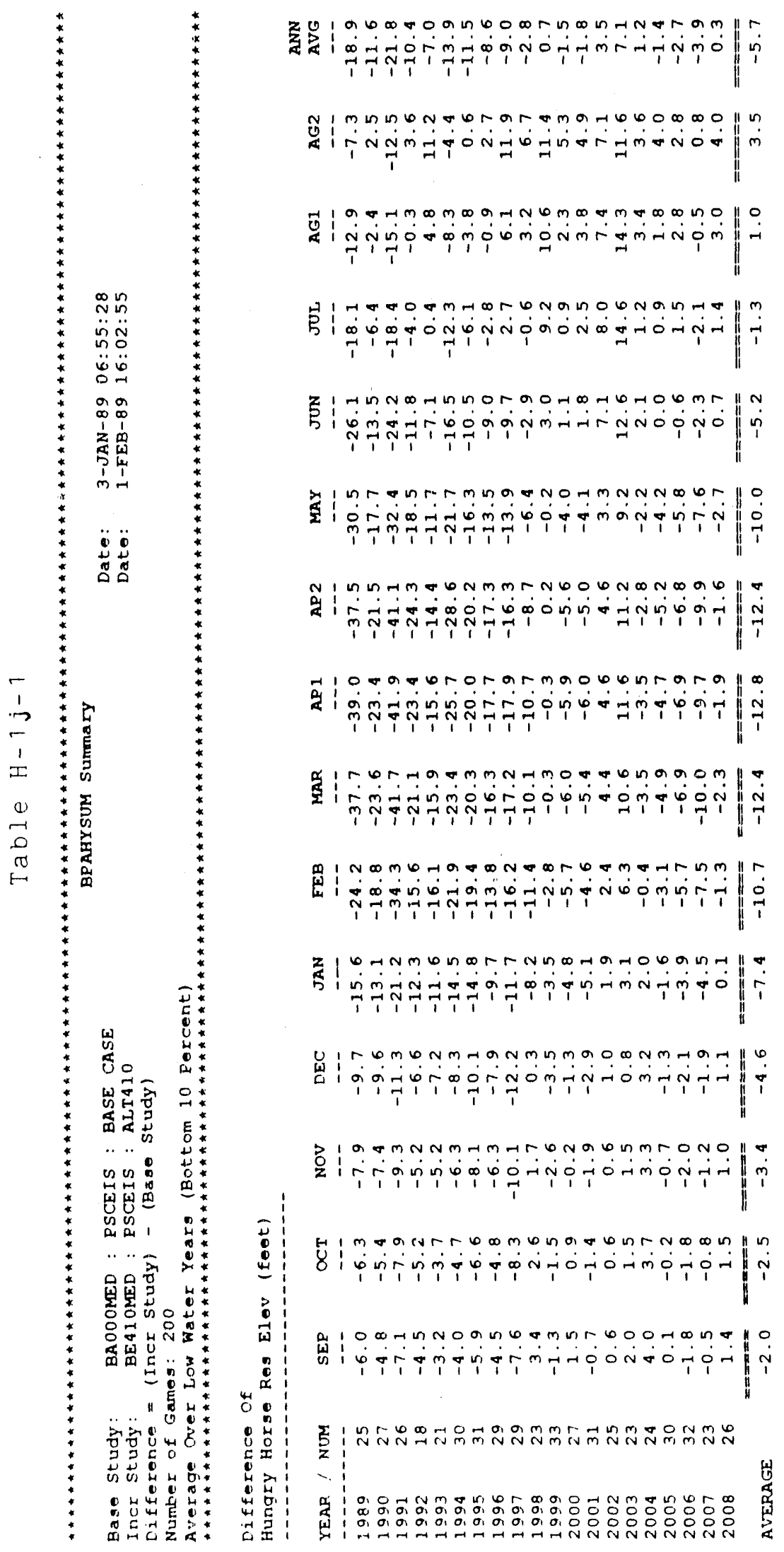

$H-1 j-3$ 


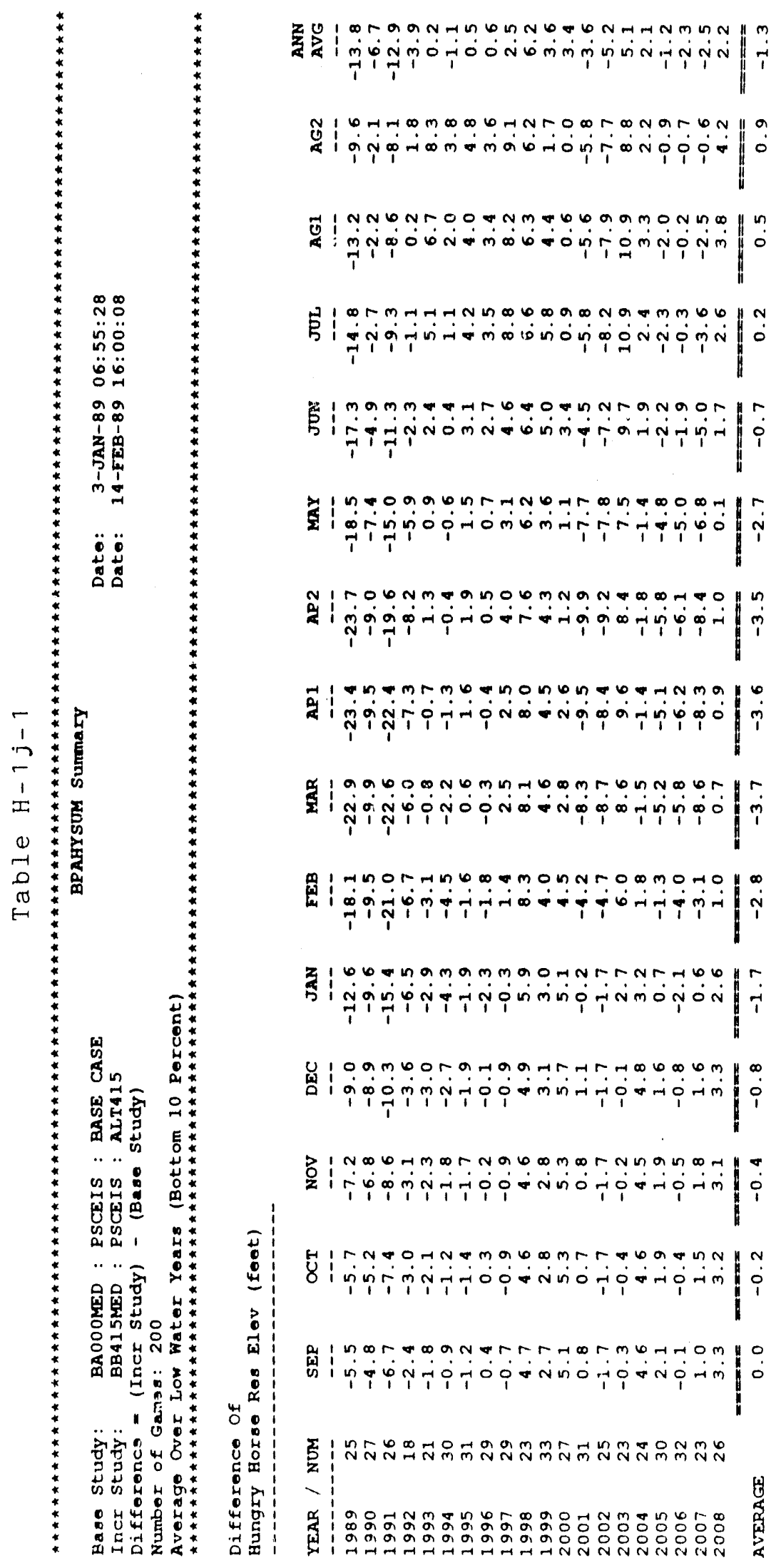




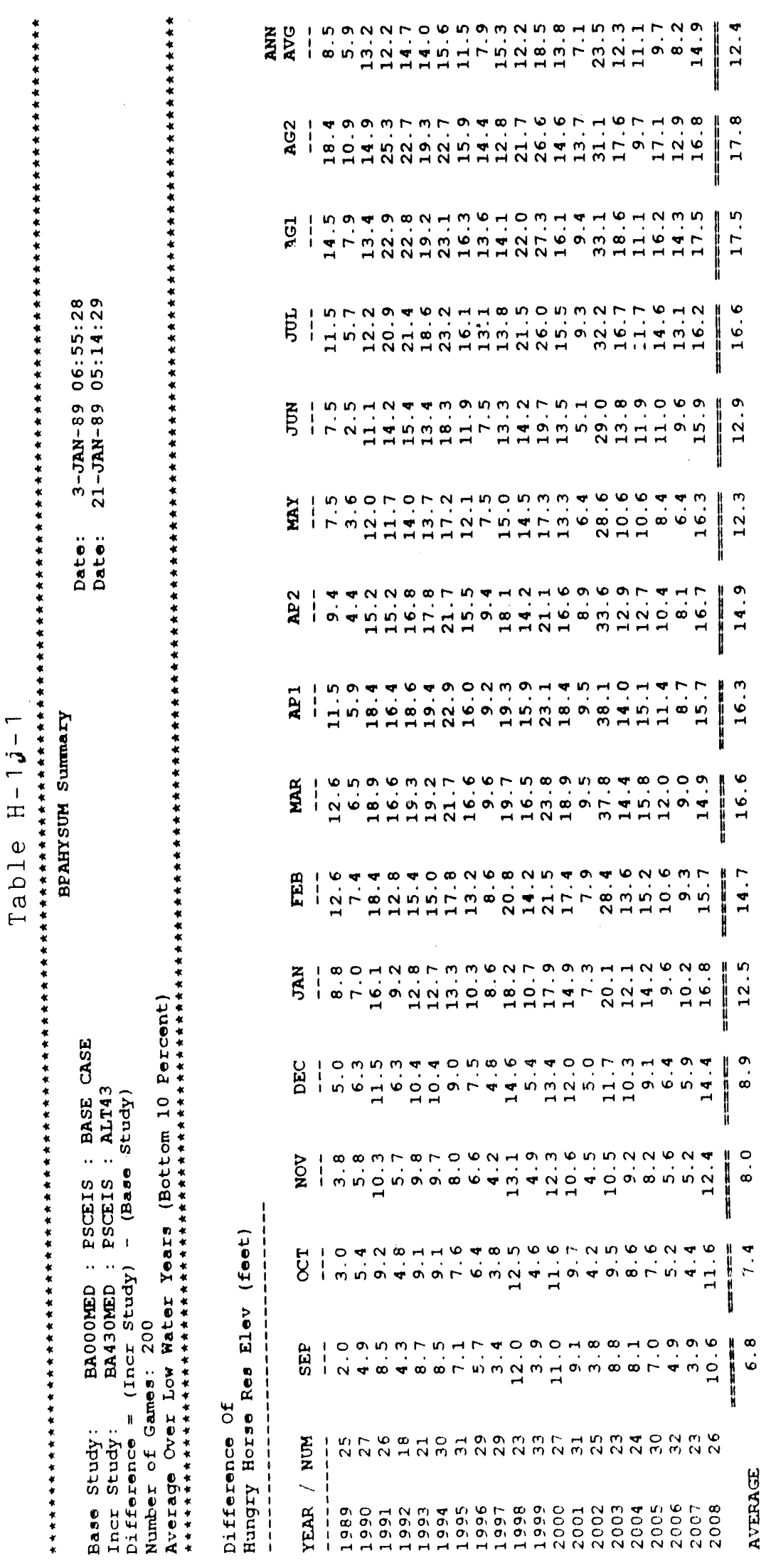

$$
H-1 j-5
$$




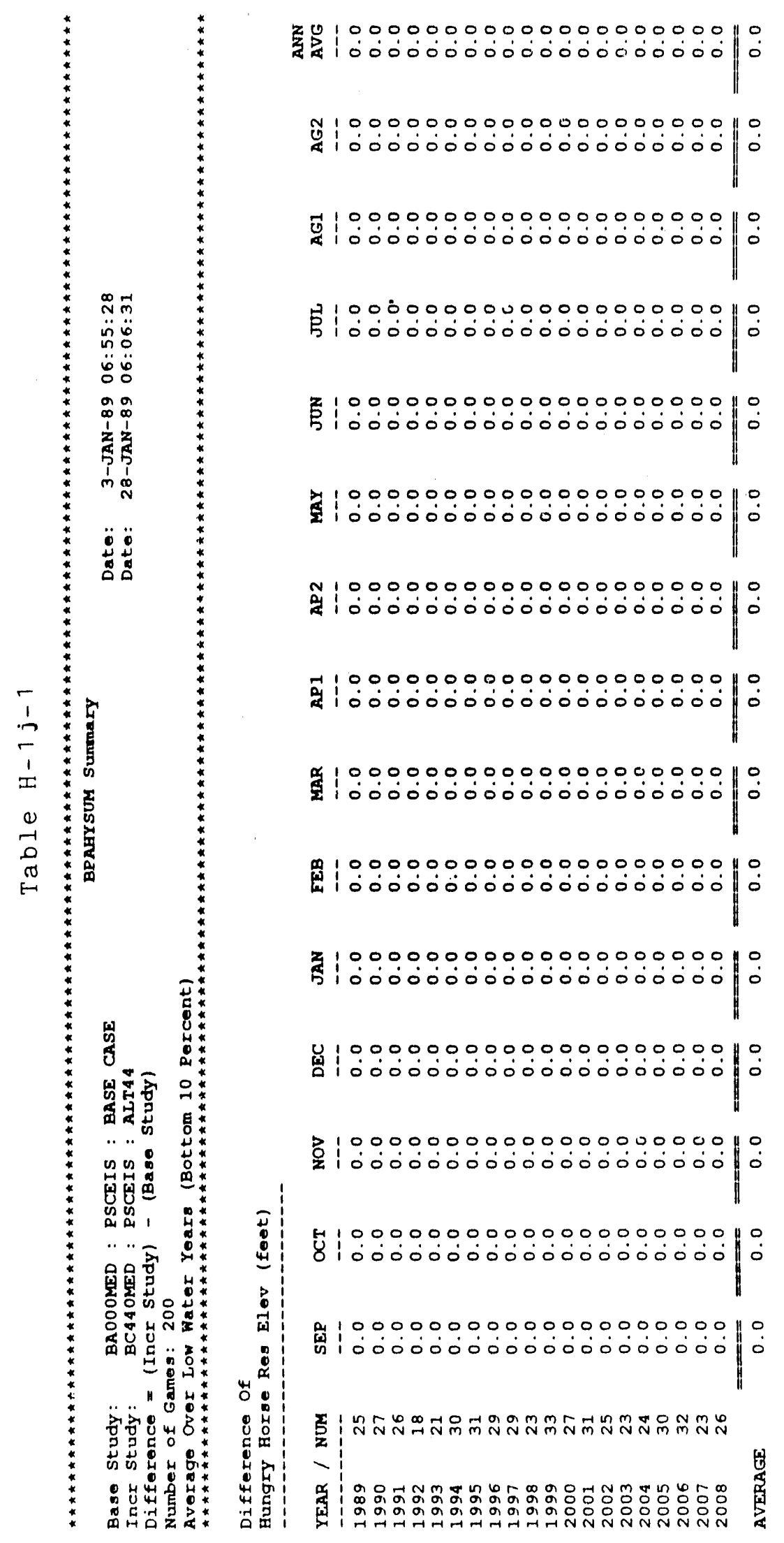

$H-1 j-6$ 







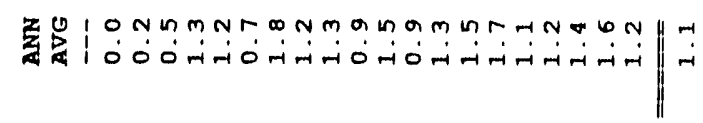

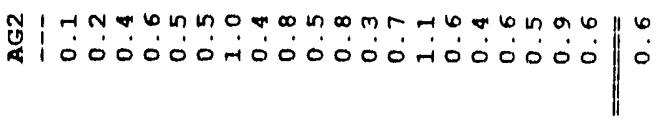

D|

100000000000000000000

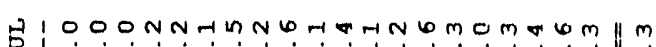

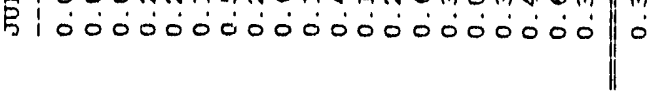

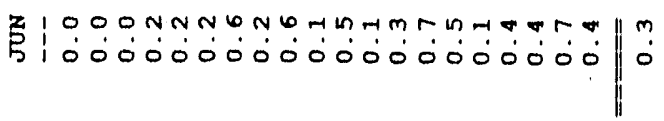

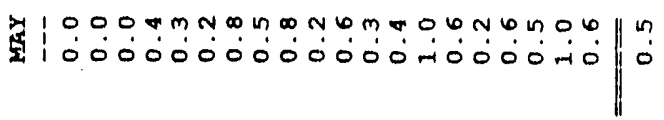

वै

ă

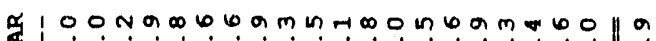

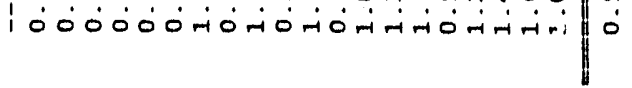

m

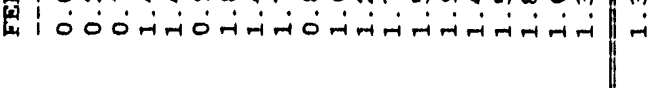

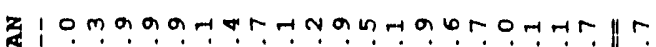

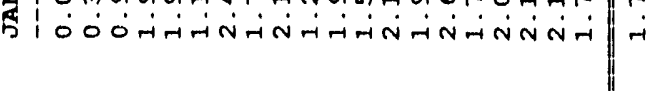

U:

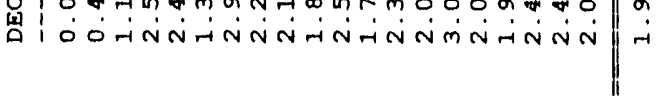

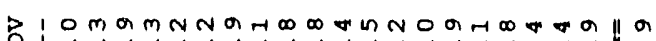

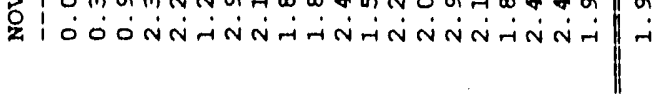

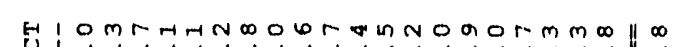

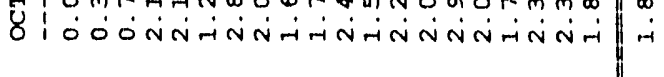

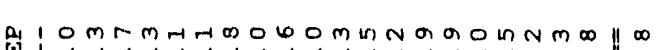

留

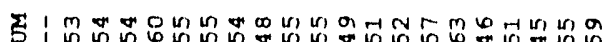

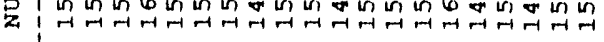

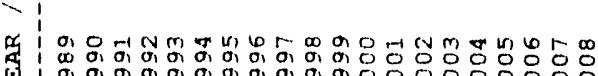

巴忄 


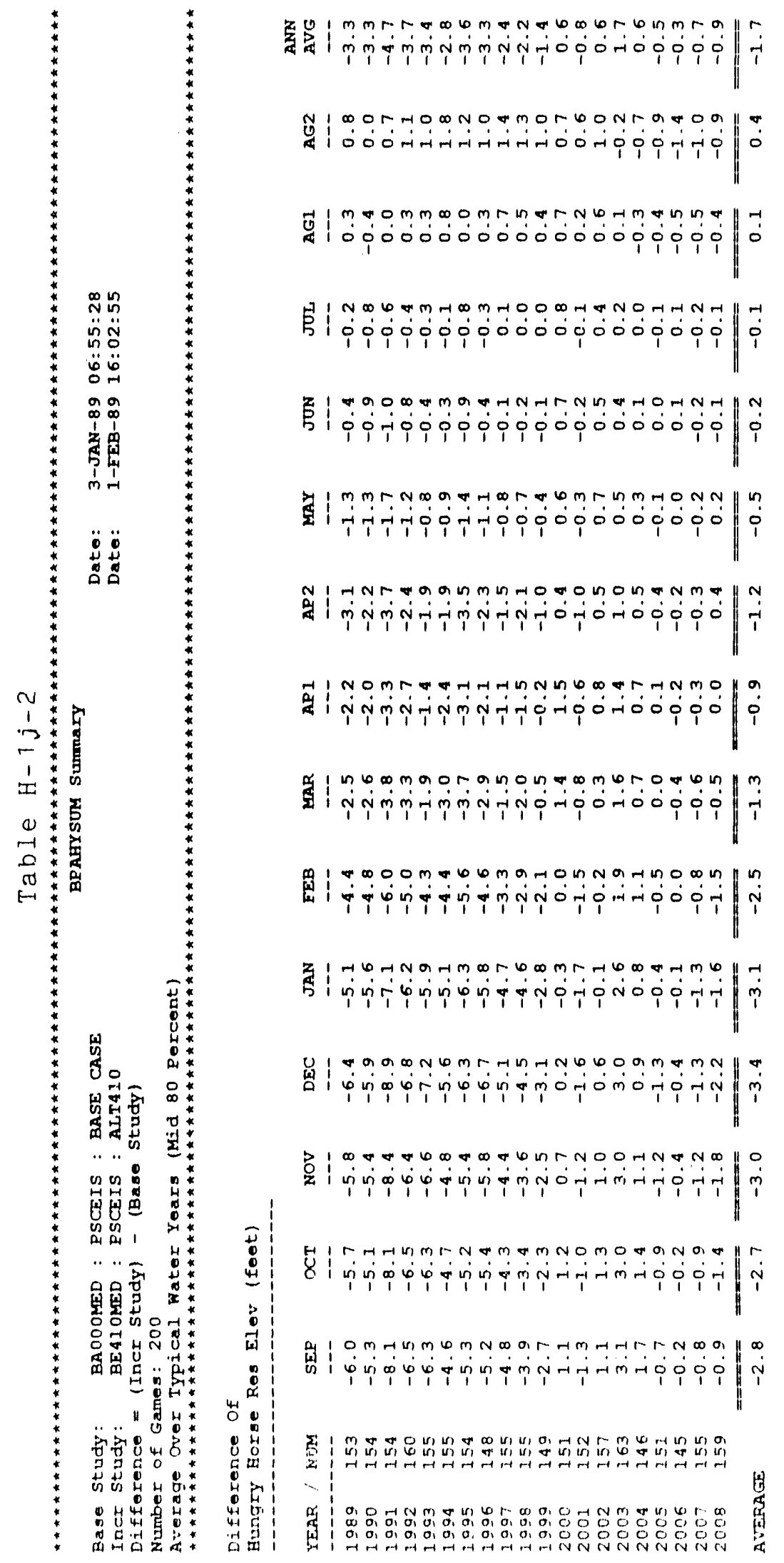




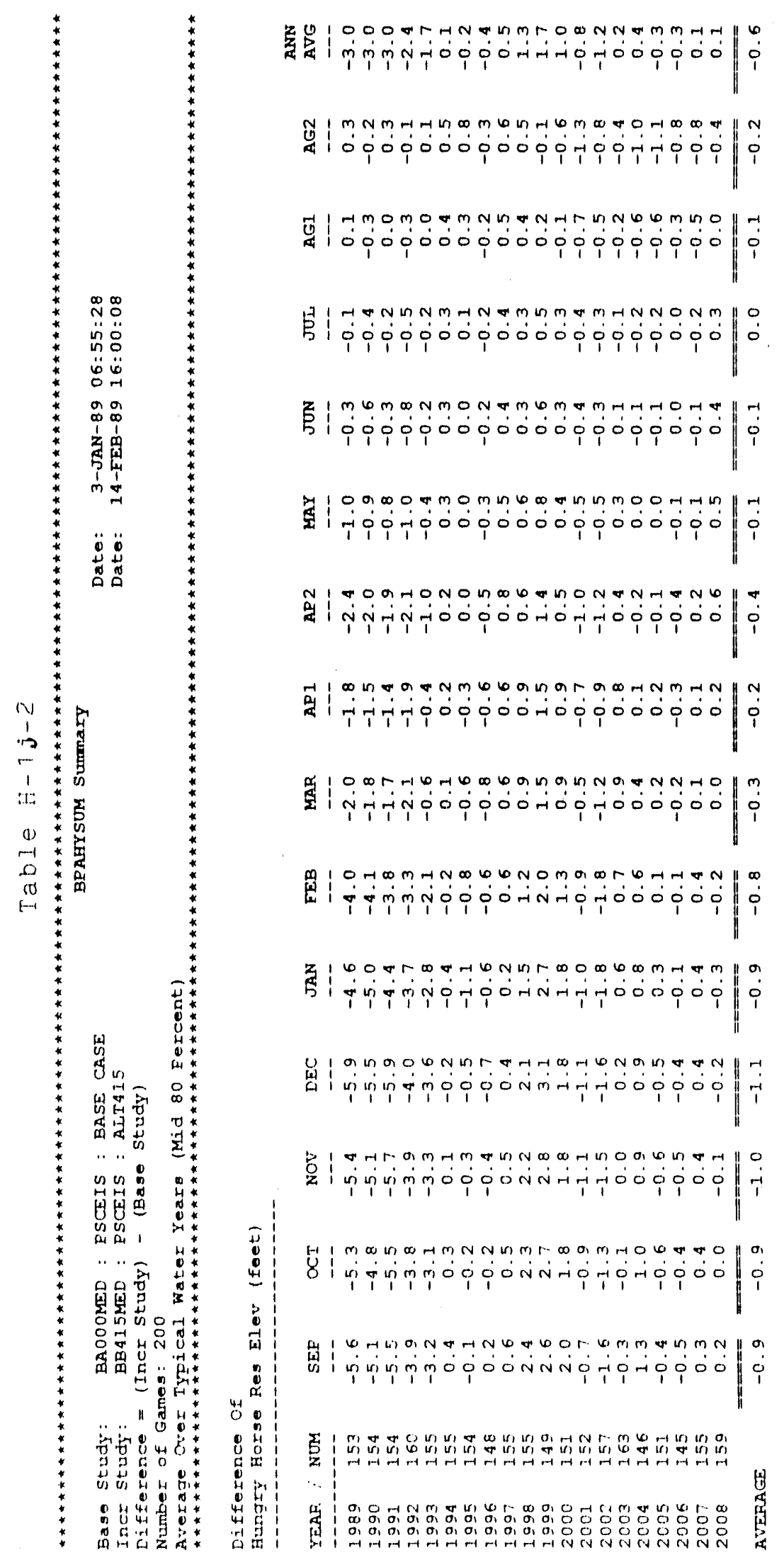


拳是| d

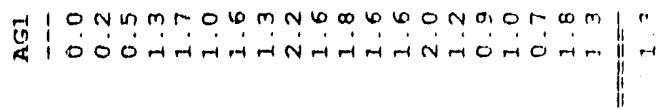

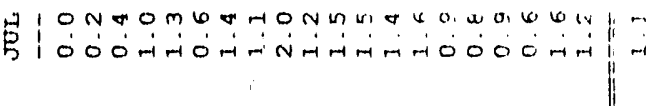

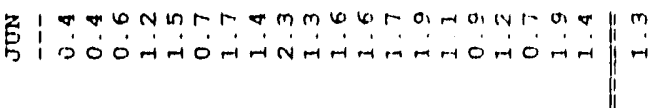

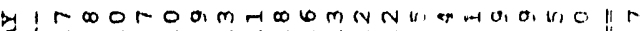

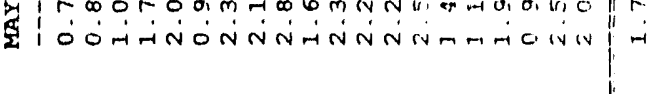

N I m MnN

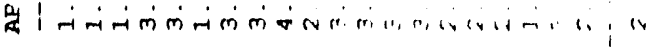

- 1 m «

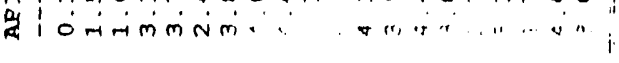

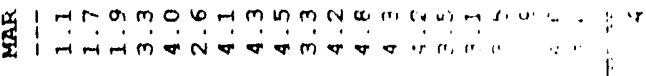

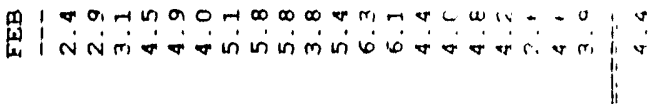

z

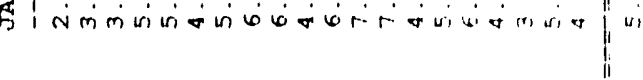

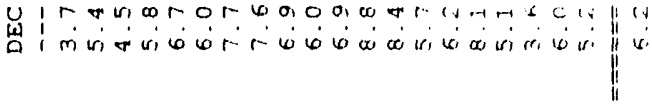

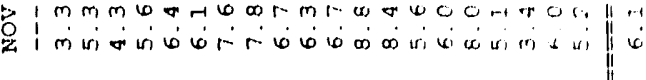

宸苨离

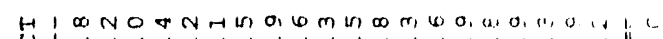

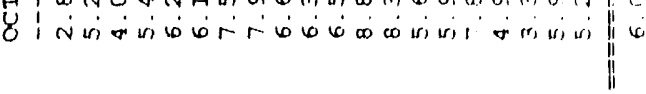

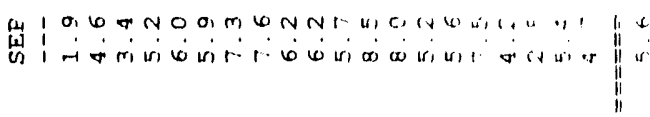

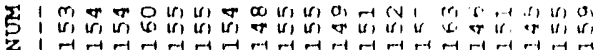

2 |ो सम

\begin{tabular}{l|l}
0 \\
0
\end{tabular} 


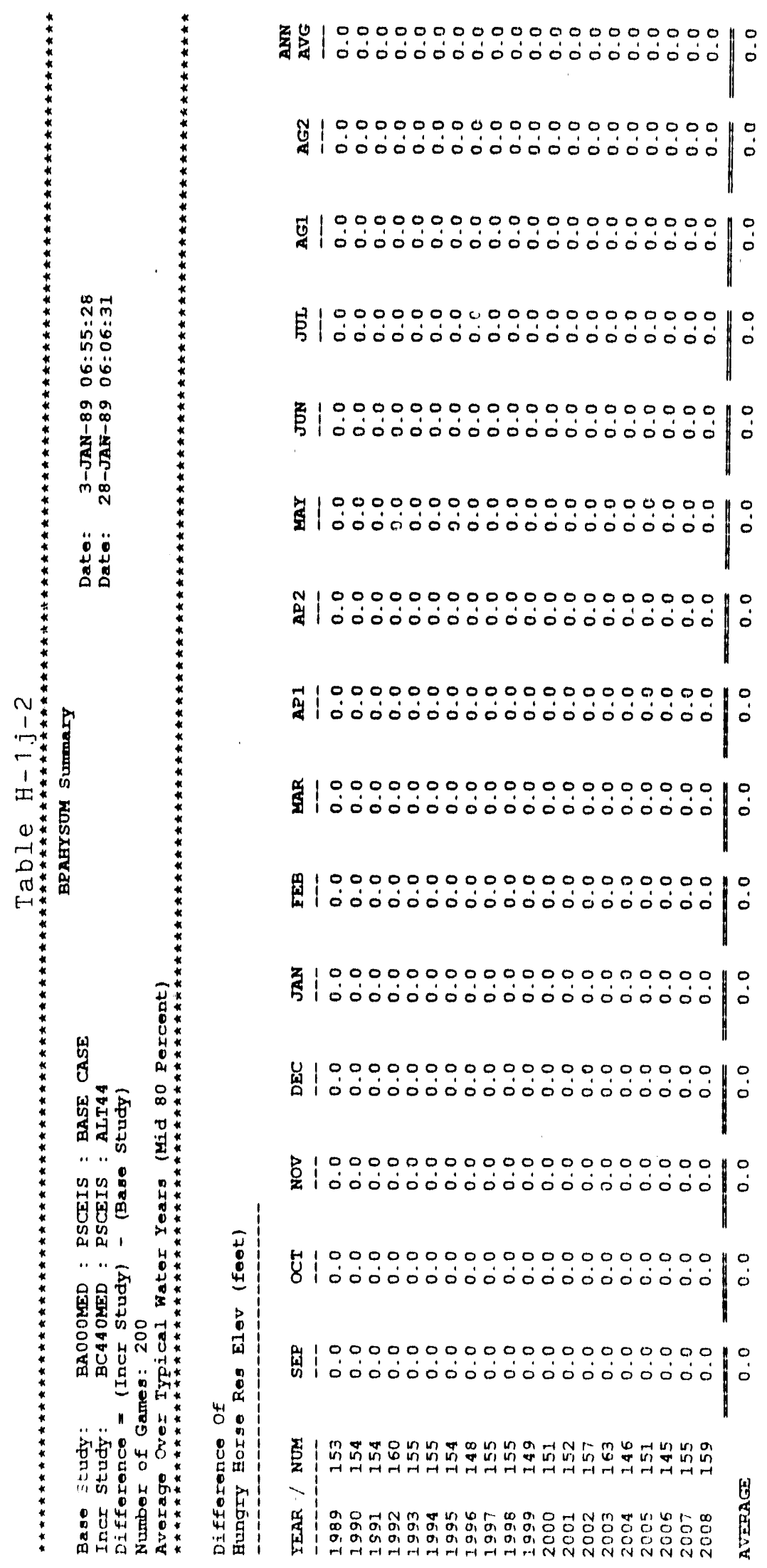




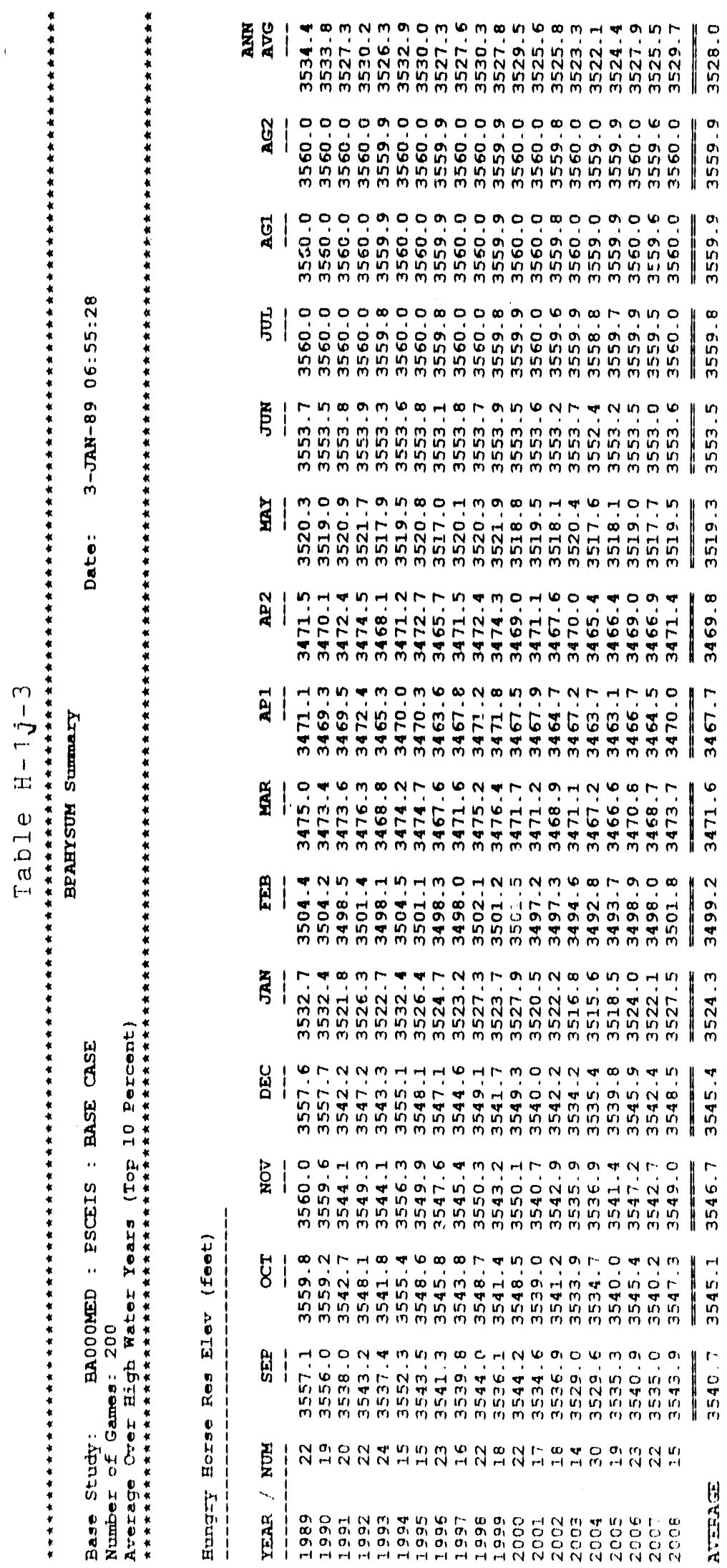




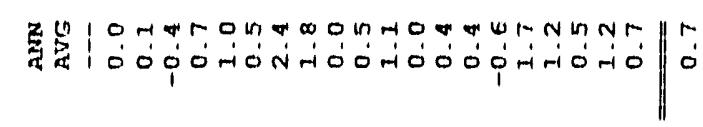

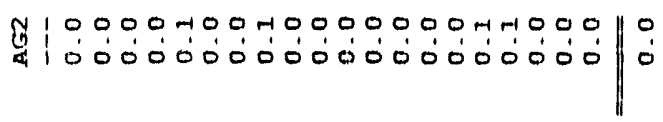

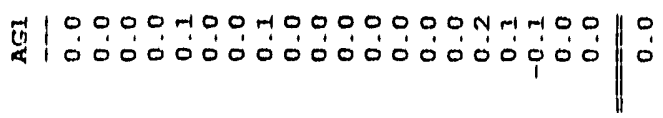

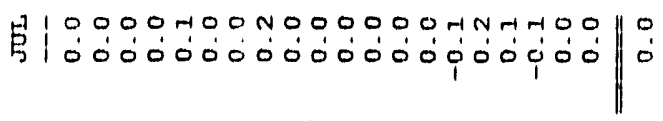

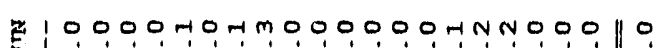

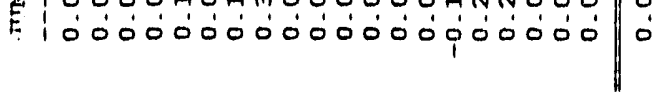

身|

先|

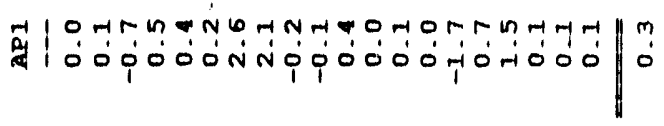

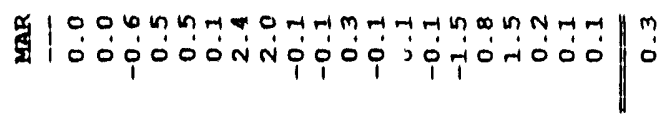

m

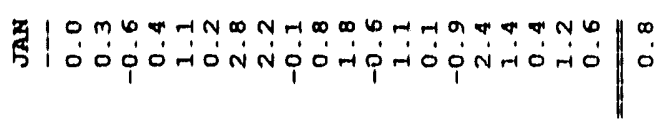

若|

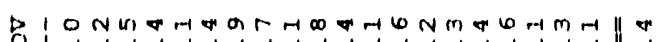

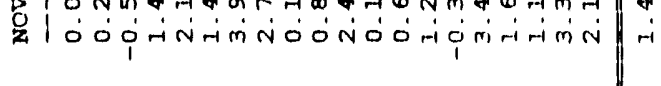

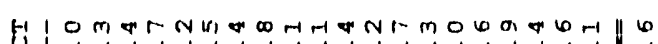

$\delta \mid \begin{aligned} & 0 \\ & 0 \\ & 0\end{aligned}$

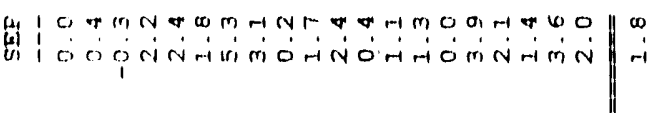

40

等

$\because$

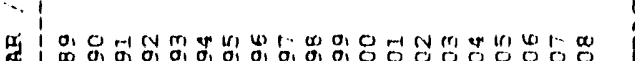

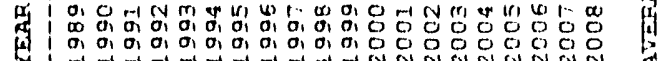




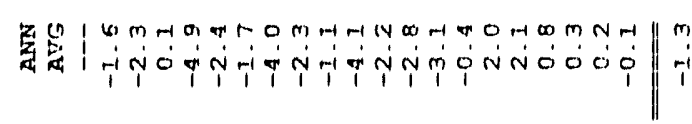

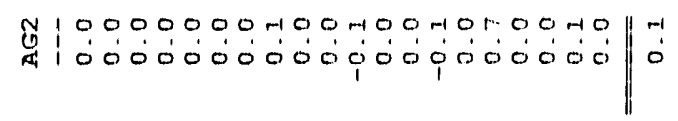

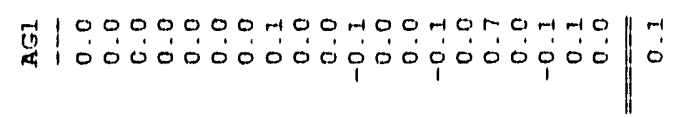

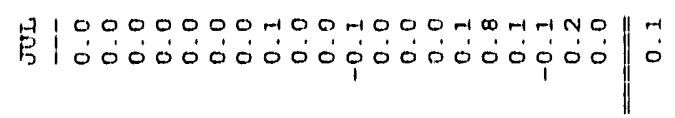

F|

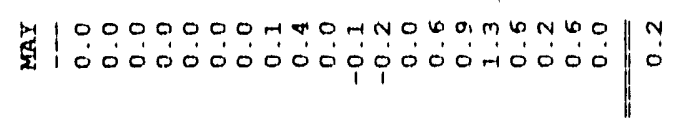

丝

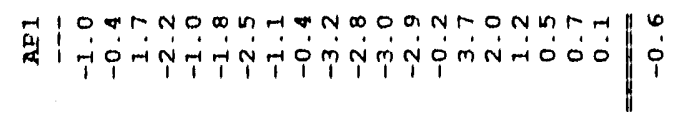

要

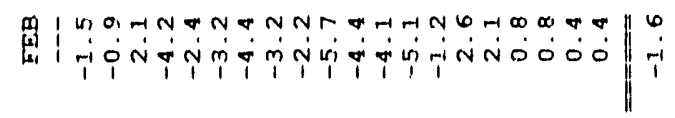

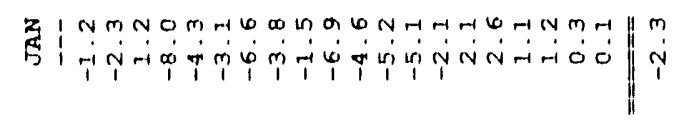

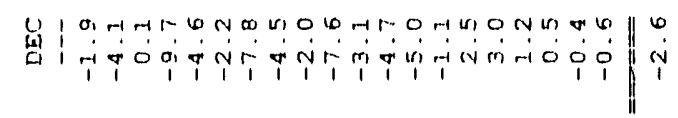

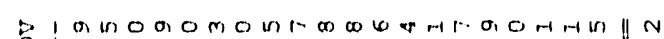

z

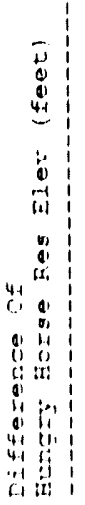

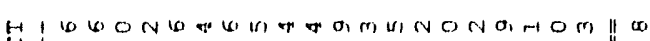

\&

a

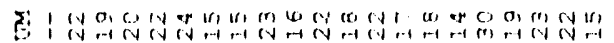

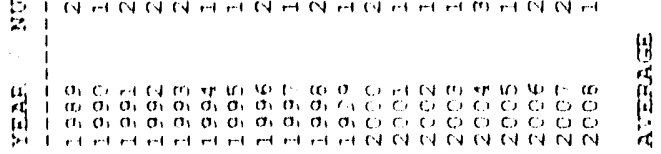




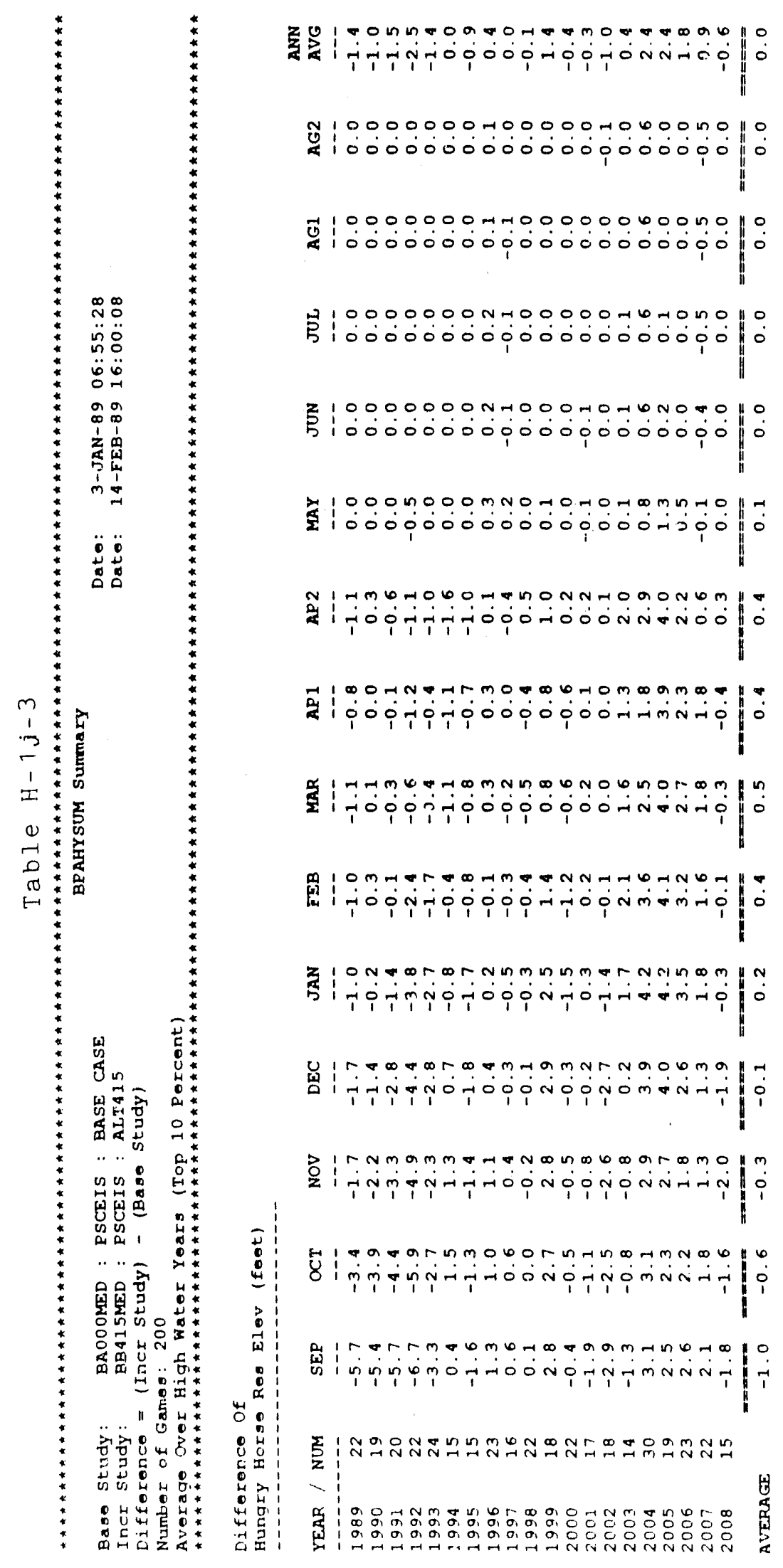

$$
H-1 j-1 F
$$




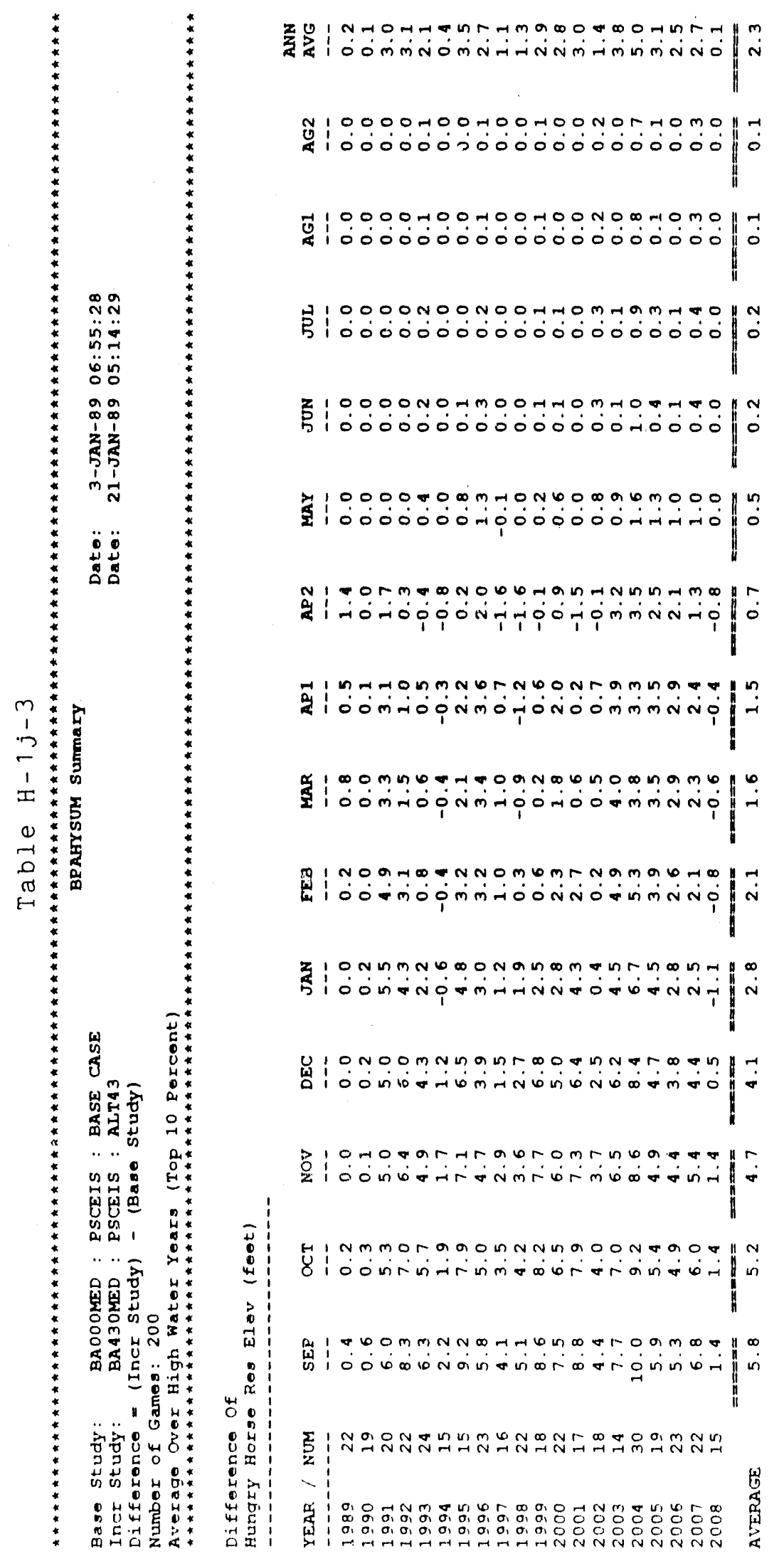




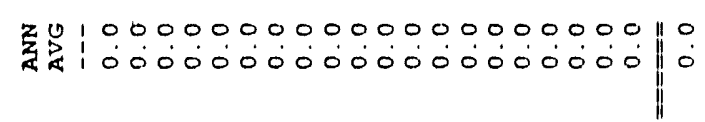

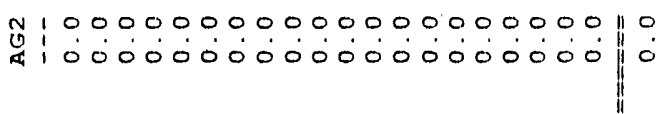

15

ค|

2100000000000000000000110

1

7100000000000000000000110

1000000000000000000000

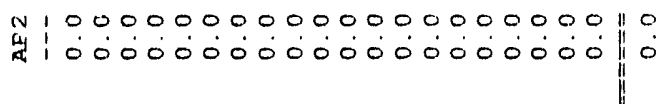

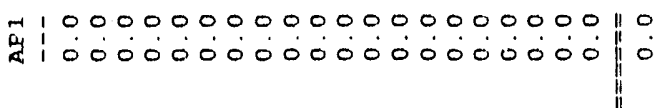

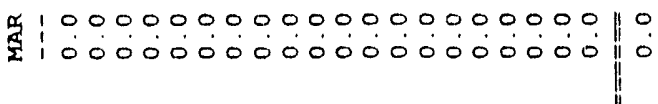

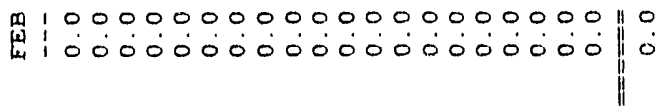

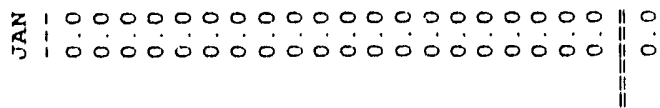

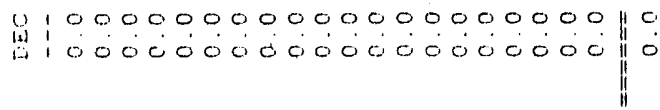

$\$ 100000000000000000000110$ z

100000000000000000000110

L

4100000000000000000000110

宸 1000000000000000000000

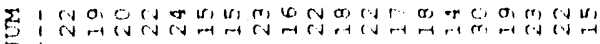

\begin{tabular}{l|lll} 
& \\
0 & 0
\end{tabular} 


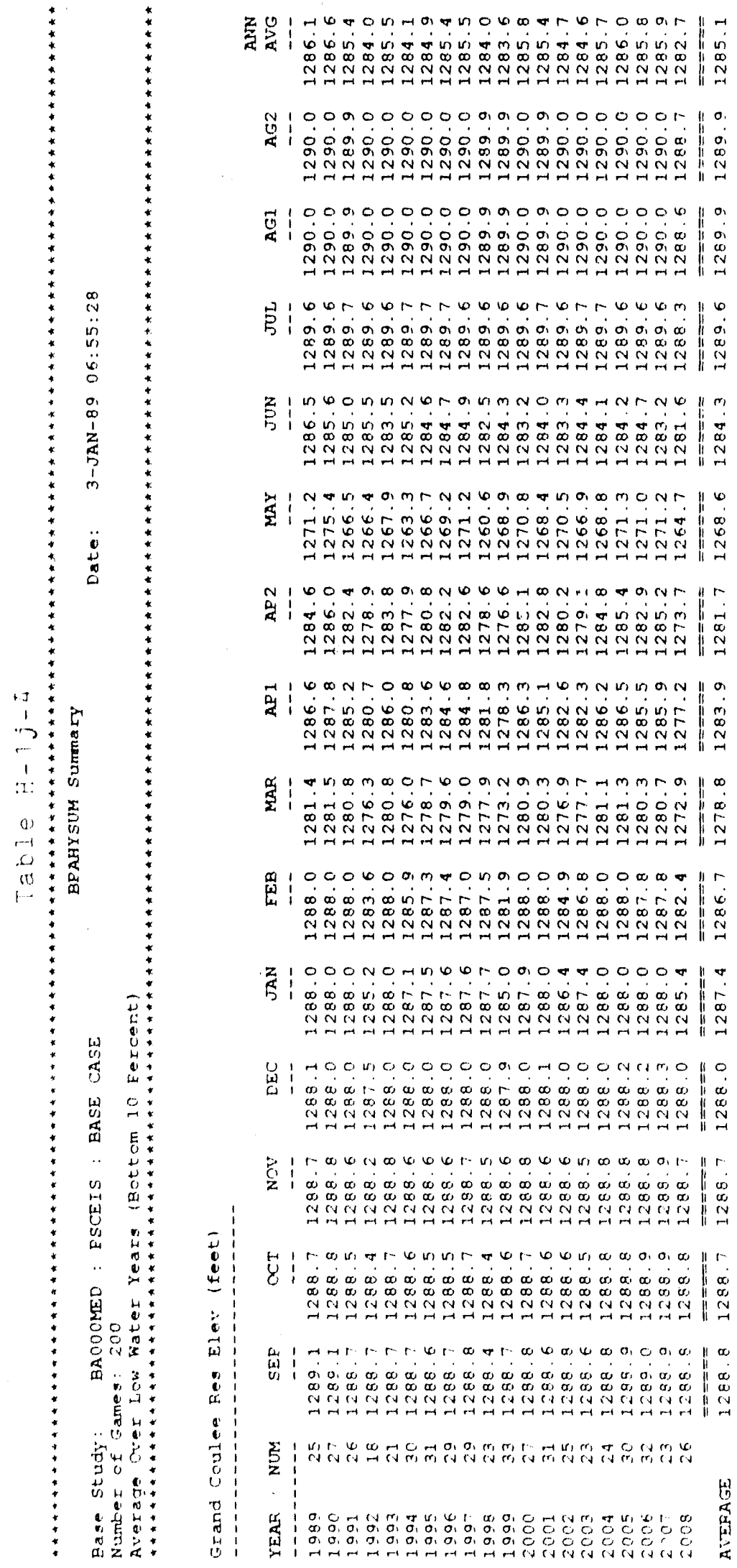




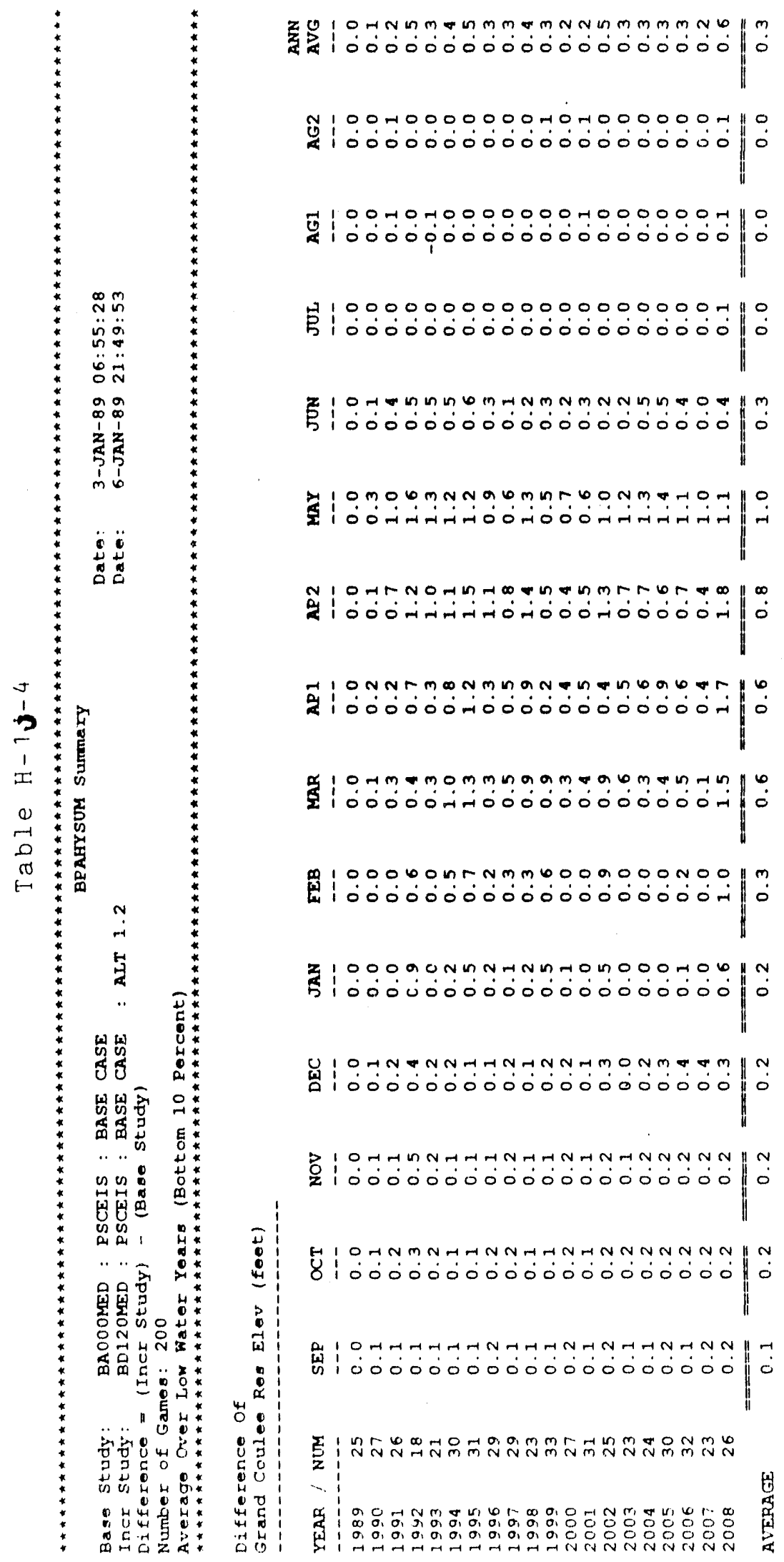




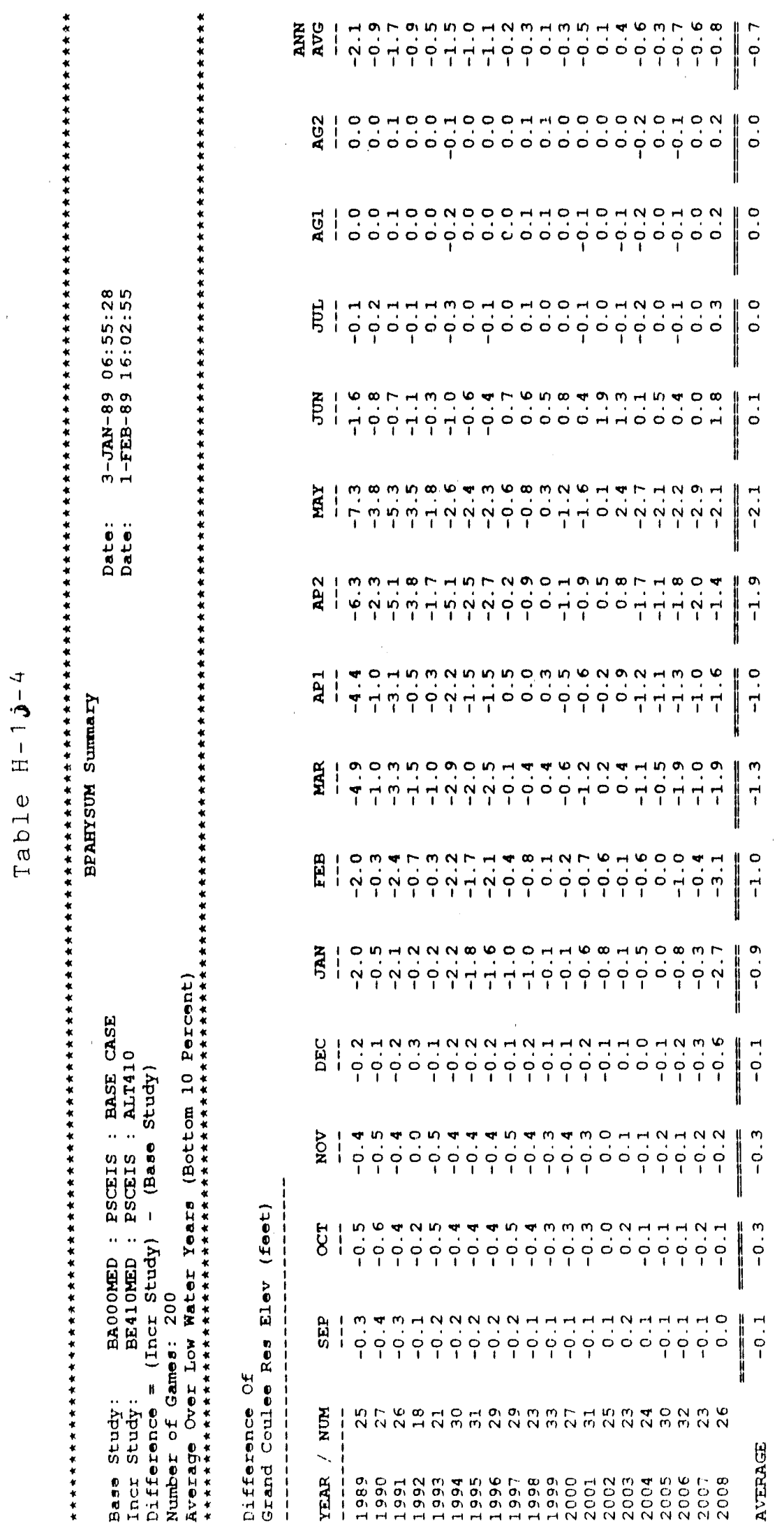




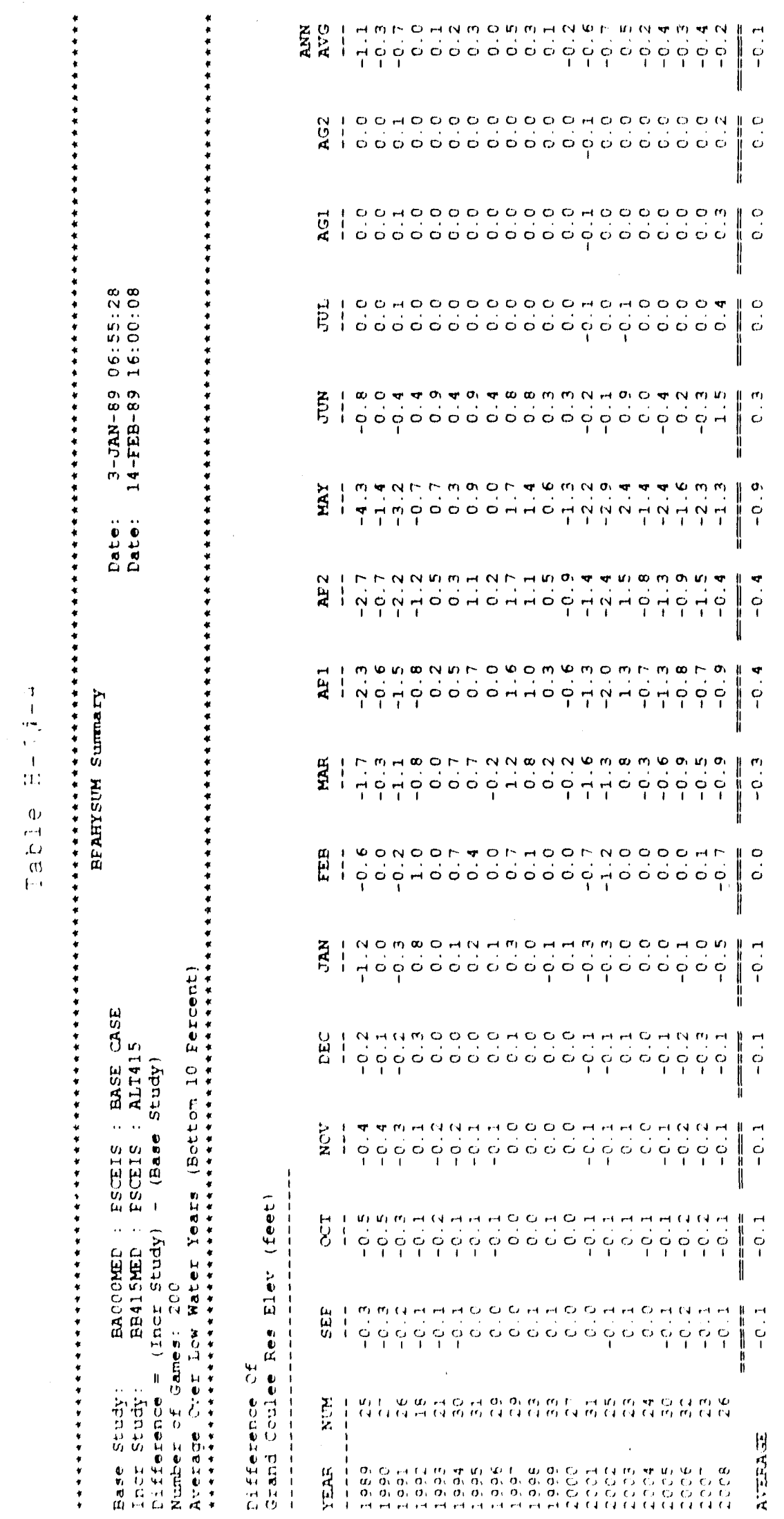




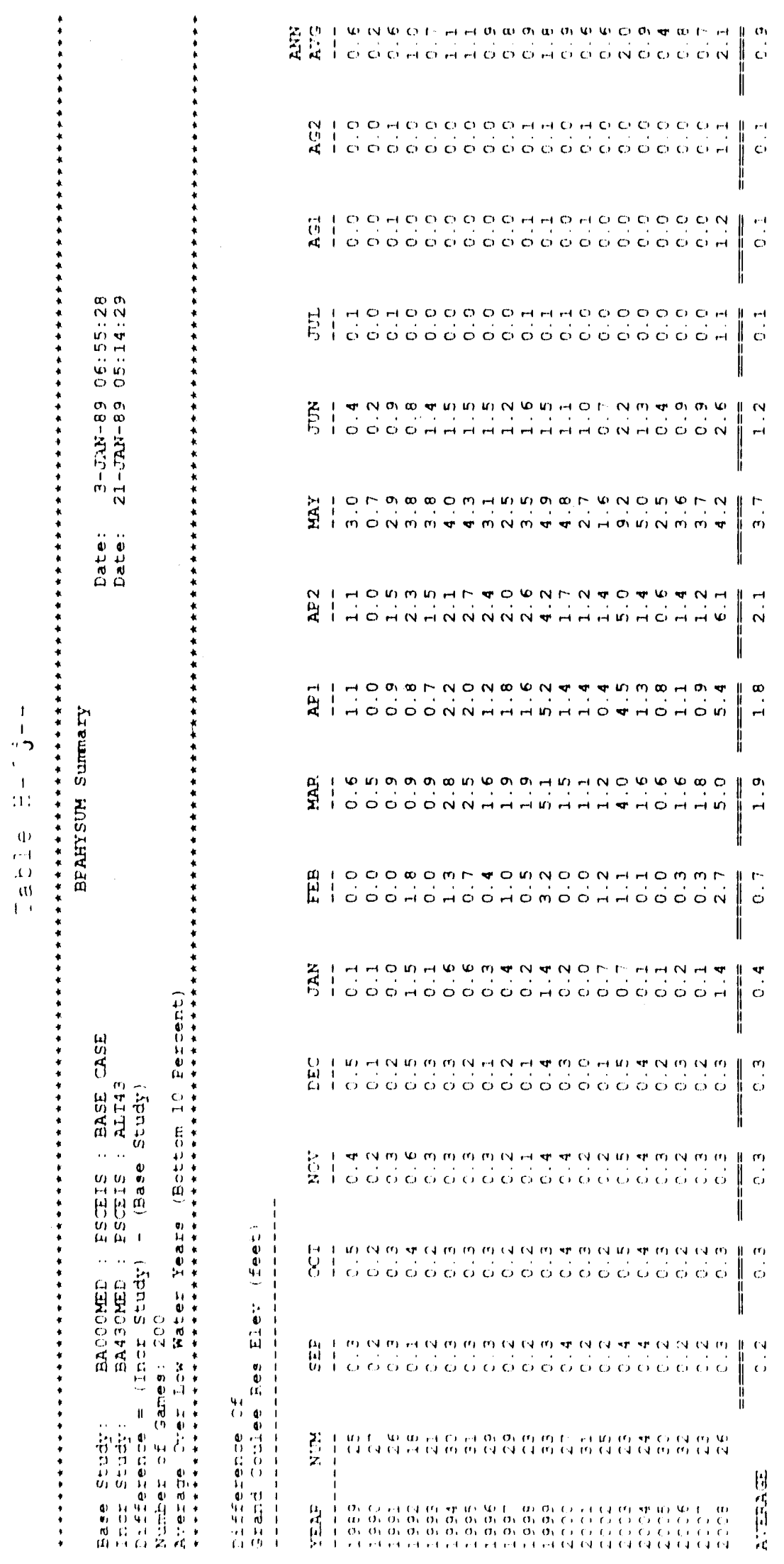




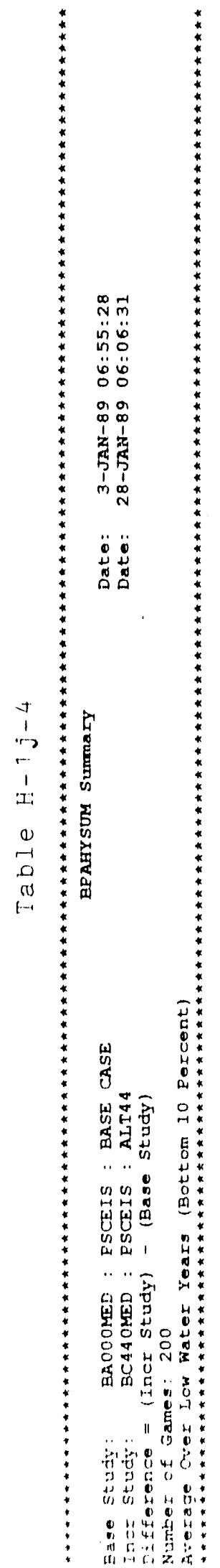

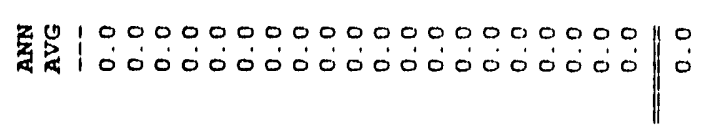

Жु

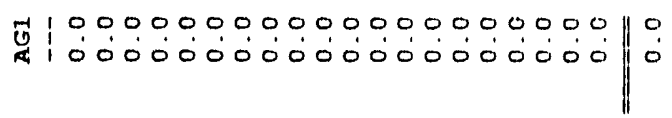

100000000000000000000110

弗|

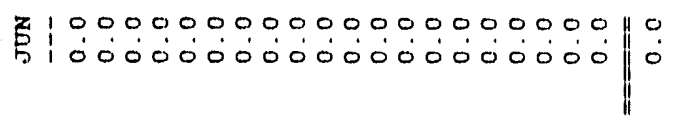

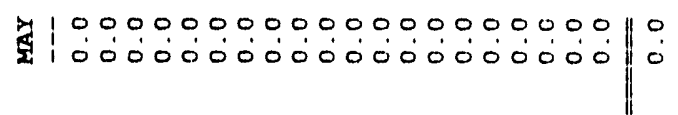

n 100000000000000000000110

a

4100000000000000000000110

A

100000000000000000000110

1:

m100000000000000000000110

A

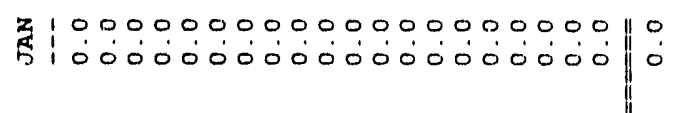

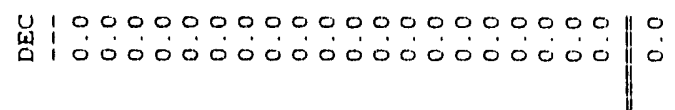

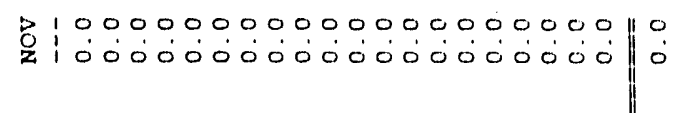

H100000000000000000000110

H|

山100000000000000000000110

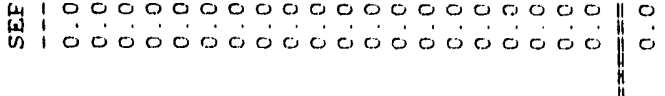

$0^{4-1}$

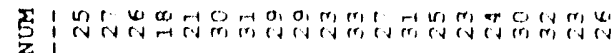

(: $01 z^{\circ}$

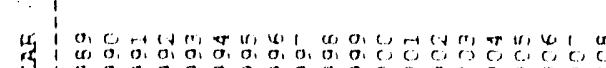

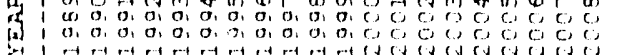




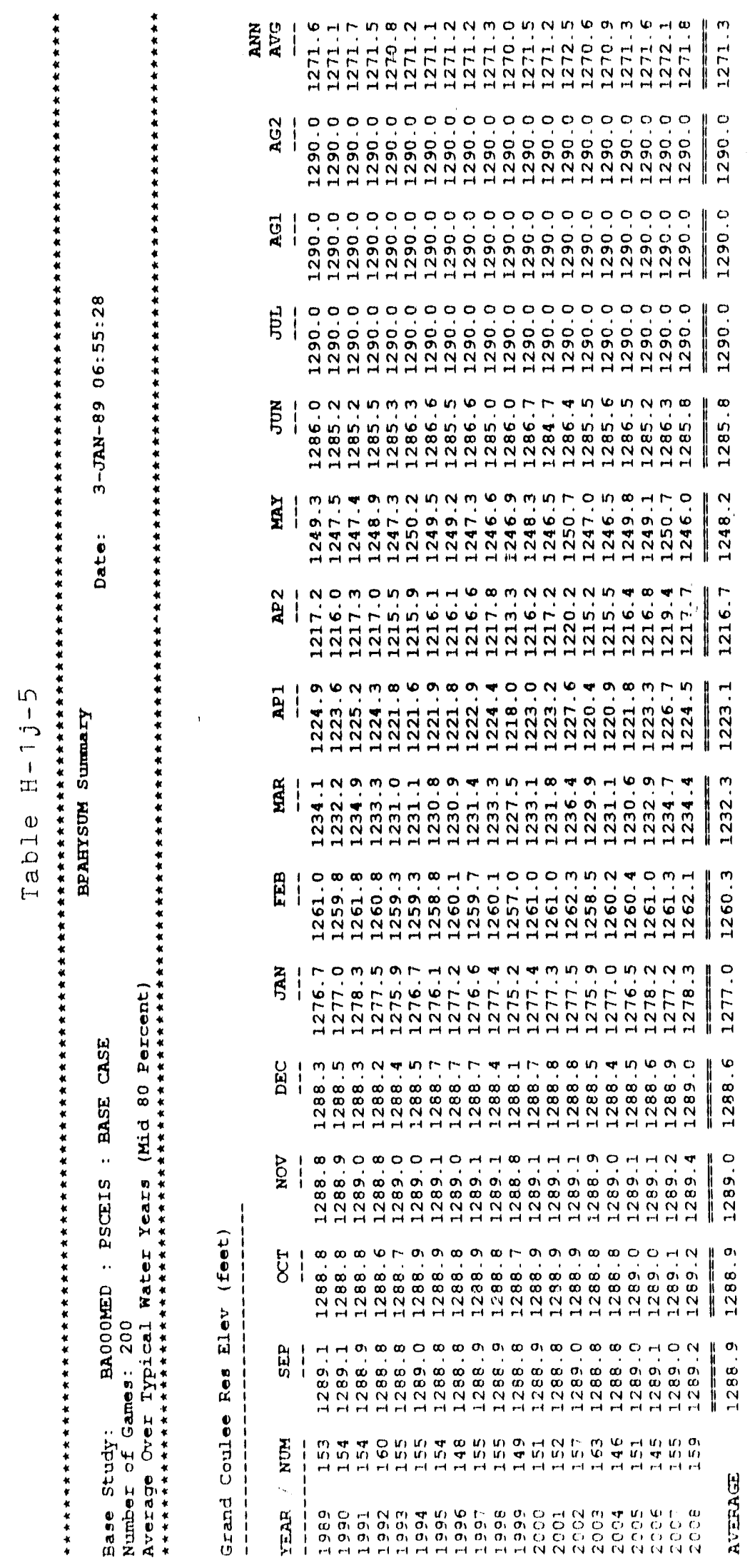




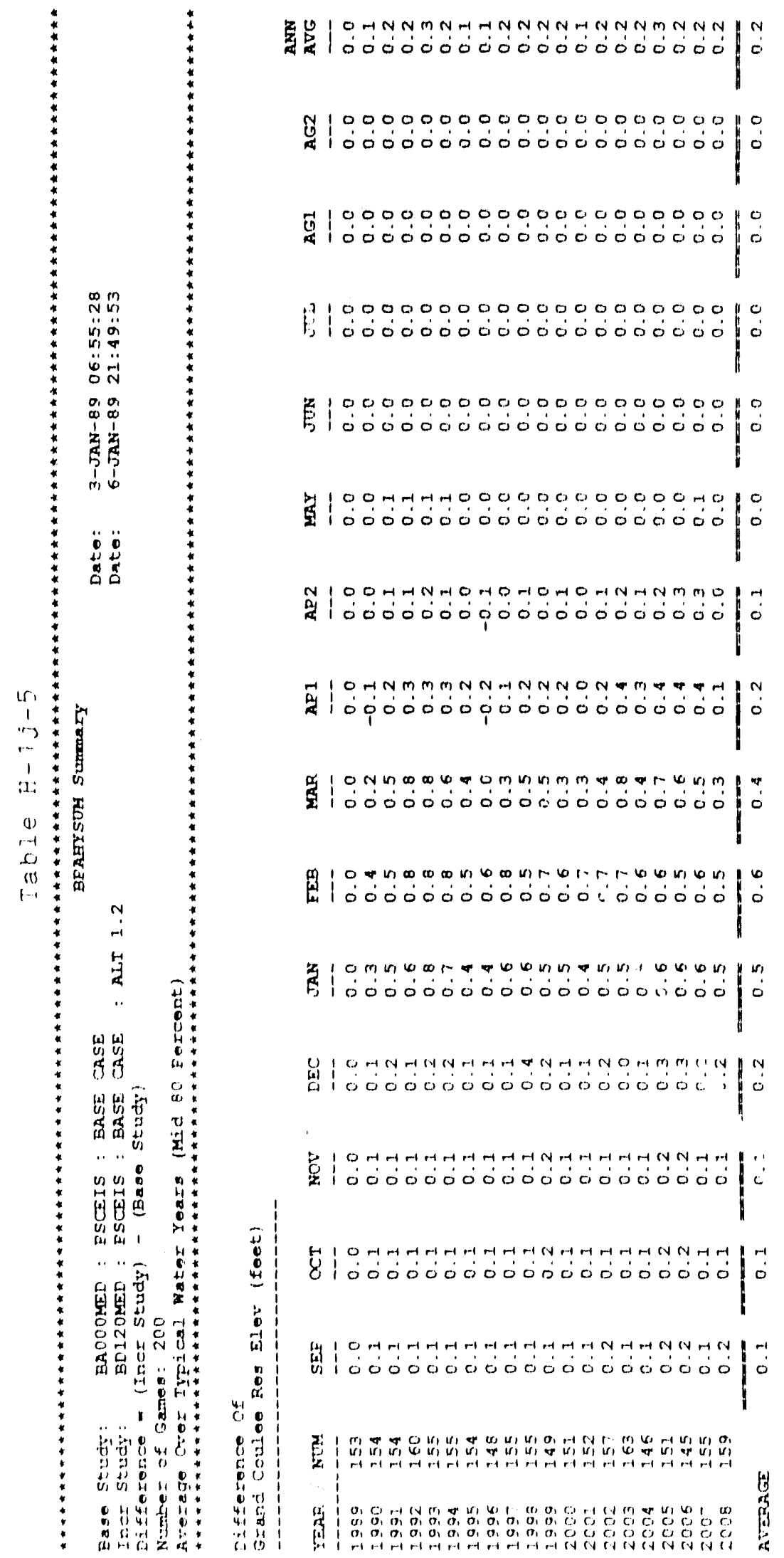

$11-1 j-i c$ 


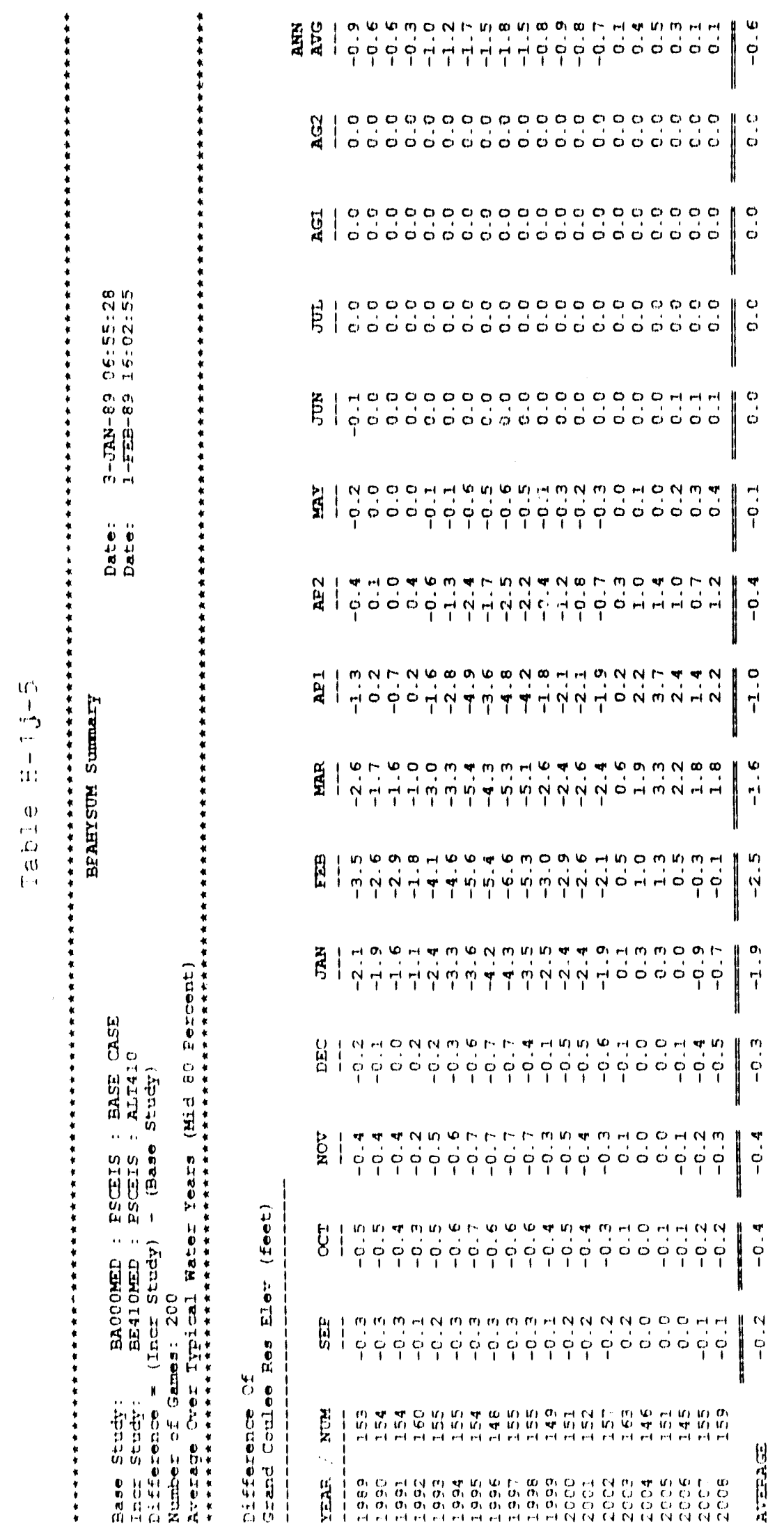




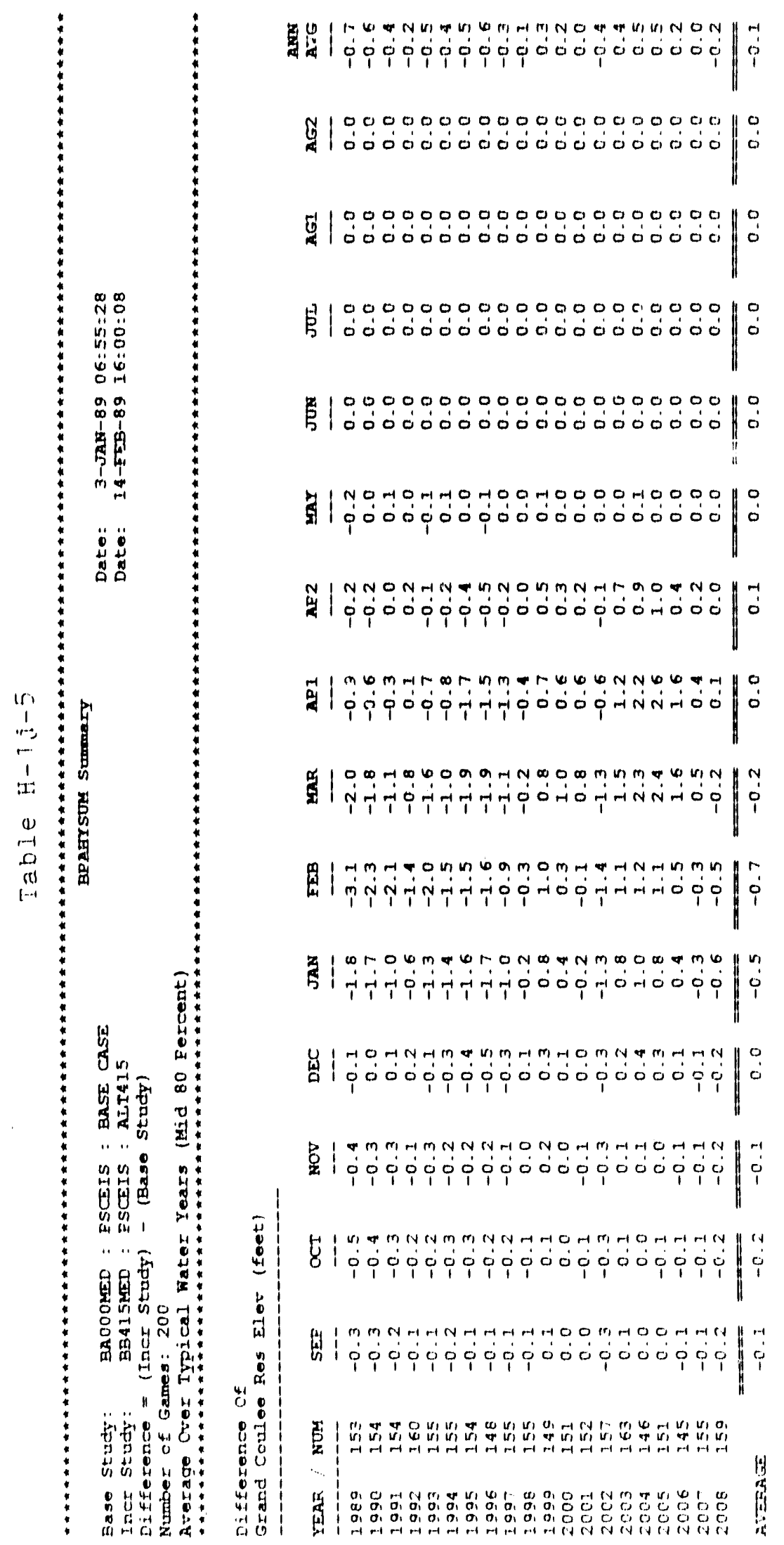




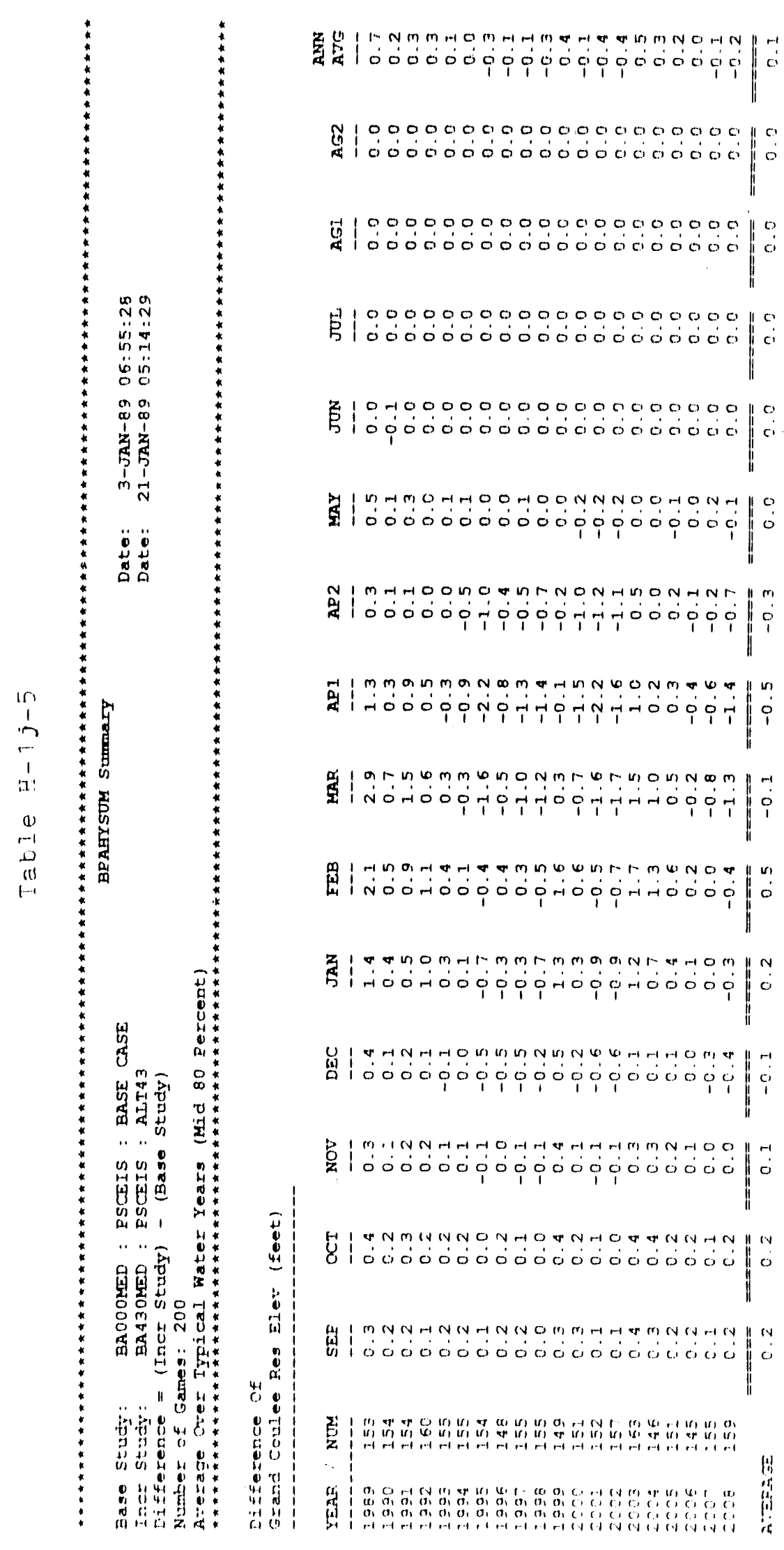


0000000000000000000010 00000000000000000000

đู

ฮ|

B|

2100000000000000000000110

5 100000000000000000000

10000000000000000000010

幽

N10000000000000000000010

स

स|:

|

100000000000000000000110

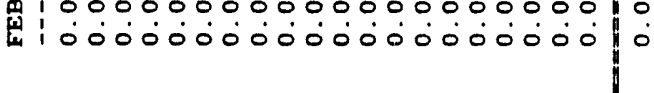

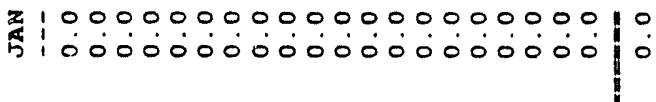

U:

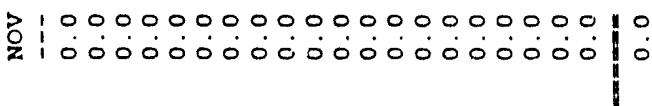

$H 1000000000000000000001$

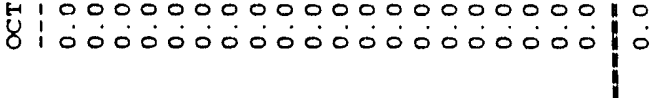

010000000000000000000010

跑100000000000000000000

它究。

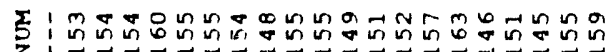

$z$

我

究 


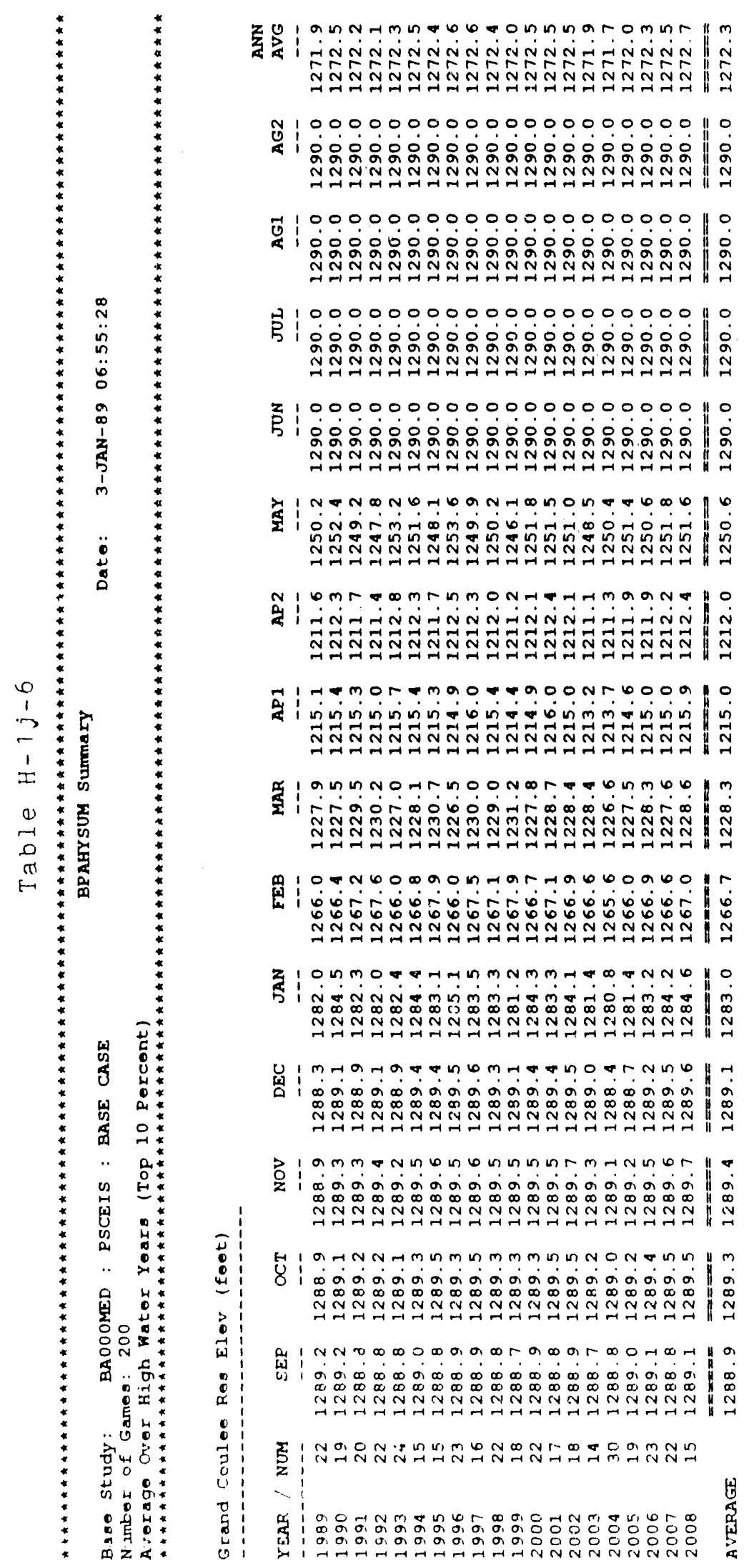




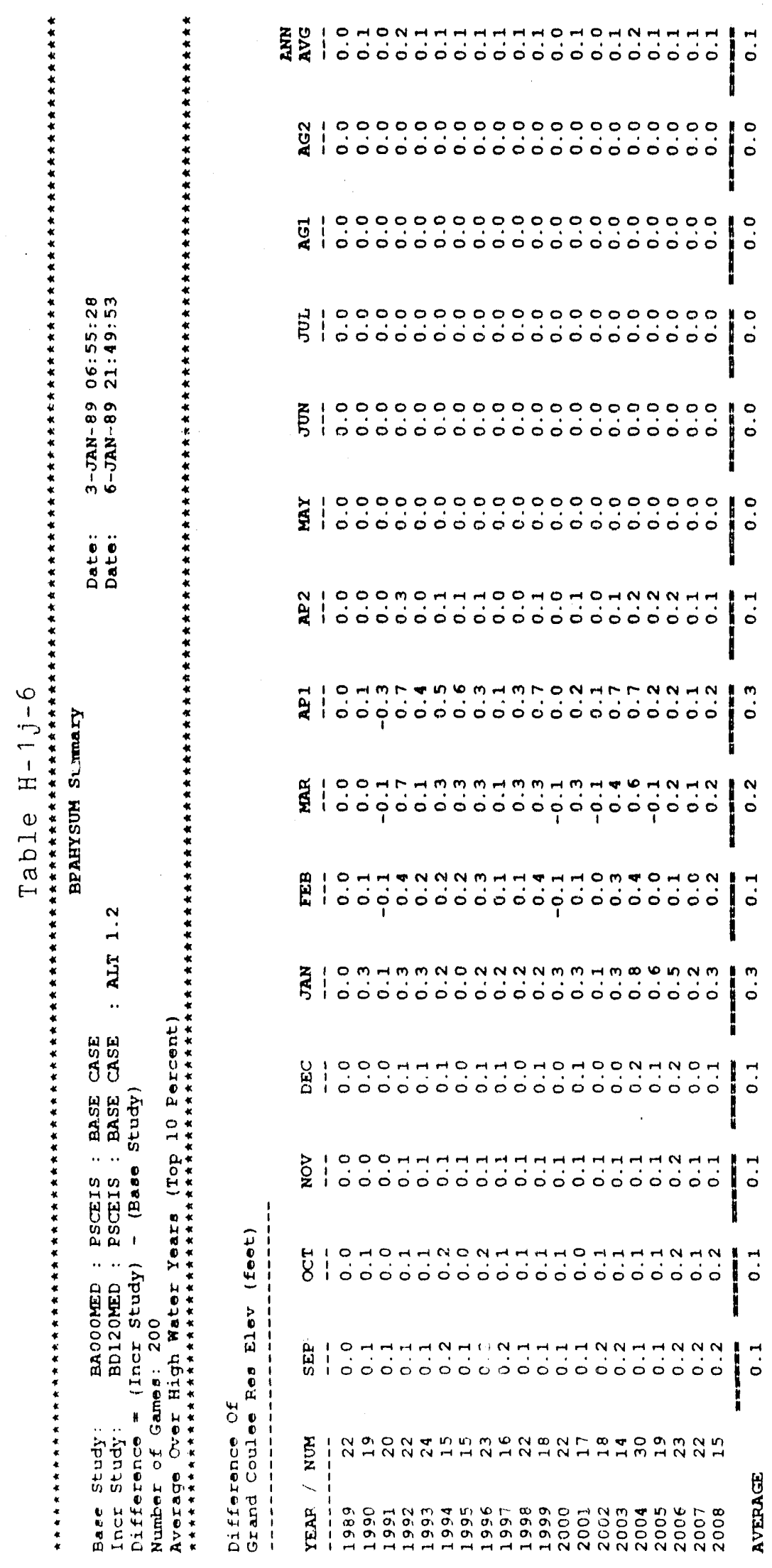

$H-1 j-32$ 


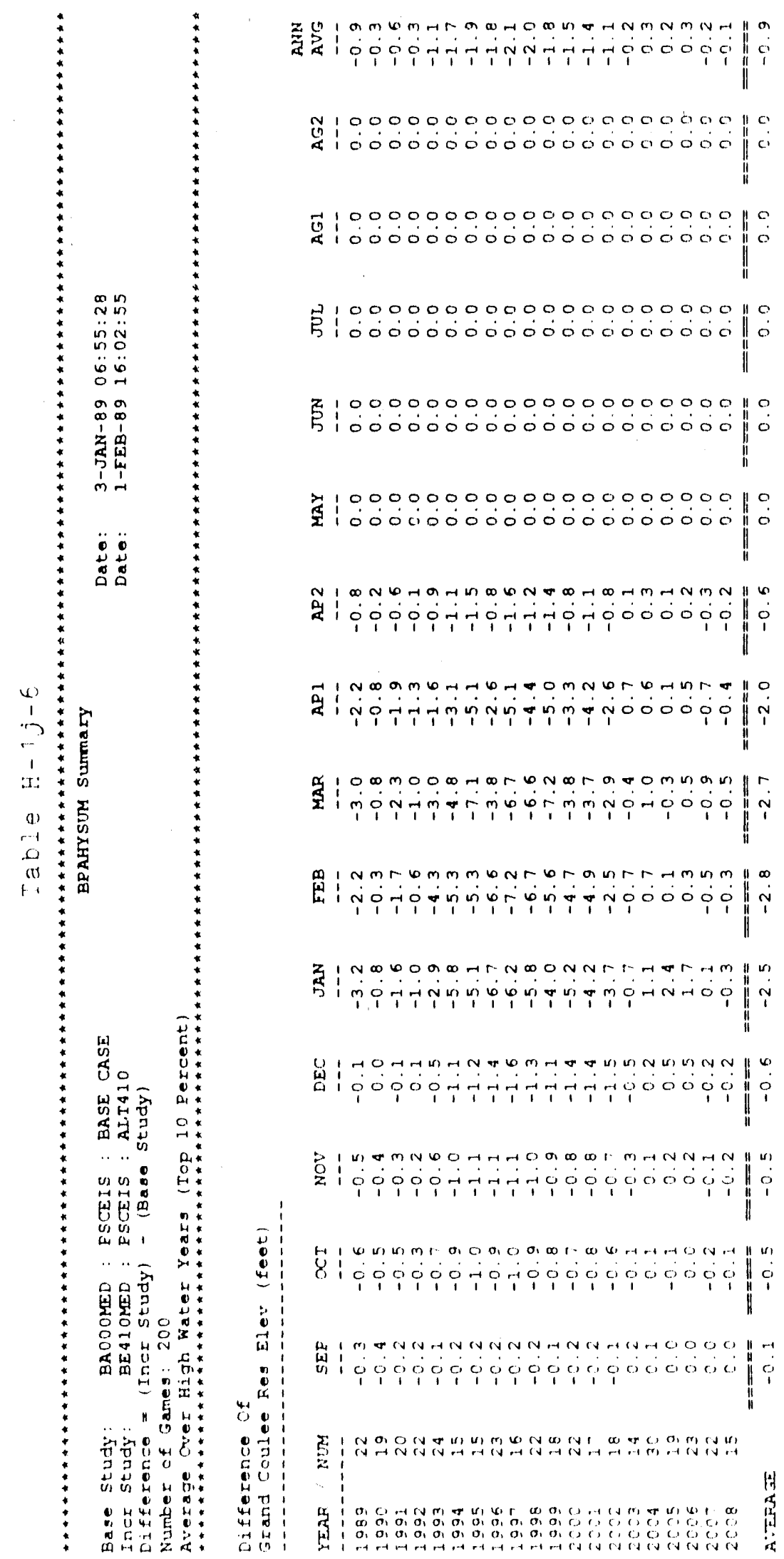




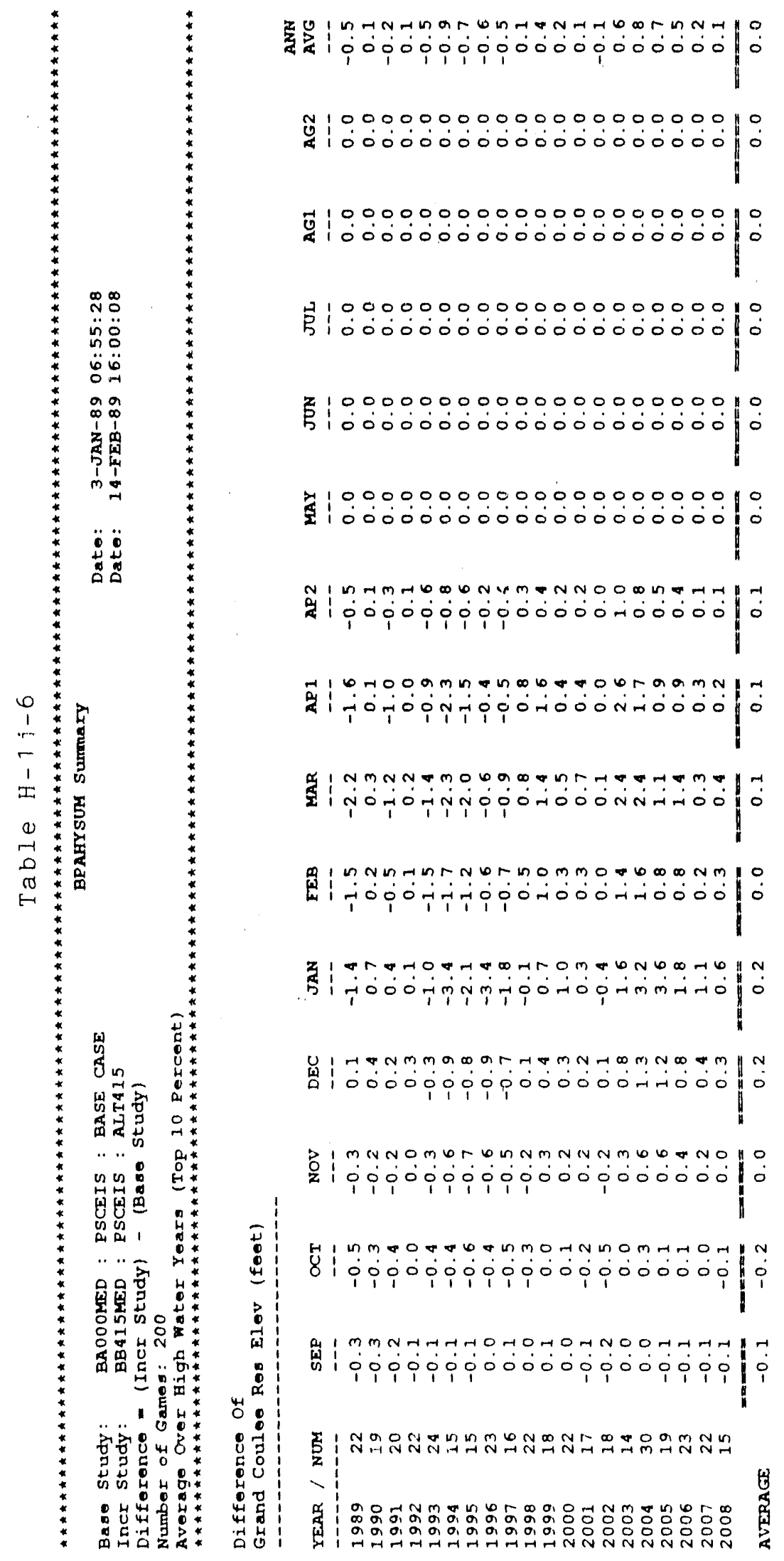




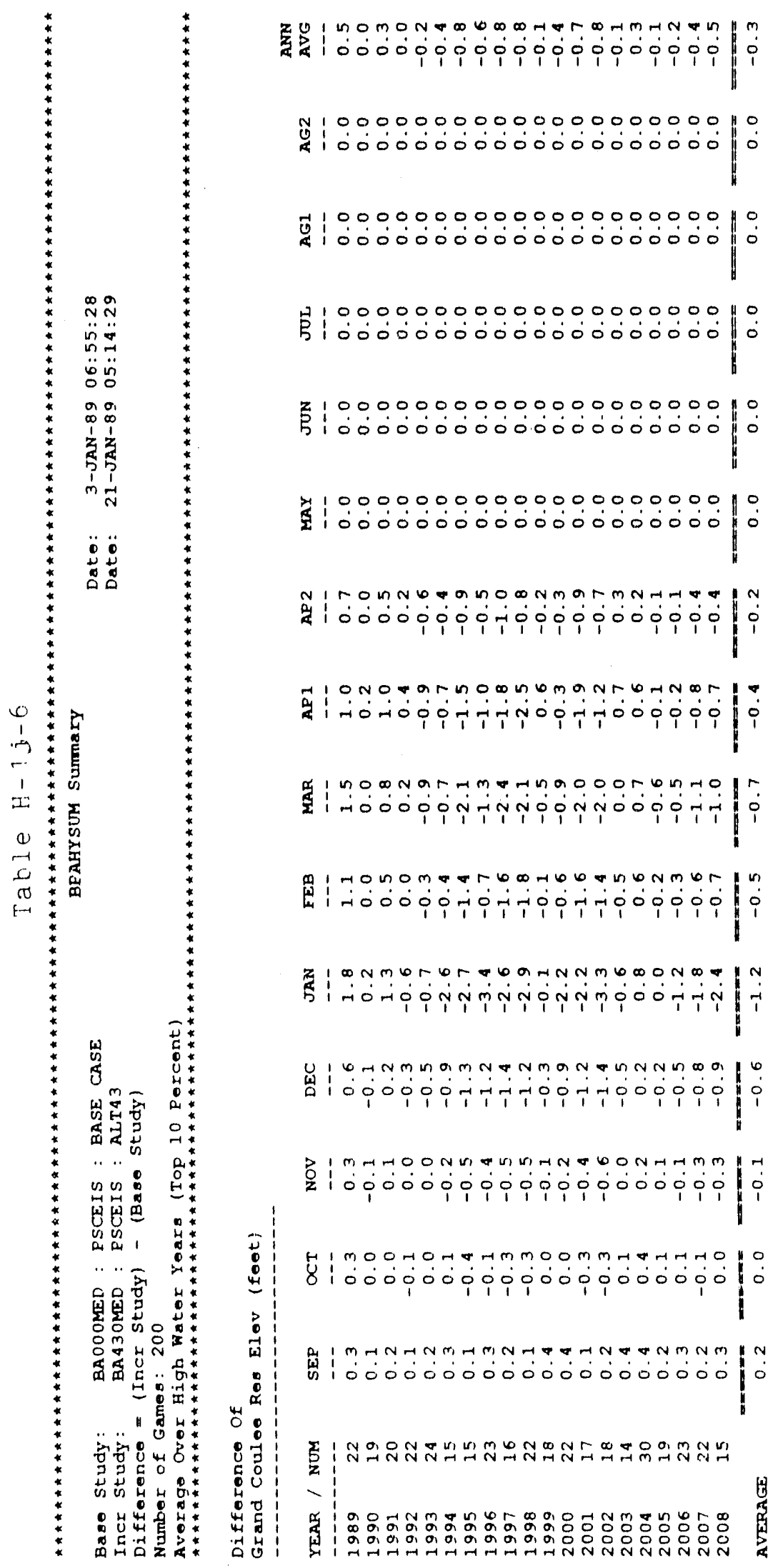




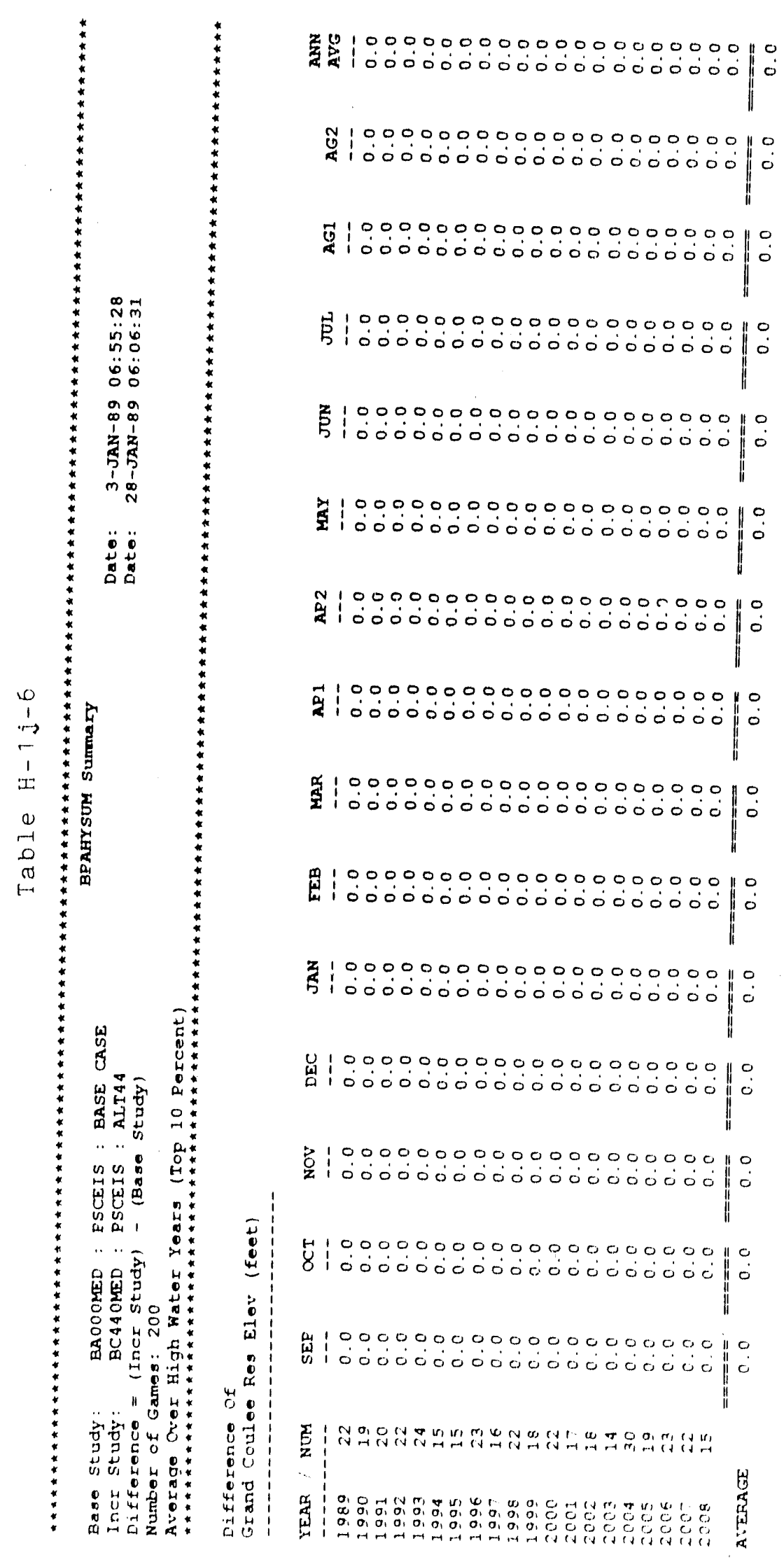




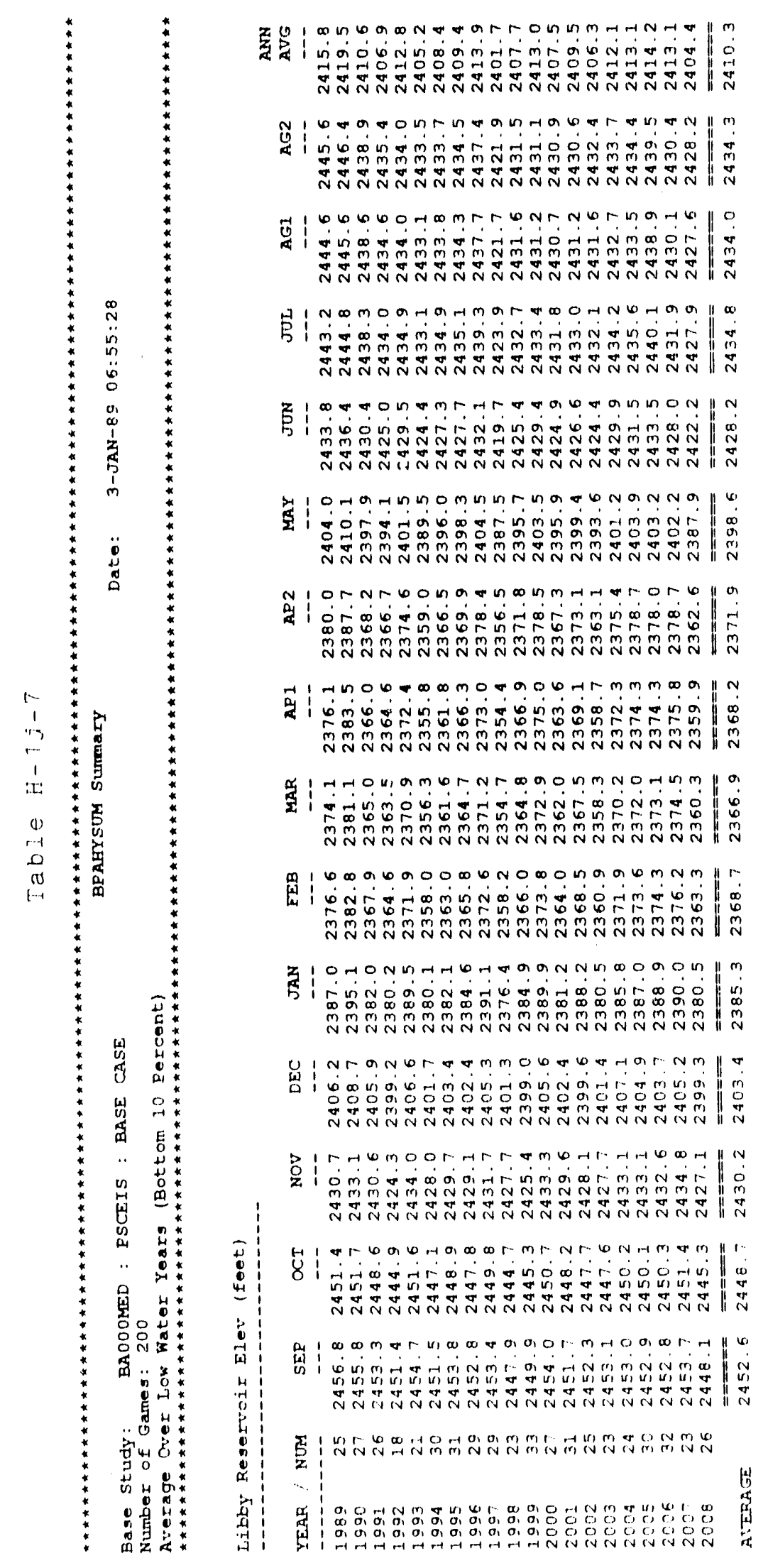




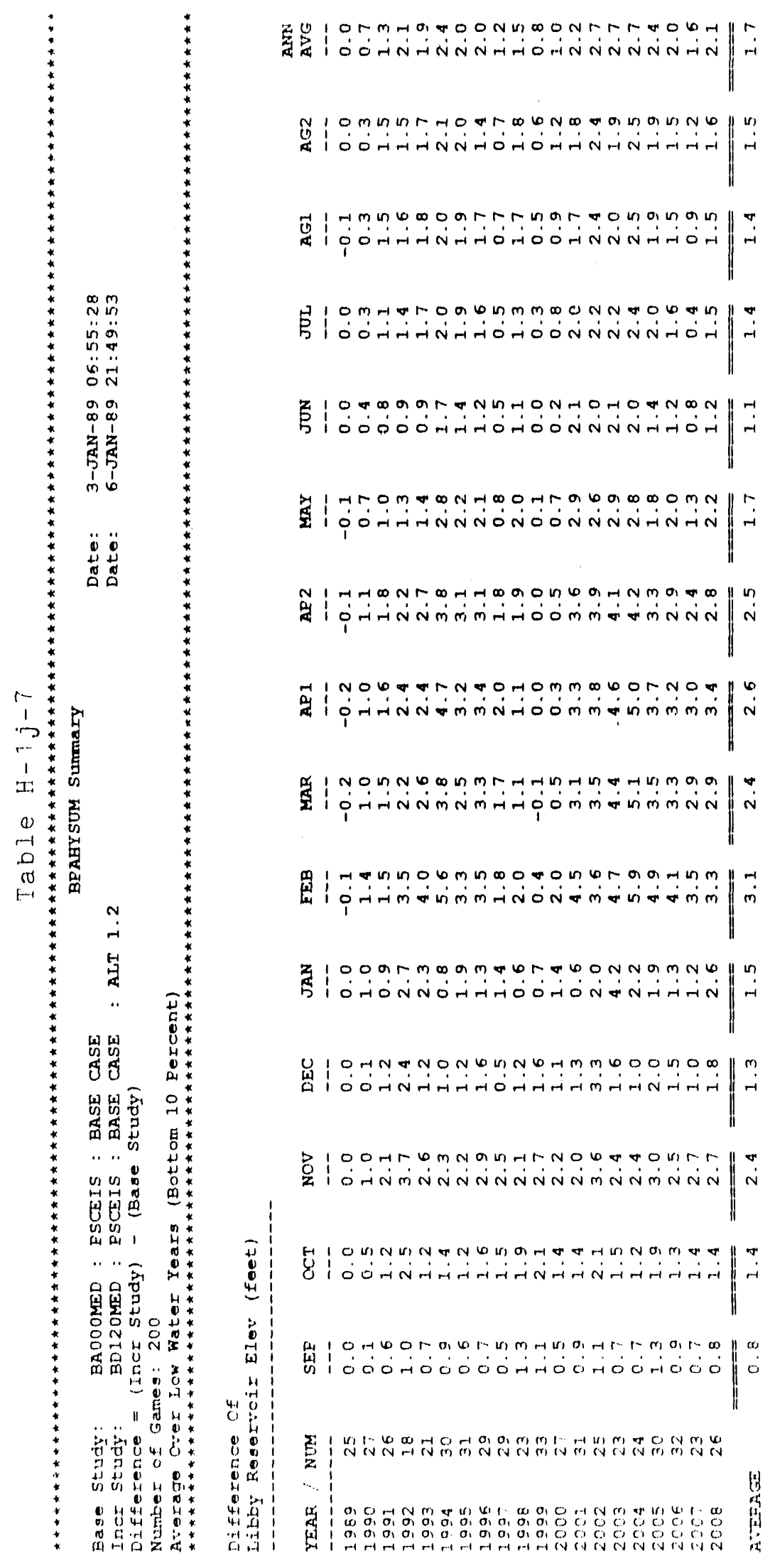

$111 \mathrm{j}-38$ 


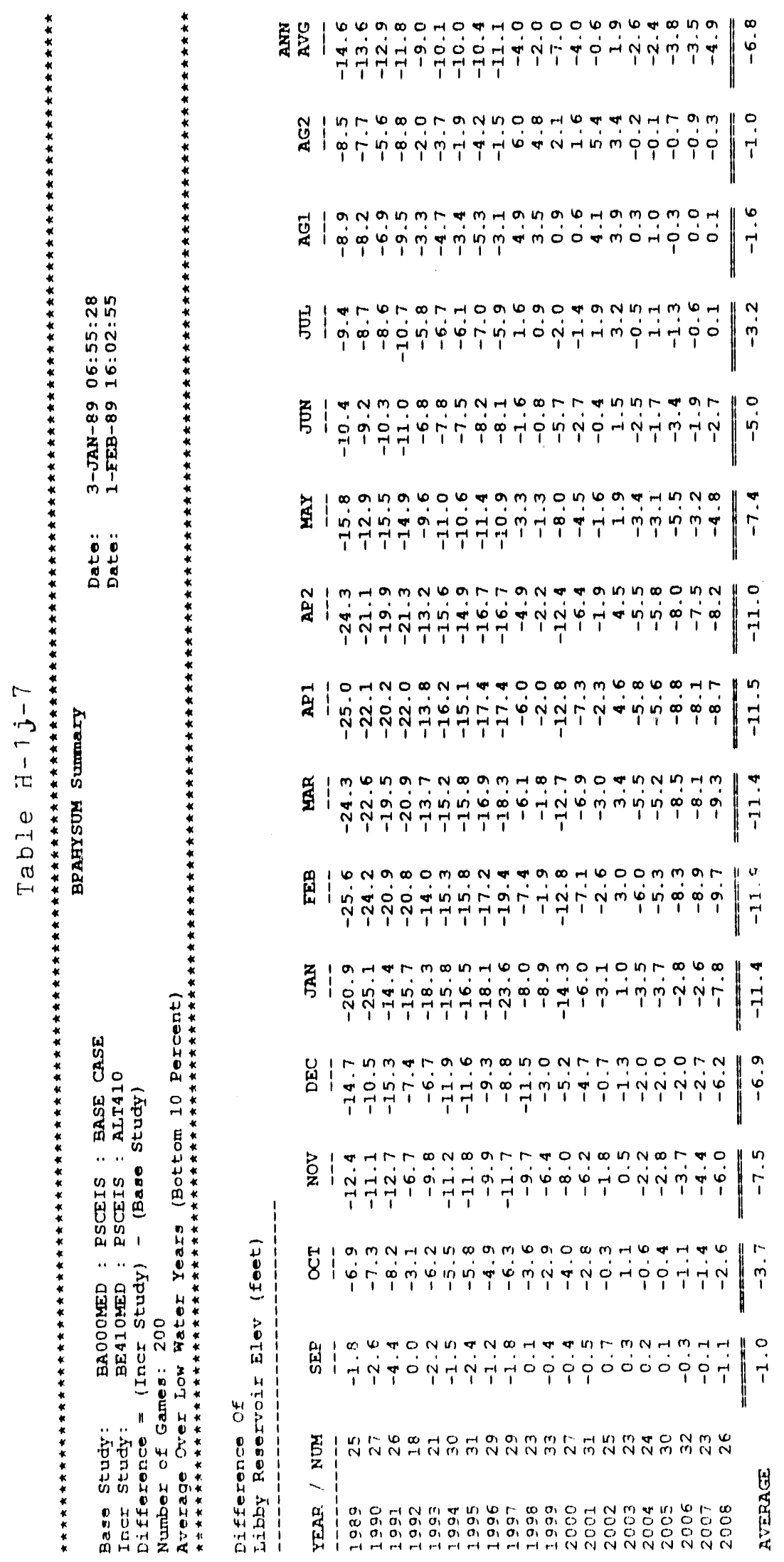




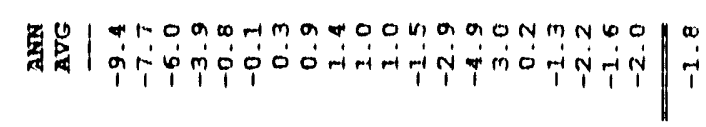

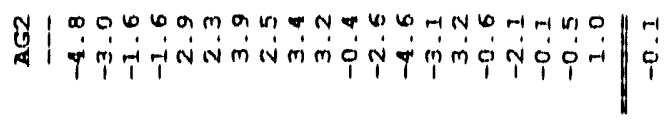

di

b|

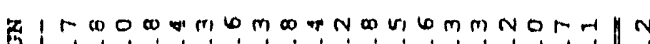

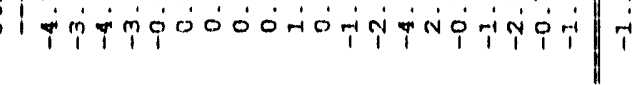

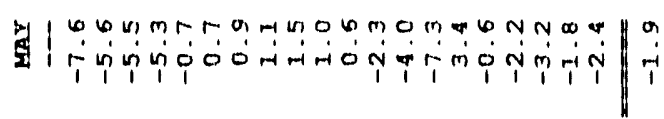

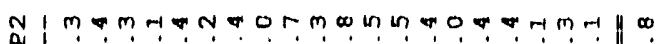

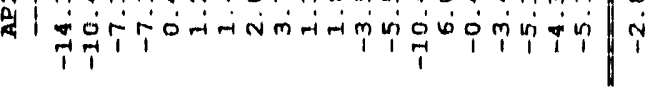

a|

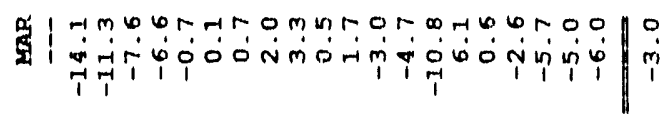

D

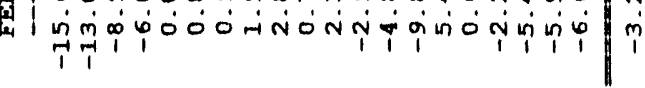

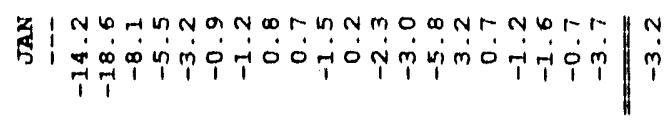

旨

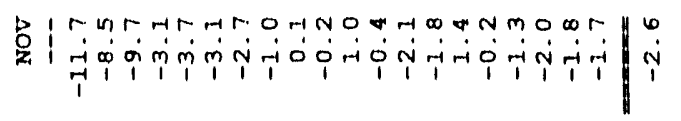

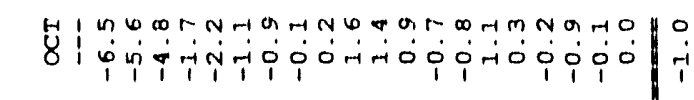

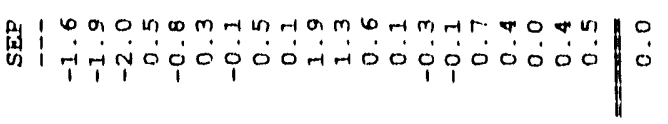

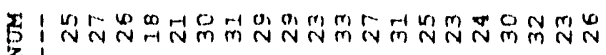

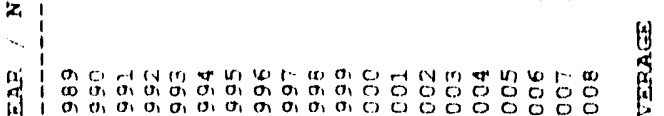

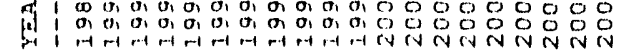




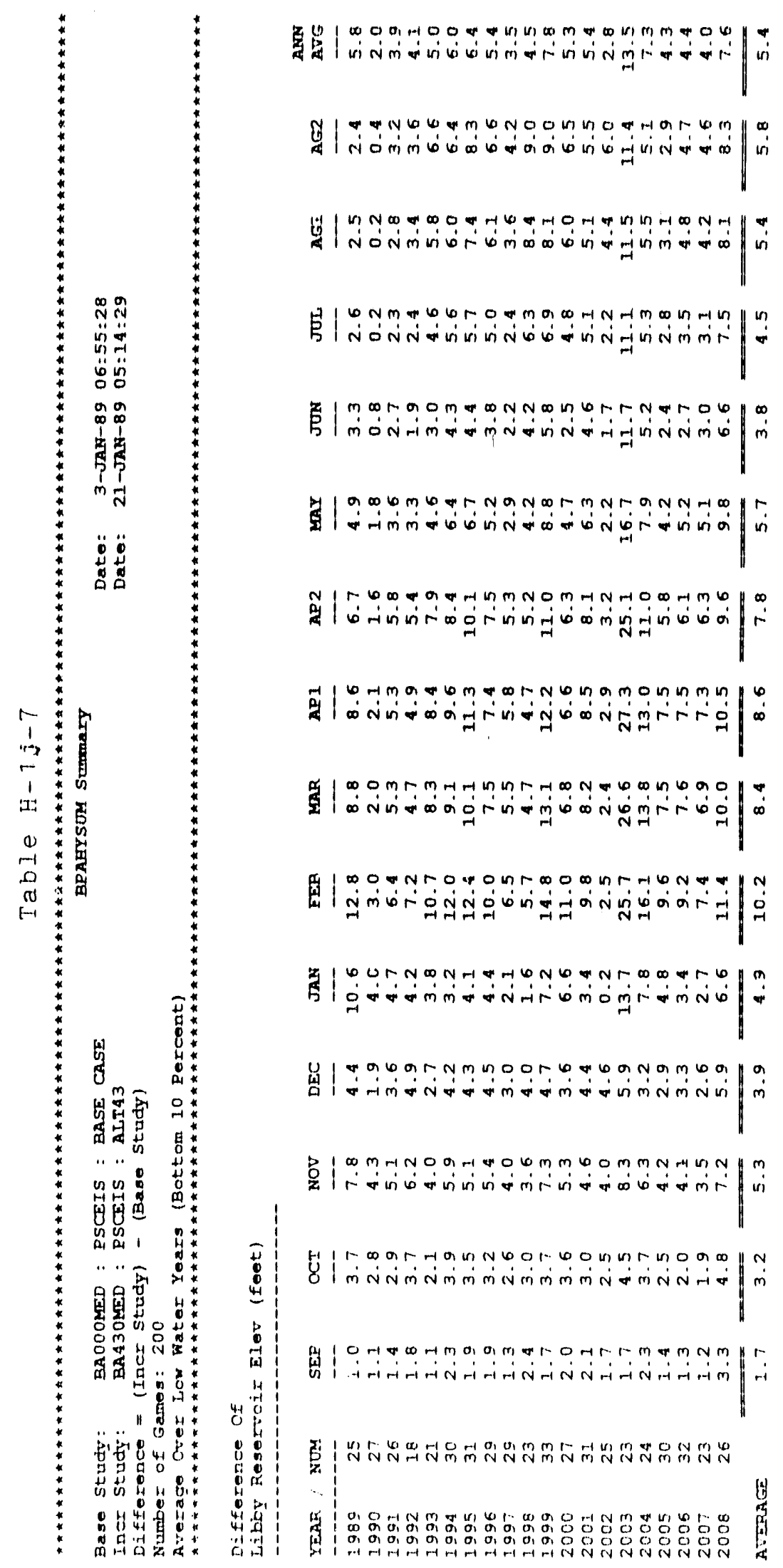

$\mid 1-1 J-41$ 


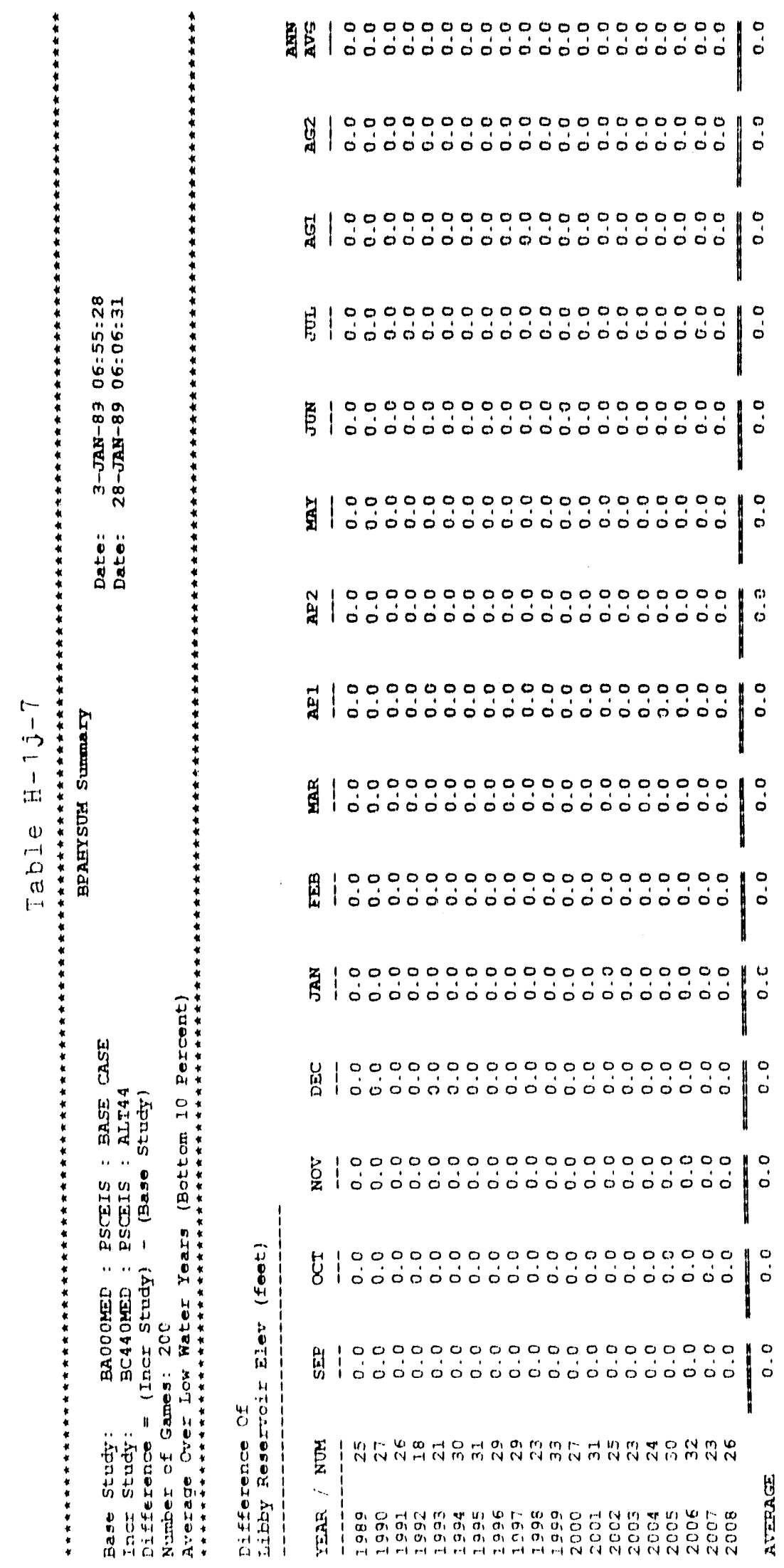




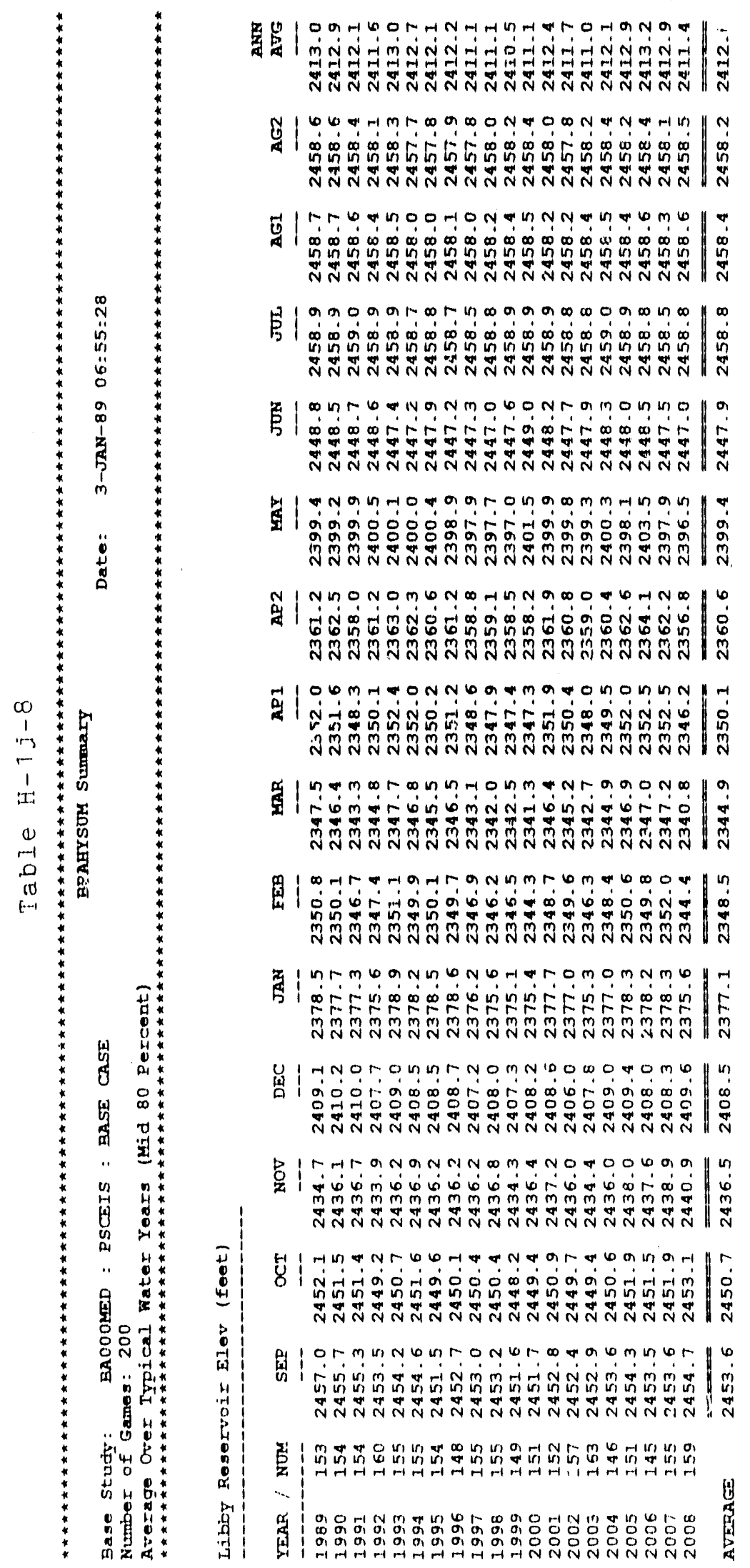

$H-1 . j-4.3$ 


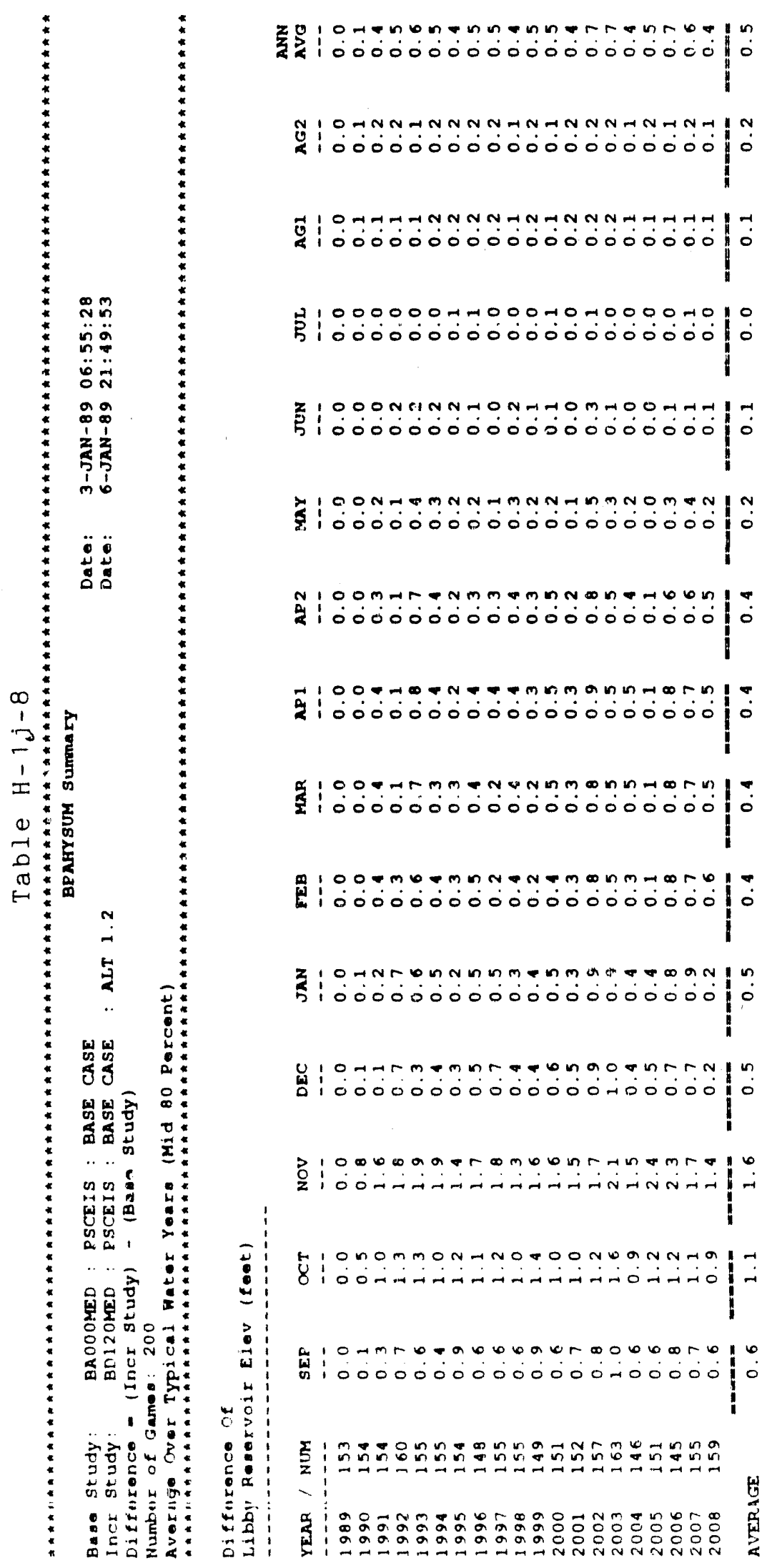




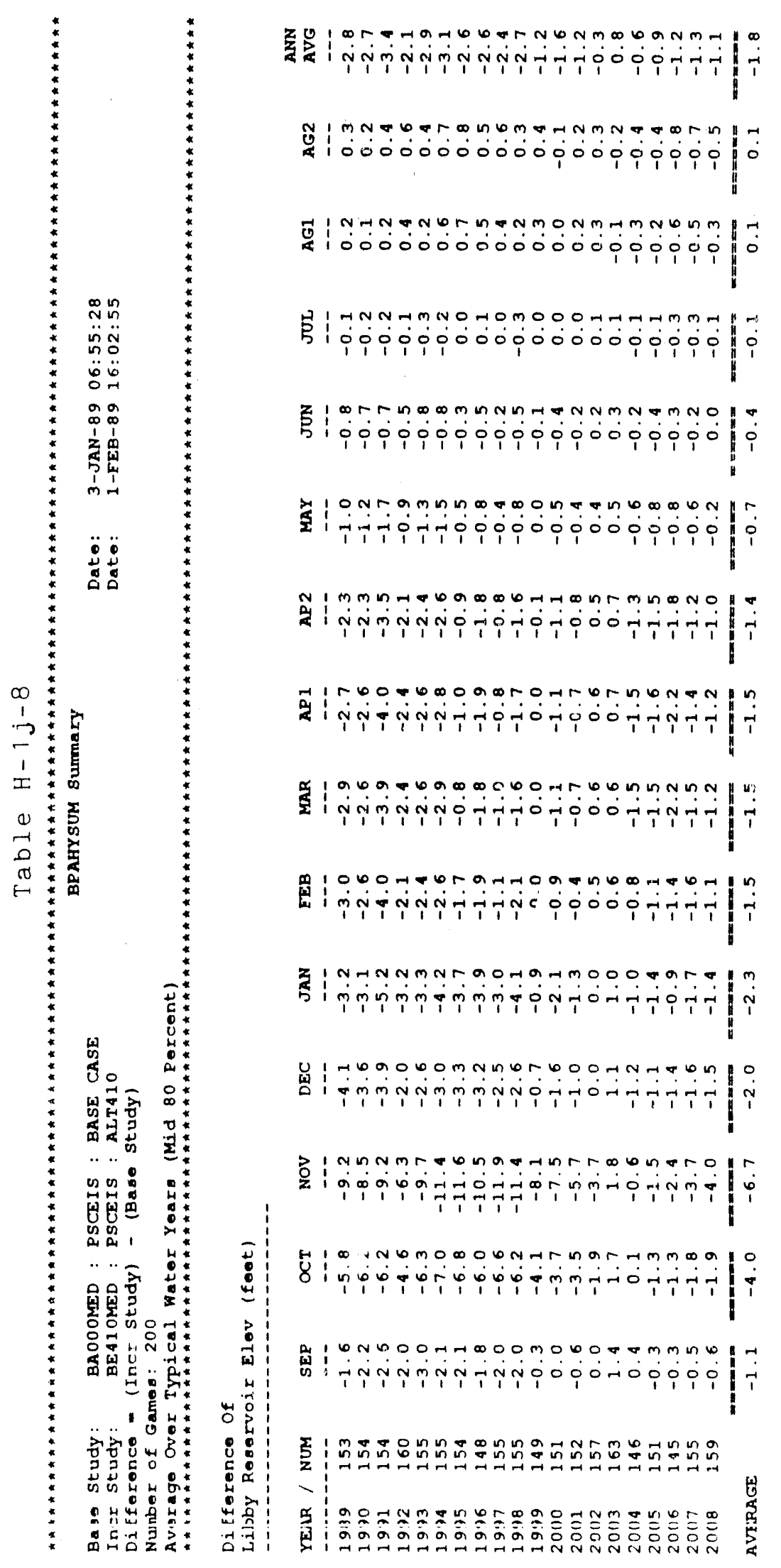

$$
H-1 j-45
$$




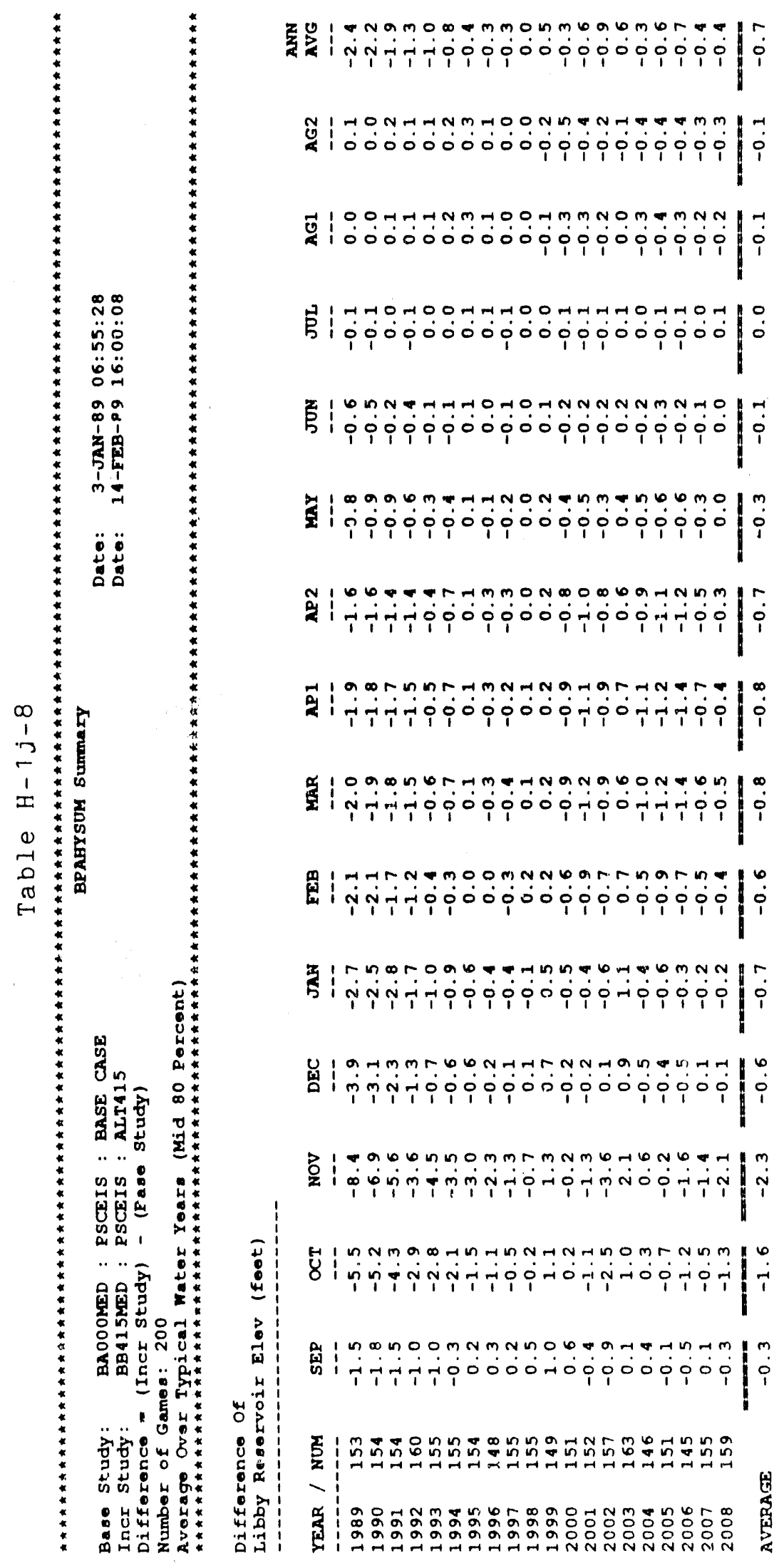




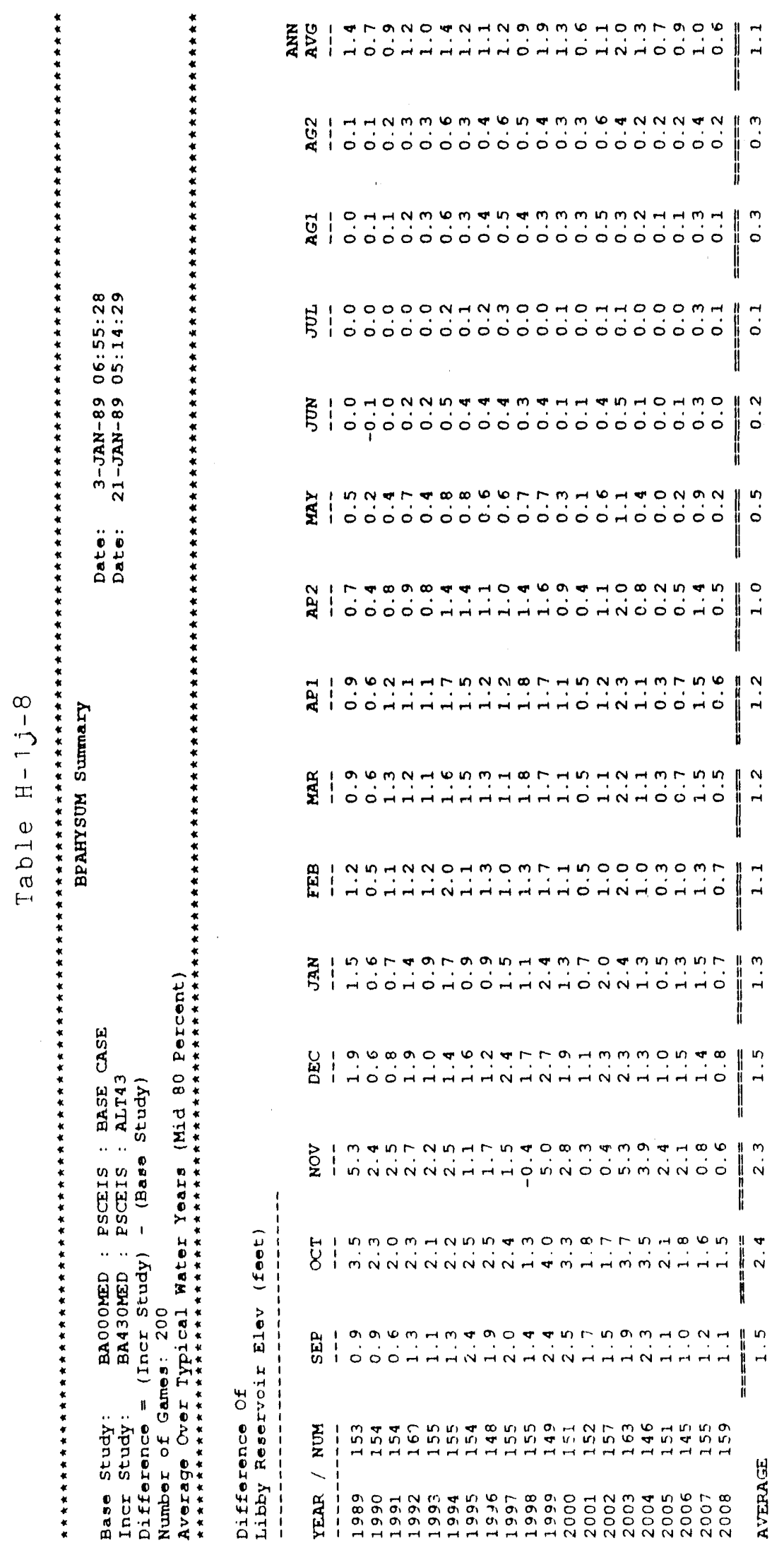




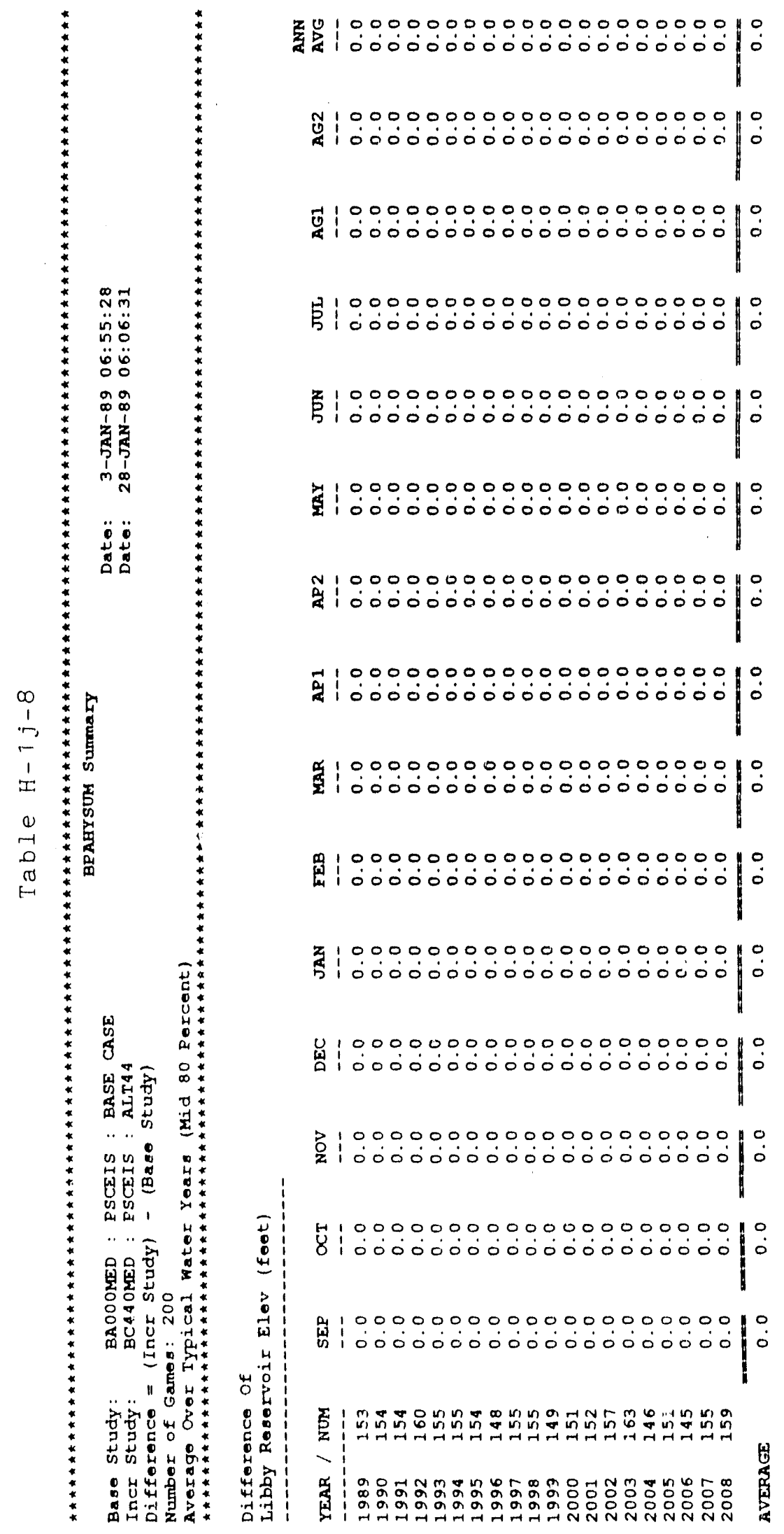




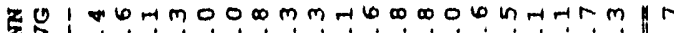

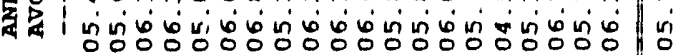

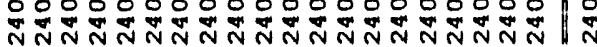

N100000000000000000000 10

ญ⿺

oิ

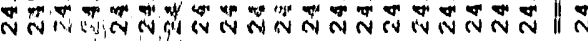

岱

10000000000000000110

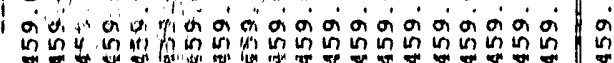

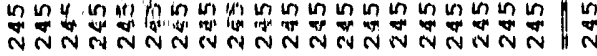

1100000000000000000000110

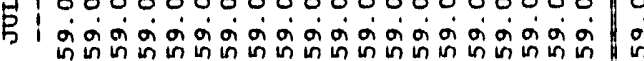
ลัN

驾 !

10000000000000000000010

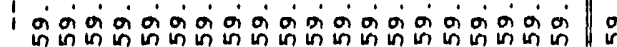

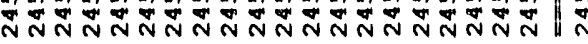

装!

or.?

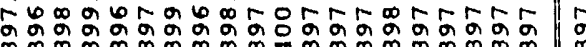

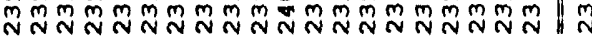

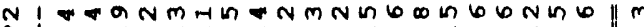

Q

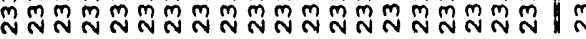

-

Oำด

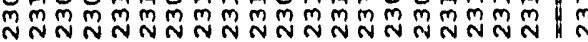

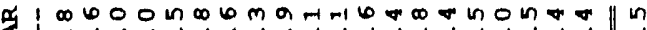

S

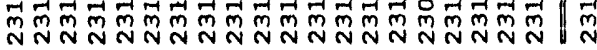

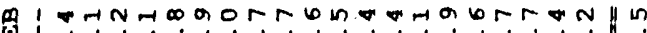

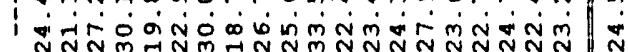

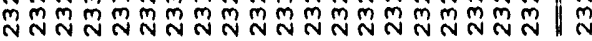

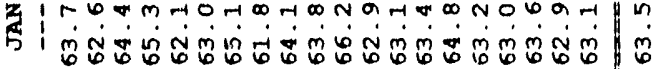

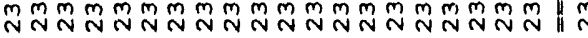

U $100000000000000000000 \mid 10$

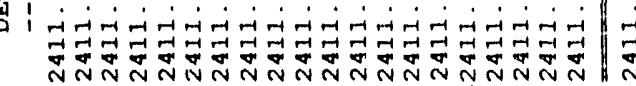

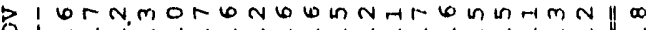

2

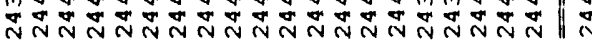

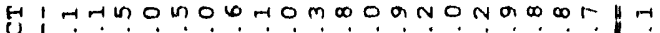

Sin日

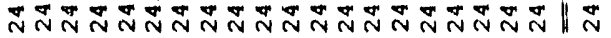

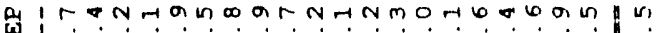

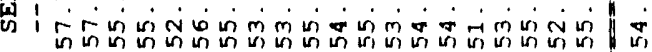

N

这

क्ष

3.

幽

拿!

急

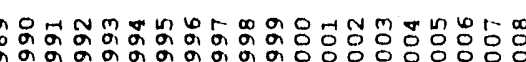

果 


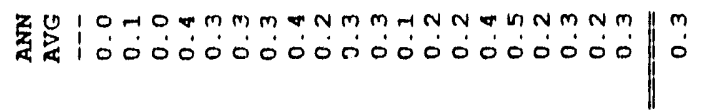

幽|

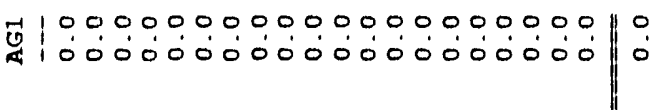

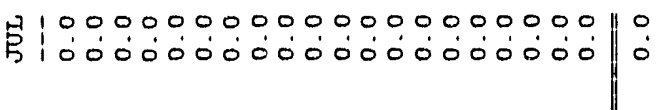

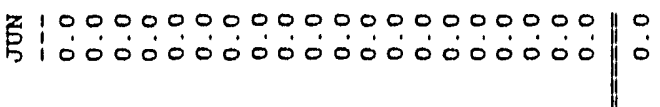

|

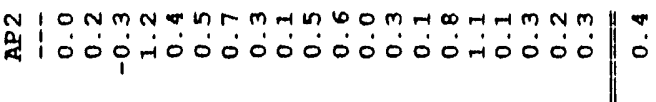

a

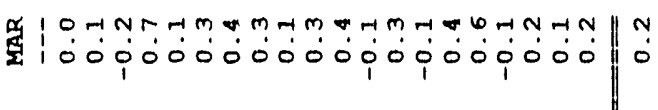

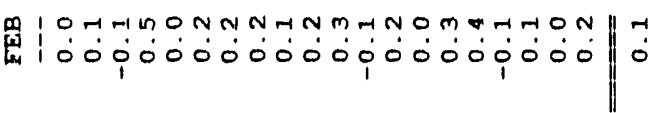

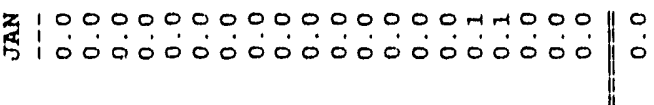

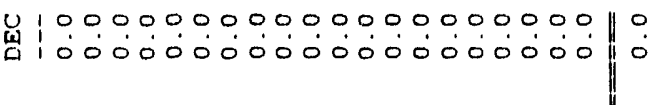

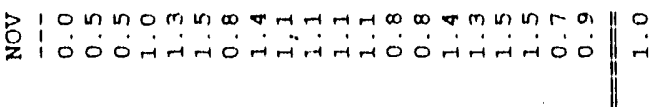

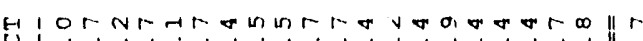

U

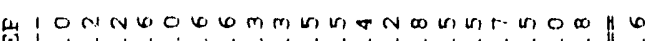

出

E

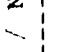

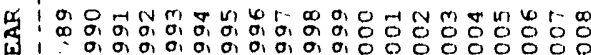

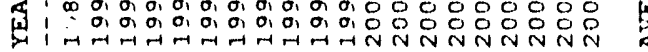




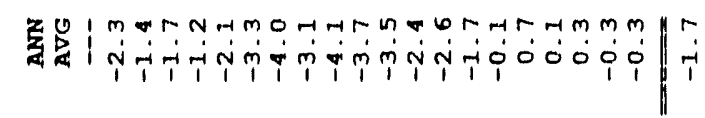

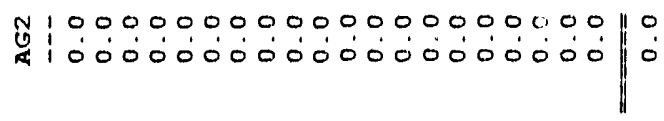

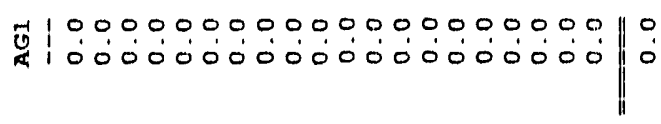

B|⿴囗十

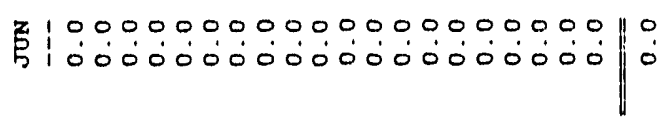

|

Q

a

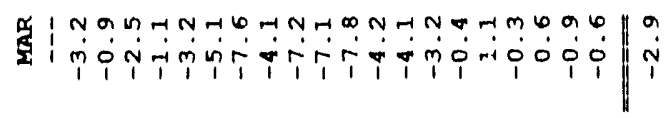

置

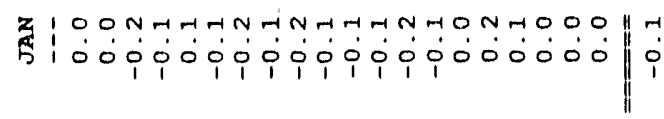

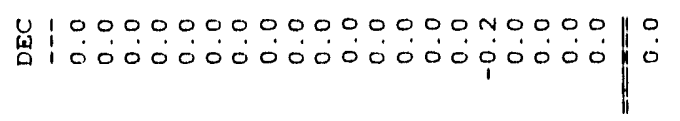

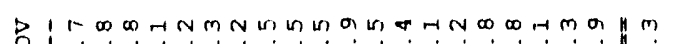

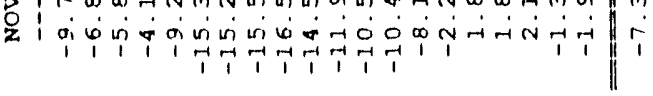

f

$\begin{array}{llll}0 & 0\end{array}$

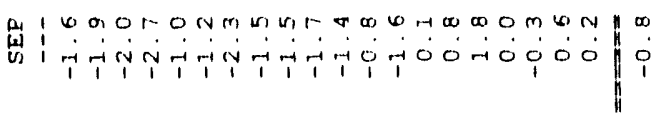

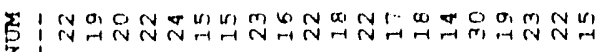

?

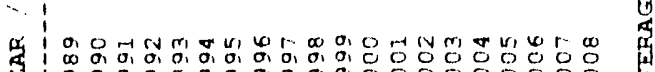

邹 


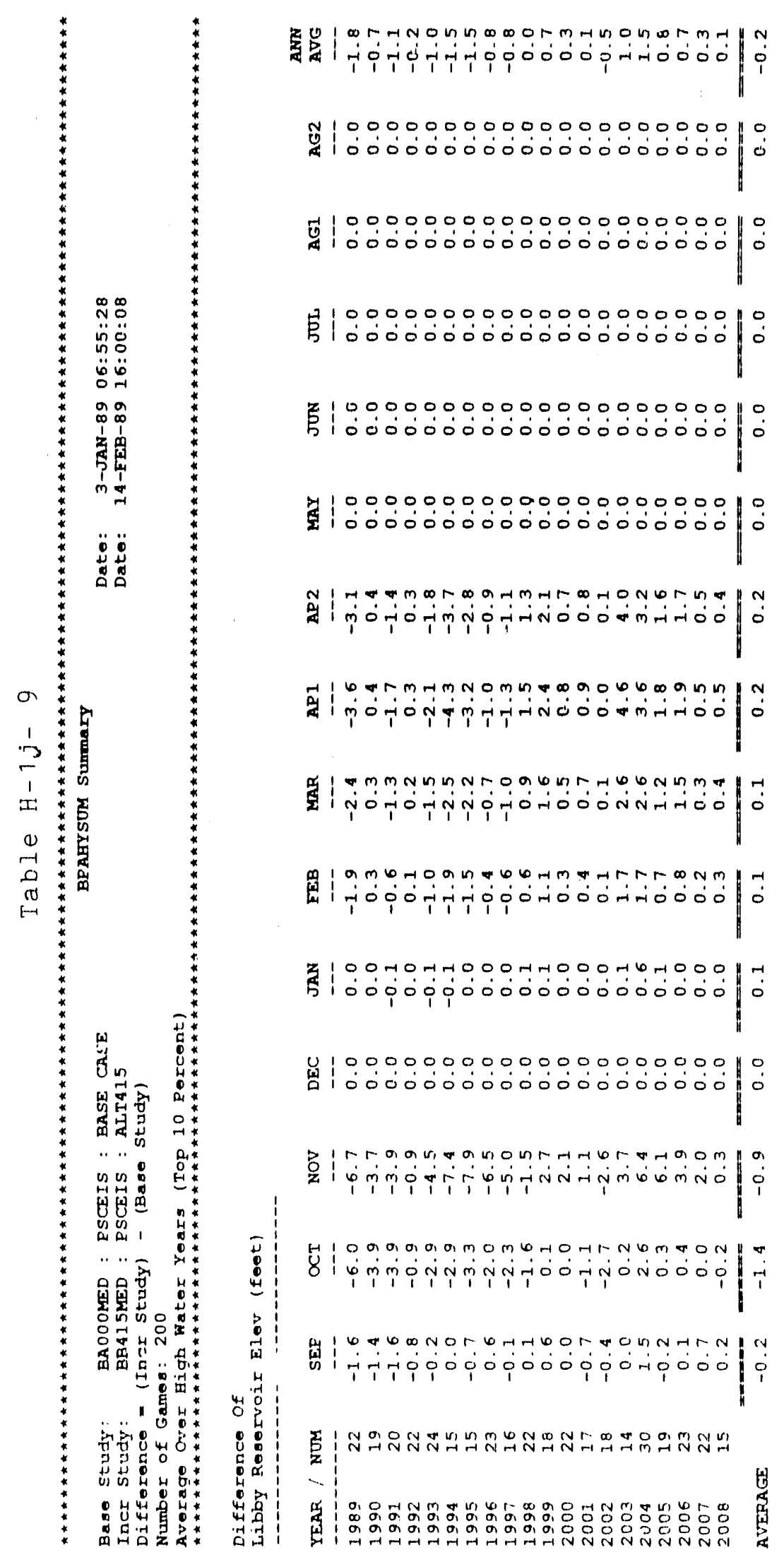




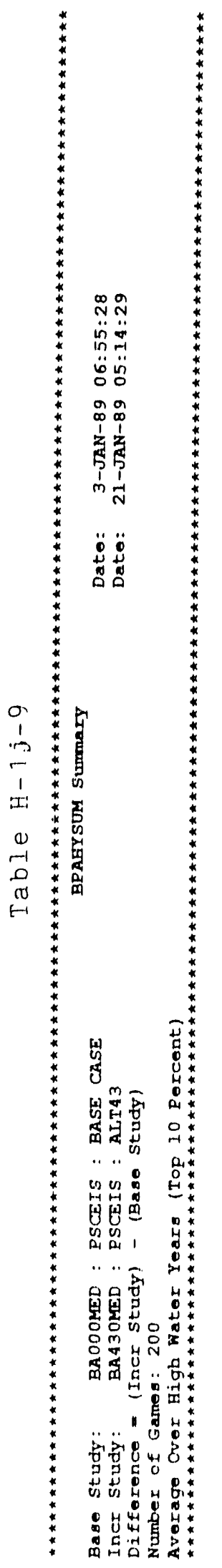

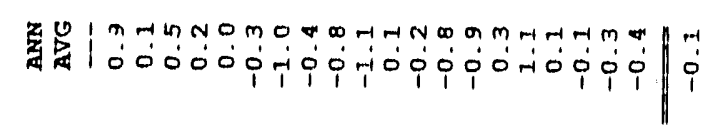

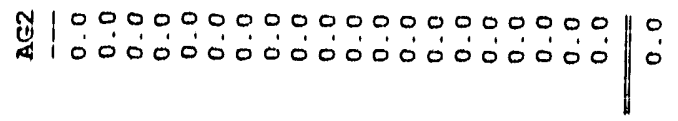

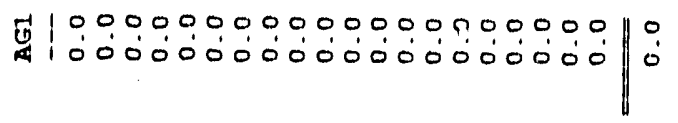

B| $\begin{aligned} & 00000000000000000000000 \\ & 00000000000000\end{aligned}$

F|

|

aै

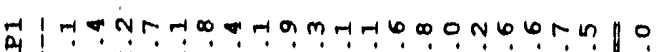

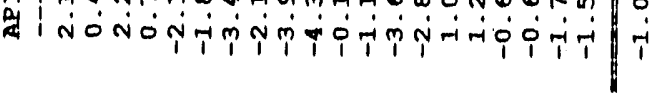

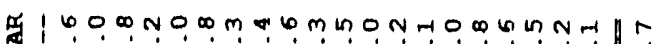

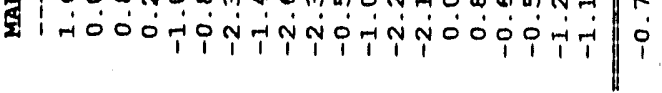

m momrrmbarrmrom

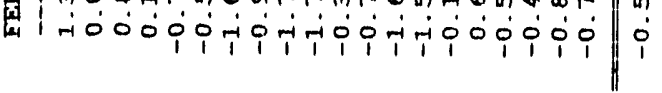

J

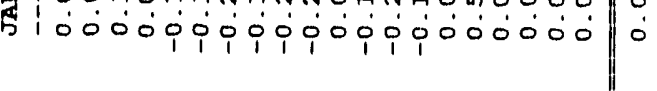

U $100000000000000000000 \| 0$

崖|

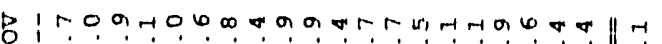

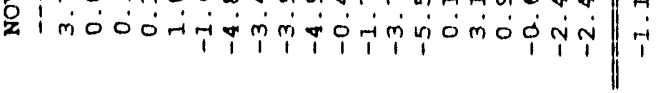

H

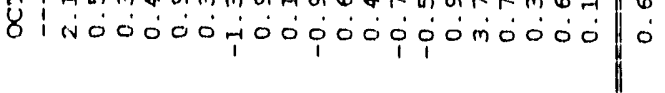

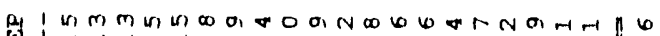

की

出年弯

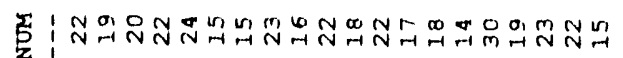

$\cdots$

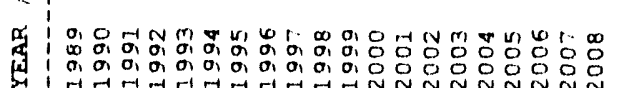

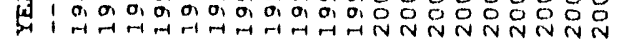




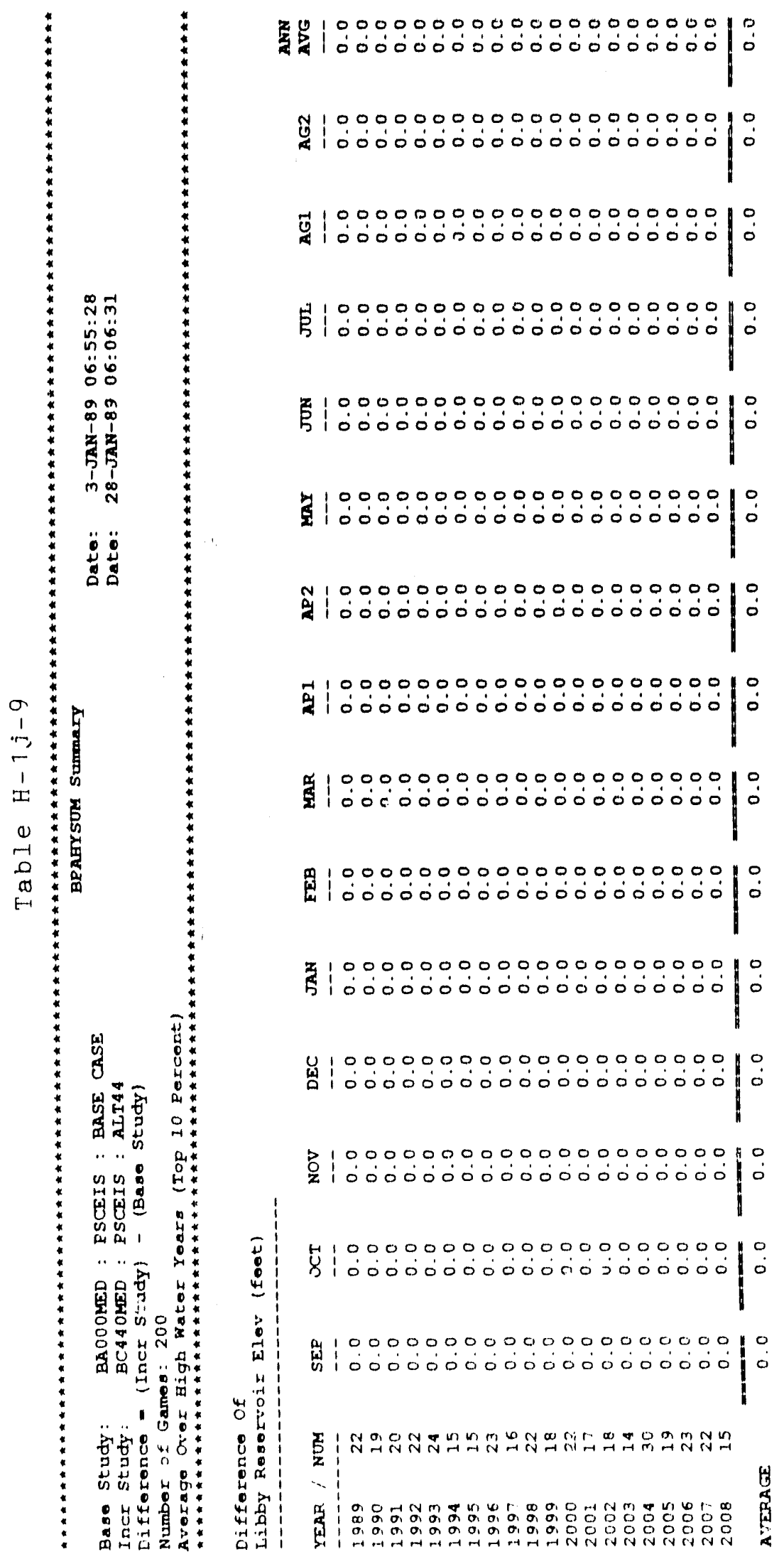









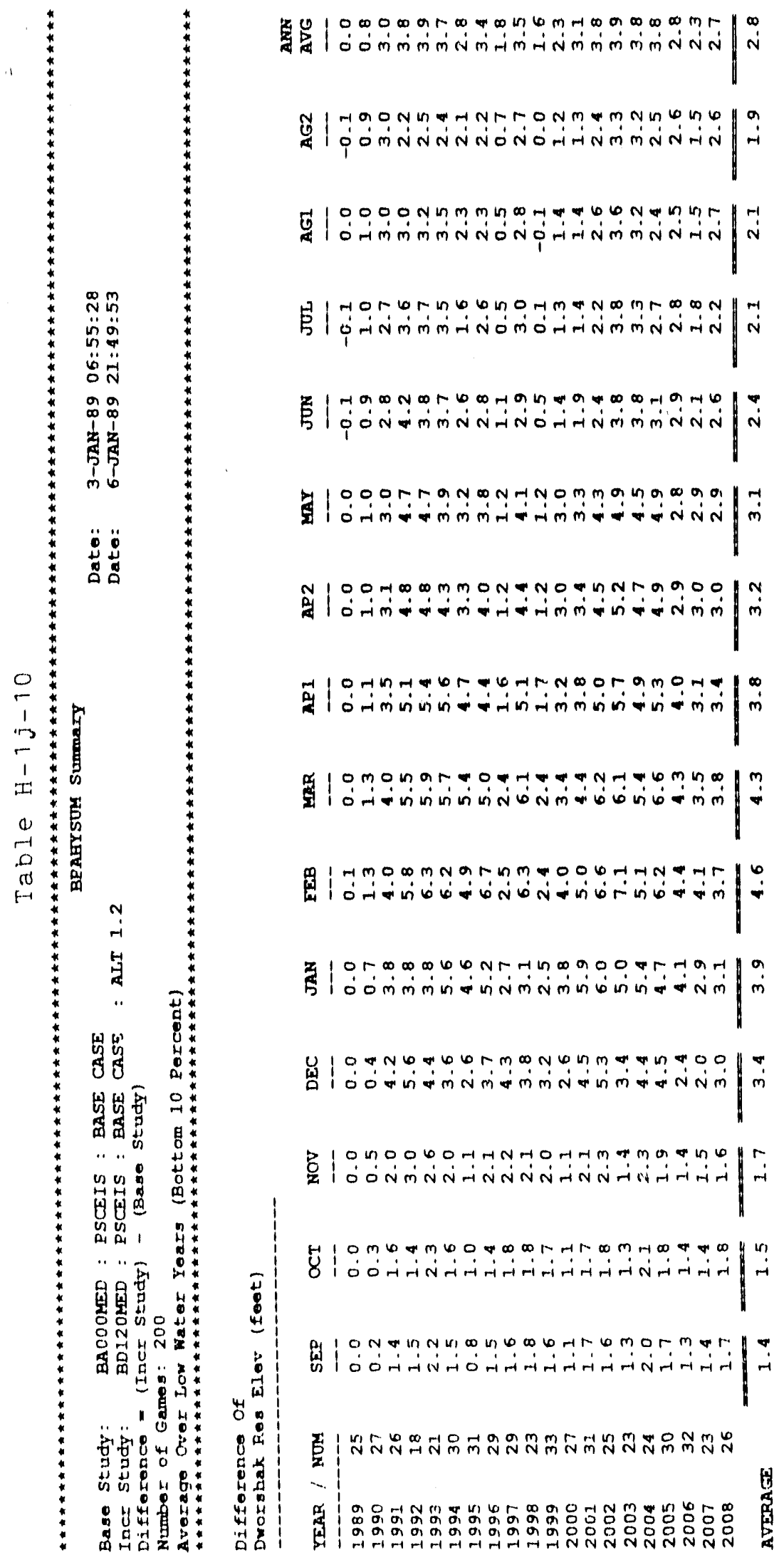

$H-1 j-56$ 


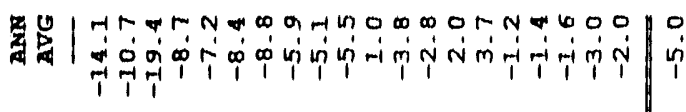

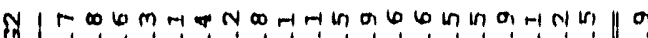

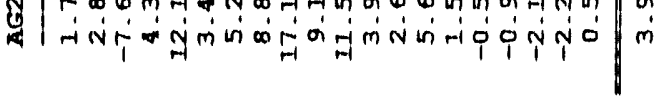

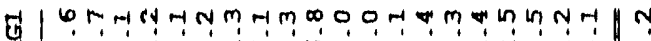

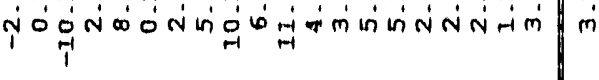

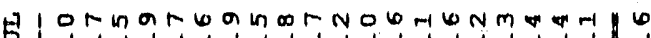

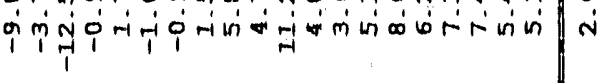

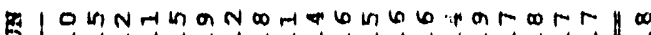
19

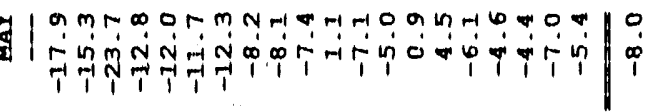

Q

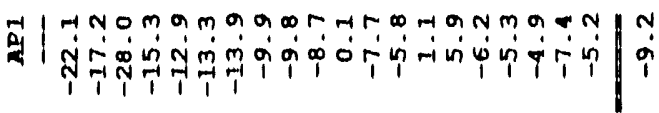

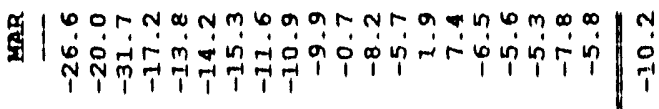

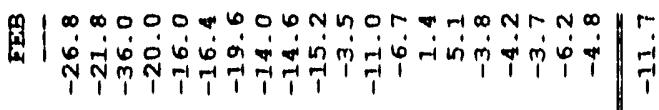

告|

峟 TT行

D In hN

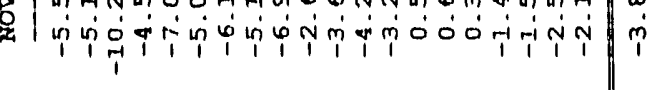

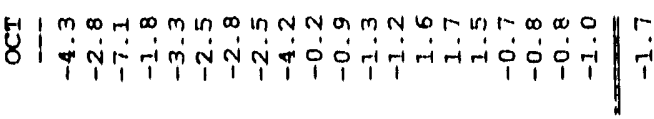

苞|

作 


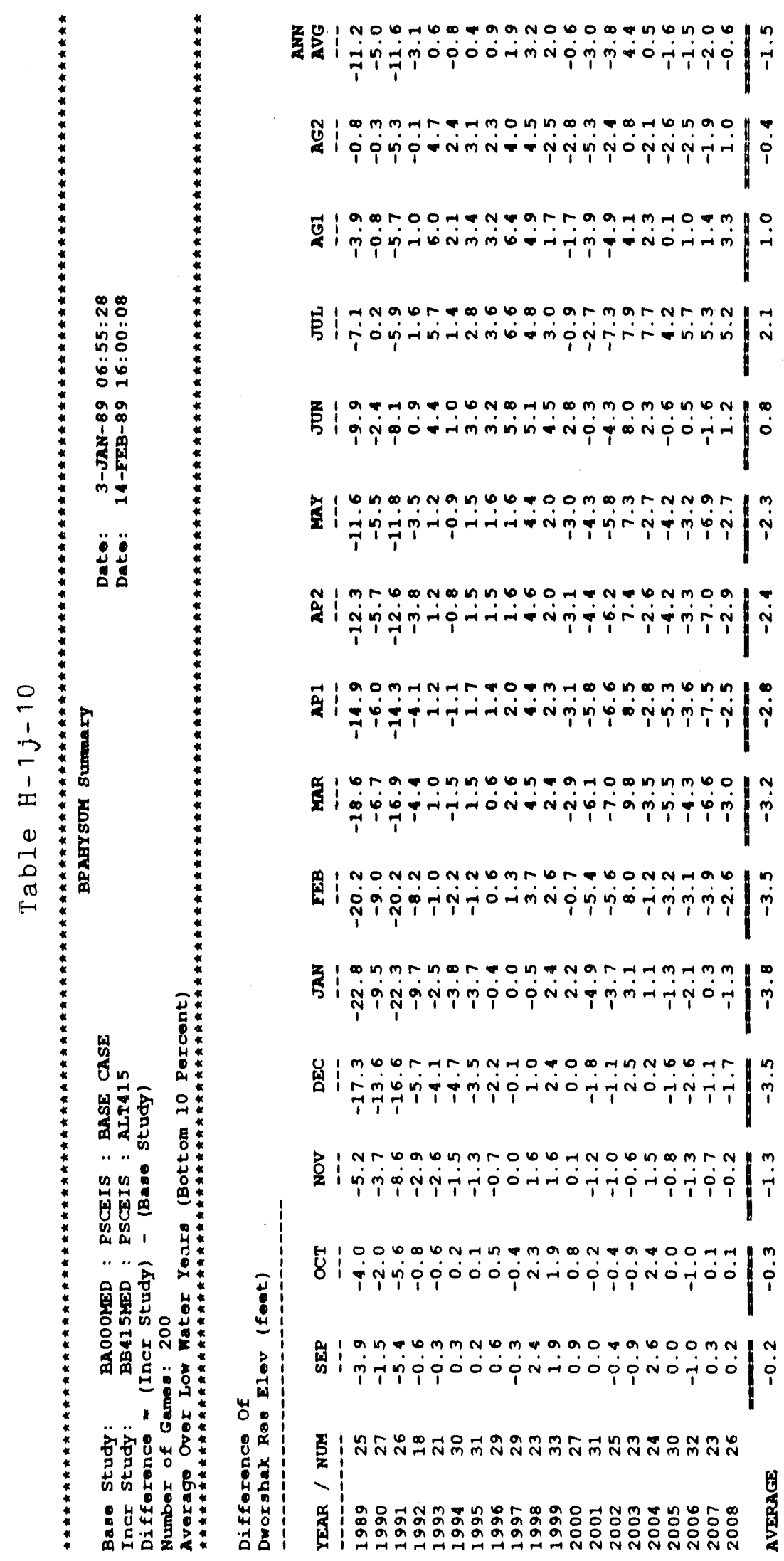




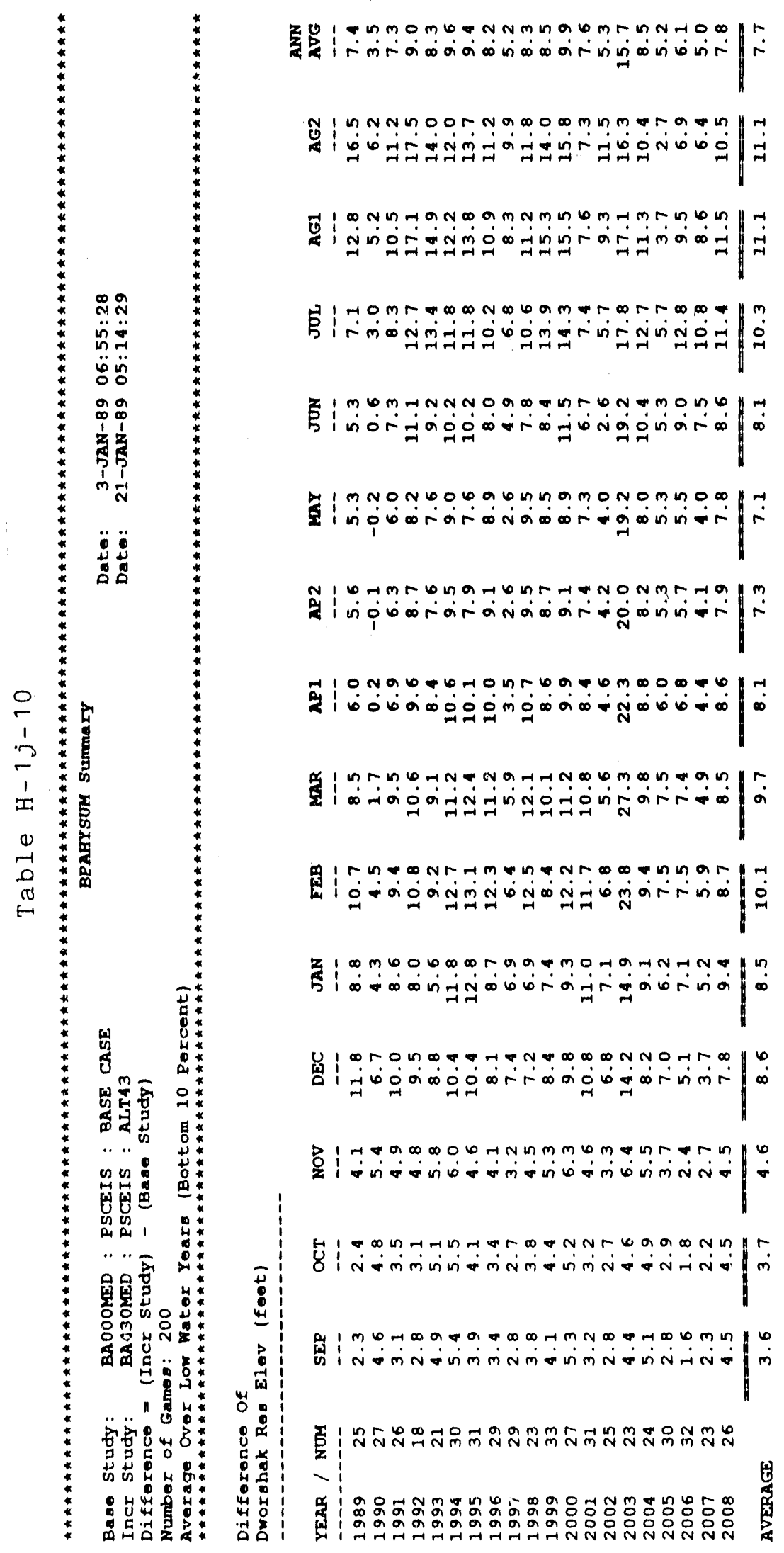

$H-1 j-59$ 


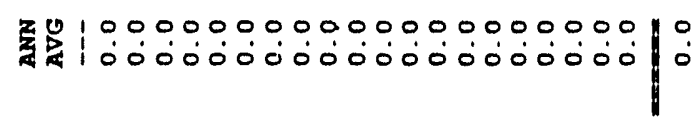

ฟै

6)

|

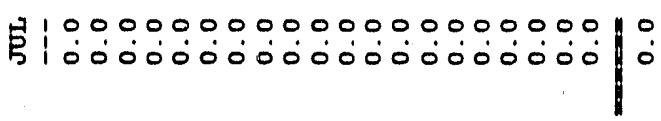

F|:00000000000000000000|:

710000000000000000000010

|

N 10000000000000000000010

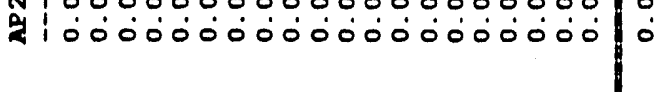

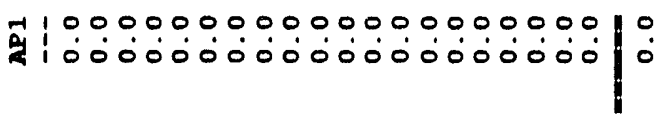

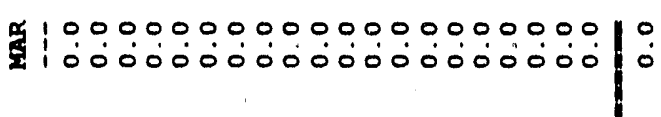

10000000000000000000010

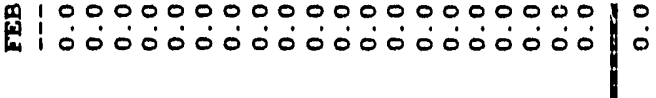

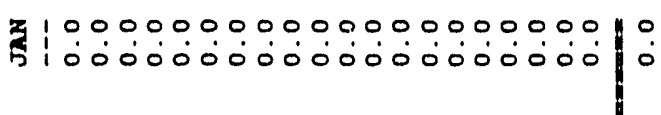

岛

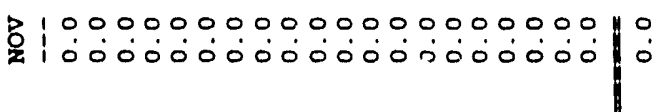

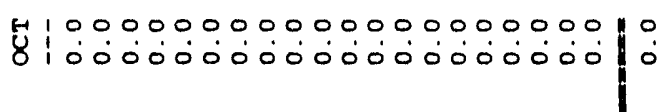

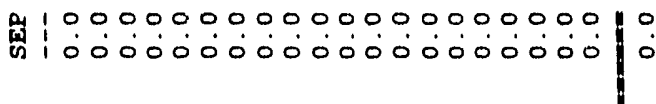

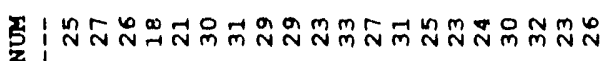
2

承

\section{象}




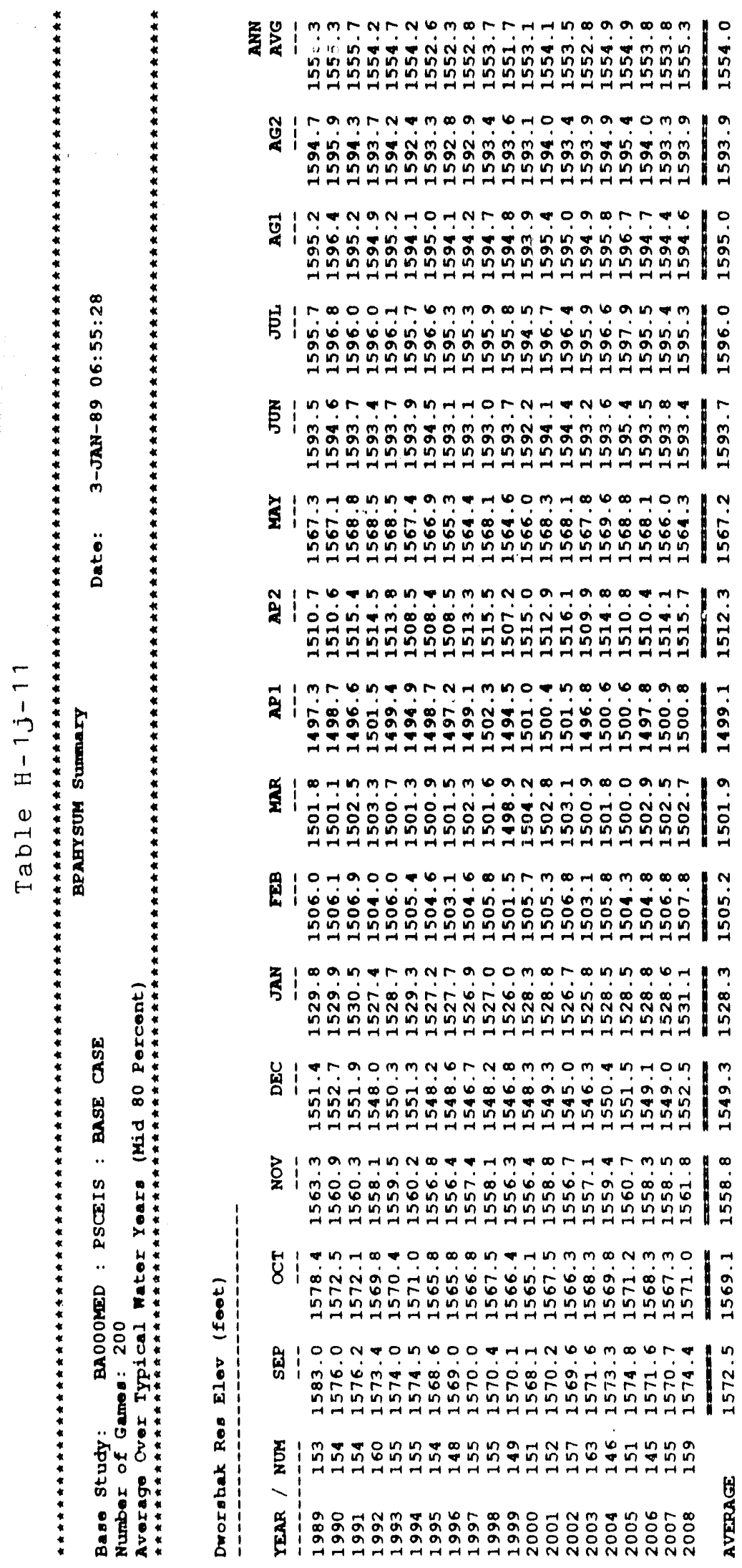




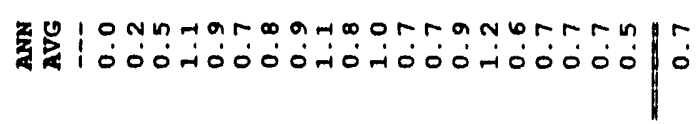

ת) पु

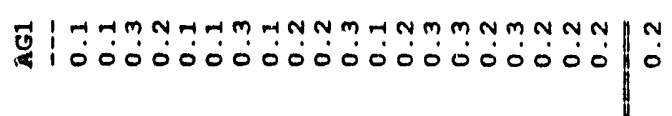
ह| |

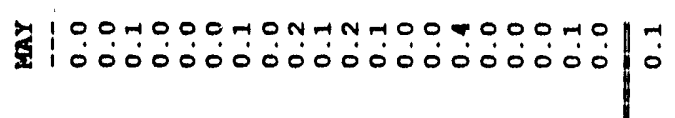

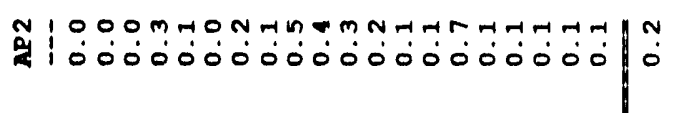
gat |

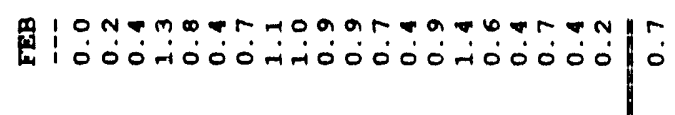

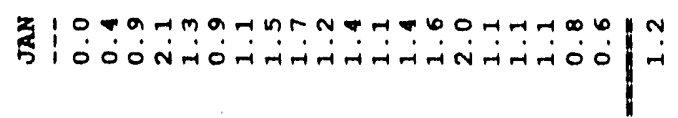

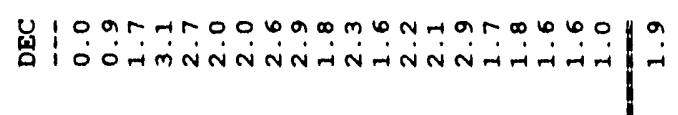
Ol 女|

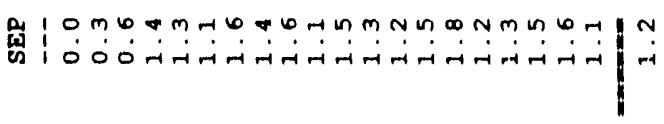

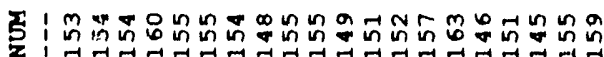
$-1$ ำ

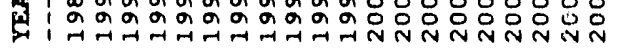




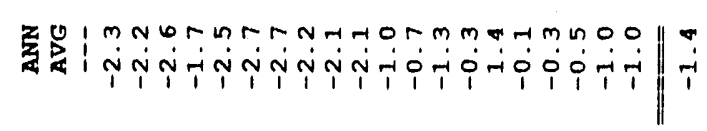

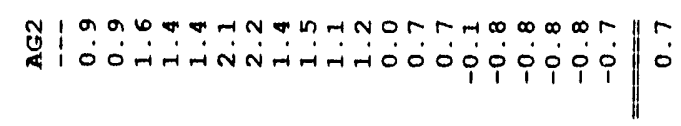

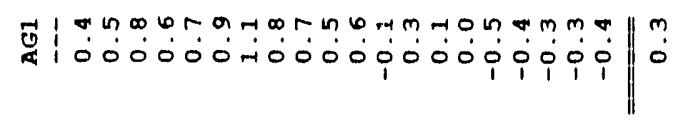

S|

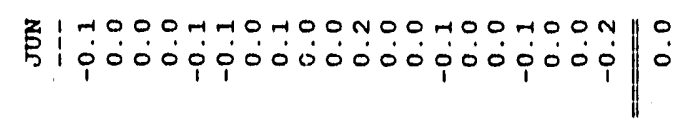

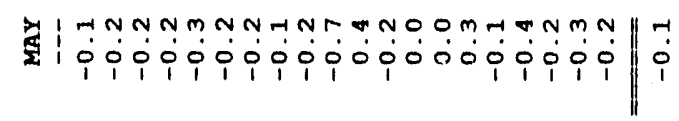

$m$
and

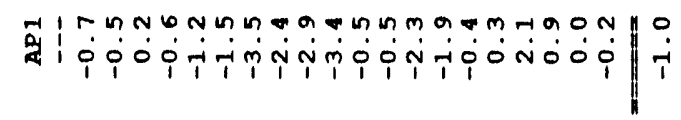

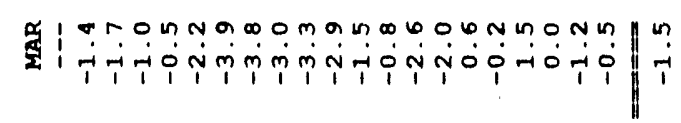

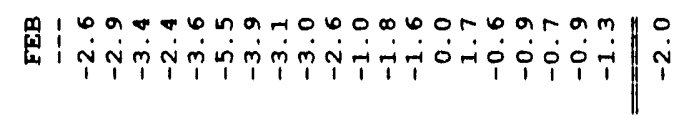

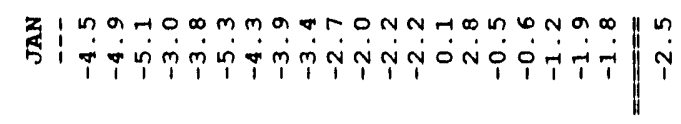

曾

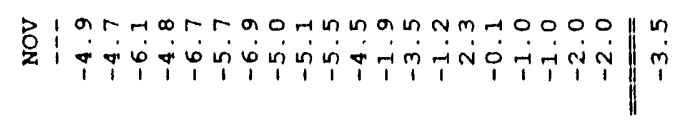

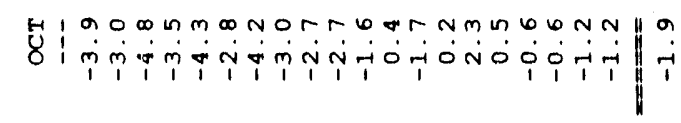

M

出:

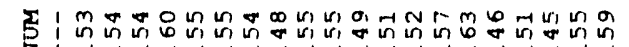

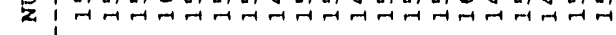

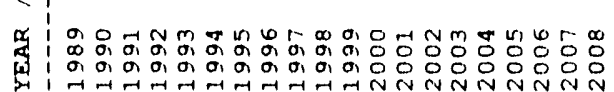




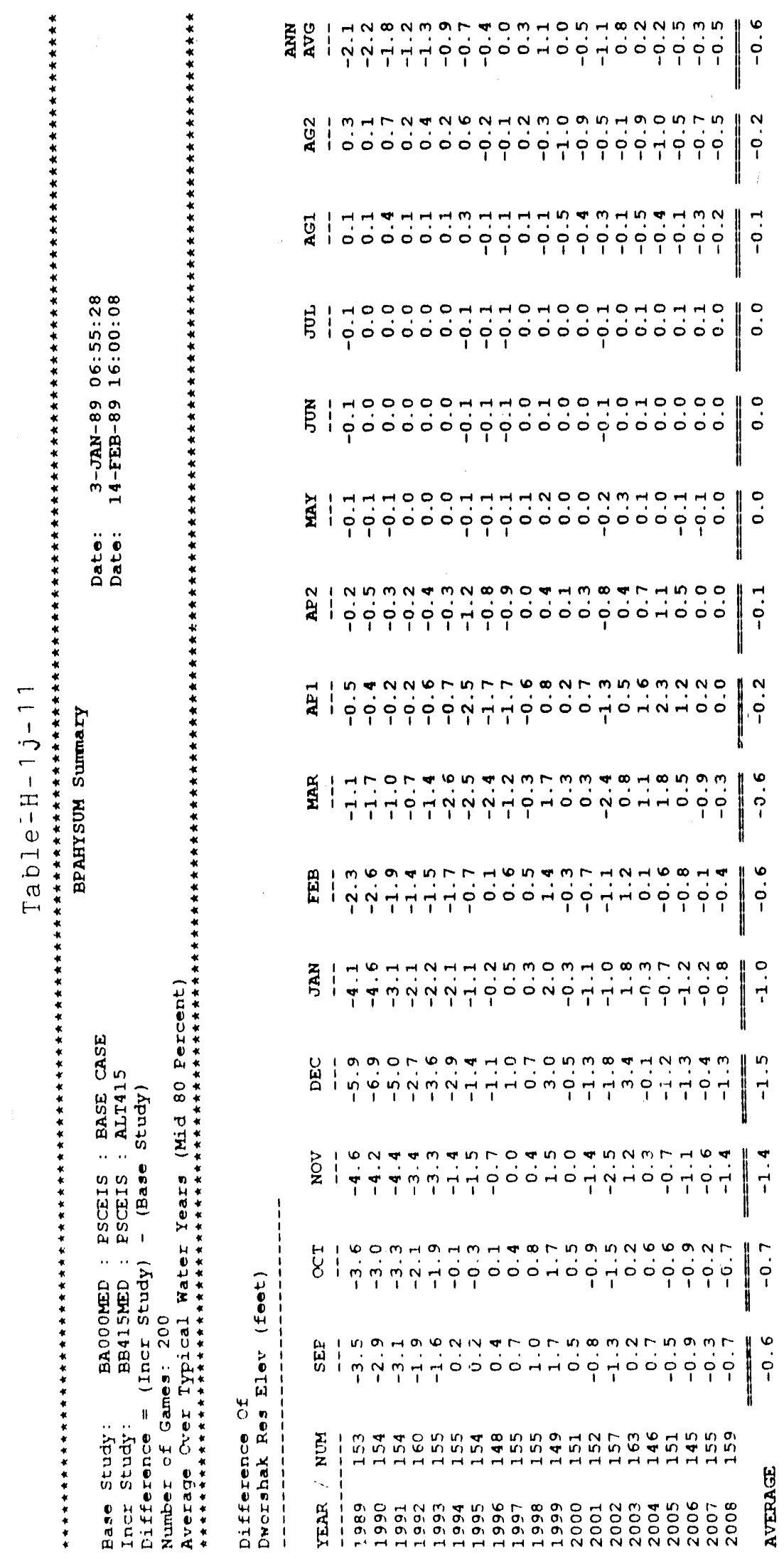




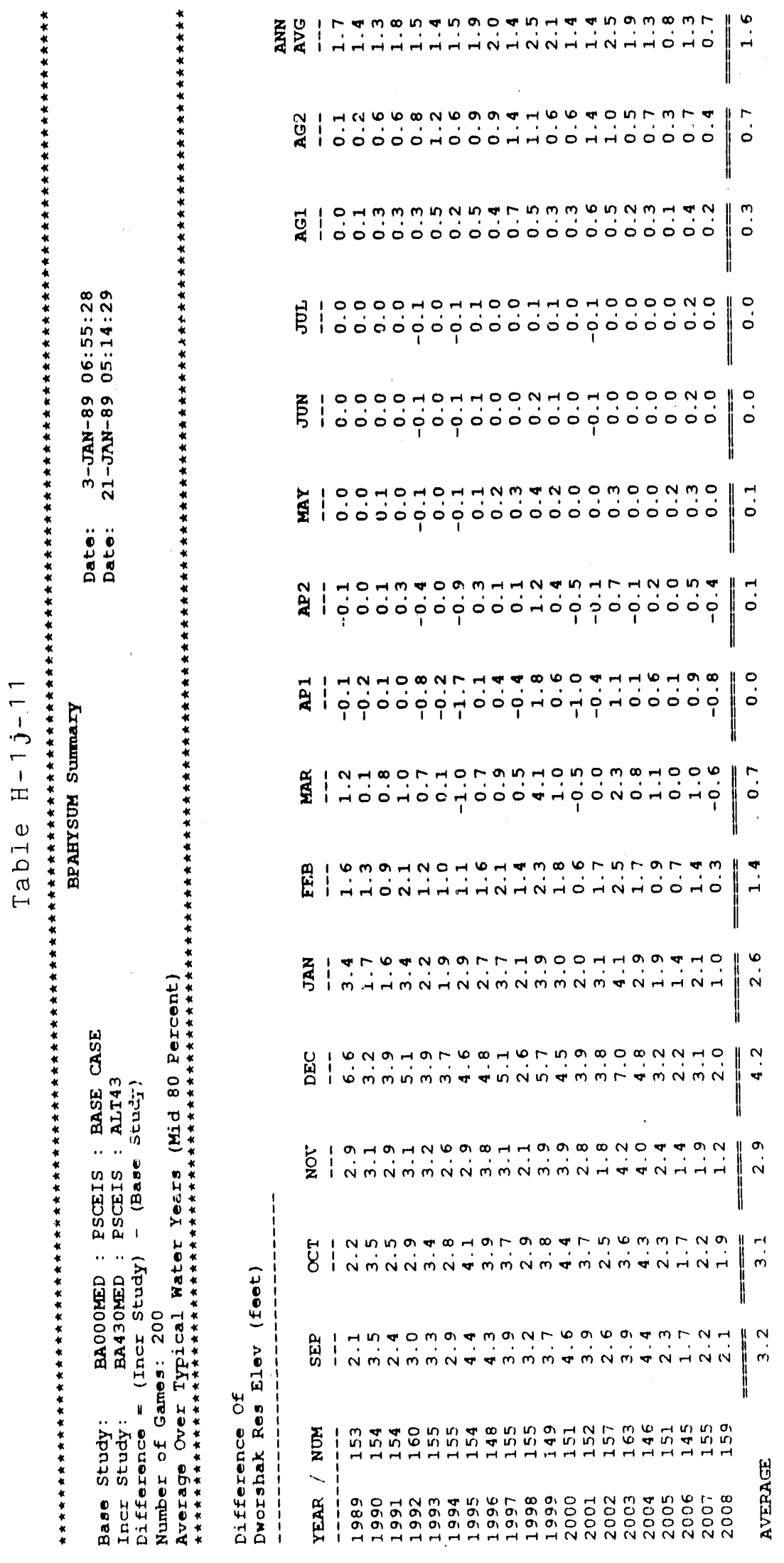




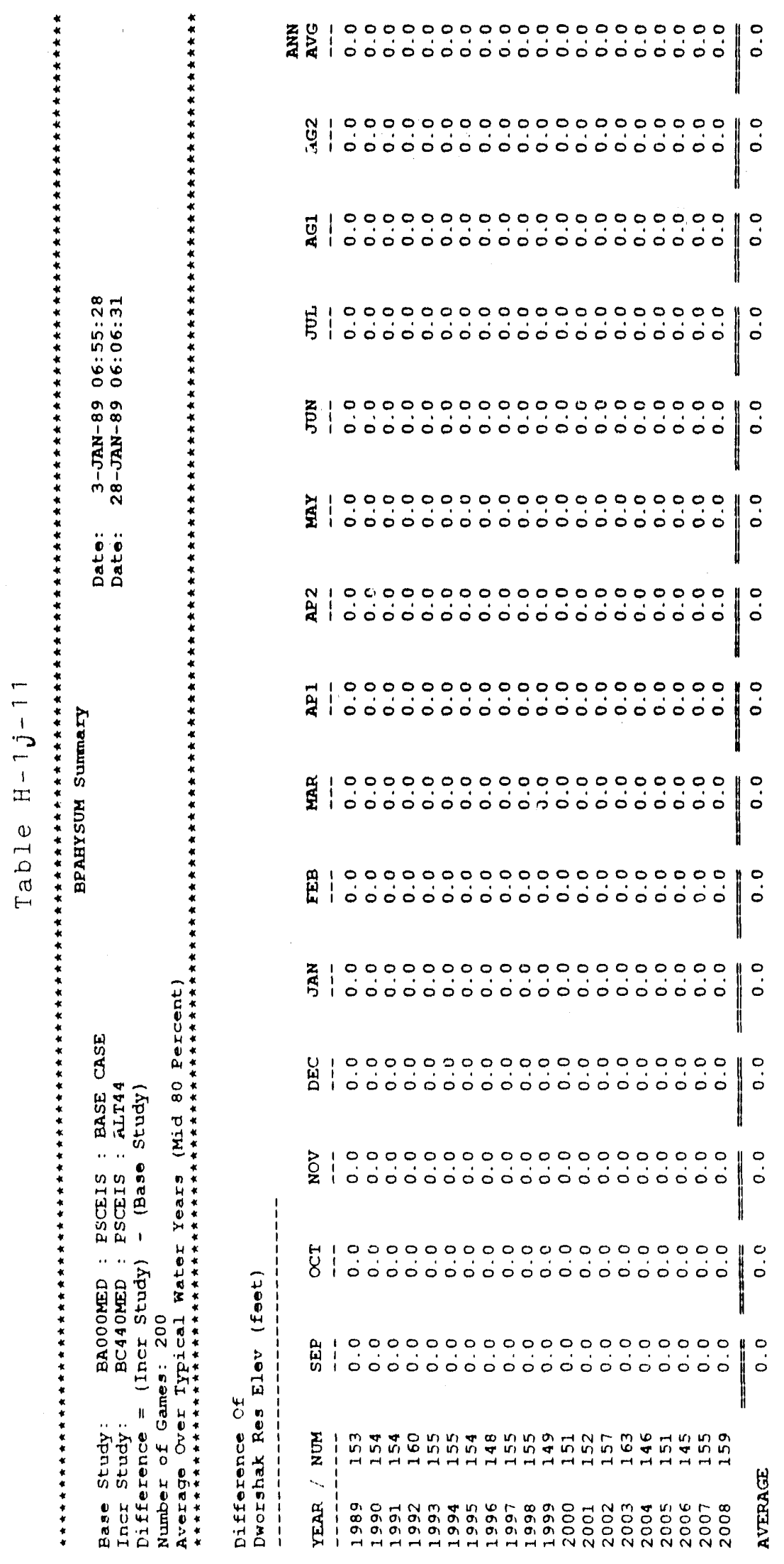




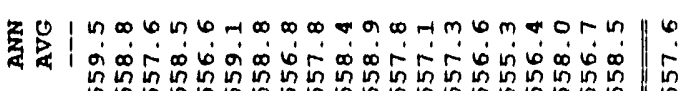

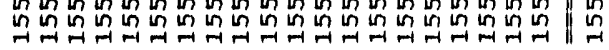

N 100000000000000000000110

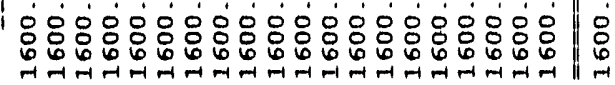

$1100000000000000000000 \mid 10$ 8
0
0
0

$100000000000000000000 \mid 10$

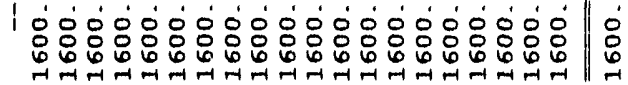

2100000000000000000000110

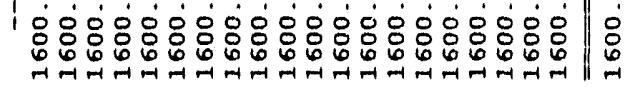

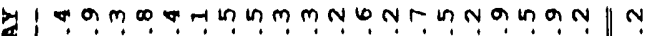

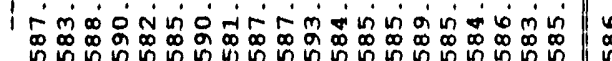

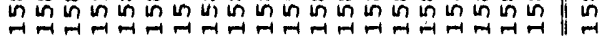

a m MOMOMNG MOMNGNOMNGN||

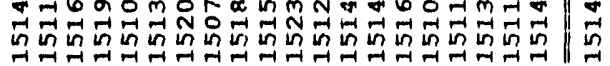

a

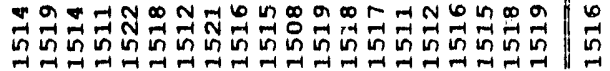

J

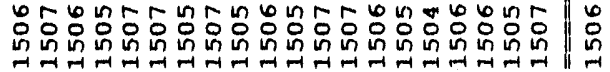

*

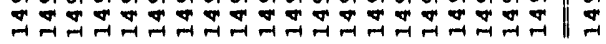

Z INNNMNNGINGHDGNONON

|

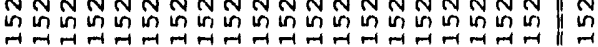

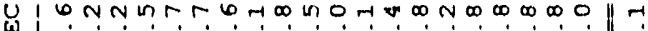

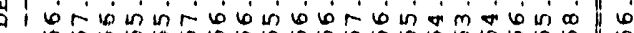

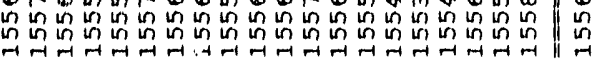

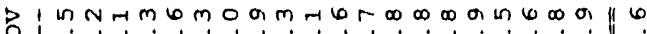

|

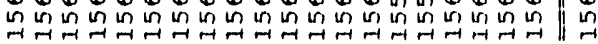

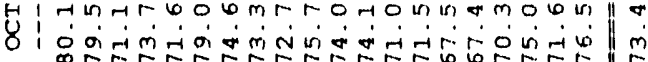

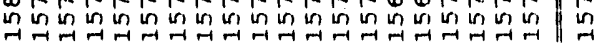

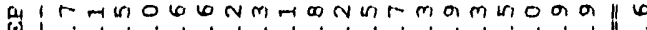

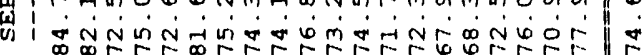

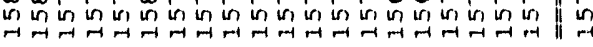

E $\rightarrow 1$

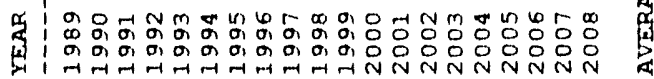




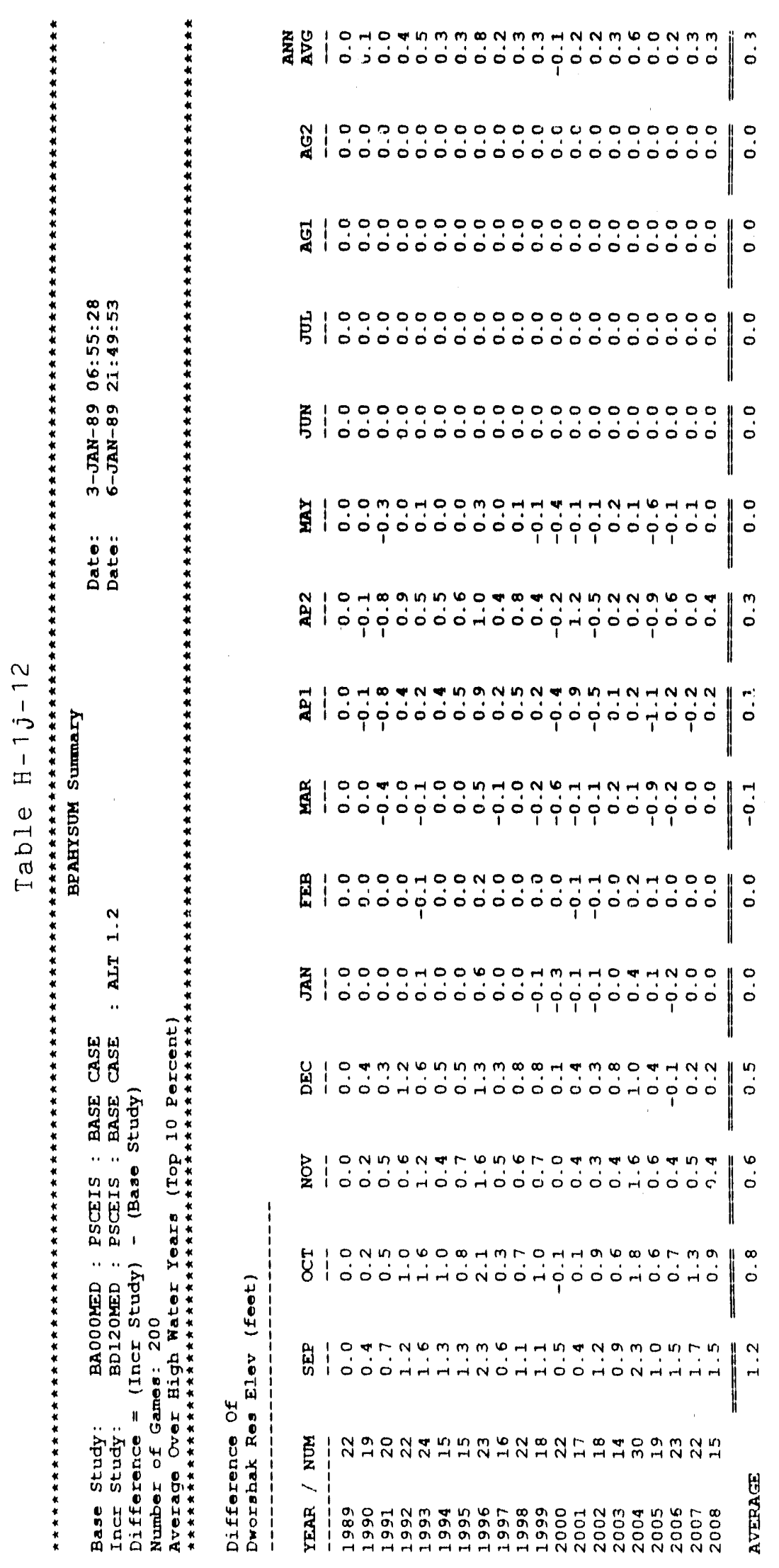




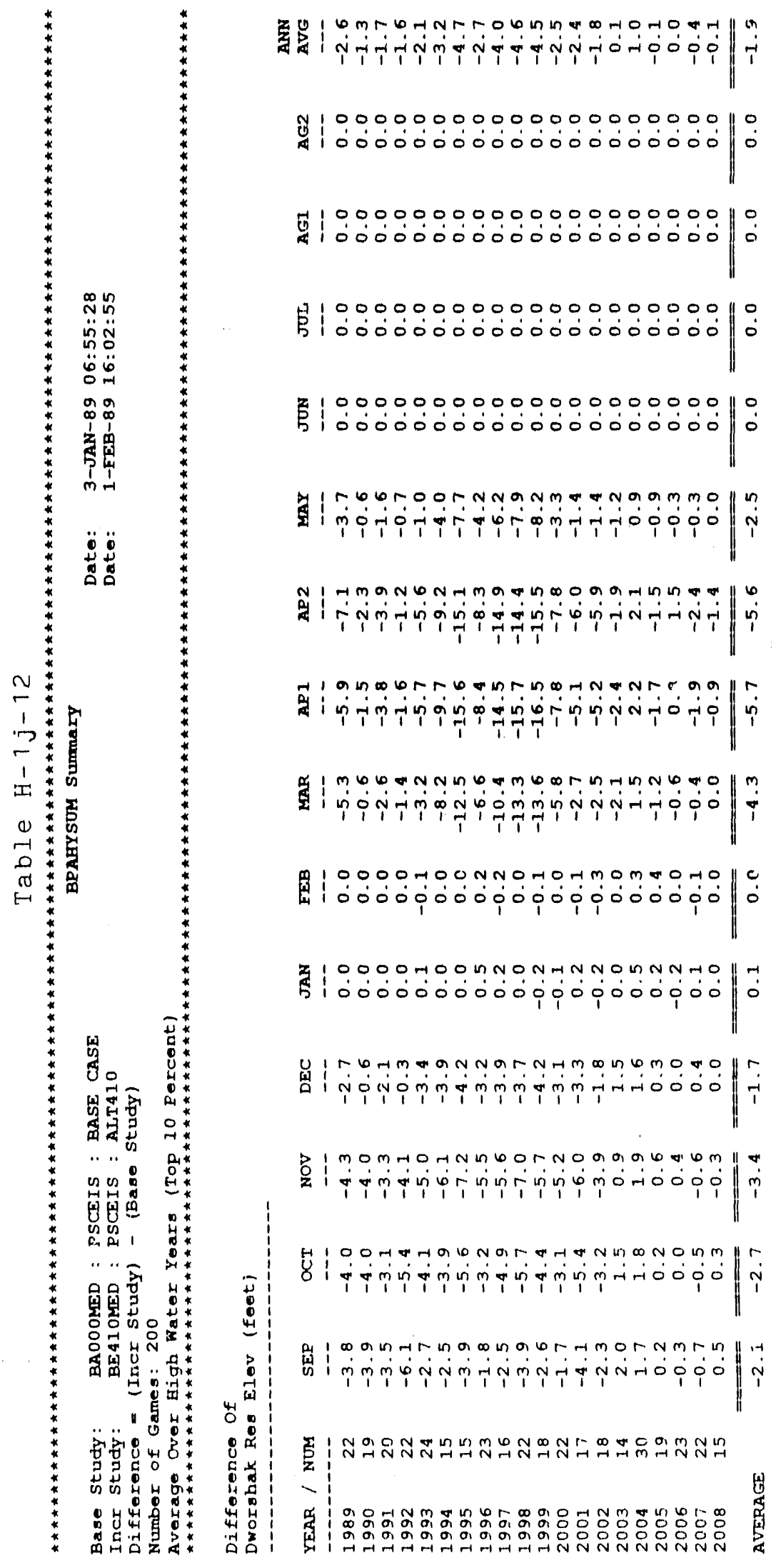

$$
13-1, j-69
$$




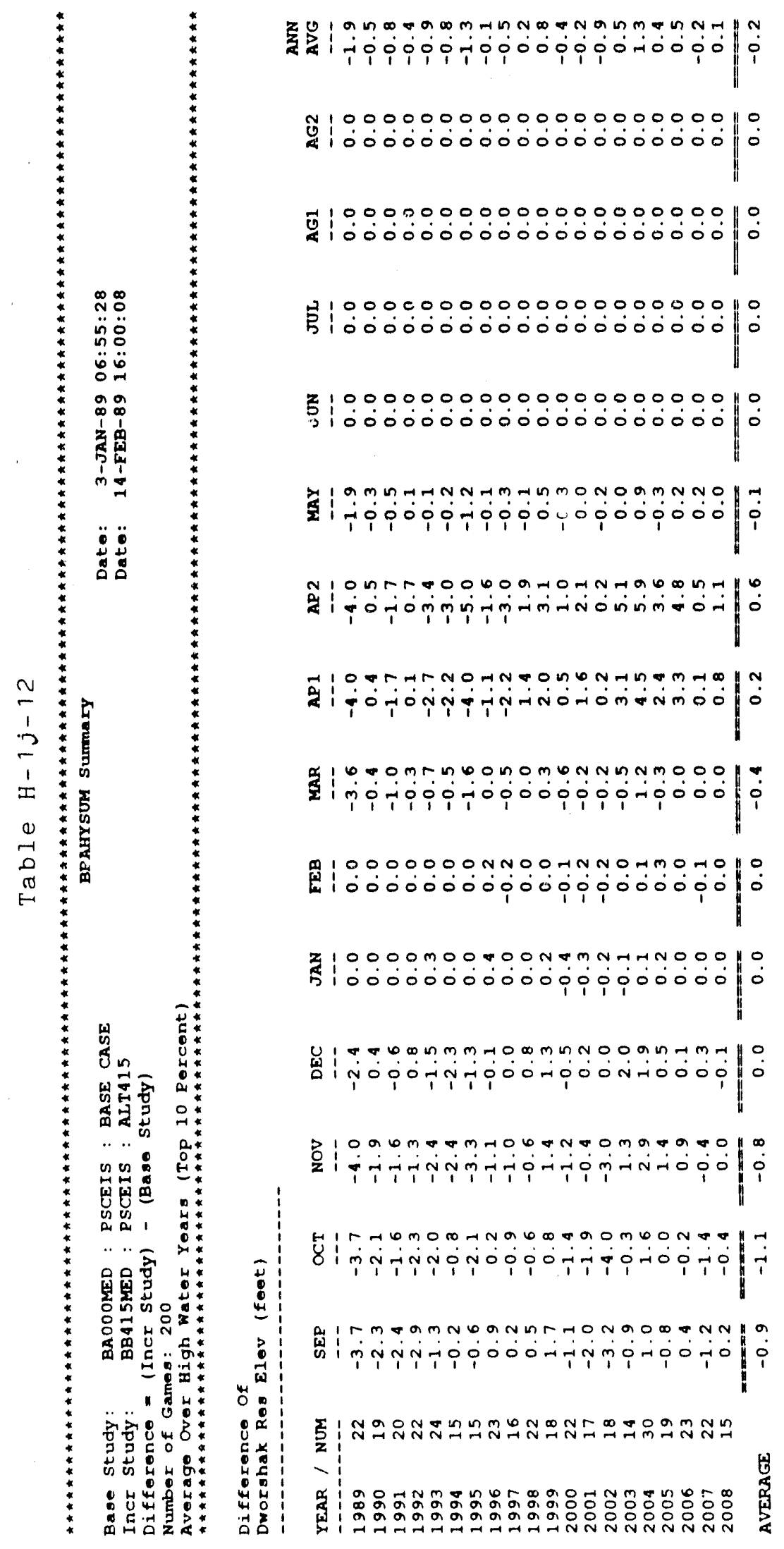




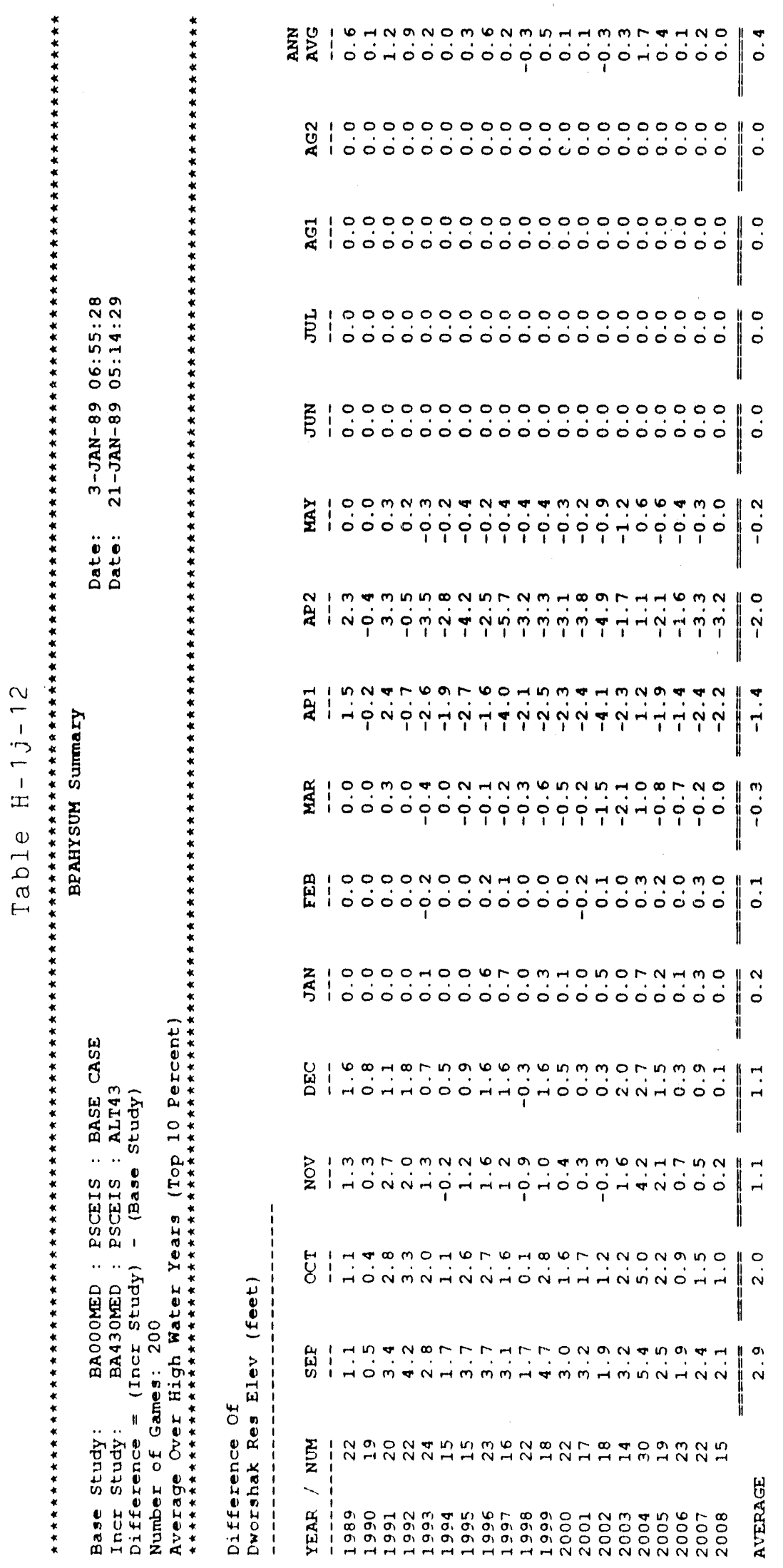




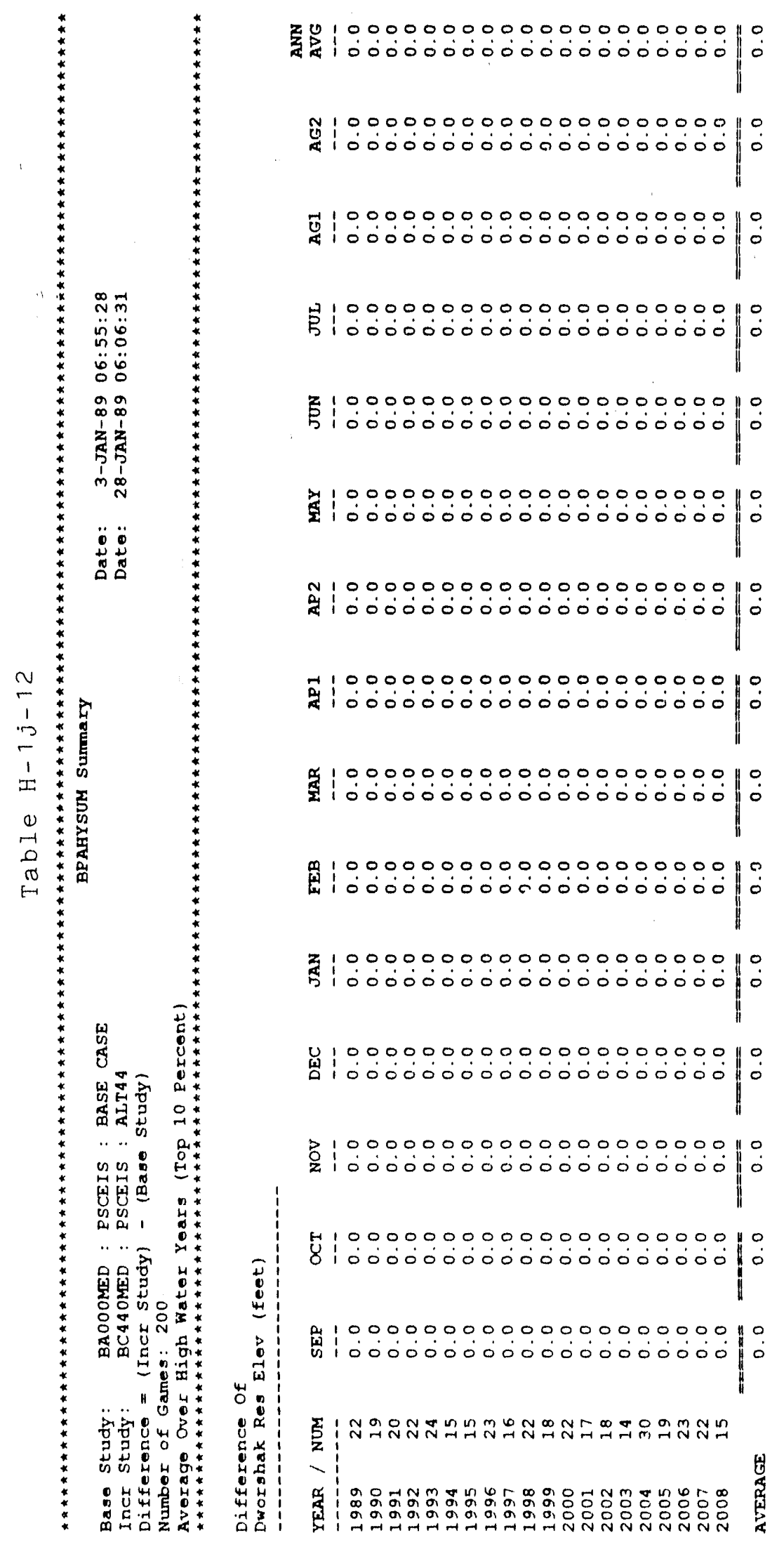

$H-1 j-72$ 


\section{H-1k}

FREQUENCY OF CHANGE IN RESERVOIR ELEVATIONS GREATER THAN 5 FEET 


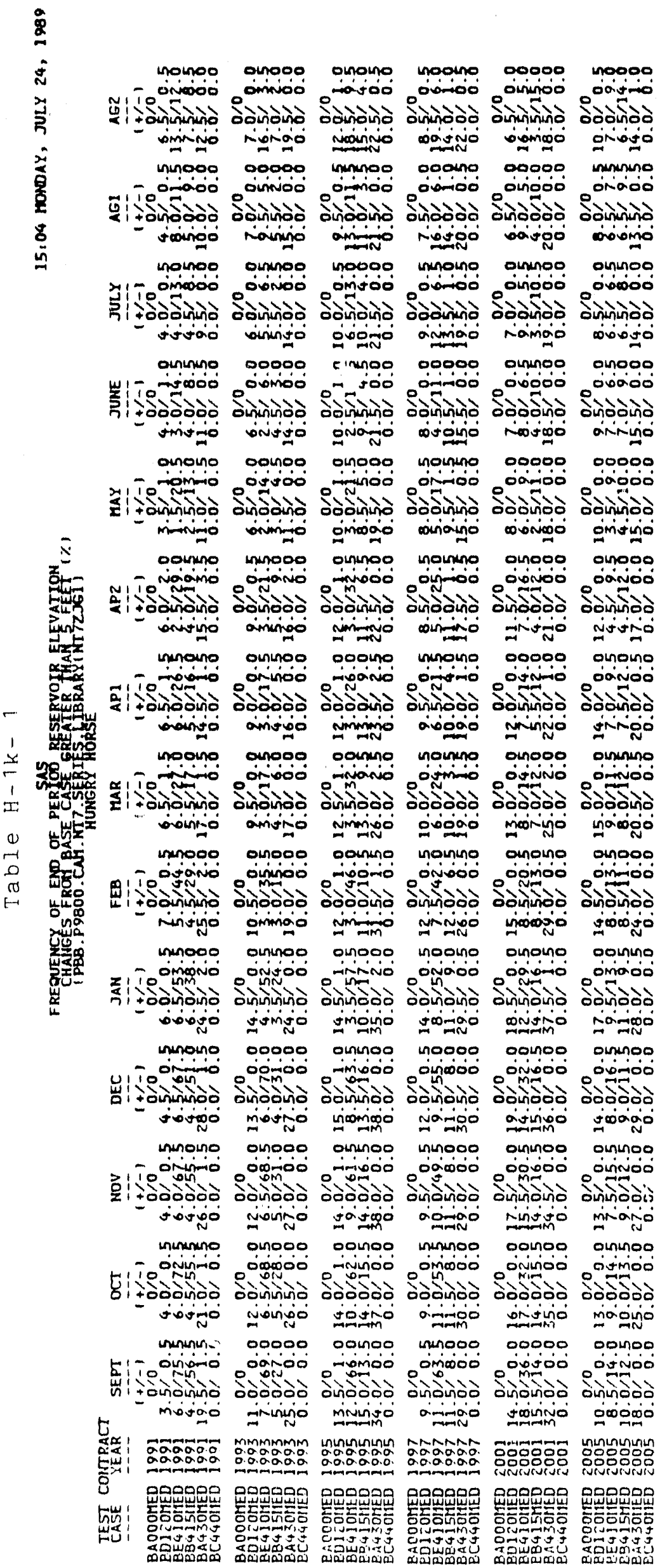


00000

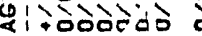
00000

- वंoióo ind 00000

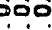

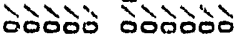
D́óóo

00000

00000 -

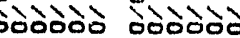

نं00ं

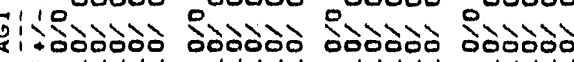

00000

00000

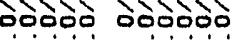

0ं0000

סं0ं0ं0

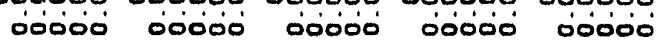

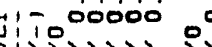

गitò

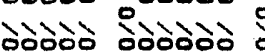

000000000

cóóio

סं0்ió

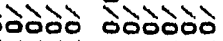

10.00000

00000000000000000000

ouninoo 0000000000 mo000 00000 00m00

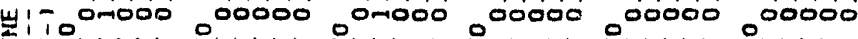

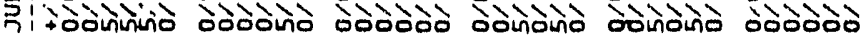

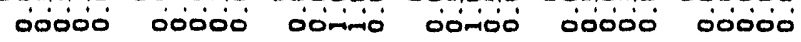

olnunoo olnunino olninoo uninooo oodino aninoo

सं

I unoooo ooguno oolnoo oininino ounouno unininino

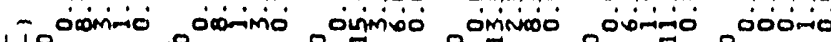

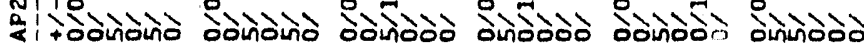

- iminio ónimo romimo óninio óónio minó

oolnino 00000 olnunoo olninoo 00000 unLinoo

- murvino minvo onimo

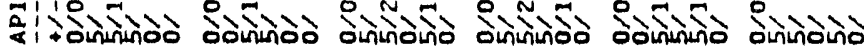

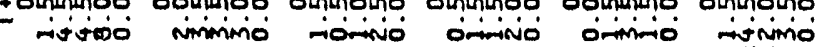

(1)

$\frac{14}{4}$

- nomino

OnODO

00000

oooino

noo0o unininoo

31000

Th000

inionio

a rin

- minivina

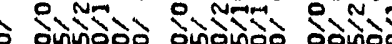

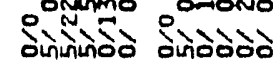

unouno

10 onm

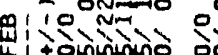

oninimo

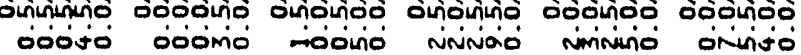

oininos 00000 Dolnino oounoo doinino ouninino

$1000 \mathrm{~m}$

o omino cijión

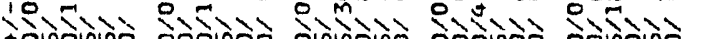

000000000000000000000000000000

U1 10000

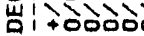

-

$$
0000
$$

1100000

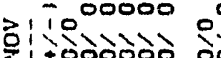

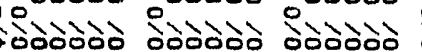

00000

$0000000000 \quad 010000$

1000000 00000 00000

$81+00$

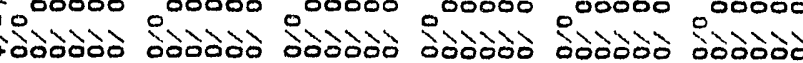

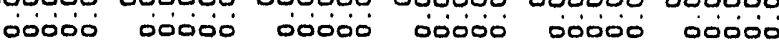

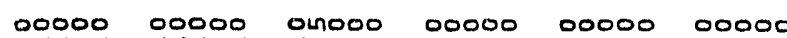

II

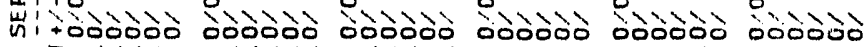

- 00000 00000 00000 00000 00000 00000

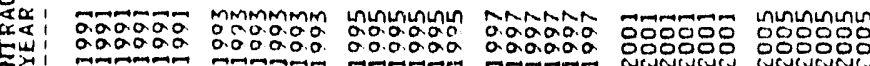

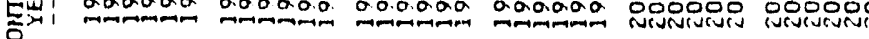

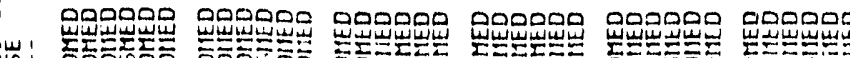

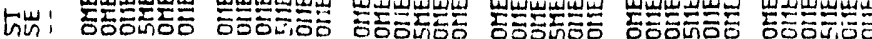

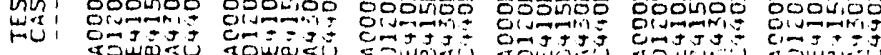

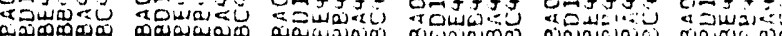




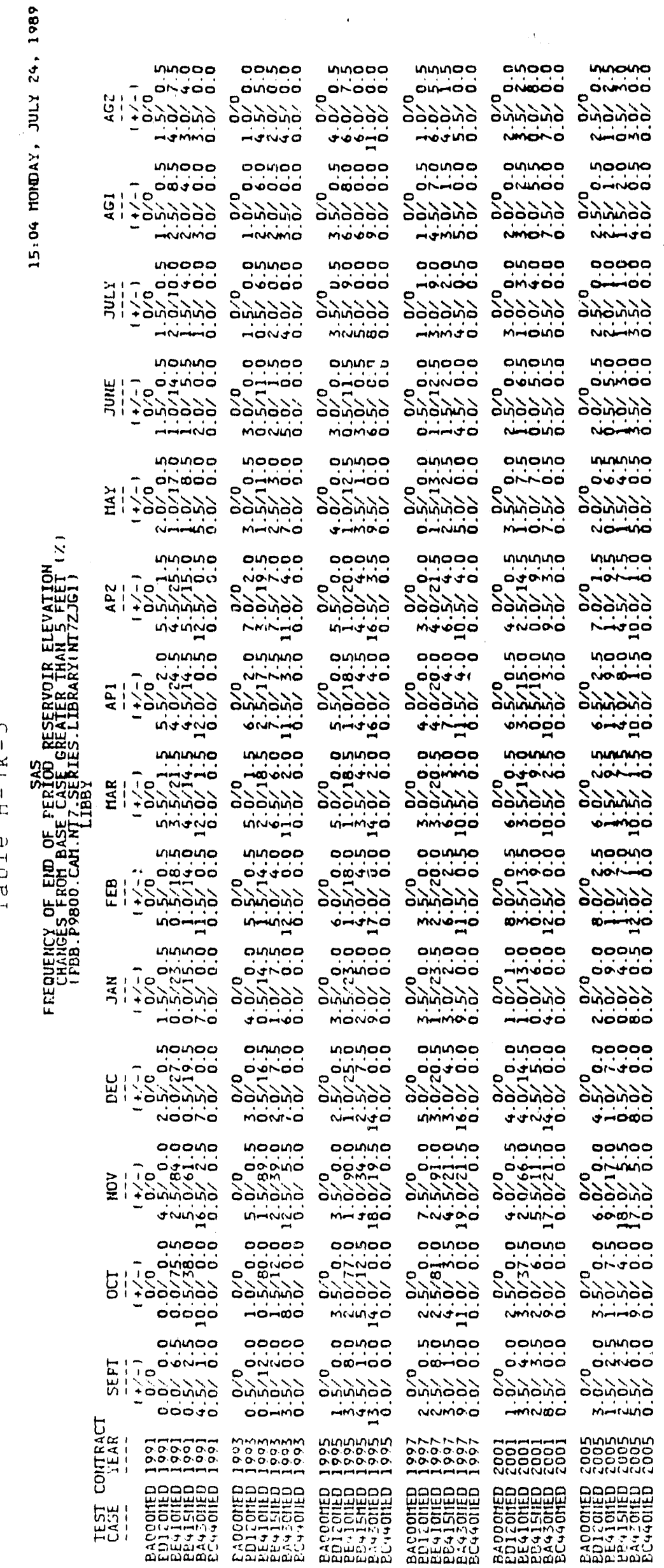




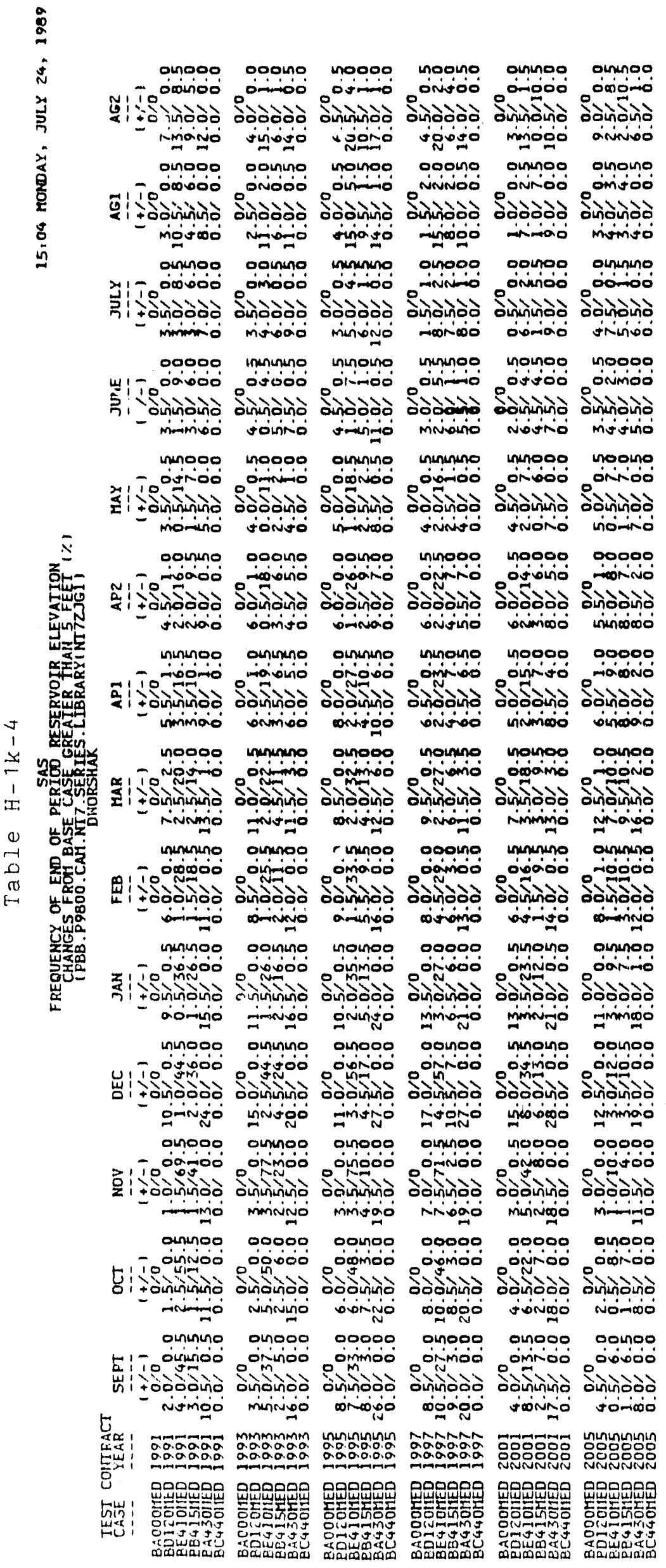

$11-1 k-4$ 
H-2

Recreation 


\title{
Recreation Analysis
}

\author{
Recreation Analysis for Albeni Falls
}

Recreation impacts for alternatives analyzed with the Systems Analysis Model (SAM) at Albenl Falls (Lake Pend Oreille) are analyzed in terms of the probability of the elevation of that reservolr being at an elevation of 2,054 feet or more at the end of Aprl1. That level enhances the annual Kokanee and Kamloops Fishing Derby, which occurs around May 1 each year. Table H-2-l shows the probability of the elevation of Lake Pend Orellle exceeding 2,054 feet at the end of April. These data are given only for the same years as were used in the analysis of lmpacts on fish, since the data are derlved from the same data set as is used for the fish impacts analysis. Also, these probabllity data were only developed for the alternatives with expected load sizes and gas prices, consistent with the recreation analysis for the other reservolrs described below. If there is interest in seeing data on the probabllity of Lake Pend Orellle being at or above 2,054 feet for other sensitivity assumptions, we will provide this data upon request.

\section{Table $\mathrm{H}-2-1$}

\section{PROBABILITY OF ALBENI FALLS ELEVATION EXCEEDING 2054 FEET AT THE END OF APRIL}

\section{(Expected Loads and Gas Prices)}

$\begin{array}{lcccccc}\text { Alternative } & 91 & .93 & \underline{95} & \underline{97} & \underline{01} & \underline{05} \\ \text { No Action } & .960 & .935 & .910 & .880 & .920 & .920 \\ \text { Alt. 1.2 } & .965 & .940 & .920 & .910 & .925 & .920 \\ \text { Alt. 4.1, Case A } & .940 & .945 & .905 & .890 & .910 & .915 \\ \text { Alt. 4.1, Case B } & .890 & .910 & .845 & .855 & .920 & .910 \\ \text { Alt. } 4.3 & .990 & .950 & .930 & .825 & .930 & .925 \\ \text { Alt. } 4.4 & .9601 / & .9351 / & .9101 / & .8801 / & .9201 / & .9201 /\end{array}$

I/ Values for Alternative 4.4 are assumed to be the same as for No Action since there were no other differences in hydro operations between the two in the SAM results.

Development of Recreation Indices

In order to determine and compare potential impacts of Power Sales

Contract alternatives which were analyzed with the Systems Analys is Model (SAM) on recreation at Federal storage reservoirs, a method of converting SAM output (reservoir elevations) to recreation impact was needed. A method was developed for the Intertie Development and Use Environmental 
Impact Statement which was used for this EIS This method was based on avaliable data relating recreation sites to reservolr elevations for the reservolrs studied. In general, this relationship was based on boat ramp elevations. In the cases of Libby and Dworshak, avallable information on recreation use as it relates to reservolr elevation was used.

Because of the relatively small differences in the recreation indices observed among the alternatives with expected loads and gas prices, the reacreation indices were not computed for the other (sensitivity) assumptions regarding size of Northwest and Southwest loads and gas prices. If there is interest in seeing recreation indices computed for other sensitivity assumptions, we wlll provide this data upon request.

Grand Coulee --

In order to compare alternatives, elevation data were converted to an overall 'recreation index' for each alternative. This was generally based upon the elevations required to utllize boat ramps and marlinas. For each SAM simulation, one point was given for each usable boat ramp or marina, The points were then totalled for all 200 slmulations for each alternative to provide a 'recreation index'. Recreation indices were developed for the alternatives studied with SAM using end-of-perlod elevations for May, June, July, August 15 and August 31.

The following facilities were given one point for being avallable (a reservolr elevation greater than or equal to the stated elevation).

Facility

Evans

Bradbury Beach

Daisy

Fort Spokane Marina

North Gorge

Jone? Bay

China Bend

Marcus I sland

Hawk Creek

Seven Bays

Gifford

Fort Spokane Campground

Porcupine Bay

Kettle Falls Campground

Kettle Falls Martna

Spring Canyon

Hunters

Enterprise

Keller Ferry
Elevation (feet)

1287

1285

1285

1283

1282

1282

1282

1281

1277

1262

1249

1247

1238

1237

1235

1234

1233

1233

1229 
Hungry Horse --

Recreation indlces were developed for each alternatlve in a manner similar to that descrlbed for Grand Coulee. One point was given for each avallable boat ramp and totals for 200 simulations were computed for each alternative.

The following facllities were glven one polnt for being avallable (a reservolr elevation greater than or equal to the stated elevation).

$$
\text { Facllity Elevation (feet) }
$$

$\begin{array}{ll}\text { Ben Creek } & 3560 \\ \text { Emmery Bay } & 3558 \\ \text { Murray Bay } & 3558 \\ \text { Don's Polnt } & 3552 \\ \text { Dorls Creek } & 3547 \\ \text { Graves Creek } & 3545 \\ \text { Lost Johnny Campground } & 3536 \\ \text { Lost Johnny Polnt Campground } & 3532 \\ \text { Devil's Corkscrew } & 3516 \\ \text { Riverside } & 3506 \\ \text { Abbot Bay } & 3473\end{array}$

Dworshak -.

Impact indices were developed for Dworshak in a sightly different manner than for Grand Coulee and Hungry Horse. Drawdown Impacts at Dwor shak reservolr have been assessed in 5-foot increllients by the U.S. Army Corps of Englneers (COE) (unpublished). The COE figures on the effects of reservolr elevation on overall recreation visitation were used in developing the recreation indices. The estimated visitation for each model simulation was summed for all 200 simulations for each alternative.

The values used, adapted from the COE data, are as follows:

$\begin{array}{lc}\text { Elevation } & \begin{array}{c}\text { Visttation } \\ \text { (percent of full } \\ \text { pool usage) }\end{array} \\ \text { Greater than } 1595 & 100 \\ \text { LE } 1595 \text { and GT } 1590 & 90 \\ \text { LE } 1590 \text { and GT } 1585 & 80 \\ \text { LE } 1585 \text { and GT } 1580 & 70 \\ \text { LE } 1580 \text { and GT } 1575 & 60 \\ \text { LE } 1575 \text { and GT } 1565 & 50 \\ \text { LE } 1565 & \end{array}$

Libby --

Impact indices for Libby were developed in a manner slimllar to those for Dworshak. Drawdown impacts at Libby have been assessed by the COE (COE. 1985). Values for recreation use at varlous reservolr elevations were 
adapted from that document and are glven below. (U.S. recreation facllitles only.)

\section{Elevation}

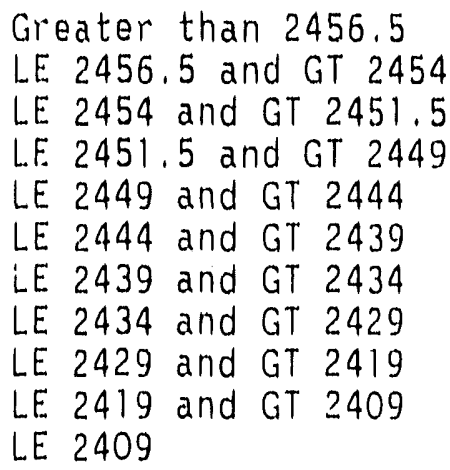

\author{
Recreation Use \\ (percent of full \\ pool usage)
}
100
99.3
96.2
92.9
88.1
82.4
75.6
73.8
71.7
69.0
67.3

The recreation Indices computed as described above are shown for Grand Coulee, Hungry Horse, Dworshak, and Libby in the following tables. 


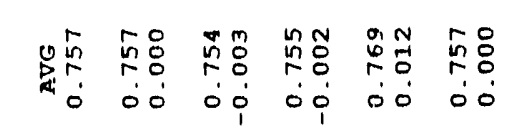

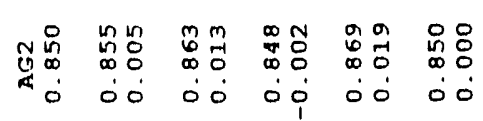

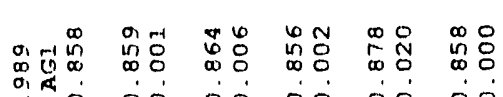

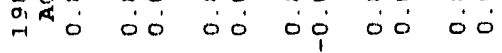

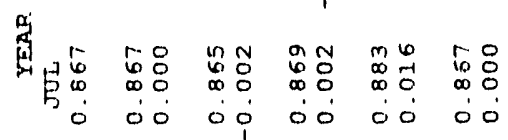

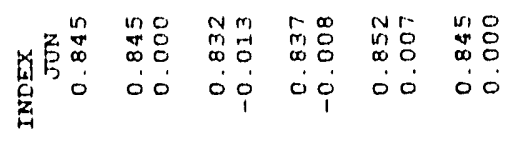

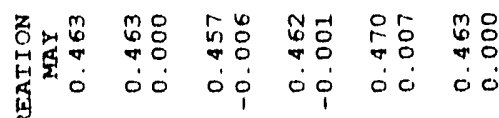$$
\text { है }
$$

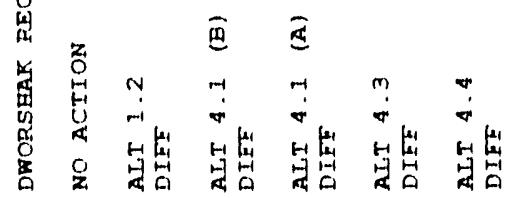

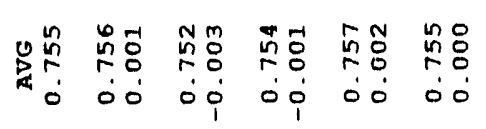

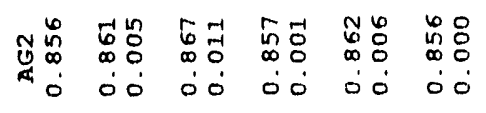

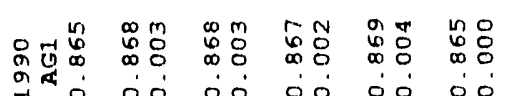

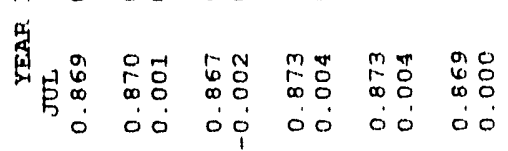

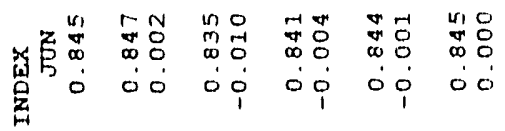

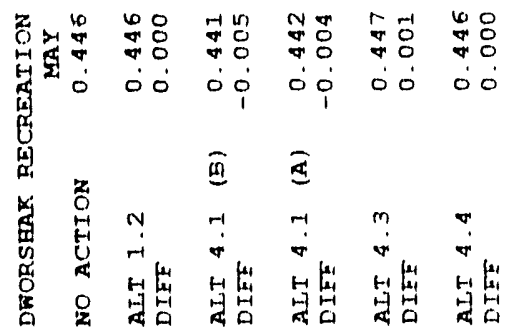

$$
11-r-b
$$




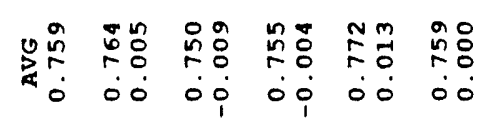

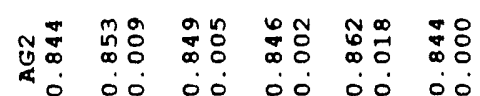

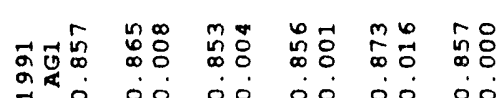

नी 00 ọ

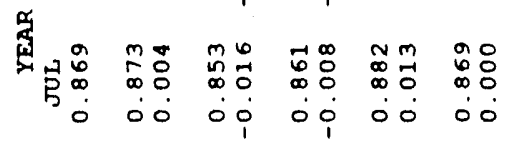

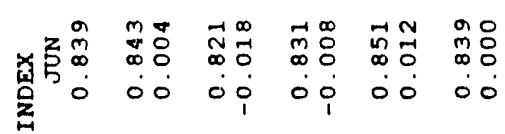

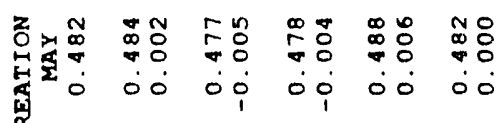

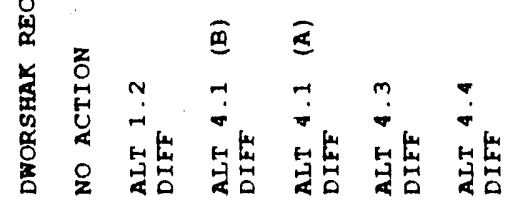

$\begin{array}{lllll}0 & 00 \\ 0 & 00 & 00 & 00 & 00 \\ 0 & 50 & 00\end{array}$

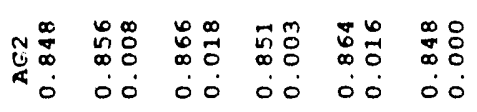

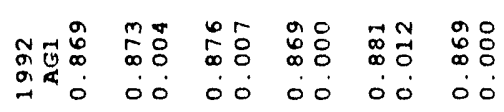

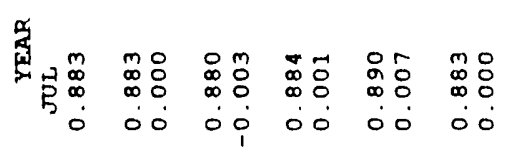

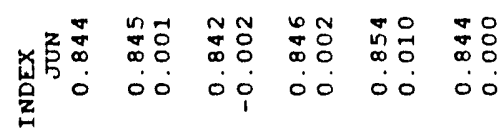

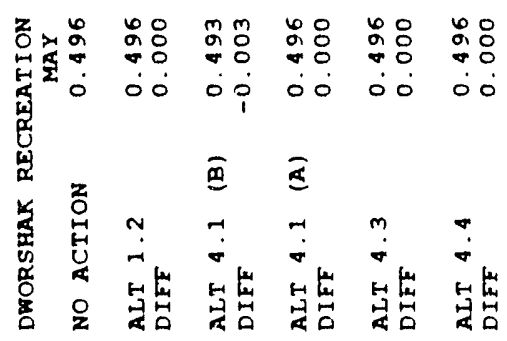




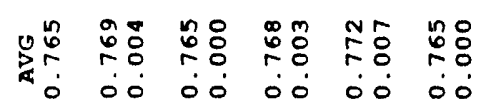

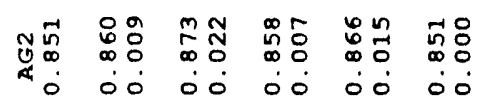

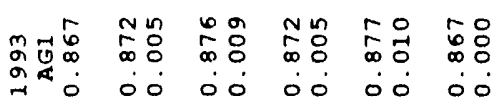

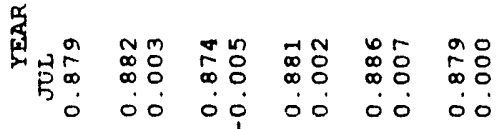

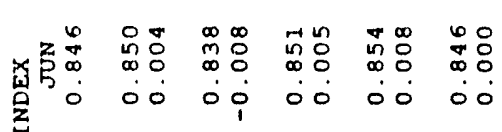

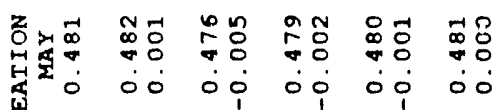

要

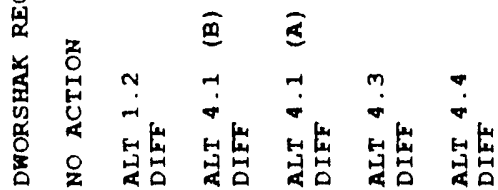

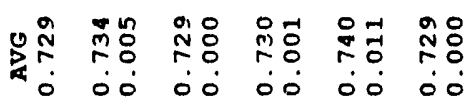

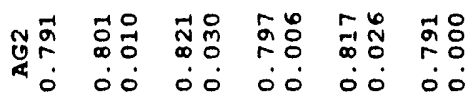

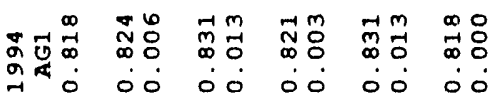

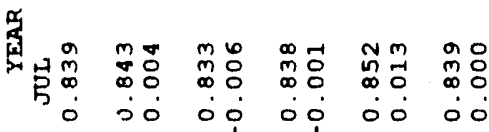

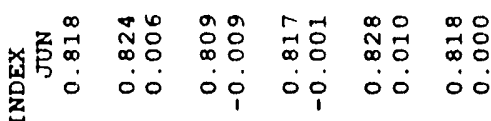

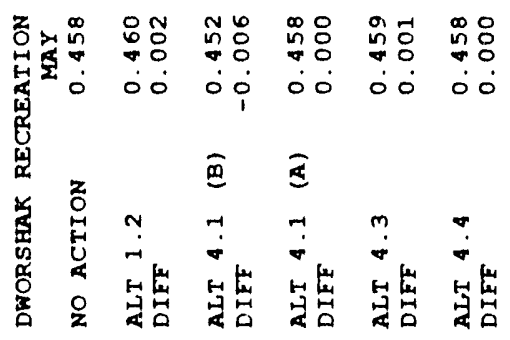



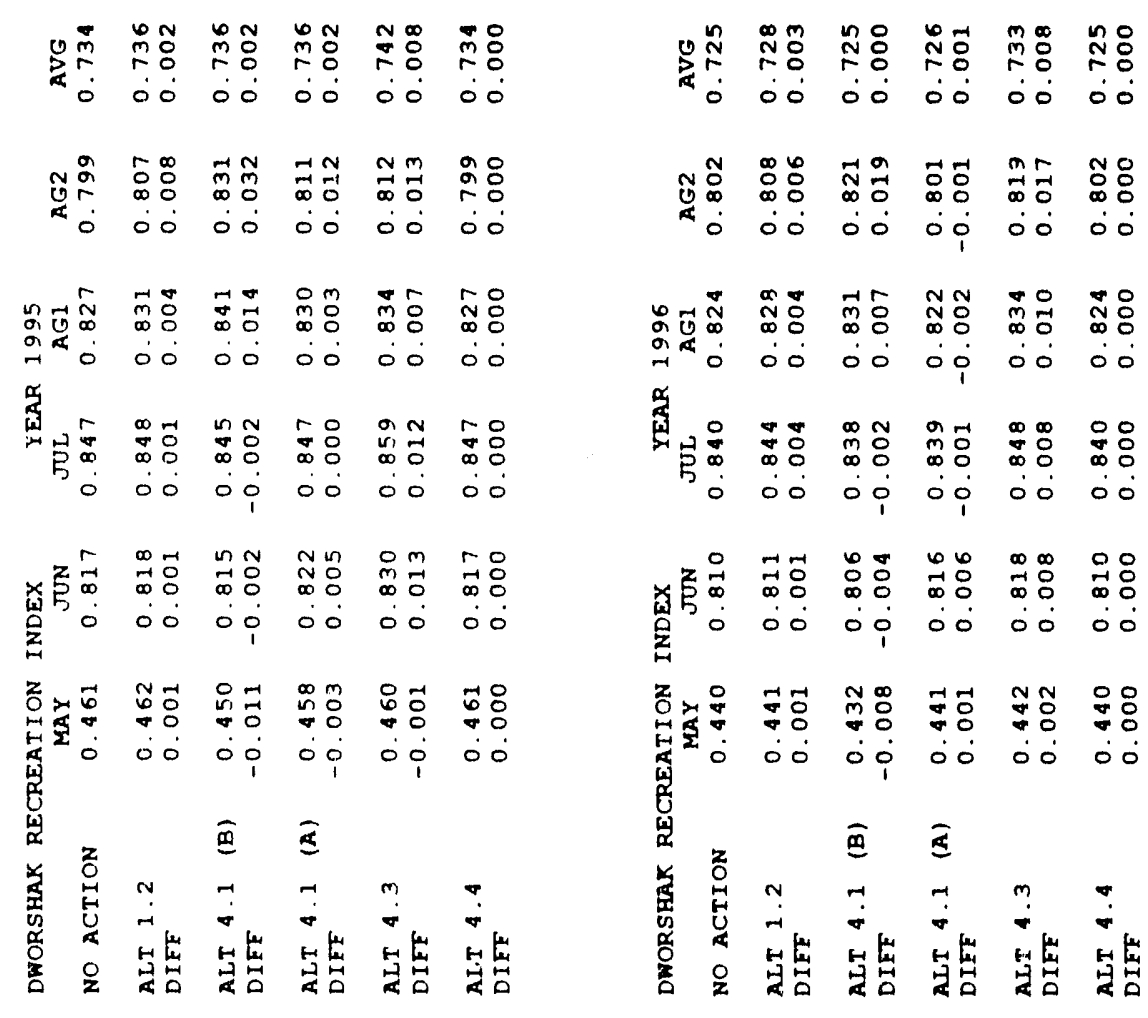

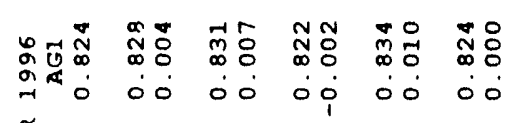

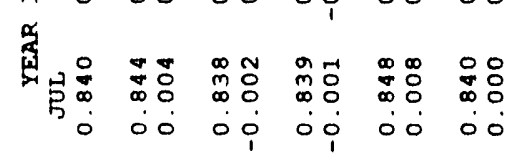

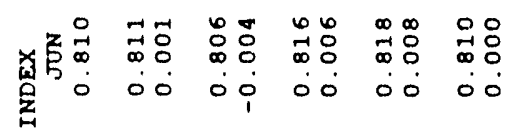

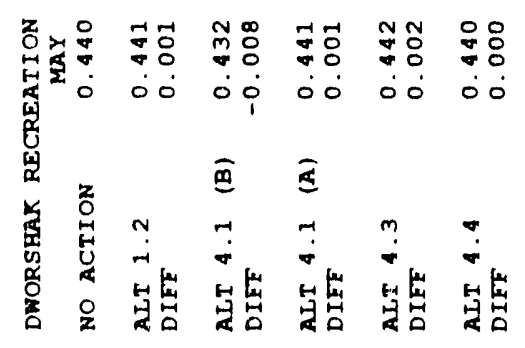

$$
H-2-8
$$




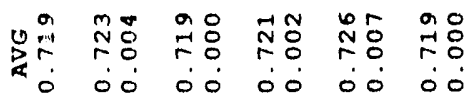

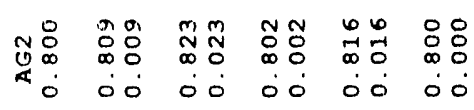

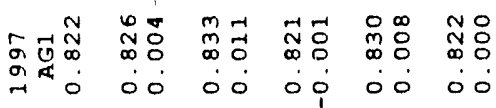

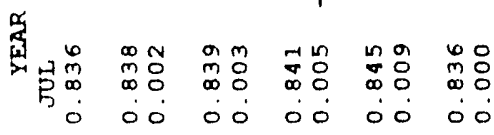

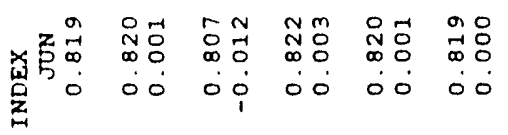

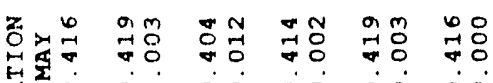
स⿺辶一

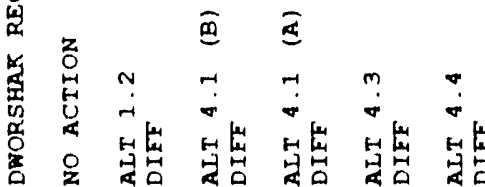

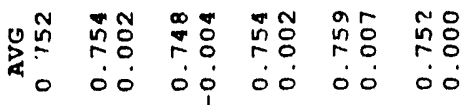

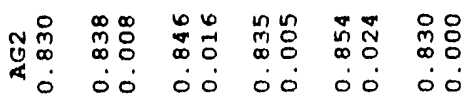

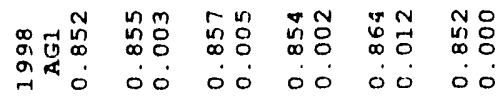

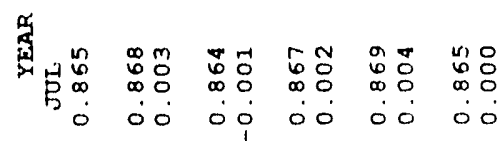

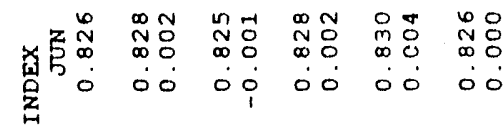

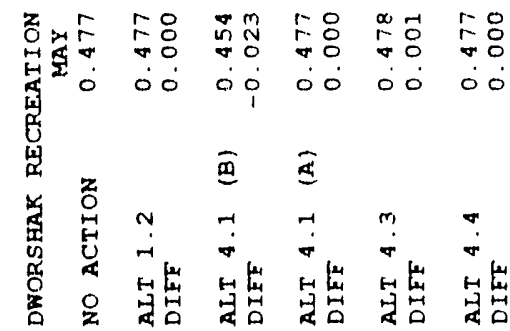




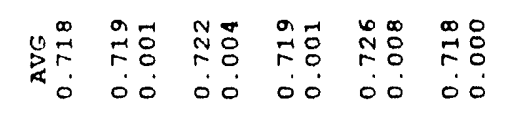

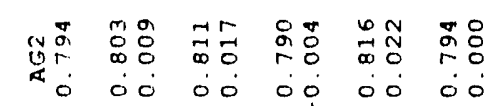

م.

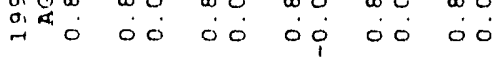

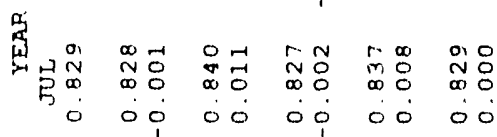

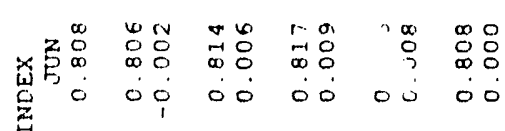

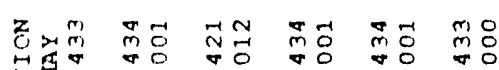

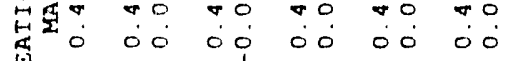
岂 出可画

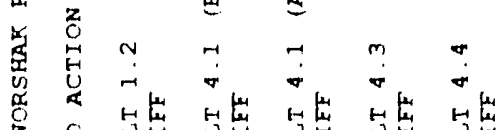

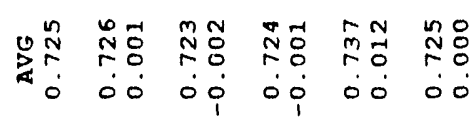

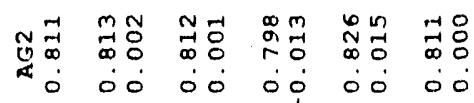

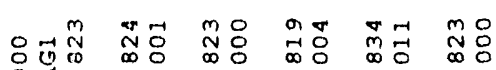

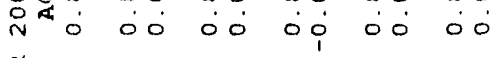

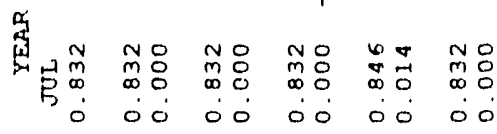

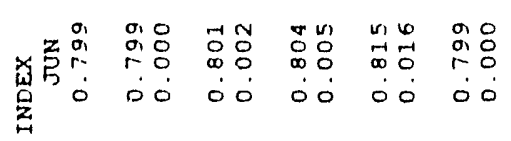

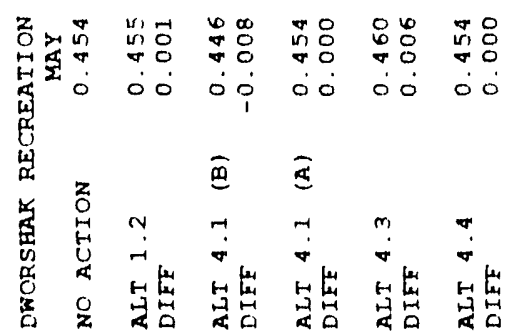




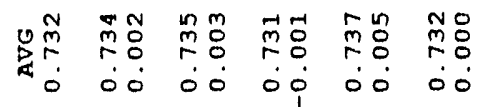

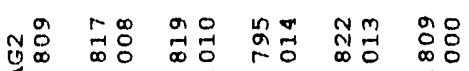

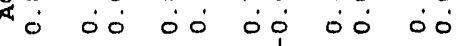

거에

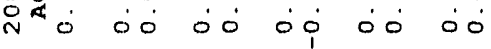

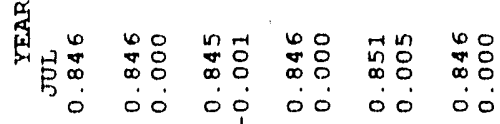

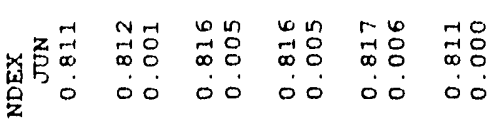

芩

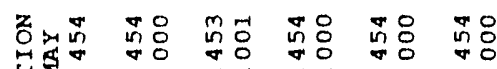

स्री

\&

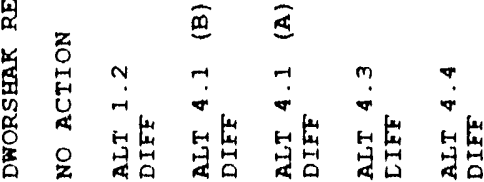

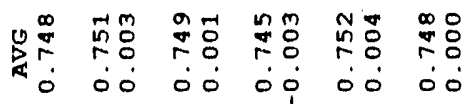

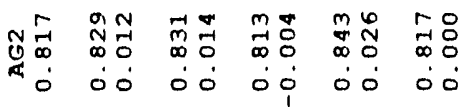

구에 त्र 00 ०0

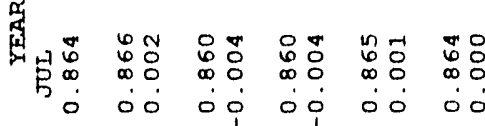

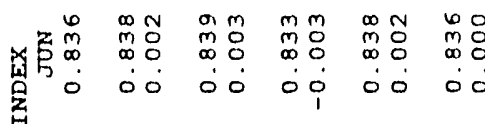

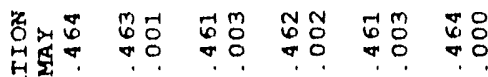

और

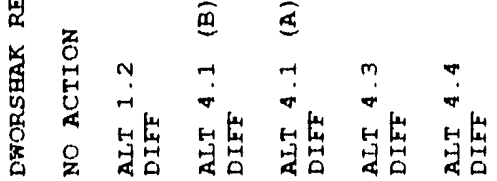




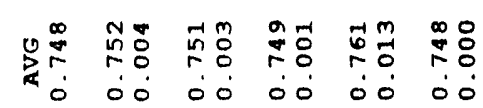

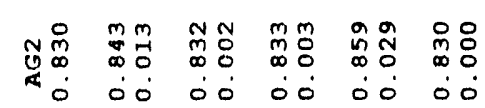

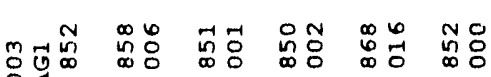

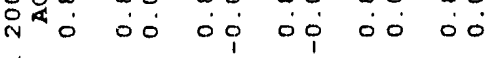

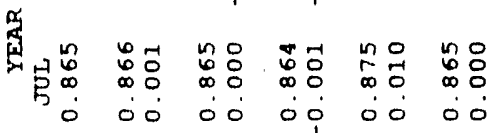

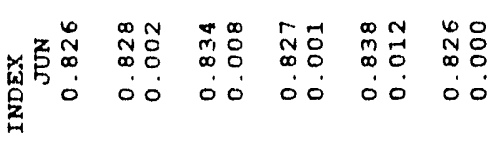

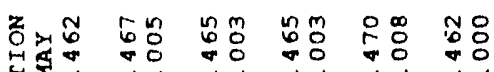

U⿺辶寸

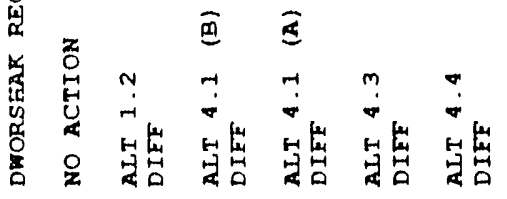

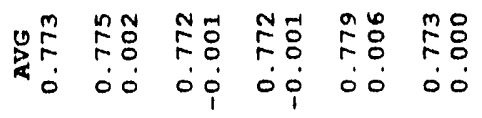

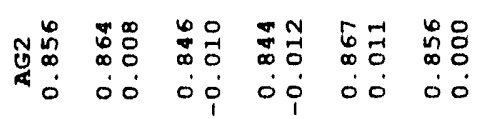

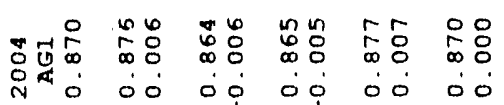

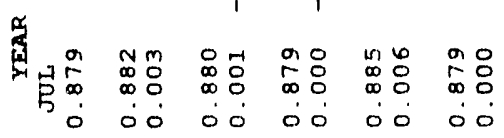

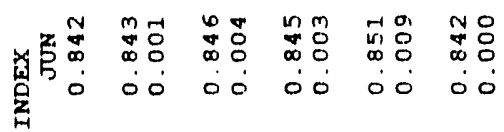

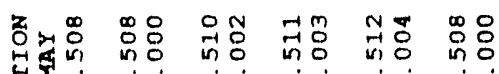

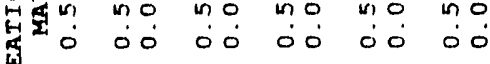

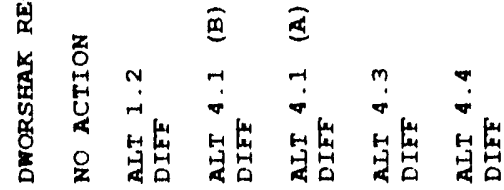




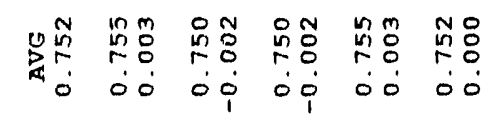

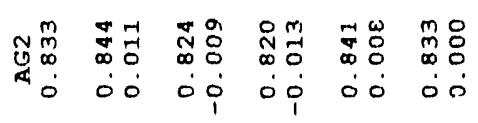

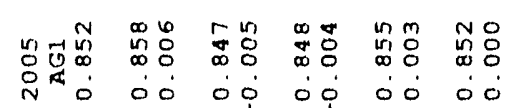

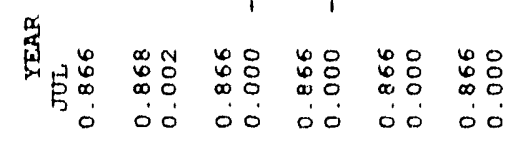

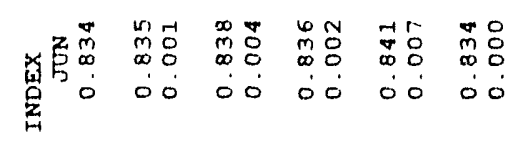

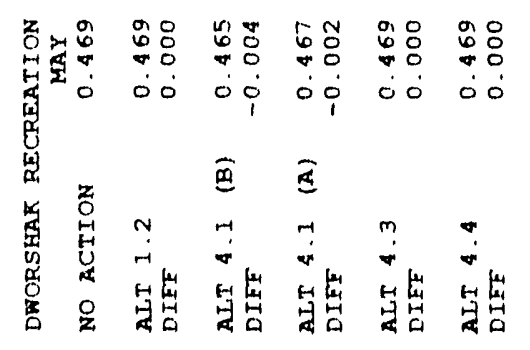

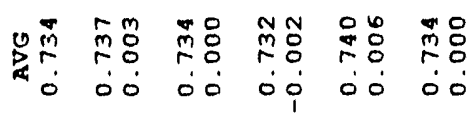

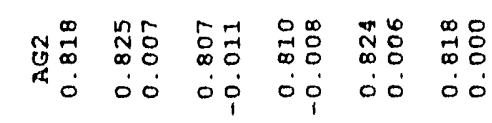

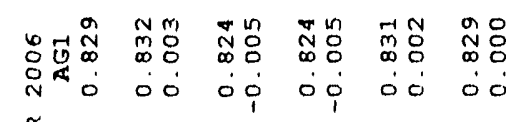

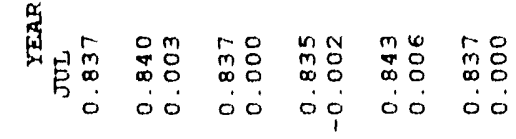

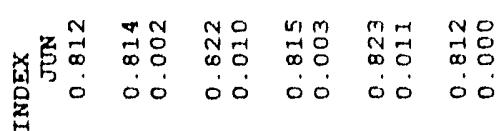

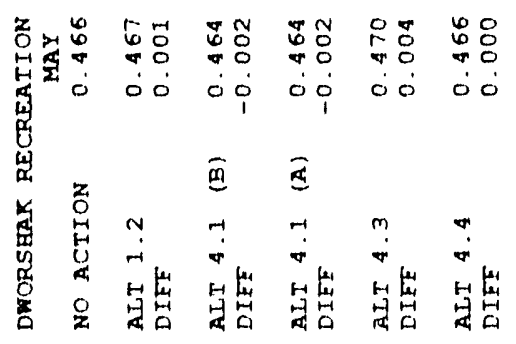




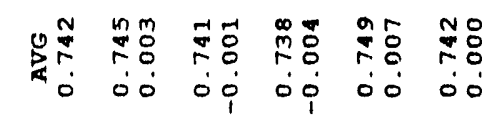

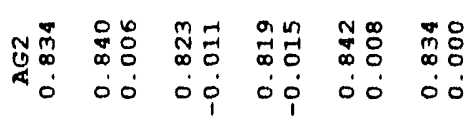

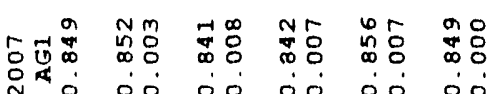

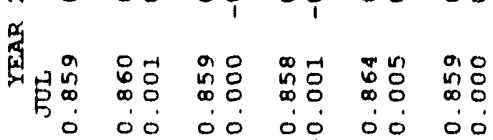

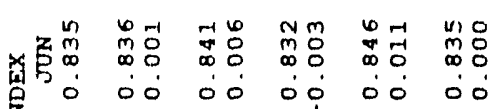$$
\text { H }
$$

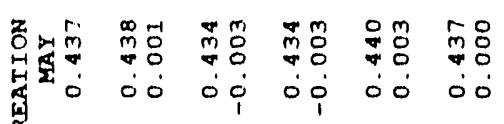

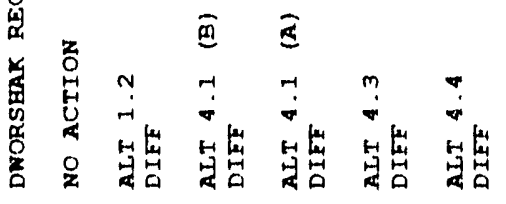

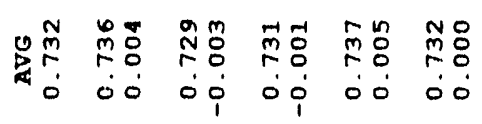

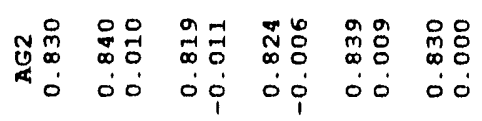

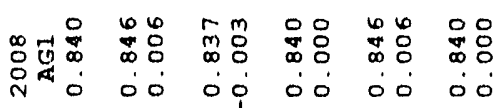

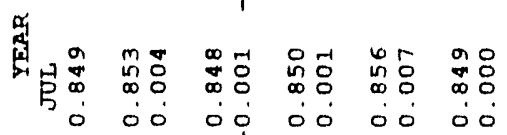

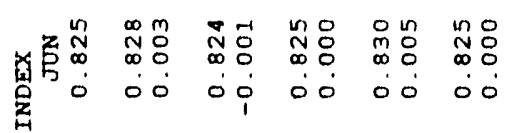

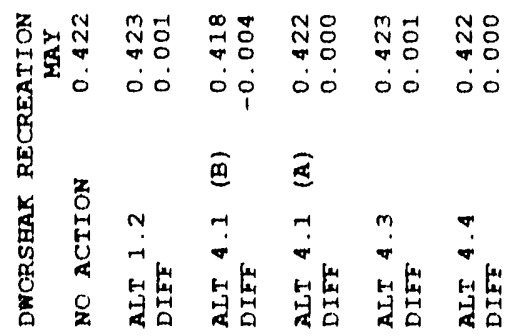


$N$
1
1
0
0
0
0

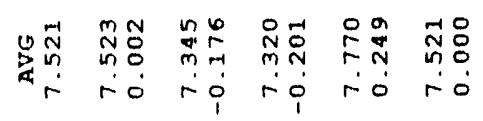

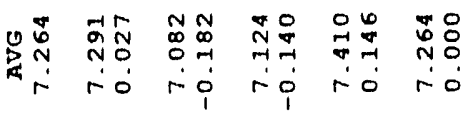

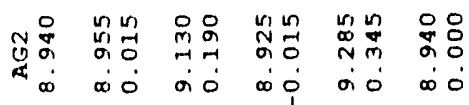

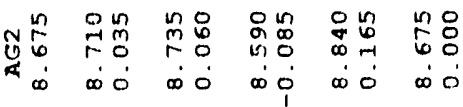

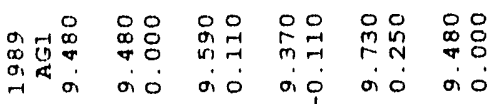

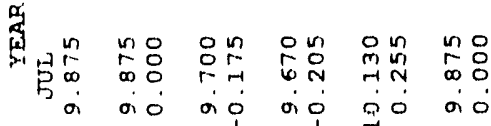

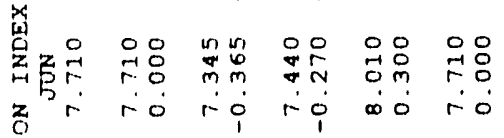

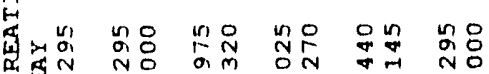

mi ni mo mo mo

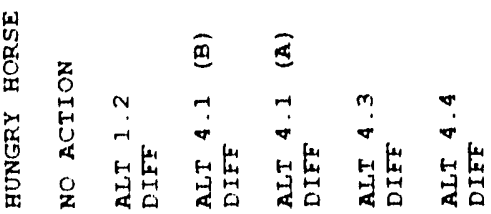

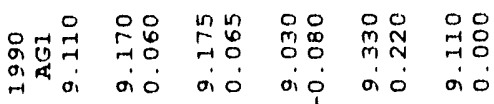

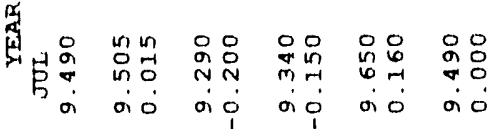

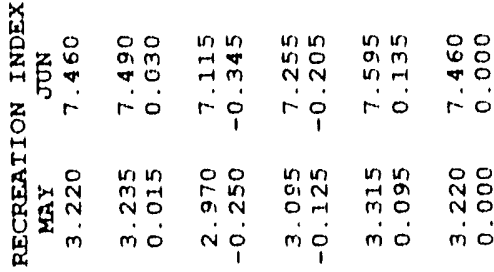

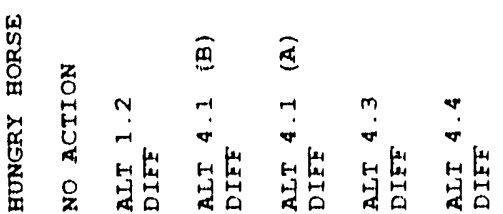




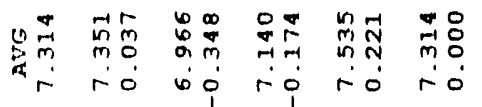

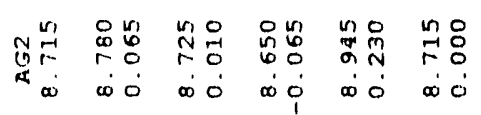

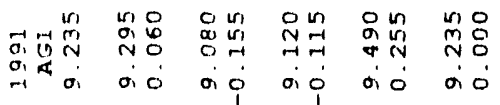

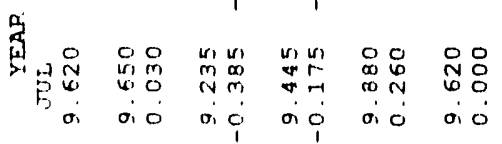

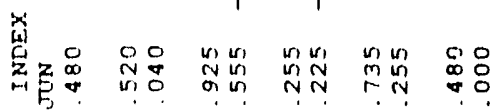
zir ro bi rio ro ro

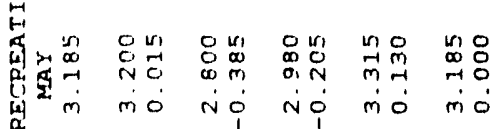

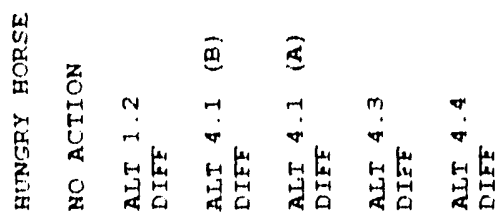

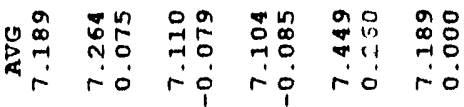

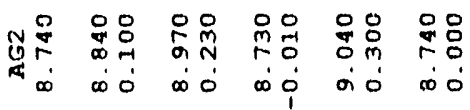

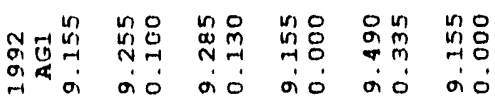

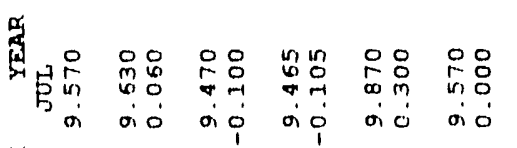
离离足 z r rio rióio rio

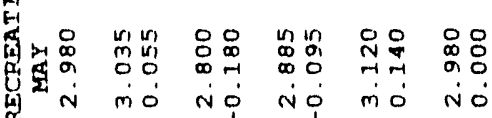

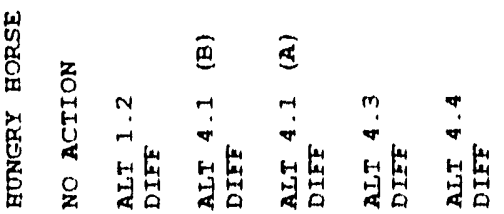




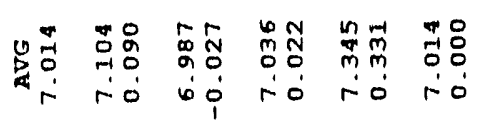

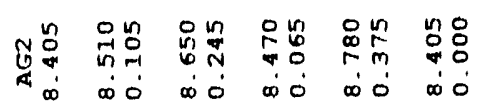

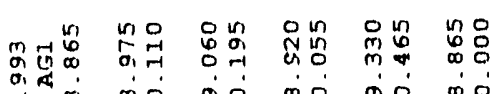

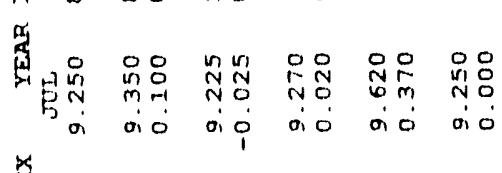

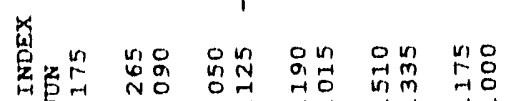

z $r$ ro rio ro ro

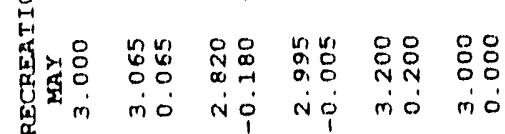

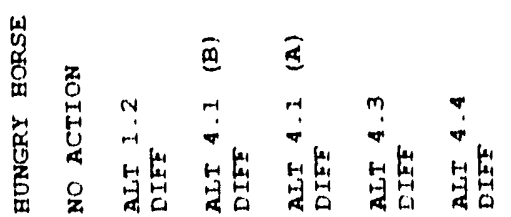

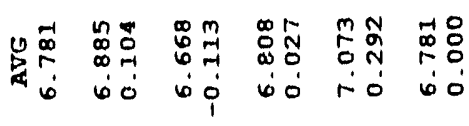

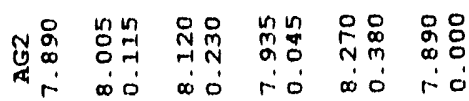

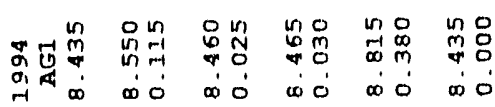

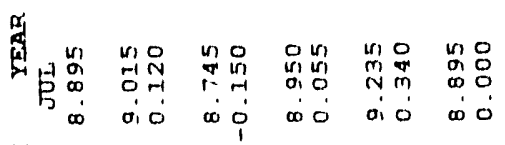

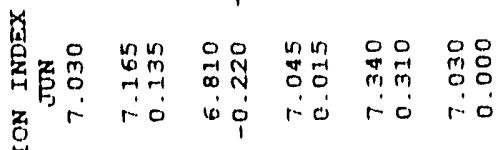

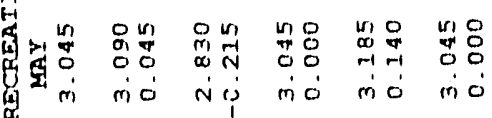

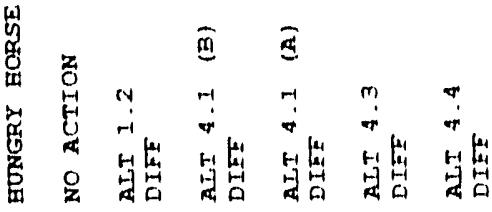




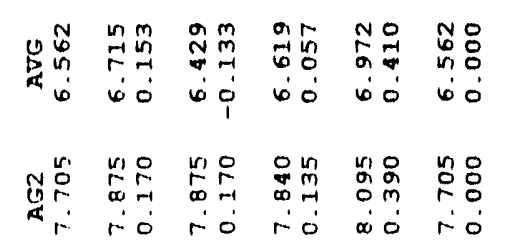

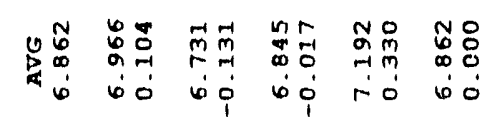

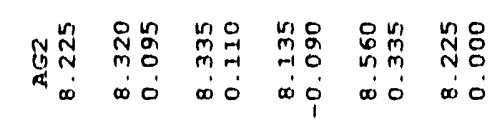

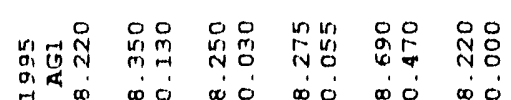

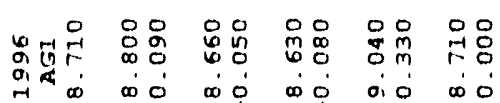
1
1

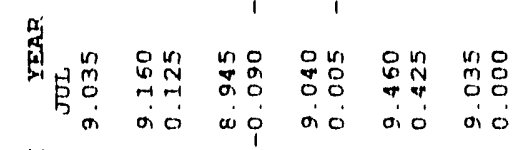

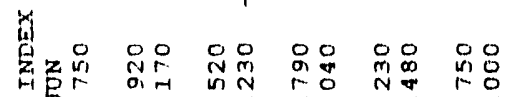
दु

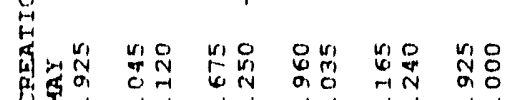
幦

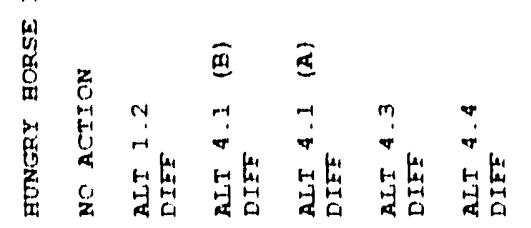

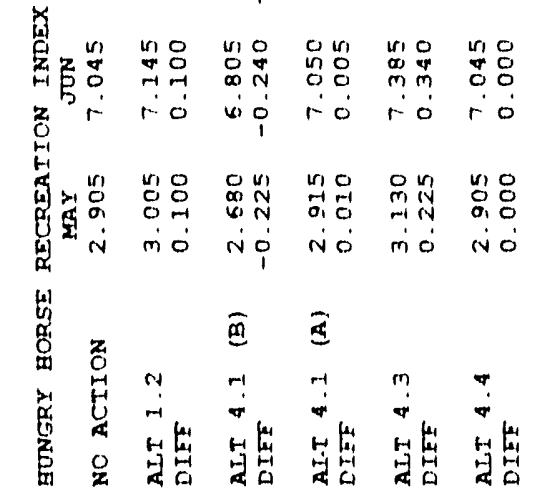




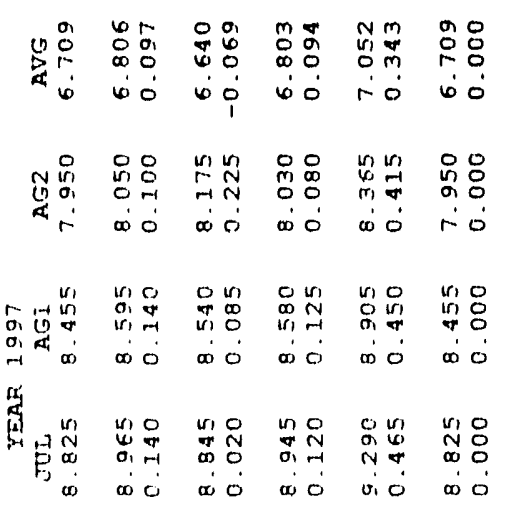

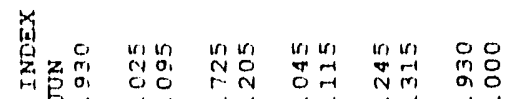

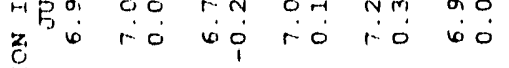

$c_{\substack{1 \\-1}}^{2}$

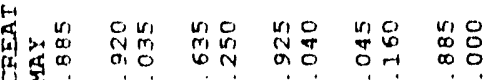

(a) ${ }_{a} N$ NO NO NO mi No

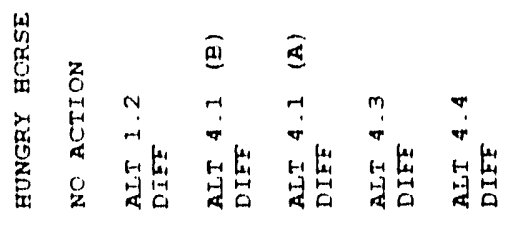

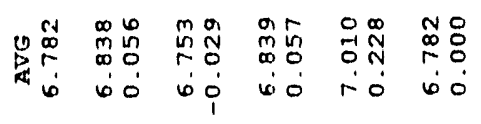

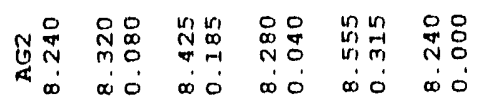

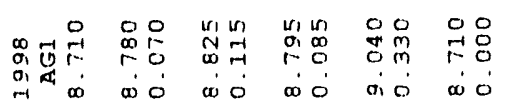

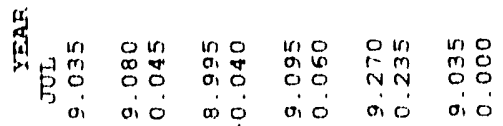

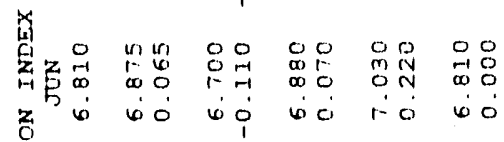

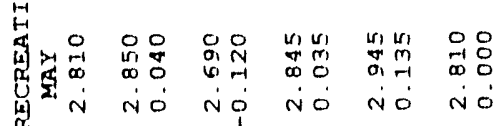

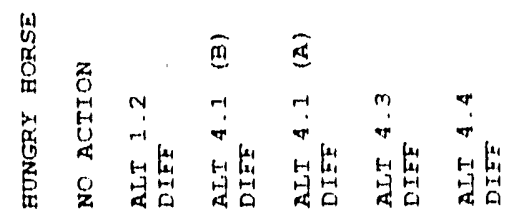




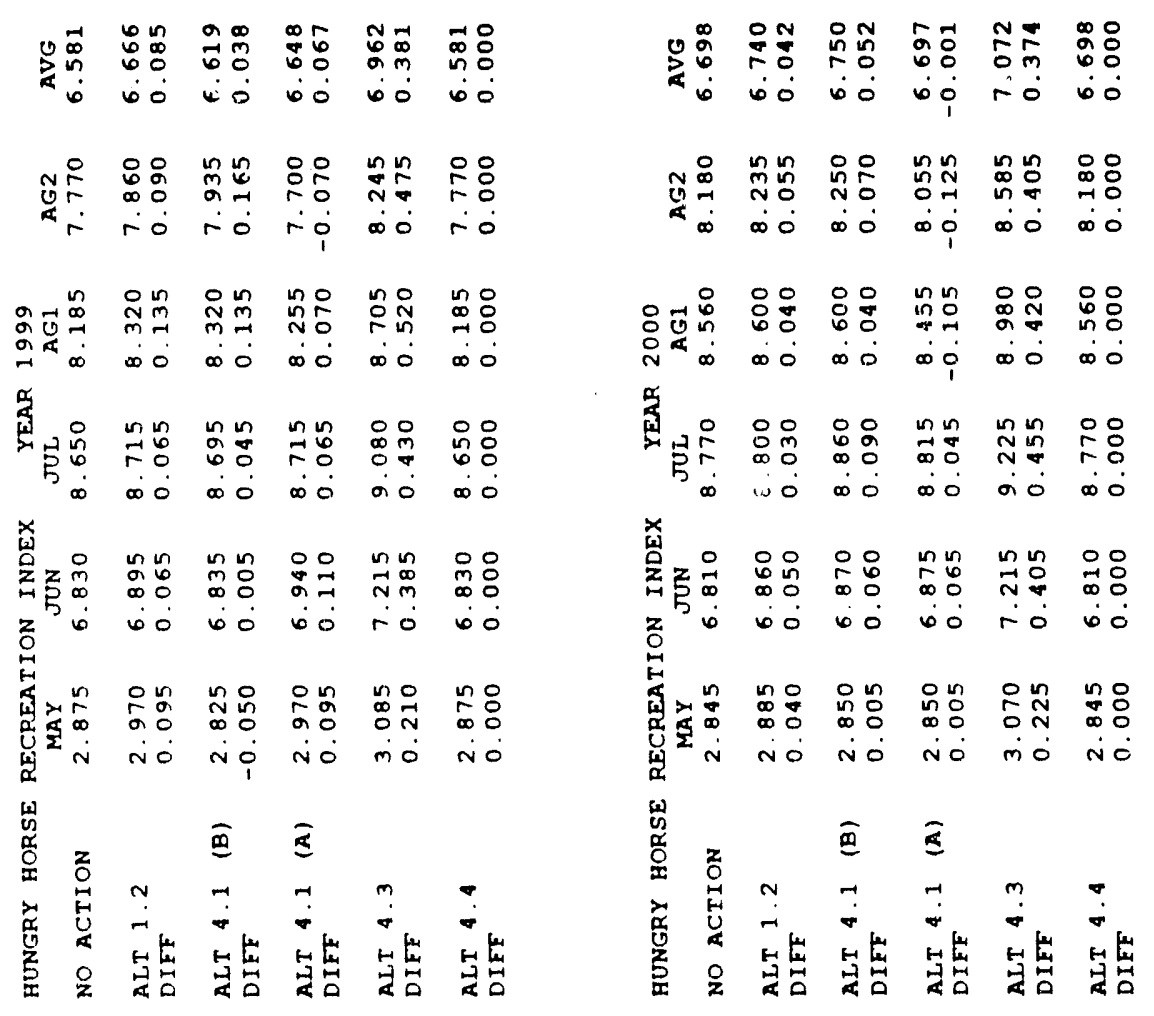




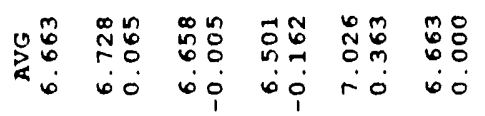

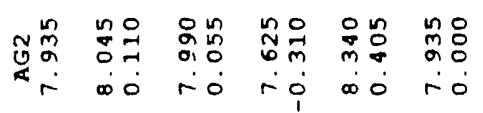

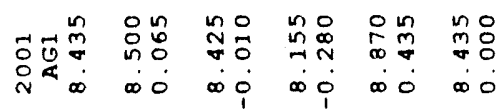

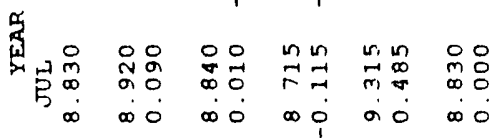

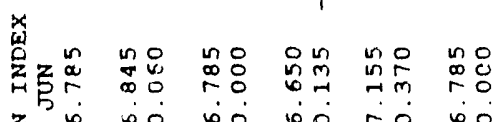

z bo bo மo r

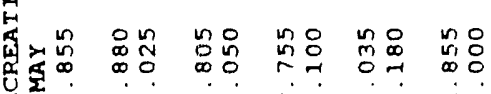

प्य No rio ni mo no

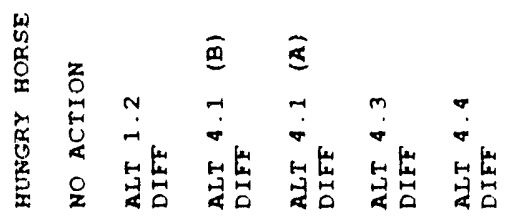

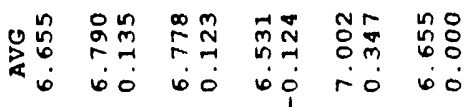

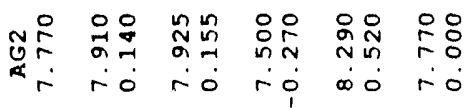

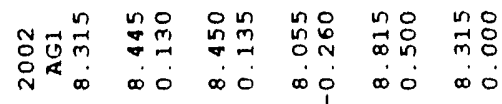

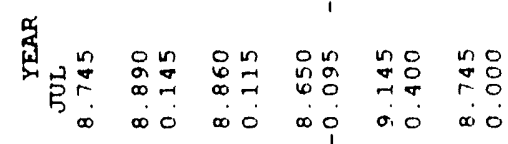

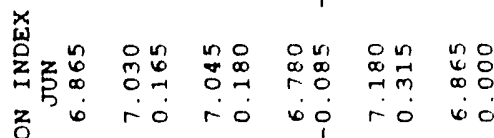

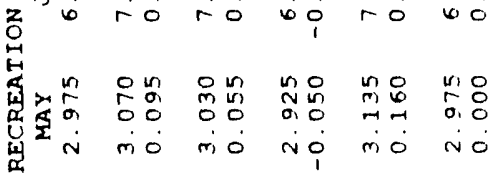

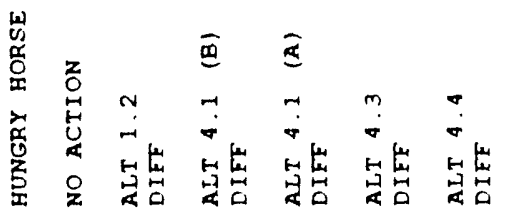




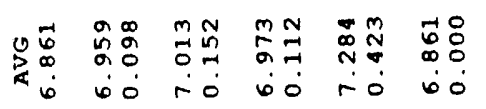

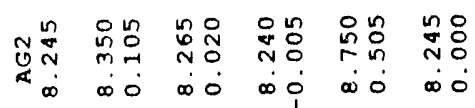

깅뮤

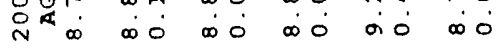

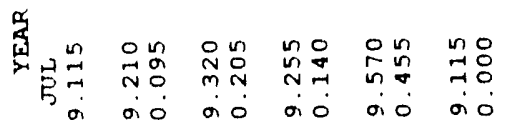

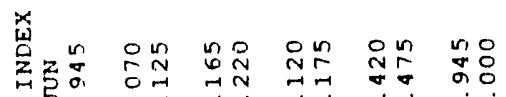

zo rio rio rio rio

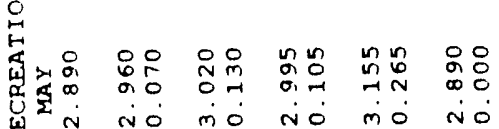

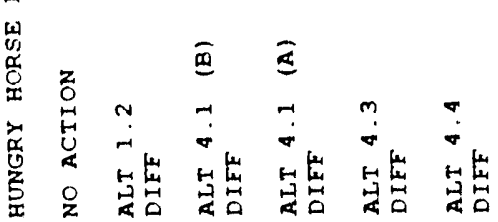

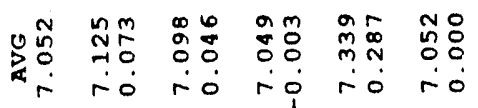

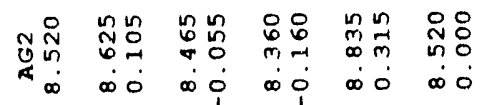

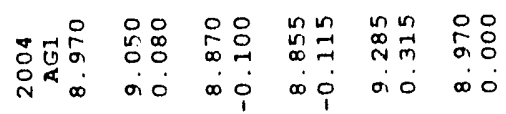

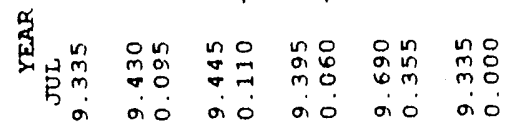

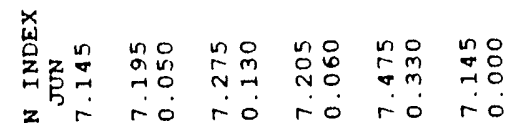

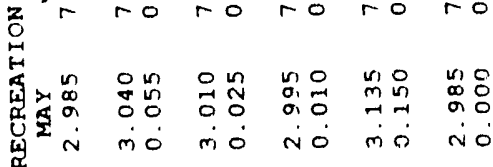

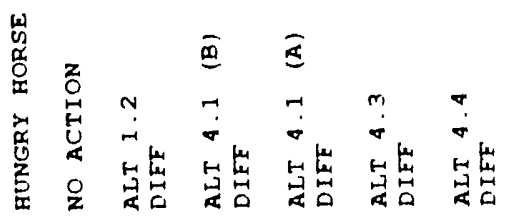




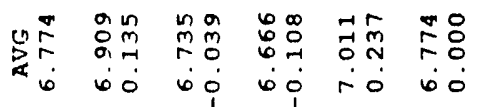

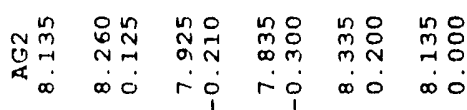

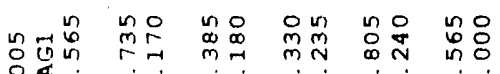

N $\infty 0^{\circ} \infty 0_{i} \infty 0^{\circ} \infty 0^{\circ}$

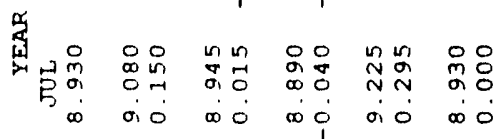

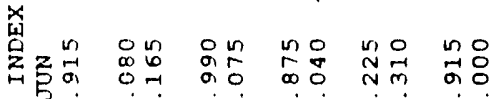

$z$ z r.

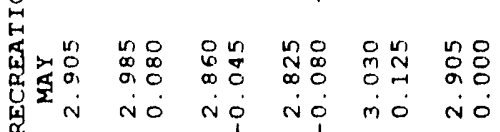

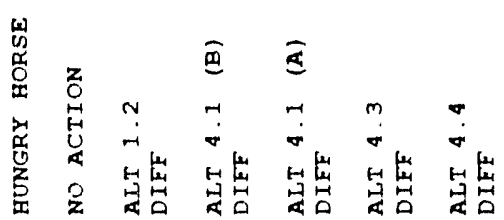

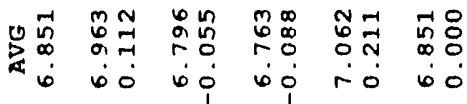

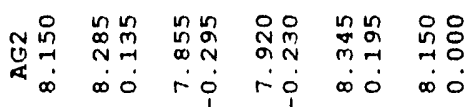

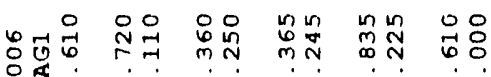

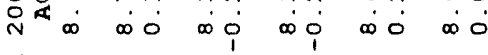

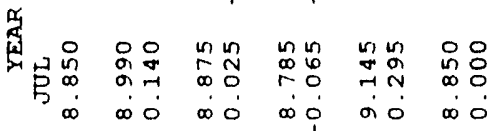

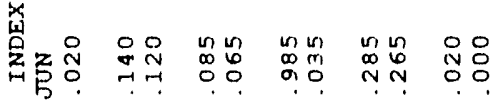

$z \dot{0}$ ro rio bo ro ro

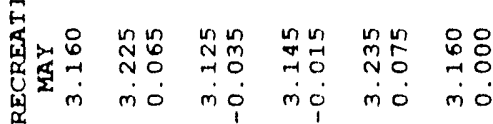

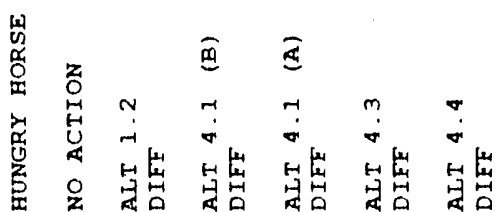




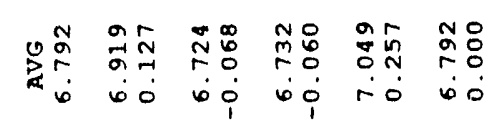

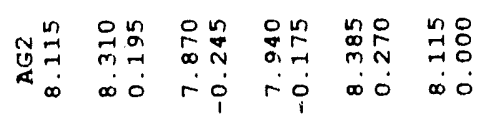

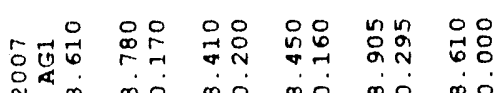

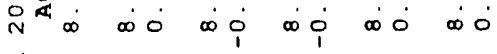

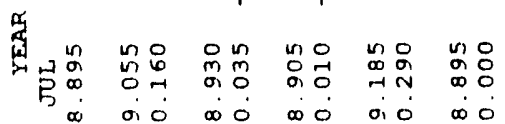

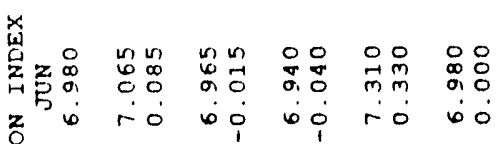

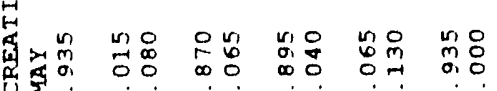

ज्ञ

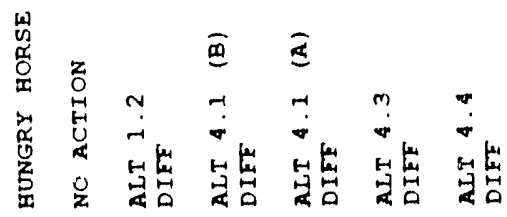

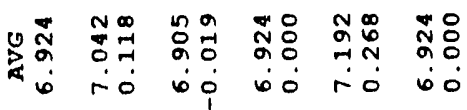

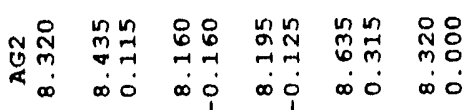

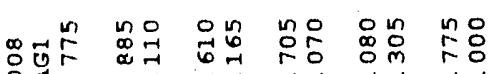
त्र

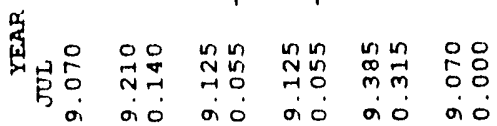

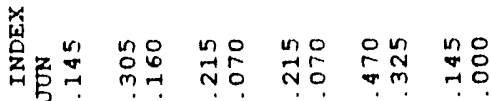
zr ro ro rí ro ro

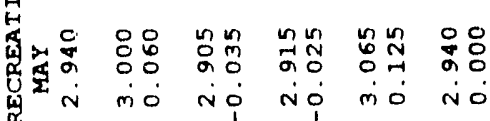

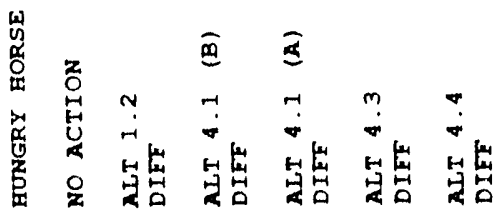




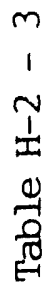

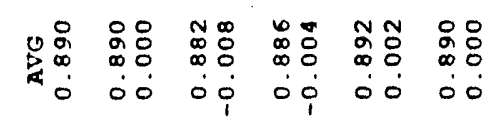

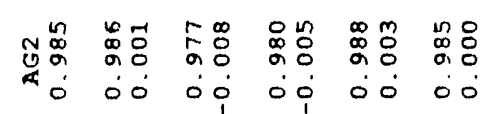

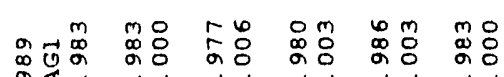



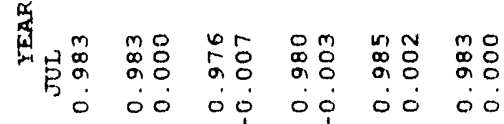

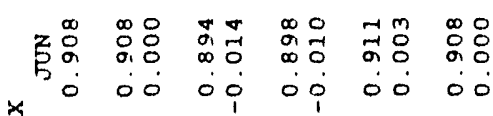

解

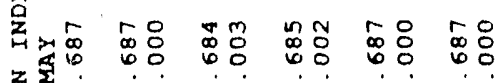

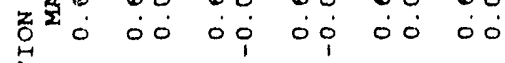$$
\text { 19. }
$$

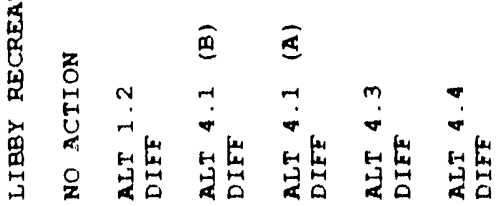

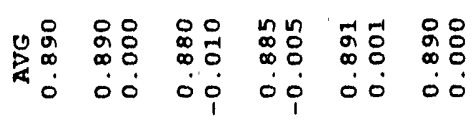

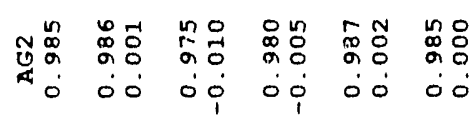

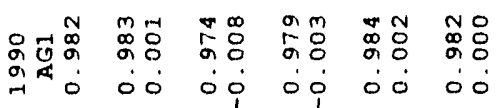

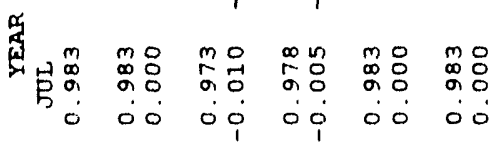

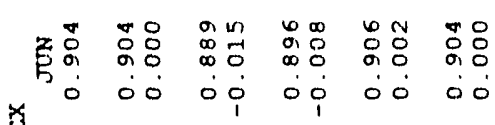

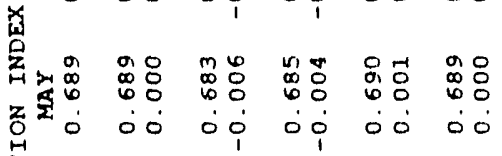

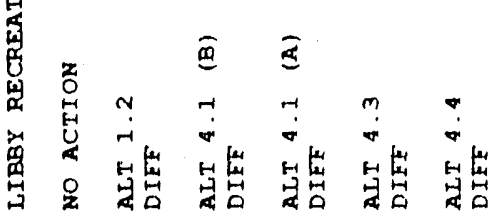




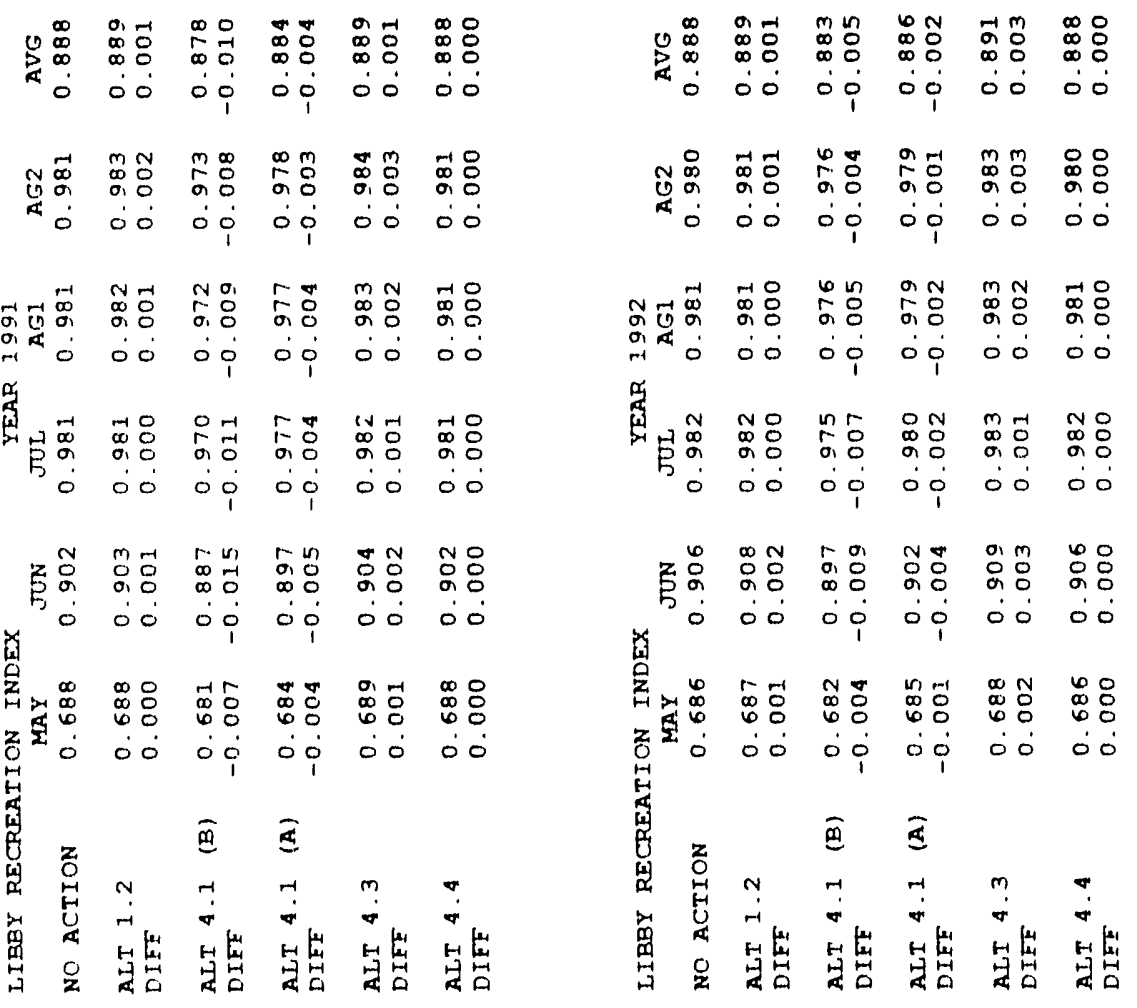




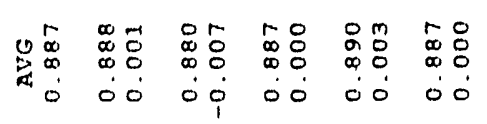

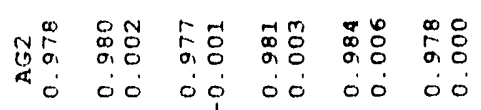

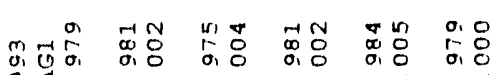

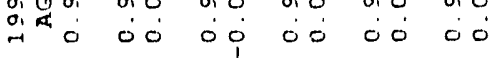

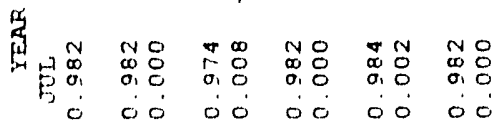

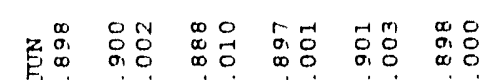

苗

o o jo op ó oo

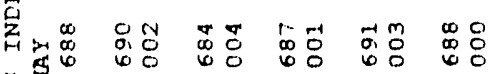

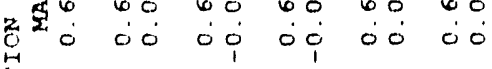

F

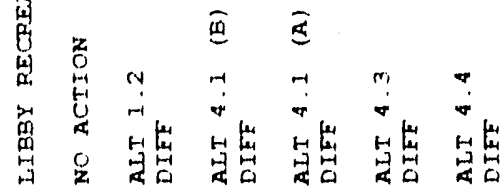

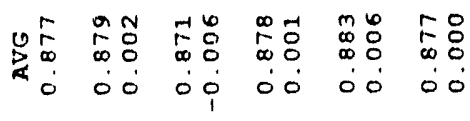

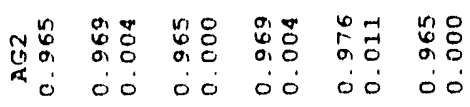

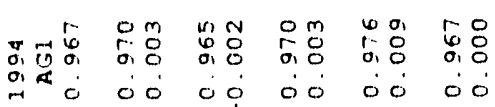

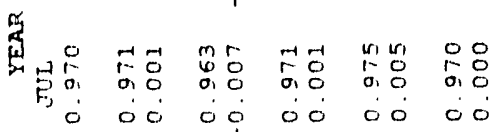

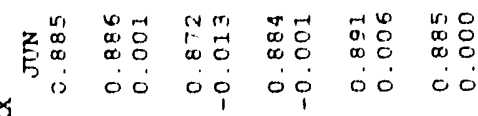

前

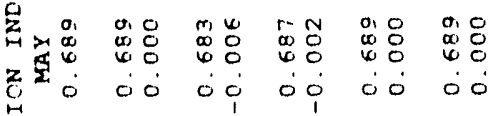

要

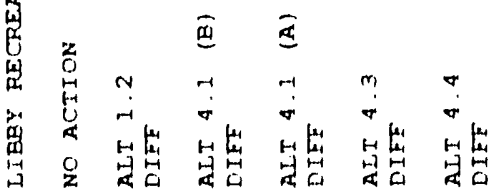




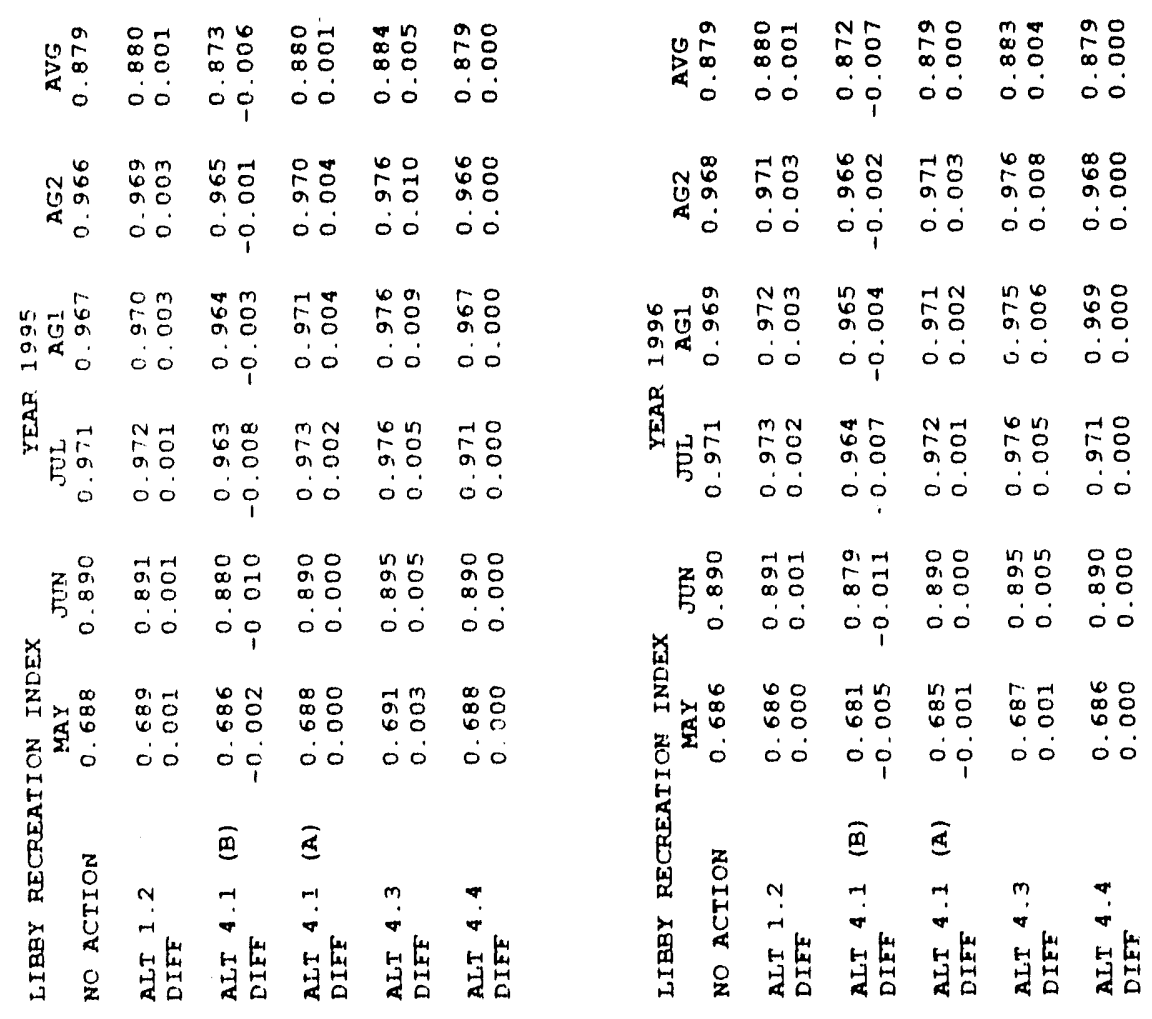




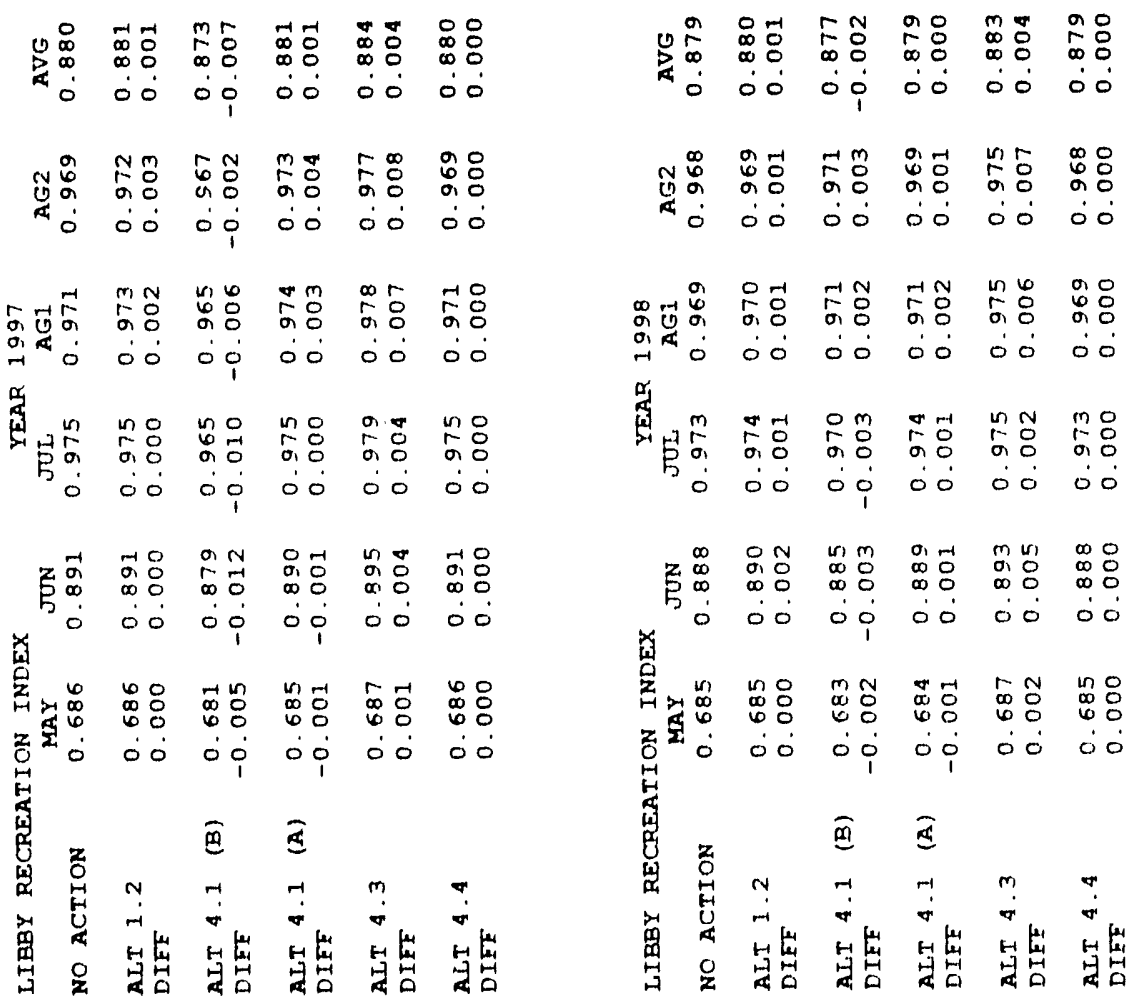




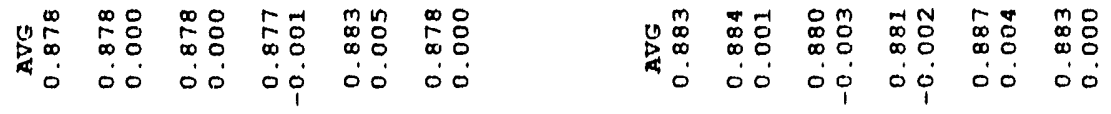

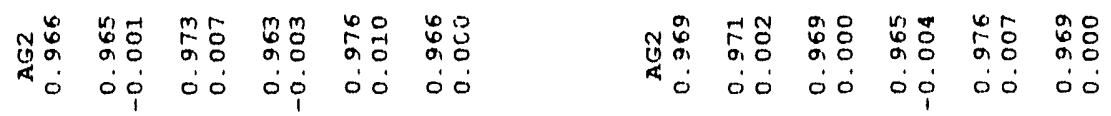

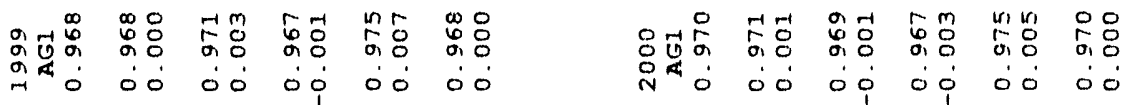

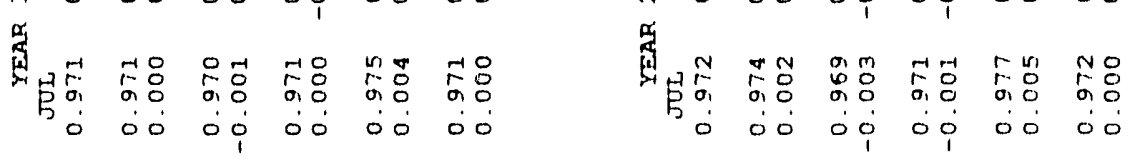

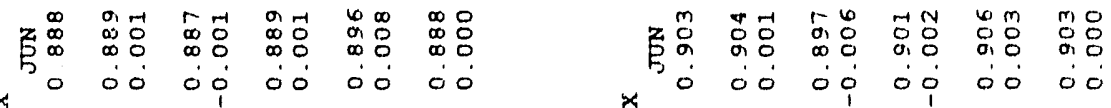

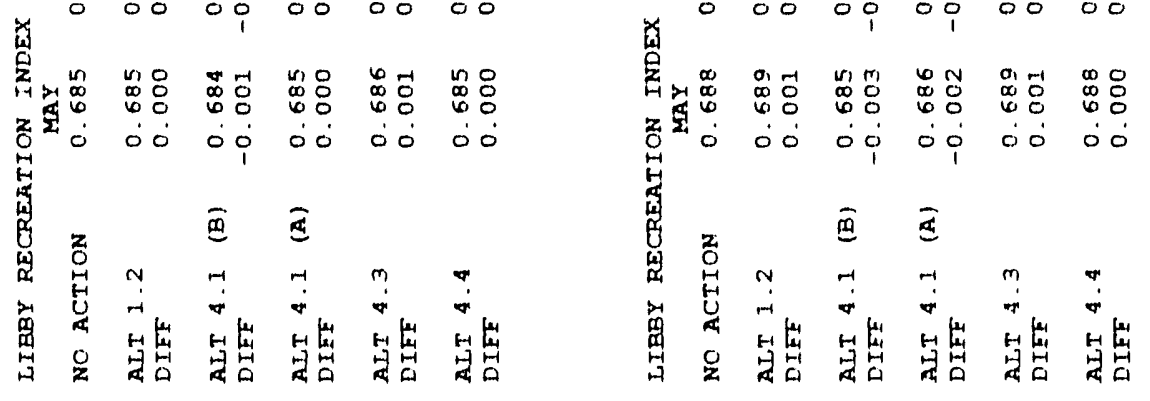




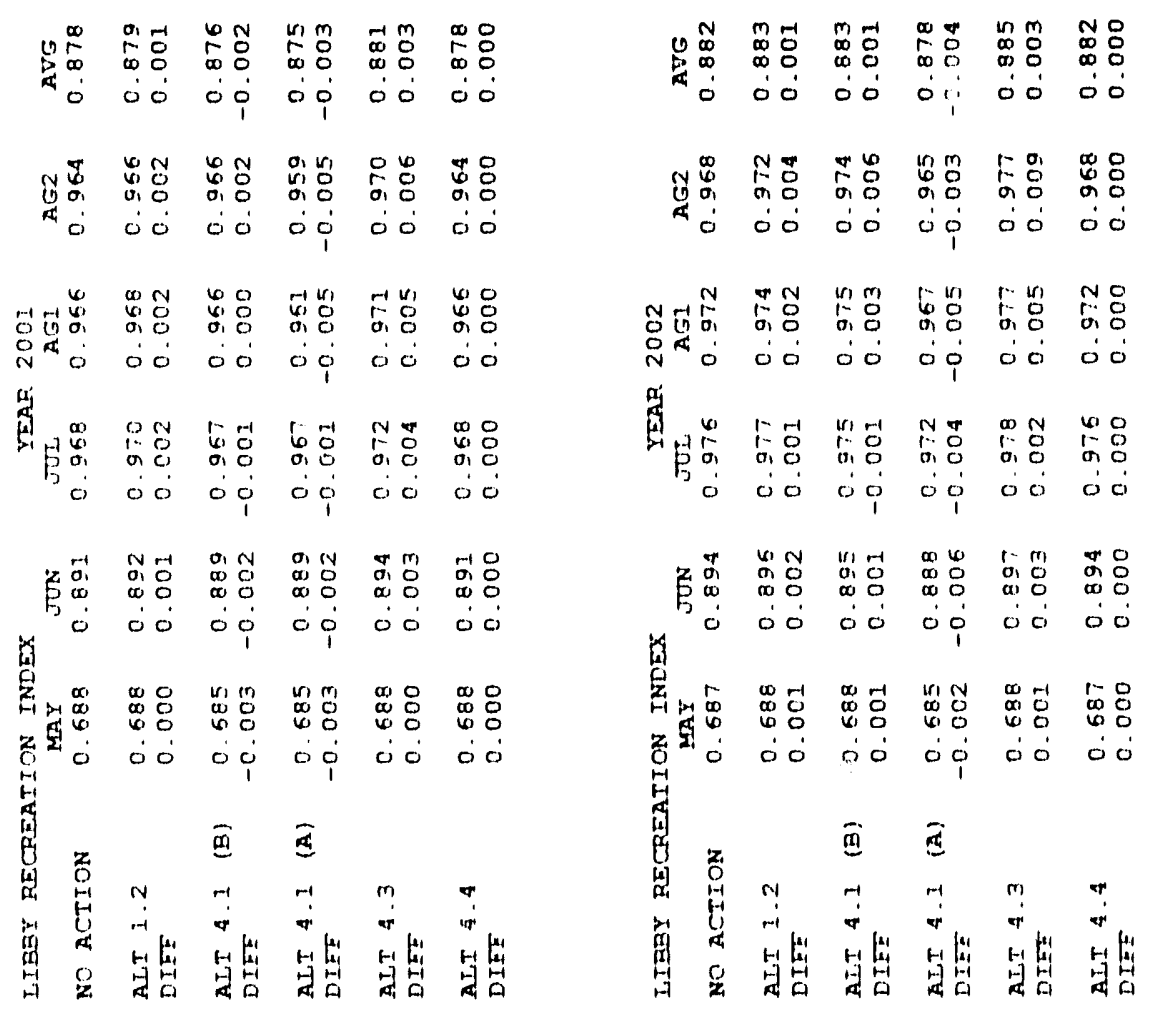




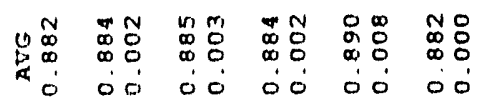

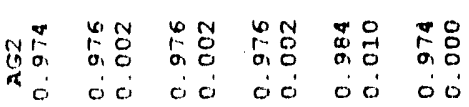

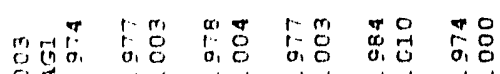

î ó ó cio cio

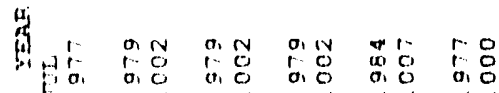

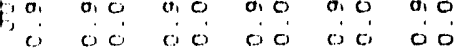

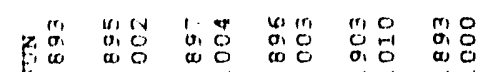

0 ó do do co ó

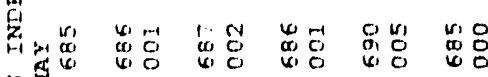

चु

(1)

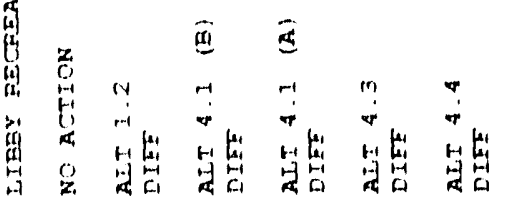

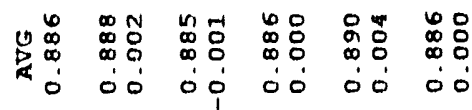

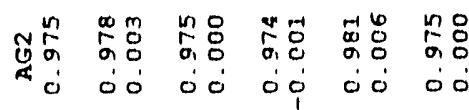

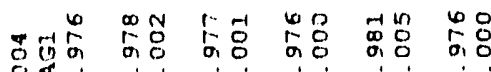

ट्र

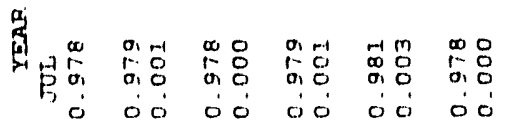

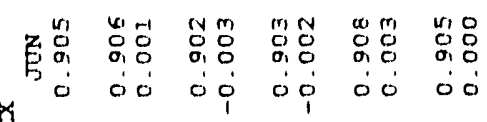

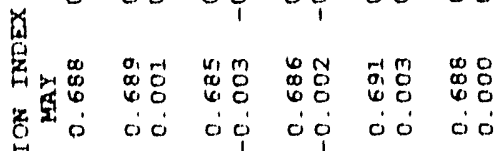

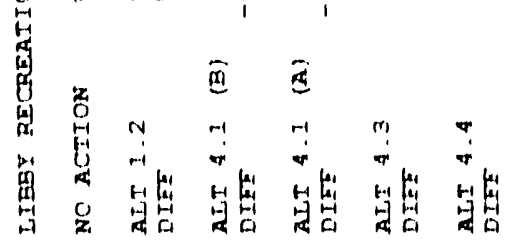




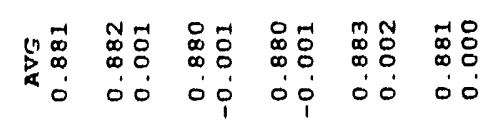

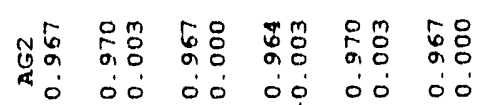

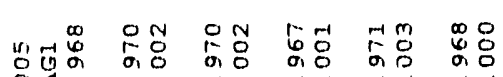

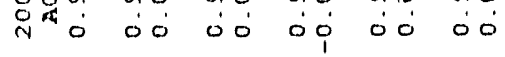

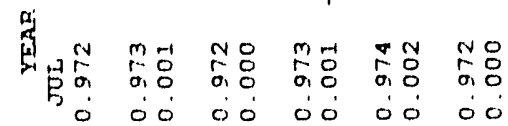

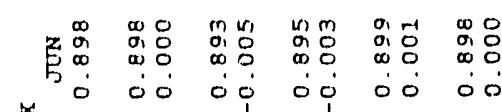

.

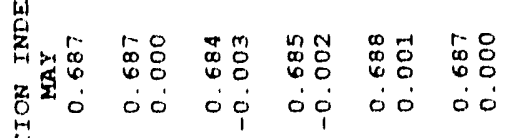

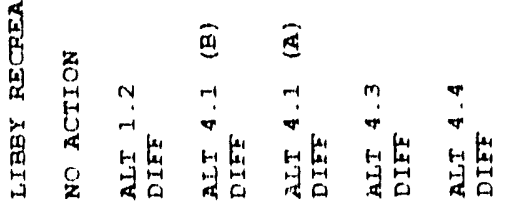

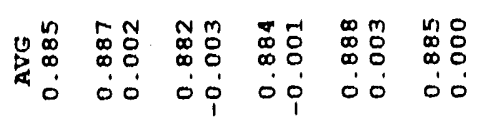

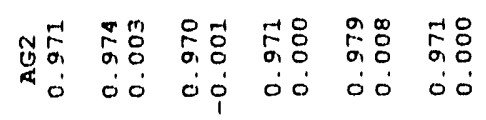

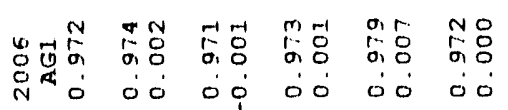

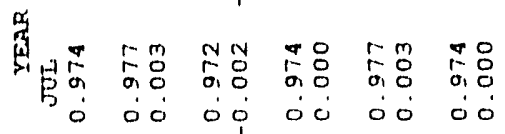

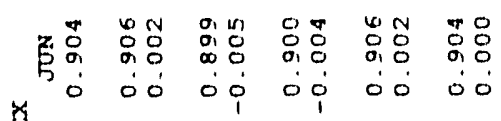

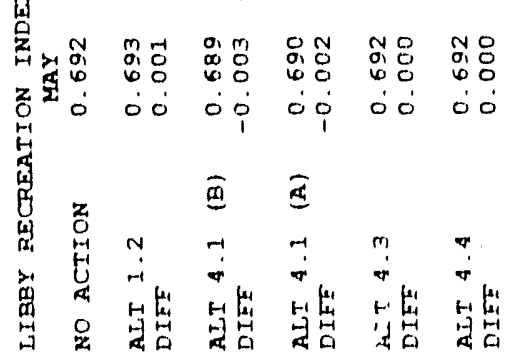




\begin{tabular}{|c|c|c|c|c|c|c|c|c|c|c|c|}
\hline 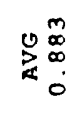 & 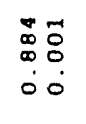 & $\begin{array}{c}1 \\
\infty \\
\infty \\
\infty \\
0 \\
0 \\
0 \\
1\end{array}$ & $\begin{array}{l}0: \overrightarrow{0} \\
\infty \\
\infty \\
0 \\
0 \\
1\end{array}$ & $\begin{array}{l}\text { 足 } \\
\infty \\
\infty \\
0 \\
0 \\
0 \\
0\end{array}$ & $\begin{array}{l}10 \\
\infty \\
\infty \\
0 \\
0 \\
0\end{array}$ & 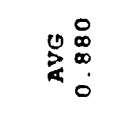 & 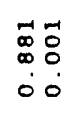 & $\begin{array}{l}0.0 \\
0 \\
\infty \\
0 \\
0 \\
0 \\
1\end{array}$ & $\begin{array}{l}00 \\
0 \\
0 \\
0 \\
0 \\
0 \\
1\end{array}$ & $\begin{array}{cc}m & m \\
\infty & 0 \\
\infty & 0 \\
0 & 0 \\
0 & 0 \\
0 & 0\end{array}$ & 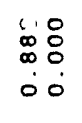 \\
\hline & $\begin{array}{l}\bar{T} \\
\hat{a} \\
0 \\
0 \\
0 \\
0\end{array}$ & \begin{tabular}{l}
00 \\
\multirow{2}{0}{$: 0$} \\
00 \\
0 \\
1
\end{tabular} & $\begin{array}{l}0: 0 \\
000 \\
0: 0 \\
0 \\
1\end{array}$ & 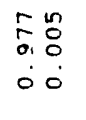 & $\begin{array}{l}\text { No: } \\
50 \\
\vdots \\
0 \\
0\end{array}$ & ชูญ & 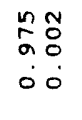 & 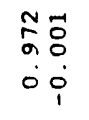 & $\begin{array}{l}N=1 \\
\hat{0} 00 \\
00 \\
0 \\
1\end{array}$ & $\begin{array}{l}90 \\
50: \\
0: 0 \\
0 \\
0\end{array}$ & 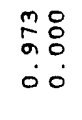 \\
\hline & $\begin{array}{l}5 \\
6.8 \\
100 \\
00\end{array}$ & 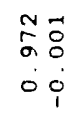 & $\begin{array}{l}m: \\
50 \\
0 \\
0 \\
0 \\
0\end{array}$ & $\begin{array}{l}5: 0 \\
0.8 \\
10 \\
00\end{array}$ & $\begin{array}{l}\text { mo: } \\
\text { ă: } \\
00 \\
00\end{array}$ & & $\begin{array}{l}n \\
50 \\
\vdots 0 \\
00\end{array}$ & $\begin{array}{l}\text { T⿱口 } \\
\text { ă } \\
\vdots \\
0 \\
0\end{array}$ & 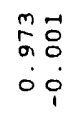 & 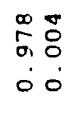 & $\begin{array}{l}5: \\
\vdots \\
\vdots \\
0 \\
0 \\
0\end{array}$ \\
\hline & $\begin{array}{l}n 0 \\
50 \\
\vdots 0 \\
0 \\
0 \\
0\end{array}$ & $\begin{array}{l}m \text { ñ } \\
\vdots 0 \\
\vdots \\
0 \\
0 \\
1\end{array}$ & $\begin{array}{l}r:-1 \\
0 \\
0 \\
0 \\
0 \\
0 \\
1\end{array}$ & 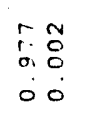 & $\begin{array}{l}n \text { no } \\
20: 0 \\
00 \\
00\end{array}$ & & $\begin{array}{l}0.0 \\
200 \\
\vdots 0 \\
00\end{array}$ & $\begin{array}{l}n \text { no } \\
5 \\
0 \\
\vdots \\
0 \\
0 \\
0\end{array}$ & $\begin{array}{l}0 \\
50 \\
50 \\
0 \\
0 \\
0\end{array}$ & 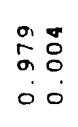 & 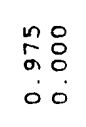 \\
\hline 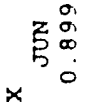 & $\begin{array}{l}: \overrightarrow{0} \\
\vdots 00 \\
0: 0\end{array}$ & 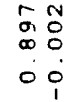 & $\begin{array}{l}\hat{0} 0 \\
\infty \\
\infty \\
0 \\
0 \\
0 \\
0\end{array}$ & $\begin{array}{l}\overrightarrow{0} \tilde{0} \\
0 \\
0 \\
0 \\
0\end{array}$ & 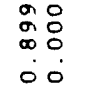 & & $\begin{array}{ll}2 & : \\
\infty & : \\
0 & 0 \\
0 & 0\end{array}$ & 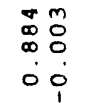 & 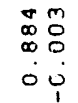 & $\begin{array}{ll}\infty & -1 \\
\infty & 0 \\
\infty & 0 \\
0 & 0 \\
0 & 0\end{array}$ & $\begin{array}{l}0: 0 \\
\infty \\
\infty \\
\infty \\
\vdots \\
0 \\
0\end{array}$ \\
\hline$\underbrace{\infty}_{b}$ & 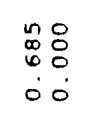 & 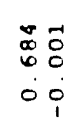 & 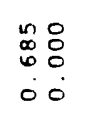 & \begin{tabular}{ll}
5 & \multirow{2}{0}{} \\
0 & 0 \\
0 & 0 \\
0 & 0
\end{tabular} & 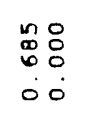 & 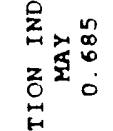 & 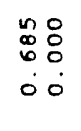 & 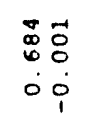 & $\begin{array}{l}\overrightarrow{0} 0 \\
0 \\
0 \\
0 \\
0 \\
0 \\
1\end{array}$ & $\begin{array}{l}0 \\
0 \\
0 \\
4 \\
0 \\
0 \\
0\end{array}$ & $\begin{array}{l}n \\
\infty \\
0: \\
\vdots 0 \\
00\end{array}$ \\
\hline $\begin{array}{l}z \\
0 \\
0 \\
0 \\
\dot{0} \\
0 \\
z\end{array}$ & 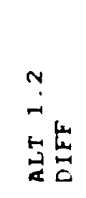 & $\vec{~}$ & 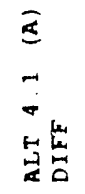 & $\begin{array}{l}m \\
\dot{\sigma} \\
\text { 宸点 }\end{array}$ & 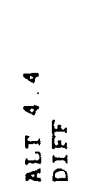 & 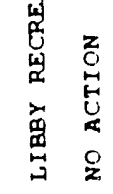 & 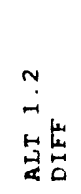 & 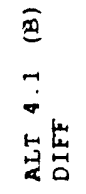 & 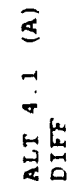 & 旁 & 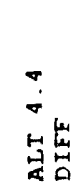 \\
\hline
\end{tabular}




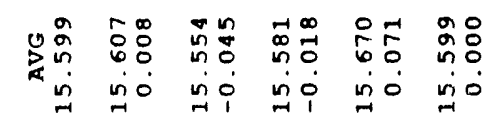

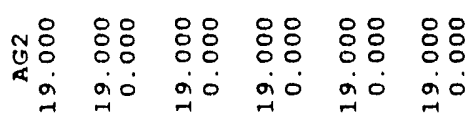

न

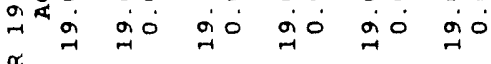

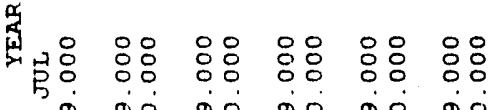

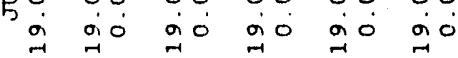

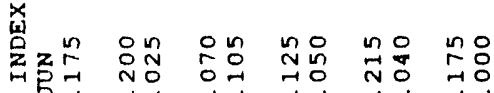

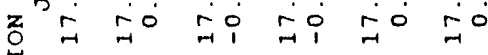

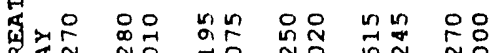

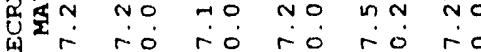

2

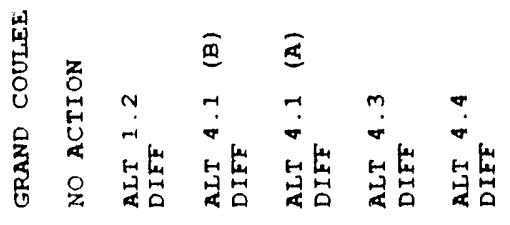

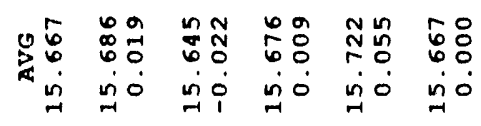

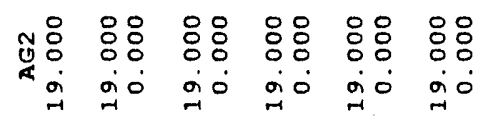

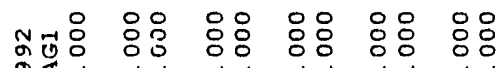

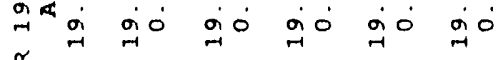

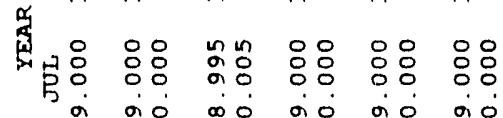
a jo

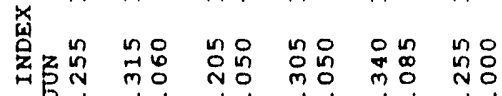

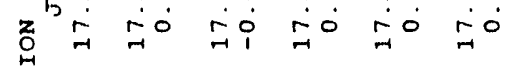

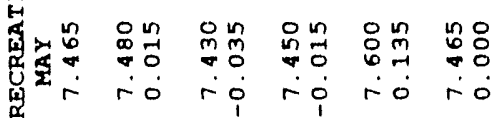

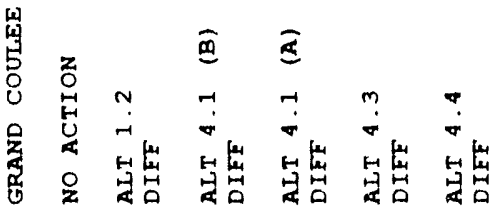




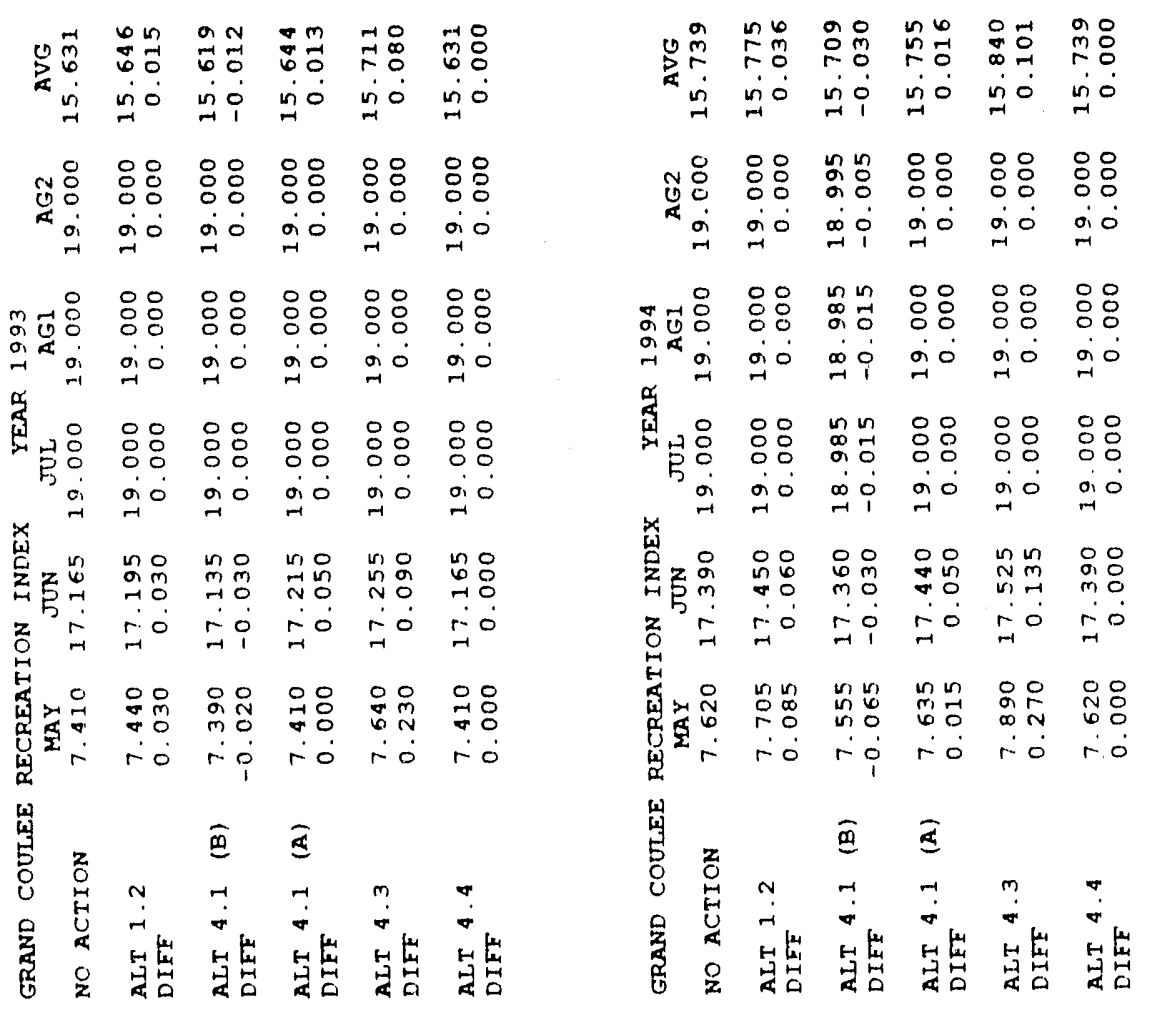




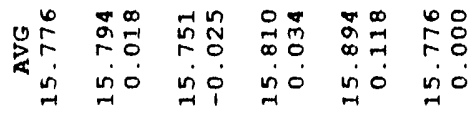

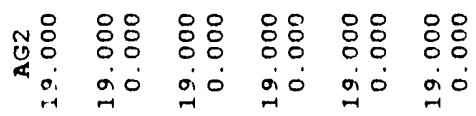



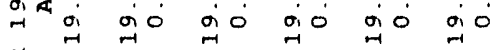

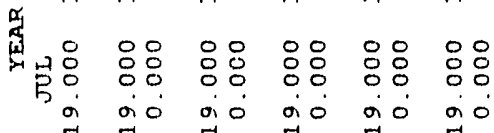
蛋出 z

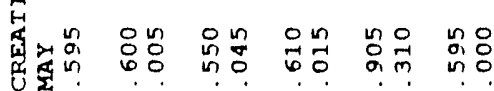

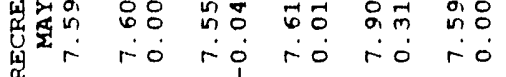

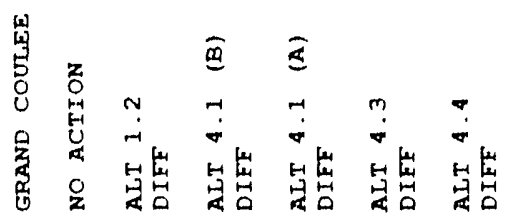

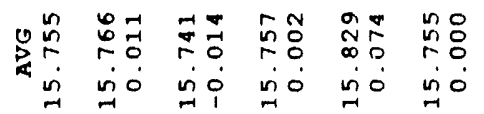

$\begin{array}{lll} & 8 & 0\end{array}$

넝요

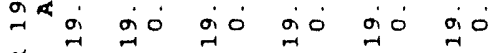

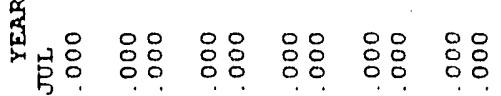

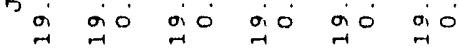

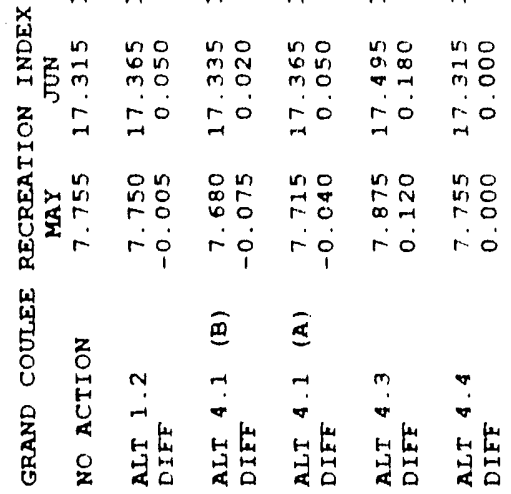




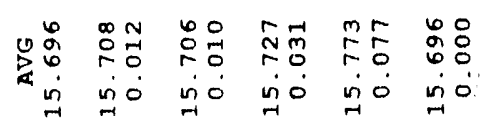

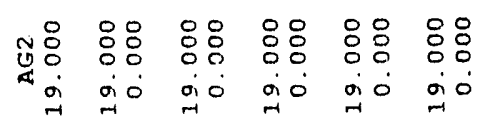

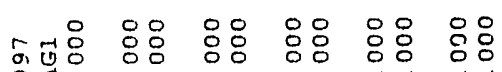
क्र

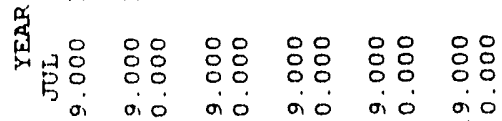
$x$ म

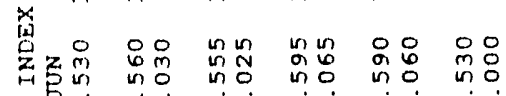
z

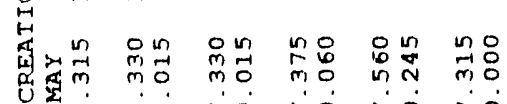

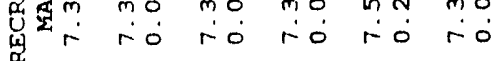

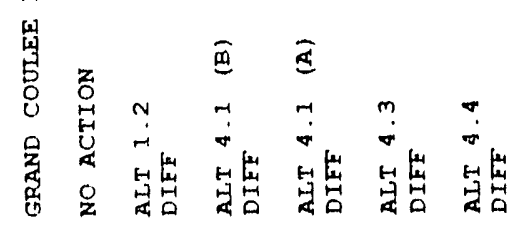

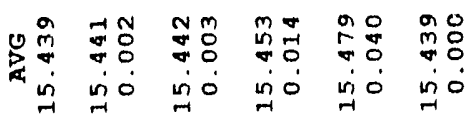

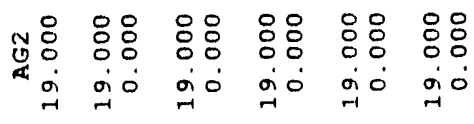

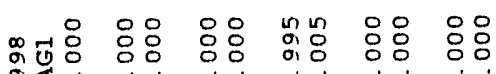
Oे

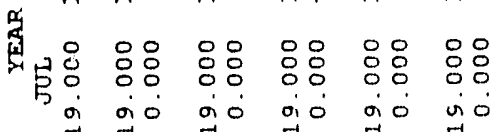

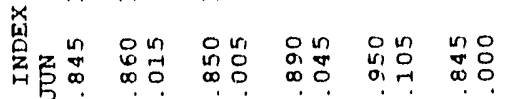
z

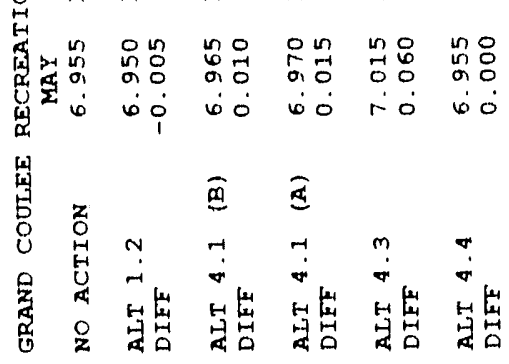
$H-2-39$ 


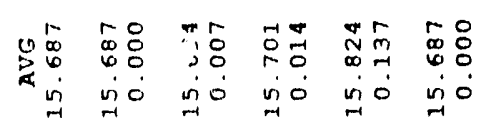

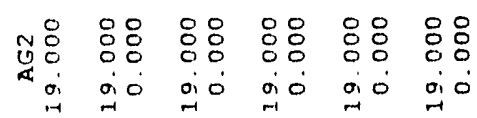

․

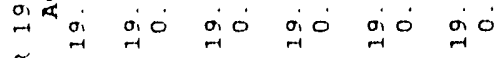

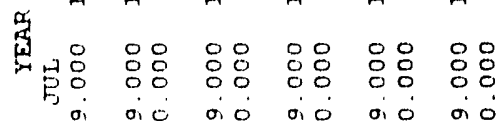

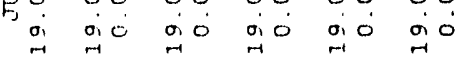

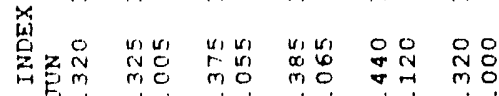

$z \Rightarrow$ तo

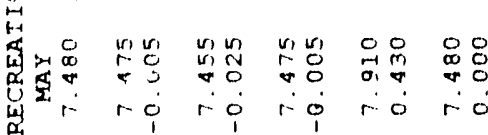

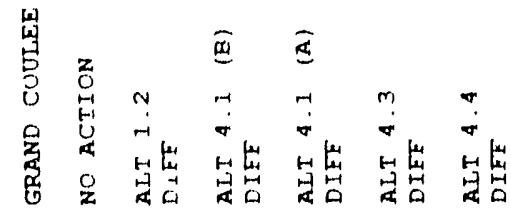

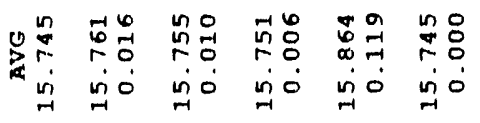

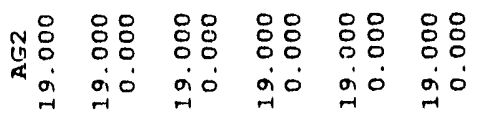

언

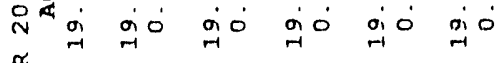

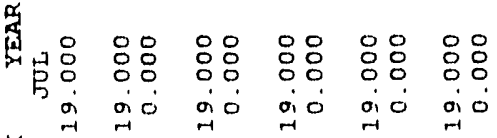

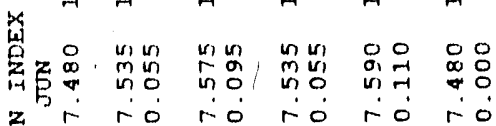
帝

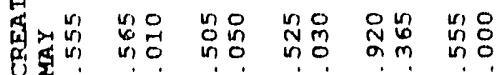

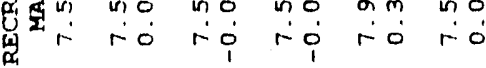

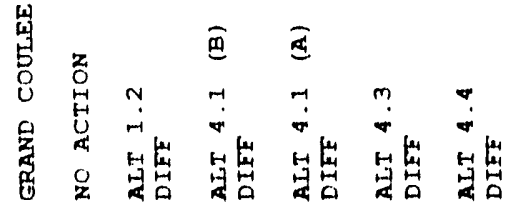




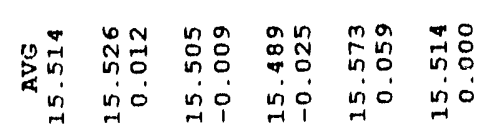

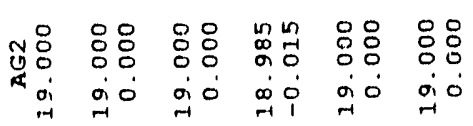
벙요

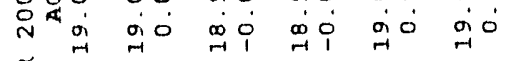

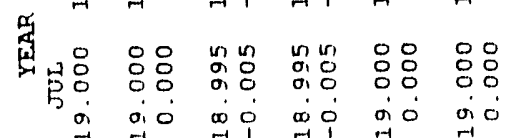

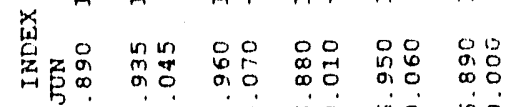

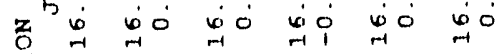

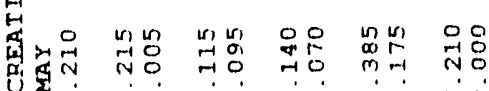

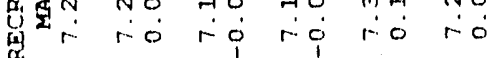

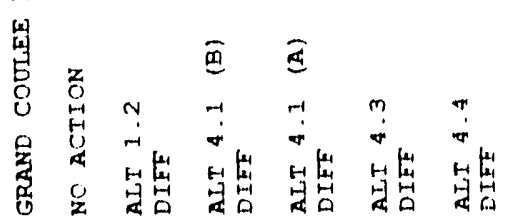

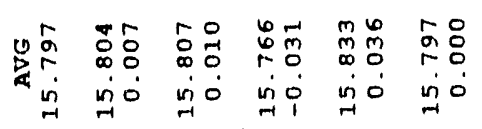

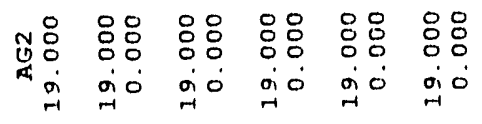

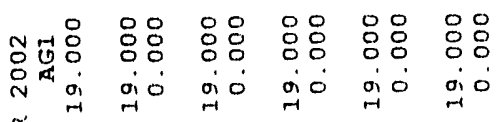

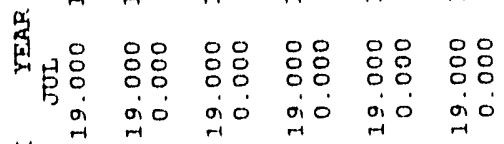

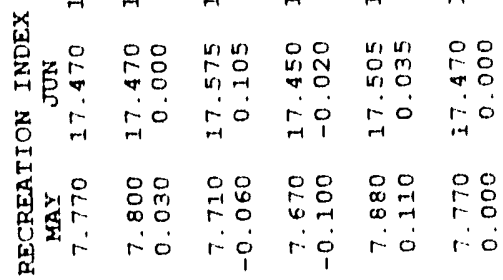

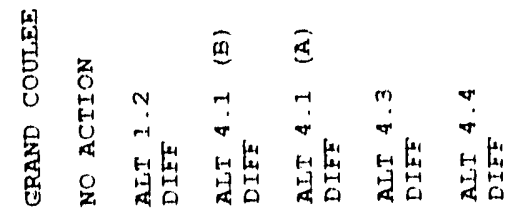




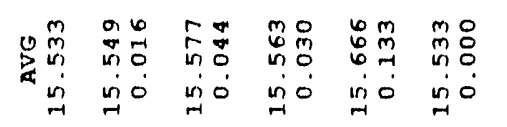

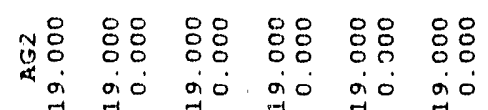

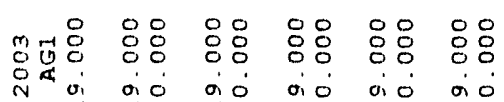

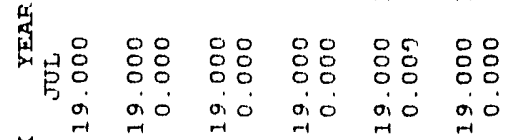

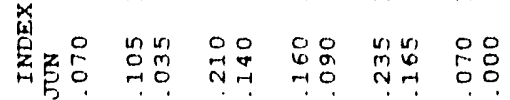

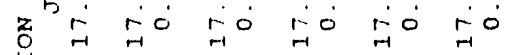

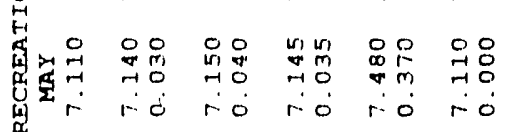

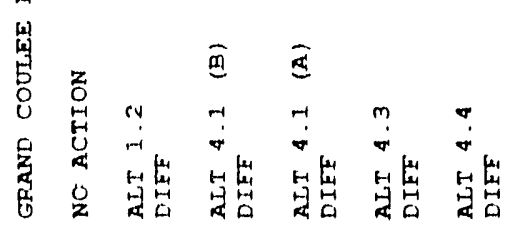

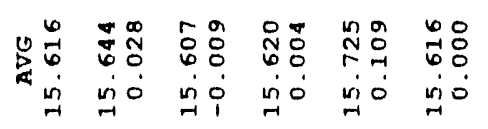

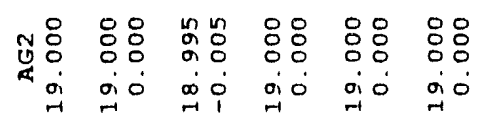

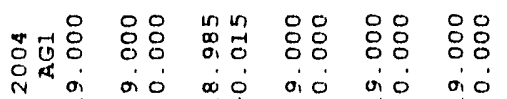

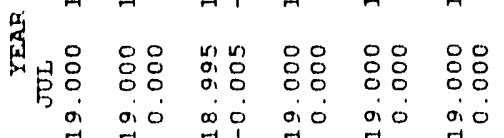

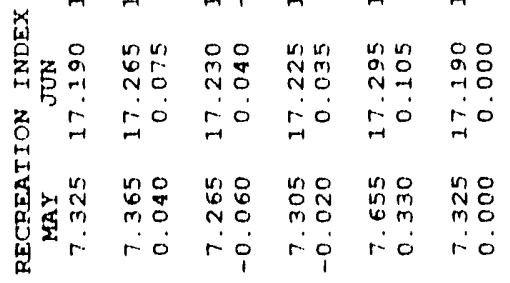

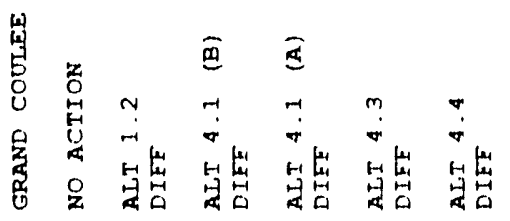




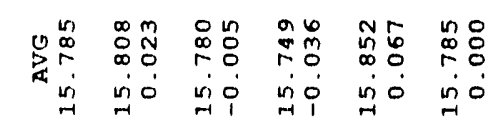

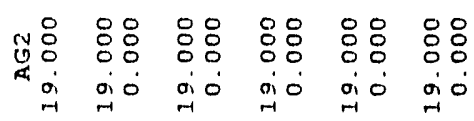

넝

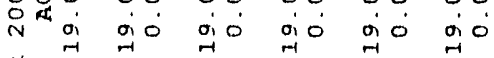

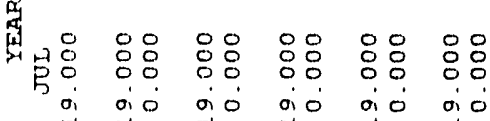

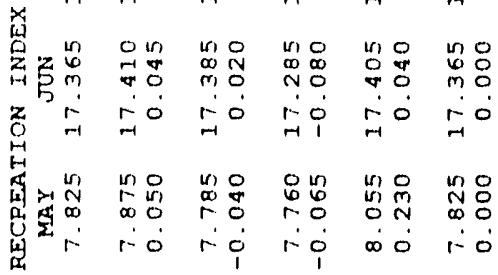

盟

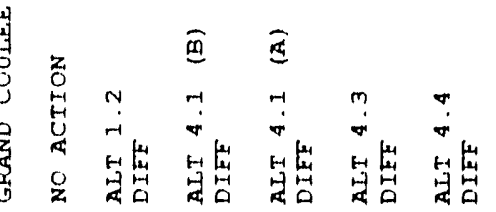

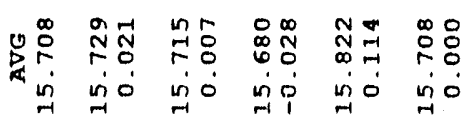

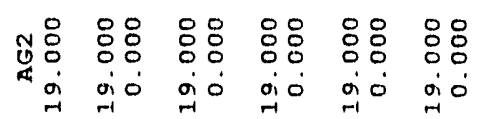

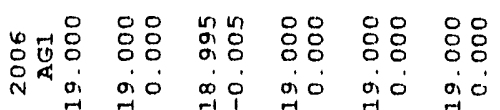

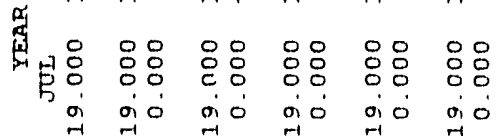

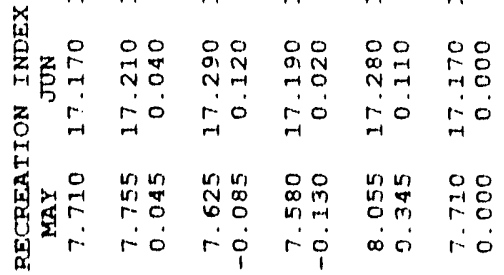

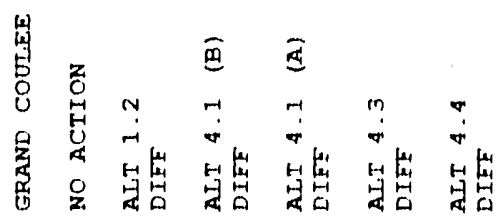




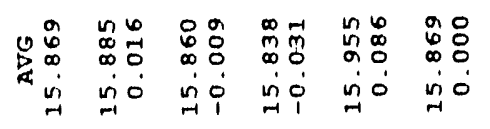

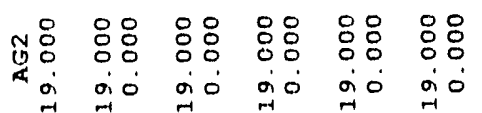

던

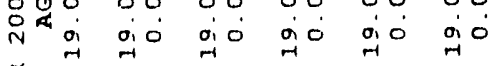

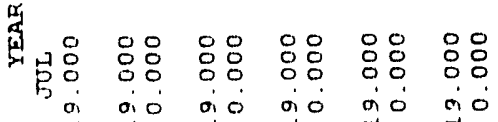

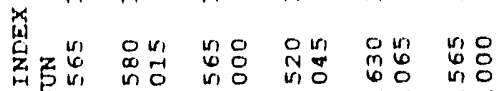

z

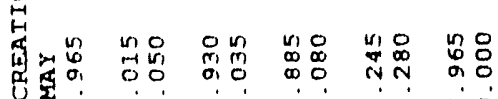

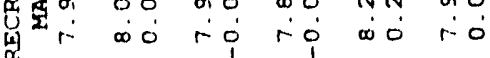

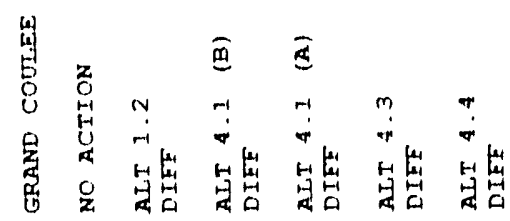

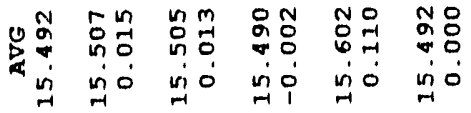

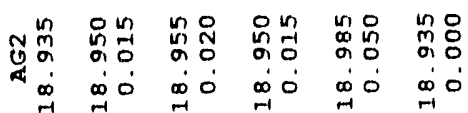

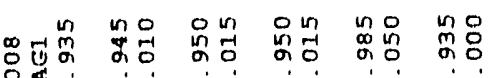

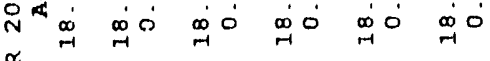

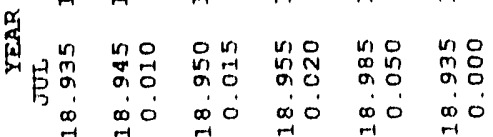

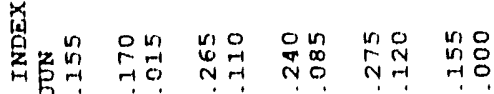
z

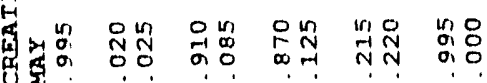

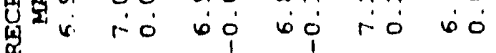

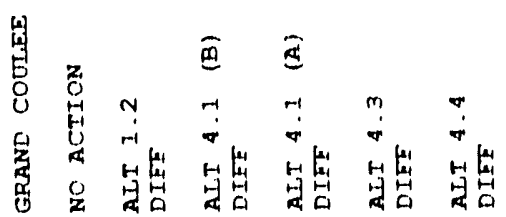


H-3

Irrigation 


\section{Irrigation}

lirgation tompacts were assessed on the bas ls of the probabllity of the elevation at Giand Coulee (Lake Roosevelt). Pumps for the Columbla Basin Profect are located at Grand Coulee. As the level of lake Roosevelt drops, pumplng becomes more dffflcult; at some levels, pumps wlll not operate or may be dallaged if ruis. There is currently a reculuement for Lake Roosevelt to be at or above 1,240 feet at the end of May for lrregatlon. If that constralnt is not met, there would be some potential for drawdown of Banks Lake, which would have an adverse effech on the fishery thereln and recreatlon thereon. Table H-.3-1 shows the probabllltes of the elevation at Grand Coulee betng at: or above 1240 feet at the end of May for all alternatives.

\section{TABLE H-3-1 \\ PROBABILITY OF ELEVATION AT GRAND COUL.EE BEING AT OR ABOVE 1240 FEET A'T THE END OF MAY}

\begin{tabular}{cccc} 
YEAR & $\begin{array}{c}\text { PROBABILITY } \\
\text { (percent) }\end{array}$ & YEAR & $\begin{array}{c}\text { PROBABILITY } \\
\text { (percent) }\end{array}$ \\
\hline 1989 & 83 & 1999 & 85 \\
1990 & 83 & 2000 & 79.5 \\
1991 & 79 & 2001 & $7 \% .5$ \\
1992 & $8 c .5$ & 2002 & 83.5 \\
1993 & 81 & 2003 & 80 \\
1994 & 81.5 & 2004 & 80 \\
1995 & 81 & 2005 & 84.5 \\
1996 & 84 & 2006 & 82 \\
1997 & 81.5 & 2007 & 88.5 \\
1998 & 78.5 & 2008 & 75.5
\end{tabular}

IT Probablitites were the same for all alternatlves. Fallure to be above elevation 1240 at the end of May is the result of an end of May flood control elevation of less than 1240.0 feet. 


$$
H-4
$$

Probability of July Reflll 


\section{Probability of July Refill}

One of the parameters computed by the Systems Analysis Model (SAM) is the probability of refill of the Northwest hydrosystem reservoirs by the end of July. Refill by that time has some implications for reservoir elevation related impacts such as recreation, but, more importantly, it is a criteria in coordinated system operations which affects how the system is operated in subsequent operating years. Tables $\mathrm{H}-4-1$ and $\mathrm{H}-4-2$ show the probabilities of refill for all the alternatives analyzed with SAM for the assumptions of expected loads and gas price and high Northwest loads. Probabilities of refill for the other sensitivity assumptions (low Northwest loads, high

Southwest loads, low Southwest loads, high gas price, and low gas price) are available upon request.

TABLE $H-4-1$

PROBABILITY OF JULY REFILL (EXPECTED LOADS AND GAS PRICE)

\begin{tabular}{lllllll} 
& \multicolumn{7}{c}{ ALTERNATIVES } \\
YEAR & NO ACTION & 1.2 & C.1 & 4.1 & \\
\hline 1989 & 0.905 & 0.905 & 0.875 & 0.875 & 0.920 & 0.905 \\
1990 & 0.885 & 0.885 & 0.865 & 0.850 & 0.900 & 0.885 \\
1991 & 0.900 & 0.910 & 0.880 & 0.860 & 0.920 & 0.900 \\
1992 & 0.900 & 0.905 & 0.895 & 0.890 & 0.905 & 0.900 \\
1993 & 0.890 & 0.880 & 0.880 & 0.865 & 0.895 & 0.890 \\
1994 & 0.855 & 0.860 & 0.850 & 0.830 & 0.865 & 0.855 \\
1995 & 0.845 & 0.845 & 0.835 & 0.800 & 0.870 & 0.845 \\
1996 & 0.855 & 0.855 & 0.840 & 0.830 & 0.870 & 0.855 \\
1997 & 0.835 & 0.830 & 0.830 & 0.810 & 0.855 & 0.835 \\
1998 & 0.870 & 0.870 & 0.870 & 0.850 & 0.875 & 0.870 \\
1999 & 0.810 & 0.815 & 0.815 & 0.795 & 0.855 & 0.810 \\
2000 & 0.840 & 0.835 & 0.835 & 0.840 & 0.860 & 0.840 \\
2001 & 0.855 & 0.855 & 0.835 & 0.845 & 0.860 & 0.855 \\
2002 & 0.845 & 0.845 & 0.840 & 0.840 & 0.855 & 0.845 \\
2003 & 0.865 & 0.865 & 0.875 & 0.875 & 0.905 & 0.865 \\
2004 & 0.880 & 0.875 & 0.875 & 0.860 & 0.895 & 0.880 \\
2005 & 0.860 & 0.860 & 0.845 & 0.855 & 0.860 & 0.860 \\
2006 & 0.825 & 0.825 & 0.840 & 0.825 & 0.835 & 0.825 \\
2007 & 0.845 & 0.845 & 0.855 & 0.845 & 0.860 & 0.845 \\
2008 & 0.875 & 0.880 & 0.875 & 0.865 & 0.885 & 0.875
\end{tabular}


TABLE H-4-2

PROBABILITY OF JULY REFILL

(HIGH NORTHWEST LOADS)

\begin{tabular}{lcccccc} 
& \multicolumn{7}{c}{ ALTERNATIVES } \\
YEAR & NO ACTION & 1.2 & $\begin{array}{c}4.1 \\
\text { CASE A }\end{array}$ & CASE $B$ & 4.3 & 4.4 \\
\hline 1989 & 0.905 & 0.910 & 0.905 & 0.870 & 0.905 & 0.905 \\
1990 & 0.870 & 0.870 & 0.870 & 0.865 & 0.870 & 0.870 \\
1991 & 0.880 & 0.885 & 0.880 & 0.885 & 0.880 & 0.880 \\
1992 & 0.885 & 0.880 & 0.890 & 0.890 & 0.880 & 0.885 \\
1993 & 0.890 & 0.885 & 0.885 & 0.880 & 0.880 & 0.890 \\
1994 & 0.830 & 0.840 & 0.825 & 0.845 & 0.830 & 0.830 \\
1995 & 0.845 & 0.830 & 0.835 & 0.840 & 0.835 & 0.845 \\
1996 & 0.840 & 0.840 & 0.845 & 0.840 & 0.835 & 0.840 \\
1997 & 0.835 & 0.830 & 0.845 & 0.820 & 0.820 & 0.835 \\
1998 & 0.855 & 0.860 & 0.855 & 0.875 & 0.860 & 0.855 \\
1999 & 0.825 & 0.820 & 0.825 & 0.820 & 0.845 & 0.825 \\
2000 & 0.840 & 0.835 & 0.840 & 0.830 & 0.865 & 0.840 \\
2001 & 0.845 & 0.845 & 0.840 & 0.835 & 0.860 & 0.845 \\
2002 & 0.845 & 0.855 & 0.860 & 0.840 & 0.890 & 0.845 \\
2003 & 0.885 & 0.895 & 0.880 & 0.875 & 0.900 & 0.885 \\
2004 & 0.895 & 0.880 & 0.890 & 0.875 & 0.900 & 0.895 \\
2005 & 0.850 & 0.855 & 0.860 & 0.860 & 0.860 & 0.850 \\
2006 & 0.845 & 0.840 & 0.845 & 0.835 & 0.840 & 0.845 \\
2007 & 0.865 & 0.855 & 0.860 & 0.865 & 0.880 & 0.865 \\
2008 & 0.870 & 0.865 & 0.885 & 0.890 & 0.875 & 0.870
\end{tabular}




\section{H-5}

Changes in Thermal Plant Operations 


\section{Operation of Resources, Summarized by Type}

The analyses performed with the System Analysis Model (See Appendix G-1) produced projections of future operation of the region's generating resources. These projections, shown in Tables $\mathrm{H}-5-1$ and $\mathrm{H}-5-2$, are summarized by resource type. Table $\mathrm{H}-5-1$ contains results for the medium loads and gas prices scenario, while Table H-5-2 contains results under high Northwest loads. Similar tables showing projected resource operations for other serisitivity assumptions (high and low Southwest loads, high and low gas prices, and low Northwest loads) are available upon request.

In Tables $\mathrm{H}-5-1$ and $\mathrm{H}-5-2$, the values given for the No Action Alternative are actual projected values from SAM. Values given for all other alternatives, however, are incremental relative to the No Action Alternative (i.e., value = alternative result - No Action result). The following information is given by column:

(1) the year being summarized;

(2) the alternative;

(3) total hydro generation;

(4) total nuclear generation (including any new resources);

(5) total coal generation (including any new resources);

(6) total combustion turbine generation;

(7) energy resulting from the release of water covered under the current non-treaty storage agreement;

(8) the total of exchange energy and use of storage outside the region;

(9) use of short-term energy purchases which were reserved by the LCMM;

(10) purchases from B.C. Hyrdo;

(11) total generation occurring in SAM (Note: This does not include use of conservation, firm impacts, or miscellaneous small resources since SAM treats these as reductions to load). 


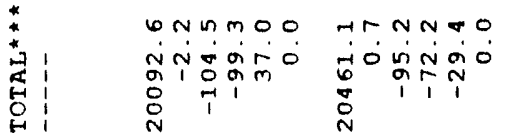

manoro

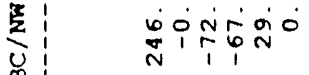

or on in $m=0$

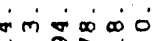
m

000000 000000

000000

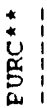

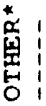

000000

-00000

000000

o. 00 in

000000

000000 mon

भ०जि०

006060

monha

$-1+i-10$

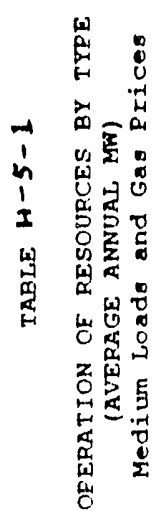

密

Lomono

ñ.

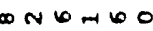

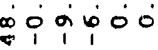

$\ln =000$

miorio

aramoo

aromingo:

-

: niotio mompo

r-⿻

Womao nnnao

H:

in ingino

miñó

ormol mo romino

arinnto $\therefore \rightarrow \infty \sin ^{\circ}$

ONGORO WOOLRO

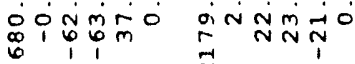

붕

0,00000

in

00000

in

$0 \sin m 0$

- 1000

min o sono

तitring

OO-mmo

$\underset{\infty}{\infty} \lim ^{\infty} \infty 0^{\circ}$

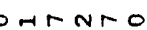

o

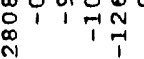

mo0000 in 00000

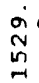

in 00000

Nं0.00

100000

mo0000

in

amoro n-ONmo

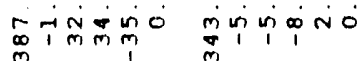

$\operatorname{ans} \infty \rightarrow$

ôn

10000

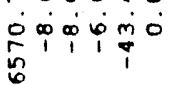

Dmmato

inginisio

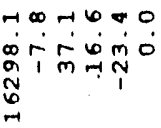

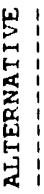
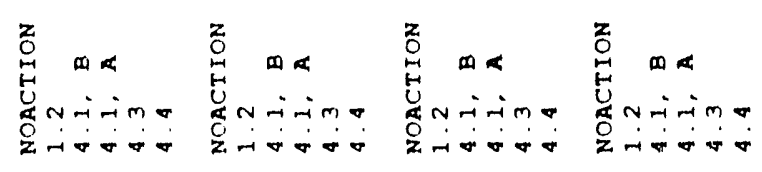

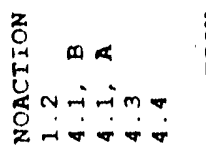

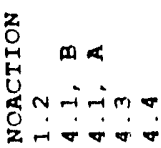

象

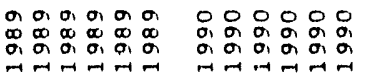

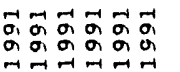

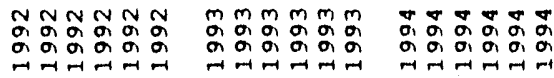




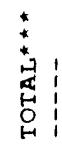

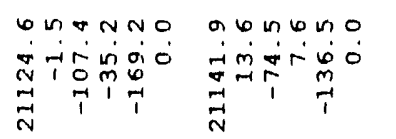

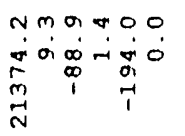

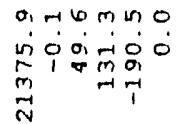

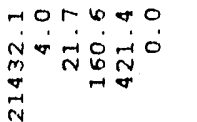

oin 0 a 40

morico

$\stackrel{m}{N}$ जi

\&

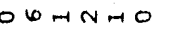

momato ram mo

$\operatorname{lot} \theta 0$

บे

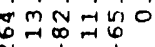

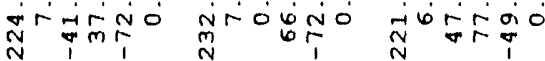

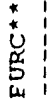

0,0000

OOODOO

000090

000000

000000000000

000000

- 0000 0.0000 00000

* I rormo mmmino nmmoro

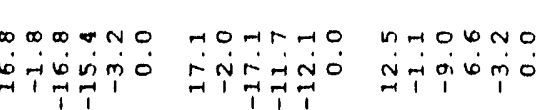

:

$0 \rightarrow 00$ i

NMNi

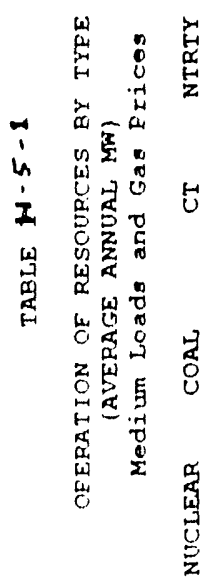

000000000000000000 H

000000000000000000

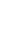

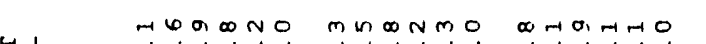

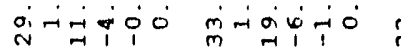

mingino

onotio

nommo nmormo

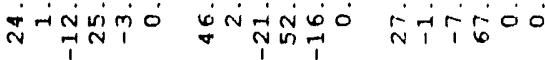

060000

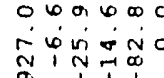

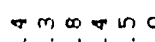
(2)

nNmTOR

an

THono antano

N

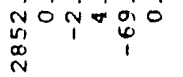

:0

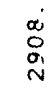

$a 00000$
$i 00000$
$m_{1} 000$
$n$

$\infty 00000$
$\prod_{\substack{n \\ n \rightarrow 1}}^{\infty} 000000$

700000

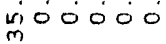

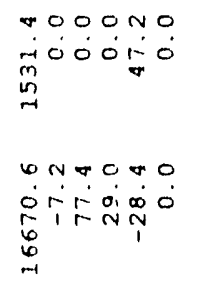

mérigo

nho osto

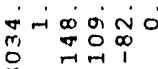
in

品

1.0.0 vio

Nomaloo

amintoo

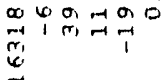

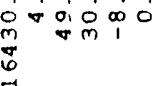

نู

$\operatorname{rom} m-0$

$m$

西

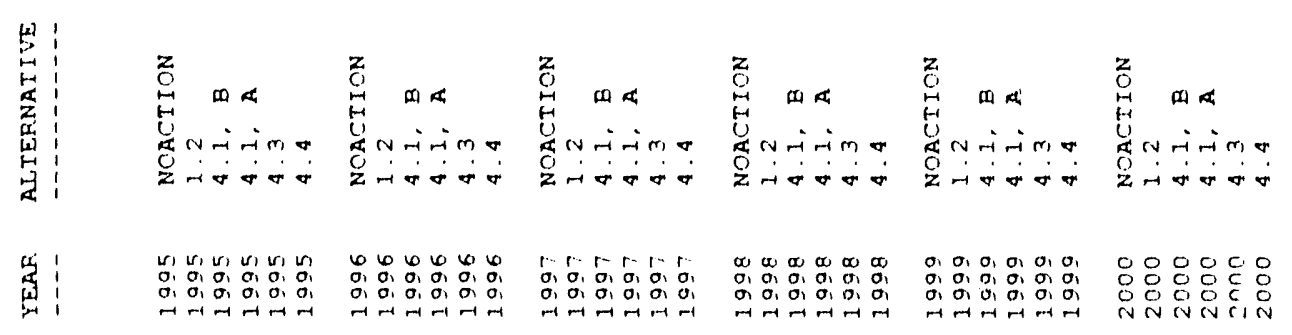




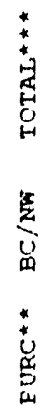

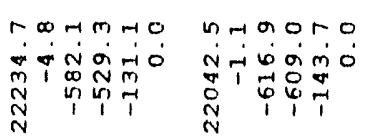

ry nos o r o

min

o num no ho

i

$r m$ um 00

$00 n m-10$

学

$\begin{array}{ccccc}-1 & 0 & 0 & -1 & 0 \\ 0 & 1 & 0 \\ 0 & 1 & 0 & 0 \\ 0 & N & 0 \\ N & 7 & 1 \\ N & 1 & \end{array}$

क्षि०

N

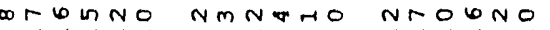

E

norom

no 00 in 0

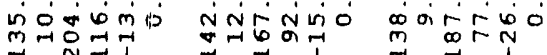

* $1 \quad 000000000000000000$

000000000000

000000

000000 000000

Oं०்

000000

000000

䀡

angroo aOd a mo r

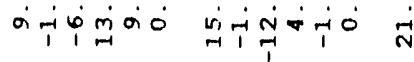

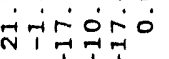

$\infty m+\infty$

$\ln 060$

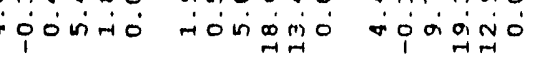

000000000000 000000

000000

000000000000

000000

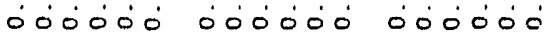

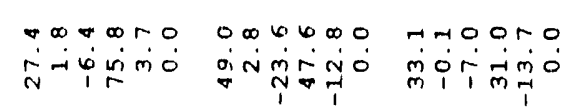

rmooro

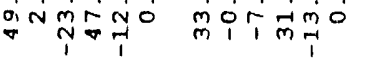

ontmino ontono

arobo lombara $\sin \left(\frac{10,00}{10}\right.$

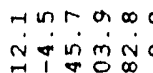

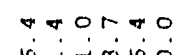

$m+\frac{1}{2+100}$

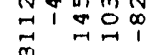

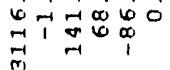

ơnd

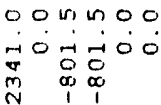

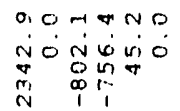

rooina 0

No $\operatorname{rim}_{\infty} \min _{\infty}$

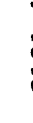

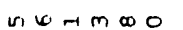

$\rightarrow \infty 6000$

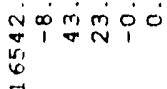

离

on 0000

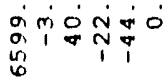

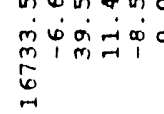

a

coritio

\begin{tabular}{l|l}
0 \\
0 \\
0 \\
0
\end{tabular}

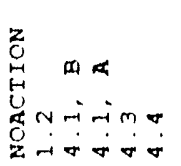

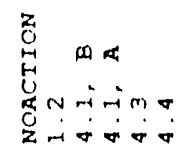

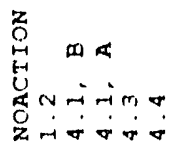

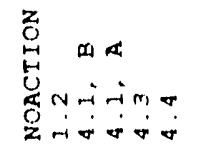

驾泺

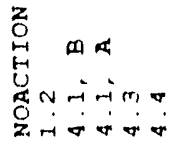

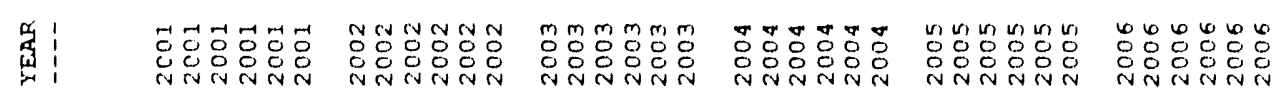




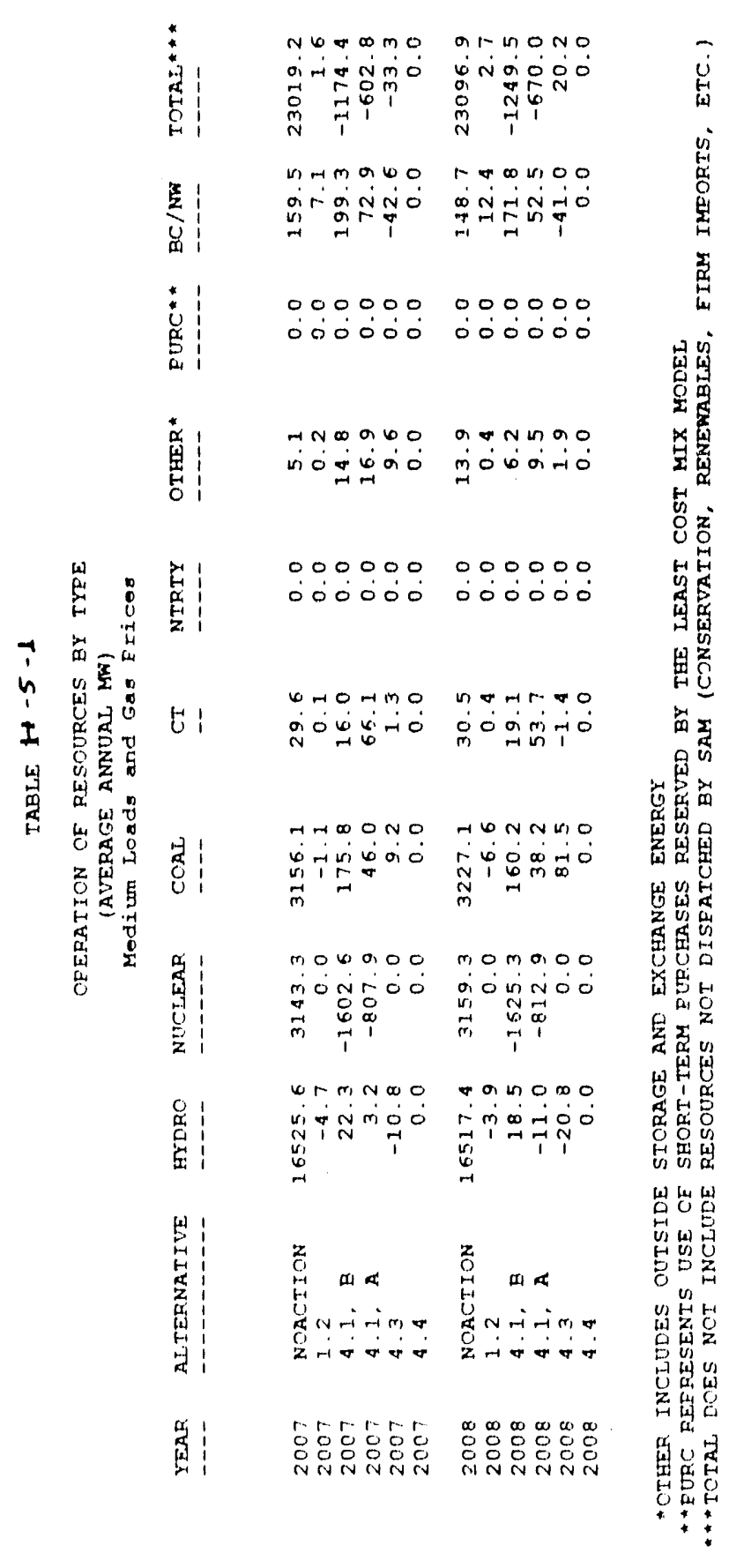

$H-5-5$ 


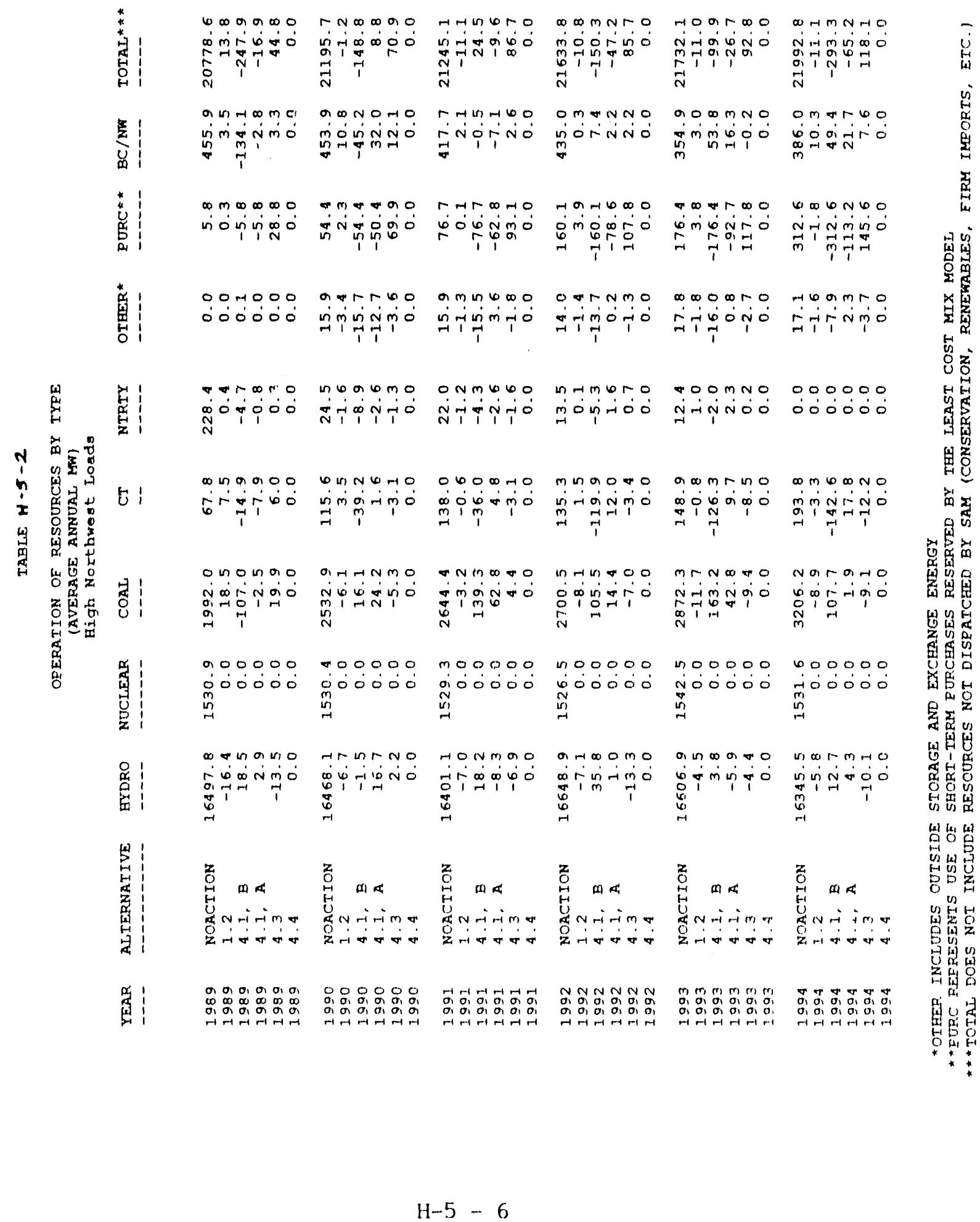




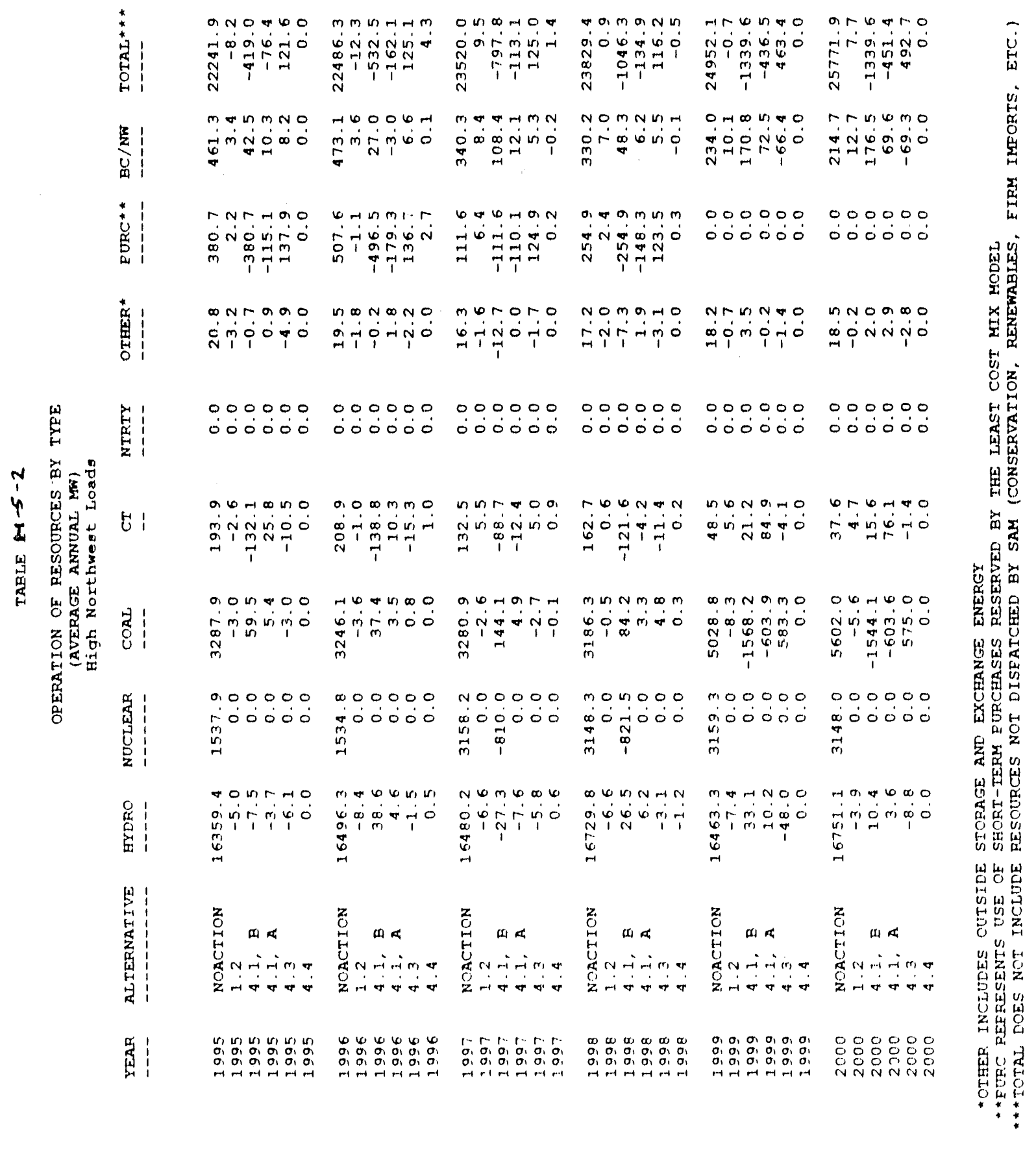


:

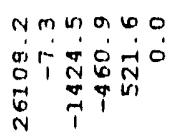

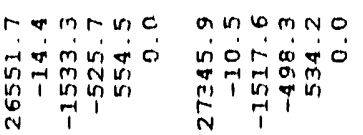

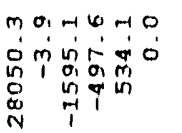

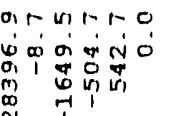

h⿻

$\infty 6$ nn $m$ \%

比!

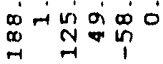

mamroo

rin miño

n?mUn?

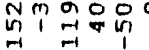

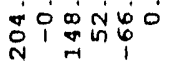

त

mon m r r t o

Niom

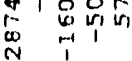

\begin{tabular}{l|l}
$*$ \\
$\vdots$ \\
$\vdots$
\end{tabular}

000000

000000000000

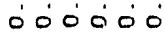

0ं0்00

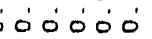

000000

○ं0ல00

000000000000

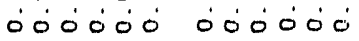

罩!

0,0000

OnLHOO DWH-HO

HONho

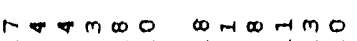

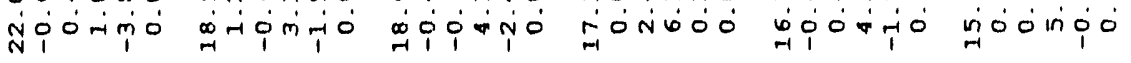

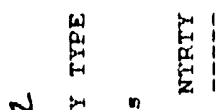

000000

$0,0,000$

0.0000

ó0ं0ं

000000

000000

000000000000

in

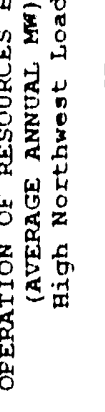

E)

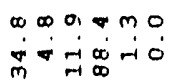

monao

000000

ÓOல0ं0

00000

000000

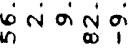

onintao anmino

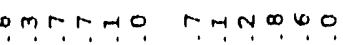

$a_{1}^{\infty} \operatorname{lin}_{n \rightarrow 1}$

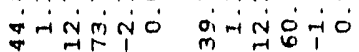

moRhino

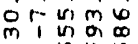

$m_{0}^{m}$

vim mon

क तरा

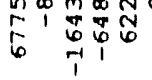

$09 \pi m 00$

niक

m) romo

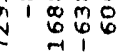

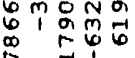

HoONOO

rinatio

om 0 nno 0

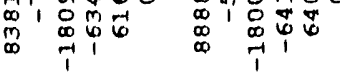

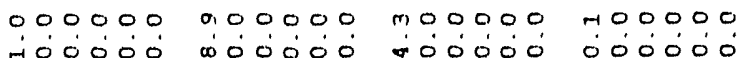

in 00000

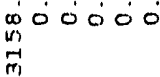

边

蕰

000000

mió

min

000000

m

nemano

anderto

amouno

$m$ man no

$\min _{0}^{\infty}$

क निं vimo

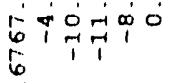

OMNOWO

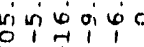

量

जió一

7

$m m-6 m a$

$8 \pi 4000$

号

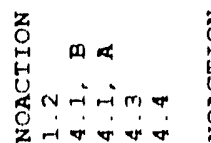

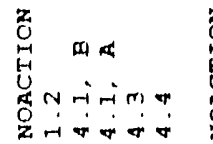

总 ma

蚫

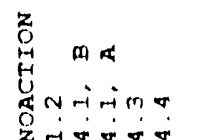

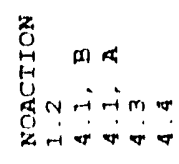

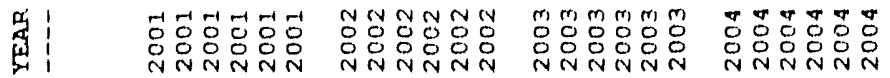

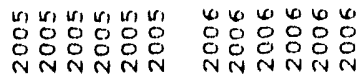




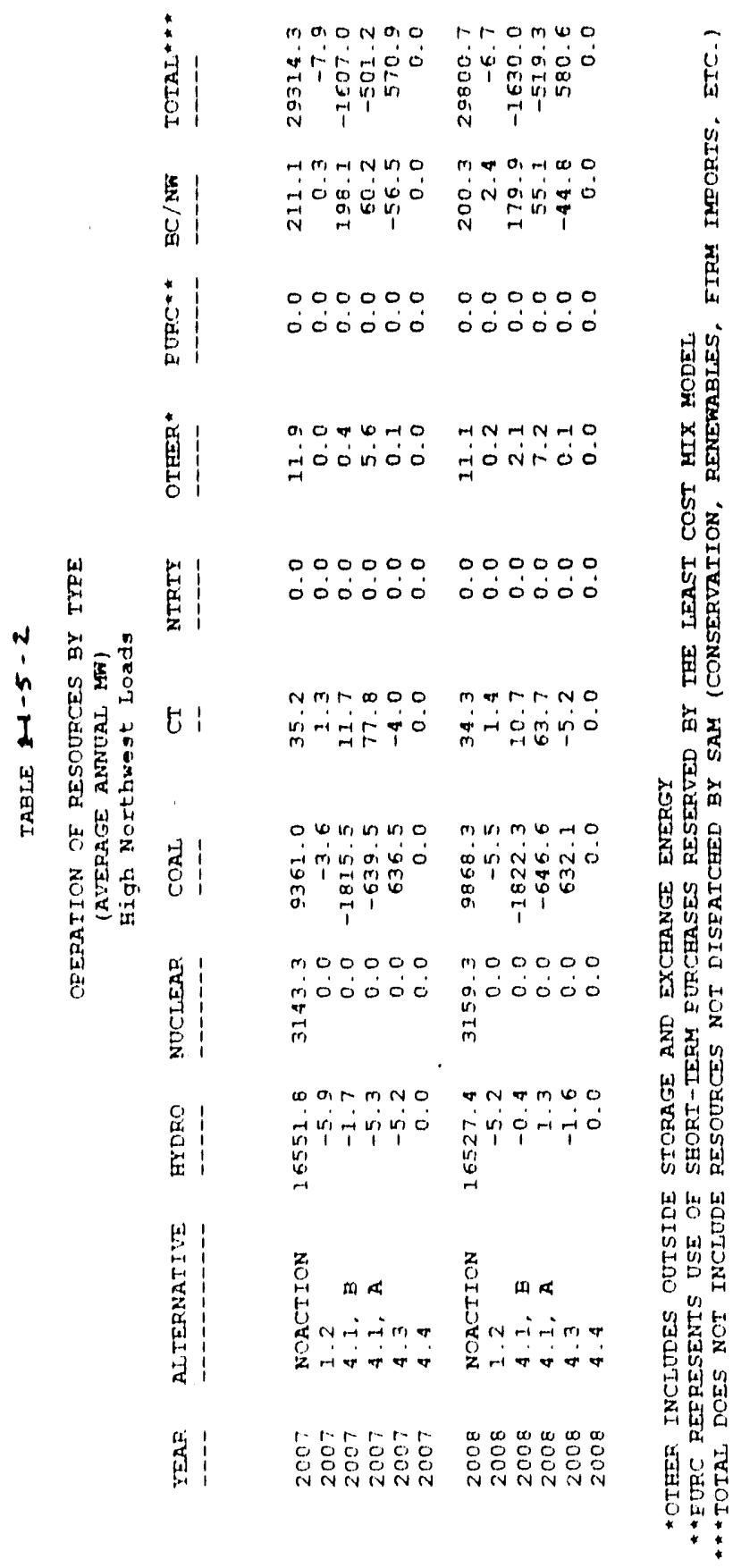

$H-5-9$ 


$$
H-6
$$

Operation of Existing Coal Plants 


\section{Operation of Existing Coal Plants}

The analyses performed with the Systems Analys ls Model (See Appendlx $(-1$ ) produced projections of future operation of extsting coal-fired generating plants which serve the reglon. These projections are provided ln Tables H-6-I and H-6-2. for the assumptions of expected loads and gas prices and high Northwest Loads. Stmllar Tables showing projected coal plant operatlons for other sensitivity assumptions (Low Northwest Loads, High Southwest Loads, Low Southwest Loads, High Gas Prlce, and Low Gas Price) are avallable upon request. In Tables H-6-I and H-6-2, the values glven for "No Actlon" for each plant are actual projected values from SAM. Values glven for each other alternative by plant are dlfferences for that alternattve from the value glven above it by plant for "No Action". The last column of each Table shows generation and generation changes from No Actlon for "generlc coal plants whlch are added in some cases by the LCMM to meet load fitrim load growth. 


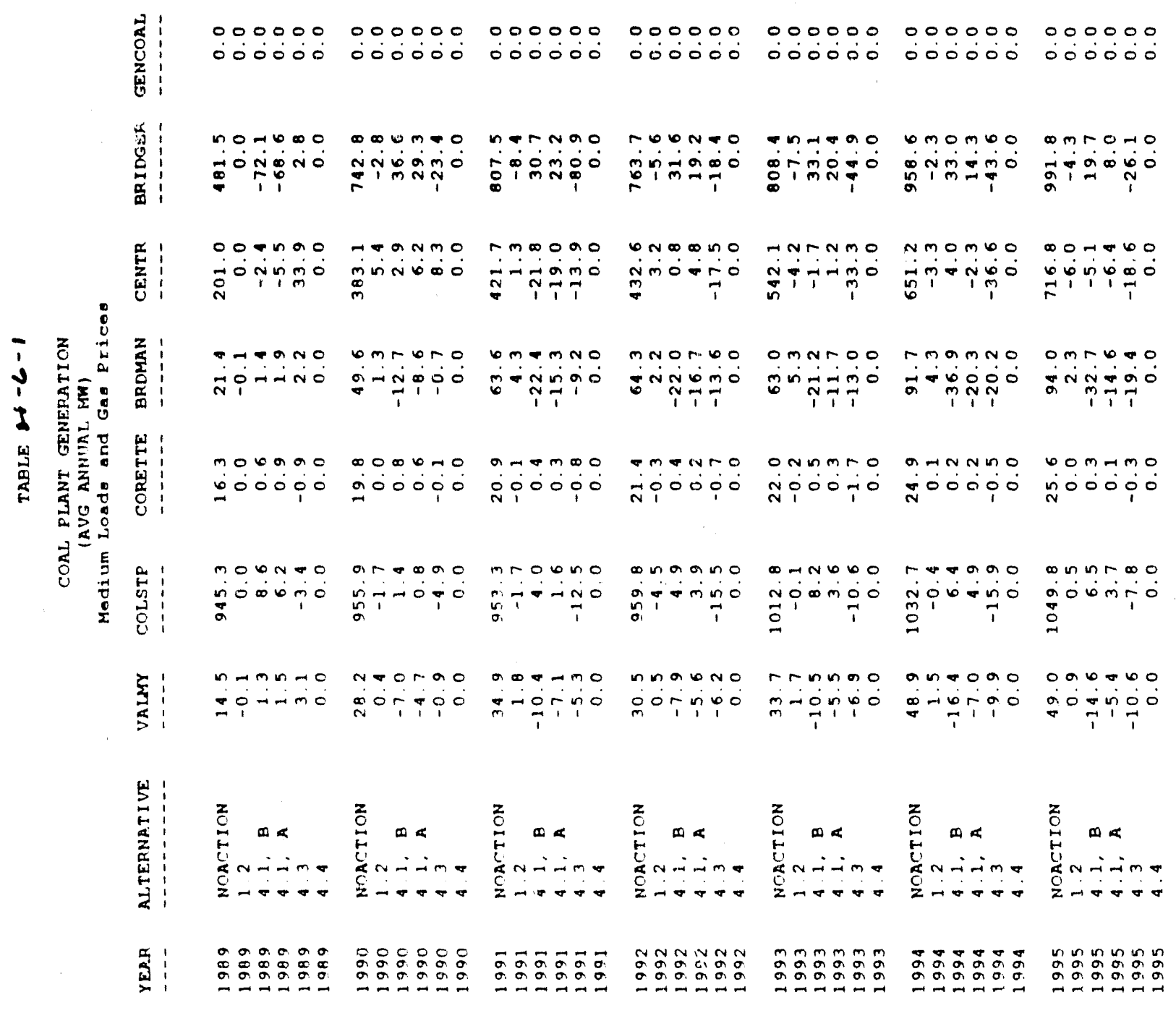




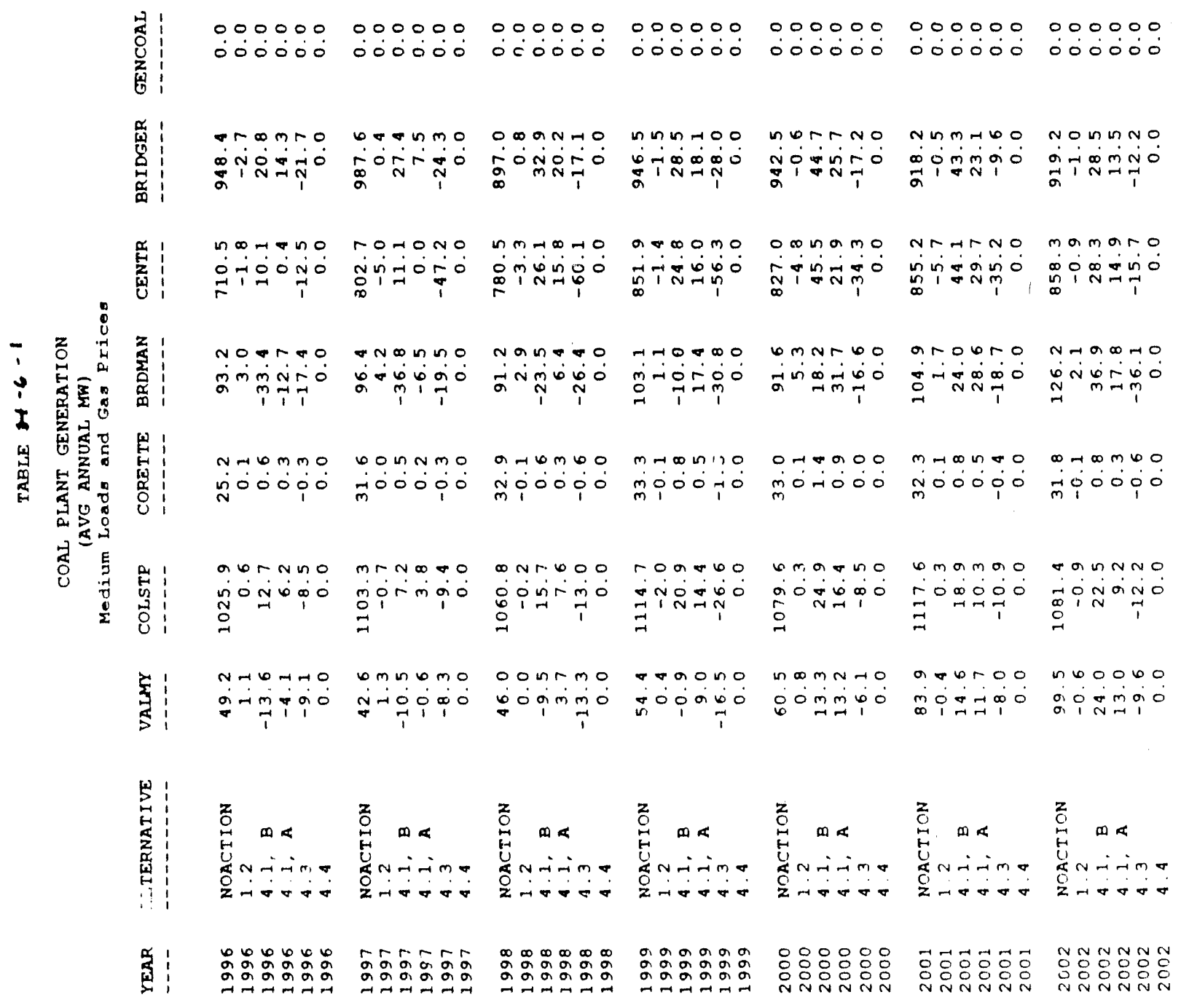




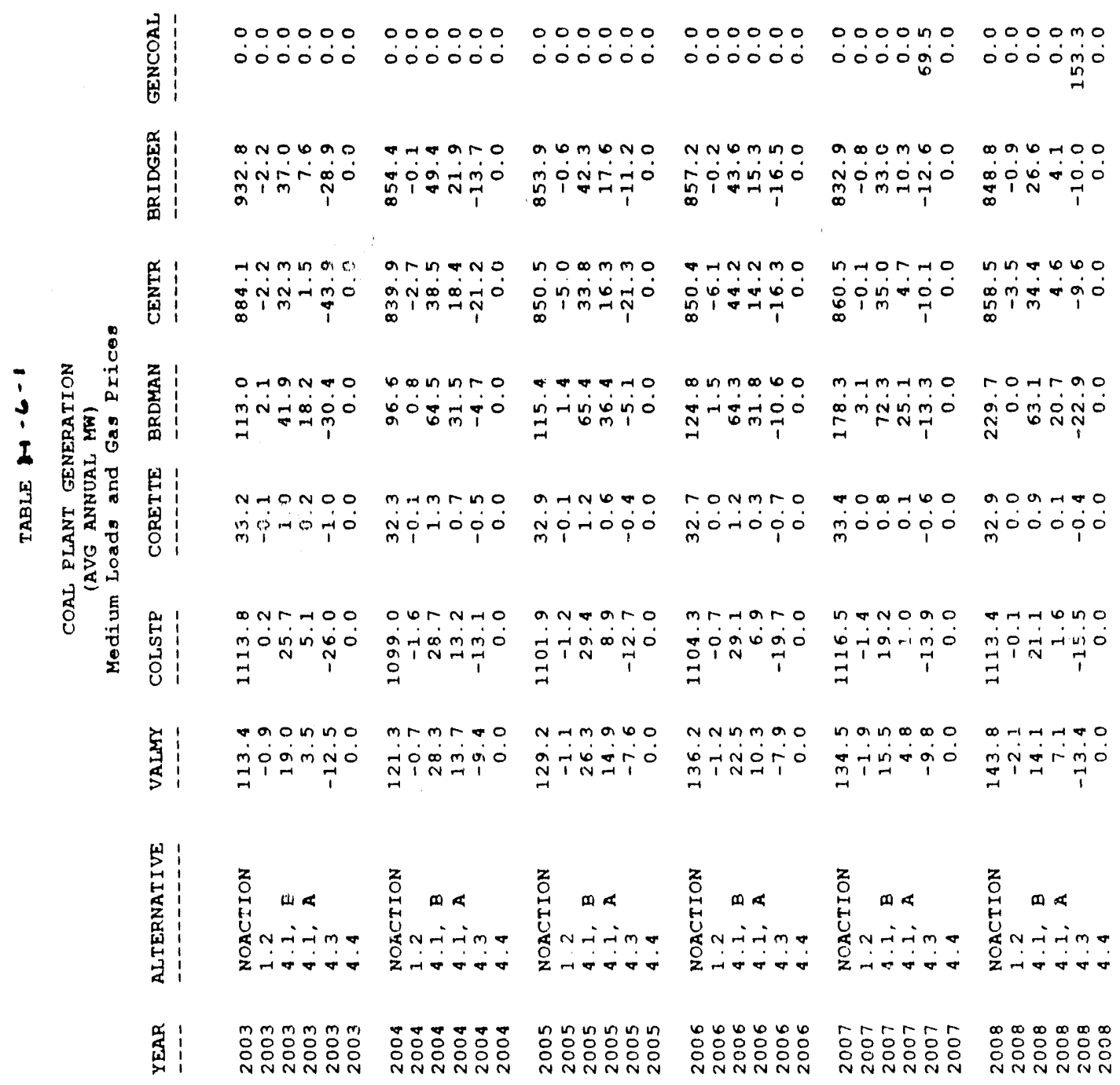




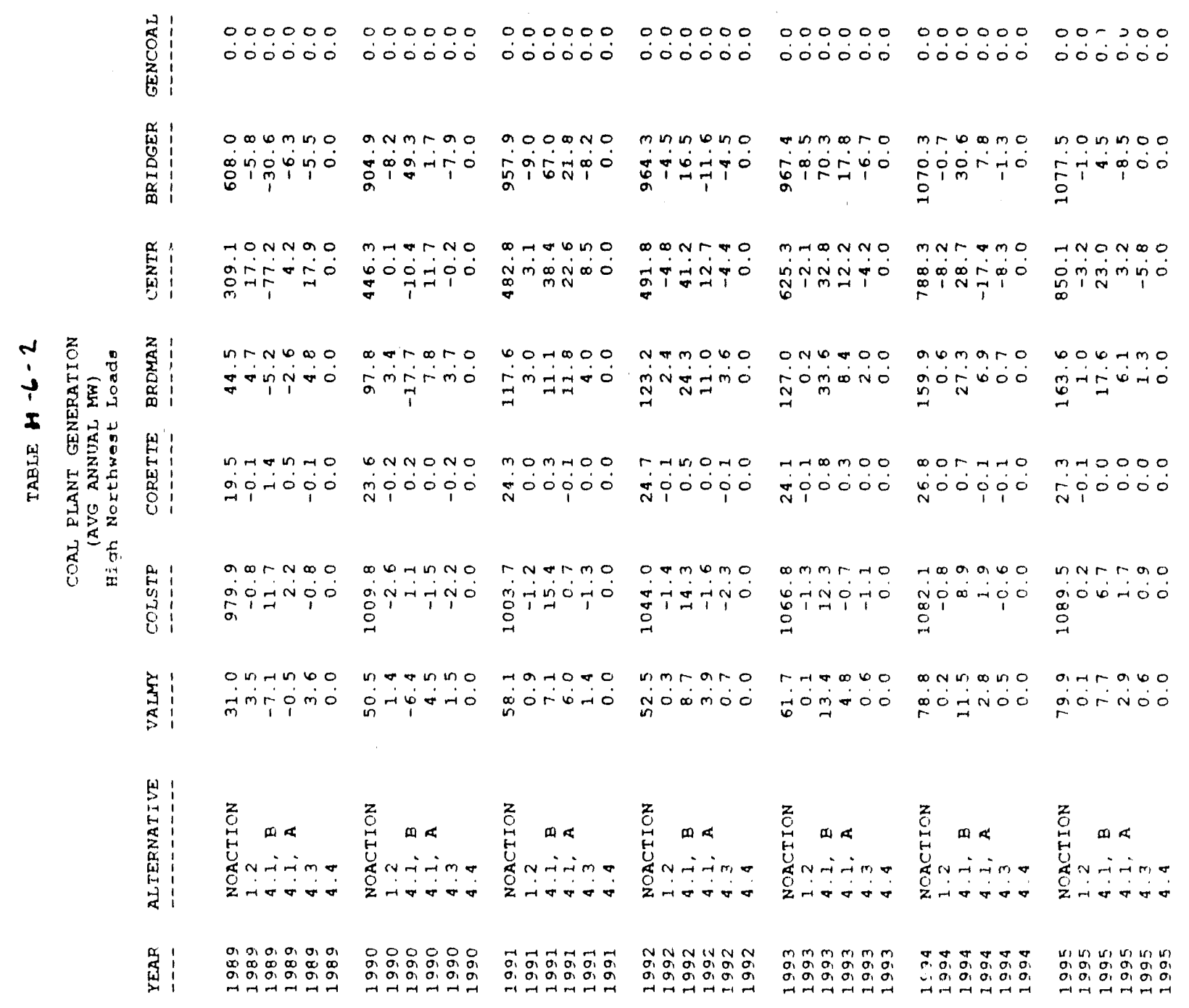

$H-t)-5$ 


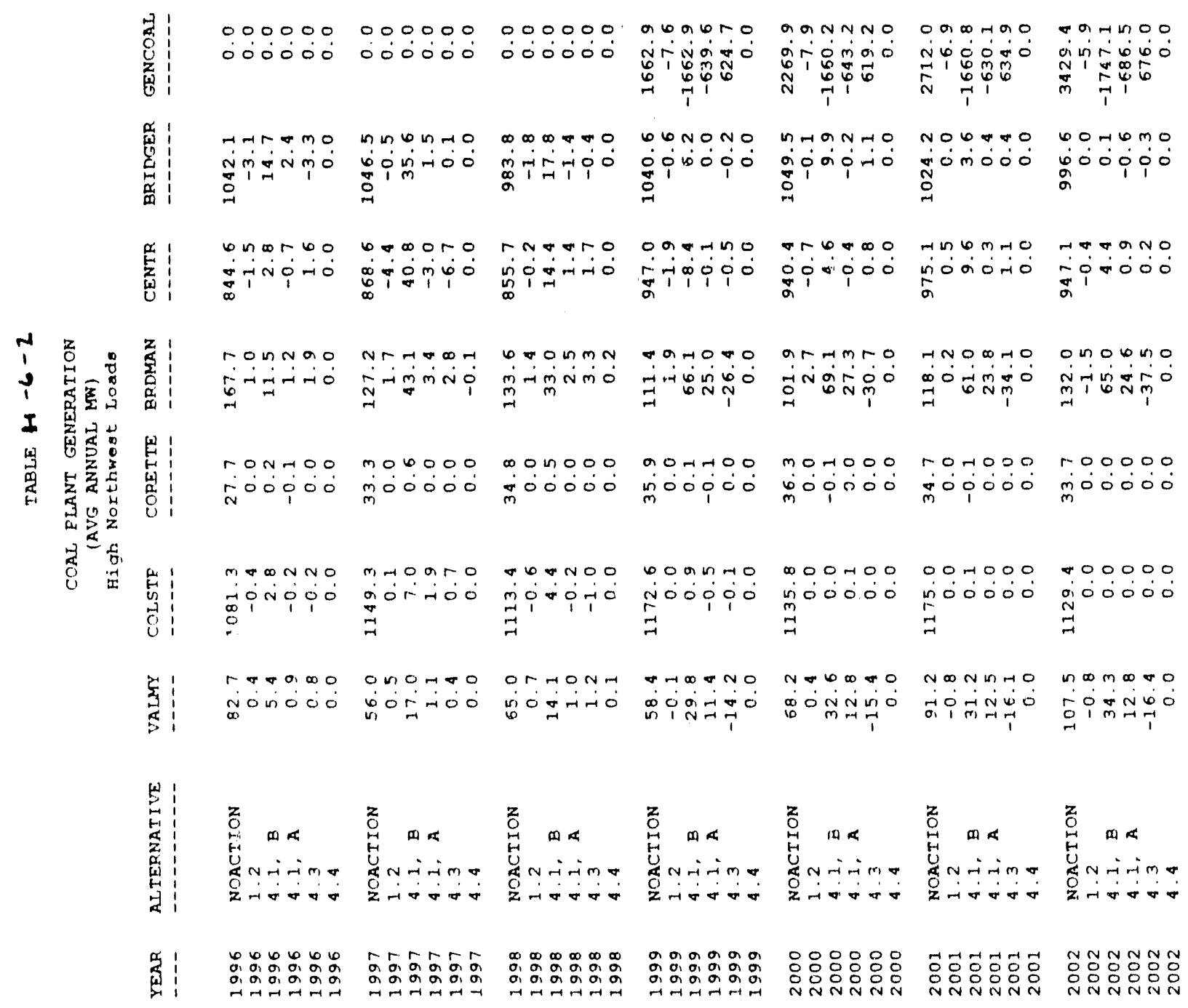



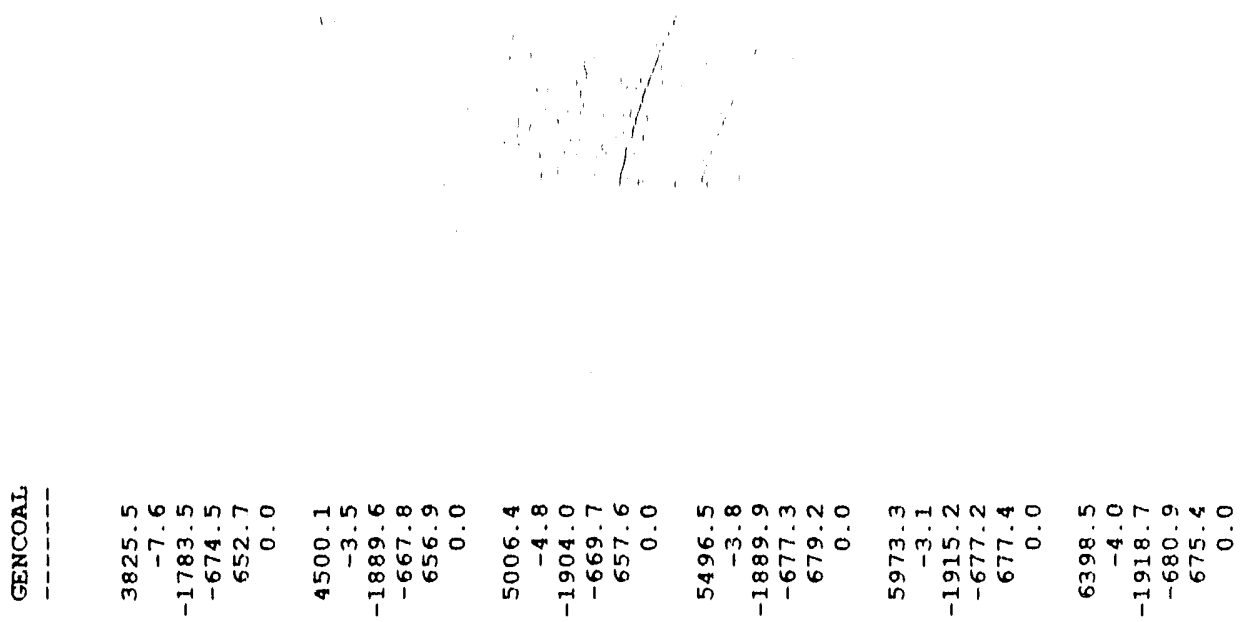

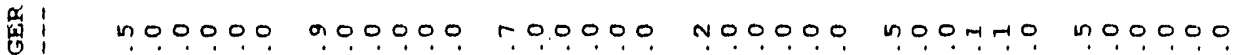

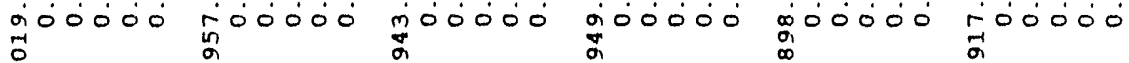
崖|

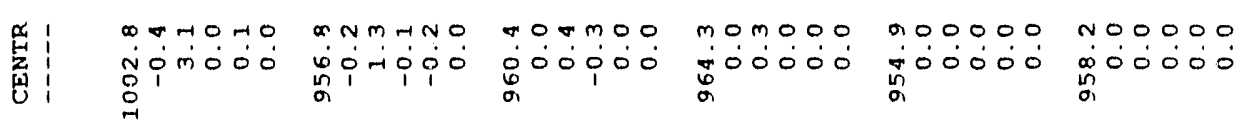

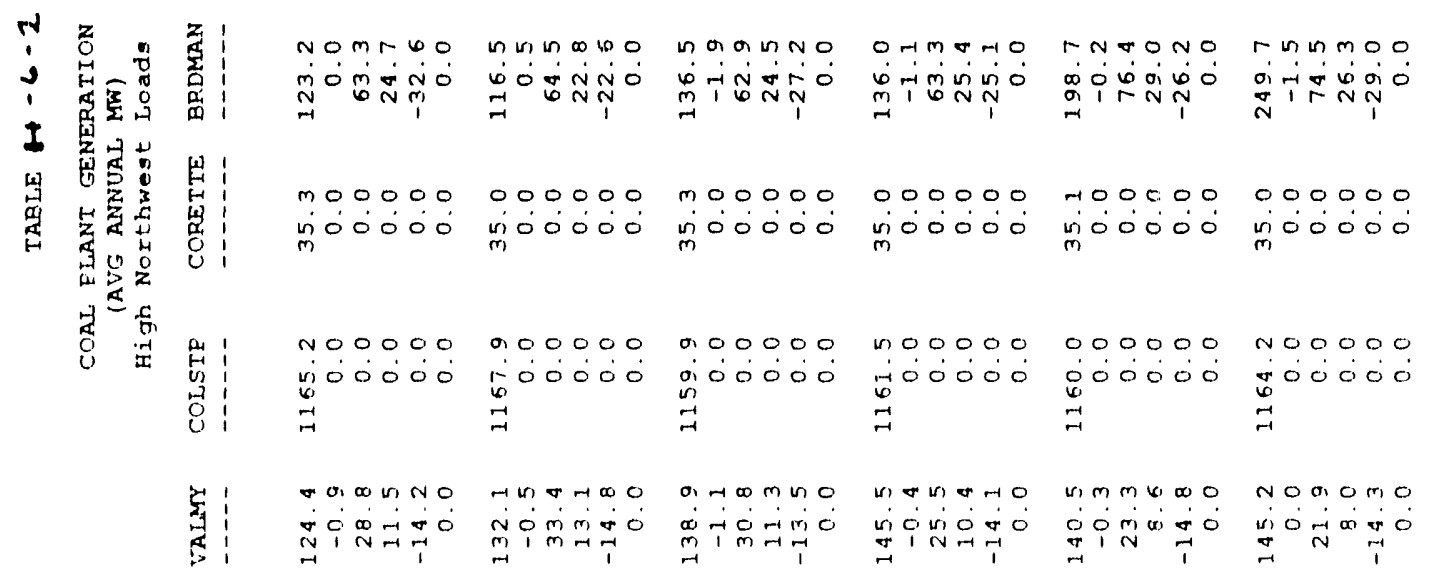

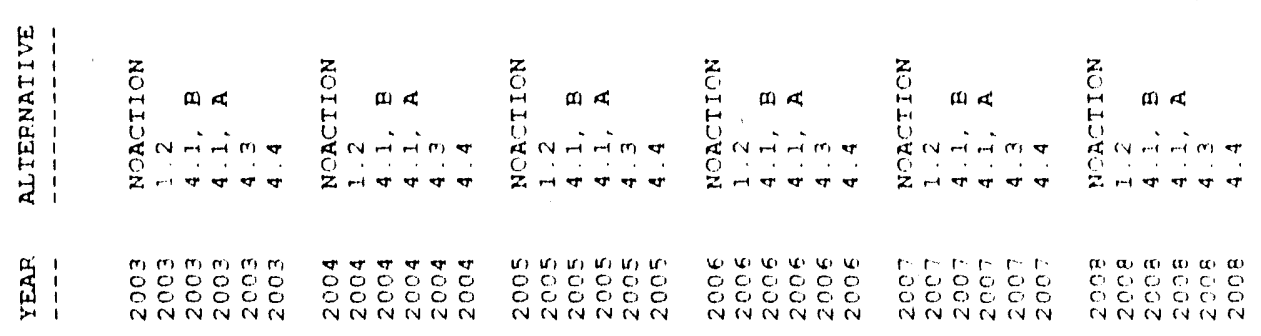




$$
H-7
$$

Air Quality Analysis--Coal and Combustion Turbine Plants 


\section{Combustion Turbine Air Quallty Analysis}

A methodology for analyzing alr quality impacts from changes in generation from existing combustion turbine factlities included in the SAM had not been developed for the Intertle Development and Use Environmental Impact statement. Changes in generation at existing combustion turbines were generally projected by SAM to be small and only the Beaver facility tended to be affected substantially.

An analysis of the Frederickson Combustion Turbine facility (Final Report: Economic Analysis of the Environmental Effects of the Fredrickson Combustion Turbine Electric Generator, ECO Northwest, 4/84, P. III-8) used a Gausstan plume model to project maximum impacts of alr pollutants from the plant. These impacts when firing natural gas were maximum nitrogen oxide concentrations of $0.016 \mathrm{\mu g} / \mathrm{m}^{3}$ and maximum particulate concentrations of $0.0014 \mathrm{\mu g} / \mathrm{m}^{3}$. When firing distillate fuel oll, maximum ambient concentrations were $0.014 \mu \mathrm{g} / \mathrm{m}^{3}$ for nitrogen oxides, $0.0014 \mu \mathrm{g} / \mathrm{m}^{3}$ for particulates, and $0.021 \mu \mathrm{g} / \mathrm{m}^{3}$ for sulfur dioxide. Average ground level concentrations were projected to be about one tenth of these values. Average concentrations were based on 1500 hours of operation per year, a plant factor of about 17 percent. All these concentrations were negligible when compared to ambient air quality standards.

A field measurement program using sulfur hexaflouride ( $S F_{6}$ ) as a tracer showed that ambient air concentrations of nitrogen oxides and sulfur dioxide from the Beaver combustion turbine facility, when operated in combined cycle mode, are far below the air quality regulatory standards (Air Quality Impact Study of Combined Cycle Operation at the Beaver Combustion Turbine Plant, Phase I: Summary of Field Measurement Programs, Portland General Electric, $12 / 80)$.

Since the above studies indicate that amblent concentrations of air pollutants from combustion turbine facilities are very small in comparison with air quality standards. It is unlikely that any but an extremely large change in annual generation would make any substantial difference in annual average concentrations of air pollutants. Maximum air quality impacts from each plant would not be affected by any of the alternatives since these could occur at any time any of the plants is operated at capacity coincident with adverse dispersion conditions. The combustion turbine plants are sufficiently phy:ically distanced from each other that cumulative effects from operating more than one plant simultaneously are not a concern.

Because of (1) the generally small changes in generation at the existing combustion turbine racilities; (2) the low levels of ambient air pollutant concentrations seemingly associated with these kinds of facilities: and (3) the fact that the only substantial changes occurred at the Beaver plant where there was documentation of the low air quality impacts, a methodology such as was used to compute ambient air quality changes for coal plants was not developed for the existing combustion turbine facilities. It was felt that computation of air quality changes, considering the inevitable compromises in computing such values, was not going to enable any better conclusions than those drawn directly, but more qualitatively, from the information above. 


\section{Coal Plant Air Quality Analysis}

The analysis to deterintne the effects on air quallty resulting from differences in existing coal plant generation betweem alternatives for which the Systems Analysis Model (SAM) was run used the methodology developed under contract to BPA by the Offlce of Applied Energy Studles, Washington state University (1987) for the Intertie Development and Use Environmental Impact statement. The following describes the derivation of this methodology as it applies to the existing coal-fired generating plants addressed by the analysis for the Power Sales Contract EIS.

Plume calculations were performed by the contractor using the PTDIS Gaussian plume model to determine maximum hourly $\mathrm{SO}_{2}$ and total suspended particulate (TSP) concentrations downwind of each source for a range of atmospheric stablility classes. Seasonal and annual average $\mathrm{SO}_{2}$ and particulate concentrations were calculated using the COMQC climatological Gausstan plume dispersion model along with the STAR data obtained from the National Climatic Center. All changes in concentration are presented as functions of annual average generation by each plant.

\section{PTDIS HOURLY CALCULATIONS}

PTDIS is a simple Gaussian plume model that calculates plume rise using Brigg's formulations, and estimates ground-level concentrations of nonreactive species at specifled distances downwind of a single source for a specifled wind speed, mixing height, and atmospheric stablility class.

PTDIS was used in a flat-terrain mode for all power plants to screen impacts and determine which are potentially significant.

Flat-terrain calculations were performed for six atmospheric stabllity classes ranging from unstable to stable, covering downwind distances out to $50 \mathrm{~km}$ from each power plant. Prelliminary calculations were used to identify best receptor spacing in order to bracket closely the location of maximum lmpact for each stablifty condition. Model runs yielded six maximum concentrations. The results of this work were maxtmum hourly concentrations of $\mathrm{SO}_{2}$ and TSP for each power plant.

\section{ANNUAL AVERAGE COMOC CALCULATIONS}

CDMQC employs a sector-averaged Gaussian plume algorithm to calculate long-term concentrations at specific receptors caused by single or multiple point and area sources. For each source-receptor pair, the model determines the concentration assoclated with each possible combination of six wind speed classes, six stability classes, and 16 wind direction sectors. These concentrations are then weighted and summed by the joint meteorological frequency distribution contai ied in the STAR data to give a single long-term average concentration. The impacts of multiple sources are summed to give the total impact at a receptor.

In applying COMQC to specific power plants, results for each source were obtained at an array of receptors covering all wind directions at several downwind distances. 
The primary indicator of annual alr quality is the maximum annual average concentration predicted within the array of receptors. Sulfate concentrations were estimated using COMDC, assuming a first-order sulfur dioxide-to-sulfate $\mathrm{SO}_{2}$ to $\mathrm{SO}_{4}$ ) conversion rate of 1 percent per hour. The converston rate was derlved from current literature reporting field and laboratory measurements of sulfur dloxide-.sulfate chemistry in atmospherlc plumes.

\section{MODEL INPUT}

Stack parameters, emission loadings per unit of thermal output, and other source data have been obtained from EPA regional offlces, local alr pollution control districts, and utflity companles for each of the selected power plants. Thermal loadings were combined with the operatlonal levels predicted for various alternatives and assumptions concerning size of loads and gas prices to yield pollutant emission rates for each plant and for each combination of alternative and assumptions. Model input data are shown in Table $\mathrm{H}-7-1$.

Table $H-7-1$

MODEL INPUT DATA

\begin{tabular}{|c|c|c|c|c|c|c|c|}
\hline Power Plant & $\begin{array}{l}\text { Stack } \\
\text { Hejght } \\
(\mathrm{m})\end{array}$ & $\begin{array}{c}\text { Stack } \\
\text { Diameter } \\
(\mathrm{m})\end{array}$ & $\begin{array}{c}\text { Exhaust } \\
\text { Temp. } \\
\text { (K) }\end{array}$ & $\begin{array}{c}\text { Exit } \\
\text { Velocity } \\
(\mathrm{m} / \mathrm{s})\end{array}$ & \multicolumn{2}{|c|}{$\begin{array}{c}\text { Emission } \\
\text { Factor } \\
\text { (1b./MMBTU) }\end{array}$} & $\begin{array}{l}\text { Star Data } \\
\text { Location }\end{array}$ \\
\hline & & & & & & & \multirow{3}{*}{ Olympia, WA } \\
\hline \multirow[t]{2}{*}{ Centralla } & 152 & 4.3 & 388 & 33 & 1.695 & 0.00 & \\
\hline & 152 & 4.3 & 388 & 33 & 1.695 & 0.030 & \\
\hline \multirow{3}{*}{$\begin{array}{l}\text { Boardiman } \\
\text { Valmy }\end{array}$} & 200 & 6.8 & 422 & 37 & 0.780 & 0.060 & \multirow{3}{*}{$\begin{array}{l}\text { Spokane, WA } \\
\text { Lovelock, NV }\end{array}$} \\
\hline & 152 & 5.8 & 405 & 19 & 0.630 & 0.010 & \\
\hline & 139 & 5.2 & 359 & 23 & 0.120 & 0.010 & \\
\hline \multirow[t]{3}{*}{ Colstrip } & 152 & 5.0 & 366 & 32 & 0.120 & 0.040 & \multirow[t]{3}{*}{ Custer, MT } \\
\hline & 152 & 5.0 & 366 & 32 & 0.290 & 0.040 & \\
\hline & 211 & 7.3 & 372 & 32 & 0.070 & 0.050 & \\
\hline \multirow[t]{4}{*}{ Bridger } & 152 & 7.3 & 325 & 22 & 0.300 & 0.100 & \multirow[t]{4}{*}{ Rock Springs, W } \\
\hline & 152 & 7.3 & 325 & 22 & 0.300 & 0.100 & \\
\hline & 152 & 7.3 & 325 & 22 & 0.300 & 0.100 & \\
\hline & 152 & 9.4 & 325 & 17 & 0.200 & 0.100 & \\
\hline
\end{tabular}

Sources: Private communications with plant personnel and CFM-VI reports.

\section{MODEL OUTPUT}

The primary model output is impact coefficients defined in terms of $\mathrm{SO}_{2}$ and TSP concentrations per unit pollutant emission rate. The coefficients derived from tha model are shown in Table $H_{-7-2}$. Because ambient pollutant concentration is a linear function of emission rate, these lmpact coefficients can then b? used to determine changes in ambient pollutant concentration related to each alternative and set of assumptions. The results of the analysi: of air quality impacts, developed through applying the coefficients from the liodel to generation levels or changes in generation, for each 
alternative are shown in a comparative manner for the assumptions of expected loads and gas prlces and high Nortliwest loads in Tables H-7-3 and 4 . (Each page of each of these Tables is for a different year of the analys/s. The values given for "No Action" for each plant are actual projected amblent alr. pollutant concentration values derlved using the methodology described above. Values given for each other alternative by plant are differences for that alternative from the amblent atr pollutant concentration given above it by plant for "No Action".)

Atr qualtty lmpacts were stmilarly determined for other assumpt tons (sensttivities) for each alternative analyzed with SAM. These other sensitivity assumptions were: (1) low Northwest loads; (2) high Southwest loads; (3) low Southwest loads; (4) high gas price; and (5) low gas price. Air quality data like that in Tables $H-7-3$ and 4 for these other assumptions w 111 be provided upon request.

\section{Table H-7-2 \\ PACIFIC NORTHWEST \\ AIR QUALITY CALCULATION FORMULAS}

\begin{tabular}{|c|c|c|c|}
\hline \multicolumn{4}{|c|}{ Centralia } \\
\hline \multirow{2}{*}{\multicolumn{2}{|c|}{$\begin{array}{l}\text { SO2MAX } \\
\text { TSPAX }\end{array}$}} & $=$ & MWs $\star 1.0940$ \\
\hline & & $=$ & MWs * 0.0179 \\
\hline \multicolumn{2}{|c|}{ TSPMAX $=$} & MWS & $\star 0.005714$ \\
\hline SO4 & $=$ & MWS & $\star 0.0000136$ \\
\hline TSP & $=$ & MWs & $\star 0.00009529+\mathrm{SO} 4$ \\
\hline \multicolumn{4}{|c|}{ Boardman } \\
\hline \multicolumn{2}{|c|}{ SO2MAX } & $=$ & MWs * 0.2825 \\
\hline \multicolumn{2}{|c|}{ TSPMAX } & $=$ & $\mathrm{MWs} \star 0.0215$ \\
\hline 502 & $=$ & MWs & $\star 0.0005882$ \\
\hline SOL & $=$ & iw's & $\star 0.00000159$ \\
\hline TSP & $=$ & WWS & $* 0.00005348+504$ \\
\hline \multicolumn{4}{|c|}{ Colstrip } \\
\hline \multicolumn{2}{|c|}{ SO2MAX } & $=$ & MWs *0.0963 \\
\hline \multicolumn{2}{|c|}{ TSPMAX } & $=$ & MWs *0.0259 \\
\hline SO2 & $=$ & MWs & $\star 0.0004401$ \\
\hline 500 & $=$ & MWS & $* 0.00000094$ \\
\hline TSP & $=$ & MWS & $* 0.00009243+504$ \\
\hline \multicolumn{4}{|c|}{ Bridger } \\
\hline \multicolumn{2}{|c|}{ SO2MAX } & $=$ & MWs ${ }^{*} 0.2065$ \\
\hline \multicolumn{2}{|c|}{ TSPMAX } & $=$ & MWs * 0.0745 \\
\hline 502 & $=$ & MWS & $\star 0.001819$ \\
\hline 506 & $=$ & MWs & $\star 0.00000416$ \\
\hline TSP & $=$ & MWs & $\star 0.0006391+504$ \\
\hline \multicolumn{4}{|c|}{ Valiny } \\
\hline \multicolumn{2}{|c|}{$502 \mathrm{MA} X$} & & MWs *0.2186 \\
\hline \multicolumn{2}{|c|}{ TSPMAX } & & MWs *0.0057 \\
\hline 502 & $=$ & MWs & $\star 0.001696$ \\
\hline 504 & $=$ & MWs & *0.00000522. \\
\hline TSP & $=$ & MWS & $* 0.00005221+504$ \\
\hline
\end{tabular}




\section{LIMITS OF UNCERTAINTY IN AIR QUALITY ANALYSES}

\section{Gausslan Plume Calculations}

Both the maxtmum 1-hour average concentrations and the maxfmum annual average concentrations for $\mathrm{SO}_{2}, \mathrm{SO}_{4}$, and TSP were calculated using Gausstan plume models for point sources. As a result, both sets of calculations are restrlcted by the inherent uncertalnties assoctated with using a ciausian plume model of atmospherlc transport and diffuslon. These uncertalntles arlse from the assumptions of homogeneous, stattonary turbulence; steady-state conditions; and constant wind speed in the model and from the use of emplrical but nonslte specific diffuston coefflctents. It is generally assumed that these uncertalnties, under the best of conditions, limit the accuracy of a Gaussian plume calculation to approximately a factor of two.

Additional limitations to the accuracy of the results are introduced in both short-term and long-term calculations for power plants located in rough terrain. Nelther PTDIS (short-term) nor CDM (long-term) account for the effects of complex terraln. These effects generally firply that during stable conditions high surface concentrations may result from impingement of a plume upon a terrain obstacle, while during unstable or neutral conditions, the plume may pass closer to the surface than predicted for a simllar flat terrain case. The Complex Terraln Disperston Model (CTDM) now under development by EPA is designed to address the stable and neutral cases, but it was not avallable to the contractor in developing this methodology. Unfortunately, it is not possible to assign a level of uncertalnty for the effects of complex terrain since the results are extremely site dependent.

Other factors which affect the accuracy of the calculations include posstble errors in einlssion data; the use of STAR meteorological data from National Weather service sites located too far from the power plants of concern; the assumption of a 1 percent per hour flrst order conversion rate of $\mathrm{SO}_{2}$ to $\mathrm{SO}_{4}$; and the assumption that wet and dry deposition are negligible withtn the transport distance to the maximum receptor. The end result of all of these uncertainties is that the alr quality lmpact cannot be estimated to be more accurate than a factor of two in the best circumstances and in cases with complicating features the uncertalnty probably increases substantially. 


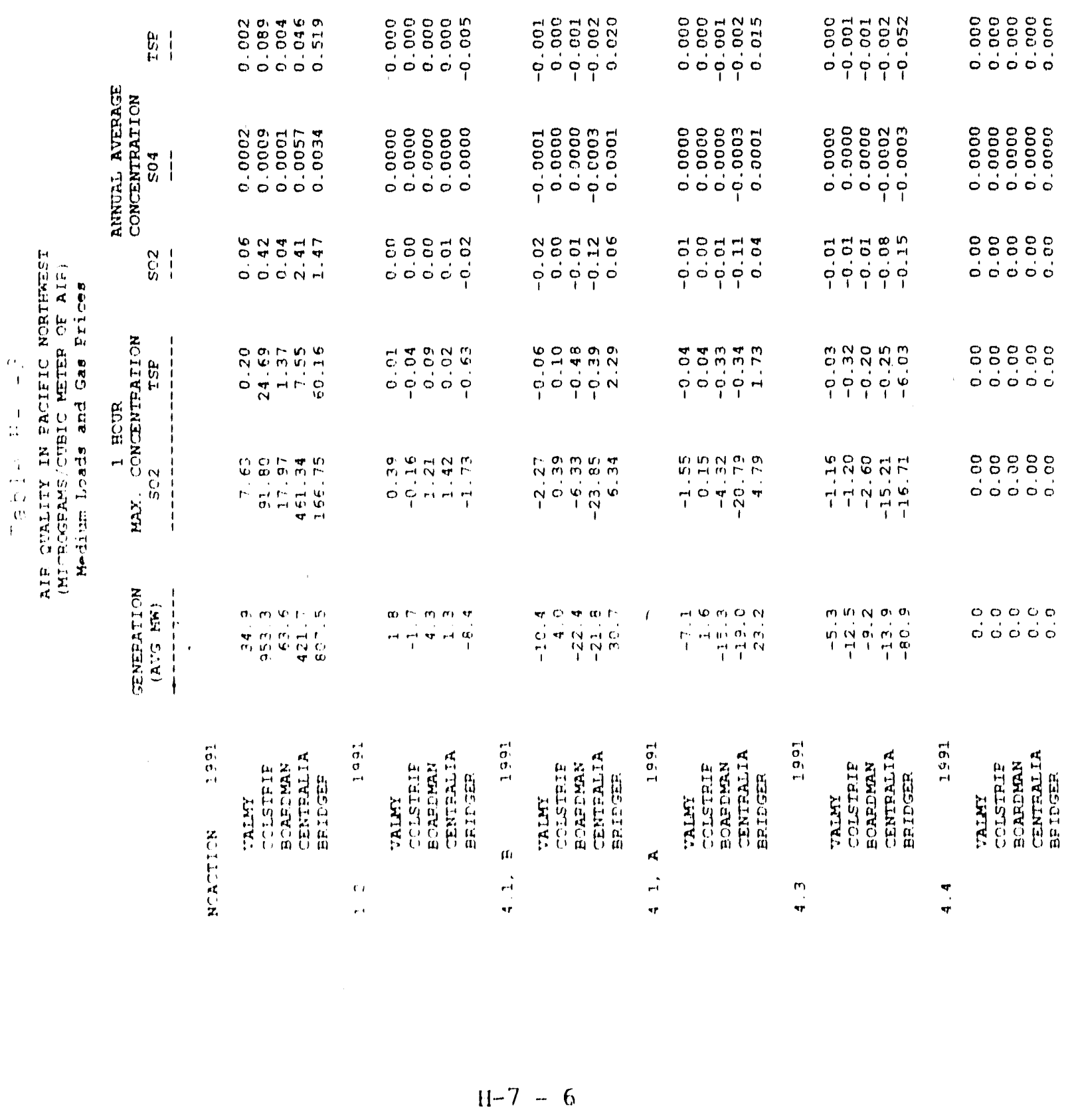




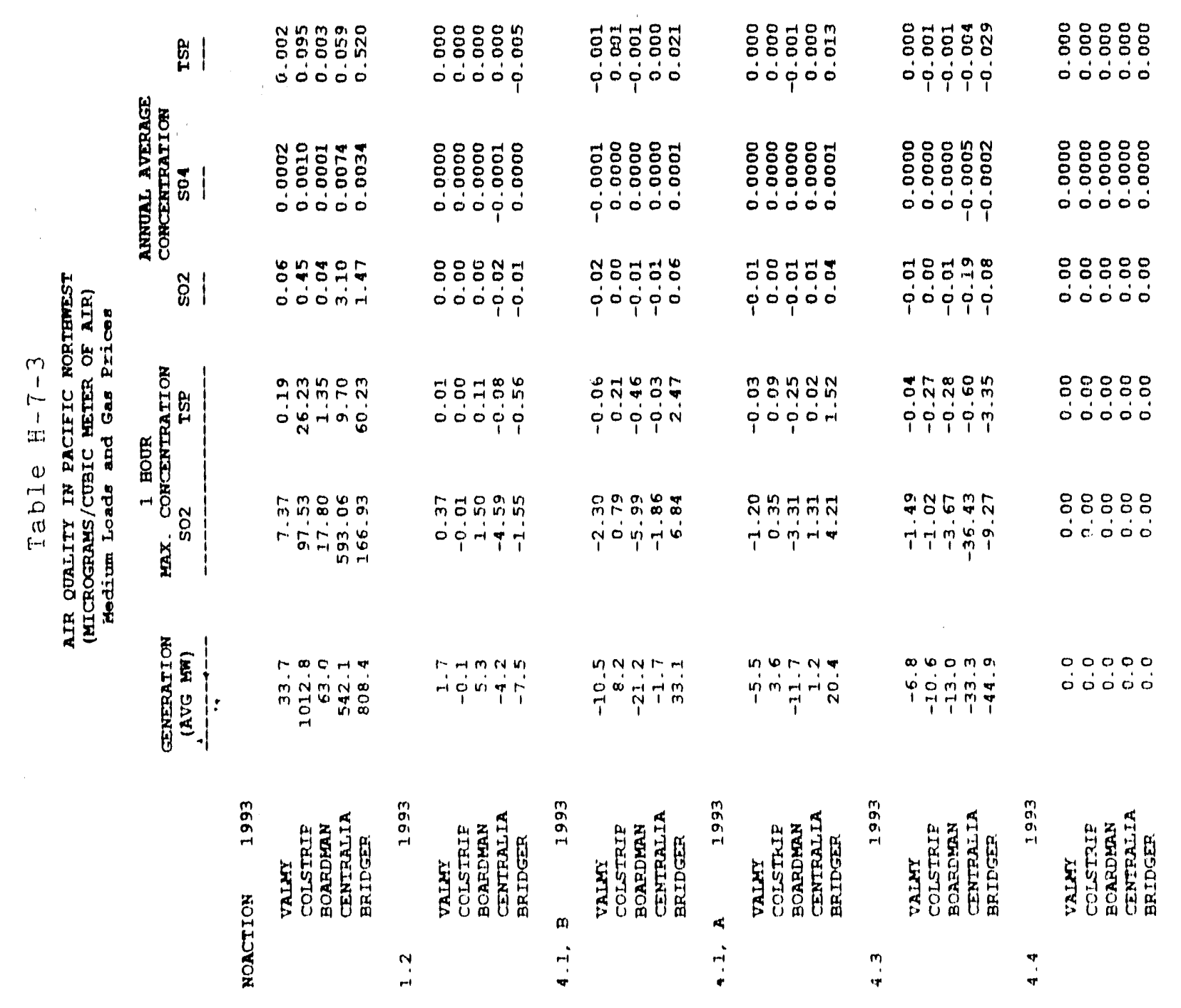

$\mathrm{H}-\mathrm{7}-\mathrm{T}$ 


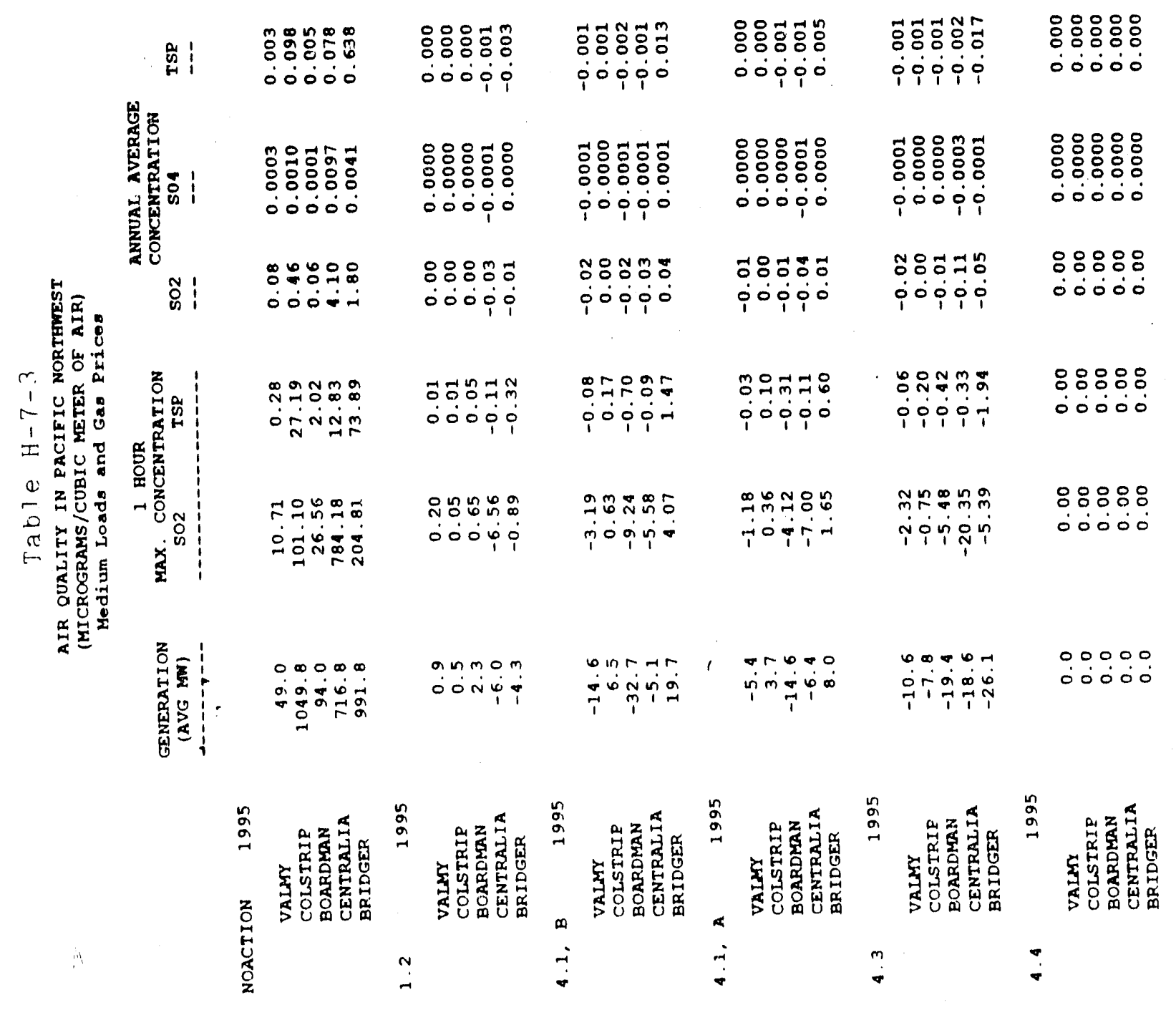

$\mathrm{H}-7-8$ 


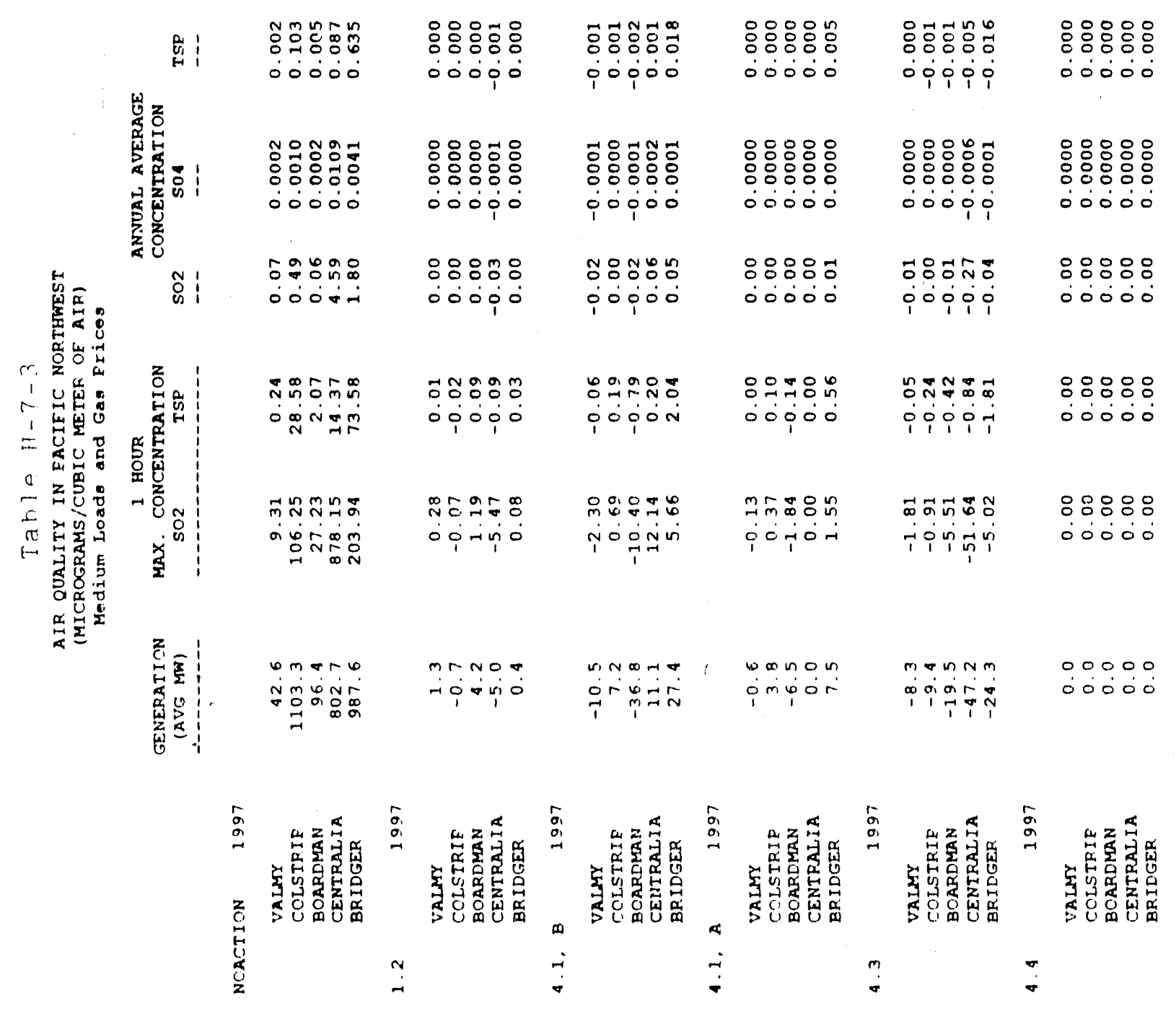




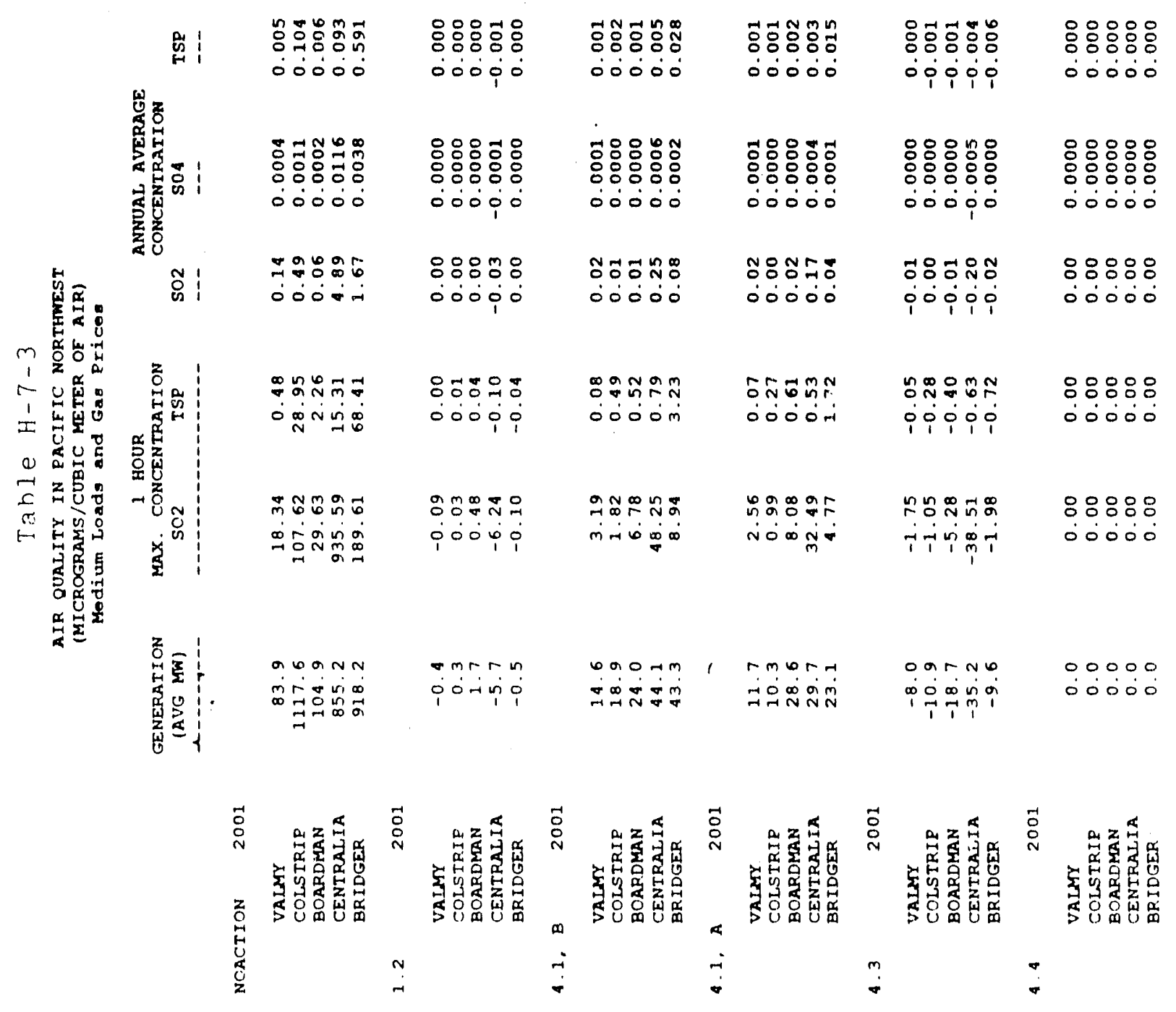

$\mathrm{H}-7-10$ 


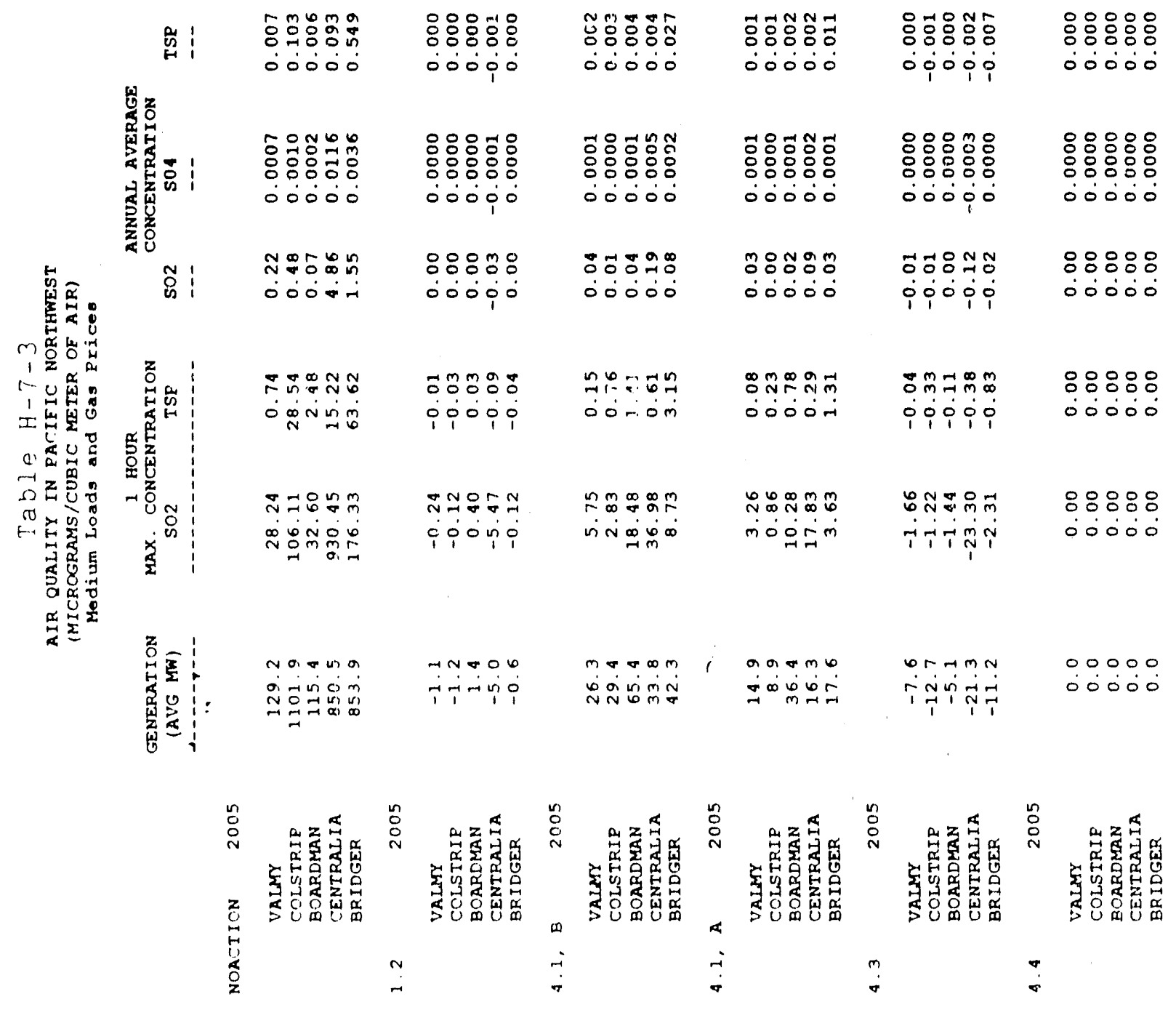




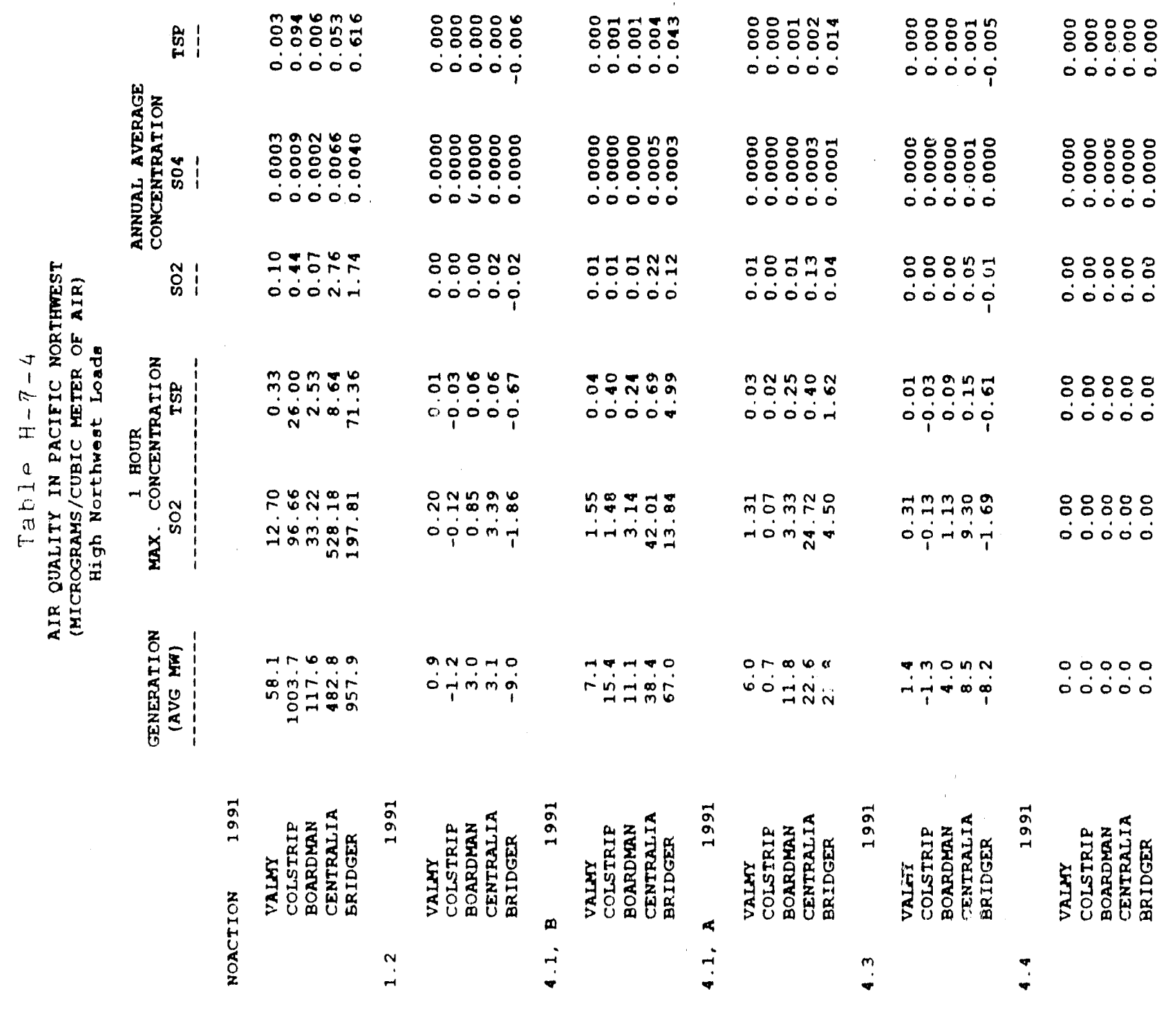




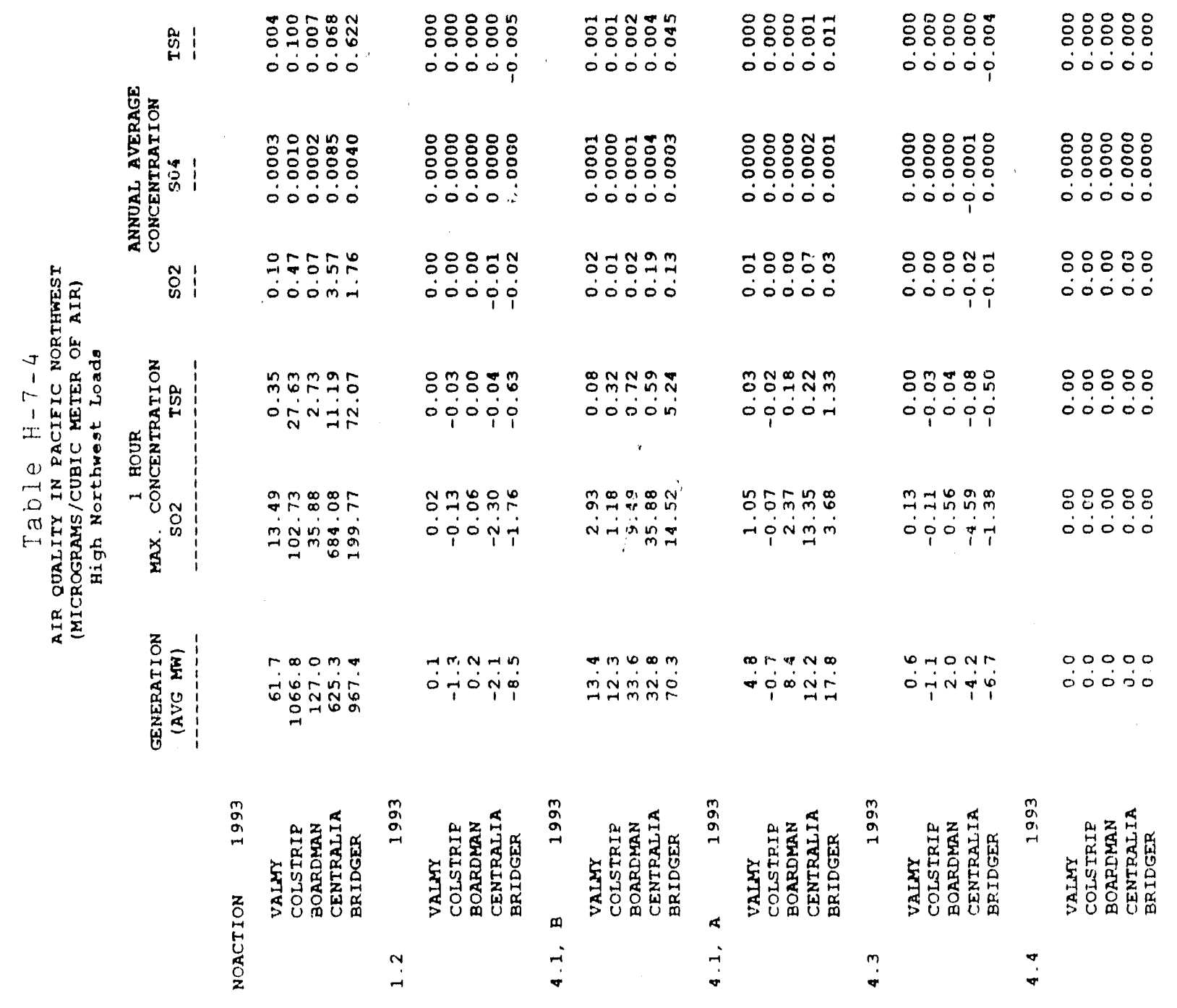




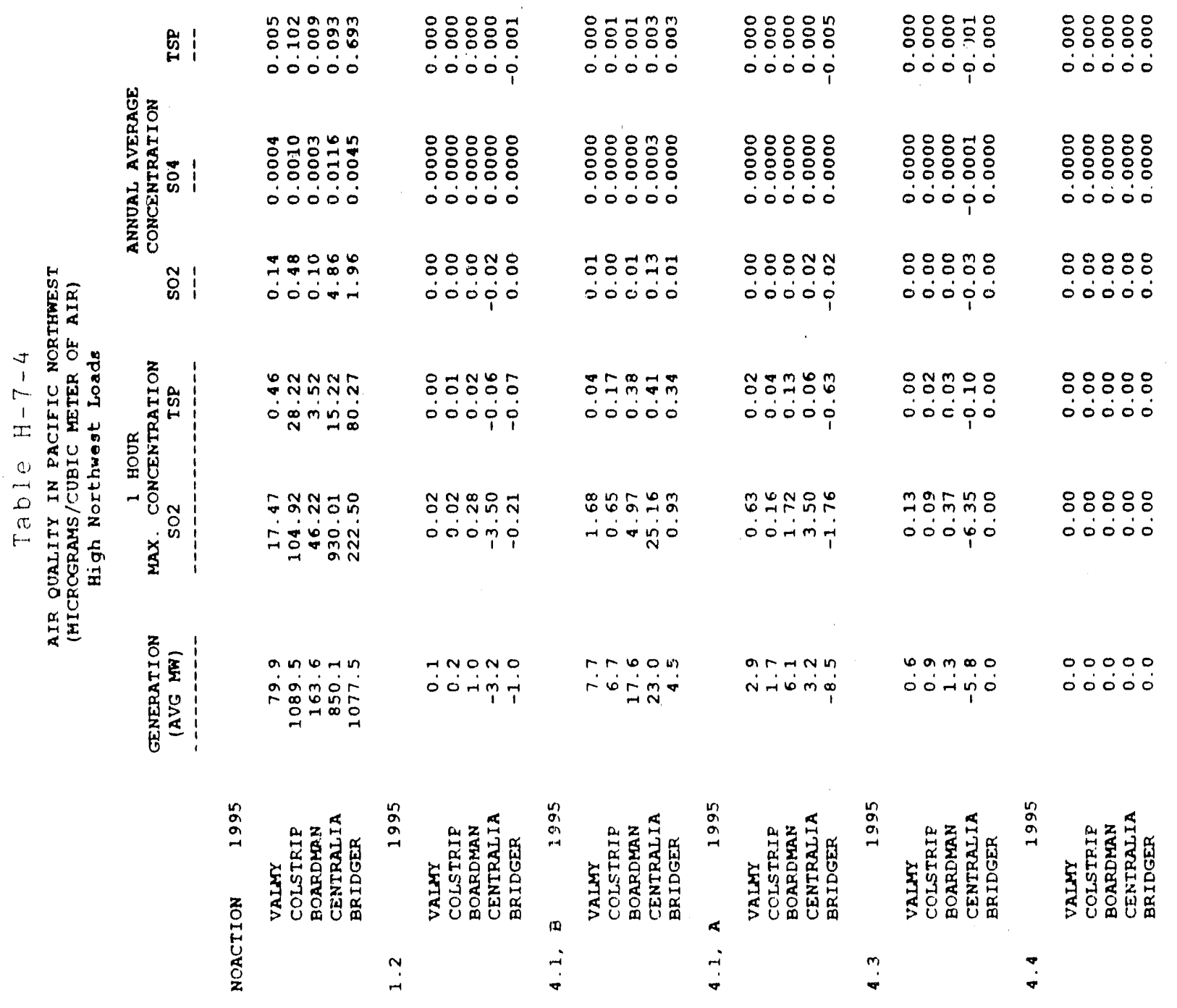




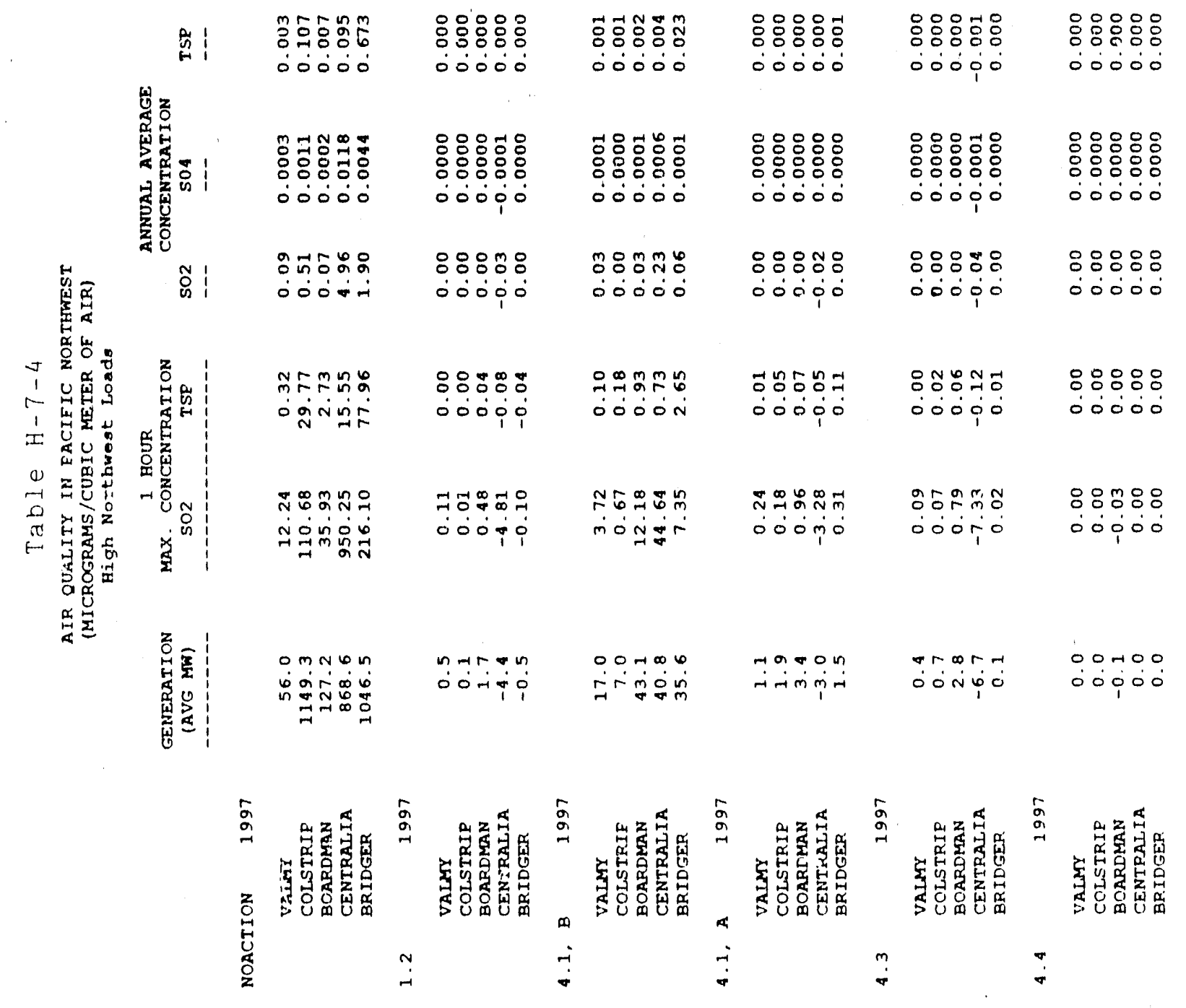




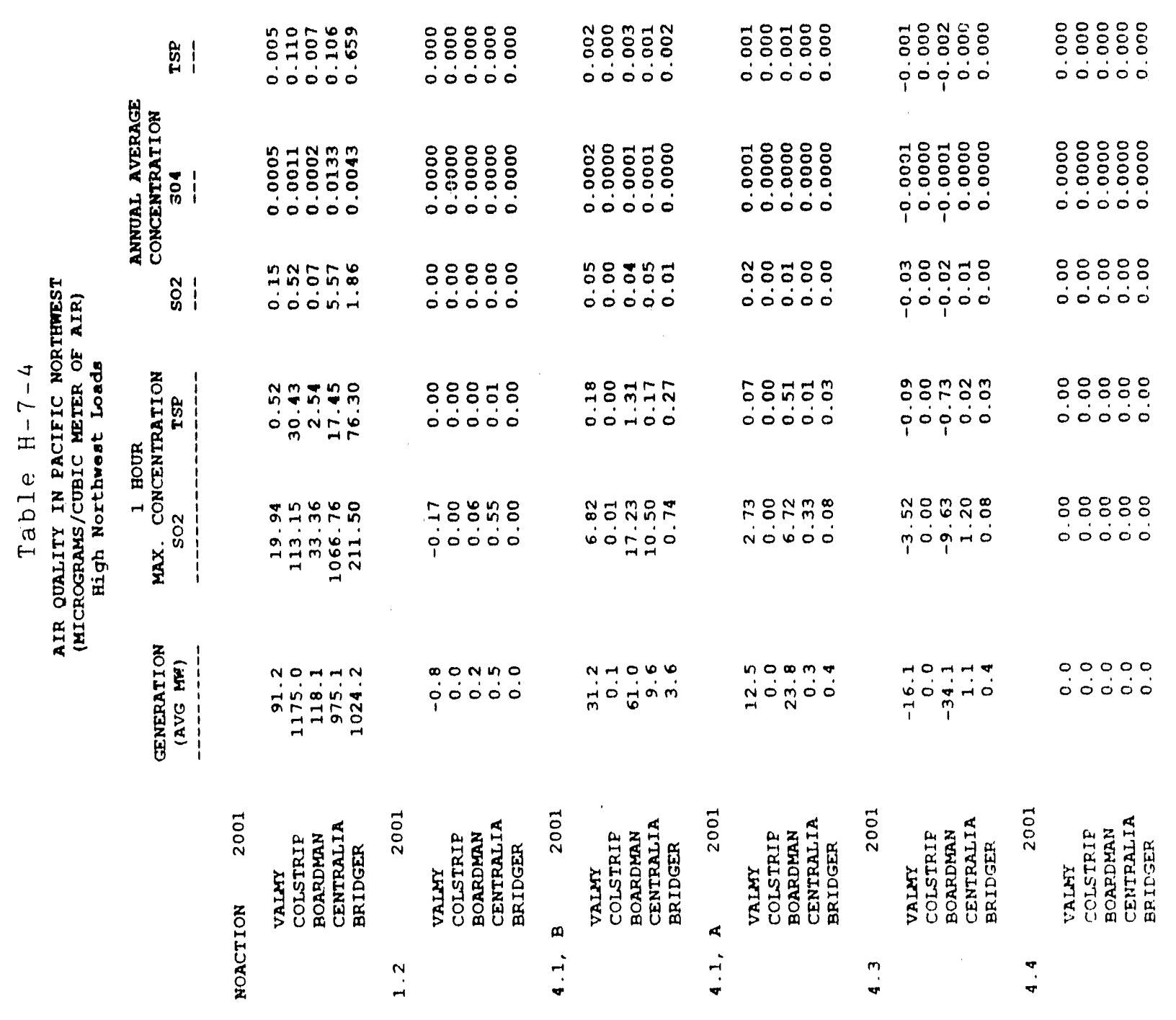

$\mathrm{H}-7-16$ 


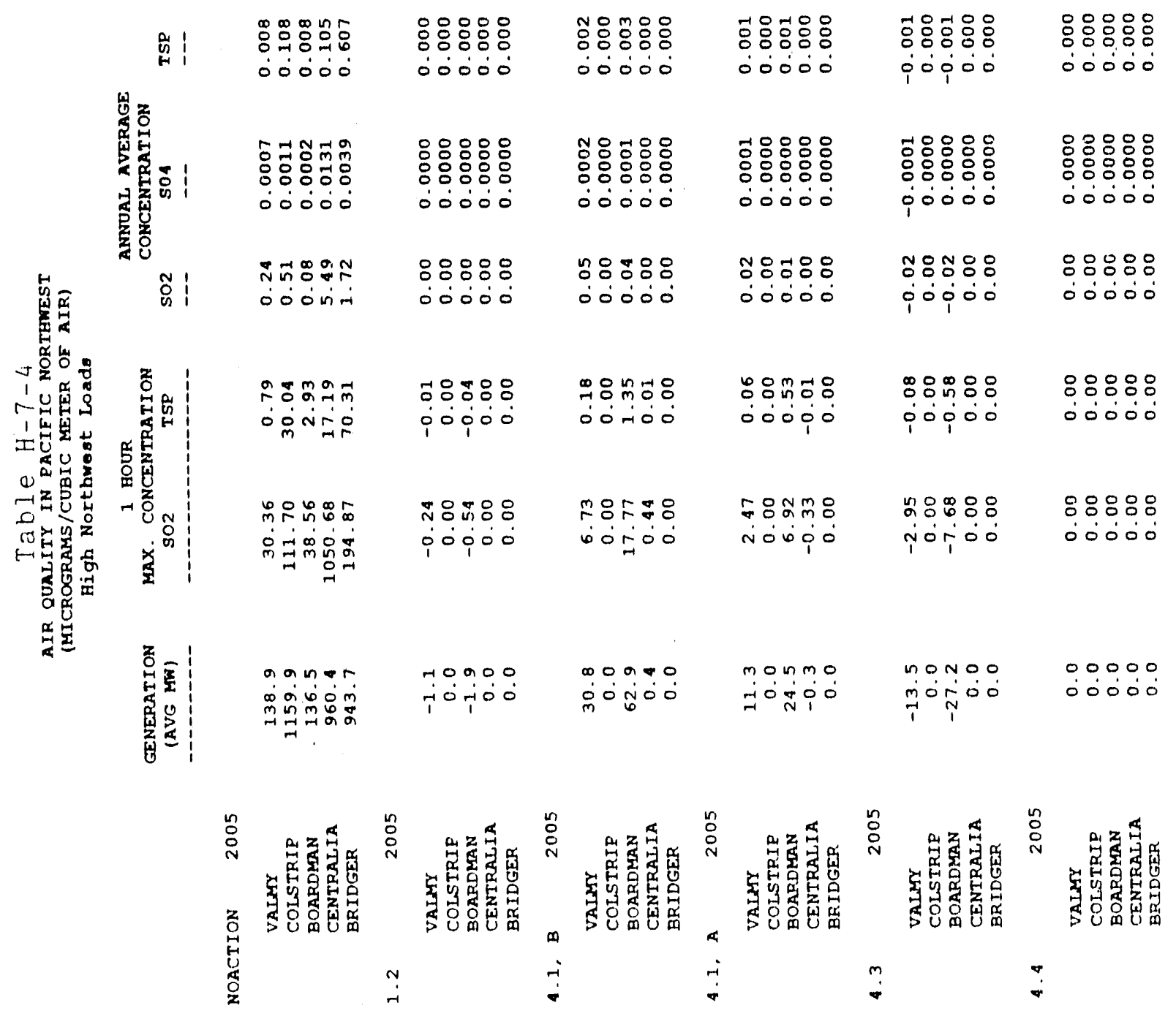


H-8

Coal Consumption, Land Use, and Water Consumption Impacts Related to Operation of Existing Coal-Fired Generating Plants 


\section{Coal Mining and Coal-Fired Generation}

Impacts of coal mining, processing and transportation, as well as impacts of the construction and operation of coal...fired generating plants in general are described in Appendices F and H-1b. This discussion is intended to present information pertinent to the specific, existing coal-flred generating plants addressed in the analyses of alternatives performed with the Systems Analys is Model (SAM). Since the changes in generation among alternatives for the Corette plant were small and the plant itself is quite small, an andysis of coal use, land use, and water consumption impacts was not performed for this plant.

Over half the nation's demonstrated coal reserves 1 les west of the Mississippi River, mostly in the nortinern Great Plains and Rocky Mountain provinces (Table H-8...1). Coal resources in these areas have several common characteristics: the Federal government owns most of the coal lands; competition for surface land use is relatively low; much of the coal is near the surface and can be easily strip-mined; the coal has a low energy value and a low sulfur content; and water resources in mining areas are scarce. In Wyoming and Montana, conditions for surface mining approach the ideal, with coal seams 50-75 feet thick and overburdens 30-50 feet thick. Over 90 percent of Western coal is mined at the surface (Offlce of Technology Assessment, 1979), and the majority of Western strip-mines have been open since the late 1960s.

Table $H-8-1$

\section{DEMONSTRATED COAL RESERVE BASE FOR SELECTED WESTERN STATES (Millions of Short Tons)}

\begin{tabular}{lcrrrr}
\multicolumn{1}{c}{ State } & $\begin{array}{c}\text { Mining } \\
\text { Method }\end{array}$ & Bituminous & Subbituminous & Lignite & $\begin{array}{r}\text { Total } \\
\text { Tonnage }\end{array}$ \\
\cline { 2 - 5 } & Surface & 281 & 0 & 0 & 281 \\
Arizona & Surface & 0 & 33,625 & 15.765 & 49,390 \\
Montand & Surface & 815 & 1,758 & 0 & 2,573 \\
New Mexico & 0 & 129 & 9 & 138 \\
Washington & Surface & 548 & 26,564 & 0 & 27,112 \\
Wyoming & Surface & 548 & &
\end{tabular}

Sources: National Coal Association, "l983 Facts About Coal" (Washington, D.C.: National Coal Association, 1983).

Office of Coal/Nuclear Electric Power and Alternative Fuels, Energy Information Administration, U.S. Department of Energy.

Table H--8-2 shows 1980-1984 coal receipts for PNW power plants. Although plants usually stockpile coal for future use, these receipts provide a relatively accurate measure of annual amounts of coal burned per individual power plant. Receipts represent cod use for all units currently operating at a generating station. 
Table $\mathrm{H}-8-2$

COAL RECEIPTS AT PACIFIC NORTHWEST POWER PLANTS

(tons)

\begin{tabular}{lrrrrrr} 
Power Plant & \multicolumn{6}{c}{ Year } \\
\cline { 2 - 4 } Boardman & $1,075,000$ & $1,164,000$ & $1,135,000$ & 1983 & & 1984 \\
Centralia & $4,00,000$ & $4,400,000$ & $4,400,000$ & $3,600,000$ & $3,600,000$ \\
Colstrip & $2,542,000$ & $2,692,000$ & $2,103,000$ & $1,499,000$ & $4,552,000$ \\
Bridger & $5,839,000$ & $6,449,000$ & $6,025,000$ & $4,317,000$ & $4,462,000$ \\
Valmy & 0 & 337,000 & 716,000 & 822,000 & 635,000
\end{tabular}

Sources: Energy Information Administration, U.S. Dept. of Energy, "Cost and Quality of Fuels for Electric Utility Plants, "U.S. Department of Energy, Washington, D.C., 1981-1985.

Table H-8-3 identifies surface coal mines serving coal-fired power plants addressed in the EIS. Several of these mines provide coal to more than one power plant; therefore, tonnage figures for individual mines do not necessarily indicate production dedicated to a single station. For example, mines in Campbell County, Wyoming, supply coal to local plants as well as to the Boardman unit in Oregon. In contrast, the Centralia mine, in Washington State, supplies only the Centralia units.

\section{Table $\mathrm{H}-8-3$}

\section{COAL MINING ACTIVITIES RELATED TO PACIFIC NORTHWEST POWER PLANTS}

\begin{tabular}{|c|c|c|c|c|c|c|c|}
\hline \multirow{2}{*}{$\begin{array}{l}\text { Power } \\
\text { Plant }\end{array}$} & \multirow{2}{*}{$\begin{array}{c}\text { Location } \\
\text { of Fue } 1 \\
\text { Source } \\
\end{array}$} & \multirow[b]{2}{*}{ Mine } & \multirow{2}{*}{$\begin{array}{l}\text { Over- } \\
\text { burden } \\
\text { (feet) }\end{array}$} & \multirow{2}{*}{$\begin{array}{l}\text { Ratio } \\
\text { (Cover/ } \\
\text { Coal) } \\
\end{array}$} & \multicolumn{3}{|c|}{ Tons Mined } \\
\hline & & & & & 1982 & 1983 & 1984 \\
\hline Boardman & Campbe 11, WY & Belle Ayre & 98 & $1.3: 1$ & $15,161,298$ & $13,825,242$ & $13,417,442$ \\
\hline Centralia & Lewis, WA & Centralia & 250 & $8: 1$ & $4,200,00$ & $4,120,000$ & $3,690,000$ \\
\hline Colstrip & Rosebua', MT & Rosebud & 150 & $4: 1$ & $9,446,905$ & $9,564,905$ & $11,907,099$ \\
\hline $\begin{array}{l}\text { Jim } \\
\text { Bridger }\end{array}$ & $\begin{array}{l}\text { Swee twater, } \\
\text { WY }\end{array}$ & Bridger & 120 & $6: 1$ & $6,100,00$ & $4,300,000$ & $4,300,000$ \\
\hline Valmy & Humbolt, UT & Underground & $d-\ldots$ & -- & $-\cdots$ & -- & -- \\
\hline $\begin{array}{l}\text { Source: } \\
\text { Note: }\end{array}$ & $\begin{array}{l}\text { eystone coal } \\
\text { Inderground min } \\
\text { hey do not cor } \\
\text { iines do. }\end{array}$ & $\begin{array}{l}\text { idustry Manu } \\
\text { s are shown } \\
\text { ribute to } 1\end{array}$ & $\begin{array}{l}\text { ual, } 19 \\
\text { n by na } \\
\text { land di }\end{array}$ & $\begin{array}{l}983-1985 \\
\text { ame and } \\
\text { isturban }\end{array}$ & $\begin{array}{l}\text { location for } \\
\text { ice to the ex }\end{array}$ & $\begin{array}{l}r \text { completene } \\
\text { xtent that }\end{array}$ & $\begin{array}{l}\text { ss but } \\
\text { urface }\end{array}$ \\
\hline
\end{tabular}


Table H-8-4 shows past and present reclamation efforts associated with coal plants in the $\mathrm{CNW}$. The values shown for land disturbed represent only those acres affected by direct coal removal, and do not include other land-use activities such as roads and power line corridors. The ratio of tons extracted to total land disrupted is a function of coal seam thickness and mining methods used.

Table $H-8-4$

\section{COAL SURFACE MINING LAND RECLAMATION ACTIVITIES RELATED TO PACIFIC NORTHWEST POWER PLANTS}

\begin{tabular}{llccr} 
Power Plant & Mine & $\begin{array}{c}\text { Coal Mined } \\
\text { BY Oct 86 I/ } \\
\text { (tons) }\end{array}$ & $\begin{array}{c}\text { Total Land } \\
\text { Disturbed 2/ } \\
\text { (acres) }\end{array}$ & $\begin{array}{r}\text { Total Land } \\
\text { Reclaimed } \\
\text { (acres) }\end{array}$ \\
\hline Boardman & Belle Ayre & $136,013,303$ & 2,316 & 451 \\
Centralia & Centralia & $54,453,000$ & 3,200 & 1,946 \\
Colstrip & Rosebud & $118,456,701$ & 2,087 & 1,166 \\
JimBridger & Bridger & $57,236,000$ & 3,800 &
\end{tabular}

Sources: Personal communication with office of Surface Mining staff, U.S. Dept of the Interior, Denver, Colorado, December 1985-January 1986.

Personal communication with Land Quality staff, Wyoming Dept. of Environmental Quality, December 1985-January 1986.

Personal communication with Mining and Minerals Division staff, New Mexico Dept. of Energy and Minerals, January 1986.

Personal communication with Manager of Permitting, Washington Irrigation and Development Company, January 1986.

I/ Tonnage mined to date is an approximate figure based on available references. None of the figures provided include tonnage mined prior to 1972. Figures for Belle Ayre and Bridger extend through 1985; for Centralia and Rosebud through 1984.

2/ Does not include land used for facilities, road, or power line corridor.

3/ Includes land in all reclamation phases.

\section{Analys is of Coal, Land, and Water Use for Existing Coal Plant:s Included in SAM}

For BPA's Intertie Development and Use Environmental Impact Statement (EIS), the Office of Applied Energy Studies at Washington State University (1987) developed coefficients under contract to BPA for use in relating electrical generation at coal-fired power plants to requirements for fuel, cooling water, and to land disturbance by strip mining operations. These same coefficients were used in this EIS to assess coal consumption, water use, and land use impacts related to coal plants. 
Coal Use Coefficients: The steps followed to derive the coal use coefficient (amount of coal used per unit of electricity generated, e.g., tons of coal/MWh) at each power plant were: (1) relate MWh generation to heat requirements using plant heat rates and then; (2) relate heat requirements to fuel requirements using heating values of the coal in use at the piant. The sources used to obtain these data included publications of the U.S. Energy Information Administration ("Cost and Quality of Fuels for Electric Utility Plants" and "Historical Plant Cost and Annual Production Expenses for Selected Electric Plants" various years). Formulae for determining changes in fuel use using the coefficients so derived are reported in Table $\mathrm{H}-8-5$.

Table H-8-5

\section{FORMULAE FOR CALCULATING COAL USE CHANGES ASSOCIATED WTIH CHANGES IN ANNUAL GENERATION FOR PACIFIC NORTHWEST COAL PLANTS (Results in units of 1,000 's of tons of coal)}

\begin{tabular}{|c|c|}
\hline Valmy & MWs \\
\hline Colstrip & MWS \\
\hline Boardman & MWS \\
\hline ntralia & MWS \\
\hline Bridger & MWs \\
\hline
\end{tabular}

Land Disturbance Coefficients: These coefficients were used to determine land disturbance associated with surface coal mining to supply coal-fired power plants serving the Pacific Northwest. The units are acres/MWh. The assumption is made that the disturbed acreage increases at the rate at which the amount of coal mined increases. Mining from thin coal seams will produce more disturbance per MWh than mining from thick seams. The data used to derive these coefficients came from various sources. Some were obtained from the mine operators, some from a proprietary data collection of the contractor, and some from the Keystone coal Industry Manual published annually by McGraw-Hill. The tons per acre of coal mined was obtained directly in some cases, but in others it was derived from the overburden thickness and overburden ratio together with the density of the coal. Formulae for the calculation of changes in land disturbance at surface coal mines are shown in Table $\mathrm{H}-8-6$.

Table H-8-6

FORMULAE FOR DETERMINING LAND DISTURBANCE CHANGES AT COAL MINES ASSOCIATED WITH CHANGES IN ANNUAL GENERATION FOR PACIFIC NORTHWEST PLANTS

(Results in acres per year; coal use values derived using the formulae in Table H-8-5)

Valmy

Colstrip

Boardman

Centralia

Bridger
Underground Mine - Not Applicable

Coal Use E 53.592

Coal Use E 58.722

Coal Use E 17.017

Coal Use E 15.062 
Water Use Coefficients: The coefficients used are presented in Table H-8-7. They were derived from data in Thomas, J. L., 1975, Water Requirements and Wastewater Potential of Coal-Energy Facilitles (In Montana Academy of Sciences (ed.), Proceedings of the Fort Union Coal Field Symposium, Vol. 2, Aquatic Ecosystems, Hagen Printing Company, Billings, MT, Pp. 179-190). Thollas gave data for water requirements of alternate cooling systems for a 1000 MWe plant operating at 70 percent capacity. The assumption is made that water use is proportional to generation level and can be expressed in units of acre-feet. per average annual MW using Thomas' data. The assumption is generally valid although the coefficients used probably result in a slight overestimation of changes in water use. However, this is strictly true only if plants are equipped with variable speed pumps. In practice, pumps may be left running during nongenerating periods to enable fast startup on demand.

Table H-8-7

\title{
FORMULAE FOR DETERMINING WATER USE FROM ANNUAL GENERATION FOR PACIFIC NORTHWEST PLANTS (Results in units of acre-feet of water)
}

\author{
Valmy $\quad$ MWs $^{*} 14.35$ \\ Colstrip MWs*21.6 \\ Boardman MWs*24.4 \\ Centralia MWs*21.6 \\ Bridger MWs*2?.6
}

All comparisons of water use by plants and discharge to surface waters were based on discharge conditions in the early 1980s. Actual stream flows in the future may be different, but no attempt was made to forecast actual stream flows for future years.

For most plants using water from surface streams, change in water use was compared to the minimum daily stream discharge for the period of record of the source water. This is a very conservative analysis and represents an extreme worst case scenario.

Measurements of stream discharge reported by the U.S. Geological survey (USGS) are estimates made with varying precision. This precision is generally known and is reported for most USGS gauge stations. Records rated as "excellent" signify that 95 percent of measured daily discharges are within 5 percent of the true value, "good" ratings are within 10 percent, "fair" within 15 percent, and "poor" have less than fair accuracy (John Bader, pers. comm., May 1987). Levels of change within the error range would be unmeasureable. In addition, surface runoff in any area varies from year to year depending largely on meteorological conditions. This variation is usually much greater than the measurement error.

For the Valmy plant which uses groundwater for cooling, a similar approach was used, but changes in water use were related to acquifer recharge rather than a streamflow. Groundwater resources are less accurately measured than surface 
water resources. Aquifer recharge is the volume of water which enters a groundwater basin, usually measured on an annual basis. It comes from precipitation in the basin, seepage from surface water, and inflow of groundwater. Often, recharge is only roughly estimated from water budgets, or is not known at all.

\section{Results of Coal Use, Land Disturbance, and Water Use Impact Analysis}

The results of the coal use analysis are shown in Table $\mathrm{H}-8-8$ and 9 . The results of the land yisturbance analysis are shown in Table $\mathrm{H}-8-10$ and 11 . Only results for expected loads and gas prices and for high Northwest loads are provided. Results for the other sensitivity assumptions (Low Northwest loads, High Southwest Loads, Low Southwest Loads, High Gas Price, and Low Gas Price) are available upon request. In Tables $\mathrm{H}-8-8$ through $\mathrm{H}-8-11$, the values given for "No Action" for each plant are actual projected values derived using the respective coefficients described above. Values given for each other alternative by plant are differences for that alternative from the value given above it by plant for "No Action." Results of the water use analysis are provided in Chapter 4 of the main body of this EIS. 

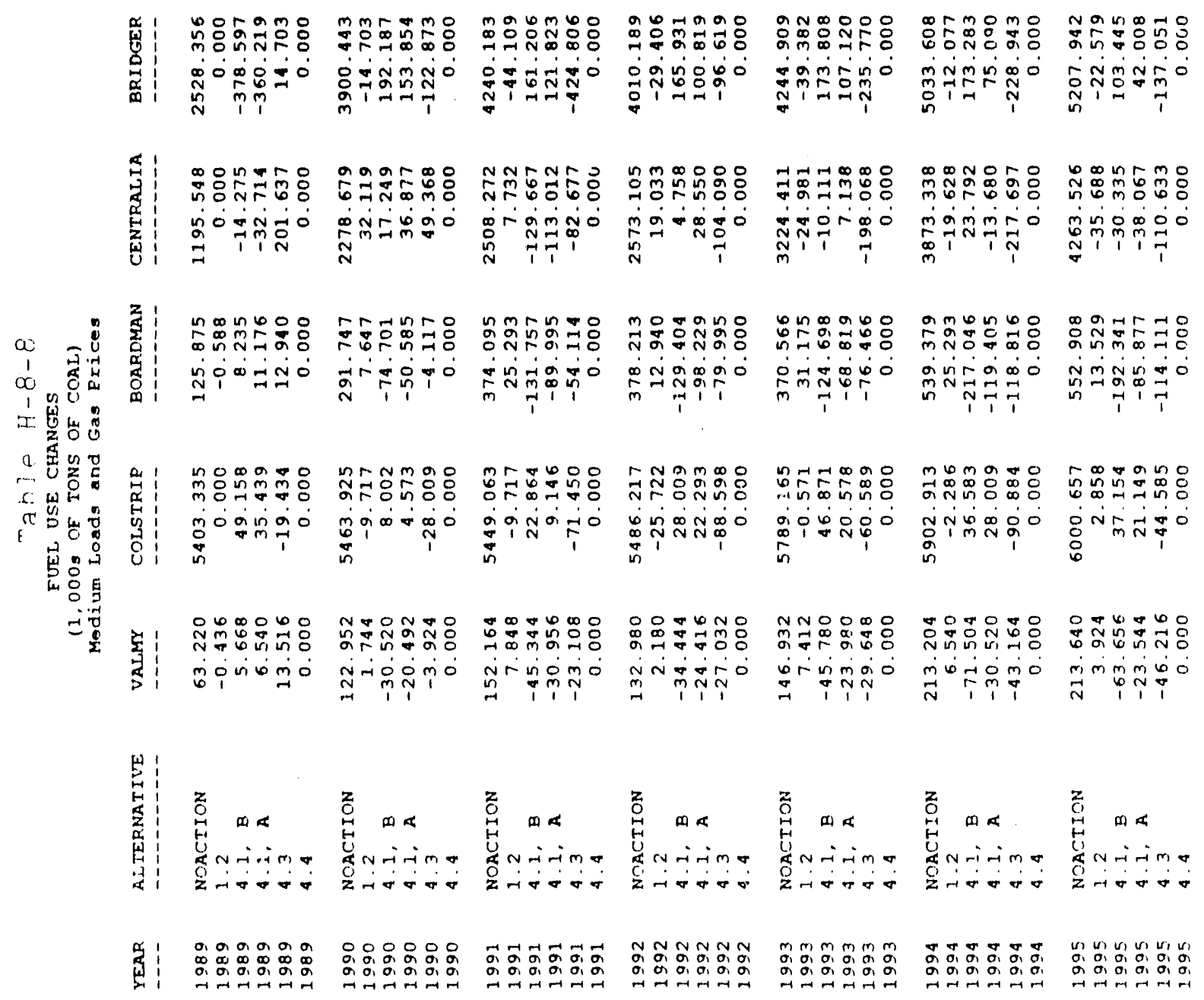


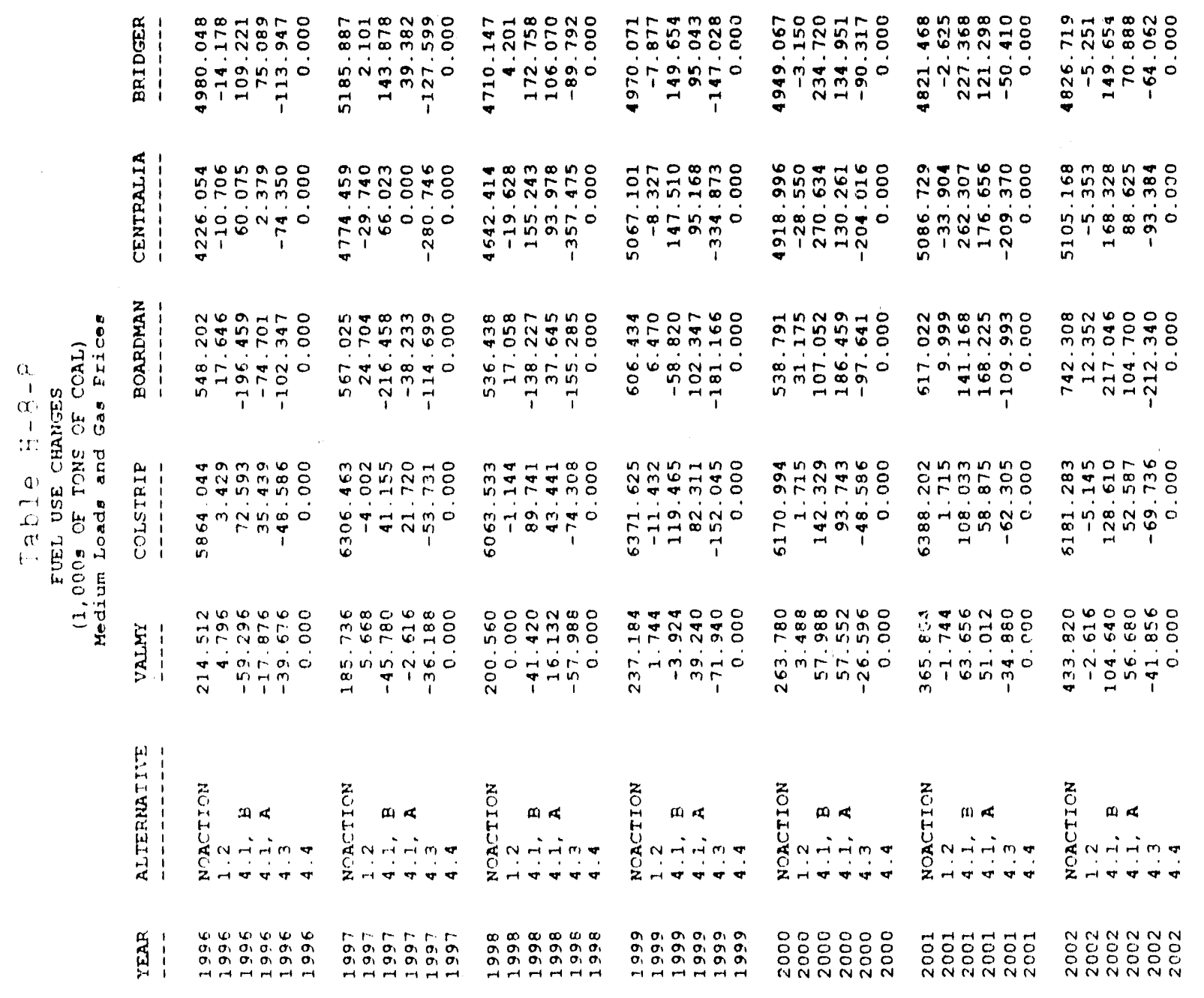




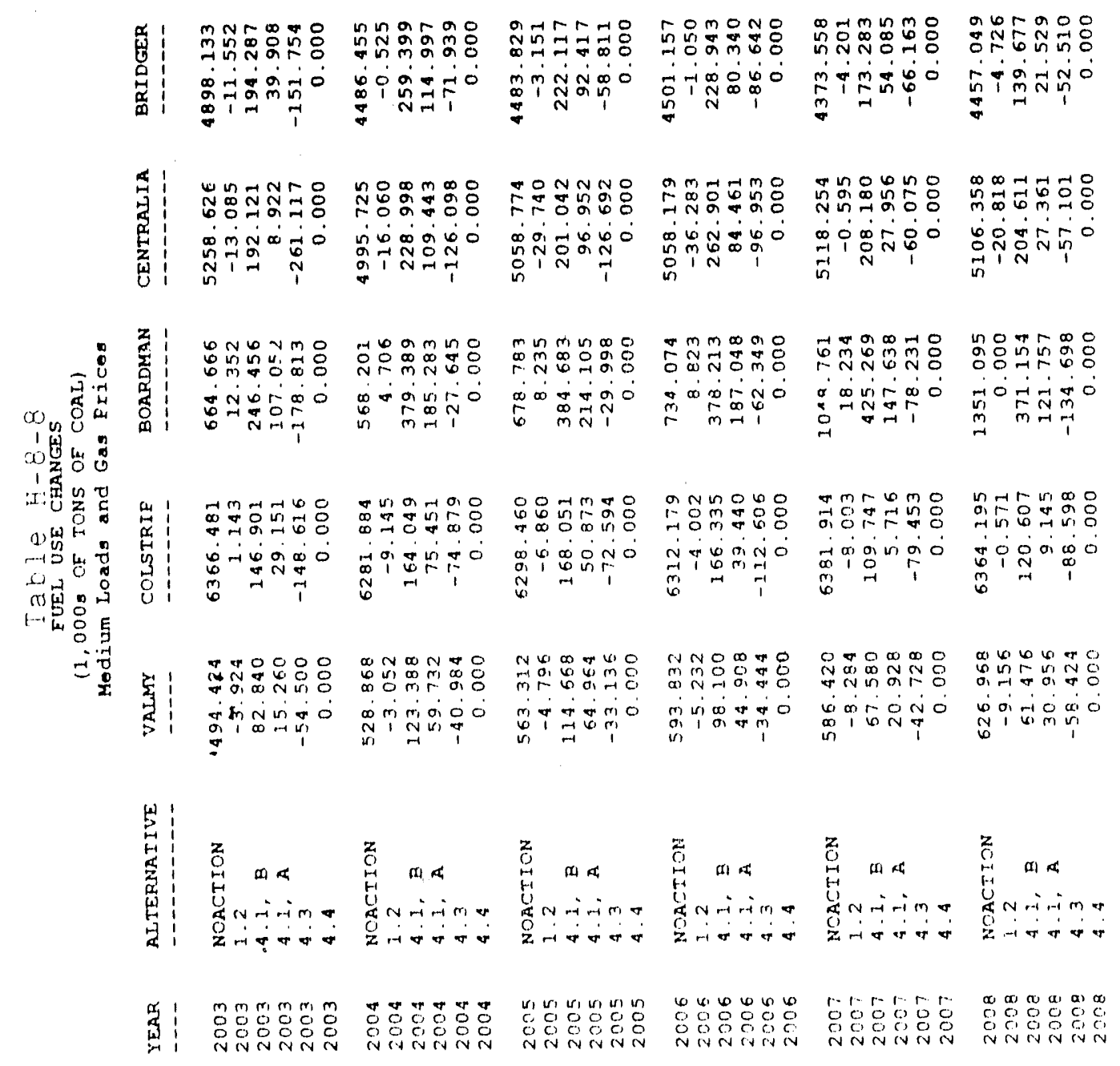




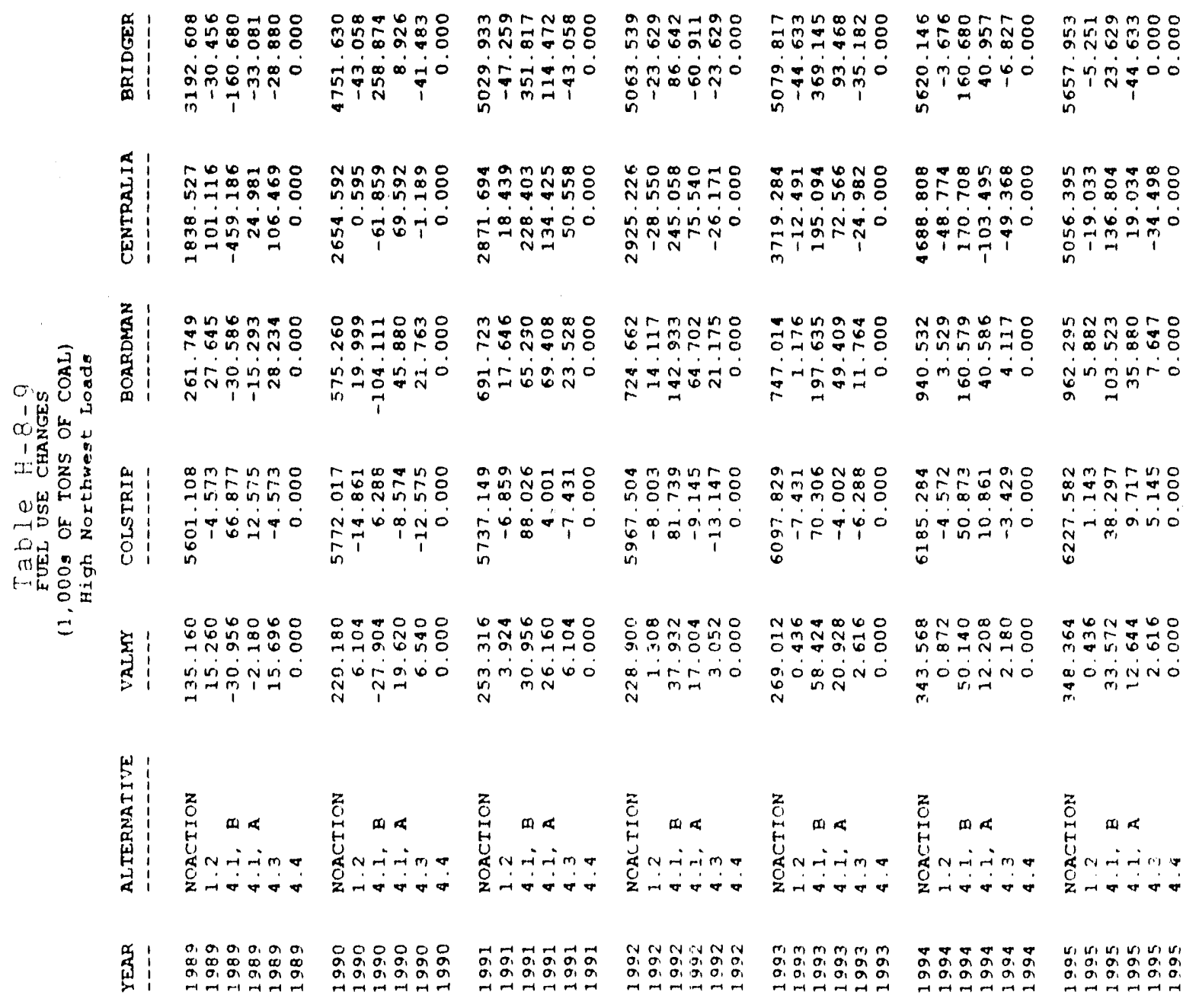




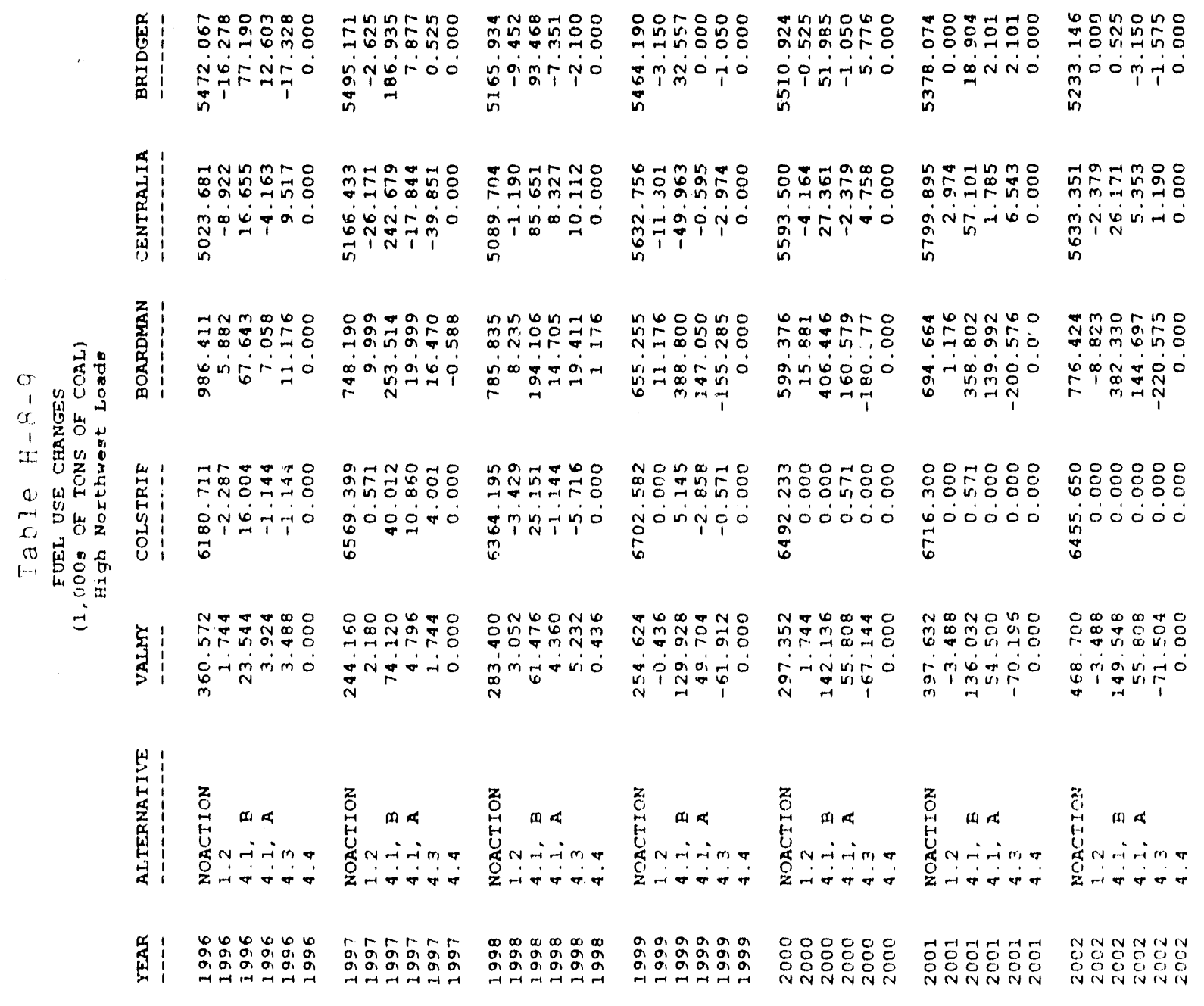




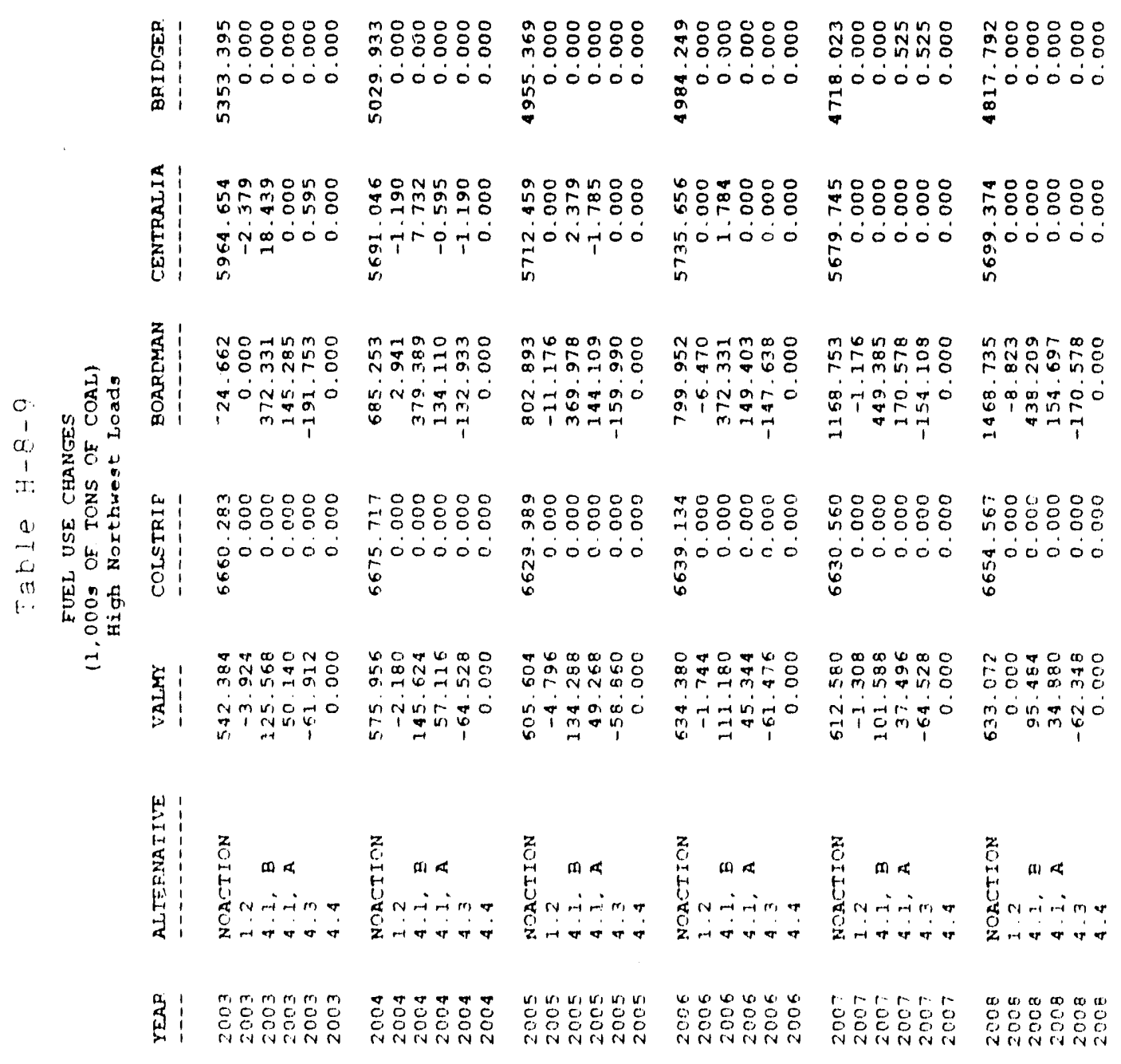




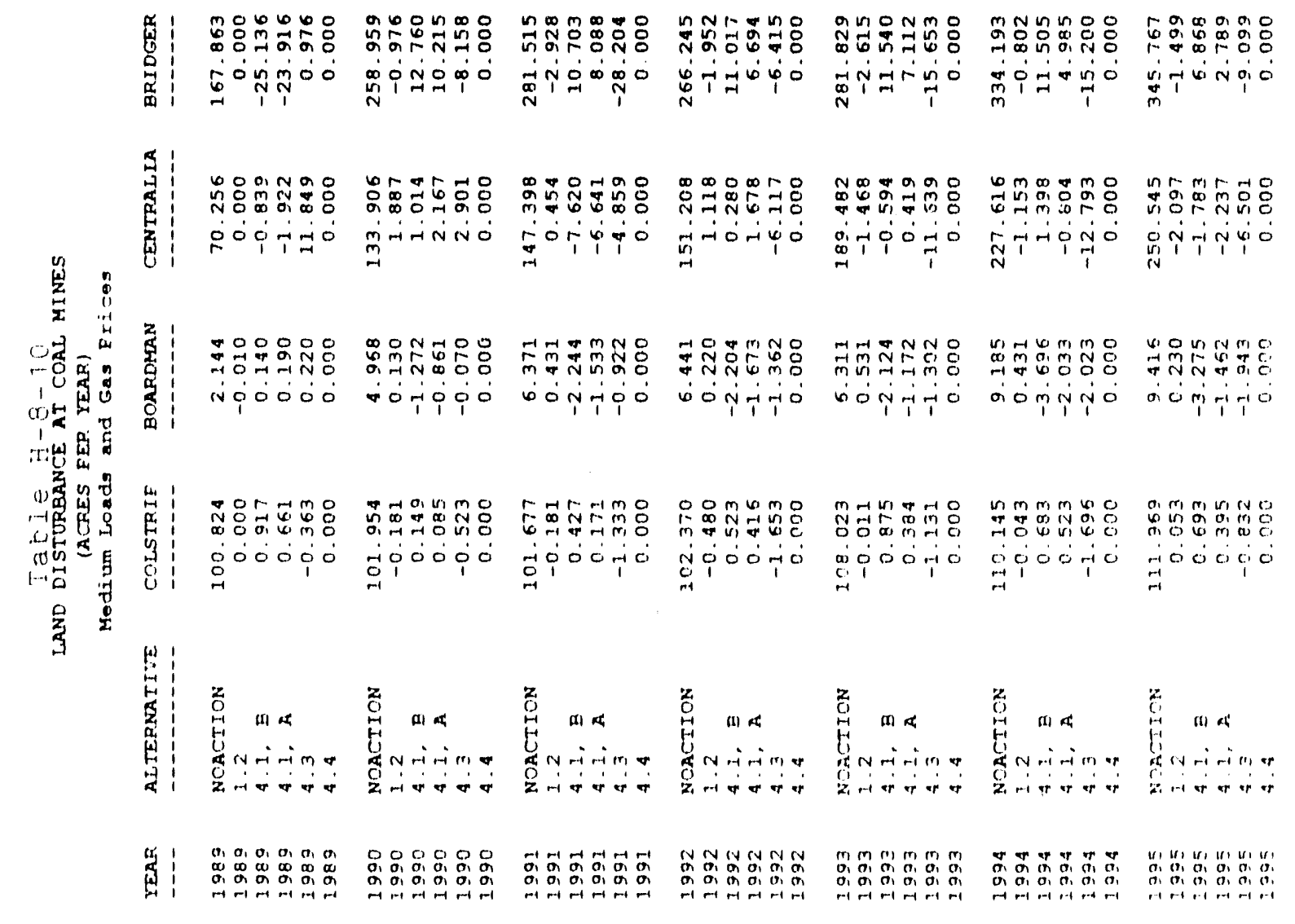




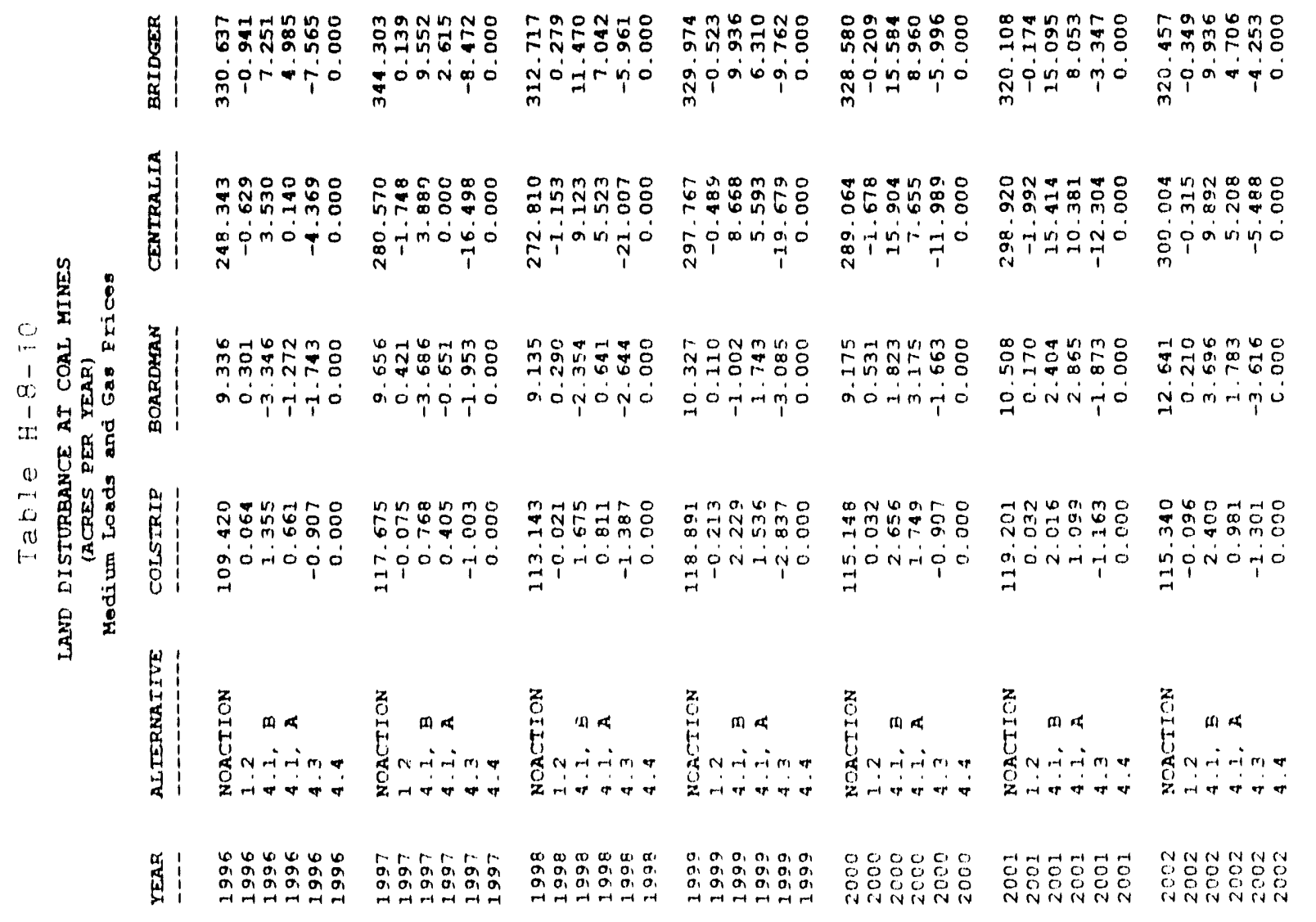




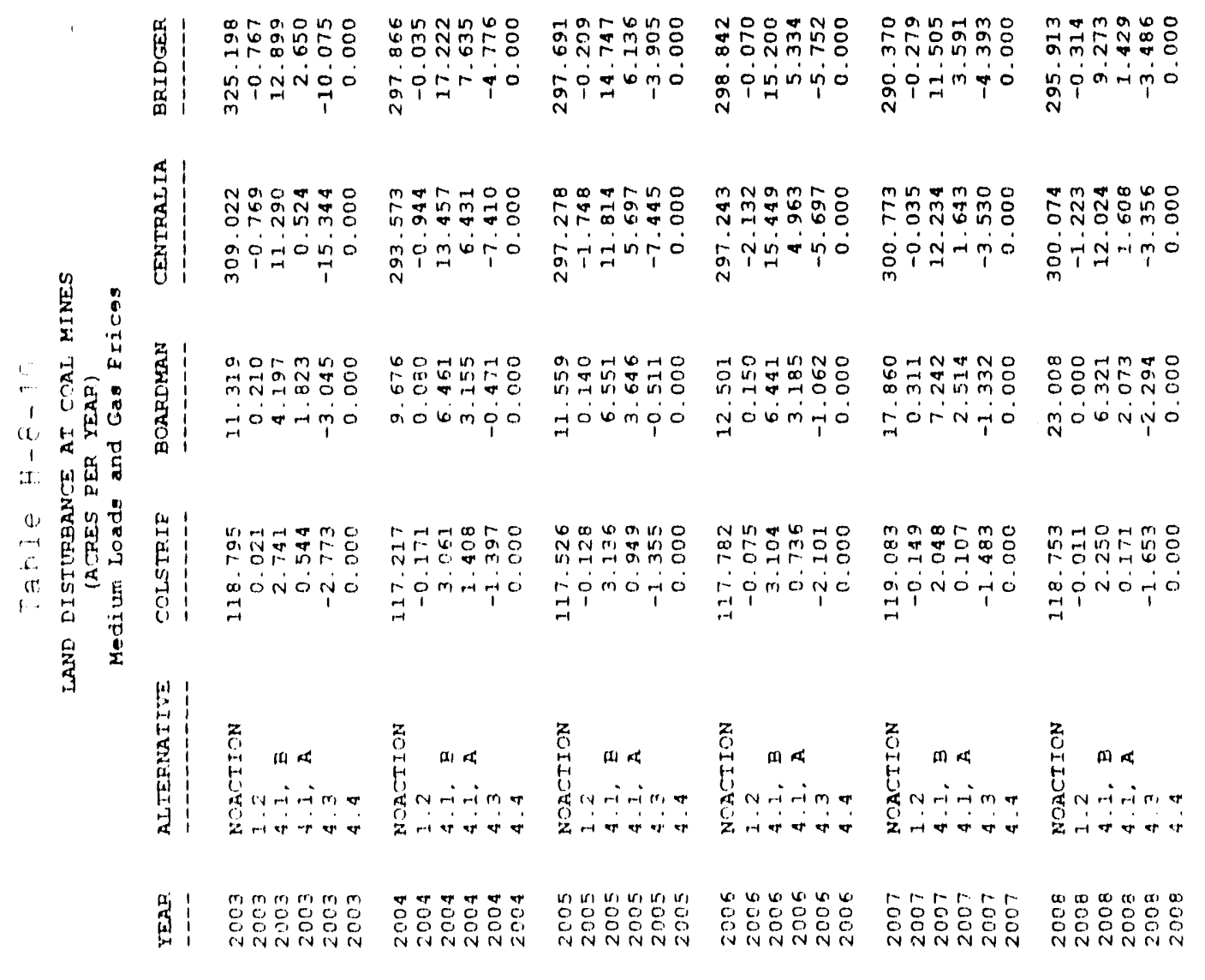




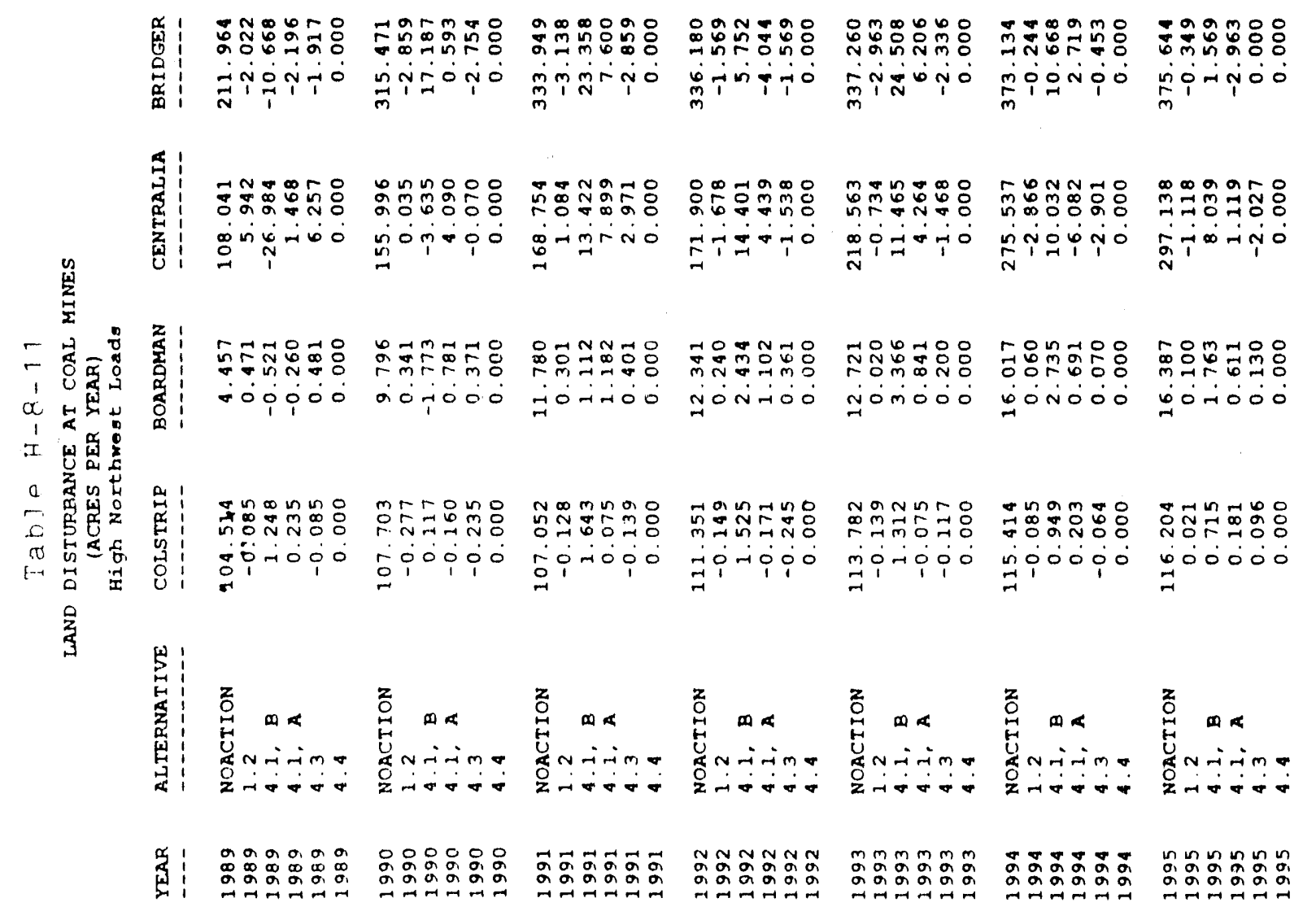




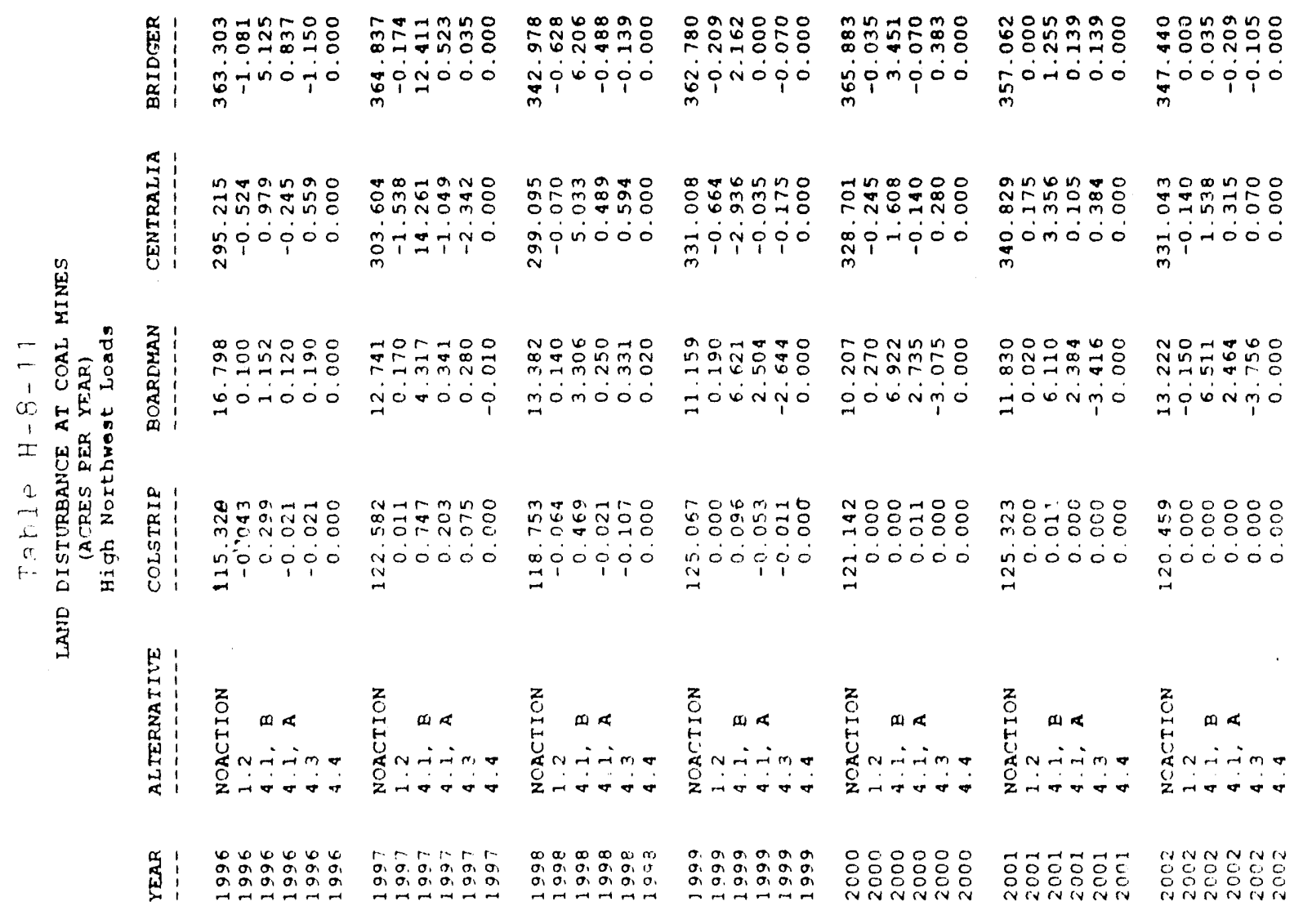

$H-8-17$ 


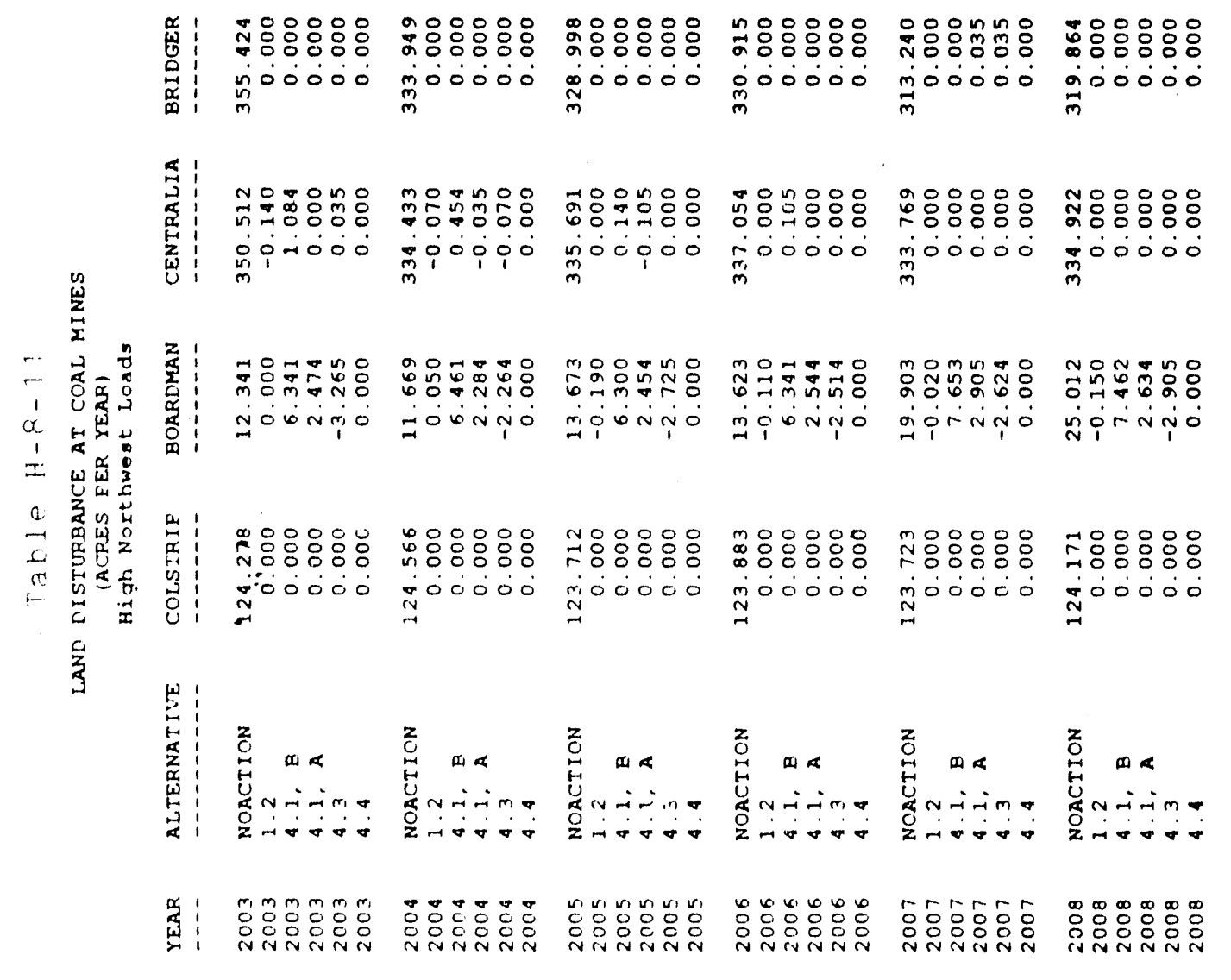


H-9

Resource Additions 


\section{Resource Additions}

The Least Cost Mix Model (LCMM) was used to determine future resource development needs within the region. These results are then input to the System Analysis Mode1 (SAM). Tables $\mathrm{H}-9-1$ and $\mathrm{H}-9-2$ show the resource additions used for each of the alternatives analyzed with sAM. Results are shown for only the expected loads and gas prices and high Northwest load scenarios. No resource additions were necessary under the low Northwest load case. Since the other sensitivity assumptions (high and low Southwest loads and high and low gas prices) do not affect Northwest resource needs, the results from the expected load scenario were used for these cases. Results from the No Action Alternative were used for Alternatives 1.2 and 4.4 , since these cases did not involve changes in the amount of firm load.

Values given for the No Action Alternative represent cumulative average annual MWs of resource additions (e.g., values for 1998 include all additions which occurred from 1989 through 1997). Values for the other alternatives are incremental to those given for the No Action Alternative. Small resources include small hydro, cogeneration, and other renewable resources. As with conservation, SAM treats these as nonschedulable resources, so they are reflected as reductions in the amount of $\mathrm{firm}$ load which must be served. Certain scenarios, primarily those with high Northwest loads, have resource needs in the near-term before major resources can be built. As a result, short-term purchases are reserved in order to maintain regional load/resource balance. These were then modeled in SAM in a manner similar to combustion turbines. Actual usage of these reserved purchases can be found in Appendix $\mathrm{H}-5$.

Table H-9-3 shows the amount of firm surplus available in SAM, given the above resource additions. Values are given for both the expected loads and gas price and high Northwest load scenarios. As with Tables $\mathrm{H}-9-\mathrm{l}$ and $\mathrm{H}-9-2$, results for Alternatives 1.2 and 4.4 are identical to the No Action Alternative, and results for the sensitivities involving gas prices and Southwest loads are identical to the medium Northwest load scenario.

An additional "resource" available to meet load is the "conversion" of existing power sales contracts to California utilities to exchanges or to capacity sales. At the time of the SAM analysis, there were two such convertible contracts, Southern California Edisun's and another with Burbank, Glendale, and Pasadena, which were converted at different times as needed for different alternatives. The timing of these conversions is shown on Table H-9-9. Since $t$ e analysis was performed, both these contracts have betn converted. 
Table H-9-1

Cumulative Resource Additions (aMW)

Medium Loads and Gas Prices

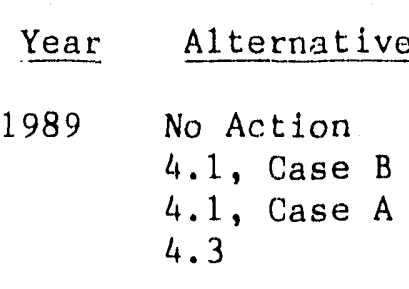

1990 No Action

4.1 , Case B

4.1, Case A

4.3

1991 No Action

4.1, Case B

4.1 , Case A

4.3

1992 No Action

4.1 , Case B

4.1, Case A

4.3

1993 No Action

4.1, Case A

4.3

1994 No Action

4.1, Case B

4.1, Case A

4.3

1995 No Action

4.1, Case B

4.1, Case A

4.3

1996 No Action

4.1, Case B

4.1, Case A

4.3

1997 No Action

4.1, Case B

4.1 , Case $A$

4.3

1998
4.1, Case B
Sma 1.1

Conservation

5

0

0

$+2$

5

0

0
+2

$+2$

5

0

0

$+2$

42

$-4$

0

$+8$

74

$-8$

0

$+20$

115

$-11$

0

$+33$

155

$-14$

0

$+86$

201

$-18$

$-2$

$+57$

244

$-23$

$-5$

$+66$

$287 \quad 324$

$-27$

$-8$

$+75$

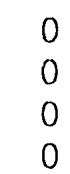

0
0
0
0

- -2

$+317$
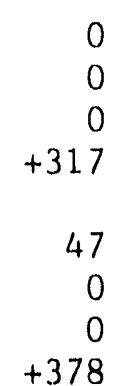

61

0

$+391$

77
0
0
+404

168

$-75$

$-75$

$+334$

183

$-108$

$-75$

$+333$
$-208$

$-200$

$+209$
Resources

Nuclear

Coa 1

Reserved

Purchases

0
0
0
0

0
0
0
0
0
0
0
0

$\begin{array}{rr}0 & 0 \\ 0 & 0 \\ 0 & 0 \\ 0 & +41\end{array}$

$\begin{array}{ll}0 & 0 \\ 0 & 0 \\ 0 & 0 \\ 0 & 0\end{array}$

$\begin{array}{ll}0 & 0 \\ 0 & 0 \\ 0 & 0 \\ 0 & 0\end{array}$

$\begin{array}{ll}0 & 0 \\ 0 & 0 \\ 0 & 0 \\ 0 & 0\end{array}$

$\begin{array}{ll}0 & 0 \\ 0 & 0 \\ 0 & 0 \\ 0 & 0\end{array}$

$\begin{array}{rr}0 & 0 \\ 0 & 0 \\ 0 & 0 \\ 0 & +6\end{array}$

$\begin{array}{rr}0 & 0 \\ 0 & 0 \\ 0 & 0 \\ 0 & +97\end{array}$

4.1, Case

4.1, Case A

4.3

$\begin{array}{ll}0 & 0 \\ 0 & 0 \\ 0 & 0 \\ 0 & 0\end{array}$


Table H-9-1

Cumulative Resource Additions (aMW)

Medium Loads and Gas Prices

(Continued)

\begin{tabular}{|c|c|c|c|c|c|c|}
\hline Year & A1ternative & Conservation & $\begin{array}{r}\text { Sma11 } \\
\text { Resources } \\
\end{array}$ & Nucloar & Coal & $\begin{array}{l}\text { Reserved } \\
\text { Purchases }\end{array}$ \\
\hline 1999 & $\begin{array}{l}\text { No Action } \\
4.1 \text {, Case B } \\
4.1 \text {, Case A } \\
4.3\end{array}$ & $\begin{array}{r}333 \\
-32 \\
-9 \\
+84\end{array}$ & $\begin{array}{r}324 \\
-208 \\
-200 \\
+209\end{array}$ & $\begin{array}{r}0 \\
0 \\
0 \\
+806\end{array}$ & $\begin{array}{l}0 \\
0 \\
0 \\
0\end{array}$ & $\begin{array}{l}0 \\
0 \\
0 \\
0\end{array}$ \\
\hline 2000 & $\begin{array}{l}\text { No Action } \\
4.1 \text {, Case B } \\
4.1 \text {, Case A } \\
4.3\end{array}$ & $\begin{array}{l}379 \\
-38 \\
-10 \\
+93\end{array}$ & $\begin{array}{r}324 \\
-208 \\
0 \\
+209\end{array}$ & $\begin{array}{r}806 \\
-806 \\
-806 \\
0\end{array}$ & $\begin{array}{l}0 \\
0 \\
0 \\
0\end{array}$ & $\begin{array}{l}0 \\
0 \\
0 \\
0\end{array}$ \\
\hline 2001. & $\begin{array}{l}\text { No Action } \\
4.1 \text {, Case B } \\
4.1 \text {, Case A } \\
4.3\end{array}$ & $\begin{array}{r}428 \\
-46 \\
-11 \\
+100\end{array}$ & $\begin{array}{r}324 \\
-208 \\
0 \\
+209\end{array}$ & $\begin{array}{r}806 \\
-806 \\
-806 \\
0\end{array}$ & $\begin{array}{l}0 \\
0 \\
0 \\
0\end{array}$ & $\begin{array}{l}0 \\
0 \\
0 \\
0\end{array}$ \\
\hline 2002 & $\begin{array}{l}\text { No Action } \\
4.1 \text {, Case B } \\
4.1 \text {, Case A } \\
4.3\end{array}$ & $\begin{array}{r}476 \\
-53 \\
-11 \\
+109\end{array}$ & $\begin{array}{r}324 \\
-208 \\
0 \\
+209\end{array}$ & $\begin{array}{r}806 \\
-806 \\
-806 \\
0\end{array}$ & $\begin{array}{l}0 \\
0 \\
0 \\
0\end{array}$ & $\begin{array}{l}0 \\
0 \\
0 \\
0\end{array}$ \\
\hline 2003 & $\begin{array}{l}\text { No Action } \\
4.1 \text {, Case B } \\
4.1 \text {, Case A } \\
4.3\end{array}$ & $\begin{array}{r}525 \\
-61 \\
-13 \\
+117\end{array}$ & $\begin{array}{r}324 \\
-208 \\
0 \\
+209\end{array}$ & $\begin{array}{r}806 \\
-806 \\
0 \\
+815\end{array}$ & $\begin{array}{l}0 \\
0 \\
0 \\
0\end{array}$ & $\begin{array}{l}0 \\
0 \\
0 \\
0\end{array}$ \\
\hline 2004 & $\begin{array}{l}\text { No Action } \\
4.1 \text {, Case B } \\
4.1 \text {, Case A } \\
4.3\end{array}$ & $\begin{array}{r}576 \\
-71 \\
-14 \\
+122\end{array}$ & $\begin{array}{r}324 \\
-208 \\
0 \\
+209\end{array}$ & $\begin{array}{r}1621 \\
-1621 \\
-815 \\
0\end{array}$ & $\begin{array}{l}0 \\
0 \\
0 \\
0\end{array}$ & $\begin{array}{l}0 \\
0 \\
0 \\
0\end{array}$ \\
\hline 2005 & $\begin{array}{l}\text { No Action } \\
4.1 \text {, Case B } \\
4.1 \text {, Case A } \\
4.3\end{array}$ & $\begin{array}{r}630 \\
-84 \\
-15 \\
+124\end{array}$ & $\begin{array}{r}324 \\
-208 \\
0 \\
+240\end{array}$ & $\begin{array}{r}1621 \\
-1621 \\
-815 \\
0\end{array}$ & $\begin{array}{l}0 \\
0 \\
0 \\
0\end{array}$ & $\begin{array}{l}0 \\
0 \\
0 \\
0\end{array}$ \\
\hline 2006 & $\begin{array}{l}\text { No Action } \\
4.1 \text {, Case B } \\
4.1 \text {, Case A } \\
4.3\end{array}$ & $\begin{array}{r}683 \\
-100 \\
-15 \\
+123\end{array}$ & $\begin{array}{r}324 \\
-208 \\
0 \\
+240\end{array}$ & $\begin{array}{r}1621 \\
-1621 \\
-815 \\
0\end{array}$ & $\begin{array}{l}0 \\
0 \\
0 \\
0\end{array}$ & $\begin{array}{l}0 \\
0 \\
0 \\
0\end{array}$ \\
\hline 2007 & $\begin{array}{l}\text { No Action } \\
4.1 \text {, Case B } \\
4.1 \text {, Case A } \\
4.3\end{array}$ & $\begin{array}{r}735 \\
-115 \\
-16 \\
+121\end{array}$ & $\begin{array}{r}324 \\
-208 \\
0 \\
+240\end{array}$ & $\begin{array}{r}1621 \\
-1621 \\
-815 \\
0\end{array}$ & $\begin{array}{r}0 \\
0 \\
0 \\
+87\end{array}$ & $\begin{array}{l}0 \\
0 \\
0 \\
0\end{array}$ \\
\hline 2008 & $\begin{array}{l}\text { No Action } \\
4.1 \text {, Case B } \\
4.1 \text {, Case A } \\
4.3\end{array}$ & $\begin{array}{r}781 \\
-130 \\
-16 \\
+118\end{array}$ & $\begin{array}{r}324 \\
-208 \\
0 \\
+240\end{array}$ & $\begin{array}{r}1621 \\
-1621 \\
-815 \\
0\end{array}$ & $\begin{array}{r}0 \\
0 \\
0 \\
+190\end{array}$ & $\begin{array}{l}0 \\
0 \\
0 \\
0\end{array}$ \\
\hline
\end{tabular}


Table H-9-2

\section{Cumulative Resource Additions (aMW) \\ High Northwest Loads}

\begin{tabular}{|c|c|c|c|c|c|c|}
\hline Year & Alternat ive & Conservation & $\begin{array}{c}\text { Sma1L } \\
\text { Resources }\end{array}$ & Nuc lear & Coal & $\begin{array}{l}\text { Reserve } \\
\text { Purchals }\end{array}$ \\
\hline \multirow[t]{4}{*}{1989} & No Action & 8 & () & 0 & 0 & 190 \\
\hline & 4.1, Case B & -1 & () & () & 0 & -1.90 \\
\hline & 4.1 , Case $A$ & 0 & 0) & 0 & 0 & -190 \\
\hline & 4.3 & 0 & 0 & 0 & () & +852 \\
\hline \multirow[t]{4}{*}{1990} & No Action & 8 & () & () & () & 665 \\
\hline & 4.1 , Case B & -1 & 0 & 0 & () & -665 \\
\hline & 4.1 , Case A & 0 & 0 & 0 & 0 & -600 \\
\hline & & 0 & 0 & 0 & 0 & +852 \\
\hline \multirow[t]{4}{*}{1991} & No Action & 8 & 411 & 0 & 0 & 742 \\
\hline & 4.1 , Case B & -1 & --411 & 0 & 0 & -742 \\
\hline & 4.1, Case A & 0 & 0 & 0 & 0 & -603 \\
\hline & 4.3 & 0 & 0 & () & 0 & +878 \\
\hline \multirow[t]{4}{*}{1992} & No Action & 87 & 415 & 0 & 0 & 1165 \\
\hline & 4.1 , Case B & -40 & -415 & 0 & 0 & -1.65 \\
\hline & 4.1 , Case A & 0 & 0 & 0 & 0 & -613 \\
\hline & 4.3 & 0 & 0 & 0 & 0 & +885 \\
\hline \multirow[t]{4}{*}{1993} & No Action & 133 & 699 & 0 & 0 & 1127 \\
\hline & 4.1, Case $B$ & -42 & -652 & 0 & 0 & -1.127 \\
\hline & 4.1 , Case $A$ & 0 & 0 & 0 & 0 & -613 \\
\hline & 4.3 & 0 & 0 & 00 & 0 & +863 \\
\hline \multirow[t]{4}{*}{1994} & No Action & 188 & 790 & 0 & 0 & 1490 \\
\hline & 4.1 , Case $B$ & -43 & -729 & 0 & 0 & -1.490 \\
\hline & 4.1, Case A & 0 & -18 & 0 & 0 & -596 \\
\hline & 4.3 & 0 & 0 & 0 & 0 & +885 \\
\hline \multirow[t]{4}{*}{1995} & No Action & $2 / 42$ & 840 & 0 & 0 & 1807 \\
\hline & 4.1, Case B & -44 & -409 & 0 & 0 & -1807 \\
\hline & 4.1, Case A & () & -18 & 0 & 0 & -656 \\
\hline & 4.3 & 0 & 0 & 0 & 0 & +885 \\
\hline \multirow[t]{4}{*}{1996} & No Action & 299 & 879 & 0 & 0 & 2205 \\
\hline & 4.1, Case B & -43 & -194 & 0 & 0 & -2042 \\
\hline & 4.1 , Case A & 0 & -17 & 0 & 0 & -813 \\
\hline & 4.3 & () & 0 & 0 & 0 & +884 \\
\hline \multirow[t]{4}{*}{1997} & No Action & 352 & 91.7 & 1.621 & 0 & 82.7 \\
\hline & 4.1 , Case B & -44 & -212 & -81.5 & 0 & -827 \\
\hline & 4.1, Case A & 0 & -18 & 0 & 0 & -814 \\
\hline & 4.3 & 0 & 0 & 0 & 0 & +885 \\
\hline \multirow[t]{4}{*}{1998} & No Action & 404 & 957 & 1621 & () & 1480 \\
\hline & 4.1 , Case B & -43 & -222 & -81.5 & () & -1480 \\
\hline & 4.1, Case A & 0 & -18 & 0 & 0 & -813 \\
\hline & 4.3 & 0 & 0 & 0 & 0 & +885 \\
\hline
\end{tabular}


Table H-9-2

Cumulative Resource Additions (aMW)

High Northwest Loads

(Continued)

\begin{tabular}{|c|c|c|c|c|c|c|}
\hline Year & Alternative & Conservation & $\begin{array}{c}\text { Sima } 11 \\
\text { Resources }\end{array}$ & Nuclear & Coal & $\begin{array}{l}\text { Reserved } \\
\text { Purchases }\end{array}$ \\
\hline \multirow[t]{4}{*}{1999} & No Action & 460 & 957 & 1621 & 2040 & 0 \\
\hline & 4.1, Case B & -4.4 & -205 & 0 & -2040 & 0 \\
\hline & 4.1 , Case A & 0 & -18 & 0 & -812 & 0 \\
\hline & 4.3 & 0 & 0 & 0 & +886 & 0 \\
\hline \multirow[t]{4}{*}{2000} & No Action & 516 & 957 & 1621 & 2721 & 0 \\
\hline & 4.1 , Case $B$ & -46 & -205 & 0 & -2034 & 0 \\
\hline & 4.1, Case A & () & -18 & 0 & -81.1 & 0 \\
\hline & 4.3 & 0 & 0 & 0 & +886 & 0 \\
\hline \multirow[t]{4}{*}{2001} & No Action & 574 & 957 & 1621 & 3164 & 0 \\
\hline & 4.1 , Case B & -47 & -205 & 0 & -2034 & 0 \\
\hline & 4.1, Case A & 0 & -18 & 0 & -811 & 0 \\
\hline & 4.3 & 0 & 0 & 0 & +886 & 0 \\
\hline \multirow[t]{4}{*}{2002} & No Action & 631 & 957 & 1621 & 3807 & 0 \\
\hline & 4.1 , Case B & -47 & -205 & 0 & -2637 & 0 \\
\hline & 4.1, Case A & 0 & -18 & 0 & -813 & () \\
\hline & 4.3 & 0 & 0 & 0 & +886 & 0 \\
\hline \multirow[t]{4}{*}{2003} & No Action & 688 & 957 & 1621 & 4271 & 0 \\
\hline & 4.1 , Case $B$ & -48 & -205 & 0 & -2097 & 0 \\
\hline & 4.1 , Case A & 0 & -18 & 0 & -814 & 0 \\
\hline & 4.3 & 0 & 0 & 0 & +886 & 0 \\
\hline \multirow[t]{4}{*}{2004} & No Action & 745 & 957 & 1621 & 4999 & 0 \\
\hline & 4.1 , Case B & -49 & -205 & 0 & -2243 & 0 \\
\hline & 4.1, Case A & 0 & -1.8 & 0 & -814 & 0 \\
\hline & 4.3 & 0 & 0 & 0 & +886 & () \\
\hline \multirow[t]{4}{*}{2005} & No Action & 802 & 957 & 1621 & 5497 & 0 \\
\hline & 4.1 , Case B & -50 & -205 & 0 & -2241 & 0 \\
\hline & 4.1 , Case A & 0 & -18 & 0 & -813 & 0 \\
\hline & 4.3 & 0 & 0 & 0 & +886 & 0 \\
\hline \multirow[t]{4}{*}{2006} & No Action & 855 & 957 & 1621 & 6021 & 0 \\
\hline & 4.1 , Case B & -51 & -205 & 0 & -2241 & 0 \\
\hline & 4.1, Case A & ) & -1.8 & 0 & -814 & 0 \\
\hline & 4.3 & 0 & 0 & 0 & +886 & () \\
\hline \multirow[t]{4}{*}{$? 007$} & No Action & 906 & 957 & 1621 & 6447 & () \\
\hline & 4.1 , Case B & -51 & -205 & 0 & -2241 & () \\
\hline & 4.1 , Case A & () & -18 & 0 & -816 & () \\
\hline & 4.3 & () & 0 & 0 & +886 & 0 \\
\hline \multirow[t]{4}{*}{2008} & No Action & 949 & 957 & 1621 & 6928 & () \\
\hline & 4.1 , Case $B$ & -50 & -205 & () & -2241 & () \\
\hline & 4.1, Case A & () & -18 & 0 & -815 & () \\
\hline & $4 \cdot 3$ & 0 & 0 & 0 & +886 & () \\
\hline
\end{tabular}




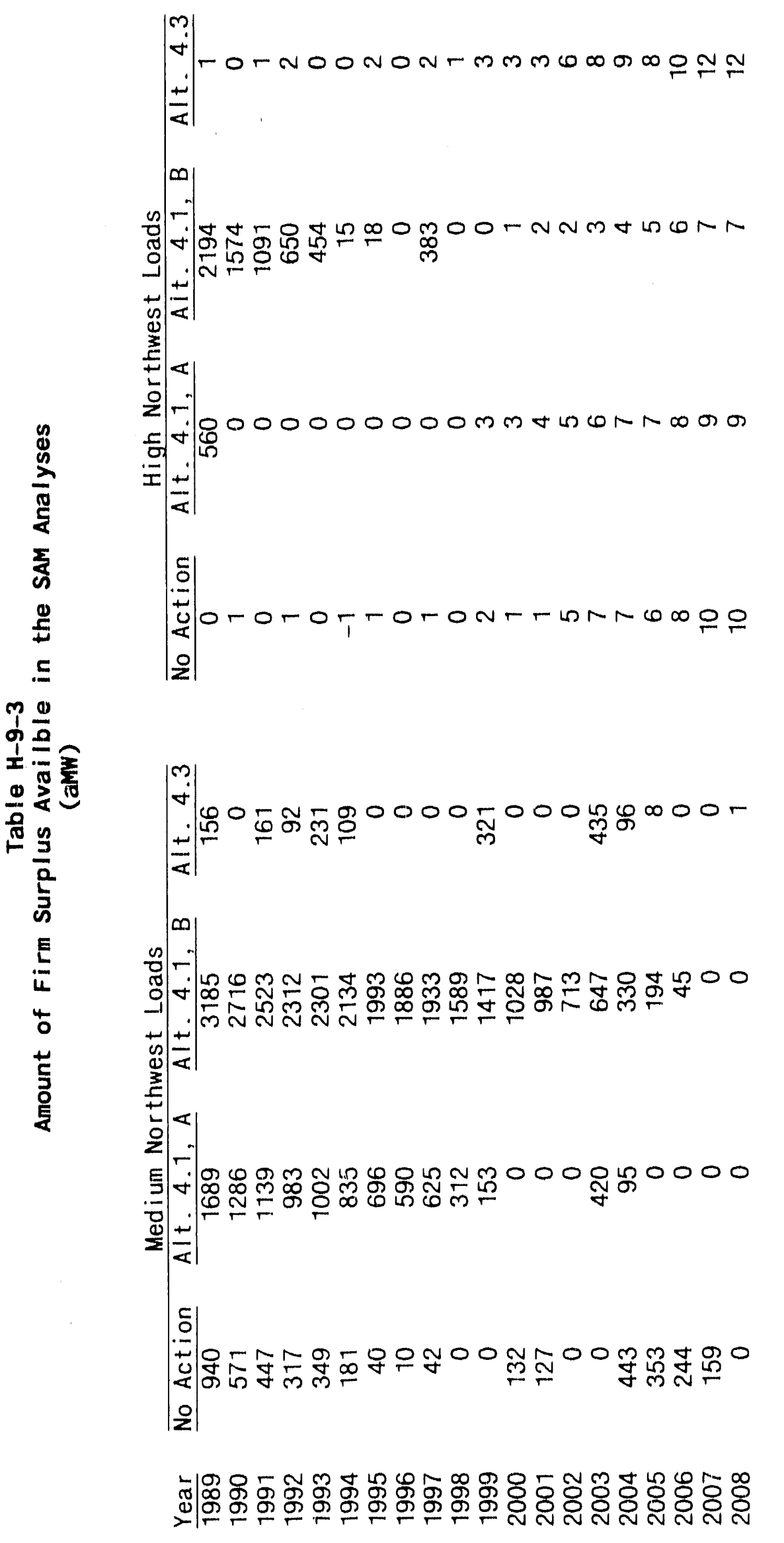

H-9-6 
TABLE $\mathrm{H}-9-4$

\section{CONVERSION OF CALIFORNIA CONTRACTS}

\section{Alternative}

Expected Loads \& Gas Price

No Action

1.2

4.1, Case A

4.1, Case B

4.3

4.4

High Northwest Loads

No Action

1.2

4.1, Case A

4.1, Case B

4.3

4.4

\section{Southern Callfornia Edison (Time of Conversion)}

June 2003

June 2003

No converston

No conversion

At start of study

June 2003

At start of study

At start of study

June 1995

June 2003

At start of study

At start of study
Burbank, Glendale, and Pasadena (Time of Conversion)

July 2004

JuLy 2004

No conversion

No Convers lon

At start of study

July 2004
At start of study

At start of study

June 1995

June 2003

At start of study

At start of study 
Append I $\mathrm{H}-10$

Programmat lo Agreement for Compl lance

With the Nat lonal HIstorlc Preservation Act 


\title{
Programmatic Agreement \\ FOR COMPLIANCE WITH THE \\ National Historic Preservatin ${ }_{\text {n }}$ Act
}

\author{
Among \\ - Bonneville Power Administration \\ - Bureau of Rexlamation, Pacific Northwest Rogion \\ - U.S. Army Corps of Engineers, North Pacific Division \\ - National Park Service, Pacific Northwest Region \\ - U.S. Forest Service, Region 1 \\ - Confederated 'Tribes of the Colville Reservation \\ - Spokane 'Iribe of Indians \\ - Idaho, Montana, and Washington State Historic Preservation Officers \\ - Advisory Council on Historic Preservation \\ Regarding

\section{Federal Columbia River Power System HYDROELECTRIC OPERATIONS}

WHEREAS, hydroeloctric projoct operations of the Federal Columbia River Power System, including power marketing policies and programs under the direct and/or indirect jurisdiction of the Bonneville Power Administration (BPA), the Bureau of Reclamation (Bureau), and the U.S. Army Corps of Engineers (Corps), may have an offect upon propertios included in, oligible for inclusion in, or potentially eligible for inclusion in the National Register of Historic Places (Register); and

WHEREAS, BPA has requested the comments of the Advisory Council on Historic Preservation (Council) pursuant to Section 106 of the National Historic Preservation Act (16 U.S.C. 470 f) and its implementing regulations, "Protection of" Historic Properties: (36 CFR Part 800); and

WHEREAS, the historic properties potentially affected are within or immediately adjacent to the reservoir drawdown zones (hereinafter affected area) in the project areas of (Grand Coulee (Lake Roosevelt) and Hungry Horse Dams, owned and operated by the Bureau, and the Dworshak, Libby (Lake Koocanusa), and Albeni Falls (Lake Pend Oreille) Dams, owned and operated by the Corps; and 
WHEREAS, the National Historic Preservation Act requires Fedoral agencies having direct or indiroct jurisdiction over an undertaking to tako into account the offect of the undertaking on historic properties; and

WHEREAS, BPA power marketing policy and program undortakings, as power system managoment actions, are under the direct and/or indiroct jurisdiction of $\mathrm{BP}$ 'A, the Bureau, and the Corps; and

WHEREAS, the BPA, the Bureau, and the Corps, in exorcising their independent power system management authorities and in fulfilling their responsibilitios for historic properties, intend to meet this shared responsibility for historic propertios in a timely manner; and

WHEREAS, the operation of the Grand Coulee Project affects land within the boundaries of the Colville Indian Reservation and the Spokane Indian Reservation, and lands administered by the National Park Service (NPS); and

WHEREAS, the Bureau, the NPS, the Confederated Tribes of the Colville Reservation (Colville 'Tribes), the Spokane T'ribe of Indians (Spokane Tribe), and other parties have ratified the Lake Roosevelt Cooperative Management Agreement; and

WHEREAS, Dworshak Reservoir, Hungry Horse Reservoir, Lake Koocanusa, and Lake Pend Oreille are partially within National Forests administered by the U.S. Forest Service, Region 1;

NOW 'THEREFORE, it is mutually agreed that BPA, the NPS, the Bureau, and the Corps will identify and manage historic properties in accordance with the following stipulations:

\section{STIPULATIONS}

BPA, the Bureau, the NPS, and the Corps will ensure that the following measures are carried out:

\section{Survey and Evaluation}

BPA will participate with the Bureau, the NPS, the Corps, the Colville Tribes, and the Spokane l'ribe, as appropriate in accordance with their respective 
jurisdictions, to complete intensive surveys ${ }^{1}$ of historic properties and properties possessing traditional cultural value to Native Americans, at the project reservoirs listed above. (Exhibit A shows the present status of historic preservation activities.) The Bureau, the NPS, the Corps, the Colville Tribe, and the Spokane Tribe will ensure that surveys are performed in accordance with accepted archaeological practices as defined in 36 CFR Part 800, Section 110 Guidelines, and the Secretary of the Interior's Standards and Guidelines. Site evaluations will be done in accordance with 36 CFR Part 63 and the abovereferenced guidelines. Surveys and evaluations will be done in consultation with the appropriate SHPO ind appropriate Native American tribes in accordance with 36 CFR Part 63.

Intensive surveys will be initiated at all affected areas within two years from execution of this Agreement, and proceed as quickly as possible thereafter. The Bureau, the NPS, the Corps, the Colville Tribes, and the Spokane Tribe, as appropriate, shall provide copies of completed survey reports to BPA, interested Native American tribes, the U.S. Forest Service, and the appropriate SHPO.

\section{Action Plans}

Once intensive surveys are completed for each affected area, the Bureau, the NPS, the Corps, the Colville Tribes, or the Spokane Tribe, as appropriate, will consult with BPA and the appropriate SHPO to develop a draft Action Plan for that area.

Action Plans will identify:

- Research design (including criteria for determining which properties may be likely to yield information important in prehistory and history);

- Determinations of Register eligibility; and

- Methods of mitigating adverse effects on Register and Register-eligible properties (including in situ preservation and law enforcement), monitoring, and curation.

Appropriate Native American tribes and traditional spiritual leaders will be consulted about properties possessing traditional cultural value to Native Americans, and provided a reasonable opportunity to comment on each draft

\footnotetext{
1 Intensive survey describes the distribution of properties in an area; determines the number, location, and condition of the properties; determines the types of properties actually present within the area; permits classification of individual properties; and records the physical extent of the specific properties. 48 id. Reg. 44716, $44722(1983)$.
} 
Action Plan, and the Forest Service will be afforded a reasonable opportunity to comment on the draft Action Plans for Dworshak Reservoir, Hungry Horse Reservoir, Lake Koocanusa, and Lake Pend Oreille. Upon completion of the coordinated draft Action Plan for each affected area (within 18 months of completion of the intensive survey for the subject project), the draft Action Plan will be submitted to the Council for review and comment.

Each final Action Plan will be implemented when mutually accepted by the managing agency or tribe, the appropriate SHPO, the Forest Service if the affected area is on Forest Service lands, and the Council. In consultation with other involved jurisdictions and affected Tribes, the lead agency for each Action Plan will prepare an annual report of activities performed during the year. The lead agency will provide copies to BPA, the Council, the appropriate SHPOs, other interested agencies, and appropriate Native American Tribes.

\section{Interim Management}

Interim management of historic properties at these project reservoirs will be conducted in accordance with the steps in the Council's regulations, 36 CFR Part 800. Until such time as the approved Action Plan is implemented, and prior to any change in operating constraints, the appropriate agency or tribe will implement the steps detailed in the regulations for identification, evaluation, and management of historic properties.

\section{Professional Qualifications}

Supervisory personnel managing the implementation of each Action Plan shall, at a minimum, meet the professional qualifications detailed in the Secretary of the Interior's "Standards and Guidelines for Archeology and Historic Preservation," 48 Fed.Reg. 44716, 44738 (1983).

\section{Other Historic Properties Management Considerations}

a. If human skeletal material is discovered during the intensive survey or during implementation of the Action Plan, the Bureau, the NPS, the Corps, the Colville Tribes, or the Spokane Tribe, as appropriate, will consult with local law enforcement authorities and the appropriate SHPO; or, if the skeletal material appears to be of Native American origin, will consult with the affected tribe and appropriate SHPO to prepare and implement a burial disposition plan in accordance with the North American Graves Protection and Repatriation Act 
(P.L. 101-601). BPA will participate in implementing the approved/agreed upon burial disposition plan.

b. The Bureau, the NPS, the Corps, the Colville Tribes, and the Spokane Tribe shall curate archaeological data, artifacts, field notes, photographs, and other records in accordance with the standards, guidelines, and principles in 36 CFR 79, "Curation of Federally-Owned or Administered Archeological Collections: Final Rule" (55 Fed. Reg. 37839); the Council's "Treatment of Archaeological Properties: A Handbook;" and in "Archeology and Historic Preservation: Secretary of the Interior's Standards and Guidelines," 48 Fed. Reg. 44716 (1983).

c. The Bureau, the NPS, the Corps, the Colville Tribes, or the Spokane Tribe shall prepare and distribute final reports to interested parties for each project listed above, for the affected area within their respective jurisdiction, within two years after full implementation of the Action Plan. Final reports will include the results of survey, evaluation, and mitigation.

6. Existing or new Memorandum of Agreement (MOA), or an existing Programmatic Agreement for the operation and management of individual project reservoirs included in this Agreement, may be substituted for this Agreement. In the absence of a substitute MOA or Programmatic Agreement, the terms of this Agreement shall be implemented for each project reservoir.

7. Any party to this Agreement may request its amendment, whereupon the parties will consult in accordance with 36 CFR 800.13 to consider such amendment.

8. If a signatory to this Agreement determines that the terms of the Agreement cannot be met, or that a change is necessary to meet the requirements of the law, that signatory will immediately request the consulting parties to consider an amendment or addendum. Any necessary amendment or addendum will be executed as defined in 36 CFR Part 800 . If a dispute arises regarding implementation of the Agreement, BPA will consult with the objecting party(ies) to resolve the dispute. If the dispute cannot be resolved, further comments will be requested from the Advisory Council, as defined in 36 CFR Part 800. 
9. Any party to this Agreement may suspend it by providing 30 days written notice to the other consulting parties. Additional consultations will then occur in an effort to resolve any issues, and to reimplement the Agreement in amended form.

10. Execution and implemencation of this Programmatic Agreement evidences that BPA, the Corps, Bureau and the NPS have satisfied their Section 106 responsibilities for hydroelectric project operations (including BPA power marketing policies and programs) affecting the reservoir drawdown areas of Grand Coulee, Hungry Horse, Dworshak, Libby, and Albeni Falls Dams.

11. All activities set forth in this Agreement are subject to availability of funds. If lack of funds results in failure to carry out the terms of this Agreement, BPA, NPS, the Bureau, and the Corps will again request the Council's comments in accordance with 36 CFR Part 800.

\section{EXHIBIT A}

\section{STATUS OF HISTORIC PRESERVATION ACTIVITIES BY PROJECT}

\begin{tabular}{|c|c|c|c|}
\hline Project & Survey & $\begin{array}{l}\text { Action Plan/ } \\
\text { Mitigation Plan }\end{array}$ & Mitigation \\
\hline Dworshak ${ }^{1}$ & Required & Required & Required \\
\hline Albeni Falls ${ }^{2}$ & Partially Completed ${ }^{3}$ & Required & Required \\
\hline Libby & Mostly Completed 4 & Completed $^{5}$ & Required \\
\hline Grand Coulee & Partially Completed & Required & Required \\
\hline Hungry Horse & Partially Completed & Required & Required \\
\hline
\end{tabular}

NOTES:

1/ The Dworshak project is presently covered under a Programmatic Agreement that addresses historic preservation activities on all operating reservoir projects within the U.S. Army Corps of Engineers Walla Walla District.

2/ The majority of lands are privately owned. Historic property investigations will require acquisition of real estate interests for site access and excavation, which will increase overall costs.

3/ Site locations have been identified, but no subsurface testing or evaluation has occurred.

4/ The U.S. Forest Service has identified additional cultural resource sites within the affected area. These sites have not been subjected to subsurface testing or evaluation.

5/ An existing Action Plan/Mitigation Plan may need to be modified as a result of subsurface testing and evaluation of recently discovered sites (see preceding footnote). 
BONNEVILLE POWER ADMINISTRATION

By:

James J. Jura, Administrator

Date:

BUREAU OF RECLAMATION, PACIFIC NORTHWEST REGION

By:

John W. Keys, III, Regional Director

Date:

U.S. ARMY CORPS OF' ENGINEERS, NOR'TH PACIFIC DIVISION

By:

MG Ernest J. Harrell, Division Engineer

Date:

NATIONAL PARK SERVICE, PACIFIC NORTHWEST REGION

By:

Charles H. Odegaard, Regional Director

Date:

U.S. FOREST SERVICE, REGION 1

By:

John W. Mumma, Regional Forester

Date:

CONFEDERATED TRIBES OF THE COLVILLE RESERVATION

By:

Jude C. Stensgar, Business Council Chairperson

Date:

SPOKANE TRIBE OF INDIANS

By:

Bruce Wynne, Business Council Chairperson

Date:

IDAHO STATE HISTORIC PRESERVATION OFFICE

By:

David Crowder, Ph.D., State Historic Preservation Officer

Date:

MONTANA STATE HISTORIC PRESERVATION OFFICE

By:

Marcella Sherfy, State Historic Preservation Officer

Date:

WASHINGTON STATE HISTORIC PRESERVATION OFFICE

By:

Jacob E. Thomas, State Historic Preservation Officer

Date:

ADVISORY COUNCIL ON HISTORIC PRESERVATION

By:

John F.W. Rogers, Chairman

Date:

Concur:

KOOTENAI TRIBE OF IDAHO

By:

Velma Bahe, Business Council Chairperson

Date: 


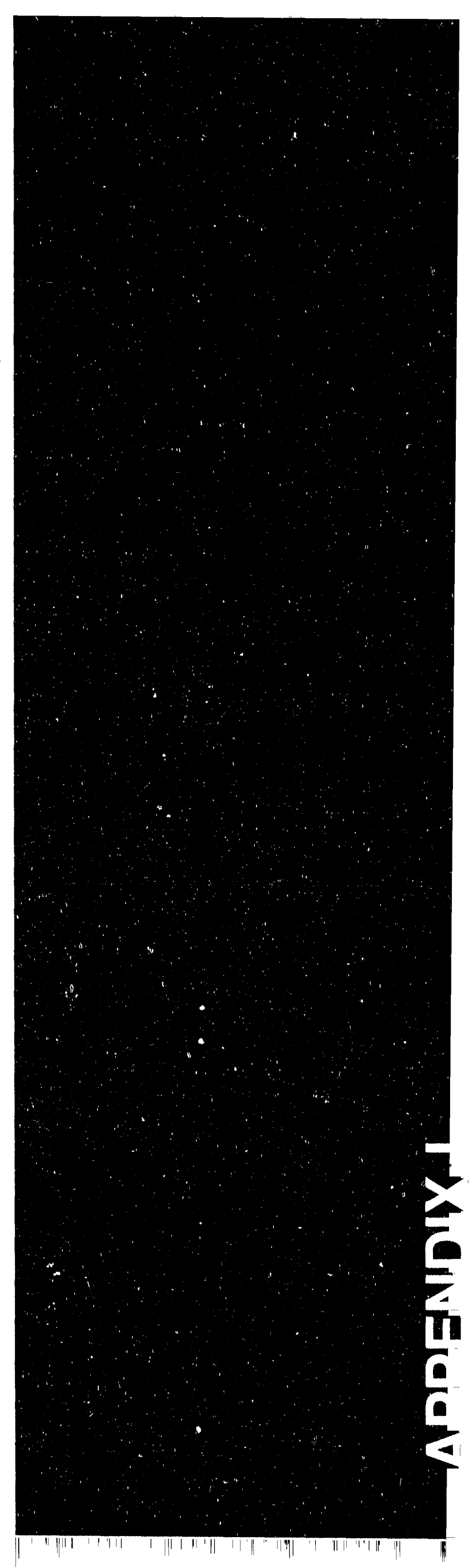


Appendix I

Public Involvement Activities 


\section{APPENDIX 1}

\section{Public Involvement Activities}

Public involvement activities for the Initial Northwest Power Sales Contracts Environmental Impact Statement (EIS) have been carrled out to fulf 111 the intent of the Council on Environmental Quality in prescribing a scoping of the project and to encourage and integrate public information and interests into the analysis of the power sales contact alternatives and the EIS process. A description and chronology of the principal public involvement activities is presented below.

3/5/85 BPA published Notice of Intent to prepared an EIS on the long-term sales contracts. Individual notices were sent to 2500 Federal, State, and local agencies, BPA customers, the Northwest Power Planning Counc 11, interest groups and others. Comments on the Notice of Intent were recelved from 16 entities.

9/19/85 BPA sent out notice of scoping meetings and solicition of comment. The notice requested interested partles to return a postcard to develop a malling list of parties who wanted to be kept informed about the EIS process. It also offered additional documents to help the public understand the power sales contracts and the issues involved. Five scoping meetings were held in October in Seattle amd Richland. Washington; Portland, Oregon; Burley, Idaho; and Missoula, Montana. Sixty-eight persons attended these meetings. By the end of this phase of the scoping process, 60 comment letters had been recelved.

10/21/85 A list of issues and alternatives raised by commenters in the scoping meetings was distributed to aid the public in formulating written comments.

12/4/85 A summary of the scoping comments, both written and orally presented at the scoping meetings, and copies of all comment letters received were sent to interested entities. A Cross Comment Process was undertaken, i.e., comments were requested both as to the accuracy of the summary and an opportunity was provided for parties to judge others comments and reconsider their own. An additional public meeting was held during this process. Fifteen additional comment letters were received.

1/23/86 At the request of interested parties, a 1 ist of prior BPA environmental documents was distributed to facilitate an understanding of the relationship of the Power Sales Contract: EIS to previous environmental analysis.

4/2/86 A Power Sales Contracts EIS Update was distributed to interested parties. This included a summary of the comments recelved during the cross Comment period and copies of the cross Comment letters. 
9/19/86 A Power Sales Contract EIS Update was sent to interested partles to inform them of progress on the EIS.

2/9/87 A draft Implementation Plan for the EIS was distributed for comment by interested parties. A public meeting was held on $3 / 24 / 87$ to discuss and take comment on the draft lmplementation plan.

5/26/87 A letter was sent to interested partles offering coples of comments on the draft Implementation Plan and a summary of them. In addition, this letter announced the formation of the Revlew Panel, consisting of representatives of customers and other interested parties, to act as a sounding board on the scope of the EIS, identification of issues to be dealt with, and the methods of analysis. The first meeting of the Revlew Panel was scheduled for June 8 and 9, 1987. From this time forward, meetings with the Revlew Panel were held as needed to discuss issues.

7/10/87 A letter was sent to the Review Panel distributing a new draft of the Implementation Plan for review and comment, with comments due July 24, 1989.

9/9/87 A letter was sent to Review Panel members distributing all comments received from them on the draft Implementation Plan of July 10, 1987, and announcing the decision to prepare a study Plan prior to finalizing the Implementation Plan. The Study Plan was to lay out the assumptions and analytical methods in greater detall than required for the Implementation Plan.

9/24/87 A Power Sales Contract EIS Update was sent to interested parties descrlbing the Review Panel's review of the draft Implementation Plan, and explaining that the Implementation Plan would be slightly delayed in order to assure that issues are accurately defined and that the proposed analysis is reasonable. Coples were offered of all Review Panel comments on the Draft Implementation Plan and a summary of these comments organized by issue and how they will be incorporated into the Implementation Plan.

2/11/88 A letter was sent to the Review Panel providing (1) a summary of changes in the alternatives proposed to be analyzed in the EIS;

(2) a summary of changes to the text of the Implementation Plan;

(3) a February 5, 1988, draft of the Implemenation Plan; and

(4) study plans for analysis of the alternatives. Comments were requested by March 4, 1988.

7/6/88 A meeting with the Review Panel was held to provide information regarding the SAM base (i.e., No Action) case. 
8/1/88 A Power Sales Contract EIS update was sent to interested parties. This Update offered coples of the Final Implementation Plan, which had been approved by the Department of Energy on June 24,1988 , upon request.

8/16/88 Coples of the Final Implementation Plan, a summary of comments on the February 11, 1988, transmittal of a draft Implementation Plan and a Study Plan, a Study Plan summary, and a summary of assumptions to be used in SAM in modeling the No Action Alternative were provided to the Revlew Panel.

10/18/88 A letter was sent to Revlew Panel members descrlbing the status of the analysis, informing them of what the partlal Draft EIS they were to review would consist of and when they could expect, and providing a list of categorles of data which would be collected from SAM.

11/18/88 A letter was sent to Review Panel members which provided an update of the EIS schedule and provided a document stating assumptions which were used in the SAM analyses.

12/23/88 A partial Draft EIS, consisting of Chapters 1 through 3, Appendix B, and Appendlx $C$, was sent to the Review Panel for review and comment. Comments were due February $3,1989$.

3/8/89 Coples of all flve comment letters from review panel members on the Partial Draft Power Sales Contract EIS were sent to each review panel member.

5/5/89 A draft report on Direct Service Industry-related analysis prepared by BPA staff for the Power Sales Contract EIS was provided to the Review Panel for review and comment with comments due May 19, 1989.

$4 / 11 / 89-$ $5 / 23 / 89$

BPA Responded to several requests from individual Review Panel members for data from the SAM analyses from Review Panel members so they could check our analyses, perform other types of analysis, and generally critique BPA's SAM analyses.

8/8-10/89 Updates were sent to the Review Panel and other interested parties providing new information on the EIS schedule.

9/8/89 Coples of significant portions of a preliminary Draft Power Sales Contract EIS were provided to the Review Panel for review and comment. Comments were due September 29, 1989.

9/18/89 Technical Appendix material related to the analysis of lmpacts on fish was provided to the Review Panel for revlew and comment. 
9/25/89 A meeting with the Review Panel was held to discuss the Preliminary Draft EIS.

11/1/89 A letter and coples of the $s 1 x$ comment letter recelved on the preliminary Draft EIS were sent to the Revlew Panel members.

12/21/89 A letter was sent to Revtew Panel members Informing them that the Draft EIS was sent to DOE for formal approval.

1/23/90 A letter was sent to the Revlew Panel members updating them on status of DOE review of Draft $E I S$.

3/5/90 Letter was sent to Revlew Panel members descrlbing the status of the Draft EIS. The document had to undergo a more thorough review process that included the offlce of the Secretary which caused a delay in the schedule. The letter also informed the Review panel that BPA is required to offer a public meeting on the Draft EIS and members would be contacted with posslble meeting dates.

10/1/90 The draft EIS was distrlbuted for public revelw and comment through $12 / 10 / 90$.

$11 / 8 / 90 \quad$ The Review Panel met to discuss the draft EIS.

$11 / 15 / 90 \quad$ A public meeting was held to recelve comments on the draft EIS.

$12 / 10 / 90 \quad$ Close of comments on the draft EIS.

12/20/90 A letter was sent to the Review Panel distributing written comment letters on the Draft EIS for their information. 


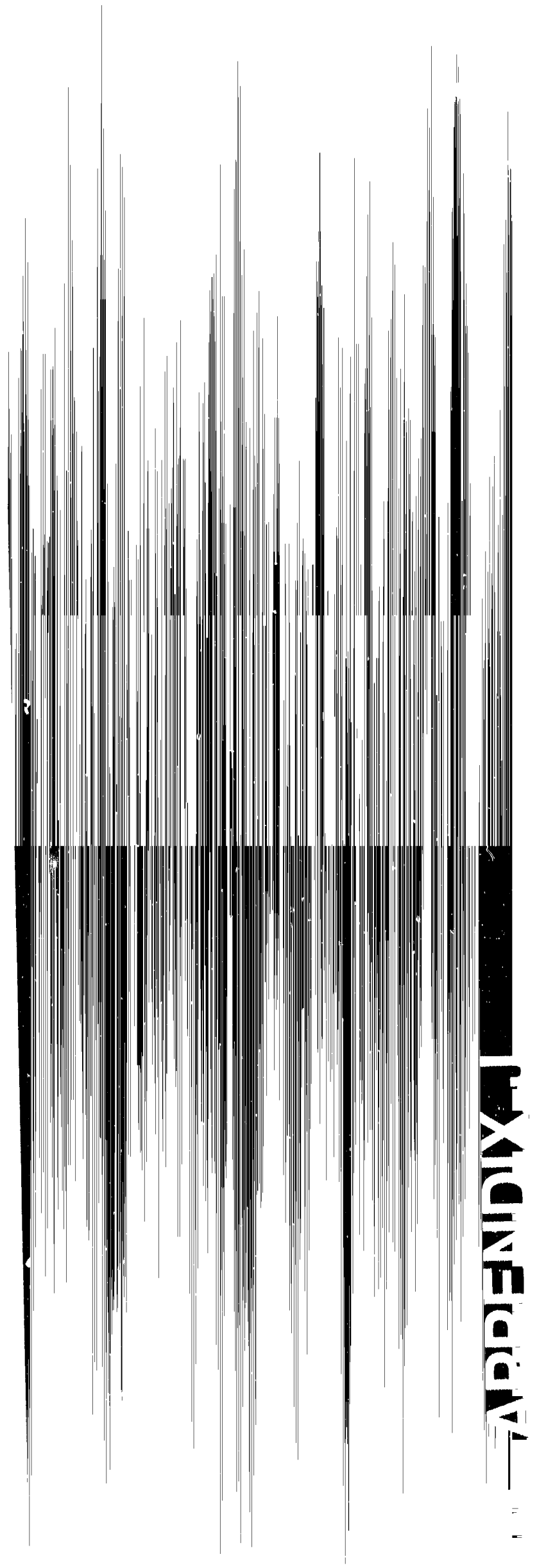




\section{APPENDIX J}

Bibl lography 


\section{APPENDIX J}

\section{Bibllography}

Archaeological and Historlcal Services. 1986. A Cultural Resources Assessment of Bonneville Power Admintstratlon's Proposed Intertie Development and Use on Lake Roosevelt, Lake Pend Orell le, Lake Koocancusa, Dworshak Reservolr, and Hungry Horse Reservolr. Eastern Washington Untversity Reports in Archaeology and History 100-52. Eastern Washington Universtty. Cheney, WA.

Balley, Robert G. 1980. "Ecoreglons of the United States." In Miscellaneous Publication No. 1391. U.S. Department of Agrtculture.

BloSystems Analysis, Inc. 1986. Long Term Intertle Development and Use. Final Report. Clearwater Consulting Corporation. Sausalito, CA.

Chance, David H. 1967. Archaeological Survey of Coulee Dam National Recreation Area. Part 2: Spring Draw-Down of 1967. Report of Investlgations 42. Laboratory of Anthropology. Washington State Untversity.

Colller, Donald, A. E. Hudson, and Arlo Ford. 1942. Archaeology of the Upper Columbla Region. University of Washington. Publications in Anthropology $9(1): 1-178$.

Corliss, David and Joseph Gallager. 1971. Progress Report: Dworshak Reservolr Excavations, Summer and Autumn, 1971. Ms., Idaho State Untversity Museum, Pocatello, ID.

Corliss, David and Joseph Gallager. 1972. Flnal Report: 1970-1971. Archaelogical Survey of the Dworshak Reservoir. Ms., Idaho State University Museum, Pocatello, ID.

"DIscovertes About Dioxin Formation Have Changed Some Mlll Operations," Pulp and Paper, Aprl1 1989, pp. 133-136.

Gaarder, Lorin R. 1968. "A Report on Archaeological Testing of Site 10-CW-5, Clearwater River, North-Central Idaho." Tebiwa 11(1):60-70.

Gough, Stan and Keo Boreson. 1985. A Cultural Resources Reconnaissance on Federal Lands in the Albeni Falls Project Area, Northern Idaho. Eastern Washington University Reports in Archaeology and History 100-50. Archaeological and Historical Services, Eastern Washington University, Cheney. Technical report published jointly with the U.S. Army Corps of Englneers, Seattle District.

Knudson, Ruthann, Robert Lee Sappington, and Michael A. Pfelffer. 1977. Assessment of the Archaeological Resource Within the Dworshak Reservoir Project Boundaries, 1976. Ms., Laboratory of Anthropology. University of Idaho. Moscow, ID. 
Lake Pend Oreille, Idaho Club. [Albeni Falls section, p. 3-12, discussion of spring Kokanee and Kamloops fishing derby.]

Larrabee, Edward and Susan Kardas. 1966. Archaeological Survey of the Grand Coulee National Resea ch Area: Part I, Lincoln County Above Normal Pool. Laboratory of Anthropology. Washington State University R port of Investigations 38 . Pullman, WA.

Masten, R. and J. Galm. 1986. A Cultural Resources Inventory for the "Grand Coulee Project," Douglas, Grant, Ferry, Lincoln, Okanogan, and Stevens Counties, Washington. Eastern Washington University Reports in Archaeology and History 100-55. Archaeological and Historical Services. Cheney, WA.

Miss, C. J. and L. Hudson. 1986. Cultural Resources Reconnaissance of the Albeni Falls Project, Northern Idaho. Cultural Resource Consultants, Inc., Sandpoint, Idaho. Technical report published jointly with the U.S. Army Corps of Engineers, Seattle District.

"Northwest Mills on EPA List of 200 Posing Biggest Cancer Risk," The Oregonian, June $6,1989, \mathrm{p} . \mathrm{Cl}$.

Northwest Power Planning Council. 1986. Northwest Conservation and Electric Power Plan.

Northwest Power Planning Council. 1987. Columbia River Basin Fish and Wildlife Program.

Northwest Power Planning Council. 1989. Issue Paper: "Assessment of Regional Progress toward Conservation Capability Building," March 13, 1989.

"Pacific Northwest Electric Power Planning and Conservation Act." House Report 96-976, Part I. House Committee on Interstate and Foreign Commerce, 96 th Congress, 2 nd session, May 15, 1980, pp. 61, 63.

Portland State University, Center for Population Research and Census.

Robare, Art. Cascade Steel Rolling Mills. Personal communication, spring 1989.

"Survey Examines Factors Affecting Brightness of Mechanical Pulps," Pulp and Paper, June 1989, pp. 60-62.

Swanson, Earl H., Jr. 1971. Archaeology in the Clearwater River Valley. Idaho.

- Swanson, Earl H., Jr. and David Corliss. 1971. Interim Report to the National Park Service: Archaeology in the Dworshak Reservoir 1970-1971. Ms. Idaho State University Museum. Pocatello, ID. 
Thomas, Alston V. and Robert R. Mierendorf. 1985. Archaeological Localities With in the Drawdown Zone and Along the Upper Margin of Dworshak Reservoir, Clearwater County, Idaho. Memo to Leo Flynn, Laboratory of Anthropology, University of Idzho, Moscow. On file: Walla Walla District Army Corps of Engineers.

U.S. Department of Commerce, Bureau of Cenzus. 1980 Census.

U.S. Department of Commerce, Bureau of Census. 1990 Census.

U.S. Department of Energy. Bonneville Power Administration. August 1977. BPA Electrical Service to the Northwest Alloys Magnesium Plant: Final Environmental Impact Statement. FES 77-31.

U.S. Department of Energy. Bonneville Power Administration. December 1980. The Role of The Bonneville Power Administration in the Pacific Northwest Power Supply System, Including Its Participation in a Hydro-Thermal Power Program: Final Environmental Impact Statement. DOE/EIS - 0066.

U.S. Department of Energy. Bonneville Power Administration. September 1981. Environmental Report: Prepared to Accompany the Final Power Sales and Residential Exchange Contracts.

U.S. Department of Energy. Bonneville Power Administration. September 1983. 1983 Wholesale Power Rate Final Environmental Impact Statement. DOE/EIS -0102-F.

U.S. Department of Energy. Bonneville Power Administration. 1984. Administrator's Record of Decision: 1984 Average System Cost Methodology.

U.S. Department of Energy. Bonneville Power Administration. 1985. DSI Options Study: Final Report. DOE/BP-476 and 477.

U.S. Department of Energy. Bonneville Power Administration. January 1985. Final Cost Sharing Principles.

U.S. Department of Energy. Bonneville Power Administration. March 1986. 1985 Conservation Supply Document. DOE/BP-626.

U.S. Department of Energy. Bonnevilie Power Administration. April 1986. Final Environmental Impact Statement: Direct Service Industry Options. DOE/EIS - 0123F.

U.S. Department of Energy. Bonneville Power Administration. 1987. 1987 Resource Strategy. DOE/BP-818.

U.S. Department of Energy. Bonneville Power Administration. July 1988. 1988 Resource Program.

U.S. Department of Energy. Bonneville Power Administration. April 1988. Final Environmental Impact Statement: Intertie Development and Use. DOE/EIS - 0125-F. 
U.S. Department of Energy. Bonneville Power Administration. May 1988. Administrator's Decision: Long-Term Intertie Access Policy.

U.S. Department of Energy. Bonneville Power Administration. May 1988. Long-Term Intertie Access Policy.

U.S. Department of Energy, Bonneville Power Administration, and Northwest Power Planning Council. November 1988. Forecast of Electricity Use in the Pacific Northwest. DOE/BP-1137.

U.S. Department of Energy. Bonneville Power Administration. December 1988. Pacific Northwest Loads and Resources Study. Technical Appendix. DOE/BP-1174.

U.S. Department of the Interior. Bonneville Power Administration. July 1977. The Role of the Bonneville Power Administration in the Pacific Northwest Power Supply System, Including its Participation in the Hydro-Thermal Power Program: A Program Environmental Statement and Planning Report. Draft Environmental Statement. DOI/DES 77-21.

Washington Office of Financial Management. 1989.

\section{APPENDIX E REFERENCES}

Roth, R., C. Blanchard, J. Harte, H. Michaels, and M. El-Ashry. 1985. The American West's Acid Rain Test. Report \#1. World Resources Institute. Berkeley, CA.

U.S. Department of Commerce. Bureau of the Census. 1983. General Social and Economic Characteristics. USGPO. Washington, D.C.

Western Systems Coordinating Council. April 1986. Summary of Estimated Loads and Resources. WSCC.

\section{APPENDIX F REFERENCES}

James, Peter. 1984. The Future of Coal. Second Edition. MacMillan Press, London.

McGraw-Hill Encyclopedia of Science \& Technology. 1987. 6th Edition.

Northwest Power Planning Counci1. 1989. 1989 Supplement to the 1986 Northwest Conservation and Electric Power Plan. 89-1.

"Power council contemplates 'greenhousing' of America." The Seattle Post-Intelligencer. February 14, 1989.

Roth, R., C. Blanchard, J. Harte, H. Michaels, and M. El-Ashry. 1985. The American West's Acid Rain Test. Report \#l. World Resources Institute. Berkeley, CA. 
"Solidifying radioactive wastes." Electric Light \& Power. Volume 67, Number 3 (March 1989).

U.S. Department of Energy. Office of Environmental Analysis. March 1983. Energy Technology Characterizations Handbook: Environmental Pollution and Control Factors. Third Edition. DOE/EP - 0093.

U.S. Department of Energy. Office of Environmental Analysis. October 1988. Energy Technologies and the Environment: Environmental Information Handbook. Fourth Edition. DOE/EH - 0077.

U.S. Department of Energy. Bonneville Power Administration. December 1980. The Role of The Bonneville Power Administration in the Pacific Northwest Power Supply System, Including Its Participation in a Hydro-Thermal Power Program: Final Environmental Impact Statement. DOE/EIS - 0066.

U.S. Department of Energy. Bonneville Power Administration. May 1983. Environmental Assessment: Proposed Power System Changes to Implement the Water Budget.

U.S. Department of Energy. Bonneville Power Administration. September 1983. 1983 Wholesale Power Rate Final Environmental Impact Statement. DOE/EIS-0102-F.

U.S. Department of Energy. Bonneville Power Administration. June 1987. Backgrounder: Understanding Indoor Radon. DOE/BP-723.

U.S. Department of Energy. Bonneville Power Administration. August 1987. Issue Backgrounder: Energy Efficient New Homes \& Indoor Air Pollutants. DOE/BP-467.

U.S. Department of Energy. Bonneville Power Administration. April 1988. Final Environmental Impact Statement: Intertie Development and Use. DOE/EIS - 0125-F.

U.S. Department of Energy. Bonneville Power Administration. August 1988. Final Environmental Impact Statement on New Energy-Efficient Homes Programs: Assessing Indoor Air Quality Options. DOE/EIS - $0127 \mathrm{~F}$.

U.S. Department of Energy. Bonneville Power Administration. December 1988. Cogeneration Potential in the Pacific Northwest: May 1988 Seminar Highlights. DOE/BP-40040-1.

U.S. Department of Energy. Bonneville Power Administration. January 1989. Report No. 10: Radon Monitoring Results from BPA's Residential Weatherization Program. DOE/BP-1193.

U.S. Department of Energy. Bonneville Power Administration. February 1989. New Energy-Efficient Homes Programs Record of Decision. 


\section{APPENDIX G REFERENCES}

Applied Economic Associates, Inc. December 1981. Update and Re-estimation of the Northwest Energy Policy Project Energy Demand Forecasting Model.

Charles Rivers Associates. September 1982. Report No. 642: Model Documentation--Draft Final Report.

Downstream Migrant Estimates for Rocky Reach and Rock Is land. 1985.

Fish Passige Center. 1986. Smolt Monitoring Program Annual Report.

John Moberly Associates. July 1984. Primary Aluminum Production Costs in the Pacific Northwest.

Pacific Northwest Utllities Conference Committee. November 1983. Methods and Theory Manual.

Resource Strategies, Inc. May 1985. Aluminum Costs and Supply Arrangements in the Pacific Northwest.

Stock Assessment of Columbia River Anadromous Salmonids. 1984. Final Report.

U.S. Army Corps of Engineers. March 1986. FISHPASS Model Concept and Application. U.S. Army Corps of Engineers, North Pacific Division.

U.S. Army Corps of Engineers. 1987. Juvenile Fish Passage Plan.

U.S. Department of Energy. Bonneville Power Administration. 1985. DSI Options Study: Final Report. DOE/BP-476 and 477.

U.S. Department of Energy. Bonneville Power Administration. April 1986. Final Environmental Impact Statement: Direct Service Industry Options. DOE/EIS - 0123F.

U.S. Department of Energy. Bonneville Power Administration. 1987. 1987 Resource Strategy. DOE/BP-818.

U.S. Department of Energy. Bonneville Power Administration. April 1988. Final Environmental Impact Statement: Intertie Development and Use. DOE/EIS - 0125-F.

\section{APPENDIX H REFERENCES}

Aldon, E. F. 1978. "Reclamation of coal-mined land in the Southwest." J. Soll Water Cons. 33:75-79.

APHA. 1980. Standard Methods for the Examination of Water and Wastewater. 15th Edition. APHA, AWWA, AND WPCF. 
Bader, John. May 1987. Hydrologist, U.S. Geological Survey. Personal communication. Sacramento, CA.

Bovee, K. 1982. A Guide to Stream Habitat Analysis Using the Instream Flow Incremental Me thodology. Instream Flow Information Paper No. 12. U.S. Fish \& Wildlife Service. FWS/OBS-82/26.

Chilgren, J. D. 1978. "The responses of prairie deer mice to a field $\mathrm{SO}_{2}$ gradient." In Proceedings of the fourth joint conference on sensing environmental pollutants. American Chemical Society, Washington, DC

Curry, R. R. 1980. "Land reclamation in western North America." In National Research Council, Energy and the Fate of Ecosystems. National Academy Press. Washington, DC

Dvorak, A., and E. Pentecost et a1. 1977. Assessment of the Health and Environmental Effects of Power Generation in the Midwest. Vol II. Ecological effects. Argonne National Laboratory. Argonne, IL:

Dvorak, A. J. et al. 1978. Impacts of Coal-Fired Power Plants on Fish, Wildlife and Their Habitats. Office of Biological Services. U.S. Fish and Wildlife Service. FWS/BS-78/29. Washington, DC

Gage, S. J. 1980. Acid Rain. EPA-600/9-79-036. Office of Research and Development, U.S. Environmental Protection Agency. Washington, DC

Garcia, J. et al. 1983. Energy Related Use Conflicts for the Columbia River Estuary. U.S. Fish and Wildlife Service. Division of Biolngical Services. Washington, DC FWS/OBS-812/60.

Garcia, J., E. Cheslak, and T. Payne. 1985. Instream Flow and Related Studies for the San Joaquin River Below Mammoth Pool Dam. Southern California Edison Company.

Gibson, J. H. 1981. Atmospheric Deposition, Its Origins and Effects: An Overview. California Symposium on Acid Precipitation. Air Resources Board. Sacramento, CA.

Giurgevich, R. and M. Moxley. Wyoming Department of Environmental Quality. December 1985 - January 1986. Personal communication.

Gordon, C. and P. Tourangeau. 1974. "Biological effects of coal-fired power plants." Fort Union Coal Field Symposium.

Harte, J. 1981. Acid Precipitation on the Western Slope of the High Colorado Rockies. California Symposium on Acid Precipitation. Air Resources Board. Sacramento, CA.

Hittman Associates, Inc. 1974. Environmental Impacts, Efficiency, and Cost of Energy Supply and Use. Vol. 1. Final Report. Hittman Associates, Inc. Columbia, MD. 
Karr. M.H. 1982. Evaluation of Flsh Flow Options: Blologlcal/Hydrological Correlations. Columbla River Inter-Tribal Fish Commission. Portland, $O R$.

Keystone Coal Industry Manual. McGraw-H111. 1983-1985.

Lewis, B. et al. 1978. A Blologist's Manual for the Evaluation of Impacts of Coal-fired Power Plants on Fish, Wildlife, and Their Habitats. Office of Blological Services. U.S. Fish and Wildiffe Service. Washington, DC FWS/OBS-78/75.

Logan, R., J. Derby and L. Duncan. 1982. Acld Precipltation and Lake Susceptibility in the Central Washington Cascades. Environmental science and Technology 16:771-775.

McCal1, J. G. 1981. A Survey of Acid Precipitation in Northern Cal ifornia. Cal ifornia Symposium on Acid Precipitation. Atr Resources Board. Sacramento, CA. Pp. 171-186.

Moyle, P. and R. Nichols. 1974. "Decline of the Native Fish Fauna of the Sierra-Nevada Foothills, Central California." Amer. Midl. Nat. $92(1): 72-83$.

National Academy of Sciences, National Academy of Engineering. 1974. Water quality criteria, 1972. USGPO. Washington, DC

National Coal Association. 1983. 1983 Facts About Coal. National Coal Association. Washington, DC

Newmann, J. R. 1980. "Effects of air emisstons on wildlife resources." U.S. Fish and Wildlife Service. Washington, DC FWS/OBS-80/40.1.

New Mexico Department of Energy and Wildlife. Mining and Minerals Division. January 1986. Personal Communication.

Office of Technology Assessment. 1979. The Direct Use of Coal. Congress of the United States, Washington, $D C$

Peterson, M. A. and D. Adler. 1982. "The effects of air pollution and acid rain on fish, wildlife, and their habitats: introduction." Air pollution and acid rain, report 3 . Office of Blological Services, U.S. Flsh and Wildlife Service. Washington, DC FWS/OBS-80/40.3.

Potter, W. 1982a. The Effects of Air Pollution and Acid Rain on Fish, Wildlife, and Their Habitats - Lakes. Eastern Energy and Land Use Team, Biological Services Program, U.S. Fish and Wildlife Service. FWS/OBS-80/40.4.

Potter, W. 1982b. The Effects of Air Pollution and Acid Rain on Fish, Wildlife, and Their Habitats - Rivers and Streams. Eastern Energy and Land Use Team, Biological Services Program, U.S. Fish and Wildlife Service. FWS/OBS-80/40.5. 
Proctor, B., R. Thompson, J. Bunin, K. Fucik, G. Tamm, E. Wolf. 1983.

"Practices for protecting and enhancing fish and wildlife on coal inined land in the Uinta-Southwestern Utah region." Prepared for Western Energy and Land Use Team, U.S. Flsh and Wildlife Service. Washington, DC FWS/OBS-83-12.

Raleigh, R., T. Hickman, R. Solomon, and P. Nelson, 1984. Habitat Sultability Information: Ralnbow Trout. U.S. Fish and Wildlife Service. FWS/OBS-82/10.60.

Rolston, S., D. Hilbut, and D. Swift. 1977. "The ecological effects of coal strip-mining: a bibliography with abstracts." Natural Res. Ecol. Lab., Colorado State Univ., Fort Collins. Prepared for U.S. Fish and Wildlife Service. Washington, DC FWS/OBS-77-09.

Schindler et al. 1981.

Schofield, C. L. 1981. Acid Precipitation Effects on Aquatic Ecosystems. California Symposium on Acid Precipitation. Air Resources Board. Sacramento, CA.

Shilling, M. U.S. Office of Surface Mining. Western Technical Center. Personal Communication. Denver, CO.

Soholt, L. F., et al. 1980. Handling of Combustion and Emission-Abatement Waste from Coal-Fired Power Plants: Implication for Fish and Wild life Resources. U.S. Fish and Wildlife Service. Washington, DC FWS/OBS-80/33.

Thomas, J. L. 1975. Water Requirements and Wastewater Potential of Coal-Energy Facllities. In Montana Academy of Sclences (ed.). Proceedings of the Fort Union Coal Field Symposium. Vol. 2. Aquatic Ecosystems. Hagen Printing Co: Billings, MT.

Tonnessen, K. 1981. The Potential Impact of Acid Precipitation on Aquatic Ecosystems of the Western Slope of the Sierra Nevada. Cal ifornia symposium on Acid Precipitation. Air Resources Bodrd. Sacramento, CA.

U.S. Army Corps of Engineers. March 1986. FISHPASS Model Concept and Application. U.S. Army Corps of Engineers, North Pacific Division.

U.S. Department of Energy. Bonneville Power Administration. April 1988. Final Environmental Impact Statement: Intertie Development and Use. DOE/EIS - 0125-F.

U.S. Department of Energy. Energy Information Administration. August 1984. Historical Plant Cost and Annual Production Expenses for Selected Electric Plants 1982. U.S. Department of Energy. DOE/EIA-0455(82). Washington, DC

U.S. Department of Energy. Energy Information Administration. 1981-1985. Cost and Quality of Fuels for Electric Utility Plants. U.S. Department of Energy. Washington, $D C$ 
U.S. Department of Energy. Energy Information Administration. Office of Coal/Nuclear Electric Power and Alternative Fuels.

U.S. Department of the Interior. December 1985-January 1986. Office of Surface Mining. Personal communtcation. Denver, Co.

U.S. Environmental Protection Agency. 1982.

Washington Irrigation and Development Company. January 1986. Personal communication with Manager of Permitting.

Wood, D. L. 1973. "The impact of photochemical afr pollution on the mixed conifer forest ecosystem---anthropods." In 0. C. Taylor (ed.). Oxidant air pollution effects in a western Coniferous Forest Ecosystem. Air Pollution Research Center, Univ. of California, Riverside, CA. 


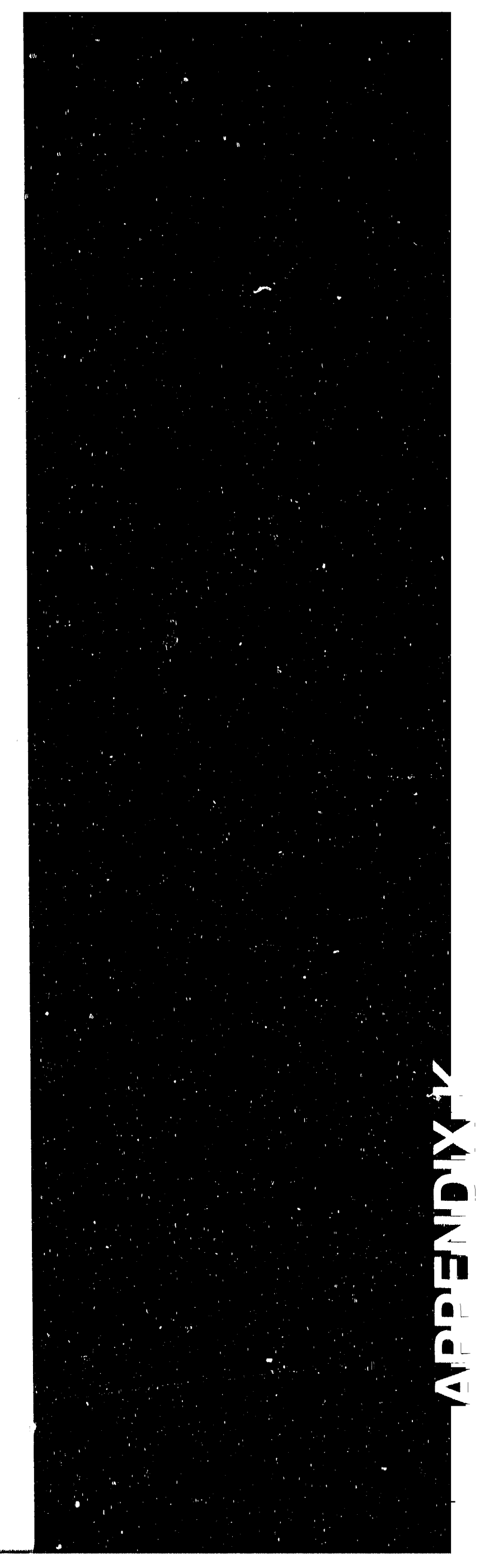




\section{Append IX K}

Pacific Northwest Electric Power Planning and Conservation Act

P.L. 96-501

(Northwest Power Act) 


\section{An Act}

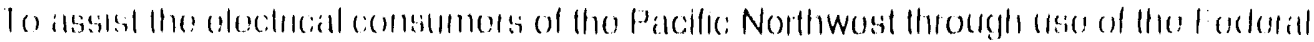

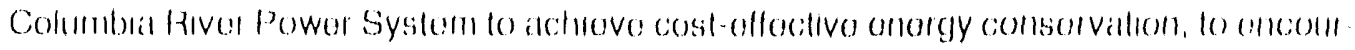

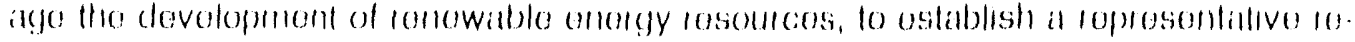

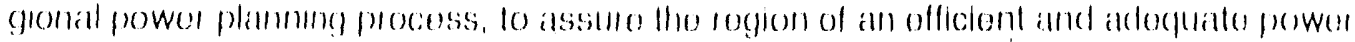
supply, and for othor punposes:

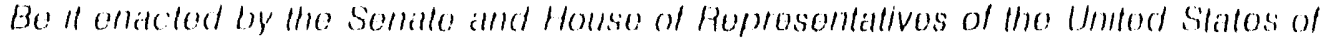
Amenca mongress assomblod.

\section{SHORT TITLE AND TABLE OF CONTENTS}

Section 1. This Act, logother with the lollowing lable of contents, may be citod as the "Pacific Northwost Eloctric Power Parning and Conservalion Act".

\section{TABLE OF CONTENTS}

Sec. 1. Short title and table of contents.

Sec. 2. Purposes

Sec. 3. Delinitions.

Sec. 4. Rogional planning and participation.

Sec. 5. Sale of power.

Sec. 6. Conservation and resource acquisition.

Sec 7 Rates

Sec. 8. Amendments to existing law.

Sec. 9. Admiristrative provisions.

Sec: 10. Savings provisions.

Soc 11 Elloctive date.

Sec. 12 Severability

\section{PURPOSES}

Section 2. The purposos of this Act, logether with the provisions of other laws applicable to the Foderal Columbia River Power System, are all intended to be construed in a consistent manner. Such purposes aro also intonded to be construed in a mannor consistent with applicable onvironmental laws. Such purposes aro:

2.(1) to encourage, through the unique opportunity provided by the Federal Columbia River Power System ...-

2.(1)(A) conservation and efficiency in the use of electric powor, and

2.(1)(B) the development of ronewable resources within the Pacilfic Norlliwesst.

2.(2) to assure the Pacific Northwost of an adoquate, efficient economicail. and relable power supply:

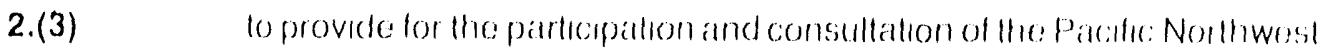
States, local governments, consumer's, customers, users of the Columba Riven System

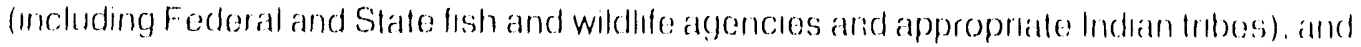
the puthle at large withmen the rogen m

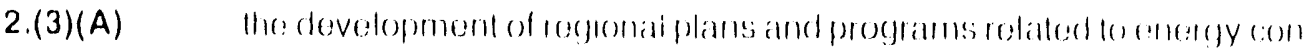

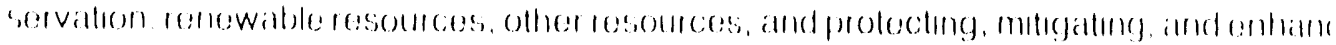
ing flsht and wilditeresenterces:

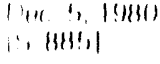

16:150:Bi3! 11010 
2.(3)(B) facilitating the orderly planning of tho rogion's power system, and

2.(3)(C) providing onvironmental quality;

2.(4) Io provide that the customers of the Bonnovillo Powor Administration and their consumors conthue to pay all costs necossary to produco, transmit, and con. serve rosources to meet the reglon's electric; powor requirements, including the amortiza. lion on a current basis of the Foderal Invostment in the Foderal Columbla River Power System:

2.(5) to insure, subject to the provisions of this Act -...

2.(5)(A) that the authorittes and responsibilities of Stato and local governments, electric utility systems, water management agencies, and other non-Foderal entities for the reçulation, planning, conservation, supply, distributlon, and use of electric power shall be construed to be maintained, and

2.(5)(B) That Congress intends that this Act not be construed to limit or restrict the ability of customers to take actions in accordance with other applicable provisions of Federal or Slate law, including, but not limited 10, actions to plan, develop, and operate resources and to achieve conservation, without regard to this $\mathrm{Acl}_{\text {; }}$ and

2.(6) Io protecl, mitigate and enhance the lish and wildlife, including related spawning grounds and habitat, of the Columbia River and its tributaries, particularly ana. dromous fish which are of significanit importance to the social and economlc well-being of the Pacific Northwest and the Nation and which are dependent on suitable environmuntal conditions substantially obtainable from the management and operation of the Foderal Columbia River Power System and other power generating lacilities on the Columbia River and its tributaries.

\section{DEFINITIONS}

Section 3. As used in this Act, the torm ...

3.(1) "Acquire" and "acquisition" shall not be construed as authorizing the Administrator to construct, or have ownership of, under this Act or any other law, any electric generating lacility.

3.(2) "Administrator" moans the Admenistrator of tho Bonnoville Power Ad. ministration.

3.(3) "Conservation" meansiany reduction un olectric powor consumplion as a resull of increases in the officiency of energy uso, production, or distribution.

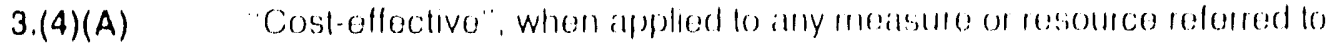
II thes Act, means that such measuro or resource must be forecatsil

3.(4)(A)(1) lo berolable and aviallable withen the thenes it is needed, and

3.(4)(A)(II) to meot or reduco the electric: power demalnd, als retermined by tho

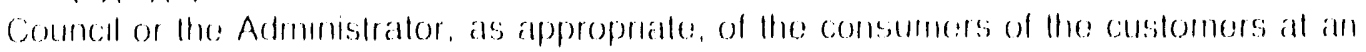

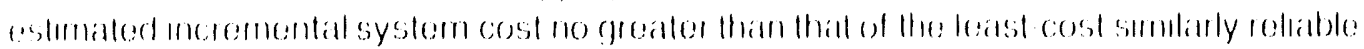

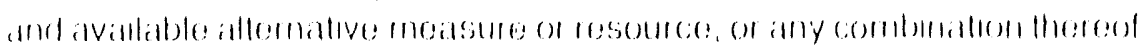

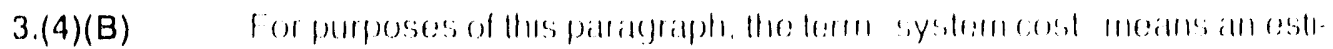

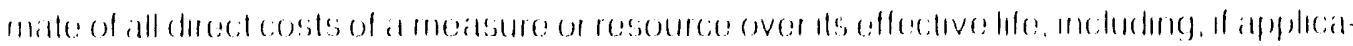

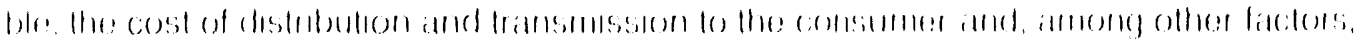




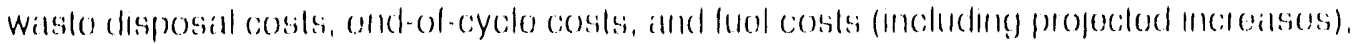

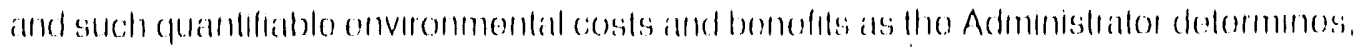

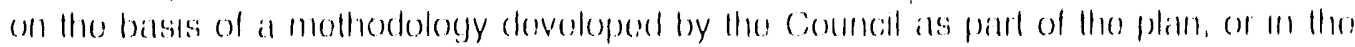

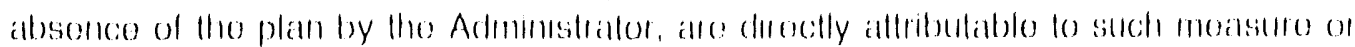
105011100

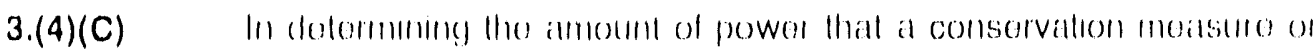

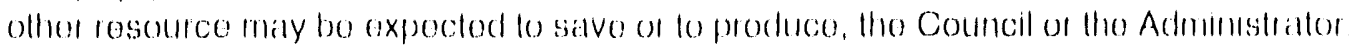

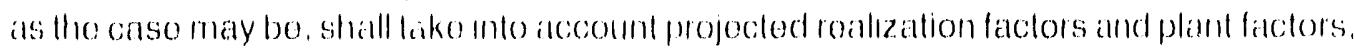
includeng appropriate hestoncal expenonco will simnlan moasuros or rosources.

3.(4)(D) For purposos of this pallagraph, tho "estimatod incromontal systom cosi" of any conservation moasure or resource shall not be treated als groater than that of any nonconservation measuro or resource unless the incremental systom cost of such conservallon measure or rosource is in excess of 110 per centum of the incromental system cost of the nonconservation measure or resource.

3.(5) "Consumer" means any end user of electric power.

3.(6) "Council" moans, unless otherwise specifically provided, the members appointed to the Pacilic Northwest Electric: Power and Conservation Planning Council established pursuant to section 4.

3.(7) "Customor" means anyono who contracts for the purchase of power from the Administrator pursuant to this Acl

3.(8) "Direct service industrial customer" means an industrial customer that contracts for the purchase of power from the Administrator for direct consumption.

3.(9) "Electric power" means electric peaking capacity, or eloctric energy, or both.

3.(10) "Federal base system rosources" means -

3.(10)(A) the Federal Columbia River Power System hydroelectric projects:

3.(10)(B) resources acquired by the Administrator under long-term contracts in force on the effective date of this Act; and

3.(10)(C) resources acquired by the Administrator in an amount necessary to replace reductions in capability of the resources referred to in subparagraphs $(A)$ and $(B)$ of this paragraph.

3.(11) "Indian tribe" means any Indian tribe or band which is located in whole or in part in the region and which has a governing body which is recognized by the Secrelary of the Interior.

3.(12) "Major resource" means any resource that -

3.(12)(A) has a planned capability greater than fifty average megawalts, and

3.(12)(B) If acquired by the Administrator, is acquired for a period of more, than five years.

3.(12) Such torm does not include any resource acquired pursuant to section $11(b)(6)$ of the Federal Columbia River Transmission System Act.

3.(13) "Now large single load" means any load associated with a new facilly. an existing facility, or an expansion of an existing facility---

3.(13)(A) which is not contracted for, or committed to, as determmed by the Ad ministrator, by a public body, cooperativo, investor-owned utility, or Fodoral agency cus. tomer pror to Soptomber 1. 1979, and 
3.(13)(B) which will result in an increase in powf.r requirements of such customer of ten average megawatts or more in any consecutive twelve-month period.

3.(14) "Pacific Northwest", "region", or "regicnal" means--

3.(14)(A) the area consisting of the States of Oregon, Washıngton, and Idaho, the portion of the State of Montana west of the Continental Divide, and such portions of the States of Nevada. Utah, and Wyoming as are within the Columbia River drainage basin; and

3.(14)(B) any contiguous areas, not in excess of seventy-five air miles from the area referred to in subparagraph $(A)$, which are a part of the service area of a rural electric cooperative customer served by the Administrator on the effective date of this Act which has a distribution system from which it serves both within and without such region.

3.(15) "Plan" means the Regional Electric Power and Conservation plan (including any amendments thereto) adopted pursuant to this Act and such plan shall apply (1) actions of the Administrator as specified in this Act.

3.(16) "Renewable resource" means a resource which utilizes solar, wind, hydro, geothermal biomass, or similar sources of energy and which either is used for electric power generation or will reduce the electric power requirements of a consumer, including by direct application.

3.(17) "Reserves" means the electric power needed to avert particular planning or operating shortages for the benefit of firm power customers of the Administrator and available to the Administrator $(A)$ from resources or $(B)$ from rights to interrupt, curtail, or otherwise withdraw, as provided by specific contract provisions, portions of the electric power supplied to customers.

3.(18) "Residential use" or "residential load" means all usual residential, apartment, seasonal dwelling and farm electrical loads or uses, but only the first four hundred horsepower during any monthly billing period of farm irrigation and pumping for any farm

3.(19) "Resource" means-

3.(19)(A) electric power, including the actual or planned electric power capability of generating facilities, or

3.(19)(B) actual or planned load reduction resulting from direct application of a renewable energy resource by a consumer. or from a conservation measure.

3.(20)

Secretary means the Secretary of Energy

\section{REGIONAL PLANNING AND PARTICIPATION}

\section{Section 4 .}

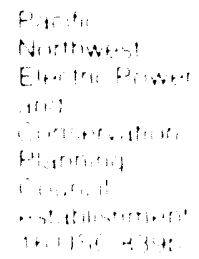

The purposes of this section are to provide for the prompt establishment and effective operation of the Pacific Northwest Electric Power and Conservation Planing Councit io further the purposes of this Act by the Council promptly preparng and adopting $(A)$ a regonal conservation and electric power phan and (B) a program fo protect. migate and enhance fish and wildife and to otherwise expeditiously and effectively

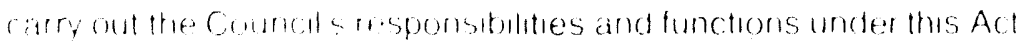

4.(a)(2) To achere such purposes and facillate cooperation among the States 1. Whato Montiand Oregon and Washongton and with the Bonneville Power Admonstra-

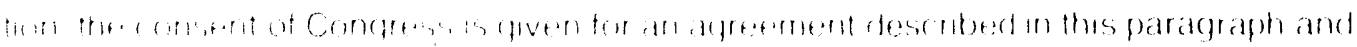

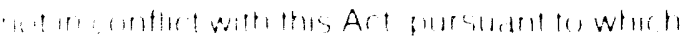


4.(a)(2)(A) there shall be established a regional agency known as the "Pacific Northwest Electric Power and Conservation Planning Council" which (1) shall have its offices in the Pacific Northwest. (11) shall carry out its functions and responsibilites in accordance with the provisions of this Act, (iil) shall continue in force and effect in accordance with the provisions of this Act, and (Iv) except as otherwise provided in this Act, shall not be considered an agency or instiumentality of the United States for the purpose of any Federal law; and

4.(a)(2)(B) two persons from each State may be appointed, subject to the applicable laws of each such State. to undertake the functions and duties of members of the Council.

4.(a)(2) The State may fill any vacancy occurring prior to the expiration of the term of any member. The appomtment of six initial members, subject to applicable State law, by June 30, 1981. by at least three of such States shall constitute an agreement by the States establishing the Council and such agreement is hereby consented to by the Congress. Upon request of the Governors of two of the States, the Secretary shall extend the June 30,1981, date for six additional months to provide more time for the States to make such appointments

4.(a)(3) Except as otherwise provided by State law, each member appointed to the Council shall serve for a term of three years, except that, with respect to members initially appointed, each Governor shall designate one member to serve a term of two years and one member to serve a term of three years. The members of the Council shall select from among themselves a chairman. The members and officers and employees of the Council shall not be deemed to be officers or employees of the United States for any purpose. The Councll shall appoint, fix compensation, and assign and delegate duties to such executive and additional personnel as the Council deems necessary to fulfill its functions under this Act, taking into account such information and analyses as are, or are likely to be, available from other sources pursuant to provisions of this Act. The compensation of the members shall be fixed by State law. The compensation of the members and officers shall not exceed the rate prescribed for Federal officers and positions at step 1 of level GS. 18 of the General Schedule.

4.(a)(4) For the purpose of providing a uniform system of laws, in addition to this Act, applicable to the Council relating to the making of contracts, conflicts-of-interost. financial disclosure, open meetings of the Council, advisory committees. disclosure of information. judicial review of Council functions and actions under this $\mathrm{Act}$, and related matters, the Federal laws applicable to such matters in the case of the Bonneville Power Administration shall apply to the Council to the extent appropriate, except that with re. spect to open meetings, the Federal laws applicable to open meetings in the case of the Federal Energy Regulatory Commission shall apply to the Souncil to the extent appropriate In applying the Federal laws applicable to financial d sclosure under the preceding sentence. such laws shall be applied to members of the Council without regard to the duration of their service on the Council or the amount of compensation recelved for such service No contract obicyation. or other action of the Council shall be construed as an obligation of the United States or an bligation secured by the full fath and credit of the United States. For the purpose of fudiciai review of any action of the Council or challenging any provision of this Act relating to functions and responsibilities of the Council notwith

Mentous alppxntment

Timo extentsum

Temes of effece

Compensiblom

451269501 
Nolice, publication in Federal Register.

Compensation

45 FR 69201

Compensation standing any other provision of law, the courts of the United States shall have exclusive jurisdiction of any such review.

4.(b)(1) If the Council is not established and its members are not timely appointed in accordance with subsection (a) of this section, or if, at any time after such Council is established and its members are appointed in accordance with subsection (a) -

4.(b)(1)(A) any provision of this Act relating to the establishment of the Council or to any substantial function or responsibility of the Council (including any function or responsibility under subsection (d) or (h) of this section or under section 6(c) of this Act) is held to be unlawful by a final determination of any Federal court, or

4.(b)(1)(B) the plan or any program adopted by such Council under this section is held by a final determination of such a court to be ineffective by reason of subsection (a) $(2)(B)$,

4.(b)(1) the Secretary shall establish the Council pursuant to this subsection as a Federal agency. The Secretary shall promptly publish a notice thereof in the Federal Register and notify the Governors of each of the States referred to in subsection (a) of this section.

4.(b)(2) As soon as practicable, but not more than thirty days after the publication of the notice referred to in paragraph (1) of this subsection, and thereafter within forty-five days after a vacancy occurs, the Governors of the States of Washington, Oregon, Idaho, and Montana may each (under applicable State laws, if any) provide to the Secretary a list of nominations from such State for each of the State's positions to be selected for such Council. The Secretary may extend this time an additional thity days. The list shall include at least two persons for each such position. The lisi. shall include such information about such nominees as the Secretary may request. The Secretary shall appoint the Council members from each Governor's list of nominations for each State's positions, except that the Secretary may decline to appoint for any reason any of a Governor's nominees for a position and shall so notify the Governor. The Governor may thereafter make successive nominations within forty-five days of receipt of such notice until nominees acceptable to the Secretary are appointed for each position. In the event the Governor of any such State fails to make the required nominations for any State position on such Council within the time specified for such nominations, the Secretary shall select from such State and appoint the Council member or members for such position. The members of the Council shall select from among themselves one member of the Council as Chairman.

4.(b)(3) The members of the Council established by this subsection who are not employed by the United States or a State shall receive compensation at a rate equal to the rate prescribed for offices and positions at level GS-18 of the General Schedule for each day such members are engaged in the actual performance of duties as members of such Council, except that no such member may be paid more in any calendar year than an officer or employee at step 1 of level GS-18 is paid during such year. Members of such Council shall be considered officers or employees of the United States for purposes of title II of the Ethics in Government Act of 1978 (5 U.S.C. app) and shall also be allowed travel expenses, including per diem in lieu of subsistencu, in the same manner as persons employed intermittently in Government service are allowed expenses under section 5703 of title 5 of the United States Code. Such Council may appoint, and assign duties 10, an executive director who shall serve at the pleasure of such Council and who shall be compensated at the rate established for GS-18 of the General Schedule. The executive director shall exercise the powers and duties delegated to such director by such Councll, 
Including the powe to appomb and fix compensation of additional persomel in accord ance with applicable Frederal law to carry out the functions and responsibilities of such Council

4.(b)(4) When id Council is established under this subsection after a Council was established pursuant to subscchon (a) of this section. the Secretary shall provide. to the greatest extent leasuble. for the transter to the Council established by this subsection of all funds, books, papers documents. equmpment, and other matters in order to lacilitate the Council's capabilty to acheve the requirements of subsections (d) and (h) of this section In order to carry out its functions and responsibilities under this Act expeditiously. the Council shall take into consideration any actions of the Council under subsection (a) and may review. modify, or confirm such actions without further proceedings

4.(b)(5)(A) Al any lime beginning one year after the plan teferred to in such subsec: tion (d) and the program referred to in such subsection (h) of this section are both finally adopted in accordance with this Act, the Council eslablished pursuant to this subsection shall be terminated by the Secretary 90 days after the Governors of three of the States referred to in this subsection jontly provide for any reason to the Secretary a written request for such termınation. Except as provided in subparagraph (B), upon such termina. IIon all functions and responsibilities of the Council under this Act shall also terminate.

4.(b)(5)(B) Upon such termination of the Council, the functions and responsibilities of the Council set forth in subsection (h) of this section shall be transferred to, and continue to be funded and carried out, jointly, by the Administrator, the Secretary of the Interior. and the Administrator of the National Marine Fisheries Service, in the same manner and to the same extent as required by such subsection and in cooperation with the Federal and the region's State fish and wildife agencies and Indian tribes reierred to in subsection (h) of this section and the Secretary shall provide for the transfer to them of all records, books. documents, funds, and personnel of such Council that relate to subsection (h) matters. In order to carry out such functions and responsibilities expeditiously, the Administrator, the Secretary of the Interior, and the Administrator of the Nationa! Marine Fisheries Service shall take into consideration any actions of the Council under this subsection, and may review. modify or confirm such actions without further proceedings, In the event the Council is terminated pursuant to this paragraph, whenever any action of the Administra. lor requires any approval or other action by the Councll, the Administrator may take such action without such approval or action, except that the Administrator may not implement any proposal to acquire a major generalıng resource or to grant billing credits involving a major generatıng resource until the expenditure of funds for that purpose is specifically authorized by Act of Congress enacted after such termination.

4.(c)(1) The provisions of this subsection shall. except as specifically provided in this subsection. apply to the Council established pursuant to either subsection (a) or (b) of this section

4.(c)(2) A majonty of the members of the Council shall constitute a quorum. Except as otherwise provided specifically in this Act. all actions and decisions of the Council shall be by majonly vote of the members present and voting. The plan or any part thereot and any amendment thereto shall not be apjoroved unless such plan or anend. ment receuves the voles of

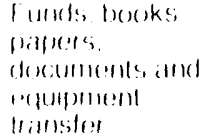

1(2)111m,1l1)!

Transter of functions

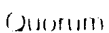




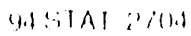

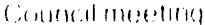

Armlunil work promeram budget avallability

Porsmomeldetal

Offis,ess equpment and s(ipplies:

Information lo conguress?

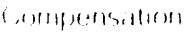
anclethe? melemente fistingell

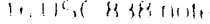
$\therefore, 1)^{1},\left(\mathrm{H}^{3} 3 \mathrm{~B}_{\mathrm{i}}\right.$

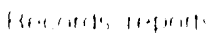
11.rite
4.(c)(2)(A) a majonty of the members apponted to the Council, including the vote of at least one member from each State with members on the Council; or

4.(c)(2)(B) at least six members of the Council.

4.(c)(3) The Council shall meet at the call of the Chairman or upon the request of any three members of the Council. If any member of the Council disagrees with respect to any matter transmitted to any. Federal or State official or any other person or wishes to express additional views concerning such matter, such member may submit a statement to accompany such matter selting forth the reasons for such disagreement or views.

4.(c)(4) The Council shall determine its organzation and prescribe its practices and procedures for carrying out its functions and responsibilities under this Act. The Council shall make available to the public a statement of its organization, practices, and procedures, and make available to the public its annual work program budget at the time the President submits his annual budget to Congress.

4.(c)(5) Upon request of the Council established pursuant to subsection (b) of this section, the head of any Federal agency is authorized to detail or assign to the Coun$\mathrm{Cil}$, on a reimbursable basis, any of the personnel of such agency to assist the Council in the performance of its functions under this Act.

4.(c)(6) At the Council's request, the Administrator of the General Services Administration shall furnish the Council established pursuant to subsection (b) of this section with such offices, equipment, supplies, and services in the same manner and to the same extent as such Administrator is authorized to furnish to any other Federal agency or instrumentality such offices, supplies, equipment, and services.

4.(c)(7) Upon the request of the Congress or any committee thereof, the Council shall promptly provide to the Congress, or to such committee, any record, report. document, material, and other information which is in the possession of the Council.

4.(c)(8) To obtain such information and advice as the Council determines to be necessary or appropriate to carry out its functions and responsibilities pursuant to this Act. the Council shall, to the greatest extent practicable, solicit engineering, economic, social, environmental, and other technical studies from customers of the Administrator and from other bodies or organizations in the region with particular expertise

4.(c)(9) The Administrator and other Federal agencies, to the extent authorized by other provisions of law, shall furnish the Council all information requested by the Counchl as necessary for performance of its functions, subject to such requirements of law concerning trade secrets and proprietary data as may be applicable.

4.(c)(10)(A) At the request of the Council, the Administrator shall pay from funds avitiable to the Administrator the compensation and other expenses of the Council as are authorzed by this $A c t$, including the reimbursement of those States with members on the Council for services and personnel to assist in preparing a plan pursuant to subsection (d) and a program pursuant to subsection (h) of this section, as the Council determines are necessary or appropriate for the performance of its functions and responsibilities. Such payments shall be included by the Administrator in his annual budgets submitted to Congress pursuant to the Federal Columba River Transmission System Act and shall be subject to the requirements of that $A c t$, including the audit requirements of section $11(d)$ of such Act The records, reports, and other documents of the Council shall be available to 
the Comptroller General for review an cormection with such audit or other review and examination by the Comptroller Goneral pursuant to othor provisions of law applicable to the Comptroller General Funds provided by the Administrator for such payments shall nol exceed ammally an amount equal 100.02 mill multiplied by the kilowatt hours of frm powe forecast to be sold by the Admmistrator during the year to be funded. In order to assist the Councils intial organzation, the Admmostator after the enactment of this Act stall promptly prepare and propose an amended anmal budget to expedite payment for Council activities.

4.(c) $(10)(B) \quad$ Notwithstanding the limitation contained in the fourth sentence of sub. paragraph $(A)$ of this paragraph. upon an annual showing by the Council that such limilatron will not permit the Council to carry out its functions and responsibilities under this Act the Adminstrator may rasse such limit up to any amount not in excess of 0.10 mill multiplied by the kilowatt hours of firm power forecast to be sold by the Administrator during the year to be funded.

4.(c)(11) The Council shall establist a voluntary scientific and statistical advisory committee to assist in the development, collection, and evaluation of such statistical. biological, economic, social, envirommental, and other scientific information as is relevant to the Council's development and amendment of a regional conservation and electric power plan.

4.(c)(12) The Council may establish such other voluntary advisory committees as it determines are necessary or appropriate to assist it in carrying out its functions and responsibilities under this Act.

4.(c)(13) The Council shall ensure that the membership for any advisory commit. tee established or formed pursuant to this section shall, to the extent feasible, include representatives of, and seek the advice of, the Federal, and the various regional. State. local, and Indian Tribal Governments, consumer groups, and customers.

4.(d)(1) Within two years after the Council is established and the members are appointed pursuant to subsection (a) or (b) of this section, the Council shall prepare. adopt, and promptly transmit to the Administrator a regional conservation and electric power plan. The adopted plan, or any portion thereof, may be amended from lime to time. and shall be reviewed by the Council not less frequently than once every five years. Prior to such adoption, pubic hearings shall be held in each Council member's State on the plan or substantial, nontechnical amendments to the plan proposed by the Council for adoption. A public hearing shall also be held in any other State of the region on the plan or amendments thereto, if the Council determines that the plan or amendments would likely have a substantial impact on that State in terms of major resources which may be developed in that State and which the Administrator may seek to acquire. Action of the Council under this subsection concerning such hearings shall be subject lo section 553 of title 5 . United States Code and such procedure as the Council shall adopt.

4.(d)(2) Following adoption of the plan and any amendment thereto, all actions of the Adminstrator pursuant to secton 6 of this Act shall be consistent with the plan and any amendment thereto except as otherwise specifically provided in thas Acl

4.(e)(1) The plan shall, as provided in this paragraph, give prority to resources, which the Council determmes to be cost-effective Priority shall be given first to conser.

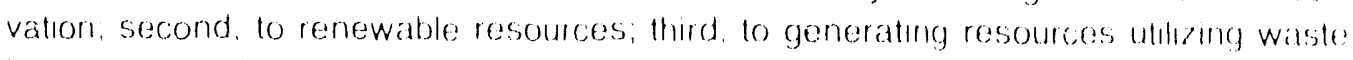

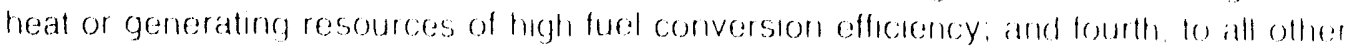
resourcess

Velumbiary siduntifes: and actusesery commentlene entablistumbul

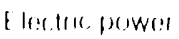
pan llansmetral in Admunctralles

Hearings 
W

4.(e)(2) The plan shall set forth a general scheme for implementing conservalion measures and developing resources pursuant to section 6 of this Act to reduce or meet the Administrator's obligations with due consideration by the Council for $(A)$ environmental quality, (B) compatibility with the existing regional power system, (C) protection, mitigation, and enhancement of fish and wild life and related spawning grounds and habitat, including sufficient quantities and qualities of flows for successful migration, survival, and propagation of anadromous fish, and (D) other criteria which may be set forth in the plan.

4.(e)(3) To accomplish the priorities established by this subsection, the plan shall include the following elements which shall be set forth in such detail as the Council determines to be appropriate:

4.(e)(3)(A) an energy conservation program to be implemented under this Act, including, but not limited to, model conservation standards;

4.(e)(3)(B) recommendation for research and development:

4.(e)(3)(C) a methodology for determining quantiliable environmental costs and benefits under section $3(4)$;

4.(e)(3)(D) a demand forecast of at least twenty years (developed in consultation with the Administrator, the customers, the States, including State agencies with ratemaking authority over electric utilities, and the public, in such manner as the Council deems appropriate) and a forecast of power resources estimated by the Council to be required to meet the Administrator's obligations and the portion of such obligations the Council determines can be met by resources in each of the priority categories referred to in paragraph (1) of this subsection which forecast (i) shall include regional reliability and reserve requirements, (ii) shall take into account the effect, if any, of the requirements of subsection (h) on the availability of resources to the Administrator, and (iii) shall include the approximate amounts of power the Council recommends should be acquired by the Administrator on a long-term basis and may include, 10 the extent practicable, an estimate of the types of resources from which such power should be acquired;

4.(e)(3)(E) an analysis of reserve and reliability requirements and cost-effective methods of providing reserves designed to insure adequate electric power at the lowest probable cost;

4.(e)(3)(F) the program adopted pursuant to subsection (h); and

4.(e)(3)(G) if the Council recommends surcharges pursuant to subsection ( $f$ ) of this section, a methodology for calculating such surcharges.

4.(e)(4) The Councit, taking into consideration the requirement that it devote its principal efforts to carrying out its responsibilities under subsections (d) and (h) of this section, shall undertake studies of conservation measures reasonably available to direct service industrial customers and other major consumers of electric power within the region and make an analysis of the estimated reduction in energy use which would result from the implementation of such measures as rapidly as possible, consistent with sound business practices. The Council shall consult with such customers and consumers in the conduct of such studies.

Model conservalton standards 4.(f)(1) Model conservation standards to be included in the plan shall include, but not be limited to, standards applicable to (A) new and existing structures, (B) utility, customer, and governmental conservation programs, and (C) other consumer actions for acheving conservation. Model conservation standards shall reflect goographic and chimatic differences within the region and other appropmate considerations, and shall be 
designed to produce all power savings that are cost-effoctive for the region and econom cally feasible for consumers, taking into account financial assistance made avalable to consumers under section 6(a) of this Act. These model conservation standards shall be adopted by the Council and included in the plan after consultation, in such manner as the Council deems appropriate, with the Administrator, States, and political subdivisions, customers of the Administrator, and the public.

4.(f)(2) The Council by a majority vote of the members of the Council is authorized to recommend to the Administrator a surcharge and the Administrator may thereafter impose such a surcharge, in accordance with the methodology provided in the plan, on customers for those portions of their loads within the region that are within states or political subdivisions which have not, or on the Administrator's customers which have not. implemented conservation measures that achieve energy savings which the Administrator determines are comparable to those which would be obtairled under such standards. Such surcharges shall be established to recover such additional costs as the Administrator determines will be incurred because such projected energy savings attributable to such conservation measures have not been achieved, but in no case may such sur. charges be less than 10 per centum or more than 50 per centum of the Administrator's applicable rates for such load or portion thereof.

4.(g)(1) To insure widespread public involvement in the formulation of regional power policies, the Council and Administrator shall maintain comprehensive programs to--

4.(g)(1)(A) inform the Pacific Northwest public of major regional power issues,

4.(g)(1)(B) obtain public views concerning major regional power issues, and

4.(g)(1)(C) secure advice and consultation from the Administrator's customers and others.

4.(g)(2) In carrying out the provisions of this section, the Council and the Administrator shall-

4.(g)(2)(A) consult with the Administrator's customers;

4.(g)(2)(B) include the comments of such customers in the record of the Council's proceedings; and

4.(g)(2)(C) recognize and not abridge the authorities of State and local governments, electric utility systems, and other non-Federal entities responsible to the people of the Pacific Northwest for the planning, conservation, supply, distribution, and use of electric power and the operation of electric generating facilities.

4.(g)(3) In the preparation, adoption, and implementation of the plan, the Council and the Administrator shall encourage the cooperation, participation, and assistance of appropriate Federal agencies, State entities, State political subdivisions, and Indian tribes. The Council and the Administrator are authorized to contract, in accordance with applicable law, with such agencies, entities, tribes, and subdivisions individually, in groups, or through associations thereof to $(A)$ investigate possible measures to be included in the plan, (B) provide public involvement and information regarding a proposed plan or amendment thereto, and (C) provide services which will assist in the implementa tion of the plan. In order to assist in the implemeritation of the plan, particularly conserva. tion, renewable resource, and fish and wildife activities, the Adminstrator, when re. quested and subject to available funds, may provide technical assistance in establishnng conservation, renewable resource, and fish and wildite objectives by mdividual States or subdivisions thereol or Indian tribes. Such objectives, it adopted by a Stiale or subdivision 


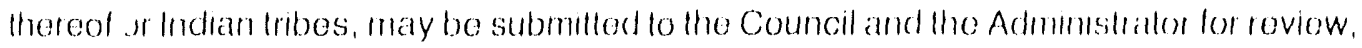
and upon approval by the Council, may be incorporated as part of the plan.

4.(h)(1)(A) The Council shall promptly develop and adopt, pursuant to this subsec:lion, a program to protect, mitigate, and enhance tish and wildlife, including relited spawning grounds and habitat, on the Columbia River and its trbutaries. Bocause of the unique history, problems, and opportunities presented by the development and operation of hydroelectric facilities on the Columbia River and its tributaries, the program, to the greatest extent possible, shall be designed to deal with that river and its tributaries as it system.

4.(h)(1)(B) This subsection shall be applicable solely to fish and wildlife, including related spawning grounds and habitat, located on the Columbia River and its tributaries. Nothing in this subsection shall alter, modify, or affect in any way the laws applicable to rivers or river systems, including electric power facilities related thereto, other than the Columbia River and its tributaries, or affect the rights and obligations of any agency, entity, or person under such laws.

4.(h)(2) The Council shall request, in writing, promptly after the Council is established under either section 4(a) or 4(b) of this Act and prior to the development or review of the plan, or any major revision thereto, from the Federal and the region's State fish and wildlife agencies' and from the region's appropriate Indian tribes, recommendations for -.....

4.(h)(2)(A) measures which can be expected to be implemented by the Administra1or, using authorities under this Act and other laws, and other Federal agencies to protect. mitigate, and enhance fish and wildlite, including related spawning grounds and habital, affected by the development and operation of any hydroelectric project on the Columbia River and its tributaries;

4.(h)(2)(B) establishing objectives for the development and operation of such projects on the Columbia River and its tributaries in a manner designed to protect, mitigate, and enhance fish and wildife; and

4.(h)(2)(C) fish and wildife management coordination and research and development (including funding) which, among other things, will assist protection, mitigation, and enhancement of anadromous fish at, and between, the region's hydroelectric dams.

4.(h)(3) Such agencies and tribes shall have 90 days to respond to such request, unless the Council extends the time for making such rocommendations. The Federal and the region's water management agencies," and the region's elect ic power producing agencies, customers, and public may submit recommendations of the type referred to in paragraph (2) of this subsection. All recommendations shall be accompanied by detailed information and data in support of the recommendations.

4.(h)(4)(A) The Council shall give notice of all recommendations and shall make the recommendations and supporting documents available to the Administrator, to the Federal and the region's State fish and wildite agencies, ${ }^{3}$ to the appropriate Indian tribes, to Federal agencies responsible for managing, operating, or regulating hydroelectric facilthes located on the Columbia River or its tributaries, and lo any custoner or other electric utlity which owns or operates any such tacility. Notice shall also be given to the public: Coples of such recommendations and supporting documonts shall be made avallable for review at the offices of the Council and shall be available for reproduction at reasonable cost.

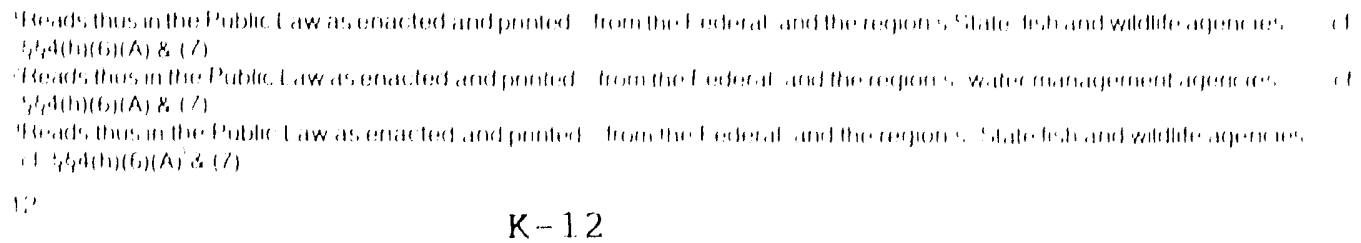




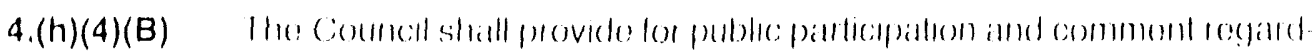

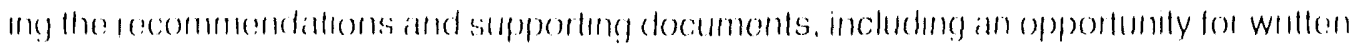

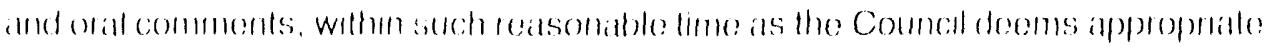

4.(h)(5) The Council shall clevelop a program on the basis ol stod recommon

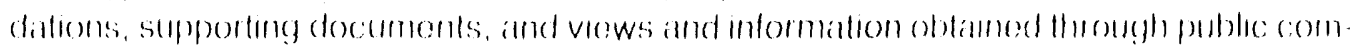

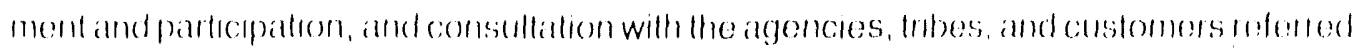

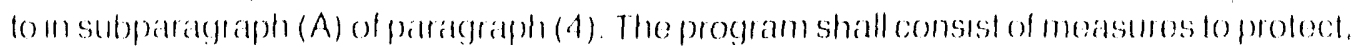

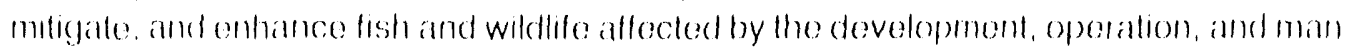

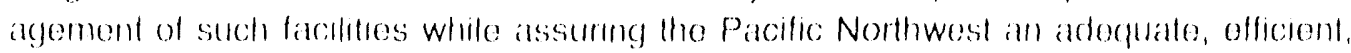
economical, and reliable power supply. Enhancoment measuros shall be included an the? program to the extent such moasures are dosigned to acheve improved protoction and mitigation

4.(h)(6) The Council shill include in the programmeasues which it dotemmos. on the basis sel forth in paragraph (5), will

4.(h)(6)(A) complement the existing and future activities of the Foderal and the region's State fish and wildife agencies and appropriate Indian tribes;

4.(h)(6)(B) be based on, and supported by, the best available scientific knowlodgo.

4.(h)(6)(C) utilize, where equally effective alternative means of achieving the same sound biological objective exist, the alternative with the minimum economic cost:

4.(h)(6)(D) be corisistent with the legal rights of appropriate Indian tribes in the region; and

4.(h)(6)(E) in the case of anadromous fish .....

4.(h)(6)(E)(i) provide for improved survival of such fish at hydroelectric facilities located on the Columbia River system; and

4.(h)(6)(E)(ii) provide flows of sufficient quality and quantily between such lacilites lo improve production, migration, and survival of such fish as necessary to meet sound biological objectives

4.(h)(7) The Council shall detemine whether each recommendation rocoived is consistent with the purposes of this Act. In the event such recommondations are unconsistent with each otiner, the Council, in consultation with appropriate entities, shall resolve such inconsistency in the program giving due weight to the recommendations, expertise. and legal rights and responsibilities of the Federal and the region's State fish and willtile: agencies and appropriate Indian tribes. If the Council does not adopt any recommonda. tion of the fish and wildife agencies and Indian tribes as part of the program or any other recommendation, it shall explain in writing, as part of the program, the basis for its fincling that the adoption of such recommendation would be -

4.(h)(7)(A) inconsistont with paragraph (5) of this subsection;

4.(h)(7)(B) inconsistent with paragraph (6) of this subsection; or

4.(h)(7)(C) less effective than the adopted recommendations for the protection. mitigation, and emhancoment of fish and wildifo.

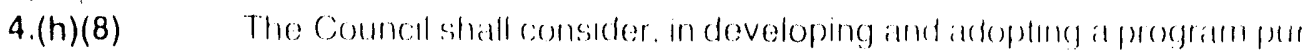
stant lo thes subsection, the followng principlos:

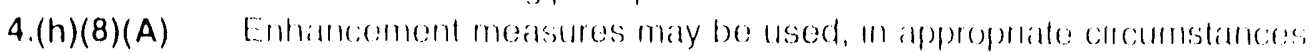
as a means of acheving offste protection and mitigation with respect fo compensition for

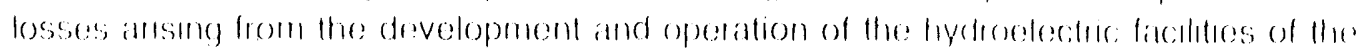

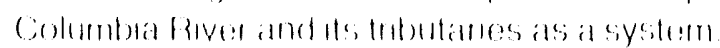

Whit|u!l, (111)/(1), (.)1111)11!1).

| 1;il, Inul Wildshle: fluter.110) 
Frill allut wiletile: prolocilon

160508338 nonte

Alleciationol lundis: (i) $\because \wedge 1,1 / 11$

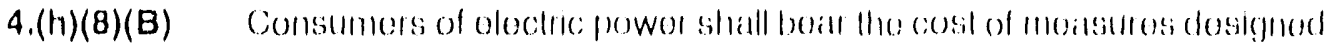

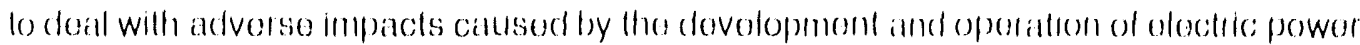
ficcilitios and prograns only.

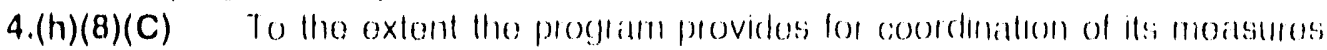
with additional moasures (including additional onhencement moassunos to doal with inn pacts callsed by factors othor than the dovelopmont and oporation of olocitric power

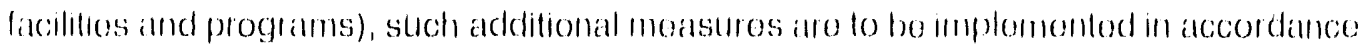

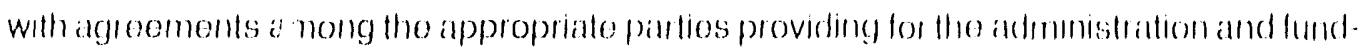
ing of such addifional moasures.

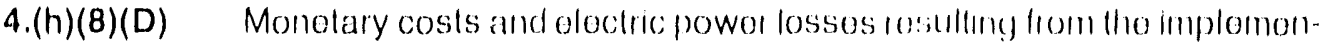
tation of the program shall be allocatod by tho Administrator consistont with individual project impacts and system-wide objoctives of this subsection.

4.(h)(9) The Council shall adopt such program or annondmonts thereto within one year after the time provided for receipt of the recommondations. Such program shail also be included in the plan adopted by the Council under subsection (d).

4.(h)(10)(A) The Administrator shall use the Bonnovillo Power Administration fund and the authoritios available to the Administrator under this $A c t$ and othor laws admirisslered by the Administrator to protect, mitigate, and onhance fish and wildilite to the extent affectod by the development and operation of any hydroelectric project of the Columbia River and its tributaries in a manner consistent with the plan, it in oxistonce, the program adopted by the Council under this subsection, and the purposes of this Act. Expenditures of the Administrator pursuant to this paragraph shall be in addition to, not in lieu of, other expenditures authorized or required from other entities under olhor agreements or provisions of law.

4.(h)(10)(B) The Administrator may mako expenditures from such fund which shall be included in the annual or supplementary budgets subrnitted to the Congress pursuant to the Federal Columbia River Transmission System Act. Any amounts included in such budget for the construction of capital facilitios with an estimated life of groater than 15 years and an estimated cost of at least $\$ 1,000,000$ shall be funded in the same manmer and in accordance with the same procedures as major transmission facilitios under the Federal Columbia River Transmission System Act.

4.(h)(10)(C) The amounts expended by the Administrator for oach activity purstant to this subsection shall be allocated as appropriate by the Administrator, in consultation with the Corps of Engineers and the Water and Power Resources Servico, among the various hydroelectric projects of the Federal Columbia River Power System. Amounts so allocated shall be allocated to the various project purposes in accordance with existing accounting procedures for the Federal Columbia River Power System.

4.(h)(11)(A) The Administrator and other Federal agencies responsiblo for manag. ing, operating, or regulating Fedoral or non-Foderal hydroolectric acilities located on the Columbia River or its tributaries shall

4.(h)(11)(A)(i) exercise such responsibulites consistent with the purposes of this $A C 1$ and other applicable laws, to adequately proted, milegate, and enhance lish and wildile, includeng related spawing grounds and habstat, alfected by sisch propects on facillites in a manner that provides equitable treatment for such fish and widdilo with the olther purposes for which such system and hacilities ane mathatged and operated: 


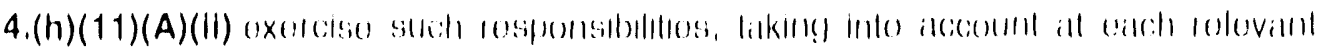

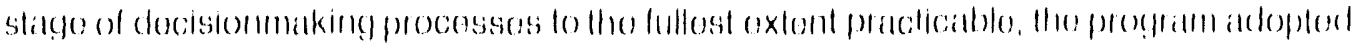

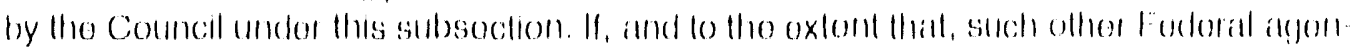

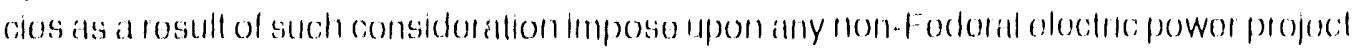

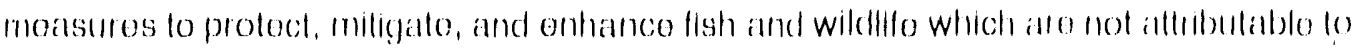
the development and oporation of such propoct, thon the rosulthen momotilly cosits and

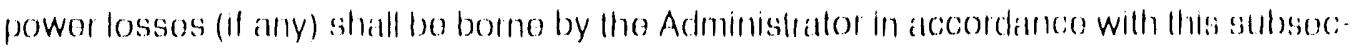
tion.

4.(h)(11)(B) Tho Administlator and such Fodoral agoncios shiall constull with tho Socrotary of the Intorion, tho Admontstrator of the Natlonal Marine Frsileries Sorvico, and the State fish and wildifo agoncies of tho region, appropriato Indian libos, and allectod projoct operators in carrying out tho provisions of this paragraph and shall, to the groatest uxtent practicablo, coordinate their actions.

4.(h)(12)(A) Boginning on October 1 of the first fiscal year alter all members to the Council are appointed initially, the Council shall submit annually a detalled report to the Committee on Enorgy and Natural Resources of the Senate and to the Committees on Interstate and Foreign Commerce and on Interior and Insular Aftairs of the House of Representatives. The report shall describe the actions taken and to be taken by the Council under this Act, including this subsection, the effectiveness of the fish and wildifo program, and potential revisions or modifications to the program to be included in the plan when adopted. Al least ninely clays prior to its submission of such report, the Council shall make available to such fish and wildlife agencies, and tribes, the Administrator and the customers a draft of such report. The Council shall establish procedures for timely comments thereon. Tho Council shall include as an appendix to such roport such comments or a summary thereot.

4.(h)(12)(B) The Administrator shall keep such committees fully and currently informed of the actions taken and to be laken by the Administrator under this Act, including this subsection.

4.(i) The Council may from time to time review the actions of the Administrator pursuant to sections 4 and 6 of this Act to determine whether such actions are consistent with the plan and programs, the oxtent to which the plan and programs is being implemented, and to assist tho Council in preparing amendments to the plan and programs.

4.(j)(1) The Council may request the Administrator to take an action under section 6 to carry out the Administrator's responsibilities under the plan.

4.(J)(2) To tho greatest extent practicable within ninety days after the Council's request, the Administrator shall respond to the Council in writing specifying....

4.(j)(2)(A) the means by which the Administrator will undertake the action or any modification thereot requestod by the Council, or

4.(j)(2)(B) the reasons why such action would not be consistent with the plian, or with the Administrator's logal obligations under this Act, or other provisions of law, whoch the Administrator shall specifically idontily.

4.(j)(3) If the Admunistrator dotermmes not to undertake the requested atction. the Council, within sixty days after notice of the Administrator's determinatlon, may roquest the Admonistrator to hold an informal hearing and make a fmal decision

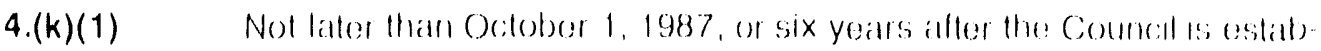

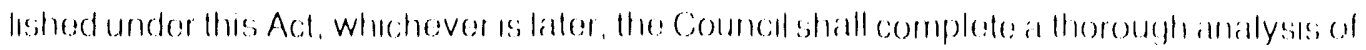

Hoviow 
(illis(1) villinl)

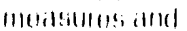

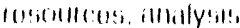

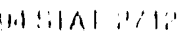

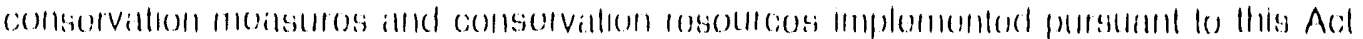

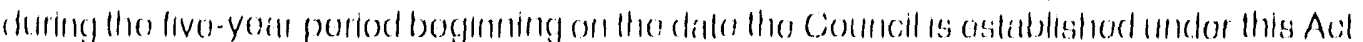

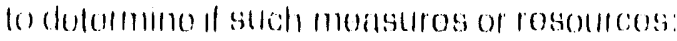

4.(k)(1)(A) havo rosultod or allo likoly lo losult in costs lo consumors in llio rogion

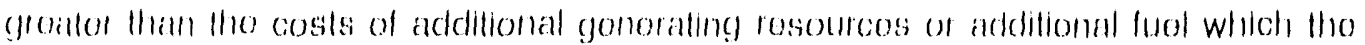

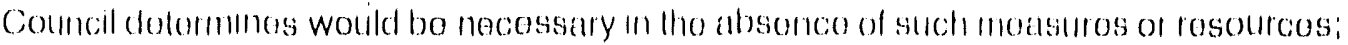

$4,(k)(1)(B)$ havo not boon or ang likoly not lo bo gonomally ogullable lo all con-

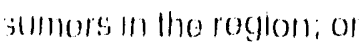

4.(k)(1)(C) havo impairod or aro likoly fo immati tho abllity of tho Admingtralor 10 callry oul his obligations under this Act and ollor laws, consistont with sound bushoss practicosi.

4.(k)(2) The Administrator maly determino that soction 3(4)(D) shall not apply to any proposed consorvation moasure or resourco if tho Administrator finds alfor rocoipt of such analysis from the Council that such moasuro or resourco would have any result or offect doscribod in subparagraph (A), (B) or (C) of paragraph (1).

\section{SALE OF POWER}

\section{Section 5 .}

5.(a) All power sales under this Act shall be subject at all timos to the proferonce and priority provisions of the Bonneville Project Act of 1937 (16 U.S.C. 832 and following) and, in particular, sections 4 and 5 thereof. Such sales shall be al rates established pursuant to section 7.

5.(b)(1) Whenever requested, the Administrator shall offer to sell to each requestang public body and cooperative entilled 10 preforence and priority under the Bonnevillo Project $\mathrm{Acl}$ of 1937 and to each requesting investor-owned utility electrlc power to meot the firm power load of such public body, cooperative or investor-owned utility in the Rogion to the extent that such firm power load exceeds -...

5.(b)(1)(A) the capability of such entity's firm peaking and onergy rosources used in the year prior to the enactment of this Act to serve its firm load in the region, and

5.(b)(1)(B) such other resources as such entity determines, pursuant to contracts undor this $A c l$, will be used to serve its firm load in the ragion.

5.(b)(1) In determining the rosources which aro usod to sorvo a firm load, for purposes of subparagraphs $(A)$ and $(B)$, any resources usod to sorvo a firm load undor such subparagraphs shall be treated as continuing to be so used, unless such use is discontinued with the consent of the Adminiotrator, or unless such use is discontinued bocause of obsolescenco, retirement, loss of resource, or loss of contract rights.

5.(b)(2) Contracts with investor-ownod utilitios shall provido that the AdminisIralor may reduco his obligations under such contracts in accordanco with soction $5(a)$ of the Bonnevillo Project Act of 1937.

5.(b)(3) In addition to his authoritos to soll doctric power under paracplaph (1),

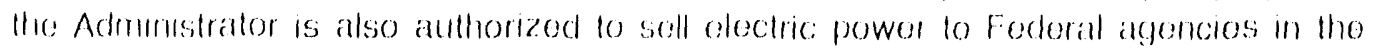
$10(j) 11$.

5.(b)(4) Salos under this subsectom shall be mado only it llo public body, coop).

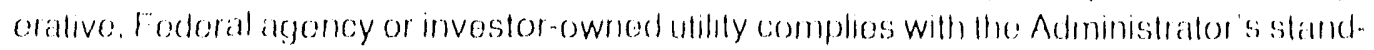

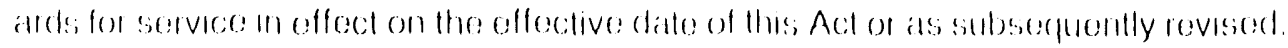

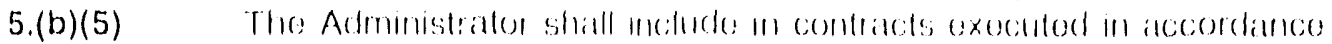

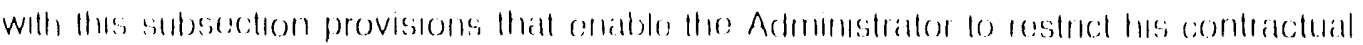

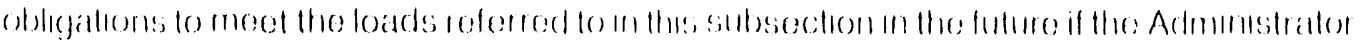

11,

$$
K-16
$$




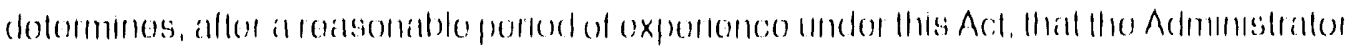

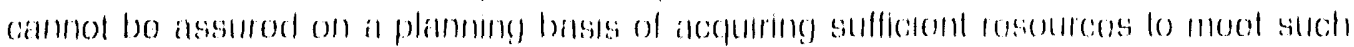

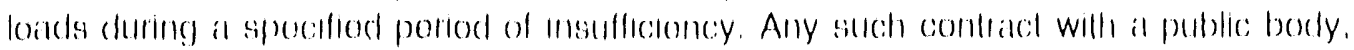

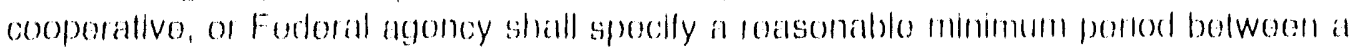

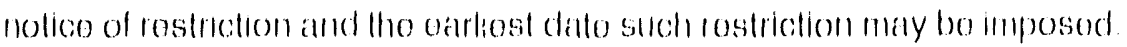

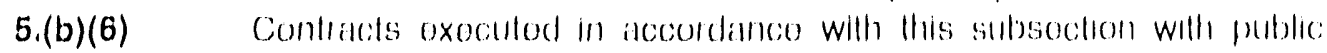
body, cooperativo, and fodoral agoncy customors shall -..

5.(b)(6)(A) provido that tho rostriction rotorred to in paragraph (b) shall not bo alpplicablo to any such customors until the operating yoar in which tho botal ol such customors firm loads to be sorved by the Admunistrator oquals or orceods the firm capability of the Fodoral baso systom resourcos;

5.(b)(6)(B) not permit restrictions which would reduce tho total contractual ontlte. mont of such customers to an amount loss than the firm capability of the Fodoral nase systom rosources; and

5.(b)(6)(C) contain a formula for determining annually, on a uniform basis, oach such customer's contractual ontitloment $10 \mathrm{firm}$ power during such a period of restriction. which formula shall not consider customer resources other than those tho customer hets dotermined, as of the eflective date of this Act, to be used to serve its own firm loads.

5.(b)(6) The formula referred to in subparagraph (C) sihall obligate the Admiristrator to provide on an annual basis only firm power needod to sorve the portion of such customer's firm load in excess of the capabillty of such customer's own firm resources determined by such customer under paragraph (1) of this subsection to be used to sorve its firm load.

5.(c)(1) Whenever a Pacific Northwest electric utllity offers to soll eloctric power to the Administrator at the average system cost of that uility's resources in oach year, the Administrator shall acquire by purchase such power and shall offer, in exchange, to sell an equivalent amount of electric power to such utillty for rosale to that utility's residential users within the region.

5.(c)(2) The purchase and exchango sale referred to in paragraph (1) of this subsection with any electric ullity shall be limited to an amount not in excess of 50 per contum of such utility's Regional residential load in the year beginning July 1, 1980, such 50 per centum limit increasing in oqual annual increments to 100 por centum of such load in the yoar boginning July 1, 1985, and oach yoar thereafter.

5.(c)(3) The cost benefits, as specified in contracts with the Administrator, of any purchase and exchange sale referred to in paragraph (1) of this subsection which are attributable to any electric utility's residential load within a State shall be passed through directly to such utility's residential loads within such State, except that a State which lies partially within and partially without the region may require that such cost benofits be distributed among all of the utility's residential loads in that State.

5.(c)(4) An eloctric utility maly torminate, upon roasonable terms and conditions agreed to by the Adminstrator and such utility prior to such tormination, its purchase and sale uncler this subsocton if the supplenontal tallo charge provided tor in section $7(b)$ (3) is applied and the cost of electric power sold to such utility under thes subsection exceods, after application of such rate chargo, tho average syston cost of powor sold by such hutility to tho Administrator under thus subsection.

Purchistse and axcillatlege !rille

I.Inolallon

Corl burmalt:

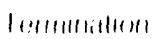


$4.4514 \because 14$

Average sustem cost

Industria:tirm power 5.(c)(5) Subject to the provisions of sections 4 and 6 , in lieu of purchasing any amount of electric power offered by a utility under paragraph (1) of this subsection, the Administrator may acquire an equivalent amount of electric power from other sources to replace power sold to such utility as part of an exchange sale if the cost of such acquisition is less than the cost o' purchasing the electric power offered by such utility.

5.(c) Exchange sales to a utility pursuant to this subsection shall not be restricted below the amounts of electric power acquired by the Administrator from, or on behalf of. such utility pursuant to this subsection.

5.(c)(7) The "average system cost" for electric power sold to the Administrator under this subsection shall be determined by the Administrator on the basis of a methodology developed for this purpose in consultation with the Council, the Administrator's customers, and appropriate State regulatory bodies in the region. Such methodology shall be subject to review and approval by the Federal Energy Regulatory Commission. Such average system cost shall not include-

5.(c)(7)(A) the cost of additional resources in an amount sufficient to serve any new large single load of the utility;

5.(c)(7)(B) the cost of additional resources in an amount sufficient to meet any additional load outside the region occurring after the effective date of this Act; and

5.(c) $(7)(C)$ any costs of any generating facility which is terminated prior to initial commercial operation.

5.(d)(1)(A) The Administrator is authorized to sell in accordance with this subsection electric power to existing direct service industrial customers. Such sales shall provide a portion of the Admınistrator's reserves for firm power loads within the region.

5.(d)(1)(B) After the effective date of this Act, the Administrator shall offer in accordance with subsection $(\mathrm{g})$ of this section to each existing direct service industrial customer an initia! long term contract that provides such customer an amount of power equivalent to that to which such customer is entitled under its contract dated January or April 1975 providing for the sale of "industrial firm power

5.(d)(2) The Administrator shall not sell electric power, including reserves, directly to new direct service industrial customers

5.(d)(3) The Administrator shall not sell amounts of electric power, including reserves. to existing direct service industrial customers in excess of the amount permitted under paragraph (1) unless the Administrator determines, atter a plan has been adopted pursuant to section 4 of this Act, that such proposed sale is consistent with the plan and that -

$G(d)(3)(A)$ additional power system reserves are required for the region's firm loads.

5.(d)(3)(B) the proposed sale would provide a cost-effective method of supp' 'ing such reserves.

5.(d)(3)(C) such loads or loads of simular character cannot provide equivalent operating or planning benetits to the region if served by an electric utility under contractual arrangements providing reserves and

5.(d)(3)(D) the Administrator has or can acquire sufficient electric power to serve such loads and

$51013)$ uniess the Council has determined such sale is consistent with the plan.

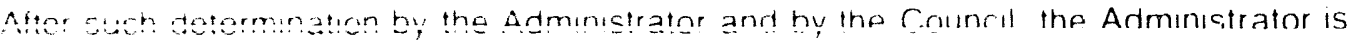
authorized to otter to existing direct service industrial customers power in such amounts in excess of the amount perritted under paragraph (1) of this subsection as the Administra- 
Ior detemmes to be necessary to provide additional power svstem reserves to meet tho regions fimm loads

5.(d)(4)(A) As used in this section. the term "existing direct service industral cus. tomer" means any direct service industral customer of the Administrator which has a contract for the purchase of electric power from the Administrator on the effective date of this Act

5.(d)(4)(B) The term "new direct service industrial customer" means any industria! entity other than an existing direct service industrial customer.

5.(d)(4)(C)(i) Where a new contract is offered in accordance with subsection $(g)$ to any existing direct service industral customer which has not received electric power prior to the effective date of this Act from the Administrator pursuant to a contract with the Administrator existing on the date of the enactment of this Act. electric power delivered under such new contract shall be conditioned on the Administrator reasonably acquiring. in accordance with this Act and within such estimated period of time (as specified in the contract) as he deems reasonable. sufficient resources to meet, on a planning basis, the load requirement of such customer. Such contract shall also provide that the obligation of the Administrator to acquire such resources to meet such load requirement shall, except as provided in clause (ii) of this subparagraph. apply only to such customer and shall not be sold or exchanged by such customer to any other person.

5.(d)(4)(C)(ii) Rights under a contract described in clause (i) of this subparagraph may be transferred by an existing direct service industrial customer referred to in clause (i) to a successor in interest in connection with a reorganization or other transfer of all major assets of such customer. Following such a transfer, such successor in interest (or any other subsequent successor in interest) may also transfer rights under such a contract only in connection with a reorganization or other transfer of all assets of such successor in interest.

5.(d)(4)(C)(iii) The limitations of clause (i) of this subparagraph shall not apply to any customer referred to in clause (1) whenever the Administrator determines that such customer is receiving electric power pursuant to a contract referre d to in such clause (ii)

5.(e)(1) The contractual entitlement to firm power niany customer from whom. or on whose behalf, the Administrator has acquired electric power pursuant to section 6 may not be restricted below the amount of electric power so acquired from, or on behalf of such customer If in any year such customer's requirements are less than such entillement. any excess of such entitlement shall be tirst made available to increase the entıtlement of other customers of the same class before being available for the entitlement of other customers For purposes of this paragraph, the following entities shall each const. tute a class

5.(e)(1)(A) public bodies and cooperatives.

5.(e)(1)(B) Federal agencies.

5.(e)(1)(C) duect service industrial and

5.(e)(1)(D) invesior ownedutilities

5.(e)(2) Any cuntractual entillement to firm power which is based on electric power acquired from or on behalf of a customer pursuant to section 6 shall be in addition to any othet contractual entilement to $\mathrm{frm}$ power not subject to restriction that such customer may have under this section for the purposes of this subsection. references to amounts of power requred by the Adminstrator pursuant to section 6 shall be deemed to

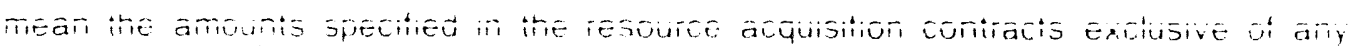

Contract rights. transter
Dofmutums

Now contract 
Long-term contracts

16 USC 9380
1.1 SIAI $\because 111$

amounts recognzed in such contracts as replacement for Federal base system resources

5.(e)(3) The Administrator shall, consistent with the provisions of this Act, insure that any restrictions upon any particular customer class made pursuant to this subsection and subsection (b) of this section are distributed equitably throughout the region.

5.( $f$ The Administrator is authorized to sell. or otherwise dispose of, electric. power, including power acquired pursuant to this and other Acts, that is surplus to his obligations incurred pursuant to subsections (b), (c), and (d) of this section in accordance with this and other Acls applicable to the Admınistrator. Including the Bonneville Project Act of 1937 (16 U.S.C. 832 and following), the Federal Columbia River Transmission System Act (16 U.S.C. 838 and following), and the Act of August 31, 1964 (16 U.S.C. $837-837 \mathrm{~h})$

5.(g)(1) As soon as practicable within nine months after the effective date of this Act, the Administrator shall commence necessary negotiations for, and offer, initial longterm contracts (within the limitations of the third sentence of section 5(a) of the Bonneville Project Act) simultaneously to -

5.(g)(1)(A) existing public body and cooperative customers and investor-owned utility customers under subsection (b) of this section:

5.(g)(1)(B) Federal agency customers under subsection (b) of this section;

5.(g)(1)(C) electric utility customers under subsection (c) of this section; and

5. (g) $(1)(D)$ direct service industrial customers under subsection $(d)(1)$.

5.(g)(2) Each customer offered a contract pursuant to this subsection shall have one year from the date of such offer to accept such contract. Such contract shall be effective as provided in this subsection.

5.(g)(3) An initial contract with a public body. cooperative or investor-owned electric utility customer or a Federal agency customer pursuant to subsection (b) of this section shall be effective on the date executed by such customer, unless another effective date is otherwise agreed to by the Administrator and the customer.

. An initial contract with an electric utility customer pursuant to subsection (c) of this section shall be effective on the date executed by such customer, but no earlier than the first day of the tenth month after the effective date of this Act.

5.(g)(5) An initial contract with a direct service industrial customer pursuant to subsection (d)(1), shall be effective on the date agreed upon by the Administrator and such customer, but no later than the first day of the tenth month after the effective date of this Act. When such contract is executed, it may for rate purposes be given retroactive effest to such first day.

5.(g)(6) Initial contracts offered public body, cooperative and Federal agency customers in accordance with this subsection shall provide that during a period of insuffi. ciency declared in accordance with subsection (b) of this section each customer's contractual entitlement shail. to the extent of its requirements on the Administrator be no less than the amount of firm power received from the Admunstrator in the year immediately preceding the period of insufficiency

5.(g)(7) The Administrator shall be deemed to have sufficient resources for the purpose of entering into the inilial contracts specified in paragraph (1)(A) through (D). 


\section{CONSERVATION AND RESOURCE ACQUISITION}

\section{Section 6.}

6.(a)(1) The Administrator shall acquire such resources through conservation, implement all such conservation measures, and acquire such renewable resources which are installed by a residential or small commercial consumer to reduce load, as the Admmistrator determunes ire consistent with the plan, or if no plan is in effect with the criteria of section $4(e)(1)$ and the considerations of section $4(e)(2)$ and, in the case of major resources, in accordance with subsection (c) of this section. Such conservation measures and such resources may include, but are nol limited to-

6.(a)(1)(A) loans and grants to consumers for insulation or weatherization, in. creased system efficiency, and waste energy recovery by direct application.

6.(a)(1)(B) technical and financial assistance to, and other cooperation with, the Administrator customer and governmental authorities to encourage maximum cost-eflective voluntary conservation and the attainment of any cost-effective conservation objectives adopted by individual States or subdivisions thereof.

6.(a)(1)(C) aiding the Administrator's customers and governmental authorities in implementing model conservation standards adopted pursuant to section $4(f)$, and

6.(a)(1)(D) conducting demonstration projects to determine the cost effectiveness of conservation measures and direct application of renewable energy resources.

6.(a)(2) In addition to acquiring electric power pursuant to section 5(c), or on a short-term basis pursuant lo section 11(b)(6)(i) of the Federal Columbia River Transmission System Act, the Administrator shall acquire, in accordance with this section, sufficientresources-..

6.(a)(2)(A) 10 meet his contractual obligations that remain atter taking into account pianned savings from measures provided for in paragraph (1) of this subsection, and

6.(a)(2)(B) to assist in meeting the requirements of section $4(\mathrm{~h})$ of this Act.

6.(a)(2) The Administrator shall acquire such resources without considering restrictions which may apply pursuant to section 5(b) of this Act.

6.(b)(1) Except as specifically provided in this section, acquisition of resources under this Act shall be consistent with the plan, as determined by the Administrator

6.(b)(2) The Administrator may acquire resources (other than major resources) under this Act which are not consistent with the plan, but which are determined by the Administrator to be consistent with the criteria of section $4(e)(1)$ and the considerations of section $4(e)(2)$ of this Act

6.(b)(3) If no plan is in effect, the Administrator may acquire resources under this Act which are determined by the Administrator to be consistent with the criteria of section $4(e)(1)$ and the considerations of section $4(e)(2)$ of this $A c t$.

6.(b)(4) The Administrator shall acquire any non-Federal resources to replace Federa, base sysiem resources only in accordance with the provisions of this section. The Administrator shall include in the contracts for the acquisition of any such non-Federal coplacement resounces provisions which will enable hom to ensure that such non-Federal replacement resounces, ale developed and operated in a manner consistent with the considerations specified in section $4(e)(2)$ of this Act.

6.(b)(5) Notwithstanding any acquisition of resources pursuant to this section the Admmastrator shail not reduce his efforts to acheve conservation and to acquire 
Publicationim

Federal

Registor

Public hearings
$94 \because 1 \wedge 1: \because / k$

renewable resources installed by a residential or small commercial consumer to reduce load, pursuant to subsection (a)(1) of this section.

6.(c)(1) For each proposal under subsection (a), (b), (1), (h) or (I) of this section to acquire a major resource, to implement a conservation measure which will conserve an amount of electric power equivalent to that of a major resource, to pay or reimburse investigation and preconstruction expenses of the sponsors of a major resource, or to grant billing credits or services involving a major resource, the Administrator shall--

6.(c)(1)(A) publish notice of the proposed action in the Federal Register and provide a copy of such notice to the Council, the Governor of each State in which facilities would be constructed or a conservation measure implemented, and the Administrator's customers:

6.(c)(1)(B) not less than sixty days following publication of such notice, conduct one or more public hearings, presided over by a hearing officers, at which testimony and evidence shall be received, with opportunity for such rebuttal and cross-examination as the hearing officer deems appropriate in the development of an adequate hearing record;

6.(c)(1)(C) develop a record to assist in evaluating the proposal which shall include the transcript of the public hearings, together with exhibits, and such other materials and information as may have been submitted to, or developed by, the Administrator; and

6.(c)(1)(D) following completion of such hearings, promptly provide to the Council and make public a written decision that includes, in addition to a determination respecting the requirements of subsection (a), (b), (f), (h), (l), or (m) of this section, as appropriate -

6.(c)(1)(D)(i) if a plan is in effcct, a finding that the proposal is either consistent or inconsistent with the plan or, notwithstanding its inconsistency with the plar., a finding that It is needed to meet the Administrator's obligations under this Act, or

6.(c)(1)(D)(ii) if no plan is in effect, a finding that the proposal is either consistent or inconsistent with the criteria of section $4(e)(1)$ and the considerations of section $4(e)(2)$ of this Act or notwithstanding its inconsistency, a finding that it is needed to meet the Administrator's obligations under this Act.

6.(c)(1)(D) In the case of subsection ( $f$ ) of this section, such decision shall be Ireated as satisfying the applicable requirements of this subsection and of subsection ( $f$ ) of this section, if it includes a finding of probable consistency, based upon the Administra. tor's evaluation of information available at the time of completion of the hearing under this paragraph. Such decision shall include the reasons for such finding.

6.(c)(2) Within sixty days of the receipt of the Admmistrator's decision pursuant to paragraph (1)(D) of this subsection, the Council may determıne by a majority vote of all members of the Council, and notify the Administrator.

6.(C)(2)(A) that the proposal is elther consistent or inconsistent with the plan, or

6.(c)(2)(B) it no plan is in effect, that the proposat is either consistent or inconsis tent with the criterla of section $4(e)(1)$ and the considerattons of section $4(e)(2)$.

6.(c)(3) The Administrator may not implement any proposal referred to in paragraph (1) that is determmed pursuant to paragraph (1) or (2) by ether the Administrator or the Council to be inconsistent with the plan or, if no plan is in effect. with the criteria of 
sectoon $4(e)(1)$ and the considerations of section 4 (e) (a)

6.(c)(3)(A) unless the Admmistrator finds that, notwithstandma such meonsisten.

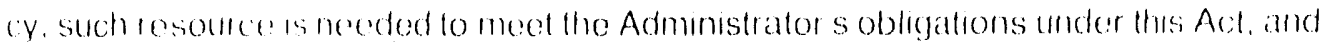

6.(c)(3)(B) Imtil the expenditure of funds for that pumpose has been specifically authorzed by Act of Congress enacted after tho date the enactment of this $A$ ot

6.(c)(4) Betore the Admmstrator motriblents any proposal refened to m para graph (1) of this sibsection, the Administrator risit

6.(c)(4)(A) submit to the appropriate commitleses of the Congress the admunstrative record of the deciston (Including any determination by the Council under paragraph (2)) and a statement of the procedures followed or to be followed for compliance wilh the National Envirommental Policy Act of 1969.

6.(c)(4)(B) publish nolice of the decision in the Federal Register, and

6.(c)(4)(C) note the proposal in the Administrator's annual or supplementary budget submittal made pursuant to the Federal Columbia River Transmission System Act ( 16 U.S.C. 838 and following).

6.(c)(4) The Administrator may not implement any such proposal until ninety days after the date on which such proposal has been noted in such budget or after the date on which such decision has been published in the Federal Register, whichever is later.

6.(c)(5) The authority of the Council to make a determination under paragraph (2)(B) if no plan is in effect shall expire on the date two years after the establishment of the Council.

6.(d) The Administrator is authorized to acquire a res,uurce, other than a major resource. whether or not such resource meets the criteria of section $4(e)(1)$ and the considerations of section $4(e)(2)$ but which he determines is an experimental, developmental, demonstration. or plot project of a lype with a potential for providing cost effective service to the region. The Admunstrator shall make no obligation for the acquisition of such resource until it is included in the annual budgets submitted to the Congress pursuant to the Federal Columbra River Transmission System Act.

6.(e)(1) In order to effectuate the priority given to conservation measures and renewable resources under this Act, the Administrator shall, to the maximum extent praclicable. make use of his authoriles under this Act to acquire conservation measures and renewable resources to implement conservation measures, and to provide credits and lechnoal and fmancial assistance for the development and implementation of such re. sources and measures (including the funding of and the securing of debt for, expenses mcumed durng the investigation and preconstruclion of resources, as authorized in sub. section (1) of this section)

6.(e)(2) To the extent conservation measures or acquisition of resources re-

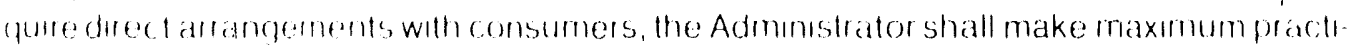
cable use of customers and local entitus capable of admunstermg and carrymg oul such arialgements.

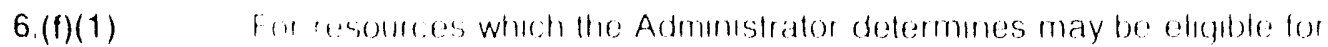

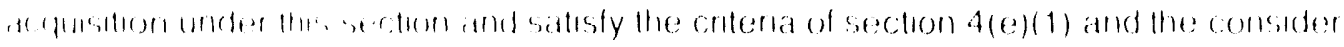

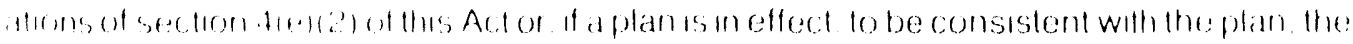

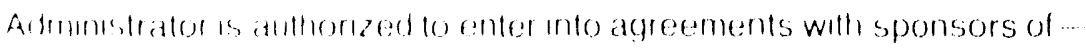

6.(f)(1)(A) arenewible resource other than a magor resource. fo fund or secure

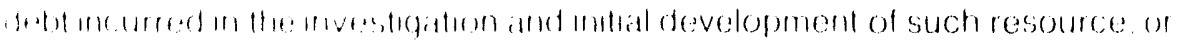


$(3) \therefore \mid \wedge 1 \because \because \cdots)$

6.(f)(1)(B) any other resource to provide for the relrmbursement of the sponsor's investigation and preconstruction expenses concening such resource (which expenses shall not include procurement of capital equipment or construction material for such 10 source).

6.(f)(1) In the case of any resource referred to in subparagraph (B) of this paragraph, such rembursement is authorized only if ....

6. $(f)(1)(B)(i)$ such resource is subsequently denied State siting approval or other necessary Foderal or State permits, or approvals,

6.(f)(1)(B)(ii) such investigation subsequently demonstrates, as determined by the Administrator, that such rescurce does not meet the criteria of section $4(e)(1)$ and the considerations of section 4(e)(2) of this Act or is not acceptable because of environmental impacts, or

6.(f)(1)(B)(iii) after such investigation the Administrator determines not to acquire the resource and the sponsor determines not to construct the resource.

6.(f)(2) ' The Administrator may exercise the authority of this subsection only after he determines that the failure to do so would result in inequitable hardship to the consumers of such sponsors. The Administrator may provide reimbursement under this subsection only for expenses incurred after the date of the enactment of this Act.

6.(f)(3) Any agreement under paragraph (1) of this subsection shall provide the Administrator an option to acquire any such resource, including a renewable resource, and shall include such other provisions, as the Administrator deems appropriate, for the Administrator's recovery from such sponsors or any assignee of the sponsors, if such sponsor or assignee continues development of the resource, of any advances made by the Administrator pursuant to such agreement.

6.(f)(4) The Administrator shall not reimburse any expense incurred by the sponsors (except necessary expenses involved in the liquidation of the resource) after the date of a final denial of application for State siting approval or after the date the Administrator determines that the resource to be inconsistent with the plan or the criteria of section $4(e)(1)$ and the considerations of section 4(e)(2).

6.(g) Al the request of the appropriate State, any environmental impact statement which may be required with respect to a resource, to the extent determined possible by the Administrator in accordance with applicable law and regulations, may be prepared joinlly and in coordination with any required environmental impact statement of the State or any other statement which serves the purpose of an environmental impact statement which is required by State law.

6.(h)(1) If a customer so requests, the Administrator shall grant billing credits to such customer, and provide services to such customer at rates established for such services, for -..

6.(h)(1)(A) conservation activities independently undertaken or continued after the effective date of this Act by such customer or political subdivision served by such customen which reduce the obligation of the Administrator that would otherwise have existed 10 acquire other resources under this $A c t$, or

6.(h)(1)(B) resources constructed, completed, or acquired after the effective date of this Act by a customer, an entity acting on behalf of such custumer, or political subdiviston served by the customer whoh reduce the obligation of the Administrator to acquire rosources under this Act. Such resources shall be renewable resources or multipurpose popects or other resorees wheh are not inconsistent with the plan or, in the absence of a 


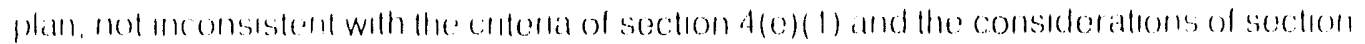
A(1) (a) of this Act

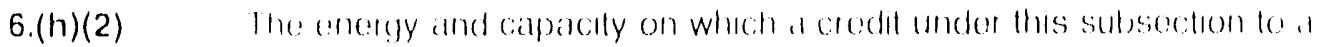
rustomor is batsed shall be the amount by wheh a conservation activity on resounce actually changes the customen s net requnement for supply of electro power on leserves from the Admmisliator

6.(h)(3) The amount of credits for conservation under this subsoction shall be sel 10 credil the customer implementing or continuing the conservation activity for which the credit is granted for the savings resulting from such activity. The rate impact on the Admmistrator s other eustomers of grantmy the credil shall be equal to the rate impact such customers would have experienced had the Admmistrator been obligated to acquire resources in an amount equal to that actually saved by the activity for which the credit is granted.

6.(h)(4) For resources other than conservation, the customer shall be credited for net costs actually incurred by such customer, an entity acting on behalf of such customer, or political subdivision served by such customer, in acquiring, constructing, or operating the resource for which the credit is granted. The rate impact to the Administrator's other customers of granting the credit shall be no greater than the rate impact such customers would have experienced had the Administrator been obligated to acquire resources in an amount equal to that actually produced by the resource for which the credil is granted.

6.(h)(5) Relail rate structures which are voluntarily implemented by the Admmistrator's customers and which induce conservation or installation of consumerowned renewable resources shall be considered, for purposes of this subsection, to be (A) conservation activities independently undertaken or carried on by such customers, or (B) customer-owned renewable resources, and shall qualify for billing credits upon the same showing as that required for other conservation or renewable resource activitios.

6.(h)(6) Plor 10 glanting any credit or providing services pursuant to this sub). section, the Admmistrator shall --

6.(h)(6)(A) comply with the notice provisions of subsection (c) of this section, and include in such notice the methodology the Administrator proposes to use in dotommung the amount of any such credit:

6.(h)(6)(B) metude the cost of such credit in the Admmistrator's annual or amended budget submitlat to the Congress made pursuant to the Federal Columbia River Trans. inssion System Ac1 (16 US. B 838(1)):

6.(h)(6)(C) requre that resounces in excess of watomer s reasonable load guowth shall have been offered to others for ownershp. pallupallon or other sponsorshmp pur

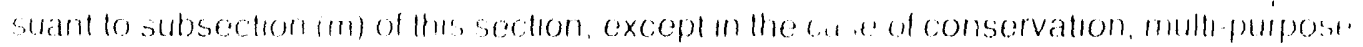

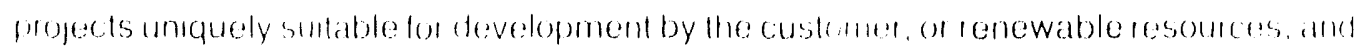

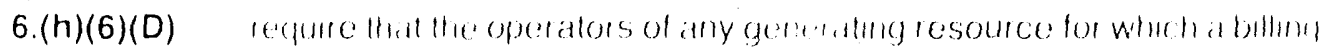

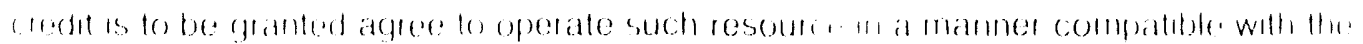

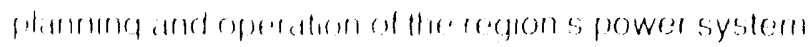

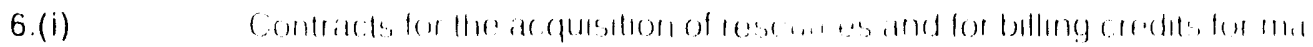

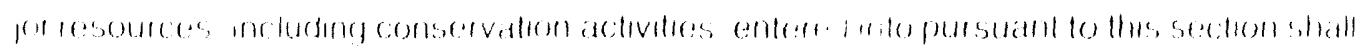

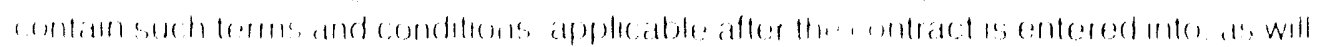

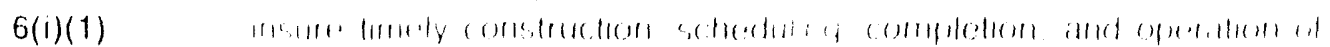
11". 
$1+1, i 1 \cap 1, \therefore 1$

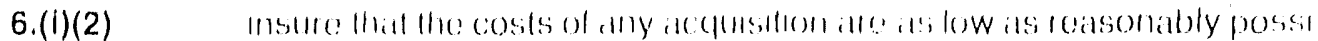

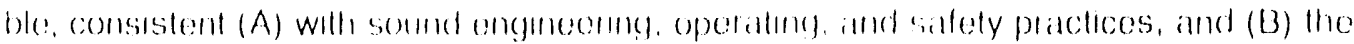

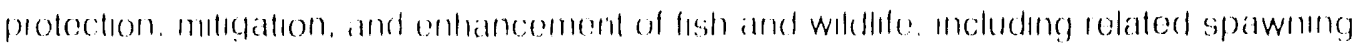
grounds and hathlat allecterlby the devolopment of streh resomcos, and

6.(i)(3) Imstre that the Admmistrator exencises effective oversight, mspection audit, and review of all aspers of such construchon and openathon

6.(1) Such contracts shall contan provisions assumg that the Admonstrator has the aullority to approve all costs of and proposials for, major modifications in con. struction, scheduling or operations and to assure that the Admmistrator is provided with such current information as he deems necessary to evaluate such construction and operatlon.

6.(j)(1) All contractual and other obligations requned to be carried out by the Administrator pursuant to this Act shall be secured solely by the Administrator's revenues received from the sale of electric power and other services. Such obligations are not, nor shall they be construed to be, general obligations of the United States, nor are such obligations intended to be or are they secured by the full faith and credit of the United States.

6.(1)(2) All contracts entered into by the Administrator for the acquisition of resources pursuant to this Act shall require that, in the sale of any obligations, all offerings and promotional material for the sale of such obligations shall include the language ccntained in the second sentence of paragraph (1) of this subsection. The Administrator shall monitor and enforce such requirement.

6.(k) In the exercise of his authorities pursuant to this section, the Administrator shall, consistent with the provisions of this Act and the Administrator's obligations to particular customer classes, insure that benefits under this section, including financial and technical assistance, conduct of conservation demonstrations, and experimental projcots, services, and billing credits, are distributed equitably throughout the region.

6.(I)(1) The Administrator is authorized and directed to investigate opportunilies for adding to the regions resources or reducing the region's power costs through the accelerated or cooperative development of resources located outside the States of Idaho. Montana. Oregon, and Washinglon if such resources are renewable resources, and are now or in the future planned or considered for eventual development by nonregional agencies or authorities that will or would own, sponsor, or otherwise develop them. The Admunstrator shall keep the Council fully and currently informed of such investigations, and seek the Council's advice as to the desirability of pursung such investigations.

6.(1)(2) The Ardmmstrator is authorized and directed to investigate periodically opportumiles for mutually beneficlal interregional exchanges of electric power that reduce the need for additional generation or generating capacity in the Pacific Northwest and the regions with wheh such exchanges may occur. The Counch shall take into consideration in formulatmy a plan such mvestigations

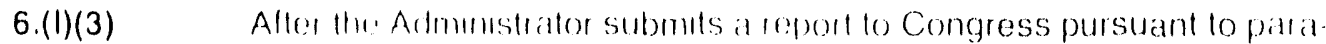

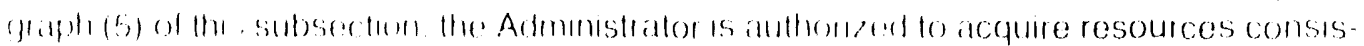

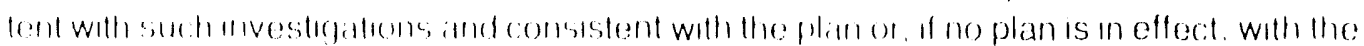

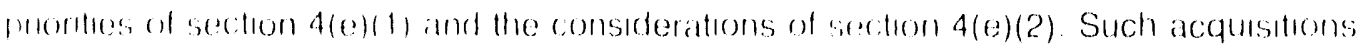

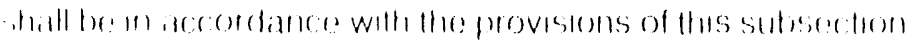




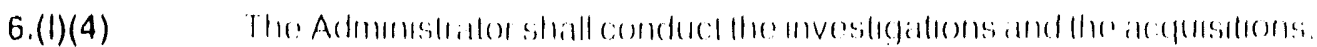

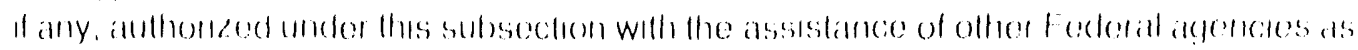
mily be alpproprlale

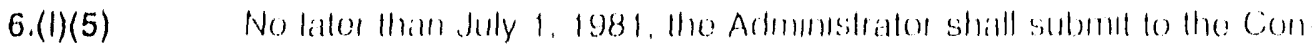

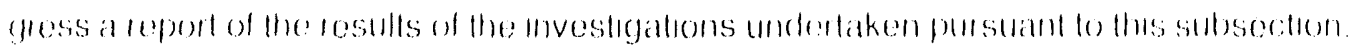

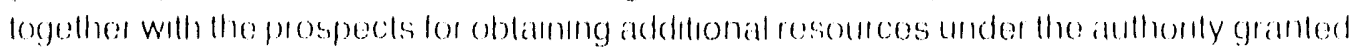

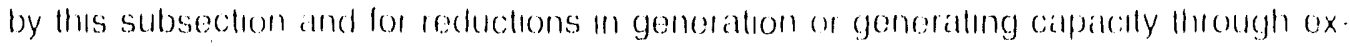
changes.

6.(m) Except as to resources under construction on the eflective date of thes Acl, the Admumstrator shall detemine moach case of a major rosource acquisilion thall a reasonable shane of the particular resource, or a roasonable equivatent, has been offored to each Pacific Norlinwest electric ulility for ownership. participation, or other sponsorship. but not in excess of the amounts noeded to meel such utility's Regional load.

\section{RATES}

\section{Section 7.}

7.(a)(1) The Administrator shall establish, and periodically review and revise. rates for the sale and disposition of electric energy and capacity and for the transmission of non-Federal power. Such rates shall be established and, as appropriate, revised to recover, in accordance with sound business principles, the costs assoclated with the acquisition, conservation, and transmission of electric power, including the amortization of the Federal investment in the Federal Columbia River Power System (including irrigation costs required to be repaid out of power revenues) over a reasonable period of years and the other costs and expenses incurred by the Administrator pursuant to this Act and other provisions of law. Such rates shall be established in accordance with sections 9 and 10 of the Federal Columbia River Transmission System Acl (16 U.S.C. 838), section 5 of the Flood Control Act of 1944, and the provisions of this Act.

7.(a)(2) Rates established under this section shall become effective only, ex. cept in the case of interim rules as provided in subsection (i)(6), upon confirmation and approval by the Federal Energy Regulatory Commission upon a finding by the Commission, that such lates ...-

7.(a)(2)(A) are sufficient to assure repayment of the Federal investment in the Federal Columbra River Power System over a reasomable number of years alter list meeting the Admmistrator's other costs,

7.(a)(2)(B) are based upon the Administrator's total system costs, and

7.(a)(2)(C) insolar as transmission rates are roncened, equitably allocate the costs of the Federal transmission system between Fuderal and non. Federal power utilz. ing such system

\section{7.(b)(1)}

The Admmmstrator shall establish a rate or rates of gonemal application for electric power sold to meet the general requiremonts of public body, cooperative. and

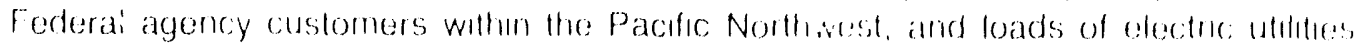

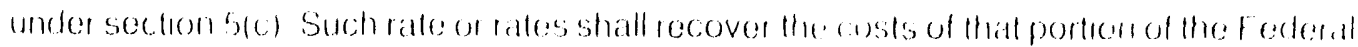

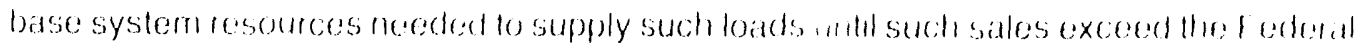

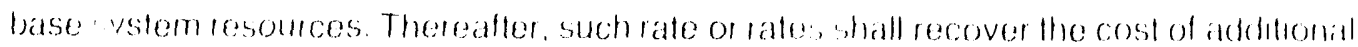

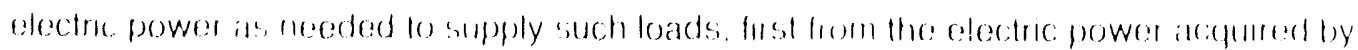

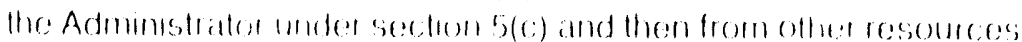

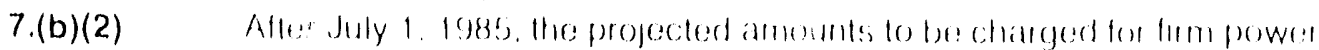

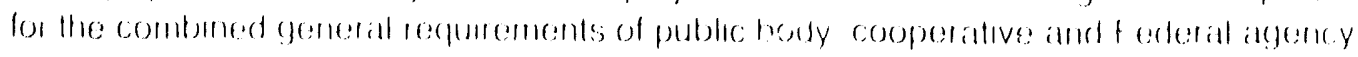

Hanell|l| Corleglests

$16119 \mathrm{SC} 83,30$

$16 \cup 5083834$

83811 $16050: 8964$ 


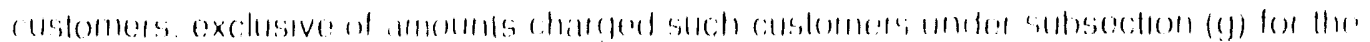

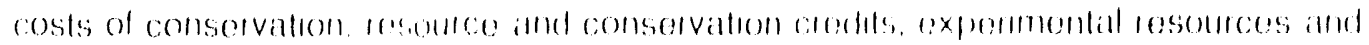

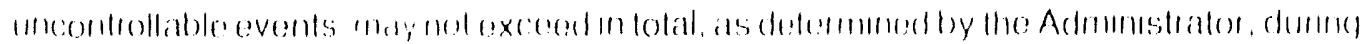

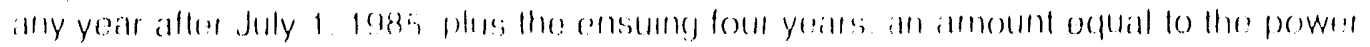

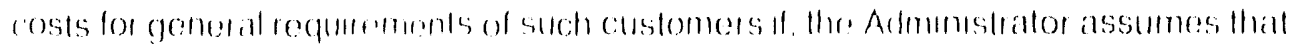

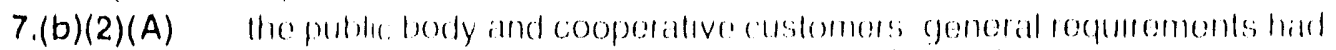

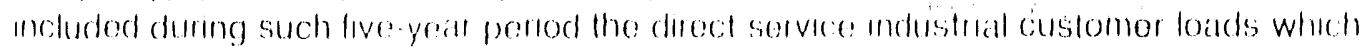
ale

7.(b)(2)(A)(1) served by the Admintstrator, and

7.(b)(2)(A)(ii) located within or adjacent to the geoglaphic sorvico boundaries of such public bodies and cooperatives:

7.(b)(2)(B) public body, cooperative, and Federal agency customers were served. during such five year period. with Federal base system rosources not obligated to other entilies under contracts existing as of the eflective date of this Act (during the remaining term of such contracts) excluding obligations to direct service industrial customer loads included in subparagraph (A) ol this paragraph:

7.(b)(2)(C) no purchases or sales by the Admmistrator as provided in section 5(c) were made during such five-year period;

7.(b)(2)(D) all resources that would have been required, during such five-year perod, to meet remaining genera! requirements of the public body, cooperative and Fedoral agency customers (other than requirements mot by the available Fedoral base system resources determined under subparagraph (B) of this paragraph) were....

7.(b)(2)(D)(l) purchased from such customers by the Administrator pursuant to seclion 6 , or

7.(b)(2)(D)(Ii) nol committed to load pursuant to section $5(b)$,

7.(b)(2)(D) and were the least expensive resources owned or purchased by public; bodies or cooperatives; and any additional needed resources were oblained at the aver age cost of all other new resonlices acquired by the Adminstrator, and

7.(E,,$(E)$ the quantifable monelary savings, durng such five-year period, lo pub)lic body, cooperative and Federal agency customens resultung from -...

7.(b)(2)(E)(i) reduced public body and cooperative finlancing costs as applied to the total amount of resources. other than Federal base system resources, identhed under subparagraph (D) of thes paragraph, and

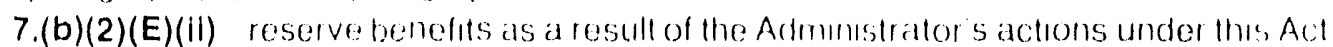
7 (b)(2)(E) were nolacheved.

7.(b)(3) Any amomints not charged to public borly. cooperative. and Federal

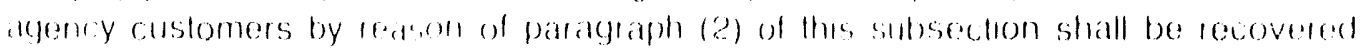

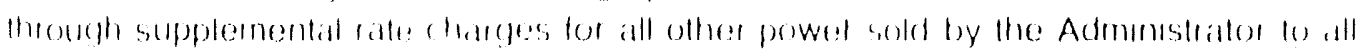

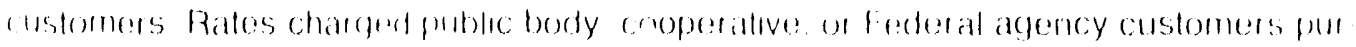

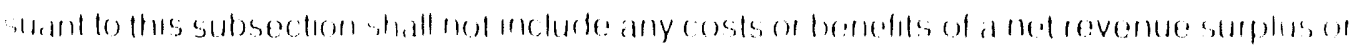

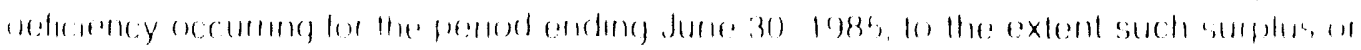

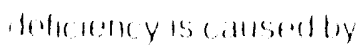

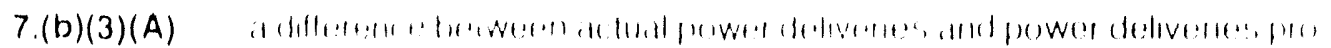

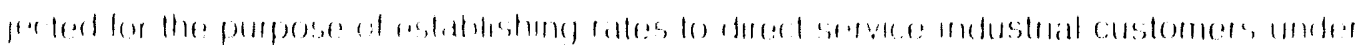

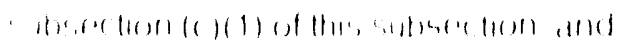

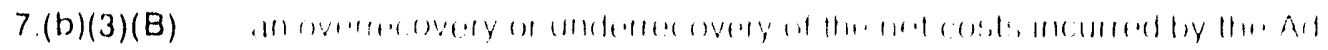

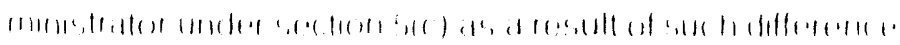




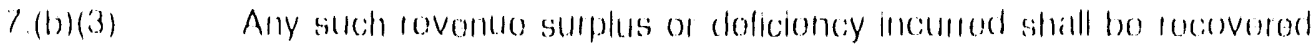

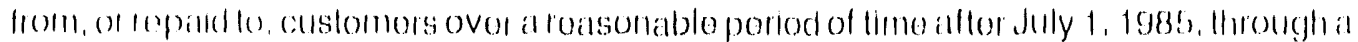

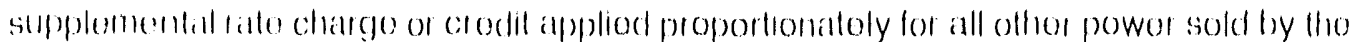
Admurnstrator al ralos ustablished undor othor subsections of this soction pror fo July 1. $1936)$

7.(b)(4) Tho lom "gonotall roquiromonts" as usud in this soclion moans tho puhle body, cooperalivo or Fodoral agoncy customer'soloctric powor purchased from the Admmistrator under soction (b)(b) of this Act, excilusivo of any now largo singlo load.

7.(c)(1) The alle or ralos applicable to diroct sorvico industrial customors shatl bo ostablishod.

7.(c)(1)(A) lor the poriod prior to Juiy 1. 1985, at a lovel which tho Administrator ostimates will be sufficiont to rocover the cost of resources the Adminstrator dotermines are requned to serve such customors' load and tho not costs incurrod by the Administrator pursuant to section 5(c) of this Acl, based upon the Administrator's projected ability to make power available to such customers pursuant to their contracts, to the extent that such costs are not recovered through rates applicablo to other customors; and

7.(c),1)(B) for the poriod beginning July 1,1985 , al a lovel which the Administrator determmes to be equitable in Ielation to the retail rates charged by the public body and cooperativo customers to their industrial consumers in the region.

7.(c)(2) The determination under paragraph (1)(B) of this subseclion shall be based upon the Administrator's applicable wholesale rates to such public body and coop. orallve custorners and the typical margins included by such public body and cooperative customers in their rolail industrial rates but shall take into account....

7.(C)(2)(A) the comparalive size and charactor of the loads servod,

7.(c)(2)(B) tho relativo cosis of electric capacity, onergy, transmission, and related delivery facilites providod and other service provisions, and

7.(c)(2)(C) diroct and indirect overhead costs,

7.(c)(2) all as related to the delivery of power to industrial customers, excopt thatl the Admmmstrator s lalos during such period shall in no event bo less than tho ratos in effect for the contract yeal ending on June 30, 1985.

7.(c)(3) The Admmestrator shall adjust such ratos to lake into account the value of power system reserves made avalable to the Administalor through his rights to intorIIn) (n cumtal service lo such duect sorvice industrial customers.

7.(d)(1) In order to avoid adverse impacts on retail rates of the Administrator's customors will low system densities, the Administrator shatl, to the extont appropmate. alyly discounts lo the falle or lates lor such customers

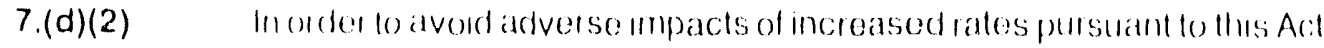

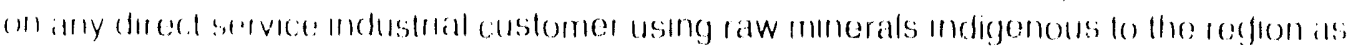

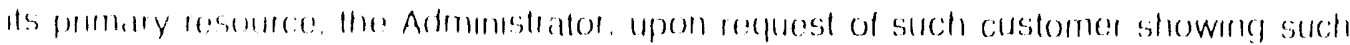

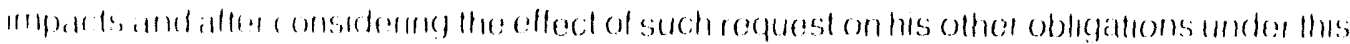

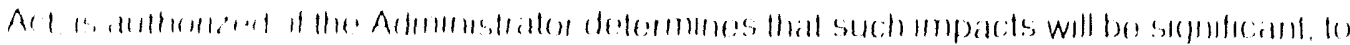

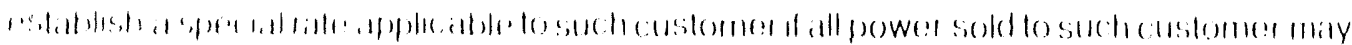

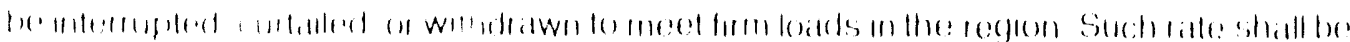

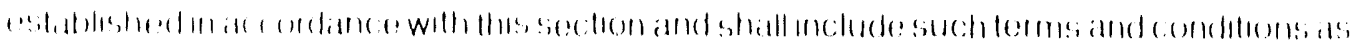

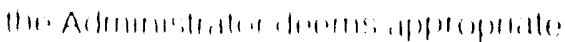


Publicallom in fordual llerplstol

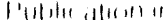

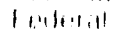

$1\{1 \cdot(1) \cdot 1 \cdot 1 \cdot 1$
$141 \cdot|\mathrm{A}|, \because 4$

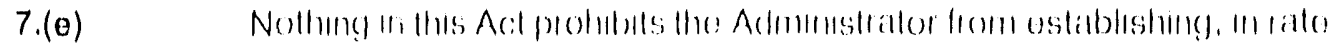

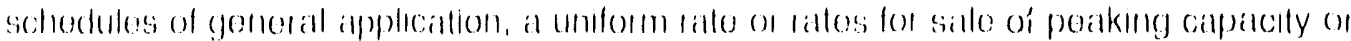

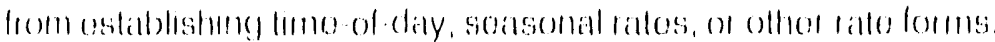

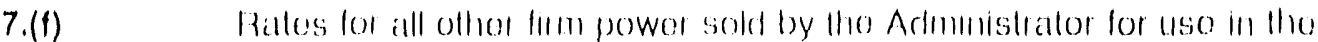

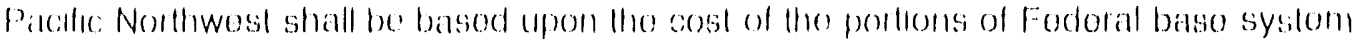
resourcos, purchases of powor undor sochon $5(0)$ of llhs Acl and additional rosourcos wheh, in the determination of the Acdminstralor, aro appliciblo lo such salos.

7.(g) Excopl to the oxtonl that tho allocalion ol costs and benetits is govornod by provisions of law in effoc: on the ofloctive dalle of this Act, or by other provisions of this section. tho Administrator shall oquitably allocalo to powor ratos, in accordance with generally accepted ralomaking principles and tho provisions of this Acl, all costs and benelits not otherwise allocated under this soction, including, but not limiled to, conservation, fish and wildite measures, uncontrollable ovents, resorves, the excess costs of experimontal resources acquired undor section 6 , tho cost of crodils granted pursuant to section 6, operating services, and the sale of or inability lo sell excess electric power.

7.(h) Nolwithstanding any other provision of this section (except the provi. sions of subsection (a) of this section), the Administrator shall adjust power rates to include any surcharges arising under section $4(f)$ of this $\mathrm{Acl}$, and shall allocate any revenues from such charges in such manner as the Administrator determines will help achieve the purposes of section $A(f)$ of this Act.

7.(1) In establishing rates under this section, the Administrator shall use the following procedures:

7.(1)(1) Notice of the proposed rates shall be published in the Federal Register with a statoment of the justification and roasons supporting such rates. Such notice shall include a date for a hearing in accordance with paragraph (2) of this subsection.

7.(1)(2) Ono or more hearings shall be conducted as expeditiously as practicable by a hearing officer to develop a full and complete record and to recelve public comment in the form of written and oral presentation of views, data, questiuns, and argument rolated to such proposed rates. In any such hearing --

7.(1)(2)(A) any person shall be provided an adequate opporlunity by the hearing officer to offer refutation or rebultal of any material submitted by any other person or the Administrator, and

7.(1)(2)(B) the hearing officer, In his discretion, shall allow a reasonable opportunity for cross examination, which, as determined by the hearing officer", is not dilatory, in order to develop information and material relovant to any such proposed rate.

7.(i)(3) In addition to the opportunity to submit oral and written material at the hearngs, any written views, data, questions, and arguments submitted by persons prior 10, or botore the close of, hearings shall be made a part of the administrative record.

7.(i)(4) Aftersuch a hoaring, tho Administrator may propose revised rates, pubInsh such proposed rates in tho Foderal Register, and conduct additional hearings in arecerdiance with thes subsection

7.(1)(5) The Admmostrator shall make a fmal decision ostablishing a rato of biles hased on the record wheh shall molude the hoarmg transcript, togethor with ox. filbls and such other matenals and information as may have boon submitted to or dovel. 


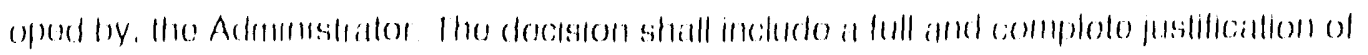

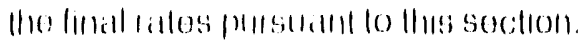

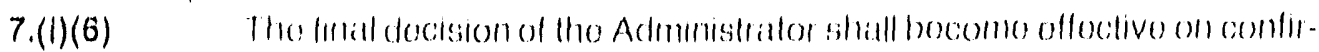

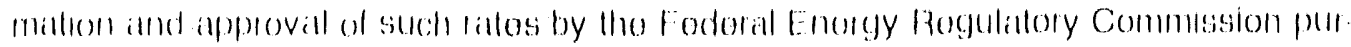

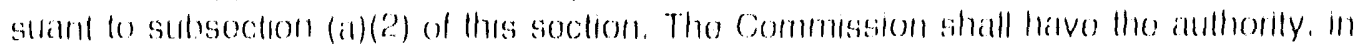
acoordanco with sach procoduros, il any, as the Commission shall promphly ostablish and

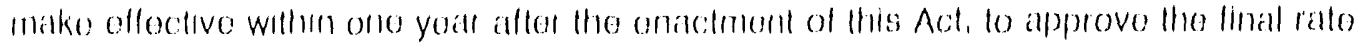

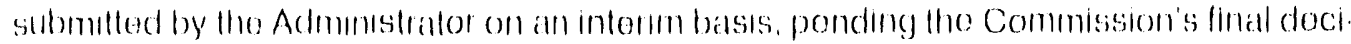

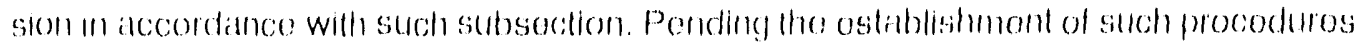

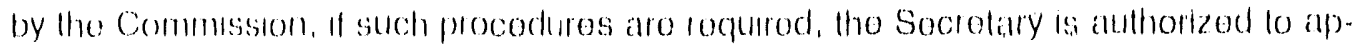

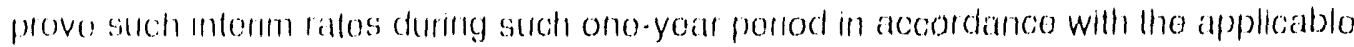
procoduros lollowod by the Socretary prior to the effectivo date of this Acl. Such interim ratos, at the discretion of the Socrotary, shall contmoo in offoct mint July 1, 1982.

7.(j) All rale schedulos adopted, and all povver billings rendorod, by the Ad. minsillator pursuant lo this section shall indicato -

7.(j)(1) tho approximate cosl contribution of differont rosource categorios to tho Administrator s atos for tho salo of onergy and caipactly, and

7.(j)(2) tho cost of resourcos acquired to moel load growth within the region and the relation of such cost to the averago cost of resources avallable to the Administra101.

7.(k) Notwithstanding any othor provision of this $\mathrm{Acl}$, all rates or rato schedules for the salo of nontirm electric power within the United Statos, but outside the region, shall be establishod after the date of this Act by the Administrator in accordance with the procedures of subsection (i) of this section (olher than the first sentence of paragraph (6) thoreol) and in accordance with the Bonneville Projoct Act, the Flood Control Act of 1944, and the Federal Columbia River Transmission System Act. Notwithstanding section $201(f)$ of the Federal Power Act, such rates or rate schedules shall becomo eflecitive after review by the Foderal Engrgy Fegulatory Commission for conformance with the roquiro. ments of such Acts and after approval thereof by the Commission. Such review shall be basod on tho record of proceedings established under subsection (i) of this section. The parties to such proceodings undor subsection (i) shall be afforded an opportunity by the Commission for an additional hearing in accordanco with the procodures ostablishod for ratomaking by the Commission pursuant to the Federal Power Act.

7.(I) In order lo lurther the purposes of this Act and to protect the consumers of the region. tho Admmistralor may nogotiato, or establisti, rates for oloctric sower sold by the Acmmostrator to any entity not located in the Unitod States which shall bo ocfuitable in relation to rales lor all olectric power which is, or may bo, purchased by the Adminstra. tor or the Admmatrator s customers from entitios outside the Unitod Statos. In ostablish ing rates other than by negotation, the provisions of subsoction (i) shall apply fo tho case of any negothatem with an entity not located on the United Statos, tho Admonstrator shall provide public nolses of any proposal to negotiate such ratos. Such negollated rales shall bo not less than the ratles ostabhshod under thes Act for nontim power sold withm the:

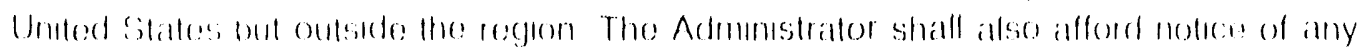

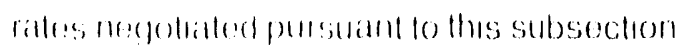

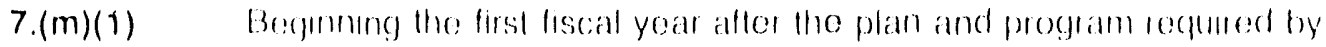

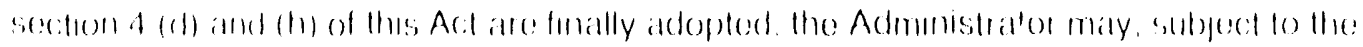

In|c|||r|r|ille!:

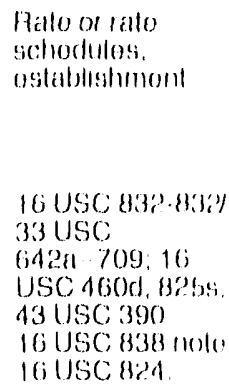

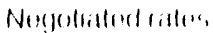
unteirle: 1) Notice:

Hisymonter: 
16 USC $838 \mathrm{a}$

Paymen formula.

16 USC 838 $838 \mathrm{k}$

16 USC 838

Ante. p. 2700

$16115 C 8339 \mathrm{~K}$ provisions of this section, make annual impact aid payments to the appropriate local governments within the region with respect to major transmission facilities of the Administrator, as defined in section $3(\mathrm{C})$ of the Federal Columbia River Transmission Act -

7. $(\mathrm{m})(1)(\mathrm{A})$ which are located within the jurisdictional boundaries of such governments.

7. $(m)(1)(B)$ which are determined by the Administrator to have a substantial impact on such governments, and

7. $(\mathrm{m})(1)(\mathrm{C})$ where the construction of such facilities, or any modification thereof, is completed after the effective date of this Act, and, in the case of a modification of an existing facility, such modification substantially increases the capacity of such existing transmission facility.

7.(m)(2) Payments made under this subsection for any fiscal year shall be determined by the Administrator pursuant to a regionwide, uniform formula to be established by rule in accordance with the procedures set forth in subsection (i) of this section. Such rule shall secome effective on its approval, after considering its effect on rates established pursuant to this section, by the Federal Energy Regulatory Commission. In developing such formula, the Administrator shall identify, and take into account, the local governmental services provided to the Administrator concerning such facilities and the associated costs to such governments as the result of such facilities.

7. $(m)(3) \quad P a y m e n t s$ made pursuant to this subsection shall be made solely from the fund established by section 11 of the Federal Columbia River Transmission System Act. The provisions of section 13 of such Act, and any appropriations provided to the Administrator under any law, shall not be available for such payments. The authorization of payments under this subsection shall not be construed as an obligation of the United States.

7.(m)(4) No payment may be made under this subsection with respect to any land or interests in land owned by the United States within the region and administered by any Federal agency (other than the Administrator), without regard to how the United States obtained ownership thereof, including lands or interests therein acquired or withdrawn by a Federal agency for purposes of such agency and subsequently made available to the Administrator for such facilities.

\section{AMENDMENTS TO EXISTING LAW}

\section{Section 8.}

8.(a) Section 11(b) of the Federal Columbia River Transmission System Act is amended by striking out "or" before "(iii)" in paragraph (6), by striking out the semicolon at the end of such paragraph (6) and inserting in lieu thereof ", or (iv) on a short term basis to meet the Administrator's obligations under section 4(h) of the Pacific Northwest Electric Power Planning and Conservation Acl;".

8.(b) Section 11(b) of the Federal Columbia River Transmission Systelin Act is amended by striking out "and" at the end of paragraph (10), by striking out the period at the end of paragraph (11) and inserting in lieu thereof ".; and", and by adding at the end thereof the following new paragraph:

"(12) making such payments, as shall be required to carry out the purposes and provisions of the Pacific Northwest Electric Power Planning and Conservation Act."

8.(c) Subsection (b) of section 13 of such Act is amended by striking out "and $11(b)(11)^{\prime \prime}$ and iriserting in lieu thereof ", 11(b)(11), and $11(b)(12)^{\prime \prime}$. 
8.(d)(1) The first sentence of subsection (a) of section 13 of such Act is amended by inserting after the word "system," the following: "to implement the Administrator's authority pursuant to the Pacific Northwest Electric Power Planning and Conservation Act (including his authority to provide financial assistance for conservation measures, renewable resources, and fish and wildlife, but not including the authurity to acquire under section 6 of that Act electric power from a generating facility having a planned capability greater than 50 average megawatts),".

8.(d)(2) The fourth sentence of such subsection (a) is amended by inserting the following before the period at the end thereof: "issued by Government corporations".

8.(d)(3) Such subsection (a) is further amended by inserting the following before the period at the end thereof: "prior to October 1, 1981. Such aggregate principal limitation shall be increased by an additional $\$ 1,250,000,000$ after October 1, 1981, as provided in advance in annual appropriation Acts, and such increased amount shall be reserved for the purpose of providing funds for conservation and renewable resource loans and grants in a special revolving account created therefor in the Fund. The funds from such revolving account shall not be deemed State or local funds".

8.(d)(4) Such subsection (a) is further amended by inserting the following after the fourth sentence thereof: "Beginning in fiscal year 1982, if the Administrator fails to repay by the end of any fiscal year all of the amounts projected immediately prior to such year to be repaid to the Treasury by the end of such year under the repayment criteria of the Secretary of Energy and if such failure is due to reasons other than $(A)$ a decrease in power sale revenues due to fluctuating streamflows or $(B)$ other reasons beyond the control of the Administrator, the Secretary of the Treasury may increase the interest rate applicable to the outstanding bonds issued by the Administrator during such fiscal year. Such increase shall be effective commencing with the fiscal year immediately following the fiscal year during which such failure occurred and shall not exceed 1 per centum for each such fiscal year during which such repayments are not in accord with such criteria. The Secretary of the Treasury shall take into account amounis that the Administrator has repaid in advance of any repayment criteria in determining whether to increase such rate. Before such rate is increased, the Secretary of the Treasury, in consultation with the Administrator and the Federal Energy Regulatory Commission, must be satisfied that the Administrator will have the ability to pay such increased rate, laking into account the Administrator's obligations. Such increase shali terminate with the fiscal year in which repayments (including repayments of the increased rate) are in accordance with the repayment criteria of the Secretary of Energy.".

8.(e) Clause (2) of section 1(b) of the Act of August 31, 1964 (78 Stat. 756) is amended to read as follows: "(2) any contiguous areas, not in excess of seventy-five airline miles from said region, which are a part of the service area of a rural electric cooperative served by the Administrator on the effective date of the Pacific Northwest Electric Power Planning and Conservation Acl which has a distribution system from which it serves both within and without said region.".

\section{ADMINISTRATIVE PROVISIONS}

\section{Section 9 .}

9.(a) Subject to the provisions of this Act, the Administrator is authorized to $161190: 83391$ contract in accordance with section 2(f) of the Bonneville Project Act of 1937 (16 U.S.C. 
42 USC 7152.

Contracts outside Pacilic Northwest. limitations and conditions

Definitions

16 USC $837 d$
$832 a(f))$. Other provisions of law applicable to such contracts on the effective date of this Act shall continue to be applicable.

9.(b) The Administrator shall discharge the executive and administrative functions of his office in accordance with the policy established by the Bonneville Project Act of 1937 (16 U.S.C. 832 and following), section 302(a) (2) and (3) of the Department of Energy Organization Act, and this Act. The Secretary of Energy, the Council, and the Administrator shall take such steps as are necessary to assure the timely implementation of this Act in a sound and business-like manner. Nothing in this Act shall be construed by the Secretary, the Administrator, or any other official of the Department of Energy to modify, alter, or otherwise affect the requirements and directives expressed by the Congress in section 302(a) (2) and (3) of the Department of Energy Organization Act or the operations of such officials as they existed prior to enactment of this Act.

9.(c) Any contract of the Administrator for the sale or exchange of electric power for use outside the Pacific Northwest shall be subject to limitations and conditions corresponding to those provided in sections 2 and 3 of the Act of August 31, 1964 (16 U.S.C. $837 \mathrm{a}$ and $837 \mathrm{~b}$ ) for any contract for the sale, delivery, or exchange of hydroelectric energy or peaking capacity generated within the Pacific Northwest for use outside the Pacific Northwest. In applying such sections for the purposes of this subsection, the term "surplus energy" shall mean electric energy for which there is no market in the Pacific Northwest at any rate established for the disposition of such energy, and the term "surplus peaking capacity" shall mean electric peaking capacity for which there is no demand in the Pacific Northwest at the rate established for the disposition of such capacity. The authority granted, and duties imposed upon, the Secretary by sections 5 and 7 of such Act (16 U.S.C. 837e and 837f) shall also apply to the Administrator in connection with resources acquired by the Administrator pursuant to this Act. The Administrator shall, in making any determination, under any contract executed pursuant to section 5 , of the electric power requirements of any Pacific Northwest customer, which is a non-Federal entity having its own generation, exclude, in addition to hydroelectric generated energy excluded from such requirements pursuant to section 3(d) of such Act (16 U.S.C. $837 \mathrm{~b}(\mathrm{~d})$ ), any amount of energy included in the resources of such customer for service to firm loads in the region if (1) such amount was disposed of by such customer outside the region, and (2) as a result of such disposition, the firm energy requirements of such customer or other customers of the Administrator are increased. Such amount of energy shall not be excluded, if the Administrator determines that through reasonable measures such amount of energy could not be conserved or otherwise retained for service to regional loads. The Administrator may sell as replacement for any amount of energy so excluded only energy that would otherwise be surplus.

9.(d) No restrictions contained in subsection (c) shall limit or interfere with the sale, exchange or other disposition of any power by any ut''ity or group thereof from any existing or new non-Federal resource if such sale, exchange or disposition does not increase the amount of firm power the Administrator would be obligated to provide to any customer. Ir addition to the directives contained in subsections (i)(1)(B) and (i)(3) and subject to:

9.(d)(1) any contractual obligations of the Administrator,

9.(d)(2) any other obligations under existing law, and 
9.(d)(3) the availability of capacity it the Federal transmission system,

9.(d) the Administrator shall provide transmission access, load factoring, storage and other services normally attendant thereto to such utilities and shall not discriminate against any utility or group thereof on the basis of independent development of such resource in providing such services.

9.(e)(1) For purposes of sections 701 through 706 of title 5, United States Code, the following actions shall be final actions subject to judicial review-

9.(e)(1)(A) adoption of the plan or amendments thereto by the Council under section 4 , adoption of the program by the Council, and any determination by the Council under section $4(h)$;

9.(e)(1)(B) sales, exchanges, and purchases of electric power under section 5 ;

9.(e)(1)(C) the Administrator's acquisition of resources under section 6 ;

9.(e)(1)(D) implementation of conservation measures under section 6 ;

9.(e)(1)(E) execution of contracts for assistance to sponsors under section $6(f)$;

9.(e)(1)(F) granting of credits under section $6(\mathrm{~h})$;

9.(e)(1)(G) final rate determinations under section 7 ; and

9.(e)(1)(H) any rule prescribed by the Administrator under section $(7)(\mathrm{m})(2)$ of this Act.

9.(e)(2) The record upon review of such final actions shall be limited to the administrative record compiled in accordance with this Act. The scope of review of such actions without a hearing or after a hearing shall be governed by section 706 or title 5 , United States Code, except that final determinations regarding rates under sec.ion 7 shall be supported by substantial evidence in the rulemaking record required by section 7 (i) considered as a whole. The scope of review of an action under section 6(c) shall be governed by section 706 of title 5, United States Code. Nothing in this section shall be construed to require a hearing pursuant to section 554,556 , or 557 of title 5 of the United States Code.

9.(e)(3) Nothing in this section shall be construed to preclude judicial review of other final actions and decisions by the Council or Administrator.

9.(e)(4) For purposes of this subsection-

9.(e)(4)(A) major resources shall be deemed to be acquired upon publication in the Federal Register pursuant to section $6(\mathrm{C})(4)(B)$;

9.(e)(4)(B) resources, other than major resources, shall be deemed to be acquired upon execution of the contract therefor;

9.(e)(4)(C) conservation measures shall be deemed to be implemented upon execution of the contract or grant therefor; and

9.(e)(4)(D) rate determinations pursuant to section 7 shall be deemed final upon confirmation and approval by the Federal Energy Regulatory Commission.

9.(e)(5) Suits to challenge the constitutionality of this Act, or any action thereunder, final actions and decisions taken pursuant to this Act by the Administrator or the Council, or the implementation of such final actions, whether brought pursuant to this Act, the Bonneville Project Act, the Act of August 31, 1964 (16 U.S.C. 837-837h), or the Federal Columbia River Transmission System Act (16 U.S.C. 838 and following), shall be filed in the United States court of appeals for the region. Such suits shall be filed within ninety days of the time such action or decision is deemed final, or, if notice of the action is required by this $A c t$ to be published in the Federal Register, within ninety days from such

Suits.

16 USC $832-832$

Notice,

publication in

Federal

Register. 
26 USC 103

"Major portion."

15 USC $79 \mathrm{et} \mathrm{seq}$

15 USC 79a notice, or be barred. In the case of a challenge of the plan or programs or amendments thereto, such suit shall be filed within sixty days after publication of a notice of such final action in the Federal Register. Such court shall have jurisdiction to hear and determine any suit brought as provided in this section. The plan and program, as finally adopted or portions thereof, or amendments thereto, shall not thereafter be reviewable as a part of any other action under this Act or any other law. Suits challenging any other actions under this Act shall be filed in the appropriate court.

9.(f) For purposes of enabling the Administrator to acquire resources necessary to meet the firm load of public bodies, cooperatives, and Federal agencies from a governmental unit at a cost no greater than the cosi which would be applicable in the absence of such acquisition, the exemption from gross income of interest on certain governmental obligations provided in section 103(a)(1) of the Internal Revenue Code of 1954 shall not be affected by the Administrator's acquisition of such resources if -

9.(f)(1) the Administrator, prior to contracting for such acquisition, certifies to his reasonable belief, that the persons for whom the Administrator is acquiring such resources for sale pursuant to section 5 of this Act are public bodies, cooperatives, and Federal agencies, unless the Administrator also certifies that he is unable to acquire such resources without selling a portion thereoi to persons who are not exempt persons (as defined in section 103(b) of such Code), and

9.(f)(2) based upon such certification, the Secretary of the Treasury determines in accordance with applicable regulations that less than a major portion of the resource is to be furnished to persons who are not exempt persons (as defined in section 103(b) of such Code).

9.(f) The certification under paragraph (1) shall be made in accordance with this subsection and a procedure and methodology approved by the Secretary of the Treasury. For purposes of this subsection, the term "major portion" shall have the meaning provided by regulations issued by the Secretary of the Treasury.

9.(g) When reviewing rates for the sale of power to the Administrator by an investor-owned utility customer under section 5(c) or 6, the Federal Energy Regulatory Commission shall, in accordance with section 209 of the Federal Power Act (16 U.S.C. $824 h)-$

9.(g)(1) convene a joint State board, and

9.(g)(2) invest such board with such duties and authority as will assist the Commission in its review of such rates.

9.(h)(1) No "Company" (as defined in section 2(a)(?) of the Public Utility Holding Company Act of 1935; 15 U.S.C. $79 b(a)(2)$ ), which owns is operates facilities for the generation of electricity (together with associated transmission and other facilities) primarily for sale to the Administrator under section 6 shail be deemed an "electric utility company" (as defined in section 2(a)(3) of the Public Utility Holding Combany Act of 1935; 15 U.S.C. $79 \mathrm{~b}(\mathrm{a})(3)$ ), within the meaning of any provision or provisions of chapter $2 \mathrm{C}$ of title 15 of the United States Code, if at least 90 per centum of the electricity generated by such company is sold to the Administrator under section 6, and if -

9.(h)(1)(A) the organization of such company is consistent with the policies of section 1 (b) and (c) of the Public Utility Holding Company Act of 1935, as determined by the Securities and Exchange Commission, with the concurrence of the Administrator, at the time of such organization; anu 
9.(h)(1)(B) participation in any facilities of such "company" has been offered to public bodies and cooperatives in the region pursuant to section $6(\mathrm{~m})$.

9.(h)(2) The Administrator shall include in any contract for the acquisition of a major resource from such "company" provisions limiting the amount of equity investment, if any, in such "company" to that which the Administrator determines will be consistent with achieving the lowest attainable hower costs attributable to such major resource.

9.(h)(3) In the case of any "company" which meets the requirements of paragraph (1), the Administrator, with the concurrence of such Commission, shall approve all significant contracts entered into by, and between, such "company" and any sponsor company or any subsidiary of such sponsor company which are determined to be consistent with the policies of section 1 (b) and (c) of the Public Utility Holding Company Act of 1935 at the time such contracts are entered into. The Administrator and the Securitles and Exchange Commission shall exercise such approval authority within sixty days after receipt of such contracts. Such contracts shall not be effective without such approval.

9.(h)(4) Paragraph (1) of this subsection shall continue to apply to any such "company" unless the Administrator or the Securities and Exchange Commission, or both, through periodic review, (A) determine at any time that the "company" no longer operates in a manner consistent with the policies of section 1 (b) and (c) of the Public Utility Holding Company Act of 1935 and in accordance with this subsection, and (B) notify the "company" in writing of such preliminary determination. This subsection shall cease to apply to such "company" thirty days after receipt of notification of a final determination thereof. A final determination shall be made only after public notice of the preliminary determination and after a hearing completed not later than sixty days from the date of publication of such notice. Such final determination shall be made within thirty days after the date of completion of such hearing.

9.(i)(1) At the request and expense of any customer or group of customers of the Administrator within the Pacific Northwest, the Administrator shall, to the extent practicable-

9.(i)(1)(A) acquire any electric power required by (i) any customer or group of customers to enable them to replace resources determined to serve firm load under section 5(b), or (ii) direct service industrial customers to replace electric puwer that is or may be curtailed or interrupted by the Administrator (other than power the Administrator is obligated to replace), with the cost of such replacement power to be distributed among the direct service industrial customers requesting such power; and

9.(i)(1)(B) dispose of, or assist in the disposal of, any electric power thai ? customer or group of customers proposes to sell within or without the region at rates and upon terms specified by such customer or group of customers, if such disposition is not in conflict with the Admınistrator's other marketing obligations and the policies of this Act'and other applicable laws.

9.(i)(2) In implementing the provisions of subparagraphs (A) and (B) of paragraph (1), the Administrator may prescribe policies and conditions for the independent acquisition or disposition of electric power by any direct service industrial customer or group of such customers for the purpose of assuring each direct service industral customer an opportunity to participate in such acquisition or disposition.
Contracts, approval

15 USC 79a

Notice; hearing

Electric power

acquisition.

policiess and

conditions 
Report

16 USC 2601

note.

Functions

Conservation and renewable resources. position establishment.

16 USC $839 \mathrm{~g}$ 9.(i)(3) The Administrator shail furnish services inciuding transmission, storage, and load factoring unless he determines such services cannot be furnished without substantial interference with his power marketing program, applicable operating limitations or existing contractual obligations. The Administrator shall, to the extent practicable, give priority in making such services available for the marketing, within and without the Pacific Northwest, of capability from projects under construction on the effective date of this Act, if such capability has been offered for sale at cost, including a reasonable rate of return, to the Administrator pursuant to this Act and such offer is not accopted withir, one year.

9.(j)(1) The Council, as soon as practicable after the enactment of this Act, shall prepare, in consultation with the Administrator, the customers, appropriate State regulatory bodies, and the public, a report and shall make recommendations with respect to the various retail rate designs which will encourage conservation and efficient use of electric energy and the installation of consumer-owned renewable resources on a cost-effective basis, as well as areas for research and development for possible application to retail utility rates within the region. Studies undertaken pursuant to this subsection shall not affect the responsibilities of any customer or the Administrator which may exist under the Public Utility Regulatory Policies Act of 1978.

9.(j)(2) Upon request, and solely on behalf of customers so requesting, the Administrator is authorized to $(A)$ provide assistance in analyzing and developing retail rate structures that will encourage cost-effective conservation and the installation of costeffective consumer-owned renewable resources; $(B)$ provide estimates of the probable power savings and the probable amount of billing credits under section $6(h)$ that might be realized by such customers as a result of adopting and implementing such retail rate structures; and $(C)$ solicit additional information and analytical assistance from appropriate State regulatory bodies and the Administrator's other customers.

9.(k) There is hereby established within the administration an executive position for conservation and renewable resources. Such executive shall be appointed by the Administrator and shall be assigned responsibility for conservation and direct-application renewable resource programs (including the administration of financial assistance for such programs). Such position is hereby established in the senior executive service in addition to the number of such positions heretofore established in accordance with other provisions of law applicable to such positions.

\section{SAVINGS PROVISIONS}

\section{Section 10.}

10.(a) Nothing in this Act shall te construed to affect or modify any right of any State or political subdivision thereof or electric utility to-

10.(a)(1) determine retail electric rates, except as provided by section 5(c)(3);

10.(a)(2) develop and implement plans and programs for the conservation, development, and use of resources; or

10.(a)(3) make energy facility' siting decisions, including, but not limited to, determining the need for a particular facility, evaluating alternative sites, and considering alternative methods of meeting the determined need. 
10.(b) Nothing in this Act shall alter, diminish, or abridge the rights and obligations of the Administrator or any customer under any contracl existing as of the effective date of this Act.

10.(c) Nothing in this Act shall alter, diminish, abridge, or otherwise affect the provisions of other Federal laws by which public bodies and cooperatives are entitled to preference and priority in the sale of federally generated electric power

10.(d) If any provision of this Act is found to be unconstitutional, then any contract entered into by the Administrator, prior to such finding and in accordance with such provisions, to sell power, acquire or credit resources, or to reimburse investigations and preconstruction expenses pursulant to section 5 , and section $6(\mathrm{a}),(\mathrm{f})$ or $(\mathrm{h})$ of this Act shall not be affected by such finding.

10.(e) Nothing in this Act shall be construed to affect or modify any treaty or other right of an Indian tribe.

10.(f) The reservation under law of electric power primarily for use in the State of Montana by reason of the const uction of Hungry Horse and Libby Dams and Reservoirs within that State is hereby affirmed. Such reservation shall also apply to 50 per centum of any electric power produced at Libby Reregulating Dam if built. Electric power so reserved shall be sold at the rate or rates set pursuant to section 7 .

10.(g) Nothing in this Act shall be construed to affect or modify the right of any State to prohibit utilities regulated by the appropriate State regulatory body from recovering, througin their retail rates, costs during any period of resource construction.

10.(h) Nothing in tris Act shall be construed as authorizing the appropriation of water by any Federal, State, or local agency, Indian tribe, or any other entity or individual. Nor shall any provision of this Act of any plan or program adopted pursuant to the Act (1) affect the rights or jurisdictions of the United States, the States, Indian tribes, or other entities over waters of any river or stream or over any groundwater resource, (2) alter, amend, repeal, interpiet, modify, or be in conflict with any interstate compact made by the States, or (3) otherwise be construed to alter or establish the respective rights of States, the United States, Indian tribes, or any person with respect to any water or water-related right.

10.(i) Nothing in this Act shall be construed to affect the validity of any existing license, permit, or certificate issued by any Federal agency pursuari to any other Federal law.

\section{EFFECTIVE DATE}

Section 11. This Act shall be etiective on the date of enactment, or October 1, 1980, whichever is later For purposes of this Act, the term "date of the enactment of this Act" means such date of enactment or October 1, 1980, whichever is later. 


\section{SEVERABILITY}

16 USC $839 \mathrm{~h}$

Section 12. If any provision of section 4(a) through (c) of this Act or any other provision of this Act or the application thereof to any person, State, Indian tribe, entity, or circumstance is held invalid, neither the remainder of section 4 or any other provisions of this Act, nor the application of such provisions to other persons, States, Indian tribes, entities, or circumstances, shall be affected thereby.

Approved December 5, 1980.

\section{LEGISLATIVE HISTORY:}

HOUSE REPORTS:

No. 96-976, $\mathrm{Pl}$. I (Comm. on Interstate and Foreign' Commerce), and No. 96-, Pt. II (Comm. on Interior and Insular Affairs).

SENATE REPORT No. 96-272 (Comm. on Energy and Natural Resources).

CONGRESSIONAL RECORD:

Vol. 125 (1979): Aug. 3, considered and passed Senate.

Vol. 126 (1980): Sept. 24, 29, Nov. 12-14, 17, considered and passed House, amended, in lieu of H.R. 8157 .

Nov. 19, Senate concurred in House amendment. 


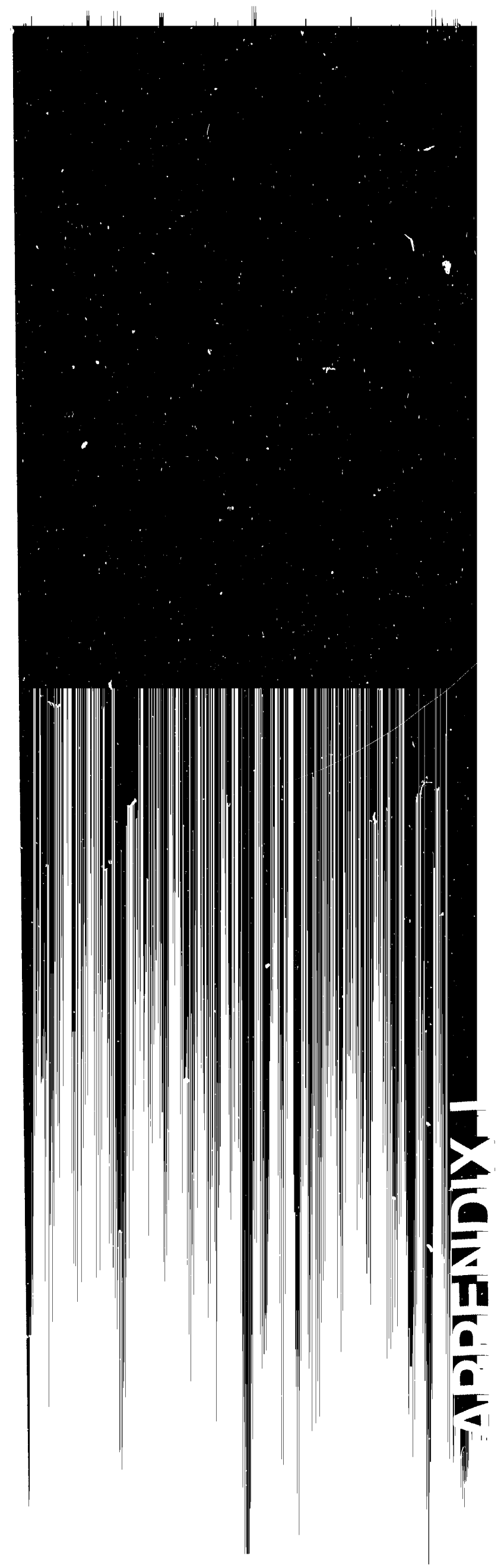




\section{Append IX L}

Biological Assessment and

Threatened and Endangered Species List 


\section{BIOLOGICAL ASSESSMENT}

\section{BACKGROUND}

On July 19, 1989, Bonneville Power Administration (BPA) requested from field offices of the U.S. Fish and Wildlife Service (USFWS) lists of threatened, endangered and candidate specles that might be affected by the alternatives in the Initial Northwest Power Sales Contracts EIS (PSC EIS). On March 20, 1991, BPA requested updated lists of threatened, endangered, and candidate species from the same USFWS fleld offices. The preferred alternative is a modification of Alternative 1.1, which includes a commitment by BPA to develop a policy to enforce compliance with the Northwest Power Planning Councll (NWPPC) Protected Areas Rule.

In terms of its effects on operations at existing generating plants, the preferred alternative is the same as the No Action Alternative (i.e., retention of the status quo provisions in the current power sales contracts), as discussed in this document. Enhanced enforcement of the Protected Areas Rule under the preferred alternative would affect new power resources by discouraging the development of new hydroelectric projects in areas designated as Protected Areas under the NWPPC Rule.

The actions under consideration in this EIS do not involve construction. The EIS analyzes BPA's two broad contractual alternatives: to preserve the contracts without change (the No Action Alternative), or to pursue modifications. With in the second alternative are five categories corresponding to major po!icy issues:

1. hydro development and operations;

2. conservation;

3. resource planning and development;

4. quality of service as a resource choice; and

5. industrial load constraints.

Environmental effects of alternatives in each of these categories are analyzed in the EIS based on the operation and development of power generation facllities in an area spanning Oregon, Washington, Idaho, Montana, and parts of California, Utah, Nevada, and Wyoming. Because of the indirect relationship between contractual provisions and the operation of generatirg resources, this Biological Assessment is predominantly qualitative in nature. Quantitative assessment was developed for some of the alternatives in the draft EIS using various computer models of power system operations and effects. Refer to Appendices $F$ and $H$ for further information and technical analyses. This analysis, as discussed in the Draft (D) EIS, showed that for the preferred alternative and the No Action Alternative, minimal or no environmental impacts would be associated with continued base operation of the Northwest power generating system.

The list of proposed or listed threatened, endangered, or candidate species obtained from the USFWS field office, and other pertinent information was used to develop the following Biological Assessment. 
Focus on Operations. This assessment addresses operations of existing facilities. Parties to the power sales contracts are expected to remain the same over time, and it is service to their loads which will affect resource operations.

It should be noted that BPA power marketing does not control the operation of generating facilities. Operation of generating resources is governed by a variety of nonpower constraints which are imposed on operators through regulatory authorities including the Federal Energy Regulatory Commission (FERC). Operation of the existing hydroelectric system and the development of new energy resources are subjects of analysis in other processes, specifically the System Operation Resiew (SOR) EIS and the Resource Program EIS. Decisions about operations at existing hydro projects will be made based on the SOR EIS, and decisions about new resource development will be made based on the Resource Program EIS. The relationship between this EIS and these other processes is explained in the DEIS.

The proposed listing of Snake River salmon runs as threatened or endangered species has resulted in discussions between BPA and the National Marine Fisheries Service (NMFS) concerning the influence of power marketing activities on operations which may affect candidate species. BPA and NMFS are in the process of determining which activities are properly subject to conferencing over potential jeopardy to candidate species.

The "No Action" (Base Case) Alternative and Relationship to Preferred Alternative. The "No Action" alternative represents the operational condition if BPA were not to implement any of the action alternatives in the EIS. "No Action" levels of operation are those which would occur without any change in the power sales contracts. The preferred alternative does not alter the operation of existing resources from "No Action" levels, but commits BPA to establishing a policy which will influence the development of new hydro resources by creating disincentives to development in NWPPC Protected Areas.

Table 1 lists those facilities which were identified as having potential for operational changes to exceed the No Action Alternative. These are the facilities for which BPA requested species lists. The table also shows those facilities for which threatened or endangered species were identified by the USFWS (Column 3): those facilities which exceeded No Action impacts under any of the alternatives studied, or, for hydroelectric facilities, which might affect fish stocks */ under any of the alternatives (Column 4); and those facilities which are consequently analyzed in this Biological Assessment (Column 5). Only those facilities identified in Table I as covered in the assessment were analyzed for impacts on threatened or endangered species.

\footnotetext{
* The only potential impacts identified at dams were on fish that are a fcod source for bald eagles. As to potential impacts on anadromous fish stocks petitioned or proposed for listing under the Endangered Species Act (ESA), $B P A$ is undertakinc separate conference with the NMFS
} 
Table 1

Facilities on the Original Request for

Threatened and Endangered Species Data

and Subsequent Results

\begin{tabular}{|c|c|c|c|c|}
\hline Column 1 & 2 & 3 & 4 & 5 \\
\hline & & & Fish & Covered in \\
\hline & & & Stocks & Biological \\
\hline Hydro Facilities & Location & $I \& E^{*} /$ & Affected? & Assessment? \\
\hline Bonneville & $O R / W A$ & YES & NO & NO \\
\hline The Dalles & $O R / W A$ & YES & NO & NO \\
\hline John Day & $O R / W A$ & YES & NO & NO \\
\hline McNary & OR/WA & YES & NO & NO \\
\hline Priest Rapids & OR/WA & YES & NO & NO \\
\hline Wanapum & WA & YES & NO & NO \\
\hline Rock Is land & WA & YES & NO & NO \\
\hline Rocky Reach & WA & YES & NO & NO \\
\hline Wells & $W A$ & YES & NO & NO \\
\hline Chief Joseph & WA & YES & NO & NO \\
\hline Ice Harbor & WA & YES & NO & NO \\
\hline Lower Monumental & WA & YES & NO & NO \\
\hline Little Goose & $W A$ & YES & NO & NO \\
\hline Lower Granite & WA & YES & NO & NO \\
\hline Libby & MT & YES & YES & YES \\
\hline Hungry Horse & MT & YES & YES & YES \\
\hline Albeni Falls & ID & NO & NO & NO \\
\hline Grand Coulee & WA & YES & NO & NO \\
\hline Dworshak & ID & YES & YES & YES \\
\hline
\end{tabular}

* Supplied by USFWS. Includes both wildlife and fish species. 
Table I (continued)

\begin{tabular}{|c|c|c|c|c|}
\hline \multirow[t]{3}{*}{ Column 1} & 2 & 3 & 4 & 5 \\
\hline & & & Exceed & Covered in \\
\hline & & & No Action & Biological \\
\hline Hydro Facillities & Location & $I \& E$ & Alternative? & Assessment? \\
\hline Colstrip $1-4$ & MT & YES & NO & YES \\
\hline Corette & MT & YES & NO & YES \\
\hline Boardman & OR & NO & NO & NO \\
\hline Centralia 182 & WA & YES & NO & YES \\
\hline Jim Bridger 1-4 & WY & YES & No & YES \\
\hline Valmy & NV & NO & NO & NO \\
\hline
\end{tabular}

Combustion Turbine

$\begin{array}{lllll}\text { Bethel } & \text { OR } & \text { YES } & \text { NO } & \text { NO } \\ \text { Beaver } & \text { OR } & \text { YES } & \text { NO } & \text { YES } \\ \text { Whitehorn 1-3 } & \text { WA } & \text { YES } & \text { NO } & \text { YES } \\ \text { Frederickson } 182 & \text { WA } & \text { YES } & \text { NO } & \text { YES } \\ \text { Fredonia } 1 \& 2 & \text { WA } & \text { YES } & \text { NO } & \text { YES }\end{array}$

Nuclear

WNP-1

WA YES

NO

NO

WNP -3

WA

YES

NO

NO

Coal Mines

Belle-Ayre
Centralia
Rosebud
Bridger

WY

YES

NO

NO

WA

YES

NO

NO

MT

YES

NO

NO

WY

YES

NO

NO 
Key Assumptions. Below are the principal assumptions used in developing this Blological Assessment.

- The information and analysis in the DEIS, and additional data developed for the final EIS provide a sufficient basis for the Blological Assessment.

- Existing facilities would be uperated within des'gn limits and capabilities in accordance with applicable laws and regulations.

- Resident fish production is adversely affected by decreased reservoir levels or streamflows.

- Anadromous fish passage and production is directly affected by forebay and streamflow levels in mainstem and tributary streams with hydroelectric dams.

- Waterfowl on the mainstem Columbia and Snake rivers would not be affected by operational actions covered by the PSC EIS.

- Quantifiable effects from the operational changes that may be possible within the alternatives to the proposed action are beyond the scope of this Biological Assessment, and must be considered on a site-by-site basis in other processes.

- No change in human use of facilities would occur as the result of these actions; therefore no additional disturbance of wildilfe would be caused.

- Where coal plant operations do not exceed the No Action Alternative, the mine supplying its ccal will also not exceed No Action.

- Where an alternatives' operations would fall below the level of the No Action Alternative, no significant impacts would occur on vegetation or wildilfe.

\section{ASSESSMENT}

The Biological Assessment is divided into three sections: (1) discussions of generic and site-specific impacts that can occur with each type of facility covered by this assessment: hydro dams, gas-fired thermal plants, coal-fired thermal plants and coal mines; (2) tables listing individual facilities, associated species, and possible impacts, with footnotes; and (3) a detailed discussion of resident fish, a food supply of the bald eagle, at the reservoirs behind Dworshak and Hungry Horse dams. 


\section{(1) DISCUSSION}

\section{Hydro Projects}

There are two basic types of power generating hydroelectric dams:

run-of-the-river, and storage. The former operate on avallable water resulting from natural processes and upstream releases. These dams, once constructed, are limited for managenent of hydro production or environmental needs. Storage dams, however, are manipulated and controlled by human intervention. Operatiun of storage dams has direct effects upon in-river and riparian fish and wildife resources.

Water level fluctuations have been shown to adversely impact populations of resident fish and the passage of adult and juvenile anadromous fish through the Columbia and Snake river systems. For existing hydro projects, compliance with NWPPC Fish and Wildi ife Program as a contract constraint would duplicate other methods of program implementation, and therefore would not effect environmental conditions. However, the application of the AWPPC's Protected Areas Rule, which applies to new hydro development, would have benefits for fish and wildilfe, which could apply both within and outside of the Columbia River Basin. These benefits would be based on the fact that new hydro would be shifted to previously determined low impact areas and away from more sensitive stream reaches. BPA has committed itself to a policy process to consider how to apply the Protected Areas Rule to BPA's power marketing activities; BPA's Long-Term Intertie Access Policy (LTIAP) requires customers using the Pacific Northwest-Pacific Southwest Intertie under the LTIAP to follow this rule with respect to new hydro developments within the columbia basin.

Other alternatives associated with hydro operations were discussed in the DEIS. It was determined that, depending upon time and place, flow pattern shifts could both benefit and harm anadromous fish populations. In all scenarios regarding flow pattern alterations, the Water Budget flows to assist fish migration were met. The addition of planned bypass systems and other planned mitigation measures at mainstem Columbia Basin dams is expected to improve anadromous fish stock survival over time.

Resident fish are primarily affected by reservoir levels since they inhabit shallow water areas along the periphery of the reservoirs. Excessive drawdowns during the period from April to September could negatively affect these resident fish. Elevation frequency changes in reservoir levels at Dworshak. Hungry Horse, and Libby during November, as discussed in the DEIS, could result in negative impacts to fish production for fall spawning kokannee and have serious impacts to resident fish populations. However, overall results from imparing data from alternative scenarios versus the base operations (No Action Alternative) showed minimum impacts on fish populations. Nesting waterfowl residing in the mainstem Columbia and Snake rivers would essentially be unaffected by water level changes due to the water displacement of these rivers and the location of roosting and nesting trees and man-made structures. None of the noted adverse impacts would occur under the preferied alternative. 
Shorter contract terms could have possible negative environmental implications should customers decide to develop new hydro resources in sensitive areas. The No Action Alternative and the preferred alternative would maintain current contract terms and thus avoid this potential.

With regard to firm load energy changes, power resources would likely be purchased to make up for any contract increase in firm load. Reservoirs would continue base operations and therefore additional fish and wildife impacts would not be expected.

\section{Thermal Plants}

Comparison of data between alternatives and the No Action Alternative for operation of coal and gas turbine generating plants did not reveal any clear trends. Impacts can occur from increased water withdrawals at coal-fired plants, however, analysis of alternatives showed effects, specifically to fish populations, to be negligible. Environmental impacts relative to air quality, land disturbances, and water use were shown to be minimal or negligible. Thermal plants will continue to operate within design and legal limits. No impacts to threatened or endangered species or their respective habitats are expected.

\section{Coal Mines}

Coal mines within the area covered by the PSC EIS process were evaluated for operational changes and compared to the No Action Alternative. Impacts were discussed for air quality, water use, and land use. Surface coal mines operate under permits and within the confines of the land areas allocated for extraction. Consequently, additional land surface disturbance is limited to the areas of identified recoverable coal.

Since mines are mandated to be operated under permit, it is BPA's conclusion that the alternatives, including the No Action Alternative, would cause no additional environmental impacts on threatened and endangered species at mines operated within the area covered by this Biological Assessment.

\section{Conservation}

"Conservation" is treated as a resource much the same as power generation. Incentives exist and are currently used by BPA customers to increase energy efficiency. Firm load deliveries are an integral part of the contracts. Surplus generating potential may be used to improve fish and wildlife habitat, however, these benefits are determined by time and place and cannot therefore be discussed with any degree of certainty in quantitative terms within this assessment.

The OFIs analysis showed no significant environmental benefits from conservation as a condition of service above the benefits of programs already drailablo to increase energyefficiency in the region. 


\section{Proposed Listings under the Endangered Species Act}

Snake River sockeye salmon have been proposed for listing as endangered and Snake River spring/summer and fall chinook have been proposed for listing as threatened by NMFS under the ESA. Potential impacts on the operation of the power system as a result of future listings, or the use of conservation and other resources to meet electrical loads, are the subjects of analysis in other documents currently under preparation, specifically, the SOR EIS and the Resource Program EIS. BPA is involved in discussions with NMFS concerning the effect of power system operations on the species proposed for listing. In addition, operational measures to enhance the survival of runs proposed for listing are the subject of analysis in the "l\$92 Columbia River Salmon Flow Measures Options Analysis/EIS" under preparation by the U.S. Army Corps of Engineers in cooperation with BPA and the Bureau of Reclamation.

\section{(2) TABLES}

Table II. Threatened and Endangered Species Potentially Affected

Table II lists those facilities where possible effects may occur on threatened or endangered species identified by the USFWS.

rable III. Findings

Table III presents conclusions for impacts on each potentially affected species. Impact review was conducted in consultation with USFWS field office personnel to focus on most likely problem areas. 
Table 11

THREATENED AND ENDANGERED SPECIES POTENTIALLY AFFECTED

\begin{tabular}{|c|c|c|}
\hline Facility & State & Species Present \\
\hline Hungry Horse & MT & $\begin{array}{l}\text { Bald Eagle(E), Peregrine Falcon (E), } \\
\text { Grizzly Bear (T), Gra'y Wolf (E) }\end{array}$ \\
\hline Libby & MT & same as Hungry Horse \\
\hline $\begin{array}{l}\text { Colstrip Coal-Fired } \\
\text { Thermal Plants } 1 .-4\end{array}$ & MT & $\begin{array}{l}\text { Bald Eagle (E), Peregrine } \\
\text { Falcon (E), Black-footed Ferret (E) }\end{array}$ \\
\hline Rosebud Coal Mine & MT & $\begin{array}{l}\text { Bald Eagle (E), Peregrine Falcon (E), } \\
\text { Black-footed Ferret (E) }\end{array}$ \\
\hline Bridger Coal Mine & WY & $\begin{array}{l}\text { Bald Eagle (E), Peregrine Falcon (E), } \\
\text { Black-footed Ferret (E), Humpbafk Chub (E), } \\
\text { Colorado Sqlawfish (E) }\end{array}$ \\
\hline Jim Bridger 1-4 & WY & same as Bridger Coal Mine \\
\hline Belle Ayre & WY & $\begin{array}{l}\text { Bald Eagle (E), Peregrine Falcon (E), } \\
\text { Black-footed Ferret (E) }\end{array}$ \\
\hline Corette Thermal Plant & WY & $\begin{array}{l}\text { Bald Eagle (E), Peregrine Falcon }(E) \text {, and } \\
\text { Black-footed Ferret (E) }\end{array}$ \\
\hline Dworshak Dam & ID & Bald Eagle (T) \\
\hline Bonneville Dam & OR/WA & Bald Eagle $(T)$, Peregri,le Falcon (E) \\
\hline The Dalles Dam & $O R / W A$ & Bald Eagle $(T)$, Peregrine Falcon (E) \\
\hline John Day Dam & OR/WA & Bald Eagle $(T)$, Peregrine Falcon (E) \\
\hline McNary Dam & $O R / W A$ & Bald Eagle $(T)$, Peregrine Falcon $(E)$ \\
\hline Priest Rapids Dam & $W A$ & Bald Eagle $(T)$, Peregrine Falcon (E) \\
\hline Wanapum Dam & WA & Bald Eagle $(T)$, Peregrine Falcon (E) \\
\hline Rock Island Dam & WA & Bald Eagle $(T)$, Peregrine Falcon (E) \\
\hline Rocky Reach Dam & WA & Bald Eagle $(T)$, Peregrine Falcon (E) \\
\hline Wells Dam & WA & Bald Eagle $(T)$, Peregrine Falcon (E) \\
\hline Chief Joseph Dam & $W A$ & Bald Eagle (T), Peregrine Falcon (E) \\
\hline Ire Harbor Dam & WA & Bald Fagle $(T)$, Peregrine Falcon (E) \\
\hline
\end{tabular}


TABLE $\mid 1$ (cont inued)

\begin{tabular}{|c|c|c|}
\hline Facllity & State & Species Present \\
\hline Lower Monumental Dam & WA & Bald Eagle (T) Peregrine Falcon (E) \\
\hline Little Goose Dam & WA & Bald Eagle $(T)$, Peregrine Falcon $(E)$ \\
\hline Lower Granite Dam & WA & Bald Eagle $(T)$, Peregrine Falcon (E) \\
\hline Grand Coulee Dam & WA & Bald Eagle $(T)$, Peregrine Falcon (E) \\
\hline Centralia $1 \& 2$ & WA & Bald Eagle (T) \\
\hline WNP-1 & WA & Bald Eagle $(T)$, Peregrine Falcon (E) \\
\hline WNP-3 & WA & $\begin{array}{l}\text { Bald Eagle }(T) \text { There are three nesting } \\
\text { territories near the project. }\end{array}$ \\
\hline Whitehorn & WA & Bald Eagle (T), Peregrine Falcon (E) \\
\hline Frederickson 1 \& 2 & WA & Bald Eagle ( $T$ ) \\
\hline Fredonia 1 \& 2 & WA & Bald Eagle (T) \\
\hline Centralia Coal Mine & WA & Bald Eagle (T) \\
\hline Bethel & OR & Bradshaw's Lomatium (E) \\
\hline Beaver & OR & Bald Eagle (T) \\
\hline Boardinan Thermal Plant & $O R$ & $\begin{array}{l}\text { Bald Eagle (T) and Peregrine Falcon (E) may } \\
\text { occur in milgration }\end{array}$ \\
\hline
\end{tabular}

$\mathrm{E}=$ Endangered

$T=$ Threatened 
(3) Resident Fish and Bald Eagles at Dworshak, Idaho:

Libby and Hungry Horse Reservolrs

Breeding, wintering, and migrating bald eagles were identifled as an endangered specles found in the areas of most facllities covered by this assessment. In reviewing operation of those facllities (see Tables I, II, and III), our conclusion is that operational changes under any of the alternatives are not likely to adversely affect the bald eagle. Operational changes at Hungry Horse, Libby, and Dworshak under some alternatives could affect the flshery resource, which may affect food supplies for bald eagles; this possibility and its effect on bald eagles are discussed below. The preferred alternative would not resull in any of the operational changes in question.

\section{Resident Fisheries}

Common resident fish species in Hungry Horse Reservoir include westslope cutthroat trout, mountain whitefish, northern squawfish, large-scake suckers, longnose suckers, and pygmy white fish (May and Weaver, 198\%). Study of these fish populations has been underway since 1983, to quantify seasonal water levels needed to maintain or enhance the reservoir fisheries.

Common resident fish species in Dworshak Reservoir include wests lope cutthroat trout, mountain whitefish, northern squawfish, large scale suckers, bridge-lipped suckers, resident rainbow, bull char, brook trout, dace, various cottids, red-side shiner, bullhead catfish, small-mouthed bass, large-mouthed bass, longnosed dace, speckled dace, chiselmouth, Paciflc lamprey, and kokanee.

Common resident fish species in lifbby Reservoir include westslope cutthroat trout, bull char, resident rainbow, and kokanee.

Information is limited on the extent of biological impacis to resident fish associated with changes in seasonal draft of the reservoirs. Alternatives discussed in the DEIS indicate that under certain water conditions, it is likely that fish species (such as westslope cutthroat, bull char, and mountain whitefish at Hungry Horse and kokanee at Dworshak) may be affected by increased drawdowns. As the DEIS analys is shows, drawdowns large enough to merit attention for potential effects on resident fish were expected to occur only a small percentage of any year. None of the alternatives examined would adversely affect resident fish populations downstream of the dams.

Significant changes in the frequency of reservoir elevations during November tan be detrimental to fish growth and to fall spawners such as kokanee. Low run-off conditions produce the greatest change in reservoir elevations.

The NWPPC Fish and Wildlife Program addresses Libby, Hungry Horse, and Dworshak operational impacts on resident fish and provides for mitigating adverse impacts. For instance, the program calls for research at Hungry Horse on reservolr elevations and fluctuations caused by hydro power operations and related to fish population stability or changes. Operational changes at Dworshak to provide coollng or "fish flows" for the Snake River may affect. reservoir elevations. However, drawdowns are expected to fall within

acceptable levels. 


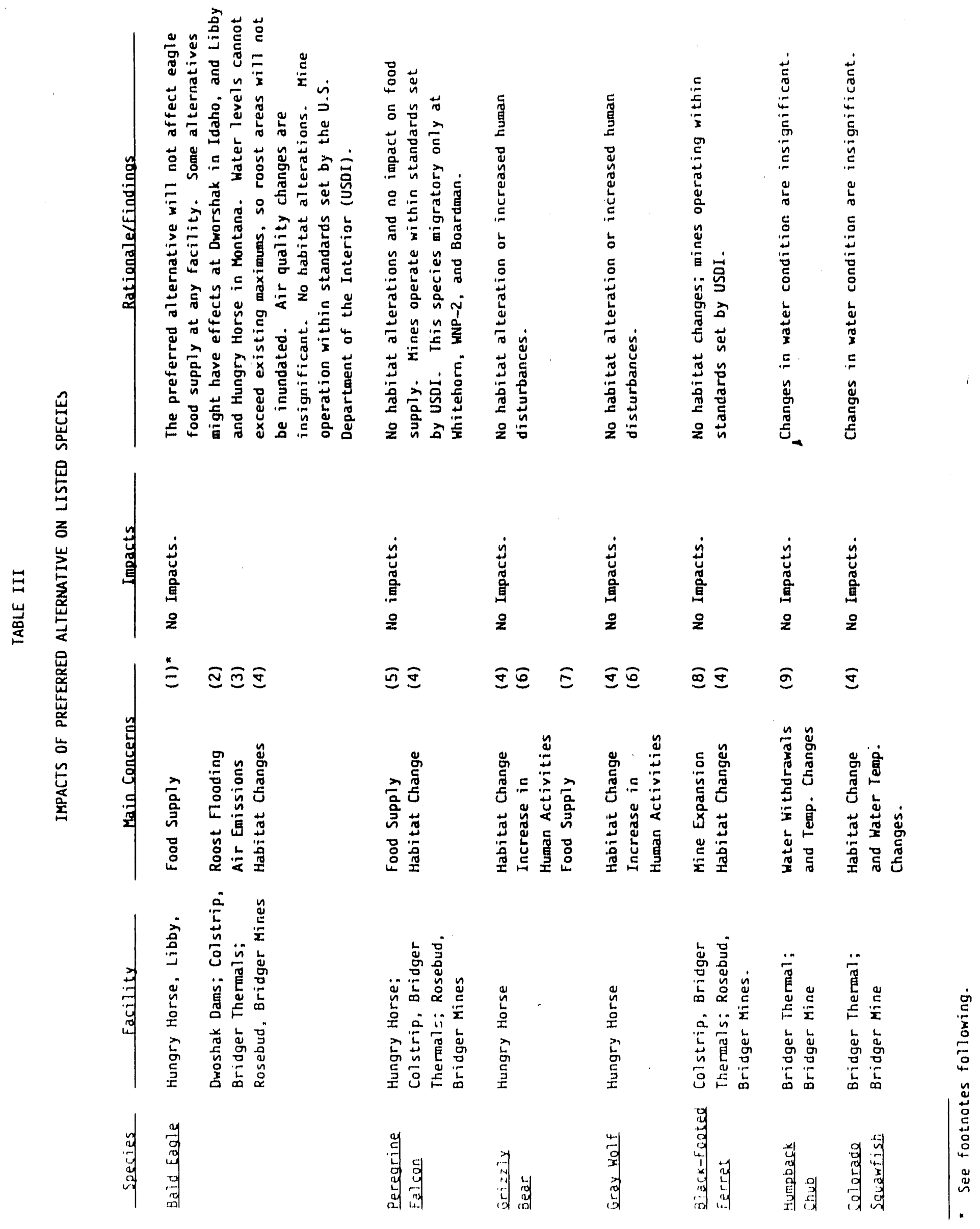


TABLE III (Continued)

FOOTNOTE DISCUSSION

(1) BALO EAGLE FOOD SUPPLY. Impacts on fish have been analyzed in depth for the EIS. The studies concluded that, although there are minor impacts on some anadromous fish stocks under some alternatives, the stocks are expected to increase due to in-place and planned mitigation. Restdent ish are not expected to be affected under the preferred alternative,

AIR QUALITY. Air pollution is a concern for several spectes tr several areas. Impact could occur directly on the spectes ttself, as well as on potentlal habttat or prey spectes. projected changes in amblent alr quallty show mintmal increases and decreases in pollutants. depending upon the alternative. All are Judged to be negligible and insigntficant.

(4) HABITAT CHANGES. No changes in habltat w111 occur for this action. No construction will occur, and operational changes, if any, are within design and license parameters.

(5) F000 SUPPLY. No impacts are expected on any prey spectes (small birds and waterfowl) used by the peregrine falcon. No changes in habltat (See No, above) for either peregrine or their prey spectes w111 occur.

(6) INCREASE IN HUMAN ACTIVITIES. Human disturbances will not increase as a result of any alternative covered by this EIs action. Factitties are in place and functioning. No construction is planned.

(7) GRIZZLY FOOO SUPPLY. Fish are an incidental part of the grizzly bear's diet at Hungry Horse (Erlcson 1987). Their food supply is otherwise unaffected.

(8) MTNES. Mine expansion was viewed as a potentlal problem, particularly in places near black-footed ferret habitat. All of the mines covered by this Assessment are on 1 ands administered by the Bureau of Land Management, and operating under a permit issued by the offlce of Surface Mining. Before these permits are issued, all applicable lawsi and regulations must be met, Including NEPA and the Threatened and Endangered Spectes Act. No action covered by the PSC-EIS would cause mine expansion directly. Should expansion occur in the future, environmental impacts would be addressed through the permit system, and all applicable laws and regulations.

(9) WATER WITHORAWALS. Withdrawals from the Green River for cooling the Bridger Thermal plant are silght and cannot be quantifled. No changes in mine operations are proposed. Therefore. no impacts due to increased water withdrawals are expected (see No. 7).

(VS6-PG-0011K) 
Bald Fagle

Bald eagles have been shown to be opportunistlc in their feeding hablts. Flelder and starkey (1980) have studied the bald eagle feeding habits within the Columbla Basin. These studies have shown that waterfowl make up

91 percent, and fish 7.7 percent of the winter food Items. During a 15-month study in that same general area (1980). Wood observed that bald eagles fed primarlly on fish; however, Wood dlso found prey remains of gulls, chukars, and mergansers. Fitzner et al. (1980), studylng wintering bald eagles on the Columbla River on the Hanford Nuclear Reservation, found no correlation between eagle numbers and salmon carcasses, but a signiflcant positive correlation for duck densittes and eagle denslties. Mcclelland et al. (1981) found a direct relationshlp between kokanee and bald eagle numbers at McDonald Creek in Glacier National Park. Bald eagles appear to be quite flexible in thelr feeding habits.

Studles have also shown that yearly and seasonal distribution and dispersal of eagles is tled to concentrated food supplies (Crenshaw 1987. Servheen 1975, Shea 1973, Stalmaster 1976). This accounts for their nomadic behaxior during the winter.

The bald eagle is a yearlong resident and migrant at Hungry Horse and Libby dams and an overwintering migrant at Dworshak. Analyses of drawdown frequencles and levels at these three projects does not indicate adverse impact on the bald eagle populations, except during low run-off perlods. Thls statement is based on the opportunistic feeding habits of eaglos, their adaptablilty and foraging behavior in relation to changing food supply; the potentlal for big game habltat improvement efforts along Hungry Horse Reservolr: the avallabllity of other food sources on tributaries to Libby and Dworshak dams; provisions in the NPPC Fish and Wlldilfe Program that provide for fishery mitigation when reservoir drawdowns due to power generation exceed specific elevations; and the commitment of BPA to manage the power generation system to avold conflict with the NPPC Fish and Wildilfe Program.

\section{CONCLUSION}

From evidence clted above, BPA has concluded that operations of the power generating facllities under the No Action Alternative, and under the element of Alternative 1.1 which BPA has selected as its preferred alternative, are not likely to adversely impact and threatened or endangered species in the project areas. 


\section{LITERATURE CITED}

CRENSHAW, J.G. 1987. Effects of the Cabinet Gorge Kokanee Hatchery on Wintering Bald Eagles in the Lower Clark Fork River and Lake Pend Orellle, Idaho. Final Report. Idaho Department of Fish and Game. Bonnevtlie Power Admin. Project 86-14.

FIELDER, PAUL C. and RONALD G. STARKEY. 1980. Wintering Bald Eagle Use Along the Upper Columbla River, Washington. IN Proc. Washington Bald Eagle Symp. June 14-15, 1980, Seattle (R. L. Knight et al., EDS).

FITZNER, RICHARD E., DONALD G. WATSON, and WILLIAM RICKARD. 1980. BaId Eagles of the Hanford National Environmental Research Park. IN Proc. Washington Bald Eagle Symp. June 14-15, 1980, Seattle (R. L. Knight et al., EDS).

MAY, B. and T. WEAVER. 1987. Quantification of Hungry Horse Reservolr Water Levels Needed to Maintain or Enhance Reservolr Fisheries. 1986 Annual Report. Montana Department of Fish, Wildlife, and Parks. Bonneville Power Admin. Project 83-465 (DOE.BP-12659-3).

MCCLELLAND, B.R., L.S. YOUNG, D.S. SHEA, P.T. MCCLELLAND, H.L. ALLEN, and E.B. SPOTTIGUE. 1981. The Bald Eagle Concentration in Glacier National Park, Montana; Origin, Growth, and Varlation in Numbers. Living Bird $20: 133-135$.

SERVHEEN, C.W. 1975. Ecology of the Wintering Bald Eagles on the Skagit River, Washington. M. S. Thesis, Univ. of Washington, Seattle. $96 \mathrm{pp}$.

SHEA, D.S. 1973. A Management Oriented Study of Bald Eagle Concentrations in Glacier National Park. M. S. Thesis, Univ. of Montana, Missoula. $78 \mathrm{pp}$.

STALMASTER, M.V. 1976. Winter Ecology and Effects of Human Activity on Bald Eagles in the Nooksack River Valley, Washington. M. S. Thesis, Western Washington State College, Bellingham, Washington. 100 pp.

U.S. DEPARTMENT OF ENERGY. Bonneville Power Administration. 1990. Initial Northwest Power Act Power Sales Contracts. Draft Environmental Impact Statement. DOE/EIS-0131.

U.S. DEPARTMENT OF ENERGY. Bonneville Power Administration. 1991. Initial Northwest Power Act Power Sales Contracts. Preliminary Final

Environmental Impact Statement (in preparation).

WOOD, BRAD. 1980. Winter Ecology of Bald Eagles at Grand Coulee Dam, Washington. IN Proc. Washington Bald Eagle Symp. June 14-15, 1980, Seattle (R. L. Knight et al., EDS). 


\section{Department of Energy}

Bonneville Power Administration

P.O. Box 3621

Portland, Oregon 97208-3621

JUL \& 1999

In reply reter to $\quad P G$

Mr. Marvin L. Plenert

Regional Director

U.S. Fish and Wildlife Service,

Region 1

$911 \mathrm{NE}$. 11 th Avenue

Portland, OR 97232-4181

Dear $\mathrm{Mr}$. Plenert:

In complying with its responsibllities under the Endangered Species Act of 1973, as amended, Bonneville Power Administration (BPA) submits to the U.S. Fish and Wildlife Service (USFWS) the enclosed Blological Assessment of effects on threatened or endangered species for the Initial Northwest Power Act Power Sales Contracts EIS (PSC EIS). Though the proposed action addressed by this EIS does not involve any major construction project and therefore, under 50 CFR $\$ 402.12(b)$, does not require a formal Biological Assessment, BPA has prepared the enclosed assessment to assist USFWS in its consideration of the potential effects of BPA's contracts on threatened or endangered species. This assessment addresses the threatened and endangered species listed in the letters from USFWS field offices received in response to BPA requests in July 1989 and March 1991. For your information, and in support of the analysis in the Blological Assessment, we have also enclosed copies of appendices to the EIS which discuss the impacts of generating resources on fish and wildilfe.

Because the subject power sales contracts are BPA's contracts for requirements service to its Pacific Northwest customers, portions of the EIS analysis address the operations of 36 hydro and thermal electric generating resources which supply the power which serves these customer loads. The effects of BPA's power sales contracts on these resources are indirect, because resource operations must conform to the requirements imposed on resource operators for both power and nonpower purposes. If additional constraints 1 imited the ability of these resources to meet customer electrical loads, the existence of BPA's contractual obligations could not compel operations which compromised the constraints; instead BPA would be required to meet its obligations from other resources through either purchases or development of new energy resources. The effects of the development of new energy resources would be subject to independent assessment. 
Other Federal decisloninaking processes currently underway will also address the operation of some or all of the existing resources and may result in actions that alter resource operation or development. These Include:

1. Proposed listings by the National Marine Fisherles Service of certain Snake River salmon specles as threatened or endangered specles under the Endangered Specles Act, with related discussions between agencles concerning appropriate actions to protect candidate species;

2. The System Operation Review process and assoclated EIS, under which BPA, the U.S. Army Corps of Engineers and the U.S. Bureau of Reclamation wlll analyze the operation of dams on the Culumbla River and its major tributarles:

3. The 1992 Columbla River Salmon Flow Measures EIS and Options Analysis, under preparation by the U.S. Army Corps of Englneers, which wlll address adjustments in Snake River flows to enhance the survival of salmon species proposed for listing: and

4. BPA's 1992 Resource Program and assoclated EIS, under which BPA will analyze the development of new conservation and generating resources.

BPA's Preferred Alternative is the element of Alternative 1.1 which requtres compliance with the Northwest Power Planning Councll's Protected Areas Rule. With respect to the operation of the generating plants addressed in the EIS, this alternative is the same as the No Action Alternative, that is, no change in operations from current practice. BPA will implement the Preferred Alternative through the development of a Protected Areas policy. This policy will be developed through a public process which will begin shortly after the completion of the Record of Decision on the PSC EIS. The effect of the policy will be to discourage developmerit of new hydroelectric projects within Protected Areas, and thus it will not result in adverse impacts on listed speries.

We have concluded that the operation of electric power facilities to meet BPA requirements obligations under the power sales contracts is not likely to adversely affect any federally listed threatened or endangered species under thls preferred Alternative. 
We would appreclate a written response to this assessment consistent with the time limits of 50 CFR $\$ 402.12(j)$. Thank you for your attention to this matter. If you should have any questions, please contact me at (503) 230-5145.

Sincerely,

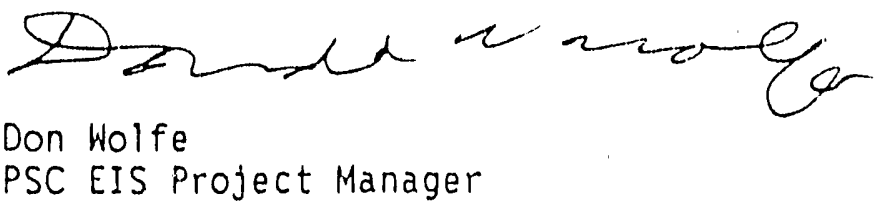

3 Enclosures:

Biological Assessment

PSC EIS Appendix. $H(l)(a)$ - Background on Fish, Wildlife and Vegetation Effects Due to Hydro Operations

PSC EIS Appendix $H(1)(b)$ - Background on Fish, Wildlife and Vegetation Effects Due to Fossil Fuel Fired Plant Operations

CC:

Mr. Russell Peterson, USFWS, Portland Field Station

Mr. Dale R. Harms, USFWS, Helena Field Station

Mr. Wayne S. White, USFWS, Sacramento Field Office

Mr. Ron Starkey, USFWS, Salt Lake City Fleld Station

Ms. Nancy J. Gloman, USFWS, Olympla Field Station

Mr. Charles H. Lobdell, USFWS, Boise Field Station

Mr. David L. Harlow, USFWS, Reno Field Station

Mr. Recd Harris, IISFWS, Cheyenne Field Station 


\section{United States Department of the Interior FISH AND WILDLIFE SERVICE}

911 N.E. 11 th Avenue

Portland, Oregon 97232-4181

OCl 91991

Mr. Don Wolfe

PSC EIS Project Manager

Bonneville Power Administration

P.O. Box 3621

Portland, Oregon 97208

Dear Mr. Wolfe:

This responds to your July 31, 1991, letter requesting U.S. Fish and Wildlife Service concurrence with your determination that the Initial Northwest Power Act Power Sales Contracts are not likely to adversely affect the bald eagle (Haliaeetus leucocephalus), peregrine falcon (Falco peregrinus), grizzly bear (Ursus arctos horribilis), gray wolf (Canis lupus), and the black-footed ferret (Mustela nigripes). We have reviewed the biological assessment prepared by your agency on this proposed action and concur with your "not likely to adversely affect" determination. In accordance with 50 CFR § 402.13, consultation pursuant to section 7 of the Endangered Species Act of 1973, as amended, is hereby terminated and no further action under this authority is necessary.

If you have any questions, contact Richard Hill or Ronel Finley at FTS 429 6150 .

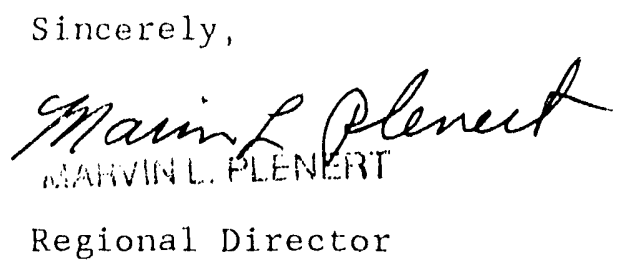




\section{Department of Energy}

Bonneville Power Administration

P.O. Box 3621

Portland, Oregon 97208-3621

MAR 201991

Inteply reter to

$P G$

Dear :

Subject: Request for Updated List of Endangered and Threatened Spectes in the Bonneville Power Administration (BPA) Service Area, for Inclusion in the Long-Term Power Sales contracts Environmental Impact Statement (EIS)

In August 1981, BPA offered its customers new long-term contracts under the Pacific Northwest Electric Power Planning and Conservation Act. As a result of the decision of the Ninth Circuit of the United States Court of Appeals in the case of Forelaws on Board V. Johnson, 743 F.2d 677 (1984), BPA is now preparing a Final EIS on these long-term contracts. Two basic types of alternatives are analyzed: (1) the no-action alternative, in which BPA would preserve the Long-Term Power Sales Contracts without change; or (2) alternatives in which BPA would pursue contract modifications (see enclosed EIS summary for additional details).

The analysis covers the effects of operation of power facilities within the affected area. It also identifies quantities and types of resources that might be needed to meet future firm power loads. The EIS includes a generic discussion of impacts associated with these resources.

These long-term contracts are with customers located throughout BPA's service area, which covers the States of Washington, Oregon, and Idaho; the portion of Montana west of the Continental Divide; and small portions of Wyoming, Utah, Nevada, and northern California. Our study area also includes areas in Montana, Nevada, and Wyoming surrounding coal plants that serve the Pacific Northwest (see enclosed area description and location maps). The affected facilities within i ese states are identified by name, location, and energy source on the enclosud list. 
In compliance with section $7(c)$ of the amended Endangered Species Act, BPA is requesting a list of endangered and threatened species that may occur in the area of any of these facilities; and any information on these species that might be avallable, such as locations and how they might be affected. BPA previously requested such a list, during preparation of the Draft EIS, by a letter dated July 19, 1989. We are now requesting an updated list for

inclusion in the Final EIS.

If possible, we would appreciate having any information you may obtain by April 30, 1991, so that we can include it in our Final EIS. If you need aduitional information, or if I can assist in any other way, please contact me at (503) $230-5145$ or FTS $429-5145$.

$$
\text { Sincerely, }
$$

Donald V. Wolfe

Project Manager

Power Sales Contract FEIS

2 Enclosures:

EIS Summary

List of Pacific Northwest Generating Facilities

DWolfe:md:5145 (VS6-PG-9815K)

bcc:

Official File (PG EQ-14-2) 


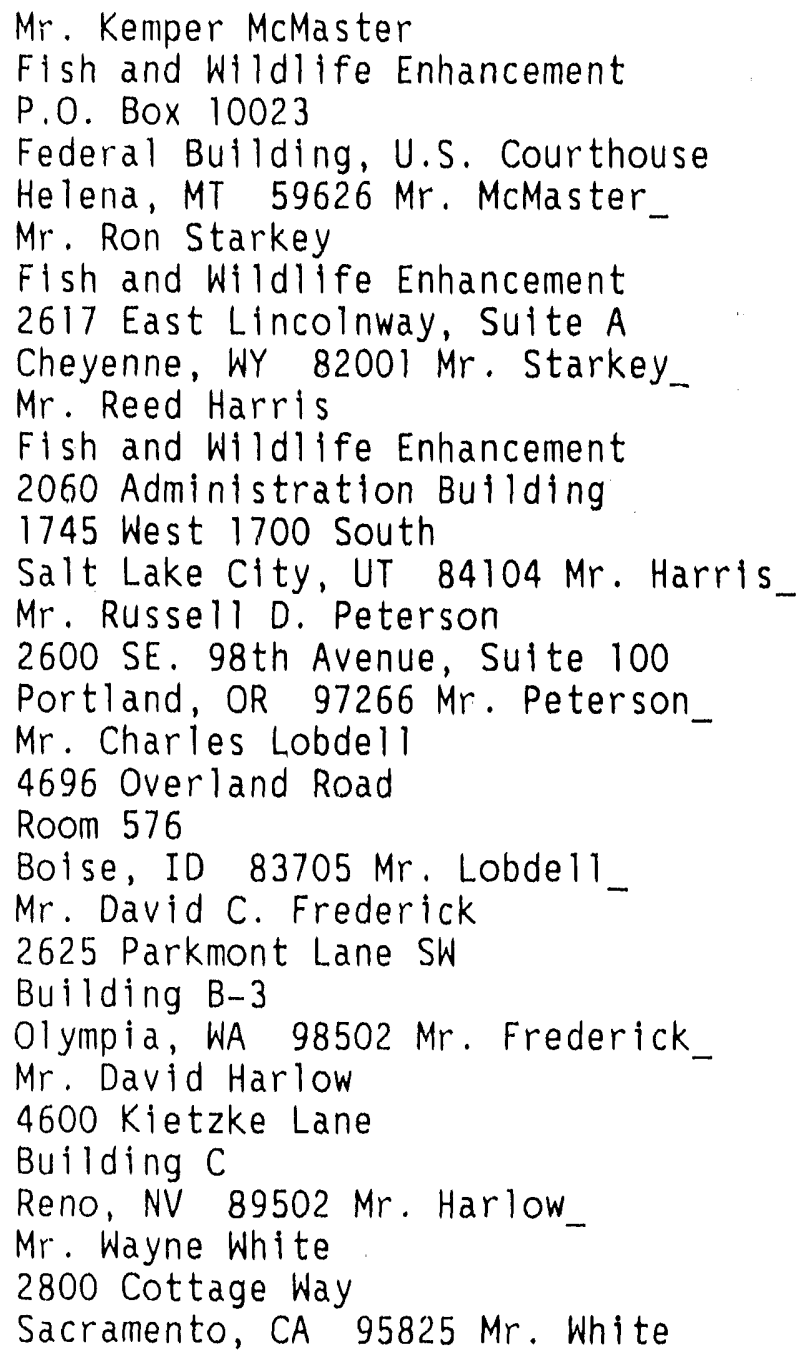




\title{
United States Department of the Interior
}

\author{
FISH AND WILDLIFE SERVICE \\ Boise Field Station \\ 4696 Overland Road, Room 576 \\ Boise, Idaho 83705
}

Apri1 9, 1991

Donald V. Wolfe

Project Manager

Department of Energy

Bonneville Power Administration

P.0. Box 3621

Portland, Oregon 97208-3621

Re: Long-Term Power Sales (EIS)

(SE File: 6003.0230)

Dear Mr. Wolfe:

As requested by your letter dated March 20, 1991 and received by this office on March 22, we have attached a list (Attachment $A$ ) of endangered and threatened, proposed, and/or candidate species that may be present in the proposed project area. The list fulfills the requirements of the U.S. Fish and Wildlife Service (Service) under Section 7 (c) of the Endangered Species Act of 1973, as amended (Act). The requirements for Federal agency compliance under the Act are outlined in Attachment B. Please reference the species list number on Attachment $A$ in all subsequent correspondence, reports, environmental assessments, environmental impact statements, biological assessments (evaluations), Coordination Act reports, etc. If a construction project is not commenced within 180 days of this response, a subsequent species list request is required by regulations.

If a listed species appears on Attachment A, a biological assessment (evaluation) is required. Should your biological assessment (evaluation) determine that a listed species is likely to be affected adversely by the project, the Bonneville Power Administration should request formal section 7 consultation through this office. If a proposed species is likely to be jeopardized by a Federal action, regulations require a conference between the Federal agency and the Service.

Candidate species that appear on Attachment A have no protection under the Act, but are included for early planning consideration. Proposed species could be formally listed and candidate species could be formally proposed and listed during project planning, thereby falling within the scope of Section 7 of the Endangered Species Act. Therefore, if they appear on Attachment A, we recommend that additional surveys be made for proposed and/or candidate species that are likely to be in your project area. If the project is likely to adversely impact a candidate species, informal consultation with this office is recommended. 
If you have any questions regarding Federal consultation responsibilities under the Act, please contact Jeri Williams of this office at FTS 554-1931 or $208-334-1931$.

Thank you for your continued interest in the Endangered Species Program.

$$
\text { Sincerely, }
$$

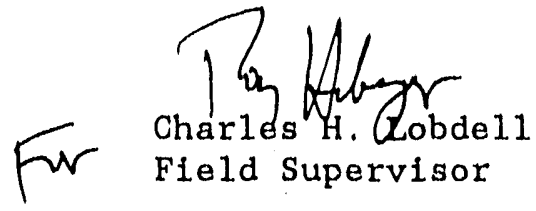

. Enclosures

cc: IDFG, Hdqtrs., Boise

IDFG, Region 1, Coeur d'Alene 
LISTED AND PROPOSED ENDANGERED AND THREATENED SPECIES, AND CANDIDATE SPECIES, THAT MAY OCCUR WITHIN THE AREA OF THE LONG-TERM POWER SALES PROJECT FWS $-1-4-91-\mathrm{SP}-482$

LISTED SPECIES

\section{Albeni Falls Faclitty}

Priest River, Bonner County

None

Dworshak Facility

Clearwater River, Clearwater County

Bald Eagle

(Haliaeetus leucocephalus)
COMMENTS

Wintering Area

\section{PROPOSED SPECIES}

None

CANDIDATE SPECIES

None 


\title{
United States Department of the Interior
}

\author{
VISH AND WILDLIFE SERVICE \\ Flsh and WLidifa Enhancomant: \\ 3704 Griflin lana SE, Sulto 102 \\ Olympla, washington 98501. \\ $206 / 753.9440$ Fit's 434.9440
}

Apt11 18, 1.991

Mr. Donald V, Wolfe

FWS Rafaranca

Profect Manager

$1-3-91-S P-272$

Department of Energy

Bornovilla Pover Admintatration

P.O. Box 3621 .

Portland, Oregon 97208-3621

Dear Mr. Wolfe:

As requested by your letter, dated March 20, 1991, and recelved in this office on March 21, enclosed is a 11 st of endangered and threatened spectes that may be present in the area of the proposed hydroelectric, thermal, nuclear, and combustion turbine generating facilities and coal mines of the pacific Northwest Power System in Washington State. The list fulfilis the refulrement of the Fish and Wildiffe Service under Section 7 (c) of the Endangared Species Act of 1973, as amended. Enclosed are the requiroments for Bonneville power Administration compliance under the Act.

Should the blological assessment determine that a listed spectes is 11kely to be affected (adversely or beneficially) by the profoct, the Bonnevillo Power Administration should request formal Section 7 consultation through this office. Even if the blologlcal assessment shows a "no effect" situation, wo would appreciate receiving a copy for our information,

Also included is a list of candidate species presently under review by this Service for consideration as endangered or threatened. Candidate species are inc lucled simply as citrance notice to fedelal agincios of spectos which may be proposed and listed in the future. However, protection provided to candidate species now may preclude possible listing in the future. If early evaluation of your profect indicates that it is likely to adversely impact a candidate species, you may wish to request technical assistance from this offico. 
Tho sockoya salmon (Onoorhynohus norka) has boan proposad to bo 1 latad as

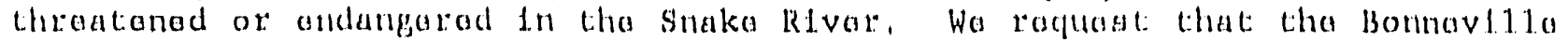

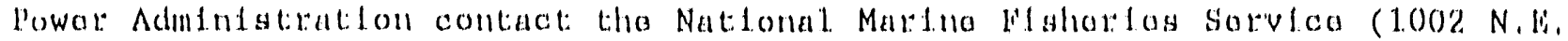
Holdaday stroat, Room 620, Portiand, Oragon 9723\%, Phond Fin's 429-5/35) lor:

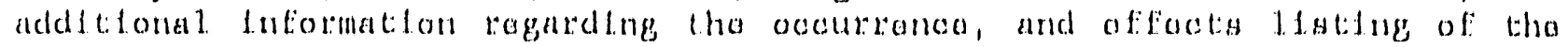

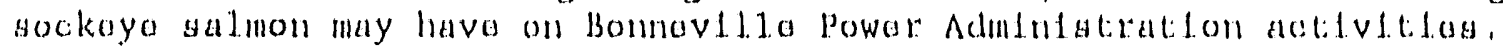

Your Intorast in andangarad spacias ta approciatad. If you havo add tional.

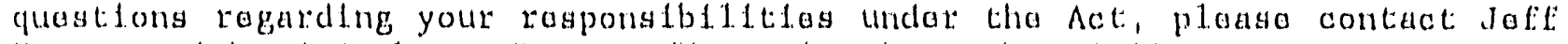

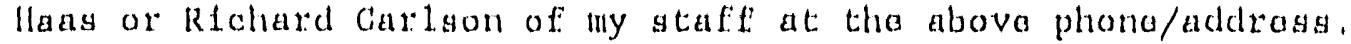

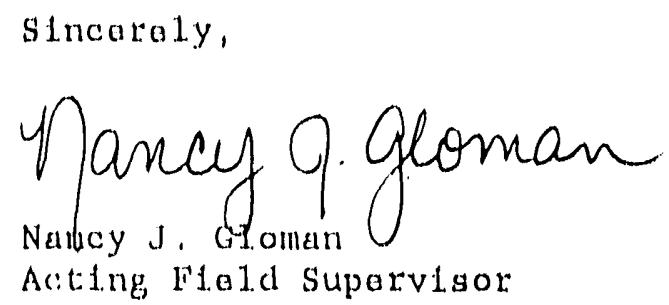

$r c / k r$

Enclosures

c: FWS-FWE, Boise (Parent1)

WDW, Olympla (Nongana)

WNHP, Olympla 
LIS'LED AND PROPOSLD LNDANGERED AND IHIREA'TENED SPECIES AND CANDIDA'TE SPECIES 'I'IA'T MAY OCCUR WITIIIN 'IHE AREA OF THE PROPOSED HYDROELEC'TRIC, THERMAL, NUCLEAR, AND COMBUS'TION GENEIRA'TING FACILI'TES AND COAL MINES OF 'IHE PACLITC NORTHWES'P POWH SYSTEM IN MUL'IIPLE COUN'L'ILS OF 'LHE S'TA'TE OF' WASHTNCTO?

$$
1-3-91-s p-30 s
$$

PACIFIC NOR'LHWS'T HYDROELECTRIG GENERATING F'ACILITIES

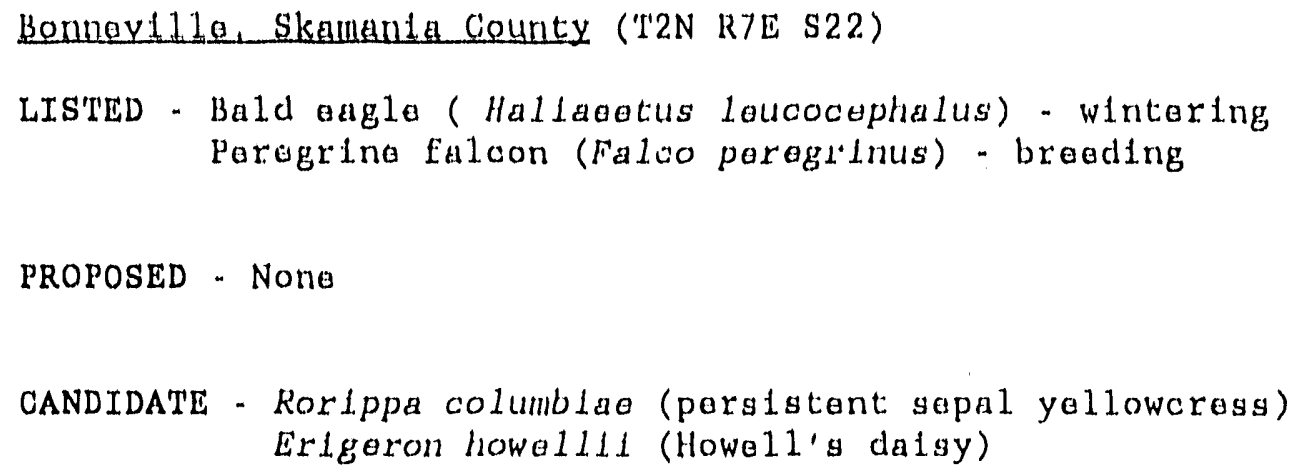

The Dallos, K1.10k1tat County ('T2N R13E S35)

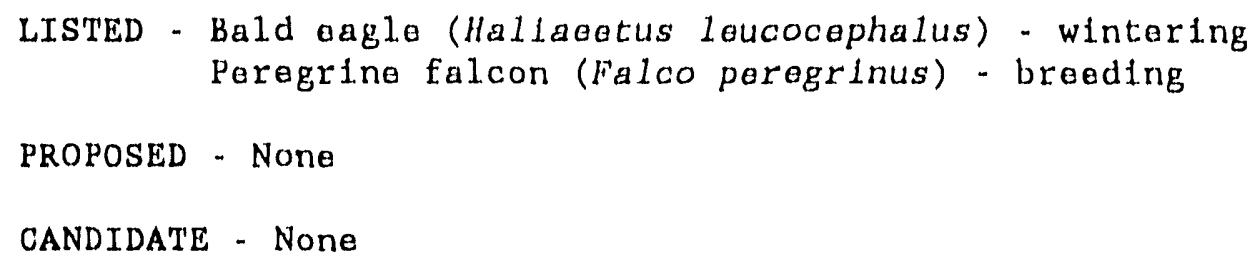




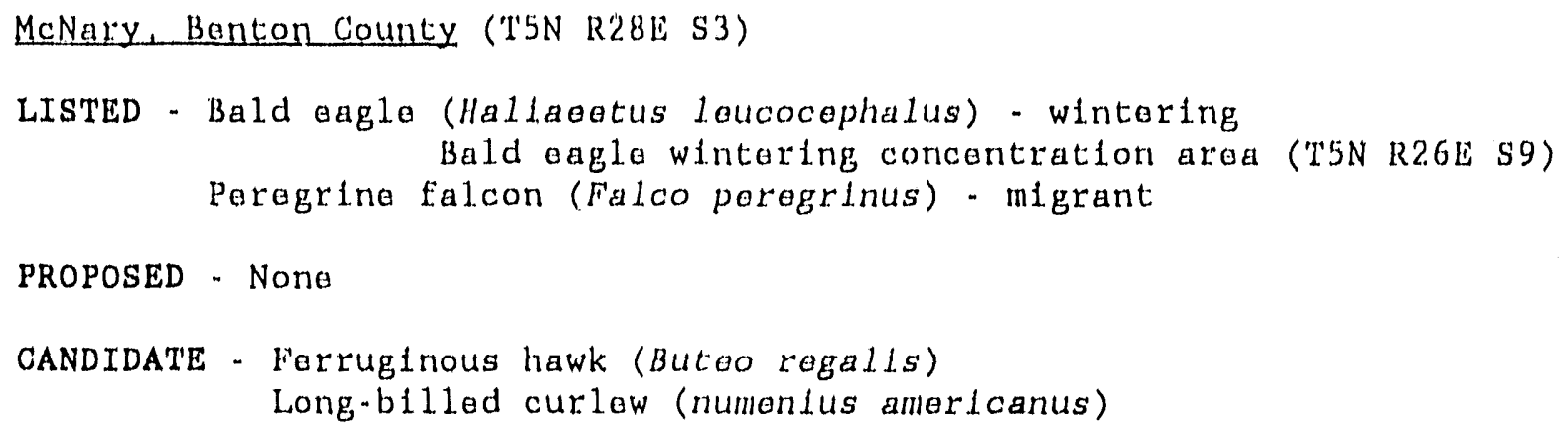


Rocky Beach, Chelan County (T24N R20E S35)

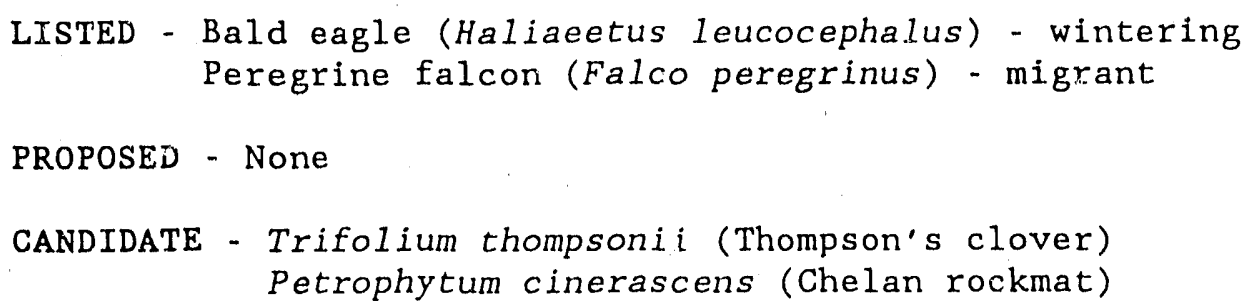

Wells, Douglas County (T28N R24E S6)

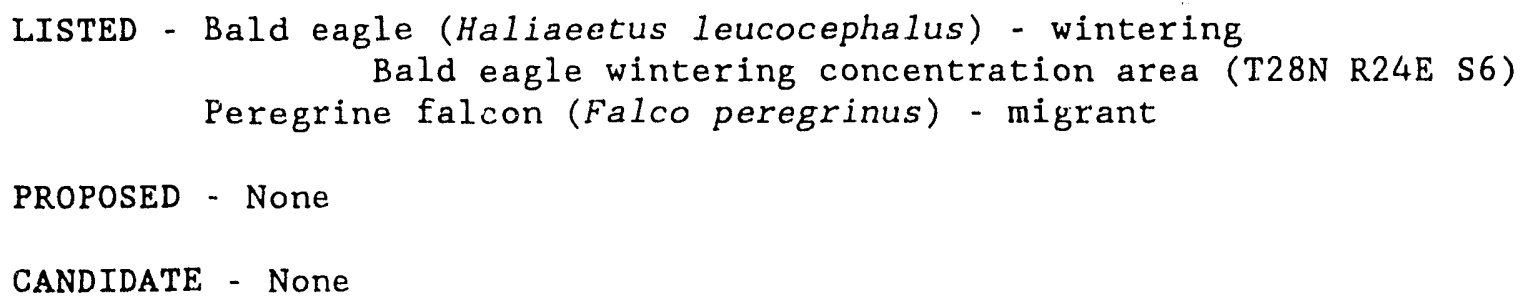


Lower Monumental. Walla Walla County (T13N R34E S34)

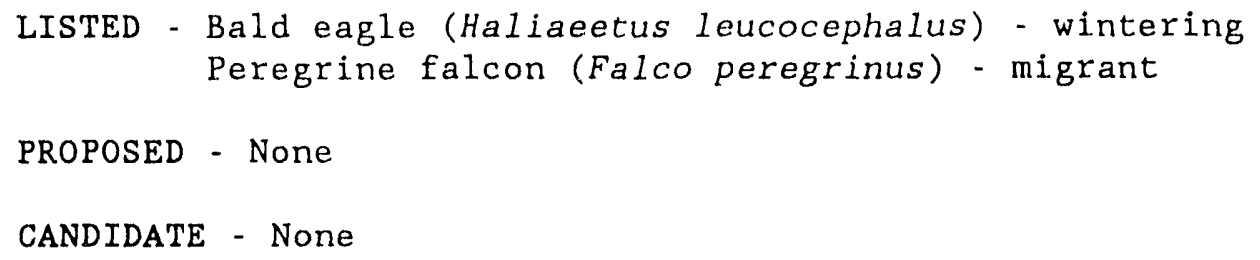


Centralia, Lewis County (T15N RiW S30)

LISTED - Bald eagle (Haliaeetus leucocephalus) - wintering

PROPOSED - None

CANDIDATE - None

PACIFIC NORTHWEST NUCLEAR GENERATING FACILITY

WNP-1, Benton County (T11N R28E S5)

LISTED - Bald eagle (Haliaeetus leucocephalus) - wintering Peregrine falcon (Falco peregrinus) - migrant

PROPOSED - None

CANDIDATE - Ferruginous hawk (Buteo regalis) - nesting may occur in the area of the project

WNP-3, Grays Harbor County (T17N R6W S18)

IISTED - Bald eagle (Haliaeetus leucocephalus) - wintering

There are 3 bald eagle nesting territories near the project (T17N R6W S12; T17N R7W S7; T17N R7W S10)

PROPOSED - None

CANDIDATE - Olympic mudminnow (Novumbra hubbsi) 
PACIFIC NORTHWEST COMBUSTION TURBINE GENERATING FACILITIES

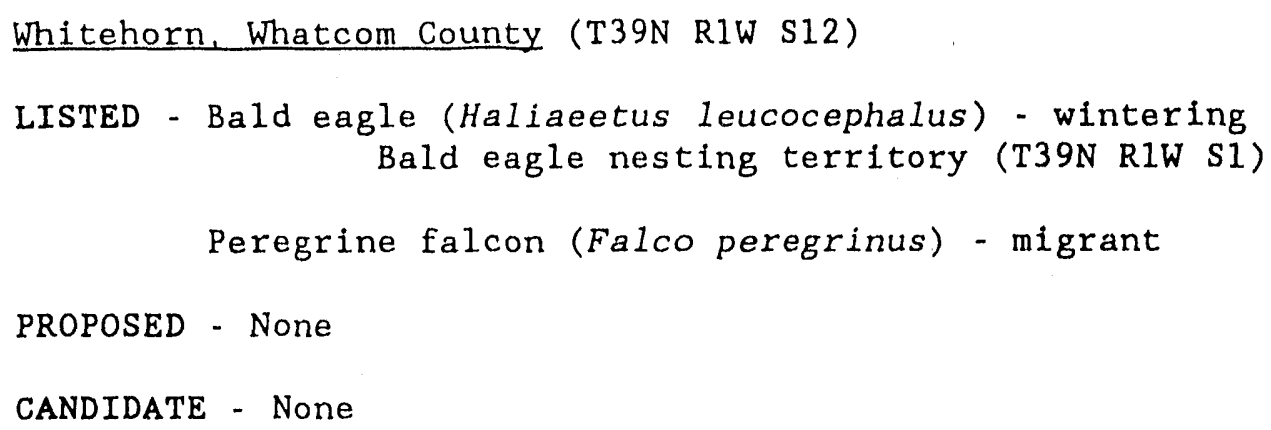

PACIFIC NORTHWEST COAL MINES

Centralia, Lewis County (T15N R1W S30)

LISTED - Bald eagle (Haliaeetus leucocephalus) - wintering PROPOSED - None

CANDIDATE - None

$$
1-33
$$


Note: Wintering bald eagle activity occurs from about October 31 through March 31. Nesting activities occur from about January 1 through August 15 .

Major concerns that should be addressed in your biological assessment of project impacts to bald eagles and peregrine falcons are:

1. Level of use of the project area by bald eagles and peregrine falcons.

2. Effect of the project on the eagle's and falcon's primary food stocks and foraging areas in all areas influenced by the project.

3. Impacts from project activities (i.e., incleased human activity, loss or degradation of habitat, increased noise levels) which may result in disturbance to bald eagles and falcons and/or their avoidance of the project area. 


\section{FEDERAL AGENCIES' RESPONSIBILITIES UNDER SECTIONS 7(a) AND 7(c) \\ OE THE EMDANGERED SFECIES ACT}

\section{SECTION 7(A) - Consultation/Conference}

Requires: 1. Federal agencies to utilize their authorities to carry out programs to conserve endangered and threatened species;

2. Consultation with FWS when a federal action may affect a listed endangered or threatened species to ensure that any action authorized, funded, or carried out by a federal agency is not likely to jeopardize the continued existence of listed species or result in the destruction or adverse modification of critical habitat. The process is initiated by the federal agency after it has determined if its action may affect (ad?ersely or beneficially) a listed species; and

3. Conference with FWS when a federal action is likely to jeopardize the continued existerce of a proposed species ar resile in destruction or an adverse modification of proposed critical habitat.

SECTION 7(c) - Biological Assessment for Construction Projects *

Requires federal agencies or their designees to prepare a Biological Assessment (BA) for construction projects only. The purpose of the BA is to identify any proposed and/or listed species which is/are likely to be affected by a construction project. The process is initiated by a federal agency in requesting a list of proposed and listed threatened and endangered species (1ist attached). The BA should be completed within 180 days after its initiation (or within such a time period as is mutually agreeable). If the BA is not initiated within 90 days of receipt of the species list, please verify the accuracy of the list with our Service. No irreversible commitment of resources is to be made during the BA process which would result in violation of the requirements under Section $7(a)$ of the Act. Planning, design, and administrative actions may be taken; however, no construction may begin.

To complete the BA, your agency or 1ts designee should: (1) conduct an onsite inspection of the area to be affected by the proposal, which may include a detailed surrey of the area to determine if the species is present and whether suitable habitat exists for either expanding the existing population or potential reintroduction of the species; (2) revien literature and scientific data to determine species distribution, habitat needs, and other biological. requirements; (3) interriew experts including those within the FWS, National Marine Fisheries Serrice, state conservation department, universities, and others who may hare data not yet published in scientific literature; (4) review and analyze the effects of the proposal on the species in terms of individuals and populations, including consideration of cumulative effects of the proposal on the species and its habitat; (5) analyze alternative actions that may provide conseryation measures; and (6) prepare a report documenting the results, including a discussion of study methods used, any problems encountered, and other relevant information. Upon completion the report should be forwarded to our Endangered Species Dirision, 2625 Parknont Lane SW, Bldg. B, Olympia, wit 98502 .

* "Construction project" means any major federal action which significantly affects the qualiz; of the hum environent (reguiring an EIS), desigred primarily to resule in the buiding or erection of human-made structures such a) dans, building, rords, pipelines, chanels, and the like This includes

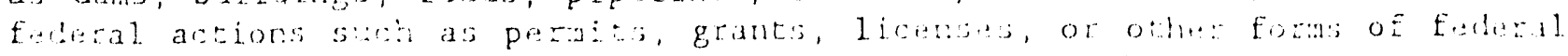

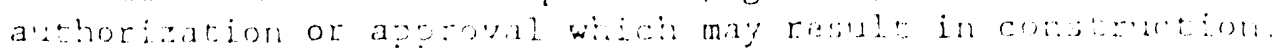




\title{
United States Department of the Interior
}

\author{
FISH AND WILDLIFE SERVICE \\ Portland Field Station \\ 2600 S.E. 98th Avenue, Suite 100 \\ Portland, Oregon 97266
}

May 7, 1991

Re: $1-7-91-S P-307$

Donald V. Wolfe

Department of Energy

Bonneville Power Administration

P.0. Box 3621

portland, Oregon 97208-3621

Dear Mr, Wolfe:

This regards your letter dated March 20, 1991, which was received by us on March 21, 1991, requesting an updated list of threatened and endangered species. A list of threatened and endangered species was provided to your agency on August 8, 1989 (Case No. 1-7-89-SP-131). You may consider this an addendum to the August 8 letter.

We have reviewed the earlier August 8,1989 , list against current information. Since this list was provided to you, the northern spotted owl was listed as threatened on June 26, 1990. Except for the change in status of the northern spotted owl, all other information on the August 8, 1989, list is still current for species under Fish and Wildlife Service jurisdiction.

Additional information regarding proposed and petitioned species for listing under the Endangered Species Act of 1973, as amended is available from the National. Marine Fisheries Service, We would advise you to contact the National Marine Fishereies Service for a list of currently listed, proposed, and petitioned threatened and endangered species.
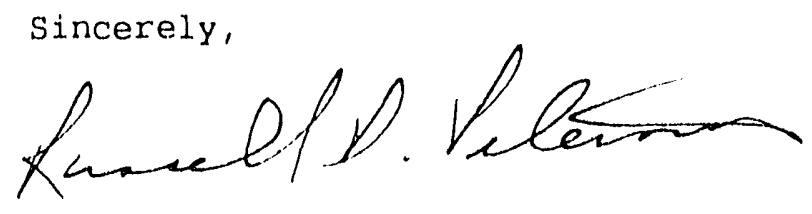

Russell D. Peterson

Field Supervisor

Attachment: August 8, $1989,1-7-89-5 P-131$

$\mathrm{DH} / \mathrm{JC} / 91 \mathrm{SP} 307$

CC: NMFS; Attn: Rob Jones

ONHP

ODFW (Nongame) 


\title{
United States Department of the Interior
}

\author{
FISH AND WILDLIFE SERVICE \\ Portland Field office \\ 727 NE 24th Avenue \\ Portland, OR 97232
}

August 8,1989

$1-7-89-S P-131$

Nandranie $S$. Tuck

Bonneville Power Administration

P.O. Box 3621

Portland, Oregon 97208-3621

Dear Nis. Tuck:

As requested by your letter dated July 19, 1989 and received by us on july 26, 1989, we have reexamined the list prepared for the Intertie Deveiopment and Use EIS. The Information presented for Bonneville, The Dalles, John Day and McNary still accurrately reflects known threatened, endangered and candidate species resources in the vicinity of the aforenamed oregon hydro facilities. However, since the project area being considered in the proposed Bonneville Power Administration Long-term Power Sales Contracts Environmental Impact Statement (EIS) is more extensive, we have attached a list of endangered and threatened species that may be present in the service area covered by your sales contract EIS. The list fulfills the requirement of the Fish and Wildlife Service under Section $7(\mathrm{c})$ of the Endangered Species Act of 1973, as amended ( 16 USC 1531 et. seq.). Bonneville Power Administration's requirements under the Act are outlined in Attachment $B$.

Should your biological assessment determine that a listed species is likely to be adversely affected by the project, Bonneville Power Administration should request formal section 7 consultation through this office. Even if your biological assessment shows a "no effect" or "beneficial effect" sjtuation, we would appreciate receiving a copy for our information.

Your interest in endangered species is appreciated. If you have any additional guestions regarding your responsibilities under the Act, please call Diana Hwang at our office, phone (503) 231-6179 or ETS 429-6179. All correspondence should include the above referenced case number.

Sincerely,

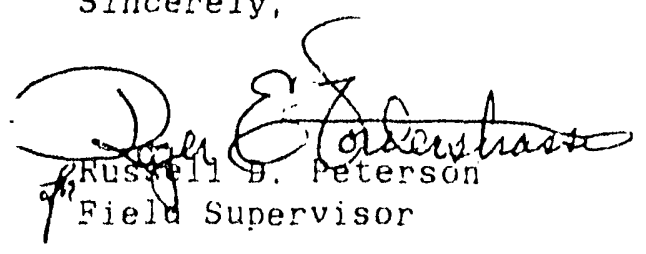


Attachment

Cc: RI FWE-SE

PFO-ES

ODFW (Nongame)

ONHP 
LISTED AND PROPOSED ENDANOERED AND THREATENED SPECIES

THA'I MAY OCCUR IN THE AREA OF THE PROPOSED

SERVICE AREAS-OPERATING PUBLIC AGENCIES AND COOPERATIVES

(DOE/BPA MAP DATED MAY 1987)

$1-7-89-S P-131$

LIS'MED SPECIES I/

Mammais

Columbian white tailed Deer Odocolleus virginianus leucurus

(E)

Columbian white-talled deer occur along the Lower Columbia River in

Clatsop (OR), Columbla (OR), and Wahkiakum (WA) Counties and in Douglas

County (OR).

BIrds

Peregrine Falcon

Falco peregrinus

(E) (CH in

Calif)

Peregrine falcons may occur throughout the state as fall and spring migrants and may overwinter in Oregon. Reintroduotion efforts are occurring along the Columbla River, Helis Canyon, Crater Lake and Lake County areas. Nesting peregrines occur in Dougias, Curry, Tillamook, Jackson, and Klamath County.

Bald Eagle Hallaeetus leucocephalus

Wintering and nesting bald eagles occur throughout the state. Nestiug concentrations occur around Upper Klamath Lake in Klamath County, around the lakes of Deschutes National Forest in Deschutes and Klamath Counties, along the Lower Columbia Rlver, and along the Umpqua River in Douglas County. Additional nesting territories are located througnout the state in the vicinity of majur water bodies, rivers, estuarjes, reservoirs, and lakes. Wintering concentrations occur in Klamath County and the Lower Columbia River. Wintering eagles may also occur along other major water bodies, reservoirs, and rivers such as the Harney Basin, Crooked River and Grancie Ronde Rivers in Oregon from October 31 to March 31. Nesting eagles may occur in Oregon from January 1 to August 31 .

Ejsin

Hutton Snring tuj Chub Gila bicolor ssp.

species is restricted to two springs along Alkaij Lake in iake County.

Foskett spring speckled Dace Rhinichthvs osculus ssp.

Species occurs in a small Coleman Valley spring in southern iake County.

Warner sucker Catoctomus warnerensis

Species occurs in Warner Valley in iake county. (Listed sept. 28, 1985)

Borax Lake Chub Gila boraxobius

Species occurs in Borax Lake in Harney County.

(E) $(\mathrm{CH})$

Invertebrates

Oregon Silverspot Butterfly speyeria zerene hippolyta

('T) (CH) 
Disfunot populations ocour at Mt. Hebo and along the orogon ooast in

Clatsop, Tllamook, and Lane Counties.

\section{plants}
MacFarlane's Four o'clook
Mitrabilis macfarlanel
(E)
[Four o'clook famdly]
Wallow County: T3N R5OE S25, T2N R48E S17
Malheur Wilre-lettuce Stephanomerla malheurensis
[Aster famlly] Harney County: T27S R30E S12
Bradshaw's lomatium Lomatium bradshawil
(E)
Species ocours in the violndty of Furn Ridge Reservolr, Cottage Grove and
Eugene in Lane County; Wlllumette Floodplain RNA and Finley NWR in
Benton County; Basket Slough NWR in Polk County, and west Salem in
Marion County.

PROPOSED SPECIES ?/

Northern spotted ow

Strlx occldentalis caurina

Species occurs from southwestern British Columbla through

western Washington, western Oregon, and the ooast range

area of northwestern Caldfornia south to San Franclsco

Bay.

(E) - Endangered

(T) - Threatened

(CH) - Crftical Habitat

(S) - Suspected

(D) - Documented

1/ U. S. Department of Interior, Fish and Wild7ife Service, Jan 1989, Endangerad and

2) Threatened Wild life and Plants, 50 CFR 17.11 and 17,12.

2/ Federalkegister VoT.54, No. 120, June 23, 1989 Proposed Rule-Northern Spotted Ow? 


\section{United States Department of the Interior \\ FISH AND WILDLIFE SERVICE \\ FISH AND WILDLIFE ENHANCEMENT \\ RENO FIILD STATION \\ 4600 Kletzke Lane, Bullding C-125 \\ Reno, Nevada 89502-5093}

May 22, 1991

File No. $11-5-91-8 P-98$

Mr. Donald V. Wolfe

Project Manager

Department of Energy

P.O. Box 3621

portland, Oregon 97208-3621

Dear Mr. Wolfe:

Subject: Specieg Llat for the Bonneville Power Adminlatration Service Area

This 1s in reply to your letter of March 20, 1991, requesting a liat of 11 ated and proposed endangered and threatened species that may occur within the area of the subject profect. We have revlewed the most recent information and to the best of our knowledge there are no federally listed or proposed apecies or candidates for Federal liating within the area of the profect.

If you have further questions, please contact sherry Barrett or me at (702) 784-5227.

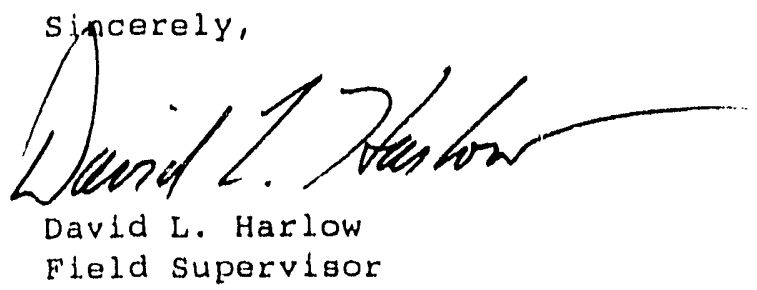




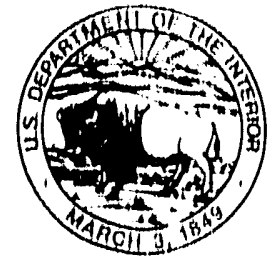

IN IIINAM Hillill Wh

\section{United States Department of the Interior}

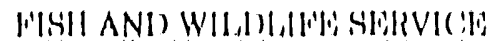

FISH AND WILDL.IFE BNIIANCLEMENT

FEDERAL. BUILIDING, US COURTHIOUSE:

301 S PARK

PO BOX 100?3

HELENA MT \$96??6

May 23, 1991

Donald V. Wolfe, Profect Manager

L.T. Power Sales Contract FEIS

Bonneville Power Admintstration

P.O. Box 3621

Portland, OR 9/208-3621

Dear Mr. Wolfe:

This responds to your March 20, 1991 request for an updated 1 ist of threatened and endangered species which may occur in the area of influence of Bonnevflle's proposed long-Term Power Sales Contracts. This letter will provide species information for the following facilities in Montana:

$$
\begin{aligned}
& \text { Hydroelectric: } \\
& \text { Libby } \\
& \text { Hungry Horse }
\end{aligned}
$$

$\frac{\text { Thermal: }}{\text { Colstrip 1-4 }}$
Corette

$\frac{\text { Ooal Mine: }}{\text { Colstrip }}$
- Lincoln County, Montana

- Flathead County, Montana

- Rosebild County, Montana

- Yellonstone County, Montana

- Rosebud County, Montana

In accordance with Section 7 (c) of the Endangered Spectes Act of 1973, as amended (ESA), we have determined that the following listed and proposed threatened or endangered (T/E) species may be present in the project area.

Listed Species

Black-footed ferret (Mustela nigrines)

Graly wolf (Canis lupus)

Grizzly bear (ursus arctos horribtlis)

Bald eagle (Haliaeetus leucocephalus)

Peregrine falcon (Ealco Derearinus)

\section{Expected Occurrence}

Potential resident in prairie dog

(Cynomys sp.) colonies - Colstrip 1-4, corette.

Resident - Libby, Hungry Horse

Resident - Libby, Hungry Horse

Year-round resident. Winter resident Migrant - All facilities.

Migrant, Potential summer resident - Nll facilities.

Proposed specios

Wone: 
Donald V. Wolfe

May 23, 1991

Page 2

Section $7(c)$ of ESA requires that Federal agencies proposing major construction actions, complete a biological assessment to determine the effects of the proposed actions on listed and proposed spectes. If a biological assessment is not required (i.e. all other actions), your agency is responstble for review of proposed activittes to determine whether 11 sted spectes may be affected. We would appreclate the opportunity to review your determination document.

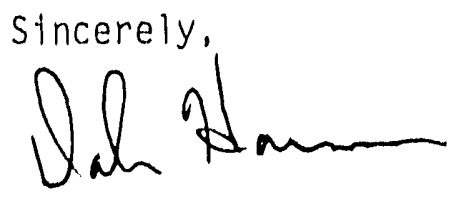

Dale R. Harms State Supervisor Montana State office

CC: L. Lockard, FWE, FWS - Kalispel1, MT 


\section{Department of Energy}

Bonneville Power Administration

P.O. Box 3621

Portland, Oregon 97208-3621

May 30,1991

In regly refer is

$P G$

Ms. Peggie Kohl

U.S. Fish and Wildlife Service

Sacramento Endangered Species Office

2800 Cottage Way, Room E-1803

Sacramento, CA 98525

Subject: Request for Updated List of Endangered and Threatened Species in the Bonneville Power Administration (BPA) Service Area, for Inclusion in the Long-Term Power Sales Contracts Environmental Impact Statement (EIS); From Previous Correspondence Coded 1-1-89-SP-944

Dear Ms. Kohl:

Based on a telephone conversation with your assistant, I am sending you additional material to assist you in responding to our recent request for updated listings of endangered and threatened species. Our request was based on previous correspondence in 1989, concerning this EIS, concerning listed specles for the portions of our service territory which are within your district. A copy of the response letter from your office, dated August 15, 1989, is enclosed for your information.

Your assistant also requested a map of our service ierritory. I have enclosed copies of maps showing the service territorles of our customer utilities, and excerpts from our authorizing legislation defining our service territory. This statutory language limits our service territory in northern California to areas within 75 air miles of the Oregon border or the Columbia River drainage, which are part of the service territory of a rural electric cooperative which serves loads within Oregon or the Columbia drainage. Specifically, this language limits the area of concern within your district to Modoc and Lassen Counties. These were the Counties addressed in your office's previous response in August 1989.

If listings of endangered and threatened species in these areas have not changed since your previous letter, it will be sufficient for our purposes for you to confirm that the listings are as shown in the attachments to your August 15, 1989. letter.

Thank you for your help.

Sincerely,

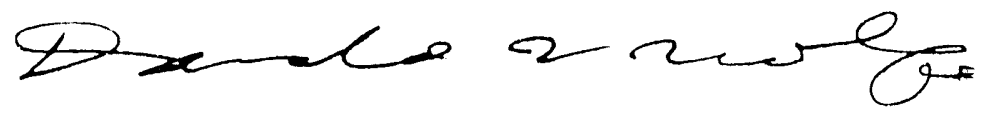

Donald V. Wolfe

Project Manager

Power Sales Contract FEIS

4 Enclosures 


\title{
United States Department of the Interior
}

\author{
FISH AND WILDLIFE SERVICE \\ Fish and Wildlife Enhancement \\ Sacramento Ficld Office \\ 28(0) Cottage Way, Room E-1803 \\ Sacramento, California 95825-1846
}

In Reply Refer To:

1-1-91-SP- 635

June 20, 1991

Mr. Donald V. Wolfe

Project Manager

Department of Energy

Bonneville Power Administration

P. O. Box 3621

Portland, Oregnn

Subject: Updated Species List for Bonneville Power Administration Service Area, Modoc and Lassen Counties, California

Dear Mr. Wolfe:

As requested by letter from your agency dated May 30, 1991, you will find attached an updated list of the listed endangered and threatened species that may be present in the subject project area. (See Attachment A.) To the best of our knowledge, no proposed species occur within the area. This list fulfills the requirement of the Fish and Wildlife Service to provide a species 1 ist pursuant to Section $7(\mathrm{c})$ of the Endangered Species Act, as amended.

Pertinent information concerning the listed species life history and distribution, and a discussion of the responsibilities of federal agencies under section 7 (c) of the Act were provided for those species addressed in response to your initial request for a species list. Attached is information concerning those listed species not previously addressed.

Formal consultation, pursuant to 50 CFR $\S 402.14$, should be initiated if you determine that a listed species may be affected by the proposed project. Informal consultation may be utilized prior to a written request for formal consultation to exchange information and resolve conflicts with respect to a isted species. If a biological assessment is required, and it is not initiated within 90 days of your receipt of this letter, you should informilly verify the accuracy of this list with our office.

Also, for your consideration, we have included a list of the candidate species that may be present in the project area. (See Attachment A.) These species are currently being reviewed by our Service and are under consideration for possible listing as endangered or threatened. Candidate species have no protection under the Endangered Species Act, but are included for your consideration as it is possible that one or more of these candidates could be proposed and listed before the subject project is completed. Should the biological assessment reveal that candidate species may be adversely affected, you may wish to contact our office for technical assistance. One of the potential benefits from such technical assistance is that by exploring, 
alternatives early in the planning process, it may be possible to avoid conflicts that could otherwise develop, should a candidate species become listed before the project is completed.

Please contact Peggie Kohl at 916/978-4866 (FTS 460-4866) if you have any questions regarding the at tached 1 ist or your responsibilities under the Fndangered Species Act.

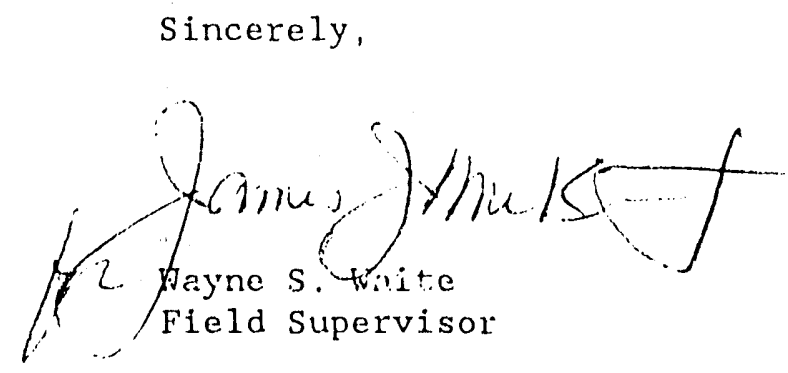

Attachments 


\author{
ATTACHMENT A \\ LISTED AND PROPOSED ENDANGERED AND THREATENED SPECIES AND \\ CANDIDATE SPECIES THAT MAY OCCUR IN THE AREA OF THE \\ BONNEVILLE POWER ADMINISTRATION SERVICE AREA \\ MODOC AND LASSEN COUNTIES, CALIFORNIA \\ (1-1-91-SP-635, JUNE 20, 1991)
}

\title{
Listed Species
}

Fish

Modoc sucker, Catostomus microps (E)

Lost River sucker, Deltistes luxatus (E)

shortnose sucker, Chasmistes brevirostris (E)

Birds

northern spotted owl, Strix occidentalis caurina ( $T$ )

American peregrine falcon, Falco peregrinus anatum (E)

\section{Candidate Species}

Fish

Goose Lake redband trout, Oncorhynchus mykiss ssp. (2)

McCloud River redband trout, Oncorhynchus mykiss ssp. (2)

rough sculpin, Cottus asperrimus (2)

Goose Lake sucker, Castostomus occidentalis lacusanserinus (2)

Cowhead Lake tui chub, Gila bicolor vaccaceps (1)

Birds

ferruginous hawk, Buteo regalis (2)

Mamma 1s

spotted bat, Euderma maculatum (2)

Sierra Nevada red fox, Vulpes vulpes necator (2)

Sierra Nevada snowshoe hare, Lepus americanus tahoensis (2)

white-footed vole, Arborimus albipes (2)

California bighorn sheep, Ovis canadensis californiana (2)

Invertebrates

Franklin's bumblebee, Bombus franklini (2)

Siskiyou ground beetle, Nebria gebleri siskiyouensis (2R)

Klamath Mountains ground beetle, Nebria sahlbergii triad (2R)

Plants

Deschutes milk-vetch, Astragalus tegetarioides (2)

Greene's mariposa, Calochortus greenei (2)

Egg Lake monkeyflower, Mimulus pygmaeus (2)

Columbia yellow-cress, Rorippa columbiae (2) 
(E) - - Endangered (T) - Threatened (CH)-Critical Habitat

(1)-Category 1: Taxa for which the Fish and Wildife Service has sufficient biological information to support a proposal to list as endangered or: threatened.

(2)--Category 2: Taxa for which existing information indicated may warrant listing, but for which substantial biological information to support a proposed rule is lacking.

(1R)-Recommended for Category 1 status.

(2R)-Recommended for Category 2 status.

$(\ddot{x})$ - Possibly extinct. 


\section{PALMATE-BRACTED BIRD'S-BEAK}

(Cordylanthus palmatus)

\section{CLASSIFICATION: Endangered 51 FR 23765}

CRITICAL HABITAT: None designated

\section{DESCRIPTION:}

This annual herb of the snapdragon family (Scrophulariaceae) attains a helght of 4 to 12 inches and produces several to many spreading ascending branches from near the base of the rnain stem. The pale stems are sparsely to densely hairy, often with glandular excretions of salt crystals evident on the herbage. The leaves and stems are grayish green and often very pale. The small pale whitish flowers, 1/2-inch to 1 inch long, are arranged in dense clusters (splkes) and densely surrounded by herbaceous leaflike bracts. Seedlings in late March or Aprll. The species flowers in late spring through the summer.

\section{DISTRIBUTION:}

Historically the species was collected from seven scattered locations in Fresno, Madera, San Joaquin, Yolo, and Colusa Countles. In 1982 a new location was discovered near Livermore in Alameda County and in 1987 a colony was discovered on the Colusa National Wild life Refuge in Colusa County. The latter stand may represent a remnant of the former populations to occur in the general area. At present four extant populations are known. These include the Livermore and Colusa NWR colonies, one near Woodland, Yolo County, and one on the Mendota State Wildlife Area, Fresno County. Additional colonies may occur in appropriate alkali sink habitats in these regions of the Central Valley and inner coast range valleys.

\section{SPECIAL CONSIDERATIONS:}

Population fluctuations are common in the palmate-bracted bird's-beak. These oscillations may be a result of changes in pollination success, rainfall patterns, freshwater influence, and marsh pollution. Consequently, researchers should take into account the unreliability of a single-season survey.

\section{REFERENCES FOR ADDITIONAL INFORMATION}

Chuang, T. I., and L. R. Heckard. 1971. Observations on root-parasitism in Cordylanthus (Scrophularlaceae). Am. J. Bot. 58:218-228.

Chuang, T. I., and L. R. Heckard. 1973. Taxonomy of Cordylanthus subgenus Hemistegia (Scrophulariaceae). Brittonia 25:135-158.

Ferris, R. S. 1918. Taxonomy and distribution of Adenostegia. Bull. Turrey Bot. Club. 45:399-423. 


\section{AMERICAN PEREGRINE FALCON}

(Falco peregrinus anatum)

CLASSIFICATION:

Endangered 35 Federal Register 16047, October 13, 1970, and 49 Federal Register 10526, March 20, 1984.

CRITICAL HABITAT: Designated in Sonoma, Napa, and Lake Cos.

DESCRIPTION:

A medium-sized, swift flying bird of prey with pointed wings. Wingspan is 3 to 4 feet. Adults have slate gray backs with white underparts that are streaked or barred in black. They have distinctive white and black facial markings.

DISTRIBUTION:

Historically nested throughout North America from the boreal forest south into Mexico, wherever suitable nesting and foraging habitat occurred. Remnant breeding populations currently occur in California, Arizona, New Mexico, Utah, Texas, and Alaska. A fow pairs nest in other states in the northeast and northwest.

SPECIAL CONSIDERATIONS:

The American peregrine falcon has suffered major population declines due principally to DDT contamination of their food chain. With the banning of DDT for use in the U.S. in 1972 and implementation of a management program, populations have for the most part stabilized. Unfortunately, pesticide data indicate that there has been a continued input of DDT into the local environments. Some nest sites are now protecied from human disturbance. Poor quality eggs are taken from the wild for artificial incubation, and young are placed in nests after hatching from wild eggs taken into captivity or laid by captive parenis.

\section{REFERENCES FOR ADOITIONAL INFORMATION:}

J. J. Hickey (ed). 1969. Peregrine falcon populations their biology and decline. Univ. of Wisconsin Press. Madison, WI.

Ratclifte, D. 1980. The peregrine falcon. Buteo Books. Vermillion, SD.

U.S. Fish and Wildlife Service. 1982. Paçific Coast Recovery Plan for the American Peregrine Falcon. Portland, OR. 87 pp. 


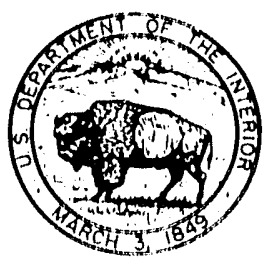

In Reply Rofor To

\section{United States Department of the Interior}

FISH AND WILDLIFE SERVICE

FISH AND WILDLIFL IENHANCLMHN'T UTAH S'TATIL OFICLI:

2078 ADMINIS'TIRA'TION BUILAING

1745 WIS'I' 1700 SOU'TH

SAL'I LAKE CI'TY, U'TAH 84104-5110

August 1, 1991

Donald $V$. Wolfe

Power Sales Contract FEIS

Bonneville Power Administration

PO BOX 3621

Portland, Oregon 97208-3621

Dear Mr. Wolfe:

We have received your letter concerning the Long-Term Power Sales Contracts Environmental Impact Statement. The materials provided have been reviewed and we find nothing of significant concern to the Fish and wildlife Service in the State of Utah. Therefore we will offer no comments.

We would be pleased to address specific issues identified by you if necessary at a later date.

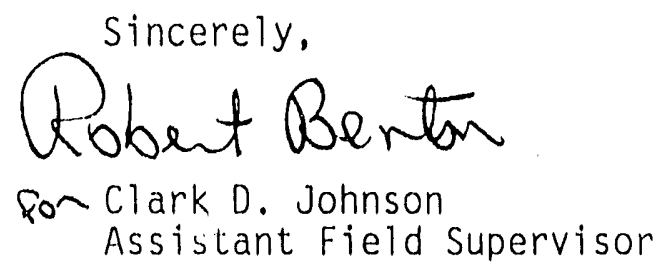




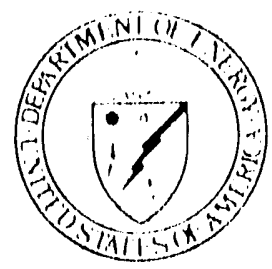

\section{Department of Energy}

Bonneville Power Administration

P.O. Box 3621

Porlland, Oregon $97208-3621$

.111. 191989

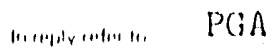

Mr. Ralph Swanson

Fish \& Wildlife Enhancement

U.S. Fish \& Wildife Service

1002 NE. Holladay Street

Portland, OR 97232-4181

Dear Mr. Swanson:

Subject: Request for List of Endangered and Threatened Species in the Bonneville Power Administration Service Area, for Inclusion in the Long-Term Power Sales Contracts Environmental Impact Statement (EIS)

In August 1981, Bonneville Power Administration (BPA) offered its customers new long-term contracts under the Pacific Northwest Electric Power Planning and Conservation Act. At that time, BPA prepared an Environmental Report to accompany the initial contract offer, but did not prepare an Environmental Assessment or an EIS. The United States Court of Appeals has since ordered $B P A$ to prepare an EIS.

BPA is now in the process of analyzing the environmental impacts of these long-term contracts in an EIS. Two basic alternatives are being analyzed: (1) the no-action alternative in which BPA would preserve the Long-Term Power Sales Contracts without change; or (2) an alternative in which BPA would pursue contract modifications (see enclosed material for additional details). The analysis covers the effects of operation of power facilities within the affected area. It also identifies quantities and types of resources that might be needed to meet future firm power loads. The EIS will include a generic discussion of impacts associated with these resources.

These long-term contracts are with customers located throughout BPA's service area, which covers the States of Washington, Oregon, and Idaho; the portion of Montana west of the Continental Divide; and small portions of Wyoming, Utah, Nevada, and northern California. Our study area also includes areas in Montana, Nevada, and Nyoming surrounding coal plants that serve the Pacific Northwest (see enclosed area description and location maps). The affected facilities within these States are identified by name, location, and energy source on the enclosed list. 
In compliance with section $7(c)$ of the amended Endangered Species Act, BPA is requesting a 1 ist of endangered and threatened species that may occur in the area of any of these facilities; and any information on these species that might be avallable, wuch as locations and how they might be affected. If no species or their critical habitat are being or will be affected by these alternatives, please notify BPA of this finding as well. The list you recently prepared for our Intertie Development and Use EIS, which covered much the same territory, is also enclosed for your information.

According to our conversation of June 30,1989 , my understanding is that Regions 2 and 6 will each take the lead to consult and coordinate the species list with their respective field offices and that each region will provide a single response to this request. We would, however, appreciate a 1 ist of contacts at the appropriate field offices, should the need arise in the future for more detalled followup during the consultation process.

If possible, we would appreciate having any information you may obtain by September 15, 1989, so that we can include it in our draft EIS. If you need additional information, or if $I$ can assist in any other way, please contact me at (503) $230-4235$ or FTS $429-4235$.

$$
\begin{aligned}
& \text { Sincerely, } \\
& \text { Nandranie s. Tuck } \\
& \text { Environmental Specialist } \\
& \text { Environmental Compliance section }
\end{aligned}
$$

4 Enclosures 


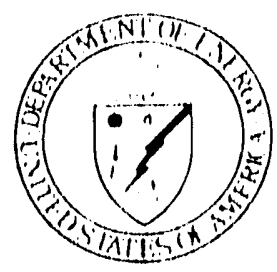

\section{Department of Energy}

Bonnevillo Power Administration

P.O. Box 3621

Portland, Oregon $97208 \cdot 3621$

JUL 191989

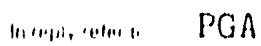

Mr. Galen Buterbaugh

Regional Director

U.S. Fish \& Wildlife Service

P.O. Box 25486

Denver Federal Center

Denver, CO 80225

Dear Mr. Buterbaugh:

Subject: Request for List of Endangered and Threatened Species in the Bonneville Power Administration Service Area, for Inclusion in the Long-Term Power Sales Contracts Environmental Impact Statement (EIS)

In August 1981, Bonneville Power Administration (BPA) offered its customers new long-term contracts under the Pacific Northwest Electric Power Planning and Conservation Act. At that time, BPA prepared an Environmental Report to accompany the initial contract of $f e r$, but did not prepare an Environmental Assessment or an EIS. The United States Court of Appeals has since ordered $B P A$ to prepare an EIS.

BPA is now in the prccess of analyzing the environmental impacts of these long-term contracts in an EIS. Two basic alternatives are being analyzed: (1) the no-action alternative in which BPA would preserve the Long-Term Power Sales Contracts without change; or (2) an alternative in which BPA would pursue contract modifications (see enclosed material for additional details). The analysis covers the effects of operation of power facilities within the affected area. It also identifies quantities and types of resources that might be needed to meet future firm power loads. The EIS will include a generic discussion of impacts associated with these resources.

These long-term contracts are with customers located throughout BPA's service area, which covers the States of Washington, Oregon, and Idaho; the portion of Montana west of the Continental Divide; and small portions of Wyoming, Utah, Nevada, and northern California. Our study area also includes areas in Montana, Nevada, and Wyoming surrounding coal plants that serve the Pacific Northwest (see enclosed area description and location maps). The affected facilities within these states are identified by name, location, and energy source on the enclosed list. 
In compliance with section $7(\mathrm{c})$ of the amended Endangered Species Act, BPA 18 requesting a 118 t of endangered and threatened species that may occur 1 n the area of any of these facilities; and any information on these spectes that might be available, such as locations and how they might be affected. If no species or their critical habltat are being or will be affected by these alternatives, please notify BPA of this finding as well. The 1 ist you recently prepared for our Intertie Development and Uae EIS, which covered much the same territory, is also enclosed for your information.

According to my conversation with Mr. Ralph Swanson of Region 2 on June 30 , 1989, my understanding 16 that Regions 2 and 6 will each take the lead to consult and coordinate the species list with thesir respective fleld offices and that each region will provide a single response to this request. We would, however, appreclate a 1 ist of contacts at the appropriate fleld offices, should the need arise in the future for more detailed followup during the consultation process.

If possible, we would appreciate having any tnformation you may obtain by September 151989 , so that we can include it in our draft EIS. If you need additional information, or if I can assist in any other way, please contact me at (503) 230-4235 or FTS 429-4235.

Sincerely,

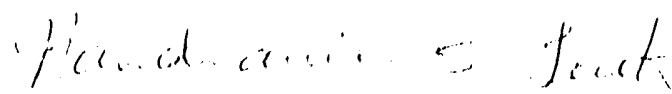

Nandranie S. Tuck

Environmental Specialist

Environmental Compliance Section

4 Enclosures 


\section{PACIFIC NORTHEEST GENERATING FACLLITIES* \\ HYDROELECTRIC}

\begin{tabular}{|c|c|c|c|c|c|}
\hline EACILITY & CQUNIY & STATE & $I_{1} \ldots$ & $R_{1}$ & S.1 \\
\hline BONNEVILLE & $\begin{array}{l}\text { Mul thomah } \\
\text { Skamanta }\end{array}$ & $\begin{array}{l}\text { OR } \\
\text { WA }\end{array}$ & $\begin{array}{l}2 \mathrm{~N} \\
2 \mathrm{~N} \\
\text { IBonneV }\end{array}$ & $\begin{array}{l}7 \mathrm{E} \\
7 \mathrm{E} \\
111 \mathrm{e} \text { Dam } 15\end{array}$ & $\begin{array}{l}21,22 \\
21,22 \\
511\end{array}$ \\
\hline THE OALLES & $\begin{array}{l}\text { Wasco } \\
\text { Kltckitat }\end{array}$ & $\begin{array}{l}\text { OR } \\
\text { WA }\end{array}$ & $\begin{array}{l}\text { IN } \\
\text { IN } \\
\text { (Dalles }\end{array}$ & $\begin{array}{r}13,14 \\
13,14 \\
0 \text { Daml } 1515\end{array}$ & $\begin{array}{ll}31, & 35 \\
31, & 35\end{array}$ \\
\hline JOHN DAY & $\begin{array}{l}\text { Sherman } \\
\text { kltckttat }\end{array}$ & $\begin{array}{l}\text { OR } \\
W A\end{array}$ & $\begin{array}{l}3 N \\
3 N \\
\text { (Rufus }\end{array}$ & $\begin{array}{rl}17 E & E \\
17 E \\
7.1 / 21)\end{array}$ & $\begin{array}{l}28 \\
28\end{array}$ \\
\hline MCNARY & $\begin{array}{l}\text { Umat } 111 \text { a } \\
\text { Benton }\end{array}$ & $\begin{array}{l}\text { OR } \\
\text { WA }\end{array}$ & $\begin{array}{l}5 \mathrm{~N} \\
5 \mathrm{~N} \\
\text { (Umat 1) }\end{array}$ & $\begin{array}{c}28 E \\
28 E \\
11 a^{7-1 / 21)}\end{array}$ & $\begin{array}{l}10 \\
3\end{array}$ \\
\hline PRIEST RAPIDS & $\begin{array}{l}\text { Yakima } \\
\text { Grant }\end{array}$ & $\begin{array}{l}\text { WA } \\
\text { WA }\end{array}$ & $\begin{array}{l}13 \mathrm{~N} \\
14 \mathrm{~N} \\
\text { (Prtest }\end{array}$ & $\begin{array}{l}23 E \\
23 E \\
t \text { Raplds } 15^{1}\end{array}$ & $\begin{array}{l}2,3 \\
35,36\end{array}$ \\
\hline WANAPUM & $\begin{array}{l}\text { Kittitas } \\
\text { Grant }\end{array}$ & $\begin{array}{l}\text { WA } \\
\text { WA }\end{array}$ & $\begin{array}{l}16 \mathrm{~N} \\
16 \mathrm{~N}\end{array}$ & $\begin{array}{l}23 E \\
23 E\end{array}$ & $\begin{array}{l}17,20 \\
16,7\end{array}$ \\
\hline ROCK ISLAND & $\begin{array}{l}\text { Douglas } \\
\text { Chelan }\end{array}$ & $\begin{array}{l}\text { WA } \\
\text { WA }\end{array}$ & $\begin{array}{l}21 \mathrm{~N} \\
21 \mathrm{~N} \\
\text { (Rocky }\end{array}$ & $\begin{array}{r}22 \mathrm{E} \\
22 \mathrm{E} \\
\text { Is } 1 \text { and Dam }\end{array}$ & $\begin{array}{l}5 \\
5 \\
\left.7-1 / 2^{\prime}\right)\end{array}$ \\
\hline ROCKY REACH & $\begin{array}{l}\text { Douglas } \\
\text { Chulan }\end{array}$ & $\begin{array}{l}\text { WA } \\
\text { WA }\end{array}$ & $\begin{array}{l}24 \mathrm{~N} \\
24 \mathrm{~N} \\
\text { (Rocky }\end{array}$ & $\begin{array}{l}20 \mathrm{E} \\
20 \mathrm{E} \\
\text { Reach Dam } 7\end{array}$ & $\begin{array}{l}35 \\
35 \\
\left.7-1 / 2^{\prime}\right)\end{array}$ \\
\hline WELLS & $\begin{array}{l}\text { Douglas } \\
\text { Chelan }\end{array}$ & WA & $\begin{array}{l}28 \mathrm{~N} \\
28 \mathrm{~N} \\
(\mathrm{We} 11 \mathrm{~s}\end{array}$ & $\begin{array}{l}24 E \\
24 E \\
\text { Dam } 7-1 / 21)\end{array}$ & 6,20 \\
\hline CHIEF JOSEPH & $\begin{array}{l}\text { Douglas } \\
\text { Okanogan }\end{array}$ & $\begin{array}{l}\text { WA } \\
\text { WA }\end{array}$ & $\begin{array}{l}29 \mathrm{~N} \\
29 \mathrm{~N} \\
\text { (Chlef }\end{array}$ & $\begin{aligned} & 25 E \\
& 25 E \\
& \text { Joseph Dam }\end{aligned}$ & $\begin{array}{l}24 \\
24 \\
7-1 / 21)\end{array}$ \\
\hline ICE HARBOR & $\begin{array}{l}\text { Walla Wa11a } \\
\text { Frank1 In }\end{array}$ & $\begin{array}{l}\text { WA } \\
\text { WA }\end{array}$ & $\begin{array}{l}8 \mathrm{~N} \\
8 \mathrm{~N} \\
\text { (Pasco }\end{array}$ & $\begin{array}{c}30 E \\
30 E \\
\left.7-1 / 2^{\prime}\right)\end{array}$ & $\begin{array}{l}2 \\
2,3\end{array}$ \\
\hline LOWER MONUMENTAL & $\begin{array}{l}\text { Wa11a Wa11a } \\
\text { Frank1 in }\end{array}$ & $\begin{array}{l}\text { WA } \\
\text { WA }\end{array}$ & $\begin{array}{l}12,13 \mathrm{~N} \\
13 \mathrm{~N} \\
\text { (Lower }\end{array}$ & 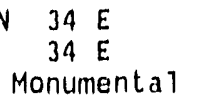 & $\begin{array}{l}2,3,34 \\
34 \\
\text { Dam } 7-1 / 21)\end{array}$ \\
\hline LITTLE GOOSE & $\begin{array}{l}\text { Columbla } \\
\text { Whitman }\end{array}$ & $\begin{array}{l}\text { WA } \\
\text { WA }\end{array}$ & $\begin{array}{l}13 \mathrm{~N} \\
13 \mathrm{~N} \\
\text { (Starbu }\end{array}$ & $\begin{array}{rl}28 & E \\
28 & E \\
\text { uck East } & 7-1\end{array}$ & $\begin{array}{l}27 \\
27 \\
1 / 211\end{array}$ \\
\hline LOWER GRANITE & $\begin{array}{l}\text { Whitman } \\
\text { Garfield }\end{array}$ & $\begin{array}{l}\text { WA } \\
\text { WA }\end{array}$ & $\begin{array}{l}14 \mathrm{~N} \\
14 \mathrm{~N} \\
\text { (Almoti }\end{array}$ & $\begin{array}{c}43 E \\
43 E \\
a-1 / 21)\end{array}$ & $\begin{array}{l}29, \quad 32 \\
32\end{array}$ \\
\hline LIBBY & Lincoln & MT & & & \\
\hline HUNGRY HORSE & Flathead & MT & & & \\
\hline ALBENI FALLS & Bonner & ID & & & \\
\hline GRAND COULEE & $\begin{array}{l}\text { Okanogan } \\
\text { Douglas }\end{array}$ & $\begin{array}{l}\text { WA } \\
\text { WA }\end{array}$ & $\begin{array}{lll}0 & 28 & N \\
0 & 28 & N \\
\text { (Grand }\end{array}$ & $\begin{array}{c}30 \mathrm{E} \\
30,31 \mathrm{E} \\
\text { Coulee 15') }\end{array}$ & 1,6 \\
\hline DWORSHAK & Clearwater & 10 & & & \\
\hline
\end{tabular}




\section{PACIFIC NORTHWEST GENERATING FACILITIES*}

\section{THERMAL}

\begin{tabular}{|c|c|c|c|c|c|c|c|}
\hline PLANI & OWNER & CIIY & STAIE & COUNTY & $T_{1}$. & $\ldots$ & -51. \\
\hline COLSTRIP $1-4$ & $M P C$ & Colstrtp & MT & Rosebud & $2 N$ & $41 E$ & 35 \\
\hline CORETTE & $M P C$ & B $1111 \mathrm{ngs}$ & MT & Yellowstone & & & \\
\hline BOARDMAN & PGE & Boardman & OR & Morrow & (Near N. & Border & \\
\hline CENTRALIA 182 & PP\&L & Centra1ta & WA & Lewis & $15 \mathrm{~N}$ & $1 \mathrm{~W}$ & 30 \\
\hline JIM BRIDGER 1-4 & PP\&L & Rock springs & WY & Sweetwater & $20 \mathrm{~N}$ & $101 \mathrm{~W}$ & 3 \\
\hline VALMY $1 \& 2$ & sterra Pactf tc & Valmy & NV & Humbo1t & $35 \mathrm{~N}$ & $43 \mathrm{E}$ & 27 \\
\hline \multicolumn{8}{|c|}{ NUCLEAR } \\
\hline PLANI & OWNEB & CIIY & SIAIE & COUNIY & $I_{1}$ & $-R_{1}$ & $s_{1}$ \\
\hline WNP-1 & WPS & Rtchland & WA & Benton & $\begin{array}{l}11 \mathrm{~N} \\
\text { (Wooded }\end{array}$ & $\begin{array}{l}28 \mathrm{E} \\
1 \mathrm{~s} 1 \text { and }\end{array}$ & $\begin{array}{c}5 \\
7-\left(2^{\prime}\right)\end{array}$ \\
\hline$W N P-3$ & WPS & Satsop & WA & Grays Harbor & $\begin{array}{l}17 \mathrm{~N} \\
\text { (Grays H }\end{array}$ & $\begin{array}{c}6 \mathrm{~W} \\
\text { arbor } 7\end{array}$ & $\begin{array}{c}18 \\
\left.-1 / 2^{\prime}\right)\end{array}$ \\
\hline
\end{tabular}

\section{COMBUSTION TURBINE}

\begin{tabular}{|c|c|c|c|c|c|c|c|c|}
\hline PLANI & OWNEB & CITY & SIAIE & SQUNTY. & & I. $\ldots$ & $R_{1}$ & $s_{1}$ \\
\hline BETHEL & $P G E$ & Salem & $\mathrm{OR}$ & Marton & & S & $2 W$ & 29 \\
\hline BEAVER & PGE & Clatskanie & $\mathrm{OR}$ & Columbta & & & & \\
\hline WHITEHORN $1-3$ & PSP\&L. & Custer & WA & Whatcom & 39 & $N$ & $1 \mathrm{~W}$ & 12 \\
\hline FREDERICK.SON 182 & PSP\&L. & Tacoma & WA & King & 18 & $N$ & $3 \mathrm{E}$ & 1 \\
\hline FREDONIA UNITS $1 \& 2$ & PSP\&L & Burlington & WA & skagit & 34 & N & $3 E$ & 9 \\
\hline
\end{tabular}

COAL MINES SUPPLYING GENERATING RESOURCES

$\begin{array}{llllll}\text { POWER PLANI } & \text { MINE } & \text { CITY } & \text { SIAIE } & \text { COUNTY } & \\ \text { BOAROMAN } & \text { Belle Ayre } & \text { Campbe11 } & \text { WY } & & \\ \text { CENTRALIA } & \text { Centralia } & \text { Centralia } & \text { WA } & \text { LeWIS } & 15 \mathrm{~N} \\ \text { COLSTRIP } & \text { Rosebud } & \text { Rosebud } & \text { MT } & 1 \mathrm{~W} \\ \text { JIM BRIDGER } & \text { Bridger } & \text { Sweetwater } & \text { WY } & 30\end{array}$

\footnotetext{
"Facilities within the "affected environment" of the Power Sales contract. EIS.
} 


\section{BPA SERVICE AREA}

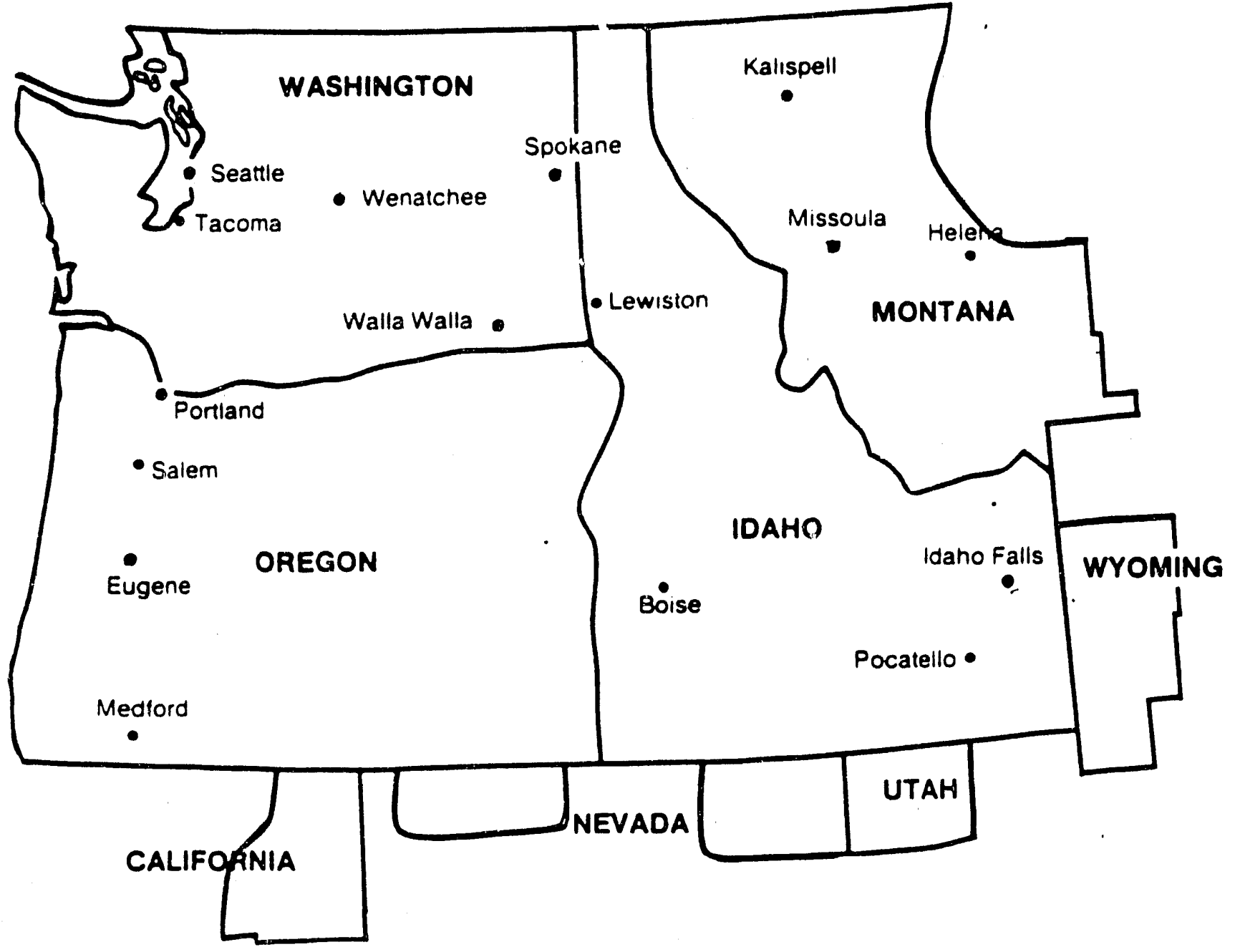




\title{
United States Department of the Interior
}

\author{
FISH AND WILDLIFE SERVICE \\ Portland Field office \\ 727 NE 24 th Avenue \\ Portland, OR 97232
}

August 3,1989

$1-7-89-S P-131$

Nandranle: $S$, Tuck

Bonneville Power Administration

P.O. Box 3621

Portland, Oregon 97208-3621

Dear Mis. Tuck:

As requested by your letter dated July ig, 1989 anc received by us on July 26. 1989, we have reexamined the list prepared for the Intertie Development and Use EIS. The Information presented for Bonneville, The Dalles, John Day and McNary still accurrately refiects known threatened, endangered and candidate species resources in the vicinity of the aforenamed oregon hyoro facilities. However, since the project area being considered in the proposed Bonneville Power Administration Long-term Power Sales Contracts Environmental Impact Statement (EIS) is more extensive, we have attached a Iist of endangered and threatened species that may be present in the service area covered by your sales contract EIs. The list fulfills the requirement of the Fish and Wildife Service under Section $7(\mathrm{c})$ of the Endangered Species Act of 1973, as amended (16 USC 1531 et. seg.). Bonneville Power Administration's requirements under the Act are outlined in Attachment $B$.

Should your biological assessment cetermine that a listed species is likely to be adversely affected by the project. Bonneville Power Administracion should request formal section 7 consultation through this offjce. Even if your biological assessment shows a "no effect" or "beneficial effect" situation, we would appreciate recelving a copy for our information.

Your interest in endangered species is appreciated. If you have any adoitional questions regarding your responsibilities under the Act, please call Diana Hwang at our office, phone (503) $331-6179$ or ETS $429-6179$. All correspondence should include the above referenced case number.

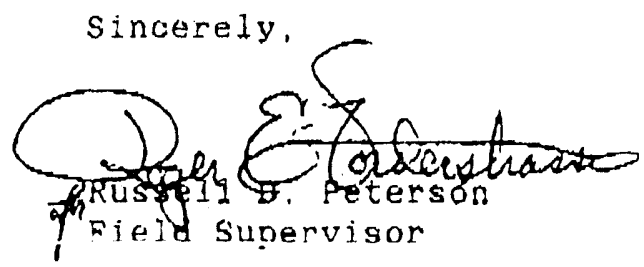


Attachment

CO: RI PWE-SE

PFO-ES

ODFW (Nongame)

ONHP 


\section{LISTED AND PROPOSED ENDANGERED AND THREATENED SPECIES \\ THAT MAY OCCUR IN THE AREA OF THE FROPOSED \\ SERVICE AREAS-OPERATING PUBLIC AGENCIES AND COOPERATIVES}

(DOE/BPA MAP DATED MAY 1987)

$$
1-7-89-5 P-131
$$

\section{LISTED SPECIES I/}

Mammajs

Columbian white tailed Deer odocolleus vireinjanus leuourus

Columbian white-tailed deer occur along the Lower Columia River in

Clatsop (OR), columbia (OR), and Wankiakum (WA) Counties and in Douglas County (OR).

\section{BIrds}

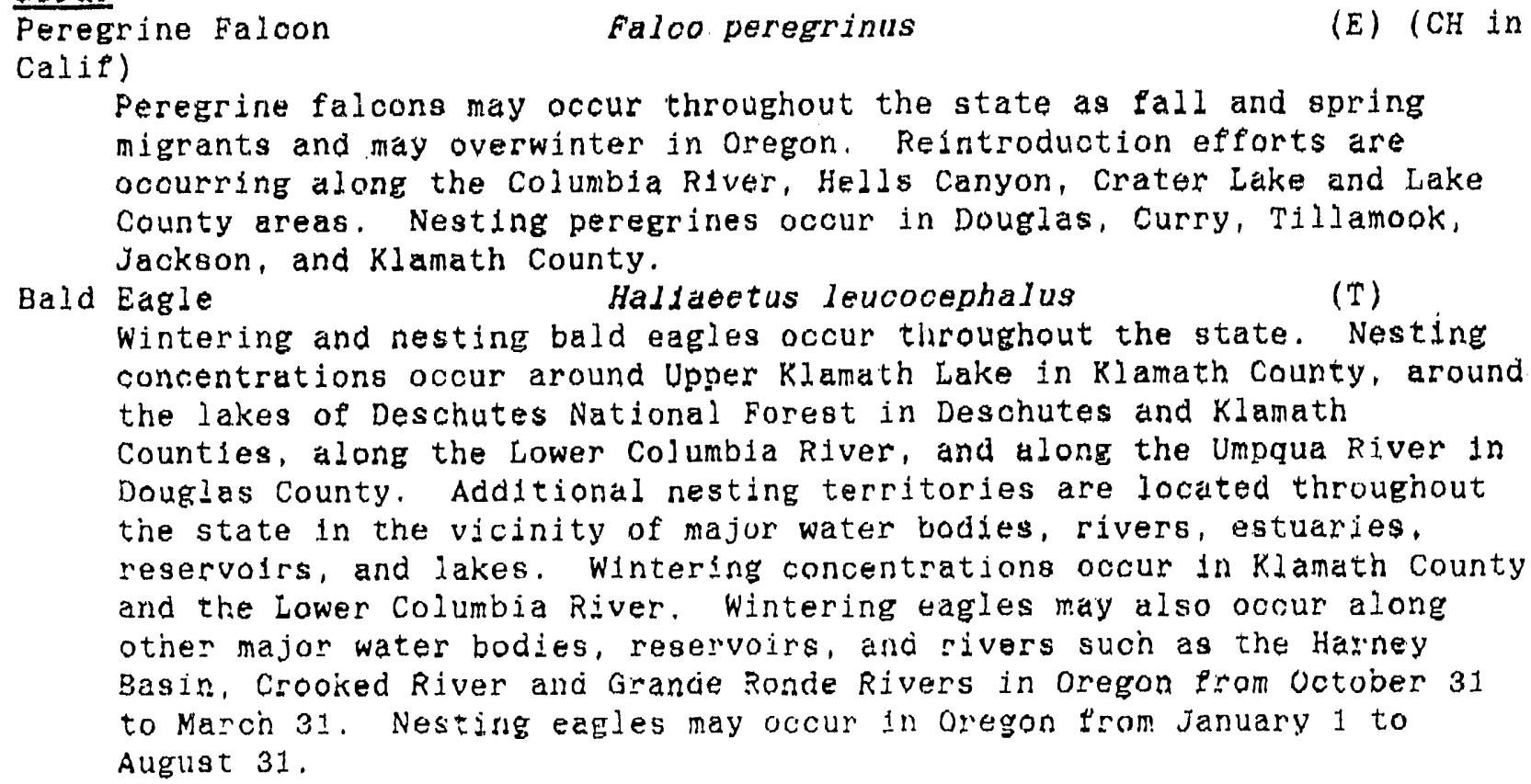

(T)

Wintering and nesting bald eagles occur throughout the state. Nesting concentrations occur around Upper Klamath Lake in Klamath County, around the lakes of Deschutes National Forest in Deschutes and Klamath Counties, along the Lower Columbia River, and along the Umpqua River in Douglas County. Additional nesting territories are located throughout the state in the vicinity of major water bodies, rivers, estuaries. reservolrs, and lakes. Wintering concentrations occur In Klamath County and the Lower Columbia River. Wintering eagles may also occur along other majon water bodies, reservoirs, and rivers such as the Harney Basin. Crooked River and Grancie Ronde Rivers in Oregon from October 31 to Marcin 31. Nestirg eagles may occur in oregon Irom January 1 to August 31 .

Fish

Hutton spring tui Chub Gila bicolor ssp.

species is restricted to two spaings along Aliall Lake in Lake County.

Foskert Spring speckled Dace Rhinichthvs osculus ssp.

Species occurs 1 a a smail Coleman Valley spring in soutbern iake County.

Warner sucker Catoctomus warnerensis

(T) (CK)

Species occurs in Warner Valley in iake County. (Listed Sept. 28, 1985)

Borax Lake Chub Gila boraxabius

(E) $(\mathrm{CH})$

Species occurs in Borax Lake in Harney County.

Invertebrates

Oregon silverspot Butterfly speveria zorene hippolyta

( T) $(\mathrm{CH})$ 
Disfunot populations oocur at Mt. Hebo and along the Oregon coast in Clatsop, Tillamook, and Lane Counties.

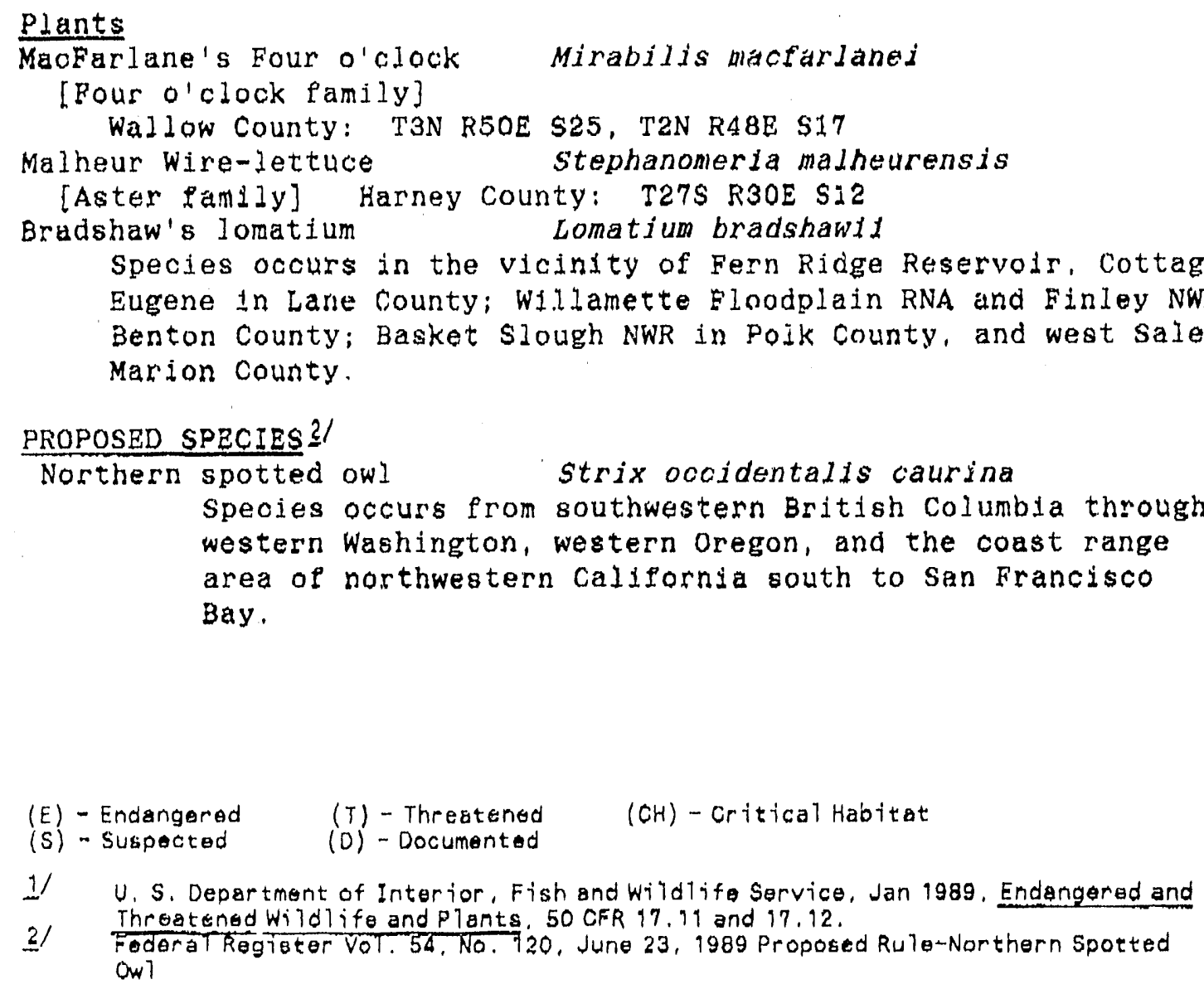

Species occurs in the vicinity of Fern Ridge Reservodr, Cottage Grove and Eugene in Lane County; Wlillamette Floodplain RNA and Finley NWR in Benton County; Basket Slough NWR in Poik county, and west Salem Ir Marion County.

PROPOSED SPECIES $2 /$

Species occurs from southwestern British Columbia through

western Washington, western Oregon, and the coast range area of northwestern California south to san Francisco Bay.

(E) - Endangered

(T) - Threatened

(CH) - Critical Habitat

1) U. S. Department of Interior. Fish and Wild life Service, Jan 1989. Endangered and OW1 


\title{
United States Department of the Interior
}

\author{
FISH AND WILDLIFE SERVICE \\ Ecological Services \\ 2625 Parkmont Lane SW, B1dg B \\ Olympia, Washington 98502
}

August 11, 1989

Ms. Nandranie S. Tuck

FWS Reference: 1-3-89-SP-305

Environmental Specialist

Department of Energy

Bonneville. Power Administration

PO Box 3621

Portland, Oregon 97208-3621

Dear Ms. Tuck:

As requested by your letter, dated July 19, 1989, and received in this office on July 26, attached is a 1 ist of endangered and threatened species (Attachment A) that may be present in the area of the proposed hydroelectric, thermal, nuclear, and combustion turbine generating facilities and coal mines of the Pacific Northwest Power System in Washington state. The 1ist fulfills the requirement of the Fish and Wildlife Service under Section $7(\mathrm{c})$ of: the Endangered Species Act of 1973, as anended. The requirements for Bonneville Power Administration compliance under the Act are outlined in Attachment $B$.

Should the biological assessment determine that a listed species is likely to be affected (adversely or beneficially) by the project, Bonneville Power should request formal. Section 7 consultation through this office. Even if: the biological assessment shows a "no effect" situation, we would appreciate receiving a copy for our information.

Also included is a list of candidate specios presently under review by this Service for consideration as endangered or threatened. Candidate species have no protection under the Endangered Species Act, and a determination of "may affect" for candidates does not require preparation of a biological assessment or consultation with the Fish and Wildife Service. Candidate species are included simply as advance notice to federal agencies of species which may be proposed and 1 isted in the future. If early evaluation of your project indicates that it is likely to adversely impact a candidate species, Bonneville Power may wish to request technical assistance from this office. 
Your interest in endangered species is appreciated. If you have additional questions regarding your responsibilities under the Act, please contact Jim Michaels or Jeff Haas of my staff at the above phone/address.

Sincerely,

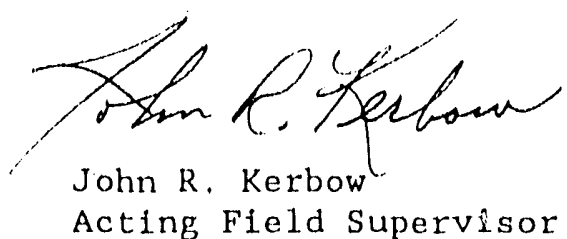

Attachments

c: WDW (Nongame)

WNHP

$\mathrm{JWH}: \mathrm{gb}$ 


\begin{abstract}
LISTED AND PROPOSED ENDANGERED AND THREATENED SPECIES AND CANDIDA'TE SPECIES THAT MAY OCCUR WITHIN THE AREA OF THE PROPOSED HYDROELECTRIC, THERMAL, NUCLEAR, AND COMBUSTION GENERATING FACILITIES AND COAL MINES OF THE PACIFIC NORTHWEST POWER SYSTEM IN MULTIPLE COUN'IIES OF THE STATE OF WASHINGTON
\end{abstract}

$1-3-89-S P-305$

PACIFIC NORTHWEST HYDROELECTRIC GENERATING FACILITIES

The Dalles, K1ickitat County (T2N R13E S35)

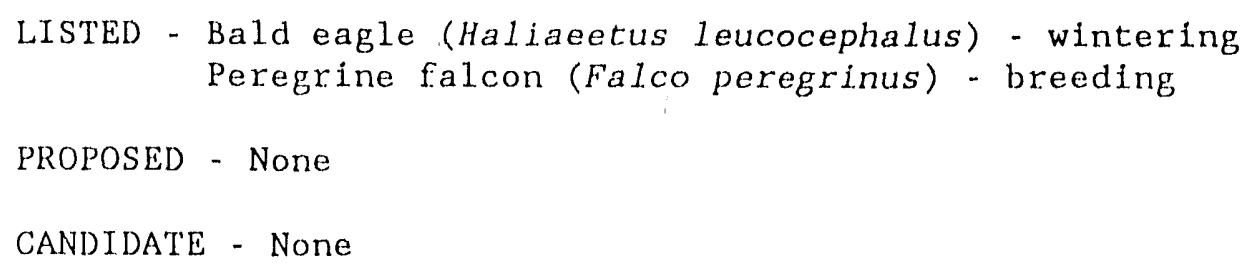




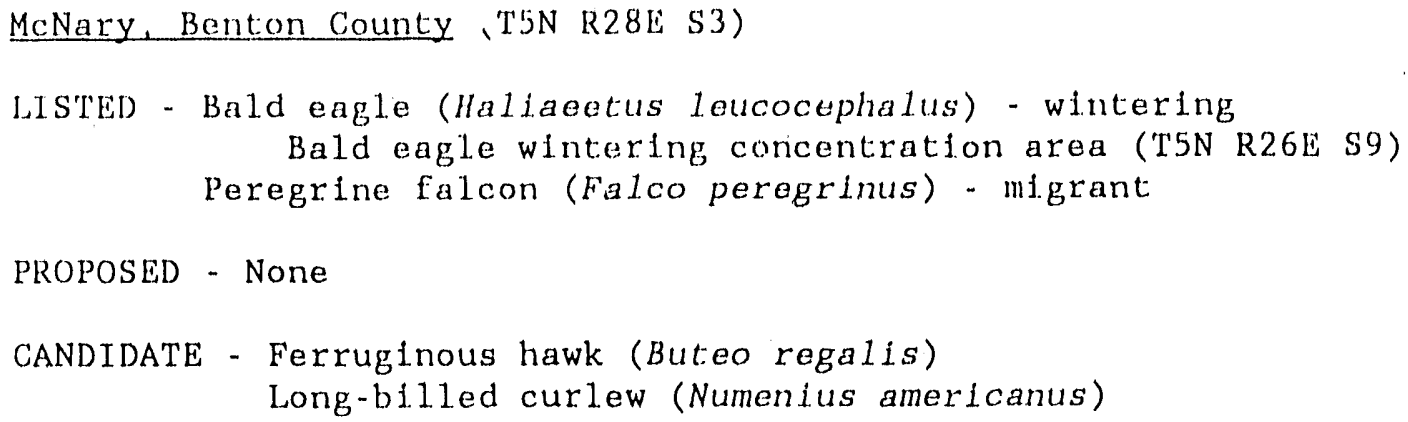

Priest Rapids, Yakima County (T13N R23E S2/3)

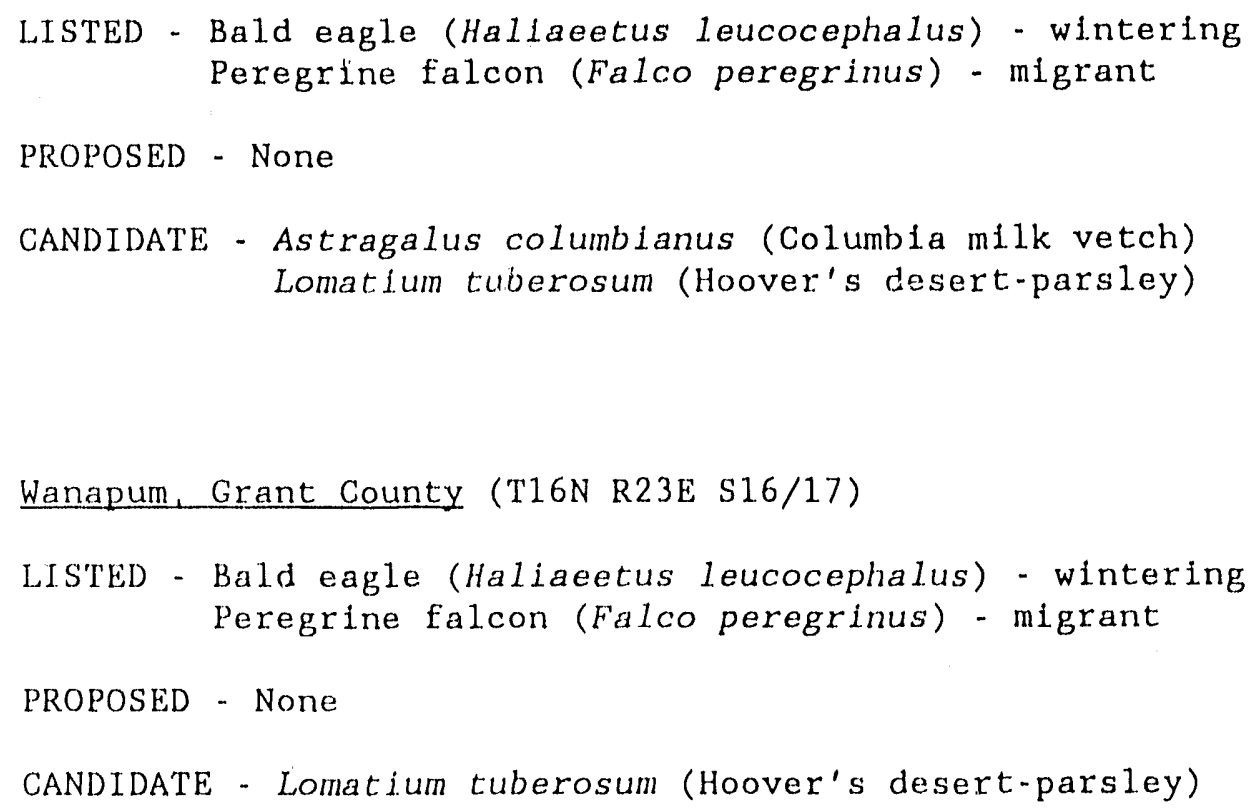

Rock Island, Douglas County (T21N R22E S5)

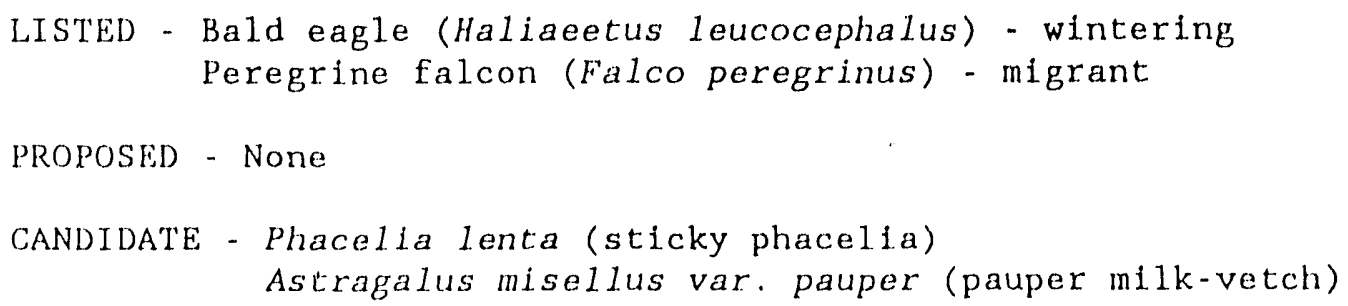


Rocky Reach, Chelan County ('I'24N R20E S35)

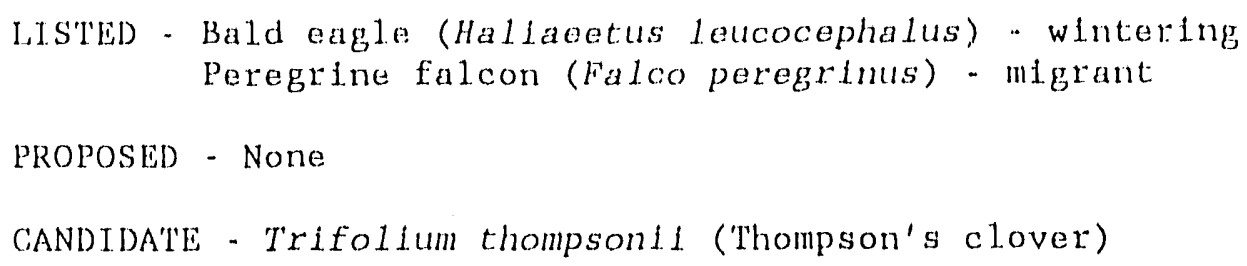


Lowar Monumental. Walla Walla Count:y ('I'13N R34E S34)

LISTED - Bald eagle (Hallaeetus letcocephalus) - wintering Poregrine falcon (Falco perogrlous) - migrant

PROPOSED - None

CANDIDATE - None

little Goose, Columbla County ('T13N R38E S27)

LISTED - Bald eagle (Hal Laeotus Leucocephalus) - wintering

Peregrine falcon (Falco peregrinus) - migrant

PROPOSED - None

CANDIDATE - None

Lower Grante, Whitman County ('I14N R43E S32)

LISTED - Bald eagle (Haliaeetus leucocephaliss) - wintering Peregrine falcon (Falco peregrinus) - migrant

PROPOSED - None

CANDIDATE - Rubus nigerrimus (northwest raspberry)

\author{
Grand Coulee, Grant County (T28N R30E S1) \\ LISTED - Bald eagle (Haliaeetus leucocephalus) - wintering \\ Bald eagle communal night roosting area (T28N R31E S\%) \\ Peregrine falcon (Falco peregrinus) - migrant \\ PROPOSED - None \\ CANDIDATE - Allium douglasili var. constrictum (Douglas' onton)
}


Contralla, Lawis County (I'LSN R1W S30)

LIS'TE) - Bald angla (Hallaogtus loucocephalus) - winterlng

PROPOSED - None

CANDIDA'TE - None

PACIFIC NOR'THWEST NUCLEAR GENERATING FACILITY

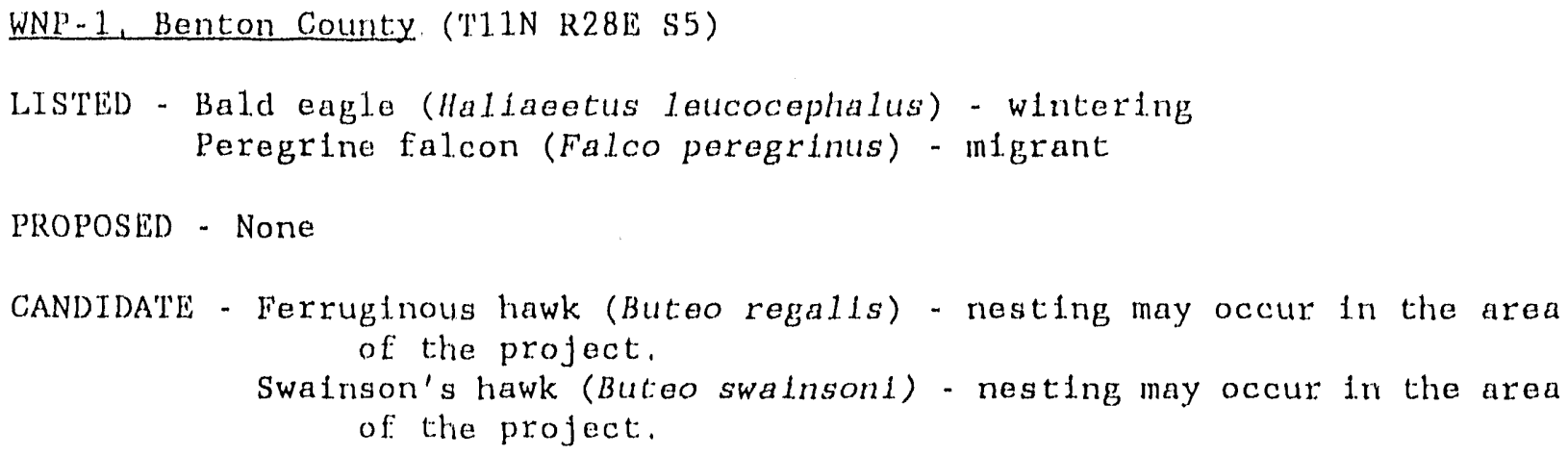

WNP-3, Grays Harbor County ('T1.7N R6W S1.8)

LISTED - Bald eagle (Haliaeetus leucocephalus) - wintering

There are 3 bald eagle nesting territories near the project

('T17N R6W S12; T17N R7W S7; T17N R7W S10)

PROPOSED - None

CANDIDATE - Olympic mudminnow (Novumbra hubbsi.)

Whitehorn. Whatcom County ('T39N R1W S12)

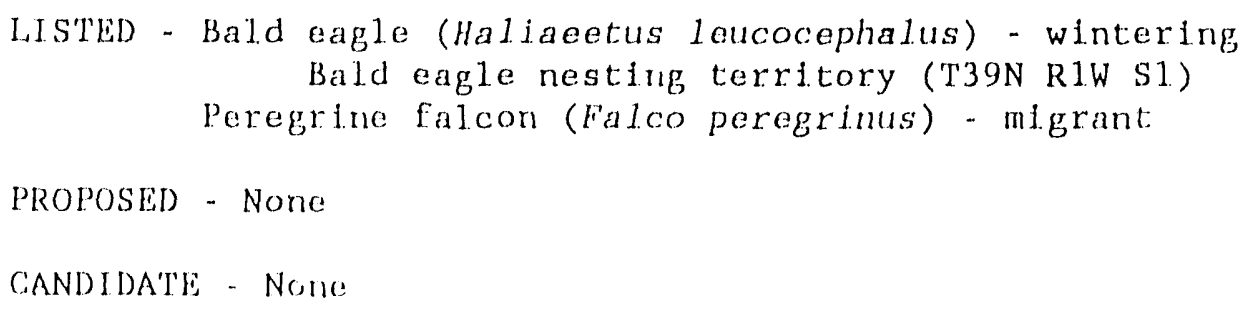


Eraclarickson 182, Plarea County ('I'18N R3E S1)

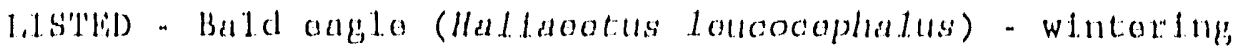

PROPOSLI) - None

GANDIDATE - Astor curtus (whito-top antor)

Fredonia Undts 1\&? Skaglt County ('I'34N R'3E S9)

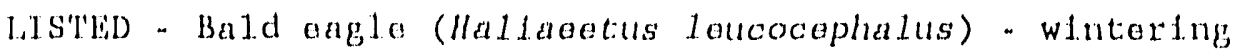

PROPOSEI) - None

PROPOSELD - None

PACIFIC NORTHWEST COAL MINES

Centralla Lewis County (T15N R1W S30)

LIS'ED - Bald eagle (Hallaeotus leucocephalus) - wintering

PROPOSED - None

CANDIDATE - None

Note: Wintering bald eagle activity occurs from about October 31 through March 31. Nesting activities occur from about January 1 through August 1.5 .

Major concerns that should be addressed in your biological assessment of: project impacts to bald eagles and peregrine falcons are:

1. Level of use of the project area by bald eagles and peregrine falcons.

2. Effect of the project on the eagle's and falcon's primary food stocks and foraging ares in all areas influenced by the project.

3. Impacts from profect activities (i.e., increased human activity, loss or: degradation of habitat, increased noise levels) which may result in disturbance to bald eagles and falcons and/or their avoldance of the project area. 
FEDERA AGENCIES' RESPONSLBLIT'TLS UNDER SEC'TONS $7(11)$ AND $7(0)$

OF 'IUE ENDANGLIRED STECTE'S AC'T'

SECTION 7(A) - Consultation/Conference

Requtres: 1. Federal agencias to utilize their authorities to carry out programs to consarve endangered and threationed spectes;

2. Consultation with FWs when a federal action may affect a liated endangered or threatoned apectes to ensure that any action authortzed, funded, or carried out by a federal agency is not 1tkely to jeopardize the continued extstence of 1 isted apectes or result in the destruction or adverse modiftcation of orttical habitat. The process is inftitated by the federal agency after it has determined if 1 ts action may

affect (adversely or benaficially) a listed spectes; and

3. Conference with IWS when a federal action is likely to jeopardize the continued existence of a proposed spectes or result in destruction or an adverse modification of proposed critical habitat.

SECTION 7 (c) - Blological Assessment for Construction Projects *

Requires federal agencies or their designees to prepare a Biological Assessment: (BA) for construction projects only. The purpose of the BA is to identify any proposed and/or listed spectes which is/are likely to be affected by a construction project. The process is intetated by a federal agency in requesting a list of proposed and listed threatened and endangered species (11st attached). The BA should be completed within 180 days after its initiation (or within such a time period as is mutually agreeable). If the $B A$ is not initiated within 90 days of receipt of the species list, please verlfy the accuracy of the list with our service. No irreversible commitment of resources is to be made during the BA process which would result in violation of the requirements under Section $7(a)$ of the Act. Planning, design, and adminstrative actions may be taken; however, no construction may begin.

To complete the BA, your agency or 1 ts designee should: (1) conduct an onsite inspection of the area to be affected by the proposal, which may include a detalled survey of the area to determine if the species is present and whether suitable habitat: exists for either expanding the existing population or potential reintroduction of the species; (2) review literature and scientific data to determine species distribution, habitat needs, and other biological requirements; (3) interview experts including those within the FWS, National Marine Fisheries Service, state conservation department, universities, and others who may have data not yet published in scien-tific literature; (4) review and analyze the effects of the proposal on the species in terms of individuals and populations, including consideration of cumulative effects of the proposal on the species and its habitiat; (5) analyze alternative actions that may provide conservation moasures; and (6) prepare a report dosumenting the results, including a discussion of study methods used, any problems encountered, and other relevant: information. Upon completion the report should be forwarded to our Endangered Species Division, 2625 Parkmont: Lane SW, Bldg. B, Olympia, WA 98502.

* "Construction project" means any major federal action which significantily affects the quality of the human environment (requiring an EIS), designed primarily to result in the building or erection of human-made structures such as dams, buidings, roads, pipelines, channels, and the like. This includes federal actions such as permits, grants, licenses, or other forms of federal. authorization or approval which may result: in construction. 


\section{United States Department of the Interior}

\section{FISH AND WILDLIFE SERVICE}

BOISE FIELD OFFICE

4696 Overland Road, Room 576

Boise, Idaho 83705

August 16,1989

Nandranie S. Tuck, Environmental Specialist

Environmental Compliance Section

Bonneville Power Administration

P.O. Eox 3621

Portland, Oregon 97208-3621

Re: $\quad 1-4-89-S P-332$

Dear Mr. Tuck:

We have reviewed your July 19, 1989 letter concerning the Long-Term Power Sales Contracts in Bonner and Clearwater counties, Idaho. We are providing a list $0^{-}$. riweatened and endangered species (Attachment $A$ ) that may be impacted by this project. This list fulfills the requirements of the Fish and Wildlife Service under Section 7 (c) of the Endangered Species Act (ESA) of 1973, as amended.

Attachment $B$ lists the continuing responsibilities as described in Section 7 (a) and (c) of the ESA. If there are any questions regarding your responsibilities under the ESA, please contact Rich Howard at the above address or by phone at 334-1806. However, pursuant to regulations under Section 7, Bonneville Power Administration should renew its species list request after 180 days past this response.

Additional information on Federally listed and candidate species and State species of special concern is available through the Idaho Department of Fish and Game's Natural Heritage Program, Attn: Craig Groves, Idaho Department of Fish and Game, $600 \mathrm{~S}$. Walnut, P.0. Box 25, Boise, Idaho 83707, phone $334-3402$.

Thank you for the opportunity to provide these comments.

Sincerely yours,

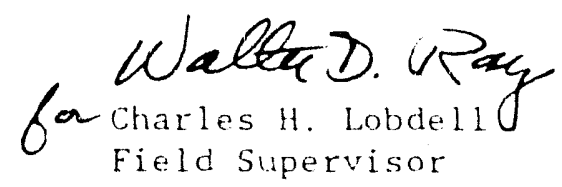

Enclosures

Co: FhS, AFWE-SE, Portland

IDFG, Hdqtes., Boise

rnfe, pogion l, Coeur d'tlone

IDF Pegion ?, lewiston 


\section{LISTED AND PROPOSED ENDANGERED AND THREATENED SPECIES, AND CANDIDATE SPECIES THAT MAY OCCUR WITH THE POWER SALES CONTRACTS AREAS \\ IN BONNER AND CLEARWATER COUNTIES, IDAHO \\ $1-4-89-S P-332$}

\section{LISTED SPECIES}

Bald Eagle (Haliaeetus leucocephalus)

Bald Eagle (Haliaeetus leucocephalus)

\section{COMMENTS}

\section{PROPOSED SPECIES}

None

CANDIDATE SPECIES

None 
FEDERAL AGENCIES' RESPONSIBILITY UNDER SECTIONS 7 (a) and (c) OF THE ENDANGERED SPECIES ACT

SECTION $7(a)$ - Consultation/Conference

Requires: 1) Federal agencies to utilize their authorities to carry out programs to conserve endangered and threatened species;

2) Consultation with FWS when a Federal action may affect a listed endangered or threatened species to insure that any action authorized, funded or carried out by a Federal agency is not likely to jeopardize the continued existence of listed species; or result in destruction or adverse modification of critical habitat; and

3) Conference with FWS when a Federal action is likely to jeopardize the cont:nued existence of a proposed species or result in destruction or adverse modification of proposed critical habitat.

SECTION 7(c) - Biological Assessment for Major Construction Activities 1/

Requires Federal agencies or their designees to prepare Biological Assessment (BA) for major construction activities. The BA analyzes the effects of the action on listed and proposed species. The process begins with a Federal agency in requesting from FWS a list of proposed and 1 isted threatened and endangered species (1ist attached). The BA should be completed within 180 days after its initiathot (or within such a time period as is mutually agreeable). If the $B A$ is not initiated within 90 days of receipt of the species list, the accuracy of the list species should be informally verified with our Service. No irreversible comitment of resources is to be made during the $B A$ process which would foreclose reasonable and prudent alternatives to protect endangered species. Planning, design, and administrative actions may be taken; however, no construction may begin.

We recommend the following for inclusion in the BA; an onsite inspection of the area to be affected by the proposal which may include a detailed survey of the area to determine if the species are present; a review of literature and scientific data to determine species' distribution, habitat needs, and other biological requirements; interviews with experts, including those within FWs, State conservation departments, universities and others who may have data not yet published in scientific literature; an analysis of the effects of the proposal on the species in terms of individuals and populations, including consideration of cumulative effects of the proposal on the species and its habitat; an analysis of alternative actions considered. The BA should document the results, including a discussion of study methods used, any problems encountered, and other relevant information. The BA should conclude whether or not a listed or proposed species will be affected. Upon completion, the BA should be forwarded to our office.

1) A major construction activity is a construction project (or other undertaking having similar physical impacts) which is a major action significantly affecting the quality of human environment as referred to in the NEPA (42 U.S.C. 4332 (2)(c). 


\title{
United States Department of the Interior
}

\author{
FISH AND WILDLIFE SERVICE \\ Sacramento Endangered Species Orfice \\ 28(0) Cottage Way, Rocm E-1823 \\ Sacramento, California 95825-1846
}

In Reply Refer 'To:

1-1-89-SP- 944

August 15, 1989

Nandranie S. Tuck

Environmental Specialist

Environmental Compliance Section

Department of Energy

Bonneville Power Administration

P.O. Box 3621

Portland, Oregon 97208-3621.

Subject: Species List for the Bonneville Power Administration Service Area Long-Term Power Sales Contract, Modoc and Lassen Counties, California

Dear Ms. Tuck:

As requested by letter from your agency dated July 19, 1989, you will find attached a list of the proposed and listed endangered and threatened species that may be present in the subject project area. (See Attachment A.) This list fulfills the requirement of the Fish and Wildlife Service to provide a species list pursuant to Section 7 (c) of the Endangered Species Act, as amended.

Some pertinent information concerning the distribution, life history, habitat requirements, and published references for the listed species is also attached. This information may be helpful in preparing the biological.

assessment for this project, if one is required. Please see Attachment $B$ for a discussion of the responsibilities Federal agencies have under Section $7(c)$ of the Act and the conditions under which a biological assessment must be prepared by the lead Federal agency or i.ts designated non-Federal representative.

Formal consultation, pursuant to $50 \mathrm{CFR} \S 402.14$, should be initiated if you determine that a listed species may be affected by the proposed project. If: you determine that a proposed species may be adversely affected, you should consider requesting a conference with our office pursuant to 50 CFR \$ 402.10. Informal consultation may be utilized prior to a written request for formal consultation to exchange information and resolve conflicts with respect to a listed species. If a biological assessment is required, and it is not initiated within 90 days of your receipt of this letter, you should informally verify the accuracy of this 1 ist with our office.

Also, for your consideration, we have included a list of the candidate species that may be present in the project area. (See Attachment. A.) These specicss are currently being, reviewed by our service and are under consideration for 
possible listing as endangered or threatened. Candidate spectes have no protection under the Endangered Species Act, but are included for your consideration as $i t$ is possible that one or more of these candidates could be proposed and 1 is ted before the subject project is completed. Should the biological assessment reveal that candidate species may be adversely affected, you may wish to contact our office for technical assistance. One of the potential benefits from such technical assistance is that by exploring alternatives early in the planning process, it may be possible to avoid conflicts that could otherwise develop, should a candidate species become listed before the project is completed.

Please contact Peggie Koh1 at 916/978-4866 (FrS 460-4866) if you have any questions regarding the attached list or your responsibilities under the Endangered Species Act.

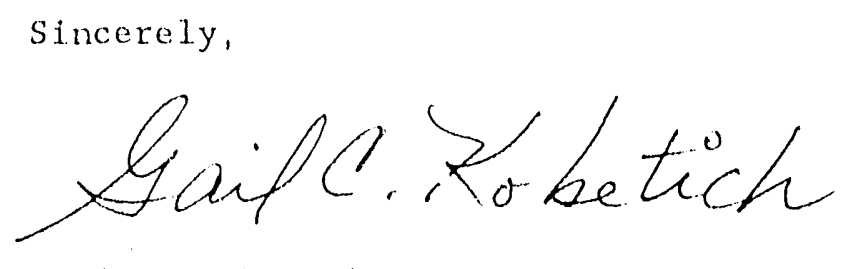

Gail C. Kobetich

Field Supervisor

Attachinents 
LISTED AND PROPOSED LNDANGERED AND THREATENED SPL(IIES AND

CANDIDATE SPECIES THAT MAY OCCUR IN THE ARLA OF THE

BONNEVILLE POWER ADMINISTRATION SERVICE AREA

LONG-TERM POWER SALES CONT'RAC'T'

MODOG AND IASSEN COUNTIES, CALIFORNIA

$$
\text { 1. }-1-89-\mathrm{SP}-944
$$

li.isted Species

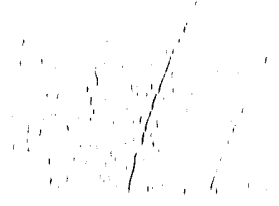

Birds

American peregrine falcon, Falco peregrinus anatum (E)

Fishes

bald eagle, Haliaeetus leucocephalus (E)

Modoc sucker, Catostomus microps (E)

\section{Proposed Species}

Birds

northern spotted owl, Strix occidentalis caurina (PT)

\section{Candidate Species}

Fishes

redband trout, Salmo sp. (2)

rough sculpin, Cottus asperrimus (2)

Goose Lake sucker, Catostomus; occidentalis lacusanserinus (2)

Mammals

Cowhead hake tui chub, Gila bicolor vaccaceps (1)

spotted bat, Euderma maculatum (2)

California bighorn sheep, Ovis canadensis californiana (2)

Plants

Deschutes milk-vetch, Astragalus tegetarioides (2)

Greene's mariposa, Calochortus greenei (2)

long-haired star-tulip, Calochortus longebarbatus var. longebarbatus (2)

Sierra Valley evening-primrose, Camissonia tanacetifolia subsp. quadriperforata (2)

prostrate buckwhat, Eriogonum prociduum (2)

Mathais' coyote-thistle, Eryngium mathiasiae (2)

Modoc bedstraw, Galium glabrescons subsp. modocense (2)

Warmer Mountains bedstraw, Galium serpenticum subsp. warnercnse (?)

Ash Creek ivesia, Ivesia pamiculata (2)

Egg Lake monkeyflower, Mimulus pygmatus (2)

lasson county bluegratss, Poa fibrata (?)

Columtia yel low-crossi, Rorippa columbias (2)

Ravendale skulloap, Scutellaria holmgreniorum (2) 
(E) - Endangered ('T) - - 'threatened (CH) - Critical llabitat:

(1) - Category 1: Taxa for which the Fish and Widdife service has sufficient biological information to support a proposal to list as endangered or threatened.

(2) - Category 2: 'laxa for which existing information indicated may warrant listing, but for which substantial biological information to support a proposed rulo is lacking. 


\section{FEDERAL AGENCIES' RESPONSIBILITIES UNDER SECTIONS $7(a)$ and $(c)$ OF THE ENDANGERED SPECIES AC'T.}

SECTION 7 (a) Consultation/Conference

Requires: 1) Federal agencies to utilize their authorities to carry out programs to conserve endangered and threatened spectes; 2) Consultation with FWS when a Federal action may affect a listed endangered or threatened species to insure that any action authorized, funded or carried out by a Federal agency is not likely to jeopardize the continued existence of listed species or result in the destruction or adverse modification of critical habitat. The process is initlated by the Federal agency after determining the action may affect a 1isted species; and 3) Conference with FWS when a Federal action is likely to jeopardize the continued existence of a proposed species or result in destruction or adverse modification of proposed critical habitat.

SECTION 7 (c) Biological Assessment--Major Construction Activity ${ }^{1}$

Requires Federal agencies or their designees to prepare a Biological Assessment (BA) for major construction activities. The BA analyzes the effects of the action ${ }^{2}$ on listed and proposed species. The process begins with a Federal agency requesting from FWS a 1 ist of proposed and listed threatened and endangered species. The BA should be completed within 180 days after its initiation (or within such a time period as is mutually agreeable). If the $B A$ is not initiated within 90 days of receipt of the 1ist, the accuracy of the species list should be informally veriffed with our Service. No irreversible commitment of resources is to be made during the BA process which would foreclose reasonable and prudent alternatives to protect endangered species. Planning, design, and administrative actions may proceed; however, no construction may begin.

We recommend the following for inclusion in the $B A$ : an on-site inspection of the area affected by the proposal which may include a detafled survey of the area to determine if the species or suitable habitat are present; a review of literature and scientific data to determire species' distribution, habitat needs, and other biological requirements; interviews with experts, including those within FWS, State conservation departments, universities and others who may have data not yet published in scientific literature; an analysis of the effects of the proposal on the species in terms of individuals and populations, including consideration of indirect effects of the proposal on the species and its habitat; an analysis of alternative actions considered. The BA should document the results, including a discussion of study methods usea, any problems encountered, and other relevant information. The BA should conclude whether or not a listed or proposed species will be affected. Upon completion, the $B A$ should be forwarded to our office.

\footnotetext{
${ }^{1}$ A construction project (or other undertaking having similar physical impacts) which is a major Federal action significantly affecting the quality of the human environment as referred to in NEPA (42 U.S.C. 4332(2)C).

2 "bffects of tho action" refers to the direct and indiract offects on an action on the species or eritical habitat, topether with the offects of other activitios that ate interrelated or interdeprodent with that ace ion.
} 


\author{
BALD EAGLE \\ (Haliaeetus leucocephalus)
}

CLASSIFICATION:

Endangered (Federal Register 43:633; February 14, 1978).

CRITICAL HABITAT: None designated.

DESCRIPTION:

Next to the California condor, the bald eagle is the largest bird in Califormla with a wingspan measuring 6 to 7 feet. Adults are brownish black with a white head and tail and yellow bill. Immatures are variously brownish black.

\title{
DISTRIBUTION:
}

Bald eagles can and do occur virtually anywhere in Callfornia during migration. They nest near water bodles in the northern portion of the state and winter throughout the state wherever suitable prey resources are available.

\section{SPECIAL CONSIDERATIONS:}

Although some bald eagle populations began to decline in the 19th century due to human persecution and habitat loss, the drastic declines in reproduction experienced by most eagle populations occurred between 1947 and 1970. Research indlcated that certain organochlorine pesticides interfered with productivity, and other pesticides were responsible for direct mortalitles. Most bald eagle populatlons are now stable or increasing in numbers.

\section{REFERENCES FOR ADDITIONAL INFORMATION:}

Detrich, P. J. 1986. The status and distribution of the bald eagle in California. M. S. Thesis. Chico State Univ., CA

Frenzel, F. W. 1984. Ecology and environmental contaminants of bald eagles in southcentral Oregon. Ph.D. Thesis. Oregon State Univ., Corvallis, OR.

Lehman, R. N., D. E. Craigee, P. L. Collins, and R. S. Griffen. 1980. An analysis of habitat requirements and site selection criteria for nesting bald eagles in California. Report by Wilderness Research Institute, Arcata, CA for U.S. Forest Service, Region 5, San Francisco, CA.

U.S. Fish and Wildife Service, 1986. Recovery plan for the Pacific Bald Eagle. Portland, OR. 


\section{AMERICAN PEREGRINE FALCON}

(Falco peregrinus anatum)

CLASSIFICATION:

Endangered 35 Federal Register 16047, October 13, 1970, and 49 Federal Register 10526, March 20, 1984.

CRITICAL HABITAT: Designated In Sonoma, Napa, and Lake Cos.

DESCRIPTION:

A medium-sized, swift flying bird of prey with pointed wings. Wingspan is 3 to 4 feet. Adults have slate gray backs with white underparts that are streaked or barred in black. They have distinctive white and black faclal markings.

DISTRIBUTION:

Historlcally nested throughout North America from the boreal forest south into Mexico, wherever suitable nesting and foraging habltat occurred. Remnant breeding populations currently occur in Callfornia, Arizona, New Mexico, Utah, Texas, and Alaska. A few palrs nest in other states in the northeast and northwest.

SPECIAL CONSIDERATIONS:

The American peregrine falcon has suffered major population declines due princlpally to DDT contamination of their food chain. With the barining of DDT for use in the U.S. In 1972 and Implementation of a management program, populations have for the most part stabilized. Unfortunately, pesticide data indicate that there has been a continued input of DDT Into the local environments. Some nest sites are now protected from human disturbance. Poor quality eggs are taken from the wild for artificial incubation, and young are placed in nests after hatching from wild eggs taken into captivity or laid by captive parents.

\section{REFERENCES FOR ADDITIONAL INFORMATION:}

J. J. Hickey (ed). 1969. Peregrine falcon populations their biology and decline. Univ, of Wisconsin Press. Madison, WI.

Ratcliffe, D. 1980. The peregrine falcon. Buteo Books. Vermillion, SD.

U.S. Fish and Wildlife Service. 1982. Pacific Coast Recovery Plan for the American Peregrine Falcon. Portland, OR. 87 pp. 


\title{
United States Department of the Interior
}

FISH AND WILDLIFE SERVICE

\author{
RENO FIELD STATION \\ 4600 Kietake Lane, Building C \\ Reno, Nevada 89502
}

August 3,1989

File No.: 1-5-89-SP-159

\begin{abstract}
Nandranie S. 'Tuck, Environmental Specialist
Environmental Compliance Section

Bonneville Power Administration

U. S. Department of Energy

P. 0. Box 3621

Portland, Oregon 97208-3621
\end{abstract}

Dear Ms. T'uck:

Your letter of July 19, 1989 to Mr. Ralph Swanson, Fish and Wildlife

Enhancement, U.S. Fish and Wildlife Service, Portland, Oregon requested a

list of endangered and threatened species which may be present in the area of or be affected by the Long-term Power Sales Contracts of the Bonnevi11. Power Administration under the Pacific Northwest Electric Power Planning and Conservation Act. This office was asked to provide you with information relative to species in the vicinity of the Valmy $1 \& 2$ thermal generating facilities in Nevada. To the best of our knowledge, no proposed, listed, or candidate species occur within the Valmy area.

This fulfills our requirement to provide a list of species under section 7 (c) of the Endangered Species Act of 1973, as amended.

If you have any questions please contact Donna withers at (702) 784-5227 or FTS 470-5227. Thank you for your interest in endangered species.

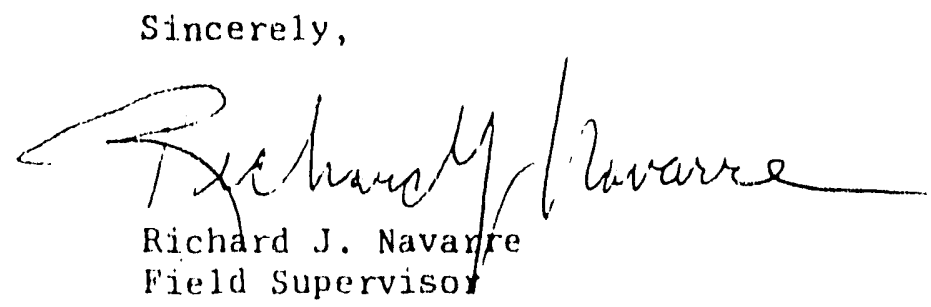

cc: Assistant Regional Director (AFWE), Portland, Oregon 


\section{United States Department of the Interior FISH ANI) WILDLILE SERVICE}

MAIIINCI ADIMRESS:

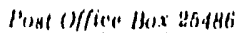

benener Fideral center

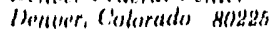

STRERT IOC ATION:

lid llnown Hind.

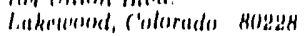

FWE

MAIL STOP 60120

St.i I IJB'S

Ms. Nandranie S. Tuck

Environmental Special ist

Bonneville Power Administration

P.0. Box 3621

Portland, Oregon 97208-3621

Dear Ms. Tuck:

This responds to your July 19, 1989, request for a list of threatened and endangered species which may occur in the area of influence of the Bonneville Power Administration's long-term power sales contracts. The information provided herein applies to the following facilities:

(1) Hungry Horse Power Plant

(2) Libby Power Plant

(3) Colstrip 1-4 Power Plant

(4) Corette Power Plant

(5) Jim Bridger Power Plant

(6) Belle Ayre Mine

(7) Rosebud Mine

(8) Bridger Mine
Flathead County, Montana

Lincoln County, Montana

Rosebud County, Montana

Yellowstone County, Montana

Sweetwater County, Wyoming

Campbell County, Wyoming

Rosebud County, Montana

Sweetwater County, Wyoming

Threatened and endangered species that may occur in the area of influence of the above facilities are listed below. Immedlately following each species are numbers corresponding to the factlities where the spectes may be found.

Colorado River Squawfish (Ptychocheilus lucius) E*

Water depletions from the Green River may affect this species downstream in the Colorado River. (5) (8)

Humpback Chub (Gila cyplia) E*

Water depletions from the Green River may affect this species downstrean in the Colorado River. (5)(8)

Bald Eagle (llal iaeetus leucocephalus) **

Yearlony resident and inigrant. All facilities.

Peregrine falcon (falco peregrinus) i*

Migrant and potential sumer resident. All facilities. 
Black footed lerrot (Mustela nigrtoes) E* potential restdent in pratrie dog towns.

$(3)(1)(5)(6)(7)$

Gray Wolf (Canis lupus) E*

Resident. (1) (2)

Grizzly Bear (Ursus arctos) T*

Residont. (1)(2)

* $E=$ Endangered, T=Threatened

Should you need further assistance or have questions about the information provided, you may contact Mr. Larry Lockard at (406) 755-7870 on Montana issues or Mr. Richard H111 at FTS 328-2374 on Wyoming issues.

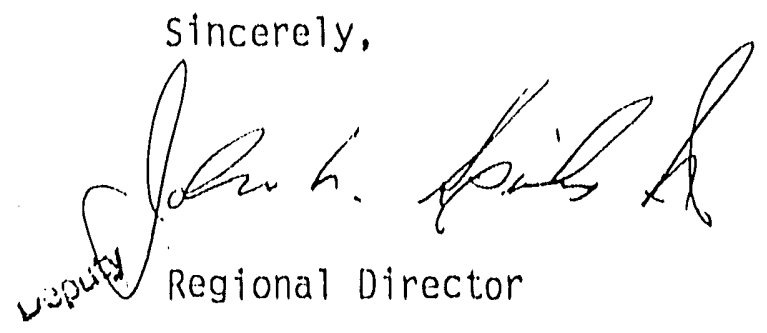



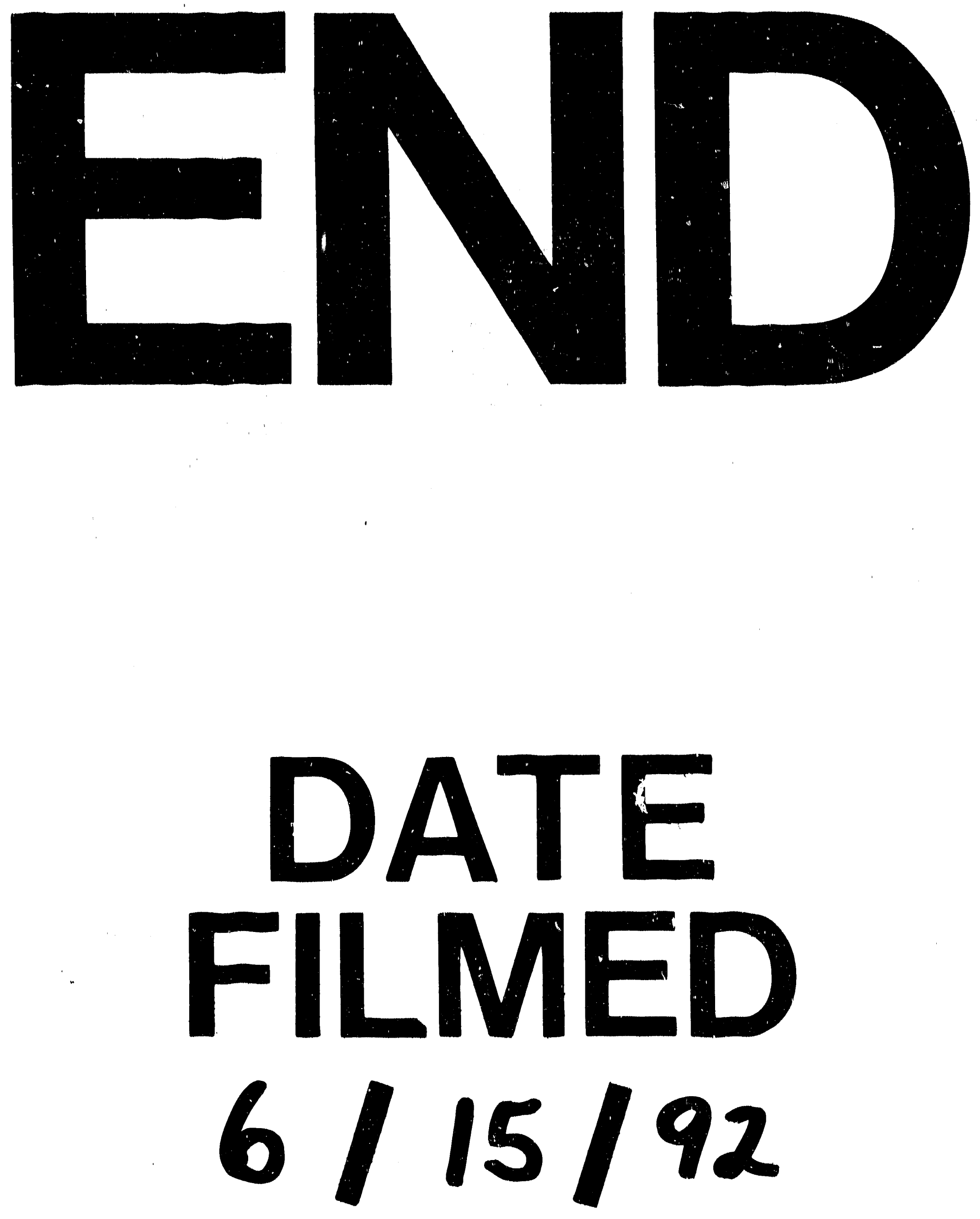

$\uparrow$ 